

\section{REVISTA BRASILEIRA DE POLÍTICAS PÚBLICAS}




\section{REVISTA BRASILEIRA DE POLÍTICAS PÚBLICAS \\ Brazilian Journal of Public Policy}

Programa de Mestrado e Doutorado em Direito do UniCEUB

Centro Universitário de Brasília

Reitor

Getúlio Américo Moreira Lopes

Presidente do Conselho Editorial do UniCEUB

Elizabeth Regina Lopes Manzur

Diretor do ICPD

João Herculino de Souza Lopes Filho

Coordenador do Programa de Mestrado e Doutorado e Editor

Marcelo Dias Varella

\section{Linha editorial}

A Revista Brasileira de Políticas Públicas tem como finalidade constituir instrumento de veiculação de trabalhos científicos e doutrinários relacionados a aspectos ligados a interação entre Políticas Públicas e Direito. Direciona, portanto, seu objeto de interesse a questões referentes a governabilidade, integração, participação cidadã, desenvolvimento e outros temas envolvendo o Estado, a Sociedade e o Direito. Sendo assim, a proposta de linha editorial a ser seguida pela Revista Brasileira de Políticas Públicas é apresentada a partir de três áreas fundamentais, que se subdividem:

1. Políticas de Estado e de Governo e democracia: teoria das políticas públicas, sistema de governo, sistema eleitoral e cidadania, sistema de partidos e reforma constitucional.

2. Políticas Públicas e desenvolvimento econômico e social: políticas de desenvolvimento econômico e produção local/regional, desenvolvimento sustentável e meio-ambiente, desenvolvimento humano e planejamento da ação governamental.

3. Avaliação em políticas públicas: teorias de avaliação em políticas públicas, metodologia de avaliação de políticas públicas e políticas de desenvolvimento, metodologia de analise jurídica de políticas públicas, resultados de analise em políticas públicas, pesquisa em políticas públicas setoriais.

\section{Comitê editorial}

Frederico Augusto Barbosa, Centro Universitário de Brasília (UniCEUB)

Gilberto Bercovici, Universidade de São Paulo (USP)

João Maurício Adeodato, Universidade Federal de Pernambuco (UFPE)

\section{Layout capa}

Departamento de Comunicação / ACC UniCEUB

\section{Diagramação}

S2 Books

\section{Disponível em:}

http://www.publicacoesacademicas.uniceub.br

e-mail: rochaalice@yahoo.com.br

\section{Circulação}

Acesso aberto e gratuito

Matérias assinadas são de exclusiva responsabilidade dos autores.

Citação parcial permitida com referência à fonte. 
Revista Brasileira de Políticas Públicas / Programa de Mestrado e Doutorado em Direito do UniCEUB. - vol. 1, no. 1 (jan./jun. 2011)- . Brasília : UniCEUB, 2011-

Semestral.

ISSN 2236-1677

Disponível também on-line: www.rbpp.uniceub.br

1. Direito. 2. Políticas Públicas. I. Programa de Mestrado e Doutorado em Direito do UniCEUB

CDU $34+338.26$

Ficha catalográfica elaborada pela Biblioteca Reitor João Herculino 


\section{Dossier Federalismo}

Forma de Estado: Federalismo e Repartição de competênCias ..................................... 2 Carlos Bastide Horbach

1. Introdução 2

2. Antecedentes históricos do modelo federal ................................................................... 4

3. Modelo federal norte-americano ................................................................................5

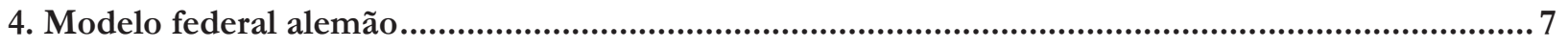

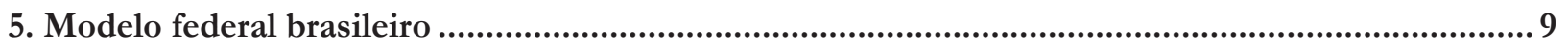

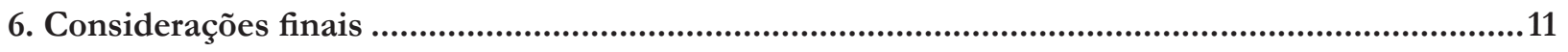

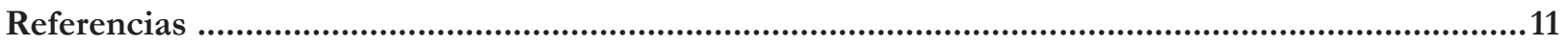

IMUNIDADE RECÍPROCA E FEDERALISMO: DA CONSTRUÇÃO NORTE-AMERICANA À ATUAL POSIÇÃO Do STF

Fernando Santos Arenhart

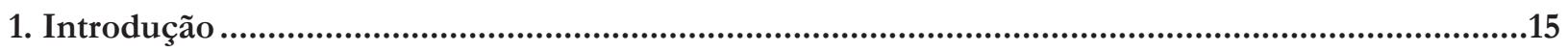

2. Origens históricas da imunidade recíproca............................................................................16

2.1 McCulloch v. Maryland e a teoria dos poderes implícitos...................................................................... 18

2.2 A evolução da reciprocal immunity of Federal and State instrumentalities............................................. 21

3. A imunidade recíproca no direito brasileiro ............................................................. 24

3.1 Da Constituição de 1891 à Emenda Constitucional n. ${ }^{\circ}$ 3/94 .................................................................. 25

3.2 Os princípios constitucionais, a imunidade recíproca e a jurisprudência do Supremo Tribunal Federal. 28

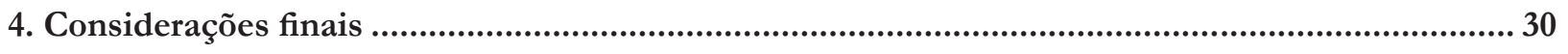

Referências.................................................................................................................31

JUSTIÇA FISCAL, PAZ TRIBUTÁRIA E OBRIGAÇÕES REPUBLICANAS: UMA BREVE ANÁLISE DA DINÂMICA JURISPRUdENCIAL TRIBUTÁRIA do SUPREMO TRIBUNAL FEdERAL ...........................................34

Luís Carlos Martins Alves Jr

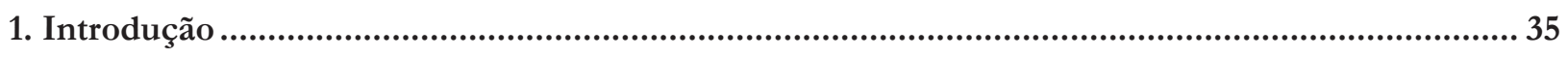

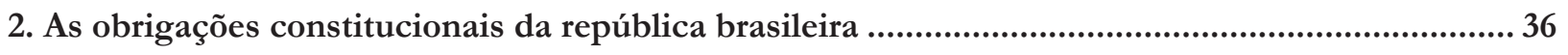

3. Algumas questões tributárias na jurisprudência do STF ....................................................42

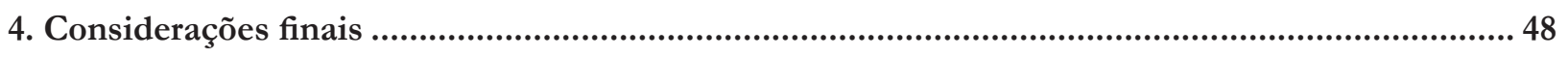

Referências................................................................................................................. 49 
Antonio Celso Batista Minhoto

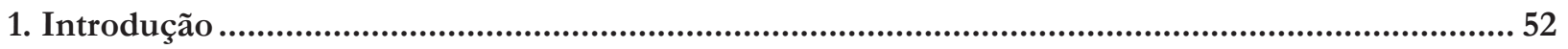

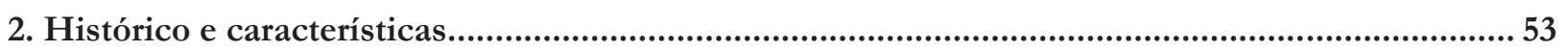

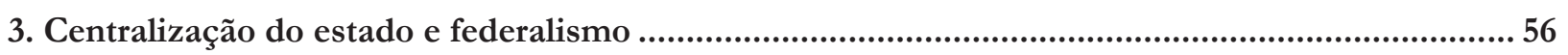

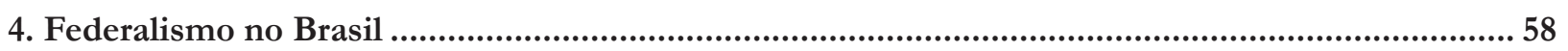

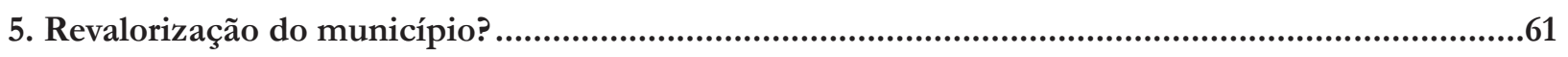

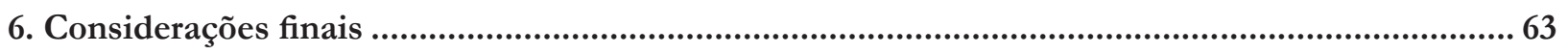

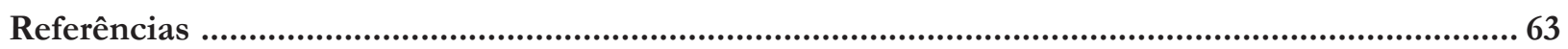

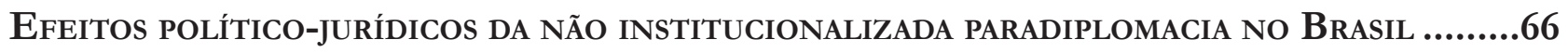
Gustavo de Souza Abreu

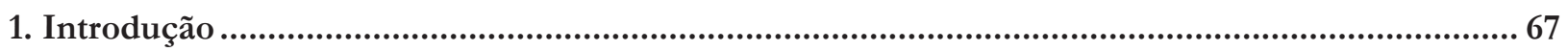

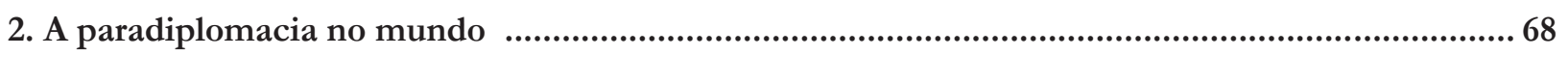

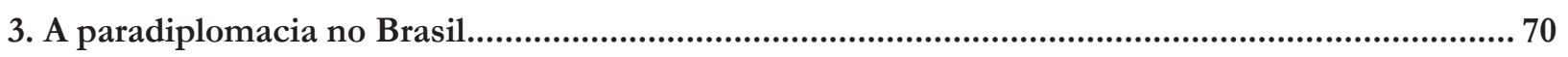

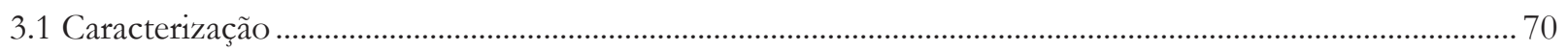

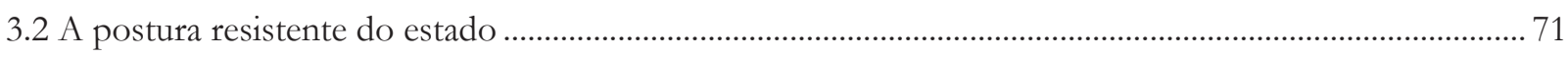

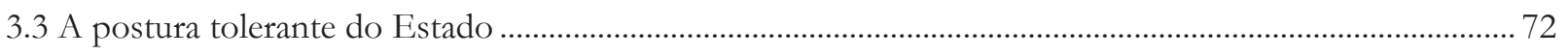

3.4 Consequências da dupla postura do Estado............................................................................................... 73

4. Constrangimentos internacionais e riscos à segurança nacional................................................... 74

4.1 A falta de critérios e condições de funcionamento da atividade paradiplomática.......................................... 74

$4.2 \mathrm{O}$ potencial de conflito com a política externa nacional.................................................................................. 74

4.3 A fragilização de certos elementos de controle da segurança nacional ........................................................ 75

4.4 A fragilização de certos elementos de controle de políticas socioeconômicas ............................................ 76

4.5 A ingerência estrangeira em assuntos internos .......................................................................................... 77

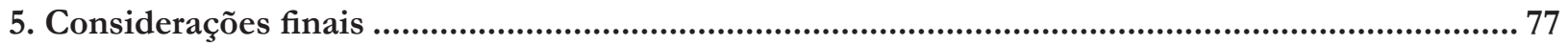

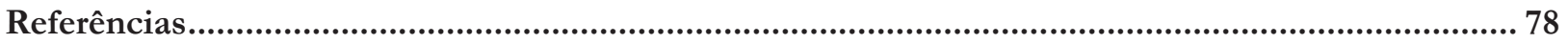

The Management of Public Natural Resource Wealth..........................................80 Paul Rose

1. Introduction 80

2. The Legal Origins of State Public Natural Resource Wealth ....................................................... 82

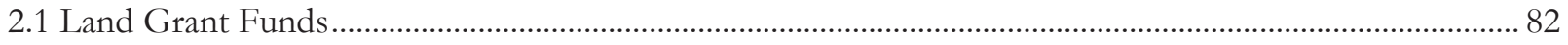

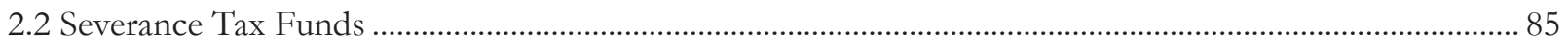

3. Policy Justifications for State Natural resource Funds ............................................................. 86

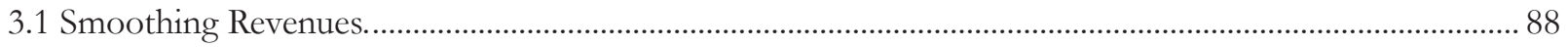


4. State Public Natural Resource Funds and the Financial Crisis.

5. Managing Short-Term Temptations

5.1 Credit Ratings Agencies as "Catalyst": The Natural Resource Fund as a Mechanism to Decrease the Cost of Public Debt...... 91

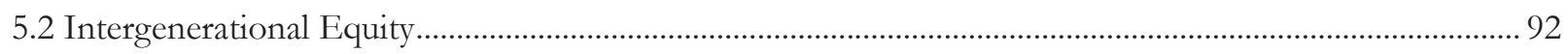

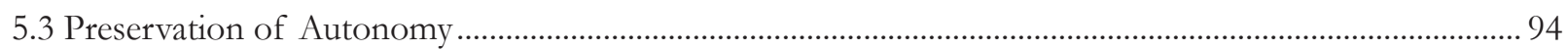

6. State natural resource funds as Bulwarks against National and International Pressures ............. 95

7. Policy Justifications Meet Political Realities: The Uses and Governance of State Natural Resource Funds

7.1 Supporting Social Programs while Seeking High Returns: The New Mexico Severance Tax Permanent Fund 98

7.2 The Many Uses of Wyoming's Severance Tax Funds ....................................................................... 100

7.3 Distribution of Severance Tax Fund Income to State General Funds ................................................. 102

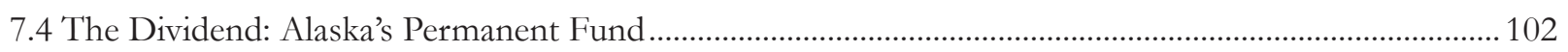

8. The Creation of the APF Dividend .....................................................................................103

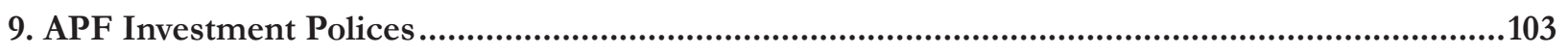

9.1 The Governance Implications of Targeted Investments and Dividends ............................................. 104

10. Investment Policies and Agency Costs ..................................................................105

11. Distribution Policies and Agency Costs ..........................................................................108

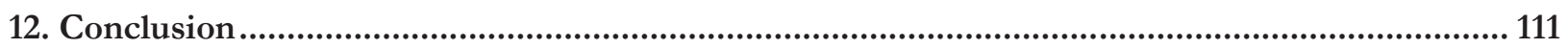

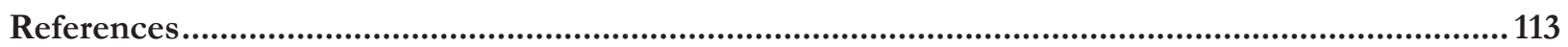

A (IN)COMPETÊNCIA DO CONAMA PARA EDIÇÃO DE NORMAS SOBRE LICENCIAMENTO AMBIEN-

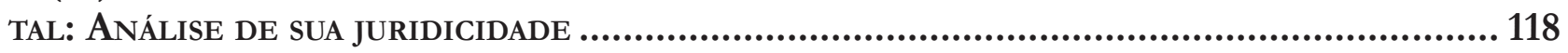
André Fagundes Lemos

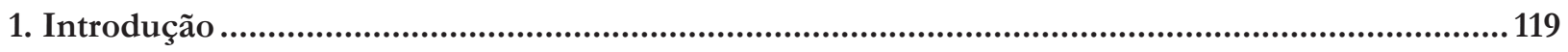

2. Sistema Nacional do Meio Ambiente ......................................................................119

2.1 Conselho Nacional do Meio Ambiente (Conama) ............................................................................. 121

3. O princípio da legalidade versus o poder regulamentar do CONAMA em matéria de licenciamento

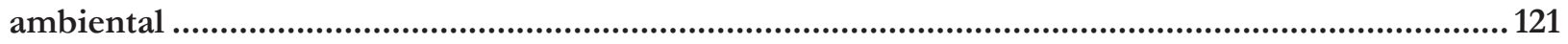

4. O poder do CONAMA para edição de normas sobre licenciamento ambiental .........................124

5. A resolução no 237 do CONAMA ....................................................................................126

6. Não recepção de dispositivos da Lei n $^{\text {o }} 6.938 / 81$ pela Constituição Federal de 1988.................130

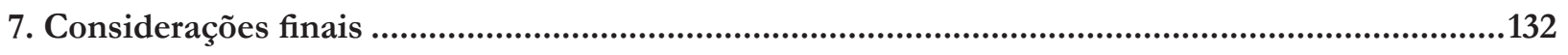

Referências.......................................................................................................................132 


\section{Artigos sobre outros temas}

TEORÍA DE LA PRESIÓN TRIBUTARIA EN BASE A LA IGUALDAD INTERGENERACIONAL: UNA PERSPECTIVA FINANCIERA Y TRIBUTARIA DEL CASO ARGENTINO................................................. 135

Luciano Carlos Rezzoagli e Bruno Ariel Rezzoagli

1. Aspectos relevantes de la Igualdad como principio en materia impositiva .136

2. Pautas del principio en el derecho argentino. Interpretación de la Corte Suprema de Justicia de la Nación 138

3. Su extensión al ámbito financiero. 141

4. Conclusiones. 144

Referências. 145

Crédito TRIbUtÁRIO: GARANTIAS, PRIVILÉgIOS E PREFERÊNCIAS. 148 Luís Carlos Martins Alves Júnior

1. Introdução 148

2. O tributo, a lei e a democracia

2. A obrigação e o crédito tributário 151

3. As garantias, os privilégios e as preferências do crédito tributário 163

4. Considerações finais 168

5. Referências 168

Tributário - O parecer PGFN/CRJ 492/2011 e os efeitos da coisa Julgada inconstitucional em face da segurança jurídica no Estado Democrático de Direito............... 174 Antônio Frota Neves

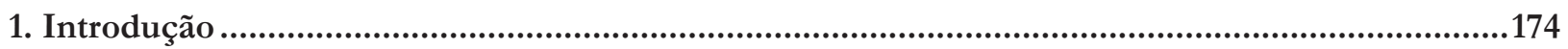

2. Análise do parecer PGFN/CRJ 492/2011 ...................................................................................175

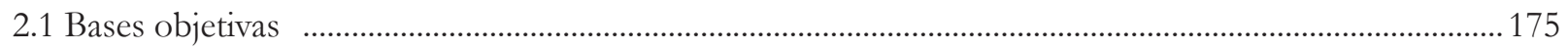

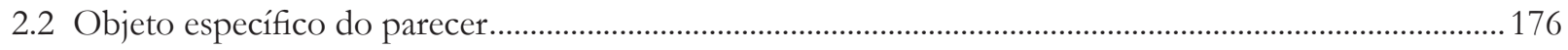

2.3 Cessação da eficácia vinculante, pro futuro, da coisa julgada inconstitucional ..........................176

2.4 Cessação da eficácia vinculante da coisa julgada em decorrência de precedente objetivo e definitivo do STF

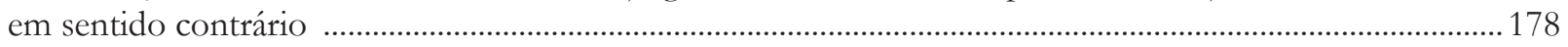

2.5 a suspensão de execução de lei pelo Senado Federal e a repercussão geral nos moldes do CPC, Art. $543-B$. 178

2.6 A cessação da eficácia vinculante da decisão tributária transitada em julgado é automática e independe de prévio reconhecimento judicial. 180

2.7 A cessação da eficácia vinculante de decisão transitada em julgado e a relativização da coisa julgada... 182

3. A coisa julgada 183 


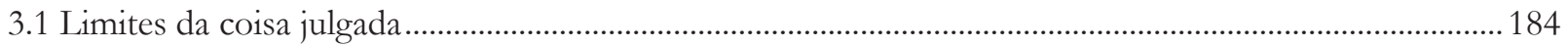

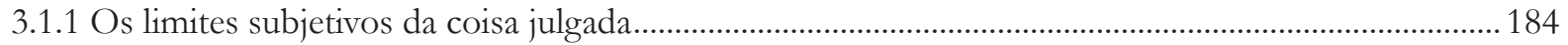

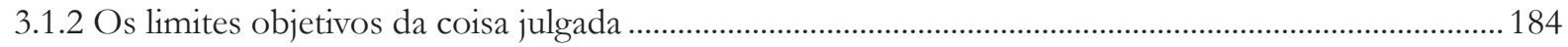

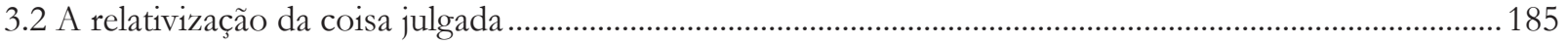

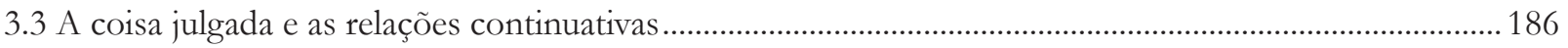

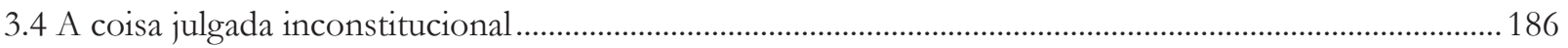

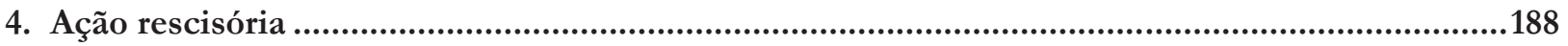

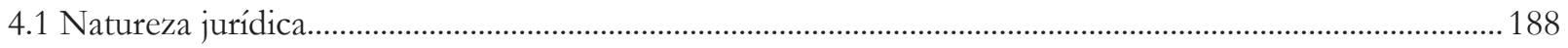

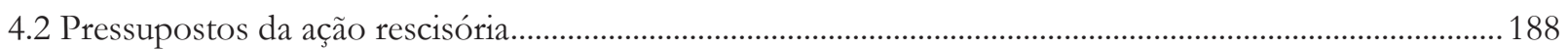

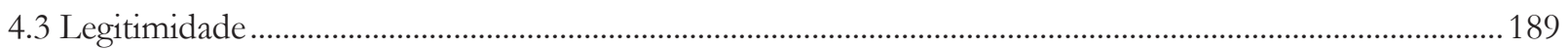

4.4 Prazo para propositura da ação rescisória ................................................................................................ 189

5. A segurança jurídica e o Estado Democrático de Direito .....................................................189

5.1 A segurança jurídica tributária diante da certeza do direito e da confiança legítima ................................. 190

5.2 A segurança jurídica, a irretroatividade, a proteção da confiança e a boa-fé............................................... 190

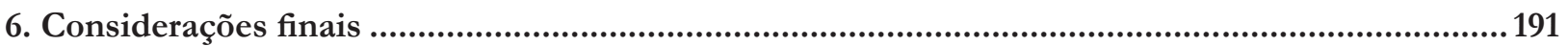

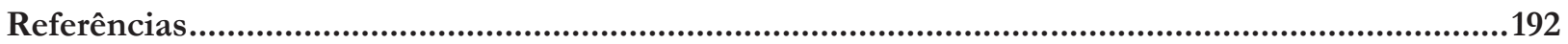

A segurança jurídica administrativa na jurisprudência do Supremo Tribunal Federal: UMA ANÁLISE ACERCA DOS FUNDAMENTOS NORMATIVOS E DOS ARGUMENTOS JURÍDICOS NOS JUL-

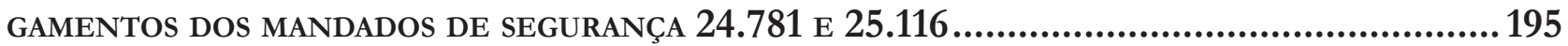

Ana Paula Sampaio Silva Pereira

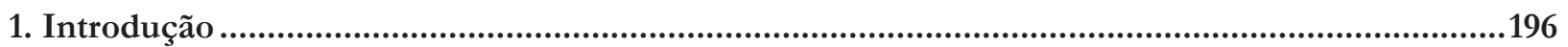

2. A segurança jurídica e a proteção da confiança ....................................................................197

2.1 Distinção terminológica: segurança jurídica x proteção à confiança............................................................. 200

2.2 O conteúdo do princípio da segurança jurídica objetiva e subjetiva ............................................................... 202

2.2.1 Dimensão objetiva: intangibilidade das situações individuais por questões objetivas..........................203

2.2.2 Dimensão subjetiva: intangibilidade das situações individuais por questões subjetivas ......................206

3 Casos práticos: o julgamento dos mandados de segurança 24.781 e 25.116 .................................... 211

3.1 Contextualização da matéria dos julgados ....................................................................................................212

3.2 Os fundamentos dos mandados de segurança 25.116/df e 24.781/df .......................................................214

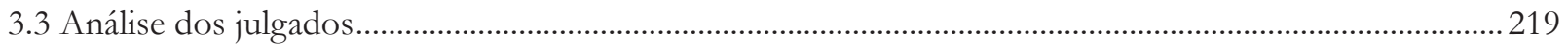

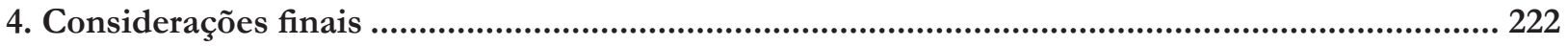

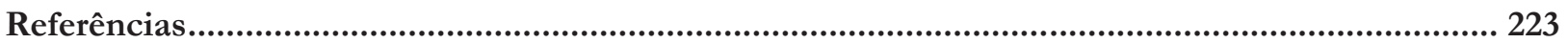


Avaliação legislativa no Brasil: apontamentos para uma nova AgENda de PesQuisa soBRE O MODO DE PRODUÇÃO DAS LEIS...............................................................229 Natasha Schmitt Caccia Salinas

1. O re (surgimento) da ciência da legislação .................................................................................... 230

2. Legística material ou metódica da legislação ................................................................................. 234

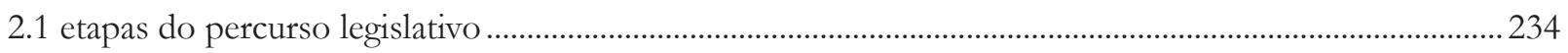

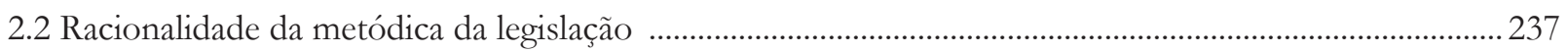

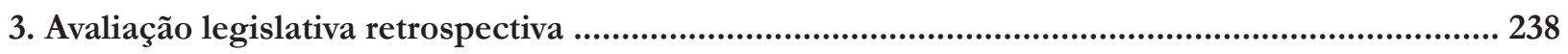

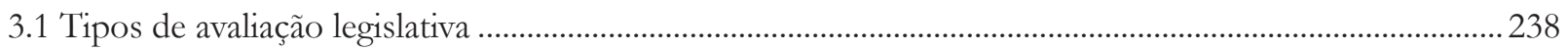

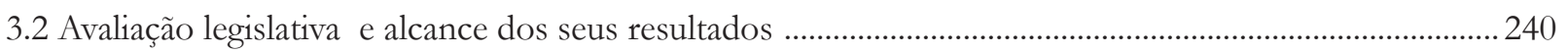

3.3 Experiências de institucionalização da avaliação legislativa ........................................................................ 241

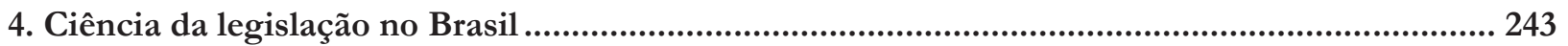

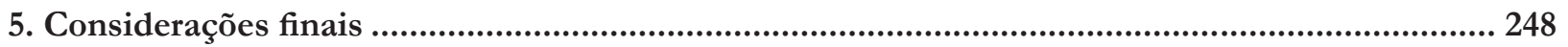

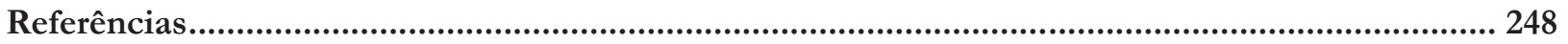

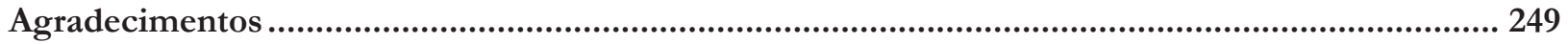

Políticas públicas, deVeres fundamentais e Concretização de direitos .................... 251 Julio Pinheiro Faro

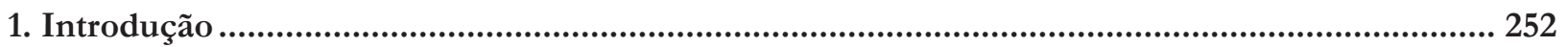

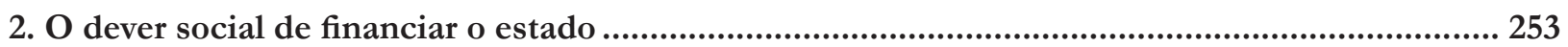

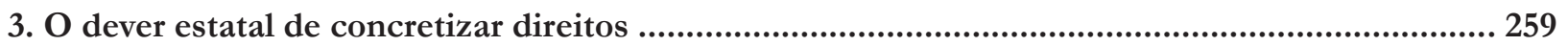

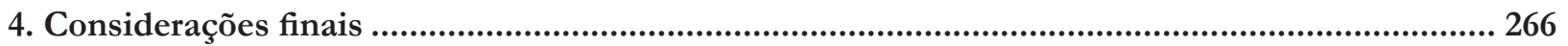

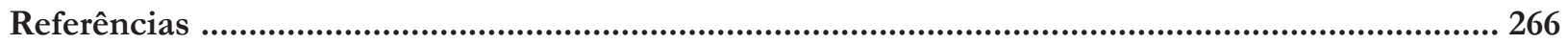

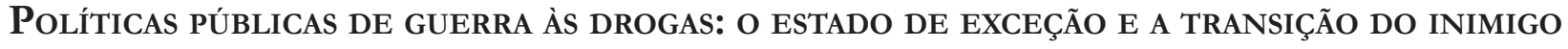
SCHMitTiano Ao HOMO SACER DE AgAMbEN .................................................... 271 João Victor Nascimento Martins

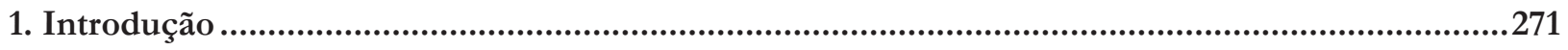

2. O inimigo em Schmitt e a política pública estadunidense de combate ao narcotráfico.............. 272

3. A política brasileira de combate ao narcotráfico e o homo sacer................................................... 276

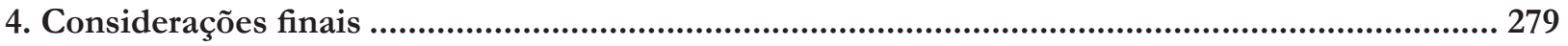

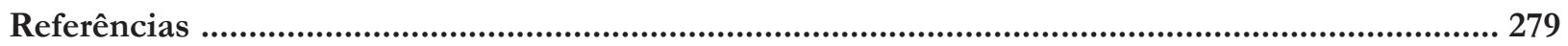


Karl-Heinz Ladeur

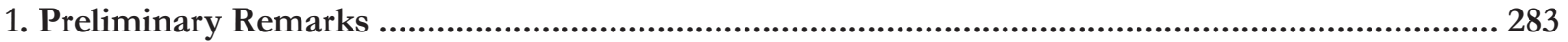

2. Protection from offensive communication in the internet (blogs etc.) ....................................... 283

2.1. The structure of media law and the transformation of social norms as its infrastructure ....................283

2.2 The great unbundling " of the media and its impact on social norms ........................................................28

3. Data protection in the internet - for a change from bureaucratic protection to net friendly procedu-

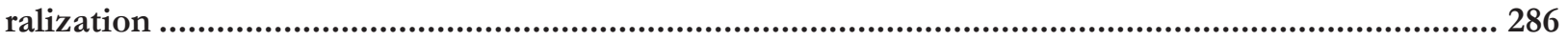

3.2 The necessity to observe the collective effects of the processing of data flows .....................................286

3.3 The self-organization of the "data-owners"vis-à-vis private actors following the example of”, „collecting societies" in the protection of intellectual property: A model for a net friendly legal instruments .............. 287

4. Criminal law and criminal procedure in the face of "risky networks" "........................................ 288

4.1 From organized criminality toward "criminal networks" - the example of Al Khaida ...........................288

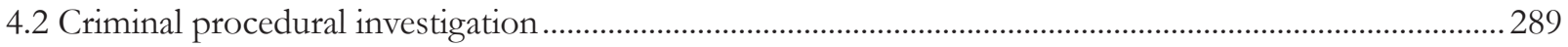

5. Contracts on the use of social media as ,networks of contracts“"? .............................................. 290

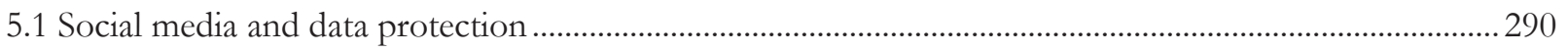

5.2 The „network contract“ as a new paradigm of private law for the ,social media“.................................. 291

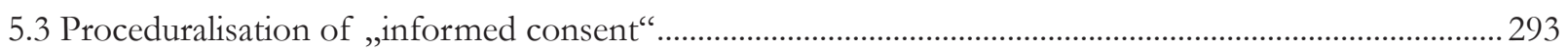

5.4 The impact of constitutional law on private ,network contracts“.............................................................224

5.5 The creation of "information brokers" and cyber courts" as components of a new institutional architec-

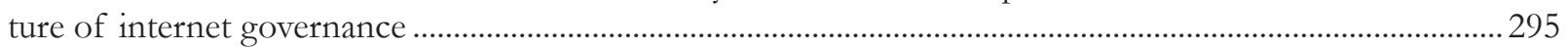

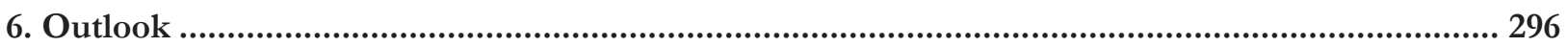

RESPONSABILIDADE CIVIL DECORRENTE DE ERRO MÉDICO...........................................298

Edilson Enedino das Chagas e Héctor Valverde Santana

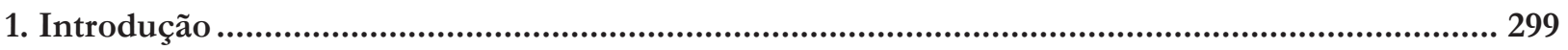

2. Falibilidade humana e factibilidade do erro médico..........................................................301

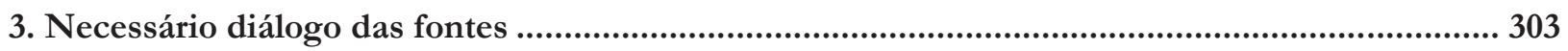

4. Teorias civilistas sobre a responsabilidade do médico........................................................... 307

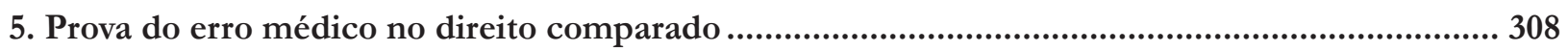

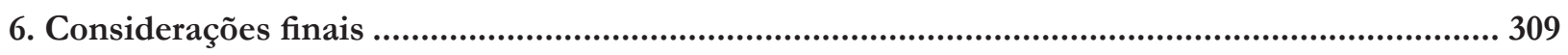

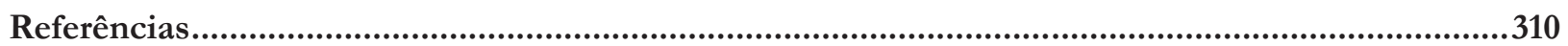


A atual geração de energia elétrica segundo a lógica de mercado e sua Ainda CaraCTERIZAÇÃO COMO SERVIÇO PÚBLICO ............................................................... 313

Humberto Cunha dos Santos

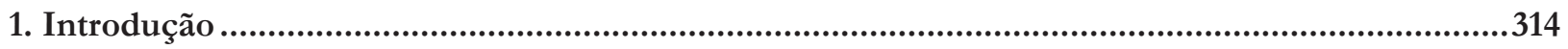

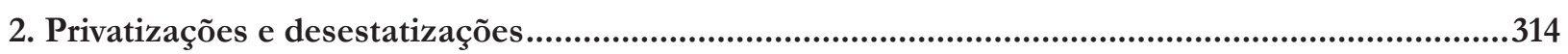

3. O modelo estatal vigente até a década de 1990......................................................................316

4 O Programa Nacional de Desestatização (PND) ...........................................................................318

5. A noção de serviços públicos..........................................................................................................321

5.1 O tratamento jurídico da energia elétrica......................................................................................................... 325

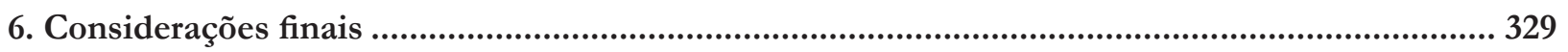

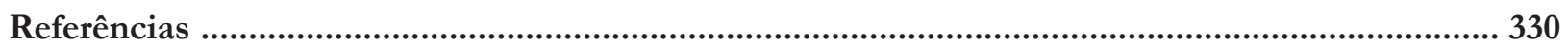

EMPRESAS, RESPONSABILIDADE SOCIAL E POLÍTICAS DE INFORMAÇÃo OBRIGATÓRIA NO BRASIL.....

Leandro Martins Zanitelli

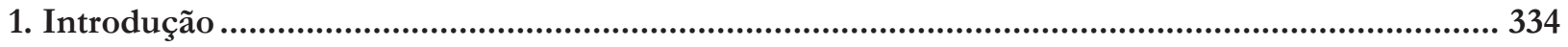

2. Políticas de informação obrigatória: definição e distinções.......................................................... 336

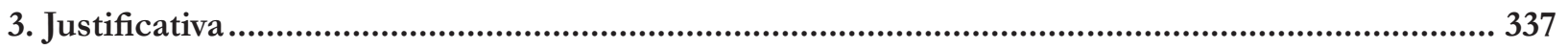

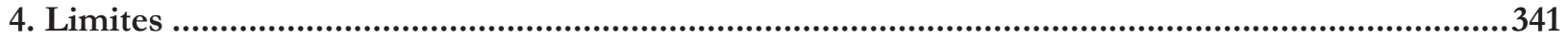

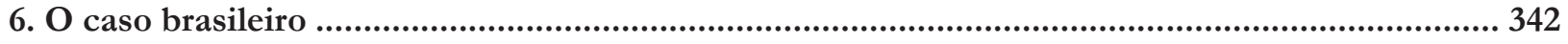

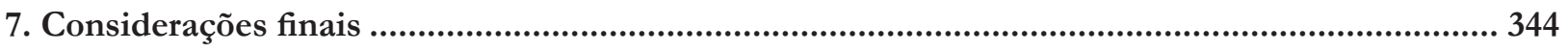

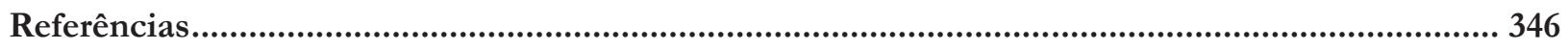

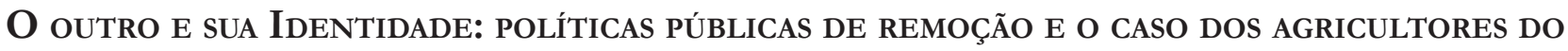
Parque Estadual da Pedra Branca/RJ.............................................................350

Andreza A. Franco Câmara

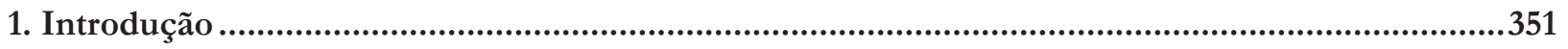

2. A política de criação de parques no brasil: o caso do parque estadual Pedra Branca ................. 352

3. A identidade do agricultor no entorno do PEPB .................................................................. 354

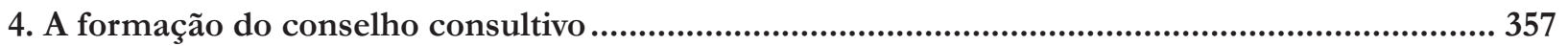

4.1 A formação do novo conselho consultivo do PEPB...................................................................................... 358

4.2 A mídia e a criminalização dos agricultores do entorno do PEPB ……………………............................. 359

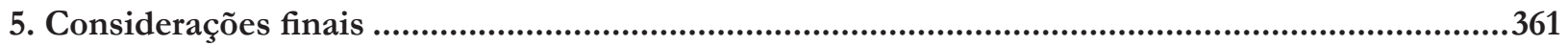

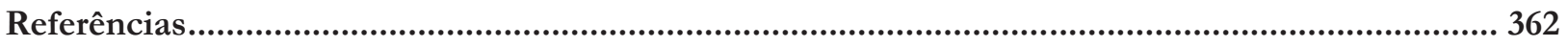




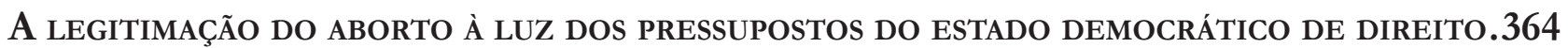
Terezinha Inês Teles Pires

1. Introdução 365

2. Democracia e liberdade política 365

3. Democracia representativa e democracia participativa................................................................ 372

4. Teorias da justiça: ética e moralidade política ….......................................................................... 377

5. Liberdade de decisão reprodutiva: um componente do pluralismo moral e religioso .................. 382

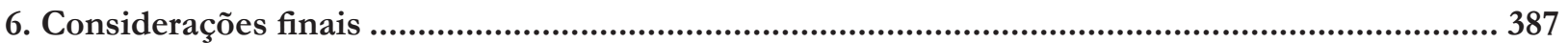

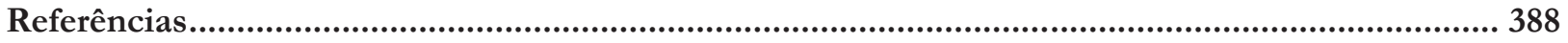

JUSPOSITIVISMO, DISCRICIONARIEDADE E CONTROLE JUDICIAL DE POLÍTICAS PÚBLICAS NO DIREITO

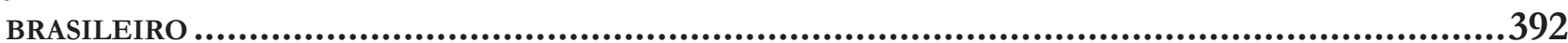

Guilherme Valle Brum

Referências

A governanÇa transnacional ambiental na Rio +20

Paulo Márcio Cruz e Zenildo Bodnar

1. Nota introdutória 407

2. Evolução do estado constitucional moderno para a sustentabilidade global

3. Necessidade de novas e efetivas estratégias políticas e jurídicas de governança transnacional ambiental 410

4. Os desafios ecológicos globais como fundamento da governança transnacional ..... 415

5. Avanços e retrocessos no tema da governança transnacional na Rio +20 417

6. Conclusões finais 419

Referências 420

O QUe É UMA BoA TESE DE DOUTORADo EM DiReito?

UMA ANÁLISE A PARTIR DA PRÓPRIA PERCEPÇÃO DOS PROGRAMAS.

Nitish Monebhurrun e Marcelo D. Varella

1. Introdução . 425

2. Uma metodologia para avaliar as teses. 427

2.1. A delimitação do universo de teses estudadas 427

2.2 Os critérios utilizados no estudo 427

2.2.1. Avaliação qualitativa 427

2.2.2. Avaliação quantitativa: Um tema polêmico. 428

3. O Levantamento das Teses de Doutorado em Direito no Brasil: teses “excelentes" e "teses aprováveis" 430 
3.1. As características das teses de doutorado no Brasil.

3.1.1 Característica substancial na argumentação das teses: a constatação de uma desordem nas teses "aprováveis"

3.1.2. As características formais das teses de doutorado no Brasil.

3.2. Os critérios comuns às teses selecionadas para um prêmio no Brasil.

4. O Valor Dado às Teses de Doutorado em Direito no Brasil.....

4.1. As teses com uma conotação funcional: um obstáculo para o fortalecimento da academia brasileira.

4.1.1. As teses que buscam apenas um título. 438

4.1.2. A busca dos títulos em detrimento da qualidade: a criação do Doutor sem vocação.......

4.2. A necessidade de teses vocacionais: uma solução para melhorar a academia brasileira

4.2.1. A necessidade de respeitar o espírito intrínseco de uma tese: um caminho para a formação de Professores.

4.2.2. Os efeitos das teses vocacionais: o posicionamento e a imagem do Brasil no âmbito acadêmico internacional.

5. Considerações finais

Referências

Normas EDITORIAIS .444

Envio dos trabalhos:. 446 


\section{REVISTA BRASILEIRA DE POLÍTICAS PÚBLICAS BRAZILIAN JOURNAL OF PUBLIC POLICY}
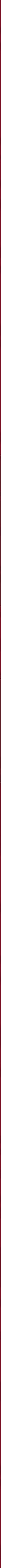


\title{
Forma de Estado: Federalismo e repartição de competências $^{1}$
}

\author{
State Formation: Federalism and Division of \\ Competences*
}

Carlos Bastide Horbach**

\section{Resumo}

O presente trabalho analisa a estrutura federativa do Estado, em especial a repartição de competências numa federação. $O$ texto também apresenta os principais traços da repartição de competências nos Estados federais americano, alemão e brasileiro.

Palavras-chave: Direito constitucional - federalismo - repartição de competências.

\section{Abstract}

This paper analyzes the federalist structure of the State, specially the division of powers within the federation. It also presents the main aspects of division of powers in American, German and Brazilian federal States.

Keywords: Constitutional law - federalism - division of powers.

\section{INTRODUÇÃo}

A expressão "forma de Estado" é compreendida tradicionalmente no direito constitucional moderno - e em especial no direito constitucional brasileiro, por força de seu emprego na Constituição de 1988 - como relacionada com a divisão territorial do poder estatal.

Assim, quando se questiona a forma de determinado Estado, o que se tem em perspectiva é o modo como é exercido o seu poder soberano no es-

* Recebido em 21/05/2013 Aprovado em 30/05/2013

** Doutor em Direito do Estado pela USP, Mestre em Direito do Estado e Teoria do Direito pela UFRGS, Professor Doutor de Direito Constitucional da Faculdade de Direito da Universidade de São Paulo - USP, Professor do Programa de Mestrado e Doutorado em Direito do Centro Universitário de Brasília - UniCEUB e Advogado. Email: carloshorbach@ uol.com.br
1 O presente artigo reproduz, com adequações pontuais, a prova escrita que o autor realizou, em $1^{\circ}$ de fevereiro de 2013, quando do concurso de ingresso na carreira docente da Faculdade de Direito da Universidade de São Paulo - USP (Departamento de Direito do Estado, Área de Direito Constitucional). O concurso compreende três fases: (1) prova escrita; (2) prova didática; e (3) julgamento de memorial com prova pública de arguição. A prova escrita observa as normas que constam do art. 139 do Regimento Geral da USP: (1) a banca examinadora organiza lista de dez pontos, com base no programa do concurso e dela dá conhecimento aos candidatos vinte e quatro horas antes do sorteio do ponto; (2) sorteado o ponto, inicia-se o prazo improrrogável de cinco horas de duração da prova; (3) durante sessenta minutos, após o sorteio, é permitida a consulta a livros, periódicos e outros documentos bibliográficos. Portanto, é neste contexto de tempo e de pesquisa que o presente trabalho deve ser compreendido, mormente no que tem de sintético, objetivo e silente. O autor agradece as importantes contribuições do Professor Doutor José Levi Mello do Amaral Junior. 
paço geográfico que lhe é próprio, com concentração ou com descentralização, que se pode dar em diversas intensidades.

Nesse quadro, os livros de direito constitucional são quase uniformes na apresentação das tipologias de forma de Estado, respondendo com modelos teóricos pré-definidos à pergunta sobre como se reparte o poder em um território. Tal divisão pode gerar Estados regionais, autonômicos, federais ou confederados; bem como a ausência de divisão - a concentração, portanto - caracterizaria o Estado unitário. ${ }^{2}$

As confederações são, hoje, uma referência histórica nos livros de direito constitucional, ainda que alguns autores insistam em mencionar o exemplo suíço - há muito convolado em federação - e outros vislumbrem em movimentos de integração regional o fenômeno redivivo da confederação. ${ }^{3}$

Por outro lado, ainda que se possa indicar muitos Estados como unitários, a moderna gestão pública impõe algum tipo de descentralização sempre, de modo que o unitarismo puro também acaba sendo um modelo ideal. Exemplo disso é a França, indicada por muitos manuais como exemplo de Estado unitário, ${ }^{4}$ mas que apresenta importantes divisões territoriais, como os departamentos e as comunas, em cuja divisão de atribuições alguns autores já enxergam traços do princípio da subsidiariedade, conceito naturalmente associado ao federalismo alemão. ${ }^{5}$

Já os Estados regionais - como a Itália -, os autonômicos - como a Espanha - e os federais - como o Brasil - são modelos teóricos que se aproximam mais à realidade das relações de poder, havendo em relação a eles vários estudos no direito constitucional contemporâneo, despertando, cada um deles, inúmeros questionamentos de elevado interesse.

O objeto do presente estudo, porém, é mais limitado: a federação. E mais, o federalismo analisado sob um ângulo específico, qual seja, o ângulo da repartição de competências, especialmente na Constituição brasileira de 1988.

Para o desenvolvimento desse objeto, a análise aqui empreendida levará em consideração uma advertência de Konrad Hesse, no seu célebre estudo "Estado federal unitário", de 1962: "A falta de uma perspectiva sobre o problema da formação do federalismo cria o risco de se obstinar em imaginações ilusórias, com todas as consequências que sempre tem o ilusionismo nas perguntas capitais da vida do Estado". 6

Desse modo, para se evitar o "ilusionismo" de que fala Hesse, será feito um exame que busca explicitar as características marcantes dos dois modelos federais que sabidamente influenciaram na construção do federalismo brasileiro: o modelo norte-americano - inspirador do sistema federal desde os albores da República - e o modelo alemão, especialmente importante na formação das vontades políticas da Assembleia Nacional Constituinte de 87/88.

Por outro lado, as palavras de Hesse em trecho distinto de seu artigo projetam outro problema a ser enfrentado no presente trabalho. Segundo o célebre autor alemão, o direito constitucional moderno - e não muito mudou nos 50 anos subsequentes à produção de seu texto - é caracterizado pela "ausência de reflexões teóricas sobre o federalismo".7

2 Nesse sentido, entre outros autores, FERREIRA FILHO, Manoel Gonçalves. Curso de direito constitucional. 36. ed. São Paulo: Saraiva, 2010. p. 75 et seq.; e SILVA, José Afonso da. Curso de direito constitucional positivo. 16. ed. São Paulo: Malheiros, 1999. p. 102 et seq.

3 MIRANDA, Jorge. Manual da direito constitucional. 3. ed. Coimbra: Coimbra, 1996. p. 268. Tomo III

4 SILVA, José Afonso da. Curso de direito constitucional positivo. 16. ed. São Paulo: Malheiros, 1999. p. 103.

5 BAUDIN-CULLIÉRE, Frédéric. Principe de subsidiarité et administration locale, Paris: L.G.D.J., 1995.

6 HESSE, Konrad. "Estado federal unitario". Escritos de derecho constitucional, Madrid: Centro de Estudios Políticos y Constitucionales, 2011. p. 189.

7 HESSE, Konrad. "Estado federal unitario". Escritos de derecho constitucional, Madrid: Centro de Estudios Políticos y Constitucionales, 2011. p. 189 
Tal constatação faz com que seja imprescindível para o estudo em andamento o recurso à jurisprudência, o que será feito por meio da citação de acórdãos da Suprema Corte americana, do Tribunal Constitucional Federal alemão e do Supremo Tribunal Federal brasileiro. Ademais, há de se recorrer, igualmente, à exegese dos textos constitucionais.

Por fim, uma última advertência de Hesse: "uma teoria do Estado federal deve fazer compreensível o conjunto". ${ }^{8}$ Ou seja, ainda que aqui o foco seja a repartição de competências, o exame pressupõe visão de sistema, o que impõe a análise, mesmo que breve, de temas genéricos relacionados com o federalismo dos ordenamentos sob enfoque.

A seguir, portanto, será apresentado um breve conjunto de antecedentes históricos do moderno federalismo (item 2), ao qual serão encadeadas análises do modelo norte-americano (item 3), do modelo alemão (item 4) e do modelo brasileiro (item 5); para que se possa, ao final, apresentar algumas conclusões sintéticas.

\section{AnteCedentes históRicos do modelo federal}

O recurso à abordagem histórica no direito corre, não raro, o risco de simplificações e deturpações, decorrentes do que se convencionou denominar de "análise evolucionista". Esse tipo de análise acaba por levar, equivocadamente, à compreensão de que a existência passada de um simples elemento integrante e característico de um instituto moderno é prova de que esse instituto tem raízes remotas, ainda que não se tenha como estabelecer uma real conexão histórica entre os fenômenos. ${ }^{9}$

Em tal equívoco parecem incorrer, por exemplo, autores que indicam as ligas formadas pelas cidades-Estado gregas, na Antiguidade Clássica, como antecedentes do federalismo, pois havia ali - pura e simplesmente - a reunião para defesa de interesses comuns. ${ }^{10}$

Igualmente pouco esclarecedora, nessa perspectiva, a indicação do feudalismo como antecedente do federalismo. Isso por que a simples fragmentação do poder político e o atrelamento das funções políticas à titularidade de direitos patrimoniais - que são as duas características essenciais do feudalismo - não levam, inexoravelmente, ao modelo federal. Se assim fosse, os Estados europeus seriam, em gênero, federações; o que definitivamente não ocorre.

Antecedente histórico específico na experiência medieval pode ser identificado no feudalismo germânico, cuja vinculação ao Sacro Império impediu as unificações nacionais dos séculos XV e XVI, gerando uma peculiar situação que somente foi equacionada com o modelo federal pela obra de Bismarck, na segunda metade do século XIX.

Essa especial experiência feudal germânica deu oportunidade, até mesmo, para a primeira teorização do federalismo, responsável pela formulação do próprio termo. Nesse sentido, importante é a contribuição de Johannes Althusius, que também formulou a primeira relação entre o federalismo e o princípio da subsidiariedade, tão caro para o moderno federalismo alemão e para o direito comunitário europeu. ${ }^{11}$

Igualmente fruto de uma experiência histórica particular é o principal antecedente do moderno federalismo, qual seja, a Confederação norte-americana.

8 HESSE, Konrad. "Estado federal unitario". Escritos de derecho constitucional, Madrid: Centro de Estudios Políticos y Constitucionales, 2011. p. 190.

9 OLIVEIRA, Luciano. Não fale do Código de Hamurabi!: a pesquisa sócio-jurídica na pós-graduação em direito". Anuário dos Cursos de Pós-Graduação em Direito - UFPE, Recife, v. 13, p. 299-330, 2003.

10 BARACHO, José Alfredo de Oliveira. Teoria geral do federalismo. Belo Horizonte: FUMARC/UCMG, 1982. p. 11 et seq.

11 GIERKE, Otto von. Giovanni Althusius e lo sviluppo storico delle teorie politiche giusnaturalistiche. Torino: Einaudi, 1974. 
Após a independência, as antigas colônias britânicas na América do Norte formaram treze Estado soberanos, com constituições próprias que se apresentam como inovadores documentos para o direito constitucional, em especial em matéria de direitos fundamentais. ${ }^{12}$

Esses Estados, porém, por meio dos Artigos da Confederação - um verdadeiro tratado à luz do direito internacional - uma união relativa, que buscava dar harmonia a suas relações institucionais e preservar suas soberanias individuais.

Tal modelo histórico, que vigorou aproximadamente por dez anos, acabou por fracassar ante falhas institucionais que são assim sintetizadas por Fernanda Dias Menezes de Almeida: a) o fato de a União legislar para os Estados e não para seus cidadãos, sem que houvesse sanção para o descumprimento de suas normas; b) a ausência de um tribunal superior comum; c) a inexistência de uma política comum de defesa; d) a necessidade de atingimento da unanimidade para as deliberações; e e) a manutenção de um comércio exterior descentralizado. ${ }^{13}$

A tentativa de superar essas falhas, promovendo "uma mais perfeita união", foi cristalizada na Constituição da Filadélfia, de 1787, consagradora do moderno modelo federal, que será a seguir analisado.

\section{Modelo federal NORTE-AMERICANO}

O modelo federal dos Estados Unidos, plasmado na normatividade da Constituição de 1787, pode ser resumido a cinco aspectos principais, que são arrolados por Bernard Schwartz nos seguintes termos: a) união de unidades autônomas - não mais soberanas - para fins comuns, mantendo suas peculiaridades, o que se reflete no lema norte-americano "e pluribus unum"; b) divisão de poderes legislativos, sendo expressamente enumerados os do ente novo - a União - e deixando-se o residual para os Estados, ainda que desde logo se tenha estabelecido uma interpretação flexível dessa regra com a teoria dos poderes implícitos, desenvolvida por John Marshall, em 1819, no caso McCulloch v. Maryland; c) atuação direta, inclusive sobre o cidadão, de cada núcleo de poder no âmbito de suas competências; d) aparelhamento de cada núcleo de poder com instituições políticas próprias, com Executivo, Legislativo e Judiciário; e e) supremacia do poder central na sua esfera de atuação, como logo no início do século XIX decidiu a Suprema Corte no caso Gibbons v. Ogden, sobre transporte fluvial interestadual. ${ }^{14}$

Esse arranjo institucional pressupõe, para dar garantias aos Estados federados e aos cidadãos, regras claras, que somente se estabilizam por meio de constituições documentais. Destarte, Karl Loewenstein afirma de modo categórico que o federalismo somente é possível por meio de constituições escritas ${ }^{15}$; constituições escritas essas que apresentem normas sobre separação de competências.

O texto da Constituição de 1787 e sua vivência nas primeiras décadas do século XIX levaram Alexis de Tocqueville a afirmar que "os deveres e os direitos do governo federal eram simples e bastante fáceis de definir, por que a União fora constituída com a finalidade de responder a algumas grandes necessidades gerais. Os deveres e direitos dos governos dos Estados eram, pelo contrário, múltiplos e complicados, por que seu governo penetrava em todos os detalhes da vida social". ${ }^{16}$

Esse quadro descrito por Tocqueville, baseado no texto constitucional, foi lentamente sendo alterado pelo "law in action" - para usar a expressão célebre de Roscoe Pound -, o qual evidencia uma dinâmica centralizadora, a partir - até mesmo - dos já mencionados casos McCulloch v. Maryland e Gibbons v. Ogden.

12 DIPPEL, Horst. História do constitucionalismo moderno. Lisboa: Fundação Calouste Gulbenkian, 2007. p. 4 et seq..

13 ALMEIDA, Fernanda Dias Menezes de. Competências na Constituição de 1988. 4. ed. São Paulo: Atlas, 2007. p. 8-9.

14 SCHWARTZ, Bernard. O federalismo norte americano atual: uma visão contemporânea. Trad. Elcio Cerqueira. Rio de Janeiro:

Forense Universitária, 1984, p. 10.

15 LOEWENSTEIN, Karl. Teoria de la constitucion. 2. ed. Barcelona: Ariel, 1970. p. 191.

16 TOCQUEVILLE, Alexis de. A democracia na América. 4. ed. Belo Horizonte: Itatiaia, 1998. p. 93. 
Tal tensão entre centralização e descentralização colocou a Suprema Corte, como tribunal da federação, na posição de principal árbitro da repartição de competências; um verdadeiro "guarda de fronteiras" do sistema federal, para se utilizar a imagem de que lançou mão Campos Salles, ao descrever a conformação do modelo brasileiro de Justiça federal.

O primeiro grande movimento de centralização se verifica nos Estados Unidos nos anos anteriores à Guerra Civil, o que leva a uma reação dos juristas do Sul, a qual tem como exemplo mais significativo a teoria da nulificação, desenvolvida por Calhoun. Segunda tal concepção, os Estados teriam o poder de anular, por meio de seus próprios Poderes Legislativos, as leis da União às quais se opusessem, deixando, portanto, de aplicá-las em seus territórios. ${ }^{17}$ Esse entendimento, que por razões óbvias não foi acatado, está nova e pitorescamente em discussão nos Estados Unidos, uma vez que a legislatura do Estado do Texas iniciou recentemente a discussão de uma emenda à Constituição local que, se aprovada, reconhecerá ao Legislativo estadual o poder de nulificação sobre leis federais.

O segundo movimento de centralização se verifica com o aumento da atuação federal, demandada pela crise que se seguiu à quebra da Bolsa de Nova York, em outubro de 1929. O New Deal proposto por Franklin D. Roosevelt, a partir de 1933, exigia a expansão das competências da União, em especial no campo da regulação econômica.

Esse aumento de atribuições decorreria, principalmente, de uma interpretação mais flexível, por parte da Suprema Corte, da competência da União para legislar sobre comércio interestadual, a chamada commerce clause da Constituição de 1787.

De início, a Suprema Corte manteve-se atrelada a sua jurisprudência descentralizadora, levando à declaração de inconstitucionalidade de várias leis federais veiculadoras de programas econômicos e sociais do New Deal.

Houve, porém, uma mudança de orientação decorrente do grande arranjo político que se seguiu à rejeição, pelo Senado americano, da proposta presidencial de remodelação da Suprema Corte, com o acréscimo de um novo juiz para cada magistrado integrante do tribunal que contasse com mais de setenta anos, no que ficou conhecido como o Court Packing Bill. ${ }^{18}$

Após 1937, portanto, iniciou-se um ciclo de centralização por meio da jurisprudência da Suprema Corte sobre a cláusula de comércio, que chegou até mesmo a considerar constitucional, por exemplo, que uma lei que proibia a plantação de trigo para consumo próprio, pois tal prática poderia, ainda que remotamente, afetar o comércio interestadual do produto. ${ }^{19}$

Tal exercício foi reforçado pela Corte Warren, a partir da década de 50 do século passado, e mantido pela Corte Burger nos anos 1970 e no início dos anos 80. Com a investidura de William Rehnquist na função de Chief Justice iniciou-se um deliberado movimento de regresso aos poderes estaduais; que somente tem surtido efeito após as indicações do Presidente George W. Bush para o tribunal, já no período, portanto, da Corte Roberts. ${ }^{20}$

A disputa sobre a commerce clause, aliás, estava presente no mais tormentoso caso julgado pela Suprema Corte no ano de 2012, relacionado com o Affordable Care Act, que normatiza os planos de assistência à saúde

17 A teoria de John C. Calhoun é sintetizada no texto "South Carolina Exposition and Protest", produzido em 1828, durante a chamada "Crise da Nulificação", que envolveu a disputa entre o governo da União e o do Estado da Carolina do Sul em torno de tarifas impostas pelo parlamento federal.

18 Para uma interessante análise do episódio, ver: CARO, Robert. Master of the Senate. New York: Vintage Books, 2002 . p. 54 et seq.

19 Sobre esse caso, Wickard v. Filburn, julgado pela Suprema Corte em 1942, ver: REHNQUIST, William H. The Supreme Court, Kindle edition. New York: Vintage Books, 2001. position 2405 et seq.

20 Para um exame jornalístico, as juridicamente preciso, desse movimento nos períodos de Rehnquist e Roberts como Chief Justice, ver os interessantes livros de TOOBIN, Jeffrey. The Nine. Inside the secret world of the Supreme Court, New York: Anchor Books, 2007. e The Oath. The Obama White House and the Supreme Court, New York: Doubleday, 2012. 
nos Estados Unidos. Novamente se discutia se o mandado legal para que os indivíduos comprassem seguros de saúde poderia, ou não, ser imposto pela União com base na competência para regular o comércio interestadual.

A Corte, num lance de engenharia jurídico-política do Chief Justice Roberts, concluiu que a commerce clause não autorizava tal mandado - o que é um significativo avanço para as correntes descentralizadoras -, mas o manteve com base no poder federal para instituir tributos; o que, mesmo sendo uma concepção questionável, livrou o tribunal de uma crise institucional, que seria somente comparável aos episódios anteriores a 1937.

A experiência norte-americana, portanto, por mais claro que seja o texto sobre repartição de competências na Constituição de 1787, demonstra a necessidade de implantação de regras mais elaboradas de coordenação de atribuições entre os níveis federados, para que não se tenha uma variação constante no tratamento da matéria.

Essa evolução se tem na experiência alemã, com a passagem do federalismo dual para um federalismo de cooperação.

\section{Modelo federal alemão}

O federalismo alemão tem causas materiais e artificiais, como bem anota Dieter Grimm. ${ }^{21}$ As causas materiais já foram indicadas no item 2, relacionadas com o Sacro Império Romano-Germânico e com a unificação promovida por Otto von Bismarck sob a égide da dinastia dos Hohenzollern.

Essa unificação fez com que os antigos setenta e dois Estados autônomos que compunham a Alemanha preservassem muitos de seus poderes, sendo o Reich uma estrutura voltada para as relações internacionais e para a defesa coletiva, tendo o Kaiser, inclusive, o sugestivo título de Supremo Senhor da Guerra.

Essas causas histórico-materiais, todavia, desapareceram com o nacional-socialismo e sua forte tendência centralizadora; tendo sido já amplamente relativizadas pela Constituição de Weimar, de 11 de agosto de 1919.

Konrad Hesse destaca que os Estados alemães da moderna federação não são, geográfica e culturalmente, os que promoveram a Unificação de Bismarck. Por isso, explicações históricas de formulações federativas modernas são muitas vezes imprestáveis, como as desenvolvidas por Carl Schmitt e R. Smend, ainda sob a vigência do texto de Weimar. ${ }^{22}$

Com o fim do nazismo, a ocupação dos aliados e, posteriormente, com o Tratado de Unificação, que incorporou à República Federal os Estados da antiga Alemanha Oriental, novas forças - completamente estranhas à tradição do federalismo alemão - forjaram a forma de Estado, de modo que as causas artificiais suplantam, hoje, as causas materiais na regulação normativa da repartição de competências no direito constitucional alemão. ${ }^{23}$

A Lei Fundamental de Bonn, de 23 de maio de 1949, traz uma repartição de competências que apresenta caráter funcional, ou seja, reserva à União (Bund) preponderantemente a função legislativa, deixando para os Estados (Länder) a execução, isto é, a função administrativa.

E essas competências administrativas - ou materiais - são controladas pela União, de modo que, quando um Land aplica equivocadamente a lei, há a possibilidade - não verificada nos mais de cinquenta anos de vi-

21 GRIMM, Dieter. "El federalismo alemán: desarrollo histórico y problemas actuales". El federalismo en Europa, Barcelona: Hacer Editorial, 1993. p. 45. 22 HESSE, Konrad. "Estado federal unitario". Escritos de derecho constitucional. Madrid: Centro de Estudios Políticos y Constitucionales, 2011. p. 193.

23 GRIMM, Dieter. "El federalismo alemán: desarrollo histórico y problemas actuales”. El federalismo en Europa. Barcelona: Hacer Editorial, 1993. p. 48 et seq. 
gência da Lei Fundamental - de se promover uma espécie de intervenção federal (Bundesæ̧wang), com prévio consentimento do Conselho Federal (Bundesrat), a casa que, no Legislativo alemão, representa os Länder. ${ }^{24}$

Essa realidade de divisão funcional de competências e de controle da execução estadual pela União faz com que Dieter Grimm e Konrad Hesse afirmem que a Alemanha constitui um Estado federal unitário. ${ }^{25}$

Tal centralização ou tal unitarismo da federação alemã é mitigada, contudo, pelas competências concorrentes, caracterizadoras de um federalismo de cooperação ${ }^{26}$ e inspiradora do constitucionalismo brasileiro.

A existência de uma competência concorrente permite, assim, a superação, ainda que circunscrita a determinadas matérias, da repartição funcional antes mencionada, habilitando o Estado (Land) a editar leis e ter, desse modo, um ordenamento jurídico próprio, distinto do da União; o que é característico do federalismo.

Por conta dessas competências concorrentes, os autores alemães, nos primeiros anos de vigência da Lei Fundamental, defenderam a assimilação, pelo texto constitucional, da teoria dos três níveis ou dos três elementos desenvolvida por Hans Kelsen. Segundo esse entendimento, o Estado federal seria caracterizado por três níveis de ordenamento jurídico: o ordenamento do Estado total federal, o ordenamento do ente político superior (Bund) e os ordenamentos dos níveis locais, os Estados membros.

Essa teoria, porém, foi rechaçada, em 1961, pelo Tribunal Constitucional Federal, ao julgar o caso Neugliederung, afirmando que o texto da Lei Fundamental não fazia distinção entre a República Federal da Alemanha - o Estado total - e a federação. Esse julgado, registre-se desde logo, não implica a impossibilidade de aplicação da teoria de Kelsen à federação brasileira, uma vez que a Constituição de 1988 afirma que a República Federativa do Brasil é formada por quatro espécies de pessoas jurídicas de direito público: a União, o Distrito Federal, os Estados e os Municípios. Assim, a teoria das leis nacionais e das leis federais, desenvolvida por Geraldo Ataliba com base em Kelsen, é compatível com a ordem constitucional brasileira. ${ }^{27}$

Voltando à experiência alemã, o art. 72 da Lei Fundamental estabelece três tipos de competências concorrentes: a) a competência concorrente básica; b) a competência concorrente necessária; e c) a competência concorrente de divergência.

Os dois primeiros tipos se assemelham em muito ao modelo brasileiro, que será a seguir analisado, Entretanto, a grande novidade do constitucionalismo alemão é a competência de divergência, introduzida na Lei Fundamental pela Reforma Constitucional de 2006. ${ }^{28}$

Segundo o art. 72, III, da Lei Fundamental os Estados podem legislar de forma contrária à União em determinadas matérias, o que coloca em evidência importantes princípios, caros ao direito constitucional alemão, como o da subsidiariedade, o da prevalência do direito federal e o da confiança federativa (Bundestreu).

As matérias arroladas no item III do art. 72 da Lei Fundamental são a caça, a proteção ambiental e paisagística, a organização do território, recursos hídricos, admissão nas universidades e títulos universitários.

Esse aspecto, ainda não completamente experimentado, representa uma significativa evolução no constitucionalismo federal alemão, reforçando sua higidez e comprovando as palavras de Hartmut Bauer, para quem o federalismo na Alemanha é um campo em construção permanente. ${ }^{29}$

24 VOGEL, J. J. "El régimen federal de la Ley Fundamental”. In: BENDA et al. Manual de derecho constitucional. trad. Antonio López Pina. Madrid: Marcial Pons, 1996. p. 665.

25 GRIMM, Dieter. "El federalismo alemán: desarrollo histórico y problemas actuales". El federalismo en Europa. Barcelona: Hacer Editorial, 1993. p. 49; HESSE, Konrad. "Estado federal unitario". Escritos de derecho constitucional. Madrid: Centro de Estudios Políticos y Constitucionales, 2011. p. 198.

26 GRIMM, Dieter. "El federalismo alemán: desarrollo histórico y problemas actuales". El federalismo en Europa. Barcelona: Hacer Editorial, 1993. p. 65.

27 ATALIBA, Geraldo. "Regime constitucional e leis nacionais e federais". Revista de Direito Público, ano XIII, v. 53-54, p. 58-76, jan./jun. 1980.

28 Para um exame da Reforma e, em especial, da competência concorrente de divergência, ver: HORBACH, Beatriz Bastide. "A competência legislativa concorrente de divergência no Direito alemão". Revista de Informação Legislativa, ano 49, n. 193, p. 171-182, jan./mar. 2012.

29 BAUER, Hartmut. Kommentierung von Art. 20 GG (Bundesstaat). In: DREIER, Horst (Org.). Grundgesetzkommentar. Frank- 


\section{Modelo federal BRASILEIRO}

Victor Nunes Leal aponta que a vocação federativa do Brasil, iniciada com as capitanias hereditárias, passa pela autonomia no Império colonial português, pelo Ato Adicional de 1834 à Constituição de 1824 e chega à República Velha. ${ }^{30}$

O Ato Adicional de 1834, aliás, é o diploma responsável pela primeira divisão territorial de competências legislativas no Brasil, uma vez que criou as Assembleias Legislativas provinciais, com poder para editar normas sobre assuntos de interesse local, marcando a primeira manifestação dessa enigmática expressão no direito constitucional brasileiro.

Essa divisão, como não poderia deixar de ser, gerava conflitos entre a lei local e a lei nacional, os quais eram resolvidos por um interessante sistema de controle de constitucionalidade exercido pela Assembléia Geral do Império, com auxílio do Conselho de Estado. ${ }^{31}$

Com a República, essas tendências federalistas foram institucionalizadas, tendo o Decreto n. 1, de 15 de novembro de 1889, transformado - como que num "golpe de mão" constitucional - as antigas Províncias em Estados federados. A partir de então, tem-se um histórico da federação no Brasil que é marcado fortemente pela centralização, em menores ou maiores graus, como nos casos da Constituição de 1937 e da Emenda Constitucional n. 1 de 1969, textos que praticamente extinguiram a dinâmica federal no Estado brasileiro.

O que se deve buscar agora, porém, é um conceito constitucionalmente adequado de federação e de repartição de competências, o que só se consegue por meio da exegese do texto constitucional vigente.

Essa é a postura do Supremo Tribunal Federal, como se pode depreender do decidido na ADI 2.024, rel. Min. Sepúlveda Pertence, DJ de 22.06.2007, cujo acórdão foi assim ementado na parte aqui interessante:

“1. A 'forma federativa de Estado' - elevado a princípio intangível por todas as Constituições da República - não pode ser conceituada a partir de um modelo ideal e apriorístico de Federação, mas, sim, daquele que o constituinte originário concretamente adotou e, como o adotou, erigiu em limite material imposto às futuras emendas à Constituição; de resto as limitações materiais ao poder constituinte de reforma, que o art. 60, \ $4^{\circ}$, da Lei Fundamental enumera, não significam a intangibilidade literal da respectiva disciplina na Constituição originária, mas apenas a proteção do núcleo essencial dos princípios e institutos cuja preservação nelas se protege".

Da Constituição de 1988 se pode retirar dois grandes grupos de repartição de competências entre União, Estados, Distrito Federal e Municípios. O primeiro diz com o poder de auto-organização dos Estados, o chamado poder constituinte decorrente, na expressão cunhada por Manoel Gonçalves Ferreira Filho. ${ }^{32} \mathrm{O}$ segundo, é o campo da divisão ordinária de competências materiais e legislativas.

O primeiro, o poder constituinte decorrente, está baseado no art. 25 da Constituição Federal e no art. 11 de seu ADCT. Tais dispositivos afirmam que os Estados podem editar suas próprias constituições, respeitados os "princípios" da Constituição Federal.

Aqui se tem o primeiro grande movimento centralizador protagonizado pelo STF, consubstanciado na doutrina das normas de observância obrigatória. Essas são normas editadas pelo poder constituinte federal cujo conteúdo implica limitação à autonomia estadual. Assim, quanto maior for o número de normas de

furt am Main: Mohr Siebeck, 2006. p. 9.

30 LEAL, Victor Nunes. Coronelismo, enxada e voto. O município e o regime representativo no Brasil. 4. ed. São Paulo: Companhia das Letras, 2012. especialmente o Capítulo II.

31 Sobre as funções do Conselho de Estado no Segundo Reinado, em especial no que toca ao controle de constitucionalidade, ver: LOPES, José Reinaldo de Lima. O Oráculo de Delfos. O Conselho de Estado no Brasil-Império, São Paulo: Saraiva, 2010.

32 FERREIRA FILHO, Manoel Gonçalves. O poder constituinte. 5. ed. São Paulo: Saraiva, 2007. p. 146 et seq. 
observância obrigatória, menor é a autonomia estadual. ${ }^{33}$ As normas de observância obrigatória acabam por definir, afinal, quão autônomos são os Estados membros.

Inicialmente, a jurisprudência do Supremo foi mais aberta nessa questão, como se pode verificar na questão específica da reprodução das normas federais de processo legislativo pelos Estados. Ao apreciar a ADI 56 - MC, rel. Min. Célio Borja, DJ de 04.08.1989, o Tribunal indeferiu a medida liminar pleiteada pelo Governador do Estado da Paraíba exatamente por não encontrar na Constituição o dispositivo "que torna obrigatória para os Estados a observância das normas dos seus artigos 61, II, $a$ e $b$ e 63, I".

E ainda concluía o Ministro Célio Borja: “Tal omissão decorre da inexistência, na lei fundamental em vigor, das numerosas regras de simetria compulsória entre as ordens jurídicas da União e dos Estados que repontavam na Carta de 1967, na redação de sua Emenda n 01/69”.

Porém, logo em seguida, o STF assentou que as normas de processo legislativo previstas na Constituição Federal aplicam-se a todos os entes federados, num movimento jurisprudencial que se manifesta, por exemplo, no julgamento da ADI 89, rel. Min. Ilmar Galvão, DJ de 20.08.1993. Isso por que as normas de processo legislativo são corolários da separação de poderes, em entendimento que vigora até o presente momento.

Ademais, a jurisprudência do STF tem flertado, nos quase vinte e cinco anos de vigência da Constituição de 1988, com o chamado princípio da simetria, segundo o qual os Estados deveriam seguir o modelo institucional federal. Exemplo dessa tendência se tem nos julgamentos da ADI 858, rel. Min. Ricardo Lewandowski, sobre processo legislativo; da ADI 3.647, rel. Min. Joaquim Barbosa, sobre as regras de afastamento do Governador do Estado do Maranhão; ou ainda da ADI 2.122, rel. Minª . Ellen Gracie, sobre o processo de reclamação junto ao Tribunal de Justiça do Estado do Ceará. Todos esses julgados indicam limitações claras das competências constituintes estaduais.

No campo das divisões ordinárias, há de se diferenciar as competências materiais - ou administrativas das competências legislativas; ambas, na lógica da Constituição de 88 , podem ser privativas - sem se entrar aqui em discussões terminológicas - ou concorrentes.

As competências materiais privativas da União são amplamente expostas no art. 21 da Constituição, marcando o grande espectro de atuação do governo federal. As competências materiais dos Estados são resumidas ao art. 25, $\llbracket 2^{\circ}$, da Constituição, relativo à exploração do gás canalizado. A competência privativa material dos Municípios está prevista no art. 30, compreendendo o tradicional "interesse local" e outras matérias, como o transporte coletivo urbano. O Distrito Federal, por sua vez, acumula, por força do art. $32, \S 2^{\circ}$, do texto constitucional as competências dos Estados e dos Municípios.

No campo legislativo, as competências arroladas são as da União no art. 22 e as dos Municípios - e do Distrito Federal parcialmente, portanto - no art. 30 da Constituição, deixando-se a competência legislativa dos Estados para o critério residual, na forma do $\int 1^{\circ}$ do art. 25 do texto constitucional federal.

O tema mais importante nessa matéria, porém, é - como destaca Fernanda Dias Menezes de Almeida ${ }^{34}$ o da competência concorrente, que se pode dar tanto no campo material - art. 23 da Constituição - quanto no campo, na forma do art. 24 da Carta da República.

Nos dois casos surge o problema da definição de limites de atuação de cada ente federado. No caso do art. 23 do texto constitucional, há a possibilidade de regulamentação desse exercício comum de poderes por meio de lei complementar, como previsto no parágrafo único do art. 23 e recentemente efetuado em relação às competências ambientais por meio da Lei Complementar n. 140/2011.

33 LEONCY, Léo Ferreira. Controle de constitucionalidade estadual. As normas de observância obrigatória e a defesa abstrata da Constituição do Estado-membro. São Paulo: Saraiva, 2007. p. 11-12.

34 ALMEIDA, Fernanda Dias Menezes de. Competências na Constituição de 1988. 4. ed. São Paulo: Atlas, 2007. p. 112 et seq. 
No caso da competência legislativa concorrente, a chave para a solução dos problemas resultantes de sua aplicação é o conceito de "norma geral", constante do art. 24, \ $1^{\circ}$, da Constituição de 1988.

Mais uma vez aqui a questão se põe de forma simples: quanto mais abrangente esse conceito de norma geral, menor a autonomia estadual. E novamente a jurisprudência do Supremo Tribunal Federal - pelo menos desde o julgamento da ADI 927, rel. Min. Carlos Velloso, DJ de 11.11.1994 - é redutora dessa autonomia estadual, concluindo, em gênero, que norma geral é o que a União edita como tal. No mesmo sentido é possível ainda citar o decidido na ADI 2.903, rel. Min. Celso de Mello, DJ 9.09.2008; e na ADI 3.059 - MC, rel. Min. Carlos Britto, DJ de 20.08.2004.

Esse entendimento reduz sobremaneira a capacidade normativa dos Estados e denota uma vocação centralizadora da jurisprudência do Supremo Tribunal Federal, que criou - nas palavras do Ministro Sepúlveda Pertence, em diversos julgados sobre a matéria - um "Estado unitário de fato".

\section{Considerações finais}

Em linhas gerais, o modelo brasileiro é devedor das experiências norte-americana e alemã, mas - como igualmente ocorre em tais sistemas - necessita de aprimoramentos, que passam menos pela reforma do texto constitucional e mais por uma viragem interpretativa do Supremo Tribunal Federal, que se tem mostrado nos últimos vinte e cinco anos - igualmente nas palavras de Sepúlveda Pertence - nostálgico da Carta decaída e de seus dispositivos centralizadores.

\section{REFERENCIAS}

ALMEIDA, Fernanda Dias Menezes de. Competências na Constituição de 1988. 4. ed. São Paulo: Atlas, 2007.

ATALIBA, Geraldo. Regime constitucional e leis nacionais e federais. Revista de Direito Público, ano XIII, v. 53-54, p. 58-76, jan./jun. 1980.

BARACHO, José Alfredo de Oliveira. Teoria geral do federalismo, Belo Horizonte: FUMARC/UCMG, 1982.

BAUDIN-CULliÉRE, Frédéric. Principe de subsidiarité et administration locale, Paris: L.G.D.J., 1995.

BAUER, Hartmut. Kommentierung von Art. 20 GG (Bundesstaat). In: DREIER, Horst (Org.). Grundgesetzkommentar. Frankfurt am Main: Mohr Siebeck, 2006.

CARO, Robert. Master of the Senate. New York: Vintage Books, 2002.

DIPPEL, Horst. História do constitucionalismo moderno. Novas perspectivas, trad. de António Manuel Hespanha e Cristina Nogueira da Silva, Lisboa: Fundação Calouste Gulbenkian, 2007.

FERREIRA FILHO, Manoel Gonçalves. Curso de direito constitucional, 36. ed. São Paulo: Saraiva, 2010.

FERREIRA FILHO, Manoel Gonçalves. O poder constituinte. 5. ed. São Paulo: Saraiva, 2007.

GIERKE, Otto von. Giovanni Althusius e lo sviluppo storico delle teorie politiche giusnaturalistiche, Torino: Einaudi, 1974.

GRIMM, Dieter. El federalismo alemán: desarrollo histórico y problemas actuales. Barcelona: Hacer Editorial, 1993.

HESSE, Konrad. Estado federal unitario. Escritos de derecho constitucional. Madrid: Centro de Estudios Políticos y Constitucionales, 2011. 
HORBACH, Beatriz Bastide. A competência legislativa concorrente de divergência no Direito alemão. Revista de Informação Legislativa, ano 49, n. 193, p. 171-182, jan./mar. 2012.

LEAL, Victor Nunes. Coronelismo, enxada e voto. O município e o regime representativo no Brasil. 4. ed. São Paulo: Companhia das Letras, 2012.

LEONCY, Léo Ferreira. Controle de constitucionalidade estadual. As normas de observância obrigatória e a defesa abstrata da Constituição do Estado-membro. São Paulo: Saraiva, 2007.

LOEWENSTEIN, Karl. Teoria de la constitucion. 2. ed. Barcelona: Ariel, 1970.

LOPES, José Reinaldo de Lima. O Oráculo de Delfos. O Conselho de Estado no Brasil-Império. São Paulo: Saraiva, 2010.

MIRANDA, Jorge. Manual da direito constitucional. 3. ed. Coimbra: Coimbra, 1996. Tomo III

OLIVEIRA, Luciano.Não fale do Código de Hamurabil: a pesquisa sócio-jurídica na pós-graduação em direito. Anuário dos Cursos de Pós-Graduação em Direito - UFPE, Recife, v. 13, p. 299-330, 2003.

REHNQUIST, William H. The Supreme Court, Kindle edition. New York: Vintage Books, 2001.

SCHWARTZ, Bernard. O federalismo norte americano atual: uma visão contemporânea. Trad. Elcio Cerqueira. Rio de Janeiro: Forense Universitária, 1984.

SILVA, José Afonso da. Curso de direito constitucional positivo. 16. ed. São Paulo: Malheiros, 1999

TOCQUEVILLE, Alexis de. A democracia na América. 4. ed. Belo Horizonte: Itatiaia, 1998.

TOOBIN, Jeffrey. The Nine. Inside the secret world of the Supreme Court, New York: Anchor Books, 2007.

TOOBIN, Jeffrey. The Oath. The Obama White House and the Supreme Court, New York: Doubleday, 2012.

VOGEL, J. J. El régimen federal de la Ley Fundamental. In: BENDA et al. Manual de derecho constitucional. Madrid: Marcial Pons, 1996. 


\section{REVISTA BRASILEIRA DE POLÍTICAS PÚBLICAS BRAZILIAN JOURNAL OF PUBLIC POLICY}
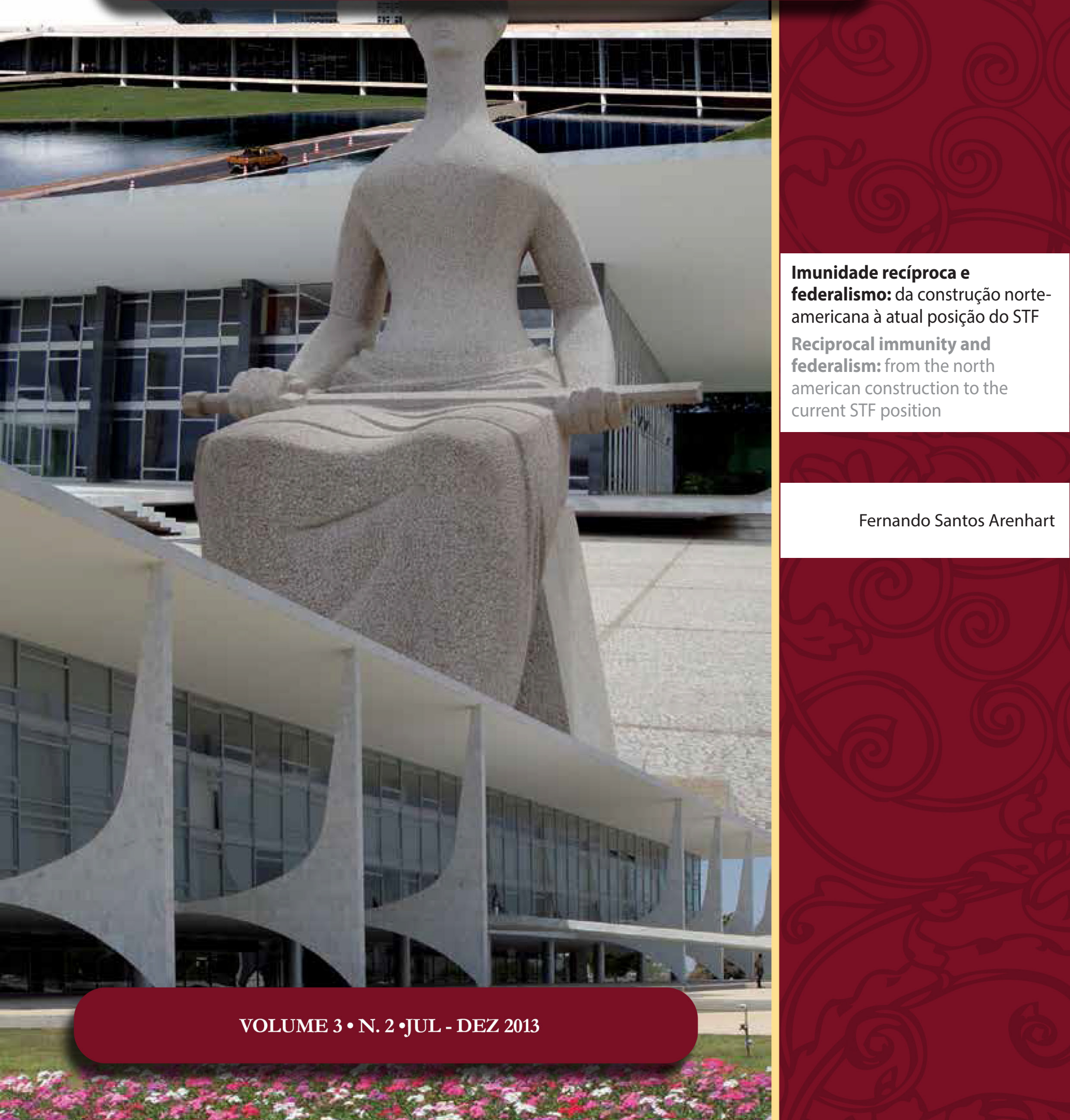


\section{Imunidade recíproca e federalismo: da construção norte-americana à atual posição do STF}

\author{
Reciprocal immunity and federalism: from \\ the north american construction to the current \\ STF position*
}

Fernando Santos Arenhart**

\section{Resumo}

Este artigo, ao abordar o tema da imunidade tributária recíproca sob uma perspectiva histórica, busca estabelecer uma relação entre tal imunidade e a evolução do federalismo. A partir do caso McCulloch v. Maryland, pretende-se comparar o seu contexto histórico com aquele existente quando da promulgação da Constituição Brasileira de 1891, traçando um paralelo entre a construção norte-americana e a positivação da imunidade recíproca nas Constituições brasileiras, verificando pontos de toque e distanciamento. A partir de então será possível estabelecer as peculiaridades da imunidade recíproca no Brasil, assim como os princípios nos quais está baseada, confrontando tal construção com os precedentes mais recentes do Supremo Tribunal Federal a respeito do tema. A conclusão a que se pode chegar é que, apesar de ser o caso McCulloch v. Maryland o ponto de partida obrigatório, a construção brasileira teve contornos particulares, especialmente devido a uma contextualização completamente diferenciada do seu Estado Federativo e da amplitude de suas Constituições, que afastaria em certo ponto a aplicação da teoria dos poderes implícitos.

Palavras-chave: tributação; imunidade recíproca; federalismo.

* Recebido em 30/10/2013 Aprovado em 16/12/2013

** Advogado, inscrito na OAB/RS sob o n. ${ }^{\circ}$ 56.377. Bacharel em Ciências Econômicas pela Universidade Federal do Rio Grande do Sul (UFRGS). Mestrando do Programa de PósGraduação em Direito da Universidade Federal do Rio Grande do Sul (PPGD-UFRGS). Email: fernandoarenhart@yahoo.com.br

\section{Abstract}

This paper, while discussing the issue of reciprocal tax immunity from a historical perspective, attempts to establish a relationship between this kind of immunity and the evolution of federalism. Starting from the McCulloch v. Maryland case, is intended to compare its historical context to that existing when the enactment of the 1891 Brazilian Constitution, drawing a parallel between the north american and the brazilian construction, checking both touch and distance points. Thenceforth, it will be possible to establish the peculiarities of the reciprocal immunity in Brazil, as well as the principles on which it is based, confronting such a construction with the latest precedents of the Supreme Court on the subject. The conclusion is that, despite being the case McCulloch v. Maryland the required starting point, the bra- 
zilian construction had particular contours, especially due to a completely different contextualization of its federal state and the breadth of its constitutions, that, at a certain point, would withdraw the application of the implied powers theory.

Keywords: taxation; reciprocal immunity; federalism.

\section{INTRODUÇÃO}

O estudo das imunidades tributárias desafia sempre o enfrentamento de questões atinentes ao poder e as limitações ao seu exercício. Nos dizeres de Aliomar Baleeiro, "O tributo é vetusta e fiel sombra do poder político há mais de 20 séculos" e, se em tempos passados decorria unicamente da vontade do soberano, hodiernamente se funda na lei como expressão máxima da vontade coletiva ${ }^{2}$. O ato de tributar é, assim, verdadeira expressão da soberania de um Estado e, ao resultar de uma exigência, confunde-se com o exercício do poder ${ }^{3}$.

Nesse sentido, ao restringir a competência tributária, a imunidade afeta negativamente um poder estatal. Não é por outra razão que a imunidade tributária compreende, na clássica definição de Aliomar Baleeiro, uma das formas de limitação constitucional ao poder de tributar ${ }^{4}$. A definição das imunidades proposta por Humberto Ávila traz à tona a relação entre estas e o exercício do poder:

A competência tributária, no entanto, é resultado da análise conjunta de duas espécies de normas jurídicas: de um lado, das normas que atribuem poder ao Estado para instituir tributos por meio da especificação dos fatos e situações que torna suscetíveis de tributação (normas de competência); de outro, das normas que subtraem poder do Estado sobre determinados fatos e situações que torna insuscetíveis de tributação (normas limitativas da competência). A parcela de poder do Estado para instituir tributos é resultado do poder que lhe atribui menos o poder que lhe é subtraído, nos termos da Constituição. ${ }^{5}$

Conforme destaca a professora Misabel Machado Derzi, "as imunidades somente adquirem sentido e função, uma vez relacionadas com as normas atributivas de poder, cuja abrangência elas reduzem" ". Nesse sentido, dentre as imunidades tributárias, pode-se afirmar que aquela insculpida no art. 150, inciso VI, alínea 'a', da Constituição Federal de 1988 (CF/88)7 , é a que mantém maior proximidade com o poder e a sua delimitação.

No caso da imunidade recíproca, objeto do presente trabalho, não há como compreendê-la corretamente sem enfrentar o tema do federalismo ${ }^{8}$ e as relações de poder que moldaram tal instituto. Tal imunidade remonta ao direito norte-americano, e sua evolução se confunde com a própria história trilhada a partir da Convenção de Filadélfia de 1787 e o surgimento dos Estados Unidos da América.

1 BALEEIRO, Aliomar. Limitações constitucionais ao poder de tributar. 7. ed. rev. e compl. por Misabel Abreu Machado Derzi. Rio de Janeiro: Forense, 1998. p. 1.

2 AMARO, Luciano. Direito tributário brasileiro. 15.ed. São Paulo: Saraiva, 2009, p. 17.

3 José Afonso da Silva explica que o poder é um fenômeno sócio-cultural e o Estado, como grupo social máximo e total, tem também o seu poder, denominado poder político. Tal poder, por sua superioridade em relação aos demais poderes sociais, caracteriza a soberania do Estado (SILVA, José Afonso da. Curso de direito constitucional positivo. 15.ed., rev. São Paulo: Malheiros, 1998, p. 110-111). 4 “[...] A imunidade é regra constitucional expressa (ou implicitamente necessária), que estabelece a não competência das pessoas políticas da Federação para tributar certos fatos e situações, de forma amplamente determinada, delimitando negativamente, por meio de redução parcial, a norma de atribuição de poder tributário. A imunidade é, portanto, regra de exceção e de delimitação de competência que atua, não de forma sucessiva no tempo, mas concomitantemente. A redução que opera no âmbito da abrangência da norma sucessiva de poder tributário é tão-só lógica, mas não temporal” (BALEEIRO, Aliomar. Direito tributário brasileiro. 11.ed. Rio de Janeiro: Forense, 2008, p. 114-116).

5 ÁVILA, Humberto. Sistema constitucional tributário. São Paulo: Saraiva, 2004, p. 209.

6 BALEEIRO, Aliomar. Limitações constitucionais ao poder de tributar. 7. ed. rev. e compl. por Misabel Abreu Machado Derzi. Rio de Janeiro: Forense, 1998, p. 231.

7 Art. 150. Sem prejuízo de outras garantias asseguradas ao contribuinte, é vedado à União, aos Estados, ao Distrito Federal e aos Municípios: [...] VI - instituir impostos sobre: a) patrimônio, renda ou serviços, uns dos outros; [...]

8 Sobre o tema, ver SOUZA JUNIOR, Cezar Saldanha; AVILA, Marta Marques (Org.). Estudos sobre o federalismo. Porto Alegre: Dora Luzzatto, 2007. 
A construção da imunidade recíproca neste país se inicia em 1819 com o julgamento do caso McCulloch v. Maryland ${ }^{9}$, tendo como pano de fundo uma séria discussão sobre o poder de tributar e suas consequências frente ao recém-formado Estado Federal americano. Não obstante tal tema ter sido abordado por Aliomar Baleeiro ${ }^{10}$ e, recentemente, por André Pedreira Ibañez ${ }^{11}$, alguns aspectos históricos ainda merecem ser apreciados para melhor entender as origens da imunidade recíproca e a sua relação com o princípio federativo.

Assim, este artigo buscará contextualizar o julgamento McCulloch v. Maryland, estabelecendo a relação da decisão da Suprema Corte dos Estados Unidos da América com a teoria dos poderes implícitos defendida por Alexander Hamilton, e o debate deste com Thomas Jefferson nos primeiros anos da independência. A partir de tal análise, será possível compreender a evolução da imunidade recíproca no direito norte-americano em paralelo com a evolução da própria federação.

A partir da construção norte-americana acerca da imunidade recíproca, pretende-se comparar o contexto histórico do caso McCulloch v. Maryland com aquele existente quando da promulgação da Constituição Brasileira de 1891, bem como as razões pelas quais tal imunidade, no Brasil, não acompanhou o debate da Suprema Corte a partir dos casos Weston v. City Council of Charleston ${ }^{12}$, The Collector v. Day ${ }^{13}$, Pollock v. Farmers' Loan \& Trust Co. ${ }^{14}$, Helvering v. Gerhardt ${ }^{15}$ e Graves v. New York ex rel. O'Keefe ${ }^{16}$.

Deste modo, importante traçar um paralelo entre a construção norte-americana e a positivação da imunidade recíproca nas Constituições brasileiras, verificando pontos de toque e distanciamento e, posteriormente, a evolução da jurisprudência do Supremo Tribunal Federal na interpretação do referido instituto.

A partir de então será possível estabelecer as peculiaridades da imunidade recíproca no Brasil, assim como os princípios nos quais está baseada, confrontando tal construção com os precedentes mais recentes do Supremo Tribunal Federal a respeito do tema. A conclusão a que se pode chegar é que, apesar de ser o caso McCulloch v. Maryland o ponto de partida obrigatório, a construção brasileira teve contornos particulares, especialmente devido a uma contextualização completamente diferenciada do seu Estado Federativo e da amplitude de suas Constituições, que afastaria em certo ponto a teoria dos poderes implícitos.

\section{Origens históricas da imUNidAde ReCíproca}

Segundo Roberta Drehmer de Miranda, o federalismo pode ser entendido como

[...] a ideia política - mormente de cunho liberal, com origem nos Founding Fathers, ou Framers of the Constitution norteamericanos - que permeia a justificação de uma dada forma de Estado formada em um país ${ }^{17}$.

O modelo federativo teve origem na realidade sócio-política norte-americana, fruto de longo processo de independência junto à Coroa Inglesa. Desde a chegada dos primeiros colonos à América do Norte, formaram-se comunidades políticas dotadas de grande autonomia, que posteriormente deram origem às treze

9 UNITED STATES. Supreme Court. McCulloch v. Maryland, 17 U.S. 316 (1819).

10 BALEEIRO, Aliomar. Limitações constitucionais ao poder de tributar. 7. ed. rev. e compl. por Misabel Abreu Machado Derzi. Rio de Janeiro: Forense, 1998.

11 IBANEZZ, André Pedreira. Imunidade recíproca: a experiência do direito norte-americano. In: DIFINI, Luiz Felipe Silveira (Org.). Imunidades tributárias e direitos fundamentais. Porto Alegre: Livraria do Advogado, 2010, p. 29-53.

12 UNITED STATES. Supreme Court. Weston v. City Council of Charleston, 27 U.S. 449 (1829).

13 UNITES STATES. Supreme Court. The Collector v. Day, 78 U.S. 113 (1870).

14 UNITES STATES. Supreme Court. Pollock v. Farmers Loan \& Trust Co., 158 U.S. 601 (1895).

15 UNITED STATES. Supreme Court. Helvering v. Gerhardt, 304 U.S. 405 (1938).

16 UNITED STATES. Supreme Court. Graves v. New York ex rel. O’Keefe, 299 U.S. 466 (1939).

17 MIRANDA, Roberta Drehmer de. O federalismo estadunidense e o "implante" ibero-americano. In: SOUZA JUNIOR, Cezar Saldanha; AVILA, Marta Marques (Org.). Estudos sobre o federalismo. Porto Alegre: Dora Luzzatto, 2007, p. 201-202. 
colônias. Os colonos ingleses mantiveram o espírito social britânico de autogoverno e a Inglaterra, por sua vez, concedeu enorme autonomia e liberdade política aos americanos ${ }^{18}$.

A consequência de tal autonomia foi que, quando do processo de independência, as colônias possuíam alto grau de organização, cada qual com sua Bill of Rights, o que levou ao centro dos debates revolucionários o problema da representação política e das liberdades dos cidadãos.

A defesa do federalismo (em oposição ao confederalismo) se deu através de inúmeros artigos ${ }^{19}$, elaborados por Alexander Hamilton, James Madison e John Jay, e que foram publicados na imprensa de Nova Iorque entre 1787 e 1788. Especialmente com relação ao tema tributação, foram escritos sete artigos (n. ${ }^{\circ}$ s 30 a 36), todos de autoria de Alexander Hamilton, o que não se deu por acaso: além de militar e filósofo político, Hamilton era economista e tinha grandes conhecimentos sobre finanças, chegando a ser nomeado por George Washington como Secretário de Tesouro do seu primeiro governo, cargo exercido de 1789 a 1795.

No início do artigo n. ${ }^{\circ} 30$, Hamilton deixa claro que o projeto federalista dependia em grande parte da capacidade do novo governo de financiar-se:

O dinheiro é considerado, muito correctamente, como o princípio vital do organismo político, como aquilo que sustenta a sua vida e movimento e o capacita para executar as suas funções mais essenciais. ${ }^{20}$

O autogoverno, portanto, dependia fundamentalmente do poder de tributação, eis que esta era a forma de se obter os recursos necessários para a sua manutenção. Hamilton chega a alertar que, sem tal capacidade de obter recursos, "Ou o povo tem de ser sujeito a pilhagem contínua, como substituto de um modo mais aceitável de suprir as necessidades públicas, ou o governo tem de mergulhar numa atrofia fatal e, em pouco tempo, perecer" 21 .

É importante ressaltar que a proposta de Constituição federalista tinha como pano de fundo a derrocada da Confederação, atribuída por Hamilton, dentre outros, à incapacidade da União de lançar impostos. Com efeito, o artigo VIII da Confederação, ao dispor sobre "as despesas da guerra e todas as outras despesas que venham a ser feitas para a defesa comum ou para o bem-estar geral”, exigia que fossem suportadas por um tesouro comum, aprovisionado pelos diversos Estados na proporção "do valor de toda a terra dentro de cada Estado" "22. Tais impostos deveriam ser lançados e cobrados sob a autoridade e direção das legislaturas estaduais dentro do período de tempo acordado pelos Estados Unidos em Congresso. Não obstante a obrigatoriedade de tal exação, a dependência tributária da União para com os Estados era evidente, tirando daquela a capacidade, na prática, de se autofinanciar. Como afirma Hamilton,

A presente Confederação, fraca como é, teve a intenção de depositar nos Estados Unidos um poder ilimitado para atender às necessidades pecuniárias na União. Mas, partindo de um princípio errado, fez isso de tal maneira que frustrou inteiramente a intenção. ${ }^{23}$

A solução encontrada pelos federalistas para superar tal problema foi uma mudança no sistema que a produziu (sistema de quotas e requisições), atribuindo à União uma autonomia tributária. Apresentando tal expediente como a única e inquestionável solução, Hamilton direciona sua argumentação para os críticos que exigem uma distinção entre tributação interna (a cargo dos Estados) e externa (a cargo da União). Afirmando que tal distinção continuaria a deixar a União à mercê dos Estados, e que não haveria garantias de que tal divisão proporcionasse recursos suficientes à manutenção da União, Hamilton relembra a "máxima do bom senso" de que "todo o PODER deve ser proporcionado ao seu OBJECTO”. Nas palavras do

18 MIRANDA, Roberta Drehmer de. O federalismo estadunidense e o "implante" ibero-americano. In: SOUZA JUNIOR, Cezar Saldanha; AVILA, Marta Marques (Org.). Estudos sobre o federalismo. Porto Alegre: Dora Luzzatto, 2007, p. 202.

19 Os denominados federalist papers consistem em 85 artigos que, em 1788, foram reunidos em uma coletânea conhecida como

"O Federalista".

20 HAMILTON, Alexander; MADISON, James; JAY, John. O federalista. Lisboa: Fundação Calouste Gulbekian, 2011 , p. 278.

21 HAMILTON, Alexander; MADISON, James; JAY, John. O federalista. Lisboa: Fundação Calouste Gulbekian, 2011 , p. 278.

22 HAMILTON, Alexander; MADISON, James; JAY, John. O federalista. Lisboa: Fundação Calouste Gulbekian, 2011 , p. 783.

23 HAMILTON, Alexander; MADISON, James; JAY, John. O federalista. Lisboa: Fundação Calouste Gulbekian, 2011 , p. 279. 
próprio Hamilton, "Acredito que isto pode ser comprovado pela história da humanidade, que no progresso usual das coisas, as necessidades de uma nação, em cada período de sua existência, serão pelo menos iguais aos seus recursos" ${ }^{\prime 2}$.

Tal afirmação é fundamental para entender a relação estabelecida entre o exercício do poder político e a competência tributária, questão fundamental do direito constitucional e tributário. Também é possível, a partir de tal afirmação, vislumbrar o que se chamou de "teoria dos poderes implícitos", defendida por Hamilton no debate que se seguiu à Constituição de 1787. Considerando a forte defesa empregada pelo manifesto federalista no sentido de não ser a Constituição uma carta excessivamente detalhista, e a consequente inexistência de uma limitação expressa aos poderes de tributar, os posteriores embates nesta área entre Estados e União delineou posições antagônicas em relação a tais limitações. De um lado se colocou a posição de Hamilton (para quem era imprescindível o fortalecimento da capacidade tributária da União), e que argumentava que a Constituição, ao outorgar poderes para determinado órgão, estava lhe outorgando implicitamente os poderes necessários para a sua execução (inclusive os tributários). De outro estavam aqueles que condicionavam o exercício de determinados poderes à expressa atribuição por parte da Constituição.

Não é por outra razão a formação de um Estado no modelo federativo nos Estados Unidos da América: era necessário garantir, ao mesmo tempo, autonomia para os agora Estados Federados, e a centralização de certas matérias políticas. Tal estrutura ficou conhecida como "federalismo de competição", o qual pode ser definido como

A estrutura de divisão territorial do poder sustentada em dois órgãos que se limitam reciprocamente, cada qual com seu campo de competências previamente definido - daí a ideia de Constituição escrita, suprema e rígida - e que, ao mesmo tempo, encontra-se em igualdade constitucional. A palavra "competição" resume bem a relação existente entre os Estados e o Governo Central, tendo em vista que eram considerados como "rivais" entre si, o que leva à necessidade de uma clara demarcação de poderes e limites para não colocar em perigo a união então perfectibilizada. ${ }^{25}$

É precisamente esta rivalidade entre Estados (fortes) e governo central (fraco), e a ausência de uma regra constitucional explícita sobre certas competências que permeia o julgamento do caso McCulloch v. Maryland, julgado pela Suprema Corte dos Estados Unidos em 1819, e considerado a origem da imunidade tributária.

Será observado ainda, através da evolução doutrinária do instituto em análise, as modificações no próprio federalismo norte-americano, refletindo, segundo Bernard Schwartz, o crescente aumento da ingerência do Governo Federal sobre assuntos tipicamente exclusivos dos Estados membros ${ }^{26}$, bem como as limitações impostas a tal crescimento.

\subsection{McCulloch v. Maryland e a teoria dos poderes implícitos}

Em 1791, o governo americano decidiu criar um banco nacional, denominado First Bank of the United States, que em 1816 foi prorrogado pelo Congresso dos Estados Unidos (Second Bank of the United States). Uma das filiais do banco, estabelecida em 1817 na cidade de Baltimore, passou a ser taxada pelo Estado de Maryland através de um ato aprovado em sua Assembleia Geral em 11 de fevereiro de $1818^{27}$. James McCulloch, caixa da filial de Baltimore, se recusou a pagar o tributo, no que foi demandado judicialmente pelo Estado de Maryland.

24 HAMILTON, Alexander; MADISON, James; JAY, John. O federalista. Lisboa: Fundação Calouste Gulbekian, 2011 , p. 280.

25 MIRANDA, Roberta Drehmer de. O federalismo estadunidense e o "implante" ibero-americano. In: SOUZA JUNIOR, Cezar Saldanha; AVILA, Marta Marques (Org.). Estudos sobre o federalismo. Porto Alegre: Dora Luzzatto, 2007, p. 206-207.

26 SCHWARTZ apud MIRANDA, Roberta Drehmer de. O federalismo estadunidense e o "implante" ibero-americano. In: SOUZA JUNIOR, Cezar Saldanha; AVILA, Marta Marques (Org.). Estudos sobre o federalismo. Porto Alegre: Dora Luzzatto, 2007, p. 208.

27 "[...] an act to impose a tax on all banks, or branches thereof, in the State of Maryland, not chartered by the legislature" (UNITED STATES. Supreme Court. McCulloch v. Maryland, 17 U.S. 316 (1819)). 
A questão posta em juízo chegou em 1819 à Suprema Corte, e, no entendimento do Chief Justice Marshall, que conduziu o julgamento, o que estava por detrás do caso era, de um lado, um Estado soberano negando vigência a um ato oriundo do legislativo da União e, de outro, um cidadão questionando a validade de um ato do legislativo do Estado.

No exame do caso, a questão foi apreciada através de duas perguntas distintas: $1{ }^{a}$ ) O Congresso tem o poder de criar um banco e este estabelecer filiais? 2. ${ }^{a}$ ) O Estado de Maryland pode taxar a filial desse banco sem violar a Constituição?

Para responder à primeira pergunta, Marshall pondera que a Constituição é uma convenção que foi submetida e ratificada pelo povo de cada Estado federado. O governo derivaria diretamente do povo, sendo ordenado e estabelecido em seu nome, a fim de formar uma união mais perfeita. Para tanto, foi necessário transformar tal aliança em um efetivo governo, concedendo poderes soberanos ao governo da União.

Afirma ainda o juiz Marshall que o governo da União, embora limitado em seus poderes, é supremo dentro de sua esfera de atuação (é o governo de todos, com poderes delegados por todos, agindo por todos), e suas leis, quando elaboradas nos termos da Constituição, constituem lei suprema do país.

Quanto aos poderes da União, a Constituição Americana dispunha sobre as competências do Congresso na Seção 8 do Artigo I, não estando incluída expressamente a possibilidade de criar um banco e estabelecer filiais. Todavia, o item 18 estabelecia a competência do Congresso para "Elaborar todas as leis necessárias e apropriadas ao exercício dos poderes acima especificados e dos demais que a presente Constituição confere ao Governo dos Estados Unidos ou aos seus Departamentos e funcionários".

Apesar do Estado de Maryland entender que a expressão "leis necessárias" tinha um sentido restrito, de forma que apenas seria possível levar a cabo apenas os meios indispensáveis ao exercício do poder conferido pela Constituição, não foi este o entendimento da Suprema Corte.

Ao comentar a o referido item 18, o Chief Justice justifica que a referida cláusula estaria entre os poderes do congresso, e não entre as limitações a esse poder, e que os itens da Seção 8 pretendem ampliar, e não diminuir, os poderes conferidos ao governo.

Para o juiz Marshall, o governo, dotado de amplos poderes, deve também ter amplos meios para a sua execução. Ou seja, os poderes conferidos ao governo implicam os ordinários meios de execução, dentre eles a criação de uma empresa. Chief Justice fundamenta seu pensamento na Seção 3 do Art. IV da Constituição:

3. O Congresso poderá dispor do território e de outras propriedades pertencentes ao governo dos Estados Unidos, e quanto a eles baixar leis e regulamentos. Nenhuma disposição desta Constituição se interpretará de modo a prejudicar os direitos dos Estados Unidos ou de qualquer dos Estados.

A conclusão unânime da corte foi no sentido de que a criação do Banco dos Estados Unidos era um ato constitucional, parte da lei suprema do país, sendo constitucional também a criação de uma filial no Estado de Maryland.

Tal conclusão reafirma a chamada teoria dos poderes implícitos, segundo a qual muito embora a Constituição não elencasse determinados poderes, os mesmos os mesmos estariam à disposição da União implicitamen$\mathrm{te}^{28}$. Tal tese era defendida por Alexander Hamilton, primeiro Secretário do Tesouro dos Estados Unidos e um dos fundadores do First Bank of United States, e fazia parte do debate federalista da época.

Prosseguindo no julgamento, a corte suprema passou a debater se, uma vez considerada constitucional a criação de um banco pela União, poderia o Estado de Maryland taxá-lo.

É a partir de então que se estabelece a tese da imunidade recíproca, construída a partir dos seguintes axiomas: 1) que o poder de criar implica o poder de preservar; 2) que o poder de destruir, quando exercido

28 IBAÑEZ, André Pedreira. Imunidade recíproca: a experiência do direito norte-americano. In: DIFINI, Luiz Felipe Silveira (Org.). Imunidades tributárias e direitos fundamentais. Porto Alegre: Livraria do Advogado, 2010, p. 31. 
por um "estranho", é hostil e incompatível com os poderes de criar e preservar; 3) que, sempre que tal incongruência existe (poder de destruir x poder de criar e preservar), aquela autoridade que é suprema deve prevalecer.

No caso em julgamento, estava em jogo o poder do Congresso de criar e manter o banco e que, frente ao poder de destruir do Estado (através da taxação), por ser este incongruente com o de criar e preservar não poderia prevalecer em face da autoridade suprema, que tem o poder de controle.

Através de tal raciocínio a corte afirmou, pela primeira vez, a imunidade tributária dos meios de ação do governo federal em face das pretensões do fisco dos Estados, cunhando a famosa frase "the powver to tax involves the power to destroy" ${ }^{29}$. Convém esclarecer que, no caso específico, a taxação da filial do banco pelo Estado tinha o nítido intuito de inviabilizar as suas atividades.

Ao justificar a imunidade, o juiz Marshall afirma que o povo de um Estado dá ao seu governo o direito de lhes taxar, assim como suas propriedades, e como as exigências do governo não podem ser limitadas, o povo não prescreve limites ao exercício desse direito, confiando no interesse do legislador e na influência que exerce sobre seus representantes para reprimi-los de cometerem abusos. Só que tal raciocínio não se aplicaria no caso da taxação da propriedade da União, pois tais meios não foram outorgados pelo povo de um Estado particular, mas sim pelo povo de todos os Estados. Assim, se o poder de criar um banco foi atribuído por todo o povo dos Estados Unidos, o poder de taxá-lo não pode ser exercido por outorga do povo de apenas um Estado em particular. Se pudesse taxar a propriedade da União, se estaria permitindo que um Estado agisse de forma a exercer sua soberania em afronta à soberania da União ${ }^{30}$.

A interpretação dada pela corte, nos termos do voto, seria a única a evitar o "confronto de soberanias". A intenção do povo americano ao instituir a União e sua constituição jamais teria sido tornar o governo geral dependente dos Estados.

Chief Justice Marshall aprecia ainda o argumento de que o poder de tributar só teria limitações no item 2 da Seção 10 do Art. I da Constituição ${ }^{31}$, e que um poder indefinido do governo da União poderia, com o tempo, retirar dos Estados (formadores da União) os meios de financiar suas próprias necessidades, os deixando inteiramente à mercê do legislativo nacional. Nesse sentido, os governos estaduais poderiam ser destruídos pelo monopólio federal.

Ao apreciar tal argumento, Marshall se aproxima da tese da reciprocidade, mas a afasta alegando que o povo dos Estados criou o governo geral e conferiu a ele o poder geral de tributação e que, como esse povo está representado no Congresso, quando ele tributa os Estados, está tributando seus constituintes, e tais

29 BALEEIRO, Aliomar. Limitações constitucionais ao poder de tributar. 7. ed. rev. e compl. por Misabel Abreu Machado Derzi. Rio de Janeiro: Forense, 1998, p.235.

30 Aliomar Baleeiro cita trecho importante do voto de Marshall em McCulloch v. Maryland: "Insistiu-se também em que, como se reconhece que o poder de tributação no governo federal e no estadual é concorrente, todo argumento que amparar o direito de o governo nacional tributar Bancos patenteados pelos Estados, apoiará igualmente o direito de os Estados tributarem Bancos patenteados pelo governo federal. O povo de todos os Estados criou o governo federal e lhe outorgou o poder federal de tributação. O povo de todos os Estados e os próprios Estados estão representados no Congresso, e, através de seus representantes, exercem este poder. Quando estes tributam as instituições patenteadas pelos Estados tributam seus representados; e esses impostos devem ser uniformes. Mas quando um Estado tributa as operações ou serviços do governo dos Estados Unidos, ele atinge instituições criadas não por seus próprios cidadãos, mas por toso o povo sobre o qual os deputados estaduais não exercem nenhum controle. Atinge medidas de um governo criado por outros e por eles mesmos, para o proveito de outros em comum com eles. A diferença é aquela que sempre existe, e sempre deve existir, entre a ação de um todo sobre uma parte, e a ação de uma parte sobre o todo, entre as leis de um governo que é declarado o supremo, e as de um governo que, quando em oposição àquelas leis, não é supremo" (BALEEIRO, Aliomar. Limitações constitucionais ao poder de tributar. 7. ed. rev. e compl. por Misabel Abreu Machado Derzi. Rio de Janeiro: Forense, 1998, p. 242-243).

31 "Nenhum Estado poderá, sem o consentimento do Congresso, lançar impostos ou direitos sobre a importação ou a exportação salvo os absolutamente necessários à execução de suas leis de inspeção; o produto líquido de todos os direitos ou impostos lançados sobre um Estado dobre a importação ou exportação pertencerá ao Tesouro dos Estados Unidos, e todas as leis dessa natureza ficarão sujeitas à revisão e controle do Congresso." 
tributos são uniformes. Por outro lado, quando um Estado tributa a União, ele age sobre instituições não criadas por seus próprios constituintes, mas sobre o povo do qual ele não têm controle.

Como se verifica, a regra de imunidade estabelecida através do caso McCulloch v. Maryland não admitia a reciprocidade, e tal se dá em razão da situação da federação americana na época. Recém formada, a União se mostrava enfraquecida em face do poder dos Estados, conforme explica Roberta Drehmer de Miranda:

\begin{abstract}
Devido ao alto grau de autonomia e independência dos estados entre si e em relação à Nação, foi necessário estabelecer parâmetros para os conflitos de competências insurgentes, de modo a não prejudicar a união federativa, ou causar uma quebra profunda no sistema. O objetivo maior, portanto, foi evitar que os Estados-Membros interfiram no funcionamento do Governo Central, como ocorreu na Confederação Americana. SCHWARTZ ressalta um leading case da Suprema Corte Americana que, interpretando o artigo VI da Constituição, conforme o voto do Judge John Marshall, asseverou que as medidas do Governo Nacional prevalecem conquanto não sejam inconstitucionais, sendo tal posicionamento diretamente decorrente do princípio do supreme law of the land previsto no dispositivo constitucional citado. ${ }^{32}$
\end{abstract}

A partir do referido leading case, a questão da imunidade tributária foi objeto de novas discussões, que, conforme será visto adiante, acompanharam a evolução do federalismo americano, no sentido do fortalecimento do governo central.

\title{
2.2 A evolução da reciprocal immunity of Federal and State instrumentalities
}

Estabelecida a tese da imunidade tributária dos poderes da União através do caso McCulloch v. Maryland, o assunto ainda retornou aos tribunais (e á Suprema Corte) diversas vezes, evoluindo para o que ficou conhecido como o princípio da reciprocal immunity of Federal and State instrumentalities.

Aliomar Baleeiro, ao tratar da imunidade recíproca nos Estados Unidos ${ }^{33}$, apresenta, além do já comentado caso McCulloch v. Maryland, os seguintes precedentes como representativos de sua evolução: Weston v. City Council of Charleston, The Collector v. Day, Pollock v. Farmers' Loan \& Trust Co., Helvering v. Gerhardt e Graves v. New York ex rel. O’Keefe. Por sua vez, André Pedreira Ibañez, ao aprofundar o exame dos precedentes apresentados por Baleeiro, os classifica em três fases evolutivas distintas ${ }^{34}$. A fim de evitar a mera repetição do trabalho já realizado pelos referidos autores, os precedentes acima serão apresentados de forma breve, concentrando-se o presente artigo em expor as decisões mais recentes da Suprema Corte americana a respeito do tema.

Em Weston v. City Council of Charleston, a discussão que se estabeleceu em juízo foi a possibilidade de tributação, por parte da Câmara Municipal de Charleston, incidente sobre a propriedade de apólices federais por particulares. Ao apreciar a questão em 1829, a Suprema Corte entendeu aplicável ao caso os mesmos fundamentos utilizados no julgamento de McCulloch v. Maryland. A fundamentação utilizada foi que a tributação sobre uma apólice do governo federal é entendida pela Corte como a tributação a um contrato, ao poder dos Estados Unidos tomarem dinheiro emprestado, o que seria inconstitucional.

Apesar de semelhante ao caso McCulloch v. Maryland, em Weston v. City Council of Charleston houve voto divergente por parte do Justice Johnson, que entendia que o imposto em questão incidia sobre os rendimentos oriundos dos juros do dinheiro, e que por tal razão não seria inconstitucional. Também divergindo, Justice Thompson, entendendo que o imposto incidia sim sobre a propriedade, aduziu que considerar tal tributo como incidente sobre os meios adotados pelo governo federal para exercer suas atribuições seria um refinamento demasiado.

32 MIRANDA, Roberta Drehmer de. O federalismo estadunidense e o "implante" ibero-americano. In: SOUZA JUNIOR, Cezar Saldanha; AVILA, Marta Marques (Org.). Estudos sobre o federalismo. Porto Alegre: Dora Luzzatto, 2007, p. 29-30.

33 BALEEIRO, Aliomar. Limitações constitucionais ao poder de tributar. 7. ed. rev. e compl. por Misabel Abreu Machado Derzi. Rio de Janeiro: Forense, 1998, p. 235-241.

34 IBAÑEZ, André Pedreira. Imunidade recíproca: a experiência do direito norte-americano. In: DIFINI, Luiz Felipe Silveira (Org.). Imunidades tributárias e direitos fundamentais. Porto Alegre: Livraria do Advogado, 2010, p. 29-53. 
Conforme afirma André Ibañez, "Enquanto no case ora analisado há uma intensa discussão se as apólices federais poderiam ser consideradas instrumentalidades do Governo Federal para o alcance de seus fins" no caso McCulloch v. Maryland o First Bank of the United States tinha uma função indispensável ao ente federal ${ }^{35}$. Portanto, Weston v. City Council of Charleston.

A segunda fase da evolução da reciprocal immunity of Federal and State instrumentalities inicia com o caso The Collector v. Day, julgado pela Suprema Corte em 1870, onde a controvérsia reside em saber se os Estados Unidos poderiam, de forma legal, estabelecer um imposto sobre o salário pago por um Estado a uma pessoa que era Juiz de Direito daquele mesmo Estado.

Baseado no precedente Dobbins v. Commissioners of Erie County ${ }^{36}$, a Suprema Corte ressaltou a relevância dos Estados e o fundamental papel exercido por tais entes na organização dos Estados Unidos e na distribuição do poder, até mesmo como forma de evitar um governo despótico ${ }^{37}$. Consagra-se neste julgamento a reciprocidade da imunidade tributária. Conforme explica Edward Setlock,

The doctrine of McCulloch $v$. Maryland was next extended to include a non-discriminatory state tax upon the income of a federal officer or employee in Dobbins v. Comissioners of Erie County. Collector v. Day established a complete reciprocity of immunities, for it state officers and employees were immune from federal taxation. Collector v. Day also recognized the equality of national and state governments in their respective spheres, although this rationale was inconsistent with the basis upon which Chief Justice Marshall put McCulloch v. Maryland, that the federal government was superior to that of the states. ${ }^{38}$

Collector v. Day, apresenta um estágio mais avançado do federalismo americano em relação àquele verificado em McCulloch v. Maryland. Enquanto neste caso havia a necessidade de afirmar a superioridade do governo federal recém formado, fortalecendo este perante os Estados, naquele se impunha refrear a sanha tributária federal em direção aos Estados. Aliomar Baleeiro, ao contextualizar historicamente o caso Collector v. Day, afirma com precisão que

Décadas depois, quando o desfecho da Guerra da Secessão consolida o poder nacional e tende a hipertrofiá-lo, a Corte, em sua benfazeja função política de restabelecer o equilíbrio das instituições federais, inicia uma segunda fase em que constrói a recíproca da imunidade dos títulos públicos e dos vencimentos dos funcionários estaduais em frente ao fisco da União. ${ }^{39}$

Ainda em uma segunda fase evolutiva, temos o julgamento, em 1895, do caso Pollock v. Farmers' Loan \& Trust Co. Neste caso, houve a tentativa de cobrança de imposto de renda federal sobre os juros derivados de apólices municipais. Trata-se, como afirma André Ibañez, de uma complexa decisão da Suprema Corte, que decidiu pela inconstitucionalidade do referido tributo ${ }^{40}$. A justificativa adotada foi que, não tendo os Estados poderes para tributar as operações ou propriedades dos Estados Unidos, este não teria poder constitucional para tributar instrumentalidades ou propriedades estaduais ${ }^{41}$.

À época, a Constituição dos Estados Unidos, na Seção 2 de seu Art. I, exigia que todos os impostos diretos fossem repartidos entre os vários Estados, e a Seção 8 do mesmo artigo exigia que os imposto diretos fossem uniformes. A decisão da Suprema Corte reconheceu que o tributo em questão não satisfazia os requisitos da Constituição, o que fez com que o Congresso reconhecesse a necessidade de uma previsão constitucional para que o imposto de renda federal pudesse valer sem a repartição entre os Estados. Tal ocorreu tão somente em fevereiro 1913, com a $16 .^{a}$ Emenda $^{42}$.

35 IBAÑEZ, André Pedreira. Imunidade recíproca: a experiência do direito norte-americano. In: DIFINI, Luiz Felipe Silveira (Org.). Imunidades tributárias e direitos fundamentais. Porto Alegre: Livraria do Advogado, 2010, p. 35.

36 UNITED STATES. Supreme Court. Dobbins v. Commissioners of Erie County, 41 U.S. 16 (1842).

37 IBANEZ, André Pedreira. Imunidade recíproca: a experiência do direito norte-americano. In: DIFINI, Luiz Felipe Silveira (Org.). Imunidades tributárias e direitos fundamentais. Porto Alegre: Livraria do Advogado, 2010, p. 37.

38 SETLOCK, Edward. Inter-governmental immunities from taxation. The Marquette Law Review, v. 23, n. 1, dec. 1938 , p. 32.

39 BALEEIRO, Aliomar. Limitações constitucionais ao poder de tributar. 7. ed. rev. e compl. por Misabel Abreu Machado Derzi. Rio de Janeiro: Forense, 1998, p. 236.

40 IBAÑEZ, André Pedreira. Imunidade recíproca: a experiência do direito norte-americano. In: DIFINI, Luiz Felipe Silveira (Org.). Imunidades tributárias e direitos fundamentais. Porto Alegre: Livraria do Advogado, 2010, p. 37.

41 IBAÑEZ, André Pedreira. Imunidade recíproca: a experiência do direito norte-americano. In: DIFINI, Luiz Felipe Silveira (Org.). Imunidades tributárias e direitos fundamentais. Porto Alegre: Livraria do Advogado, 2010, p. 38.

42 "O Congresso terá competência para lançar e arrecadar impostos sobre a renda, seja qual for a proveniência desta, sem 
Outro precedente importante foi o caso South Carolina v. United States, apreciado pela Suprema Corte em 1905, no qual ficou estabelecido que a imunidade das instrumentalidades estatais frente à tributação nacional estaria limitada àquelas funções que possuíssem um caráter "estritamente governamental", não se estendendo àquelas utilizadas pelo Estado em concorrência com empresas privadas ${ }^{43}$. No referido caso, a Corte havia rejeitado a imunidade estendida a negócio envolvendo bebidas alcoólicas conduzido pelo Estado da Carolina do Sul.

O julgamento de Helvering v. Gerhardt, em 1938, trouxe novamente à tona a discussão acerca da essencialidade de determinadas funções exercidas pelos governos estaduais. A questão debatida no caso se referia à tributação, pelo imposto de renda federal, dos salários recebidos por funcionários do Port of New York Authority, criado através de uma parceria entre os Estados de Nova Iorque e Nova Jérsei.

Apesar de inegável que o Port Authority estava desenvolvendo uma função pública para os Estados que o constituíram, o entendimento majoritário, apresentado por Justice Stone, foi no sentido de que os membros da empresa exerciam funções semelhantes à dos demais membros da sociedade, e que a incidência de imposto de renda sobre seus salários não teria o condão de atrapalhar o exercício das funções dos dois Estados. O máximo que aconteceria aos Estados seria perder a vantagem de pagar valores inferiores à taxa padrão pelos serviços prestados ${ }^{44}$. Por outro lado, a imunidade retiraria dos beneficiados o dever de sustentar financeiramente o governo nacional.

O último precedente apresentado por Aliomar Baleeiro é Graves v. New York ex rel. O’Keefe, em que se discutiu se o Estado de Nova Iorque poderia tributar de forma constitucional os salários de empregado da Home Owner's Loan Corporation, instituída pelo governo federal. Trata-se de situação inversa à apresentada em Helvering v. Gerhardt: neste, era o governo federal que pretendia tributar os salários de empregado de empresa que constituía instrumentalidade do governo Estadual.

O caso trouxe à tona novas discussões sobre as diferenças entre as imunidades concedidas ao ente federal e aos entes estaduais. Novamente coube ao Justice Stone apresentar o entendimento da Suprema Corte, que em 1939 decidiu que o imposto em questão não era discriminatório, pois não incidia sobre a Home Owner's Loan Corporation ou sobre sua propriedade ou renda. O imposto em questão também não seria suportado pela empresa ou pelo governo federal. Afastou-se então a teoria de que um imposto sobre a renda era legalmente ou economicamente um imposto sobre a sua fonte, até então sedimentado.

A mudança de posicionamento da Corte foi emblemática por rechaçar, através da manifestação do Justice Frankfurter, os argumentos apresentados por Chief Justice Marshall em McCulloch v. Maryland:

Os argumentos em que McCulloch vs. Maryland se apoia tinham suas raízes na realidade. Mas foram deformados por estéreis refinamentos sem relação com o assunto. Estes refinamentos derivavam sua autoridade de uma observação menos feliz no julgado em McCulloch vs. Maryland. Em parte, como floreio de retórica, em parte porque o estilo intelectual da época condescendia com o livre uso de absolutos. ${ }^{45}$

A partir de Graves v. New York ex rel. O’Keefe (e, em especial, a partir do Public Salary Act, de abril de 1939), ficou estabelecido o princípio da compatibilidade da tributação não discriminatória em relação à fonte, igualando o tratamento de todos os salários, sejam provenientes da atividade privada, sejam recebidos por funcionários públicos ${ }^{46}$.

distribuí-los entre os diversos Estados ou levar em conta qualquer recenseamento ou enumeração.”

43 SETLOCK, Edward. Inter-governmental immunities from taxation. The Marquette Law Review, v. 23, n. 1, dec. 1938 , p. 33.

44 IBANEZ, André Pedreira. Imunidade recíproca: a experiência do direito norte-americano. In: DIFINI, Luiz Felipe Silveira (Org.). Imunidades tributárias e direitos fundamentais. Porto Alegre: Livraria do Advogado, 2010, p. 41.

45 BALEEIRO, Aliomar. Limitações constitucionais ao poder de tributar. 7. ed. rev. e compl. por Misabel Abreu Machado Derzi. Rio de Janeiro: Forense, 1998, p. 239.

46 BALEEIRO, Aliomar. Limitações constitucionais ao poder de tributar. 7. ed. rev. e compl. por Misabel Abreu Machado Derzi. Rio de Janeiro: Forense, 1998, p. 239. 
Um último precedente merece ser analisado, eis que representa a tendência de supremacia federal no campo da tributação. Trata-se do caso New York v. United States ${ }^{47}$, julgado pela Suprema Corte em 1946, em que esta julgou o Estado de Nova Iorque devedor de impostos incidentes sobre sua exploração das águas minerais de Saratoga Springs. A justificativa seria que tal exploração não se caracterizaria como função precípua do Estado, eis que exercida em concorrência com a atividade privada.

O que desperta interesse no referido precedente é que, conforme explica Baleeiro, a Suprema Corte não admitiu a recíproca, de modo que atividades industriais da União, em diversos outros casos, escaparam da tributação local ${ }^{48}$. Tal situação caracterizaria um aumento de concentração do poder tributário nas mãos do governo federal através de uma maior participação deste em atividade tipicamente privadas ${ }^{49}$.

Conforme confirma Baleeiro, depois da primeira Guerra Mundial, houve sensível e expressiva mudança nos rumos da imunidade recíproca:

Robustecido o sentimento da unidade e da solidariedade nacional, dissipadas as desconfianças remanescentes da Secessão, as necessidades financeiras enormes oriundas das Grandes Guerras e a multiplicação dos impostos, dos quais os de renda e herança são comuns à União, a quase todos os Estados e a alguns Municípios, enfim, outros fatores políticos e sociais inspiraram o abandono da integral adesão à tese de Marshall. ${ }^{50}$

A referida mudança se deu no sentido de permitir uma concentração do poder tributário em torno do governo federal, em abandono às teses desenvolvidas em McCulloch v. Maryland, conforme já se verifica com os precedentes Helvering v. Gerhardt e Graves v. New York ex rel. O’Keefe. Nas palavras do Justice Holmes, em manifestação no caso Panhandle Oil Co. v. Knox ${ }^{51}$, de 1928, "o poder de tributar não envolve o poder de destruir enquanto existir a Suprema Corte" ${ }^{\text {" }}$.

A discussão sobre a imunidade recíproca, a partir da década de 1950, tornou-se menos importante no debate jurídico, não havendo grandes modificações na teoria estabelecida até então.

\section{A IMUNIDADE RECíPROCA NO DIREITO BRASILEIRO}

Apresentadas as raízes históricas da imunidade recíproca, impõe-se traçar um paralelo e investigar como se deu a sua introdução e evolução no direito brasileiro. Da mesma forma como ocorreu nos Estados Unidos da América, no Brasil a imunidade recíproca também possui íntima ligação com a forma federalista do Estado.

Conforme explica Roberta Drehmer de Miranda, "A experiência americana motivou muitos países a verem a forma de Estado Federativa como um modelo a ser seguido" ${ }^{53}$. Contudo, a formação do Estado Federal brasileiro se deu de forma muito diversa da ocorrida com o Estado norte-americano.

O Brasil do Império, conforme redação da Constituição de 1824, adotava uma forma unitária de Estado. Com o Ato Adicional de 1834, concedeu-se autonomia legislativa, tributária e administrativa às províncias, sendo que William Ricker identifica neste, e não na Constituição de 1891, a origem do federalismo brasileiro ${ }^{54}$.

47 UNITED STATES. Supreme Court. New York v. United States, 326 U.S. 572 (1946).

48 BALEEIRO, Aliomar. Limitações constitucionais ao poder de tributar. 7. ed. rev. e compl. por Misabel Abreu Machado Derzi. Rio de Janeiro: Forense, 1998, p. 237.

49 A REVIEW of intergovernmental immunities from taxation. Washington and Lee Law Review, v. 4, n. 1. Berkeley: The Berkeley electronic Press, 2012. p. 48.

50 BALEEIRO, Aliomar. Limitaçoes constitucionais ao poder de tributar. 7. ed. rev. e compl. por Misabel Abreu Machado Derzi. Rio de Janeiro: Forense, 1998, p. 238.

51 UNITED STATES. Supreme Court. Panhandle Oil Co. v. Knox, 277 U.S. 223 (1928).

52 BALEEIRO, Aliomar. Limitações constitucionais ao poder de tributar. 7. ed. rev. e compl. por Misabel Abreu Machado Derzi. Rio de Janeiro: Forense, 1998, p. 238.

53 MIRANDA, Roberta Drehmer de. O federalismo estadunidense e o "implante" ibero-americano. In: SOUZA JUNIOR, Cezar Saldanha; AVILA, Marta Marques (Org.). Estudos sobre o federalismo. Porto Alegre: Dora Luzzatto, 2007, p. 212.

54 ARRETCHE, Marta. Federalismo e democracia no Brasil: a visão da ciência política norte-americana. Revista São Paulo em 
Com a Proclamação da República, houve uma quebra na lenta construção institucional iniciada no Império, com o transplante, por intermédio do pensamento de Rui Barbosa, relator do projeto da Constituição Republicana, do modelo federativo norte-americano para a realidade brasileira, com uma ressalva: a referência expressa à autonomia municipal ${ }^{55}$. A inovação brasileira levou Aliomar Baleeiro a alertar sobre as limitações na invocação dos precedentes americanos na interpretação do direito positivo brasileiro:

Neste, o princípio da imunidade recíproca alcança expressamente os Municípios, que, por outro lado, não sofrem do Estado a subordinação a que os submete o Direito americano. A Constituição daquele país os ignora, de sorte que não passam de criação ou instrumentos de organização estadual. Recebem das Constituições ou das leis de cada Estado os poderes em maior ou menor escala, como também acontece na Argentina. ${ }^{56}$

Não obstante tal peculiaridade, temos ainda o fato de que a realidade brasileira apresentava um governo central forte (Estado Unitário imperial) que estava abdicando de sua autonomia em favor de Estados nascentes (antigas províncias) com a adoção da estrutura federalista. Não se identifica, em tal contexto histórico, as circunstâncias do caso McCulloch v. Maryland. Conforme será visto a seguir, a imunidade recíproca no Brasil, apesar de importada da doutrina norte-americana, não acompanhou o debate ocorrido na Suprema Corte dos Estados Unidos.

\subsection{Da Constituição de 1891 à Emenda Constitucional n. 3/94}

A primeira referência à imunidade tributária no direito brasileiro aparece no art. 10 da Constituição de $1891^{57}$, redigido por Rui Barbosa ${ }^{58}$. Impregnado pela discussão travada em McCulloch v. Maryland, tencionava Rui Barbosa "livrar da tributação hostil de Estados, no futuro, os meios de ação do governo nacional" 59 . Tal intenção fica clara com a leitura do art. 9. ${ }^{\circ}$ do Projeto do Governo Provisório, que não reconhecia a reciprocidade:

É proibido aos Estados tributar, de qualquer modo, ou embaraçar com qualquer dificuldade, ou gravame regulamentar, ou administrativo, atos, instituições ou serviços estabelecidos pelo Governo da União. ${ }^{60}$

A interpretação ao art. 10 da Constituição de 1891, que já vislumbrava a reciprocidade, era que esta se aplicava apenas na relação entre os Estados federados. Conforme explica André Pedreira Ibañez, tal artigo "proibiu que os Estados tributassem a União e tributassem outros Estados, mas não impediu que a União tributasse os Estados" $"$.

Convém ressaltar que, quando da promulgação da Constituição Republicana, já havia sido apreciado há mais de duas décadas pela Suprema Corte dos Estados Unidos o caso The Collector v. Day, que consagrou a reciprocidade da imunidade tributária entre os entes federados. Tal fato aponta para um descolamento na aplicação da jurisprudência norte-americana da época no Direito brasileiro. Há evidentemente um “atraso", que ouso atribuir a certa ofuscação decorrente do impacto causado pelo caso McCulloch v. Maryland.

\footnotetext{
perspectiva. São Paulo, n. 15, 2001, p. 23.

55 MIRANDA, Roberta Drehmer de. O federalismo estadunidense e o “implante” ibero-americano. In: SOUZA JUNIOR, Cezar Saldanha; AVILA, Marta Marques (Org.). Estudos sobre o federalismo. Porto Alegre: Dora Luzzatto, 2007, p. 213.

56 BALEEIRO, Aliomar. Limitações constitucionais ao poder de tributar. 7. ed. rev. e compl. por Misabel Abreu Machado Derzi. Rio de Janeiro: Forense, 1998, p. 241.

57 "Art 10 - É proibido aos Estados tributar bens e rendas federais ou serviços a cargo da União, e reciprocamente."

58 Explícito admirador das instituições políticas norte-americanas, Rui Barbosa foi decisivo para a adoção de uma federação clássica, do tipo americana (MIRANDA, Roberta Drehmer de. O federalismo estadunidense e o "implante" ibero-americano. In: SOUZA JUNIOR, Cezar Saldanha; AVILA, Marta Marques (Org.). Estudos sobre o federalismo. Porto Alegre: Dora Luzzatto, 2007, p. 213-214).

59 BALEEIRO, Aliomar. Limitações constitucionais ao poder de tributar. 7. ed. rev. e compl. por Misabel Abreu Machado Derzi. Rio de Janeiro: Forense, 1998, p. 246.

60 BALEEIRO, Aliomar. Limitações constitucionais ao poder de tributar. 7. ed. rev. e compl. por Misabel Abreu Machado Derzi. Rio de Janeiro: Forense, 1998, p. 246.

61 IBAÑEZ, André Pedreira. Imunidade recíproca: a experiência do direito norte-americano. In: DIFINI, Luiz Felipe Silveira (Org.). Imunidades tributárias e direitos fundamentais. Porto Alegre: Livraria do Advogado, 2010, p. 44.
} 
Com a Constituição de 1934, a imunidade tributária passou a ser prevista em seu art. 17, inciso X, com a seguinte redação:

Art. 17 - É vedado à União, aos Estados, ao Distrito Federal e aos Municípios:

[...] X - tributar bens, rendas e serviços uns dos outros, estendendo-se a mesma proibição às concessões de serviços públicos, quanto aos próprios serviços concedidos e ao respectivo aparelhamento instalado e utilizado exclusivamente para o objeto da concessão.

Parágrafo único - A proibição constante do $\mathrm{n}^{\circ} \mathrm{X}$ não impede a cobrança de taxas remuneratórias devidas pelos concessionários de serviços públicos.

Baleeiro cita Pontes de Miranda que, interpretando a norma supra, afirmava que esta vedava "[...] a tributação de bens e rendas de outras entidades públicas e não os direitos reais de outrem em bens de tais entidades, nem os créditos ou rendas de outrem contra tais entidades" ${ }^{\prime 2}$.

Com a Constituição de 1937, a imunidade recíproca ficou estabelecida em seu art. 32: “É vedado à União, aos Estados e aos Municípios: [...] c) tributar bens, rendas e serviços uns dos outros. Parágrafo único - Os serviços públicos concedidos não gozam de isenção tributária, salvo a que lhes for outorgada, no interesse comum, por lei especial". A novidade foi a exclusão dos serviços públicos concedidos da regra imunizante.

Outra questão que restava em aberto era a possibilidade do imposto de renda atingir vencimentos e juros de apólices. A interpretação que se fazia da Constituição de 1934 era no sentido de que tal tributação se situava fora da regra imunizante ${ }^{63}$. A Constituição de 1937 não solucionou o problema e, em 1939, foi publicado o Decreto-Lei n. ${ }^{\circ} 1.168$, que sujeitava ao imposto de renda todos os créditos pagos pelos cofres estaduais e municipais. Questionada a constitucionalidade do decreto em face do art. 32, c, da Constituição de 1937, decidiu o Supremo Tribunal Federal pela inconstitucionalidade da referida norma. À decisão do Supremo sucedeu o Decreto-Lei n. ${ }^{0}$ 1.564, de 1939, anulando a decisão judicial. Coube então à Suprema Corte brasileira conformar-se com tal situação, o que ocorreu no julgamento do MS n. ${ }^{\circ}$ 623, RF, 82/300. Portanto, quanto à tributação das apólices, a questão no Brasil foi resolvida definitivamente enquanto ainda estava em aberta no direito norte-americano.

Assim, quando da promulgação da Constituição de 1946, as grandes controvérsias decorrentes da imunidade recíproca já haviam sido resolvidas, seja através da consolidação da jurisprudência norte-americana, seja através da publicação do Decreto-Lei n. ${ }^{\circ}$ 1.564, em 1939. O art. 31, não obstante tenha acrescentado outras espécies de imunidades, manteve redação praticamente idêntica à Constituição de 1937 quanto à imunidade recíproca ${ }^{64}$.

Com a Carta de 1967, acrescentou-se a extensão da imunidade recíproca às autarquias no que se refere ao patrimônio, à renda e aos serviços vinculados às suas finalidades essenciais, conforme disposição do $₫ 1 .^{\circ}$ do seu art. 20 ${ }^{65}$. A Emenda Constitucional n. ${ }^{\circ}$ 1, de 1969, apenas repete a redação da Constituição de 1967 em seu art. 19.

62 BALEEIRO, Aliomar. Limitações constitucionais ao poder de tributar. 7. ed. rev. e compl. por Misabel Abreu Machado Derzi. Rio de Janeiro: Forense, 1998, p. 247.

63 BALEEIRO, Aliomar. Limitaçoes constitucionais ao poder de tributar. 7. ed. rev. e compl. por Misabel Abreu Machado Derzi. Rio de Janeiro: Forense, 1998, p. 247.

64 "Art 31 - A União, aos Estados, ao Distrito Federal e aos Municípios é vedado: [...] V - lançar impostos sobre: [...] a) bens, rendas e serviços uns dos outros, sem prejuízo da tributação dos serviços públicos concedidos, observado o disposto no parágrafo único deste artigo; [...]Parágrafo único - Os serviços, públicos concedidos, não gozam de isenção tributária, salvo quando estabelecida pelo Poder competente ou quando a União a instituir, em lei especial, relativamente aos próprios serviços, tendo em vista o interesse comum."

65 "Art 20 - É vedado à União, aos Estados, ao Distrito Federal e aos Municípios: [...] III - criar imposto sobre: a) o patrimônio, a renda ou os serviços uns dos outros; [...] $\int 1^{\circ}$ - O disposto na letra a do n..$^{\circ}$ III é extensivo às autarquias, no que se refere ao patrimônio, à renda e aos serviços vinculados às suas finalidades essenciais, ou delas decorrentes; não se estende, porém, aos serviços públicos concedidos, cujo tratamento tributário é estabelecido pelo poder concedente no que se refere aos tributos de sua competência, observado o disposto no parágrafo seguinte." 
Na Constituição de 1988, a imunidade recíproca veio prevista no art. 150, VI, 'a', repetindo a fórmula da Carta anterior. Além das autarquias, incluiu-se na norma imunizante as fundações instituídas e mantidas pelo Poder Público $\left(\$ 2^{\circ}{ }^{\circ}\right.$. Por outro lado, ficou autorizada a tributação do patrimônio, renda e serviços relacionados com a exploração de atividades econômicas regidas pelas normas aplicáveis a empreendimentos privados, ou em que haja contraprestação ou pagamento de preços ou tarifas pelo usuário, nem exonera o promitente comprador da obrigação de pagar imposto relativamente ao bem imóvel $\left(\mathbb{\int} 3 .^{\circ}\right)$.

O disposto no $\int 3 .^{\circ}$ do art. 150 da CF/88 implementa no direito brasileiro a solução encontrada pela Suprema Corte dos Estados Unidos no caso South Carolina v. United States, afastando do âmbito da imunidade recíproca as atividades econômicas praticadas pelos entes federados em concorrência com o setor privado. Todavia, ao contrário do privilégio concedido ao governo federal, a redação do $₫ 3 .^{\circ}$ do art. 150 da CF/88 garante aos Estados e Municípios a reciprocidade.

A professora Misabel Machado Derzi estabelece quatro critérios que definem a imunidade recíproca na Constituição de 1988:

a) o tratamento imunitório de reciprocidade entre a União, os Estados, o Distrito Federal e os Municípios tornase necessariamente deduzido da descentralização do poder, própria do Estado federal, ainda que não tivesse sido sucessivamente expresso nas Cartas Constitucionais brasileiras;

b) a imunidade recíproca não beneficia particulares, terceiros que tenham direitos reais, em bens das entidades públicas, nem créditos ou rendas de outrem contra tais entidades - como queria Pontes de Miranda - cessando os "odiosos" privilégios de funcionários públicos, magistrados, parlamentares ou militares; não se estende, pelos mesmos fundamentos, aos serviços públicos concedidos, nem exonera o promitente comprador da obrigação de pagar imposto relativamente ao bem imóvel (art. 150, II, $\iint 2^{\circ}$ e $3^{\circ}$ );

c) a imunidade recíproca se deduz ainda da superioridade do interesse público sobre o privado, beneficiando os bens, o patrimônio, as rendas e os serviços de cada pessoa estatal interna, como instrumentalidades para o exercício de suas funções públicas, em relação às quais não se pode falar em capacidade econômica, voltada ao lucro ou à especulação $\left(\operatorname{art.1} 150, \iint 2^{\circ}\right.$ e $\left.3^{\circ}\right)$;

d) a imunidade não beneficiará atividades, rendas ou bens estranhos às tarefas essenciais das pessoas estatais e de suas autarquias, que tenham caráter especulativo ou voltadas ao desempenho econômico lucrativo, em respeito ao princípio da livre concorrência entre as empresas públicas e privadas e à tributação segundo o princípio da capacidade contributiva $\left(\operatorname{art} .145, \Omega 1^{\circ}\right.$, art. $173, \$ \S 1^{\circ}$ e $\left.2^{\circ}\right) .^{66}$

Nesta evolução histórica da imunidade recíproca no direito brasileiro, cumpre por fim abordar a Emenda Constitucional n. ${ }^{\circ}$ 3/93, que trouxe nova regra de competência em seu art. 2. ${ }^{\circ}$, caput. "A União poderá instituir, nos termos de lei complementar, com vigência até 31 de dezembro de 1994, imposto sobre movimentação ou transmissão de valores e de créditos e direitos de natureza financeira."

Tal competência em nada afrontaria a imunidade recíproca não fosse o disposto no $\int 2 .^{\circ}$ do referido artigo: "Ao imposto de que trata este artigo não se aplica o art. 150, III, b, e VI, nem o disposto no $\int 5$. $^{\circ}$ do art. 153 da Constituição". Não obstante se tratar de uma emenda constitucional, a expressa inaplicabilidade das imunidades suscitou a Ação Direta de Inconstitucionalidade n. ${ }^{\circ} 939 / \mathrm{DF}^{67}$, ajuizada pela Confederação Nacional dos Trabalhadores no Comércio.

A procedência da ADI n. ${ }^{\circ}$ 939/DF estabeleceu definitivamente algo que já havia sido abordado implicitamente no julgamento do caso McCulloch v. Maryland: a imunidade recíproca possui forte ligação com o princípio federativo, lhe justificando e dando sentido. Por tal razão, mesmo que não viesse expressa na Constituição a imunidade recíproca teria aplicação no direito brasileiro. Assim, tratando-se o princípio federativo de cláusula pétrea ${ }^{68}$, o afastamento da imunidade recíproca, mesmo que através de emenda à constituição, se mostra inconstitucional.

66 DERZI, Misabel Abreu Machado. A imunidade recíproca, o princípio federal e a Emenda Constitucional n. 3, de 1993. Revista de Direito Tributário. São Paulo, vol. 62, 1994, p. 88-89.

67 BRASIL. Supremo Tribunal Federal. ADI 939-7/DF. Relator: Min. Sydney Sanches, 1993.

68 Art. 60, \ 4..$^{\circ}$, inciso I, da CF/88: "Não será objeto de deliberação a proposta de emenda tendente a abolir: I - a forma federativa de Estado; [...]". 

bunal Federal

Conforme arguido ao longo de todo o presente trabalho, há evidente ligação entre a imunidade recíproca e o princípio federativo. A evolução da imunidade recíproca na doutrina norte-americana nada mais é do que parte da história do federalismo nos Estados Unidos e a correspondente disputa de poder entre União e Estados. O mesmo ocorre com o tratamento da imunidade recíproca no Brasil, que evoluiu de acordo com as alterações por que passou o Estado federal ${ }^{69}$.

Além da evidente ligação com o princípio federativo, a imunidade recíproca atenderia ao princípio da igualdade, que na área tributária é examinado de acordo com o critério da capacidade econômica ${ }^{70}$, expresso no art. $145, \int 10^{\circ}$, da Constituição $\mathrm{O}^{71}$. Tal tese fundamentaria as imunidades dos entes estatais em razão da ausência de capacidade contributiva, eis que o Estado, em regra, não exerce atividade econômica típica. Ademais, os recursos dos entes federados se destinam à prestação de serviços públicos de sua competência. A tese também explicaria o motivo de exclusão das empresas públicas, organizadas em regime de Direito Privado (e que, por tal razão, exercem atividade econômica com finalidade lucrativa), da regra de imunidade.

Misabel Machado Derzi afirma então que a imunidade recíproca responde a dois princípios constitucionais: ao princípio federal e ao princípio da igualdade (que, no Direito Tributário, deve ser examinado segundo o critério da capacidade econômica). Não se fundamenta em um ou outro, mas em ambos ${ }^{72}$.

Assim, a imunidade recíproca é uma daquelas regras que, por serem logicamente dedutíveis de princípios fundamentais, independem de consagração expressa na Constituição ${ }^{73}$.

A rigor os princípios, como mandamentos nucleares, como conceitos básicos ou alicerces do sistema jurídico, tanto inspiram as normas atributivas de poder, como aquelas imunitórias. Ora explicam o sentido e a função de uma imunidade, ora a distribuição de poder entre os entes federados, ora são requisitos ou critérios de validade formal ou material para a criação de normas jurídico-tributárias. Compreendê-los é condição inafastável para a interpretação de qualquer regra. ${ }^{74}$

Paulo de Barros Carvalho afirma que

[...] encerraria imensa contradição imaginar o princípio da paridade jurídica daquelas entidades [entes constitucionais] e, simultaneamente, conceder pudessem elas exercitar suas competências impositivas sobre o patrimônio, renda e os serviços, umas com relação às outras. Entendemos, na linha do pensamento de Francisco Campos, Oswaldo Bandeira de Mello e Geraldo Ataliba, que, se não houvesse disposição expressa nesse sentido, estaríamos forçados a admitir o princípio da imunidade recíproca como corolário indispensável da conjugação do esquema federativo de Estado com a diretriz da autonomia municipal. Continuaria a imunidade, ainda que implícita, com o mesmo vigor que a formulação expressa lhe outorgou. ${ }^{75}$

Quanto às demais limitações constitucionais ao poder de tributar (legalidade, igualdade, proibição de confisco, anterioridade, irretroatividade), dizem respeito aos requisitos básicos para o exercício da competência tributária. Por tal razão, considerando a imunidade uma norma que retira certos fatos ou pessoas do âmbito de abrangência das normas atributivas de poder, não há que se falar em legalidade, igualdade, proibição de confisco, anterioridade, irretroatividade quando no trato das imunidades.

69 DERZI, Misabel Abreu Machado. A imunidade recíproca, o princípio federal e a Emenda Constitucional n. 3, de 1993. Revista de Direito Tributário. São Paulo, vol. 62, 1994, p. 87.

70 IBAÑEZ, André Pedreira. Imunidade recíproca: a experiência do direito norte-americano. In: DIFINI, Luiz Felipe Silveira (Org.). Imunidades tributárias e direitos fundamentais. Porto Alegre: Livraria do Advogado, 2010, p. 47.

71 " $\int 1^{\circ}$ - Sempre que possível, os impostos terão caráter pessoal e serão graduados segundo a capacidade econômica do contribuinte, facultado à administração tributária, especialmente para conferir efetividade a esses objetivos, identificar, respeitados os direitos individuais e nos termos da lei, o patrimônio, os rendimentos e as atividades econômicas do contribuinte."

72 DERZI, Misabel Abreu Machado. A imunidade recíproca, o princípio federal e a Emenda Constitucional n. 3, de 1993. Revista de Direito Tributário. São Paulo, vol. 62, 1994, p. 78.

73 DERZI, Misabel Abreu Machado. A imunidade recíproca, o princípio federal e a Emenda Constitucional n. 3, de 1993. Revista de Direito Tributário. São Paulo, vol. 62, 1994, p. 77.

74 DERZI, Misabel Abreu Machado. A imunidade recíproca, o princípio federal e a Emenda Constitucional n. 3, de 1993. Revista de Direito Tributário. São Paulo, vol. 62, 1994, p. 81.

75 CARVALHO, Paulo de Barros. Curso de Direito Tributário. 13. ed., rev. e atual. São Paulo: Saraiva, 2000. p. 183. 
Estabelecidas as bases para o entendimento da imunidade recíproca, cumpre, por fim, apresentar alguns posicionamentos do Supremo Tribunal Federal, de modo a delimitar a discussão estabelecida neste tribunal sobre a matéria em questão.

A questão relativa à relação entre imunidade recíproca e princípio federativo foi objeto, como já referido, da ADI n. ${ }^{\circ}$ 939/DF. No mesmo sentido tem-se a Ação Civil Originária n. ${ }^{\circ}$ 515/DF, que tramitou no Supremo Tribunal Federal, e onde o Banco Central do Brasil pleiteou o reconhecimento da imunidade tributária recíproca em relação ao IPTU e taxa de limpeza pública exigidos pelo Distrito Federal em relação a imóveis de sua propriedade. Suscitada questão de ordem no decorrer do feito acerca da competência para a apreciação da causa, a Relatora Min. Ellen Gracie ponderou:

Sendo a imunidade recíproca forma de manifestação do princípio federativo, considero possuir o conflito em questão estreita ligação com o pacto da Federação, hipótese em que esta Corte tem reconhecido, excepcionalmente, sua competência originária, no exercício outorgado pelo art. 102, I, f, da CF. ${ }^{76}$

A tese de que a capacidade contributiva fundamentaria a imunidade recíproca foi enfrentada pelo Supremo Tribunal Federal quando do exame da Ação Direta de Inconstitucionalidade n. ${ }^{0} 3.89 / \mathrm{DF}^{77}$, julgada improcedente. O Ministro Joaquim Barbosa, Relator do caso, ao apreciar a tese de imunidade dos serviços de registros públicos, cartorários e notariais quanto ao ISSQN, a afastou em razão da cobrança pelos serviços prestados por notários e registradores denotar evidente capacidade contributiva, afastando a imunidade recíproca.

Sobre a aplicação da imunidade recíproca a empresa pública que exerce atividade econômica, o Supremo Tribunal Federal assim se manifestou:

EMENTA: CONSTITUCIONAL. TRIBUTÁRIO. ECT - EMPRESA BRASILEIRA DE CORREIOS E TELÉGRAFOS: IMUNIDADE TRIBUTÁRIA RECÍPROCA: C.F., art. 150, VI, a. EMPRESA PÚBLICA QUE EXERCE ATIVIDADE ECONÔMICA E EMPRESA PÚBLICA PRESTADORA DE SERVIÇO PÚBLICO: DISTINÇÃO. TAXAS: IMUNIDADE RECÍPROCA: INEXISTÊNCIA. I. - As empresas públicas prestadoras de serviço público distinguem-se das que exercem atividade econômica. A ECT - Empresa Brasileira de Correios e Telégrafos é prestadora de serviço público de prestação obrigatória e exclusiva do Estado, motivo por que está abrangida pela imunidade tributária recíproca: C.F., art. 22, X; C.F., art. 150, VI, a. Precedentes do STF: RE 424.227/ SC, 407.099/RS, 354.897/RS, 356.122/RS e 398.630/SP, Ministro Carlos Velloso, 2 a Turma. II. - A imunidade tributária recíproca -- C.F., art. 150, VI, a -- somente é aplicável a impostos, não alcançando as taxas. III. - R.E. conhecido e improvido. ${ }^{78}$

Quanto aos conceitos de "renda", "patrimônio" e "serviços" e a sua interpretação, o entendimento do Supremo Tribunal Federal é no sentido de não ampliar a imunidade tributária de forma que esta alcance o contribuinte de fato do imposto:

EMENTA:AGRAVOREGIMENTALNOAGRAVODEINSTRUMENTO.TRIBUTÁRIO.FORNECIMENTO DE ENERGIA ELÉTRICA PARA ILUMINAÇÃO PÚBLICA. ICMS. IMUNIDADE INVOCADA PELO MUNICÍPIO. IMPOSSIBILIDADE. 2. A jurisprudência do Supremo firmou-se no sentido de que a imunidade de que trata o artigo 150, VI, a, da CB/88, somente se aplica a imposto incidente sobre serviço, patrimônio ou renda do próprio Município. 3. Esta Corte firmou entendimento no sentido de que o município não é contribuinte de direito do ICMS, descabendo confundi-lo com a figura do contribuinte de fato e a imunidade recíproca não beneficia o contribuinte de fato. Agravo regimental a que se nega provimento. ${ }^{79}$

No que se refere ao $\int 2 .^{\circ}$ do art. 150 da CF/88, é pacífico o entendimento do Supremo Tribunal Federal de que a imunidade recíproca pode ser estendida às empresas públicas e sociedades de economia mista que prestem serviço público de execução obrigatória e exclusiva do Estado:

RECURSO EXTRAORDINÁRIO. CONCESSÃO DE EFEITO SUSPENSIVO. PRESENÇA DOS PRESSUPOSTOS AUTORIZADORES DA TUTELA. AÇÃO CAUTELAR SUBMETIDA A REFERENDO. TRIBUTÁRIO. IMUNIDADE RECÍPROCA. ART. 150, VI, a, DA CONSTITUIÇÃO FEDERAL. 1.

76 BRASIL. Supremo Tribunal Federal. Ação Civil Originária n. ${ }^{\circ}$ 515/DF. Relatora: Min. Ellen Gracie, 2002.

77 BRASIL. Supremo Tribunal Federal. ADI 3.089-2/DF. Relator: Min. Carlos Britto/Min. Joaquim Barbosa, 2008.

78 BRASIL. Supremo Tribunal Federal. RE 364.202. Relator: Min. Carlos Velloso, 2004.

79 BRASIL. Supremo Tribunal Federal. AI 671.412 AgR. Relator: Min. Eros Grau, 2008. 
Plausibilidade jurídica do pedido (fumus boni juris) diante do entendimento firmado por este Tribunal quando do julgamento do RE 407.099/RS, rel. Min. Carlos Velloso, $2^{\text {a }}$ Turma, DJ 06.8.2004, no sentido de que as empresas públicas e sociedades de economia mista prestadoras de serviço público de prestação obrigatória e exclusiva do Estado são abrangidas pela imunidade tributária recíproca prevista no art. 150, VI, a, da Constituição Federal. 2. Exigibilidade imediata do tributo questionado no feito originário, a caracterizar o risco de dano irreparável ou de difícil reparação (periculum in mora). 3. Decisão cautelar referendada. ${ }^{80}$

Temos ainda recente decisão que, ao apreciar a pedido de extensão da imunidade tributária recíproca à Empresa Brasileira de Infraestrutura Aeroportuária - INFRAERO, na qualidade de empresa pública prestadora de serviço público, reconheceu tal imunidade com base em jurisprudência consolidada no tribunal:

RECURSO. Extraordinário. Imunidade tributária recíproca. Extensão. Empresas públicas prestadoras de serviços públicos. Repercussão geral reconhecida. Precedentes. Reafirmação da jurisprudência. Recurso improvido. É compatível com a Constituição a extensão de imunidade tributária recíproca à Empresa Brasileira de Infraestrututa Aeroportuária - INFRAERO, na qualidade de empresa pública prestadora de serviço público. ${ }^{81}$

Por fim, cumpre destacar o ajuizamento, junto ao STF, por parte da Casa da Moeda do Brasil, de Ação Cível Originária (ACO 2107) em face do Estado do Rio de Janeiro, por meio da qual pede o reconhecimento da imunidade recíproca e devolução de valores cobrados por este a título ICMS. A cobrança do tributo teria ocorrido quando a Casa da Moeda contratou, por meio de licitação, empresa localizada na Suíça para implantar uma moderna linha de produção para a fabricação das novas cédulas de real. Como a empresa contratada estava localizada no exterior, a Casa da Moeda teve que importar o equipamento que fazia parte do contrato, cobrando o Estado do Rio de Janeiro ICMS na operação.

A Casa da Moeda, em sua inicial, pleiteia a aplicação ao caso do entendimento do STF no RE 364.202, onde foi reconhecida a imunidade recíproca da ECT - Empresa Brasileira de Correios e Telégrafos, eis que de empresa pública prestadora de serviço público. No caso da Casa da Moeda, a fabricação se dá em regime de exclusividade e, de algum modo, tem caráter obrigatório. Não há como não concluir que, mantida a jurisprudência atual, a referida ação será julgada procedente.

\section{Considerações finais}

O presente estudo buscou, ao analisar a construção norte-americana acerca da imunidade recíproca, estabelecer de forma explícita a relação entre tal instituto e o princípio federativo. O caso McCulloch v. Maryland explicitou a tensão existente na recém formada federação norte-americana, e a disputa pelo poder político. Originária de uma aliança entre Estados autônomos, a federação norte-americana necessitava limitar o poder dos Estados-membros, fortalecendo, por outro lado, a União. Estabeleceu-se, assim, a teoria dos poderes implícitos.

Com a evolução da federação, a construção da Suprema Corte acerca da imunidade foi se modificando. Em um primeiro momento, garantiu a supremacia da União; em seguida, estabeleceu maior igualdade entre os Estados federados através da garantia da reciprocidade. Por fim, permitiu uma concentração de poder em torno de União. Tais movimentos acompanharam as tendências da Federação, em razão de sua íntima ligação.

A experiência americana, importada pelo Brasil, aqui se desenvolveu também de acordo com a evolução do pacto federativo. Todavia, ao contrário do caso norte-americano, no Brasil a federação nasceu com Estados enfraquecidos e um governo central forte. Além disso, a federação brasileira garantia o Município como um dos entes federados. Tais peculiaridades fizeram com que houvesse um "descolamento" entre a evolução doutrinária norte-americana e brasileira acerca da imunidade recíproca.

80 BRASIL. Supremo Tribunal Federal. AC 1.851QO. Relator: Min. Ellen Gracie, 2008.

81 BRASIL. Supremo Tribunal Federal. ARE 638.315 RG, Relator: Min. Cezar Peluso, 2011. 
A íntima ligação entre imunidade recíproca e federação permeia o entendimento moderno sobre a questão de modo a ser possível afirmar ser a imunidade recíproca cláusula pétrea por carregar em si o princípio federativo. Apesar de expressa no art. 150, VI, a, da Constituição Federal de 1988, a imunidade recíproca poderia ser inferida mesmo se não tivesse sido escrita na Constituição.

Após examinar as diversas questões atinentes à imunidade recíproca, bem como apurar os principais julgados do Supremo Tribunal Federal a respeito do termo, pode-se concluir que a delimitação e interpretação da imunidade recíproca depende, antes de mais nada, do modelo federativo que se pensa para o Estado brasileiro. Nesse sentido, demonstra-se a importância do papel do Supremo Tribunal Federal no julgamento dos casos em que se discute a imunidade recíproca.

\section{REFERÊNCIAS}

A REVIEW of intergovernmental immunities from taxation. Washington and Lee Law Review, v. 4, n. 1. Berkeley: The Berkeley electronic Press, 2012. Disponível em: <http://scholarlycommons.law.wlu.edu/wlulr/ vol4/iss1/7>. Acesso em: 23 maio 2012.

AMARO, Luciano. Direito tributário brasileiro. 15.ed. São Paulo: Saraiva, 2009.

ANDRADE, Rita de Cássia. Das imunidades tributárias como forma de limitação ao poder de tributar e como medida de garantia de princípios fundamentais. Revista Brasileira de Direito Tributário e Finanças Públicas. Porto Alegre, v. 13, p. 5-34, mar./abr. 2009.

ARRETCHE, Marta. Federalismo e democracia no Brasil: a visão da ciência política norte-americana. Revista São Paulo em perspectiva. São Paulo, n. 15, 2001.

ÁVILA, Humberto. Sistema constitucional tributário. São Paulo: Saraiva, 2004.

BALEEIRO, Aliomar. Limitações constitucionais ao poder de tributar. 7. ed. rev. e compl. por Misabel Abreu Machado Derzi. Rio de Janeiro: Forense, 1998.

Direito tributário brasileiro. 11.ed. Rio de Janeiro: Forense, 2008.

BASTOS, Celso Ribeiro. Curso de Direito Constitucional. 19. ed., atual. São Paulo: Saraiva, 1998.

BRASIL. Supremo Tribunal Federal. ADI 939-7/DF. Relator: Min. Sydney Sanches, 1993.

. Supremo Tribunal Federal. Ação Civil Originária n. ํ 515/DF. Relatora: Min. Ellen Gracie, 2002.

. Supremo Tribunal Federal. RE 364.202. Relator: Min. Carlos Velloso, 2004.

. Supremo TribunalFederal. ADI 3.089-2/DF. Relator: Min. Carlos Britto/Min. Joaquim Barbosa, 2008.

. Supremo Tribunal Federal. AI 671.412 AgR. Relator: Min. Eros Grau, 2008.

. Supremo Tribunal Federal. AC 1.851QO. Relator: Min. Ellen Gracie, 2008.

. Supremo Tribunal Federal. ARE 638.315 RG, Relator: Min. Cezar Peluso, 2011.

CARVALHO, Paulo de Barros. Curso de Direito Tributário. 13. ed., rev. e atual. São Paulo: Saraiva, 2000.

CORDEIRO, Rodrigo Aiache. Princípios constitucionais tributários. Porto Alegre: Sergio Antonio Fabris, 2006.

DERZI, Misabel Abreu Machado. A imunidade recíproca, o princípio federal e a Emenda Constitucional n. 3, de 1993. Revista de Direito Tributário. São Paulo, vol. 62, p. 76-98, 1994.

FERNANDES JÚNIOR, Jorge Batista. Imposto Predial e Territorial Urbano e a imunidade tributária dos imóveis do INSS. Revista Brasileira de Direito Tributário e Finanças Públicas. Porto Alegre, v. 17, p. 39-55, nov./dez. 2009. 
HAMILTON, Alexander; MADISON, James; JAY, John. O federalista. Tradução de Viriato SoromenhoMarques e João C. S. Duarte. Lisboa: Fundação Calouste Gulbekian, 2011.

IBAÑEZ, André Pedreira. Imunidade recíproca: a experiência do direito norte-americano. In: DIFINI, Luiz Felipe Silveira (Org.). Imunidades tributárias e direitos fundamentais. Porto Alegre: Livraria do Advogado, 2010, p. 29-53.

MELO, José Correa de. A federação e o império: uma análise da forma de estado no Brasil - Império. In: SOUZA JUNIOR, Cezar Saldanha; AVILA, Marta Marques (Org.). Estudos sobre o federalismo. Porto Alegre: Dora Luzzatto, 2007, p. 220-273.

MIRANDA, Roberta Drehmer de. O federalismo estadunidense e o "implante" ibero-americano. In: SOUZA JUNIOR, Cezar Saldanha; AVILA, Marta Marques (Org.). Estudos sobre o federalismo. Porto Alegre: Dora Luzzatto, 2007, p. 195-219.

MORAES, Alexandre de. Constituição do Brasil interpretada e legislação constitucional. 7. ed. atual. até a EC no 55/07. São Paulo; Atlas, 2007.

SETLOCK, Edward. Inter-governmental immunities from taxation. The Marquette Law Review, v. 23, n. 1, dec. 1938, p. 32-35.

SILVA, José Afonso da. Curso de direito constitucional positivo. 15.ed., rev. São Paulo: Malheiros, 1998.

SOUZA JUNIOR, Cezar Saldanha; AVILA, Marta Marques (Org.). Estudos sobre o federalismo. Porto Alegre: Dora Luzzatto, 2007.

STURTZ, Gabriel Pinós. Natureza jurídica da imunidade e demais formas de não tributação. In: DIFINI, Luiz Felipe Silveira (Org.). Imunidades tributárias e direitos fundamentais. Porto Alegre: Livraria do Advogado, 2010, p. 129-148.

UNITED STATES. Supreme Court. McCulloch v. Maryland, 17 U.S. 316 (1819).

. Supreme Court. Weston v. City Council of Charleston, 27 U.S. 449 (1829). . Supreme Court. Dobbins v. Commissioners of Erie County, 41 U.S. 16 (1842). . Supreme Court. The Collector v. Day, 78 U.S. 113 (1870). . Supreme Court. Pollock v. Farmers Loan \& Trust Co., 158 U.S. 601 (1895). . Supreme Court. South Carolina v. United States, 199 U.S. 437 (1905). . Supreme Court. Panhandle Oil Co. v. Knox, 277 U.S. 223 (1928). . Supreme Court. Helvering v. Gerhardt, 304 U.S. 405 (1938). . Supreme Court. Graves v. New York ex rel. O’Keefe, 299 U.S. 466 (1939). . Supreme Court. New York v. United States, 326 U.S. 572 (1946). 


\section{REVISTA BRASILEIRA DE POLÍTICAS PÚBLICAS BRAZILIAN JOURNAL OF PUBLIC POLICY}
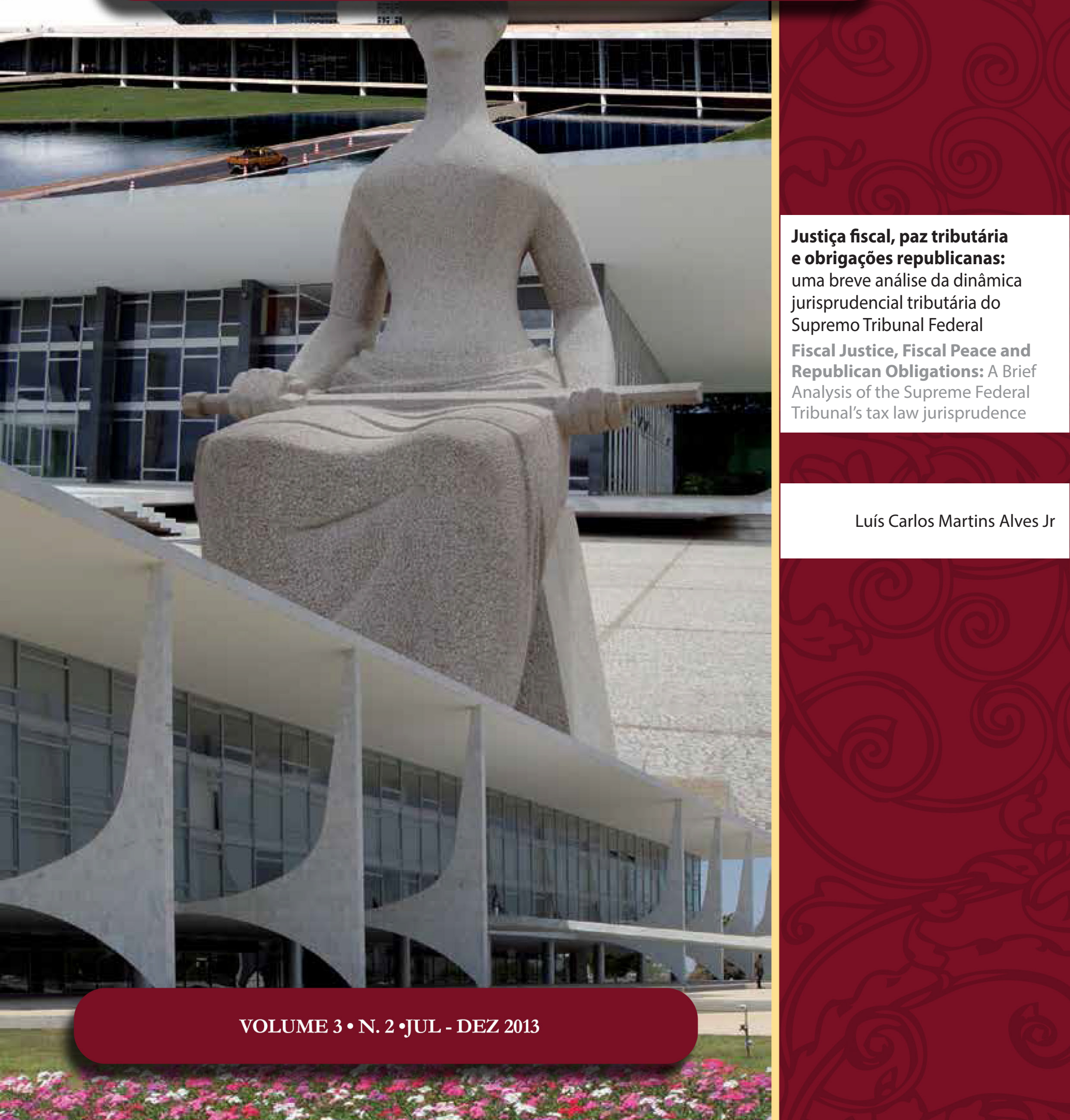


\title{
Justiça fiscal, paz tributária e obrigações republicanas: uma breve análise da dinâmica jurisprudencial tributária do Supremo Tribunal Federal $^{1}$
}

\author{
Fiscal Justice, Fiscal Peace and Republican \\ Obligations: A Brief Analysis of the Supreme \\ Federal Tribunal's tax law jurisprudence*
}

Luís Carlos Martins Alves Jr**

\section{Resumo}

Neste texto será feita uma análise da dinâmica jurisprudencial do Supremo Tribunal Federal em matéria tributária, especialmente no tocante aos temas da "justiça fiscal" e da "paz tributária", esta também compreendida como "segurança jurídico-tributária". A finalidade deste artigo visa verificar se o Tribunal, em sua prática judicante, tem favorecido a um sistema jurídico-constitucional tributário justo e seguro. É necessário verificar se a Corte tem julgado as questões tributárias em estrita obediência à Constituição, sem descurar das necessidades sociais e da realidade econômica do Brasil.

Palavras-chave: Direito constitucional. Direito tributário. Justiça fiscal. Paz tributária. Segurança jurídica. Supremo Tribunal Federal.

\section{Abstract}

This paper will be an analysis of the dynamics of Brazilian Supreme Court jurisprudence on tax matters, especially regarding issues of "Tax Justice" and "Peace Tax", this understood as "safe legal and tax". The purpose of this paper is to determine wheter the Court, in its adjucative practice has favored a legal and constitutional tax system fair and safe. It's necessary verofy that the Court has dismissed the tax issues in strict obedience to the Constitution, without neglecting the needs of social and economic reality of Brazil.

Keywords: Constitutional Law. Tax Law. Tax equity. Tax peace. Legal certainty. Brazilian Supreme Court.

1 Artigo construído a partir de palestra proferida no III Congresso Brasileiro de Filosofia do Direito Brasileiro, na Pontifícia Universidade Católica de Minas Gerais, campus Serro MG, em 30.8.2012. Em homenagem aos meus diletos amigos Igor Mauler Santiago e José Emílio Medauar Ommati, que cumpriram as promessas de que se tornariam juristas brilhantes. 


\section{INTRODUÇÃO}

O presente texto tem como objeto a dinâmica jurisprudencial do Supremo Tribunal Federal em matéria tributária, especialmente no tocante aos temas da "justiça fiscal" e da "paz tributária", esta também compreendida como "segurança jurídico-tributária". A finalidade deste artigo visa verificar se o Tribunal, em sua prática judicante, tem favorecido a um sistema jurídico-constitucional tributário justo e seguro.

Algumas questões são suscitadas. A justiça tem sido um parâmetro normativo nos julgamentos da Corte? E o postulado da paz, aqui entendido como fim dos conflitos, das controvérsias, das dúvidas e das incertezas, que também pode ser chamada de segurança jurídica, tem sido alcançado e realizado pela jurisprudência do STF no julgamento das questões fiscais? No plano da realidade, o contribuinte, seja pessoa física, seja pessoa jurídica, pode confiar na jurisprudência do Supremo Tribunal Federal em matéria tributária, no sentido de que as decisões da Corte traduzem e consubstanciam a indispensável segurança e a desejada justiça?

Com efeito, o tributo é um ônus econômico decorrente do suposto bônus de se conviver em uma determinada sociedade. ${ }^{2}$ Os tributos são instrumentos indispensáveis para as relevantes políticas públicas do Estado, pois os recursos financeiros são obtidos precipuamente mediante a sua cobrança. ${ }^{3}$ Eles - os tributos - servem, basicamente, tanto para financiar o Estado quanto para modificar as condutas e hábitos sociais, como sucede, por exemplo, com a alta tributação sobre determinados bens ou produtos, como as bebidas alcoólicas e os fumígeros. Ou seja, os tributos têm finalidades eminentemente fiscais arrecadatórias ou extrafiscais pedagógicas. ${ }^{4}$

Tenha-se que o tributo se confunde com o poder estatal sobre as vidas e as liberdades humanas. Daí porque Aliomar Baleeiro ${ }^{5}$ ter dito que onde se ergue o poder do Estado estende-se a sombra do poder de tributar. Nessa perspectiva, é preciso estudar e compreender o fenômeno tributário como instrumento fundamental para o financiamento do Estado ou como instrumento normativo indutor de comportamentos humanos. Nessa toada, conhecer o sistema tributário, tanto em seu aspecto estático (textos normativos) quanto em seu aspecto dinâmico (práticas administrativas e judiciais), bem como no seu aspecto acadêmico (os discursos doutrinários).

Cuide-se, no entanto, que, nos sistemas democráticos, os tributos devem ser justos, no sentido de repartidos entre a maior quantidade possível de contribuintes e adequados às reais necessidades do Estado, e devem permitir que esses contribuintes tenham segurança e confiança no próprio sistema jurídico. Eis a razão de se estudar, de modo aprofundado, os principais postulados normativos da atividade tributária do Estado: a justiça e a segurança jurídica. O tributo é seguro se sua cobrança é pautada pelo consentimento dos contribuintes e segundo os padrões normativos previamente estabelecidos e conhecidos por eles - os contribuintes. ${ }^{6}$

Na construção deste artigo será visitado o texto da Constituição e a dinâmica jurisprudencial do Supremo Tribunal Federal. É necessário verificar se a Corte tem julgado as questões tributárias em estrita obediência à Constituição, sem descurar das necessidades sociais e da realidade econômica do Brasil.

Utiliza-se o termo "dinâmica jurisprudencial" porque o Direito deve ser compreendido como "organismo vivo", que deve se adaptar às realidades e às necessidades para continuar válido e vigente. ${ }^{7}$ O mesmo sucede com os magistrados e os tribunais: devem se adaptar aos tempos que vivem, sob pena de serem ignorados.

2 RAWLS, John. Uma teoria da justiça. Trad. Almiro Piseta e Lenita Esteves. São Paulo: Martins Fontes, 2000.

3 NABAIS, José Casalta. O dever fundamental de pagar impostos: contributo para a compreensão constitucional do estado fiscal contemporâneo. Coimbra: Almedina, 1998.

4 COELHO, Sacha Calmon Navarro. Curso de direito tributário brasileiro. 8. ed. Rio de Janeiro: Forense, 2005.

5 BALEEIRO, Aliomar. Limitações constitucionais ao poder de limitar. 7. ed. Rio de Janeiro: Forense, 2005.

TIPKE, Klaus. Moral tributária do Estado e dos contribuintes. Porto Alegre: Sergio Antonio Fabriz, 2012.

7 LUHMANN, Niklas. Introducão à teoria dos sistemas. Rio de Janeiro: Vozes, 2009. 
Todo "organismo", para continuar sobrevivendo e existindo, necessita de se adaptar. Quem não se adapta não sobrevive. ${ }^{8}$

\section{As OBRIGAÇõES CONSTITUCIONAIS DA REPÚBLICA BRASILEIRA}

A República Federativa do Brasil, ou seja, a União Federal, os Estados-membros, os Municípios e o Distrito Federal, que se pretende e que se quer um Estado que seja Democrático e de Direito, tem, como fundamentos, naquilo que interessa imediatamente ao tema, "[...] a dignidade da pessoa humana, os valores sociais do trabalho, a livre iniciativa e a soberania popular" (art. $1^{\circ}$ ).

Forte nesses alicerces político-normativos, a República (o todo e as suas aludidas partes componentes União Federal, Estados-membros, Municípios e Distrito Federal) elegeu os seguintes objetivos fundamentais:

[...] construir uma sociedade livre, justa e solidária; garantir o desenvolvimento nacional; erradicar a pobreza e a marginalização e reduzir as desigualdades sociais e regionais; e promover o bem de todos, sem preconceitos de origem, raça, sexo, cor, idade e quaisquer outras formas de discriminação (art. $3^{\circ}$, itens, CF). ${ }^{9}$

Tenha-se que, já no Preâmbulo da Constituição, estão revelados os parâmetros valorativos que animaram os esforços normativos dos representantes políticos no exercício do poder constituinte originário, no sentido de que fosse assegurado "[...] o exercício dos direitos sociais e individuais, a liberdade, a segurança, o bem-estar, o desenvolvimento, a igualdade e a justiça como os valores supremos" ${ }^{10}$ de nossa Pátria.

A Constituição Federal de 1988 é um texto normativo ambicioso. Regula múltiplas e complexas tarefas para os poderes públicos, para os indivíduos, para a sociedade (o conjunto de pessoas ou coletividades) que se encontram no território brasileiro. Muitas - senão a totalidade - dessas tarefas estabelecidas pela Constituição têm custos e esses custos e despesas necessitam de ser suportados por "alguém".11

Com efeito, as promessas constitucionais sociais implicam ônus financeiros ou para o Estado (aqui entendido como Poder Público) ou para as empresas ou para os indivíduos ou para todos. O Estado não produz nem gera riquezas. O Estado se apropria das riquezas geradas ou produzidas pelos indivíduos e pelas empresas. Quem gera riqueza é a sociedade, por meio dos indivíduos e das empresas. Essa apropriação se dá, sobretudo, por meio de tributos. Os tributos são a apropriação por parte do Estado de parcela das riquezas geradas ou produzidas pelos indivíduos e empresas. Via tributos, o Estado se financia para o desenvolvimento de suas atividades. Não é tarefa precípua do Estado gerar riquezas. É sua tarefa viabilizar (ou não atrapalhar) a geração de riquezas.

Mas por quais motivos o Estado necessita tanto dos tributos que arrecada dos indivíduos e das empresas? ${ }^{12}$ Por que o Estado transfere parte das riquezas produzidas pela sociedade para si? ${ }^{13}$ As respostas podem ser encontradas na Constituição.

Com efeito, a Constituição estabeleceu, no artigo $6^{\circ}$, que são:

[...] direitos sociais a educação, a saúde, a alimentação, o trabalho, a moradia, o lazer, a segurança, a previdência social, a proteção à maternidade e à infância e a assistência aos desemparados. Essas promessas constitucionais exigem esforços do Poder Público. E esses esforços custam muito dinheiro. É preciso ter dinheiro para concretizar de modo ótimo esses direitos fundamentais. ${ }^{14}$

8 DARWIN, Charles. A origem das espécies. Trad. John Green. São Paulo: Martin Claret, 2004.

9 Constituição da República Federativa do Brasil, promulgada em 5.10.1988.

10 Constituição da República Federativa do Brasil, promulgada em 5.10.1988.

11 GALDINO, Flavio. Introdução à teoria dos custos dos direitos: direitos não nascem em árvores. Rio de Janeiro: Lumen Juris, 2005.

12 HOLMES, Stephen, SUNSTEIN, Cass. The Cost of Rights: Why Liberty Depends on Taxes. New York: W. Norton \& Company, 2000.

13 GODOY, Arnaldo. Os custos dos direitos. Embargos Culturais. Revista Consultor Jurídico, São Paulo, 2013. Disponível em: <www. conjur.com.br>. Acesso em: 19.10.2013.

14 Constituição da República Federativa do Brasil, promulgada em 5.10.1988. 
A Constituição estabelece, no artigo $7^{\circ}$, inciso IV, que é direito do trabalhador urbano ou rural que trabalhe ao menos 44 horas por semana:

[...] um salário-mínimo que seja capaz de atender a suas necessidades vitais básicas e às de sua família com moradia, alimentação, educação, saúde, lazer, vestuário, higiene, transporte e previdência social. Esse salário-mínimo será suportado pelos empregadores particulares ou estatais, ou pelo Estado via benefícios da seguridade social (art. 201, $\left.\int 2^{\circ}, \mathrm{CF}\right) \cdot \cdot^{15}$

Essas promessas constitucionais sociais, que exigem prestações ou ações positivas do Estado, são caras. $\mathrm{Na}$ Constituição, em seu artigo 23, itens, está disciplinada a competência comum da União, dos Estados, dos Municípios e do Distrito Federal ${ }^{16}$ Não é preciso ser um gênio em matemática ou economia para saber que as tarefas constitucionais implicam gastos, pois exigem ações político-administrativas concretas. Quem pagará a conta? Como essa conta será paga?

$\mathrm{Na}$ Constituição, no Título VII, que versa sobre a Ordem Econômica e Financeira - que tem por fim assegurar a todos existência digna -, nos Capítulos II e III, que cuidam respectivamente da Política Urbana e da Política Agrícola e Fundiária e da Reforma Agrária, o constituinte regula tema social delicado, que também tem impacto nas finanças públicas.

Mas as generosas bondades constitucionais encontram o seu estuário no Título VIII que versa sobre a Ordem Social, entre os artigos 193 a 232. Nesses aludidos dispositivos constitucionais, estão reveladas as facetas éticas e morais do Estado brasileiro, com a normatização da bondade e da misericórdia, que deveria ser em defesa dos hipossuficientes (aqueles que sozinhos não conseguem se bastar).

O citado Título VIII é a regulação jurídica da bondade e, segundo dispõe o artigo 193, tem como base o primado do trabalho e, como objetivo o bem-estar e a justiça social. Mas, reitera-se na insistência cansativa, essa generosidade normativa tem custos. Não há direitos fundamentais sociais gratuitos. Todos os direitos fundamentais sociais custam caro. Indaga-se: quem vai pagar a conta? Como esse dinheiro será arrecadado? Nada obstante, eis alguns desses direitos que revelam a "mão visível do Estado" nas desequilibradas relações humanas.

Comecemos com a própria ideia constitucional de Seguridade Social, que compreende um "[...] conjunto integrado de ações de iniciativa dos Poderes Públicos e da sociedade, destinadas a assegurar os direitos

15 Eis um dado curioso e revelador do aspecto patrimonialista do Estado brasileiro, que está muito longe de ser uma República que a todos trata com igualdade e dignidade, como tão bem assinalou Raymundo Faoro no clássico “Os Donos do Poder". É que o cidadão que recebe um salário-mínimo deve usar esse salário para si e para sua família, e deve, com esse salário, que é mínimo, arcar com as suas necessidades vitais básicas, com moradia, alimentação, educação, saúde, lazer, vestuário, higiene, transporte e previdência social. Tudo com um salário-mínimo. O mínimo salário deve cobrir as máximas despesas do trabalhador e as de sua família. Mas os "nobres" (e aqui o termo nobre é no sentido de pertencente à nobreza, uma casta que se julga superior, um "estamento") políticos e altos burocratas do Estado, que ganham muito mais do que um salário-mínimo, recebem auxílios de várias ordens: moradia, alimentação, transporte, creche, saúde, carros oficiais (muitas vezes usados para fins particulares) etc. Vejam: com um salário-mínimo o cidadão deve viver, alimentar-se, transportar-se, limpar-se, educar-se, cuidar-se, precaver-se para o futuro etc. Mas um "nobre" parlamentar ou magistrado ou um "alto" membro da elite estatal não consegue "sobreviver" apenas com o seu "salário". Ele necessita desses vários auxílios. Há algo de errado nessa equação. Quem ganha pouco tem de aprender a viver com o pouco. Mas quem ganha muito não pode viver com esse muito, necessita de muito mais. Quem paga a conta? Como e com que dinheiro essa conta é paga?

16 Art. 23. É competência comum da União, dos Estados, do Distrito Federal e dos Municípios: I - zelar pela guarda da Constituição, das leis e das instituições democráticas e conservar o patrimônio público; II - cuidar da saúde e assistência pública, da proteção e garantia das pessoas portadoras de deficiência; III - proteger os documentos, as obras e outros bens de valor histórico, artístico e cultural, os monumentos, as paisagens naturais notáveis e os sítios arqueológicos; IV - impedir a evasão, a destruição e a descaracterização de obras de arte e de outros bens de valor histórico, artístico ou cultural; V - proporcionar os meios de acesso à cultura, à educação e à ciência; VI - proteger o meio ambiente e combater a poluição em qualquer de suas formas; VII - preservar as florestas, a fauna e a flora; VIII - fomentar a produção agropecuária e organizar o abastecimento alimentar; IX - promover programas de construção de moradias e a melhoria das condições habitacionais e de saneamento básico; X - combater as causas da pobreza e os fatores de marginalização, promovendo a integração social dos setores desfavorecidos; XI - registrar, acompanhar e fiscalizar as concessões de direitos de pesquisa e exploração de recursos hídricos e minerais em seus territórios; XII - estabelecer e implantar política de educação para a segurança do trânsito. Parágrafo único. Leis complementares fixarão normas para a cooperação entre a União e os Estados, o Distrito Federal e os Municípios, tendo em vista o equilíbrio do desenvolvimento e do bem-estar em âmbito nacional. 
relativos à saúde, à previdência e à assistência social, com 'universalidade da cobertura e do atendimento"' (art. 194, itens, CF).

Entre os artigos 196 e 200 da Constituição Federal estão arrolados enunciados normativos relativos à saúde, “[...] que deve ser direito de todos e dever do Estado, e que deve ser garantido mediante políticas sociais e econômicas que visem à redução do risco de doenças e de outros agravos e ao acesso universal e igualitário às ações e serviços para sua promoção, proteção e recuperação".

Segundo a Constituição, "[...] as ações e serviços de saúde devem integrar uma rede regionalizada e hierarquizada e devem constituir um sistema único que deve disponibilizar atendimento integral, com prioridade para as atividades preventivas, sem prejuízo dos serviços assistenciais". ${ }^{17}$

O constituinte ainda se deu ao luxo de proibir a participação direta ou indireta de empresas ou capitais estrangeiros na assistência à saúde no País (art. 199, \ $3^{\circ}, \mathrm{CF}$ ). Indaga-se: a quem interessa essa proibição? Quem ganha com a ausência de concorrência e competitividade internacional? Quem perde com essa ausência?

Depois da saúde, a seguridade social alcança a previdência, que é geral, contributiva e obrigatória. ${ }^{18}$ Nos dispositivos sobre a previdência social, está disciplinado o modelo brasileiro de aposentadoria para aqueles que não têm regime próprio de previdência (os servidores públicos e os militares). É a previdência de um Estado-"providência", aquele que "acredita" que tudo pode, que tudo vê e que tudo realiza. Ou seja, parece que o Estado brasileiro se acha "onipotente", "onisciente" e "onipresente". Esse Estado "providencial", verdadeira secularização do "poder divino" ou divinização do "poder temporal (ou secular)", mostra-se eloquente ao cuidar da assistência social. ${ }^{19}$

Pois bem, essas são as principais promessas constitucionais relativas à seguridade social. E essas promessas são tão sérias, que o Supremo Tribunal Federal já decidiu que o Poder Público (ou União ou Estados ou

17 Esse Sistema Único de Saúde, conhecido pela sigla SUS, recebeu diretamente da Constituição as seguintes competências: Art. 200. Ao sistema único de saúde compete, além de outras atribuições, nos termos da lei: I - controlar e fiscalizar procedimentos, produtos e substâncias de interesse para a saúde e participar da produção de medicamentos, equipamentos, imunobiológicos, hemoderivados e outros insumos; II - executar as ações de vigilância sanitária e epidemiológica, bem como as de saúde do trabalhador; III - ordenar a formação de recursos humanos na área de saúde; IV - participar da formulação da política e da execução das ações de saneamento básico; V - incrementar em sua área de atuação o desenvolvimento científico e tecnológico; VI - fiscalizar e inspecionar alimentos, compreendido o controle de seu teor nutricional, bem como bebidas e águas para consumo humano; VII - participar do controle e fiscalização da produção, transporte, guarda e utilização de substâncias e produtos psicoativos, tóxicos e radioativos; VIII - colaborar na proteção do meio ambiente, nele compreendido o do trabalho. Esse sistema lembra aquele personagem infantil que tem uma roupa azul, com uma sunga vermelha, que tem um "S" no peito, vindo de um planeta chamado "Kripton". Podemos dizer que o SUS é um "super-sistema". É o SUPER-SUS. O danado é que esse "Super-SUS" (ou o próprio "Super-Estado"), assim como o "Superman" também tem um "ponto fraco", tem a sua "kriptonita". Qual seria a essa "kriptonita"? A resposta me foi dada por um aluno de graduação: o pobre. De fato, o pobre é a "kriptonita" do "Super-Estado" brasileiro. Na hora em que a pessoa pobre necessita da força e do amparo do Estado, ele - o "Super-Estado" - fica fraquinho, acanhado. Deixa um pobre precisar de saúde, educação, segurança, justiça, paz, prosperidade, oportunidades, transporte etc. para ver como o Estado é fraco em sua tarefa. Ou seja, quando o pobre necessita do "escudo" protetor do Estado, esse "escudo" é frágil, mas se o Estado pretende usar o seu "porrete" contra o pobre...

18 Art. 201. A previdência social será organizada sob a forma de regime geral, de caráter contributivo e de filiação obrigatória, observados critérios que preservem o equilíbrio financeiro e atuarial, e atenderá, nos termos da lei, a: I - cobertura dos eventos de doença, invalidez, morte e idade avançada; II - proteção à maternidade, especialmente à gestante; III - proteção ao trabalhador em situação de desemprego involuntário; IV - salário-família e auxílio-reclusão para os dependentes dos segurados de baixa renda; V pensão por morte do segurado, homem ou mulher, ao cônjuge ou companheiro e dependentes, observado o disposto no $\ 2^{\circ}$. Esse citado $\int 2^{\circ}$ determina que nenhum benefício terá valor mensal inferior ao salário-mínimo, e no $\int 4^{\circ}$ está assegurado o reajustamento dos benefícios para preservar-lhes, em caráter permanente, o "valor real".

19 Art. 203. A assistência social será prestada a quem dela necessitar, independentemente de contribuição à seguridade social, e tem por objetivos: I - a proteção à família, à maternidade, à infância, à adolescência e à velhice; II - o amparo às crianças e adolescentes carentes; III - a promoção da integração ao mercado de trabalho; IV - a habilitação e reabilitação das pessoas portadoras de deficiência e a promoção de sua integração à vida comunitária; V - a garantia de um salário mínimo de benefício mensal à pessoa portadora de deficiência e ao idoso que comprovem não possuir meios de prover à própria manutenção ou de tê-la provida por sua família, conforme dispuser a lei. 
Municípios) não pode invocar a cláusula da "reserva do possível” para se furtar do cumprimento de suas obrigações constitucionais. ${ }^{20}$

20 BRASIL. Supremo Tribunal Federal. Agravo em Recurso Extraordinário n. 639.337. Relator Ministro Celso de Mello. Julgamento em 23.8.2011. EMENTA: E M E N T A: CRIANÇA DE ATÉ CINCO ANOS DE IDADE - ATENDIMENTO EM CRECHE E EM PRÉ-ESCOLA - SENTENÇA QUE OBRIGA O MUNICÍPIO DE SÃO PAULO A MATRICULAR CRIANÇAS EM UNIDADES DE ENSINO INFANTIL PRÓXIMAS DE SUA RESIDÊNCIA OU DO ENDEREÇO DE TRABALHO DE SEUS RESPONSÁVEIS LEGAIS, SOB PENA DE MULTA DIÁRIA POR CRIANÇA NÃO ATENDIDA - LEGITIMIDADE JURÍDICA DA UTILIZAÇÃO DAS “ASTREINTES” CONTRA O PODER PÚBLICO - DOUTRINA - JURISPRUDÊNCIA - OBRIGAÇÃO ESTATAL DE RESPEITAR OS DIREITOS DAS CRIANÇAS - EDUCAÇÃO INFANTIL - DIREITO ASSEGURADO PELO PRÓPRIO TEXTO CONSTITUCIONAL (CF, ART. 208, IV, NA REDAÇÃO DADA PELA EC N 53/2006) - COMPREENSÃO GLOBAL DO DIREITO CONSTITUCIONAL À EDUCAÇÃO - DEVER JURÍDICO CUJA EXECUÇÃO SE IMPÕE AO PODER PÚBLICO, NOTADAMENTE AO MUNICÍPIO (CF, ART. 211, \ $2^{\circ}$ ) - LEGITIMIDADE CONSTITUCIONAL DA INTERVENÇÃO DO PODER JUDICIÁRIO EM CASO DE OMISSÃO ESTATAL NA IMPLEMENTAÇÃO DE POLÍTICAS PÚBLICAS PREVISTAS NA CONSTITUIÇÃO - INOCORRÊNCIA DE TRANSGRESSÃO AO POSTULADO DA SEPARAÇ̃̃O DE PODERES - PROTEÇ̃̃O JUDICIAL DE DIREITOS SOCIAIS, ESCASSEZ DE RECURSOS E A QUESTÃO DAS "ESCOLHAS TRÁGICAS" - RESERVA DO POSSÍVEL, MÍNIMO EXISTENCIAL, DIGNIDADE DA PESSOA HUMANA E VEDAÇÃO DO RETROCESSO SOCIAL - PRETENDIDA EXONERAÇÃO DO ENCARGO CONSTITUCIONAL POR EFEITO DE SUPERVENIÊNCIA DE NOVA REALIDADE FÁTICA - QUESTÃO QUE SEQUER FOI SUSCITADA NAS RAZÕES DE RECURSO EXTRAORDINÁRIO -PRINCÍPIO "JURA NOVIT CURIA" - INVOCAÇÃO EM SEDE DE APELO EXTREMO - IMPOSSIBILIDADE - RECURSO DE AGRAVO IMPROVIDO. POLÍTICAS PÚBLICAS, OMISSÃO ESTATAL INJUSTIFICÁVEL E INTERVENÇÃO CONCRETIZADORA DO PODER JUDICIÁRIO EM TEMA DE EDUCAÇÃO INFANTIL: POSSIBILIDADE CONSTITUCIONAL. - A educação infantil representa prerrogativa constitucional indisponível, que, deferida às crianças, a estas assegura, para efeito de seu desenvolvimento integral, e como primeira etapa do processo de educação básica, o atendimento em creche e o acesso à pré-escola (CF, art. 208, IV). - Essa prerrogativa jurídica, em consequência, impõe, ao Estado, por efeito da alta significação social de que se reveste a educação infantil, a obrigação constitucional de criar condições objetivas que possibilitem, de maneira concreta, em favor das "crianças até 5 (cinco) anos de idade" (CF, art. 208, IV), o efetivo acesso e atendimento em creches e unidades de pré-escola, sob pena de configurar-se inaceitável omissão governamental, apta a frustrar, injustamente, por inércia, o integral adimplemento, pelo Poder Público, de prestação estatal que lhe impôs o próprio texto da Constituição Federal. - A educação infantil, por qualificar-se como direito fundamental de toda criança, não se expõe, em seu processo de concretização, a avaliações meramente discricionárias da Administração Pública nem se subordina a razões de puro pragmatismo

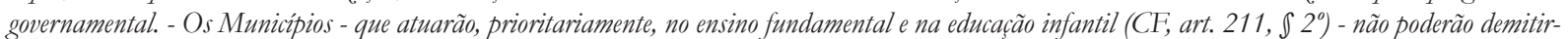
se do mandato constitucional, juridicamente vinculante, que lhes foi outorgado pelo art. 208, IV, da Lei Fundamental da República, e que representa fator de limitação da discricionariedade político-administrativa dos entes municipais, cujas opções, tratando-se do atendimento das crianças em creche (CF, art. 208, IV), não podem ser exercidas de modo a comprometer, com apoio em juízo de simples conveniência ou de mera oportunidade, a eficácia desse direito básico de indole social. - Embora inquestionável que resida, primariamente, nos Poderes Legislativo e Executivo, a prerrogativa de formular e executar políticas públicas, revela-se possivel, no entanto, ao Poder Judiciário, ainda que em bases excepcionais, determinar, especialmente nas hipóteses de políticas públicas definidas pela própria Constituição, sejam estas implementadas, sempre que os órgãos estatais competentes, por descumprirem os encargos político-jurídicos que sobre eles incidem em caráter impositivo, vierem a comprometer, com a sua omissão, a eficácia e a integridade de direitos sociais e culturais impregnados de estatura constitucional. DESCUMPRIMENTO DE POLÍTICAS PÚBLICAS DEFINIDAS EM SEDE CONSTITUCIONAL: HIPÓTESE LEGITIMADORA DE INTERVENÇÃO JURISDICIONAL. - O Poder Público - quando se abstém de cumprir, total ou parcialmente, o dever de implementar políticas públicas definidas no próprio texto constitucional - transgride, com esse comportamento negativo, a própria integridade da Lei Fundamental, estimulando, no âmbito do Estado, o preocupante fenômeno da erosão da consciência constitucional. Precedentes: ADI 1.484/DF, Rel. Min. CELSO DE MELLO, v.g.. - A inércia estatal em adimplir as imposições constitucionais traduz. inaceitável gesto de desprezo pela autoridade da Constituição e configura, por isso mesmo, comportamento que deve ser evitado. É que nada se revela mais nocivo, perigoso e ilegítimo do que elaborar uma Constituição, sem a vontade de fazêe-la cumprir integralmente, ou, então, de apenas executá-la com o propósito subalterno de torná-la aplicável somente nos pontos que se mostrarem ajustados à conveniência e aos desígnios dos governantes, em detrimento dos interesses maiores dos cidadãos. - A intervenção do Poder Judiciário, em tema de implementação de políticas governamentais previstas e determinadas no texto constitucional, notadamente na área da educação infantil (RTJ 199/1219-1220), objetiva neutralizar os efeitos lesivos e perversos, que, provocados pela omissão estatal, nada mais traduz̨em senão inaceitável insulto a direitos básicos que a própria Constituição da República assegura à generalidade das pessoas. Precedentes. A CONTROVÉRSLA PERTINENTE À "RESERVA DO POSSÍVEL” E A INTANGIBILIDADE DO MÍNIMO EXISTENCIAL: A QUESTÃO DAS "ESCOLHAS TRÁGICAS". - A destinação de recursos públicos, sempre tão dramaticamente escassos, faz instaurar situações de conflito, quer com a execução de políticas públicas definidas no texto constitucional, quer, também, com a própria implementação de direitos sociais assegurados pela Constituição da República, dai resultando contextos de antagonismo que impõem, ao Estado, o encargo de superá-los mediante opções por determinados valores, em detrimento de outros igualmente relevantes, compelindo, o Poder Público, em face dessa relação dilemática, causada pela insuficiência de disponibilidade financeira e orçamentária, a proceder a verdadeiras "escolhas trágicas", em decisão governamental cujo parâmetro, fundado na dignidade da pessoa humana, deverá ter em perspectiva a intangibilidade do minimo existencial, em ordem a conferir real efetividade às normas programáticas positivadas na própria Lei Fundamental. Magistério da doutrina. - A cláusula da reserva do possível - que não pode ser invocada, pelo Poder Público, com o propósito de fraudar, de frustrar e de inviabilizar a implementação de políticas públicas definidas na própria Constituição - encontra insuperável limitação na garantia constitucional do minimo existencial, que representa, no contexto de nosso ordenamento positivo, emanação direta do postulado da essencial dignidade da pessoa bumana. Doutrina. Precedentes. - A noção de "mínimo existencial", que resulta, por implicitude, de determinados preceitos constitucionais (CF, art. $1^{\circ}$, III, e art. $3^{\circ}$, III), compreende um complexo de prerrogativas cuja concretização revela-se capaz. de garantir condicões 
A denominada "cláusula da reserva do possível" consiste em uma fundamentação normativa, de base factual e financeira, que eximiria o Poder Público do dever de cumprir com as suas obrigações sociais, tendo em vista a sua "impossibilidade" financeira ou administrativa. Ou seja, segundo o STF, se o Poder Público prometeu, via Constituição, deve cumprir. Mas, indaga-se: donde vem o poder econômico do Estado? Que outras tarefas deverão ser sacrificadas?

Cuide-se que as tarefas constitucionais éticas vão além. O Estado é responsável pela educação, cultura e desporto, conforme o disposto nos artigos 205 a 216. Segundo a Constituição, “[...] a educação é direito de todos e dever do Estado e da família, e será promovida e incentivada com a colaboração da sociedade, visando ao pleno desenvolvimento da pessoa, seu preparo para o exercício da cidadania e sua qualificação para o trabalho"21. Tarefa ambiciosa. Educar é preparar o indivíduo para que ele possa realizar os seus projetos pessoais de vida, a sua autoestima, onde quer que ele queira. Isso é o básico do ensino.

O indivíduo educado é aquele que tem a real possibilidade de concretizar os seus sonhos. É o indivíduo com habilidades e capacidades máximas (e não as costumeiras mínimas) que possam viabilizar, em qualquer tempo e lugar, a plenitude de suas possibilidades e potencialidades. ${ }^{22}$

Pois bem, o Estado avocou para si essa gigantesca responsabilidade. É bem verdade que pede o auxílio da família e da própria sociedade. O Estado, por meio das escolas públicas (estatais), pode até instruir, mas quem educa de verdade é a Família. ${ }^{23}$

adequadas de existência digna, em ordem a assegurar, à pessoa, acesso efetivo ao direito geral de liberdade e, também, a prestações positivas originárias do Estado, viabilizadoras da plena fruição de direitos sociais básicos, tais como o direito à educação, o direito à proteção integral da criança e do adolescente, o direito à saúde, o direito à assistência social, o direito à moradia, o direito à alimentação e o direito à segurança. Declaraşão Universal dos Direitos da Pessoa Humana, de 1948 (Artigo XXV). A PROIBICÁA DO RETROCESSO SOCLAL COMO OBSTÁCULO CONSTITUCIONAL À FRUSTRACÁO E AO INADIMPLEMENTO, PELO PODER PÚBLICO, DE DIREITOS PRESTACIONAIS. - O princípio da proibição do retrocesso impede, em tema de direitos fundamentais de caráter social, que sejam desconstituídas as conquistas já alcançadas pelo cidadão ou pela formação social em que ele vive. - A cláusula que veda o retrocesso em matéria de direitos a prestações positivas do Estado (como o direito à educação, o direito à saúde ou o direito à segurança pública, v.g.) traduz, no processo de efetivação desses direitos fundamentais individuais ou coletivos, obstáculo a que os niveis de concretização de tais prerrogativas, uma vez. atingidos, venham a ser ulteriormente reduzidos ou suprimidos pelo Estado. Doutrina. Em conseqüência desse princípio, o Estado, após haver reconhecido os direitos prestacionais, assume o dever não só de torná-los efetivos, mas, também, se obriga, sob pena de transgressão ao texto constitucional, a preservá-los, abstendo-se de frustrar - mediante supressão total ou parcial - os direitos sociais já concretiz̨ados. LEGITIMIDADE JURÍDICA DA IMPOSIÇÃO, AO PODER PÚBLICO, DAS "ASTREINTES”. - Inexiste obstáculo jurídicoprocessual à utilização, contra entidades de direito público, da multa cominatória prevista no $\int 5^{\circ}$ do art. 461 do CPC. A "astreinte" - que se reveste de função coercitiva - tem por finalidade especifica compelir, legitimamente, o devedor, mesmo que se cuide do Poder Público, a cumprir o preceito, tal como definido no ato sentencial. Doutrina. Jurisprudência.

21 Constituição da República Federativa do Brasil, promulgada em 5.10.1988.

22 Mas que habilidades básicas (porém máximas, insista-se) deve ter esse indivíduo? O que é que ele deve saber? Ele deve saber ler, escrever e calcular, como reverbera João Marcéllo Favella de Macêdo Claudino Fernandes. Se além dessas três habilidades, esse indivíduo ainda for criativo e for possuidor de um excelente caráter e de uma correta moralidade, melhor ainda. É a formação educacional perfeita. Esse deve ser o ensino básico fundamental. Ou seja, a educação deve possibilitar que ele saiba ler, compreender e escrever muito bem um texto em português. E também que seja capaz de ler, compreender e de escrever em outro idioma, preferencialmente o inglês e o espanhol. Em um passado distante, era grego e latim, amanhã... Além dessa capacidade de leitura, de compreensão e de escrita, tanto no português, quanto no inglês e no espanhol, esse indivíduo deve ter um ágil e agudo raciocínio lógico-matemático. Ele deve saber fazer cálculos e ponderações. Com essas habilidades básicas (porém insisto em seu grau ótimo), esse indivíduo estará apto a aprender outros conhecimentos e novas habilidades, em qualquer lugar e tempo, e poderá se desenvolver plenamente: seja como trabalhador (ou profissional), seja como cidadão. Ele poderá ser uma pessoa em sua plenitude existencial, confiante e com autoestima. Essa é a principal tarefa da educação: criar as condições para que a pessoa seja plena.

23 Algumas reflexões sobre essa questão. Primeiro o que cuida da gratuidade do ensino prestado nos estabelecimentos oficiais. Com efeito, o ensino deve ser prestado gratuitamente para aqueles que não podem pagar por ele: os manifestamente carentes e os necessitados. Os que podem pagar devem pagar. O fato de o ensino ser prestado pelo Estado, pelo Poder Público, não o torna necessariamente gratuito. É preciso superar esse paradigma, verdadeiro dogma, de que tudo que é público é gratuito. Só deve ser "gratuito" o serviço público educacional para quem não pode pagar. E mesmo nessa hipótese é importante que haja alguma contraprestação por parte do indivíduo, como, por exemplo, serviços educacionais comunitários. O outro aspecto que merece reflexão diz respeito ao "piso dos professores públicos". Neste País, o "piso" é do magistério. O "teto" é da magistratura (art. 37, XI, CF). Que presente temos? Que futuro teremos? Uma Nação onde o magistério está no "piso", no "chão", e a magistratura está no "teto", no "céu", é uma Nação que necessita refletir profundamente acerca dos seus valores mais caros e mais relevantes. O maior e melhor salário público deste País deveria ser para o professor de matemática do ensino fundamental, com dedicação exclusiva, que tenha especialização, mestrado, doutorado e livre-docência, bem como publicações relevantes. Que seja uma verdadeira sumidade 
Educação é tão importante que não deveria estar nas mãos do Estado (Governo), mas da sociedade, da família e dos indivíduos. A educação, na mão da sociedade (famílias e indivíduos), deve ser usada para civilizar, para libertar, para permitir que o indivíduo possa ser o que ele quiser ser, e não ser aquilo que os outros queiram que ele seja. Educar é preparar o indivíduo para que ele tenha condições de explorar todas as suas potencialidades. ${ }^{24}$

Mas não é só a educação que a Constituição impõe como tarefa social do Estado. Além dela - a educação - temos a cultura e o desporto, como já assinalamos. A cultura, segundo a Constituição, será viabilizada e garantida a todos pelo Estado, com o pleno exercício dos respectivos direitos e acesso às suas fontes nacionais, com o apoio e o incentivo à valorização e a difusão de suas manifestações (arts. 215 e 216, CF). Também é dever do Estado: “[...] fomentar práticas desportivas formais e não-formais, como direito de todos e de cada um, devendo o Poder Público incentivar o lazer, como forma de promoção social” (art. 217, CF).

Em terreno próximo ao da educação, a Constituição determina que: “[...] o Estado promova e incentive o desenvolvimento científico, a pesquisa e a capacitação tecnológica, tendo em vista, no geral, o bem público, o progresso das ciências, a solução dos problemas brasileiros e o desenvolvimento do sistema produtivo nacional e regional" (art. 218, itens, CF).

Ainda na seara das promessas constitucionais ambiciosas, a Constituição dispõe acerca dos denominados direitos de $3^{\text {a }}$ geração: os ambientais. ${ }^{25}$

na arte de fazer o aluno aprender matemática e de raciocinar com rigor e com lógica.

Com excelentes professores no ensino fundamental básico, bem preparados, bem remunerados, bem estimulados e entusiasmados, não necessitaremos de tantos juízes, promotores, advogados, delegados, auditores, fiscais, policiais, fóruns, delegacias, presídios e de todo o aparato de repressão estatal. Com excelentes professores no ensino fundamental básico, teremos uma sociedade mais civilizada, mais harmônica, mais pacífica, com indivíduos cônscios de seus deveres e de seus direitos. Uma sociedade educada e civilizada se constrói investindo no magistério, em vez da magistratura. As melhores inteligências e os mais bem preparados e qualificados devem ser canalizados para o magistério, e não para a magistratura. Precisamos de bons professores. Quanto melhor for o professor, menos trabalho sobrará para o juiz (e para o promotor, para o defensor, para o advogado, para o delegado, para o fiscal, ou seja, para o aparato de poder do Estado). Mas será que suas excelências os magistrados (e os demais acima citados) permitirão isso? Será que essas aludidas figuras permitirão que os professores tenham uma remuneração mais vantajosa? Será que nós, os profissionais do direito, os "sacerdotes" desse "Deus secularizado que é o Estado", os conhecedores dessa "religião secularizada que é o Direito", vamos permitir isso? Será que aceitaremos que a sociedade e os indivíduos, por meio da Educação, sejam mais importantes que o Estado, por meio do seu Direito? As respostas a essas indagações são fundamentais. Que tipo de povo queremos ser? Um povo educado e livre ou um povo algemado, subalternizado?

24 Indaga-se: o Estado brasileiro tem alcançado essa missão? O indivíduo brasileiro, especialmente o nascido no seio de uma família carente de recursos econômicos, é preparado para ser o que ele quiser ser, ou ele é aquilo que mal consegue ser? A resposta é negativa. E a confissão de culpa do Estado se deu com as cotas para ingresso nas universidades públicas. O Estado brasileiro reconheceu a sua total incapacidade e incompetência para cuidar da Educação do povo, especialmente das pessoas mais carentes economicamente, independentemente da cor, da etnia, dos credos e das crenças ou das orientações e tendências sexuais. A Educação básica fornecida pelo Estado brasileiro está falida há muito tempo. Em vez de investir nela, o Estado optou pelo caminho mais fácil das cotas, em vez de fazer a coisa certa, no caso, canalizar as melhores inteligências e os maiores recursos para o ensino básico fundamental, o Estado preferiu o caminho simplista das cotas. Deveria o Estado reconhecer que ele não tem competência para educar o povo brasileiro e deixar que a sociedade e a família cuidem desse bem público. A educação deve ser pública, mas não deve ser estatal. Com efeito, quanto custa uma educação de boa qualidade para tornar uma pessoa verdadeiramente apta para o trabalho e para a cidadania? E não qualquer trabalho ou qualquer cidadania, mas o trabalho altamente qualificado que essa pessoa queira desenvolver ou da cidadania plena, que essa pessoa queira participar. Quanto à sociedade e o Estado, estão dispostos a gastar com educação? 25 Art. 225. Todos têm direito ao meio ambiente ecologicamente equilibrado, bem de uso comum do povo e essencial à sadia qualidade de vida, impondo-se ao Poder Público e à coletividade o dever de defendê-lo e preservá-lo para as presentes e futuras gerações. $\int 1^{\circ}$ - Para assegurar a efetividade desse direito, incumbe ao Poder Público: I - preservar e restaurar os processos ecológicos essenciais e prover o manejo ecológico das espécies e ecossistemas; II - preservar a diversidade e a integridade do patrimônio genético do País e fiscalizar as entidades dedicadas à pesquisa e manipulação de material genético; III - definir, em todas as unidades da Federação, espaços territoriais e seus componentes a serem especialmente protegidos, sendo a alteração e a supressão permitidas somente através de lei, vedada qualquer utilização que comprometa a integridade dos atributos que justifiquem sua proteção; IV exigir, na forma da lei, para instalação de obra ou atividade potencialmente causadora de significativa degradação do meio ambiente, estudo prévio de impacto ambiental, a que se dará publicidade; V - controlar a produção, a comercialização e o emprego de técnicas, métodos e substâncias que comportem risco para a vida, a qualidade de vida e o meio ambiente; VI - promover a educação ambiental em todos os níveis de ensino e a conscientização pública para a preservação do meio ambiente; VII - proteger a fauna e a flora, vedadas, na forma da lei, as práticas que coloquem em risco sua função ecológica, provoquem a extinção de espécies ou submetam 
Mas a sanha reguladora da Constituição de 1988 foi além. Dispôs, cheia de boas intenções, sobre família, criança, adolescente, jovem e idoso (arts. 226 a 230, CF). A Constituição procurou normatizar tudo, nada lhe escapa, tudo é matéria constitucional. Recordando os enunciados constitucionais bondosos, temos algumas das mais belas passagens de textos normativos da história da humanidade. É rica e refinada a estética da Constituição. ${ }^{26}$

A Constituição determina tarefas e responsabilidades para os pais, para as famílias e para os filhos.27 Se essas promessas constitucionais se tornassem realidade, nós poderíamos nos orgulhar de sermos brasileiros. Com efeito, cuidar das crianças, dos idosos e das pessoas com deficiências, além de proteger os adolescentes e os jovens, revela um profundo senso moral, revela que é possível saber o que é o certo. A dificuldade consiste em fazer a "coisa certa".

Por fim, a Constituição (artigos 231 e 232) dispõe sobre a situação dos índios, reconhecendo-lhes a sua organização social, costumes, línguas, crenças e tradições, bem como os direitos originários sobre as terras que tradicionalmente ocupam, competindo à União demarcá-las, proteger esse povo e fazer respeitar todos os seus bens. Em relação aos indígenas, que são tão brasileiros assim como todos os demais, e merecem ser tratados com respeito e consideração, o Estado deve viabilizar que eles também - os índios - possam ter acesso à melhor educação, ao ensino de línguas (português, inglês e espanhol), ao ensino de matemática e ao desenvolvimento de seu raciocínio lógico, pois ele - o índio - não é "bicho", é gente e deve ser tratado como tal: com respeito e consideração. ${ }^{28}$

Com isso, finalizam-se as promessas constitucionais sociais. Esses mandamentos implicam custos. Donde virá o dinheiro para tornar realidade, para concretizar em ponto ótimo essas obrigações? O dinheiro decorrerá diretamente do Estado ou dos tributos arrecadados pelo Estado?

\section{Algumas QUestões tributárias Na JURISPRUdênCia do STF}

À luz do texto constitucional, os mandamentos contidos nos dispositivos da Ordem Econômica e Financeira (arts. 170 a 192, CF), percebe-se que a atividade produtiva não compete ao Estado, mas sim aos

os animais à crueldade.

26 Art. 226, $\int 7^{\circ}$ - Fundado nos princípios da dignidade da pessoa humana e da paternidade responsável, o planejamento familiar é livre decisão do casal, competindo ao Estado propiciar recursos educacionais e científicos para o exercício desse direito, vedada qualquer forma coercitiva por parte de instituições oficiais ou privadas. Art. 226, \ $8^{\circ}$ - O Estado assegurará a assistência à família na pessoa de cada um dos que a integram, criando mecanismos para coibir a violência no âmbito de suas relações. Art. 227. É dever da família, da sociedade e do Estado assegurar à criança, ao adolescente e ao jovem, com absoluta prioridade, o direito à vida, à saúde, à alimentação, à educação, ao lazer, à profissionalização, à cultura, à dignidade, ao respeito, à liberdade e à convivência familiar e comunitária, além de colocá-los a salvo de toda forma de negligência, discriminação, exploração, violência, crueldade e opressão. $\int$ $1^{\circ} \mathrm{O}$ Estado promoverá programas de assistência integral à saúde da criança, do adolescente e do jovem, admitida a participação de entidades não governamentais, mediante políticas específicas e obedecendo aos seguintes preceitos: I - aplicação de percentual dos recursos públicos destinados à saúde na assistência materno-infantil; II - criação de programas de prevenção e atendimento especializado para as pessoas portadoras de deficiência física, sensorial ou mental, bem como de integração social do adolescente e do jovem portador de deficiência, mediante o treinamento para o trabalho e a convivência, e a facilitação do acesso aos bens e serviços coletivos, com a eliminação de obstáculos arquitetônicos e de todas as formas de discriminação.

27 Art. 229. Os pais têm o dever de assistir, criar e educar os filhos menores, e os filhos maiores têm o dever de ajudar e amparar os pais na velhice, carência ou enfermidade. Art. 230. A família, a sociedade e o Estado têm o dever de amparar as pessoas idosas, assegurando sua participação na comunidade, defendendo sua dignidade e bem-estar e garantindo-lhes o direito à vida.

28 Índio deve ter acesso aos bens de consumo e às facilidades do desenvolvimento econômico, tecnológico e científico da humanidade. Como diz Rafael Favetti “[...] índio pode ter iphone, ipad, perfil no facebook, viajar de avião, divertir-se em Orlando, passar lua-de-mel em Paris, por seus filhos para estudar nas melhores escolas e universidades..." Eles - os índios - devem participar do desenvolvimento cooperativo entre os povos. Eles - os índios - são povo brasileiro. E como brasileiros devem ser tratados. Nessa perspectiva, o índio educado, assim como qualquer outra pessoa educada, pode decidir o seu destino, em vez de viver o destino que lhe foi traçado, seja pelo Estado seja pelos seus ancestrais. A pós-modernidade também deve ser viabilizada para os índios, em vez de aprisioná-los na pré-modernidade. Ou seja, em vez de ser visto e tratado como "índio", deve ser visto e tratado como pessoa que tem direito a viver os seus sonhos e as suas potencialidades, e de usufruir tudo de bom que a humanidade tem a oferecer. 
indivíduos e às empresas, que são corporações vocacionadas ao lucro. Segundo a Constituição, é assegurado a todos o livre exercício de qualquer atividade econômica, independentemente de autorização de órgãos públicos, salvo nos casos previstos em lei (art. 170, parágrafo único, CF).

Nessa toada, nos termos da Constituição e ressalvados os casos nela previstos, a exploração direta de atividade econômica pelo Estado só será permitida quando necessária aos imperativos da segurança nacional ou a relevante interesse coletivo, conforme definido em lei (art. 173, CF). Isso significa que a regra é a atividade produtiva particular. A exceção é a atividade produtiva estatal. ${ }^{29}$

Visto que as principais receitas do Estado decorrem dos tributos, aproximamo-nos do tema central de nossa intervenção. Com efeito, a Constituição Federal é uma Constituição Tributária. Os dispositivos constitucionais tributários são vários e cuidam de modo analítico e minucioso desse tema (Título VI - Da Tributação e do Orçamento, arts. 145 a 169, CF), de sorte que o sistema tributário brasileiro está praticamente desenhado no texto da Constituição.

A Constituição Federal concedeu ao tributo um destaque normativo privilegiado. Os tributos brasileiros são os seguintes: impostos, taxas, contribuições e empréstimos compulsórios. Na Constituição está delimitada a competência tributária de cada um dos entes da República. O texto informa quais são os tributos que poderão ser criados e instituídos pela União, quais poderão ser criados e instituídos pelos Estados e quais poderão ser criados e instituídos pelos Municípios. Essa já uma primeira garantia de segurança dos contribuintes.

Tenha-se, por oportuno e necessário, que a Constituição dispõe de modo explícito acerca das "Limitações Constitucionais ao Poder de Tributar" (arts. 150 a 152, CF). Isso significa que a Constituição pretende constranger o poder estatal de tributar. No embate entre o Fisco e o Contribuinte, o "escudo" constitucional serve para proteger o contribuinte contra o "porrete" tributário do Estado. ${ }^{30}$ Essas disposições tributárias

29 É de se indagar: no Brasil de hoje, ainda se faz necessária a existência de "empresas estatais", no caso, de empresas públicas e de sociedades de economia mista? Há razão para os monopólios estatais? Para mim a resposta é negativa. O Brasil de hoje, para ter futuro, não se pode dar ao luxo de possuir "empresas estatais". Nem deve ter monopólios de caráter econômico ou de prestação de serviços. Não há mais justificativas convincentes da necessidade da existência dessas "empresas estatais", nem dos monopólios estatais, exceto o monopólio criação das leis, da cobrança dos tributos, dos julgamentos, dos cumprimentos das sentenças, das prisões, ou seja, o monopólio da "violência" e da produção normativa. Muitas dessas "empresas estatais" já prestaram relevantes serviços ao País, mas hoje elas não necessitam de continuar sob as rédeas governamentais. Todas elas deveriam ter o capital aberto, ser privatizadas, com a venda de suas ações nas bolsas de valores. Dessas "estatais", o Estado deve cobrar tributos, em vez de ser sócio ou gestor. Aonde pretendo chegar? Quanto mais forte e pulsante for a iniciativa privada, mais tributos poderão ser arrecadados. Para que o Estado consiga cumprir com as suas obrigações sociais, ele deve abdicar de sua atuação empresarial. O mundo empresarial é o mundo da concorrência e da competitividade. O Estado não sabe conviver na concorrência e na competitividade. Daí porque se faz necessária a venda de todas, sem exceção, “empresas estatais", especialmente daquelas que evocam sentimentos atávicos de nacionalismo e de patriotismo. A Pátria não necessita de o Estado empresário. A Pátria e os brasileiros que nela vivem necessitam de segurança, de justiça, de educação, de saúde, de estradas, de aeroportos, ferrovias, hidrovias, infovias e de tudo que possa melhorar o crescimento econômico e o nosso desenvolvimento social. Sem produção de riquezas, não há distribuição de rendas. A melhor maneira de diminuir a quantidade de pobres consiste em aumentar a quantidade de ricos. Não é fustigando nem castigando os ricos ou desestimulando as empresas que reduziremos as misérias deste País. É justamente o contrário do pensamento do "senso comum" que atribui ao rico a causa da pobreza. Pobreza se combate com riqueza. Aumentemos as riquezas que o efeito benéfico será a diminuição da quantidade de pobres. Mas, insisto, o Estado não gera riquezas nem produz nada. Quem faz isso são os indivíduos empreendedores, que o Estado deve incentivar e premiar. Indaga-se: o Estado pretende abrir mão desse poder empresarial? As corporações sindicais dos trabalhadores dessas “empresas estatais" e as dos empresários que se beneficiam dessas "estatais" permitirão? E a sociedade, povo brasileiro, o que quer?

30 O Estado brasileiro é "pantagruélico", é "faminto", e procura arrecadar com voracidade. Qual a razão? As respostas podem ser encontradas nas suas tarefas. A Constituição destinou ao Estado múltiplas tarefas. O Estado se agigantou, tornou-se "paquidérmico", oneroso, dispendioso. Logo o primeiro passo para a diminuição da carga tributária passa pela diminuição do tamanho do Estado. Se a sociedade quer um Estado "gigante", "providencial", deve arcar com o financiamento dele. Mas será que é isso que a sociedade quer? Será que esse Estado é o mais indicado para o povo brasileiro? Pessoalmente, entendo que não. Entendo que quanto mais forte e gigantesco for o Estado, mais fraca será a sociedade e mais acanhado será o indivíduo. Mas, essa é uma decisão que compete à sociedade como um todo. Que tipo de sociedade queremos ter? Que tipo de cidadania queremos exercer? Que tipo de gente queremos ser? As respostas indicarão os caminhos de nossa Nação e os caminhos que individualmente cada um de nós pretende seguir. Mas, nada obstante o caráter panfletário dessas reflexões, remanescem questões judiciais sobre a cobrança de tributos, com 
estão esparramadas no texto, como se percebe dos enunciados relativos às contribuições da seguridade social. Essas contribuições também são tributos, pois são obrigatórias e compulsórias.

Os tributos são válidos se criados e instituídos em estrita obediência aos comandos constitucionais. Essa é a missão precípua do Supremo Tribunal Federal em matéria tributária: garantir que o Estado crie ou institua tributos em conformidade com a Constituição e garantir que o Estado possa cobrar dos contribuintes os tributos instituídos em harmonia com a Constituição. Vejam que a "via é de mão dupla": proteger o contribuinte em face das eventuais inconstitucionalidades tributárias do Estado e permitir que o Estado cobre dos contribuintes os tributos instituídos de acordo com a Constituição. ${ }^{31}$

Estado democrático de direito exige o tributo legalmente válido e moralmente justo. Ao Fisco (Fazenda Pública), nas sociedades livres, não interessa extorquir o contribuinte, mas tão somente recolher aquilo que lhe é devido. O contribuinte responsável, nas sociedades livres, deve cumprir com as suas obrigações fiscais e pagar o tributo devido. Ao "Fisco" o que é do "Fisco", em paródia ao Santo que habitou em nosso meio.

Pois bem, como tem sido a dinâmica jurisprudencial do STF nesse campo? Vejamos alguns casos concretos apreciados pela Suprema Corte brasileira.

No Recurso Extraordinário n. $377.457^{32}$, que versou sobre a validade jurídica da revogação, por meio de lei ordinária, da isenção da COFINS concedida, por meio de lei complementar formal, às sociedades civis de profissão regulamentada, o Tribunal desproveu a pretensão dos contribuintes.

A questão tributária de fundo não oferecia maiores dificuldades, pois a isenção tributária estava concedida por lei complementar formal, mas que era materialmente ordinária. Sendo assim, poderia a lei ordinária revogar a isenção instituída via lei complementar, pois se cuidava de lei formalmente complementar, mas materialmente ordinária. Todavia, havia um ingrediente problemático. É que o Superior Tribunal de Justiça havia editado a Súmula 276 com o seguinte teor: "As sociedades civis de prestação de serviços profissionais são isentas da Cofins, irrelevante o regime tributário adotado".

Ora, havia uma súmula de um Tribunal Superior, daquele é considerado a segunda Corte mais importante do País. Ante esse quadro, foi submetida ao STF a questão da modulação dos efeitos, para que somente a partir do julgamento da questão no STF fosse restabelecida a cobrança do aludido tributo. Era uma questão de segurança tributária. Os contribuintes se fiaram em uma Súmula do STJ e em vários precedentes dessa Corte Superior. É evidente que isso, por si só, seria mais do que suficiente para proteger o contribuinte da retroatividade da decisão do STF. Nada obstante essa situação, o STF entendeu que não era o caso de modular os efeitos de sua decisão e estabeleceu que desde 1996 era devida a COFINS pelas sociedades civis de profissão regulamentada. Esse entendimento enfraqueceu a ideia de segurança e de confiabilidade tributária. Qual a mensagem transmitida pelo STF? Não devem os contribuintes confiar nas decisões pacificadas nos outros tribunais. Esse tipo de mensagem enfraquece as demais instâncias judiciais.

Esse entendimento do Tribunal se fiou em precedente estabelecido no julgamento do Recurso Extraordinário n. $370.682^{33}$, que discutiu o tema do creditamento de IPI dos produtos isentos, não tributados ou

forte apelo aos ideais constitucionais de justiça e de paz, aqui entendida como segurança jurídica.

31 ALVES JR., Luís Carlos Martins. Direito Constitucional Fazendário. Brasília: AGU, 2011.

32 BRASIL. Supremo Tribunal Federal. Recurso Extraordinário n. 377.457. Relator Ministro Gilmar Mendes. Plenário. Julgado em 17.9.2008. Acórdão Publicado em 19.12.2008. EMENTA: Contribuição social sobre o faturamento - COFINS (CF, art. $195, \mathrm{I}) .2$. Revogação pelo art. 56 da Lei 9.430/96 da isenção concedida às sociedades civis de profissão regulamentada pelo art. $6^{\circ}$, II, da Lei Complementar 70/91. Legitimidade. 3. Inexistência de relação hierárquica entre lei ordinária e lei complementar. Questão exclusivamente constitucional, relacionada à distribuição material entre as espécies legais. Precedentes. 4. A LC 70/91 é apenas formalmente complementar, mas materialmente ordinária, com relação aos dispositivos concernentes à contribuição social por ela instituída. ADC 1, Rel. Moreira Alves, RTJ 156/721. 5. Recurso extraordinário conhecido mas negado provimento.

33 BRASIL. Supremo Tribunal Federal. Recurso Extraordinário n. 370.682. Redator Ministro Gilmar Mendes. Plenário. Julgado em 25.6.2007. Acórdão Publicado em 19.12.2007. EMENTA: Recurso extraordinário. Tributário. 2. IPI. Crédito Presumido. Insumos sujeitos à alíquota zero ou não tributados. Inexistência. 3. Os princípios da não-cumulatividade e da seletividade não ensejam direito de crédito presumido de IPI para o contribuinte adquirente de insumos não tributados ou sujeitos à alíquota zero. 4. Recurso 
tributados à alíquota zero, o STF rejeitou a proposta de modulação dos efeitos da declaração de inconstitucionalidade, por entender que a questão apreciada e decidida não cuidou de nova jurisprudência, mas tão somente de reversão de precedente.

Um dos aspectos aduzidos pelo Tribunal, para não conceder a requestada modulação dos efeitos temporais, consistiu na possibilidade de se criarem situações diferenciadas entre os contribuintes, pois alguns pagariam o tributo devido e outros deixariam de pagar, o que maltrataria o postulado da justiça.

No entanto, no julgamento do Recurso Extraordinário n. 556.664 ${ }^{34}$ o Tribunal palmilhou outro caminho. Nesse mencionado julgamento, que decretou a inconstitucionalidade dos artigos 45 e 46 da Lei 8.212/91, no tocante aos prazos prescricionais e decadenciais das contribuições da seguridade social, o Tribunal entendeu que os valores já pagos e que não foram objeto de reivindicação, seja judicial ou administrativa, não deveriam ser devolvidos, de modo que foram considerados legítimos os recolhimentos efetuados em conformidade com os prazos previstos nos citados artigos 45 e 46 da Lei 8.212/91.

Qual a mensagem do Tribunal nesse julgamento? Que todo contribuinte, na dúvida, não deve pagar ou, se pagar, deve discutir o pagamento na esfera judicial ou administrativa. Foi uma decisão provocadora de litigiosidade. Andou bem o STF? No plano de política judiciária, a resposta é negativa, pois o contribuinte se vê na contingência de questionar todo e qualquer tributo e pedir a repetição dos pagamentos feitos.

Além do mais, o Estado não pode invocar as suas deficiências como justificadora do descumprimento de seus deveres. Ou seja, o Estado não pode se beneficiar das situações de modulação de efeitos se acaso ele - o Estado - deu causa para a decretação de inconstitucionalidade. Seria se beneficiar de sua própria "torpeza jurídica". Cuide-se, a bem da verdade, que, não raras vezes, a causa ensejadora da situação que necessita da modulação dos efeitos decorre da demora da prestação jurisdicional. Ou seja, não raras vezes, o responsável é o Poder Judiciário e, em particular, o próprio Supremo Tribunal Federal, quando demora a definir as controvérsias ou quando modifica sem justo motivo a sua jurisprudência. O Judiciário, e o STF em particular, é um dos responsáveis por essa situação de insegurança tributária, quando se demora na definição das controvérsias ou quando hesita na firmeza de sua jurisprudência. Por isso, a despeito das falhas do Estado-legislador ou do Estado-administrador, é preciso reconhecer e apontar as falhas do Estado-juiz.

E no tocante ao plano da Justiça, como o Supremo Tribunal Federal tem decidido? Há decisões declarando a invalidade do tributo, por violação do parâmetro normativo da Justiça? Ou reconhecendo a sua validade por ser justo? Qual a ideia de justiça tributária do STF? A ideia de justiça está intimamente ligada à ideia de igualdade, de isonomia, de equidade, bem como a de capacidade contributiva.

extraordinário provido.

34 BRASIL. Supremo Tribunal Federal. Recurso Extraordinário n. 556.664. Relator Ministro Gilmar Mendes. Plenário. Julgado em 12.6.2008. Acórdão Publicado em 14.11.2008. EMENTA: PRESCRIÇÃO E DECADÊNCIA TRIBUTÁRIAS. MATÉRIAS RESERVADAS A LEI COMPLEMENTAR. DISCIPLINA NO CÓDIGO TRIBUTÁRIO NACIONAL. NATUREZA TRIBUTÁRIA DAS CONTRIBUIÇÕES PARA A SEGURIDADE SOCIAL. INCONSTITUCIONALIDADE DOS ARTS. 45 E 46 DA LEI 8.212/91 E DO PARÁGRAFO ÚNICO DO ART. $5^{\circ}$ DO DECRETO-LEI 1.569/77. RECURSO EXTRAORDINÁRIO NÃO PROVIDO. MODULAÇÃO DOS EFEITOS DA DECLARAÇÃO DE INCONSTITUCIONALIDADE. I. PRESCRIÇÃO E DECADÊNCIA TRIBUTÁRIAS. RESERVA DE LEI COMPLEMENTAR. As normas relativas à prescrição e à decadência tributárias têm natureza de normas gerais de direito tributário, cuja disciplina é reservada a lei complementar, tanto sob a Constituição pretérita (art. 18, \ $1^{\circ}$, da CF de 1967/69) quanto sob a Constituição atual (art. 146, b, III, da CF de 1988). Interpretação que preserva a força normativa da Constituição, que prevê disciplina homogênea, em âmbito nacional, da prescrição, decadência, obrigação e crédito tributários. Permitir regulação distinta sobre esses temas, pelos diversos entes da federação, implicaria prejuízo à vedação de tratamento desigual entre contribuintes em situação equivalente e à segurança jurídica. II. DISCIPLINA PREVISTA NO CÓDIGO TRIBUTÁRIO NACIONAL. O Código Tributário Nacional (Lei 5.172/1966), promulgado como lei ordinária e recebido como lei complementar pelas Constituições de 1967/69 e 1988, disciplina a prescrição e a decadência tributárias. III. NATUREZA TRIBUTARIA DAS CONTRIBUIÇÕES. As contribuições, inclusive as previdenciárias, têm natureza tributária e se submetem ao regime jurídico-tributário previsto na Constituição. Interpretação do art. 149 da CF de 1988. Precedentes. IV. RECURSO EXTRAORDINÁRIO NÃO PROVIDO. Inconstitucionalidade dos arts. 45 e 46 da Lei 8.212/91, por violação do art. 146, III, b, da Constituição de 1988, e do parágrafo único do art. $5^{\circ}$ do Decreto-lei 1.569/77, em face do $\int 1^{\circ}$ do art. 18 da Constituição de 1967/69. V. MODULAC ÁO DOS EFEITOS DA DECIS ÃO. SEGURANÇA JURIDICA. São legítimos os recolbimentos efetuados nos prazos previstos nos arts. 45 e 46 da Lei 8.212/91 e não impugnados antes da data de conclusão deste julgamento. 
Nessa senda, o Supremo Tribunal Federal tem um entendimento que não pode, sob pretexto da justiça ou da igualdade, conceder benefícios fiscais, como sucedeu no julgamento do Recurso Extraordinário n. $405.579^{35}$ que cuidou da extensão às importadoras de pneus dos benefícios concedidos às empresas montadoras.

A mesma fundamentação influenciou a decisão do Tribunal na discussão sobre o tratamento tributário diferenciado do SIMPLES para as microempresas. Cuidava-se, na referida hipótese, do julgamento da Ação Direta de Inconstitucionalidade n. $1.643^{36}$.

No julgamento, ainda que precário da Ação Cautelar n. $1.109^{37}$, a Corte entendeu que não viola a isonomia tributária a sobrecarga fiscal incidente sobre as instituições financeiras, tendo em vista os ditames constitucionais.

No concernente ao imposto de renda das pessoas físicas, o Tribunal decidiu que os contribuintes não têm direito à correção monetária das tabelas, como ocorreu no julgamento do Recurso Extraordinário n. $388.312^{38}$.

35 BRASIL. Supremo Tribunal Federal. Recurso Extraordinário n. 405.579. Relator Ministro Joaquim Barbosa. Plenário. Julgado em 1․12.2010. Acórdão Publicado em 4.8.2011. Ementa: CONSTITUCIONAL. TRIBUTÁRIO. IMPOSTO DE IMPORTAÇÃO. PNEUS. BENEFÍCIO FISCAL. REDUÇÃO DE 40\% DO VALOR DEVIDO NAS OPERAÇÕES REALIZADAS POR MONTADORAS. PEDIDO DE EXTENSÃO A EMPRESA DA ÁREA DE REPOSIÇÃO DE PNEUMÁTICOS POR QUEBRA DA ISONOMIA. IMPOSSIBILIDADE. LEI FEDERAL 10.182/2001. CONSTITUIÇÃO FEDERAL (ARTS. 37 E 150, II). CÓDIGO TRIBUTÁRIO NACIONAL (ART. 111). Sob o pretexto de tornar efetivo o princípio da isonomia tributária, não pode o Poder Judiciário estender benefício fiscal sem que haja previsão legal específica. No caso em exame, a eventual conclusão pela inconstitucionalidade do critério que se entende indevidamente restritivo conduziria à inaplicabilidade integral do benefício fiscal. A extensão do benefício àqueles que não foram expressamente contemplados não poderia ser utilizada para restaurar a igualdade de condições tida por desequilibrada. Precedentes. Recurso extraordinário provido.

36 BRASIL. Supremo Tribunal Federal. Ação Direta de Inconstitucionalidade n. 1.643. Relator Ministro Maurício Corrêa. Plenário. Julgado em 5.12.2002. Acórdão Publicado em 14.3.2003. EMENTA: ACÃO DIRETA DE INCONSTITUCIONALIDADE. SISTEMA INTEGRADO DE PAGAMENTO DE IMPOSTOS E CONTRIBUIÇÕES DAS MICROEMPRESAS E EMPRESAS DE PEQUENO PORTE. CONFEDERAÇÃO NACIONAL DAS PROFISSÕES LIBERAIS. PERTINÊNCIA TEMÁTICA. LEGITIMIDADE ATIVA. PESSOAS JURÍDICAS IMPEDIDAS DE OPTAR PELO REGIME. CONSTITUCIONALIDADE. 1. Há pertinência temática entre os objetivos institucionais da requerente e o inciso XIII do artigo $9^{\circ}$ da Lei 9317/96, uma vez que o pedido visa a defesa dos interesses de profissionais liberais, nada obstante a referência a pessoas jurídicas prestadoras de serviços. 2. Legitimidade ativa da Confederação. O Decreto de 27/05/54 reconhece-a como entidade sindical de grau superior, coordenadora dos interesses das profissões liberais em todo o território nacional. Precedente. 3. Por disposição constitucional (CF, artigo 179), as microempresas e as empresas de pequeno porte devem ser beneficiadas, nos termos da lei , pela "simplificação de suas obrigações administrativas, tributárias, previdenciárias e creditícias, ou pela eliminação ou redução destas” (CF, artigo 179). 4. Não há ofensa ao princípio da isonomia tributária se a lei, por motivos extrafiscais, imprime tratamento desigual a microempresas e empresas de pequeno porte de capacidade contributiva distinta, afastando do regime do SIMPLES aquelas cujos sócios têm condição de disputar o mercado de trabalho sem assistência do Estado. Ação direta de inconstitucionalidade julgada improcedente.

37 BRASIL. Supremo Tribunal Federal. Ação Cautelar n. 1.109. Redator Ministro Ayres Britto. Plenário. Julgado em 31.5.2007. Acórdão publicado em 19.10.2007. EMENTA: PROCESSO CIVIL. MEDIDA CAUTELAR. EFEITO SUSPENSIVO A RECURSO EXTRAORDINÁRIO. INSTITUIÇÃO FINANCEIRA. CONTRIBUIÇÃO PREVIDENCIÁRIA SOBRE A FOLHA DE SALÁRIOS. ADICIONAL. \ $1^{\circ}$ DO ART. 22 DA LEI No 8.212/91. A sobrecarga imposta aos bancos comerciais e às entidades financeiras, no tocante à contribuição previdenciária sobre a folha de salários, não fere, à primeira vista, o princípio da isonomia tributária, ante a expressa previsão constitucional (Emenda de Revisão n ${ }^{\circ} 1 / 94$ e Emenda Constitucional n ${ }^{\circ} 20 / 98$, que inseriu o $\ 9^{\circ}$ no art. 195 do Texto permanente). Liminar a que se nega referendo. Processo extinto.

38 BRASIL. Supremo Tribunal Federal. Recurso Extraordinário n. 388.312. Redatora Ministra Cármen Lúcia. Plenário. Julgado em 1․8.2011. Acórdão publicado em 11.10.2011. EMENTA: RECURSO EXTRAORDINÁRIO. DIREITO CONSTITUCIONAL E ECONÔMICO. CORREÇÃO MONETÁRIA DAS TABELAS DO IMPOSTO DE RENDA. LEI N. 9.250/1995. NECESSIDADE DE LEI COMPLEMENTAR E CONTRARIEDADE AOS PRINCÍPIOS DA CAPACIDADE CONTRIBUTIVA E DO NÃO CONFISCO. RECURSO CONHECIDO EM PARTE E, NA PARTE CONHECIDA, A ELE NEGADO PROVIMENTO. 1. Ausência de prequestionamento quanto à alegação de inconstitucionalidade formal da Lei n. 9.250/1995 por contrariedade ao art. 146, inc. III, alínea a, da Constituição da República. 2. A vedação constitucional de tributo confiscatório e a necessidade de se observar o princípio da capacidade contributiva são questões cuja análise dependem da situação individual do contribuinte, principalmente em razão da possibilidade de se proceder a deduções fiscais, como se dá no imposto sobre a renda. Precedentes. 3. Conforme jurisprudência reiterada deste Supremo Tribunal Federal, não cabe ao Poder Judiciário autorizar a correção monetária da tabela progressiva do imposto de renda na ausência de previsão legal nesse sentido. Entendimento cujo fundamento é o uso regular do poder estatal de organizar a vida econômica e financeira do país no espaço próprio das competências dos Poderes Executivo e 
Ainda em relação ao Imposto de Renda Pessoa Física, o Tribunal tem uma jurisprudência defensiva, no sentido de não conhecer, a questão das limitações normativas dos valores despendidos com educação, sob o entendimento de cuidar-se de matéria infraconstitucional e que se cuidaria da hipótese de o Judiciário atuar como legislador "positivo", como se vê no julgamento do Agravo de Instrumento n. $724.817^{39}$.

Nada obstante essa jurisprudência defensiva, o STF deverá se manifestar novamente e diretamente sobre esse tema, em face da decisão da Corte Especial do TRF da $3^{a}$ Região que declarou inconstitucional a limitação aos valores gastos com educação na dedução da base de cálculo do IRPF, sob a justificativa de que essas limitações ferem direitos fundamentais individuais e sociais. Essa aludida decisão do TRF3 foi tomada nos autos da Arguição de Inconstitucionalidade n. 0005067-86.2002.4.03.6100, Processo n. 2002.61.00.005067$0^{40}$.

Cuide-se que o Conselho Federal da Ordem dos Advogados do Brasil ajuizou a Ação Direta de Inconstitucionalidade n. $4.927,{ }^{41}$ postulando a decretação da inconstitucionalidade dos preceitos normativos que limitam

Legislativo. 4. Recurso extraordinário conhecido em parte e, na parte conhecida, a ele negado provimento.

39 BRASIL. Supremo Tribunal Federal. Agravo de Instrumento n. 724.817. Relator Ministro Dias Toffoli. Primeira Turma. Julgado em 7.2.2012. Acórdão publicado em 9.3.2012. EMENTA Agravo regimental no agravo de instrumento. IRPF. Lei no 9.250/95. Limitações à dedução com despesas para educação. Ofensa reflexa. Impossibilidade de atuação do judiciário como legislador positivo. Precedentes desta Corte. 1. A discussão relativa à limitação da dedução, na declaração de ajuste anual do imposto de renda, dos valores pagos a título de educação, na forma da Lei $n^{\circ}$ 9.250/95, insere-se no âmbito infraconstitucional, sendo certo, ainda, que eventual ofensa à Constituição, caso ocorresse, dar-se-ia de forma reflexa ou indireta. Precedentes desta Corte. 2. Impossibilidade do Poder Judiciário atuar como legislador positivo para estabelecer isenções, reduções de tributos e deduções de despesas da base de cálculo. Tais hipóteses são sempre dependentes de lei que as preveja. 3. As alegações deduzidas no agravo são insuficientes para infirmar a fundamentação que ampara a decisão agravada, a qual se encontra em sintonia com a orientação jurisprudencial deste Supremo Tribunal Federal. 4. Agravo regimental não provido.

40 BRASIL. Tribunal Regional Federal da 3a Região. Arguição de Inconstitucionalidade Cível n. 0005067-86.2002.4.03.6100 SP, Processo n. 2002.61.00.005067-0 SP. Relator Desembargador Federal Mairan Maia. Órgão Especial. Julgado em 28.3.2012. Acórdão publicado em 14.5.2012. Ementa: CONSTITUCIONAL. TRIBUTÁRIO. IMPOSTO DE RENDA. PESSOA FÍSICA. LIMITES À DEDUÇÃO DAS DESPESAS COM INSTRUÇÃO. ARGUIÇÃO DE INCONSTITUCIONALIDADE. ART. 8, II, "B”, DA LEI No 9.250/95. EDUCAÇÃO. DIREITO SOCIAL FUNDAMENTAL. DEVER JURÍDICO DO ESTADO DE PROMOVÊ-LA E PRESTÁ-LA. DIREITO PÚBLICO SUBJETIVO. NÃO TRIBUTAÇÃO DAS VERBAS DESPENDIDAS COM EDUCAÇÃO. MEDIDA CONCRETIZADORA DE DIRETRIZ PRIMORDIAL DELINEADA PELO CONSTITUINTE ORIGINÁRIO. A INCIDÊNCIA DO IMPOSTO SOBRE GASTOS COM EDUCAÇÃO VULNERA O CONCEITO CONSTITUCIONAL DE RENDA E O PRINCÍPIO DA CAPACIDADE CONTRIBUTIVA. 1. Arguição de inconstitucionalidade suscitada pela e. Sexta Turma desta Corte em sede de apelação em mandado de segurança impetrado com a finalidade de garantir o direito à dedução integral dos gastos com educação na Declaração de Ajuste Anual do Imposto de Renda Pessoa Física de 2002, ano-base 2001. 2. Possibilidade de submissão da quaestio juris a este colegiado, ante a inexistência de pronunciamento do Plenário do STF, tampouco do Pleno ou do Órgão Especial desta Corte, acerca da questão. 3.O reconhecimento da inconstitucionalidade da norma afastando sua aplicabilidade não configura por parte do Poder Judiciário atuação como legislador positivo. Necessidade de o Judiciário - no exercício de sua típica função, qual seja, averiguar a conformidade do dispositivo impugnado com a ordem constitucional vigente - manifestar-se sobre a compatibilidade da norma impugnada com os direitos fundamentais constitucionalmente assegurados. Compete também ao poder Judiciário verificar os limites de atuação do Poder Legislativo no tocante ao exercício de competências tributárias impositivas. 4. A CF confere especial destaque a esse direito social fundamental, prescrevendo o dever jurídico do Estado de prestá-la e alçando-a à categoria de direito público subjetivo. 5. A educação constitui elemento imprescindível ao pleno desenvolvimento da pessoa, ao exercício da cidadania e à livre determinação do indivíduo, estando em estreita relação com os primados basilares da República Federativa e do Estado Democrático de Direito, sobretudo com o princípio da dignidade da pessoa humana. Atua como verdadeiro pressuposto para a concreção de outros direitos fundamentais. 6 . A imposição de limites ao abatimento das quantias gastas pelos contribuintes com educação resulta na incidência de tributos sobre despesas de natureza essencial à sobrevivência do indivíduo, a teor do art. $7^{\circ}, \mathrm{IV}, \mathrm{da} \mathrm{CF}$, e obstaculiza o exercício desse direito. 7. Na medida em que o Estado não arca com seu dever de disponibilizar ensino público gratuito a toda população, mediante a implementação de condições materiais e de prestações positivas que assegurem a efetiva fruição desse direito, deve, ao menos, fomentar e facilitar o acesso à educação, abstendo-se de agredir, por meio da tributação, a esfera jurídico-patrimonial dos cidadãos na parte empenhada para efetivar e concretizar o direito fundamental à educação.8. A incidência do imposto de renda sobre despesas com educação vulnera o conceito constitucional de renda, bem como o princípio da capacidade contributiva, expressamente previsto no texto constitucional. 9. A desoneração tributária das verbas despendidas com instrução configura medida concretizadora de objetivo primordial traçado pela Carta Cidadã, a qual erigiu a educação como um dos valores fundamentais e basilares da República Federativa do Brasil. 10. Arguição julgada procedente para declarar a inconstitucionalidade da expressão "até o limite anual individual de R \$1.700,00 (um mil e setecentos reais)" contida no art. $8^{\circ}$, II, "b”, da Lei $n^{\circ} 9.250 / 95$.

41 BRASIL, Supremo Tribunal Federal. Ação Direta de Inconstitucionalidade n. 4.927. Relatora Ministra Rosa Weber. Requerente: Conselho Federal da Ordem dos Advogados do Brasil. Requeridos: Presidente da República e Congresso Nacional, 2013. 
os valores gastos com educação na dedução da base de cálculo do IRPF. Será uma grande oportunidade para o STF enfrentar a questão do valor normativo da educação.

À luz dos precedentes do Supremo Tribunal Federal, e da perspectiva de que para a Corte não é dado ao Judiciário, em matéria tributária, inovar o ordenamento jurídico como legislador positivo, a expectativa é no sentido da reforma do acórdão recorrido do TRF 3 e da improcedência do pedido da referida ADI 4.927. Mas, haja vista o posicionamento da Corte em outras matérias, com uma postura ativista em nome da dignidade da pessoa humana, não será um espanto se o STF chancelar a decisão do TRF 3 e julgar procedente o pedido da OAB.

Com efeito, a $1^{\text {a }}$ Turma do STF, no RE $202.149^{42}$, estendeu às máquinas gráficas a imunidade concedida ao papel, contida no art. 150, inciso VI, alínea “d”, CF. Essa decisão supera jurisprudência da Corte ${ }^{43}$, inclusive sumulada (Súmula 657/STF: “[...] a imunidade prevista no art. 150, VI, d, CF, abrange os filmes e papéis fotográficos necessários à publicação de jornais e periódicos”.

\section{Considerações finais}

A depender do prisma que se enxerguem as decisões da Corte, pode-se dizer que o Supremo Tribunal Federal tem cometido algumas falhas em sua missão constitucional de viabilizar a justiça fiscal e de consolidar a segurança tributária.

Segundo a crítica exposta em várias teses jurídico-acadêmicas, ${ }^{44} 454647$ o Supremo Tribunal Federal tem tomado decisões fiscalmente injustas e que trazem insegurança tributária para os contribuintes. E essas decisões afetam a credibilidade institucional da Corte e quebram a confiança no sistema jurídico-tributário.

O STF, em seus julgamentos, deve discernir as situações nas quais o tributo é constitucionalmente válido, permitindo a sua cobrança, e que saiba proteger o contribuinte nas hipóteses de o Estado extrapolar dos rigorosos limites dos mandamentos da Constituição.

O tributo há de ser legalmente devido e moralmente justo. O tributo há de ser uma contraprestação legítima do contribuinte ao Estado, pelos seus gastos e despesas. Do contrário, vale a advertência de Proudhon acerca do que é ser governado pelo Estado:

Ser governado significa ser vigiado, inspecionado, espionado, dirigido, legiferado, numerado, regulado, recrutado, doutrinado, catequizado, controlado, conferido, avaliado, aquilatado, censurado e comandado por criaturas que não têm o direito, nem a sabedoria, tampouco a virtude para tal. Ser governado significa ter todas as suas atividades e transações observadas, registradas, computadas, tributadas, timbradas, medidas, numeradas, calculadas, licenciadas, autorizadas, admoestadas, obstruídas, proibidas, emendadas, corrigidas e punidas. Significa, a pretexto da utilidade pública e em nome do interesse geral, ser coagido a contribuir, disciplinado, depenado, explorado, monopolizado, extorquido, oprimido, lesado e roubado; depois, à menor resistência, à primeira palavra de reclamação, ser reprimido, multado, difamado, perseguido,

42 BRASIL, Supremo Tribunal Federal. Recurso Extraordinário n. 202.149. Redator Ministro Marco Aurélio. Recorrente: União Federal. Recorrido: Grupo Editorial Sinos S/A. Ementa do acórdão: CONSTITUIÇÃO FEDERAL. Extraia-se da Constituição Federal, em interpretação teleológica e integrativa, a maior concretude possível. IMUNIDADE - "LIVROS, JORNAIS, PERIÓDICOS E O PAPEL DESTINADO A SUA IMPRESSÃO” - ARTIGO 150, INCISO VI, ALÍNEA “D”, DA CARTA DA REPÚBLICA - INTELIGÊNCIA. A imunidade tributária relativa a livros, jornais e periódicos é ampla, total, apanhando produto, maquinário e insumos. A referência, no preceito, a papel é exemplificativa e não exaustiva.

43 RREE 204.234, 174.476, 190.761, 207.462, 212.112, 190.700, 212.297, 203.706, 238.570 e 203.859.

44 ANDRADE, Fábio Martins de. Modulação em matéria tributária: o argumento pragmático ou consequencialista de cunho econômico e as decisões do STF. São Paulo: Quartier Latin, 2011.

45 ÁVILA, Humberto. Segurança jurídica: entre permanência, mudança e realização no direito tributário. São Paulo: Malheiros, 2011.

46 DERZI, Misabel Abreu Machado. Modificações da jurisprudência no direito tributário: proteção da confiança, boa-fé objetiva e irretroatividade como limitações constitucionais ao Poder Judicial de Tributar. São Paulo: Noeses, 2009.

47 TORRES, Heleno Taveira. Direito constitucional tributário e segurança jurídica: metódica da segurança jurídica do sistema constitucional tributário. São Paulo: Revista dos Tribunais, 2012. 
caçado, maltratado, espancado, desarmado, amarrado, estrangulado, aprisionado, julgado, condenado, fuzilado, deportado, sacrificado, vendido e traído; e, para coroar tudo isso, ser objeto de escárnio, ridículo, zombaria, injúria e desonra. Isso é governo; isso é justiça; isso é moralidade.

\section{REFERÊNCIAS}

ALVES JR., Luís Carlos Martins. Direito Constitucional Fazendário. Brasília: AGU, 2011.

ANDRADE, Fábio Martins de. Modulação em matéria tributária: o argumento pragmático ou consequencialista de cunho econômico e as decisões do STF. São Paulo: Quartier Latin, 2011.

ÁVILA, Humberto. Segurança jurídica: entre permanência, mudança e realização no direito tributário. São Paulo: Malheiros, 2011.

BALEEIRO, Aliomar. Limitacõos constitucionais ao poder de limitar. 7. ed. Atualizada por Misabel Abreu Machado Derzi. Rio de Janeiro: Forense, 2005.

BRASIL. Supremo Tribunal Federal. Ação Cautelar n. 1.109. Redator Ministro Ayres Britto. Plenário. Julgado em 31.5.2007.

BRASIL. Supremo Tribunal Federal. Ação Direta de Inconstitucionalidade n. 1.643. Relator Ministro Maurício Corrêa. Plenário. Julgado em 5.12.2002.

BRASIL. Supremo Tribunal Federal. Ação Direta de Inconstitucionalidade n. 4.927. Relatora Ministra Rosa Weber. Requerente: Conselho Federal da Ordem dos Advogados do Brasil. Requeridos: Presidente da República e Congresso Nacional, 2013.

BRASIL. Supremo Tribunal Federal. Agravo de Instrumento n. 724.817. Relator Ministro Dias Toffoli. Primeira Turma. Julgado em 7.2.2012.

BRASIL. Supremo Tribunal Federal. Agravo em Recurso Extraordinário n. 639.337. Relator Ministro Celso de Mello. Julgamento em 23.8.2011.

BRASIL. Supremo Tribunal Federal. Recurso Extraordinário n. 202.149. Redator Ministro Marco Aurélio. Recorrente: União Federal. Recorrido: Grupo Editorial Sinos S/A.

BRASIL. Supremo Tribunal Federal. Recurso Extraordinário n. 370.682. Redator Ministro Gilmar Mendes. Plenário. Julgado em 25.6.2007.

BRASIL. Supremo Tribunal Federal. Recurso Extraordinário n. 377.457. Relator Ministro Gilmar Mendes. Plenário. Julgado em 17.9.2008.

BRASIL. Supremo Tribunal Federal. Recurso Extraordinário n. 388.312. Redatora Ministra Cármen Lúcia. Plenário. Julgado em $1^{\circ}$. 8.2011.

BRASIL. Supremo Tribunal Federal. Recurso Extraordinário n. 405.579. Relator Ministro Joaquim Barbosa. Plenário. Julgado em $1^{\circ}$. 12.2010.

BRASIL. Supremo Tribunal Federal. Recurso Extraordinário n. 556.664. Relator Ministro Gilmar Mendes. Plenário. Julgado em 12.6.2008.

BRASIL. Tribunal Regional Federal da $3^{\mathrm{a}}$ Região. Arguição de Inconstitucionalidade Civel n. 000506786.2002.4.03.6100 SP, Processo n. 2002.61.00.005067-0 SP. Relator Desembargador Federal Mairan Maia. Órgão Especial. Julgado em 28.3.2012.

COELHO, Sacha Calmon Navarro. Curso de direito tributário brasileiro. 8. ed. Rio de Janeiro: Forense, 2005.

DARWIN, Charles. A origem das espécies. Trad. John Green. São Paulo: Martin Claret, 2004. 
DERZI, Misabel Abreu Machado. Modificações da jurisprudência no direito tributário: proteção da confiança, boa-fé objetiva e irretroatividade como limitações constitucionais ao Poder Judicial de Tributar. São Paulo: Noeses, 2009.

GALDINO, Flavio. Introducão à teoria dos custos dos direitos: direitos não nascem em árvores. Rio de Janeiro: Lumen Juris, 2005.

GODOY, Arnaldo. Os custos dos direitos. Embargos Culturais. Revista Consultor Jurídico, São Paulo, 2013. Disponível em: <www.conjur.com.br >. Acesso em 19.10.2013.

HOLMES, Stephen, SUNSTEIN, Cass. The Cost of Rights: Why Liberty Depends on Taxes. New York: W. Norton \& Company, 2000.

LUHMANN, Niklas. Introdução à teoria dos sistemas. Trad. Ana Cristina Arantes Nasser. Rio de Janeiro: Vozes, 2009.

NABAIS, José Casalta. O dever fundamental de pagar impostos: contributo para a compreensão constitucional do estado fiscal contemporâneo. Coimbra: Almedina, 1998.

RAWLS, John. Uma teoria da justiça. Trad. Almiro Piseta; Lenita Esteves. São Paulo: Martins Fontes, 2000.

TIPKE, Klaus. Moral tributária do Estado e dos contribuintes. Trad. Luiz Dória Furquim. Porto Alegre: Sergio Antonio Fabriz, 2012.

TORRES, Heleno Taveira. Direito constitucional tributário e segurança jurídica: metódica da segurança jurídica do sistema constitucional tributário. São Paulo: Revista dos Tribunais, 2012. 


\section{REVISTA BRASILEIRA DE POLÍTICAS PÚBLICAS BRAZILIAN JOURNAL OF PUBLIC POLICY}
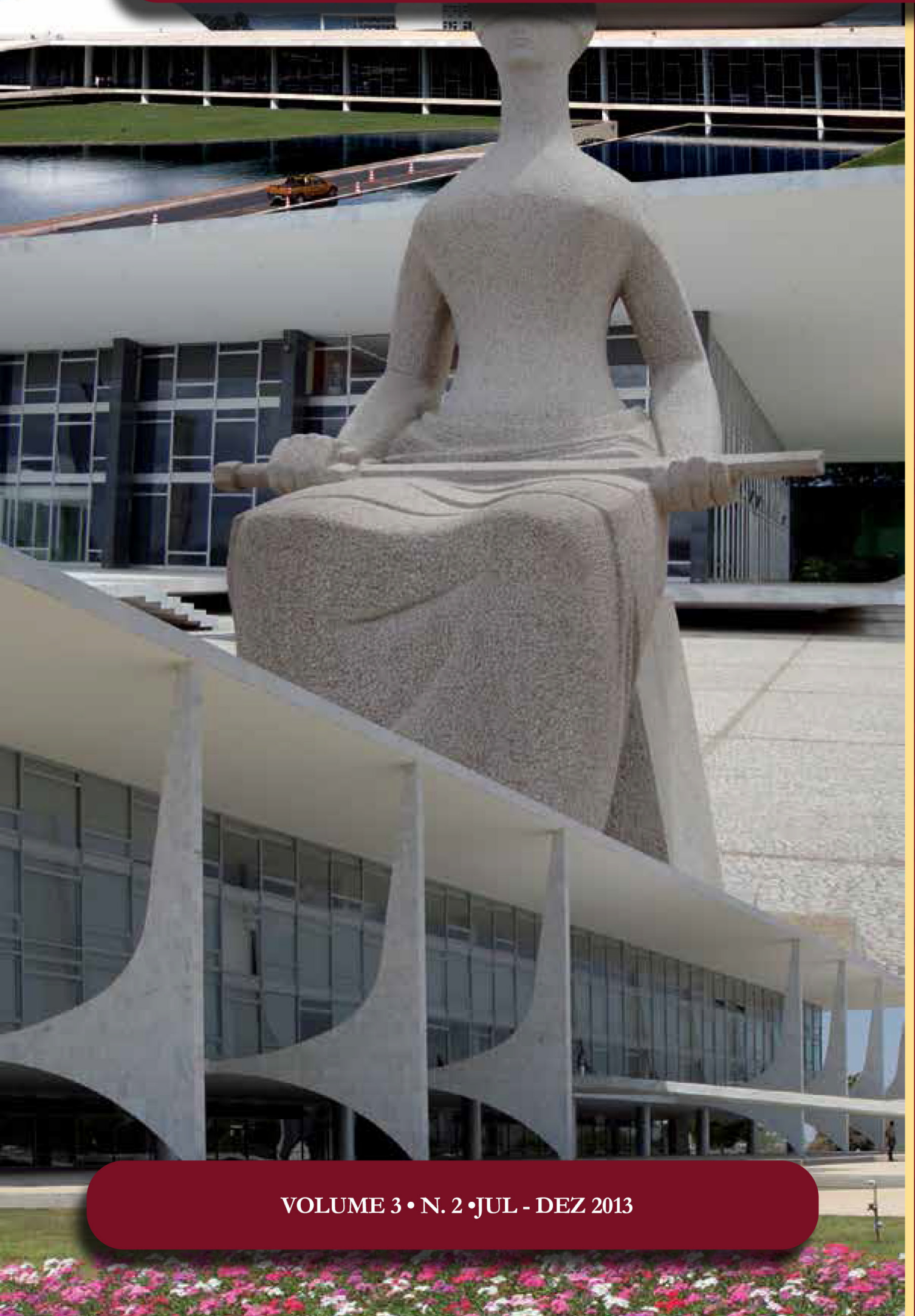

Federalismo, estado federalista e a revalorização do município: um novo caminho para o século $\mathrm{XXI}$ ?

Federalism, federalist state and the municipality reapreciation: a new path to the 21 th century?

Antonio Celso Batista Minhoto 


\title{
Federalismo, estado federalista e a revalorização do município: um novo caminho para o século XXI?
}

\section{Federalism, federalist state and the municipality reapreciation: a new path to the 21 th century ** $^{*}$}

Antonio Celso Batista Minhoto**

\begin{abstract}
The federalist ideal is admired since many years. It's a model that, in its theory, brings unit and autonomy at the same time for any kind of state. But, all long from the modern human history, we can see changes in this model, that, sometimes, represented more centralization and autonomy lose. Brasil adopted the federal state model in 1889, within the Republic movement, but, until today, this model suffers the consequences of cultural and political values linked with the time when Brasil was a colonie and, further, an imperium.
\end{abstract}

Keywords: Federalism. Autonomy. Centralization. Society organization. Brazilian municipality.

\section{Resumo}

O ideal federalista é admirado desde há muito tempo. É um modelo que, em teoria, traz unidade e autonomia ao mesmo tempo para qualquer tipo de Estado. Mas, ao longo da moderna história humana, podemos ver modificações nesse modelo que, algumas vezes, representaram maior centralização e perda de autonomia. O Brasil adotou o modelo federal em 1889, com o advento da República, mas até hoje se ressente de vários aspectos culturais e políticos afetos à fase de Colônia e Império, aspectos centralizadores.

Palavras-chave: Federalismo. Autonomia. Centralização. Organização da sociedade. Município brasileiro.

* Recebido em 26/02/2013 Aprovado em 14/05/2013

** Doutor em Direitos Fundamentais; Mestre em Direito Político e Economico; Bacharel em Direito; Professor Titular na area de Direito Público na USCS (São Caetano do Sul); Professor Titular do Programa de Mestrado da Universidade de Marilia. Email: antonio@baetaminhoto.com.br

\section{INTRODUÇão}

Nota-se na Europa, especialmente, mas não exclusivamente, certa retomada dos ideais federais ou, ainda, dos ideais que inspiraram a formação ou a criação do Estado federal, transformando-o naquela que é talvez a forma mais bem sucedida de Estado.

Junto com esse reavivamento do federalismo, ou até provavelmente em razão dele, se nota do mesmo modo uma valorização crescente da vida co- 
munitária mais descentralizada, vale dizer aquela vivida na cidade, organizada politicamente como município, o que, a nosso ver, atrai uma visão mais aproximada sobre tais aspectos e como o Estado de Direito pode se inserir nesse contexto.

Inicialmente, tem-se uma visão histórica e conceitual sobre o Estado federal, indicando suas características e sua evolução ao longo da história moderna do Estado. Desenvolvida essa parte, pontua-se acerca da revalorização do federalismo, do município, da vida comunitária e de como isso pode se desdobrar futuramente, a partir de exemplos atuais.

O campo de estudo delineado contempla vários aspectos do federalismo. Contudo, cumpre notar, já de plano, como sendo a ocupação primeira a análise do papel do federalismo na atualidade, no panorama mundial, e não só no tocante ao aspecto estritamente jurídico ou político, mas na busca de demonstrar outros itens surgidos de tal análise, notadamente as diversas implicações sociais ligadas ao tema do federalismo, tudo isso sem perder de vista o necessário e inicial viés histórico do objeto de estudo, tomando por base originária, porém, o Estado federal nascido ou criado pela Constituição Norte-Americana de 1789.

\section{Histórico E CARActerísticas}

É de notório saber que o federalismo é apontado, por vários doutrinadores e teóricos, como a forma ideal de Estado. ${ }^{1}$ Mais à frente, serão analisadas algumas características que supostamente fazem do federalismo um modelo a ser seguido, na visão de muitos. No momento, muito embora não seja aqui o escopo central de estudo, tem-se uma primeira indagação: levando-se em conta que a confederação é hoje, como forma de Estado, mero registro histórico e que os estados organizados na forma unitária estão já há tempos se descentralizando cada vez mais, aproximando-se de forma marcante da forma estatal federal, por que o federalismo conquistou, e isso não há como negar, essa posição próxima de uma quase unanimidade, quando se discute formas de Estado?

A resposta para essa questão parece repousar em dois aspectos: capacidade de adaptação (flexibilidade ou mesmo elasticidade) e ausência de opcôes viáveis. De fato, nenhuma outra forma estatal apresenta a adaptabilidade do federalismo, ensejando até mesmo a confecção de diversos tipos ou modelos de federalismo ao redor do mundo, ou seja, o norte-americano, o alemão, o suíço, o soviético, o canadense, o brasileiro, o mexicano e outros mais que, cada qual à sua maneira, trataram de promover modificações personalistas de acordo com seus traços característicos ou peculiares, mantendo apenas os matizes mais marcantes e essenciais do sistema federal, tais como repartição de competências e autonomia constitucional dos Estados-membros, por exemplo. ${ }^{2}$

Aliás, e nesse particular, a Federação Suíça é sempre citada quando se trata de trazer exemplos de uma aplicação bastante particularizada do sistema federativo. Como é notório, a Suíça possui regiões rigidamente demarcadas, os chamados cantões, sendo esses, por sua vez, agrupados em regiões maiores, possuindo cada uma delas sua própria língua (italiano, alemão, francês e romanche) e, claro, sua própria cultura e costumes.

Em decorrência dessa valorização da localidade, da regionalidade, algo expresso, especialmente em termos culturais, é o suíço reconhecidamente como um ser local ou, pelo menos, regional por excelência. A vida local/regional é de vital importância ao suíço.

Para o suíço, portanto, ter um Estado federal "é muito mais a afirmação da autonomia cantonal frente ao poder central, que a integraşão dos cantões num Estado Federativo". ${ }^{3}$ Nesse passo, a Suíça dispõe, inclusive, de instrumen-

1 TOCQUEVILLE, Alexis de. A democracia na América. São Paulo: Martins Fontes, 1998. p. 182; RUSSOMANO, Rosah. O princípio do federalismo na constituição brasileira. Rio de Janeiro: Livraria Freitas Bastos, 1965. p. 20; e CAVALCANTI, Amaro. Regimen federativo e a republica brasileira. Rio de Janeiro: Imprensa Nacional, 1900. p. 119-125.

2 HORTA, Raul Machado. Estudos de direito constitucional. Belo Horizonte: Del Rey, 1995. p. 348.

3 GARCIA, Alberto Barrena. El federalismo em Suiza. Madrid: Coleccion Inst. Politicas, 1970. p. 43. 
tos legislativos com poder de adição à Constituição Federal, os denominados "decretos federais de alcance geral" que, por seu turno, podem ser promulgados até mesmo em dissonância ou clara divergência com o texto constitucional federal, bastando, para tanto, que a matéria seja considerada urgente. ${ }^{4}$

O suíço, desse modo, vive sob um sistema federativo, mas de tal modo modificado que findou por criar um sistema profundamente particularizado, não obstante siga sendo uma federação. Essa flexibilidade do federalismo, essa elasticidade, permitindo uma adaptação praticamente casuística, transmite muito de sua força e de seu prestígio como forma estatal.

Com relação à acima alegada falta de opções viáveis, vê-se que, muito embora existam exemplos históricos do Estado unitário até mesmo na época moderna - Brasil Imperial -, ainda hoje se têm exemplos de Estados ditos por alguns como Unitários Descentralizados ${ }^{5}$ (Espanha, Itália e Portugal), estes sequer podem ser vistos como sendo possuidores da centralização típica dos Estados Unitários antigos, exibindo, bem ao revés, uma unidade estatal descentralizada em regiões - daí sua denominação de Estado Regional por alguns autores $^{6}$ - francamente inspirada no federalismo.

Pode-se ver, por outro lado, que a confederação "é atualmente uma referência histórica, pois já encerrou sua trajetória no domínio da organização dos Estados," razão pela qual se pode constatar, finalmente, que também por esse aspecto conseguiu o federalismo se impor num âmbito mundial, ao menos no mundo ocidental.

Portanto, e como visto acima, o desenvolver da história foi algo bastante contributivo na consolidação do federalismo como forma de Estado. Se, porém, resta evidente que o Estado federalista se impôs com largo auxílio da proverbial ausência de outras opções viáveis na marcha da história, não menos evidente configura-se a constatação de que as qualidades dessa forma estatal foram decisivas para consolidar sua posição de hegemonia.

Amaro Cavalcanti, em obra do começo do Século XX sobre o federalismo, listou as qualidades que entendia estarem presentes no federalismo: a) melhor aceitação das diversidades regionais; b) repartição do progresso; c) a federação dificulta o despotismo; d) Estados-membros naturais e geograficamente isolados se veem capazes de se integrarem a um todo maior; e) a repartição do poder com o estado-membro alivia a carga do poder federal e prestigia a participação daquele na vida nacional; f) a repartição do poder federal com o estado-membro estimula o povo, mais próximo a este último, a participar da vida política do país. ${ }^{8}$

Essas qualidades, nada obstante, devem ser vistas cum grano salis. A ideia de que o federalismo poderia ser uma espécie de anteparo ao despotismo parece ser algo exagerado e uma idiossincrasia do autor mencionado. Regimes de fundo totalitário, como a Alemanha de Hitler, a União Soviética de Stalin e a Itália de Mussolini, surgiram em ambientes ao menos razoavelmente descentralizados, muito embora tenham experimentado depois, é fato, um processo de atomização.

Também a questão da maior participação política do povo nos negócios do Estado, por ser este organizado como uma federação, traduz simples expectativa, mera projeção. A lógica faz supor que se valorizando o interesse local ou regional ter-se-á um interesse maior da população em tratar de tais interesses, mais próximos de sua realidade, mas não há dados concretos que suportem essa concepção.

Precisa-se ainda tratar com a justiça devida as reflexões de Amaro Cavalcanti, pois ele também elenca as potenciais falhas do federalismo. Deveras, o fato de que o Estado federal tenha se tornado uma forma de estado inspiradora não o coloca como um sistema livre de inconvenientes, desvantagens ou falhas que, de um modo ou outro, podem vir à tona e comprometer sua essencial unidade. E essas, segundo Cavalcanti,

4 GARCÍA, Alberto Barrena. El federalismo em Suiza. Madrid: Coleccion Inst. Politicas, 1970. p. 49-50.

5 HORTA, Raul Machado. Estudos de direito constitucional. Belo Horizonte: Del Rey, 1995. p. 361.

RAMOS, Dircêo Torrecillas. O federalismo assimétrico. São Paulo: EDUSP, 1997. p. 30-31.

HORTA, Raul Machado. Estudos de direito constitucional. Belo Horizonte: Del Rey, 1995. p. 345.

8 CAVALCANTI, Amaro. Regimen federativo e a republica brasileira. Rio de Janeiro: Imprensa Nacional, 1900. p. $119-125$. 
são: a) enfraquecimento do poder central; b) constante possibilidade de dissolução; c) falta de uniformidade na legislação e na administração; d) enfraquecimento internacional do estado; e) necessidade vital de identidade cultural (latu sensu). ${ }^{?}$

Também aqui a parcimônia deve guiar a análise. A experiência mostra que um dos maiores desafios do federalismo não é exatamente o de se gerar um poder central fraco, mas, ao contrário, de gestar um que seja forte demais. O Brasil é sempre citado neste particular eis que a União (o poder central no Brasil), de fato, possui vasto rol de competências dispostas na Constituição Federal, tornando-a titular de expressiva parcela do poder estatal.

A possibilidade constante de dissolução também não parece ser uma ameaça concreta ao Estado federal, a ponto de se ver nisso uma "falha". Evidentemente observam-se dissoluções estatais aqui e ali ao longo da história. Mas não parece ser correto debitar tais situações, mesmo que de modo parcial, à organização do estado na forma de uma federação. Outros elementos atuam de modo mais pungente, como a cultura, os costumes, a tradição e os desejos de independência reprimidos no passado, às vezes, com profunda violência.

Na verdade, um aspecto que deve ser levado em conta na disseminação do federalismo é sua aplicação em solo norte-americano. De fato, uma análise mais acurada da história mostra como grande propulsor do federalismo moderno a nação considerada como sua criadora, os Estados Unidos da América (EUA).

A Inglaterra praticamente instituiu, já em meados da Idade Moderna, a ideia então ainda inaplicada na época de um Estado Liberal. Essa ideia, como se sabe, desenvolveu-se largamente ao longo de várias dezenas de anos, atingindo seu ápice aplicativo em fins do Século XVIII, conjuntamente aos movimentos revolucionários observados na França e nos EUA.

Esse modelo estatal trazia em sua essência os ideais de repartição de poder, mas, principalmente, os instrumentos de limitação desse mesmo poder, aspectos de relevo numa Europa já bastante desgastada pelos regimes absolutistas. O liberalismo era visto como o único meio ou a única alternativa a essa situação, porque "o estado liberal se caracteriza como um estado de direito, fundado não mais somente na vontade do soberano (que não reconhece superiores), mas na supremacia da le?". ${ }^{10}$

A lei passava a ser o grande instrumento regulador do Poder, regulador de fato, porque obviamente a lei existia antes do liberalismo, mas com muito mais acanhamento aplicativo e com muito menos prestígio. Nesse ambiente, surgem a independência e a constituição federalista norte-americanas, contemplando todos os valores liberais e as esperanças naturalmente depositadas pelos habitantes do novo mundo, esperanças também alimentadas pelo continente europeu.

Miquel Caminal ${ }^{11}$ ressalta que o federalismo europeu teve suas origens fundadas em dois marcos teóricos radicalmente distintos, quais sejam: as teorias federalistas influenciadas pela poliarquia medieval que defendia um equilíbrio territorial dos poderes frente à soberania absoluta do Estado, desde Althusis e até Montesquieu; e as teorias federalistas baseadas na soberania do indivíduo frente à soberania do Estado-nação, partidárias da divisão territorial do poder e da subordinação da autoridade central às partes federadas, teses de Pi y Margall e Proudhon.

Os dois fundamentos teóricos tinham como pontos coincidentes a vigorosa crítica ao Estado absoluto e a necessidade de dividir e compartilhar a soberania e foram superados pelos ventos nacionalistas dos Séculos XIX e XX, que trouxeram o ideal do paradigma federativo como modelo dominante de um Estado nacional.

Ainda segundo Miquel Caminal, a implantação de um Estado nacional nas repúblicas do Novo Mundo não tinha fundamento histórico se não como referência ao processo de colonização e se afigurava como crucial:

9 CAVALCANTI, Amaro. Regimen federativo e a Republica brasileira. Rio de Janeiro: Imprensa Nacional, 1900. p. 112-118.

10 AMATO, Giuliano. Forme di stato e forme di governo. Bologna: Il Mulino, 1984, p. 53.

11 CAMINA, Miquel. Nacionalismo y Federalismo. In: ANTÓN MELLÓN, Joan. (ed.) Ideologías y movimientos políticos contemporâneos. Madrid: Tecnos, 1998. p. 106-107. 
El federalismo, sin embargo, fue inevitable e imprescindible em aquellos territórios estatales del Nuevo Mundo (EEUU) (1776), Canadá (1864), Brasil (1891)-, o bien em colonias pluriculturares que accedieron a la independência política - India (1947), Nigeria (1960) -, donde la implantación del estado nacional no tenía más fundamento histórico de las partes federadas y el federalismo constituía la terapêtica adecuada para construir y salvaguardar la unidade de la nación. ${ }^{12}$

Como, concomitantemente a isso, os mesmos EUA mostravam-se como uma nação progressista, em franco desenvolvimento, o federalismo americano foi sendo visto como modelo ideal pelo restante do mundo e isso, frise-se, muito mais pela pujança econômica que o país exibia, do que propriamente pelas vantagens de seu sistema federal de Estado.

O raciocínio era, aproximadamente, o seguinte: se os EUA estão se desenvolvendo a olhos vistos e adotaram esse sistema, este deve ser o ideal para as nações em geral, devendo ser adotado por todos os outros países para a obtenção dos mesmos resultados. Claro que esse não é o único motivo, eis que o federalismo efetivamente possui as suas qualidades intrínsecas, mas é um dado relevante, nomeadamente quanto à propagação da ideia em si.

Os norte-americanos criaram um modelo de Estado federal altamente descentralizado, ao menos inicialmente, instituindo o modelo dos poderes enumerados para a união e os poderes não enumerados para os Estados-membros. Mais à frente, já em 1789, contudo, a décima emenda constitucional instituía ou fixava o raio de ação dos poderes dos estados federados, declarando expressamente que "os poderes não delegados aos Estados Unidos pela Constituição, nem proibidos por ela aos Estados, são reservados, respectivamente, aos Estados on ao povo". ${ }^{13}$

Marcava-se a época do federalismo dual, em que os governos estaduais e o governo federal possuíam rígida repartição de poderes. Um respeitado constitucionalista americano asseverou que "nesta visão, o equilíbrio apropriado necessário ao funcionamento de um sistema federal é assegurado e mantido pela estrita demarcação da autoridade federal e estadual." ${ }^{14}$ Mas o dualismo não perseverou até os dias atuais, embora permanecesse o diferencial do poder comum legitimado diretamente pelos cidadãos.

\section{Centralização do estado e federalismo}

Os princípios liberais, nos fins do Século XIX e início do Século XX, já não encontravam a consagração que haviam experimentado em seu auge como modelo ideológico social-político-estatal.

O Estado com um viés social mais pronunciado, um nacionalismo por vezes extremado, aspectos que, ainda mais, acabaram dando ensejo para o futuro surgimento do Estado intervencionista, tomava assento no rol dos eventos históricos relevantes. Esse caldo social-nacionalista, típico do início do Século XX, que em alguns aspectos ainda se formava, gerou profundas mudanças no modelo estatal vigente, sendo que estas agiram de forma direta sobre o federalismo e suas características.

A descentralização perdia força, a autonomia dos Estados-membros passava a ser mitigada, relativizada e aos poucos substituída pelo poder central onipresente e, em certos momentos, onipotente. Os objetivos nacionalistas mostravam-se mais ambiciosos, as atribuições da União eram crescentes e a força dos mercados via-se questionada diante de "um estado que sobrepõe sua vontade a vontade dos particulares" colocava até mesmo em xeque o exercício da democracia.

12 CAMINA, Miquel. Nacionalismo y Federalismo. In: ANTÓN MELLÓN, Joan. (Ed.) Ideologías y movimientos politicos contemporâneos. Madrid: Tecnos, 1998. p. 107.

13 HORTA, Raul Machado. Estudos de direito constitucional. Belo Horizonte: Del Rey, 1995. p. 350.

14 SCHWARTZ, Bernard. O federalismo norte-americano atual. Rio de Janeiro: Forense Universitária, 1992. p. 26.

15 AMATO, Giuliano. Forme di stato e forme di governo. Bologna: Il Mulino, 1984. p. 62. 
Era, destaque-se, um Estado que via suas funções aumentarem cada vez mais. ${ }^{16}$ Até como consequência natural disso, outro fenômeno também surgia, qual seja a federalização das competências estaduais. ${ }^{17}$ Manuel Garcia Pelayo explicava este último aspecto, bem como a centralização que se apresentava, elencando três motivos básicos: a) guerras e depressões, como elementos que reforçam a unidade; b) atividade empresarial do Estado, incrementada pela ampliação dos órgãos e serviços estatais; c) e aumento da complexidade estrutural econômica, trazendo para a esfera federal assuntos anteriormente só afetos aos Estados-membros. ${ }^{18}$

Muito embora essa centralização sofresse pesadas críticas, o fato é que ela prevaleceu, tomando extraordinária força com o advento do New Deal do presidente norte-americano Franklin Delano Roosevelt, configurando-se num estado intervencionista por natureza, sendo ainda característica marcante desse novo ambiente, ou dessa nova configuração, uma notável centralização do poder central em detrimento da descentralização política anteriormente observada, abrindo-se espaço para uma concepção do modelo federal nominada, algum tempo depois, de federalismo cooperativo.

Veja-se que a décima emenda constitucional norte-americana foi, nessa época, posta de lado e assim o foi pela própria Suprema Corte em 1941, declarando o referido tribunal máximo que a referida emenda "traz̧ia em si um truísmo sem maior importância prática". ${ }^{19}$

Após a $2^{\mathrm{a}}$ Guerra Mundial, essa centralização não mudou substancialmente de figura, apenas transmutando-se num Estado de caráter intervencionista de perfil mais elaborado, o chamado Welfare State, ou Estado do Bem-Estar Social, do Estado provedor por excelência, cujo embrião, como exposto, estava lá no início do Século XX, mas de modo mais evidente a partir dos anos trinta como resposta à grande depressão dos anos vinte nos EUA, notadamente em seu ápice no ano de 1929 com a quebra da Bolsa de Valores de Nova York.

O New Deal, gestado e posto em marcha num Estado ainda bastante centralizado e interventivo, funcionava, e efetivamente foi assim que ocorreu, como uma espécie de "contrato social" entre o Estado e o povo. ${ }^{20}$ Trouxe consigo um rompimento com o modelo de Estado baseado no federalismo dual, com competências federais e estaduais rigidamente demarcadas e lançou as bases, como vimos, não só do Welfare State, mas mesmo de uma visão que poderíamos nominar como "justo assistencialismo" (Fair Deal), posta em marcha tempos depois, dos anos sessenta em diante do Século XX, especialmente com a promulgação do Civil Rights Act, de 1964.

O fato é que os conflitos surgidos até a primeira metade do Século XX, de certa forma, justificaram a perda da descentralização estatal, antes incensada como qualidade fundamental do federalismo (o que é de fato verdadeiro). Para defender a nação, preservar seus valores e principalmente manter a unidade se mostrava aceitável abrir mão da independência dos entes componentes do Estado federal, estados e municípios, em prol de uma força única mais coesa.

$\mathrm{Na}$ contemporaneidade, muito embora com algumas mutações neste quadro, o fato é que se vivem resquícios fortes daquela época. Obviamente o tom grandiloquente de recuperação e disciplina, típicos do New Deal, mudou, mas o fato é que o Congresso Nacional Americano continua tutelando bastante e, baseado na interpretação dos interesses interestaduais, pode legislar e regular praticamente tudo, da matéria mais genérica possível, até o interesse substancialmente local. ${ }^{21}$

16 MAUÉS, Antonio Gomes Moreira. Poder e democracia: o pluralismo político na Constituição de 1988. São Paulo: EDUSP, 1998 , p. 113.

17 HORTA, Raul Machado. Estudos de direito constitucional. Belo Horizonte: Del Rey, 1995. p. 351.

18 PELAYO apud HORTA, Raul Machado. Estudos de direito constitucional. Belo Horizonte: Del Rey, 1995. p. 352.

19 DALLARI, Dalmo de Abreu. O estado federal. São Paulo: Ática, 1986. p. 45-46.

20 Franklin Delano Roosevelt, presidente dos EUA nessa época, dizia aos norte-americanos, em tom messiânico: "Precisamos nos movimentar como um exército treinado e leal disposto a sacrificar-se pelo bem de uma disciplina comum, porque sem tal disciplina nenhum progresso se far, nenbuma liderança se torna efetiva" (apud SCHWARTZ, Bernard. O federalismo norte-americano atual. Rio de Janeiro: Forense Universitária, 1992. p. 31).

21 SCHWARTZ, Bernard. O federalismo norte-americano atual. Rio de Janeiro: Forense Universitária, 1992. p. 36; 
Adicionando-se ao comentário acima outro fato político relevante, que vem a ser a postura norte-americana de preservação de um determinado rol de valores, supostamente ligados à democracia, à liberdade e ao respeito à dignidade humana, em âmbito mundial, o que levou alguns autores a qualificarem tal postura como um "policiamento" do Mundo, é forçosa a conclusão de uma centralização de poder com a União cuja eventual reversão em prol de uma descentralização para os Estados-membros se afigura cada vez mais improvável. $^{22}$

\section{Federalismo no Brasil}

Discorrer sobre federalismo no Brasil é falar, historicamente, do advento da República em 1889 e a consequente derrocada da Monarquia. Antes disso, na fase colonial, experimentou o país longo período de uma espécie de confederalismo informalmente disposto, época das capitanias hereditárias que se reportavam diretamente a Portugal e, em determinadas situações, eram mesmo incentivadas pelo governo central lusitano a seccionarem-se do todo em que se viam inscritas como parte.

Mais à frente, com a vinda da coroa portuguesa ao Brasil - chegada de Dom João VI com a família real, em 1808 -, o Império viu-se como um Estado unitário. De todo modo, a fase imperial do Estado brasileiro não conheceu o modelo federativo. O que havia era um rudimento de desconcentração em prol dos estados, na verdade províncias, e mesmo o município era uma instância vista, então, como um mal necessário, onde grassavam a improvisação e a desorganização políticas. ${ }^{23}$

Instituída a federação pelo texto constitucional de 1891, o que se constata é que o próprio povo brasileiro jamais se deu conta ou mesmo ocupou-se de alguma forma em defender ou valorizar a descentralização e o respeito ao sistema federativo em que, nominalmente, se estribava a república, ${ }^{24}$ isso por razões culturais e de costumes já bastante sedimentadas, como mencionado.

Muito embora o primeiro texto constitucional de 1891 tenha expressamente disposto as limitações de atuação da União junto aos Estados-membros (Artigo $5^{\circ}$ ), o fato é que essas limitações foram sendo inobservadas ao longo do Século XX. Campos Salles, Presidente da República entre 1898 e 1902, notabilizou-se pela adoção da chamada política dos estados, "embora o vulgo a haja designado por "política dos governadores". ${ }^{25}$

O fato, contudo, é que as preocupações descentralizantes do paulista Campos Salles encontraram muito mais críticas do que um eco de reforço às suas intenções. É preciso entender, neste ponto, que a descentralização traz também responsabilidades e compromissos, o que principalmente os Estados-membros (pelo menos a maioria) não estavam dispostos a suportar.

Sofrendo também o Brasil as influências do nacionalismo europeu e do New Deal norte-americano, promulgou duas cartas constitucionais, de 1934 e 1937, em que, ambas, muito embora declarem inspirar-se na Constituição Federal de 1891 e defendam a forma federativa e a descentralização do Estado, denotaram forte caráter nacionalista, enxergando os Estados-membros como meras unidades intermediárias afirmadoras do Estado nacional. ${ }^{26}$

22 CORWIN, Edward. American constitutional history. New York: Harper \& Row, 1964. p. 37.

23 Victor Nunes Leal, grande estudioso das questões municipais, é citado por Carmem Lúcia Antunes Rocha, afirmando, assim, que "não se pode, entretanto, compreender o funcionamento das instituiç̃oes daquele tempo, inclusive das autoridades locais, com a noção moderna da separação de poderes, baseada na divisão das funcões em legislativas, executivas e judiciárias. Havia, neste terreno, atordoadora confusão, exercendo as mesmas autoridades funções públicas de qualquer naturez̧a, limitadas quantitativamente pela definição, nem sempre clara, de suas atribuiç̃oes, e subordinadas a um controle gradativo, que subia até o Rę". (LEAL, Victor Nunes Leal apud ROCHA, Carmem Lúcia Antunes. O município no sistema constitucional brasileiro. Belo Horizonte: EDUFMG, 1982. p. 49-50).

24 HORTA, Raul Machado. Estudos de direito constitucional. Belo Horizonte: Del Rey, 1995. p. 355.

25 CAETANO, Marcelo. A federação. Forense: Rio de Janeiro, 1987. p. 49.

26 Pugnavam os constituintes chamados de nacionalistas em 1933 que deveria haver "a ampliação dos seus (da União) meios de 
A Constituição de 1934, promulgada como resultado de notória pressão social sobre Vargas, especialmente a Revolução Constitucionalista de 1932, ainda possuía um viés mais libertário ao menos nominal.

Mas sua vigência foi curta e o ano de 1937 trouxe uma nova constituição - nominada posteriormente de Polaca por ter se inspirada na constituição polonesa então vigente - como reboque do golpe instituidor do Estado novo, experimentou-se, então, uma centralização bastante extremada, para não se mencionar os consectários próprios de um regime de exceção, sendo, na verdade, um texto de caráter meramente subsidiário em face de um projeto de poder mais amplo expresso por Vargas. ${ }^{27}$

Salvo algumas modificações, de certo modo menores, as constituições federais seguintes, 1946 e 1967 - e mesmo, de algum modo, a atual de 1988 -, padecem do mesmo mal que já as afligia nos textos anteriores, sendo este o de dispor o poder estatal de forma federalista e supostamente descentralizada, mas terminam por prestarem-se a perpetuação de um centralismo bastante exacerbado.

Por outro lado, dizer que o Brasil vive uma crise em seu sistema federativo é incorporar-se a uma massa de críticos vasta que, nada obstante, tem suas plausíveis razões, muitas vezes nada inova e nem busca as motivações dessa situação. Em outras palavras, tornou-se lugar-comum criticar as imperfeições de nosso federalismo.

Vivencia-se, no Brasil, uma crise federativa, bem de se ver, praticamente desde o início da República. No passado, as razões já foram suficientemente expostas, tal como no caso da entrada em cena do Estado nacional e a supervalorização da União como meio de criar-se uma identidade nacional, gerando, segundo se acreditava, um fortalecimento da Nação em nível internacional.

De 1946 em diante, o que se viu foi a formação lenta e firme de um Estado calcado num assistencialismo por parte da União em relação aos Estados-membros, tornando-se estes últimos meros receptores de recursos federais, advindos de vários meios, tais como orçamentários, creditícios, bancários, transformando o Estado brasileiro no que alguns denominam de federalismo cooperativo, a exemplo do termo cunhado nos EUA, muito embora, em diversas ocasiões, somente uma das partes coopere. ${ }^{28}$

Para essa situação, também conta-se com a adoção de vários instrumentos federais criados com o escopo de desenvolver os Estados-membros e os municípios, tais como SUDENE, SUDAM, SUDESUL, CODEVASF e outros, que, muito embora tenham realizado várias obras em suas regiões de atuação, prestaram-se muito mais como instrumento de dependência dos recursos federais, servindo de moeda política de troca com lideranças políticas locais e perpetuação de um modo clientelista de atuação estatal.

Como outro elemento dificultador da adoção de um federalismo de fato, teve-se a questão dos bancos estaduais, alimentados por longo tempo por dinheiro federal, dinheiro esse mal aplicado em seus estados de origem ou mesmo envolvido em desvios ou negociatas de políticos locais, buscando financiar suas campanhas políticas, notadamente a partir de 1982.

A privatização de tais bancos a partir dos anos noventa mitigou o problema, mas não modificou o quadro de dependência acima comentado. Tudo isso, por fim e na verdade, denota a total ausência do tão incensado pacto federativo, vale dizer um pacto em que as regras sejam efetivamente cumpridas. ${ }^{29}$

atuação sobre a coletividade brasileira e a restrição de determinados excessos de autonomia local", trecho dos anais da Convenção Nacional do Clube de 3 de Outubro, apud CAETANO, Marcelo. A federação. Forense: Rio de Janeiro, 1987. p. 52.

27 D’AVILA, Luiz Felipe. A federação brasileira. In: BASTOS, Bastos (Org.). Por uma nova federação. São Paulo: Revista dos Tribunais, 1995. p. 53-76. Nesta Constituição (1934), havia a previsão de um sistema misto de votação para a câmara dos deputados, sendo uma parte escolhida pelo voto direto e outra pelo voto indireto.

28 HORTA, Raul Machado. Perspectivas do Federalismo Brasileiro. Belo Horizonte: UNMG, 1990. p. 30; RAMOS, Dircêo Torrecillas. O federalismo assimétrico. São Paulo: EDUSP, 1997. p. 270; FRANCO, Afonso Arinos de Melo. Curso de direito constitucional brasileiro. Forense: Rio de Janeiro, 1958. p. 163; TRIGUEIRO, Osvaldo apud SARAIVA, Paulo Lopo. Federalismo regional. Saraiva: São Paulo, 1978. p. 58. Nesta última obra, Saraiva ainda cita manifestação do senador potiguar Dinarte Mariz, já em 1971, que bem traduz o sentimento do assistencialismo dos representantes dos estados-membros, ou pelo menos de alguns deles: "É preciso que o Governo federal tome de quem tem para dar a quem não tem, em vez de dar a quem tem para escravizar a quem não tem".

29 CASTRO, Marcus Faro de. Considerações preliminares sobre o federalismo e politica econômica no Brasil após 1980. São Paulo: Conselho 
Observa-se que desde o final da ditadura militar, em 1985, com o advento da chamada Nova República e, de modo especial, com a promulgação da Constituição de 1988, criou-se uma expectativa muito grande em termos de uma efetiva descentralização política na organização política do Estado brasileiro, o que, formalmente, foi plenamente contemplado no texto constitucional.

Mas aspectos culturais e costumes arraigados ao longo de dezenas de anos findaram por exibir, assim, entraves bastante naturais ao atendimento relativamente às expectativas - que mesmo atualmente seguem frustradas - ligadas ao implemento do chamado pacto federativo. Pontuando essa questão, um conhecido estudioso desse tema chegou a declarar que esse pacto não é cumprido porque a Nova República brasileira apresentou um debate político de baixo conteúdo filosófico. ${ }^{30}$

Muito embora se fale bastante a respeito do tema federalismo no Brasil atual, com o aparecimento de otimistas falando em "reedificação da república federal",31 outros pugnando a volta da "política de governadores",, e o governo federal esforçando-se para comprovar que luta pela autonomia dos Estados-membros e que " $o$ Estado precisa conviver com formas descentralizadas de governo," 33 não se tem ainda uma ideia clara sobre o que de fato irá ocorrer.

$\mathrm{Na}$ esteira das análises de momento, observou o início dos anos 2000, o que alguns denominavam como excesso de poder dos municípios, o que gerou, juntamente com o endividamento notoriamente exacerbado dos Estados-membros, a conturbada promulgação da Lei de Responsabilidade Fiscal no Congresso Nacional, justamente no ano 2000.

A lei em foco é permeada ou pelo menos inspirada por um sentimento positivo, uma vontade deliberada, ostensiva e expressa de se inserir um mínimo de responsabilidade sobre os ombros dos governantes locais e regionais em relação aos gastos por eles mesmos promovidos na condução de seus governos, levando-os, assim, a uma gestão mais transparente, disciplinada e consequente.

Mas a prática ou os fatos observados nesses doze anos são pródigos em demonstrar a enorme dificuldade em se modificar a mentalidade dos governantes locais e regionais. O maior município do país, São Paulo, possui uma dívida de 52 bilhões de reais junto à União, dívida esta formada em momento anterior ao da promulgação da Lei de Responsabilidade Fiscal acima indicada e que está sendo fruto de recente renegociação entre as partes envolvidas. ${ }^{34}$

Dissertar sobre poder municipal ou, em melhor, na sua construção, acerca de poder para os municípios, é adentrar em tópicos como descentralização e regionalização do Poder Estatal, itens da máxima importância. Objeto de intensos debates, a descentralização do poder Estatal, especialmente no que concerne aos municípios, é matéria sempre em pauta nas discussões constitucionais.

O Brasil, muito embora sofra críticas rigorosas por sua forma de se estruturar quanto à concessão de um poder e de uma autonomia quase inéditas aos municípios - excetuando-se apenas a Suíça e a Alemanha, sendo que esta última, além de conferir um grande poder aos seus municípios, criou as chamadas microrregiões municipais, espécie de associação de municípios ${ }^{35}$-, anda numa forma de vanguarda no trato do tema, uma vez que a tendência mundial atual, especialmente na Europa, é a valorização da localidade, da pequena esfe-

Brasileiro de Relações Internacionais, 1997. p. 67.

30 SELCHER, Wayne apud RAMOS, Dircêo Torrecillas. O federalismo assimétrico. São Paulo: EDUSP, 1997. p. 270.

31 HORTA, Raul Machado. Perspectivas do Federalismo Brasileiro. Belo Horizonte: UNMG, 1990. p. 361.

32 CASTRO, Marcus Faro de. Considerações preliminares sobre o federalismo e política econômica no Brasil após 1980. São Paulo: Conselho Brasileiro de Relações Internacionais, 1997. p. 67.

33 FERREIRA, Aloysio Nunes. Secretário Geral da Presidência, O Globo, Rio de Janeiro, 01 maio 2000.

34 MOURA, Rafael Moraes; MONTEIRO, Tânia. Dilma dá aval a negociação de dívida de São Paulo com União. Estadão, 30 out. 2012. Disponível em: <http://www.estadao.com.br/noticias/nacional,dilma-da-aval-a-negociacao-de-divida-de-sao-paulo-comuniao,953068,0.htm>. Acesso em: 20 nov. 2012.

35 LÄSSING, Horts. O papel da esfera municipal no modelo federativo alemão. São Paulo: Centro de Estudos Konrad-Adenauer-Stiftung, 1995. p. 49-53. 
ra, da comunidade local e da aplicação da ideia contida na Encíclica Quarentessimo anno, em que Pio XI diz:

"Aquilo que puder ser feito por uma entidade menor não deve ser atribuido a uma entidade maior."

A exemplo do quanto já se comentou acima sobre o peso dos aspectos culturais, tradicionais, de costumes e hábitos desenvolvidos ao longo de anos a fio, também aqui, ao se abordar o município, tal aspecto não poderia ser negligenciado. Hoje o município é parte integrante da federação, é ente político autônomo, mas, como a lógica faz supor, sua localização na organização estatal brasileira, até 1988, era extremamente acanhada, para não dizer quase inexistente.

O Império Português, centralizador por sua própria natureza, não poderia mesmo conceber autonomia municipal e menos ainda concordar que esta pudesse redundar em transferência de poder estatal central para essas unidades comunais, muito embora a vinda da família real portuguesa ao Brasil para fixar residência tenha trazido certo arejamento à questão e ensejado, ainda, a constituição de certos poderes no município, poderes estes que, contudo, acabaram por se estabelecer muito mais pela ausência do poder central, do que por um real ou concreto estímulo à autonomia municipal.

Pode-se afirmar, assim, que a Constituição de 1988 se ombreou às disposições mais avançadas no trato do município, inserindo como membro efetivo, independente, autônomo, com competências próprias, mas o suporte social, político e cultural a essas avançadas previsões não foi levado em conta e, quando se observa uma centralização do poder central e uma dependência do município frente a este poder - havendo mesmo municípios total e absolutamente dependentes desse poder central -, constata-se haver ainda um largo trecho para ser caminhado a fim de verter a positivação formal para a prática.

Mesmo no campo formal há entraves relevantes. Assim, como em relação a outros tantos assuntos referentes ao Estado brasileiro, adotaram-se determinados princípios para o tema em análise, notadamente o da valorização do município e o que pugna pela solução local para as problemáticas locais, mas, ao mesmo tempo, não se concedeu, de fato, poder aos municípios para que legislem, por exemplo, sobre as matérias mais relevantes, restando-lhes apenas e de forma genérica, tal como ocorre com os estados membros, legislar sobre assuntos de interesse local (Art. 30, inciso I, Constituição Federal), em oposição a grande amplitude legislativa conferida à União (Art. 22, inciso I, Constituição Federal).

Destarte, a descentralização de poder estatal é princípio norteador do texto constitucional como um todo (Art. $3^{\circ}$, inciso III, Constituição Federal), mas as ferramentas e as previsões do mesmo texto constitucional não acompanham esse propósito de forma ideal ou pelo menos satisfatória.

Unindo as carências culturais, cultura política e social, com algumas falhas formais, observa-se um resultado final não exatamente desalentador, mas que exibe um largo trajeto a ser transposto. Desse modo, parece que a efetividade real do tão incensado pacto federativo demanda ainda muitos esforços e ajustes, a fim de alcançar um ponto interessante de aplicabilidade no Brasil.

\section{ReVAlorizaçÃo do MUNICíPIO?}

Sendo o foco do estudo o federalismo brasileiro, poder-se-ia sofrer a tentação de se circunscrever as críticas a uma eventual má utilização do sistema federativo ao caso do Estado brasileiro apenas. Todavia, se vê que, em verdade, o federalismo como forma de Estado encontra-se numa crise, de proporções internacionais, cujo desenlace é difícil prever.

O objeto deste exame não permite essa digressão, o que demandaria uma ampliação considerável do seu espectro analítico. O que se nota é que os brasileiros possuem desafios peculiares, próprios, mas também se deve visualizar essa questão num todo maior. As peculiaridades da sociedade brasileira, assim, encontram eco também no ambiente externo em pelo menos alguns pontos. 
Nota-se que, como uma projeção ideal, a valorização do município integra as agendas de todos os governantes. Difícil encontrar quem possa defender nos tempos que fluem, de modo desabrido e expresso, a centralização estatal, com a consequente subtração de poder e influência dos municípios, das localidades e das regionalidades. Mas o discurso é um, e a prática é outra.

Maquiavel dizia que a ética política nada tem a ver com a ética cristã e que o político, para atingir seus objetivos, deveria dispor de astúcia e boas estratégias. Se o pensador italiano estava correto - e a história da política parece lhe dar razão -, então somente a conjugação de dois elementos poderá reverter esse quadro: maior participação do povo nos negócios do Estado, ou seja, mais democracia; e busca da formação de políticos com mentalidade administrativa, política e social distinta da que observamos atualmente.

O movimento da história, caracteristicamente pendular, se verdadeiro, pode estar oferecendo nova oportunidade para que a liberdade, a autonomia e o autogoverno experimentado pelos grupamentos humanos pós-feudalismo - que, nas vilas e cidades de então, implementavam algo que hoje é inclusive buscado como modelo ideal para regramento humano, a volta ao índice mais básico, o retorno ao trato das questões mais próximas do cidadão como forma de limitação do poder estatal e a aproximação do indivíduo dos negócios sociais geridos pelo Estado -, foi rigorosamente fundamental e não apenas para alçar o federalismo a uma posição de destaque frente aos sistemas que lhe eram opostos, mas também como célula fundamental da vivência de um direito mais moderno.

O burgo medieval, especialmente aquele existente no declínio do feudalismo, era autonormativo e só conhecia os limites que se autoimpunha, numa situação diametralmente oposta àquela verificada no feudo, em que a lei, a ordem e o poder eram enfeixados de forma rígida e estática na figura única do senhor feudal. Não por outra razão, quando da concepção do estado federalista, o município foi visto como uma unidade fundamental e legítima de exercício de poder estatal a ser considerada de forma real, ainda que limitada em seu autogoverno.

Como um contraponto necessário, deve-se destacar que a tendência aqui em trato está ainda longe de ser linear ou de se desenvolver de forma inexorável. Além das dificuldades próprias do modelo estatal brasileiro, o mundo mostra evidentes resistências à adoção desse modelo mais descentralizado.

O "não" dado pela Dinamarca em plebiscito para adesão ao Tratado de Maastricht; a resistência da Inglaterra em integrá-lo (o que só fez de forma parcial e sem adotar o Euro como moeda única); e mesmo a situação dos EUA que, após o atentado de 11 de setembro de 2001, abertamente adotaram uma política centralizadora em todos os sentidos; tudo isso mostra que há forças contrárias a essa integração federalista ou, dito de outra forma, há forte resistência a esse projeto e a esse desejo de descentralizar o poder estatal e de buscar maior integração entre as nações com essa estrutura organizacional de poder menos atomizada.

Surgem nesse contexto, ainda mais, as crises financeiras de 2008 e a de 2010, sendo que esta última englobou não só as finanças, mas também a atividade econômica e principalmente a geração de empregos, lançando especialmente a Europa - mas também de modo mais mitigado os EUA - num de seus piores cenários sociais desde a $2^{\mathrm{a}}$ Grande Guerra.

Ao lado de aspectos afetos a qualquer crise econômica, como baixa atividade empresarial, desemprego, inadimplência e cortes em programas sociais, a crise europeia atual tem por traços marcantes, e peculiares, a falta de horizontes, a desesperança e a falta de confiança no futuro.

Com 22,9\% e 13,2\% de desemprego na camada mais jovem de suas populações, respectivamente para Espanha e Portugal, ${ }^{36}$ por exemplo, se veem com pouquíssimas opções: baixo empreendedorismo, retração

36 ESQUERDA.NET. Portugal e Espanha são os países da OCDE onde o desemprego mais aumenta. Disponível em: <http://www.esquerda.net/artigo/portugal-e-espanha-s\%C3\%A3o-os-pa\%C3\%ADses-da-ocde-onde-o-desemprego-mais-aumenta >. Acesso em: 17 jan. Num outro dado bastante interessante por seu conteúdo revelador, observe-se que "em Portugal, 130 empresas da construção civil faliram em 2011". A BOLA.PT: outros mundos. Disponível Em: http://www.abola.pt/mundos/ver.aspx?id=317374. Acesso em: 23 
de investimentos e, como se disse, uma quase ausência de horizontes aos que iniciam sua jornada no mercado de trabalho, a juventude.

\title{
6. Considerações finais
}

São em momentos de crise que as oportunidades de mudança real vicejam com mais força. A situação atual, notadamente no chamado mundo desenvolvido, é de indefinição. Seria a valorização do município um caminho viável para a superação desse quadro? Ou, ao revés, assistir-se-á a um recrudescimento da centralização estatal tão presente no passado?

Sem embargo de tal contraponto, e como foi possível constatar pela manifestação de diversos autores citados ao longo deste estudo, a inclusão parece ser uma ideia apropriada quando se imagina qual modelo jurídico se busca para o Século XXI, fazendo com que se afaste do formalismo adotado para a promoção e implementação do justo, afinal:

\begin{abstract}
Se se trata de criar um espaço público, num mundo globalizado e complexo, as vozes a serem escutadas não podem ficar restritas a uma representação formal dos governos. Certamente, o maior desafio para conseguir uma autêntica democratização da política internacional consiste em produzir um espaço público de acesso relativamente irrestrito e com capacidade real de influir no processo decisório sobre questões globais. ${ }^{37}$
\end{abstract}

Acreditar em autonormatividade, numa sociedade complexa como a atual, seria um idealismo excessivo e até pernicioso.

Resgatar, no entanto, uma proximidade do direito com sua base humana mais elementar pode implicar em uma inclusão de mais vozes em seu exercício, bem como criar uma real possibilidade, via edificação de um ambiente propício para tanto, de uma postura mais inclusiva, que possa fazer possível o nascimento de um novo direito, não necessariamente como uma manifestação dos modelos alternativos já mencionados, mas, certamente, algo distinto do que se tem na contemporaneidade.

Aceitar o inexorável processo de globalização que torna esmaecidas as fronteiras dos diversos sistemas estatais do mundo e a crescente proliferação de normas internacionais que faz esvanecidas até mesmo as soberanias dos Estados ${ }^{38}$ com a construção de um novo modelo estatal desde as comunidades espontaneamente gestadas nas sociedades, pode permitir que se extraia algo mais equilibrado e coerente com a tábua axiológica que o Estado deve defender, com maior legitimidade do que os entes estatais possuem hoje.

Nesse federalismo renovado, as assimetrias podem ser niveladas com a valorização do município, permitindo-se a inclusão daquele que é a razão de ser da ordem jurídica: o ser humano.

\section{REFERÊNCIAS}

AMATO, Giuliano. Forme di stato e forme di governo. Bologna: Il Mulino, 1984.

CAETANO, Marcelo. A federação. Rio de Janeiro: Forense, 1987.

fev. 2012.

37 LEIS, Héctor Ricardo. Globalização e democracia: necessidade de oportunidade de um espaço público transnacional. Revista brasileira de ciências sociais, ano 10, n. 28, jul. 1995.

38 Fritjof Capra lembra que "A ascensão da sociedade em rede foi acompanhada pelo declínio do Estado como entidade soberana. Metidos em redes globais de turbulentos fluxos financeiros, os governos são cada vez menos capazes de controlar a política econômica nacional; já não podem dar a seus cidadãos as vantagens tradicionais do estado de bem-estar social; estão perdendo a guerra contra uma nova economia globalizada do crime; e sua autoridade e legitimidade são cada vez mais postas em questão.” CAPRA, Fritjof. As conexões ocultas. São Paulo: Cultrix:Amana-Key, 2009. p. 159-160. 
CAMINA, Miquel. Nacionalismo y Federalismo. In ANTÓN MELLÓN, Joan (Ed.) Ideologías y movimientos politicos contemporâneos. Madrid: Tecnos, 1998.

CAPRA, Fritjof. As conexões ocultas. São Paulo: Cultrix: Amana-Key, 2009.

CASTRO, Marcus Faro de. Considerações preliminares sobre o federalismo e política econômica no Brasil após 1980. São Paulo: Conselho Brasileiro de Relações Internacionais, 1997.

CAVALCANTI, Amaro. Regimen federativo e a republica brasileira. Rio de Janeiro: Imprensa Nacional, 1900.

CORWIN, Edward. American constitutional history. New York: Harper \& Row, 1964.

D’AVILA, Luiz Felipe. A federação brasileira. In: BASTOS, Celso (Org.). Por uma nova federação. São Paulo: Revista dos Tribunais, 1995.

DALLARI, Dalmo de Abreu. O estado federal. São Paulo: Ática, 1986.

FERREIRA, Aloysio Nunes. Secretário Geral da Presidência, O Globo, Rio de Janeiro, 01 maio $2000 .$.

FRANCO, Afonso Arinos de Melo. Curso de Direito Constitucional Brasileiro. Forense: Rio de Janeiro, 1958.

GARCIA, Alberto Barrena. El federalismo em Suiza. Madrid: Coleccion Inst. Politicas, 1970.

HORTA, Raul Machado. Estudos de Direito Constitucional. Belo Horizonte: Del Rey, 1995.

HORTA, Raul Machado. Perspectivas do Federalismo Brasileiro. Belo Horizonte: UNMG: 1990

LÄSSING, Horts. O papel da esfera municipal no modelo federativo alemão. São Paulo: Centro de Estudos KonradAdenauer-Stiftung, 1995.

LEIS, Héctor Ricardo. Globalização e democracia: necessidade de oportunidade de um espaço público transnacional. Revista Brasileira de Ciências Sociais, ano 10, n. 28, jul. 1995.

MAUÉS, Antonio Gomes Moreira. Poder e democracia: o pluralismo político na constituição de 1988. São Paulo: EDUSP, 1998.

MOURA, Rafael Moraes; MONTEIRO, Tânia. Dilma dá aval a negociação de dívida de São Paulo com União. Estadão, 30 out. 2012. Disponível em: <http://www.estadao.com.br/noticias/nacional,dilma-daaval-a-negociacao-de-divida-de-sao-paulo-com-uniao,953068,0.htm>. Acesso em: 20 nov. 2012.

RAMOS, Dircêo Torrecillas. O federalismo assimétrico. São Paulo: EDUSP, 1997.

ROCHA, Carmem Lúcia Antunes. O município no sistema constitucional brasileiro. Belo Horizonte: EDUFMG, 1982.

RUSSOMANO, Rosah. O princípio do federalismo na constituição brasileira. Rio de Janeiro: Freitas Bastos, 1965. SARAIVA, Paulo Lopo. Federalismo regional. São Paulo: Saraiva, 1978.

SCHWARTZ, Bernard. O federalismo norte-americano atual. Rio de Janeiro: Forense Universitária, 1992.

TOCQUEVILlE, Alexis de. A democracia na América. São Paulo: Martins Fontes, 1998. 


\title{
Efeitos político-jurídicos da não institucionalizada paradiplomacia no Brasil
}

\author{
Political-legal effects of the \\ noninstitutionalized paradiplomacy in Brazil*
}

Gustavo de Souza Abreu**

\section{Resumo}

O Estado brasileiro resiste à institucionalização da atividade paradiplomática e isso dificulta a aplicação de certas políticas públicas direcionadas ao desenvolvimento socioeconômico de estados e municípios, além de comprometer a credibilidade do país e aspectos da segurança nacional. Este artigo tem por objetivo analisar brevemente o fenômeno da paradiplomacia, apontando as consequências de sua continuidade nos padrões vigentes. Primeiramente, são apresentados aspectos conceituais e alguns modelos de paradiplomacias institucionalizadas no mundo. A seguir, o fenômeno é contextualizado no Brasil, onde se identifica um problema jurídico materializado por iniciativas de governos locais no plano internacional que, a rigor, seriam da competência da União. Constata-se que o Estado apresenta posturas opostas em relação à questão: é resistente à institucionalização, por temer a perda de soberania; mas é tolerante quanto ao seu exercício, diante da inexorabilidade do fenômeno. Dessa dúbia postura, resultam quatro consequências: (i) prejuízos ao desenvolvimento local e regional; (ii) insegurança jurídica; (iii) constrangimentos no plano internacional; e (iv) riscos à segurança nacional. Na parte fundamental da análise, destacando as duas últimas consequências, argumenta-se que o caráter não institucional da paradiplomacia conduz a um problema político-jurídico para o Estado. Finalmente, conclui-se pela imprescindibilidade da institucionalização da atividade, ressaltando-se as implicações negativas da continuidade do padrão vigente. Mesmo sem apresentar um modelo jurídico para a solução do problema, o artigo abre perspectivas para reflexões nessa direção, com a originalidade de juntar aos argumentos já conhecidos na literatura a questão dos constrangimentos internacionais e dos riscos à segurança nacional.

Palavras-chave: Paradiplomacia. Política externa. Políticas públicas. Soberania. Subsidiariedade. Segurança nacional.

* Recebido em 03/07/2013 Aprovado em 25/07/2013

** Assessor de política e estratégia do Ministério da Defesa e Mestre em Direito pelo Centro Universitário de Brasília (Uniceub). Email: elvabreu@uol.com.br

\section{Abstract}

The Brazilian State resists in institutionalizing the paradiplomacy. This attitude hampers the construction of certain public policies aimed towards social and economic development in states and municipalities and compromises the country's credibility and national security. The aim of this article is to make a brief analysis about paradiplomacy, focusing on the consequences of the continuity of this noninstitutionalized activity. Firstly, conceptual as- 
pects and some models of institutionalized paradiplomacies around the world are presented. Secondly, the phenomenon is contextualized in Brazil, where a legal problem is materialized by the growing development of procedures in the international field that do not observe some constitutional competencies that are exclusives of central power. With regard to this phenomenon the State adopts opposite postures: resists to institutionalization, fearing losing sovereignty, but is tolerant by perceiving its inevitability. Keeping the dubious attitude results in four important consequences: ( $)$ damage to regional development, (ii) legal uncertainty, (iii) constraints in the international field, and (iv) risks to national security. In the fundamental part of this analysis, highlighting the last four consequences, it is argued that the paradiplomacy with no institutionalization carries on to a political-legal problem to the State. Finally, it concludes that the institutionalization of paradiplomacy in Brazil is essential and points out to the negative implications if the legislation in force is maintained. The article does not intend to find a solution to the problem; however it opens up some ways of thinking about this matter, with the originality of joining well-known arguments to a new approach related to international constraints and national security risks.

Keywords: Paradiplomacy. Foreign policy. Public policies. Sovereignty. Subsidiarity. National security.

\section{INTRODUÇÃo}

Este artigo traz à reflexão a questão da não institucionalizada paradiplomacia no Brasil. A temática em si não constitui novidade na literatura acadêmica nacional que, de um modo geral, destaca as dificuldades enfrentadas por estados e municípios no campo do diálogo internacional e critica o desinteresse e a acomodação dos tomadores de decisão que pouco fazem no sentido de institucionalizar a atividade.

O que de novo se quer apresentar é uma perspectiva dos constrangimentos a que o Estado brasileiro se submete ao permanecer passivo, sob o duvidoso argumento de que, ao descentralizar poderes para o exercício de certos atos internacionais que lhes são tradicionalmente próprios, estaria perdendo soberania. Em verdade, como se buscará demonstrar, ao permanecer inflexível e ao mesmo tempo tolerante, o Estado brasileiro propicia, paradoxalmente, o fomento de procedimentos à margem da lei que podem justamente comprometer o seu poder soberano.

Para além do ordenamento jurídico interno, diante da percepção das fronteiras não mais como uma linha de separação de interesses nacionais, mas como loci de aproximação de Estados, há de se pretender que regras jurídicas mais ou menos comuns sejam observadas. Nesse sentido, tem-se uma leitura da temática da paradiplomacia inscrita na tendência de mundialização do Direito, tendo em vista a necessidade da existência de regras mínimas para a regulação de espaços internacionais comuns nos quais entes subnacionais possam atuar sem ferir o princípio da soberania dos Estados.

Há vários exemplos no mundo em que a flexibilização das leis de alguns países trouxe resultados bastante positivos; alguns apresentando regras especiais para certos entes subnacionais, outros adotando-as para todas as unidades de seus territórios. No caso brasileiro, percebe-se o aumento gradual das negociações internacionais que muitas vezes resultam em "acordos" entre estados e municípios com seus congêneres de outros países e até mesmo com organizações internacionais. Ora, tais procedimentos são da competência da União, por intermédio de sua diplomacia formal. Por outro lado, mesmo diante dessa ilegalidade a olhos vistos, poucas são as iniciativas legislativas no sentido de adaptação da norma ao mundo dos fatos.

A essência da questão em debate se insere em uma discussão maior que é o federalismo e as suas contradições a partir da Constituição Federal de 1988. Mas esse não é o escopo deste artigo, que se limita, meramente, a analisar a crescente paradiplomacia no país e suas consequências para a sociedade e para o Estado. 


\section{A PARADIPLOMACIA NO MUNDO}

A dificuldade de aceitação da paradiplomacia não é uma exclusividade do Brasil. Como se verá neste tópico, a questão tem merecido atenção de estudiosos em diversas partes do mundo, ensejando soluções jurídicas diferenciadas para atender a realidades em contextos nacionais muito próprios.

A diplomacia consiste, em linhas gerais, na condução de negociações no plano internacional por representantes dos Estados com a perspectiva de atender aos interesses definidos pelas políticas externas de seus governos, normalmente relacionadas a temas de guerra e paz, economia, tecnologia, meio ambiente, comércio e cultura. Como se sabe, é a ação diplomática desses representantes nacionais especializados - os diplomatas - que engendra a teia de interesses mútuos que pode culminar, segundo rito próprio, com a celebração de tratados que legitimam as vontades estatais e consensuais no campo do Direito Público Internacional, garantindo os atos e responsabilidades decorrentes.

Entretanto, diante da dinâmica da globalização, unidades subnacionais (províncias, estados, departamentos, cantões e até mesmo de níveis inferiores) têm protagonizado iniciativas no plano internacional que contrariam a lógica de poder tradicional consagrada pelo sistema westphaliano. $\mathrm{Na}$ tentativa de solucionar problemas regionais que lhes afetam diretamente, esses atores não tradicionais da cena internacional - que talvez não estejam merecendo a devida atenção dos Estados que integram - têm se lançado na "arte diplomática", buscando alcançar resultados que a rigor são da competência da diplomacia oficial estatal. Assim, certas negociações estão cada vez mais sendo conduzidas por representantes de unidades subnacionais, caracterizando uma atividade que passou a ser denominada pelo neologismo paradiplomacia - ou cooperação internacional descentralizada -, que encontra fundamentos na teoria democrática e em conceitos como mundialização do Direito, autodeterminação dos povos, subsidiariedade, identidade, soberania relativa e outras teorias afins.

Com maior ou menor grau de intensidade, identifica-se uma tendência dos Estados nacionais em descentralizar competências para seus entes subnacionais; estes, por sua vez, veem-se aptos a se relacionarem com seus correspondentes de outros Estados. Vencidos alguns desafios, talvez a paradiplomacia seja um dia absorvida por todos os Estados em seus ordenamentos internos, como instrumento de mundialização do Direito. Para isso, o Direito precisa exercer o seu papel organizativo. "Se é verdade que a mundialização conduz a uma relação progressiva de competência exclusiva dos Estados em prol das competências compartilhadas, o papel do Direito seria o de edificar princípios de organização dos povos para organizar o compartilhamento de competências de modo compatível com a soberania". ${ }^{1}$

Conceitualmente, paradiplomacia se refere a uma emergente capacidade do exercício da política externa por unidades subnacionais; ou seja, refere-se à participação dessas unidades, independente do Estado central, na busca de seus próprios interesses na arena internacional. ${ }^{2}$ Também é apresentada como uma atividade com a função de integração e de cooperação, na qual a racionalização da política externa realizada por uma soma de esforços entre o governo federal e as unidades subnacionais poderia produzir resultados positivos para a diplomacia nacional. Nessa linha de argumentação, propõe-se uma descentralização da política externa, na qual o governo central atuaria como coordenador da ação externa de suas unidades, de forma a garantir uma harmonia entre todos os Estados subnacionais e deles com a política nacional para o plano externo. Essa autonomia de unidades subnacionais contribuiria para o alcance de objetivos mais concretos em termos de política externa, maiores avanços nas negociações e maior satisfação dos interesses regionais. ${ }^{3}$ Alguns auto-

1 DELMAS-MARTY, Mireille. Três desafios para um direito mundial. Tradução e posfácio de Fauzi Hassan Choukr. Rio de Janeiro: Lumen Juris, 2003. p. 171.

2 WOLFF, Stefan. Paradiplomacy: scope, opportunities and challenges. Bologna Center Journal of International Affairs, John Hopkins University (UK), v. 10, 2007. Disponível em: <http://bcjournal.org/volume-10/>. Acesso em: 24 fev. 2012. WOLFF é Ph.D. em Ciência Política na London School of Economics e professor da University of Nottingham (Reino Unido).

3 SOLDATOS, Panayotis; MICHELMANN, Hans. Federalism and international relations: the role of subnational units. Oxford: Clar- 
res registram um tipo particular de paradiplomacia: a protodiplomacia, que seria um ativismo político segundo o qual governos locais buscam apoio internacional para causas independentistas.

O fenômeno encontra razões consistentes para o seu incremento, mesmo diante de fortes resistências dos Estados. Razões de ordem econômica, política e cultural explicam as motivações que conduzem os entes subnacionais a atuarem no plano internacional. ${ }^{4}$ Entre as razões de ordem econômica, assinala-se, principalmente, a cooperação transfronteiriça na promoção de infraestrutura e a resolução de problemas comuns (produção, comércio, educação, saúde, meio ambiente), por julgarem os governos locais que os governos centrais não dedicam suficiente atenção às suas necessidades prementes ou não estão equipados para tanto. Razões de ordem política são as decorrentes de aspirações nacionalistas que buscam alcançar a independência política, ou um meio para obtenção de maior reconhecimento junto à comunidade internacional ou ainda quando identificam um declínio de confiança depositada nos governos centrais nacionais. As razões de ordem cultural são as motivações típicas dos Estados multinacionais com relação às suas diásporas, revestindo-se de intenção política e ou religiosa, quando as minorias étnicas buscam influenciar a mobilização de governos subnacionais para obtenção de apoio e assistência em suas pátrias de origem no trato com os governos dos Estados que as abrigam.

Existem modelos emblemáticos de paradiplomacias institucionalizadas no mundo. ${ }^{5}$ Alguns Estados apresentam regramentos gerais para todos os seus entes subnacionais e outros apresentam regramentos diferenciados. Encontramos, por exemplo, na Alemanha, na Argentina, no Canadá e na Suíça, regramentos gerais uniformes para as suas unidades. $\mathrm{Na}$ Alemanha, constitucionalmente, tem-se como obrigatório para o Estado a consulta a suas unidades - os länder - sempre que a matéria tratada venha a afetar questões de suas competências; os länder podem, inclusive, concluir tratados internacionais. Na nossa vizinha Argentina, com a reforma constitucional de 1994, há a possibilidade de as provinciais celebrarem tratados internacionais, desde que não estejam em desacordo com a política exterior da nação e não afetem as faculdades delegadas ao governo federal ou o crédito público da nação, sendo necessário o conhecimento prévio do Congresso Nacional. No Canadá, os governos provinciais participam ativamente das negociações internacionais, como, por exemplo, no âmbito da NAFTA. Para a assinatura do Protocolo de Kyoto, foi necessário realizar reuniões para a discussão e consentimento entre as províncias canadenses. Muitas delas possuem escritórios de representação no exterior. De acordo com a Constituição da Suíça, a condução das relações externas é de competência federal, porém, o seu exercício deverá levar em consideração a vontade dos cantões.

Entre os Estados que apresentam regramentos diferenciados dentro de um mesmo território, figuram a Bélgica, a Espanha e o Reino Unido. Na Bélgica, o governo de Flandres pode celebrar tratados com terceiras partes, dispor de representações no exterior, participar com delegados em negociações multilaterais e participar formalmente da formulação das políticas externas belgas em suas áreas de interesse. O governo central tem apenas um papel de coordenação. Outro exemplo desse modelo é a Catalunha. Muito embora a Constituição da Espanha explicitamente retenha a competência pelas relações internacionais no governo central, a Catalunha goza de poderes especiais por conta do sistema de devolução de poderes, especialmente nas áreas de economia, educação e turismo. A região celebra acordos com outras entidades e assume o papel de "pátria-mãe" das coetnias fora do território espanhol. O Reino Unido opera um sistema assimétrico de devolução das regiões da Irlanda do Norte, da Escócia e do País de Gales com diferentes níveis de autonomia do governo central em Westminster. A mais autônoma é a Escócia, mesmo assim, sua presença na arena internacional é restrita, podendo promover a imagem positiva no exterior e interesses da região quanto à política de devolução na União Europeia e além

endon Press, 1990. p. 220. SOLDATOS é professor de Ciência Política na Université de Montréal (Canadá) e coeditor do Journal of European Integration (Luxembugo) e a quem se atribui o primeiro uso do termo "paradiplomacia".

4 LESSA, José Vicente da Silva. Paradiplomacia no Brasil e no mundo: o poder de celebrar tratados dos governos não centrais. Viçosa, MG: UFV, 2007. p. 36.

5 Ver LESSA, José Vicente da Silva. Paradiplomacia no Brasil e no mundo: o poder de celebrar tratados dos governos não centrais. Viçosa, MG: UFV, 2007. p. 45-105. O autor apresenta, resumidamente, alguns modelos mais característicos de paradiplomacias no mundo. 
dela; e ainda, celebrar acordos de cooperação dentro da União Europeia com a Bavária, Catalunha e comitês regionais das regiões marítimas.

Nos exemplos apresentados, ainda que colocados de maneira superficial, percebe-se que as constituições recepcionaram o conceito de descentralização de alguns poderes antes exclusivos do ente central, aumentando a autonomia das subunidades no campo das relações internacionais. Para tal, criaram condições e critérios para o funcionamento da atividade paradiplomática, tanto nas próprias cartas magnas quanto na legislação regulamentadora, mas sempre deixando claro que o controle soberano estatal é inegociável.

\section{A paradiplomacia no Brasil}

\subsection{Caracterização}

Reduzido ao essencial para o propósito deste trabalho, a paradiplomacia que se efetiva no Brasil pode ser caracterizada como sendo um fenômeno: (i) inescapável, por conta de irrefreável processo globalizante que o estimula; (ii) fático, uma vez que se manifesta concretamente e em tendência crescente no país; e (iii) desejável, uma vez que traz, em tese, benefícios a comunidades locais e regionais. Essas três características por si só não constituiriam um problema no campo do Direito se a atividade fosse exercida com o devido respaldo no ordenamento jurídico nacional. Mas não é. Não obstante a constatação de se tratar de um fenômeno real e crescente, o procedimento entra em conflito com a Constituição que remete à competência da União o trato de questões internacionais.

Para que se tenha uma ideia geral da dinâmica crescente e aparentemente inevitável da paradiplomacia no país, José Vicente Lessa, na obra já citada, destaca em sua pesquisa a existência de sessenta e cinco ocorrências da atividade em estados e municípios, em 2006, com vizinhos, países europeus e asiáticos e com os Estados Unidos. As relações internacionais mantidas por esses entes subnacionais brasileiros acontecem especialmente na região de fronteira e ou onde o vetor socioeconômico está imerso intensamente nas dinâmicas dos fluxos econômicos globalizantes.

Tendo como quadro referencial aquelas razões que impulsionam a paradiplomacia no mundo - de ordem econômica, política e cultural - é possível afastar as principais causas políticas e culturais e identificar claramente as de ordem econômica no caso brasileiro. O Brasil não é um Estado multinacional e tampouco experimentou diásporas. Também não se configuram minorias étnicas com interesse e capacidade para mobilização de governos estaduais ou municipais com vistas à obtenção de "assistência em suas pátrias de origem". Assim, não se identificam razões de ordem cultural motivadoras da paradiplomacia em território nacional. Também as razões de ordem política - "aspirações nacionalistas" e "busca de reconhecimento junto à comunidade internacional" - não constituem fatores que motivam a paradiplomacia brasileira, apesar da percepção que ocorre algum "declínio de confiança depositada no governo central".

São as razões de ordem econômica que melhor justificam a reprodução da paradiplomacia no Brasil. É perceptível que os entes subnacionais buscam captar investimentos, ampliar mercados, promover negócios entre empresas, transferir ou absorver tecnologias e estimular o turismo. Nas áreas contíguas com os vizinhos sul-americanos, buscam implementar programas mais duradouros de cooperação transfronteiriça, como na promoção de obras de infraestrutura e na resolução de problemas de interesse comum referentes à produção e ao comércio que findam por impactar outros campos, como o da educação e o da saúde.

O problema que se apresenta não são as negociações em si - até desejáveis sob certo ângulo diante dos imperativos contemporâneos que determinam a máxima integração no sistema econômico transnacional. O problema é o fato de ocorrerem em manifesto descumprimento da norma constitucional, como pode ser depreendido dos dispositivos enunciados a seguir: 
(a) do art. 21 - compete à União "manter relações com Estados estrangeiros e participar de organizações internacionais" (inciso I).

(b) do art. 49 - é da competência exclusiva do Congresso Nacional "resolver definitivamente sobre tratados, acordos ou atos internacionais que acarretem encargos gravosos ao patrimônio nacional" (inciso I).

(c) do art. 52 - dispõe que compete privativamente ao Senado Federal "autorizar as operações externas de natureza financeira, de interesse da União, dos Estados, do Distrito Federal, dos Territórios e dos Municípios" (inciso V).

(d) do art. 84 - dispõe que compete privativamente ao Presidente da República "celebrar tratados, convenções e atos internacionais, sujeitos a referendo do Congresso Nacional” (inciso VIII).

A rigor, portanto, não há espaço no Direito Público Interno para o exercício legal da paradiplomacia, uma vez que "manter relações com Estados estrangeiros" compete à União, sem extensão dessa competência aos membros da federação. Quando essa atividade informal abrange a celebração de acordos, mais grave se torna a irregularidade, uma vez que é da competência privativa do Presidente da República "celebrar tratados" e que mesmo esses estão sujeitos a rito próprio no Congresso Nacional.

No fluxo de uma tendência global de descentralização de poderes centrais, o Estado brasileiro se mostra confuso e incapaz de se ajustar à realidade dos fatos, tornando-se refém de sua própria legislação e da ação pouco perceptível de forças de sua estrutura que se digladiam nos bastidores da política, inspiradas em princípios universais, muitas vezes descolados do interesse nacional.

\subsection{A postura resistente do estado}

Quando se pensa em relações internacionais conduzidas por entes subnacionais, a primeira reação é de possível perda de soberania, por sugerir a concessão de determinado grau de autonomia. A doutrina clássica do Direito, quando interpreta as soberanias nacionais, vincula o conceito de soberania à capacidade do Estado, entre outros atributos, em conduzir sua política externa e manter relações diplomáticas com Estados estrangeiros. Nessa linha doutrinária tradicional, teme-se que, ao permitir que os entes subnacionais conduzam suas próprias relações internacionais, a soberania do governo central possa ser ameaçada pela existência de projetos que não coincidam com os do Estado. Acredita-se que "[...] o crescente envolvimento internacional das entidades subnacionais tem sido um movimento que os governos nacionais tendem a ver negativamente, ou ao menos a manter dentro de estreitos limites. A concepção realista, estatocêntrica, sugere que a coerência e a unidade da política exterior sejam necessárias para evitar qualquer vantagem para adversários ou mesmo para parceiros."

E assim, sob argumento político baseado no princípio da soberania, o poder central do Estado brasileiro reluta em ceder parte de sua prerrogativa de "manter relações com Estados estrangeiros". O entendimento é que essa relutância ocorre porque existe uma cultura institucional, de viés conservador, que determina procedimentos que se orientam em sentido oposto à tendência mundial, contrariando os anseios dos estados e municípios. Nesse viés, o princípio da subsidiariedade do direito comunitário europeu, quando invocado, é de imediato afastado, argumentando-se que não dará respostas precisas aos problemas nacionais.

Estudos realizados no Brasil indicam que os órgãos do poder central apresentam diferentes percepções quanto à questão da descentralização das ações da União nessa matéria, manifestando-se como "forças" que atuam em sentidos opostos - uma "força centrípeta" e uma "força centrífuga" - na relação entre o governo central e os poderes locais.? A "força centrípeta” representaria o pensamento e ações dos órgãos do governo

6 VIGEVANI, Tullo. Problemas para a atividade internacional das unidades subnacionais: estados e municípios brasileiros. Revista Brasileira de Ciências Sociais, São Paulo, v. 21, n. 62, p. 128, 2006.

7 CACHAPUZ DE MEDEIROS, Antonio Paulo. Introdução. In: LESSA, José Vicente da Silva. Paradiplomacia no Brasil e no 
central que até permitem ações autônomas das unidades subnacionais desde que as regule e as controle; já a "força centrífuga", como se verá mais adiante e como o termo sugere, operaria no sentido da descentralização com o mínimo de controle.

$\mathrm{Na}$ corrente resistente, conservadora, percebe-se que ainda permeia no inconsciente dos tomadores de decisão incrustados na administração dos três Poderes o apego ao subjetivismo da soberania. Grande parte dos políticos, diplomatas, militares, aplicadores e intérpretes do Direito no plano federal reagem a qualquer ideia que possa sugerir perda de soberania, alinhados que são com a perspectiva realista na qual o Estado central continua sendo o único ator legítimo para lidar com as tratativas no campo internacional. São esses agentes que participam dos processos decisórios de órgãos federais e atuam como "força centrípeta", constituindo-se em fator que dificulta ou mesmo impede o desenvolvimento da atividade paradiplomática no rumo da institucionalização.

Esse proceder resistente do poder central talvez ocorra em face da ausência de instituições suficientemente maduras para lidar com esse fenômeno historicamente recente no campo das relações internacionais, que é observado nos três níveis da administração pública brasileira. Se a avaliação é correta, é de se supor que em horizonte não muito distante as instituições amadureçam e consigam desatar o nó em que o país se encontra.

A Constituição Federal de 1988 fortaleceu o princípio do federalismo a ponto de inserir em seu corpo uma cláusula pétrea que impede apresentação de emendas que intentem abolir a forma federativa de Estado ( $\left(4^{\circ}\right.$, artigo 60 ), além de outros dispositivos que trazem a leitura de uma diminuição da centralização do poder da União observada nas Cartas anteriores. Entretanto, o que se constata nas últimas décadas é a manutenção de rígido controle da União em várias matérias que a legislação foi conformando para atender a demandas políticas, seja cerceando a autonomia das unidades, seja impedindo que se promova uma progressiva liberalização.

\subsection{A postura tolerante do Estado}

Embora a Constituição Federal apresente limites à atuação internacional de seus entes federados, a paradiplomacia é na prática "tolerada" no Brasil. Diante da escassez de recursos e da diversidade de interesses da população, o Estado de hoje enfrenta sérias dificuldades para alcançar o bem-estar social, sobretudo em razão de sua estrutura de poder centralizada, burocratizada e hierarquizada. Essa circunstância gera espaço para a atuação de outros entes mais identificados com as necessidades locais e regionais. Nesse contexto, ganha espaço no Brasil a visão da paradiplomacia sob a ótica do princípio da subsidiariedade aplicado no direito comunitário europeu.

O princípio da subsidiariedade encontra-se destacado no artigo $5^{\circ}$ do Tratado da Comunidade Europeia, consolidado no ordenamento jurídico comunitário no contexto do processo de integração, a partir do Tratado de Maastricht. Existe como filosofia desde a Grécia antiga e se firmou historicamente na Doutrina Social da Igreja Católica. A União Europeia definiu uma abordagem global para a aplicação do princípio da subsidiariedade, prevendo princípios fundamentais, diretrizes e procedimentos com a finalidade de prestigiar as comunidades regionais. Tal princípio é rotineiramente enfatizado nas principais decisões políticas nas quais é destacado o caráter de obrigatoriedade de sua observância. ${ }^{8}$

A nossa própria Constituição Federal abre perspectivas nesse campo ao ampliar as atribuições de estados e municípios - com o pacto federativo - que fortalecem a discussão sobre a possibilidade de permitir-lhes

mundo: o poder de celebrar tratados dos governos não centrais. Viçosa, MG: UFV, 2007. p. 29-38.

8 O Parecer do Comitê das Regiões da União Europeia (2011), no item "B. Subsidiariedade", "Recorda que o Tratado de Lisboa faz uma referência explícita à autonomia local e regional e à dimensão local e regional do princípio da subsidiariedade, o que significa que a UE tem de respeitar as competências dos órgãos de poder local e regional quando propõe e adopta nova legislação baseada em competências partilhadas.". Parecer do Comité das Regiões sobre regulamentação inteligente, de 11/10/2011, publicado no Jornal Oficial (da União Europeia) no C 009, de 11/01/2012, p. 0014 - 0017. Disponível em: <http://eur-lex.europa.eu/LexUriServ/ LexUriServ.do?uri=OJ:C:2012:009:0014:01:PT:HTML>. Acesso em: 28 fev. 2012. 
efetividade no trato de ações internacionais descentralizadas. Como consequências concretas dessa flexibilização, em 2003, foi criado a Assessoria de Cooperação Internacional Federativa do Ministério das Relações Exteriores, bem como, em 2004, a Subchefia de Assuntos Federativos da Presidência da República. São indicativos de uma maior atenção da União com as questões federativas e internacionais quando comparados com os períodos históricos precedentes. No entanto, “[...] a orientação geral desse processo não é clara e também não há homogeneidade no governo no sentido de procurar elevar a capacidade nacional de promoção da inserção internacional dos governos subnacionais". "

Dentro da perspectiva de que existem "forças" na relação entre o governo central e os poderes locais que operam em sentidos opostos, os órgãos que se manifestam como "força centrífuga" apresentam um caráter inovador, não atribuindo ao subjetivismo da soberania um valor além daquele visualizado no plano prático. Inspirados no princípio da subsidiariedade - ou não - os tomadores de decisão que constituem essa força centrífuga acham-se compelidos a compreender melhor as demandas das unidades subnacionais. Nos órgãos do poder central, as iniciativas no rumo da institucionalização são tênues quando comparadas ao poder das forças centrípetas; mas ocorrem, e em tendência crescente. Assim, diante da percepção, por um lado, da inexorabilidade do fenômeno, e por outro, da inspiração no princípio da subsidiariedade por parte dos órgãos e agentes da estrutura do poder central, identifica-se hoje um Estado tolerante quanto ao crescimento a olhos vistos de um modelo de paradiplomacia que opera na informalidade jurídica.

\subsection{Consequências da dupla postura do Estado}

Resumidamente, tem-se que o Estado brasileiro mostra-se resistente quanto à flexibilização da paradiplomacia por temer perder parte da autoridade soberana sobre seus membros. Para isso, invoca o princípio clássico da soberania em ações e omissões que se manifestam a partir dos tomadores de decisão que mobíliam os órgãos do poder central, dificultando o desenvolvimento da paradiplomacia. Ao mesmo tempo, o Estado é tolerante, na medida em que percebe a paradiplomacia como fenômeno inescapável, manifestando essa tolerância em ações conduzidas por alguns tomadores de decisão dos órgãos federais que relativizam o princípio da soberania, inspirados no princípio da subsidiariedade. Ocorre, pois, uma dupla circunstância em que o Estado é ao mesmo tempo resistente e tolerante com o exercício não institucionalizado da paradiplomacia.

Da postura resistente, decorre o sentido de negação das iniciativas no rumo da institucionalização. Da postura tolerante, tem-se a não coibição da ilegalidade, implicando uma quase "autorização" à continuidade da dinâmica instaurada. Diante desse desenho, e não se visualizando em horizonte perceptível a alteração concreta desse status quo, podem ser apontadas quatro consequências ao Estado brasileiro que se acham inter-relacionadas: (i) prejuízos ao desenvolvimento local e regional; (ii) insegurança jurídica; (iii) constrangimentos no plano internacional; e (iv) riscos à segurança nacional.

A primeira consequência - os prejuízos socioeconômicos - é decorrente do caráter restritivo da norma, que inibe uma maior participação nas transações econômicas e nas iniciativas conjuntas no campo social, freando os interesses de estados e municípios que aspiram incrementar seus intercâmbios visando à melhoria das condições de vida locais.

A questão da insegurança jurídica gerada dispensa maiores comentários. É de se supor que as tratativas que ocorrem no cotidiano dos entes subnacionais contenham um fator de risco jurídico intrínseco, tanto para os entes subnacionais quanto para os estrangeiros congêneres que, cientes da ocorrência de certas transações, a rigor, ao arrepio da lei, sustentam-se no ideário racionalista pacta sunt servanda e apostam na não necessidade de apelo a tribunais caso o acordado não se conforme com os fatos.

9 CENTRO DE ESTUDOS DE CULTURA CONTEMPORÂNEA (PUC-SP). Gestão Pública e Inserção Internacional das Cidades. $1^{\circ}$ Relatório Científico (Processo FAPESP nº 03/12953-0). São Paulo: CEDEC, 2006. Disponível em: <http://www.labmundo.org/ disciplinas/VIGEVANI_paradiplomacia_primeiro_segundo_relatorio_cientificos.pdf>. Acesso em: 29 fev. 2012. 
As terceira e quarta consequências - os constrangimentos internacionais ao Estado e riscos à segurança nacional - constituem o foco deste artigo e são apresentadas como uma nova perspectiva de enxergar a questão quando comparada à abordagem de outros autores, no tópico que se segue.

\section{Constrangimentos internacionais e riscos à Segurança nacional}

\subsection{A falta de critérios e condições de funcionamento da atividade paradiplomática}

Apesar de o pacto federativo sugerir alguma descentralização do poder central, a Constituição Federal não sinalizou e nem se previu regulação amiúde para o trato das possíveis ações descentralizadas de entes subnacionais no campo internacional. O Governo Federal apenas monitora empiricamente a paradiplomacia nacional; mas é um monitoramento frágil, incapaz de proporcionar ao Estado um termômetro que indique o real nível de cooperação internacional e suas implicações para a política exterior. Justamente por quase não existirem critérios e condições, várias ações se efetivam a revelia do olhar do Estado e podem comprometer os interesses nacionais e até mesmo dos próprios interessados. Diante da falta de critérios jurídicos claros e bem definidos, a atuação descentralizada no âmbito internacional guarda um potencial de risco para o Estado ou, no mínimo, submete-o a constrangimentos.

A ausência de um monitoramento formal por parte dos órgãos federais não permite a adequada avaliação da cooperação internacional descentralizada, dificultando a distinção entre experiências bem e mal sucedidas. Em não havendo uma definição clara de objetivos e nem indicadores de mensuração para avaliar se determinado projeto está, de fato, trazendo benefícios ao ente e ao país ou não, a cooperação descentralizada pode passar ao largo do interesse nacional.

Como o Estado brasileiro se mantém com a dupla postura diante da paradiplomacia, determinando uma situação de continuidade sem institucionalidade, não é factível a criação de suficientes mecanismos legais que permitam ao Governo Federal o adequado monitoramento e avaliação da ação internacional em seus diferentes graus de descentralização. Essa situação constitui o principal fator que propicia a existência de riscos e constrangimentos. O problema deixa de ser apenas no campo jurídico e passa a ser político - da high politics, no dizer dos realistas - uma vez que envolve a própria questão da soberania do Estado.

\subsection{0 potencial de conflito com a política externa nacional}

Adotemos como definição simplificada de política externa o conjunto de objetivos políticos que um determinado Estado almeja alcançar nas suas relações com os demais países do mundo, concebida com a finalidade de proteger os interesses nacionais de um país com vistas à segurança nacional, à prosperidade socioeconômica e à preservação de valores nacionais.

Os governos locais cada vez mais se lançam em iniciativas no campo internacional que visam ao incremento do desenvolvimento socioeconômico de seus estados e municípios. Enxergam oportunidades para a solução de problemas a partir da cooperação com congêneres no além-fronteira, advindo resultados práticos de maneira muito mais eficaz que aqueles proporcionados pelo poder central. Esses governos não estão necessariamente preocupados com os difusos “interesses nacionais” e as suas políticas públicas, especialmente daquelas regiões mais afastadas geograficamente do poder central, não são necessariamente harmônicas e ou convergentes com a política externa do governo central, estabelecendo-se assim uma relação que pode ser conflituosa. 
Assinala-se na ação paradiplomática dos entes subnacionais um potencial de conflito com a política externa do Estado que os integra. Tal potencial é um tema recorrente, tanto na literatura como na práxis, apesar da pouca probabilidade que conflitos se manifestem no Brasil.

A literatura indica que, apesar dos riscos, isso dificilmente acontece, a não ser quando há crises abertas do sistema federativo, como ocorreu no Canadá nos anos de 1960, ou quando há intenções secessionistas por algum motivo - étnico, linguístico, nacional ou outro -, como sucedeu na ex-Iugoslávia na década de 1990. De todo modo, esse conflito potencial - ou suas formas de resolução - entre governos locais e governo central é um ponto central quando se discute a política externa dos entes subnacionais. ${ }^{10}$

A ação dos entes subnacionais no Brasil depende muito mais da correlação entre forças políticas, capazes de tolher ou incentivar iniciativas no plano internacional, do que de uma orientação racional conduzida pelo Estado (leia-se "Itamaraty"). Como se sabe, essas forças com interesses políticos locais não são necessariamente alinhadas com os interesses da federação, o que supõe um risco inerente de conflito com a política exterior capaz de deixar o Estado sob constrangimento, na medida em que não consegue explicar o alinhamento dos interesses locais com os nacionais perante a comunidade internacional.

\subsection{A fragilização de certos elementos de controle da segurança nacional}

A paradiplomacia conduzida à revelia da União pode conter elementos que ensejam ameaças potenciais no campo da segurança nacional. Não é de se supor que preocupações mais elevadas com a segurança do Estado nacional sejam levadas em conta durante as negociações locais e regionais, até mesmo porque ameaças dessa natureza são de difícil percepção. Quando muito, os governos locais tratam da defesa nacional como sinônimo de segurança pública, em matérias relacionadas ao combate a crimes e ilícitos transnacionais, de natureza meramente policial.

Assim, tratativas que resultam, por exemplo, em abertura de uma estrada ou construção de uma ponte interligando dois países, que por um lado corresponde a uma demanda de integração socioeconômica regional, pode por outro viés estar ensejando a criação de uma "penetrante" - para usar a terminologia militar - que terá importantes repercussões nos planejamentos estratégicos da defesa nacional. A partir daquele fato consumado, por exemplo, a via de acesso aberta pode eventualmente dificultar a defesa territorial, ao possibilitar o acesso de meios militares estrangeiros, a partir de bases localizadas em cidades a milhares de quilômetros da fronteira - uma preocupação, portanto, absolutamente imperceptível aos olhos dos paradiplomatas locais. Quando uma tratativa como essa é conduzida pela diplomacia estatal, por certo o Conselho de Defesa Nacional (Lei 6.634/79) é ouvido pelo Itamaraty e opina quanto às implicações para a segurança nacional, sugerindo, por exemplo, uma estrutura de ponte mais ou menos larga - para possibilitar/inviabilizar a passagem de uma coluna de blindados de certa categoria, conforme avaliação estratégica militar. Ou, ainda, poderia apresentar parâmetros a serem seguidos quanto ao vão da ponte como determinante técnica de passagem de certas classes de embarcações.

Não é improvável o desenho de um cenário que contemple, por exemplo, imensas terras indígenas na faixa de fronteira da Amazônia em que populações locais sejam manipuladas com relativa facilidade por organizações não governamentais não alinhadas com os interesses nacionais. ${ }^{11}$ Essas organizações, em boa medida de caráter internacional, costumam manter regulares "negociações" com organizações similares do outro lado da fronteira, não raro, recorrendo a princípios como o de autodeterminação dos povos, e podem vir a trazer embaraços políticos ao Estado se não forem adequadamente monitoradas. ${ }^{12}$

10 VIGEVANI, Tullo. Problemas para a atividade internacional das unidades subnacionais: estados e municípios brasileiros. Revista Brasileira de Ciências Sociais, São Paulo, v. 21, n. 62, p.130, periodicidade, 2006.

11 Não há indicativos que apontem para a conformação dessa situação, mas a hipótese não pode ser descurada. O autor é assessor de política e estratégia do Ministério da Defesa e participa da elaboração de cenários de segurança que contemplam o espaço definido pela faixa de fronteira na Amazônia.

12 A Política de Defesa Nacional (PDN), no capítulo "4. BRASIL", destaca que "A Amazônia brasileira, com seu grande poten- 
Nessa linha de argumentação, existe ainda a hipótese, que não pode deixar de ser considerada, de que outros Estados estimulem posicionamentos contrários ao governo central, ensejando, em caso extremo, um quadro de guerra civil. Nestes dois casos, a paradiplomacia promovida é qualificada como protodiplomacia.

Presentemente, existe uma tentativa de diminuição de um importante mecanismo de controle da faixa de fronteira. A Confederação Nacional de Municípios tem se manifestado nos fóruns em que organiza ou participa com postura que promove campanha para a redução ou mesmo extinção da faixa de fronteira de 150 quilômetros. ${ }^{13}$ Esse instrumento jurídico que tem origem no período imperial está resguardado pela Constituição Federal em seu artigo 20 e regulamentado pela Lei 6.634/79. O dispositivo remete ao Conselho de Defesa Nacional o crivo de assentimento prévio para autorizar certas atividades consideradas estratégicas, entre elas o estabelecimento de indústrias sensíveis e atividades econômicas estrangeiras. Essa campanha tem encontrado eco em parlamentares que regularmente apresentam propostas legislativas no sentido de alterar aquele dispositivo legal. Não deixa de ser um reflexo da paradiplomacia não institucionalizada que não consegue calibrar o interesse dos entes subnacionais levando em conta o interesse nacional.

\subsection{A fragilização de certos elementos de controle de políticas socioeconômicas}

Uma associação de estados subnacionais fronteiriços de países vizinhos ${ }^{14}$ que, mediante "acordo internacional" regional, delibere sobre facilidade de trânsito de seus nacionais sem maiores restrições, com vistas a proporcionar maior liberdade no ir e vir das populações, pode ensejar um indesejável fluxo migratório, além de facilitar o ingresso de criminosos transnacionais, ou mesmo causar um problema diplomático se provocar uma dinâmica populacional imprevista, determinando a transposição de grandes aglomerados pelas fronteiras.

Essas mesmas unidades subnacionais, ao "acordar", por exemplo, sobre ingênuas trocas comerciais de produtos agrícolas ou mesmo de animais, sob o rótulo de economia de "subsistência", podem estar satisfazendo interesses imediatos dos fronteiriços, mas possa também, sem se darem conta, possibilitar e até estimular o ingresso de pragas e zoonoses, cujos órgãos reguladores não participaram das negociações. A possibilidade de o Amapá se constituir em porta de entrada da praga agrícola "mosca da carambola", oriunda da Guiana Francesa, é uma ilustração desse risco, caso a cooperação transfronteiriça ocorra sem instrumento de controle do Ministério da Agricultura Pecuária e Abastecimento. ${ }^{15}$

No campo das operações externas de natureza financeira, não obstante as limitações impostas pela Constituição Federal, que exige a autorização pelo Senado (art. 52, inciso V), ainda assim, há risco de eventual endividamento ultrapassar a barreira da autonomia. Diante da percepção acerca da lentidão do processo de autorização pelo Senado, e até mesmo das ingerências políticas, entes subnacionais poderiam se obrigar externamente em extensão maior do que internamente podem fazê-lo, sem o aval do poder central. Como desfazer tal constrangimento se a União não atuou como garantidora do endividamento?

cial de riquezas naturais e de biodiversidade, é foco da atenção internacional. [...]. Estas características facilitam a prática de ilícitos transacionais e crimes conexos, além de possibilitar a presença de grupos com objetivos contrários aos interesses nacionais". 2005, p. 10 .

13 "Ainda que não esteja explicitamente caracterizada nos dispositivos legais, a filosofia do modelo brasileiro de faixa de fronteira contempla, por um lado, a preocupação com a segurança nacional e, por outro, a intenção de levar o desenvolvimento às regiões mais afastadas dos centros do poder. Segurança e desenvolvimento constituem um binômio cuja dinâmica se estabelece, idealmente, por via da integração das regiões abrangidas ao núcleo central do país". ABREU, Gustavo de Souza. Modelo brasileiro de faixa de fronteira: um imperativo estratégico a ser mantido ou uma concepção ultrapassada? Revista A Defesa Nacional, Rio de Janeiro, n. 815, p. 33, 2009.

14 Um exemplo de associação dessa natureza é a "Iniciativa MAP" - Associação dos Estados/Províncias de Madre de Dios (Bolívia), Acre (Brasil) e Pando (Peru).

15 No âmbito das negociações Brasil-França, por conta do Acordo-Quadro entre esses países (Decreto 2.200/97), ao lado das tratativas de cooperação transfronteiriça oficiais conduzidas pelo Itamaraty, e com participação de diversos ministérios, ocorrem "negociações" paralelas em todos os níveis, tendo como atores o Estado do Amapá, o Município de Oiapoque, empresas privadas e organizações não governamentais, interagindo com os correspondentes da parte francesa. 
As hipóteses e exemplos apresentados têm por base situações concretas extraídas da realidade nacional. Algumas delas são portadoras de graus de risco ao Estado; outras podem causar consideráveis prejuízos econômicos, sociais, ambientais e à saúde humana e animal. O certo é que, no mínimo, podem causar embaraços à diplomacia oficial, além de forçar o Governo Federal a tomar providências internas que, por certo, desagradarão às populações das regiões envolvidas.

\subsection{A ingerência estrangeira em assuntos internos}

A ação de governos nacionais e agências internacionais que utilizam a cooperação como forma de ingerência política, econômica e cultural no campo doméstico de outro Estado é uma prática internacional pouco revelada, mas muito comum, já que esse tipo de atividade normalmente foge ao controle dos governos centrais, principalmente daqueles que não aceitam em seu ordenamento jurídico a paradiplomacia.

Há também a ingerência de organizações não governamentais e empresas privadas que oferecem uma cooperação técnica ou financeira a estados e municípios, via terceiro setor, em troca da exploração de recursos naturais, por exemplo. A facilidade é obtida pela permeabilidade que o campo da paradiplomacia não institucionalizada oferece. Uma ilustração dessa ingerência são as atividades internacionais na Amazônia em que a biodiversidade brasileira é não raro pirateada, contando inclusive com o consentimento de nacionais.

Politicamente, tem-se uma ingerência estrangeira no poder soberano do Estado brasileiro.

\section{Considerações finais}

Não há modelo único ou ideal de paradiplomacia no mundo; os países que adotam tal procedimento possuem regras muito específicas, levados em conta os aspectos econômicos, políticos e culturais, dentro de contextos históricos muito próprios.

A realidade brasileira é muito peculiar. Não temos movimentos rumo à secessão, mas temos uma extensa fronteira de quase $17.000 \mathrm{~km}$, com dez países, com interação socioeconômico local e regional em variados graus em ritmo crescente. Temos estados como São Paulo, com um PIB que se assemelha ao de países europeus, portanto com uma agenda de tratativas internacionais muito intensas, convivendo em um mesmo espaço territorial nacional que o Amapá, cujas demandas culturais recebem tintas indígenas e francesas e busca incessantemente uma porta para a Europa a partir da integração fronteiriça. Enfim, amostras nacionais que bem exemplificam a natureza diversa dos interesses de entes subnacionais no espaço internacional, determinando a ocorrência de "diplomacias" suis generis conduzidas por governos estaduais e municipais que buscam uma forma diferente de incrementar suas políticas públicas de desenvolvimento social e econômico.

O fenômeno da paradiplomacia no Brasil é caracterizado como inescapável, de tendência crescente e desejável por parte das comunidades locais e regionais. Contudo, também se caracteriza pela não institucionalidade, uma vez que se processa em descumprimento ao texto constitucional ao não observar certas competências do poder central no trato de questões internacionais.

Um dos aspectos conclusivos é que o Estado brasileiro apresenta uma dupla postura quanto à paradiplomacia: resiste à institucionalização, mas tolera a prática. Com essa postura, da qual não se evidenciam mudanças em horizonte visível, identificam-se quatro importantes consequências: prejuízos socioeconômicos a entes subnacionais, insegurança jurídica, constrangimentos ao Estado e riscos a certos aspectos da segurança nacional. Estas duas últimas, em particular, decorrem da não vigência de suficientes e adequados critérios e condições legais de funcionamento da atividade, uma vez que a Constituição nem sequer considera o seu exercício formal como competência dos membros federados, não deixando abertura para que a legislação ordinária regule a atividade e estabilize os eventuais conflitos no jogo entre demandas regionais e locais e os interesses federativos. 
Apresenta-se como solução ao problema a tomada de iniciativas, além do discurso, visando ao estabelecimento de um modelo jurídico-institucional adequado ao exercício da atividade paradiplomática pelos estados e municípios, dentro de certos limites, seja por aperfeiçoamento do texto constitucional, seja pelo reconhecimento e legitimação das atuações dos governos subnacionais em legislação infraconstitucional, com a definição clara de critérios e condições de funcionamento, no rumo da institucionalização. O Estado deve dizer claramente o "quanto" de sua soberania pode ser dividido, cedido, delegado. A permanecer pouco inclinado a mudanças, invocando o princípio da soberania, mas ao mesmo tolerante, submete-se a riscos e constrangimentos que, no extremo, poderiam levá-lo, paradoxalmente, até mesmo à perda da autoridade soberana.

Com a institucionalização, a União e os membros federados poderão exercer seus poderes de modo menos conflituoso, com ganhos socioeconômicos para as comunidades que em grande parte dependem do resultado das negociações diretas com seus congêneres internacionais, além de não deixar em xeque a credibilidade brasileira por conta de acordos não reconhecidos pelo Direito Internacional Público e não arriscar a soberania do País, por conta de uma remota, extrema, mas não descartável hipótese de tentativa de emancipação de um ente subnacional, como registra a História em outros contextos.

\section{REFERÊNCIAS}

ABREU, Gustavo de Souza. Modelo brasileiro de faixa de fronteira: um imperativo estratégico a ser mantido ou uma concepção ultrapassada? Revista A Defesa Nacional, Rio de Janeiro, n. 815, p. 33, 2009.

BRASIL. Politica de Defesa Nacional (PDN). Brasília, 2005.

CENTRO DE ESTUDOS DE CULTURA CONTEMPORÂNEA (PUC-SP). Gestão Pública e Inserção Internacional das Cidades. $1^{\circ}$ Relatório Científico (Processo FAPESP nº 03/12953-0). São Paulo: CEDEC, 2006. Disponível em: <http://www.labmundo.org/disciplinas/VIGEVANI_paradiplomacia_primeiro_segundo_relatorio_cientificos.pdf >. Acesso em: 29 fev. 2012.

DELMAS-MARTY, Mireille. Três desafios para um direito mundial. Tradução e posfácio de Fauzi Hassan Choukr. Rio de Janeiro: Lumen Juris, 2003.

LESSA, José Vicente da Silva. Paradiplomacia no Brasil e no mundo: o poder de celebrar tratados dos governos não centrais. Viçosa, MG: UFV, 2007.

SOLDATOS, Panayotis; MICHELMANN, Hans. Federalism and international relations: the role of subnational units. Oxford: Clarendon Press, 1990.

UNIÃO EUROPEIA. Relatório Anual sobre a Subsidiariedade 2010. Ponto 5 da 128. In: REUNIÃO DA MESA DO COMITÊ DAS REGIÕES, p 2-3. Bruxelas, 4 de março de 2011. Disponível em: <http://extranet. cor.europa.eu/subsidiarity/Documents/ Subsidiarity annual report 2010/Subsidiarity Annual Report 2010_ cdr57_11_pt.pdf>. Acesso em: 06 mar. 2012.

VIGEVANI, Tullo. Problemas para a atividade internacional das unidades subnacionais: estados e municípios brasileiros. Revista Brasileira de Ciências Sociais, São Paulo, v. 21, n. 62, 2006.

WOLFF, Stefan. Paradiplomacy: scope, opportunities and challenges. Bologna Center Journal of International Affairs, John Hopkins University (UK), v. 10, 2007. Disponível em: < http:/ /bcjournal.org/volume-10/>. Acesso em: 24 fev. 2012. 


\section{REVISTA BRASILEIRA DE POLÍTICAS PÚBLICAS BRAZILIAN JOURNAL OF PUBLIC POLICY}
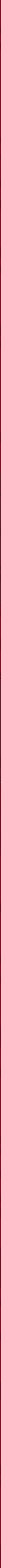


\title{
The Management of Public Natural Resource Wealth
}

\author{
A gestão da riqueza dos recursos naturais \\ público*
}

Paul Rose**

\begin{abstract}
As improved but often more environmentally-obtrusive technologies such as hydraulic fracturing facilitate the extraction of billions of dollars in natural resource wealth, more states are now faced with a welcome but exceedingly complex set of problems: Who should benefit from natural resources extracted from public lands? If the state retains much of this wealth in the form of tax receipts, how should these funds be spent? What do states owe to the communities from which these resources were extracted? What do states owe to future generations? While these are questions of first impression for a few, fortunate states, a number of states have been trying to address these issues for decades, and have enacted a variety of responses that have crucial implications for the states, their citizens, and their natural environments.
\end{abstract}

This article proceeds by providing, in Part I, historical background on the crucial legal developments which allowed state public natural resource funds to develop. In Part II, the article turns to the first of the two central questions by introducing the principal policy justifications of state public natural resource funds through a review of the stated objectives of the funds, the funds' governance and distributions mechanisms, the role the funds play in state policy making and budgeting, and the aspects of federalism implicated by the state funds. Part III then analyzes the operations of the funds in light of the policy justifications identified in the article. The article concludes by showing how governance weaknesses often limit the effectiveness of funds in achieving their policy goals, and suggests ways in which states can create appropriate legal and governance structures to enhance their funds' effectiveness.

* Recebido em 09/04/2013

Aprovado em 22/05/2013

** Associate Professor of Law, Ohio State University - Moritz College of Law. The author thanks Ashby Monk, Dale Oesterle, and many helpful participants at the Central States Law School Association Conference, The Midwest Corporate Legal Scholars Conference, and faculty workshops at the Hebert Law Center at Louisiana State University and Moritz College of Law at the Ohio State University. Thanks also to Timothy Allen, Tiffany Lacore, Chase Thompson, and Megan Walker for excellent research assistance. Email: rose.933@osu.edu

\section{INTRODUCTION}

As improved but often more environmentally-obtrusive technologies such as hydraulic fracturing facilitate the extraction of billions of dollars in natural resource wealth, ${ }^{1}$ more states are now faced with a welcome but exceedingly complex set of problems: Who should benefit from natural re-

1 For example, The Bakken Formation, which covers parts of North Dakota and Montana, has been estimated to hold as much as 503 billion barrels of oil. N.D. Indus. Comm'n, Bakken Formation Reserve Estimates (2006), available at http://www.nd.gov/ndic/ic-press/ bakken-form-06.pdf. 
sources extracted from public lands? If the state retains much of this wealth in the form of tax receipts, how should these funds be spent? What do states owe to the communities from which these resources were extracted? What do states owe to future generations? While these are questions of first impression for a few, fortunate states, a number of states have been trying to address these issues for decades, and have enacted a variety of responses that have crucial implications for the states, their citizens, and their natural environments.

Alaska's story is illustrative. The land that eventually became the State of Alaska was acquired from Russia in 1867 for $\$ 7.2$ million—about 2 cents an acre. Although the land attained much attention when gold was discovered along the Klondike River in 1896, Alaska remained a relative obscurity in terms of subnational status, first labeled a "department," then a "district," and finally a "territory." Alaska did not attain statehood until 1959. As was customary with new entrants to the union, the federal government provided the state with extensive land grants to provide the states with an economic foundation. Unlike with prior federal land grants, in which states were typically granted designated parcels of each township, the federal government gave Alaska the right to choose 103 out of the 365 million granted acres of land within the State of Alaska. In what has been described as "the single most important decision in the state's history," the state selected 1.6 million acres near Prudhoe Bay as a portion of that 103 million-acre endowment. The state knew that oil drilling in the area was likely to be profitable, though they significantly underestimated the profitability of the wells, initially projecting that oil leases in Prudhoe Bay would bring in $\$ 11$ million. The leases instead brought in $\$ 900$ million. $^{3}$

How should a state spend nearly a billion dollars in natural resource wealth? The question was of deep, lasting importance to Alaskans, and of immediate significance to money managers and consultants who rushed in to offer advice. Lehman Brothers suggested a solution that subsequent state funds have also considered: the deposit of the funds into a capital improvement account, which would serve as a backing for bonds issued for various public works projects throughout the state. Others suggested using the funds more directly to combat state needs, including "extreme rural poverty, inadequate or nonexistent schools and public facilities, and a lack of basic services." ${ }^{4}$ These uses seemed consistent with the concept of a land grant as an economic catalyst that helps new states catch up to a basic standard of living enjoyed by other states in the Union. In particular, spending on education served this present need while also connecting future generations to the benefits provided by the natural resources. ${ }^{5}$ Some, including legislators, expressed concerned with government growth and the potentially corrupting influence of a large pool of funds at the disposal of state politicians. ${ }^{6}$

Ultimately, the $\$ 900$ million was spent in a variety of ways, primarily focused on projects with intergenerational impact, such as infrastructure and education. ${ }^{7}$ Afterwards, however, many Alaskans experienced "buyer's remorse" and questioned the spending choices. But as money continued to come in from Alaskan oil fields, the question again presented itself: how should a state spend money it receives through the extraction of its natural resources? Granted, a state can (and states often do) restrict the extraction of natural resources. But as resources are extracted, states must determine the appropriate trade-offs for extraction of these resources, and they must confront the question of what duties the state owes to current and future constituencies that are affected by resource extraction.

One of the most important policy responses to the challenge of managing natural resource wealth has been the creation of public natural resource funds that hold monies generated by resource extraction in a

2 Dave Rose \& Charles Wohlforth, Saving for the Future: My Life and the Alaska Permanent Fund 118 (2008).

3 Id. at 118 (citing State of Alaska Dep't of Revenue, What's Happening to Alaska's Money_An Explanation 17 (1971)).

$4 \quad$ Id. at 119.

5 Id.

6 Id. at 119-20 (citing Representative Tom Fink's position that "the oil money [was] a problem as much as an opportunity," and that "if you have a big surplus, it's just an attractive nuisance like gambling or prostitution." (Interview by Charles Wohlforth with Tom Fink, former Speaker, Alaska House of Representatives (Jan. 4, 2006)).

$7 \quad I d$. 
permanent trust. Because state public natural resource funds operate within a federalist system, they create unique challenges and concerns; some of these concerns, including the taxation of resource extraction by states and the allocation of federal spending among states, are made weightier because of the Financial Crisis and subsequent Congressional efforts to reduce governmental spending. State public natural resource funds also raise important concerns about state governance and state management of public resource wealth. This article illuminates these issues by asking two essential questions: First, what are the policy justifications for public natural resource funds? Second, does the legal and governance framework of these funds operate ensure the funds achieve their stated goals?

This article proceeds by providing in Part I historical background on the crucial legal developments which allowed state public natural resource funds to develop. In Part II, the article turns to the first of the two central questions by introducing the principal policy justifications of state public natural resource funds through a review of the stated objectives of the funds, the funds' governance and distributions mechanisms, the role the funds play in state policy making and budgeting, and the aspects of federalism implicated by the state funds. The article identifies several common justifications for state resource funds, including revenue smoothing, intergenerational equity, and autonomy preservation.

Part III then analyzes the operations of the funds in light of these policy justifications. The operational choices of funds include how states invest, and what states do with the returns from those investments. These choices have important governance implications, as the choices affect not only the returns from the investments but can also either enhance or reduce agency costs and rent-seeking by politicians and asset managers. The article concludes by showing how governance weaknesses often limit the effectiveness of funds in achieving their policy goals, and suggests ways in which states can create appropriate legal and governance structures to enhance their funds' effectiveness.

\section{The Legal Origins of State Public Natural Resource Wealth}

State natural resource funds primarily arise from two separate legal origins. The first and much older type is the land grant fund. ${ }^{8}$ The second, more recent type of fund is the severance tax fund. The following two sections describe the legal origins—-egislative and judicial—of each of these types of funds.

\subsection{Land Grant Funds}

The origins of many natural resource permanent funds date to the $18^{\text {th }}$ century; indeed, the legislation creating these funds predates the U.S. Constitution. While the original 13 colonies inherited a property tax base that helped to support public school systems and other vital governmental services, the Western territories had no public financial infrastructure. Some members of the Continental Congress feared that as settlements expanded in the new territories under federal control, land speculation would quickly ensue, natural resources would be depleted, and, most worryingly, "the fragile new Union might fracture if settlements decided to secede or establish non-democratic governments."

\footnotetext{
8 Indeed, these funds may comfortably fit in the definition of "sovereign wealth funds" (SWFs), and if this premise is accepted, U.S. land grant funds are, by a wide margin, the oldest SWFs in the world. Many sovereign wealth fund experts consider U.S. land grant and severance tax funds to be SWFs. See, e.g., Largest Sovereign Wealth Funds by Assets Under Management, SWF Institute, http:// www.swfinstitute.org/fund-rankings/ (last visited Jan. 26, 2013).

9 Ctr. on Educ. Policy, Public Schools and the Original Federal Land Grant Program 5 (2011), available at http:/ /www.cep-dc.org/ cfcontent_file.cfm?Attachment=Usher_Paper_FederalLandGrants_041311.pdf.
} 
The legislative response to these concerns was set out in two acts: the Land Ordinance of $1785^{10}$ and the Northwest Ordinance of $1787 .{ }^{11}$ The Land Ordinance of 1785 required a survey and division of western lands into townships of seven square miles with 36 sections in each township. The statute also stated that " $[\mathrm{t}]$ here shall be reserved for the United States out of every township, the four lots, being numbered 8, 11, 26, 29, and out of every fractional part of a township, so many lots of the same numbers as shall be found thereon," and that " $[t]$ here shall be reserved the lot No. 16, of every township, for the maintenance of public schools within the said township." This brief provision provided the crucial funding mechanism for state public schools, and placed public school lands literally and figuratively in the center of the township structure. ${ }^{12}$

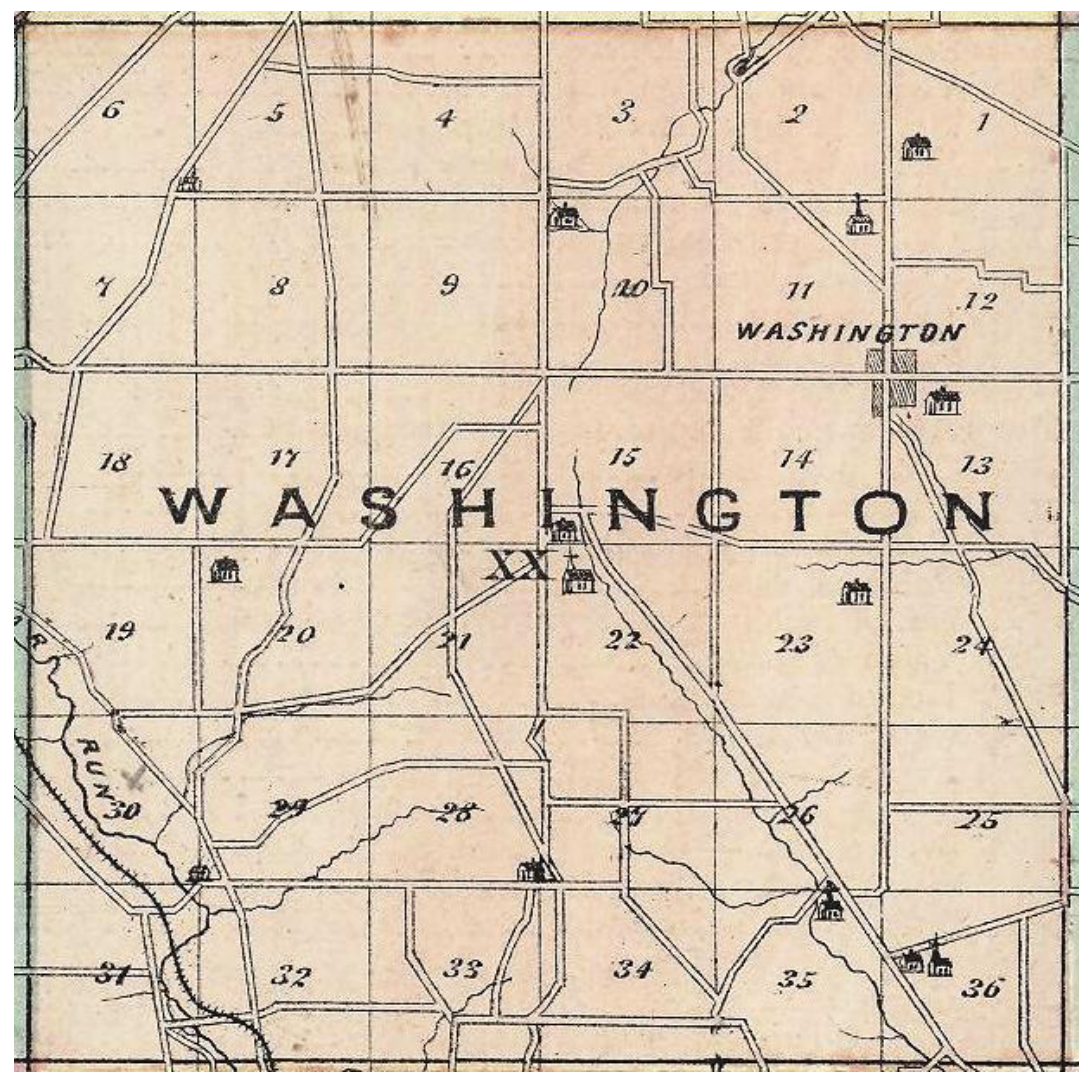

Washington Township, Ohio. Source: ATLAS MAP OF RICHLAND COUNTY, OHIO. Compiled, Drawn \& Published from Personal Graminations \& Surveys by A.T. Andreas. Chicago, Ill., 1873, p. 72.

The Continental Congress also hoped that the public school system would inculcate in future generations of students the democratic principles upon which the Union had been founded. ${ }^{13}$ As Justice Cambell wrote in Cooper v. Roberts (1855), the Land Ordinance Act of 1785 had a definite purpose, declared to consecrate the same central section of every township of every state which might be added to the federal system, to the promotion "of good government and the happiness of mankind," by the spread of "religion, morality, and knowledge," and thus, by a uniformity of local association, to plant in the heart of every community the same sentiments of grateful reverence for the wisdom, forecast, and magnanimous statesmanship of those who framed the institutions for these new states, before the constitution for the old had yet been modeled. ${ }^{14}$

10 U.S. Continental Congress, An Ordinance for Ascertaining the Mode of Disposing of Lands in the Western Territory (May 18, 1785). 11 U.S. Continental Congress, An Ordinance for the Government of the Territory of the United States, North-West of the River Ohio (July 13, 1787).

12 Because the same section was set aside in each township without regard to the condition of the lands, the sixteenth sections vary dramatically in quality and usefulness. Some are mineral rich, some are arid, some are forested, etc. Later grants also reserved a second section, Section 36, for public schools and other public institutional recipients. See, e.g., Wyoming Enabling Act of July 10, 1890, ch. 664, 26 Stat. 222, and a handful of land grants provided for four sections: 2, 16, 32 and 36. See Peter W. Culp, Diane B. Conradi \& Cynthia C. Tuell, Trust Lands in the American West: A Legal Overview and Policy Assessment 10, available at http:// www.lincolninst.edu/subcenters/managing-state-trust-lands/publications/trustlands-report.pdf .

13 Ctr. on Educ. Policy, supra note 9, at 10.

14 Cooper v. Roberts, 59 U.S. 173, 178 (1855). 
The second Congressional act, the Northwest Ordinance of 1787, provided the more formal mechanisms by which states would apply for statehood, to be achieved through the passage of an Enabling Act for each state, which would set out the specific land grant. ${ }^{15}$ Despite the intentions of the Northwest Ordinance, the process of moving from catalyzing land grants to viable school systems was often slow and inconsistent. ${ }^{16}$ The typical structure involved the grant for the benefit of the state's schools. This structure has been viewed as creating a trusteeship, with the federal government as the settler, the township (or, later, the state government as trustee), and the township school system as the beneficiaries of the trust. However, a legal trust was not created by these early statutes, and states had considerable authority to use the lands in whatever manner they saw appropriate. In 1835, Michigan was the first state to create a permanent school fund, with restrictions on the sale of the lands, coincident with its entry into the Union in $1837 .{ }^{17}$ Other states followed Michigan's model, although it was not until the Colorado Enabling Act of 1875 the U.S. Congress itself specifically placed restrictions on the sale of lands set aside for public schools, and that the sales of such lands would constitute a "permanent school fund." 18 The trust relationship was not created by the federal government, the logical settler of a trust of lands granted by the federal government for the support of state schools, but by states through their own constitutions or statutes. Colorado's 1876 Constitution, for example, contains a provision stating that the public school fund "shall forever remain inviolate and intact," and the interest from the fund "shall be expended in the maintenance of the schools of the State," 19 and requires the legislature to ensure that the land grants are "judiciously located and carefully preserved and held in trust subject to disposal, for the use and benefit of the respective objects for which said grants of land were made." 20

Many of the original grant lands have been sold, with most states taking the view that the pressing needs of fledgling school systems required substantial and immediate funding through sales, rather than a trickle of funding through leasing of the trust lands. In Oregon, for example, the state engaged in a systematic liquidation of state trust lands "based on the theory that once this property was in private hands, the lands would generate more revenue for the state in property taxes than it would in public ownership." ${ }^{21}$ According to one recent review, "the states created before 1850 have sold all or most of their granted lands. California, which joined the Union in 1850, now retains only $10 \%$ of its original grant lands. On the other hand, newer states still hold a majority of their grant lands; approximately $87 \%$ of lands in Nevada and $75 \%$ in Arizona are in federal holding." 22 The lands are, as Culp, Conradi and Tuell report, "actively managed for a diverse range of uses, including: timber, grazing, mining for oil and gas and other minerals, agriculture, commercial and residential development, conservation, and recreational uses such as hunting and fishing." ${ }^{23}$ Aside from direct payments into local school systems, the revenues generated from these trusts also support school bond financings, school construction projects, and provide limited support to a wide range of other institutions, including universities, hospitals, and even penitentiaries.

15 The Texas Permanent School Fund ("TPSF") is a notable exception to the standard public school funding mechanism provided in the Land Ordinance of 1785 and the Northwest Ordinance of 1787. The TPSF was established in 1854, making it one of the oldest permanent funds in the world. Unlike the other land grant funds, which were established by a direct grant by the U.S. government of federal land to newly admitted states in order to support public education, the TPSF was created by grants and funding provided by the State of Texas itself. First, the Texas legislature appropriated $\$ 2,000,000$ for the TPSF out of a $\$ 10$ million payment from the U.S. government in exchange for relinquishing claims to lands claimed by the former Republic of Texas. Tex. Permanent Sch. Fund, 2010 Comprehensive Annual Financial Report 5 (2010), available at http:/ / ritter.tea.state.tx.us/psf/PSF_Annual_Report.pdf.

16 Ctr. on Educ. Policy, supra note 9, at 11.

17 Id. at 13.

18 Colorado Enabling Act of Mar. 3, 1875, ch. 139, 18 Stat. 474, para 11.

19 Colo. Const. of 1876 , art. IX, $₫ 5$.

20 See id. at art. IX, $\mathbb{} 10$.

21 Culp et al., supra note 12, at 14.

22 Ctr. on Educ. Policy, supra note 9, at 2.

23 Id. 
Culp, Conradi and Tuell find 18 states with appreciable land trusts still in operation. Some of these natural resource funds produce very little revenue as a proportion of the state's overall education budget. For example, in 2004 California's trust lands provided only $0.01 \%$ of the state's education budget. In New Mexico, by contrast, trust lands provided $14.33 \%$ of the educational budget. ${ }^{24}$

\subsection{Severance Tax Funds}

The legal origins of the second type of state natural resource fund, severance tax-based permanent funds, are also tied to federal action; in the case of severance tax funds, it was a $20^{\text {th }}$ century Supreme Court decision, rather than an $18^{\text {th }}$ century act of Congress, that served as the legal foundation for these funds.

Through a 1973 legislative act, New Mexico was the first state to use severance tax revenues on natural resources, including copper, timber, and rare and precious metals, to establish a permanent fund. While New Mexico and other natural resource-rich states benefit from the extraction of these resources, the benefits are offset by significant costs. Indeed, when one hears of a "resource curse" affecting countries with abundant natural resources, the term refers not only to the tragedy that lower economic development is frequently associated with resource-rich countries, but also that the land is often made much worse as a result of the extraction of resources. The land may no longer be arable, ground water may become polluted, and air quality may be compromised. It is this particular aspect of resource extraction that led Former New Mexico Governor Jerry Apodaca to exclaim:

Let there be no mistake- the West will not become an energy colony for the rest of the nation. We will not sacrifice our greatest assets-our blue skies and clear streams, our unblemished plains and mountains-to an endless national thirst for energy. 25

As discussed below, severance taxes imposed by resource-rich states are thus set at levels that are designed to produce revenues that offset the burdens associated with resource extraction, while accounting for the value that resource extraction already brings to a state (aside from the tax revenues) in terms of employment and related benefits to local economies. Resource extractors and the states that are net importers of these resources have historically viewed severance taxes as, in the words of two commentators, "ill-disguised attempts to carve out larger shares of the profits derived from resource extraction. These larger shares are said to be unrelated to the costs the states incur from stepped-up mining." ${ }^{26}$ On the other hand, resource-rich states have countered that "mining depletes their physical wealth, imposes undesirable consequences on portions of their population, and may foreclose other developmental alternatives." ${ }^{27}$ Under this view, severance taxes are a way to force resource-poor states to pay for the negative externalities-both short term and long term-created by resource extraction. ${ }^{28}$ If severance taxes on states over-compensate the resource-rich state, however, then the state enjoys a form of federal subsidy. On the other hand, if the severance tax fails to adequately compensate the state, the state is subsidizing other states.

These issues were litigated in Commonwealth Edison v. Montana. The State of Montana imposed a severance tax on coal mined in the state; appellants, a collection of Montana coal producers and out-of-state energy companies, argued that the tax violated the Commerce Clause and the Supremacy Clause of the U.S Constitution. The trial court upheld the tax, and the Montana Supreme Court upheld the trial court decision.

24 Culp et al., supra note 12, at 59.

25 See Lee Peters, An Outline for Development of Cost-Based State Severance Taxes, 20 Nat. Resources J. 913, 913 (1980) (quoting Jerry Apodaca, Governor of New Mexico).

26 Michael B. Browde \& Charles T. DuMars, State Taxation of Natural Resource Extraction and the Commerce Clause: Federalism's Modern Frontier, 60 Or. L. Rev. 7, 8 (1981).

27 Id.

28 For example, the United States Department of Agriculture, Natural Resources Conservation Service, lists as of 1998 approximately two dozen federally-funded projects relating to water quality alone. N.M. Food \& Agric. Council Water Quality Subcomm., Federal Funding Sources for Water Quality Activities, U.S. Dep’t of Agric., Nat'l Res. Conservation Serv., (Aug. 1998), available at http:// www.nm.nrcs.usda.gov/technical/water/fund.html. 
The case was then argued before the U.S. Supreme Court. Justice Marshall, writing for a 6-3 majority, evaluated the tax under the four-part test set out in Complete Auto Transit, which allows a state tax if it "[1] is applied to an activity with a substantial nexus with the taxing State, [2] is fairly apportioned, [3] does not discriminate against interstate commerce, and [4] is fairly related to services provided by the State." 29 The satisfaction of the first two prongs of the test was stipulated by all parties. The court found that Montana's severance tax did not discriminate against interstate commerce under Complete Auto Transit since the tax was applied without regard to whether the end-users were in- or out-of-state. Appellants sought to show that the tax was not "fairly related to the services provided by the State" by providing evidence that the tax receipts exceeded the benefits of the tax provided to the coal mining industry. The court found this to be a misreading of Complete Auto Transit's fourth prong. Citing Wisconsin v. J.C. Penney Co. ", "the incidence of the tax as well as its measure [must be] tied to the earnings which the State . . has made possible, insofar as government is the prerequisite for the fruits of civilization for which, as Mr. Justice Holmes was fond of saying, we pay taxes." Under this broad reading of the taxing power, "the 'operating incidence' of the tax . $\ldots$ is on the mining of coal within Montana. Because it is measured as a percentage of the value of the coal taken, the Montana tax is in 'proper proportion' to appellants' activities within the State, and, therefore, to their "consequent enjoyment of the opportunities and protections which the State has afforded" in connection with those activities."

The court also found the severance tax in compliance with the Supremacy Clause. Although several federal acts regulated mineral leasing on federal lands (and a significant amount of Montana severance taxes came from extraction activities on federal lands), the court found that Congress specifically allowed for severance taxes on federal lessees pursuant to $\$ 32$ of the Mineral Lands Leasing Act of $920 .{ }^{31}$ Likewise, the tax was not held to be in not unconstitutional "on the alleged ground that it frustrates national energy policies, reflected in several federal statutes, encouraging production and use of coal," ${ }^{32}$ the court refusing to accept “appellants' implicit suggestion that these general statements demonstrate a congressional intent to preempt all state legislation that may have an adverse impact on the use of coal." ${ }^{\text {33 }}$

Although the decision in Commonwealth Edison gave mineral-rich states the legal justification for severance taxes, not all states have used these taxes to create permanent funds. The historical roots of public natural resource funds often tap cultural and partisan political sources, as in Alaska, but funds must ultimately arise as a clear policy choice by legislative and executive bodies, and this policy must be justified to the electorate. After all, the money could be used in many different ways: saved in a "rainy-day fund" for use in difficult economic times, spent on programs directly benefiting the communities most affected, spent widely on economic programs, and so on. The fundamental question, then, is why do these funds exist? In the next part, this article will attempt to provide answers to this question by setting out the principal policy explanations for public natural resource funds.

\section{Policy Justifications for State Natural resource Funds}

The most obvious answer to the question of why states have these funds-that the states simply had large amounts of revenues and so created a vehicle to hold those revenues_-merely tells us that state legisla-

29 Complete Auto Transit, Inc. v. Brady, 430 U.S. 274, 279 (1977).

30311 U.S. 435, 446 (1940).

31 Section 32 states, inter alia, that "That nothing in this Act shall be constructed or help to affect the rights of the States or other local authority to exercise any rights which they may have including the right to levy and collect taxes upon improvements, outputs of mines, or other rights, property, or assets of any lessee of the United States." Mineral Lands Leasing Act of 1920, 41 Stat. 437 (1920), 30 U.S.C. $\int 181$ et seq. (2012).

32 Commonwealth Edison Co. v. Montana, 453 U.S. 610.

33 Id. at 633. 
tures decided to hold at least some of the revenue for a time rather than immediately spend it (as some other states do). But why retain these funds? And when (if ever) and how should the states spend the funds? This Part and the next address those questions both descriptively and normatively, first by focusing attention on the various justifications for state public natural resource funds, and second by describing how states invest the funds coming into their funds.

U.S. state natural resource funds may be considered, both in sources of revenue and in policy justification, to be a type of sovereign wealth fund (SWF). ${ }^{34}$ Much of the academic literature on SWFs explains them in terms of political risk, or the potential use of SWFs as political tools. The use of a SWF as a political tool is but one among many explanations for the existence of SWFs, and while it may be true that some SWFs are used for political purposes on occasion (though there exists scant evidence of this), less nefarious purposes seem to drive the creation of most SWFs, whether at the national or state level. Indeed, for the first state public natural resource funds, an educational purpose was directly tied to the creation of the funds.

This Part critically examines the purposes underlying the creation of state funds, which in turn provides a foundation to analyze whether the state fund's governance and distribution mechanisms effectively achieve these purposes. For land grant funds, the initial purpose was essentially to provide the equivalent of a property tax base for the benefit of public schools, but the initial reason may not be the exclusive justification for the operation of a state land grant fund. Other justifications may arise as the fund matures. Although the specific reasons justifying the existence of a SWF are expressed in unique ways, the various justifications may be grouped together under several general categories. None of the justifications are necessarily exclusive, although for most SWF sponsors one or two justifications will predominate. Because the state funds described in this article all have their origin in natural resource commodities sales, focusing primarily on justifications for commodity funded SWFs (as opposed to the justifications for funds generated from currency reserves) gives the greatest insight into the intended function of state natural resource funds. ${ }^{35}$

34 A workable definition of a SWF is a "government-owned and controlled (directly or indirectly) investment fund that has no outside liabilities or beneficiaries (beyond the government or the citizenry in abstract) and that invests its assets, either in the short or long term, according to the interests and objectives of the sponsoring government." Ashby H.B. Monk, Is CalPERS a Sovereign Wealth Fund?, ISSUE IN BRIEF (Ctr. for Ret. Res. at Bos. C., Boston, M.A.), Dec. 2008, at 1, 4, http://www.publicpensionsonline. $\mathrm{com} /$ public/images/CalPERS\%20Sovereignity.pdf. To this definition we can further narrow the concept of SWFs to include only funds that operate under an "endowment" model, so that the fund produces income through investment of the fund's corpus, with only the income distributed. Under this definition, some of the oldest SWFs are not foreign funds, but the public natural resource funds created by acts of the U.S. Congress and state legislatures over a century ago.

35 "Dutch disease," one of the justifications for national SWFs, is not applicable to state natural resource funds. Dutch disease refers to the phenomenon wherein resource exports lead to rising currency appreciation, which in turn affects the relative pricing of manufactured goods from the same country. As the currency appreciates, other products become less competitive, resulting in a distortion to the economy, and possibly a reduction in total exports. However, U.S. states do not have their own currencies and states would not (and probably could not) reasonably expect to regulate a response to whatever effect their mineral, oil and gas sales would have on the national currency. Additionally, sovereign wealth funds have also been explained as products of state capitalism, as effectively described by Gilson and Milhaupt: "[S]ome major developing countries (China foremost among them) increasingly reflect a form of state capitalism - what we call the new mercantilism. In this form, the country is the unit whose value is to be maximized, with a corresponding increase in the role of the national government as a direct participant in and coordinator of the effort." Ronald J. Gilson \& Curtis J. Milhaupt, Sovereign Wealth Funds and Corporate Governance: A Minimalist Response to the New Mercantilism, 60 Stan. L. Rev. 1345, 1346 (2008). Mercantilist theories seem inapt to describe state public natural resource fund behavior since international trade policy is primarily regulated at the national level. However, state funds could be seen as expressing a kind of state capitalism to the extent that they are used to directly fund social policy initiatives. As a general matter, it may be difficult to extricate the political from the economic when analyzing SWF creation and behavior. SWF and state-owned enterprise investments occur against a backdrop of political relations between the SWF sponsor country and the target investment's home country, and it should not be surprising that warm economics accompanies warm politics. For example, Jiang describes a significant reduction in Chinese investment in Canada from 2006 to 2009, as the newly elected conservative government attempted a "cold politics, warm economics" approach to China, with the result that "Canada lost ground to China on the economic and trade fronts." Wenran Jiang, The Dragon Returns: Canada in China's Quest for Energy Security 16 (Canadian Int'l Council, China Papers No. 19, Oct. 2010), available at http://www.asiapacific.ca/sites/default/files/filefield/the_dragon_returns-_canada_in_chinas_quest_for_energy_security_-_wenran_jiang.pdf. The investments themselves may also be made for hybrid political-economic purposes, of course: investments by Chinese enterprises and Chinese SWFs form part of the "go-out" strategy of the central government to seek out and secure reliable sources of energy and materials around the world in order to meet domestic manufacturing and energy demands. 


\subsection{Smoothing Revenues.}

As commodity prices fluctuate, governments that are dependent on commodity sales for a portion of their revenues may have difficulty in planning expenditures in the face of revenue volatility. As Monk explains, "volatile commodity revenues have a negative impact on the growth of resource-rich countries ... [and] [f]luctuating revenues make it extremely difficult to pursue a prudent fiscal policy, especially over the long-term which, in turn, aggravates other problems in resource economies." ${ }^{36}$ Norway's SWF is perhaps the best example of the creation of a SWF in response to this problem. ${ }^{37}$ Used in this way, SWFs serve as a kind of self-renewing rainy-day fund that may be drawn down maintain domestic economic stability: "In this sense, countries have not established SWFs because they are resource-rich; they established SWFs because being a resource dependent economy means their societies are vulnerable to changes in the global market for commodities." 38 This same logic applies to American state natural resource funds. In making the case for a severance tax fund to West Virginia lawmakers, Mike Sullivan, former governor of Wyoming, noted that Wyoming's fund contributes about $13 \%$ of the total general fund, ${ }^{39}$ and that Wyoming "had difficulty just balancing the budget. We would have had trouble taking care of the most necessary needs. Probably we could not have balanced our budget without it." 40 He stated that "[w]e're a resource state, just as you are, and we've seen the peaks and the valleys. I think it clearly smooths out some of the peaks and valleys." ${ }^{41}$ As described in the next section, this "smoothing" typically results from a stable source of revenue, rather than from draw-downs in time of crisis.

\section{State Public Natural Resource Funds and the Financial Crisis}

Although state natural resource funds create a long-term source of revenue that will persist after revenue generating resources are depleted, state severance tax funds generally do not draw from their funds to smooth out lumpy earnings or to meet revenue shortfalls in the short term, nor do they generally draw from the funds even in times of crisis. State constitutions and statutes, as discussed in more detail below, generally limit the ability of the state government to spend any more than the income produced by the fund, which limits the effectiveness of the fund as a large-scale revenue-smoothing device if the income of the fund makes up only a small percentage of the state budget.

With the exception of Alabama, state natural resource funds do not appear to have a general "rainy day" function as part of their funds' objectives. Even in Alabama, the ATF only lends money to state rainy day funds, and the ATF must be repaid within 6 or 10 years, depending on the type of loan. While there is some "smoothing" that may be achieved through these loans, the founding and governance documents of the ATF, as with the other state natural resource funds, do not suggest that smoothing revenues is a primary purpose or justification for the funds.

36 Ashby H.B. Monk, Sovereignty in the Era of Global Capitalism 9 (Apr. 10. 2010) (working paper), available at http://ssrn.com/ abstract=1587327 (citing Richard M. Auty. \& Raymond Frech Mikesell, Sustainable Development in Mineral Economies, (1998)); see also Mikesell, R. L., Explaining the Resource Curse, with Special Reference to Mineral-Exporting Countries, 23 Res. Policy 191, 191-99 (1997); Paul Stevens, Resource Impact - Curse or Blessing? (Apr. 22, 2003) (working paper).

37 Monk, supra note 36, at 9 (reporting that "the establishment of Norway's SWF was based on the potential short-term costs of fluctuating revenues for macroeconomic stability, which is a characteristic shared by many commodity-based economies" (citing Gordon L. Clark \& Ashby Monk, The Norwegian Government Pension Fund: Ethics Over Efficiency, 3 Rotman Int'l J. Pension Mgmt. 14 (2010); Gordon L. Clark \& Ashby Monk, Resource Wealth and the Ethics of Global Investment: The Legitimacy and Governance of Norway's Sovereign Wealth Fund, 42 Env't \& Plan. 1723 (2010)).

38 Id. at 10. Emphasis in the original.

39 Id.

40 Id.

41 Dan Heyman, Would Mineral Trust Fund Work in West Virginia?, Pub. News Serv. (Feb. 6, 2012), available at http://www.publicnewsservice.org/index.php?/content/article/24683-1. 
As Governor Sullivan noted, smaller-scale revenue smoothing is sometimes possible with natural resource funds. For example, the income from land grant trust funds may have allowed some states to weather the Financial Crisis slightly better than others. Although states do not receive a large amount of education funding from land grant SWFs, the funding may have been sufficient to act as a buffer for some states, allowing them to avoid cuts to K-12 education. At least 34 states made cuts to K-12 education during the Financial Crisis, but states with large land grant funds, including Texas, New Mexico and Wyoming, were not among them. ${ }^{42}$

But wasn't the Financial Crisis - a once-in-a-generation event that has severely strained state budgetsthe kind of event that would justify the use of the corpus of state severance tax funds? There is some evidence that, in response to the Financial Crisis, foreign-controlled SWFs did, in fact, respond to the crisis by pulling money out of some foreign assets and reinvesting it in local businesses or infrastructure. Balin reports that between June 2008 and late 2009 ten different sovereign wealth funds participated in stabilization efforts, including direct capitalization of banks, the purchase of domestic real estate, and financing budget shortfalls. ${ }^{43}$ While such a response might seem justified, it also creates the impression (which SWFs have been at pains to avoid) that SWFs can be politically manipulated. SWFs are thus in a quandary-the use of a SWF as a rainy day fund may alleviate some of the shocks created by severe economic downturns, but it may also increase the risk that the fund could be used as a political expedient. Balin argues that this "re-coupling of SWFs with their sovereign governments may also create an undesirable follow-on effect: governments may now be rhetorically better-positioned to squander national resources for short-term political gain." ${ }^{44}$ Clark and Knight describe this risk as a temptation requiring a principled approach to political decision-making:

\begin{abstract}
In modern democracies, subject to the ups and downs of electoral cycles, the short-term political advantages of spending windfall earnings are readily apparent; it is also apparent that the beneficiaries of long-term investment are often not represented in the political process. Put more formally, the democratic political process heavily discounts the future - the discount rate being the product of the length of the political cycle, the degree to which sectional interests underwrite the power of governing parties, and the synchronization of the political cycle with the economic cycle. ${ }^{45}$
\end{abstract}

Succumbing to this temptation also had another negative effect for SWFs. As Balin reports, prior to the Financial Crisis many SWF fund managers did not believe that their fund would be tapped by the national government for current spending needs, and so their portfolios contained relatively few liquid assets such as cash, bonds, and interest-bearing deposits, and instead favored riskier, less liquid but higher-yielding assets like corporate equities, venture capital, and real estate; "When sovereigns did call upon SWFs to participate in domestic stabilization efforts, some managers were caught by surprise, forcing them to sell assets at substantial losses to cover their sovereign's funding request." ${ }^{36}$

\title{
5. Managing Short-Term Temptations
}

State natural resource funds are, of course, susceptible to the same temptations as national SWFs. Texas provides an example of how budget pressures have affected state natural resource funds, and of how the legal structure is related to the temptation presented by the fund. Texas created a permanent endowment fund, the Permanent Health Fund, with the tobacco settlement funds it receives under the MSA. However,

42 Nicholas Johnson, Phil Oliff, \& Erica Williams, An Update on State Budget Cuts (Ctr. on Budget \& Policy Priorities, Washington, D.C.), Feb. 9, 2011 at 1, 10-12, available at http:/ /www.cbpp.org/files/3-13-08sfp.pdf.

43 Brian J. Balin, The Impact of the Global Economic Crisis on Sovereign Wealth Funds, 24 Asian-Pac. Econ. Literature 1, 4 (2010).

44 Id.

45 Gordon L. Clark \& Eric R. W. Knight, Temptation and the Virtues of Long-Term Commitment: The Governance of Sovereign Wealth Fund Investment, 1 Asian J. Int'l Law 321, 328 (2011).

46 Balin, supra note 43, at 4 (citing an interview with S. Steinitz, January 21, 2010). 
in an effort to cover large cuts to the funding of state health-related institutions, Texas senate budget writers voted to liquidate the fund and distribute the corpus to the institutions. ${ }^{47}$ Again, however, this liquidation seems more likely with tobacco settlement funds than natural resource-based funds because of a weaker link to intergenerational equity concerns.

Most state natural resource funds have attempted to avoid such issues through incorporating within their founding documents the strong commitment device mentioned above: the corpus of the funds generally can only be drawn down through a constitutional amendment, which will require a vote of the citizens of the state. However, even though the corpus may not be spent, legislators may still attempt to maximize short term gains in order to maximize the amount of funds available to them during their terms of office. To structurally and statutorily discourage such behavior, states typically have legal restrictions on the kinds of investments that natural resource funds can make (discussed in Part III, infra), which make it more difficult for those administering the natural resource fund to sacrifice long-term prosperity for short-term benefits.

The robustness of these measures is ultimately dependent on the will of the citizens, because they may, by constitutional amendment (or by demanding a statutory amendment), either change the mandated fund allocations or other investment restrictions, or allow for the fund corpus to be drawn down. However, in the case of Wyoming, at least, voters have shown a surprising resilience to the temptations to draw down on the PWMTF. The issue came to a head in 2005 when the Wyoming Attorney General issued an informal opinion that only the severance tax portion of the PWMTF was untouchable. Subsequently, a House Joint Resolution called for a constitutional amendment specifying that "all monies deposited in the Permanent Wyoming Mineral Trust Fund are inviolate permanent funds of the state." 48 The original language of the Wyoming constitutional provision creating the PWMTF was rather vague, stating only that the "fund shall remain inviolate." ${ }^{49}$ The proposed amendment sought to clarify that " $[\mathrm{t}]$ he fund, including all monies deposited in the fund from whatever source, shall remain inviolate." ${ }^{50}$ In the 2006 general election, voters overwhelmingly — by a 3-1 margin — approved the proposed amendment. ${ }^{51}$ Consequently, the language of Art $15, \int 19$ of the Wyoming constitution now more clearly affirms that the corpus of the fund is untouchable and only the income can be spent by the legislature. Part of the explanation for the lopsided vote lies in the fact that what was at stake was not whether funds would be distributed directly to the citizens of the state, as in Alaska, but rather whether the legislature should be granted additional funds to be spent at its discretion. When presented in this light, the outcome of the vote is predetermined.

Alabama's voters also recently resisted efforts to use the Alabama Trust Fund for stabilization purposes. In 2010, Alabama voters resoundingly voted against a constitutional amendment that would have allowed for a legislative appropriation of the ATF for state and local transportation purposes. ${ }^{52}$ This vote is significant because, unlike Wyoming's vote, the issue was presented to voters in the midst of the Financial Crisis, yet they refused to allow for additional funds to be appropriated to the legislature. In 2012, however, a similar vote to tap into the fund passed by a 28 point margin. What changed? In part, the answer lies in how the issue was presented to voters. In 2010, the ballot measure presented to voters read,

Proposing an amendment to the Constitution of Alabama of 1901, as amended, relating to the Alabama Trust Fund, to provide for the appropriation of funds in the Alabama Trust Fund to be distributed for state and local transportation purposes and to provide for funds for the County and Municipal Government Capital Improvement Fund.

47 Curt W. Olson, Tobacco settlement money goes up in flames, Texas Budget Source (Apr. 13, 2011), http://www.texasbudgetsource. com/2011/04/tobacco-settlement-money-goes-up-in-flames/.

48 H.R.J. Res. HJ0004, $58^{\text {th }}$ Leg. (Wyo. 2006) (enacted).

49 Id.

$50 \quad I d$.

51 Statewide Ballot Issues Official Summary, Wyo. Sec'y of State (Nov. 7, 2006), available at http://soswy.state.wy.us/Elections/ Docs/2006/06Results/06General/SW_Const.Amendments_Summary.pdf.

52 See Canvas of Results, General Election, Ala. Sec'y of State 198 (Nov. 2, 2010) available at http://www.sos.state.al.us/Downloads/ election/2010/general/2010GeneralResults-AllStateAndFederalOfficesAndAmendments-CompleteWithWrite-inAppendix.pdf. 
The measure was defeated by 14 points. In 2012, again facing a funding crisis, legislators in Alabama framed the constitutional amendment differently:

Proposing an amendment to the Constitution of Alabama of 1901, to provide adequate funding for the State General Fund budget, to prevent the mass release of prisoners from Alabama prisons, and to protect critical health services to Alabama children, elderly, and mothers by transferring funds from the Alabama Trust Fund to the State General Fund beginning with the state's 2012-2013 fiscal year and concluding with the state's 2014-2015 fiscal year; to provide a new procedure for distributions made from the Alabama Trust Fund beginning 2012-2013 fiscal year; to create a County and Municipal Government Capital Improvement Trust Fund advisory committee; and to provide further for distributions made from the County and Municipal Government Capital Improvement Trust Fund.

Alabama's 2012 vote seems the exception, not the rule, and the result of the vote is perhaps more due to the alarmist language of the ballot measure than a belief by voters that the state should turn its natural resource fund into a rainy day fund. In other cases, voters have kept permanent funds permanent. The reliability of the constitutional amendment as a commitment device derives from the checks-and-balances within the amendment itself: the legislature only has access to the income of the funds, the public does not have direct access to the funds, and the legislature cannot grant itself additional funds without the approval of the public. While other kinds of commitment devices (such as heightened standards of duty) may provide security that the funds will be less susceptible to political manipulation, the constitutional amendments and statutory restrictions discussed here provide a robust and time-tested means of reducing political opportunism and short-termism.

\subsection{Credit Ratings Agencies as "Catalyst": The Natural Resource Fund as a Mechanism to De- crease the Cost of Public Debt}

Credit ratings agencies may also play a significant role in catalyzing the formation of sovereign wealth funds both here and abroad. Credit ratings agencies recognize that while the typical legal structure of the natural resource fund as a permanent fund means that the natural resource fund cannot serve as a reserve or rainy day fund, the income generated by the fund produces a relatively stable source of income for the state. ${ }^{53}$ An example of how a state may be influenced by the credit rating agencies is apparent in West Virginia's debate on whether to create a severance tax-based fund. West Virginia has been advised that, among other benefits, a severance tax permanent fund will "[b]uild assets toward the state's unfunded pension and long-term liabilities (West Virginia ranked $4^{\text {th }}$ highest in the nation, according to Moody's Investors Service) and improve the state's credit rating." ${ }^{54}$ An investment bank also advised Alaska to use its original $\$ 900$ million lease payment as a credit-enhancing backstop fund. ${ }^{55}$

Because the creation of a natural resource fund can improve the state's credit rating, the state's cost of capital can be lowered in two ways. First, as in the case of Wyoming, the existence of the natural resource fund improves the state's credit rating, ${ }^{56}$ which in turn makes the state's debt issuances relatively more marketable. This allows the state to offer debt with a relatively lower rate of return, thereby producing interest payment savings for the state.

53 See, e.g., Standard \& Poors, Wyoming; General Obligation (Jan. 15, 2013), available at http://treasurer.state.wy.us/pdf/bondcreditrating012813.pdf ("Wyoming's permanent mineral trust is established by the state constitution (Article 15, section 19) and constitutionally receives a $1.5 \%$ mineral severance tax. The corpus in the mineral trust fund cannot be spent, although the fund income is deposited as unrestricted income in the general fund.") at 4.

54 Jill Kriesky, Economist, W. Va. Ctr. on Budget \& Policy, Presentation to the Joint Commission on Economic Development: Creating a Severance Tax Permanent Fund in the Mountain State (June 13, 2011), available at http://www.wvpolicy.org/downloads/ Eco_Div061611.pdf.

55 Rose \&Wohlforth, supra note 2, at 118.

56 See Press Advisory, Office of Wyoming State Treasurer Joseph B. Meyer, State's Issuer Credit Rating Upgraded (May 10 , 2011) (attributing the AAA S\&P rating in part to " $[\mathrm{m}]$ aintenance of large general fund balances, despite the cyclical components of the state's economic base, enhanced by the existence of a permanent fund, whose interest earnings are available for general fund expenditures"). 
The existence of a state natural resource fund may also have a second and perhaps even more beneficial effect. A state natural resource fund that by statute provides support for locally-issued bonds (such as municipal school bonds) may help those municipalities issue debt at relatively lower rates, thereby incrementally reducing the need for direct state support. Texas provides an example of how this works in practice. The Texas Permanent School Fund guarantees local school district bonds, allowing the local school districts to effectively piggy-back on the ratings of the State of Texas. ${ }^{57}$ Ely reports that " $[\mathrm{s}]$ tates with substantial natural resources followed the lead of Texas' PSF to create programs that leverage royalty-supported permanent funds." 58

The benefits derived from natural resource fund support of local bond financing seems to be significant from the point of view of the individual school districts, but not very substantial when compared to the overall educational budget of the state. Before the Financial Crisis, most school districts issuing debt would have been able to purchase private bond insurance as a credit enhancement and would have received interest rate savings comparable to what a PSF guarantee would provide. However, Ely reports that after the Financial Crisis "no active insurer has comparable credit quality to the PSF's 'AAA' rating and access to a competitive insurance market is more limited for issuers with lower credit quality." ${ }^{59}$ Ely estimates that a total annual interest cost savings to school districts of $\$ 140$ million. ${ }^{60}$ He notes, however, that "the savings are small when compared to either the annual Texas formula assistance of nearly $\$ 17$ billion or school district property tax revenues of almost $\$ 18.8$ billion in 208. Annual savings for Texas school districts, at the full $\$ 140$ million annual estimate, are less than one percent of state formula assistance.”61

Although the credit enhancement effect of a state natural resource fund may provide some benefits to both local and state governments, the lower cost of capital may result in an "overinvestment" by governments. Overinvestment can occur because as the cost of capital is lowered, the government may undertake projects with a lower rate of return than those in the private markets. ${ }^{62}$ This in turn may result in the "crowding out" of superior private projects as funding flows to inferior public projects. ${ }^{63}$

Arguably, the effects of these funding shifts are primarily felt in the larger national and perhaps even international markets for debt issuances. In other words, a municipal bond is one of thousands of issuances in the debt markets, and the effects of the credit enhancement of a particular state will be dispersed across the markets rather than concentrated at the level of the state's private issuers. From the point of view of the state, then, the credit enhancement provided by a natural resource fund is a low-cost means of lowering the overall cost of capital for numerous governmental entities without significant negative effects on local private businesses. In the case of West Virginia, a natural resource fund based on a coal severance tax is thought to have the potential to achieve these savings with relatively limited local effects (ignoring the broader market effects of a shift in funding from private to public projects), because the tax is a "[h]ighly exportable tax (e.g. $87 \%$ of coal produced in WV is exported) with little effect on employment, production, and business location decisions."

\subsection{Intergenerational Equity}

SWFs and natural resource funds are also thought to be a mechanism for ensuring intergenerational equity; this is particularly true of land grant trust funds and severance tax trust funds. The term intergener-

57 See Dwight Denison, Wenli Yang \& Zhirong Zhao, Is Management Performance a Factor in Municipal Bond Credit Ratings? The Case of Texas School Districts, 27 Pub. Budgeting \& Fin. 86 (2007).

58 Todd Ely, Indirect Aid for Uncertain Times: State Credit Enhancement Programs for School Districts 17 (Mar. 25, 2011) [need permission to cite].

$59 \quad I d$. at 28.

60 Id.

61 Id.

62 Id. at 13.

63 Ely, supra note 58, at 13.

64 Kriesky, supra note 54, at 19. 
ational equity is somewhat ambiguous, as it can refer both to an imperative to save present capital in order to use it to satisfy future commitments, such as pension benefits, or as an imperative to save it specifically for the benefit of future generations, irrespective of commitments to present generations. In ageing populations, intergenerational equity suggests a fairness concern that if a citizen has paid taxes and social security or equivalent public pension payments, they have a proper claim on the government for a reasonable income in their retirement. Intergenerational equity can also refer to a principle of distributive justice: the primary concern in this sense of the term is not that present generations may enjoy some of the fruits of their life's work through government benefits in retirement, but that future generations should be able to enjoy the fruits of the nation's resources just as present generations have. Thus, a natural resource fund is not created so that (or merely that) it may provide a present generation with an acceptable standard of retirement benefits, but also that future generations should also benefit from the sale of a finite store of resources taken from the land that they are to inherit. ${ }^{65}$

Intergenerational justifications for saving a portion of present wealth have also been used to justify university endowments. As Tobin explains:

The trustees of an endowed institution are the guardians of the future against the claims of the present. Their task is to preserve equity among generations. The trustees of an endowed university . . assume the institution to be immortal. They want to know, therefore, the rate of consumption from endowment which can be sustained indefinitely. ... In formal terms, the trustees are supposed to have a zero subjective rate of time preference. ${ }^{66}$

The concerns for present and future generations overlap as the obligations owed to older generations saddle younger generations with enormous commitments that can affect the quality of life of future generations through heavier tax burdens and reduced benefits. Australia created its Future Fund with these concerns in mind: as stated by then-Treasurer Peter Costello, the Future Fund was "designed to fund Australia to meet the costs of the ageing of the population," and "in particular, unfunded superannuation liabilities." ${ }^{67}$ Similar concerns have also driven other resource-rich countries to create SWFs.

Generally, the concept of setting aside funds to provide for future generations, as opposed to shorter-term spending to businesses or support institutions that may or may not be valuable to future generations, is not without controversy. In the context of endowment funds, which also raise intergeneration concerns, Hansmann argued:

There is every reason to believe that, over the long run, the economy will continue to grow in the future as it has in the past and that future students will therefore be, on average, more prosperous than students are today, just as today's students are more prosperous than their predecessors. Thus, equity does not call for a transfer of wealth through saving, from the present generation to later ones. On the contrary, it would seem more equitable to have future generations subsidize the present. ${ }^{68}$

Likewise, Andrew Rozanov questions the principle of intergenerational equity:

[S]hould one suppress current consumption and capital formation by the present generation in an underdeveloped economy - all for the sake of maximising financial savings of future generations? And what would future generations actually prefer: inheriting a broadly diversified global financial portfolio or a broadly diversified, highly advanced local economy, which provides plenty of local employment opportunities and a solid entrepreneurial potential? ${ }^{69}$

Alaska's experience provides a good example of how the intergenerational equity debate helped shape the purpose of the APF. Proponents of the APF offered several rationales for the creation of the Alaska Permanent Fund: first, the Fund would "help to create an investment base from which to generate future income. Then, when oil revenues ran out, there would still be a major source of state revenues to pay out the costs of government services;" second, the APF would "remove a significant portion of the oil revenues from the leg-

65 Brett M. Frischmann, Some Thoughts on Shortsightedness and Intergenerational Equity, 36 Loy. U. Chi. L.J. 457 (2005).

66 Henry Hansmann, Why Do Universities Have Endowments?, 19 J. Legal Stud. 3, 14 (1990) (quoting James Tobin, What is Permanent

Endowment Income?, 64 Am. Econ. Rev. 427, 427 (1974)).

67 Clark \& Knight, supra note 45, at 12.

68 Hansmann, supra note 66, at 14.

69 Andrew Rozanov, Sovereign Wealth Funds: Defining Liabilities, 4 St. Street Global Advisors 1, [ ] (May 2007). 
islative spending stream, thus reducing the opportunities for excessive spending by the Legislature;" and third, the fund would prudently "transform" oil wealth into a "renewable source of wealth for future generations."." Although the APF had several clear purposes for its existence, the particular means of achieving these general goals had not yet crystallized by the time the APF began receiving funds. The debate focused on generational issues: should the APF be managed as an investment fund that would distribute income over the long-term, or should it be managed as a development bank and used to "force-feed" Alaska's economy in the short-term?"1 This second possibility is not necessarily inconsistent with the third rationale, intergenerational wealth transfer, justifying the creation of the APF. By using the APF as a development bank, providing loans and grants to Alaskan businesses, the fund could increase the number of small businesses in Alaska, which would serve to increase the number of jobs and broaden the economy, thereby ultimately decreasing the dependence of the state on oil and other natural resource revenues. On the other hand, a development bank would increase the possibility of political mischief as the Fund could be used as a mechanism for political patronage.

Those arguing in favor of the investment fund model were motivated by the protection of the principal managed by the APF. They believed the APF should manage the funds in accordance with the prudent investor rule and only make investments that were of "trust-grade quality" at market rates. Ultimately, the proponents of the investment fund model prevailed, although the state allocated some funds that were not part of the $25 \%$ of revenues dedicated to the APF to create several state agencies ${ }^{72}$ charged with achieving some of the short-term goals envisioned by the proponents of the development bank model.

By contrast, a mixed objective model prevailed in New Mexico and Wyoming. A mixed model indicates political compromise (with some wanting the funds spent on pressing current needs, while others wanting to save the funds), but also complicates the goal of using a natural resource fund to promote intergenerational equity. The mixed model requires a state to make bets on present funding opportunities in the hope these will pay out for both present and future generations. Or, in the case of some state agency recipients of state natural resource fund dollars, there may in fact be no particular goal of providing for future generations or for the general economic welfare of the state; short-term regional or local needs may control.

Aside from state-level concerns about the appropriate means of providing for future generationswhether to use a natural resource fund as a development fund or an investment vehicle, for example-significant federal concerns come into play. When combined with a fiscal federalism in which states receive increasingly large federal subsidies, the issue of intergenerational equity includes not merely whether and how present citizens of natural resource fund sponsor-states should subsidize future citizens, but also whether other states' citizens should subsidize present and future sponsor-state citizens despite the existence of a state natural resource fund.

\subsection{Preservation of Autonomy}

Although intergenerational equity may be the primary stated reason for the creation of a state natural resource fund, they can be also explained as a tool to preserve autonomy and sovereignty. This function may occur first at the level of the citizenry of the SWF sponsor state or, second, at the level of the elites that govern the SWF sponsor state. In the first case, focusing on the preservation of autonomy of the citizenry, Monk notes that the government of the Maldives believed a SWF would help it buy new land should global warming submerge all or part of the country. Likewise, subnational national governments have viewed SWFs as enabling independence from national governments. ${ }^{73}$

70 Clark \& Knight, supra note 45 , at 12.

$71 \quad I d$. at 7.

72 These agencies include the Alaska Housing Finance Corporation, the Alaska Industrial Development and Export Authority, and the Alaska Renewable Resources Corporation.

73 Monk writes that "Greenland recently set up a SWF for the purpose of facilitating independence from Denmark. Likewise, 
Hatton and Pistor offer a description of the second type of autonomy preservation. Focusing on China, Singapore, Kuwait, and Abu Dhabi, which they state are "without representative democracy, or where the institutions of democracy are clearly subordinate to authoritarian rule," Hatton and Pistor argue that "SWFs act to maximize the domestic autonomy of the ruling elite in the sponsor-country." ${ }^{\prime 4}$ In such states, these elites are not directly accountable to the public in general, and "it is easy to see how "governmental interest" becomes tied to the personal interests of the ruling elite. Indeed, the internal governance structures of the SWFs themselves ensure that SWF management is directly accountable to the ruling elite in each sponsor country." 75

\section{State natural resource funds as Bulwarks against National and International Pressures}

Because state natural resource funds operate in a federalist system with a powerful national government, there is little reason to believe that state natural resource funds exist to provide protection for its citizens against the forces of globalization. Even if such a purpose were intended, it would show remarkable prescience given that many state natural resource funds date from periods when globalization was either a non-existent or unimportant issue for state citizens. It is also unlikely that state natural resource funds could serendipitously serve such a role, given their limited effect on state economies. However, as Monk has pointed out, some SWFs are not designed to serve as a bulwark ${ }^{76}$ against international forces so much as against national forces. The question thus arises as to whether state natural resource funds could be used as vehicles to maximize state autonomy within the federal system. For instance, could a state natural resource fund be used as a substitute for federal funding, thus eliminating the need of the state to comply with obligations the federal government might attach to such grants? ${ }^{77}$ The perhaps surprising answer is that state natural resource funds do not serve this function, and, in fact, states with large natural resource funds (with the exception of Texas) also tend to be the states that receive the most federal funding, as shown in the graph below.

Scotland mooted the idea of a SWF to facilitate independence from the UK. Even South Australia's Commissioner for Aboriginal Engagement, Klynton Wanganeen, saw a SWF as an innovative tool to help Aboriginal communities support themselves instead of relying upon government welfare. . Viewed in this light, SWFs are perceived by some policymakers to be a means of insulating completely against the outside world; the SWF is seen to be a tool to allow the state sponsor to continue with institutions, plans or policies that, in a totally open and competitive world, would be sub-optimal." Monk, supra note 36, at 23-24.

74 Kyle Hatton \& Katharina Pistor, Maximizing Autonomy in the Shadow of Great Powers: The Political Economy of Sovereign Wealth Funds 10 (Columbia Law Sch. Working Paper No. 395, 2011), available at

http://ssrn.com/abstract $=1787565$.

75 Id.

76 This idea was seminally proposed in Gordon L. Clark and Ashby H. B. Monk, Government of Singapore Investment Corporation (GIC): Insurer of Last Resort and Bulwark of Nation-State Legitimacy, 23 Pac. Rev. 429 (2010).

77 For a discussion of the tension between states and federal government with respect to funding and compliance, see Bruce J. Casino, Federal Grants-In-Aid: Evolution, Crisis, and Future, 20 Urb. Law. 25, 40 (1988). 
Federal Aid to State and Local Governments, Per Capita Amounts by State, by Agency:

Fiscal Year 2009
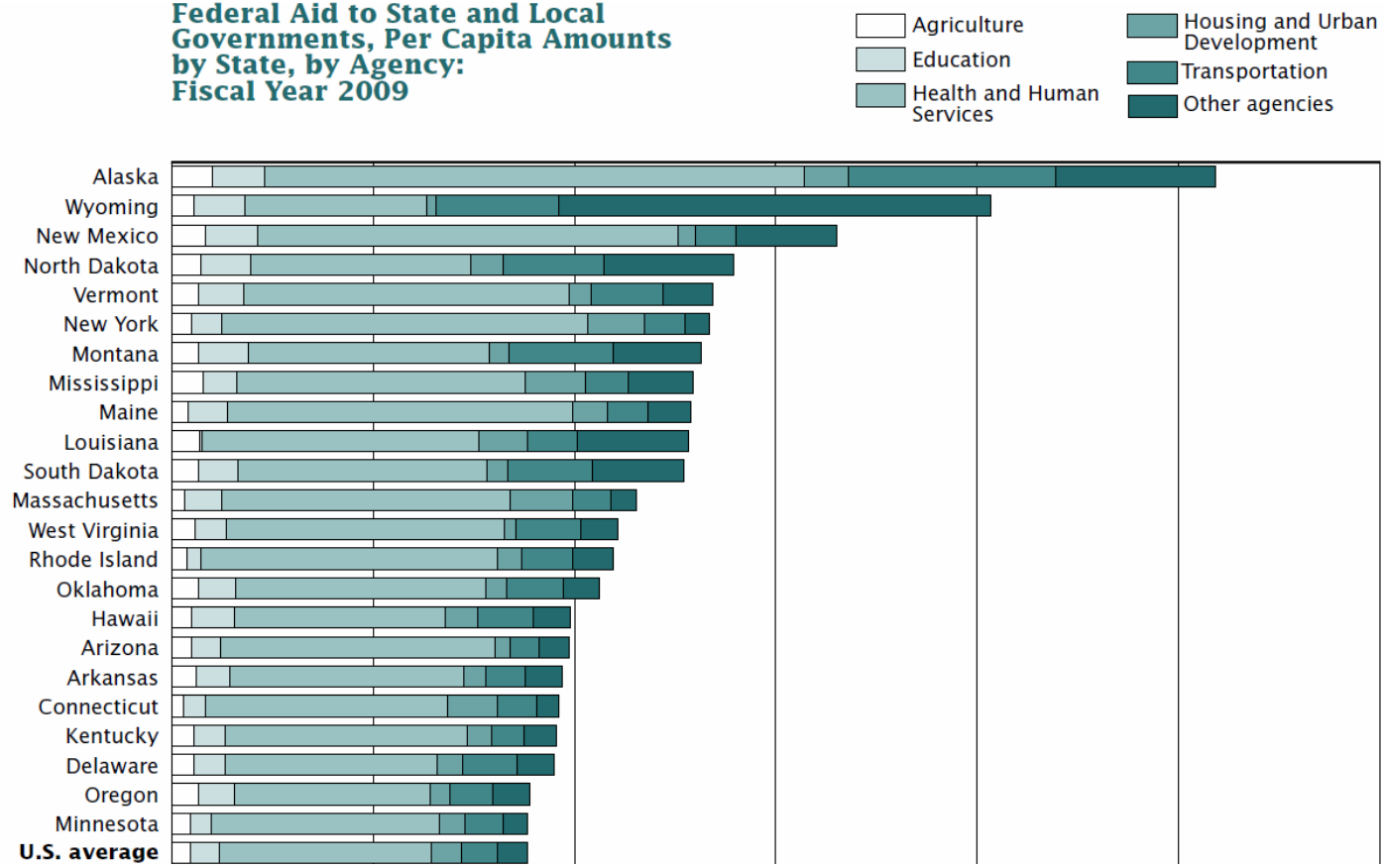

U.S. Census Bureau, 2010

Although there are numerous policy explanations for these aid patterns, the irony of this federal funding is striking. Alaska, for example, is known for rugged individualism that sometimes translates into animus against the federal government; yet as a New York Times reporter recently stated, Alaska is a paradox, "a nation-size state of about 700,000 souls where many seem to revile the federal government even as their politicians excel at reeling in and spending its money." ${ }^{\prime 78}$ Alaska has long enjoyed significant federal funding, so much so that a finance scholar at the University of Iowa recently purported to demonstrate that "in financial terms, [the purchase of] Alaska has clearly been a negative net present value project for the United States."79

Wyoming, on the other hand, is considering the drastic step of refusing federal education funds because at least some legislators do not want to accept the federal guidelines, regulations and reporting requirements which reportedly burden local school districts. ${ }^{80}$ Since income taxation of Wyoming individuals and entities contributes at least in part to this funding, however, Wyoming would in effect be funding other states' educational systems. For reasons I will address below, this is not necessarily an inequitable outcome.

As a general matter, state natural resource funds simply do not produce the kind of revenue that would allow for complete autonomy, even in a limited area like education policy. Considering just the nine states that hold approximately $85 \%$ of all remaining trust lands in the lower 48 states, New Mexico receives by far the largest percentage of public school funding from its permanent fund at approximately $14 \%$. No other state receives more than $5 \%$ of its public school funding from its permanent fund. By comparison, of the $\$ 1.13$ trillion spent at the state level on education for the 2010-2011 school year, the U.S. Department of Education contributed about $10.8 \%$ of the total. ${ }^{81}$ While a state natural resource fund may provide a state with flexibility in its spending, it does not serve as a replacement for federal funding.

78 Michael Powell, How Alaska Became a Federal Aid Magnet, N.Y. Times Economix (Aug. 18, 2010, 3:20 PM), http://economix. blogs.nytimes.com/2010/08/18/how-alaska-became-a-federal-aid-magnet/.

79 David Barker, Was the Alaska Purchase a Good Deal? 36 (August 10, 2009), http://www.news-releases.uiowa.edu/2009/ november/David\%20Barker-Alaska.pdf.

80 Jackie Borchardt, Bill Targets Facts About Federal Education Funding in Wyoming, Casper Star-Tribune (Jan. 16, 2011), http:/ / trib. $\mathrm{com} /$ news/state-and-regional/govt-and-politics/article_b06ee50d-2c03-5ef6-9d89-4d29d76831cb.html.

81 U.S. Dep't of Educ., The Federal Role in Education, Ed.gov, http://www2.ed.gov/about/overview/fed/role.html (last visited Jan. 30, 2013). 
What explains the large amount of federal funding that flows to Alaska, Wyoming and New Mexico? Like many Western states, these states have vast territories that require roads, bridges and other transportation funding to facilitate interstate commerce, but also have relatively sparse populations, translating into a high per-capita distribution of federal funds. Not all (or even most) of the federal funds go to highway projects, however. Significant portions go to Medicaid/Medicare costs, to educational funding, and to innumerable other "programmatic requests" for federal funding.

The large amount of federal funding of state programs raises concerns about the equity in allocation of federal resources. It is perhaps a truism, but one worth repeating, that the allocation of federal funds may be more a result of the political acumen of particular state representatives than of a reasoned process of analysis and prioritization of needs among the citizens of all states and territories. As a matter of public governance, however, it is worth asking the question of whether this allocation is equitable, and whether the federal government has appropriate mechanisms in place to reduce the likelihood that inequitable allocations are made. ${ }^{82}$

Federal funding to states with natural resource funds raises the additional question of interstate equity: given the resource wealth that these states enjoy, should the federal government continue to fund natural resource fund-owning states at these levels? This article will not attempt to do more than raise this extremely complex question, but it is a critical question that should be addressed by policymakers not only in the United States but in other jurisdictions that have or are considering the creation of subnational SWFs. The implication of high funding levels for natural resource fund-owner states is that other states are effectively subsidizing states that are resource-rich. As subnational entities are more integrated within the national government and economy, this may be less of a concern, but where a bright-line form of political federalism or quasi-independence obtains, such an arrangement seems correspondingly less equitable. If an increasingly larger part of the benefits and services provided to citizens come from federal rather than state dollars, should the federal government receive a portion of the severance taxes collected by resource-rich states?

\section{Policy Justifications Meet Political Realities: The Uses and Governance of State Natural Resource Funds}

The preceding Part addressed the first of the two central questions indicated at the beginning of the article by describing the policy justifications for public natural resource funds. This Part now moves to the second question: how does the legal and governance framework in which these funds operate ensure the funds achieve their stated goals? The argument thus far has shown how the key choices discussed abovehow to spend natural resource funds and whether to provide a dividend-have important political and fund governance implications. Transferring high-level justifications for natural resource funds into sound fund governance is exceedingly difficult, and state natural resource funds differ significantly in their management philosophies. The differences are particularly apparent when considering the management of severance tax funds. This article will argue that states often fail to provide an appropriate governance structure for their funds, and are falling short of the policy justifications described in Part I.

Some states may have more than one fund in operation. Land grant funds and severance tax funds may have come about for somewhat different reasons, and may operate somewhat differently. State trust lands

82 As examples of the sort of mechanism that seeks to address potential inequalities, President Obama vowed in his 2011 State of the Union address to veto any legislation containing "earmarks", and the House of Representatives has also stated that it will not approve legislation containing "earmarks." Instead, members of the House are to make "programmatic requests" for funding. A.B. Stoddard, Earmarks indelible in Congress, The Hill's Pundits Blog (Nov. 24, 2010, 3:22 PM), http://thehill.com/blogs/pundits-blog/ lawmaker-news/130691-earmarks-indelible-in-congress. It is unclear whether the distinction between earmarks and programmatic requests is meaningful. 
are typically invested through an investment division operating within the state's land management department or the state's education department, or, in the case of states with a severance tax fund, both of the state's natural resource funds are managed by a single investment entity that may operate as a stand-alone entity. In Texas, for example, the Permanent School Fund ("PSF") is managed by the State Board of Education, while the administrative activities for the PSF are handled by an investment division of the Texas Education Agency. In New Mexico, on the other hand, both the Land Grant Permanent Fund and the Severance Tax Permanent Fund investments are managed by the State Investment Council (“SIC").

Because the income generated by the funds is typically dedicated to various public entity beneficiaries, land grant funds traditionally do not invest funds in social programs as, discussed below, some states do with their severance tax funds, nor can revenues from trust lands be redirected to other purposes. Texas is again an exception to the rule, however, as legislation passed in 2007 allows the State Land Commissioner to designate some funds that would have been deposited in the PSF to be redirected to a "real estate special fund account," and also expanded the PSF's investment authority, allowing the PSF to invest in "land; interests in real property for biological, commercial, geological, cultural or recreational purposes ... [to make investments] to protect, maintain, or enhance the value of public school lands; [or, to make investments to] acquire ... an investment or interest in public infrastructure, or other interests." ${ }^{83}$

The balance of this Part provides case studies of the three largest state severance tax funds, the Alaska Permanent Fund ("APF"), the Wyoming Permanent Mineral Trust Fund ("WPMTF"), and the New Mexico Severance Tax Permanent Fund ("STPF"), and briefly describes the governance structure, investment policies and distribution mechanisms of the funds. Most state natural resource funds use outside investment managers to help invest some or all of their funds, and fiduciary standards and asset allocation requirements serve to constrain the behavior of the funds and their investment managers. Aside from these similarities, the three funds discussed in this Part have considerably different investment goals, ranging from an aggressive, total return-focused management style that produces a large annual cash dividend for Alaskans, to mixed total return and social investment strategies in Wyoming and New Mexico. After describing these models, the article then turns to the governance implications of the models, and concludes that a dividend model provides a more sound governance structure than mixed-motive, budget-expanding models.

\subsection{Supporting Social Programs while Seeking High Returns: The New Mexico Severance Tax Permanent Fund}

New Mexico's State Investment Council ("SIC") is tasked with management of the STPF. The SIC is chaired by the Governor of New Mexico and has ten other members, including the State Treasurer, the Commissioner of Public Lands, the Secretary of the Department of Finance and Administration, four public members appointed by the Legislative Council, one of whom must be the Chief Financial Officer "of a state institution of higher learning," ${ }^{84}$ and three Governor appointees. Public members are appointed with the advice and consent of the New Mexico Senate, and must be confirmed by the Senate. ${ }^{85}$ Additionally, New Mexico has a Private Equity Investment Advisory Committee, chaired by a SIC member and including three additional public members and the State Investment Officer. ${ }^{86}$ The public members selected to serve on the SIC must be "qualified by competence and not less than ten years' experience in the field of investment or finance." 87

83 Tex. Nat. Res. Code Ann. \51.402 (2007).

84 N.M. Stat. Ann. S 6-8-2 (West 1978); see also Council Members, New Mexico State Investment Council, http://www.sic.state. nm.us/council_members.htm (last visited Jan. 30, 2013).

85 Id.

86 Private Equity Advisory Committee, New Mexico State Investment Council, http://www.sic.state.nm.us/peiac.htm (last visited Jan. 30, 2013).

87 N.M. Stat. Ann. \6-8-3(B) (West 1978). 
As with states natural resource funds generally, the SIC and its managers are obligated by statute to apply a "prudent investor" standard of care; in the case of New Mexico, the standard is that found in the Uniform Prudent Investor Act (UPIA). ${ }^{88}$ The SIC's general investment policy also states that "[i]nvestments of the fund shall be diversified to minimize the risk of significant losses. Total return, which includes realized and unrealized gains, plus income, less expenses, is the primary goal of the Funds." ${ }^{\prime 9}$

Notwithstanding this basic total return focus, the investment activities of the SIC from STPF funds are complicated by numerous statutory imperatives. When the STPF was formed, New Mexico's legislature created a patchwork of investment targets for the STPF, with a specific social policy associated with each type of investment target. The legislature effected this by separating the fund's investment into two general categories: "differential rate investments" and "market rate investments." Differential rate investments are intended to "stimulate the economy of New Mexico and to provide income to the severance tax permanent fund," while market rate investments are only intended "to provide income to the severance tax permanent fund." 1

The investment criteria for market rate investments are relatively standard and similar to those employed by other large institutional investors. The investment policies place limitations on the total amount of equity securities that may be owned, for instance, and restrict the percentage of ownership of any given company. On the other hand, the list of differential rate investment targets reveals a remarkable effort at social engineering on the state level, with some of the investments paralleling federal efforts. Among other things, the SIC may make investments in mortgage pass-through securities (stimulating the mortgage market and increasing home ownership levels), New Mexico small businesses, and the New Mexico film industry. ${ }^{92}$

\begin{tabular}{|l|l|}
\hline \multicolumn{1}{|c|}{ Differential Rate Investment } & Limitations \\
\hline Conventional mortgage pass-through securities & $\$ 100,000,000$ \\
\hline New Mexico business investments & $20 \%$ of the STPF \\
\hline Educational loan notes & $\$ 10,000,000$ \\
\hline Educational institution research and development facilities revenue bonds & $10 \%$ of the STPF \\
\hline New Mexico private equity funds and business investments & $9 \%$ of the STPF \\
\hline Employers mutual company revenue bonds & $\$ 10,000,000$ \\
\hline Deposits in New Mexico financial institutions & $20 \%$ of the STPF \\
\hline Deposits in New Mexico credit unions & Not Limited \\
\hline New Mexico lottery revenue bonds & $\$ 3,000,000$ \\
\hline Investment in obligations issued for corrections facilities & Not Limited \\
\hline Investment in obligations issued for state capitol buildings and renovations & $\$ 10,155,000$ \\
\hline Investment in films to be produced in New Mexico & $6 \%$ of the STPF \\
\hline
\end{tabular}

88 The standard requires the manager to "invest and manage trust assets as a prudent investor would, by considering the purposes, terms, distribution requirements and other circumstances of the trust. In satisfying this standard, the trustee shall exercise reasonable care, skill and caution, [and] a trustee's investment and management decisions respecting individual assets must be evaluated not in isolation but in the context of the trust portfolio as a whole and as a part of an overall investment strategy having risk and return objectives reasonably suited to the trust." Unif. Prudent Investor Act $\$ 2$ (a)-(b) (1995), available at http://www.uniformlaws.org/shared/docs/ prudent\%20investor/upia_final_94.pdf; see also N.M. Stat. Ann. \45-7-602 (West 1978); SIC General Investment Policy, N.M. State Inv. Council (Mar. 14, 2008), available at http://www.sic.state.nm.us/PDF\%20files/080314\%20SIC\%20GENERAL\%20INVESTMENT\%20POLICY-Final.pdf.

89 SIC General Investment Policy, supra note 88, at 1.

90 N.M. Stat. Ann. \$ 7-27-5 (West 1978).

91 Id.

92 The various statutes setting out the limitations for differential rate investments are found in N.M. STAT. ANN. \ 7-275.3 through \ 7-27-5.26. See also New Mex. St. Leg., Summary of Economically Targeted Investments (May 31, 2010), available at .http://www.nmlegis.gov/lcs/handouts/SIC $\% 20$ Presentation $\% 20$ to $\% 20 I O C \% 20 J u l y \% 202--S u m m a r y \% 20$ of $\% 20$ Economically $\% 20$ Targeted $\% 20$ Investments.pdf. 
The State Investment Council has published detailed investment policies for its private equity, film, real estate, mortgage loan, and hedge fund investments. Overall, the general investment policy of the SIC attempts to balance the two objectives of the differential rate program of the STPF-first, to produce a "risk adjusted rate of return under the Prudent Investment Rule," New Mexico" " - by ensuring that "credit quality is maintained and risk is minimized, market-based yields that are proportional to the assumed risks are obtained, each investment will stimulate the economy of New Mexico on a continuing basis, each investment will expand business activity in the state, and each investment will promote the creation and preservation of jobs."

\subsection{The Many Uses of Wyoming's Severance Tax Funds}

Wyoming also has multiple objectives for its severance tax fund investment program. The general policy for Wyoming trust funds requires the State Loan and Investment Board to invest public funds "in a manner that strives for maximum safety, provides adequate liquidity to meet all operating requirements, and achieves the highest possible investment return consistent with the primary objectives of safety and liquidity." 95 Wyoming holds the Board, the state treasurer, and any fiduciary appointee (such as an external manager) to the prudent investor standard set out in the Uniform Prudent Advisor Act as enacted by Wyoming. ${ }^{96}$ The Board is made up of the Governor (as President of the Board), the Secretary of State, the State Auditor, the State Treasurer, and the State Superintendent of Public Instruction. The State Treasurer handles most of the monitoring of external managers and is tasked with setting up internal controls systems and developing and recommending investment policies, among other things. ${ }^{97}$ All of these officials are elected in statewide general elections and serve a four-year term.

Wyoming has set out by statute a set of permissible investments and investment allocations. The statutes contain only two significant restrictions on investments. First, only up to $35 \%$ of the fund may be invested in common stocks. Second, prior board approval must be obtained before the state is allowed to invest in "alternative investments." "The Board's investment policy adds to these restrictions by prohibiting self-dealing transactions, floating rate securities, individual certificates of deposit, letter stock and other unregistered equity, commodities (if not part of an alternative investment), most real estate transactions, natural resource properties, and short sales and margin transactions. ${ }^{99}$ Derivatives may be used to manage risk, and the use of derivatives, 'in pursuit of strategies to achieve 'above market' performance is considered speculative and is strictly forbidden,”100 except as part of an approved alternative investment program.

Like New Mexico, Wyoming's statutes also expressly permit state natural resource funds to invest in various investments that further targeted social policies. Among other things, the state treasurer is permitted to invest (or in some cases, pledge) up to $\$ 25$ million in non-delinquent federally guaranteed or insured higher

93 SIC General Investment Policy, supra note 88, at 13.

94 Id.

95 State of Wyo. State Loan and Inv. Bd., Master Investment Policy and Sub-Policies 3 (June 3, 2010), available at http://treasurer.state.wy.us/pdf/investmentpolicy060310.pdf. Along with safety of principal and liquidity, the Board also lists the following "objectives and priorities": Yield; Recognition of differing objectives and needs of various fund portfolios; Conformance with state law and other pertinent legal restrictions; Maximization of the total rate of return on investment consistent with the foregoing objectives; Diversification by asset type, security and investment manager in order to smooth the volatility of quarterly returns. Id. 96 Wyo. Stat. Ann. \4-10-901 to -913 (West 1977). The standard requires, inter alia, that a trustee "invest and manage trust assets as a prudent investor would, by considering the purposes, terms, distribution requirements and other circumstances of the trust." Wyo. Stat. Ann. S 4-10-901 (West 1977).

97 State of Wyo. State Loan and Inv. Bd., supra note 95, at 6-7.

98 "Alternative investments" are defined as "investments in nontraditional asset classes or in traditional asset classes which are utilized in a nontraditional strategy." Wyo. Stat. Ann. S 9-4-714(a)(i) (West 1977). The statutes grant authority, however, for the state's chief investment officer (by statute, the state treasurer) to invest funds in any investment authorized by the legislature or authorized or approved by the board. Wyo. Stat. Ann. \9-4-715 (West 1977).

99 State of Wyo. State Loan and Inv. Bd., supra note 95, at 11.

100 Id. at 11-12. 
education loans from any nonprofit Wyoming corporation organized to acquire such loans; $;^{101}$ up to $\$ 300$ million from the common school account in the permanent land fund to guarantee school district bonds; ${ }^{102}$ up to $\$ 100$ million to guarantee local government bonds; ${ }^{103}$ and, “to promote economic development," the state treasurer may invest up to $\$ 100$ million in industrial development bonds issued by joint powers boards, municipalities or counties. ${ }^{104}$ The state treasurer may not invest more than $\$ 50$ million "for a specific public purpose authorized or directed by the legislature," although the amount may be adjusted by recommendation of the state treasurer and approval by a Board subcommittee on capital financing and investments. ${ }^{105}$

The state investment policy also sets out various portfolio guidelines. For example, the state may only own one percent or less of the common stock of any corporation, ${ }^{106}$ and only up to one and one-half percent of the total book value of the funds may be invested in the common stock of any corporation. ${ }^{107}$ Like many funds, Wyoming also acknowledges the challenge of matching its investment policy to its fiduciary duties when a higher return may be generated with investments that are at odds with other social, ethical and political goals. In a somewhat convoluted provision, the state investment policy attempts to discourage certain investments while reaffirming its commitment to invest in the economic interest of the fund:

The Board is concerned with terrorism and human rights violations occurring worldwide, yet recognizes its fiduciary responsibility to invest only in the best economic interest of the portfolio. While the Board cannot make investments based on social or political objectives, it does consider the economic effects of social and humanitarian issues in the analysis of investments. The Board seeks to avoid investments that support terrorism or the violation of human rights. As such, the Board will require its investment managers to acknowledge that they will seek to avoid such investments. ${ }^{108}$

The actual investment of the funds is outsourced to a number of different external managers, including core plus fixed income managers, corporate fixed income managers, mortgage fixed income managers, global/emerging market fixed income managers, public equity managers, cash and extended cash managers, private equity (alternative investment) managers, real estate (alternative investment) managers, overlay strategy (alternative investment) managers, and absolute return (alternative investment) managers. ${ }^{109}$

The subpolicy for the PWMTF provides additional detail on the strategy, distributions and allocation of the PWMTF. Under this subpolicy, in accordance with statute, the corpus of the PWMTF is inviolate; only income and capital gains may be distributed. ${ }^{110}$ The subpolicy notes, however, that the state legislature has often directed portions of the PWMTF to "directed investments" mandated by the legislature, and therefore "only the remaining portion is available for discretionary investments by the State Treasurer's Office." 111 Because the legislature may withdraw significant portions of the PWMTF, "the fund must be managed to allow an extensive range of investment maturities that will provide for funds availability for directed investments as they come into existence as mandated by the Legislature."112

101 Wyo. Stat. Ann. \ 9-4-715(f) (West 1977) (repealed by Laws 2011, ch. 129, § 207, eff. July 1, 2011).

102 Wyo. Stat. Ann. \$ 9-4-715(g) (West 1977).

103 Wyo. Stat. Ann. S 9-4-715(h) (West 1977).

104 Wyo. Stat. Ann. S 9-4-715(m) (West 1977). Investments under this statute require the recommendation of the Wyoming business council created by W.S. 9-12-103, and also require written approval of the governor. A number of other restrictions also apply, and new investments of this type are not allowed to be made as of June 30,2011. Id.

105 Wyo. Stat. Ann. \9-4-715(n) (West 1977).

106 State of Wyo. State Loan and Inv. Bd., supra note 95, at 12. However, “[a]n exception may be made for Alternative Investments and for companies with a market capitalization below $\$ 5$ Billion.”

107 Id.

108 The policy imposes the following requirement on its investment managers: "Investment Managers are required to check portfolio holdings no less frequently than quarterly against the companies listed on the Specially Designated Nationals List and the countries listed on the Lists of Sanctioned Countries, maintained by the U.S. Treasury Department Office of Foreign Assets Control ("OFAC"), to ensure that the companies or countries on the list are not represented in the portfolios. If a current holding appears on the list at the time of the quarterly check, the Manager will eliminate the position from the portfolio within a reasonable period of time and will not make additional purchases unless the issuer is removed from the OFAC list." Id.

109 Id. at $12-16$.

110 Id. at 25-26.

111 State of Wyo. State Loan and Inv. Bd., supra note 95, at 25-26.

112 However, "a specially managed portion" of the PWMLTF must be held inviolate," even against the occasional legislative 


\subsection{Distribution of Severance Tax Fund Income to State General Funds}

In the case of both New Mexico and Wyoming, most of the income from their severance tax fund is deposited in the state's general funds. Under the Constitution of the State of New Mexico, the STPF distributes $4.7 \%$ of the average of the year-end market values of the fund for the immediately preceding five calendar years. The distributions are made in 12 equal monthly increments. The fund distributions are "appropriated by the legislature as other general operating revenue is appropriated for the benefit of the people of the state."

As with New Mexico, the income from the PWMTF is deposited in the state's general fund. ${ }^{113}$ The PWMTLF provides a large portion of Wyoming's general fund. In 2008, for example, the PWMLTF contributions made up $24 \%$ of the state's general fund. In 2009 the PWMLTF contributed $12.7 \%$ of the state's general fund, and in 2010 the PWMLTF was expected to contribute $13.6 \%{ }^{114}$ The constitution also provides that the legislature may specify "conditions and terms under which monies in the fund may be loaned to political subdivisions of the state." 115 The PWMTLF presently loans money under several programs, including the Farm Loan Program, the Joint Powers Act Loan Program (providing loans to local governments), and the Hot Springs State Park Loan Program (providing loans for capital improvements to businesses in the park). ${ }^{116}$

\subsection{The Dividend: Alaska's Permanent Fund}

The Alaska Permanent Fund ("APF") is directly overseen by the Alaska Permanent Fund Corporation ("APFC"), a state-owned entity that operates as a "quasi-independent state entity, designed to be insulated from political decisions yet accountable to the people as a whole." 117 The establishment of a corporation as a separate entity, rather than as an agency within the state government, is intended to "protect the Fund's long-term performance by keeping it as removed as possible from short-term political considerations." 118 Yet at the same time, the APF was created as a means of controlling political power; while the fund's structure (as set out by Alaska's constitution and statutes) prevent the APF from being employed for short-term political uses, the dividend structure, described below, imposes on the government overseers of the APF the incentive to maximize the value of the fund.

The APFC retains direct political accountability through an annual APFC report to the Legislative Budget and Audit Committee, and through approval of the APFC budget by the Legislature. ${ }^{119}$ The APFC also has a six-person Board of Trustees, all of which are appointed by the governor. Four of the trustees are public members, and two are cabinet members (the Commissioner of Revenue and another cabinet member selected by the governor). The four public appointees must possess "recognized competence and expertise in finance, investment and other business management-related fields." The public appointees serve staggered four-year terms, and each year one of them is elected to serve as the chair of the Board.

mandate; "[t]hese funds are to be invested for the long term to produce a higher return without the cash flow or legislatively directed investments." Id.

113 Wyo. Const. art. 15, S 19 (2011).

114 Permanent Mineral Trust Fund (PMTF), Wyo. Taxpayers Ass'n, http://www.wyotax.org/PMTF.aspx (last visited Jan. 30, 2013).

115 Wyo. Const. art. 15, $\int 19$ (2011).

116 State of Wyo. Office of State Lands and Invs., Summary of State Loan Programs and Associated Loan Loss Reserve Funds 1 (April 30, 2011), available at http://slf-web.state.wy.us/osli/BoardMatters/2011/0611/SLIB/Loan0611.pdf. The combined loan balances for fiscal year 2011 were approximately $\$ 44$ million. Id. at Schedule 1 . Loan interest rates vary by program and range from $4 \%$ to $10 \%$. Id. at $2-3$.

117 Alaska Permanent Fund Corp., An Alaskan's Guide to the Permanent Fund 31 (2009), available at http://www.apfc.org/ home/Media/publications/2009AlaskansGuide.pdf.

118 Id.

119 Id. 


\section{The Creation of the APF Dividend}

The distinguishing feature of Alaska's fund is that a significant portion of the income generated by the fund is paid out to Alaskan citizens in the form of an annual dividend. The dividend is paid out according to a specific formula as set out by statute. ${ }^{120}$ After this calculation, a determination is made as to whether there are sufficient funds in the earnings reserve account to pay the dividend. The dividend may not be paid out of the principal ${ }^{121}$

The APF paid out over $\$ 16.7$ billion to Alaskans between 1982 and 2008. For many Alaskans, particularly native Alaskans and those in rural Alaska, the dividend is a major source of income.

\section{APf Investment Polices}

In the early years of the APF, the fund's investment policy was based on traditional asset allocation techniques, and was heavily invested in bonds. However, in 2009 the Board of Trustees "recognized that some investments might have more in common with investments from other asset classes with regard to their expected levels of risk and return." For example, corporate bonds may not act like U.S. Treasuries as much as they act like stock; "this makes sense when you consider that the companies that issue these corporate bonds are the same companies traded in the stock markets." Under its new strategy, the Board thus determined to group assets by risk characteristics, rather than by asset class. So rather than grouping assets as stocks, bonds, cash, etc., the APF now classifies investments as "Cash," "Interest Rates," "Company Exposure," "Real Assets," and "Special Opportunities." "Cash" includes liquid instruments with durations of less than 12 months. "Interest rates" includes low credit-risk securities such as U.S. Treasury bonds and non-U.S. government bonds. "Company Exposure" includes investment grade and high-yield bonds, U.S. and foreign stocks, bank loans and private equity investments. "Real Assets" includes real estate, infrastructure, and Treasury inflation protected securities (TIPS). The "Special Opportunities" category includes, among other things, absolute return assets, distressed debt, and commercial mortgage-backed securities.

The discussion surrounding the move to this new strategy in 2009 reveals the grip of the APF's governance mechanisms. When the managers approached the Board about the shift (after significant consultation with external advisors), the Board initially balked. APF Chief Investment Officer Jeff Scott proposed moving money into a hedge fund investment, but encountered some resistance. ${ }^{122}$ Trustee Nancy Blunck expressed concern that APF staff was moving too quickly into alternative investments, and the Board and

120 The dividend is essentially calculated by averaging the net income of the APF over the past five years, multiplied by 21 percent, divided by 2 , then divided by the number of eligible applicants. In 2010, the amount was calculated as follows (amounts in thousands, except individual dividend amount): Net income from previous five years, $\$ 8,171$; multiplied by $21 \%=\$ 1,716$, divided in half $=\$ 858$, then after various minor adjustment are made, the total is divided by the estimated number of dividend applicants: $\$ 822,100,000 / 641,595=\$ 1281.00$ (rounded to nearest whole dollar).

121 As succinctly reported in a recent news article, The Permanent Fund's value is divided into two categories — principal and "realized gains." The categories let managers calculate how much can be used for state expenses and how much is off limits from such spending. The principal is the value of the assets owned by the corporation at any given time, and it's off limits, as mandated by the Alaska Constitution. The realized gains are dividends, rents, bond interest payments and profits from sales of assets, and they can be spent by the Legislature.

As of June 30, the realized gains account held more than $\$ 2$ billion. By law, up to half that account can be used to pay the Alaska Permanent Fund Dividend to Alaskans. The formula that's used to calculate the dividend put the full cost of the October 2010 checks at $\$ 858$ million, so the account held enough to pay the bill. The Legislature approved that spending.

Editorial, Steady Hands: Permanent Fund Managers Oversee Continued Recovery, Fairbanks Daily News-Miner (Feb. 6, 2011, 1:49 AM), available at http://newsminer.com/view/full_story/11289912/article-Steady-hands--Permanent-Fund-managers-oversee-continued-recovery.

122 Pat Forgey, Permanent Fund's New Investment Strategy Raises Concerns, JuneauEmpire.com (June 23, 2009), http:/ /juneauempire. $\mathrm{com} /$ stories/062309/sta_453704024.shtml. 
the public were not "in the loop." "This is public money," stated Blunck, "It is not corporate money, it's not private money." 123 The relationship between political accountability and fund performance is evident here: the Board operates with the knowledge of how important the dividend payout is to Alaskans, and is very reluctant to jeopardize a consistent payout. They thus have a political incentive to maintain strict control over APF fund managers. At the same time, letting the public "in the loop," may affect the performance of the Fund as the market generally becomes aware of the fund's strategy before the fund may execute the strategy. Another trustee, Pat Galvin, also voiced concern with the move to alternative investments: "It seems to me like we are being slow-walked down a path with these incremental decisions." ${ }^{24}$ Scott expressed frustration at the comments, stating "if I can't do anything, I need to know." 125 Ultimately Galvin indicated that the Board may want to reconsider whether it should invest in hedge funds, but did not block the proposal. ${ }^{126}$

\subsection{The Governance Implications of Targeted Investments and Dividends}

If appropriately structured and managed, a state natural resource fund can act as a governance mechanism for controlling governmental use of income from resources-a large-scale governmental commitment device. A natural resource fund can enhance accountability in several ways. First, a natural resource fund typically forms part of a structure to redirect certain revenues and places restrictions on how those revenues may be spent. In a corporate context, this would be akin to taking some spending discretion away from managers by forcing a certain amount of income to be reserved. This decision may be the result of a desire to restrict government expenditures generally, but it may also have a more partisan political objective. For instance, Oklahoma's legislature recently sought to create a natural resource fund (the bill providing for the creation of the natural resource fund was ultimately vetoed by the governor), and some have speculated that the fund was designed in part to serve as "a policy tool implemented by Republicans (i.e. fiscal conservatives) to discipline the spending of a Democratic governor." 127

Public natural resource funds can also serve as mechanisms for leveraging political accountability through trustee accountability: the management of the fund should produce clear results that allow for citizens to judge the quality of the fund management. While elected officials rarely have a direct hand in managing natural resource fund investments, at least some officials typically serve on boards that oversee state natural resource funds. They are thus ultimately responsible for the overall direction of the fund (subject to constitutional and statutory parameters) and for the selection of asset managers of the fund. Politically, the politician is incentivized to manage the fund well so as to ensure re-election. Since politicians are elected by current rather than future citizens, they may also have the incentive to maximize the welfare of the present generation of voters at the expense of future voters. The private law concept of trustee fiduciary duties is grafted onto constitutional and statutory restrictions on the use of funds to temper politicians' incentives to benefit present generations at the expense of future generations. As with fiduciaries in private settings, transparency and accountability are key to managing the agency costs under this framework. As will be discussed below, cash transfers such as Alaska's offer a relatively clear and transparent signal of management quality, thereby providing a significant impact on political accountability. On the other hand, a poorly designed natural resource fund merely layers agency costs on agency costs—managerial agency costs may

\footnotetext{
$123 \quad$ Id.

$124 \quad I d$.

$125 \quad$ Id.

126 Id.

127 Ashby Monk, Oklahoma Loves SWFs, Oxford SWF Project (March 5, 2010), http://oxfordswfproject.com/2010/03/05/ oklahoma-loves-swfs/. Commenter Rien Huizer agrees, and states that the SWF is a tool to "make vote buying by the other side harder," and finds it an "interesting use of [government surplus] (similar to the Australian Future Fund), but here in a country that has severe budgetary problems." Posting of Rien Huizer to Monk, supra (Mar. 7, 2010, 12:24 AM). But this, of course is the result of a federalist form of government, and the fact that local surpluses not only do not have a significant effect on the federal budget, but also do not seem to have the effect of decreasing the funds granted to states with significant natural resource revenues.
} 
be layered onto existing political agency costs. If the results of the fund are either not transparent or are ignored because the fund has little impact on the lives of current citizens, agency costs are likely to increase because politicians may not be incentivized to contain them. The natural resource fund may thus become a vehicle for rent-seeking at the expense of both present and future generations.

\section{Investment Policies and Agency Costs}

Investment constraints written into the investment policies of the state-and in some cases, state statutes and even the state constitution-are often intended to serve as agency cost reducing mechanisms by restricting the ability of the managers to invest in riskier assets. As described below, these restrictions most often take the form of hard asset allocation rules, as well as lists of permissible investments. These fixed restrictions can serve as agency cost reduction mechanisms, but the restrictions can also limit the returns of the fund and expose the fund to additional, uncompensated risks. Perhaps because of the relatively larger size of the fund and because of its dividend policy, Alaska has been the most active state in matching its investment policies with current best practices for asset management. As discussed earlier, Alaska, like many national SWFs and other large asset managers (such as CalPERS), is moving away from a traditional asset allocation approach to a "factor-based" or "risk-oriented" approach. These approaches classify assets by risk characteristics, rather than simply by broad asset class labels such as "corporate bonds" or "US public equities." As Monk explains, "an asset allocation based on equities, bonds, and alternatives may ultimately be providing very little diversification in terms of the underlying factors that drive returns. So, by focusing on the factors, an investor can better grasp what asset classes will provide the desired risk exposures." ${ }^{28} \mathrm{He}$ also notes how the Financial Crisis demonstrated the dangers of an asset-focused portfolio:

During the credit crunch, the "asset-oriented" approach didn't provide the amount of diversification that the funds had expected/hoped. All the assets in their portfolios seemed to be moving in the same direction: down. For example, take CalPERS, which is one of the most diversified investors in the world. It lost $\$ 100$ billion in roughly 18 months — the fund was worth $\$ 260$ billion in October 2007 and touched $\$ 160$ billion in March $2009 .{ }^{129}$

While a factor-based approach "allows a better understanding of risk-return trade-offs," 130 as Ang argues, it also provides a more precise means of tailoring the fund's investments to its payout model because "SWFs with different governance structures and payout rules have different optimal bundles of factors." 131 Creating a factor-based approach is complicated in Alabama, however, where the asset allocation strategies are defined by the state constitution, and a new strategy would need to receive public approval. In other states, the complication is somewhat less daunting because only the legislature would need to approve amendments to state statutes governing the investment policies of the funds.

Investment policies can also create classic governance problems like self-dealing and waste. Notwithstanding the fact that New Mexico, for example, has general policies that appear oriented to measurable economic outcomes, using STPF revenues for differential rate investments creates numerous (and apparently justified $)^{132}$ concerns about how those funds will be allocated and increases the risk of political patronage. New Mexico's history of limited public spending and a Constitutionally-mandated balanced budget (along

128 Ashby H. B. Monk, The Appeal of Factor-Based Allocations, Oxford SWF Project (Feb. 9, 2011), http://oxfordswfproject. com/2011/02/09/the-appeal-of-factor-based-allocations/.

129 Id.

130 Andrew Ang, The Four Benchmarks of Sovereign Wealth Funds 1, 19 (Sept. 10, 2010) (working paper), available at http:// papers.ssrn.com/sol3/papers.cfm?abstract_id $=1680485$.

131 Id.

132 In 2011, the SIC filed lawsuits in state and federal court alleging that former SIC officials were engaged in pay-to-play schemes. The Shoe Finally Drops: New Mexico Files Lawsuits in Federal and State Courts in "Pay to Play" Scandal, Capitol Report New Mexico (May 6, 2011), available at http://www.capitolreportnewmexico.com/?p=4365. 
with the allocation limitations mentioned above) eased concerns over wasteful spending. ${ }^{133}$ The investment choices have been presented not as mere subsidies, but as investments in industries that should develop over time, produce a significant return for the state economy, and, if possible, become self-sustaining. In discussing New Mexico's film investments, for example, former Governor Bill Richardson stated '[o]ur main objective is to become a supportive satellite of Hollywood .... 'We don't want to be greedy with this, but for a state with low per capita income, it's a way for us to attract a clean, environmentally friendly industry that leaves a positive impact." 134

New Mexico's experience with film investment reveals the difficulty of effectively pursuing its dual-objective investment approach. New Mexico's film loan program was moderately successful in enticing film projects to the state, ${ }^{135}$ with New Mexico recently (and perhaps unfortunately) branded as "Tamalewood." 136 However, the SIC recently made significant changes to its film investment policies because of concerns that the state was not achieving adequate returns from the program. Indeed, the state has not made a loan under the program since 2008. ${ }^{137}$ A primary problem was that the state apparently did not fully understand (or neglected to account for) the fact that it was unlikely to receive interest payments on its loans if the payout is contingent on a film's profitability. ${ }^{138}$ Essentially, New Mexico took the position of a junior creditor, and so only after more senior film creditors were paid could New Mexico begin to collect interest on its loans. Often, the films did not make enough money to pay out any interest to New Mexico, and so the state only received its principal in return. Out of nearly $\$ 240$ million loaned to film producers of 23 films from 20012011, only 1 film produced a profit to New Mexico. ${ }^{139}$

Because of these losses, the SIC made substantial changes to its film investments policies: under prior investment rules, New Mexico provided zero-interest loans to film and television producers; under new guidelines, the state will lend at the national prime rate plus 1.5\%. Additionally, in an effort to more tightly link film investment to local economic impacts, $75 \%$ of the loan recipient's film crew (with exceptions for the director, producer, and certain other employees) must be New Mexicans (up from $60 \%$ ), ${ }^{140} 75 \%$ of the

133 Considering spending of STPF funds on the film industry, for example, reporter Simon Romero writes that "there was little resistance to legislation allowing the state to invest in film projects. In fact, the state's finances allowed officials to expand the authority and influence of its film commission while other states were cutting back." Simon Romero, Coming Soon to a Screen Near You: New Mexico, N.Y. Times Media (Jan. 26, 2004), http://www.nytimes.com/2004/01/26/business/media-coming-soon-to-a-screennear-you-new-mexico.html.

134 Id.

135 Several major recent films have been filmed in New Mexico, including Cowboys \& Aliens, Iron Man 2, True Grit, Transformers, and No Country for Old Men, among many others. A list of television programs and films shot in New Mexico may be found at The History of Film in New Mexico, N.M. Film Office, http://www.nmfilm.com/nm_filmography.aspx (last visited Jan. 30, 2013). For a list of the outstanding loans made under the film investment program, see Film Investment Program: Outstanding Loans (2010), available at http://www.sic.state.nm.us/PDF\%20files/3E2\%20-\%20NM\%20Film\%20Investment \%20Program\%20-02012-3110\%20-\%20Final.pdf. For a discussion of the investment selection process, see Joshua Schonauer, Star Billing? Recasting State Tax Incentives for the "Hollywood" Machine, 71 Ohio St. L.J. 381 (2010). For an analysis of the impact of New Mexico's film industry tax credits and investments on New Mexico's economy, see Ernst \& Young, Economic and Fiscal Impacts of the New Mexico Film Production Tax Credit (2009), available at http://www.sic.state.nm.us/PDF\%20files/NM_Film_Credit_Impact_Analysis.Final.pdf. 136 The name "Tamalewood" has been copyrighted by Leonard Sanchez, who appears to bear responsibility for the term: "I was working on a film in Taos in September of 2005 when I came up with the name Tamalewood. I mentioned it to someone I shouldn't have trusted and the next thing I knew, The Santa Fe Reporter was using it as a headline. Nevertheless, I own the legally registered Service Mark "Tamalewood" in the state of New Mexico and I've applied for federal registration of my Service Mark." Leonard Sanchez, History of "Tamalewood", Tamalewood, http://www.tamalewood.tv/HISTORY_OF_TAMALEWOOD_.html (last visited Jan. 30, 2013).

137 Dan Boyd, Film Loans Fizzle, ABQJournal.com (May 1, 2013), available at http://www.abqjournal.com/main/2013/05/01/ news/film-loans-fizzle-2.html.

138 Larry Barker \& Jason Auslander, State Film Loans, a Flop for Taxpayers, krqe.com (May 25, 2011, 10:00 PM), available at http:// www.krqe.com/dpp/news/larry_barker/state-film-loans-a-flop-for-taxpayers.

139 Id.

140 Trip Jennings, Investment Panel Alters Film Loan Rules, The New Mexican (May 24, 2011), available at http://www.santafenewmexican.com/Local\%20News/Investment-panel-alters-film-loan-rules. 
crew payroll must go to New Mexicans, ${ }^{141}$ and $85 \%$ of a loan recipient's shooting schedule must be in New Mexico (up from a "majority"). The SIC also determined to fire Peter Dekom, a Hollywood entertainment lawyer who had helped New Mexico create and advise on its film loan program. Mr. Dekom was paid $\$ 2,153,566$ over the course of his engagement with the SIC, making $\$ 260,000$ a year under his most recent contract (after taking a pay cut from $\$ 370,000$ under his prior agreement), although he was reportedly only required to work for the SIC a total of 30 hours a month. ${ }^{142}$

Concerns have also arisen over the purpose of the New Mexico Small Business Investment Corporation ("NMSBIC"), which receives funds from the STPF. The NMSBIC operates independently from the management of the SIC, and the NMSBIC has its own mission: "to create new job opportunities by making equity or debt investments in New Mexico small business in cooperation with financial professionals." 143 SIC board member Doug Brown explains that the SIC and the NMSBIC thus have a "fundamental conflict" between the SIC's purpose and the NMSBIC's mission, "given that the SIC's primary duty is to bring the best possible return on the state's investments—regardless of any social benefit associated with the enterprise-while the SBIC's primary goal is to help small businesses thrive, not necessarily to make money for the state." ${ }^{144}$

Some members of the SIC have viewed the NMSBIC as a "social program"145 and believe its funding should originate from the general funds of the state "at levels determined appropriate by the legislature and governor" rather than from an investment program using permanent funds. ${ }^{146}$ Part of the anxiety for SIC members stems from the fact that while the NMSBIC selects how to appropriate funds, it does not do so under the same "prudent man" investment criteria that govern SIC investments; as stated by NMSBIC chairman Paul Goblet, "We're not governed by the 'prudent man rule."147 This difference reflects the fundamental tension not just between the SIC and state agencies, but between the differential rate investments and the market rate investments dichotomy created by New Mexico when it created the STPF. Because the state has an investment program that operates according to a profit-maximization rule but is at the same time required to fund agencies that have broader social goals, the SIC will be faced with governance difficulties as it attempts to manage an agent which, by statutory authority, has incentives that are misaligned with its own. The SIC is currently attempting to remedy these governance issues by appointing new members to the NMSBIC board, considering changes to the statute governing the NMSBIC, specifically considering how the NMSBIC makes investment decisions, and by issuing a request for proposals from independent investment advisers to help oversee NMSBIC decisions. ${ }^{148}$ The sensible goal of the SIC seems to be to align

141 Id. Again, with exceptions for directors, producers, and certain other employees.

142 Rob Nikolewski, SIC Extends \$260,000 a Year Contract to Film Consultant, Capitol Report New Mexico (July 27, 2010), available at http://www.capitolreportnewmexico.com/?tag=new-mexico-film-commission. Mr. Dekom allegedly had conflicts of interest in his role with the SIC because at the same time he represented the SIC "he advise[d] producers and directors about doing business in New Mexico while, at the same time, his law firm writes contracts and represents Hollywood clients who make and distribute movies and television shows." Id.

143 Minutes, New Mexico State Investment Council (Apr. 26, 2011), available at http://www.sic.state.nm.us/PDF\%20files/ SIC\%20MINUTES\%204-26-2011.pdf.

144 Rob Nikolewski, The State’s Small Business Agency Has Lost \$9 Million; Is This a Big Deal?, Capitol Report New Mexico (Apr. 26, 2011), available at http://www.capitolreportnewmexico.com/2011/04/the-states-small-business-agency-has-lost-9-million-is-this-abig-deal/.

145 Minutes, supra note 143, at 13.

146 Id.

147 Rob Nikolewski, The SIC Tries to Rein in the State's Small Business Corporation: “We've Got an Agency That's Running Loose”, Capitol Report New Mexico (May 27, 2011), available at http://www.capitolreportnewmexico.com/2011/05/the-sic-tries-to-rein-in-thestates-small-business-corporation-weve-got-an-agency-thats-running-loose/. In response to this, SIC member Leonard Lee Rawson noted, "But we have to book your assets. This is where the tension builds." Id. In an interview, Rawson also stated, "Their assets are recorded on our books as part of the Permanent Fund, and yet they have no accountability to us, no accountability to the Governor and really to the legislature. And so they're kind of out there doing their own thing, and the responsibility, the accountability and the authority aren't combined together." Rob Nikolewski, Rawson on NM Small Business Investment Agency, YouTube (May 27, 2011), http://youtu.be/i9cGzduWVKI.

148 Nikolewski, The SIC Tries to Rein in the State's Small Business Corporation, supra note 147. 
investment decisions with an overall profit-maximization focus, which will necessitate significant legislative effort.

Wyoming's directed investments program presents similar concerns. Directed investments represent an opportunity for political patronage and waste, and it is seems unlikely that Wyoming's voters would approve such a potential use of severance tax funds if the issue were put to a statewide referendum; the state appears to recognize the governance concern directed investments create, and has considered evaluating its policies regarding legislatively-designated investments. ${ }^{149}$

Political patronage and waste are not the only concerns with directed investment programs, however. In the case of New Mexico's struggling film and other private sector investments, serious questions were raised not only about the possibility of corruption but also the losses incurred by the fund. To be sure, an investment focused on job or economy growth should not be expected to produce a direct return as large as an investment focused purely on financial returns. However, many of these investments will not only fail to produce a positive net return, but may actually produce losses. The losses may decrease the legitimacy of the state, in the eyes of its citizens, as a manager of the state's wealth. ${ }^{150}$ A crisis of legitimacy may be allayed with careful metrics that demonstrate how the investment resulted in a certain number of jobs or provided other measurable benefits, although in the federal context such claims have been met with some suspicion. ${ }^{151}$

\section{Distribution Policies and Agency Costs}

The distribution imperative- how and when to pay out the earnings of the fund-necessarily impacts the governance of the fund. Most state natural resource funds are designed to lock away the corpus of the fund from the legislature, and most share the goal of doing so for the benefit of future generations. How those funds are dispensed to future generations varies significantly. For New Mexico, Texas and Wyoming, a portion of the revenues generated from the states' mineral wealth is distributed to educational recipients, as required by state and/or Congressional fiat. Other revenues are generated through severance taxes, and the income from these funds goes into the state budgets, although, as noted above, some states set aside funds for targeted investment. Alabama also sets aside some of its revenues for specific purposes, such as the Alabama Forever Wild Land Trust. Whether the funds are sent to school districts, subfunds like the Forever Wild Land Trust, or to the general budget, the state intercedes as a mechanism for determining the appropriate allocation of resources to citizens and future citizens. With targeted investments in New Mexico, secondary mechanisms — the film council and the NMSBIC, for example_-also play a role in determining the allocation of resources. On the other hand, Alaska uses a direct mechanism—the annual dividend

149 For example, a 1997 state audit report noted that "[o]ur research on selected states with significant permanent funds and on the pension funds of several states suggests that they do targeted investing under two circumstances: they either have defined guidelines for making such investing in targeted investments, or do so only when such investments result in at least a market rate of return. Unlike these comparators, Wyoming's investment in LDIs for public infrastructure, economic development projects, and social programs generates reduced earnings." The report recommends that "[i]n the future, the Legislature could consider defining the terms and conditions under which it will accept less-than-market returns on its investments." Wyo. Legislature Mgmt. Audit Comm., Legislatively Designated Investments (May 1997), available at http://legisweb.state.wy.us/progeval/reports/1997/ldi/ldi.htm.

150 As Monk states, "over the long-term, any fund focused on development will likely pay a price for this in financial returns (since the fund's investment decision-making is as equally focused on "jobs" as it is on "profits"). And, as a result, the SWF could end up losing some of its domestic legitimacy due to a perception of "wasted resources" through loss-making investments (even if the fund is nonetheless successful at creating jobs or bringing technologies from abroad)." Ashby Monk, Khazanab: Commercial and Strategic Success?, Oxford SWF Project (Oct. 11, 2010), http://oxfordswfproject.com/2010/10/11/khazanah-commercial-andstrategic-success/.

151 See, e.g., Eleanor Clift, White House's Job-Creation Dodge, The Daily Beast (Sept. 13, 2011, 12:00 AM), http://www.thedailybeast. com/articles/2011/09/12/white-house-won-t-risk-predicting-stimulus-job-creation-numbers.html (stating that following accusations of fabricating employment numbers from the first Obama Administration stimulus package, the Administration would not provide estimates of the number of jobs President Obama's Jobs Act would provide). 
payment - to transfer wealth to future (and present) generations. As will be discussed in more detail below, Alaska's dividend was designed in large part to get money out of the hands of politicians and to make politicians more accountable to citizens.

The distribution imperative and the governance structure of a fund are inextricably bound. From the perspective of the APF's mandate, the issue becomes quite clear: make sufficient returns to pay out a substantial dividend. This creates a simpler governance structure: the fund is designed to achieve this goal, and is required to focus on the bottom line. If we look at the fiduciary framework that promotes this goal, it should likewise be narrowly focused. As the legislative mandate narrows, so too should the range of permissible activity and the scope of acceptable (non-liable) conduct. A broader focus will be difficult to reconcile with accountability, because non-economic results will not be easily quantifiable. The scrutiny on Alaska's fund has reflected this connection between accountability and payout. As noted above, the actions of Alaska's fund managers are on occasion heavily scrutinized, making it difficult for them to act in the markets without signaling to the markets exactly what they plan to do.

New Mexico, on the other hand, has taken a different view of how the fund should pay out its earnings. Instead of paying out annual dividends, New Mexico's fund pays into the general fund. Also, instead of investing simply to maximize the returns to the fund, New Mexico makes numerous differential-rate investments designed to provide funding to various programs or industries the New Mexico legislature has determined need the benefit of governmental funding. This creates a different sort of governance problem, as the sphere of accountability must expand to match the increased sphere of permissible use of the funds, in some cases for programs that may not repay the fund or the state for years, if ever. If non-economic goals (or economic goals that are not readily quantifiable) are an integral part of a fund's mission, traditional fiduciary concepts such as the "prudent man rule" are perhaps not appropriate measures of the duty of the manager for such funds. When NMSBIC chairman Paul Goblet stated that "We're not governed by the "prudent man rule," he was exposing the tension between accountability and non-economic goals. This is not to say that funds should never have non-economic goals, but to acknowledge that when funds do have non-economic goals, they introduce a new set of agency costs to the parent fund or state. The state already has agency costs at the fund manager level, and funds often have common agency costs as multiple principals push the fund to do one thing or another. ${ }^{152} \mathrm{~A}$ firm set of investment policies helps eliminate common agency costs, but as non-economic factors come into play, investment policies become more difficult to create and to enforce. For example, a policy to invest in only public companies expresses a decision to narrow the range of permissible actions and to avoid certain types of risks.

On the other hand, a subfund with a mandate to invest in emerging companies not only accepts those risks, but also may be doing so for broader social goals: to increase the prominence of a certain industry in the state, to produce jobs in a certain part of the state, or (in the case of film investments) perhaps to increase tourism in the state. While such purposes may be legitimate political goals worthy of the investment of public funds, empowering agents to enact such goals creates a set of costs that are difficult to manage. The desire to keep such costs under control is precisely the reason why New Mexico is now making a push to contain both their film project investments and their investments through the NMSBIC. With complexity of the mandate comes complexity of the investment management structure and a corresponding increased need to create appropriate governance mechanisms to manage the agency costs created by the investment management structure.

The objective to provide for intergenerational equity — which, as stated above, is a primary reason for the creation of many state natural resource funds-is complicated by the lack of a defined end-goal for the fund; state natural resource funds operate like university endowments in that they are designed to exist

152 See, e.g., Avinash Dixit, Power of Incentives in Private Versus Public Organizations, 87 Am. Econ. Rev. 378, 378-79, (1997). Dixit argues that "a distinct feature of government bureaucracies is that they must answer to multiple principals," and "the executive, ... Congress, courts, media and organized lobbies, all have a say." Id. 
in perpetuity, and do not have a set date at which the corpus of the fund is to be distributed. This means, in practical terms, that the goal of most state funds is to transfer wealth to future generations through the income generated by the fund that is then paid to the general budget of the state. In the case of Alaska, the transfer occurs more directly, through payments to citizens. There are several reasons why Alaska's transfer mechanism arguably produces a more efficient result for citizens and future citizens. Primarily, a state natural resource fund's distributions to the general budget can be thought of as an increasing tax upon the citizens, yet it is a tax increase that occurs incrementally and perhaps without representation. An incremental tax, largely increasing without notice, will likely not face challenge from the citizenry. It is probably also safe to assume the increases in distributions from a state natural resource fund are not typically met with corresponding decreases in the tax burden for citizens (although Alaska and Wyoming, notably, do not impose a state income tax). What mechanisms are in place to ensure that the funds are spent in a way that will maximize the benefits to present and future generations? It is likely that the increase is spent on bureaucratic increase, but since direct taxes, such as a state income tax, are not increased, the citizenry does not feel the pain of the increase and so is not motivated to hold the legislature accountable.

SWF and natural resource fund sponsor states can also promote accountability of elected officials by requiring that some of the fund revenues are paid out through direct cash transfers. As Moss explains,

\begin{abstract}
Cash transfers from natural resource revenues would give citizens strong incentives to carefully monitor the incoming revenue, management of the resources, and how it is distributed. Because citizens would now have a direct personal stake in the resource, cash transfers would likely create an intense constituency for responsible management and demands for accountability. It is one thing to stand by quietly as oil reserves are mismanaged when the oil rents are kept in an offshore bank account or are distributed as patronage to a select few. It is quite another thing when the mismanagement of those oil fields threatens a direct source of income. This was the primary purpose of the Alaska plan: to limit government waste by creating greater incentives for citizens to hold their governments accountable. ${ }^{153}$
\end{abstract}

From the perspective of the natural resource fund as accountability mechanism, the benefit of paying a dividend as opposed to merely sequestering the funds for future generations is that the government is not able to hoard funds which, as discussed above, may prevent an expansion of government that may provide relatively weaker benefits for future generations, compared to a cash distribution. The question for the citizens of a state with a natural resource fund is whether they believe that placing the interest earned by the natural resource fund into the states' general fund is a better use of the funds than the distribution of some or all of that interest to the citizens in the form of an annual dividend like Alaska's. ${ }^{154}$

Aside from the accountability effect an natural resource fund-and particularly one paying dividends to its citizens - may have on state government, Moss also argues that cash payments like Alaska's have two important equitable effects. First, cash transfers are more equitable and "pro-poor" compared to fund distributions solely to the state's general budget in that a "uniform and universal cash payment would instead allocate equally to every citizen (ideally, including children),"155 and would avoid regional spending disparities. Second, cash transfers "would have immediate and significant economic benefits for poor households_-and ultimately for development. . . Indeed, it is hard to imagine any public services that would deliver an immediate income benefit of, say $10 \%$, to the poor other than cash transfers." ${ }^{156}$

It is important to note that moving to a cash transfer system does not obviate the intergenerational equity function of a state natural resource fund. It simply implies that the governance of state natural resource

153 Todd Moss, Oil to Cash: Fighting the Resource Curse through Cash Transfers 8 (Ctr. for Global Dev., Working Paper 237, 2011), available at http://www.cgdev.org/files/1424714_file_Oil2Cash_primer_FINAL.pdf (citing Ugo Fasano, Review of the Experience with Oil Stabilization and Savings Funds in Selected Countries (2000) (working paper)).

154 Note that the question is not whether the state can adequately manage the funds as an investment manager-in the case of Alaska or New Mexico, the state is clearly assumed to be capable of investing the funds appropriately. Rather, the issue is what the states should do with the interest generated by the SWF.

155 Moss, supra note 153, at 8.

156 Id. 
funds may be improved by allocating some funds to present individual uses, which can have the salutary effects of enhancing accountability of state management of the funds, and reducing or eliminating natural expansion of state budgets in response to an increasing fund distribution.

A distribution structure designed to create accountability typically affects the asset allocation of the fund. Funds must be structured so that they can meet liabilities as they arise. If a state legislature or a state's citizenry demands an annual revenue stream, the fund must hold sufficiently liquid assets to pay out of the fund as required. SWFs and natural resource funds are generally thought to be patient, long-term investors able to take advantage of certain asset classes (such as private equity, infrastructure and real estate) that are unattractive to many other investors. ${ }^{157}$ However, to the extent that state natural resource funds are expected to pay out annual distributions, the state funds will invest more like pension funds with set distribution imperatives rather than as other funds which have no set liabilities and, consequently, a truly long-term investment focus.

Lessons from some SWFs' response to the Financial Crisis are instructive, as Balin highlights the connection between accountability and asset allocation:

\begin{abstract}
In response to this new need to realize positive returns over a shorter time horizon and keep funds on-hand for sovereign stabilisation, fund managers have increased their cash positions and shifted some assets into securities that offer payouts over a shorter period. Increased scrutiny of SWF returns by democratic and authoritarian states alike has also put pressure on managers to focus on shorter time horizons. . Although the demand for stable positive returns may spur some SWFs to invest in safer assets such as investment grade bonds, a demand for high short-term returns could also spur SWF managers to take on more risk. As annual SWF returns are now more closely scrutinized by sovereign governments, SWF executives could feel pressured to focus on more risky, speculative assets that could generate high initial returns but could later destroy value in an SWF's portfolio. ${ }^{158}$
\end{abstract}

For Alaska, then, the increased accountability created by its payout structure may have some negative effect on the total returns generated by the fund if fund managers and supervising politicians respond to pressures to produce short term gains (and it is not clear that they are). If so, it is also unclear whether the agency costs that the distribution mechanism is designed to reduce are less than the returns that would flow from a longer-term approach. Just as Alaska may struggle with this issue, states that receive income from their natural resource funds may also be subject to the same temptations in that legislators may want to increase returns in the short term so that they maximize the funds available to them in their terms of office. As discussed earlier, however, these temptations may be mitigated with investment restrictions. The restrictions attempt (though not always successfully) to balance the agency problems presented by natural resource funds with the need for a responsive and flexible money management policy. The consequences of this balancing of accountability and asset selection by natural resource funds are a worthwhile subject for future empirical investigation.

\title{
12. ConcLusion
}

In analyzing the primary purposes for creating and maintaining state natural resource funds, it is clear that the governance structures and distribution imperatives for the funds not only often fail to achieve these purposes, but often are serious impediments to the funds' success. First, state natural resource funds are not typically used to smooth revenue fluctuations in the short term, although the funds are designed to help protect revenues in the long term (for example, when the state no longer has significant severance tax revenues because of mineral depletion). This is by design: states have typically put in place constitutional and statutory safeguards that provide the legislature with access only to the income, but not the corpus, of the funds. These

157 Adam Dixon \& Ashby H.B. Monk, Rethinking the Sovereign in Sovereign Wealth Funds 16 (Aug. 3, 2010) (working paper), available at http://papers.ssrn.com/sol3/papers.cfm?abstract_id=1652701.

158 Balin, supra note 43, at 5. 
safeguards help reduce rent-seeking and agency costs. On the other hand, the restrictions also inhibit the ability of the state to deal with significant economic crises, such as the Financial Crisis that began in 2007-08.

Second, the typical mechanisms for providing for intergenerational equity, the primary justification for many state natural resource funds, appear to be relatively inefficient methods of transferring wealth to future generations. The largest and most important state natural resource funds, severance tax funds, usually pay income into the general fund. As noted above, a state natural resource fund's distributions to the general budget operate as an increasing tax upon the citizens if we assume that the funds are held in trust for the citizens of the state and not merely in trust for the government administration itself. As the size of the natural resource fund increases, appropriate mechanisms do not appear to be in place to ensure that the funds generated by the natural resource fund are spent wisely. One such mechanism would be to ensure by statute or through the constitution that increases in funds distributed to the general budget by the natural resource fund result in proportionate decreases in the citizens' tax burdens. Alternatively, states could put limits on how the funds are used, so that natural resource fund distributions are directed to spending initiatives that are tied to direct benefits for citizens, and that this spending would not result in reductions in other spending priorities or tax increases to present such spending reductions. Essentially, appropriate rules should ensure that increases in natural resource fund distributions do not merely result in increased government waste. Alaska has dealt with this problem in part by distributing much of the cash generated by its natural resource fund directly to its citizens. Alaska does not distribute the corpus of the fund to its citizens, however, thus protecting the fund for future generations of Alaskans.

Third, while some nations use SWFs as a bulwark against the forces of globalization, state natural resource funds typically do not use their natural resource funds to enhance their autonomy. In fact, as discussed above, many states with large natural resource funds are also among the highest recipients of federal aid. This curious fact should again highlight issues of equity that were first raised several decades ago as mineral-rich states began charging severance taxes. While it is clear that the revenue-generating activities that provide income for state natural resource funds create numerous negative externalities for the states, these externalities are increasingly paid for through federal programs, rather than through state funds. For example, in 1970, around the time when many severance tax funds were being formed, federal funding of health-related programs (which should compensate for significant negative externalities associated with mining operations) amounted to around $\$ 20$ billion (inflation adjusted). By 2007, federal funding of health programs exceeded $\$ 200$ billion. ${ }^{159}$ Because the federal government is increasingly important—from a budgetary perspective- to state citizens since the formation of most state natural resource funds, states with natural resource funds may be unfairly compensated for the externalities that severance taxes (and severance tax funds) were designed to address. In effect, states without such natural resource funds may be subsidizing states with such funds.

Finally, despite some of the concerns with state natural resource funds discussed above, natural resource funds may, if properly designed, leverage political accountability through market accountability. This is especially likely to be the case in Alaska, where an easily identified, market-related result- the annual dividend payment-encourages citizen attention to the government's management of state resources. On the other hand, a poorly designed and poorly governed natural resource fund is likely to increase problems with political accountability, as the natural resource fund adds another means of rent-seeking by politicians and others. Natural resource funds that follow (even in part) an economic development model are particularly likely to have higher agency costs and rent-seeking. By contrast, an investment fund model that does not include economic development initiatives should be significantly easier to manage, from agency cost perspective, than an economic development model. Funds that follow an investment mandate have, by design, a narrower mandate that is easily measured by yearly returns. As the legislative mandate narrows, so to should the range of permissible activity and the scope of acceptable (non-liable) conduct. A broader focus, such as

159 Chris Edwards, Federal Aid to the States Historical Cause of Government Growth and Bureaucracy, Policy Analysis No. 593 (CATO Inst., Washington, D.C.), May 22, 2007, at 7, available at http://www.cato.org/pubs/pas/pa593.pdf. 
a mandate to provide for general economic development initiatives, will be more difficult to reconcile with accountability, because non-economic results will not be easily quantifiable.

\section{REFERENCES}

Alaska Permanent Fund Corp. “An Alaskan's Guide to the Permanent Fund” 2009: 31. Web. <http://www. apfc.org/home/Media/publications/2009AlaskansGuide.pdf>.

Alaska Secretary of State. "Canvas of Results, General Election." 2 Nov. 2010: 198. Web. <http://www. sos.state.al.us/Downloads/election/2010/general/2010GeneralResults-AllStateAndFederalOfficesAndAmendments-CompleteWithWrite-inAppendix.pdf $>$.

Ang, Andrew. “The Four Benchmarks of Sovereign Wealth Funds.” 10 Sept. 2010: 1,19. Web. <http:// papers.ssrn.com/sol3/papers.cfm?abstract_id $=1680485>$.

Balin, Brian, J. "The Impact of the Global Economic Crisis on Sovereign Wealth Funds." Asian-Pac. Econ. Literature 24.1 (2010): 1-8. Print.

Barker, David. "Was the Alaska Purchase a Good Deal?” 10 Aug. 2009. Web. <http://www.news-releases. uiowa.edu/2009/november/David\%20Barker-Alaska.pdf>.

Barker, Larry and Jason Auslander, "State Film Loans, a Flop for Taxpayers." krqe.com. 25 May 2011. Web. <http://www.krqe.com/dpp/news/larry_barker/state-film-loans-a-flop-for-taxpayers>.

Borchardt, Jackie. "Bill Targets Facts About Federal Education Funding in Wyoming." Casper Star-Tribune. 16 Jan. 2011. Web. <http://trib.com/news/state-and-regional/govt-and-politics/article_b06ee50d-2c03-5ef69d89-4d29d76831cb.html>.

Boyd, Dan. "Film Loans Fizzle.” ABQJournal.com. 1 May 2013 Web. <http://www.abqjournal.com/ main/2013/05/01/news/film-loans-fizzle-2.html>.

Browde, Michael B. and Charles T. DuMars. "State Taxation of Natural Resource Extraction and the Commerce Clause: Federalism’s Modern Frontier.” Oregon Law Review 60 (1981): 7-58. Print.

Capitol Report New Mexico. "The Shoe Finally Drops: New Mexico Files Lawsuits in Federal and State Courts in "Pay to Play” Scandal." 6 May 2011. Web. <http:/ /www.capitolreportnewmexico.com/?p=4365>.

Casino, Bruce J. “Federal Grants-In-Aid: Evolution, Crisis, and Future.” Urban Lanyer 20.1 (1988): 25-72. Print.

Clark, Gordon L. and Eric R. W. Knight. "Temptation and the Virtues of Long-Term Commitment: The Governance of Sovereign Wealth Fund Investment." Asian Journal of International Law 1 (2011): 321-348. Print.

---. "Government of Singapore Investment Corporation (GIC): Insurer of Last Resort and Bulwark of Nation-State Legitimacy.” Pacific Review 23.4 (2010): 429-451. Print.

---. “The Norwegian Government Pension Fund: Ethics Over Efficiency.” Rotman International Journal of Pension Management 3 (2010): 14-19. Print.

---. "Resource Wealth and the Ethics of Global Investment: The Legitimacy and Governance of Norway's Sovereign Wealth Fund.” 42 Env't \& Plan. 1723 (2010). Print.

---. "The Legitimacy and Governance of Norway's Sovereign Wealth Fund: The Ethics of Global Investment." Environment and Planning 42 (2010): 1723-1738. Print.

Center on Education Policy. "Public Schools and the Original Federal Land Grant Program" (2011): 5. Web. $<$ http://www.cep-dc.org/cfcontent_file.cfm?Attachment=Usher_Paper_FederalLandGrants_041311.pdf>. 
Clift, Eleanor. "White House's Job-Creation Dodge." The Daily Beast. 13 Sept. 2011. Web. <http://www. thedailybeast.com/articles/2011/09/12/white-house-won-t-risk-predicting-stimulus-job-creation-numbers.html>.

Culp, Peter W., Diane B. Conradi and Cynthia C. Tuell. "Trust Lands in the American West: A Legal Overview and Policy Assessment” Lincoln Institute of Land Policy. 2005. Web. < http://www.lincolninst.edu/ subcenters/managing-state-trust-lands/publications/trustlands-report.pdf > .

Denison, Dwight, Wenli Yang and Zhirong Zhao. "Is Management Performance a Factor in Municipal Bond Credit Ratings? The Case of Texas School Districts.” Public Budgeting and Finance 27.4 (2007): 86-98. Print.

Dixit, Avinash. "Power of Incentives in Private Versus Public Organizations." The American Economic Review 87.2 (1997): 378-382. Print.

Dixon, Adam and Ashby H.B. Monk. "Rethinking the Sovereign in Sovereign Wealth Funds." 16 (working paper), Web. 3 Aug. 2010 <http://papers.ssrn.com/sol3/papers.cfm?abstract_id=1652701>.

Edwards, Chris. "Federal Aid to the States Historical Cause of Government Growth and Bureaucracy." Policy Analysis No. 593. (CATO Inst., Washington, D.C.), at 7, Web. 22 May 2007 <http://www.cato.org/ pubs/pas/pa593.pdf >.

Ely, Todd. "Indirect Aid for Uncertain Times: State Credit Enhancement Programs for School Districts." Association of Education Finance and Policy Conference, 17 (Mar. 25, 2011).

Ernst \& Young. "Economic and Fiscal Impacts of the New Mexico Film Production Tax Credit." 2009. Web. <http://www.sic.state.nm.us/PDF\%20files/NM_Film_Credit_Impact_Analysis.Final.pdf>.

Forgey, Pat. "Permanent Fund's New Investment Strategy Raises Concerns." JuneauEmpire.com. 23 June 2009. Web. <http://juneauempire.com/stories/062309/sta_453704024.shtml>.

Frischmann, Brett M. "Some Thoughts on Shortsightedness and Intergenerational Equity." Loyola University Chicago Law Journal 36 (2005): 457-467. Print.

Gilson, Ronald J. and Curtis J. Milhaupt. "Sovereign Wealth Funds and Corporate Governance: A Minimalist Response to the New Mercantilism.” Stanford Law Review 60.5 (2008) 1345-1369. Print.

Hansmann, Henry. "Why Do Universities Have Endowments?” The Journal of Legal Studies 19.1 (1990): 3-42. Print. (quoting James Tobin, What is Permanent Endowment Income?, 64 Am. Econ. Rev. 427, 427 (1974))

Hatton, Kyle and Katharina Pistor. "Maximizing Autonomy in the Shadow of Great Powers: The Political Economy of Sovereign Wealth Funds." 10 (Columbia Law Sch. Working Paper No. 395, 2011), Web. $<$ http://ssrn.com/abstract $=1787565>$.

Heyman, Dan. "Would Mineral Trust Fund Work in West Virginia?” Pub. News Serv. 6 Feb. 2012. Web. <http://www.publicnewsservice.org/index.php?/content/article/24683-1>.

Jennings, Trip. "Investment Panel Alters Film Loan Rules.” The New Mexican. 24 May 2011. Web. <http:// www.santafenewmexican.com/Local\%20News/Investment-panel-alters-film-loan-rules>.

Jiang, Wenran. “The Dragon Returns: Canada in China's Quest for Energy Security.” 16 (Canadian Int'l Council, China Papers No. 19, Oct. 2010), Web. <http://www.asiapacific.ca/sites/default/files/filefield/ the_dragon_returns-_canada_in_chinas_quest_for_energy_security_-_wenran_jiang.pdf $>$.

Johnson, Nicholas, Phil Oliff, and Erica Williams. "An Update on State Budget Cuts." Center on Budget \& Policy Priorities. Washington, D.C. at 1, 10-12, 9 Feb. 2011 Web. <http://www.cbpp.org/files/3-13-08sfp.pdf>.

Mikesell, R. L. "Explaining the Resource Curse, with Special Reference to Mineral-Exporting Countries." Resources Policy 23.4 (1997) 191-199. Print. 
Monk, Ashby. (see also Monk, Ashby H.B.). "Khazanah: Commercial and Strategic Success?” Oxford SWF Project. 11 Oct. 2010. Web. <http://oxfordswfproject.com/2010/10/11/khazanah-commercial-and-strategic-success/>.

---. "Oklahoma Loves SWFs." Oxford SWF Project. 5 Mar. 2010. Web. <http://oxfordswfproject. com/2010/03/05/oklahoma-loves-swfs/>. Posting of Rien Huizer (Mar. 7, 2010, 12:24 AM).

Monk, Ashby H. B. (see also Monk, Ashby)."The Appeal of Factor-Based Allocations." Oxford SWF Project. 9 Feb 2011. Web. <http://oxfordswfproject.com/2011/02/09/the-appeal-of-factor-based-allocations/>.

---. “Is CalPERS a Sovereign Wealth Fund?” ISSUE IN BRIEF (Ctr. for Ret. Res. at Bos. C., Boston, M.A.), Dec. 2008, at 1, 4, Web. <http://www.publicpensionsonline.com/public/images/CalPERS\%20Sovereignity.pdf>.

---. "Sovereignty in the Era of Global Capitalism." 9 (working paper), 10 Apr. 2010. Web. <http://ssrn. com/abstract=1587327> (citing Richard M. Auty. \& Raymond Frech Mikesell, Sustainable Development in Mineral Economies, (1998)).

Moss, Todd. "Oil to Cash: Fighting the Resource Curse through Cash Transfers." 8 (Ctr. for Global Dev., Working Paper 237, 2011), Web. <http:/ /www.cgdev.org/files/1424714_file_Oil2Cash_primer_FINAL.pdf>, (citing Ugo Fasano, Review of the Experience with Oil Stabilization and Savings Funds in Selected Countries (2000) (working paper)).

New Mexico Film Office. “The History of Film in New Mexico.” Web. 30 Jan. 2013 <http://www.nmfilm. com/nm_filmography.aspx>.

New Mexico Food \& Agriculture Council Water Quality Subcommittee. "Federal Funding Sources for Water Quality Activities.” U.S. Dep’t of Agric., Nat'l Res. Conservation Serv. Aug. 1998. Web. <http://www. nm.nrcs.usda.gov/technical/water/fund.html>.

New Mexico State Investment Council. “Council Members.” Web. 20 Jan 2013 < http://www.sic.state. nm.us/council_members.htm>.

---. "Minutes." 26 Apr. 2011. Web. <http://www.sic.state.nm.us/PDF\%20files/SIC\%20MINUTES\%20 4-26-2011.pdf>.

---. "Private Equity Advisory Committee.” Web. 30 Jan 2013 <http://www.sic.state.nm.us/peiac.htm>.

---. "SIC General Investment Policy." 14 Mar. 2008. Web. <http://www.sic.state.nm.us/PDF\%20files/080314\%20SIC\%20GENERAL\%20INVESTMENT\%20POLICY-Final.pdf>.

---. Film Investment Program: Outstanding Loans (2010), Web. <http://www.sic.state.nm.us/PDF\%20 files $/ 3$ E2\%20-\%20NM\%20Film\%20Investment\%20Program\%20-\%2012-31-10\%20-\%20Final.pdf>.

Nikolewski, Rob. "Rawson on NM Small Business Investment Agency." YouTube. 27 May 2011. Web. $<$ http://youtu.be/i9cGzduWVKI>.

---. "SIC Extends $\$ 260,000$ a Year Contract to Film Consultant."

Capitol Report New Mexico. 27 July 2010. Web. <http://www.capitolreportnewmexico.com/?tag=new-mexico-film-commission>.

---. "The SIC Tries to Rein in the State's Small Business Corporation: 'We've Got an Agency That's Running Loose." Capitol Report New Mexico. 27 May 2011. Web. <http:/ /www.capitolreportnewmexico.com/2011/05/ the-sic-tries-to-rein-in-the-states-small-business-corporation-weve-got-an-agency-thats-running-loose/ $>$.

---. “The State’s Small Business Agency Has Lost \$9 Million; Is This a Big Deal?” Capitol Report New Mexico. 26 Apr. 2011. Web. <http://www.capitolreportnewmexico.com/2011/04/the-states-small-businessagency-has-lost-9-million-is-this-a-big-deal/> .

North Dakota Indusustrial Commission. "Bakken Formation Reserve Estimates." 2006. Web. <http:// www.nd.gov/ndic/ic-press/bakken-form-06.pdf>. 
Olson, Curt W. “Tobacco Settlement Money Goes Up in Flames.” Texas Budget Source. 13 Apr. 2011. Web. <http://www.texasbudgetsource.com/2011/04/tobacco-settlement-money-goes-up-in-flames/>.

Peters, Lee. "An Outline for Development of Cost-Based State Severance Taxes." Natural Resources Journal 20.4 (1980): 913-931. Print. (quoting Jerry Apodaca, Governor of New Mexico).

Powell, Michael. "How Alaska Became a Federal Aid Magnet." N.Y. Times Economix. 18 Aug. 2010. Web. <http://economix.blogs.nytimes.com/2010/08/18/how-alaska-became-a-federal-aid-magnet/>.

Romero, Simon. "Coming Soon to a Screen Near You: New Mexico." N.Y. Times Media. 26 Jan. 2004. Web. <http://www.nytimes.com/2004/01/26/business/media-coming-soon-to-a-screen-near-you-new-mexico. html>.

Rose, Dave and Charles Wohlforth. Saving for the Future: My Life and the Alaska Permanent Fund. Epicenter, 2008. Print.

Rozanov, Andrew. “Sovereign Wealth Funds: Defining Liabilities.” 4 State Street Global Advisors 1 (May 2007).

Sanchez, Leonard. "History of "Tamalewood"." Tamalewood. Web. 30 Jan. 2013 < http://www.tamalewood. tv/HISTORY_OF_TAMALEWOOD_html>.

Schonauer, Joshua. "Star Billing? Recasting State Tax Incentives for the "Hollywood" Machine." Obio State Law Journal 71 (2010): 381-415. Print.

SWF Institute. “Largest Sovereign Wealth Funds by Assets Under Management.” Web. 26 Jan. 2013 <http:// www.swfinstitute.org/fund-rankings/>.

Standard \& Poors. “Wyoming; General Obligation.” Wyoming State Treasurer’s Office. Web. 15 Jan. 2013 $<$ http://treasurer.state.wy.us/pdf/bondcreditrating012813.pdf > .

"Steady Hands: Permanent Fund Managers Oversee Continued Recovery." Editorial. Fairbanks Daily NewsMiner. 6 Feb. 2011. Web. <http://newsminer.com/view?full_story/11289912/article-Steady-hands--Permanent-Fund-managers-oversee-continued-recovery $>$.

Stevens, Paul. "Resource Impact - Curse or Blessing?” (Apr. 22, 2003) (working paper).

Stoddard, A.B. “Earmarks Indelible in Congress.” The Hill's Pundits Blog. 24 Nov. 2010. Web. <http:/ / thehill. com/blogs/pundits-blog/lawmaker-news/ 130691-earmarks-indelible-in-congress $>$.

U.S. Department of Education. “The Federal Role in Education.” Ed.gov. Web. 30 Jan 2013 <http://www2. ed.gov/about/overview/fed/role.html>.

Wyoming State Loan and Investment Board. "Master Investment Policy and Sub-Policies." 3 June 2010. Web. <http://treasurer.state.wy.us/pdf/investmentpolicy060310.pdf>.

Wyoming Office of State Lands and Investments. "Summary of State Loan Programs and Associated Loan Loss Reserve Funds.” 30 Apr. 2011. Web. <http://slf-web.state.wy.us/osli/BoardMatters/2011/0611/ SLIB/Loan0611.pdf>.

Wyoming, Office of Wyoming State Treasurer Joseph B. Meyer, Press Advisory, "State's Issuer Credit Rating Upgraded (May 10, 2011) State’s Issuer Credit Rating Upgraded (May 10, 2011)

Wyoming Secretary of State. "Statewide Ballot Issues Official Summary." 7 Nov. 2006. Web. <http:/ / soswy. state.wy.us/Elections/Docs/2006/06Results/06General/SW_Const.Amendments_Summary.pdf>.

Wyoming Legislature Management Audit Committee. "Legislatively Designated Investments." May 1997. Web. <http://legisweb.state.wy.us/progeval/reports/1997/ldi/ldi.htm>.

Wyoming Taxpayers Association. "Permanent Mineral Trust Fund (PMTF)." Web. 30 Jan 2013 <http:// www.wyotax.org/PMTF.aspx>. 


\section{REVISTA BRASILEIRA DE POLÍTICAS PÚBLICAS BRAZILIAN JOURNAL OF PUBLIC POLICY}
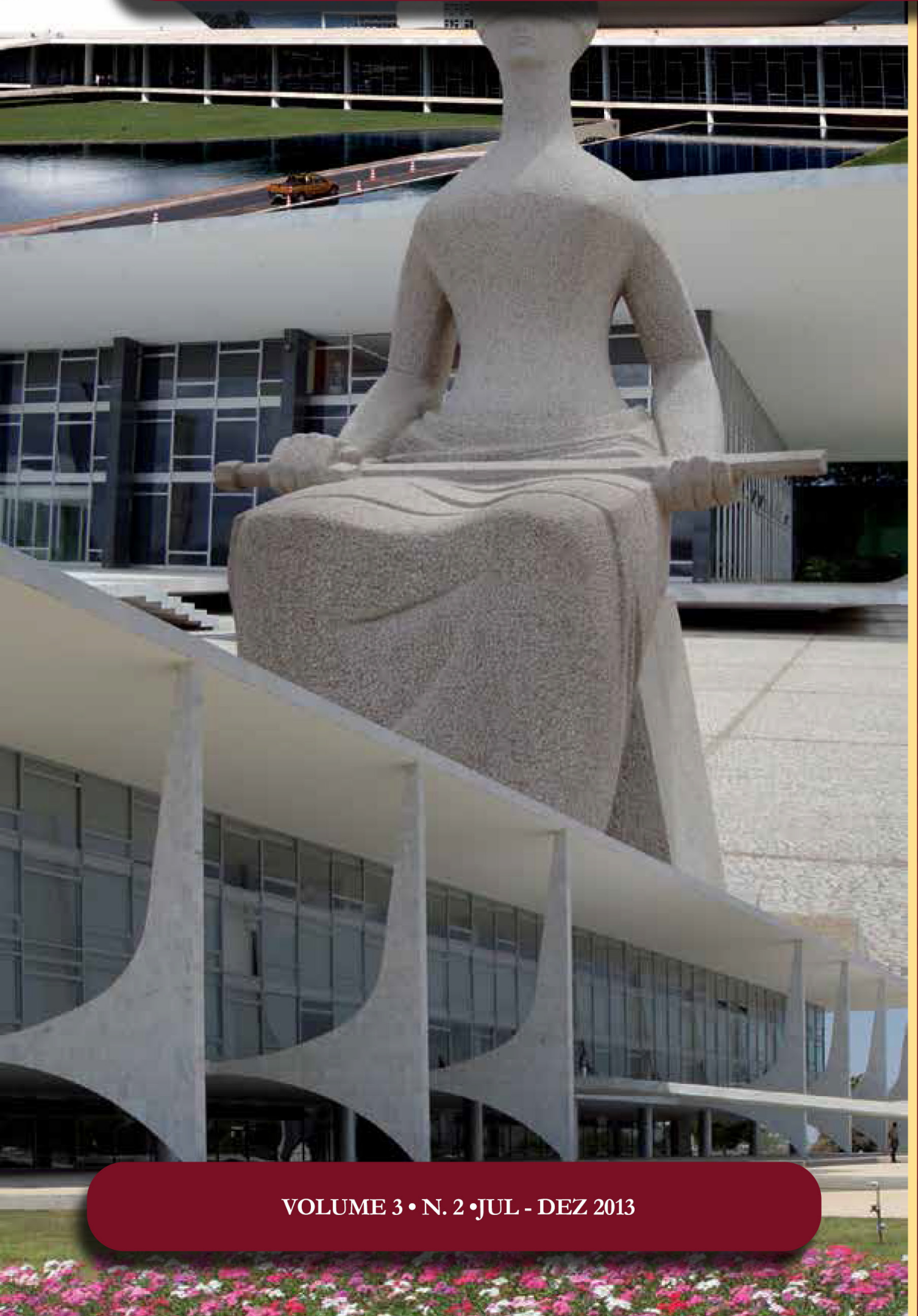

A (in)competência do CONAMA para edição de normas sobre licenciamento ambiental: Análise de sua juridicidade

The CONAMA (in) competence for issue of licensing standards for environmental Analysis of its legality 


\title{
A (in)competência do CONAMA para edição de normas sobre licenciamento ambiental: Análise de sua juridicidade
}

\author{
The CONAMA (in) competence for issue \\ of licensing standards for environmental \\ Analysis of its legality*
}

André Fagundes Lemos**

\section{Resumo}

O objeto deste trabalho é examinar a compatibilidade vertical das normas em relação às resoluções editadas pelo Conselho Nacional de Meio Ambiente (CONAMA) no que tange ao licenciamento ambiental. Analisam-se se os dispositivos da Lei n ${ }^{\circ}$ 6938/1981, que dispõem sobre as atribuições do CONA$\mathrm{MA}$, e que foram recepcionados pela Ordem Constitucional vigente. Busca-se verificar se o CONAMA detém atribuição para atuar como protagonista na edição de normas relativas ao licenciamento ambiental, bem como, se as resoluções do CONAMA, principalmente a de $n^{\circ} 237$, tem averbação constitucional em um cenário de dúvidas e ponderações doutrinárias e jurisprudenciais.

Palavras-chaves: CONAMA. Lei nº 6938/1981. Resoluções. Constituição Federal.

\section{Abstract}

The object of this paper is to examine the compatibility of vertical standards in relation to the resolutions issued by the National Council for the Environment (CONAMA) in relation to environmental licensing. It analyzes whether the provisions of Law 6938/81 on the tasks that have been approved by CONAMA Constitutional Order in force. Search to see if the CONAMA holds assignment to act as the lead on the issue of standards for environmental licensing and, if the resolutions of CONAMA, mainly of $\mathrm{n}^{\circ} 237$, has annotation constitutional against a backdrop of doubts and ponderings doctrinal and jurisprudential.

Keywords: CONAMA. Law n 6938/1981. Resolutions. Federal Constitution. 


\section{INTRODUÇÃo}

Os acontecimentos negativos das últimas décadas fizeram com que a preocupação ambiental, principalmente no que se refere à degradação, passasse a incorporar a preocupação diária do mundo.

Diariamente somos informados sobre queimadas, degelo, aumento de temperatura, os malefícios causados pela descontrolada emissão de carbono, desmatamento com a finalidade de venda da madeira e de criação de pastos para a pecuária, contaminação do solo e subsolo, poluição de rios e mares, chuvas ácidas etc.

A partir do instante em que o ser humano passa a sentir de forma considerável os malefícios na sua saúde, na produção e no dia a dia, ele começa a procurar alternativas de prevenção, precaução ou reparação ambiental.

Um dos instrumentos utilizados pelo Estado para controlar ou mitigar a degradação ambiental é a criação de leis, de resoluções e de órgãos ambientais que tenham finalidade de preservação ambiental.

O primeiro instrumento nesse sentido que surge no Brasil foi a Lei $n^{\circ}$ 6.938/1981 em que se tentou seguir os ditames da Convenção de Estocolmo de 1972.

Após, presencia-se outra inovação que se dá com a Constituição Federal de 1988, em que se estipulou pela primeira vez um capítulo inteiramente dedicado ao meio ambiente, tratando-o como um direito fundamental para as presentes e futuras gerações, cabendo ao Estado e a coletividade preservá-lo.

Dentre os órgãos ambientais encarregados da proteção ambiental, tem-se o Conselho Nacional de Meio Ambiente (CONAMA), que possui atribuições originadas pela lei da Política Nacional de Meio Ambiente.

O CONAMA, na tentativa de cumprir as disposições da Lei no 6.938/1981 e da Constituição Federal de 1988, passou a editar normas que, em princípio, são destinadas à proteção ambiental. No entanto, devido aos excessos de temas e de atividades ambientais cumuladas com a carência de aprofundamento jurídico-profissional, as resoluções acabaram por ultrapassar os limites impostos ao poder regulamentar. Por tal fato, as resoluções passaram a tratar de assuntos adstritos à reserva legal.

Nessa senda, o presente artigo pretende analisar as normas brasileiras referentes ao meio ambiente afetas às atribuições cometidas ao Conselho Nacional de Meio Ambiente para edição de normas e critérios de licenciamento ambiental.

\section{Sistema Nacional do Meio Ambiente}

O Sistema Nacional do Meio Ambiente (SINAMA) foi instituído pela Lei no 6.938, de 31 de agosto de 1981, que dispõe sobre a Política Nacional do Meio Ambiente, seus fins e mecanismos de formulação e aplicação e outras providências. Referida Lei é regulamentada pelo Decreto n 99.274, de 06 de junho de 1990, sendo constituído pelos órgãos e entidades da União, dos Estados, do Distrito Federal, dos Municípios e pelas fundações instituídas pelo Poder Público, responsáveis pela proteção e melhoria da qualidade ambiental.

Nesse sentido, dispõe o artigo $3^{\circ}$ do referido Decreto:

Art. $3^{\circ}$ O Sistema Nacional do Meio Ambiente (SISNAMA), constituído pelos órgãos e entidades da União, dos Estados, do Distrito Federal, dos Municípios e pelas fundações instituídas pelo Poder Público, responsáveis pela proteção e melhoria da qualidade ambiental, tem a seguinte estrutura:

I - Órgão Superior: o Conselho de Governo;

II - Órgão Consultivo e Deliberativo: o Conselho Nacional do Meio Ambiente (CONAMA);

III - Órgão Central: a Secretaria do Meio Ambiente da Presidência da República (SEMAM/PR);

IV - Órgãos Executores: o Instituto Brasileiro do Meio Ambiente e dos Recursos Naturais Renováveis - IBAMA e o Instituto Chico Mendes de Conservação da Biodiversidade - Instituto Chico Mendes; 
V - Órgãos Seccionais: os órgãos ou entidades da Administração Pública Federal direta e indireta, as fundações instituídas pelo Poder Público cujas atividades estejam associadas às de proteção da qualidade ambiental ou àquelas de disciplinamento do uso de recursos ambientais, bem assim os órgãos e entidades estaduais responsáveis pela execução de programas e projetos e pelo controle e fiscalização de atividades capazes de provocar a degradação ambiental; e

VI - Órgãos Locais: os órgãos ou entidades municipais responsáveis pelo controle e fiscalização das atividades referidas no inciso anterior, nas suas respectivas jurisdições.

Percebe-se que a estrutura é descentralizada e abrangente sendo que, na prática, transfere-se aos Estados e Municípios parte das decisões de ordem político-ambiental, bem como a sua execução quase que por completo.

No mesmo sentido, é a expressão do art. $6^{\circ}$ da lei de Política Nacional do Meio Ambiente:

Art. $6^{\circ}$ - Os órgãos e entidades da União, dos Estados, do Distrito Federal, dos Territórios e dos Municípios, bem como as fundações instituídas pelo Poder Público, responsáveis pela proteção e melhoria da qualidade ambiental, constituirão o Sistema Nacional do Meio Ambiente - SISNAMA, assim estruturado:

I - órgão superior: o Conselho de Governo, com a função de assessorar o Presidente da República na formulação da política nacional e nas diretrizes governamentais para o meio ambiente e os recursos ambientais.

II - órgão consultivo e deliberativo: o Conselho Nacional do Meio Ambiente (CONAMA), com a finalidade de assessorar, estudar e propor ao Conselho de Governo, diretrizes de políticas governamentais para o meio ambiente e os recursos naturais e deliberar, no âmbito de sua competência, sobre normas e padrões compatíveis com o meio ambiente ecologicamente equilibrado e essencial à sadia qualidade de vida.

III - órgão central: a Secretaria do Meio Ambiente da Presidência da República, com a finalidade de planejar, coordenar, supervisionar e controlar, como órgão federal, a política nacional e as diretrizes governamentais fixadas para o meio ambiente.

IV - órgão executor: o Instituto Brasileiro do Meio Ambiente e dos Recursos Naturais Renováveis, com a finalidade de executar e fazer executar, como órgão federal, a política e diretrizes governamentais fixadas para o meio ambiente.

V - Órgãos Seccionais: os órgãos ou entidades estaduais responsáveis pela execução de programas, projetos e pelo controle e fiscalização de atividades capazes de provocar a degradação ambiental.

VI - Órgãos Locais: os órgãos ou entidades municipais, responsáveis pelo controle e fiscalização dessas atividades, nas suas respectivas jurisdições.

Percebe-se que a única diferença entre tais normas se refere à alocação do Instituto Chico Mendes de Conservação da Biodiversidade (Instituto Chico Mendes) como órgão executor. Este é acrescido ao art. $3^{\circ}$ do Decreto no 99.274/90 devido a uma alteração originada pelo art. $1^{\circ}$ do Decreto no $6.792 / 09$, que dispôs sobre a nova composição e funcionamento do Conselho Nacional do Meio Ambiente - CONAMA.

A atuação do SISNAMA se dará mediante articulação coordenada dos órgãos e entidades que o constituem, observado o acesso da opinião pública às informações relativas às agressões ao meio ambiente e às ações de proteção ambiental, na forma estabelecida pelo CONAMA.

Para a melhor doutrina, a decisão do legislador de descentralizar veio a calhar, haja vista a extensão territorial brasileira. Nessa estrutura, ficam os Estados, o Distrito Federal e os Municípios encarregados da regionalização das medidas emanadas do SISNAMA, elaborando normas e padrões supletivos e complementares.

O modelo de gerenciamento instituído pela Lei no 6.938/1981, que antecede a Constituição Federal de 1988, incumbe aos Estados-membros a tarefa executiva, ficando o ente federal encarregado de apenas editar normas gerais. Os Estados-membros e os Municípios podem legislar supletivamente. Aqueles devem observar a legislação geral e os estes, além da geral, têm que se ater à legislação estadual.

Destarte, dispõe o $\$ 1^{\circ}$ e $2^{\circ}$ do art. $3^{\circ}$ da Lei ${ }^{\circ} 6.938 / 1981$ :

$\int 1^{\circ}$ - Os Estados, na esfera de suas competências e nas áreas de sua jurisdição, elaborarão normas supletivas e complementares e padrões relacionados com o meio ambiente, observados os que forem estabelecidos pelo CONAMA.

$\int 2^{\circ}$ Os Municípios, observadas as normas e os padrões federais e estaduais, também poderão elaborar as normas mencionadas no parágrafo anterior. 
Os órgãos seccionais prestarão informações sobre os seus planos de ação e programas em execução, consubstanciadas em relatórios anuais, que serão consolidados pelo Ministério do Meio Ambiente, em um relatório anual sobre a situação do meio ambiente no País, a ser publicado e submetido à consideração do CONAMA, em sua segunda reunião do ano subsequente.

\subsection{Conselho Nacional do Meio Ambiente (Conama)}

O Conselho Nacional do Meio Ambiente (CONAMA) é o órgão consultivo e deliberativo do Sistema Nacional do Meio Ambiente (SISNAMA) e foi instituído pela Lei no 6.938/1981, que dispõe sobre a Política Nacional do Meio Ambiente.

O CONAMA é composto por Plenário, CIPAM, Grupos Assessores, Câmaras Técnicas e Grupos de Trabalho. O Conselho é presidido pelo Ministro do Meio Ambiente e sua Secretaria Executiva é exercida pelo Secretário-Executivo do MMA ${ }^{1}$.

Segundo o art. $6^{\circ}$, inciso II da Lei n ${ }^{\circ} 6.938 / 1981$, o CONAMA tem a finalidade de assessorar, estudar e propor ao Conselho de Governo, diretrizes de políticas governamentais para o meio ambiente e os recursos naturais e deliberar, no âmbito de sua competência, sobre normas e padrões compatíveis com o meio ambiente ecologicamente equilibrado e essencial à sadia qualidade de vida.

\footnotetext{
Art. $6^{\circ}$ - Os órgãos e entidades da União, dos Estados, do Distrito Federal, dos Territórios e dos Municípios, bem como as fundações instituídas pelo Poder Público, responsáveis pela proteção e melhoria da qualidade ambiental, constituirão o Sistema Nacional do Meio Ambiente - SISNAMA, assim estruturado:

II - órgão consultivo e deliberativo: o Conselho Nacional do Meio Ambiente (CONAMA), com a finalidade de assessorar, estudar e propor ao Conselho de Governo, diretrizes de políticas governamentais para o meio ambiente e os recursos naturais e deliberar, no âmbito de sua competência, sobre normas e padrões compatíveis com o meio ambiente ecologicamente equilibrado e essencial à sadia qualidade de vida.
}

A atuação do CONAMA se destaca pela edição de resoluções no que tange aos assuntos ambientais, no entanto, defendemos a hipótese de que esse poder de emitir resoluções não pode ser exercido com fim de inovar o ordenamento jurídico, devendo se pautar apenas na função de regulamentar o disposto da lei sobre assuntos técnicos ambientais.

Outra colocação, conforme será visto no próximo capítulo, diz respeito ao art. 25 dos Atos de Disposições Constitucionais Transitórias (ADCT) da Constituição Federal, ao indagar se os poderes do CONAMA de emitir resolução estariam afetados. Entendemos que na Resolução n ${ }^{\circ}$ 237, quando o CONAMA extrapola seus limites regulamentares e distribui a competência licenciadora entre a União, Estado e Municípios, estaria atuando onde apenas o Congresso Nacional deveria atuar e por isso estaria sua resolução revogada pelo referido artigo do ADCT.

Art. 25 - Ficam revogados, a partir de cento e oitenta dias da promulgação da Constituição, sujeito este prazo a prorrogação por lei, todos os dispositivos legais que atribuam ou deleguem a órgão do Poder Executivo competência assinalada pela Constituição ao Congresso Nacional, especialmente no que tange a:

I - ação normativa;

II - alocação ou transferência de recursos de qualquer espécie.

\section{O PRINCÍPIO DA LEGALIDADE VERSUS O PODER REGULAMENTAR Do CONAMA EM MATÉRIA DE LICENCIAMENTO AMBIENTAL}

O princípio da legalidade, ou da Reserva Legal, vem a lume, em nosso ordenamento jurídico, através do art. $5^{\circ}$, inciso II, da Constituição Federal, que dispõe que "ninguém será obrigado a fazer ou deixar de fazer alguma coisa senão em virtude de lei”.

1 Disponível em: <http://www.mma.gov.br/port/conama/estr.cfm>.Acesso em: 20.10.2013 
O princípio da legalidade deita suas raízes no movimento Iluminista do século XVIII, que se insurgiu contra abusos e arbitrariedades do absolutismo monárquico que imperava até então, inserindo-se numa lógica em que o poder estatal é restrito, tendo como principal papel garantir direitos mínimos para os indivíduos, aos quais somente pode ser imposta a prática ou a abstenção de determinada conduta ou algo, se houver lei prévia o determinando ou proibindo.

A passagem do Estado absoluto ao Estado liberal da modernidade significou o estabelecimento de limites ao exercício do poder político. O filósofo John Locke, que viveu ao final do século XVIII, foi o seu grande precursor ao postular a defesa dos interesses individuais em face dos abusos governamentais a partir do reconhecimento de direitos naturais e inalienáveis do homem.

Com efeito, nesse novo paradigma de Estado, o indivíduo passa a ser titular de direitos impondo limitações ao poder estatal, sob a forma de prestações negativas, possuindo primazia em relação ao Estado.

O princípio da legalidade foi o grande vetor da passagem do Estado absoluto ao Estado liberal, em que se procurou estabelecer limites ao exercício do poder político. Em tal paradigma de Estado, ganha relevo a noção de que as restrições aos direitos dos indivíduos e a imposição de obrigações somente podem ser estabelecidas mediante leis genéricas e abstratas editadas pelo próprio povo, ainda que indiretamente, no exercício da soberania popular, o que torna o comando impessoal, e não fruto de um arbítrio autoritário, assegurando, assim, a igualdade de tratamento entre os seus destinatários.

Ademais, além de conferir segurança e impedir desigualdades injustificadas, a lei passou a ser vista também como uma norma necessariamente justa, por se tratar de expressão da razão humana, impondo uma limitação ao poder estatal, e condicionando a sua atuação e a sua própria existência à promoção do bem comum e do mínimo indisponível, resguardando os direitos e garantias individuais.

Dessa forma, o Estado de Direito torna-se uma supragarantia para o indivíduo, por impor restrições ao poder estatal e garantir as liberdades do indivíduo, que deve ser respeitado em sua individualidade.

O princípio da legalidade guarda ainda grande correlação com o princípio da segurança jurídica, e vice-versa, haja vista que somente haverá segurança jurídica a impedir o império do reino das incertezas, da arbitrariedade e da instabilidade se, em matéria de direito penal, as garantias individuais forem respeitadas, e o indivíduo não for aniquilado em sua liberdade, de modo a ser punido por atitudes que, à época, não possuíam um grau elevado de reprovabilidade social, sem imputação em lei, ao passo que somente será concretizada a segurança jurídica se houver respeito ao princípio da legalidade.

No que tange à reserva de lei, a doutrina a classifica em absoluta ou relativa. A primeira tem lugar quando "[...] se exija do legislador que esgote o tratamento da matéria no relato da norma, sem deixar espaço remanescente para a atuação discricionária dos agentes públicos que vão aplicá-la”, enquanto a segunda se configura quando não é necessário um esgotamento da matéria pela via legislativa, permanecendo imprescindível, porém, que o legislador estabeleça os parâmetros exigíveis à atuação do administrador (BARROSO, 2003, p.169).

No último caso, elucidativa é a explicação de José Afonso da Silva (2000, p. 424-425):

É relativa à reserva constitucional de lei quando a disciplina da matéria é em parte admissível a outra fonte diversa da lei, sob a condição de que esta indique as bases em que aquela deva produzir-se validamente. Assim é quando a Constituição emprega fórmulas como as seguintes: 'nos termos da lei', 'no prazo da lei', 'na forma da lei', 'com base na lei', 'nos limites da lei', 'segundo critérios da lei'. São, em verdade, hipóteses em que a Constituição prevê a prática de ato infralegal sobre determinada matéria, impondo, no entanto, obediência a requisitos ou condições reservados à lei. Por exemplo, é facultado ao Poder Executivo, por decreto, alterar alíquotas dos impostos sobre importação, exportação, produtos industrializados e operações de crédito etc., atendidas as condições e os limites estabelecidos em lei $\left(\operatorname{art.} 153, \int 1^{\circ}\right)$.

No que tange à edição de normas em matéria de licenciamento ambiental, o art. 225, $\int 1^{\circ}$, inciso IV, consagra a reserva de lei relativa quando remete à disciplina legal a exigência, estudo prévio de impacto am- 
biental para instalação de obra ou atividade potencialmente causadora de significativa degradação do meio ambiente.

Com efeito, em matéria de licenciamento ambiental e exigência de estudo prévio de impacto ambiental, a Constituição Federal da margem a que a sua disciplina possa vir expressa em fonte normativa de categoria inferior, mas desde que a lei indique as bases em que se deve dar tal regulação.

Contudo, não foi isso que fez a Lei no 6.938/1981, em seu art. $8^{\circ}$. Aqui, ao invés de estabelecer os parâmetros mínimos para o estabelecimento de normas e critérios sobre licenciamento ambiental, ela somente tratou de delegar tal competência ao CONAMA, calando a respeito dos aspectos a serem regulamentados.

A teor da dicção do referido dispositivo legal, o CONAMA, por meio de ato administrativo normativo, poderia inovar o ordenamento jurídico e dispor da matéria como bem entender, sem que lhe fossem indicadas as balizas legais para tanto, exorbitando de seu poder regulamentar.

A legitimidade normativa ato administrativo ocorre exatamente pela existência prévia de lei que o defina. Se não há ordem normativa precedente que construa a conduta devida pelo administrador, ainda que se trate de ato jurídico, não é considerado como ato de função estatal. (GUERRA, 2004).

No escólio de Guerra (2004):

A lei cede espaço à norma e ao regulamento, como forma de alargamento do campo de atuação do agente público executivo.

Nesse sentido, pode-se aceitar que o regulamento se constitui num ato administrativo gerador de norma jurídica, de alcance geral e abstrato, proveniente da Administração Pública, cujo fim é o exercício ordenado da função administrativa, concomitantemente à execução de lei cuja efetividade demande ação administrativa.

Os regulamentos constroem preceitos tangíveis, mas não específicos na materialidade do ato regulado. O Poder Executivo detém o poder (constitucional e legal) de editar normas jurídicas de caráter genérico e abstrato, a fim de que, no plano do Estado de Direito, a lei editada pela vontade da maioria social (através da função legislativa do Parlamento) seja ordenada e executada para todos, independendo de categoria, coletividade, comunidade ou individualidade.

O poder regulamentar, pelo exposto, decorre do desdobramento e da explicitação daquilo que já contém a lei, mas não pode ir além e inovar o ordenamento jurídico.

Por se tratar de uma espécie de ato administrativo normativo, a resolução encerra o exercício de parcela do poder regulamentar, daí porque indispensável é sua análise a partir do exercício desta atribuição do Poder Executivo $^{2}$. (SARLET, 2008, p. 10).

Nesse sentido, o art. 84, inciso IV, da Constituição Federal estatui que compete ao Presidente da República, e por extensão, às autoridades administrativas de escalão inferior cujos atos se exprimem por meio de resolução, expedir decretos e regulamentos para a fiel execução das leis.

No caso da Resolução no 237 do CONAMA, usando da competência que lhe delegou a Lei no 6938/1981, o conselho, que, a rigor, deveria se ater ao seu poder regulamentar, à míngua de um dispositivo legal versando sobre a disciplina do licenciamento ambiental, tratou de regulamentar toda a matéria sem que houvesse um desdobramento de prévia disciplina legal.

2 Celso Antonio Bandeira de Mello (apud SARLET, 2008, p. 10) ao tratar do tema aduz que: “[...] tudo quanto se disse a respeito do regulamento e de seus limites aplica-se, ainda com maior razão, a instruções, portarias, resoluções, regimentos ou quaisquer outros atos gerais do Executivo. É que, na pirâmide jurídica, alojam-se em nível inferior ao próprio regulamento. Enquanto este é ato do Chefe do Poder Executivo, os demais assistem a autoridades de escalão mais baixo e, de conseguinte, investidas em poderes menores. Tratando-se de atos subalternos e expedidos, portanto, por autoridades subalternas, por via deles o Executivo não pode exprimir poderes mais dilatados que os suscetíveis de expedição mediante regulamento. Assim, toda a dependência e subordinação do regulamento à lei, bem como os limites em que se há de conter, manifestam-se revigoradamente no caso de instruções, portarias, resoluções regimentos ou normas quejandas" (grifo nosso). 
Ademais, em um Estado Democrático de Direito, toda imposição ou abstenção de condutas somente pode se consubstanciar no âmbito de um devido processo que estabeleça um espaço dialógico discursivo no qual as partes potencialmente afetadas pelo provimento legislativo devem se reconhecer coautores de tal ato, o que, no âmbito do processo legislativo, compreende a discussão dos projetos de lei nas casas que compõem o Congresso Nacional, que lhes conferem legitimidade.

Nessa senda, conforme Dhenis Cruz Madeira (2009, p. 32):

[...] ao viger uma lei (que deverá passar pela regência principiológica do devido processo legislativo), a mesma não é capaz de se auto legitimar, razão pela qual anseia por um controle popular (discursivo e processualizado). Nessa esfera, os argumentos e alegações dialógicos são circunscritos pelas normas constitucionais, as quais traçam as bases e os limites do discurso jurídico que, no Direito Democrático, clama por um médium linguístico.

Assim, a positivação do princípio da legalidade no texto constitucional é o ponto de partida do discurso normativo, delineando alguns conceitos básicos (falseáveis e abertos à crítica) que a serem empregados no discurso processualizado.

É inadmissível que um ato normativo, expedido por autoridade administrativa, como é o caso do CONAMA, em postura solispsita, ao invés da lei editada por meio dos representantes do povo, venha a definir no âmbito do discurso legislativo normas e critérios para o licenciamento ambiental. É inconstitucional, não só pela violação ao princípio da legalidade, como ainda ao princípio democrático.

No paradigma do Estado Democrático de Direito, não se pode admitir a interpretação solitária de uma autoridade supostamente sábia e justa, haja vista que o resultado dessa atividade interpretativa (o provimento) deve ser fruto de construção compartilhada pelos interessados.

Com efeito, sob o prisma do princípio da legalidade, somente a lei formalmente falando, como norma genérica e abstrata editada pelo Poder Legislativo, detém legitimidade democrática para impor ao cidadão a observância de normas sobre o licenciamento ambiental, e nunca um ato normativo emanado de autoridade administrativa, como é o caso do CONAMA, ao qual cabe tão somente a tarefa de regulamentar aquilo que está previsto de maneira imprecisa em lei.

Contudo, em certas matérias, como é o caso do estudo prévio de impacto ambiental e do próprio licenciamento ambiental, por força de disposição constitucional, tal exigência é mitigada e a lei pode delegar a disciplina da matéria à outra fonte normativa de estatura inferior (atos administrativos), conquanto que traga em seu texto os pressupostos sobre o assunto, e isso definitivamente não foi o que ocorreu com o art. $8^{\circ} \mathrm{da}$ Lei $n^{\circ} 6.938 / 1981$.

\section{4 . O PODER do CONAMA PARA EDIÇÃo DE NORMAS SOBRE LICENCIAMENTO AMBieNTAL}

A Lei n ${ }^{\circ} 6.938 / 1981$, que dispõe sobre a política nacional do meio ambiente, ao prever textualmente o licenciamento ambiental em seu art. $9^{\circ}$, inciso IV, consagra-o como um dos mais importantes instrumentos para o alcance dos objetivos nela preconizados, os quais necessariamente passam pela preservação ambiental.

Contudo, a despeito dessa gênese legal ocorrida antes mesmo do advento da Carta Política de 1988, em nosso ordenamento jurídico, a base de tal instituto repousa no art $225, \sqrt{ } 1^{\circ}$, inciso IV, da $\mathrm{CF} / 88$, o qual, ao exigir estudo prévio de impacto ambiental para instalação de obra ou atividade potencialmente causadora de significativa degradação do meio ambiente, acabou consagrando o licenciamento ambiental considerando a imbricação que há entre ambos os institutos.

O fundamento do licenciamento ambiental pode ser encontrado também na qualidade de "bem de uso comum do povo" que o art. 225, caput, da CF/88 atribuiu ao meio ambiente, o que o torna um bem de todos em geral e de ninguém em particular e afasta qualquer pretensão de direito subjetivo à sua utilização, 
a qual só se legitima mediante autorização do poder público, que atua como gestor desse bem (MILARÉ, 2011, p. 509).

Consoante o escólio de Thomé (2012, p. 249), licenciamento ambiental pode ser definido como:

Um procedimento administrativo pelo qual o órgão ambiental competente licencia a localização, instalação, ampliação e a operação de empreendimentos e atividades utilizadoras de recursos ambientais, consideradas efetiva ou potencialmente poluidoras ou daquelas que, sob qualquer forma, possam causas degradação ambiental, considerando as disposições legais e regulamentares e as normas técnicas aplicáveis ao caso.

O art. $8^{\circ}$ da Lei no 6.938/1981 estatui que compete ao CONAMA: "I - estabelecer, mediante proposta do IBAMA, normas e critérios para o licenciamento de atividades efetiva ou potencialmente poluidoras, a ser concedido pelos Estados e supervisionado pelo IBAMA".

Extrai-se desse dispositivo que, ao invés de trazer as normas e os critérios para o licenciamento ambiental, a Lei delega tal atribuição ao CONAMA, que a exercita por meio de resoluções que, nas palavras de Antônio Zanollo Neto (2007, p. 87), são “[...] os atos administrativos normativos reservados para deliberação, vinculados a diretrizes e normas técnicas, critérios e padrões relativos à proteção ambiental e ao uso sustentável dos recursos ambientais". No caso do licenciamento ambiental, dita regulamentação foi editada por meio da Resolução no 237/1997.

Assim, a Lei no 6.938/1981, editada sob a égide da ordem constitucional anterior, atribuiu poderes normativos e regulamentares ao CONAMA que, atualmente, são exclusivos do legislador e não coadunam com a constituição vigente.

O CONAMA, a despeito da delegação estatuída no art $8^{\circ}$ da 6.938/1981, ao editar resoluções contendo normas sobre o licenciamento ambiental, exorbitou de seu poder regulamentar e invadiu competência legislativa que, a teor dos artigos 24, inciso VI, e 44 c/c 48 da Constituição Federal é privativa do Congresso Nacional e das casas legislativas dos demais entes federados.

Pensar o contrário, conforme lembrado por Alexandre de Morais (apud NETO, 2007, p. 91) seria o mesmo que admitir que o Conselho Monetário Nacional pudesse criar impostos e que o Conselho Nacional de Política Criminal e Penitenciária pudesse definir crimes.

Outro indicativo de que art. $8^{\circ}$ da Lei n ${ }^{\circ} 6.938 / 1981$ não foi recepcionado pela ordem constitucional vigente é o art 25 do Ato das Disposições Constitucionais Transitórias (ADCT), o qual rechaça textualmente a possibilidade de norma infraconstitucional delegar a órgão do Poder Executivo competência assinalada pela Constituição ao Congresso Nacional, especialmente no que tange à ação normativa, senão vejamos:

Art 25- Ficam revogados, a partir de cento e oitenta dias da promulgação da Constituição, sujeito este prazo a prorrogação por lei, todos os dispositivos legais que atribuam ou deleguem a órgão do Poder Executivo competência assinalada pela Constituição ao Congresso Nacional, especialmente no que tange a:

I - ação normativa;

A esse respeito, a Constituição Federal dispõe nos artigos 44 e 48, respectivamente, que “[...] o Poder Legislativo é exercido pelo Congresso Nacional [...]” e que "cabe ao Congresso Nacional, com a sanção do Presidente da República, não exigida esta para o especificado nos arts. 49, 51 e 52, dispor sobre todas as matérias de competência da União [...]".

Entre as matérias sujeitas à competência legislativa concorrente da União, o art.25, inciso, da Constituição Federal elenca "florestas, caça, pesca, fauna, conservação da natureza, defesa do solo e dos recursos naturais, proteção do meio ambiente e controle da poluição".

Em razão de o licenciamento ambiental se relacionar umbilicalmente com cada uma dessas matérias, depreende-se que, por extensão, ele próprio também é uma matéria de competência legislativa da União a ser exercitada pelo Congresso Nacional no exercício do Poder Legislativo e não pelo CONAMA.

Isso nos leva a concluir que o CONAMA, ao estabelecer normas e critérios para o licenciamento ambiental, invadiu competência do Congresso Nacional e desafiou o comando do art. 25 do ADCT. 
Além do mais, art. $8^{\circ}$ da Lei $n^{\circ}$ 6.938/1981 não se compatibiliza com os ditames do preceito normativo do art. $225, \int 1^{\circ}$, inciso IV, da $\mathrm{CF} / 88$, na medida em que este remete à lei a definição dos critérios acerca da exigência de estudo prévio de impacto ambiental e ante a imbricação que há entre este instrumento de política ambiental e o licenciamento ambiental, infere-se que o segundo também só pode ter seus critérios e normas definidos por lei e não ato normativo editado pelo poder executivo, ao qual, conforme já sublinhado, compete tão somente regulamentar aquilo que já se encontra expresso em lei, sem jamais inovar o ordenamento jurídico.

Por outro lado, existe posicionamento diverso no sentido de que o art 25 do ADCT não afetou o poder de regulamentar do CONAMA.

Uma das atuações mais destacadas do CONAMA refere-se ao poder de editar Resoluções, as quais não foram vetadas pela $\mathrm{CF} / 88$, em virtude do art 25 do ADCT [...].

Isso porque somente foram abrangidos os órgãos do Poder Executivo que estivessem exercendo funções que a $\mathrm{CF} / 88$ reservou ao Congresso, o que não ocorre no caso do CONAMA.

Conforme Álvaro Mirra, na regulamentação feita pelo CONAMA, não há exercício de competência delegada, mas sim exercício de poder regulamentar por órgão executivo, colegiado, decorre expressamente da lei 6.938/1981, de forma específica para a normatização do licenciamento ambiental e do Estudo de Impacto Ambiental. (MARCHESAN; STEIGLEDER; CAPPELLI, 2011, p. 85).

\section{A RESOlUÇÃo No 237 do CONAMA}

A Resolução no 237 do Conselho Nacional do Meio Ambiente (CONAMA) define os critérios de distribuição de competência entre os entes federados para o licenciamento de empreendimentos e atividades causadores de impacto ambiental a que se refere o art. 10 da Lei no 6.938/1981; na tentativa de se regulamentar o disposto do art 23 da Constituição Federal de 1988, nos incisos III, VI, VII e seu parágrafo único.

Eis o dispositivo da Constituição Federal:

Art. 23 - É competência comum da União, dos Estados, do Distrito Federal e dos Municípios:

III - proteger os documentos, as obras e outros bens de valor histórico, artístico e cultural, os monumentos, as paisagens naturais notáveis e os sítios arqueológicos;

VI - proteger o meio ambiente e combater a poluição em qualquer de suas formas;

VII - preservar as florestas, a fauna e a flora;

Parágrafo único - Leis complementares fixarão normas para a cooperação entre a União e os Estados, o Distrito Federal e os Municípios, tendo em vista o equilíbrio do desenvolvimento e do bem-estar em âmbito nacional.

Os artigos $4^{\circ}, 5^{\circ}$ e $6^{\circ}$ da Resolução $n^{\circ} 237$ do CONAMA trazem a distribuição de competências no que tange ao licenciamento ambiental numa tentativa constitucionalmente equivocada de regulamentar os dispositivos constitucionais acima mencionados. Referida tentativa que vem sendo praticada desde a edição da Resolução concede ao Instituto Brasileiro do Meio Ambiente e dos Recursos Naturais Renováveis IBAMA a competência para licenciar empreendimentos e atividades com significativo impacto ambiental de âmbito nacional ou regional.

Aos Estados e Distrito Federal, no exercício de competência estadual, compete o licenciamento de empreendimentos e atividades localizados ou desenvolvidos em mais de um Município ou em unidades de conservação de domínio estadual ou do Distrito Federal, localizados ou desenvolvidos nas florestas e demais formas de vegetação natural de preservação permanente relacionadas no artigo $2^{\circ}$ da Lei no 4.771/1965, cujos impactos ambientais diretos ultrapassem os limites territoriais de um ou mais Municípios e delegados pela União aos Estados ou ao Distrito Federal, por instrumento legal ou convênio.

Já em relação aos Municípios, compete o licenciamento ambiental de empreendimentos e atividades de impacto ambiental local e daquelas que lhe forem delegadas pelo Estado por instrumento legal ou convênio, nos seguintes termos: 
Art. $5^{\circ}$ - Compete ao órgão ambiental estadual ou do Distrito Federal o licenciamento ambiental dos empreendimentos e atividades:

I - localizados ou desenvolvidos em mais de um Município ou em unidades de conservação de domínio estadual ou do Distrito Federal;

II - localizados ou desenvolvidos nas florestas e demais formas de vegetação natural de preservação permanente relacionadas no artigo $2^{\circ}$ da Lei $\mathrm{n}^{\circ} 4.771$, de 15 de setembro de 1965 , e em todas as que assim forem consideradas por normas federais, estaduais ou municipais;

III - cujos impactos ambientais diretos ultrapassem os limites territoriais de um ou mais Municípios;

IV - delegados pela União aos Estados ou ao Distrito Federal, por instrumento legal ou convênio.

Parágrafo único. O órgão ambiental estadual ou do Distrito Federal fará o licenciamento de que trata este artigo após considerar o exame técnico procedido pelos órgãos ambientais dos Municípios em que se localizar a atividade ou empreendimento, bem como, quando couber, o parecer dos demais órgãos competentes da União, dos Estados, do Distrito Federal e dos Municípios, envolvidos no procedimento de licenciamento.

Art. $6^{\circ}$ - Compete ao órgão ambiental municipal, ouvidos os órgãos competentes da União, dos Estados e do Distrito Federal, quando couber, o licenciamento ambiental de empreendimentos e atividades de impacto ambiental local e daquelas que lhe forem delegadas pelo Estado por instrumento legal ou convênio. (Grifo nosso).

Prova de tal equivoco é o Projeto de Lei Complementar (PLC) n 388 de 2007 encaminhado ao Congresso Nacional com o propósito de regulamentar o art. 23 da Constituição Federal de 1988 (CF/88).

A esse respeito:

O Governo Federal resolveu, em 2007, tomar uma série de medidas desenvolvimentistas, numa iniciativa que denominou de Programa de Aceleração do Crescimento - PAC. Entre estas medidas encontram-se o Projeto de Lei Complementar $n^{\circ} 388 / 2007$, encaminhado ao Congresso Nacional com o propósito de regulamentar o art. 23 da Constituição Federal de 1988.

Merece especial atenção que o objetivo da nova norma proposta pelo poder executivo, em várias entrevistas concedidas por alguns próceres da política nacional, não foi justificado pela necessidade de melhorar o sistema de licenciamento, mas na necessidade de agilizar o licenciamento para possibilitar os investimentos e evitar os impasses surgidos para a execução de obras e empreendimentos de grande porte por conta de ações judiciais (TRENNEPOHL, 2005, p. 237).

Apesar disso, o projeto não traz grandes inovações, vez que de mais relevante vem estabelecer princípios relacionados à abrangência dos impactos e de segurança nacional como fatores determinante para o licenciamento. No entanto, a sua maior importância não está escrita em seus artigos e parágrafos, mas sim na interpretação constitucional que traz no sentido de que a norma constitucional do art 23 é, nos ensinamento de José Afonso da Silva, uma norma constitucional de eficácia limitada devendo ser complementada pelo Poder Legislativo. O autor assevera que a norma de eficácia limitada tem aplicabilidade mediata ou reduzida, pois essa norma constitucional depende de norma infraconstitucional para produzir efeito.

Moraes (2002, p. 41), aduz:

Tradicional a classificação das normas constitucionais, dada por José Afonso da Silva em relação a sua aplicabilidade em normas de eficácia plena, contida e limitada.

\section{$[\ldots]$}

Por fim, normas constitucionais de eficácia limitada são aquelas que apresentam "aplicabilidade indireta, mediata e reduzida, porque somente incidem totalmente sobre esses interesses, após uma normatividade ulterior que lhes desenvolva a aplicabilidade" (por exemplo: CF/88 art 192, $₫ 3^{\circ}$ : as taxas de juros reais, nelas incluídas comissões e quaisquer outras remunerações direta ou indiretamente referidas à concessão de crédito, não poderão ser superiores a $12 \%$ ao ano; a cobrança acima deste limite será conceituada como crime de usura, punido, em todas as suas modalidades, nos termos que a lei determinar).

Destarte, não caberia ao CONAMA a competência legislativa de regulamentar o dispositivo constitucional. Prova disso é o preâmbulo proposto pelo PLC 388 que dispõe sobre a regulamentação de dispositivos do art. 23 da Constituição:

Fixa normas para a cooperação entre a União, os Estados, o Distrito Federal e os Municípios, nas ações administrativas decorrentes do exercício da competência comum relativas à proteção das paisagens naturais notáveis, à proteção 
do meio ambiente, ao combate à poluição em qualquer de suas formas e à preservação das florestas, da fauna e da flora, previstas no art. 23, incisos III, VI e VII, da Constituição. (Grifo nosso).

Não obstante, colaciona-se a distribuição de competência referente ao licenciamento ambiental estipulado pelo PLC n 388/ 2007:

Art. $6^{\circ}$ Para os fins do art. $5^{\circ}$, são ações administrativas da União, dentre outras:

$[\cdots]$

$\mathrm{XV}$ - promover o licenciamento ambiental das atividades ou empreendimentos, a saber:

a) que causem ou possam causar impacto ambiental direto de âmbito nacional ou regional;

b) localizados ou desenvolvidas conjuntamente no Brasil e em país limítrofe;

c) localizados na plataforma continental, na zona econômica exclusiva, em terras indígenas ou em unidades de conservação da União, exceto em Áreas de Proteção Ambiental - APAs, onde deverá ser observado o critério do impacto ambiental direto das atividades ou empreendimentos;

d) destinados a pesquisar, lavrar, produzir, beneficiar, transportar, armazenar e dispor material radioativo, em qualquer estágio, ou que utilizem energia nuclear em qualquer de suas formas e aplicações, mediante parecer da Comissão Nacional de Energia Nuclear - CNEN; e

e) empreendimentos e atividades militares que servem a defesa nacional, na forma da Lei;

(...)

Art $7^{\circ}$ Para os fins do art $5^{\circ}$, são ações administrativas dos Estados e do Distrito Federal, dentre outras:

$[\cdots]$

XIV - promover o licenciamento ambiental das atividades ou empreendimentos, a saber:

a) que causem ou possam causar impacto ambiental direto de âmbito estadual; e

b) localizados em unidades de conservação do Estado ou do Distrito Federal,

exceto em Áreas de Proteção Ambiental - APAs, onde deverá ser observado o critério do impacto ambiental direto das atividades ou empreendimentos;

$[\cdots]$

Art. $8^{\circ}$ Para os fins do art. $5^{\circ}$, são ações administrativas dos Municípios, dentre outras:

$[\cdots]$

XIV - promover o licenciamento ambiental das atividades ou empreendimentos, a saber:

a) que causem ou possam causar impacto ambiental direto de âmbito local; e

b) localizados em unidades de conservação do Município, exceto em Áreas de Proteção Ambiental - APAs, onde deverá ser observado o critério do impacto ambiental direto das atividades ou empreendimentos; (Grifo nosso).

Percebe-se que em nenhum dos dispositivos do projeto há a delegação de competência para formulação de normas referentes ao meio ambiente, o que é totalmente compatível com o direito positivo nacional e a tripartição de competência dos entes da administração direta brasileira prevista na constituição, no sentido de que o único órgão encarregado de produzir norma afeta ao licenciamento ambiental é o Poder Legislativo.

A regulamentação de dispositivo constitucional somente pode ser feita por meio da via legislativa e nunca por intermédio de ato normativo administrativo, que pode regulamentar apenas a lei.

No entanto, o PLC no 388 de 2007 foi declarado prejudicado em face da aprovação, em Plenário, da Emenda Substitutiva Global de Plenário no 1 vide PLP no 12/2003 que se transformou na Lei Complemen$\operatorname{tar} \mathrm{n}^{\circ} 140 / 2011$.

A Lei Complementar n ${ }^{\circ}$ 140, de 8 de dezembro de 2011, fixa normas, nos termos dos incisos III, VI e VII do caput e do parágrafo único do art. 23 da Constituição Federal, para a cooperação entre a União, os Estados, o Distrito Federal e os Municípios nas ações administrativas decorrentes do exercício da competên- 
cia comum relativas à proteção das paisagens naturais notáveis, à proteção do meio ambiente, ao combate à poluição em qualquer de suas formas e à preservação das florestas, da fauna e da flora; e altera a Lei ${ }^{\circ}$ 6.938, de 31 de agosto de 1981.

Os arts. $7^{\circ}, 8^{\circ}, 9^{\circ}$ e $10^{\circ}$ praticamente repetem o disposto dos arts. $6^{\circ}, 7^{\circ}$ e $8^{\circ}$ do $\mathrm{PLC} \mathrm{n}^{\circ} 388 / 2007$, nos seguintes termos:

Art. $7^{\circ}$ São ações administrativas da União:

$[\ldots]$

XIV - promover o licenciamento ambiental de empreendimentos e atividades:

a) localizados ou desenvolvidos conjuntamente no Brasil e em país limítrofe;

b) localizados ou desenvolvidos no mar territorial, na plataforma continental ou na zona econômica exclusiva;

c) localizados ou desenvolvidos em terras indígenas;

d) localizados ou desenvolvidos em unidades de conservação instituídas pela União, exceto em Áreas de Proteção Ambiental (APAs);

e) localizados ou desenvolvidos em 2 (dois) ou mais Estados;

f) de caráter militar, excetuando-se do licenciamento ambiental, nos termos de ato do Poder Executivo, aqueles previstos no preparo e emprego das Forças Armadas, conforme disposto na Lei Complementar no 97, de 9 de junho de 1999;

g) destinados a pesquisar, lavrar, produzir, beneficiar, transportar, armazenar e dispor material radioativo, em qualquer estágio, ou que utilizem energia nuclear em qualquer de suas formas e aplicações, mediante parecer da Comissão Nacional de Energia Nuclear (CNEN); ou

h) que atendam tipologia estabelecida por ato do Poder Executivo, a partir de proposição da Comissão Tripartite Nacional, assegurada a participação de um membro do Conselho Nacional do Meio Ambiente (CONAMA), e considerados os critérios de porte, potencial poluidor e natureza da atividade ou empreendimento;

$[\cdots]$

Art. $8^{\circ}$ São ações administrativas dos Estados:

$[\ldots]$

XIV - promover o licenciamento ambiental de atividades ou empreendimentos utilizadores de recursos ambientais, efetiva ou potencialmente poluidores ou capazes, sob qualquer forma, de causar degradação ambiental, ressalvado o disposto nos arts. $7^{\circ} \mathrm{e} 9^{\circ}$;

XV-promover o licenciamento ambiental de atividades ou empreendimentos localizados ou desenvolvidos em unidades de conservação instituídas pelo Estado, exceto em Áreas de Proteção Ambiental (APAs);

$[\cdots]$

Art. $9^{\circ}$ São ações administrativas dos Municípios:

$[\ldots]$

XIV - observadas as atribuições dos demais entes federativos previstas nesta Lei Complementar, promover o licenciamento ambiental das atividades ou empreendimentos:

a) que causem ou possam causar impacto ambiental de âmbito local, conforme tipologia definida pelos respectivos Conselhos Estaduais de Meio Ambiente, considerados os critérios de porte, potencial poluidor e natureza da atividade; ou

b) localizados em unidades de conservação instituídas pelo Município, exceto em Áreas de Proteção Ambiental (APAs);

$[\ldots]$

Art. $10^{\circ}$. São ações administrativas do Distrito Federal as previstas nos arts. $8^{\circ}$ e $9^{\circ}$. (Grifos nosso).

Da mesma forma que o projeto de lei mencionado, a Lei Complementar $n^{\circ} 140$, nos dispositivos supra, aborda apenas a competência material da União, Estado ou Município em matéria de licenciamento ambiental, não se referindo à competência de tais entes para legislar sobre o assunto por ser tal poder inerente 
ao Legislativo Nacional. Chama atenção também que a LC nº140 não reproduz os ditames do art. $6^{\circ}$, $\ 1^{\circ}$, da Lei n ${ }^{\circ}$ 6.938/1981, no qual os Estados e Municípios estariam adstritos às resoluções do CONAMA para legislarem sobre meio ambiente.

Outro dispositivo que demonstra a necessidade de lei em sentido estrito para regulamentar os dispositivos constitucionais é o Projeto de Lei no 3.729/2012 que dispõe sobre o licenciamento ambiental e visa regulamentar o inciso IV do $\ 1^{\circ}$ do art. 225 da Constituição Federal. Referido Projeto, no entanto, foi apensado ao Projeto de Lei n 266 de 2007 que visa alterar a Lei no 9.985, de 2000, regulamentar o art 225, S $1^{\circ}$, incisos I, II, III e VII da Constituição Federal, instituir o Sistema Nacional de Unidades de Conservação da Natureza e dar outras providências, no que se refere à compensação por significativo impacto ambiental. Este até o momento está aguardando parecer da Comissão de Meio Ambiente e Desenvolvimento Sustentável (CMADS).

Art. 225 - Todos têm direito ao meio ambiente ecologicamente equilibrado, bem de uso comum do povo e essencial à sadia qualidade de vida, impondo-se ao Poder Público e à coletividade o dever de defendê-lo e preservá-lo para as presentes e futuras gerações.

$[\ldots]$

$\llbracket 1^{\circ}$ - Para assegurar a efetividade desse direito, incumbe ao Poder Público:

I - preservar e restaurar os processos ecológicos essenciais e prover o manejo ecológico das espécies e ecossistemas;

II - preservar a diversidade e a integridade do patrimônio genético do País e fiscalizar as entidades dedicadas à pesquisa e manipulação de material genético;

III - definir, em todas as unidades da Federação, espaços territoriais e seus componentes a serem especialmente protegidos, sendo a alteração e a supressão permitidas somente através de lei, vedada qualquer utilização que comprometa a integridade dos atributos que justifiquem sua proteção;

$[\cdots]$

\section{NÃo ReCEPÇÃo de dispositivos da Lei No $\mathbf{6 . 9 3 8 / 8 1}$ Pela Constituição Federal de 1988.}

A Lei n ${ }^{\circ}$ 6. 938/1981 é anterior à Constituição Federal de 1988, mas aqueles que advogam a sua recepção consideram que o foi pelo art 23, inciso VI da Constituição Federal.

Citado disposto constitucional foi regulamentado pela LC n 140/2011 supramencionada.

A respeito de dispositivos da lei não recepcionados pela Constituição Federal, o primeiro a ser indagado é o $\ 1^{\circ}$ do art. $6^{\circ}$ :

Art. $6^{\circ}$ - Os órgãos e entidades da União, dos Estados, do Distrito Federal, dos Territórios e dos Municípios, bem como as fundações instituídas pelo Poder Público, responsáveis pela proteção e melhoria da qualidade ambiental, constituirão o Sistema Nacional do Meio Ambiente - SISNAMA, assim estruturado:

$\int 1^{\circ}$ - Os Estados, na esfera de suas competências e nas áreas de sua jurisdição, elaborarão normas supletivas e complementares e padrões relacionados com o meio ambiente, observados os que forem estabelecidos pelo CONAMA.

$\int 2^{\circ}$ Os Municípios, observadas as normas e os padrões federais e estaduais, também poderão elaborar as normas mencionadas no parágrafo anterior. (Grifos nosso).

Percebe-se que, caso o Estado-membro ou Município desejem, nas esferas de suas competências e nas áreas de suas jurisdições, emitir normas supletivas e complementares relacionadas ao meio ambiente, poderão fazê-lo desde que sejam observadas as disposições das normas do CONAMA.

No entanto, tal assertiva causa extrema inquietude vez que uma lei estadual ou municipal não pode nunca se subordinar a um ato normativo oriundo de um órgão da administração indireta, pois a norma que estabelece a repartição de atribuição ou competências somente pode vir expressa na Constituição Federal. 
No mesmo sentido, caso se admita que uma lei estadual ou municipal possa ser condicionada por uma resolução do CONAMA, o poder e a função legislativa estadual e municipal estariam sendo limitados, o que colide frontalmente com a tripartição de poderes e com a repartição de competência constitucional ofendendo, assim, a própria República e o próprio Estado Democrático de Direito.

Corroborando esse entendimento:

Patrícia Silveira tece críticas ao poder regulamentar do CONAMA, destacando que o parágrafo $1^{\circ}$ do art. $6^{\circ}$ da Lei 6.938/81, não foi recepcionado pela Constituição Federal de 1988. Por conseguinte, "uma lei criada em nível estadual não se subordina às resoluções do CONAMA, pois a norma que rege primordialmente a repartição de competência é a Constituição [...]”. (MARCHESAN; STEIGLEDER; CAPPELLI, 2011, p. 85).

Percebe-se também que a Lei Complementar n 140, que regulamentou o inciso VI do art 23 da Constituição Federal e que é o mesmo inciso que fundamenta a recepção da Lei no $6.938 / 1981$, não trouxe nenhum dispositivo que corrobore o sentido dessa lei, o que demonstra a hipótese sustentada neste trabalho.

Outros dispositivos que merecem atenção são:

Art. $8^{\circ}$ Compete ao CONAMA:

I - estabelecer, mediante proposta do IBAMA, normas e critérios para o licenciamento de atividades efetiva ou potencialmente poluidoras, a ser concedido pelos Estados e supervisionado pelo IBAMA;

VI - estabelecer, privativamente, normas e padrões nacionais de controle da poluição por veículos automotores, aeronaves e embarcações, mediante audiência dos Ministérios competentes;

VII - estabelecer normas, critérios e padrões relativos ao controle e à manutenção da qualidade do meio ambiente com vistas ao uso racional dos recursos ambientais, principalmente os hídricos. (Grifos nosso).

Percebe-se que, por este artigo e incisos, o CONAMA passa a ter competência legislativa o que é totalmente contrário à Constituição Federal que nunca delegou competência legislativa a um órgão administrativo. A distribuição de competência legislativa é feita pela Constituição Federal, como os arts. 22 XII e 24 VI.

Art. 22 - Compete privativamente à União legislar sobre:

XII - jazidas, minas, outros recursos minerais e metalurgia;

Art.24 - Compete à União, aos Estados e ao Distrito Federal legislar concorrentemente sobre:

VI - florestas, caça, pesca, fauna, conservação da natureza, defesa do solo e dos recursos naturais, proteção do meio ambiente e controle da poluição.

Nesse sentido, aduz:

Adverte, ainda, que as competências do CONAMA fixadas nos incisos VI e VII do art. $8^{\circ}$ da Lei nº 6.938/1981 devem adaptar-se à nova ordem constitucional, "cabendo ao CONAMA, no máximo, a regulamentação de algo já instituído pela legislação, na qual não for aplicável, necessariamente, princípio da reserva lega (MARCHESAN; STEIGLEDER; CAPPELLI, 2011, p. 85).

Destarte, duas interpretações restam aos dispositivos da Lei no 6.938/1981 já mencionados. A primeira é a interpretação conforme a Constituição sem redução de texto, declarando a não recepção do termo "norma" e, assim, o restante mencionado passaria a se moldar à nova interpretação constitucional, vez que os critérios e padrões poderiam ser criados pelo CONAMA por serem assuntos técnicos, observando que nunca poderiam limitar o pode legislativo estadual e municipal.

A segunda alternativa, utilizando-se do princípio interpretação conforme a Constituição, é conferir nova interpretação ao dispositivo no sentido de que a palavra "norma" passe a significar "resolução", que pela relação de compatibilidade vertical das normas nacionais estaria abaixo da Constituição, das leis complementares e das leis ordinárias. Dessa forma, os poderes legislativos, sejam da União, dos Estados ou dos Municípios nunca teriam sua competência constitucional de legislar limitada por uma resolução de um órgão administrativo. 


\section{Considerações finais}

O presente artigo, ao abordar o poder regulamentar do CONAMA em matéria de licenciamento ambiental, analisou a compatibilidade vertical entre as normas editadas pelo COMANA nessa área e a Constituição Federal, demonstrando que o CONAMA, na qualidade de órgão do Poder Executivo da União, não detém competência para a edição de normas sobre licenciamento ambiental.

Ao legislar sobre o assunto, o CONAMA, a despeito de congregar a participação de vários setores do poder público e da sociedade civil em sua composição, subtrai da sociedade, representada nas casas legislativas dos diversos níveis federativos, a discussão amadurecida e plural da matéria, retirando a legitimidade de suas proposições.

Conforme demonstrado, o art. $8^{\circ}$ da 6.938/1981 atribuiu ao CONAMA competência para a edição de normas e definição de critérios para o licenciamento ambiental; contudo, tal dispositivo não foi recepcionado pala ordem constitucional vigente tendo em conta que, além das implicações do princípio da legalidade, o art 25 do ADCT rechaça textualmente a possibilidade de dispositivo infraconstitucional delegar a órgão do Poder Executivo competência assinalada pela Constituição ao Congresso Nacional, especialmente no que tange à ação normativa;

Desenvolveu-se a ideia de que o CONAMA, a despeito da delegação estatuída no art. 8 da 6.938/1981, ao editar resoluções contendo normas sobre o licenciamento ambiental, exorbitou de seu poder regulamentar e invadiu competência legislativa que, a teor dos artigos 24, inciso VI, e 44 c/c 48 da CF/ 88 é privativa do Congresso Nacional e das casas legislativas dos demais entes federados.

Além do que, conforme sublinhado, a Resolução n 237 do CONAMA, não se compatibiliza com os ditames do preceito normativo do art. $225, \sqrt{ } 1^{\circ}$, inciso $\mathrm{IV}$, da $\mathrm{CF} / 88$, na medida em que este remete à lei a definição dos critérios acerca da exigência de estudo prévio de impacto ambiental para instalação de obra ou atividade potencialmente causadora de significativa degradação do meio ambiente;

Destarte, ao longo do trabalho, foi confirmada a hipótese de que o CONAMA não detém poder normativo em matéria de licenciamento ambiental, podendo apenas fixar critérios de natureza técnica destinados a regulamentar a previsão que há de vir expressa em lei formalmente falando.

\section{REFERÊNCIAS}

AMADO, Frederico Augusto di Trindade. Direito ambiental esquematizado. 2. ed. São Paulo: Método, 2011.

BARROSO, Luís Roberto. Interpretação e aplicação da Constituição: fundamentos de uma dogmática constitucional transformadora. 5. ed. São Paulo: Saraiva, 2003.

BRASIL. Constituição (1988). Constituição da República Federativa do Brasil, 1988. Brasília: Senado Federal; Centro Gráfico, 1988.

Lei no 6.938, de 31 de Agosto de 1981. Dispõe sobre a Política Nacional do Meio Ambiente, seus fins e mecanismos de formulação e aplicação, e dá outras providências. Diário Oficial, Brasília, 2 set. 1981. CARVALHO, Kildare Gonçalves. Direito Constitucional. 14. ed. Belo Horizonte: Del Rey, 2008, 1.352 p. COSTA, Beatriz de Souza. Meio ambiente como direito à vida: Brasil, Portugal, Espanha. Belo Horizonte: Editora O lutador, 2010. 128 p.

FIORILLO, Celso Antônio Pacheco. Curso de direito ambiental. 12. ed. São Paulo: Saraiva, 2011. 
GUERRA, Glauco Martins. Princípio da Legalidade e Poder Normativo: dilemas da autonomia regulamentar. 2004. Disponível em: < http://www.mng.com.br/pdf/02_Artigos-MNG-Legalidade_PoderNormativo.pdf $>$. Acesso em: 2 nov. 2012.

MADEIRA, Dhenis Cruz. Processo de conhecimento \& cognição: uma inserção no estado democrático de direito. 1. reimp. Curitiba: Juruá, 2009. .

MARCHESAN, Ana Maria Moreira; STEIGLEDER, Annelise Monteiro; CAPPELLI, Sílvia. Direito Ambiental. 6. ed. Porto Alegre: Verbo Jurídico, 2011, 376 p.

MORAES, Alexandre. Direito Constitucional. 12. ed. São Paulo: Atlas, 2002, 836 p.

NETO, Antônio Zanollo et al. In: ROCHA, João Carlos de Carvalho; FILHO, Tarcísio Humberto Parreiras Henriques; CAZETTA, Ubiratan. (Orgs.). Política nacional do meio ambiente: 25 anos da Lei n. 6.938/81. Belo Horizonte: Del Rey, 2007, p. 81-94.

OLIVEIRA, Antônio Inagê de Assis. Introdução à Legislação Ambiental Brasileira e Licenciamento Ambiental. Rio de Janeiro: Lumen Juris, 2005, 658 p.

RIBEIRO, José Cláudio Junqueira. Gestão Ambiental Municipal em Minas Gerais. Belo Horizonte: FEAM, 2002, 79 p.

ROCHA, João Carlos de Carvalho et al. Política nacional do meio ambiente: 25 anos da Lei n. 6.938/81. Belo Horizonte: Del Rey, 2007.

SARLET, Ingo Wolfgang. As resoluções do CONAMA e o princípio da legalidade: a proteção ambiental à luz da segurança jurídica. Revista Juridica, Brasília, v. 10, n. 90, p. 1-25, edição especial, abr./maio 2008. Disponível em: <www.planalto.gov.br/revistajuridica>. Acesso em: 2 nov. 2012.

SILVA, José Afonso da. Aplicabilidade das normas constitucionais. 6. ed. São Paulo: Malheiros, 2003.

Direito ambiental constitucional. 7. ed. São Paulo: Malheiros, 2009.

SIRVINSKAS, Luís Paulo. Manual de direito ambiental. 10. ed. São Paulo: Saraiva, 2012.

TRENNEPOHL, Curt. Licenciamento ambiental. 3. ed. Niterói: Impetus, 2010, 368 p. 


\section{REVISTA BRASILEIRA DE POLÍTICAS PÚBLICAS BRAZILIAN JOURNAL OF PUBLIC POLICY}
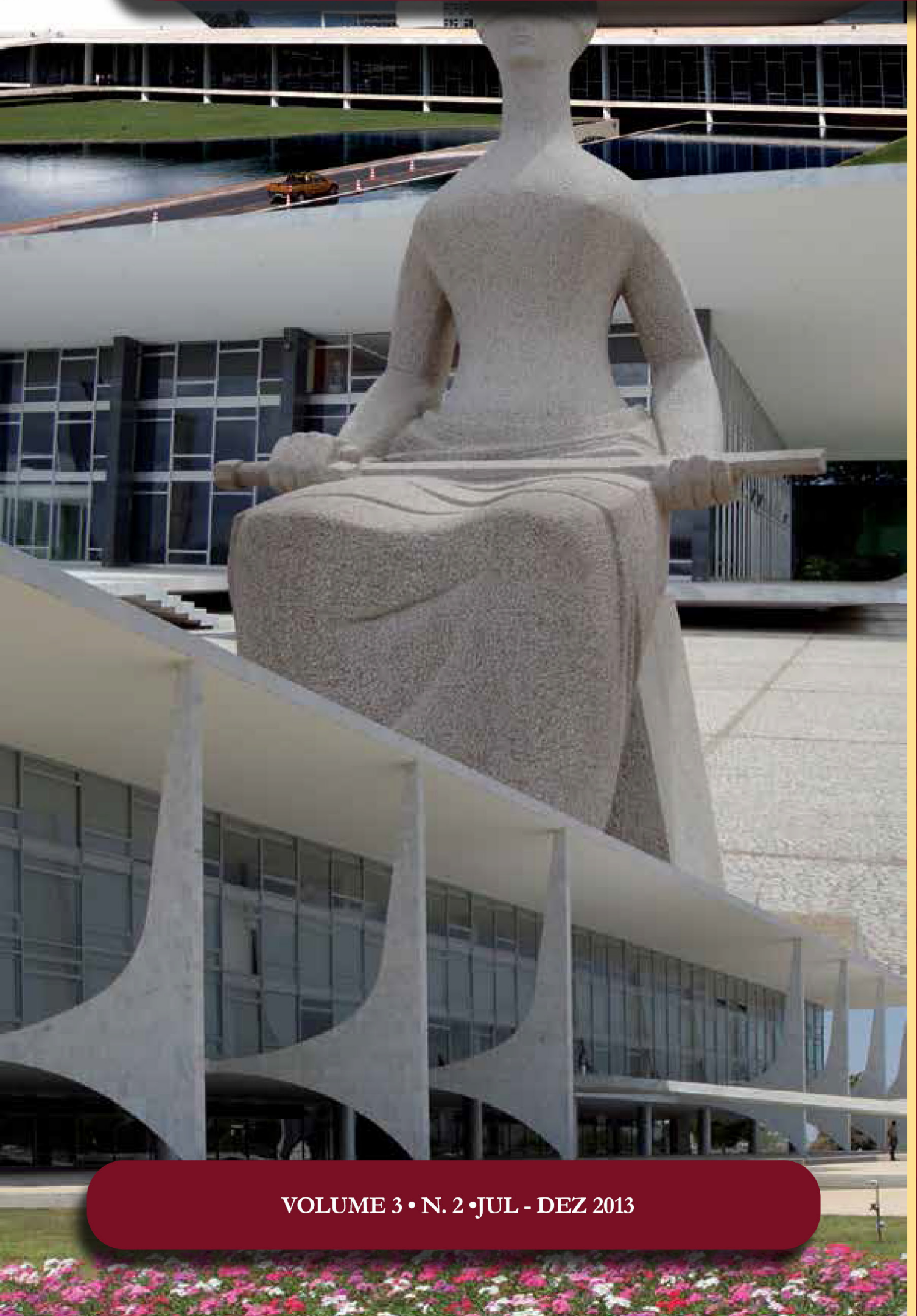

Teoría de la presión tributaria en base a la igualdad intergeneracional: una perspectiva financiera y tributaria del caso argentino

Theory of Fiscal Pressure Based on the Intergenerational Equality: An Argentinian Financial and Fiscal Perspective

Luciano Carlos Rezzoagli 


\title{
Teoría de la presión tributaria en base a la igualdad intergeneracional: una perspectiva financiera y tributaria del caso argentino
}

\author{
Theory of Fiscal Pressure Based on the \\ Intergenerational Equality: An Argentinian \\ Financial and Fiscal Perspective*
}

Luciano Carlos Rezzoagli**

Bruno Ariel Rezzoagli***

\section{Resumen}

En este trabajo se presenta una teoría inédita respecto a la utilización del principio de Igualdad en materia tributaria y financiera como medida que busca la paridad de tratamiento entre las generaciones de contribuyentes, situación que obliga, no solamente a los tribunales en las decisiones que al respecto les toque decidir en la órbita de sus competencias, sino, y fundamentalmente, al legislador, para asegurar una presión tributaria idónea en los impuestos y las cargas públicas de manera intergeneracional.

Palabras claves: Igualdad. Imposición. Justicia.

* Recebido em 28/08/2013

Aprovado em 08/10/2013

** Abogado. Magister y Doctor en Derecho Financiero y Tributario por la Universidad de Salamanca, España (graduado con mención honorífica). Consultor financiero en México y Estados Unidos del 2004 al 2009 (acreditado en Naciones Unidas, año 2005). Realización de un Postdoctorado por el Conicet, investigador del Instituto de Investigación de Estado, Territorio y Economía (IIETE) y del Centro de Investigación de la Facultad de Ciencias Jurídicas y Sociales (FCJS) de la Universidad Nacional del Litoral (UNL). Profesor y Coordinador académico del Doctorado en Derecho de la FCJS - UNL, Santa Fe. Email: lrezzoagli@fcjs.unl. edu.ar

*** Contador. Magister y Doctor en Derecho Administrativo Económico por la Universidad de Salamanca (España). Cuenta con un postdoctorado en Fiscalización Pública por el Conicet. Actualmente trabaja en la Oficina de Anticorrupción y Transparencia perteneciente al Ministerio de Justicia del Poder Ejecutivo de la Provincia de Santa Fe, y es Coordinador Académico de la Maestría en Administración Pública de la FCE - UNL, Santa Fe. Email: brezzoagli@hotmail.com

\section{Abstract}

In this paper we presents an unpublished theory with respect to the use of the principle of Equality in tributary and financial matter like measurement that looks for the parity of treatment between the generations of contributors, situation that forces, not only to the courts in the decisions that on the matter are called on to them to decide in the orbit of their competitions, but, and essentially, to the legislator, to assure suitable a tributary pressure in the taxes and the obligations owned to government intergenerational way.

Keywords: Equality. Imposition. Justice.

\section{Resumo}

Este artigo apresenta uma teoria inédita sobre o uso do princípio da igualdade na tributação e financeira, como o tratamento busca a paridade entre gerações de contribuintes, o que obriga não só para os tribunais em decisões tocá-los a decidir sobre a órbita das suas competências, mas também, e principalmente, o legislador, para garantir a carga tributária adequada em impostos e encargos públicos de uma forma intergeracional.

Palavras-chave: Igualdade. Tributação. Justiça. 


\section{Aspectos ReleVANTES de La IgUaldad COMO PRINCIPIO EN MATERIA IMPOSITIVA}

La igualdad es otra garantía de los derechos del contribuyente, formalizada con el advenimiento del sistema republicano de gobierno, tras la revolución francesa de 1789, que la consagró en la Carta de Derechos del Hombre y del Ciudadano como un derecho natural positivizado al abolir toda diferencia de nacimiento, raza, sangre y religión, pues en las pasadas monarquías existieron grupos sociales que estaban exentos de obligaciones tributarias, como la nobleza y el clero.

Sin embargo, debemos destacar que mientras en la revolución francesa la nota relevante o chispa detonadora del cambio fue la desigualdad existente entre los individuos generada por todo un entramado jurídico de privilegios y distinciones de clases, en la revolución americana (Estados Unidos) el fundamento se encontró en la exigencia de libertad. Esto explica por qué la Constitución de los Estados Unidos de América de 1787 no estableció expresamente el principio de Igualdad, que recién adquirió jerarquía constitucional expresa en la Enmienda XIV de 1966, mediante la cláusula de igual protección de leyes (equal protection clause).

Ahora bien, el principio de Igualdad no es un principio advenedizo; lo ubicamos en el siglo XVI, con posterioridad al descubrimiento de América, al descubrimiento de los nativos americanos como una nueva raza para el europeo, con el desarrollo de la escuela española misionera en el nuevo continente, entre los que destacaron Suárez, Covarrubias y Francisco De Vitoria.

Pero, ¿̇a qué igualdad se refería la famosa Ley de Suárez?, evidentemente a una igualdad de naturaleza, de los hombres ante Dios. Todos somos iguales ante Dios, es una característica de la Ley Natural. Ahora bien, con el transcurso del tiempo, el desarrollo del pensamiento ilustrado, la razón frente al dogma, el enciclopedismo, y podríamos decir de forma cruenta en la revolución francesa, la igualdad evolucionó a una aportación más técnica, mas jurídica.

La pregunta ya no era si los hombres eran iguales ante Dios, sino si tenían los mismos derechos y deberes frente al ordenamiento jurídico, es decir, si los hombres eran iguales ante los propios hombres, pues se estaba poniendo fin a las concepciones monárquicas y clasistas.

Leibholz, considera la igualdad como el principio constitucional que prohíbe la creación y aplicación de normas arbitrarias, extendiendo la aplicación de dicho principio no sólo a los tribunales sino también al legislador. Sin embargo, no llega a definir la arbitrariedad pues considera que su contenido es mutable y puede ser aplicado caso por caso en modo objetivo como lo contrario a lo razonable ${ }^{1}$.

Para Tipke y Lang², la justificación objetiva y razonable para fundamentar la "desigualdad" no es suficiente, sino que, además, debe ser adecuada, idónea y proporcional para alcanzar la finalidad perseguida. De esta forma se introduce la noción de proporcionalidad que indica cuando una restricción de un derecho fundamental es admisible o no.

Todos somos iguales ante la ley, así nace la igualdad formal o de tratamiento, que se desplaza al ámbito tributario y se centra en el reparto del coste de los servicios públicos ${ }^{3}$, lo cual es lógico si analizamos que ya los tributos no se utilizaban para mantener al monarca y la nobleza, sino que debían comenzar a satisfacer las necesidades del propio pueblo.

La igualdad tributaria es una consecuencia de la igualdad de todos ante la ley, que es uno de los principios en que se asienta el sistema moderno y democrático de gobierno. En la Constitución Argentina adquiere una

1 LEIBHOLZ, G. Die gleichbeit vor dem gesetz: Eine studie auf rechtesvergleichender und rechtsplhilosophicher grundlage. Zweite, durch eine reihe erganzerder beitrage erweiterte auflage. Munchen: Verlag C. H. Beck, 1959.

2 TIPKE, K. y LANG, J. citados en : AICEGA ZUBILLAGA, J. M. La utilización extrafiscal del tributo y los principios de justicia tributaria. Bilbao: Vasco, 2001. p. 155.

3 GONZÁLEZ GARCÍA, E. Serie de Conferencias en Derecho Tributario. Buenos Aires: Asociación Argentina de Estudios Fiscales, 1994. p. 10. 
relevancia especial en cuanto a su amplitud, los nacionales y extranjeros son iguales, salvo en los derechos políticos (art. $20 \mathrm{CNA}$ ). Asimismo, señala Luqui ${ }^{4}$, se trata de una garantía incita en la forma republicana de gobierno, verdadera auto limitación del poder del Estado frente al individuo. Dicha garantía está incorporada al sistema de la Constitución que la considera un derecho natural de las personas, como la libertad, la propiedad y la vida.

Por consiguiente, la igualdad natural de todos los hombres, su igual capacidad jurídica, y la imparcialidad en la aplicación del derecho, son, pues, los pilares del sistema. Como establece Lejeune Valcárcel, "toda norma que, apartándose de los mencionados presupuestos estableciera diferencias y tratos discriminatorios entre sus ciudadanos se considerará arbitraria y contraria al fundamental principio de Igualdad"5. De esta forma todas las personas son consideradas iguales ante la ley y titulares de los mismos derechos, más sin que ello signifique pretender influir, mediante tratamientos diferenciados en la estructura de la sociedad, ante situaciones de desigualdades de hecho, que impiden el disfrute de esos derechos que la ley consagra ${ }^{6}$.

La utilización de criterios de igualdad formal o ante la Ley como principio rector de justicia permite el entronque con el principio de igualdad en su ámbito material, que, como señala Abbamonte ${ }^{7}$, debe ser aplicado en el sentido de no sólo tratar igualmente a todos, sino de eliminar las desigualdades de hecho que impidan la plena participación de todos los trabajadores en la vida económica, política y social del país. Entre los instrumentos más utilizados en el ámbito impositivo para justificar esta manifestación material del principio se encuentran los incentivos fiscales contenidos en las leyes de promoción de zonas y actividades, o las leyes de emergencia económica ${ }^{8}$.

Pérez de Ayala ${ }^{9}$, tras analizar ciertas consideraciones especulativas acerca de la igualdad, sostiene que precisa un andamiaje que le permita ser un principio real y plenamente operativo. Esta prenda sólo puede alcanzarse dándole contenido, sustancia desde el principio de capacidad contributiva.

En la doctrina alemana, tradicionalmente el principio de igualdad ha supuesto una prohibición de arbitrariedad. Dicha arbitrariedad se producirá cuando, atendiendo al criterio de comparación elegido (el cual debe tener reconocido en la comunidad jurídica un valor de justicia) o la naturaleza material, existieran desigualdades que carecieran de justificación objetiva y razonable. La igualdad no supone uniformidad sino que se vulnera cuando arbitrariamente se establecen discriminaciones entre contribuyentes respecto de los cuales no media justificación objetiva de diferenciación ${ }^{10}$

Tal como manifiesta González García ${ }^{11}$, es curioso como Tribunales de distintos países, como el alemán, el italiano y el español, por nombrar algunos, abordan los mismos fundamentos para dar contenido a principios diferentes, como son el de Igualdad y el de Capacidad Contributiva. Esto es así porque la igualdad se proyecta, como no podía ser de otra manera, en el ámbito fiscal, estableciéndose como criterio central de distribución de las cargas públicas.

4 LUQUI, J. C. La obligación tributaria. Buenos Aires: Depalma, 1989. p. 89.

5 LEJEUNE VALCÁRCEL, E. Aproximación al principio constitucional de igualdad tributaria. En: Seis estudios sobre derecho constitucional e internacional tributário. Madrid: Derechos Reunidas, 1980. p. 122.

6 SPISSO, R. Derecho constitucional tributário. 2. ed. Buenos Aires: Depalma , 2000, p. 325.

7 ABBAMONTE, G. Principi di diritto finanziario. Napoli: Liguori, 1974, p.50-51.

8 Es curioso que más tarde desapareciera de las Constituciones Francesas la alusión al principio, permitiendo afirmar que éste sólo correspondía a la igualdad ante la ley y no ante el impuesto, transformándose el concepto jurídico inicial en una noción económica de igualdad objetiva de los ciudadanos en la equidad fiscal y evolucionando de aquí a una nueva noción jurídica de solidaridad ante el impuesto.

9 PÉREZ DE AYALA, J. L. Las cargas públicas: principios para su distribución, HPE, n. 59, 1979. p. 96.

10 LASÁRTE ÁLVAREZ, J. Los principios de justicia tributaria según la jurisprudencia constitucional: jurisprudencia del tribunal constitucional en materia financiera y tributaria (1981 - 1989): sentencias, autos y comentários. Madrid: Tecnos, 1990. P. 93-96.

11 GONZÁLEZ GARCÍA, E. Serie de conferencias en derecho tributario. Buenos Aires: Asociación Argentina de Estudios Fiscales, 1994. p. 10. 


\section{Pautas del principio en el derecho argentino. Interpretación de la Corte Suprema de Justicia de la Nación}

La Constitución proclama en su artículo 16: "La Nación Argentina no admite prerrogativas de sangre, ni de nacimiento; No hay en ella fueros personales ni títulos de nobleza. Todos los habitantes son iguales ante la ley, y admisibles en los empleos sin otra condición que la idoneidad. La igualdad es la base del impuesto y de las cargas públicas".

Al emplear éste artículo el término "base del impuesto y de las cargas públicas", coloca al principio de Igualdad como estandarte rector del ámbito tributario. En palabras de Bielsa, "nuestra Constitución sigue el principio aristotélico de la igualdad, que consiste en tratar igual a los iguales y desigual a los desiguales" 12 .

En el plano tributario, la población, entendida como el conjunto de ciudadanos, juega un rol vital en la recaudación de los recursos del Estado. La igualdad del art. 16 constitucional se manifiesta en este ámbito en el respeto de la capacidad contributiva (aptitud del ciudadano para contribuir al sostenimiento del gasto público en función de su patrimonio y sus necesidades) aplicable de manera perfecta a los impuestos y en el desarrollo del beneficio ${ }^{13}$ en las tasas (criterio de proporcionalidad entre el servicio recibido y el costo resultante) y contribuciones de mejoras (proporcionalidad entre el monto exigido por la obra realizada y el aumento del valor inmobiliario o la calidad de vida).

En este sentido, la Corte Suprema de Justicia de la Nación ha expresado: "El texto de tal disposición, inspirada por la conciencia democrática de sus autores, que abominan toda primacía ilegítima que no admite prerrogativas de sangre ni de nacimiento, que suprime los títulos de nobleza y los fueros personales, para declarar enseguida, que todos los habitantes son iguales ante la ley, demuestra con toda evidencia cual es el alto propósito que la domina: el derecho de todos a que no se establezcan excepciones o privilegios que excluyan a unos de los que se les concede a otros en iguales circunstancias ("Fallos": 16:118; 101:401). No es, pues, la nivelación absoluta de los hombres lo que se ha proclamado, aspiración quimérica y contraria a la naturaleza humana, sino su igualdad relativa, propiciada por una legislación tendiente a la protección, en lo posible, de las desigualdades naturales" ${ }^{\text {. }}$. Por lo tanto, la igualdad de tratamiento, tiene relevancia en tanto y en cuanto el régimen tributario en general y cada tributo en particular se apliquen atendiendo a las capacidades contributivas de las personas.

Todos los ciudadanos tenemos la obligación de aportar con nuestros recursos al sostenimiento de los gastos públicos, y el estado tiene la obligación de tratar igual a los iguales y desigual a los desiguales teniendo como premisa básica la riqueza y las necesidades de cada ciudadano.

La Corte Suprema de Justicia de la Nación desde antiguo viene sosteniendo que no son iguales las cosas diferente, trátese de objetos o de industrias de distinta clase, y, por lo tanto, para que el principio de igualdad en el impuesto y en las cargas públicas sea una realidad no debe ni puede referirse sino a cosas iguales y del mismo género, que constituya la igualdad de la cual habla la disposición indicada. Un ejemplo de la posición adoptada por nuestro máximo Tribunal lo constituye la sentencia dictada en la causa "Cía. Unión Telefónica del Río de la Plata c. Municipalidad de Rosario", sentencia de 15 de Septiembre de $1903^{15}$, cuando considera que no es violatorio de la garantía de igualdad el impuesto a las patentes aplicado por la Municipalidad de Rosario a las compañías telefónicas y no a otras industrias.

12 BIELSA, R. Estudios de derecho público: derecho fiscal. Buenos Aires: Depalma, 1951. p. 148.

13 La Teoría del Beneficio establece que debemos pagar los servicios públicos en relación de lo que recibimos, y fue acuñada indudablemente por las Haciendas Locales en lo referente a Tasas y Contribuciones Especiales o de Mejoras. Para Griziotti la capacidad de pago es la causa última del deber de pagar el tributo, en cuanto manifestación indirecta de la causa primera, que es la participación del contribuyente en los beneficios derivados de los servicios públicos. GRIZIOTTI, B. Il principio di la capacitá contributiva e le sue aplicaz̧ioni: saggi sul rinnovamento dello studio della scienza delle finanze e del diritto finanziario. Milán: Giuffré, 1953. p. 300-301.

14 "Fallos": 151: 359 (“Don Eugenio Díaz Vélez c. Provincia de Buenos Aires”, sentencia de 20 de junio de 1928).

15 "Fallos": 98: 70. 
Pese a que esta antigua postura de la Corte se mantiene, con algunos matices, hasta hoy, puede afirmarse que los primeros fallos en 1863 hasta el año 1923, fecha en que se dictó el fallo "Unanué c. Municipalidad de la Capital"16, "corresponden a una etapa caracterizada por la falta de criterio para medir la igualdad ante el impuesto y las cargas públicas, porque, afirmar que se debe dar igual trato fiscal en igualdad de circunstancias nada dice del criterio utilizado para medir la igualdad de circunstancias; no se identifica el criterio de comparación aplicable en el juicio de igualdad.

Esta falta de justificación permite considerar compatible con el principio del artículo 16 CNA cualquier clasificación o categoría de contribuyentes creada por el legislador siempre que, dentro de su categoría, los individuos sean tratados igualmente. Por poner un caso límite, mediante la implementación de esta lógica podría considerarse acorde con el principio de Igualdad un impuesto sobre automóviles de color verde,

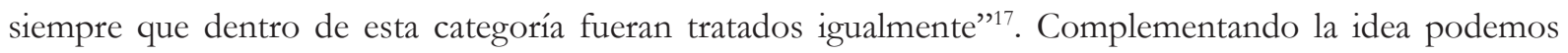
mencionar que la historia es rica en este tipo de ejemplos, como ocurrió en México en el tiempo del liderato de Antonio de Padua María Severino López de Santa Anna y Pérez de Lebrón, más conocido como el General Antonio López de Santa Anna, en donde existían tributos a las ventanas y a la posesión de perros ${ }^{18}$.

A pesar de que el principio de Capacidad Contributiva como fundamento y medida de la imposición daría luz para solucionar estos problemas (puesto que lo que deben gravarse son exclusivamente manifestaciones de riqueza), otros criterios fueron también utilizados para complementar y entender el principio de Igualdad en nuestro país.

La importancia del caso Unanué ${ }^{19}$ se manifiesta en el esfuerzo de la Corte en buscar un motivo razonable o una razón substancial para comparar situaciones y establecer la razonabilidad de las clasificaciones frente a la exigencia de la igualdad ante el impuesto y las cargas públicas ${ }^{20}$, habiendo podido resolver, como era hasta entonces su criterio, limitándose a declarar que los Stud eran tratados igualmente frente al impuesto.

En este sentido, la existencia de un MOTIVO RAZONABLE es suficiente para que la distinción legislativa no vulnere el principio de Igualdad ${ }^{21}$, así, con posterioridad al fallo anteriormente mencionado, la Corte en forma reiterada ha establecido que "la garantía del artículo 16 CNA no impide que el legislador contemple en forma distinta situaciones que considere diferentes, con tal que la discriminación no sea arbitraria ni importe ilegítima persecución o indebido privilegio de personas o grupos de personas, aunque su fundamento sea opinable"22.

Así pues, desde el caso "Unanué c. Municipalidad de la Capital”, son numerosos los casos de aplicación del criterio de razonabilidad en la formación de categorías y en la elección del principium divisionis ${ }^{23}$, nos

16 "Fallos": 138:313 ("Don Ignacio Unanué c. Municipalidad de la Capital", sentencia de 20 de Agosto de 1923).

17 GARCÍA ETCHEGOYEN, M. F. El principio de capacidad contributiva: estudio en Italia, España y Argentina. Tesis (Doctoral)Universidad de Salamanca, Salamanca, 2002. p. 269-270. En el mismo sentido se puede consultar su obra El principio de capacidad contributiva. Evolución dogmática y proyección en el Derecho Argentino. Buenos Aires: Abaco, 2004.

18 Ciertamente atentatorios contra la capacidad contributiva como fundamento de la imposición. Remitimos al lector a la relación que debe necesariamente existir entre Igualdad y Capacidad Contributiva, en sus dos vertientes, como fundamento y medida de la imposición. 19 En este caso una Ordenanza Municipal establecía una tasa o derecho de inscripción, licencia, análisis e inspección sobre locales que alojen caballos de carrera - stud. Los actores alegaron la vulneración del principio de igualdad porque la tasa se graduó de manera diferente cuando se trató de locales que alojaban caballos de carrera, que cuando se trataba de caballerizas que silaban caballos de coches. La Corte, en este sentido, se expresó de la siguiente manera: “(...) cuando un impuesto es establecido sobre ciertas clases de bienes o de personas debe existir alguna base razonable para las clasificaciones adoptadas, por lo que debe existir una razón substancial de peso para que cierto grupo de personas o propiedades sean catalogados en grupos distintos (...) el valor de los animales que alojen, etc.". De esta manera se hizo del Stud una categoría especial dentro del género caballerizas. "Fallos": 138: 313 ("Don Ignacio Unanué c. Municipalidad de la Capital", sentencia de 20 de Agosto de 1923).

20 GARCÍA ETCHEGOYEN, M. F. El principio de capacidad contributiva: estudio en Italia, España y Argentina. Tesis (Doctoral)Universidad de Salamanca, Salamanca, 2002. p. 275.

21 CASÁS, J. O. Presión fiscal e inconstitucionalidade: las garantías constitucionales ante la presión del conjunto de tributos que recaen sobre el sujeto contribuyente). Buenos Aires: Depalma, 1992. p.109.

22 "Fallos": 190: 231 ("Dolores Cobo de Macchi di Cellere c. Pcia. De Córdoba", sentencia de 21 de Julio de 1941); "Fallos": 210: 885 ("Petrus S.A. de minas c. Nación Argentina", sentencia de 28 de Abril de 1948), entre otras.

23 Remitimos al lector para un estudio detallado del principio de Razonabilidad, lo cual no es objeto del presente trabajo, a otras obras especializadas en el tema, como LINARES, J. F. Razonabilidad de las leyes: el debido proceso como garantía innominada en la 
limitaremos a comentar brevemente algunos por considerarlos los más interesantes. En el caso "Guardian Assurance" 24 , la Corte consideró razonable la distinción entre compañías domiciliadas en el extranjero y compañías domiciliadas en el país; rechazó la suposición de que con esa distinción se haya querido hacer un distingo entre capitales argentinos y extranjeros, vedado por la Constitución, y entendió implícitamente que es de justicia fomentar la incorporación de capitales al país gravando aquellos que no lo hacen realmente.

En el caso "Dolores Cobo"25, la Corte consideró razonable que a propiedades rurales valiosas se les aplique un impuesto progresivo no establecido a las de menor valor y a las propiedades urbanas, debido a que encontró razonable la valoración que hizo el legislador en cuanto procuró hacer justicia social con el impuesto progresivo sobre los latifundios (con cierto paralelismo al impuesto español sobre tierras infrautilizadas en Andalucía).

En el causa "Masson de Gil"26 se estableció que una ordenanza impositiva municipal que impuso la misma carga para inmuebles edificados y no edificados, y sin distinguir el valor de estos últimos, resultó contraria a la regla de la Igualdad del artículo 16 CNA pues no basta que la Municipalidad de Santa Rosa haya ordenado con criterio discrecional los objetos de imposición y que dentro de cada grupo o clase de grupo los contribuyentes paguen igual impuesto para que pueda decirse que con ello se salva el principio de Igualdad. Es necesario que se funde en diferencias razonables y no de selección arbitraria ("Fallos": 149: 417; "Fallos": 138: 313; "Fallos": 161: 390; entre otros), por lo que el impuesto fue declarado confiscatorio.

En el caso "Larralde y otros" ${ }^{27}$, el Alto Tribunal entendió que la aplicación del impuesto territorial a cada condómino teniendo en cuenta el valor del inmueble total y no sólo de la parte indivisa, no es contraria al régimen del Código Civil relativo al Condominio, por lo que no se viola el principio de Igualdad al no ser una decisión arbitraria.

En la causa "Severo Larroca", la Corte analizó la cuestión desde un ángulo de Igualdad ante la Ley, consideró irrazonable (aunque no utilizó textualmente dicha expresión) la formación de una categoría impositiva única conformada por Abogados que perciben honorarios y que deben depositar el $30 \%$ de ellos a favor de la Caja Forense para ser distribuidos en su mayor parte entre los demás abogados y procuradores de la matrícula. Ello por razón de que no se da ninguna relación desde el punto de vista del origen de los fondos entre quien aporta y quien se beneficia, lo que hace más clara la inconstitucionalidad. Aquí se consideró la norma impugnada como violatoria del derecho de propiedad.

En la causa "Hermitage c. Poder Ejecutivo Nacional", del 15 de Junio de 2010, en relación al pago del Impuesto de Ganancia Mínima Presunta, se produce un conflicto respecto de las presunciones que toma el legislador en función de los activos y la capacidad contributiva real de la empresa, por lo que la Corte establece: "En efecto, la problemática de las presunciones en materia tributaria es el resultado de la tensión de dos principios: el de justicia tributaria y el de capacidad contributiva, y es por ello, que requieren un uso inteligente, concreto y racional. Es en el supuesto de las presunciones denominadas iuris et de iure, en el que la cuestión adquiere su mayor dramatismo, pues hay veces que el legislador para 'simplificar acude al resolutivo método de no admitir la prueba en contrario, cercenando la posibilidad de que el contribuyente utilice, frente a la Administración, algunos de los medios jurídicos de defensa. Que con esto se consigue seguridad jurídica es indudable; pero tal vez la aplicación del principio de capacidad contributiva se vea relegado e irrespetado por tales aseguramientos... la iniquidad de esta clase de previsión, se pondría en evidencia ante la comprobación fehaciente de que aquella renta presumida por la ley, lisa y llanamente, no ha existido" (fundamento 10 y 15).

Constitución Argentina. 2. ed. Buenos Aires: Astrea, 2002.

24 "Fallos": 150: 89 (“Guardian Assurance Company Limited c. Gobierno Nacional”, sentencia de 12 de Diciembre de 1927).

25 "Fallos": 190:309 ("Dolores Cobo de Machi di Cellere c. Pcia. De Córdoba”, sentencia de 21 de Julio de 1941.

26 "Fallos": 195:270 ("Malvina Mason de Gil c. Municipalidad de Santa Rosa", sentencia de 12 de Abril de 1943).

27 "Fallos": 243: 98 ("Lorenzo Larralde y otros", sentencia de 2 de Marzo de 1959). 
Como vemos hasta aquí, el criterio de la Razonabilidad es utilizado por el Máximo Tribunal como un elemento que coadyuva, en el caso concreto, al cumplimiento del Principio de Igualdad de tratamiento de las capacidades contributivas consagrado en nuestro artículo 16 CNA.

Resulta interesante, también, mencionar, que el Tribunal Constitucional Español señaló en la sentencia (STC) 76/1990, de 26 de abril de dicho año, en su F.J. número 10 la siguiente fórmula para entender el alcance del principio de Igualdad en función del criterio de razonabilidad:

1- No toda desigualdad de trato en la ley supone una infracción de la Constitución Española, sino que dicha infracción la produce sólo aquella desigualdad que introduce una diferencia entre situaciones que pueden considerarse iguales y que carece de una justificación objetiva y razonable.

2- El principio de igualdad exige que a iguales supuestos de hecho se apliquen iguales consecuencias jurídicas, debiendo considerarse iguales dos supuestos de hecho cuando la utilización o introducción de elementos diferenciadores sea arbitraria y carezca de un fundamento racional.

3- El principio de igualdad no prohíbe al legislador cualquier desigualdad de trato sino sólo aquellas que resulten artificiosas o injustificadas por no venir fundadas en criterios objetivos y suficientemente razonables de acuerdo con los criterios de valor generalmente aceptados.

4- Para que la diferenciación resulte constitucionalmente lícita no basta con que lo sea el fin que con ella se persigue, sino que es indispensable además que las consecuencias jurídicas que resulten de tal distinción sea adecuadas y proporcionadas a dicho fin, de manera que la relación entre la medida adoptada, el resultado que se produce y el fin pretendido por el legislador superen un juicio de proporcionalidad en sede constitucional, evitando resultados especialmente gravosos y desmedidos.

Ahora bien, todo análisis de la igualdad (formal y material) en materia tributaria fue estructurado teniendo en cuenta la posición de los ciudadanos frente al tributo en un momento temporal determinado y ante circunstancias particularizadas, tal como señala Pérez de Ayala, "en realidad, sólo pueden establecerse proposiciones sobre igual o desigual aptitud refiriéndolas a las realidades económicamente grabadas por un impuesto determinado. Esto es lógico, ya que todo impuesto debe definir su hecho imponible tomando como fundamento un determinado tipo de realidades económicas que se gravan en cuanto es pago de ese impuesto específico"28.

Sin embargo, atendiendo a unas de las preguntas centrales que han marcado el desarrollo de este escrito, ¿puede aplicarse el principio de igualdad como criterio base para la planeación financiera del Estado tomando como centro la carga que deberá afrontar la población económicamente activa vigente durante dicho proceso? En definitiva, ¿puede también la igualdad ampliar y transformar su protección al ciudadano, ya no en el ámbito exclusivamente tributario sino en el ámbito financiero?, ¿̇o es que este principio no actúa en todas las ramas del derecho?

\section{Su EXTENSIÓN AL ÁmBITO FINANCIERO}

Claus Offe ${ }^{29}$, analiza a las sociedades capitalistas tardías como sistemas estructurados conformados por tres subsistemas interdependientes pero de forma organizada. El primer subsistema se encuentra conformado por las estructuras de socialización, que se guían por el uso de reglas normativas, el segundo subsistema se encuentra conformado por la producción de bienes y las relaciones de intercambio de la economía, y el tercer subsistema se encuentra organizado por los mecanismos de poder y coacción política administrativa

28 PÉREZ DE AYALA, J. L. Los principios de justicia en el impuesto en la constitución española. En: . Fiscalidad y Constitución: consejo superior de cámaras de comercio, industria y navegación. Madrid, 1986. p. 58.

29 OFFE, C. Contradicciones en el Estado de Bienestar. Madrid: Alianza Universitaria 1990. 
del Estado. La planeación, ejecución y control de la economía se encuentra subordinada a la acumulación de capital privado por ser este el principal promotor de la fuerza de trabajo, los sistemas normativos y político-coercitivos se subordinan al principio organizativo dominante del intercambio, una Teoría de la Crisis de tal sociedad se puede identificar con los procesos que desafían el dominio de este principio central.

Si tomamos como premisa inicial que un incremento desmesurado del gasto público puede generar mayores tributos erosionando el poder adquisitivo de la población, y esto impide el crecimiento de actividades económicas de empresas y particulares debido al aumento de dicha tributación, que en ciertos casos puede resultar confiscatorio. Consideramos, siguiendo a Rezzoagli y Alurralde, que "uno de los objetivos del sistema tributario debe consistir en disminuir la presión tributaria, tomando en consideración especialmente los costos de recaudación y administración de los tributos" ${ }^{30}$.

Si la igualdad es la base del impuesto y de las cargas públicas, entonces la planeación respecto a la recaudación de los fondos públicos que recae y obliga a la población a tributar (impuestos y cargas públicas), ¿no debe estructurarse teniendo como base la búsqueda de una presión tributaria equitativa generacionalmente?, ¿puede aplicarse el principio de igualdad de manera intergeneracional?

Por nuestra parte estamos convencidos que el Estado, en una economía de escala (nacional, provincial y municipal) debe atender a la Igualdad Intergeneracional para planear de la manera más eficiente el desarrollo de un sistema financiero y tributario que garantice la menor presión fiscal para cada generación. Más aún, la adecuada planeación en el endeudamiento y en la creación o desarrollo de impuestos y cargas públicas justifican que en momentos de crisis, como, por ejemplo, la crisis financiera internacional de mediados de 2008, pueda combatirse y solventarse racionalmente entre varias generaciones de contribuyentes, con una adecuada y equitativa presión tributaria ${ }^{31}$, y no volcarse todo el peso del colapso en la generación actual.

Esto es así debido a que la planeación financiera debe analizarse siempre desde la perspectiva ingreso-gasto, cuya relación queda satisfactoriamente explicada a partir del principio de suficiencia financiera, el cual establece que las autorizaciones de gastos contenidas en los presupuestos si bien obedecen a necesidades públicas a satisfacer no pueden desatender las fuentes de financiación a las que el Estado puede recurrir ${ }^{32}$.

Como sabemos, existen cinco fuentes de recursos para solventar el gasto público: recursos provenientes del patrimonio y actividades estatales, recursos tributarios (al cual hacemos referencia para la aplicación del principio de Igualdad Intergeneracional), recursos provenientes del crédito público, recursos derivados de la emisión monetaria y recursos provenientes de sanciones patrimoniales; siendo los recursos tributarios los que adquieren una importancia trascendental desde el punto de vista cuantitativo.

A su vez, debemos traer a colación, para justificar este razonamiento, el art. 12 de la Ley 25.917 -régimen de responsabilidad fiscal- que dispone que "El producido de la venta de activos fijos de cualquier naturaleza y el endeudamiento del Gobierno nacional, de las provincias y de la Ciudad Autónoma de Buenos Aires no podrán destinarse a gastos corrientes ni generar aumentos automáticos para el ejercicio siguiente, excepto operaciones de crédito para reestructurar deuda en condiciones más favorables a ellas, el financiamiento proveniente de Organismos Multilaterales de Crédito y el proveniente de programas nacionales de financiamiento con destino a obras públicas y fines sociales. Queda expresamente establecido, que la venta de activos fijos, podrá destinarse a financiar erogaciones de capital”.

30 REZZOAGLi, B. A. y ALURRALDE, A. M. Manual de finanzas públicas. México: Morevallado, 2008. p. 58.

31 Las leyes tributarias y las planeaciones financieras afectan a un gran número de individuos por lo que se ven abocadas a seguir criterios genéricos de tipificación al no ser posible, por razones de practicabilidad, contemplar la magnitud de casos individuales. De esta forma, para saber si una determinada medida tributaria es acorde con el principio de Igualdad, es necesario llevar a cabo una comparación entre distintos grupos de posibles obligados tributarios.

32 MIAJA FOL, M. El gasto público. En: VEGA, Santiago Fuentes (Coord.). El gasto público: ejecución y control. 2. ed. Madrid: Instituto de Estudios Fiscales, 1999. Fiscales, Madrid, 1999. p. 40. Dicho autor aclara que no se debe identificar suficiencia financiera con potestad tributaria, dado que las fuentes de financiación de las administraciones públicas son muy variadas y no se sustentan exclusivamente sobre el sistema tributario, aun cuando éste constituya el elemento fundamental de la mencionada financiación. p. 40-41. 
Siguiendo esta línea de análisis, ante un escenario de crisis como el actual, la principal preocupación de la gestión gubernamental se centra el cubrir los gastos que son necesarios para el normal funcionamiento de su administración, siendo el gasto de personal la erogación por antonomasia a la que debe hacer frente el Estado en el corto plazo. Si bien uno de los principios presupuestarios tradicionales es justamente el de la "no afectación de recursos" (los recursos no tienen una afectación específica sino que se destinan a rentas generales), resulta obvio que la recaudación tributaria es la fuente principal para cubrir los gastos públicos, tal como es el caso, de los gastos en personal. Además, no podría recurrirse en modo alguno a operaciones de crédito para atender gastos corrientes.

Por lo tanto, la situación planteada (crisis) podría dificultar la realización de obras públicas, algunas de las cuales pueden incluso llegar a ser significativas para incrementar la capacidad productiva de la provincia o del país -según se trate-, las cuales únicamente se llevarían a cabo mediante endeudamiento, cuyo servicio de la deuda estará constituido por la amortización del capital y el pago de los intereses, comisiones y otros cargos que eventualmente puedan haberse convenido en las citadas operaciones.

Así pues, la ejecución de determinadas obras públicas traerá aparejado las correspondientes amortizaciones de capital y pago de intereses por una cierta cantidad de años; lo cual deberá preverse en los futuros ejercicios presupuestarios y atenderse con los ingresos a recaudar en aquéllos, siendo la tributación la fuente principal de toda financiación. Ello, desde nuestro punto, derivaría, en caso de no haber una reactivación económica, en una mayor presión fiscal para los contribuyentes durante el período de pago de la deuda.

Sin embargo, el plazo de financiación de la obra pública no siempre se corresponde con la vida útil de la misma. En este sentido resulta injusto y atentatorio al principio de igualdad intergeneracional que una generación de contribuyentes pueda solventar el gasto público que se traduce en obras que aprovecharán varias generaciones, siendo además importante resaltar que puede suceder que la generación que solventa con el peso del sistema tributario el costo, o parte del mismo, de las obras realizadas, no pueda beneficiarse de las mismas por el prolongado tiempo de realización (pensemos en una carretera, un puente extenso inter ciudades, un túnel subfluvial, etc).

Como se puede apreciar, la idea de igualdad intergeneracional que proponemos en un plano jurídico - financiero - institucional, refiere a la presión tributaria que se aplica a los contribuyentes intergeneracionales para solventar las inversiones públicas, a su vez, dichas inversiones implican un flujo de beneficios a través de un período significativo ${ }^{33}$. Si las inversiones aumentan el nivel de bienestar o el nivel de vida de las generaciones futuras, la igualdad intergeneracional exige que dichas generaciones carguen con los costos de aquéllas, y uno de los caminos posibles puede ser el endeudamiento ${ }^{34}$.

Existen autores que refieren a la utilización de la "equidad intergeneracional" como criterio exclusivamente económico en busca de la eficiencia en la utilización de recursos financieros (su visión es exclusivamente respecto a optimizar el gasto), sin embargo, y pese a que coincidimos con la utilización del componente generacional para buscar la eficiencia u optimización de los recursos públicos, debemos advertir que no puede generalizarse este criterio para que obtenga validez general debido a que el óptimo social y el individual no siempre son iguales, y menos aún afirmarse que métodos (como el de VAN), que únicamente consideran los flujos de consumo mediante el descuento temporal de las generaciones presentes, conducen a decisiones óptimas respecto al nivel de inversión intergeneracional ${ }^{35}$.

33 YÁÑEZ, J. Principios a considerar en la descentralización de las finanzas públicas (locales). Revista Estudios Públicos, Santiago de Chile, n. 45, 1992. p. 348.

34 YÁÑEZ, J. Principios a considerar en la descentralización de las finanzas públicas (locales). Revista Estudios Públicos, Santiago de Chile, n. 45, 1992. p. 348. Por nuestra parte, aclaramos que si bien la eficiencia y economía son reglas de buena conducta a las que habrá de ajustarse la Administración Pública en su actuación financiera, el endeudamiento exige también de una correcta planificación, ya que los servicios de la deuda serán cubiertos en ejercicios posteriores incidiendo en la pertinente estimación de los recursos públicos a recaudar y de las acciones necesarias para su concreción. Por lo que el endeudamiento debe planificarse, y dicha planeación no sólo debe atender normas de eficiencia y economía sino también a la justicia material del gasto.

35 HULTKRANTZ, L. Forestry and the bequest motive. Journal of Environmental economics and Management, v. 22, 1992. p. $164-177$. 
Otros autores ven a la equidad intergeneracional un criterio informador para buscar el desarrollo sustentable, optimizar el consumo y preservar el medio ambiente, destacando que no es lo mismo considerar la asignación eficiente del consumo propio a lo largo de la vida que considerar las posibilidades de consumo de los no nacidos. El análisis convencional habla de asignación inter temporal y obvia las fuertes implicaciones de sus prescripciones al ignora los intereses de las generaciones futuras, e incluso ignora su posible existencia. Los individuos futuros no tienen dotación alguna en el mercado actual y su bienestar depende de lo que les sea legado ${ }^{36}$. Debemos entregar a las generaciones venideras un mundo que desde la estabilidad ambiental les brinde las mismas oportunidades de desarrollo que tuvimos nosotros. Este principio tiene relación directa con la base ética del orden ambiental, la solidaridad y su paradigma ${ }^{37}$

Respetando estas consideraciones de la equidad intergeneracional al ámbito ambiental y al gasto eficiente, consideramos, por lo que es el objeto de nuestro escrito, que la visión de análisis debe centrarse fundamentalmente en la presión tributaria que se ejerza a cada generación de contribuyentes como premisa fundamental antes que analizar la efectividad o la racionalidad del propio gasto (situación que presentamos y justificamos a lo largo de todo el escrito) y hasta el momento nunca tratado a nivel doctrinal, y que forma parte integral del principio de Igualdad, valor fundamental del sistema tributario en un estado de derecho.

Si coincidimos con la idea de que el principio de igualdad no prohíbe al legislador cualquier desigualdad de trato sino sólo aquellas que resulten artificiosas o injustificadas por no venir fundadas en criterios objetivos y suficientemente razonables, y además que la relación entre la medida adoptada, el resultado que se produce y el fin pretendido por el legislador superen un juicio de proporcionalidad en sede constitucional, evitando resultados especialmente gravosos y desmedidos, es una obligación trascendental para el Estado cumplir con una planeación financiera y tributaria que cumpla generacionalmente con dichos contenidos.

Aunque la Igualdad no supone uniformidad, se vulnera cuando arbitrariamente se establecen discriminaciones entre contribuyentes respecto de los cuales no media razón objetiva de diferenciación. Así, siguiendo los criterios del Tribunal Constitucional Alemán, y coincidiendo con García Frías, "el principio de Igualdad se realiza o manifiesta grupalmente, debido a que las leyes afectan a gran número de individuos por lo que se ven abocadas a seguir criterios genéricos de tipificación al no ser posible, por razones de practicabilidad, contemplar la magnitud de casos individuales...por lo tanto, para saber si una medida es acorde con el principio de Igualdad, es necesario llevar a cabo una comparación entre distintos grupos de obligados tributarios"38.

\section{Conclusiones}

La población es un recurso que puede influir en la economía y, también, desde esta perspectiva, debe considerarse en la planeación para el desarrollo. Por sí sola no tiene un peso positivo o negativo, pero en interacción con un cierto escenario económico y con determinada dinámica social puede coadyuvar a generar condiciones favorables al desarrollo económico de una nación, el peso que deben soportar las generaciones de contribuyentes debe planearse y estructurase en función de una equitativa distribución de coste - beneficio a nivel macro, atendiendo a las posibilidades de disfrute de la población en cuanto a generalidad y no respecto de cada individuo en particular.

Por lo tanto, la planeación financiera y presupuestaria debe atender al elemento del estado que en definitiva constituye el soporte de toda política recaudatoria: la población. Más allá de de una justificación política partidista o de temores respecto de la implementación de una planeación financiera que trascienda

36 PADILLA ROSA, E. Equidad intergeneracional y sostenibilidad: las generaciones futuras en la evaluación de políticas y proyectos. Barcelona: Universitad Autónoma de Barcelona, 2001. p. 21-22.

37 TRIGO REPRESAS, F. A.; LÓPEZ MESA, M. J. Tratado de la responsabilidad Civil. Buenos Aires: La Ley, 2004. v. 3. p. 546.

38 GARCÍA FRÍAS, A. Influencia de la jurisprudencia del Tribunal Constitucional Alemán en el IRPF. Cuadernos Jurídicos, n. 44, 1996. p. 36. 
a más de un gobernante de turno, lo cual se puede solucionar con un adecuado y consensuado sistema de adopción y control de medidas implementadas al efecto ${ }^{39}$, resulta lógico que la igualdad, principio rector de cualquier Estado de Derecho, deba también aplicarse a la planeación financiera en tanto que el peso de los impuestos y las cargas públicas resulten equitativos, atendiendo a la presión tributaria empleada en el tiempo a la población (renovación generacional de ciudadanos - contribuyentes).

¿Porque se debe considerar al principio de igualdad sólo, o exclusivamente, en el marco de un ejercicio fiscal o del devengo efectivo de un impuesto? ¿Porque la carga de una obra pública, distinta de la contribución de mejoras (cuyo beneficio está individualizado), recae en los contribuyentes vigentes durante el desarrollo de la misma (en cualquier forma de pago de la obra) sin atender a la potencialidad de goce general de futuras generaciones poblacionales? ¿Acaso no son las generaciones futuras también acreedoras de tales beneficios? ¿No debería el principio de Igualdad en su matiz intergeneracional guiar la planeación financiera de esos actos en función del goce potencial de las distintas generaciones de ciudadanos? No parece justo recargar sobre la población actual el costo, por ejemplo, de una obra que va a favorecer contribuyentes futuros tanto o más que los presentes.

El trato dispensado al sector poblacional considerado contribuyente activo en la actualidad es injusto y quiebra el principio de igualdad al tratar desigual a iguales sin criterios objetivos y razonables para el ejercicio de la presión tributaria aplicada intergeneracionalmente de manera arbitraria, debido a que los beneficios (entendidos como posibilidad de disfrute poblacional general y no particularizado a caso concreto) que producen determinadas inversiones públicas ${ }^{40}$ no son discrecionales para unos y para otros. La capacidad económica y el beneficio entendido como oportunidad de goce general, debe calcularse también intergeneracionalmente.

\section{REFERÊNCIAS}

ABBAMONTE, G. Principi di diritto finanziario. Napoli: Liguori, 1974.

AICEGA ZUBILLAGA, J. M.: La utilización extrafiscal del tributo y los principios de justicia tributaria. Bilbao: Vasco, 2001.

BIELSA, R. Estudios de derecho público: derecho fiscal. Buenos Aires: Depalma, 1951.

CASÁS, J. O. Presión fiscal e inconstitucionalidade: las garantías constitucionales ante la presión del conjunto de tributos que recaen sobre el sujeto contribuyente. Buenos Aires: Depalma, 1992.

GARCÍA FRÍAS, A. Influencia de la jurisprudencia del Tribunal Constitucional Alemán en el IRPF. Cuadernos Jurídicos, n. 44, 1996.

GARCÍA ETCHEGOYEN, M. F. El principio de capacidad contributiva: estudio en Italia, España y Argentina. Tesis (Doctoral)-Universidad de Salamanca, Salamanca, 2002.

GARCÍA ETCHEGOYEN, M. F. El principio de capacidad contributiva: evolución dogmática y proyección en el Derecho Argentino. Buenos Aires: Abaco, 2004.

GONZÁLEZ GARCÍA, E. Serie de conferencias en derecho tributario. Buenos Aires: Asociación Argentina de Estudios Fiscales, 1994.

GRIZIOTTI, B. Il principio di la capacitá contributiva e le sue aplicażioni: Saggi sul rinnovamento dello studio della scienza delle finanze e del diritto finanziario. Milán: Giuffré, 1953.

39 La inexistencia de técnicas presupuestarias o financieras para calcular o atender a este principio rector no lo invalida, sino que manifiesta una exigencia, de imperiosa necesidad, en el desarrollo y tratamientos de las mismas.

40 Cuyas características escapan de la finalidad de este escrito pero que necesariamente deben fijarse en un ámbito de consenso y gestión política - administrativa para la toma de decisiones. 
HULTKRANTZ, L. Forestry and the bequest motive. Journal of Environmental economics and Management, v. 22, 1992.

LASÁRTE ÁLVAREZ, J. Los principios de justicia tributaria según la jurisprudencia constitucional: jurisprudencia del tribunal constitucional en materia financiera y tributaria (1981 - 1989): sentencias, autos y comentários. Madrid: Tecnos, 1990.

LEJEUNE VALCÁRCEL, E. Aproximación al principio constitucional de igualdad tributaria. En: Seis estudios sobre derecho constitucional e internacional tributário. Madrid: Derechos Reunidas, 1980.

LEIBHOLZ, G. Die gleichheit vor dem geset:. Eine studie auf rechtesvergleichender und rechtsplbilosophicher grundlage. Zweite, durch eine reihe erganzerder beitrage erweiterte auflage. Munchen: Verlag C. H. Beck, 1959.

LINARES, J. F. Razonabilidad de las leyes: el debido proceso como garantía innominada en la Constitución Argentina. 2. ed. Buenos Aires: Astrea, 2002.

LUQUI, J. C. La obligación tributaria. Buenos Aires: Depalma, 1989.

MIAJA FOL, M. El gasto público. En: VEGA, Santiago Fuentes (Coord.). El gasto público: ejecución y control. 2. ed. Madrid: Instituto de Estudios Fiscales, 1999.

OFFE, C. Contradicciones en el Estado de Bienestar. Madrid: Alianza Universitaria, 1990.

PADILLA ROSA, E. Equidad intergeneracional y sostenibilidad: las generaciones futuras en la evaluación de políticas y proyectos. Barcelona: Universitad Autónoma de Barcelona, 2001.

PÉREZ DE AYALA, J. L. Las cargas públicas: principios para su distribución, HPE n. 59, 1979.

PÉREZ DE AYALA, J. L. Los principios de justicia en el impuesto en la constitución española. En: Fiscalidady Constitución: consejo superior de cámaras de comercio, industria y navegación. Madrid, 1986.

REZZOAGLI, B. A. y ALURRALDE, A. M.: Manual de finanzas públicas, fondo editorial Morevallado, México, 2008.

SPISSO, R. Derecho constitucional tributário. 2. ed. Buenos Aires: Depalma, 2000.

TRIGO REPRESAS, F. A.; LÓPEZ MESA, M. J. Tratado de la responsabilidad Civil. Buenos Aires: La Ley, 2004. v. 3.

YÁÑEZ, J. Principios a considerar en la descentralización de las finanzas públicas (locales). Revista Estudios Públicos, Santiago de Chile, n. 45, 1992. 


\title{
Crédito tributário: garantias, privilégios e preferências
}

\author{
Tax credit: guarantees, privileges and \\ preferences*
}

Luís Carlos Martins Alves Júnior**

\section{Resumo}

Neste texto será feita uma abordagem do instituto normativo do crédito tributário, especialmente no tocante às suas garantias, privilégios e preferências. Nesta análise serão visitados preceitos contidos no Código Tributário Nacional (Lei n. 5.172, de 25.10.1966), além de apreciadas algumas decisões judiciais do Superior Tribunal de Justiça e do Supremo Tribunal Federal. O texto analisa institutos normativos relevantes para a adequada compreensão do crédito tributário, como a obrigação tributária, o fato gerador e o lançamento tributário. Na construção deste texto, além dos dispositivos legais, evocou-se o magistério tributário da doutrina brasileira, bem como se ventilou acerca dos aspectos socialmente maléficos do tradicional hábito de não cumprimento das leis, sejam fiscais ou não, que vicejam em solo brasileiro.

Palavras-chave: Direito tributário. Código Tributário Nacional. Crédito tributário. Precedentes judiciais. Magistério doutrinário.

\section{Abstract}

This paper will be a normative approach of the institute tax liability, especially as regard its enforcement, privileges and preferences. This analysis Will be visitede precepts contained in the Brazilian Tax Code (Law n. 5,172, of 10.25.1966), and enjoyed some judgments of the Brazilian Superior Court and the Brazilian Supreme Court. This paper analyzes regulatory institutes relevant to a proper understanding of the tax, as the tax liability, the taxable event, the tax assessment. In the construtcion of this paper, in addition of the legal provisions, raised up the teaching of the doctrine Brazilian tax as well as fanned about socially harmful aspects of the traditional habito $\mathrm{f}$ not complyng with the laws, wheter or not tax, which grow up on Brazilian soil.

Keyords: Tax law. Brazilian Tax Code. Tax liability. Judicial precedente. Doctrinal magisterium.

* Recebido em 25/04/2013 Aprovado em 13/08/2013

** Doutor em Direito pela UFMG. Procurador da Fazenda Nacional. Professor do Programa de Mestrado e Doutorado em Direito do UNICEUB. Email: lcmartinsalves@gmail.com

\section{INTRODUÇÃo}

O presente texto analisa os institutos normativos das garantias, dos privilégios e das preferências do crédito tributário. Nesta análise, além dos aludidos institu- 
tos, serão visitadas figuras normativas que gravitam ao redor do crédito tributário, como sucede com a obrigação tributária, com o seu fato gerador, com o lançamento tributário e com a dinâmica da própria administração tributária.

A justificativa do tema decorre da relevância do instituto do crédito tributário para a dinâmica fiscal e econômica brasileira, pois esse instituto normativo consiste na autorização para as administrações fazendárias cobrarem, ou dos contribuintes, ou dos responsáveis, os tributos moral e legalmente devidos.

A finalidade da análise consiste em apresentar, tanto nos aspectos estáticos (textos normativos), quanto nos dinâmicos (decisões judiciais), bem como nos acadêmicos (magistério doutrinário), a situação real do crédito tributário no Brasil, enfocando os seus principais ângulos. O trabalho pretende revelar algumas facetas do crédito tributário.

\section{O tributo, A LeI E A DEMOCRACIA ${ }^{1}$}

Onde se ergue o poder do Estado se projeta a sombra do poder de tributar, na clássica passagem de Aliomar Baleeiro. ${ }^{2}$ Conquanto seja o poder de tributar uma decorrência do poder do Estado, imensas são as dificuldades que os Fiscos, federal, estaduais ou municipais, sofrem na cobrança dos seus créditos. ${ }^{3}$ Ocorre que o crédito tributário, apesar de todas as suas garantias e privilégios legais, ${ }^{4}$ sofre do mesmo mal que acomete o crédito em geral neste País: a dificuldade em ser recuperado. ${ }^{5}$

Neste complexo Brasil, as leis, os contratos, as sentenças ou os decretos não são "levados muito a sério",

1 Na clássica obra "O Mercador de Veneza", de William Shakespeare, o mercador e cristão Antônio empenha uma libra de sua carne, como cláusula penal, na hipótese de não cumprimento do contrato que assinara e se comprometera junto ao judeu Shylock. O contrato é assinado em Veneza, onde deverá ser executada a aludida cláusula penal, tendo em vista o descumprimento da promessa contratual avençada. O próprio Antônio, às vésperas da execução da citada cláusula penal, compreendia que o Doge (chefe político) da República de Veneza não poderia deixar de atender à reivindicação do judeu Shylock e deveria permitir o integral cumprimento do contrato. É que, se acaso o Doge não garantisse a fiel execução do contrato e de sua respectiva cláusula penal, a justiça do Estado ficaria comprometida e Veneza deixaria de ser um local seguro para os negócios, uma vez que os contratos não seriam mais protegidos pelas leis nem pelos juízes. Nessa peça teatral, em Veneza, contrato assinado era contrato cumprido. Todos sabem o resultado do julgamento acerca do cumprimento dessa mencionada "cláusula penal": se o judeu exercesse o seu direito de execução sofreria pena de morte, pois, segundo as leis venezianas, estava impedido de derramar uma gota de sangue cristão. Pois bem, se na Veneza shakespeariana o crédito era sagrado, em nosso País ele é profano. SHAKESPEARE, William. O mercador de Veneza: 1596. São Paulo: Martins Fontes, 2006.

2 BALEEIRO, Aliomar. Limitações constitucionais ao poder de limitar. 7. ed. Atualizada por Misabel Abreu Machado Derzi. Rio de Janeiro: Forense, 2005.

3 A imagem histórica dos "cobradores de impostos" não é das mais atrativas. Esse aludido caráter profano do crédito tributário se torna mais evidente a partir das Sagradas Escrituras, pois os "publicanos - cobradores de impostos" estavam, segundo os padrões religiosos da época da anunciação evangélica, no rol dos grandes pecadores. BÍBLIA Sagrada. Novo Testamento. Mateus, capítulo 21, versículo 31; Lucas, capítulo 19, versículos 1-9.

4 BRASIL. Lei n. 5.172, de 25.10.1966. Código Tributário Nacional, Capítulo VI - Garantias e Privilégios do Crédito Tributário, arts. 183 a 193. Local: Editora, ano.

5 Com efeito, o IPEA - Instituto de Pesquisa Econômica e Aplicada -, em pesquisa realizada entre novembro de 2009 e fevereiro de 2011, divulgada em janeiro de 2012, revelou que somente 2,8\% das execuções fiscais federais resultam em algum leilão judicial, com ou sem êxito. Do total de processos, em apenas $0,3 \%$ dos casos o pregão gera recursos suficientes para satisfazer integralmente o débito, enquanto que a adjudicação dos bens do executado extingue a dívida em $0,4 \%$ dos casos. $\mathrm{Na}$ aludida pesquisa, o IPEA, por meio de entrevistas junto aos órgãos do Judiciário, percebeu a pouca efetividade dos leilões, dada a sua burocrática complexidade, de modo que muitas das varas federais implantadas nos últimos cinco anos anteriores a essa pesquisa jamais realizaram qualquer pregão. O IPEA revelou que, em decorrência das execuções fiscais, 25,8\% implicam no pagamento integral da dívida; em 36,8\% ocorrem a extinção pelo reconhecimento de decadência ou de prescrição; $18,8 \%$ decorrem do cancelamento da inscrição do débito e 13\% de sua remissão. Segundo o IPEA, em regra, as execuções fiscais ou fracassam absolutamente, ou recuperam integralmente o débito. O IPEA revelou que a taxa de êxito do executado, via embargos ou exceção de pré-executividade, chega a 22,5\%. Daí porque o IPEA ter indicado que não vale a pena, no aspecto estritamente econômico, ajuizar execuções fiscais abaixo de $\mathrm{R} \$ 20.000,00$. Todavia, continuou o IPEA, essa implantação de novo piso deveria vir acompanhada de implementação de medidas de redução do risco moral (moral hą̧ard) associado ao não pagamento de tributos. BRASIL. Instituto de Pesquisa Econômica e Aplicada. Custo e tempo do processo de execução fiscal promovido pela Procuradoria Geral da Fazenda Nacional (PGFN). Comunicados do IPEA, Brasília, n. 127, 2012. Disponível em: <www.ipea.gov.br>. Acesso em: 
tampouco se pode falar em um "império do direito". ${ }^{6}$ Neste gigantesco País, é difícil o respeito às leis, ${ }^{7}$ visto que não são poucos os refratários ao cumprimento de suas obrigações e deveres. ${ }^{8}$ É traço atávico dos brasileiros.

Essa lamentável tradição brasileira de não cumprimento das leis e de costumeiro desrespeito ao Direito deita suas raízes no período colonial. A partir daquele cenário social e político, deixar de recolher os tributos à Coroa lusitana significava um ato de desobediência civil e de insubmissão ao poderio português. Assim, enquanto o Brasil esteve sob o domínio de Portugal, o não pagamento de impostos poderia ter sentido "político". ${ }^{10} \mathrm{Na}$ longa experiência brasileira, o Estado tem sido maior e mais importante que a sociedade. ${ }^{11}$

Nada obstante, cuide-se que houve momentos em nossa história que o não pagamento de tributos poderia ser justificado como ato legítimo em oposição a um Estado ilegítimo, a partir de 5 de outubro de 1988, com o pleno restabelecimento das franquias democráticas e com a consolidação do Estado de Direito, esse tipo de postura passou a ser moralmente inaceitável e juridicamente inadmissível. Com efeito, desde a promulgação da vigente e reinante Constituição da República, a nenhuma pessoa natural ou jurídica é dado o direito moral e legítimo de não pagar os tributos, salvo se obtiver expressa autorização judicial, legislativa ou administrativa. ${ }^{12}$

Ninguém tem o direito de não pagar as próprias dívidas fiscais. Ninguém tem o direito de não honrar com os próprios compromissos tributários. É um dever cívico o pagamento dos débitos. É obrigação republicana cobrar dos devedores. É um truísmo, mas, no Estado Democrático de Direito, todo aquele que não cumpre com o dever de cooperação social, dentro de suas capacidades e possibilidades, sobrecarrega os demais. ${ }^{13}$ Assim, sempre que algum contribuinte, seja pessoa natural ou jurídica, deixar de pagar os tributos legalmente devidos, ele sobrecarregará com ônus excessivo os que estão honrando com os compromissos e deveres fiscais. ${ }^{14}$

Nos regimes políticos democráticos, ninguém tem o direito - jurídico ou moral - de não pagar os tributos devidos, salvo nas situações excepcionais e explicitamente reconhecidas pelo próprio Estado (legislador, administrador ou julgador). ${ }^{15}$ E por que no Estado Democrático de Direito o não pagamento de tributos não pode ser visto como ato legítimo de desobediência civil? A resposta consiste no fato de que a desobediência civil pressupõe que os legítimos canais de manifestação das insatisfações estejam obstruídos. ${ }^{16}$ Nas

6 "Império do Direito" e "Levando os Direitos a sério", como todos sabem, são algumas expressões que se tornaram famosas graças ao magistério doutrinário de Ronald Dworkin, um dos maiores jusfilósofos de todos os tempos, recentemente falecido (14.2.2013), autor de importantes livros: The Philosofal os Law, Taking Rights Seriously, Law's Empire, A Matter of Principle, Life's Dominion, Sovereign Virtue, Is Democracy Possible Here?, Freedom's Law, Justice in Robes, A Badly Flawed Election: Debating Bush v. Gore, The Supreme Court Phalanx, Justice for Hedgebogs e Reason and Imagination: The Selected Correspondence of Learned Hand. Quase todos esses livros estão disponíveis em traduções para o português.

7 Essa combinação é explosiva: falta de ética das pessoas aliada à falta de responsabilidade dos agentes estatais. Eis uma das causas de nossos problemas de convivência social e de desobediência aos mandamentos normativos que devem regular a vida coletiva de modo civilizado e humanizado. "Ou restaura-se a moralidade, ou locupletemo-nos todos". Frase de Stanislaw Ponte Preta, pseudônimo de Sérgio Porto. PRETA, Stanislaw Ponte. O melhor de Stanislaw Ponte Preta. São Paulo: José Olympio, 2011.

8 E essa tradição de desobediência não se restringe apenas ao campo fiscal. Tomemos, à guisa de exemplo, o que sucede em relação às regras de trânsito, especialmente nas grandes cidades brasileiras. Infelizmente nas nossas metrópoles, onde deveria reinar a urbana civilidade, vivenciamos verdadeira selvageria e irracionalidade caótica no trânsito, pois não são poucos os que desrespeitam os mais comezinhos padrões de convivência. A razão dessa situação caótica não está na ausência de leis ou regulamentos, mas de educação cívica das pessoas e de incompetência dos poderes estatais. Ou a lei deve valer para todos, ou não vale para ninguém. No Brasil, infelizmente, para poucos, especialmente para os poderosos, as leis somente servem se lhes forem convenientes. Ora a civilidade de um povo se mede também pelo respeito e obediência às leis e às instituições.

9 HOLANDA, Sérgio Buarque de. Raízes do Brasil. 26. ed. São Paulo: Companhia das Letras, 1995.

10 Tenha-se que com a chegada da familia real portuguesa, instalando no Brasil a sede do império lusitano, tem início uma nova fase na tributação brasileira. Todavia, foi mantido o eixo de pesada carga fiscal, decorrência de um culto exagerado que se presta ao Estado, como assinala Arnaldo Godoy. GODOY, Arnaldo Sampaio de Moraes. História da tributação no período joanino: 1808-1821. Brasília: ESAF, 2008. p. 147.

11 FAORO, Raymundo. Os donos do poder: formação do patronato brasileiro. 7. ed. Rio de Janeiro: Globo, 2001. p. 163-275.

12 Eis a imensa responsabilidade ética dos procuradores fiscais. Com esteio no postulado republicano e em homenagem ao princípio da igualdade de todos perante a lei, os procuradores fiscais têm o dever jurídico e moral de cobrar todos os tributos que estejam sob sua responsabilidade.

13 RAWLS, John. Uma teoria da justiça. Trad. Almiro Piseta e Lenita Esteves. São Paulo: Martins Fontes, 2000.

14 TIPKE, Klaus. Moral tributária do Estado e dos contribuintes. Trad. Luiz Dória Furquim. Porto Alegre: Sergio Antonio Fabriz, 2012.

15 NABAIS, José Casalta. O dever fundamental de pagar impostos: contributo para a compreensão constitucional do estado fiscal contemporâneo. Coimbra: Almedina, 1998.

16 COSTA, Nelson Nery. Teoria e realidade da desobediência civil. Rio de Janeiro: Forense, 1990. 
democracias, insatisfeitos, incomodados e injustiçados podem mudar a situação dentro de procedimentos legítimos e pacíficos, usando dos instrumentos jurídicos e políticos disponíveis. ${ }^{17}$

Nas democracias, é possível, dentro da lei, mudar o sistema social e político. É possível mudar a própria lei. ${ }^{18}$ Nos regimes políticos democráticos, plurais e abertos, como tem sido o brasileiro desde 1988, é possível disputar e ganhar eleições, sejam os partidos da situação, sejam os de oposição. Nas sociedades abertas e democráticas, é possível conquistar as mentes e os corações das pessoas por meio do diálogo, da palavra, do convencimento, da razão e da verdade. ${ }^{19}$

$\mathrm{Na}$ democracia, o indivíduo, ser humano e humanizado, deve ter vez, voz e voto. ${ }^{20}$ No regime de liberdades democráticas, a divergência de opiniões e o dissenso ideológico devem ser seriamente considerados e efetivamente respeitados. As maiorias dominantes não têm o direito de extinguir as minorias. ${ }^{21}$ Nessa perspectiva, nos regimes democráticos nos quais deve reinar o Estado de Direito, não pagar os tributos devidos viola o pacto social fundante da coletividade. É indecente furtar-se, sem justo e válido título, ao cumprimento dos deveres cívicos e das obrigações tributárias.

Nas democracias legítimas e nas repúblicas decentes, as leis devem ser respeitadas e obedecidas por todos: sejam governantes poderosos ou humildes cidadãos, sejam ricos ou pobres, homens ou mulheres, brancos ou negros, crentes ou ateus. Ou seja, nos regimes democráticos e republicanos, todos, independentemente de suas características, devem pautar suas ações e seus comportamentos em conformidade com o direito e com a justiça. Ninguém deve estar acima das leis.

No Brasil republicano e democrático, os tributos devidos, legalmente válidos e moralmente justos, devem ser cobrados. Não sem razão que o recepcionado Código Tributário Nacional, ${ }^{22} \mathrm{em}$ seu artigo $3^{\circ}$, dispõe que a atividade administrativa fiscal é plenamente vinculada, ou seja, não depende da vontade, da discricionariedade ou dos caprichos da autoridade fiscal à cobrança de tributos. É um imperativo legal e moral. Tributo devido é tributo que se deve cobrar/pagar.

Mas qual tributo se deve pagar? Como se sabe que se deve pagar um tributo? Quem deve pagar o tributo? Quanto se deve pagar? Quem pode cobrar esse tributo devido? As respostas a essas indagações necessitam que visitemos o sentido jurídico e o alcance normativo de "obrigação tributária", ${ }^{23}$ de "crédito tributário" 24 e da própria dinâmica da "administração tributária". ${ }^{25}$ Após essas visitas, surpreenderemos o tema específico desta intervenção: as garantias e os privilégios do crédito tributário. ${ }^{26}$

\section{A ObRIGAÇÃo E O CRÉDItO tRIBUTÁRIO}

O crédito tributário é o direito que possui a Fazenda Pública, após o lançamento válido, de exigir o pagamento de determinado tributo. Nos termos do art. 142, CTN, a constituição do crédito tributário pressupõe o lançamento, que vem a ser:

[...] o procedimento administrativo tendente a verificar a ocorrência do fato gerador da obrigação correspondente,

17 HABERMAS, Jürgen. Jürgen. Direito e democracia: entre facticidade e validade. Trad. Flávio Beno Siebeneichler. Rio de Janeiro: Tempo Brasileiro, 2003.

18 BOBBIO, Norberto. O futuro da democracia. Trad. Marco Aurélio Nogueira. São Paulo: Paz e Terra, 2000.

19 POPPER, Karl. A sociedade aberta e seus inimigos. Trad. Milton Amado. São Paulo: Itatiaia, 1987.

20 MAGALHÃES, José Luiz Quadros de. Poder municipal: paradigmas para o estado constitucional brasileiro. Belo Horizonte: Del Rey, 1997.

21 KELSEN, Hans. A democracia. Trad. Ivone Castilho Benedeti e outros. São Paulo: Martins Fontes, 1993.

22 CTN, Art. $3^{\circ}$. Tributo é toda prestação pecuniária compulsória, em moeda ou cujo valor nela se possa exprimir, que não constitua sanção de ato ilícito, instituída em lei e cobrada mediante atividade administrativa plenamente vinculada.

23 CTN, Arts. 113 a 138.

24 CTN, Arts. 139 a 193.

25 CTN, Arts. 194 a 208.

26 CTN, Arts. 183 a 193. 
determinar a matéria tributável, calcular o montante do tributo devido, identificar o sujeito passivo e, sendo o caso, propor a aplicação da penalidade cabível.

Por expressa determinação legal, “[...] a atividade de lançamento é vinculada e obrigatória, sob pena de responsabilidade funcional”. (CTN, art. 142, parágrafo único).

Veja-se que a lei determina que somente o lançamento dá à Fazenda Pública o direito de cobrar o crédito tributário. Isso não significa que somente se houver o lançamento é que surge o dever de pagar o tributo. Com efeito, a cobrança do crédito tributário requer o prévio lançamento; mas é possível que o sujeito passivo da obrigação tributária pague a dívida fiscal antes de ocorrido o lançamento administrativo, pela simples existência do fato gerador, como preceitua o art. 150, caput e $\int 1^{\circ}$, do CTN.

Nos artigos 113 e 114, do mesmo código, estão enunciados os sentidos normativos de "obrigação tributária" e de "fato gerador". Esses temas foram objeto de considerações dos maiores nomes do direito tributário nacional, tendo em vista as confusões terminológicas e normativas decorrentes de sua inadequada compreensão e aplicação. Eis alguns desses geniais tributaristas: Aliomar Baleeiro, ${ }^{27}$ Rubens Gomes de Sousa, ${ }^{28}$ Amílcar de Araújo Falcão, ${ }^{29}$ Souto Maior Borges, ${ }^{30}$ Alfredo Augusto Becker, ${ }^{31}$ Geraldo Ataliba, ${ }^{32}$ Paulo de Barros Carvalho, ${ }^{33}$ Sacha Calmon, ${ }^{34}$ e Misabel Derzi, ${ }^{35}$ dentre outros destacados nomes da justributarística brasileira.

Nada obstante as eventuais disceptações doutrinárias, esses termos encontram-se consagrados normativamente, inclusive com reconhecimento constitucional, como se vê nos dispositivos relativos aos tributos e às contribuições sociais (CF, arts. 145 a 156; e art. 195, itens). O "fato gerador" dá ensejo à "obrigação tributária" e ao seu consequente "crédito tributário"; mas, insista-se, somente com o "lançamento tributário" surge o direito de a Fazenda Pública cobrar o tributo devido.

Quanto ao fato gerador da obrigação tributária, há o enunciado contido no parágrafo único do art. 116, CTN, acrescentado pela Lei Complementar n. 104/2001, que preceitua:

[...] a autoridade administrativa poderá desconsiderar atos ou negócios jurídicos praticados com a finalidade de dissimular a ocorrência do fato gerador do tributo ou a natureza dos elementos constitutivos da obrigação tributária, observados os procedimentos a serem estabelecidos em lei ordinária. ${ }^{3637}$

O aludido preceito normativo foi atacado via Ação Direta de Inconstitucionalidade (ADI) n. 2.446, proposta perante o Supremo Tribunal Federal (STF), pela Confederação Nacional da Indústria (CNI). ${ }^{38}$ O Tribunal ainda não se pronunciou sobre a validade jurídica do objurgado dispositivo normativo. Esse julgamento é de vital importância para as administrações tributárias, pois se trata de um mandamento de moralidade jurídica.

Com efeito, é postulado universal do direito dos povos civilizados que ninguém pode se beneficiar da própria torpeza. Em matéria tributária, devem ser draconianas as consequências normativas e administrativas para todos que visem fraudar a verdade fiscal. ${ }^{39} \mathrm{~A}$ citada determinação legal consiste nisto: permitir que a fiscalização tributária não considere atos fraudulentos ou que visem, de modo aparentemente legal, adulterar a legitimidade da

27 BALEEIRO, Aliomar. Direito tributário brasileiro. 11. ed. Atualizado por Misabel Derzi. Rio de Janeiro: Forense, 2005.

28 SOUSA, Rubens Gomes. Compêndio de legislação tributária. São Paulo: Resenha Tributária, 1975.

29 FALCÃO, Amílcar de Araújo. O fato gerador da obrigação tributária. São Paulo: RT, 1973.

30 BORGES, José Souto Maior. Lançamento tributário. 2. ed. São Paulo: Malheiros, 1999.

31 BECKER, Alfredo Augusto. Teoria geral do direito tributário. 3. ed. São Paulo: Lejus, 1998.

32 ATALIBA, Geraldo. Hipótese de incidência tributária. 5. ed. São Paulo: Malheiros, 1992.

33 CARVALHO, Paulo de Barros. Dreito tributário: fundamentos jurídicos da incidência. 7. ed. São Paulo: Saraiva, 2009.

34 CALMON, Sacha. Teoria geral do tributo e da exoneração tributária. São Paulo: RT, 1982.

35 DERZI, Misabel. Direito tributário, direito penal e tipo. 2.ed. São Paulo: RT, 2007.

36 ROLIM, João Dácio. Normas antielisivas tributárias. São Paulo: Dialética, 2001.

37 PEREIRA, Cesar A. Guimarães. Elisão tributária e função administrativa. São Paulo: Dialética, 2001.

38 BRASIL. Supremo Tribunal Federal. Ação direta de inconstitucionalidade n. 2.446. Requerente: Confederação Nacional da Indústria. Requeridos: Presidente da República e Congresso Nacional. Relatora originária: Ministra Ellen Gracie. Relatora redistribuída: Ministra Cármen Lúcia. Local, 2001.

39 GODOI, Marciano Seabra de. Fraude a la ley y conflicto em la aplicación de las leyes tributarias. Madrid: Instituto de Estudios Fiscales, 2005. 
tributação. Para a adequada solução desse problema normativo, o STF deverá investigar as circunstâncias fáticas que deram ensejo a esse questionado preceito normativo, bem como perspectivar a finalidade desse mandamento jurídico em sintonia com os dispositivos constitucionais e com os valores protegidos pelo sistema jurídico. ${ }^{40} 41$

De efeito, o STF e todos os demais órgãos judiciários brasileiros, sejam singulares, sejam colegiados, devem sempre pautar as decisões com esteio no ordenamento jurídico e nas práticas normativas válidas e intersubjetivamente aceitáveis. As decisões judiciais em matéria tributária devem ser em absoluta conformidade com o ordenamento jurídico, pois não é dado à autoridade judicial, no exercício de sua competência, desconsiderar os preceitos normativos. ${ }^{42}$

A fidelidade aos mandamentos jurídicos extraídos direta ou indiretamente da Constituição, das leis, dos tratados e dos demais provimentos normativos é a principal garantia decorrente do princípio da segurança jurídica. ${ }^{43} 45$ Eis a razão de o sistema tributário nacional ser tão extensivo e, ante esse caráter amiúde analítico, tornar-se tão complexo e problemático, pois além de um feixe de preceitos tributários contidos na Constituição, tem-se invencível legislação federal, estadual, distrital e municipal regulando o fenômeno tributário. ${ }^{46}$

Volta-se à obrigação e ao crédito tributário. No CTN, art. 119, está disposto que o sujeito ativo da obrigação tributária é a pessoa jurídica de direito público, titular da competência para exigir o seu cumprimento. A pessoa obrigada ao pagamento de tributo ou penalidade pecuniária é o sujeito passivo da obrigação. Esse sujeito passivo pode ser o próprio contribuinte ou o responsável tributário (CTN, arts. 121 e 122).

No art. 123 do CTN há relevante garantia fiscal, uma vez que preceitua que as convenções particulares não podem ser opostas à Fazenda Pública para modificar a definição legal do sujeito passivo das respectivas obrigações tributárias, salvo exceção legal específica. Ainda no plano da normatização da sujeição passiva, os arts. 124 a 127 disciplinam os institutos da solidariedade, da capacidade e do domicílio tributário, quase sempre em sentido favorável ao cumprimento dos deveres fiscais dos contribuintes ou responsáveis. Cuidese que, no tocante à solidariedade tributária, por exemplo, não há que se falar em benefício de ordem, de modo que o Fisco pode escolher entre os sujeitos passivos os mais adequados para a solvência do crédito.

Também não podem ser opostas ao Fisco as eventuais irregularidades, informalidades ou incapacidades dos sujeitos passivos, como forma de escapar do cumprimento das obrigações tributárias. No concernente ao domicílio tributário do sujeito passivo, como garantia ao crédito, a legislação permite à autoridade administrativa que recuse o domicílio eleito, quando impossibilite ou dificulte a arrecadação ou a fiscalização do tributo (art. 127, $\int 2^{\circ}$ do CTN).

$\mathrm{Na}$ Constituição Federal, art. $150, \sqrt{ } 7^{\circ}$, foi dado reforço normativo ao instituto da responsabilidade tributária, quando dispôs que :

[...] a lei poderá atribuir a sujeito passivo de obrigação tributária a condição de responsável pelo pagamento de imposto ou contribuição, cujo fato gerador deva ocorrer posteriormente, assegurada a imediata e preferencial restituição da quantia paga, caso não se realize o fato gerador presumido.

No CTN, a responsabilidade tributária está regulada no capítulo V, arts. 128 a 138. O tema acerca da validade e da conveniência da técnica fiscal da substituição tributária, corolário da responsabilidade tributária, tem sido objeto de vários questionamentos judiciais, inclusive com manifestações do Supremo Tribunal Federal.

40 TORRES, Ricardo Lobo. Normas de interpretação e integração do direito tributário. 4. ed. Rio de Janeiro: Renovar, 2006.

41 ANDRADE, José Maria Arruda de. Interpretação da norma tributária. São Paulo: MP, 2006.

42 GAMA, Tácio Lacerda. Competência tributária: fundamentos para uma teoria da nulidade. São Paulo: Noeses, 2009.

43 ÁVILA, Humberto. Segurança jurídica: entre permanência, mudança e realização no direito tributário. São Paulo: Malheiros, 2011.

44 TORRES, Heleno Taveira. Direito constitucional tributário e segurança jurídica. São Paulo: RT, 2011.

45 ANDRADE, Fábio Martins de. Modulação em matéria tributária: o argumento pragmático ou consequencialista de cunbo econômico e as decisões do STF. São Paulo: Quartier Latin, 2011.

46 CARrAZA, Roque Antônio. Curso de direito constitucional tributário. 25. ed. São Paulo: Malheiros, 2009. 
O Tribunal iniciou o julgamento das ADIs n. $2.675^{47}$ e n. 2.777, ${ }^{48} \mathrm{em} 26$ de novembro de 2003, havendo até o presente momento 10 votos prolatados, com cinco pela procedência e cinco pela improcedência.

No aludido julgamento, faltava colher o voto do ministro Ayres Britto; mas, em face de sua aposentadoria, é de se aguardar a posse de novo ministro para que essas ADIs sejam finalmente decididas. Nada obstante, o Tribunal reconheceu a repercussão geral de questões relativas à substituição tributária nos autos dos RREE $596.832,{ }^{49} 593.849^{50}$ e $598.677 . .^{51}$

Esse tema não é novo para o STF. No julgamento da ADI n. 1.851, ${ }^{52}$ o Tribunal chancelou a técnica segundo a qual o "fato gerador presumido" é válido e que a sua devolução preferencial ocorre na hipótese de não realização. O Tribunal decidirá, nos aludidos feitos, se, na hipótese de base de cálculo inferior à presumida, é lícito ao contribuinte a restituição proporcional.

Não há expressa vedação constitucional a essa possibilidade, cabendo ao legislador fiscal a conveniência desse tipo de medida. O Tribunal deve fazer juízo de "legalidade jurídica", em vez de juízo de "conveniên-

47 BRASIL. Supremo Tribunal Federal. Supremo Tribunal Federal. Ação direta de inconstitucionalidade n. 2.675. Requerente: Governador do Estado de Pernambuco. Requerida: Assembléia Legislativa do Estado de Pernambuco. Relator originário: Ministro Carlos Velloso. Relator: redistribuído: Ministro Ricardo Lewandowski. Local, 2002.

48 BRASIL. Supremo Tribunal Federal. Ação direta de inconstitucionalidade n. 2.777. Relatoria originária Ministro Sydney Sanches. Relatoria redistribuída Ministro Teori Zavascki. Requerente: Governador do Estado de São Paulo. Requerida: Assembleia Legislativa do Estado de São Paulo. Local, 2002.

49 BRASIL. Supremo Tribunal Federal. Recurso Extraordinário n. 596.832. Recorrentes: Posto de Gasolina Rei de Mesquita Ltda e outros. Recorrida: União Federal (Fazenda Nacional). Relator: Ministro Marco Aurélio. Local, 2009. Ementa do acórdão do reconhecimento da repercussão geral no RE 596.832: "PIS E COFINS - SUBSTITUIÇÃO TRIBUTÁRIA - ARTIGO 150, § 7", DA CONSTITUIÇÃO FEDERAL - RECOLHIMENTO A MAIOR - DEVOLUÇÃO - ADINS No 2.675-5/PE E 2.777-8/ SP - VOTAÇÃO EMPATADA - RECURSO EXTRAORDINÁRIO EM PROCESSO SUBJETIVO - Possui repercussão geral a controvérsia sobre o cabimento da restituição dos valores recolhidos a maior a título de PIS e COFINS quando a base de cálculo inicialmente estimada for superior à base de cálculo real, considerado o regime de substituição tributária".

50 BRASIL. Supremo Tribunal Federal. Recurso Extraordinário n. 593.849. Recorrente: Parati Petróleo Ltda. Recorrido: Estado de Minas Gerais. Relator: Ministro Ricardo Lewandowski. Local, 2008. Ementa do acórdão que reconheceu a repercussão geral: “CONSTITUCIONAL. TRIBUTÁRIO. ICMS. RESTITUIÇÃO DA DIFERENÇA DO IMPOSTO PAGO A MAIS NO REGIME DE SUBSTITUIÇÃO TRIBUTÁRIA. BASE DE CÁLCULO PRESUMIDA E BASE DE CÁLCULO REAL. ART. 150, § 7², DA CF. ADI 2.675/PE, REL. MIN. CARLOS VELLOSO E ADI 2.777/SP, REL. MIN. CEZAR PELUSO, QUE TRATAM DA MESMA MATÉRIA E CUJO JULGAMENTO JÁ FOI INICIADO PELO PLENÁRIO. EXISTÊNCIA DE REPERCUSSÃO GERAL”. 51 BRASIL. Supremo Tribunal Federal. Recurso Extraordinário n. 598.677. Recorrente: Estado do Rio Grande do Sul. Recorrida: Juliana Enderle Fontoura. Relator: Ministro Dias Toffoli. Local, 2009. Ementa do acórdão que reconheceu a repercussão geral: "EMENTA DIREITO TRIBUTÁRIO. ICMS. OPERAÇÕES INTERESTADUAIS. REGIME DE PAGAMENTO ANTECIPADO SEM SUBSTITUIÇÃO TRIBUTÁRIA. DECRETO ESTADUAL. FATO GERADOR DO TRIBUTO. COBRANÇA ANTECIPADA. EXISTÊNCIA DE REPERCUSSÃO GERAL”.

52 BRASIL. Supremo Tribunal Federal. Ação direta de inconstitucionalidade n. 1.851. Requerente: Confederação Nacional do Comércio. Requerido: Estado de Alagoas. Relator: Ministro Ilmar Galvão. Local, 1998. Ementa do acórdão: "TRIBUTÁRIO. ICMS. SUBSTITUIÇÃO TRIBUTÁRIA. CLÁUSULA SEGUNDA DO CONVÊNIO $13 / 97$ E $\int S 6^{\circ}{ }^{\circ}$ E $7 .^{\circ}$ DO ART. 498 DO DEC. N. ${ }^{\circ}$ 35.245/91 (REDAÇÃO DO ART. $1 .^{\circ}$ DO DEC. N. ${ }^{\circ}$ 37.406/98), DO ESTADO DE ALAGOAS. ALEGADA OFENSA AO $\int 7 .^{\circ}$ DO ART. 150 DA CF (REDAÇÃO DA EC 3/93) E AO DIREITO DE PETIÇÃO E DE ACESSO AO JUDICIÁRIO. Convênio que objetivou prevenir guerra fiscal resultante de eventual concessão do benefício tributário representado pela restituição do ICMS cobrado a maior quando a operação final for de valor inferior ao do fato gerador presumido. Irrelevante que não tenha sido subscrito por todos os Estados, se não se cuida de concessão de benefício (LC 24/75, art. 2. ${ }^{\circ}$, INC. 2. ${ }^{\circ}$ ). Impossibilidade de exame, nesta ação, do decreto, que tem natureza regulamentar. A EC n. ${ }^{\circ}$ 03/93, ao introduzir no art. 150 da $\mathrm{CF} / 88$ o $\int 7 .^{\circ}$, aperfeiçoou o instituto, já previsto em nosso sistema jurídico-tributário, ao delinear a figura do fato gerador presumido e ao estabelecer a garantia de reembolso preferencial e imediato do tributo pago quando não verificado o mesmo fato a final. A circunstância de ser presumido o fato gerador não constitui óbice à exigência antecipada do tributo, dado tratar-se de sistema instituído pela própria Constituição, encontrando-se regulamentado por lei complementar que, para definir-lhe a base de cálculo, se valeu de critério de estimativa que a aproxima o mais possível da realidade. A lei complementar, por igual, definiu o aspecto temporal do fato gerador presumido como sendo a saída da mercadoria do estabelecimento do contribuinte substituto, não deixando margem para cogitar-se de momento diverso, no futuro, na conformidade, aliás, do previsto no art. 114 do CTN, que tem o fato gerador da obrigação principal como a situação definida em lei como necessária e suficiente à sua ocorrência. $\mathrm{O}$ fato gerador presumido, por isso mesmo, não é provisório, mas definitivo, não dando ensejo a restituição ou complementação do imposto pago, senão, no primeiro caso, na hipótese de sua não-realização final. Admitir o contrário valeria por despojar-se o instituto das vantagens que determinaram a sua concepção e adoção, como a redução, a um só tempo, da máquina-fiscal e da evasão fiscal a dimensões mínimas, propiciando, portanto, maior comodidade, economia, eficiência e celeridade às atividades de tributação e arrecadação. Ação conhecida apenas em parte e, nessa parte, julgada improcedente". 
cia política". Quanto ao instituto em si da substituição tributária, tenha-se que o Tribunal tem mantido sua chancela a essa técnica fiscal, corolário da responsabilidade tributária, reitera-se: RREE $603.191,{ }^{53} 213.396,{ }^{54}$ $194.382^{55}$ e $266.523 .^{56}$

Além da substituição, no citado capítulo relativo à Responsabilidade Tributária, encontram-se preceitos sobre a responsabilidade dos sucessores (arts. 129 a 133 do CTN), que visam guarnecer os créditos tributários, tornando-os mais objetivos. Tenha-se que a Lei Complementar n. 118/2005 introduziu modificações e

53 BRASIL. Supremo Tribunal Federal. Recurso Extraordinário n. 603.191. Recorrente: Construtora Locatelli Ltda. Recorrida: União Federal (Fazenda Nacional). Relatora: Ministra Ellen Gracie. Local, 1999. Ementa do acórdão: "EMENTA: DIREITO TRIBUTÁRIO. SUBSTITUIÇÃO TRIBUTÁRIA. RETENÇÃO DE 11\% ART. 31 DA LEI 8.212/91, COM A REDAÇÃO DA LEI 9.711/98. CONSTITUCIONALIDADE. 1. Na substituição tributária, sempre teremos duas normas: a) a norma tributária impositiva, que estabelece a relação contributiva entre o contribuinte e o fisco; b) a norma de substituição tributária, que estabelece a relação de colaboração entre outra pessoa e o fisco, atribuindo-lhe o dever de recolher o tributo em lugar do contribuinte. 2. A validade do regime de substituição tributária depende da atenção a certos limites no que diz respeito a cada uma dessas relações jurídicas. Não se pode admitir que a substituição tributária resulte em transgressão às normas de competência tributária e ao princípio da capacidade contributiva, ofendendo os direitos do contribuinte, porquanto o contribuinte não é substituído no seu dever fundamental de pagar tributos. A par disso, há os limites à própria instituição do dever de colaboração que asseguram o terceiro substituto contra o arbítrio do legislador. A colaboração dele exigida deve guardar respeito aos princípios da razoabilidade e da proporcionalidade, não se lhe podendo impor deveres inviáveis, excessivamente onerosos, desnecessários ou ineficazes. 3. Não há qualquer impedimento a que o legislador se valha de presunções para viabilizar a substituição tributária, desde que não lhes atribua caráter absoluto. 4 . A retenção e recolhimento de $11 \%$ sobre o valor da nota fiscal é feita por conta do montante devido, não descaracterizando a contribuição sobre a folha de salários na medida em que a antecipação é em seguida compensada pelo contribuinte com os valores por ele apurados como efetivamente devidos forte na base de cálculo real. Ademais, resta assegurada a restituição de eventuais recolhimentos feitos a maior. 5. Inexistência de extrapolação da base econômica do art. 195, I, a, da Constituição, e de violação ao princípio da capacidade contributiva e à vedação do confisco, estampados nos arts. $145, \$ 1^{\circ}$, e 150 , IV, da Constituição. Prejudicados os argumentos relativos à necessidade de lei complementar, esgrimidos com base no art. 195, $\$ 4^{\circ}$, com a remissão que faz ao art. 154, I, da Constituição, porquanto não se trata de nova contribuição. 6. Recurso extraordinário a que se nega provimento. 7. Aos recursos sobrestados, que aguardavam a análise da matéria por este STF, aplica-se o art. 543-B, § $3^{\circ}$, do CPC”.

54 BRASIL. Supremo Tribunal Federal. Recurso Extraordinário n. 213.396. Recorrente: Estado de São Paulo. Recorrida: Diasa Distribuidora e Importadora de Automóveis S/A. Relator: Ministro Ilmar Galvão. Local, 1997. "TRIBUTÁRIO. ICMS. ESTADO DE SÃO PAULO. COMÉRCIO DE VEÍCULOS NOVOS. ART. 155, \2², XII, B, DA CF/88. CONVÊNIOS ICM Nº 66/88 (ART. 25) E ICMS N N $^{0}$ 107/89. ART. $8^{\circ}$, INC. XIII E $\int 4^{\circ}$, DA LEI PAULISTA N ${ }^{\circ}$ 6.374/89. O regime de substituição tributária, referente ao ICM, já se achava previsto no Decreto-Lei n ${ }^{\circ} 406 / 68$ (art. 128 do CTN e art. $6^{\circ}$, \S $3^{\circ}$ e $4^{\circ}$, do mencionado decreto-lei), normas recebidas pela Carta de 1988, não se podendo falar, nesse ponto, em omissão legislativa capaz de autorizar o exercício, pelos Estados, por meio do Convênio ICM no 66/88, da competência prevista no art. 34, \ $8^{\circ}$, do ADCT/88. Essa circunstância, entretanto, não inviabiliza o instituto que, relativamente a veículos novos, foi instituído pela Lei paulista $\mathrm{n}^{\circ} 6.374 / 89$ (dispositivos indicados) e pelo Convênio ICMS $\mathrm{n}^{\circ}$ $107 / 89$, destinado não a suprir omissão legislativa, mas a atender à exigência prevista no art. $6^{\circ}, \$ 4^{\circ}$, do referido Decreto-Lei n ${ }^{\circ} 406 / 68$, em face da diversidade de estados aos quais o referido regime foi estendido, no que concerne aos mencionados bens. A responsabilidade, como substituto, no caso, foi imposta, por lei, como medida de política fiscal, autorizada pela Constituição, não havendo que se falar em exigência tributária despida de fato gerador. Acórdão que se afastou desse entendimento. Recurso conhecido e provido.”

55 BRASIL. Supremo Tribunal Federal. Recurso Extraordinário n. 194.382. Recorrente: Estado de São Paulo. Recorrida: Divesca Veículos Ltda. Relator: Ministro Maurício Correa. Local, 1995. Ementa do acórdão: "RECURSO EXTRAORDINÁRIO. TRIBUTÁRIO. SUBSTITUIÇÃO TRIBUTÁRIA. IMPRESCINDIBILIDADE DE QUE ESSA HIPÓTESE ESTEJA PREVISTA EM LEI. LEGITIMIDADE DO INSTITUTO JURÍDICO. NÃO-CONHECIMENTO DO RECURSO ESPECIAL. INOCORRÊNCIA DO FENÔMENO DA SUBSTITUIÇÃO DE JULGADO. PREJUDICIALIDADE DO RECURSO EXTRAORDINÁRIO. ALEGAÇÃO IMPROCEDENTE. 1. Não-conhecimento do recurso especial pelo Superior Tribunal de Justiça. Prejudicialidade do recurso extraordinário simultaneamente interposto, tendo em vista o fenômeno processual da substituição de julgado previsto no artigo 512 do Código de Processo Civil. Alegação improcedente. O acórdão somente substituiria a decisão recorrida se o recurso houvesse sido conhecido e provido. 2. É responsável tributário, por substituição, o industrial, o comerciante ou o prestador de serviço, relativamente ao imposto devido pelas anteriores ou subseqüentes saídas de mercadorias ou, ainda, por serviços prestados por qualquer outra categoria de contribuinte. 3. Legitimidade do regime de substituição tributária, dado que a cobrança antecipada do ICMS por meio de estimativa "constitui simples recolhimento cautelar enquanto não há o negócio jurídico de circulação, em que a regra jurídica, quanto ao imposto, incide”. Entendimento doutrinário. Recurso extraordinário conhecido e provido.”

56 BRASIL. Supremo Tribunal Federal. Recurso Extraordinário n. 266.523. Recorrente: Ricar Automóveis Ltda. Recorrido: Estado de Minas Gerais. Relator: Ministro Mauríco Correa. Local, 2000. Ementa do acórdão: “AGRAVO REGIMENTAL EM RECURSO EXTRAORDINÁRIO. TRIBUTÁRIO. SUBSTITUIÇÃO TRIBUTÁRIA. LEGITIMIDADE. BASE DE CÁLCULO PRESUMIDA E VALOR REAL DA OPERAÇÃO. DIFERENÇAS APURADAS. RESTITUIÇÃO. 1. É responsável tributário, por substituição, o industrial, o comerciante ou o prestador de serviço, relativamente ao imposto devido pelas anteriores ou subseqüentes saídas de mercadorias ou, ainda, por serviços prestados por qualquer outra categoria de contribuinte. Legitimidade do regime de substituição tributária declarada pelo Pleno deste Tribunal. 2. Base de cálculo presumida e valor real da operação. Diferenças apuradas. Restituição. Impossibilidade, dada a ressalva contida na parte final do artigo $150, \int 7^{\circ}$, da Constituição Federal, que apenas assegura a imediata e preferencial restituição da quantia paga somente na hipótese em que o fato gerador presumido não se realize. Agravo regimental não provido". 
excepcionou a objetividade do crédito tributário para as situações de falência ou de recuperação judicial.

Nessa toada de proteção ao crédito tributário, no CTN, arts. 134 e 135, estão enunciados preceitos relativos à responsabilidade de terceiros, com especial ênfase para as enunciados preceitos relativos à responsabilidade de terceiros, com especial ênfase para as hipóteses de atos praticados com excesso de poderes ou infração de lei, contrato social ou estatutos. A jurisprudência do Superior Tribunal de Justiça tem sido no sentido de aplicar essa cláusula tributária de modo restritivo, como se viu no julgamento do REsp n. 1.101.728. ${ }^{57}$

No STF, nos autos do RE 562.276, ${ }^{58}$ foi declarada a inconstitucionalidade do art. 13 da Lei n. 8.620/93, na parte em que determinou que os sócios das empresas por cotas de responsabilidade limitada responderiam solidariamente, com seus bens pessoais, pelos débitos junto à Seguridade Social. É de ver, portanto, que, para esses tribunais, o instituto da responsabilização de terceiros deve ser utilizado com extrema cautela pela administração tributária.

57 BRASIL. Superior Tribunal de Justiça. Recurso Especial n. 1.101.728. Recorrente: Borda do Campo Indústria e Comércio Ltda. Recorrido: Estado de São Paulo. Relator: Ministro Teori Zavascki. Local, 2008. Ementa do acórdão: “TRIBUTÁRIO. RECURSO ESPECIAL. EXECUÇÃO FISCAL. TRIBUTO DECLARADO PELO CONTRIBUINTE. CONSTITUIÇÃO DO CRÉDITO TRIBUTÁRIO. PROCEDIMENTO ADMINISTRATIVO. DISPENSA. RESPONSABILIDADE DO SÓCIO. TRIBUTO NÃO PAGO PELA SOCIEDADE. 1. A jurisprudência desta Corte, reafirmada pela Seção inclusive em julgamento pelo regime do art. 543-C do CPC, é no sentido de que 'a apresentação de Declaração de Débitos e Créditos Tributários Federais - DCTF, de Guia de Informação e Apuração do ICMS - GIA, ou de outra declaração dessa natureza, prevista em lei, é modo de constituição do crédito tributário, dispensando, para isso, qualquer outra providência por parte do Fisco’ (REsp 962.379, $1^{\text {a }}$ Seção, DJ de 28.10.08). 2. É igualmente pacífica a jurisprudência do STJ no sentido de que a simples falta de pagamento do tributo não configura, por si só, nem em tese, circunstância que acarreta a responsabilidade subsidiária do sócio, prevista no art. 135 do CTN. É indispensável, para tanto, que tenha agido com excesso de poderes ou infração à lei, ao contrato social ou ao estatuto da empresa (EREsp 374.139/RS, $1^{\text {a }}$ Seção, DJ de 28.02.2005). 3. Recurso especial parcialmente conhecido e, nessa parte, parcialmente provido. Acórdão sujeito ao regime do art. 543-C do CPC e da Resolução STJ 0808”. 58 BRASIL. Supremo Tribunal Federal. Recurso Extraordinário. 562.276. Recorrente: União Federal (Fazenda Nacional). Recorrido: Owner's Bonés Promocionais Ltda - ME. Relatora: Ministra Ellen Gracie. Local, 2007. Ementa do acórdão: "DIREITO TRIBUTÁRIO. RESPONSABILIDADE TRIBUTÁRIA. NORMAS GERAIS DE DIREITO TRIBUTÁRIO. ART 146, III, DA CF. ART. 135, III, DO CTN. SÓCIOS DE SOCIEDADE LIMITADA. ART. 13 DA LEI 8.620/93. INCONSTITUCIONALIDADES FORMAL E MATERIAL. REPERCUSSÃO GERAL. APLICAÇÃO DA DECISÃO PELOS DEMAIS TRIBUNAIS. 1. Todas as espécies tributárias, entre as quais as contribuições de seguridade social, estão sujeitas às normas gerais de direito tributário. 2. O Código Tributário Nacional estabelece algumas regras matrizes de responsabilidade tributária, como a do art. 135, III, bem como diretrizes para que o legislador de cada ente político estabeleça outras regras específicas de responsabilidade tributária relativamente aos tributos da sua competência, conforme seu art. 128. 3. O preceito do art. 124, II, no sentido de que são solidariamente obrigadas 'as pessoas expressamente designadas por lei', não autoriza o legislador a criar novos casos de responsabilidade tributária sem a observância dos requisitos exigidos pelo art. 128 do CTN, tampouco a desconsiderar as regras matrizes de responsabilidade de terceiros estabelecidas em caráter geral pelos arts. 134 e 135 do mesmo diploma. A previsão legal de solidariedade entre devedores - de modo que o pagamento efetuado por um aproveite aos demais, que a interrupção da prescrição, em favor ou contra um dos obrigados, também lhes tenha efeitos comuns e que a isenção ou remissão de crédito exonere a todos os obrigados quando não seja pessoal (art. 125 do CTN) - pressupõe que a própria condição de devedor tenha sido estabelecida validamente. 4. A responsabilidade tributária pressupõe duas normas autônomas: a regra matriz de incidência tributária e a regra matriz de responsabilidade tributária, cada uma com seu pressuposto de fato e seus sujeitos próprios. A referência ao responsável enquanto terceiro (dritter Persone, terzo ou tercero) evidencia que não participa da relação contributiva, mas de uma relação específica de responsabilidade tributária, inconfundível com aquela. O "terceiro" só pode ser chamado responsabilizado na hipótese de descumprimento de deveres próprios de colaboração para com a Administração Tributária, estabelecidos, ainda que a contrario sensu, na regra matriz de responsabilidade tributária, e desde que tenha contribuído para a situação de inadimplemento pelo contribuinte. 5. O art. 135, III, do CTN responsabiliza apenas aqueles que estejam na direção, gerência ou representação da pessoa jurídica e tão-somente quando pratiquem atos com excesso de poder ou infração à lei, contrato social ou estatutos. Desse modo, apenas o sócio com poderes de gestão ou representação da sociedade é que pode ser responsabilizado, o que resguarda a pessoalidade entre o ilícito (má gestão ou representação) e a consequência de ter de responder pelo tributo devido pela sociedade. 6. O art. 13 da Lei 8.620/93 não se limitou a repetir ou detalhar a regra de responsabilidade constante do art. 135 do CTN, tampouco cuidou de uma nova hipótese específica e distinta. Ao vincular à simples condição de sócio a obrigação de responder solidariamente pelos débitos da sociedade limitada perante a Seguridade Social, tratou a mesma situação genérica regulada pelo art. 135, III, do CTN, mas de modo diverso, incorrendo em inconstitucionalidade por violação ao art. 146, III, da CF. 7. O art. 13 da Lei 8.620/93 também se reveste de inconstitucionalidade material, porquanto não é dado ao legislador estabelecer confusão entre os patrimônios das pessoas física e jurídica, o que, além de impor desconsideração ex lege e objetiva da personalidade jurídica, descaracterizando as sociedades limitadas, implica irrazoabilidade e inibe a iniciativa privada, afrontando os arts. $5^{\circ}$, XIII, e 170, parágrafo único, da Constituição. 8. Reconhecida a inconstitucionalidade do art. 13 da Lei 8.620/93 na parte em que determinou que os sócios das empresas por cotas de responsabilidade limitada responderiam solidariamente, com seus bens pessoais, pelos débitos junto à Seguridade Social. 9. Recurso extraordinário da União desprovido. 10. Aos recursos sobrestados, que aguardavam a análise da matéria por este STF, aplica-se o art. 543-B, $₫ 3^{\circ}$, do CPC”. 
Outro tópico que merece atenção consiste na responsabilidade por infração (arts. 136 a 138 do CTN). O Código dispõe que, salvo disposição legal em contrário, “[...] a responsabilidade por infrações da legislação tributária independe da intenção do agente ou do responsável e da efetividade, natureza e extensão dos efeitos do ato". Ou seja, a infração tributária é objetiva. Todavia, o CTN torna a responsabilidade do agente pessoal em algumas situações particulares (art. 137). Cuide-se que, por meio do instituto da "denúncia espontânea" da infração (art. 138, CTN), exclui-se a responsabilidade e as sanções normativas decorrentes do cometimento das infrações.

Trilhando os dispositivos contidos no CTN, alcança-se o Título III que versa sobre o "crédito tributário". Preceitua o Código (arts. 139 a 141) que "[...] o crédito tributário decorre da obrigação principal e tem a mesma natureza desta". Nada obstante, continua o CTN, “[...] as circunstâncias que modificam o crédito tributário, sua extensão ou seus efeitos, ou as garantias ou os privilégios a ele atribuídos, ou que excluem sua exigibilidade, não afetam a obrigação tributária que lhe deu origem".

É um aparente paradoxo. Mas é só uma aparência, pois o que o CTN dispõe que, não obstante seja o crédito tributário uma decorrência da obrigação tributária, com ela não se confunde, tendo a sua autonomia jurídica e o seu próprio regime normativo. ${ }^{59}$ Nessa linha, como já aludido, o direito da Fazenda Pública de exigir o cumprimento da obrigação tributária se dá com o lançamento tributário. Sem lançamento, não há crédito, e, sem crédito, não há direito de cobrar.

O lançamento, regulado entre os artigos 142 a 150 do CTN, é um dos temas mais relevantes do direito tributário. ${ }^{60}$ Segundo o disposto no Código, há três modalidades de lançamento tributário: o de ofício, o por declaração do contribuinte e o por homologação da Fazenda.

No Judiciário brasileiro houve grande disceptação no tocante ao prazo de repetição de indébito tributário em relação aos tributos sujeitos ao lançamento por homologação, resultando em entendimento pacificado na "Tese dos $5+5$ ", como se infere no julgamento do EREsp n. $644.736 .{ }^{61}$ Em face dessa jurisprudência, foi editada a Lei Complementar n. 118/2005, que procurou normatizar essa interpretação.

Sucede que o STF, nos autos do RE n. 566.621, ${ }^{62}$ decretou a inconstitucionalidade da aplicação retroativa

59 SCHOUERI, Luís Eduardo. Direito Tributário. São Paulo: Saraiva, 2011. p. 519-529.

60 BORGES, José Souto Maior. Lançamento tributário. 2. ed. São Paulo: Malheiros, 1999.

61 BRASIL. Superior Tribunal de Justiça. Embargos de Divergência no Recurso Especial n. 644.736. Embargante: União Federal (Fazenda Nacional). Embargado: Caxangá Veículos Ltda. Relator: Ministro Teori Zavascki. Local, 2007. Ementa do acórdão: “CONSTITUCIONAL. TRIBUTÁRIO. REPETIÇÃO DE INDÉBITO. TRIBUTOS SUJEITOS A LANÇAMENTO POR HOMOLOGAÇÃO. PRAZO PRESCRICIONAL. LC 118/2005. INCONSTITUCIONALIDADE DA APLICAÇÃO RETROATIVA. 1. Sobre a prescrição da ação de repetição de indébito tributário de tributos sujeitos a lançamento por homologação, a jurisprudência do STJ (1 ${ }^{\text {a }}$ Seção) assentou o entendimento de que, no regime anterior ao do art. $3^{\circ}$ da LC $118 / 05$, o prazo de cinco anos, previsto no art. 168 do CTN, tem início, não na data do recolhimento do tributo indevido, e sim na data da homologação expressa ou tácita - do lançamento. Assim, não havendo homologação expressa, o prazo para a repetição do indébito acaba sendo de dez anos a contar do fato gerador. 2. A norma do art. $3^{\circ}$ da LC 118/05, que estabelece como termo inicial do prazo prescricional, nesses casos, a data do pagamento indevido, não tem eficácia retroativa. É que a Corte Especial, em sessão de 06/06/2007, DJ 27.08.2007, declarou inconstitucional a expressão 'observado, quanto ao art. $3^{\circ}$, o disposto no art. 106, I, da Lei no 5.172 , de 25 de outubro de 1966 - Código Tributário Nacional', constante do art. 4º segunda parte, da referida Lei Complementar. 3. Embargos de divergência a que se nega provimento".

62 BRASIL. Supremo Tribunal Federal. Recurso Extraordinário n. 566.621. Recorrente: União Federal (Fazenda Nacional). Recorrido: Ruy Cesar Abella Ferreira. Relatora: Ministra Ellen Gracie. Local, 2007. Ementa do acórdão: “DIREITO TRIBUTÁRIO - LEI INTERPRETATIVA - APLICAÇÃO RETROATIVA DA LEI COMPLEMENTAR N 118/2005 - DESCABIMENTO - VIOLAÇÃO À SEGURANÇA JURÍDICA - NECESSIDADE DE OBSERVÂNCIA DA VACACIO LEGIS - APLICAÇÃO DO PRAZO REDUZIDO PARA REPETIÇÃO OU COMPENSAÇÃO DE INDÉBITOS AOS PROCESSOS AJUIZADOS A PARTIR DE 9 DE JUNHO DE 2005. Quando do advento da LC 118/05, estava consolidada a orientação da Primeira Seção do STJ no sentido de que, para os tributos sujeitos a lançamento por homologação, o prazo para repetição ou compensação de indébito era de 10 anos contados do seu fato gerador, tendo em conta a aplicação combinada dos arts. 150, \ $4^{\circ}, 156$, VII, e 168, I, do CTN. A LC 118/05, embora tenha se auto-proclamado interpretativa, implicou inovação normativa, tendo reduzido o prazo de 10 anos contados do fato gerador para 5 anos contados do pagamento indevido. Lei supostamente interpretativa que, em verdade, inova no mundo jurídico deve ser considerada como lei nova. Inocorrência de violação à autonomia e independência dos Poderes, porquanto a lei expressamente interpretativa também se submete, como qualquer outra, ao controle judicial quanto 
contida no art. $4^{\circ}$ da mencionada LC n. 118/2005. Manteve, contudo, incólume o art. $3^{\circ}$, de modo que foi superada a "Tese dos $5+5$ " e o prazo foi reduzido, portanto, de 10 anos contados do fato gerador para cinco anos contados do pagamento indevido.

Após cuidar do lançamento tributário, o CTN disciplina, entre os artigos 151 a 155, as hipóteses de suspensão do crédito tributário. Segundo o Código, suspendem a exigibilidade do crédito: a) a moratória; b) o depósito do seu montante integral; c) as reclamações e os recursos, nos termos da legislação; d) a concessão de liminar ou de tutela antecipada ou em mandado de segurança ou em outras espécies de ação judicial; e) o parcelamento.

O Código continua o tratamento normativo da moratória e do parcelamento. Em relação à moratória, dispõe no parágrafo único do art. 154 que ela não "[...] aproveita aos casos de dolo, fraude ou simulação do sujeito passivo ou do terceiro em benefício daquele". A rigor, esse tipo de preceito normativo deveria ser desnecessário, pois é postulado universal dos direitos e deveres dos povos civilizados que ninguém pode se beneficiar de sua própria torpeza. Mas, neste País, infelizmente, se tudo não estiver bem escrito e bem enunciado, mesmos as "obviedades" se tornam excêntricas, e um ato torpe se torna um ato juridicamente válido e admissível.

Após tratar das hipóteses de suspensão do crédito tributário, o CTN, nos artigos 156 a 174, normatiza as modalidades de extinção do crédito. Segundo o Código, extinguem o crédito tributário: a) o pagamento; b) a compensação; c) a transação; d) a remissão; e) a prescrição; f) a decadência; g) a conversão do depósito em renda; h) o pagamento antecipado e homologado; i) a decisão administrativa irreformável e judicialmente insindicável; j) a decisão judicial passada em julgado; e k) a dação em pagamento em bens imóveis.

O pagamento, para a Fazenda Pública, é o melhor instrumento de extinção do crédito tributário. Mas, uma vez que o devedor fiscal se recusa a pagar a dívida tributária, de melhor e mais simples, ela se transforma na mais complexa de todas as modalidades de extinção do crédito tributário.

O Código regula o dever da Fazenda Pública de repetir (ou devolver) o que foi indevidamente pago aos cofres públicos. Com efeito, nos Estados Democráticos de Direito, que devem se pautar pela "legítima legalidade", o poder deve se contentar em receber o que lhe seja efetivamente devido, nem a mais nem a menos. Os contribuintes devem pagar o estritamente devido. O que for indevidamente pago deve ser devolvido a quem pagou.

Nessa linha, a interpretação a ser dada ao preceito contido no artigo 166 merece cuidadosa atenção. Enuncia o citado dispositivo que:

[...] a restituição de tributos que comportem, por sua natureza, transferência do respectivo encargo financeiro somente será feita a quem prove haver assumido referido encargo, ou, no caso de tê-lo transferido a terceiro, estar por este expressamente autorizado a recebê-la.

O STF editou duas Súmulas tendo esse tema como pano de fundo: a n. 71, de 13.12.1963, e a n. 546, de 3.12.1969. Na Súmula n. 71, está enunciado que “[...] embora pago indevidamente, não cabe restituição de tributo indireto", e na Súmula n. 546, que "[...] cabe a restituição do tributo pago indevidamente, quando reconhecido

à sua natureza, validade e aplicação. A aplicação retroativa de novo e reduzido prazo para a repetição ou compensação de indébito tributário estipulado por lei nova, fulminando, de imediato, pretensões deduzidas tempestivamente à luz do prazo então aplicável, bem como a aplicação imediata às pretensões pendentes de ajuizamento quando da publicação da lei, sem resguardo de nenhuma regra de transição, implicam ofensa ao princípio da segurança jurídica em seus conteúdos de proteção da confiança e de garantia do acesso à Justiça. Afastando-se as aplicações inconstitucionais e resguardando-se, no mais, a eficácia da norma, permite-se a aplicação do prazo reduzido relativamente às ações ajuizadas após a vacatio legis, conforme entendimento consolidado por esta Corte no enunciado 445 da Súmula do Tribunal. O prazo de vacatio legis de 120 dias permitiu aos contribuintes não apenas que tomassem ciência do novo prazo, mas também que ajuizassem as ações necessárias à tutela dos seus direitos. Inaplicabilidade do art. 2.028 do Código Civil, pois, não havendo lacuna na LC 118/08, que pretendeu a aplicação do novo prazo na maior extensão possível, descabida sua aplicação por analogia. Além disso, não se trata de lei geral, tampouco impede iniciativa legislativa em contrário. Reconhecida a inconstitucionalidade art. $4^{\circ}$, segunda parte, da LC 118/05, considerando-se válida a aplicação do novo prazo de 5 anos tão-somente às ações ajuizadas após o decurso da vacatio legis de 120 dias, ou seja, a partir de 9 de junho de 2005. Aplicação do art. 543-B, \ $3^{\circ}$, do CPC aos recursos sobrestados. Recurso extraordinário desprovido". 
por decisão, que o contribuinte de 'de jure' não recuperou do contribuinte 'de facto' o 'quantum' respectivo'.

Nada obstante as intenções do legislador, chanceladas pela Suprema Corte, é de rigor que o Estado não deve se apropriar indevidamente do que não lhe seja de direito. Assim, entendo que aquele que recolheu tributo indevido tem o direito a sua repetição. Insiste-se que o Estado Democrático de Direito é o "poder legal e legítimo". É ilegítimo que o Estado se aproprie de valores indevidos.

Dentro dessa "legítima legalidade", o CTN regula os institutos da prescrição e da decadência tributárias. A rigor, ocorrido o fato gerador da obrigação tributária nasce, em princípio, o dever do sujeito passivo de pagar o tributo. O direito da Fazenda de exigir esse pagamento somente ocorre com a constituição, via lançamento, do crédito tributário. É uma situação aparentemente paradoxal. Se a ocorrência do fato gerador da obrigação tributária implica o dever do sujeito passivo, em princípio, como a outra "face dessa moeda" deveria surgir o direito da Fazenda. Mas, não é essa a sistemática do Código. O direito da Fazenda surge com o crédito. O crédito surge com o lançamento, e não com o fato gerador da obrigação tributária.

Pois bem, um dos postulados éticos supremos dos sistemas jurídicos dos povos civilizados consiste na segurança ou na paz. ${ }^{63} \mathrm{O}$ tempo é um fator de estabilização, de segurança e de paz. As situações jurídicas devem ocorrer dentro de determinados marcos temporais. Esse aspecto ético do Direito foi bem capturado pelo ministro Cezar Peluso, nos autos do RE n. 363.889, ${ }^{64}$ que cuidou dos temas coisa julgada e ação de investigação de paternidade, ocasião em que Sua Excelência afirma que "[...] ninguém consegue viver dignamente sem certeza jurídica".

Como viver em um mundo incerto, inseguro e sem paz é muito perigoso, cuidou o CTN de estabelecer os prazos para que a Fazenda constituísse o seu crédito e, uma vez constituído, pudesse cobrá-lo (arts. 173 e 174). Assim, conforme preceitua o Código, o prazo decadencial de constituição do crédito se dá em cinco anos. E o prazo prescricional para a sua cobrança também se expira em cinco anos. Por esse mesmo postulado de segurança jurídica, o contribuinte também dispõe de prazos para exigir da Fazenda a devolução do indevidamente pago, conforme já aludimos.

E, antes de se alcançar o capítulo específico das garantias e privilégios do crédito tributário, passa-se pelo Capítulo V que versa sobre a exclusão do crédito tributário (arts. 175 a 182). Segundo o CTN, excluem o crédito tributário: a isenção e a anistia.

Ainda viceja no solo jurídico brasileiro um forte debate acerca das similitudes e das diferenças entre os institutos tributários da isenção e da imunidade. Cuide-se que esse debate não é só acadêmico, pois há manifestações do STF que a partir da distinção entre isenção e imunidade ensejam consequências normativas

63 ÁVILA, Humberto. Seguranca jurídica: entre permanência, mudança e realização no direito tributário. São Paulo: Malheiros, 2011.

64 BRASIL. Supremo Tribunal Federal. Recurso Extraordinário n. 363.889. Recorrentes: Ministério Público do Distrito Federal e Territórios e outro. Recorrido: Goiá Fonseca Rates. Relator: Ministro Dias Toffoli. Local, 2002. Ementa do acórdão: "EMENTA RECURSO EXTRAORDINÁRIO. DIREITO PROCESSUAL CIVIL E CONSTITUCIONAL. REPERCUSSÃO GERAL RECONHECIDA. AÇÃO DE INVESTIGAÇÃO DE PATERNIDADE DECLARADA EXTINTA, COM FUNDAMENTO EM COISA JULGADA, EM RAZÃO DA EXISTÊNCIA DE ANTERIOR DEMANDA EM QUE NÃO FOI POSSÍVEL A REALIZAÇÃO DE EXAME DE DNA, POR SER O AUTOR BENEFICÁRIO DA JUSTIÇA GRATUITA E POR NÃO TER O ESTADO PROVIDENCIADO A SUA REALIZAÇÃO. REPROPOSITURA DA AÇÃ̃O. POSSIBILIDADE, EM RESPEITO À PREVALÊNCIA DO DIREITO FUNDAMENTAL À BUSCA DA IDENTIDADE GENÉTICA DO SER, COMO EMANAÇÃO DE SEU DIREITO DE PERSONALIDADE. 1. É dotada de repercussão geral a matéria atinente à possibilidade da repropositura de ação de investigação de paternidade, quando anterior demanda idêntica, entre as mesmas partes, foi julgada improcedente, por falta de provas, em razão da parte interessada não dispor de condições econômicas para realizar o exame de DNA e o Estado não ter custeado a produção dessa prova. 2. Deve ser relativizada a coisa julgada estabelecida em ações de investigação de paternidade em que não foi possível determinar-se a efetiva existência de vínculo genético a unir as partes, em decorrência da não realização do exame de DNA, meio de prova que pode fornecer segurança quase absoluta quanto à existência de tal vínculo. 3. Não devem ser impostos óbices de natureza processual ao exercício do direito fundamental à busca da identidade genética, como natural emanação do direito de personalidade de um ser, de forma a tornar-se igualmente efetivo o direito à igualdade entre os filhos, inclusive de qualificações, bem assim o princípio da paternidade responsável. 4. Hipótese em que não há disputa de paternidade de cunho biológico, em confronto com outra, de cunho afetivo. Busca-se o reconhecimento de paternidade com relação a pessoa identificada. 5. Recursos extraordinários conhecidos e providos". 
distintas, como sucedeu no julgamento do direito de creditamento IPI nas hipóteses de insumos imunes ou isentos ou sujeitos à alíquota zero: RREE $212.484,{ }^{65} 357.277,{ }^{66} 353.657,{ }^{67} 370.682^{68}$ e $566.819 .{ }^{69}$

Pois bem, nada obstante essas distinções normativas, na linha do magistério doutrinário de Sacha Calmon, ${ }^{70} \mathrm{a}$ isenção é a exoneração legalmente qualificada, enquanto que a imunidade é a exoneração constitucionalmente qualificada, ou seja, a diferença entre a imunidade e a isenção encontra-se no veículo normativo: a isenção é veiculada pela lei e a imunidade pela Constituição.

Em reforço a essa perspectiva, colhe-se o disposto no art. 150, $₫ 6^{\circ}, \mathrm{CF}$, preceituando que :

[...] qualquer subsídio ou isenção, redução de base de cálculo, concessão de crédito presumido, anistia ou remissão, relativos a impostos, taxas e contribuições, só poderá ser concedido mediante lei específica, federal, estadual ou municipal, que regule exclusivamente as matérias acima enumeradas ou o correspondente tributo ou contribuição, sem prejuízo do disposto no art. 155, \ $2^{\circ}$, XII, g.

É de ver, portanto, que se cuida de uma garantia constitucional ao crédito tributário. Nada obstante, tenha-se que para o contribuinte o que efetivamente importa é se ele deve pagar e quanto ele deve pagar de tributo. Se houver norma exonerando do dever de pagar ou diminuindo o quanto se deve pagar, para o contribuinte pouco importa o veículo normativo ou o nome do instituto exonerativo, se imunidade, não incidência, isenção, redução de base de cálculo, redução de alíquota, alíquota zero etc.

Essa especial proteção do crédito tributário decorre de alguns hábitos equivocados de política fiscal no Brasil. Não são raras as políticas fiscais que manipulam os tributos com finalidades extrafiscais, com indesejáveis consequências, como sucede, por exemplo, com as "guerras fiscais" entre Estados ou entre Municípios.

Não se está a infirmar a possibilidade de o Estado usar os tributos com finalidades extrafiscais, pois em

65 BRASIL. Supremo Tribunal Federal. Recurso Extraordinário n. 212.484. Redatoria Ministro Nelson Jobim. Recorrente: União Federal (Fazenda Nacional). Recorrida: Vonpar Refrescos S/A, 1997. Ementa do acórdão: "CONSTITUCIONAL. TRIBUTÁRIO. IPI. ISENÇÃO INCIDENTE SOBRE INSUMOS. DIREITO DE CRÉDITO. PRINCÍPIO DA NÃO CUMULATIVIDADE. OFENSA NÃO CARACTERIZADA. Não ocorre ofensa à CF (art. 153, $\int 3^{\circ}$, II) quando o contribuinte do IPI credita-se do valor do tributo incidente sobre insumos adquiridos sob o regime de isenção. Recurso não conhecido".

66 BRASIL. Supremo Tribunal Federal. Recurso Extraordinário n. 357.277. Redatoria Ministro Nelson Jobim. Recorrente: União Federal (Fazenda Nacional). Recorrida: Cooperativa Vinícola Garibaldi. Local, 2002. Ementa do acórdão: "CONSTITUCIONAL. TRIBUTÁRIO. IPI. CREDITAMENTO. INSUMOS ISENTOS, SUJEITOS À ALÍQUOTA ZERO. Se o contribuinte do IPI pode creditar o valor dos insumos adquiridos sob o regime de isenção, inexiste razão para deixar de reconhecer-lhe o mesmo direito na aquisição de insumos favorecidos pela alíquota zero, pois nada extrema, na prática, as referidas figuras desonerativas, notadamente quando se trata de aplicar o princípio da não-cumulatividade. A isenção e a alíquota zero em um dos elos da cadeia produtiva desapareceriam quando da operação subseqüente, se não admitido o crédito. Recurso não conhecido".

67 BRASIL. Supremo Tribunal Federal. Recurso Extraordinário n. 353.657. Recorrente: União Federal (Fazenda Nacional). Recorrida: Madeireira Santo Antônio Ltda. Relator: Ministro Marco Aurélio. Local, 2002. Ementa do acórdão: "IPI - INSUMO - ALÍQUOTA ZERO - AUSÊNCIA DE DIREITO AO CREDITAMENTO. Conforme disposto no inciso II do $\ 3^{\circ}$ do artigo 153 da Constituição Federal, observa-se o princípio da não-cumulatividade compensando-se o que for devido em cada operação com o montante cobrado nas anteriores, ante o que não se pode cogitar de direito a crédito quando o insumo entra na indústria considerada a alíquota zero. IPI -INSUMO - ALÍQUOTA ZERO - CREDITAMENTO - INEXISTÊNCIA DO DIREITO - EFICÁCIA. Descabe, em face do texto constitucional regedor do Imposto sobre Produtos Industrializados e do sistema jurisdicional brasileiro, a modulação de efeitos do pronunciamento do Supremo, com isso sendo emprestada à Carta da República a maior eficácia possível, consagrando-se o princípio da segurança jurídica".

68 BRASIL. Supremo Tribunal Federal. Recurso Extraordinário n. 370.682. Recorrente: União Federal (Fazenda Nacional). Recorrida: Indústria de Embalagens Plásticas Guará Ltda. Relator: Ministro Ilmar Galvão. Local, 2003. Ementa do acórdão: “Recurso extraordinário. Tributário. 2. IPI. Crédito Presumido. Insumos sujeitos à alíquota zero ou não tributados. Inexistência. 3. Os princípios da não-cumulatividade e da seletividade não ensejam direito de crédito presumido de IPI para o contribuinte adquirente de insumos não tributados ou sujeitos à alíquota zero. 4. Recurso extraordinário provido".

69 BRASIL. Supremo Tribunal Federal. Recurso Extraordinário n. 566.819. Recorrente: Jofran Embalagens Ltda. Recorrida: União Federal (Fazenda Nacional). Relator: Ministro Marco Aurélio. Local, 2007. Ementa do acórdão: "IPI - CRÉDITO. A regra constitucional direciona ao crédito do valor cobrado na operação anterior. IPI - CRÉDITO - INSUMO ISENTO. Em decorrência do sistema tributário constitucional, o instituto da isenção não gera, por si só, direito a crédito. IPI - CRÉDITO - DIFERENÇA - INSUMO - ALÍQUOTA. A prática de alíquota menor - para alguns, passível de ser rotulada como isenção parcial - não gera o direito a diferença de crédito, considerada a do produto final”.

70 COELHO, Sacha Calmon Navarro. Curso de direito tributário brasileiro. 8. ed. Rio de Janeiro: Forense, 2005, p. 876. 
algumas situações isso se faz necessário, como ocorre, por exemplo, com a forte oneração de fumígeros ou de bebidas alcoólicas, cuja principal finalidade é pedagógica, visando desestimular o consumo desses produtos nocivos e insidiosos à saúde das pessoas.

Mas o que se tem acompanhado é uma política tributária voltada, não raras vezes, para atender a outras finalidades, com a utilização de instrumentos fiscais como se fossem instrumentos de incentivo econômico. Esse uso equivocado do direito tributário é nocivo à coletividade. E tais práticas normativas problemáticas normalmente se transformam em questões judiciais.

Mas essas questões judiciais problemáticas se tornam dramáticas quando o contribuinte confia na legislação estadual ou municipal e essa legislação é posteriormente declarada inconstitucional, devendo o contribuinte pagar valores que julgava não devidos. ${ }^{71}$ Para essas situações excepcionais o sistema jurídico tem o instituto normativo da modulação dos efeitos.

Tanto a doutrina quanto a jurisprudência brasileira agasalham o dogma da nulidade da lei declarada inconstitucional. Assim, ela não pode ter produzido efeitos válidos e a decisão judicial que decreta a sua inconstitucionalidade tem caráter "declaratório" e com efeitos retroativos.

Sem embargo da vetustez desse dogma e da respeitabilidade de seus defensores, entendo que a tese kelseniana da anulabilidade da lei inconstitucional, em vista do caráter constitutivo do reconhecimento da inconstitucionalidade - a decisão e dos efeitos prospectivos - é mais coerente com a vida real. ${ }^{72}$ Com efeito, sob a égide da Constituição de 1988, e tendo em perspectiva o julgamento da Ação Direta de Inconstitucionalidade n. $2{ }^{73}$ restou pacificado no seio da jurisprudência brasileira o entendimento segundo o qual a lei inconstitucional é nula ab initio.

Todavia, em situações excepcionais, o STF admite a possibilidade de afastar esse dogma da nulidade com a concessão de efeitos prospectivos, acolhendo a tese da anulabilidade, com esteio nos artigos 27 e 11, das respectivas Leis n. 9.868/99 e n. 9.882/99, que autorizam o Tribunal, por aprovação de 2/3 dos Ministros, tendo em vista razões de segurança jurídica e/ou de excepcional interesse social, modular os efeitos das decisões de inconstitucionalidade no controle concentrado de constitucionalidade.

No controle difuso, o Tribunal também tem precedentes no sentido da manipulação dos efeitos das decisões nos feitos de controle difuso de constitucionalidade, como ocorreu no julgamento do RE n. 197.917. ${ }^{74}$

71 ANDRADE, Fábio Martins de. Modulação em matéria tributária: o argumento pragmático ou consequencialista de cunho econômico e as decisões do STF. São Paulo: Quartier Latin, 2011.

72 KELSEN, Hans. Jurisdição constitucional. 3. ed. São Paulo: Martins Fontes, 2013.

73 BRASIL. Supremo Tribunal Federal. Ação Direta de Inconstitucionalidade n. 2. Requerente: Federação Nacional dos Estabelecimentos de Ensino - FENEN. Requerido: Presidente da República. Relator: Ministro Paulo Brossard. Local, 1988. Ementa do acórdão: “CONSTITUIÇÃO. LEI ANTERIOR QUE A CONTRARIE. REVOGAÇÃO. INCONSTITUCIONALIDADE SUPERVENIENTE. IMPOSSIBILIDADE. 1. A lei ou é constitucional ou não é lei. Lei inconstitucional é uma contradição em si. A lei é constitucional quando fiel à Constituição; inconstitucional na medida em que a desrespeita, dispondo sobre o que lhe era vedado. $\mathrm{O}$ vício da inconstitucionalidade é congênito à lei e há de ser apurado em face da Constituição vigente ao tempo de sua elaboração. Lei anterior não pode ser inconstitucional em relação à Constituição superveniente; nem o legislador poderia infringir Constituição futura. A Constituição sobrevinda não torna inconstitucionais leis anteriores com ela conflitantes: revoga-as. Pelo fato de ser superior, a Constituição não deixa de produzir efeitos revogatórios. Seria ilógico que a lei fundamental, por ser suprema, não revogasse, ao ser promulgada, leis ordinárias. A lei maior valeria menos que a lei ordinária. 2. Reafirmação da antiga jurisprudência do STF, mais que cinqüentenária. 3. Ação direta de que se não conhece por impossibilidade jurídica do pedido".

74 BRASIL. Supremo Tribunal Federal. Recurso Extraordinário n. 197.917. Recorrente: Ministério Público do Estado de São Paulo. Recorrida: Câmara Municipal de Mira Estrela. Relator: Ministro Maurício Corrêa. Local, 1987. Ementa do acórdão: "RECURSO EXTRAORDINÁRIO. MUNICÍPIOS. CÂMARA DE VEREADORES. COMPOSIÇÃO. AUTONOMIA MUNICIPAL. LIMITES CONSTITUCIONAIS. NÚMERO DE VEREADORES PROPORCIONAL À POPULAÇÃO. CF, ARTIGO 29, IV. APLICAÇÃO DE CRITÉRIO ARITMÉTICO RÍGIDO. INVOCAÇÃO DOS PRINCÍPIOS DA ISONOMIA E DA RAZOABILIDADE. INCOMPATIBILIDADE ENTRE A POPULAÇÃO E O NÚMERO DE VEREADORES. INCONSTITUCIONALIDADE, INCIDENTER TANTUM, DA NORMA MUNICIPAL. EFEITOS PARA O FUTURO. SITUAÇÃO EXCEPCIONAL. 1. O artigo 29, inciso IV da Constituição Federal, exige que o número de Vereadores seja proporcional à população dos Municípios, observados os limites mínimos e máximos fixados pelas alíneas a, b e c. 2. Deixar a critério do legislador municipal o estabelecimento da composição das Câmaras Municipais, com observância apenas dos limites máximos e mínimos do preceito (CF, artigo 29) é tornar sem sentido a previsão constitucional expressa da proporcionalidade. 3. Situação real e 
No recente julgamento do RE n. 586.453, ${ }^{75}$ a Corte decidiu que a exigência para modular os efeitos de decisão em matéria constitucional necessita da aprovação de $2 / 3$ dos membros, nos mesmos moldes do que ocorre com o controle concentrado e abstrato de constitucionalidade. O Tribunal, por questão de coerência normativa, aproximou o modelo processual do recurso extraordinário com repercussão geral do modelo processual do controle concentrado de constitucionalidade.

Mas eis uma situação peculiar do sistema jurídico brasileiro. Nos termos do art. 97 da Constituição Federal, "[...] somente pelo voto da maioria absoluta de seus membros ou dos membros do respectivo órgão especial poderão os tribunais declarar a inconstitucionalidade de lei ou ato normativo do Poder Público". Assim, no caso do STF, somente seis votos podem declarar uma norma inconstitucional, mas para modular os efeitos da decisão são necessários oito votos.

Ora, o que é mais importante? Declarar a inconstitucionalidade ou modular os efeitos das decisões? À luz da dinâmica jurisprudencial do STF, modular os efeitos é mais importante do que declarar a inconstitucionalidade de uma norma. A rigor, deveria ser o contrário: para declarar uma norma inconstitucional, deveria ser exigido o voto de oito ministros ou 2/3 dos membros de um Tribunal ou de seu órgão especial, enquanto que a modulação poderia ser feita pelo quorum da maioria simples. ${ }^{76}$

A modulação dos efeitos de uma decisão judicial não passa de um ato de política judiciária, pautada pela conveniência e pela oportunidade. Insiste-se, o grave não é a modulação de efeitos, mas a declaração de inconstitucionalidade. Por que a defesa da anulabilidade das leis e a modulação de seus efeitos? Porque no mundo real, entre o início de um processo legislativo e o fim de um processo judicial dista longo prazo.

No mundo real, das situações concretas da vida, as leis vigem até decisão judicial ou legislativa em contrário. Assim, enquanto não houver decisão judicial suspendendo a validade e a eficácia de uma lei, essa lei deve continuar vigendo e produzindo efeitos jurídicos. Passados vários anos, uma decisão judicial, ainda que seja do STF, declarando a inconstitucionalidade de uma lei não pode desprezar todo o período de vigência normativa dessa lei. Isso provocaria incerteza, insegurança, instabilidade, enfim, provocaria o caos. E o direito é ordem. A razão de ser do sistema jurídico é impor a ordem sobre o caos. De modo que, decisão judicial provocadora de caos é uma não decisão. Direito é paz com justiça.

contemporânea em que Municípios menos populosos têm mais Vereadores do que outros com um número de habitantes várias vezes maior. Casos em que a falta de um parâmetro matemático rígido que delimite a ação dos legislativos Municipais implica evidente afronta ao postulado da isonomia. 4. Princípio da razoabilidade. Restrição legislativa. A aprovação de norma municipal que estabelece a composição da Câmara de Vereadores sem observância da relação cogente de proporção com a respectiva população configura excesso do poder de legislar, não encontrando eco no sistema constitucional vigente. 5. Parâmetro aritmético que atende ao comando expresso na Constituição Federal, sem que a proporcionalidade reclamada traduza qualquer afronta aos demais princípios constitucionais e nem resulte formas estranhas e distantes da realidade dos Municípios brasileiros. Atendimento aos postulados da moralidade, impessoalidade e economicidade dos atos administrativos (CF, artigo 37). 6. Fronteiras da autonomia municipal impostas pela própria Carta da República, que admite a proporcionalidade da representação política em face do número de habitantes. Orientação que se confirma e se reitera segundo o modelo de composição da Câmara dos Deputados e das Assembleias Legislativas (CF, artigos 27 e 45, \ $1^{\circ}$ ). 7. Inconstitucionalidade, incidenter tantun, da lei local que fixou em 11 (onze) o número de Vereadores, dado que sua população de pouco mais de 2600 habitantes somente comporta 09 representantes. 8. Efeitos. Princípio da segurança jurídica. Situação excepcional em que a declaração de nulidade, com seus normais efeitos ex tunc, resultaria grave ameaça a todo o sistema legislativo vigente. Prevalência do interesse público para assegurar, em caráter de exceção, efeitos pro futuro à declaração incidental de inconstitucionalidade. Recurso extraordinário conhecido e em parte provido".

75 BRASIL. Supremo Tribunal Federal. Recurso Extraordinário n. 586.453. Recorrente: Fundação Petrobrás de Seguridade Social - PETROS. Recorrida: Petróleo Brasileiro S/A - PETROBRAS. Relatora: Ministra Rosa Weber. Local, 2008. Extrato da decisão: "O Tribunal resolveu questão de ordem no sentido da exigência de quorum de 2/3 para modular os efeitos da decisão em sede de recurso extraordinário com repercussão geral, vencidos os Ministros Dias Toffoli, Luiz Fux, Gilmar Mendes e Celso de Mello, que entendiam haver a necessidade de maioria absoluta. Participaram da votação na questão de ordem os Ministros Teori Zavascki e Rosa Weber. Em seguida, o Tribunal modulou os efeitos da decisão para reconhecer a competência da justiça trabalhista para processar e julgar, até o trânsito em julgado (20.2.2013)".

76 A Comissão de Constituição e Justiça da Câmara dos Deputados aprovou a admissibilidade da PEC - Proposta de Emenda à Constituição n. 33/11 que "Altera a quantidade mínima de votos de membros de tribunais para declaração de inconstitucionalidade de leis; condiciona o efeito vinculante de súmulas aprovadas pelo Supremo Tribunal Federal à aprovação pelo Poder Legislativo e submete ao Congresso Nacional a decisão sobre a inconstitucionalidade de Emendas à Constituição". Disponível em: <www. camara.gov.br>. Acesso em: 
Retorna-se ao crédito tributário. Chega-se nas suas garantias e privilégios.

\section{As GARANTIAS, OS PRIVILÉGIOS E AS PREFERÊNCIAS DO CRÉDITO TRIBUTÁRIO}

O Código Tributário Nacional (arts. 183 a 193, Capítulo VI), coerentemente, preceitua que “[...] as garantias atribuídas neste Capítulo ao crédito tributário não exclui outras que sejam expressamente previstas em lei, em função da natureza ou das características do tributo a que se refiram”. É de ver, portanto, que, no plano dos textos legislativos, o crédito tributário goza de especial proteção, e todo reforço em favor do fortalecimento do crédito tributário é justificado por sua posição sobranceira.

No art. 184, CTN, tem dispositivo de grande proteção ao crédito tributário, na medida em que somente os bens e as rendas que a lei declare absolutamente impenhoráveis estarão fora do alcance da responsabilidade tributária. Isso significa que somente lei federal pode indicar quais bens e rendas estão fora da garantia do crédito tributário. Somente a lei pode indicar o que não será alcançado pela responsabilização tributária.

Nada obstante o rol de bens impenhoráveis no art. 649 do Código de Processo Civil, é de se interpretar o art. 184, CTN, em sentido mais robusto, pois a execução do crédito tributário é especial e, na dúvida entre a aplicação de uma lei geral ou de uma lei específica, prevalece a específica. A jurisprudência contrária ao crédito tributário é excepcional, como ocorre na hipótese de proteção ao bem de família, nos termos da Lei n. 8.009/1990, desde que não sejam de tributos ou contribuições decorrentes do próprio imóvel.

Todavia, o STF, apreciando questões tributárias envolvendo os Correios, tem decidido que a ECT - Empresa Brasileira de Correios e Telégrafos - não pode ter os próprios bens penhoráveis para o pagamento de dívidas, sejam fiscais, trabalhistas ou de qualquer natureza, por força do disposto no art. 12 do Decreto-lei n. 509/1969, excepcionando a regra disposta no art. 173, \ 2 ${ }^{\circ}$, CF, como se vê nos autos dos RREE n.220.906 $6^{77}$ e n. $601.392 .^{78}$

77 BRASIL. Supremo Tribunal Federal. Recurso Extraordinário n. 220.906. Recorrente: ECT - Empresa Brasileira de Correios e Telégrafos. Recorrido: Ismar José da Costa. Relator: Ministro Maurício Corrêa. Local, 1997. Ementa do acórdão: 'RECURSO EXTRAORDINÁRIO. CONSTITUCIONAL. EMPRESA BRASILEIRA DE CORREIOS E TELÉGRAFOS. IMPENHORABILIDADE DE SEUS BENS, RENDAS E SERVIÇOS. RECEPÇÃO DO ARTIGO 12 DO DECRETO-LEI Nº 509/69. EXECUÇÃO. OBSERVÂNCIA DO REGIME DE PRECATÓRIO. APLICAÇÃO DO ARTIGO 100 DA CONSTITUIÇÃO FEDERAL. 1. À empresa Brasileira de Correios e Telégrafos, pessoa jurídica equiparada à Fazenda Pública, é aplicável o privilégio da impenhorabilidade de seus bens, rendas e serviços. Recepção do artigo 12 do Decreto-lei no 509/69 e não-incidência da restrição contida no artigo $173, \int 1^{\circ}$, da Constituição Federal, que submete a empresa pública, a sociedade de economia mista e outras entidades que explorem atividade econômica ao regime próprio das empresas privadas, inclusive quanto às obrigações trabalhistas e tributárias. 2. Empresa pública que não exerce atividade econômica e presta serviço público da competência da União Federal e por ela mantido. Execução. Observância ao regime de precatório, sob pena de vulneração do disposto no artigo 100 da Constituição Federal. Recurso extraordinário conhecido e provido".

78 BRASIL. Supremo Tribunal Federal. Recurso Extraordinário n. 601.392. Redatoria Ministro Gilmar Mendes. Recorrente: ECT - Empresa Brasileira de Correios e Telégrafos. Recorrido: Município de Curitiba. Relator: Ministro Gilmar Mendes. Local, 2009. Extrato da decisão: “Os serviços prestados pela Empresa Brasileira de Correios e Telégrafos - ECT estão abrangidos pela imunidade recíproca (CF, art. 150, VI, a, e $\iint 2^{\circ}$ e $3^{\circ}$ ). Essa a orientação do Plenário que, ao concluir julgamento, por maioria, proveu recurso extraordinário interposto de acórdão em que se limitara o colimado benefício aos serviços tipicamente postais mencionados no art. $9^{\circ}$ da Lei 6.538/78. A Corte de origem entendera lícito ao município recorrido a cobrança de Imposto sobre Serviços - ISS relativamente àqueles não abarcados pelo monopólio concedido pela União — v. Informativos 628 e 648. Na sessão de 16.11.2011, o Min. Ayres Britto registrou, de início, que a manutenção do correio aéreo nacional e dos serviços postais e telegráficos pela recorrente não poderia sofrer solução de continuidade, de maneira a ser obrigatoriamente sustentada pelo Poder Público, ainda que lhe gerasse prejuízo. Além do mais, reputou possível a adoção de política tarifária de subsídios cruzados, porquanto os Correios realizariam também direitos fundamentais da pessoa humana — comunicação telegráfica e telefônica e o sigilo dessas comunicações -, em atendimento que alçaria todos os municípios brasileiros (integração nacional) com tarifas módicas. Assinalou que, na situação dos autos, a extensão do regime de imunidade tributária seria natural, haja vista que a recorrente seria longa manus da União, em exercício de atividade absolutamente necessária e mais importante do que a própria compostura jurídica ou a estrutura jurídico-formal da empresa. O Min. Gilmar Mendes, em reforço ao que referido, ressaltou que a base do monopólio da ECT estaria sofrendo esvaziamento, tornando-se ultrapassada, diante da evolução tecnológica. Ressurtiu que a recorrente, mesmo quando exercesse atividades fora do regime de privilégio, sujeitar-se-ia a condições decorrentes desse status, não extensíveis à iniciativa privada, a exemplo da exigência de prévia licitação e da realização de concurso público. Concluiu que, enquanto não houvesse a mudança preconizada na ADPF 46/DF (DJe de 26.2.2010), a imunidade 
O STF, no caso da ECT, tem entendido que a empresa tem, para efeitos de dívidas fiscais e trabalhistas, o mesmo regime jurídico das pessoas jurídicas de direito público; mas, no recente julgamento do RE n. $589.998,{ }^{79}$ que cuidava da eventual estabilidade do servidor público, preconizada no art. 41, CF, o Tribunal entendeu inaplicável aos empregados da ECT.

Nos citados leading cases que reconheceram esse regime jurídico de direito público da ECT, o Tribunal, enfrentando uma penhora dos bens da ECT, decorrente do cumprimento de decisão judicial em execução trabalhista, criou a figura do "precatório informal" e da "interpretação constitucional com base no próprio Supremo".

O "precatório informal” foi o que disse o ministro Nelson Jobim. Sua Excelência (fl. 479, RE n. 220.096) afirma que a ECT recebe um ofício do TRT e faz um lançamento. Ou seja, sem nenhuma base normativa, a ECT paga suas dívidas com espeque em um "precatório informal". À míngua dessa base normativa, o ministro Ilmar Galvão indagou se esse entendimento é firmado no "direito natural”, pois não há respaldo no "direito positivo brasileiro". O ministro Moreira Alves rebate dizendo que não é por direito natural, mas com base em interpretação do Supremo Tribunal Federal (fls. 479-483).

Mas, indaga-se: a interpretação do STF tem base normativa constitucional? Não. O parâmetro do Tribunal foi ele mesmo, pois o sistema normativo vigente (art. 100, CF) não autorizava o Tribunal a decidir que a ECT pagasse os seus débitos via precatórios informais. Nenhum tribunal pode decidir as causas com base em si próprio. Há de existir um parâmetro normativo válido e vigente, sob pena de se cair no arbítrio e no despotismo judicial. Toda decisão judicial, seja de que grau for, deve estar em conformidade com o ordenamento jurídico, deve estar em sintonia com o Direito e com a Justiça.

Juiz ou tribunal que decide com base em si mesmo, lembra o barão de Munchausen. Esse folclórico e ilustre personagem narrava uma estória segundo a qual ele e seu cavalo caíram em um lago. Estavam afundando, mas o barão teve a ideia de se puxar pelos próprios cabelos, e retirou a si e a seu cavalo apenas com a força de seu braço soerguendo-se, pelas próprias tranças do cabelo, sem nenhum ponto de apoio externo. ${ }^{80}$

Foi o que fez o Tribunal no citado exemplo. Em rigor, todas as vezes que um juiz ou tribunal decide sem amparo no ordenamento jurídico, ele faz às vezes de barão de Munchausen. Esse tipo de comportamento judicial enfraquece a confiança no sistema jurídico, e a quebra de confiança no Direito é ruim para a credibilidade das instituições. Crédito é credibilidade.

O CTN, no art. 185, enuncia que “[...] presume-se fraudulenta a alienação ou oneração de bens ou rendas, ou o seu começo, por sujeito passivo em débito para com a Fazenda Pública, por crédito tributário regularmente inscrito como dívida ativa". Essa presunção é afastada se o sujeito passivo reservar valores suficientes para garantir o pagamento de seus débitos devidamente inscritos (art. 185, parágrafo único).

A Lei Complementar n. 118/2005 acrescentou ao CTN o artigo 185-A que dispôs de reforço processual à proteção do crédito ao permitir que, mediante ordem judicial, sejam postos em indisponibilidade os bens e os direitos patrimoniais do devedor, inclusive com o bloqueio eletrônico de ativos financeiros. Essas medidas constritivas são draconianas, mas ou a proteção ao crédito tributário é forte e é para valer, ou não há que se falar em garantia do crédito. Cuide-se que, nos termos do art. 204, CTN, a dívida regularmente inscrita goza de presunção de certeza e liquidez e tem efeito de prova pré-constituída, podendo, todavia, ser ilidida

recíproca aplicar-se-ia em relação ao ISS, sob pena de desorganização desse serviço, dado que os municípios o tributariam de modo distinto. RE 601392/PR, rel. orig. Min. Joaquim Barbosa, red. p/ o acórdão Min. Gilmar Mendes, 28.2.2013. (Informativo STF n. 696, 1. 3.2013)”.

79 BRASIL. Supremo Tribunal Federal. Recurso Extraordinário n. 589.998. Recorrente: ECT - Empresa Brasileira de Correios e Telégrafos. Recorrido: Humberto Pereira Rodrigues. Relator: Ministro Ricardo Lewandowski. Local, 2008. Extrato da decisão: “O Tribunal deu provimento parcial ao recurso extraordinário para reconhecer a inaplicabilidade do art. 41 da Constituição Federal e exigir-se a necessidade de motivação para a prática legítima do ato de rescisão unilateral do contrato de trabalho, vencidos parcialmente os Ministros Eros Grau e Marco Aurélio. O Relator reajustou parcialmente seu voto. Em seguida, o Tribunal rejeitou questão de ordem do advogado da Empresa Brasileira de Correios e Telégrafos - ECT que suscitava fossem modulados os efeitos da decisão. Plenário, 20.03.2013 (Informativo STF n. 699)".

80 RASPE, Rudolf Erich. As aventuras do barão de Munchausen. Trad. Ana Goldberger. São Paulo: Iluminuras, 2013. p. 66. 
mediante prova inequívoca a cargo do sujeito passivo ou de terceiro interessado.

No título do visitado Capítulo VI, constam os termos "garantias" e "privilégios", mas o Código, a partir do art. 186, dispõe sobre "preferências". Segundo o CTN, o crédito tributário prefere a quaisquer outros créditos, exceto os decorrentes da legislação trabalhista ou de acidente de trabalho, bem como na hipótese de falência, em relação aos créditos extraconcursais.

A jurisprudência do STJ tem admitido que os créditos alimentares tenham preferência sobre os créditos tributários, mas dúvidas pairam em relação aos honorários advocatícios.

Inicialmente, o Tribunal entendeu que os créditos de honorários advocatícios seriam alimentares e teriam preferência sobre os créditos tributários (REsp 608.028). ${ }^{81}$ Posteriormente (e atualmente), essa orientação se modificou e, segundo o STJ, os créditos tributários preferem aos honorários advocatícios (EResp n. 1.146.066) ${ }^{82}$

Nada obstante o entendimento segundo o qual os créditos alimentares preferem aos créditos tributários, é possível entender que essa preferência decorre em relação àqueles oriundos de sentenças judiciais ou de pensões alimentícias, diretamente envolvidos na controvérsia judicial. Sendo assim, não é equivocado o entendimento do STJ no sentido de que os créditos tributários preferem aos honorários advocatícios.

Tema que interessa à Federação é concernente ao concurso de preferências disposto no parágrafo único do art. 187 do CTN. Segundo o Código, o crédito da União prefere em relação aos créditos dos Estados e Municípios; os dos Estados preferem aos dos Municípios. O STF tem a Súmula n. 563, de 15.12.1976: “[...] o concurso de preferência a que se refere o art. 187 do Código Tributário Nacional é compatível com o disposto no art. $9^{\circ}$, I, da Constituição Federal".

É defensável a tese, segundo a qual, em face da Constituição de 1988, esse preceito deve ser interpretado de outra maneira, pois não há hierarquia normativa entre a União, os Estados e os Municípios, uma vez que existente, isso sim, uma repartição constitucional de competências políticas e administrativas. ${ }^{83}$

O Código disciplina outras preferências do crédito tributário, como a que determina o pagamento preferencial dos créditos vencidos ou vincendos em face de créditos habilitados em inventários, arrolamentos ou processos de liquidação judicial (arts. 189 e 190).

O CTN, no art. 191, preceitua que "[...] a extinção das obrigações do falido requer prova de quitação de todos os tributos”. E no art. 191-A, “[...] a concessão de recuperação judicial depende da apresentação da prova de quitação de todos os tributos". Determina o Código, no art. 192, que “[...] nenhuma sentença de julgamento de partilha ou de adjudicação será proferida sem prova de quitação de todos os tributos relativos aos bens do espólio, ou às suas rendas”.

E, como último dispositivo do citado Capítulo VI, tem-se o disposto no art. 193:

81 BRASIL. Superior Tribunal de Justiça. Recurso Especial n. 608.028. Recorrentes: Alfredo Cândido Santos Ferreira e outro. Recorridos: Caninha Camponesa Centro Oeste Distribuidora de Bebidas Ltda e outra. Relatora: Ministra Nancy Andrighi. Local, 2005. Ementa: "Civil. Recurso especial. Ação de execução. Concurso de credores. Crédito tributário. Crédito de honorários advocatícios. Natureza alimentar. Ordem de preferência. Os honorários advocatícios, mesmo de sucumbência, têm natureza alimentar. A aleatoriedade no recebimento dessas verbas não retira tal característica, da mesma forma que, no âmbito do Direito do Trabalho, a aleatoriedade no recebimento de comissões não retira sua natureza salarial. A ausência de subordinação é irrelevante. Subordinação é um dos elementos de uma relação de emprego, mas não é o elemento específico que justifica a natureza alimentar do salário. O que a justifica é a necessidade de o empregado recebê-lo para viabilizar sua sobrevivência, aspecto que também se encontra no trabalho não subordinado prestado pelo causídico. Sendo alimentar a natureza dos honorários, estes preferem aos créditos tributários em execução contra devedor solvente. Inteligência do art. 186 do CTN”. Recurso especial a que se dá provimento.

82 BRASIL. Superior Tribunal de Justiça. Embargos de Divergência em Recurso Especial. Embargante: Claudionor Siqueira Benite. Embargada: Fazenda Nacional. Relator: Ministro Francisco Falcão. Local, 2010. Ementa: “CRÉDITOS DECORRENTES DE HONORÁRIOS ADVOCATÍCIOS. PRIVILÉGIO EM RELAÇÃO AOS CRÉDITOS TRIBUTÁRIOS. INEXISTÊNCIA. ARTIGOS 24 DA LEI 8.90694 e 186 DO CTN. I - Não obstante possua natureza alimentar e detenha privilégio geral em concurso de credores, o crédito decorrente de honorários advocatícios não precede ao crédito tributário, que sequer se sujeita a concurso de credores e prefere a qualquer outro, seja qual for o tempo de sua constituição ou a sua natureza (artigos 24 da Lei 8.90694 e 186 do CTN). II - Embargos de divergência improvidos".

83 CARVALHO, Paulo de Barros. Curso de direito tributário. 22. ed. São Paulo: Saraiva, 2010. p. 649-650. 
[...] salvo quando expressamente autorizado por lei, nenhum departamento da administração pública da União, dos Estados, do Distrito Federal ou dos Municípios, ou sua autarquia, celebrará contrato ou aceitará proposta em concorrência pública sem que contratante ou proponente faça prova da quitação de todos os tributos devidos à Fazenda Pública interessada, relativos à atividade em cujo exercício contrata ou concorre.

Esses são os preceitos normativos contidos no CTN sobre as garantias, privilégios e preferências do crédito tributário, sem embargo da existência de outras normas de reforço do crédito. Mas, como enuncia o próprio CTN, essas garantias, privilégios e preferências não se esgotam no específico capítulo nem mesmo no próprio Código.

Convém tecer breves considerações a respeito da Administração Tributária e o poder dever de fiscalização do Estado (arts. 194 a 208). O Tribunal enfrentará novamente a questão da quebra do sigilo bancário ou financeiro diretamente pelas autoridades administrativas, nos autos do RE n. $601.314 .{ }^{84}$ Diz-se novamente porque a Corte, nos autos do RE n. 389.808, ${ }^{85}$ decidiu que, sem ordem judicial, não pode a administração tributária quebrar o sigilo bancário dos contribuintes.

Essa decisão foi um duro golpe na fiscalização tributária e poderá ocasionar imensos prejuízos à recuperação

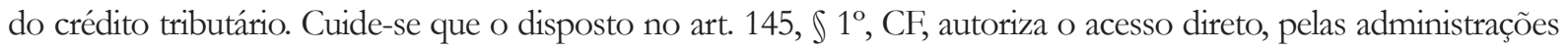
tributárias, dos dados financeiros e bancários dos contribuintes, sem necessidade de uma ordem judicial, bastando, tão somente, o devido processo administrativo, que já é bastante rigoroso nessas hipóteses de sigilo bancário e sigilo fiscal. Além do citado preceito, o art. 37, incisos XVIII e XXII, CF, dá suporte normativo à preponderância do Fisco e a uma integração das administrações fazendárias, visando, insista-se, ao fortalecimento do crédito tributário.

\section{A Constituição Federal é uma Constituição Tributária.}

Outro tema sensível para as administrações fazendárias consiste na jurisprudência do STF em relação às sanções políticas. Com efeito, o Tribunal tem uma tendência jurisprudencial segundo a qual os eventuais ônus administrativos que venham a constranger o devedor fiscal são sanções políticas. Essa linha interpretativa da Corte tem de ser vista com bastante cautela, pois o eventual afrouxamento da fiscalização e de ônus administrativos pode ensejar a práticas reiteradas de descumprimento da legislação tributária.

Ora, esse nocivo hábito tem afetado, inclusive, a concorrência e a competitividade entre os agentes econômicos, pois, insista-se, o não cumprimento das obrigações fiscais de alguns criará desequilíbrios com os que cumprem os seus deveres. O Tribunal tem várias manifestações sobre esse tema das sanções políticas:

84 BRASIL, Supremo Tribunal Federal. Recurso Extraordinário n. 601.314. Recorrente: Márcio Holcman. Recorrida: União Federal (Fazenda Nacional). Relator: Ministro Ricardo Lewandowski. Local, 2009: "EMENTA: CONSTITUCIONAL. SIGILO BANCÁRIO. FORNECIMENTO DE INFORMAÇÕES SOBRE MOVIMENTAÇÃO BANCÁRIA DE CONTRIBUINTES, PELAS INSTITUIÇÕES FINANCEIRAS, DIRETAMENTE AO FISCO, SEM PRÉVIA AUTORIZAÇÃO JUDICIAL (LEI COMPLEMENTAR 105/2001). POSSIBILIDADE DE APLICAÇÃO DA LEI 10.174/2001 PARA APURAÇÃO DE CRÉDITOS TRIBUTÁRIOS REFERENTES A EXERCÍCIOS ANTERIORES AO DE SUA VIGÊNCIA. RELEVÂNCIA JURÍDICA DA QUESTÃO CONSTITUCIONAL. EXISTÊNCIA DE REPERCUSSÃO GERAL”.

85 BRASIL. Supremo Tribunal Federal. Recurso Extraordinário n. 389.808. Recorrente: G.V.A. Indústria e Comércio S/A. Recorrida: União Federal (Fazenda Nacional). Relator: Ministro Marco Aurélio. Local, 2003. "EMENTA: SIGILO DE DADOS - AFASTAMENTO. Conforme disposto no inciso XII do artigo $5^{\circ}$ da Constituição Federal, a regra é a privacidade quanto à correspondência, às comunicações telegráficas, aos dados e às comunicações, ficando a exceção - a quebra do sigilo - submetida ao crivo de órgão equidistante - o Judiciário - e, mesmo assim, para efeito de investigação criminal ou instrução processual penal. SIGILO DE DADOS BANCÁRIOS - RECEITA FEDERAL. Conflita com a Carta da República norma legal atribuindo à Receita Federal - parte na relação jurídico-tributária - o afastamento do sigilo de dados relativos ao contribuinte". 
Súmulas n. $70,{ }^{86}$ n. $323^{87}$ e n. $547,{ }^{88}$ ADI n. $173,{ }^{89}$ AC n. $1.657,{ }^{90}$ ADI n. $395^{91}$ e RE n. $413.782,{ }^{92}$ dentre outros.

86 BRASIL. Supremo Tribunal Federal. Súmula n. 70, Local, de 13 de dezembro de 1963. "[...] é inadmissível a interdição de estabelecimento como meio coercitivo para cobrança de tributo".

87 BRASIL. Supremo Tribunal Federal. Súmula n. 323. Local, de 13 de dezembro de 1963. [...] é inadmissível a apreensão de mercadorias como meio coercitivo para pagamento de tributos".

88 BRASIL. Supremo Tribunal Federal. Súmula n. 547. Local, de 3 de dezembro de 1969. "[...] não é lícito à autoridade proibir que o contribuinte em débito adquira estampilhas, despache mercadorias nas alfândegas e exerça suas atividades profissionais".

89 BRASIL, Supremo Tribunal Federal. Ação Direta de Inconstitucionalidade n. 173. Requerente: Confederação Nacional da Indústria. Requeridos: Presidente da República e Congresso Nacional. Relator: Ministro Joaquim Barbosa. Local, 1990. Ementa: "CONSTITUCIONAL. DIREITO FUNDAMENTAL DE ACESSO AO JUDICIÁRIO. DIREITO DE PETIÇÃO. TRIBUTÁRIO E POLÍTICA FISCAL. REGULARIDADE FISCAL. NORMAS QUE CONDICIONAM A PRÁTICA DE ATOS DA VIDA CIVIL E EMPRESARIAL À QUITAÇÃO DE CRÉDITOS TRIBUTÁRIOS. CARACTERIZAÇÃO ESPECÍFICA COMO SANÇÃO POLÍTICA. AÇÃO CONHECIDA QUANTO À LEI FEDERAL 7.711/1988, ART. 1º I, III E IV, PAR. $1^{\circ}$ A $3^{\circ}$, E ART. $2^{\circ}$. 1. Ações diretas de inconstitucionalidade ajuizadas contra os arts. $1^{\circ}$, I, II, III e IV, par. $1^{\circ}$ a $3^{\circ}$ e $2^{\circ}$ da Lei 7.711/1988, que vinculam a transferência de domicilio para o exterior (art. $1^{\circ}$, I), registro ou arquivamento de contrato social, alteração contratual e distrato social perante o registro público competente, exceto quando praticado por microempresa (art. $1^{\circ}$, III), registro de contrato ou outros documentos em Cartórios de Registro de Títulos e Documentos (art. $1^{\circ}, \mathrm{IV}$, a), registro em Cartório de Registro de Imóveis (art. $1^{\circ}, \mathrm{IV}, \mathrm{b}$ ) e operação de empréstimo e de financiamento junto a instituição financeira, exceto quando destinada a saldar dívidas para com as Fazendas Nacional, Estaduais ou Municipais (art. $1^{\circ}, \mathrm{IV}, \mathrm{c}$ ) - estas três últimas nas hipóteses de o valor da operação ser igual ou superior a cinco mil Obrigações do Tesouro Nacional - à quitação de créditos tributários exigíveis, que tenham por objeto tributos e penalidades pecuniárias, bem como contribuições federais e outras imposições pecuniárias compulsórias. 2. Alegada violação do direito fundamental ao livre acesso ao Poder Judiciário (art. $5^{\circ}, \mathrm{XXXV}$ da Constituição), na medida em que as normas impedem o contribuinte de ir a juízo discutir a validade do crédito tributário. Caracterização de sanções políticas, isto é, de normas enviesadas a constranger o contribuinte, por vias oblíquas, ao recolhimento do crédito tributário. 3. Esta Corte tem historicamente confirmado e garantido a proibição constitucional às sanções políticas, invocando, para tanto, o direito ao exercício de atividades econômicas e profissionais lícitas (art. 170, par. ún., da Constituição), a violação do devido processo legal substantivo (falta de proporcionalidade e razoabilidade de medidas gravosas que se predispõem a substituir os mecanismos de cobrança de créditos tributários) e a violação do devido processo legal manifestado no direito de acesso aos órgãos do Executivo ou do Judiciário tanto para controle da validade dos créditos tributários, cuja inadimplência pretensamente justifica a nefasta penalidade, quanto para controle do próprio ato que culmina na restrição. É inequívoco, contudo, que a orientação firmada pelo Supremo Tribunal Federal não serve de escusa ao deliberado e temerário desrespeito à legislação tributária. Não há que se falar em sanção política se as restrições à prática de atividade econômica objetivam combater estruturas empresariais que têm na inadimplência tributária sistemática e consciente sua maior vantagem concorrencial. Para ser tida como inconstitucional, a restrição ao exercício de atividade econômica deve ser desproporcional e não-razoável. 4. Os incisos I, III e IV do art. $1^{\circ}$ violam o art. $5^{\circ}$, XXXV da Constituição, na medida em que ignoram sumariamente o direito do contribuinte de rever em âmbito judicial ou administrativo a validade de créditos tributários. Violam, também o art. 170, par. ún. da Constituição, que garante o exercício de atividades profissionais ou econômicas lícitas. Declaração de inconstitucionalidade do art. 1º, I, III e IV da Lei 7.711/'988. Declaração de inconstitucionalidade, por arrastamento dos parágrafos $1^{\circ}$ a $3^{\circ}$ e do art. $2^{\circ}$ do mesmo texto legal". "CONSTITUCIONAL. TRIBUTÁRIO. SANÇÃO POLÍTICA. PROVA DA QUITAÇÃO DE CRÉDITOS TRIBUTÁRIOS NO ÂMBITO DE PROCESSO LICITATÓRIO. REVOGAÇ̃̃O DO ART. 1ª II DA LEI 7.711/1988 PELA LEI 8.666/1993. EXPLICITAÇÃO DO ALCANCE DO DISPOSITIVO. AÇÃO DIRETA DE INCONSTITUCIONALIDADE NÃO CONHECIDA QUANTO AO PONTO. 5. Ação direta de inconstitucionalidade não conhecida, em relação ao art. 1º II da Lei 7.711/1988, na medida em que revogado, por estar abrangido pelo dispositivo da Lei 8.666/1993 que trata da regularidade fiscal no âmbito de processo licitatório. 6. Explicitação da Corte, no sentido de que a regularidade fiscal aludida implica 'exigibilidade da quitação quando o tributo não seja objeto de discussão judicial' ou 'administrativa'. Ações Diretas de Inconstitucionalidade parcialmente conhecidas e, na parte conhecida, julgadas procedentes.” 90 BRASIL, Supremo Tribunal Federal. Ação Cautelar n. 1.657. Requerente: American Virginia Indústria e Comércio, Importação e Exportação de Tabacos Ltda. Requerida: União Federal (Fazenda Nacional). Relator: Ministro Joaquim Barbosa. Local, 2007. Ementa: "RECURSO. Extraordinário. Efeito suspensivo. Inadmissibilidade. Estabelecimento industrial. Interdição pela Secretaria da Receita Federal. Fabricação de cigarros. Cancelamento do registro especial para produção. Legalidade aparente. Inadimplemento sistemático e isolado da obrigação de pagar Imposto sobre Produtos Industrializados - IPI. Comportamento ofensivo à livre concorrência. Singularidade do mercado e do caso. Liminar indeferida em ação cautelar. Inexistência de razoabilidade jurídica da pretensão. Votos vencidos. Carece de razoabilidade jurídica, para efeito de emprestar efeito suspensivo a recurso extraordinário, a pretensão de indústria de cigarros que, deixando sistemática e isoladamente de recolher o Imposto sobre Produtos Industrializados, com conseqüente redução do preço de venda da mercadoria e ofensa à livre concorrência, viu cancelado o registro especial e interditados os estabelecimentos".

91 BRASIL, Supremo Tribunal Federal. Ação Direta de Inconstitucionalidade n. 395. Requerente: Conselho Federal da Ordem dos Advogados do Brasil. Requerida: Assembleia Legislativa do Estado de São Paulo. Relatora: Ministra Cármen Lúcia. Local, 1990. Ementa: "AÇÃ̃O DIRETA DE INCONSTITUCIONALIDADE. ART. 163, \ $7^{\circ}$, DA CONSTITUIÇÃO DE SÃO PAULO: INOCORRÊNCIA DE SANÇÕES POLÍTICAS. AUSÊNCIA DE AFRONTA AO ART. 5, INC. XIII, DA CONSTITUIÇÃO DA REPÚBLICA. 1.

A retenção da mercadoria, até a comprovação da posse legítima daquele que a transporta, não constitui coação imposta em desrespeito ao princípio do devido processo legal tributário. 2. Ao garantir o livre exercício de qualquer trabalho, ofício ou profissão, o art. $5^{\circ}$, inc. XIII, da Constituição da República não o faz de forma absoluta, pelo que a observância dos recolhimentos tributários no desempenho dessas atividades impõe-se legal e legitimamente. 3. A hipótese de retenção temporária de mercadorias prevista no art. 163, \ $7^{\circ}$, da Constituição de São Paulo, é providência para a fiscalização do cumprimento da legislação tributária nesse território e consubstancia exercício do poder de polícia da Administração Pública Fazendária, estabelecida legalmente para os casos de ilícito tributário. Inexiste, por isso mesmo, a alegada coação indireta do contribuinte para satisfazer débitos com a Fazenda Pública. 4. Ação Direta de Inconstitucionalidade julgada improcedente". 92 BRASIL. Supremo Tribunal Federal. Recurso Extraordinário n. 413.782. Recorrente: VARIG S/A. Recorrido: Estado de Santa Catarina. Relator: Ministro Marco Aurélio. Local, 2004. Ementa: “DÉBITO FISCAL - IMPRESSÃO DE NOTAS FISCAIS - PROIBIÇÃO 
Em linha de princípio é de se entender que a vedação às sanções políticas tributárias deve ocorrer na hipótese de ato ou procedimento estatal for manifestamente desarrazoado e desproporcional, colocando em risco a atividade empresarial ou econômica lícita do contribuinte.

Nessa perspectiva, após a visitação à estática normativa (textos), à dinâmica normativa (decisões judiciais) e à doutrina jurídica (magistério acadêmico), vê-se que o crédito tributário, apesar de todos os esforços da administração tributária, ainda está longe de ser plenamente eficaz. Com efeito, os agentes fiscais, neste País, estão longe de conquistarem o indispensável respeito para que as leis tributárias sejam obedecidas ou temidas. ${ }^{93} 94$

\section{Considerações finais}

As leis não têm pernas, nem braços, nem bocas. É preciso que alguém corra, pegue ou fale por elas. Mas de nada adiantam muitos braços, pernas e bocas se os destinatários das leis não quiserem voluntariamente aderir a elas. Não há braços, pernas e bocas suficientes para garantirem o fiel cumprimento de todas as leis. A livre adesão e a obediência às leis, especialmente as lícitas e as legítimas, é o melhor caminho para a estabilidade social.

O crédito tributário, nos regimes políticos democráticos, consiste na legítima e lícita pretensão da Fazenda Pública em cobrar os valores que lhe sejam devidos pelos contribuintes ou responsáveis. Nos sistemas legítimos, ninguém tem o direito jurídico ou moral de não cumprir com as suas obrigações sociais e jurídicas.

A despeito de uma legislação protetiva do crédito tributário, os juízes e os tribunais brasileiros tendem a decidir no sentido de restringirem os poderes e as faculdades da fiscalização da administração tributária, ampliando substantivamente as prerrogativas dos contribuintes ou responsáveis devedores.

Essa orientação jurisprudencial deve ser influência de um passado autoritário dos governos brasileiros, de modo que, contra a sanha arrecadatória dos Fiscos, faz-se necessário opor freios. Todavia, nos regimes democráticos, tanto os Fiscos quanto os contribuintes devem pautar suas condutas em rigorosa obediência ao Direito e à Justiça. Se acaso, o Fisco ou o contribuinte se desviarem dos caminhos da legalidade, deve o Judiciário corrigir esses desvios, de modo a garantir a higidez e a idoneidade do crédito tributário.

\section{REFERÊNCIAS}

ANDRADE, Fábio Martins de. Modulação em matéria tributária: o argumento pragmático on consequencialista de cunho econômico e as decisões do STF. São Paulo: Quartier Latin, 2011.

- INSUBSISTÊNCIA. Surge conflitante com a Carta da República legislação estadual que proíbe a impressão de notas fiscais em bloco, subordinando o contribuinte, quando este se encontra em débito para com o fisco, ao requerimento de expedição, negócio a negócio, de nota fiscal avulsa".

93 SUASSUNA, Ariano. O Auto da Compadecida. 11. ed. Rio de Janeiro: Agir, 1975.

94 ARRAES, Guel; FALCÃO, Adriana; FALCÃO, João. O Auto da Compadecida: adaptação da obra de Ariano Suassuna. Rio de Janeiro: Rede Globo, 1999. Recorde-se outra peça shakespeariana, mas da autoria de Ariano Suassuna intitulada o "Auto da Compadecida", na sua adaptação para o cinema/televisão, que também tem uma "cláusula penal” similar à contida em "O Mercador de Veneza". Mas nesse caso, outra passagem desse clássico da arte brasileira. Cuida-se da ordem do cangaceiro "capitão" Severino de Aracaju para que um "cabra" seu atire no padre e no bispo. O jagunço diz que não gosta de matar padre não, que dá um azar danado, mas que "capitão" mandou, está mandado. E atira matando os sacerdotes católicos. É o que muitas vezes ocorre com os procuradores fiscais. Nem sempre gostam de fazer o que fazem: cobrar tributos. Mas se a "capitã” Lei mandou está mandado. Não tem alternativa a não ser cobrar os tributos legalmente devidos. De preferência, sem ter de cortar uma libra de carne ou uma "tira de couro". E sem ter de derramar uma gota de sangue. 
ANDRADE, José Maria Arruda de. Interpretação da norma tributária. São Paulo: MP, 2006.

ARRAES, Guel; FALCÃO, Adriana; FALCÃO, João. O Auto da Compadecida: adaptação da obra de Ariano Suassuna. Rio de Janeiro: Rede Globo, 1999.

ATALIBA, Geraldo. Hipótese de incidência tributária. 5. ed. São Paulo: Malheiros, 1992.

ÁVILA, Humberto. Segurança jurídica: entre permanência, mudança e realização no direito tributário. São Paulo: Malheiros, 2011.

BALEEIRO, Aliomar. Direito tributário brasileiro. 11. ed. Atualizado por Misabel Derzi. Rio de Janeiro: Forense, 2005.

BALEEIRO, Aliomar. Limitações constitucionais ao poder de limitar. 7. ed. Atualizada por Misabel Abreu Machado Derzi. Rio de Janeiro: Forense, 2005.

BECKER, Alfredo Augusto. Teoria geral do direito tributário. 3. ed. São Paulo: Lejus, 1998.

BÍBLIA Sagrada. Novo Testamento. Mateus, capítulo 21, versículo 31; Lucas, capítulo 19, versículos 1-9.

BOBBIO, Norberto. O futuro da democracia. Tradução de Marco Aurélio Nogueira. São Paulo: Paz e Terra, 2000 .

BORGES, José Souto Maior. Lançamento tributário. 2. ed. São Paulo: Malheiros, 1999.

BRASIL. Instituto de Pesquisa Econômica e Aplicada. Custo e tempo do processo de execução fiscal promovido pela Procuradoria Geral da Fazenda Nacional (PGFN). Comunicados do IPEA, Brasília, n. 127, 2012. Disponível em: <www.ipea.gov.br>. Acesso em:

BRASIL. Lei n. 5.172, de 25.10.1966. Código Tributário Nacional, Capítulo VI - Garantias e Privilégios do Crédito Tributário, arts. 183 a 193. Local: Editora, ano.

BRASIL. Superior Tribunal de Justiça. Embargos de Divergência em Recurso Especial. Embargante: Claudionor Siqueira Benite. Embargada: Fazenda Nacional. Relator: Ministro Francisco Falcão. Local, 2010.

BRASIL. Superior Tribunal de Justiça. Embargos de Divergência no Recurso Especial n. 644.736. Embargante: União Federal (Fazenda Nacional). Embargado: Caxangá Veículos Ltda. Relator: Ministro Teori Zavascki. Local, 2007.

BRASIL. Superior Tribunal de Justiça. Recurso Especial n. 1.101.728. Recorrente: Borda do Campo Indústria e Comércio Ltda. Recorrido: Estado de São Paulo. Relator: Ministro Teori Zavascki. Local, 2008.

BRASIL. Superior Tribunal de Justiça. Recurso Especial n. 608.028. Recorrentes: Alfredo Cândido Santos Ferreira e outro. Recorridos: Caninha Camponesa Centro Oeste Distribuidora de Bebidas Ltda e outra. Relatora: Ministra Nancy Andrighi. Local, 2005.

BRASIL. Supremo Tribunal Federal. Ação Cautelar n. 1.657. Requerente: American Virginia Indústria e Comércio, Importação e Exportação de Tabacos Ltda. Requerida: União Federal (Fazenda Nacional). Relator: Ministro Joaquim Barbosa. Local, 2007.

BRASIL. Supremo Tribunal Federal. Ação Direta de Inconstitucionalidade n. 173. Requerente: Confederação Nacional da Indústria. Requeridos: Presidente da República e Congresso Nacional. Relator: Ministro Joaquim Barbosa. Local, 1990.

BRASIL. Supremo Tribunal Federal. Ação Direta de Inconstitucionalidade n. 395. Requerente: Conselho Federal da Ordem dos Advogados do Brasil. Requerida: Assembleia Legislativa do Estado de São Paulo. Relatora: Ministra Cármen Lúcia. Local, 1990.

BRASIL. Supremo Tribunal Federal. Ação direta de inconstitucionalidade n. 2.446. Requerente: Confederação Nacional da Indústria. Requeridos: Presidente da República e Congresso Nacional. Relatora originária: Mi- 
nistra Ellen Gracie. Relatora redistribuída: Ministra Cármen Lúcia. Local, 2001.

BRASIL. Supremo Tribunal Federal. Ação direta de inconstitucionalidade n. 2.675. Requerente: Governador do Estado de Pernambuco. Requerida: Assembléia Legislativa do Estado de Pernambuco. Relator originário: Ministro Carlos Velloso. Relator: redistribuído: Ministro Ricardo Lewandowski. Local, 2002.

BRASIL. Supremo Tribunal Federal. Ação direta de inconstitucionalidade n. 2.777. Relatoria originária Ministro Sydney Sanches. Relatoria redistribuída Ministro Teori Zavascki. Requerente: Governador do Estado de São Paulo. Requerida: Assembleia Legislativa do Estado de São Paulo. Local, 2002.

BRASIL. Supremo Tribunal Federal. Ação direta de inconstitucionalidade n. 1.851. Requerente: Confederação Nacional do Comércio. Requerido: Estado de Alagoas. Relator: Ministro Ilmar Galvão. Local, 1998.

BRASIL. Supremo Tribunal Federal. Ação Direta de Inconstitucionalidade n. 2. Requerente: Federação Nacional dos Estabelecimentos de Ensino - FENEN. Requerido: Presidente da República. Relator: Ministro Paulo Brossard. Local, 1988.

BRASIL. Supremo Tribunal Federal. Recurso Extraordinário n. 194.382. Recorrente: Estado de São Paulo. Recorrida: Divesca Veículos Ltda. Relator: Ministro Maurício Correa. Local, 1995.

BRASIL. Supremo Tribunal Federal. Recurso Extraordinário n. 197.917. Recorrente: Ministério Público do Estado de São Paulo. Recorrida: Câmara Municipal de Mira Estrela. Relator: Ministro Maurício Corrêa. Local, 1987.

BRASIL. Supremo Tribunal Federal. Recurso Extraordinário n. 212.484. Redator: Ministro Nelson Jobim. Recorrente: União Federal (Fazenda Nacional). Recorrida: Vonpar Refrescos S/A. Local, 1997.

BRASIL. Supremo Tribunal Federal. Recurso Extraordinário n. 213.396. Recorrente: Estado de São Paulo. Recorrida: Diasa Distribuidora e Importadora de Automóveis S/A. Relator: Ministro Ilmar Galvão. Local, 1997.

BRASIL. Supremo Tribunal Federal. Recurso Extraordinário n. 220.906. Recorrente: ECT - Empresa Brasileira de Correios e Telégrafos. Recorrido: Ismar José da Costa. Relator: Ministro Maurício Corrêa. Local, 1997.

BRASIL. Supremo Tribunal Federal. Recurso Extraordinário n. 266.523. Recorrente: Ricar Automóveis Ltda. Recorrido: Estado de Minas Gerais. Relator: Ministro Mauríco Correa. Local, 2000.

BRASIL. Supremo Tribunal Federal. Recurso Extraordinário n. 353.657. Recorrente: União Federal (Fazenda Nacional). Recorrida: Madeireira Santo Antônio Ltda. Relator: Ministro Marco Aurélio. Local, 2002.

BRASIL. Supremo Tribunal Federal. Recurso Extraordinário n. 357.277. Redatoria Ministro Nelson Jobim. Recorrente: União Federal (Fazenda Nacional). Recorrida: Cooperativa Vinícola Garibaldi. Local, 2002.

BRASIL. Supremo Tribunal Federal. Recurso Extraordinário n. 363.889. Recorrentes: Ministério Público do Distrito Federal e Territórios e outro. Recorrido: Goiá Fonseca Rates. Relator: Ministro Dias Toffoli. Local, 2002.

BRASIL. Supremo Tribunal Federal. Recurso Extraordinário n. 370.682. Recorrente: União Federal (Fazenda Nacional). Recorrida: Indústria de Embalagens Plásticas Guará Ltda. Relator: Ministro Ilmar Galvão. Local, 2003.

BRASIL. Supremo Tribunal Federal. Recurso Extraordinário n. 389.808. Recorrente: G.V.A. Indústria e Comércio S/A. Recorrida: União Federal (Fazenda Nacional). Relator: Ministro Marco Aurélio. Local, 2003.

BRASIL. Supremo Tribunal Federal. Recurso Extraordinário n. 413.782. Recorrente: VARIG S/A. Recorrido: Estado de Santa Catarina. Relator: Ministro Marco Aurélio. Local, 2004.

BRASIL. Supremo Tribunal Federal. Recurso Extraordinário n. 566.621. Recorrente: União Federal (Fazenda Nacional). Recorrido: Ruy Cesar Abella Ferreira. Relatora: Ministra Ellen Gracie. Local, 2007. 
BRASIL. Supremo Tribunal Federal. Recurso Extraordinário n. 566.819. Recorrente: Jofran Embalagens Ltda. Recorrida: União Federal (Fazenda Nacional). Relator: Ministro Marco Aurélio. Local, 2007.

BRASIL. Supremo Tribunal Federal. Recurso Extraordinário n. 586.453. Recorrente: Fundação Petrobrás de Seguridade Social - PETROS. Recorrida: Petróleo Brasileiro S/A - PETROBRAS. Relatora: Ministra Rosa Weber. Local, 2008.

BRASIL. Supremo Tribunal Federal. Recurso Extraordinário n. 589.998. Recorrente: ECT - Empresa Brasileira de Correios e Telégrafos. Recorrido: Humberto Pereira Rodrigues. Relator: Ministro Ricardo Lewandowski. Local, 2008.

BRASIL. Supremo Tribunal Federal. Recurso Extraordinário n. 593.849. Recorrente: Parati Petróleo Ltda. Recorrido: Estado de Minas Gerais. Relator: Ministro Ricardo Lewandowski. Local, 2008.

BRASIL. Supremo Tribunal Federal. Recurso Extraordinário n. 596.832. Recorrentes: Posto de Gasolina Rei de Mesquita Ltda e outros. Recorrida: União Federal (Fazenda Nacional). Relator: Ministro Marco Aurélio. Local, 2009.

BRASIL. Supremo Tribunal Federal. Recurso Extraordinário n. 598.677. Recorrente: Estado do Rio Grande do Sul. Recorrida: Juliana Enderle Fontoura. Relator: Ministro Dias Toffoli. Local, 2009.

BRASIL. Supremo Tribunal Federal. Recurso Extraordinário n. 601.314. Recorrente: Márcio Holcman. Recorrida: União Federal (Fazenda Nacional). Relator: Ministro Ricardo Lewandowski. Local, 2009.

BRASIL. Supremo Tribunal Federal. Recurso Extraordinário n. 601.392. Redatoria Ministro Gilmar Mendes. Recorrente: ECT - Empresa Brasileira de Correios e Telégrafos. Recorrido: Município de Curitiba. Relator: Ministro Gilmar Mendes. Local, 2009.

BRASIL. Supremo Tribunal Federal. Recurso Extraordinário n. 603.191. Recorrente: Construtora Locatelli Ltda. Recorrida: União Federal (Fazenda Nacional). Relatora: Ministra Ellen Gracie. Local, 1999.

BRASIL. Supremo Tribunal Federal. Recurso Extraordinário. 562.276. Recorrente: União Federal (Fazenda Nacional). Recorrido: Owner's Bonés Promocionais Ltda - ME. Relatora: Ministra Ellen Gracie. Local, 2007.

BRASIL. Supremo Tribunal Federal. Súmula n. 323. Local, de 13 de dezembro de 1963.

BRASIL. Supremo Tribunal Federal. Súmula n. 547. Local, de 3 de dezembro de 1969.

BRASIL. Supremo Tribunal Federal. Súmula n. 70, Local, de 13 de dezembro de 1963.

CALMON, Sacha. Teoria geral do tributo e da exoneração tributária. São Paulo: RT, 1982.

CARRAZA, Roque Antônio. Curso de direito constitucional tributário. 25. ed. São Paulo: Malheiros, 2009.

CARVALHO, Paulo de Barros. Curso de direito tributário. 22. ed. São Paulo: Saraiva, 2010.

CARVALHO, Paulo de Barros. Direito tributário: fundamentos jurídicos da incidência. 7. ed. São Paulo: Saraiva, 2009.

COELHO, Sacha Calmon Navarro. Curso de direito tributário brasileiro. 8. ed. Rio de Janeiro: Forense, 2005, p. 876.

COSTA, Nelson Nery. Teoria e realidade da desobediência civil. Rio de Janeiro: Forense, 1990.

DERZI, Misabel. Direito tributário, direito penal e tipo. 2. ed. São Paulo: RT, 2007.

FALCÃO, Amílcar de Araújo. O fato gerador da obrigação tributária. São Paulo: RT, 1973.

FAORO, Raymundo. Os donos do poder: formação do patronato brasileiro. 7. ed. Rio de Janeiro: Globo, 2001.

GAMA, Tácio Lacerda. Competência tributária: fundamentos para uma teoria da nulidade. São Paulo: Noeses, 2009. 
GODOI, Marciano Seabra de. Fraude a la ley y conflicto em la aplicación de las leyes tributarias. Madrid: Instituto de Estudios Fiscales, 2005.

GODOY, Arnaldo Sampaio de Moraes. História da tributação no período joanino: 1808-1821. Brasília: ESAF, 2008

HABERMAS, Jürgen. Direito e democracia: entre facticidade e validade. Trad. Flávio Beno Siebeneichler. Rio de Janeiro: Tempo Brasileiro, 2003.

HOLANDA, Sérgio Buarque de. Raizes do Brasil. 26. ed. São Paulo: Companhia das Letras, 1995.

KELSEN, Hans. A democracia. Trad. Ivone Castilho Benedeti e outros. São Paulo: Martins Fontes, 1993.

KELSEN, Hans. Jurisdição constitucional. 3. ed. São Paulo: Martins Fontes, 2013.

MAGALHÃES, José Luiz Quadros de. Poder municipal: paradigmas para o estado constitucional brasileiro. Belo Horizonte: Del Rey, 1997.

NABAIS, José Casalta. O dever fundamental de pagar impostos: contributo para a compreensão constitucional do estado fiscal contemporâneo. Coimbra: Almedina, 1998.

PEREIRA, Cesar A. Guimarães. Elisão tributária e função administrativa. São Paulo: Dialética, 2001.

POPPER, Karl. A sociedade aberta e seus inimigos. Trad. Milton Amado. São Paulo: Itatiaia, 1987.

PRETA, Stanislaw Ponte. O melhor de Stanislaw Ponte Preta. São Paulo: José Olympio, 2011.

RASPE, Rudolf Erich. As aventuras do barão de Münchhausen. Trad. Ana Goldberger. São Paulo: Iluminuras, 2013.

RAWLS, John. Uma teoria da justiça. Trad. Almiro Piseta e Lenita Esteves. São Paulo: Martins Fontes, 2000.

ROLIM, João Dácio. Normas antielisivas tributárias. São Paulo: Dialética, 2001.

SCHOUERI, Luís Eduardo. Direito Tributário. São Paulo: Saraiva, 2011, p. 519-529.

SHAKESPEARE, William. O mercador de Veneza: 1596. Trad. F. Carlos de Almeida Cunha Medeiros e Oscar Mendes. São Paulo: Martins Fontes, 2006.

SOUSA, Rubens Gomes. Compêndio de legislação tributária. São Paulo: Resenha Tributária, 1975.

SUASSUNA, Ariano. O Auto da Compadecida. 11. ed. Rio de Janeiro: Agir, 1975.

TIPKE, Klaus. Moral tributária do Estado e dos contribuintes. Trad. Luiz Dória Furquim. Porto Alegre: Sergio Antonio Fabriz, 2012.

TORRES, Heleno Taveira. Direito constitucional tributário e segurança jurídica. São Paulo: RT, 2011.

TORRES, Ricardo Lobo. Normas de interpretação e integração do direito tributário. 4. ed. Rio de Janeiro: Renovar, 2006. 


\section{REVISTA BRASILEIRA DE POLÍTICAS PÚBLICAS BRAZILIAN JOURNAL OF PUBLIC POLICY}
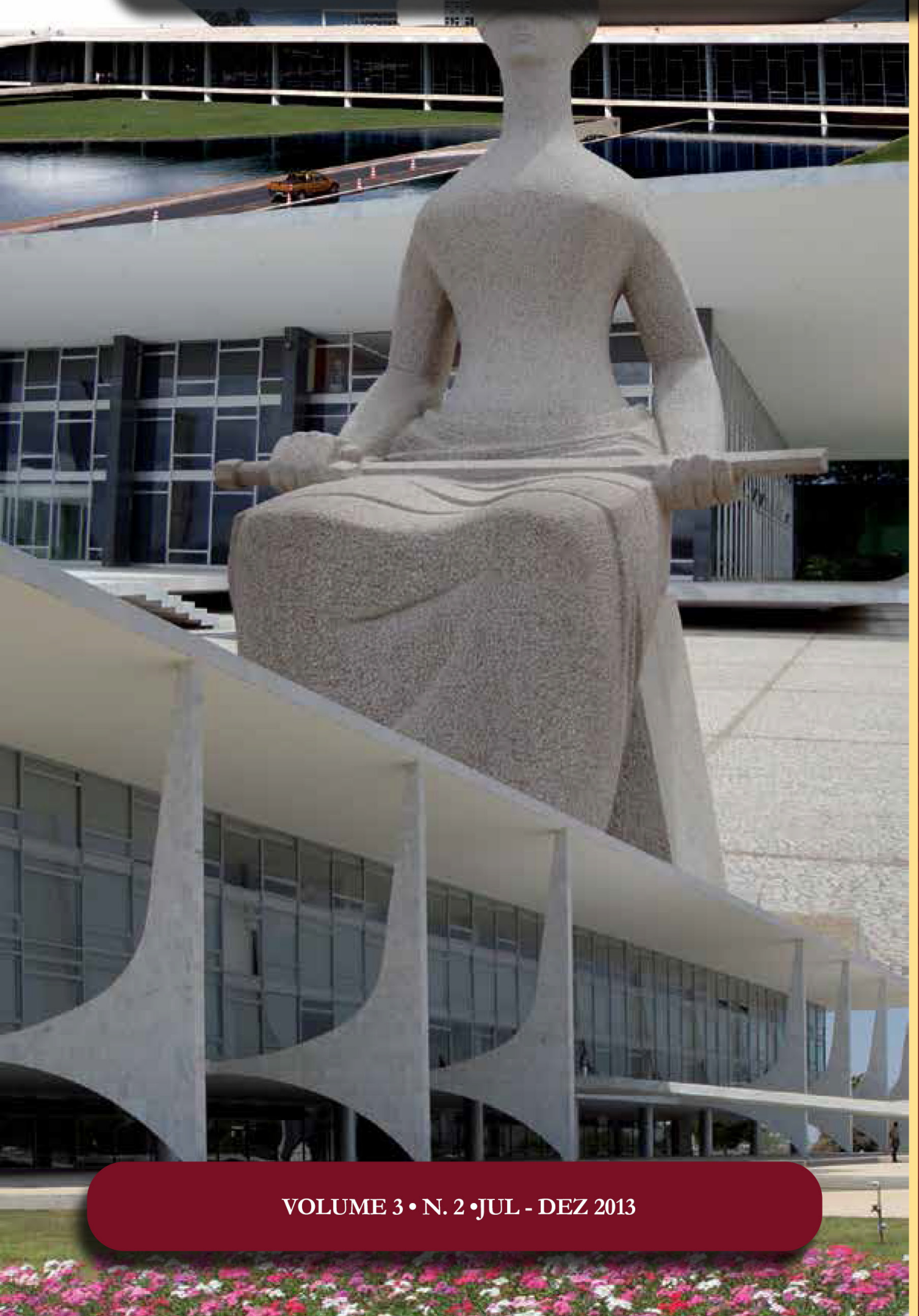

Tributário - O parecer PGFN/CRJ 492/2011 e os efeitos da coisa julgada inconstitucional em face da segurança jurídica no Estado Democrático de Direito 


\title{
Tributário - O parecer PGFN/CRJ 492/2011 e os efeitos da coisa julgada inconstitucional em face da segurança jurídica no Estado Democrático de Direito*
}

\author{
Antônio Frota Neves**
}

\section{Resumo}

O estudo da coisa julgada inconstitucional em matéria tributária ganhou uma importância singular em face do Parecer PGFN/CRJ 492/2011, uma vez que criou onerosidade ao contribuinte em desacordo com o arcabouço jurídico, notadamente, princípios basilares da Constituição Federal que, constituídos como garantias fundamentais, têm proteção máxima do legislador constituinte originário: a coisa julgada, a segurança jurídica e a limitação ao poder de tributar.

Palavras-chave: Inconstitucionalidade, coisa julgada, rescisória, segurança jurídica, relações continuativas.

\section{INTRODUÇÃo}

O presente artigo aborda uma análise reflexiva acerca do Parecer PGFN/ CRJ 492/2011, no qual se trata de um posicionamento jurídico-dogmático do Poder Executivo, por meio de sua Procuradoria Geral da Fazenda Nacional - PGFN que gera, de regra, uma situação onerosa aos contribuintes.

O referido Parecer é uma construção argumentativa, cujas premissas serão analisadas no decorrer deste estudo e que orientou e recomendou procedimentos fiscais e administrativos, a partir de sua publicação, no âmbito federal, a todas as unidades da própria Procuradoria da Fazenda Nacional como às unidades da Receita Federal do Brasil, notadamente, aos respectivos auditores fiscais.

Em linhas gerais, a questão nuclear é o perecimento da coisa julgada em matéria tributária, nas relações tributárias de trato sucessivo, cujo fundamento legal da sentença foi invalidada por decisão superveniente do Supremo Tribunal Federal - STF, seja declarando constitucional lei que outrora amparava decisão liminar em sentido contrário, seja declarando inconstitucional lei que outrora fundamentava decisão em posição oposta, em que ocorrendo tal situação, o desfazimento dos efeitos da coisa julgada ocorrerá automaticamente, sem necessidade alguma de novo crivo judicial, se já transcorrido lapso temporal da ação rescisória.

O que se objetiva neste artigo é a demonstração da exorbitância do Poder Executivo em face dos direitos fundamentais apregoados pela Constituição Federal - CF, ofensa às limitações ao poder de tributar, cujas garantias são esteio da segurança jurídica, proteção concedida pelo Estado aos cidadãos, sendo cláusulas de máxima segurança, portanto, irreformáveis.

\footnotetext{
** Professor universitário na Faculdade Pro-
jeção; aluno especial do Curso de Doutorado
em Direito no UNICEUB; advogado. advfro-

** Professor universitário na Faculdade Pro-
jeção; aluno especial do Curso de Doutorado
em Direito no UNICEUB; advogado. advfro-

** Professor universitário na Faculdade Pro-
jeção; aluno especial do Curso de Doutorado
em Direito no UNICEUB; advogado. advfrota@yahoo.com.br

Recebido em 28/04/2013 Aprovado em 27/08/2013
} 
Procurou-se balizar os contrapontos ao Parecer PGFN, utilizando-se das mesmas fontes, ou seja, na jurisprudência da nossa Magna Corte como também de respeitável doutrina nacional.

Assim, analisar-se-á diretamente o próprio Parecer PGFN/CRJ 492/2011 em seus pontos mais relevantes e contraditórios ao sistema jurídico vigente, à boa doutrina e à predominância da jurisprudência.

Complementando a referida análise, direcionar-se-á um especial enfoque aos institutos da coisa julgada formal e material, sendo mais específico o enfoque na coisa julgada material, pois é o objeto preponderante deste estudo bem como os meios disponíveis de se desconstituir a coisa julgada material com modificações jurisprudenciais supervenientes; tudo isso, em face da segurança jurídica, levando-se em conta o Estado Democrático Direito por que passa o país.

\title{
2. ANÁlise do parecer PGFN/CRJ 492/2011
}

O Parecer de autoria da Procuradora da Fazenda Nacional, Luana Vargas Macedo defende as seguintes teses: (i) a ocorrência de modificações fáticas ou jurídicas, no âmbito do STF, supervenientes às decisões judiciais com trânsito em julgado em matéria tributária, pertinentes às relações jurídicas de trato sucessivo, automaticamente faz cessar a eficácia vinculante, profuturo, daqueles julgados, em relação à exigibilidade das obrigações dos fatos geradores recorrentes; (ii) ocorrendo as modificações fáticas ou jurídicas ditas no item anterior, ainda no lapso decadencial da ação rescisória, nasce para o Estado o direito de pleitear retroativamente, obedecida a prescrição quinquenal, o tributo não pago.

\subsection{Bases objetivas}

Logo no início do parecer sub examine, faz-se a seguinte referência (MACEDO, 2011, p. 199):

\begin{abstract}
A alteração das circunstâncias fáticas ou jurídicas ao tempo da prolação de decisão judicial voltada à disciplina de uma dada relação jurídica de trato sucessivo faz surgir uma relação jurídica tributária nova, que, por isso, não é alcançada pelos limites objetivos que balizam a eficácia vinculante da referida decisão judicial. Daí por que se diz que, alteradas as circunstâncias fáticas ou jurídicas existentes à época da prolação da decisão, esta naturalmente deixa de produzir efeitos vinculantes, dali para frente, dada a sua natural inaptidão de alcançar a nova relação jurídica tributária.
\end{abstract}

É perceptível tratar-se de um sofisma, considerando a validade aparente da tese levantada, num contexto estanque, dissociado do arcabouço jurídico em sua inteireza, senão, veja-se, portanto, que o ponto fulcral do parecer é a desconstituição da relação jurídica na qual se baseara a decisão judicial que transitou em julgado, para inferir-se diante das alterações fáticas ou jurídicas supervenientes, agora estar diante de uma nova relação jurídica sem nenhum liame que a ligue a qual fora objeto da análise na sentença passado em julgado.

Ora, se isso fosse verdade, o artigo 471, inciso I, do CPC, seria letra morta da lei; não teria nenhuma razão de sua existência, pois trata exatamente da questão primeira levantada no Parecer sob estudo: “[...] relação jurídica continuativa que sobreveio modificação no estado de fato ou de direito; caso em que poderá a parte pedir revisão do que foi estatuído na sentença” (grifou-se). Ou seja, o legislador ordinário, em correto respeito à coisa julgada, remeteu ao Estado Juiz, a tarefa de verificar em quais contornos essa eventual modificação no estado de fato ou de direito se coadunam com os termos da sentença transitada em julgado. De certo, não ficará ao arbítrio de nenhuma das partes, estabelecer esses contornos.

E logo no item 2, do referido Parecer, traçam-se as bases com que a Fazenda Nacional pretende sustentar suas considerações argumentativas acerca dos efeitos da coisa julgada inconstitucional, notadamente, quando se tratar de relações jurídicas tributárias continuativas, cujos atributos dos precedentes do STF enquadrar-se-ão: 
(i) todos os formados em controle concentrado de constitucionalidade, independentemente da época em que prolatados; (ii) quando posteriores a 3 de maio de 2007, aqueles formados em sede de controle difuso de constitucionalidade, seguidos, ou não, de Resolução Senatorial, desde que, nesse último caso, tenham resultado de julgamento realizado nos moldes do art. 543-B do CPC; (iii) quando anteriores a 3 de maio de 2007, aqueles formados em sede de controle difuso de constitucionalidade, seguidos, ou não, de Resolução Senatorial, desde que, nesse último caso, tenham sido oriundos do Plenário do STF e confirmados em julgados posteriores da Suprema Corte.

Assim, as bases objetivas e temporais do referido Parecer podem ser explicitadas da seguinte maneira, os precedentes do STF: a) quando se tiver operado em controle concentrado de constitucionalidade, pois, seus efeitos, por natureza são erga omnes, ou seja, de pronto, a todos vinculam; b) quando posteriores a 3 de maio de 2007 (data que passou a vigorar a repercussão geral, em decorrência de alteração do Regimento Interno do STF, adaptado ao previsto no CPC, art. 543-B), cujo precedente tenha-se operado no controle difuso de constitucionalidade, desde que seguido de Resolução Senatorial; c) quando posteriores a 3 de maio de 2007, mesmo não seguidos de Resolução Senatorial, mas tenham sido julgados nos moldes do CPC, art. 543-B; d) quando anteriores a 3 de maio de 2007, aqueles oriundos do controle difuso de constitucionalidade, desde que tenham sido seguidos por Resolução Senatorial, ou caso não, sejam oriundos do Plenário do STF e confirmados em julgados posteriores desta Corte.

\subsection{Objeto específico do parecer}

É responder ao seguinte questionamento: (MACEDO, 2011, p. 200) “[...] em que medida a eficácia da decisão transitada em julgado que se volta para uma relação jurídica tributária sucessiva, considerando-a existente ou inexistente, é impactada, em relação aos seus desdobramentos futuros, pela superveniência de jurisprudência do STF em sentido contrário ao sufragado pela referida decisão?"(grifou-se).

É, desse modo, objeto específico do referido Parecer, a relação jurídica tributária, cuja hipótese de incidência, renova-se periodicamente, ou de forma recorrente, como por exemplos são o IR (Imposto sobre a Renda), o IPI (Imposto sobre Produtos Industrializados), o ICMS (Imposto sobre Circulação de Mercadorias e Serviços), o ISS (Imposto Sobre Serviços de qualquer natureza), dentre outros. E, ocorrendo decisão do STF em sentido contrário ao que dava suporte a determinado direito do contribuinte, esse direito deixa de existir, nascendo para a Fazenda Pública novo direito.

\subsection{CessaÇÃo da EFICÁCIA VINCULANTE, PRo FUtURO, dA COISA JULGAdA INCONSTITUCIONAL}

O Parecer se vale, nesse quesito, de uma construção argumentativa dedutiva, a partir da seguinte premissa: (Macedo, 2011, p. 205):

[...] as modificações nas circunstâncias jurídicas existentes ao tempo da prolação da decisão tributária posteriormente
transitada em julgado capazes de fazer cessar a sua eficácia vinculante são aquelas que, quando ocorridas, fazem
surgir uma relação jurídica tributária nova, diversa da deduzida inicialmente na demanda e, por isso mesmo, não
alcançada pelos limites objetivos da coisa julgada ali formada. Portanto, são aquelas que impactam ou alteram o
próprio sistema jurídico vigente - assim entendido como o conjunto de normas (regras e princípios) predestinadas
a disciplinar o convívio social -, representando, de certa forma e sob algum aspecto, 'direito novo'[...].

Percebe-se, claramente, o esforço do Parecer em dar uma elasticidade diferente às relações jurídicas tributárias de natureza continuativa, buscando trazer um efeito diverso do preconizado pelo legislador, em flagrante desrespeito à coisa julgada, notadamente quando se previu: CPC, art. 471 [...], "I - se, tratando-se de relação jurídica continuativa, sobreveio modificação no estado de fato ou de direito; caso em que poderá a parte pedir a revisão do que foi estatuído na sentença”. Repita-se, mais uma vez, determinou o legislador que somente o Poder Judiciário poderá apreciar os contornos da nova situação jurídica ou fática diante do 
enunciado sentencial que transitou em julgado, como meio e como mecanismo de proteção constitucional à coisa julgada.

E, após colocar como ponto de partida a premissa acima transcrita, o Parecer exemplifica como acontecimento óbvio, de ocorrência recorrente, circunstância jurídica provável capaz de alterar o status quo ante - instituição de nova lei ou modificações na própria lei existente, o que caracterizaria como "direito novo". Isso, por si só, seria suficiente para cessação da eficácia dos efeitos vinculantes da sentença passado em julgado, oriundos de relações jurídicas tributárias continuativas.

No tópico 18 do Parecer sob estudo, traz-se a lume, uma decisão do Superior Tribunal de Justiça STJ, cujo relator fora o Ministro Teori Zavascki, no MS 11045, Corte Especial, DJE 25/02/2010: “[...]. Tratando-se de relação jurídica de trato continuado, a eficácia temporal da sentença permanece enquanto se mantiverem inalterados esses pressupostos fáticos e jurídicos que lhe serviram de suporte [...]”. E no tópico 19, acrescenta que não só a alteração da legislação faz cessar os efeitos vinculantes como também as modificações jurisprudenciais consolidadas do STF.

É indiscutível a retidão do raciocínio inserto no Parecer, entretanto, necessário registrar que o Poder Judiciário aprecie e avalie o esquadro dessas modificações diante do que foi prolatado na sentença que transitou em julgado, sob pena de passar o Poder Executivo a usurpar a competência do Judiciário nessa seara.

Há de se consignar que a segurança jurídica, base do Estado Democrático de Direito, em especial no campo do Direito Tributário, tem nos seus pilares "previsibilidade" e "calculabilidade", a certeza jurídica de que necessita para estabelecer uma série de ações pragmáticas com vistas ao desenvolvimento de suas atividades, notadamente, as sociedades empresárias componentes de um universo concorrencial altamente acirrado. E é nesse escopo, que Fábio Martins de Andrade (2011, p. 276-277), enuncia:

A previsibilidade - que é o 'núcleo conceitual' da noção de segurança jurídica -, por sua vez, desdobra-se em duas dimensões distintas, quais sejam: a certeza quanto à norma aplicável às relações sociais que se estabelecem (certeza jurídica ou estabilidade) e a expectativa ou confiança quanto à situação de cada um nas relações sociais de que participa (proteção da confiança).

Aqui não se discute se ocorre ou não a cessação da eficácia da coisa julgada inconstitucional. O que se discute, de fato, é, obedecido o sobreprincípio da segurança jurídica, aí incluídos todos no contexto constitucional, naturalmente os de proteção do contribuinte, a necessidade da verificação dos contornos e reflexos da decisão do STF à coisa julgada e sua adequação aos princípios da não surpresa, no que tange às limitações ao Poder de Tributar do Estado.

O próprio legislador processual civil CPC, art. 468, determinou que "[...] a sentença, que julgar total ou parcialmente a lide, tem força de lei nos limites da lide e das questões decididas". Ora, se a coisa julgada tem força de lei, é lei intrapartes, portanto, deve se submeter aos princípios do Direito Tributário tal qual, qualquer lei, ou seja, deve obediência aos princípios da Irretroatividade, da Anterioridade e da regra da nonagesimal.

E assim, para Humberto Ávila (2012, p. 205-206), a CF/88, composta de sistemas e subsistemas, coordenados e harmônicos entre si, revela, em conformidade com o Estado Democrático de Direito, uma moldura de segurança jurídica, e em especial, o Sistema Tributário Nacional, cujo plexo jurídico desenha com segurança os tributos que: “[...] podem ser instituídos (art. 145, 148 e 149, 153 e ss., 155 e ss. e 195 e ss.), como devem ser cobrados (art. 150, I), quando puderem ser exigidos (art. 150, I e III) e em que medida podem restringir os direitos fundamentais dos contribuintes (art. 150, II e IV)".

Fica muito claro que qualquer alteração normativa em matéria tributária, necessariamente, deverá obedecer ao regramento protetivo do contribuinte, previsto no Sistema Tributário Nacional. E, fazendo coisa julgada, o Acórdão que declarou inconstitucional determinada lei ou ato normativo federal, terá força de lei e, consequentemente, deverá submeter-se à segurança jurídica preconizada nas limitações ao poder de tributar. 

definitivo do STF em sentido contrário

A configuração desse fenômeno jurídico vem expresso no Parecer sob estudo, da seguinte forma (Macedo, p. 208):

[...] para que um precedente do STF seja capaz de efetivamente alterar ou impactar o sistema jurídico vigente, agregando-lhe um elemento novo, faz-se necessário que nele se possam identificar duas características essenciais: primeira - que se trate de decisão que enfrenta uma dada questão constitucional de forma objetiva, resolvendo-a em tese, sem qualquer apego a dados subjetivos da demanda concreta; segunda - que essa decisão, além de objetiva, seja definitiva, ou seja, esteja vocacionada a representar a palavra final da Suprema Corte acerca da questão constitucional apreciada, dando-lhe solução estável, apta a se aplicar à generalidade das situações que, eventualmente, apresentem questão idêntica.

É de se notar, nessa abordagem, que mais uma vez o Parecer traz um sofisma, ou seja, apresenta uma tese absolutamente verdadeira para justificar uma segunda que em nada congrui com a primeira, senão, veja-se: (i) não se discute que as decisões do STF, notadamente, as que geram efeito erga omnes, a todos vinculam; (ii) entretanto, não é verdade que essa assertiva, por si só, tem o condão, pela análise do Poder Executivo, e possa fazer um juízo de conformação com a coisa julgada. Portanto, percebe-se, com clareza, que a primeira assertiva não serve e não autoriza o Poder Executivo a proceder à desconsideração, ao seu alvitre da coisa passado em julgado.

Se assim fosse, não precisaria a Fazenda Pública valer-se da Ação Rescisória para cobrar eventuais tributos decorrentes da coisa julgada inconstitucional com efeitos "ex tunc". Nessa linha de raciocínio, bastar-lheia, inscrever na Dívida Ativa os contribuintes que se encontrassem em tal situação fiscal. Pelo contrário, tão duvidoso é o direito da Fazenda Nacional, que o próprio Parecer orienta a impetração das referidas ações rescisórias para, eventualmente, recuperar os tributos devidos e que, amparados por decisão judicial, transitados em julgado, não foram pagos.

Para Heleno Taveira Torres (2012, p. 389), ao analisar os efeitos da coisa julgada inconstitucional, nas relações jurídicas tributárias de natureza continuativa, ou ditas de trato sucessivo, quando essa inconstitucionalidade se opera supervenientemente ao trânsito em julgado, “[...] é imodificável pela simples acomodação da jurisprudência em sentido diverso da lide e das questões nela decididas. [...] Alegações de isonomia ou de afetação à concorrência não colhem oportunidade para justificar a exclusão da coisa julgada".

O que se percebe, portanto, é uma tentativa de remediar a inépcia da Fazenda Nacional, quando não utilizou de todos os recursos disponíveis, no caso concreto, seja por insuficiência dos seus quadros operativos, seja por desídia, de forma a levar questões contrárias ao seu interesse ao crivo da mais Alta Corte do país. E agora, tenta consertar o que não deveria ter acontecido por sua própria negligência. Esse é o preço da segurança jurídica e da proteção constitucional aos direitos fundamentais e ao Estado Democrático de Direito, e em especial à coisa julgada material.

\section{5 a suspensão de execução de lei pelo Senado Federal e a repercussão geral nos moldes do CPC, Art. 543-B}

O Parecer PGFN/CRJ 492/2011 traz a discussão do tema (MACEDO, 2011, p. 208-220), pinçando votos de poucos ministros do STF e opiniões doutrinárias minudentes, levando a acreditar tratar-se de matéria pacificada, tanto no âmbito do Supremo Tribunal Federal quando na doutrina majoritária.

Apresenta como exemplo a Reclamação Constitucional n. 4.335/AC, cuja relatoria pertence ao ministro Gilmar Ferreira Mendes, e que em apertada síntese trata de Habeas Corpus impetrado para possibilitar a progressão de regime em decorrência de julgamento de inconstitucionalidade do $\ 1^{\circ}$, do artigo $2^{\circ}$, da Lei 8.072/1990, portanto, em controle difuso de constitucionalidade. Ocorre, porém, que naquela reclamação, 
apenas o relator e o ministro Eros Grau votaram pela sua procedência, enquanto que os ministros Joaquim Barbosa e Sepúlveda Pertence foram pela improcedência, cujo julgamento foi interrompido pelo pedido de vista do ministro Ricardo Lewandoswski.

Até aquela data (meados de 2007), não havia o Senado Federal se manifestado na forma da CF/88, artigo 52, inciso X (suspensão de execução de lei declarada inconstitucional pelo STF). Em nenhum instante, o STF decidiu que a competência atribuída pelo legislador constituinte ao Senado Federal quanto à suspensão da eficácia de lei declarada inconstitucional fosse letra morta. A uma porque não está entre as atribuições do STF e a duas porque seria a mais flagrante usurpação de competência.

Quanto aos Recursos Extraordinários julgados sob a égide da Lei 11.418/2006, cuja eficácia iniciou-se em 03 de maio de 2007, quando foi alterado o Regimento Interno do STF, introduzindo-se o instituto da Repercussão Geral, dando efetividade ao CPC, artigo 543-B, não alterou a força da CF, em relação ao Senado Federal na sua competência para suspender a execução de lei julgada inconstitucional pelo STF, pois inexiste em nosso sistema jurídico revogação tácita de normativo constitucional. Inconcebível imaginar que a publicização de Resolução do Senado Federal nos moldes do artigo 52, X, da CF, teria função de mero folhetim de notícia.

No item 32 do Parecer, sob comento, (MACEDO, 2012, p. 213) traz-se a seguinte indagação: "resta saber, todavia, se aquela segunda diferença apontada como existente entre essas duas decisões, qual seja, a extensão - erga omnes ou interpartes - da eficácia vinculante delas emanadas, ainda persiste, ou não, nos dias atuais" (grifou-se). E logo em seguida no item 33, arremata: “[...] segundo aqui se entende, a feição objetiva e definitiva assumidas pelas decisões proferidas pelo STF nos moldes do art. 543-B do CPC, em sede de controle difuso de constitucionalidade, que em nada difere daquela que marca as decisões proferidas em controle concentrado [...]".

Quer a Fazenda Nacional, por meio de um silogismo, declarar ineficaz a norma constitucional que atribui competência ao Senado Federal para suspender a eficácia de norma julgada inconstitucional no controle difuso.

E é por isso que o STF até o momento não se pronunciou acerca desse melindrado assunto. O que por si só, tal inquestionável dúvida desautorizaria o Poder Executivo tratar o assunto como pacificado e criar onerosidade aos contribuintes, tornando nosso sistema tributário ainda mais inseguro, cujas consequências são altamente danosas aos capitais investidores que procuram portos mais seguros, notadamente, sob o ponto de vista jurídico.

Abstraindo-se, com muito esforço, para aceitar a inexigência de Resolução Senatorial, nos moldes da CF, artigo 52, X, conforme citado no Parecer à lição de Eduardo Appio (2008, p. 22) em que textua: “[...] desde fevereiro de 2008, quando então o Supremo Tribunal Federal passou a considerar que as decisões proferidas em sede de controle difuso (concreto), que até então atingiam apenas as partes (interpartes), também poderiam - a exemplo do controle concentrado - atingir terceiros [...]".

É forçoso concluir que essa interpretação não autoriza o Poder Executivo elaborar um juízo de conformação entre a coisa julgada material e os efeitos da inconstitucionalidade de lei declarada assim pelo STF. A vinculação erga omnes de tais decisões exaradas pelo STF, quer nos moldes do controle difuso, submetido à repercussão geral, quer no controle concentrado, é que a administração pública não poderá ficar inerte em tais casos, ou seja, necessariamente, não pode decidir discricionariamente se recorrerá ou não ao Poder Judiciário, no sentido de requerer a revisão dos efeitos da coisa julgada inconstitucional, pois somente aí ocorrerá o juízo de conformação ou verificação nos exatos termos da sentença transitada em julgado e a lei declarada inconstitucional.

E o Parecer junta alguns doutrinadores, pinçando novamente algumas decisões monocráticas, tanto do STF como do STJ, no sentido dessa vinculação erga omnes das decisões no controle difuso (concreto) de 
constitucionalidade pelo STF. Entretanto, o próprio Parecer se curva no item 41, conforme se transcreve (MACEDO, 2011, p. 217), in verbi:

[...] em que pesem todos os argumentos acima aventados, é certo que - especialmente à luz de uma interpretação literal da CF/88 e do CPC, bem como diante de dogmas tradicionais incorporados no sistema jurídico brasileiro e até o momento não integralmente superados, ainda não é possível se afirmar, com os ares peremptórios que uma afirmação assume, que as decisões proferidas pela Suprema Corte, em sede de controle difuso de constitucionalidade das leis, ainda que formadas nos moldes do art. 543-B do CPC, quando não seguidas por Resolução editada com fulcro no art. 52, inc. $\mathrm{X}$ da $\mathrm{CF} / 88$, ostentam eficácia vinculante erga omnes. O entendimento que ainda parece predominar, mormente, em setores mais conservadores da doutrina e da jurisprudência dos Tribunais, é o de que a extensão da eficácia vinculante é fator de distinção entre as decisões proferidas pelo STF em controle difuso e concentrado de constitucionalidade, sendo certo, ademais, que o art. 543-B do CPC, apesar de conferir aos precedentes formados sob as suas vestes uma força persuasiva especial e diferenciada, não lhes imprimiu, propriamente, força vinculante erga omnes.

Apesar de reconhecer que parte substancial da doutrina e jurisprudência diverge na questão da eficácia erga omnes, das decisões proferidas pelo STF, em controle difuso de constitucionalidade, ainda assim, o Parecer, de moto próprio, pela Fazenda Pública Federal, concluiu pela validade da referida eficácia e nesse escopo direciona suas orientações.

\subsection{A cessação da eficácia vinculante da decisão tributária transitada em julgado é automáti- ca e independe de prévio reconhecimento judicial}

Realmente, esse é o ponto fulcral, contrário à segurança jurídica, à coisa julgada, aos direitos e às garantias fundamentais, não reconhecendo sequer as garantias constitucionais protetivas ao contribuinte, no que pertine às limitações constitucionais ao poder de tributar.

O Parecer sob exame faz referência a uma solitária posição doutrinária de Zavascki (2012, p. 139-140) acerca da cessação automática da eficácia vinculante da decisão transitada em julgado, conforme adiante relatado:

[...] a ação de revisão é indispensável apenas quando a relação jurídica material de trato continuado comportar, por disposição normativa, o direito potestativo antes referido [...]. Afora casos dessa natureza, a modificação do estado de fato ou de direito produz imediata e automaticamente a alteração da relação jurídica mesmo quando esta tiver sido certificada por sentença, conforme anteriormente assinalado.

Em esforço hercúleo, numa excepcional abstração das garantias constitucionais, consegue-se perpassar por todas as discussões anteriores, no que tange à relativização da coisa julgada material inconstitucional, nas relações jurídicas tributárias continuativas, ainda assim, não se pode imaginar, à míngua de uma análise judicial de conformação entre o teor do novo direito ou nova situação fática com os exatos fundamentos da sentença transitada em julgado.

Veja-se a lição de Torres (2012, p. 390), quando aborda os efeitos da coisa julgada que se fundou em lei tida por inconstitucional que posteriormente o STF a declarou constitucional:

[...] No que concerne à declaração de constitucionalidade, nos casos protegidos pelo manto da coisa julgada que tenham declarado a inconstitucionalidade da lei no caso concreto, preservada a coisa julgada material e atendidos os critérios de segurança jurídica quanto à irretroatividade, para que seja iniciada a cobrança do crédito tributário (efeitos ex nunc), deve-se observar ademais o princípio da anterioridade, após a notificação dos órgãos competentes, bem como as regras pertinentes à prescrição.

Pode-se observar, portanto, que o pretenso direito subjetivo da Fazenda Pública de constituir o crédito tributário, de forma automática, a partir da decisão do STF que modificou sua jurisprudência, com reflexos nos fundamentos que embasaram a coisa julgada material, em matéria tributária, favorável ao contribuinte, não se sustenta numa análise doutrinária, jurisprudencial e lógica no contexto normativo da Constituição Federal de 1988.

Tal raciocínio encontra-se embasado no voto do ministro Celso de Melo, por ocasião do julgamento do 
RE 594350/RS, e que, dada sua importância para o presente estudo, conforme citado por Torres (2012, p. 391), faz-se necessário transcrevê-lo, ainda que parcialmente, a fim de se obter uma compreensão do pensamento do decano da mais Alta Corte, in verbi:

[...] A sentença de mérito transitada em julgado só pode ser desconstituída mediante ajuizamento de específica ação autônoma de impugnação (ação rescisória) que haja sido proposta na fluência do prazo decadencial previsto em lei, pois, com o exaurimento do referido lapso temporal, estar-se-á diante da coisa soberanamente julgada, insuscetível de ulterior modificação, ainda que o ato sentencial encontre fundamento em legislação que, em momento posterior, tenha sido declarada inconstitucional pelo STF, quer em sede de controle abstrato, quer no âmbito da fiscalização incidental de constitucionalidade. A doutrina do STF que haja declarado inconstitucional determinado diploma legislativo em que se apóie o título judicial, ainda que impregnada de eficácia 'ex tunc', como sucede com os julgamentos proferidos em sede de fiscalização concentrada (RTJ 87/758 - RTJ 164/506-509 RTJ 201/765), detém-se ante a autoridade da coisa julgada, que traduz, nesse contexto, limite insuperável à força retroativa resultante dos pronunciamentos que emanam, 'in abstracto', da Suprema Corte.

No mesmo sentido, Misabel Derzi (2009, p. 552), ao analisar o momento de vigência inicial dos efeitos em decorrência de modificações jurisprudenciais inovadoras, que altera jurisprudência anterior, faz o seguinte apelo:

[...] deverá ser o marco decisivo. Todos aqueles atos-fatos pretéritos, (porque ocorridos antes do início da vigência da nova jurisprudência), sob a vigência do precedente superado, deverão ser protegidos. Resulta daí que nem os fatos, propriamente ditos, nem os efeitos que deles decorrem poderão ser atingidos pela mudança de orientação, pela jurisprudência inovadora. A modulação dos efeitos da decisão nova deveria ser a regra, tal a força do princípio da irretroatividade entre nós. Não tem cabimento pretender saber se, antes do termo inicial da vigência da norma judicial inovadora, o contribuinte teria depositado confiança legítima na jurisprudência superada, e em que grau. Assim como a confiança é pressuposta em relação às leis, o mesmo raciocínio, mais objetivo, deverá comandar a aplicação do princípio da irretroatividade às modificações jurisprudenciais.

Dessa forma, o sobreprincípio da segurança jurídica imanente ao Estado Democrático de Direito, cujos fundamentos encontram-se esposados sobejamente nos direitos e garantias fundamentais preconizados pela Constituição Federal, cujos limites impostos ao legislador (que pode mais, pois legitimamente sufragado pela vontade popular) encontram na proibição da retroatividade das leis um óbice ao seu poder, porque não encontraria o mesmo óbice o magistrado, executor das vontades do primeiro.

E mais adiante Derzi (2009, p. 556) alinhava:

[...] nas situações em que as modificações jurisprudenciais atingem fatos jurídicos não completos, em que parte de sua formação está no passado e outra parte no presente e futuro, o princípio da proteção da confiança ganha o contorno completo de justiça prospectiva. Temporalmente, e essa á a vocação da responsabilidade pela confiança, estarão envolvidos o passado, o presente e o futuro. Quando as promessas públicas são traídas, a questão que se põe, de forma consistente, é: o que deverá atenuar as frustrações relativas àquilo que se teria alcançado, se não tivesse havido a intervenção do Estado (a modificação da jurisprudência), abortando-se a promessa, o incentivo, o benefício. Tecnicamente, não se deve falar em vedação de retroação, mas antes de confiança a proteger e de boa-fé objetiva.

Depreende-se que, notadamente, o contribuinte-empresa direciona suas ações em confiança ao Estado de Direito presente, planejando seu futuro, com investimentos e dispêndios baseados na boa-fé objetiva que deve pairar sobre as ações do Estado em relação à segurança jurídica; por isso, é inconcebível que o mesmo Estado que desencadeou uma série de ações por parte do contribuinte, em dado momento futuro, estabeleça que aquelas regras não são mais válidas. Isso é motivo mais que suficiente para gerar uma grande retração na legítima confiança que paira sobre os agentes econômicos.

O Parecer PGFN/CRJ 492/2011, em última análise, traz, de forma recorrente, a ideia de que o direito novo, criado pela decisão da Suprema Corte, nas três situações objeto do referido parecer, equivale à lei nova, com os mesmos efeitos e reflexos do devido processo legislativo. Conforme Marins (2012, p. 686-687), tal não ocorre, pois o direito novo criado pelo Estado-Juiz é muitíssimo diferente do direito novo criado pelo Estado-Legislador:

Em suma, o Parecer defende que a alteração ulterior de circunstâncias fáticas ou jurídicas existentes ao tempo da prolação de decisão judicial direcionada à nova relação jurídica tributária de trato sucessivo, ou continuativo, tem 
como conseqüência o surgimento de nova relação jurídico-tributário. Logo, os efeitos dessa decisão não podem alcançar a relação jurídico-tributária nova, fruto da alteração das circunstâncias fáticas ou jurídicas e, portanto, estas não poderiam ser alcançadas pelos limites objetivos que circundam a eficácia vinculante da decisão judicial em voga. Assim, após a alteração das circunstâncias fáticas ou jurídicas existentes à época da decisão, restariam afastados os efeitos da decisão transitada em julgado, pois referente à circunstância jurídica ou fática objeto da decisão.

$[\cdots]$

Esse raciocínio, no entanto parte de falsa premissa segundo a qual haveria 'nova relação jurídico-tributária'. A premissa é falsa porque inexiste nova relação, mas simplesmente a mesmíssima relação passa a ser interpretada de forma diversa. O objeto material da lide permanece sendo exatamente o mesmo: saber-se se determinado dispositivo legal que define a relação fática entre a Fazenda e o contribuinte é ou não constitucional. Esse é o objeto último da coisa julgada que estabelece a norma individual e concreta sobre exatamente esta questão, de modo que esta relação permanecerá disciplinada por esta norma individual (constitucionalidade in concreto de determinada lei) até que sobrevenha outra norma individual que a infirme.

Nota-se claramente que o pano de fundo de toda fundamentação do referido Parecer diz respeito à natureza jurídica do direito criado a partir de uma nova decisão da Suprema Corte, quando em confronto com a coisa julgada material nas relações jurídico-tributárias de trato sucessivo ou continuativas. Bem, como já se disse, desfeito esse entendimento, rui toda proposição argumentativa ínsita naquele Parecer.

Assim, não é demais repetir que a coisa julgada material, mesmo aquelas que têm seus efeitos repercutindo pro futuro, somente por decisão judicial, seja por meio de ação rescisória, se no lapso temporal que couber, ou seja, por intermédio de ação revisional, pois a alteração jurídica que produz efeitos imediatos e automáticos somente se dá por lei nova, lei no sentido estrito que obedeceu ao devido processo legislativo e não mais que isso.

\subsection{A cessação da eficácia vinculante de decisão transitada em julgado e a relativização da coisa julgada}

O Parecer sob comento, em seus itens 82 a 85 (MACEDO, 2011, p. 229-230), traz um fragmento argumentativo esdrúxulo, tentando fazer crer que a cessação da eficácia vinculante de decisão transitada em julgado em face de posterior precedente objetivo e definitivo do STF e a relativização dessa coisa julgada são fenômenos muito distintos e em nada se relacionando.

Pois bem, a uma que a relativização da coisa julgada não se volta exclusivamente para o passado como orienta tal Parecer, mas também mitiga os efeitos prospectivos; a duas que a cessação da eficácia vinculante de coisa julgada material nada mais é que a relativização ou mitigação dos seus efeitos, portanto, puro jogo linguístico, cujo objetivo é descurar-se do realismo pragmático que funda os direitos e garantias constitucionais imutáveis, pois tem sua proteção nas cláusulas pétreas da Carta Magna.

Nessa linha de raciocínio o único desembocadouro estaria no CPC, artigo 471, in verbi: "Nenhum juiz decidirá novamente as questões já decididas, relativas à mesma lide, salvo: I - se, tratando-se de relação jurídica continuativa, sobreveio modificação no estado de fato ou de direito; caso em que poderá a parte pedir a revisão do que foi estatuído na sentença; [...]”. Ou seja, não escaparia da necessidade de socorrer-se ao Poder Judiciário para o exame de conformação entre o direito novo ou a situação fática nova e os exatos termos da sentença que transitou em julgado.

Mais uma vez percebe-se que o desenlace das relações jurídicas oriundas da coisa julgada material não poderá ocorrer de forma instantânea e automática como quer a Fazenda Pública Federal. Assim, somente e mediante uma ação revisional conforme preconiza a lei poderá, em relação à coisa julgada material, alterar seus efeitos ou eliminá-los. 


\title{
3. A coisa JULGADA
}

A proteção à coisa julgada é direito fundamental prescrito na Constituição Federal, de 1988 - CF/88 mais precisamente no artigo $5^{\circ}$, inciso XXXVI, in verbi - “[...] a lei não prejudicará o direito adquirido, o ato jurídico perfeito e a coisa julgada”; desse modo é garantia irreformável, amparada pelas cláusulas pétreas, previstas no artigo $60, \sqrt{\int} 4^{\circ}:$ “[...] não será objeto de deliberação a proposta de emenda tendente a abolir: ... IV - os direitos e garantias individuais".

Inicialmente, há que se registrar severas discussões acerca desses institutos, em especial ao conceito, se de índole constitucional ou de competência do legislador ordinário. Para Gilmar Mendes Ferreira (2008, p. 461), “[...] a conveniência ou não de dispor sobre matéria tão sensível e controvertida no âmbito da legislação ordinária é suscitada, não raras vezes, tendo em vista o risco de deslocamento da controvérsia do plano constitucional para o legal”. E mais adiante faz menção que, nessa seara, a tripartição dos conceitos presta-se tão somente a elucidar algumas questões embaraçosas, pois, o direito adquirido é a base de sustentação dos demais conceitos. Para isso, basta se verificar o voto do ministro Moreira Alves, no RE 226.855/RS:

\begin{abstract}
Há grande diferença entre o Tribunal não admitir ofensa direta à Constituição quando se alega ofensa ao princípio da legalidade e a questão do direito adquirido. Com efeito, se o princípio da reserva legal total, ou seja, o de que ninguém está obrigado a fazer ou deixar de fazer alguma coisa senão em virtude de lei, der margem ao recurso extraordinário desde que se alegue que o direito infraconstitucional não foi aplicado ao caso concreto, colocaremos o Superior Tribunal de Justiça em disponibilidade remunerada, porque toda violação de direito infraconstitucional dará margem a recurso extraordinário para esta Corte.
\end{abstract}

O conceito de coisa julgada vem previsto, pelo menos de forma ampla, na Lei de Introdução às Normas de Direito Brasileiro - LINDB, em seu artigo $6^{\circ}, \sqrt{\$} 3^{\circ}$. - "Chama-se coisa julgada ou caso julgado a decisão judicial de que já não caiba recurso", o que, para alguns doutrinadores, tal conceito encontra-se superado, enquanto para outros, tal conceito é o da coisa soberanamente julgada, ou seja, que já não caiba nem mais a ação rescisória; bem como também no Código de Processo Civil - CPC, em seu artigo 467: "Denomina-se coisa julgada material a eficácia, que torna imutável e indiscutível a sentença, não mais sujeita a recurso ordinário ou extraordinário."

Já para Elpídio Donizetti (2008, p. 372), o conceito de coisa julgada trazido pelo legislador é obscuro e incompleto, e ao fazê-lo, "[...] leva em conta o aspecto da imutabilidade e da indiscutibilidade da sentença, e não das relações jurídicas, de cunho processual ou material [...]. Todavia, não são esses efeitos que se tornam imutáveis, mas o conteúdo da decisão proferida, ou seja, a norma individual criada para aquele caso concreto".

A coisa julgada pode gerar efeitos endoprocessuais apenas ou cumulado com efeitos extraprocessuais; no primeiro caso, diz-se que resolveu apenas aspecto da relação processual, na qual não se analisou o mérito da relação jurídica, e nesse caso, chama-se de coisa julgada formal (hipóteses do artigo 267, do Código de Processo Civil - CPC), enquanto que nos casos que o órgão judicante resolve o mérito da questão conflituosa (hipóteses do artigo 269, do CPC), diz-se que operou a coisa julgada material, ou operaram-se efeitos endos e extraprocessuais.

Entretanto, a coisa julgada vem despida dos conceitos de justiça, porque a esta não persegue, pelo contrário, é fator e instrumento de pacificação social de forma a se evitar a eternização dos conflitos, trazendo segurança jurídica nas relações em digladiação, ainda que, para isso, traga embutida alguma sorte de injustiça (DIDIER JÚNIOR, 2012, p. 417). Assim, a natureza da coisa julgada não busca em primeiro lugar a justiça, que lhe é subjacente, porque mais do que nunca se precisa de previsibilidade e certeza jurídica nas já conturbadas relações sociais e econômicas do mundo globalizado.

O direito como fenômeno social deve perseguir a paz e a permanente busca pela felicidade do povo sobre o qual incide suas normas. Deve aliar-se aos agentes econômicos, dar-lhes segurança; o que não significa ser-lhes submisso. É preciso encontrar um ponto de conforto para que não lhes afugente. Portanto, 
a segurança jurídica como primado maior da $\mathrm{CF} / 88$, trazendo em seu núcleo a certeza, a calculabilidade e a previsibilidade em seus pontos estruturantes, tem na coisa julgada a qualidade de direito fundamental, garantia individual irretocável, servindo-lhe de alicerce protetivo diante mesmo de maiorias ocasionais e da superforça imperativa do Estado, em suas três vertentes de poderes: o Executivo, o Legislativo e o próprio Judiciário.

\subsection{Limites da coisa julgada}

A coisa julgada tem seus limites definidos na parte dispositiva da sentença, e isso se extrai da própria lei: "A sentença, que julgar total ou parcialmente a lide, tem força de lei nos limites da lide e das questões decididas" (CPC, artigo 468).

E o próprio legislador exclui do âmbito da coisa julgada: "I - os motivos, ainda que importantes para determinar o alcance da parte dispositiva da sentença; II - a verdade dos fatos, estabelecida como fundamento da sentença; III - a apreciação da questão prejudicial, decidida incidentalmente no processo" (CPC, artigo 469).

É a partir dessas exclusões que se indaga, de fato, quais os termos que fazem coisa julgada, ou seja, quais são os seus limites, subjetiva e objetivamente.

\subsubsection{Os limites subjetivos da coisa julgada}

É cediço que a sentença que julga total ou parcialmente a lide tem força de lei entre as partes, não beneficiando, nem prejudicando terceiros (CPC, artigos 468 e 472). Isso, sem dúvidas, são os efeitos subjetivos da sentença e não poderia ser diferente. Entretanto, em relação aos seus limites subjetivos, pode produzir efeitos (i) contra todos, ou seja, erga omnes, quando se referirem a ações de natureza coletiva, discutindo direitos e interesses difusos ou coletivos, que são exemplos, a ação popular (Lei 4.717/65), a ação civil pública (Lei 7.347/85) e as ações coletivas de que trata a Lei 8.078/90 (Código de Defesa do Consumidor - CDC); (ii) nas ações, cujas sentenças produzam efeitos secundum eventum litis (ou conforme o resultado do litígio), o que ocorre nos mesmos casos citados no item anterior, quando a respectiva ação for julgada improcedente por insuficiência de provas. Neste caso, qualquer outro cidadão poderá demandar outra ação, desde que se valha de nova prova; (iii) ocorrerá efeitos ultrapartes nas ações, cujas sentenças atinjam apenas uma determinada e especial categoria de pessoas, quando favorável, ultrapassará as partes envolvidas no litígio para alcançar os demais membros da categoria (Coelho, 2007, p. 462-465).

\subsubsection{Os limites objetivos da coisa julgada}

Pelos menos em dois dispositivos o legislador processual civil (CPC) modelou os limites objetivos da coisa julgada. No artigo 128, quando diz que "[...] o juiz decidirá a lide nos limites em que foi proposta, sendo-lhe defeso conhecer de questões, não suscitadas, a cujo respeito a lei exige a iniciativa da parte". Também no artigo 460, ao proclamar que "[...] é defeso ao juiz proferir sentença, a favor do autor, de natureza diversa da pedida, bem como condenar o réu em quantidade superior ou em objeto diverso do que lhe foi demandado".

Assim sendo, os limites objetivos da coisa julgada deverão ficar circunscritos ao pedido e à causa de pedir, embora se deva considerar fatos levantados na contestação como impeditivo, modificativo ou extintivo de direitos, bem como eventuais pedidos em sede de reconvenção ou pedido contraposto (DIDIER JÚNIOR, 2012, p. 486). 
É bem verdade que os limites objetivos estabelecidos pelo legislador podem ser excepcionados quando o juiz, na sentença, decidir acerca de questões de interesse público e que por dever de ofício deverá fazê-lo notadamente, quando envolver interesses e direitos coletivos ou difusos, como é o caso de questões ambientais.

\subsection{A relativização da coisa julgada}

Os defensores desse instituto, cujos debates têm se aprofundado no último decênio, fundamentam suas teses no princípio da supremacia da Constituição Federal, pois, não se poderia conceber a intangibilidade da coisa julgada mesmo quando ela afrontasse diretamente os princípios traçados pela mais alta Lei do país.

Doutrinadores de escol, como Humberto Theodoro Júnior, Juliana Cordeiro, José Augusto Delgado e Cândido Dinamarco Rangel, enfileiram-se na defesa da relativização da coisa julgada.

Para Delgado (2001, p. 9-11), o Direito deve ser e é visto como ciência normativa cujo pilar de sustentação é a realidade social para a qual tem sua razão de ser, e sendo essa realidade mutante e dinâmica, a ciência acompanha a transformação da sociedade e por isso não é possível mais conviver com o dogma de imutabilidade de uma decisão que afronta moral e juridicamente todo o ordenamento social, dada a sua extrema injustiça e que tenha espelhado unicamente a vontade do julgador indo de encontro à realidade dos fatos.

E mais adiante, Delgado complementa: "O tratamento dado pela Carta Maior à coisa julgada não tem o alcance que muitos intérpretes the dão. [...]. O que a Carta Política inadmite é a retroatividade da lei para influir na solução dada, a caso concreto, por sentença de que já não caiba recurso". Delgado, por fim, radicaliza sua posição quando afirma que "[...] a sentença judicial, mesmo coberta com o manto da coisa julgada, não pode ser veículo de injustiças".

Para Humberto Theodoro Júnior e Juliana Cordeiro Faria (2006, p. 128), a intangibilidade da coisa julgada é princípio de natureza processual, albergado por norma infraconstitucional, portanto, inferior aos demais preceitos constitucionais, cuja supremacia não pode ser afastada em decorrência daquela, que ressaltam: “[...] a coisa julgada será intangível enquanto tal apenas quando conforme a Constituição. Se desconforme, estar-se-á diante do que a doutrina vem denominando de coisa julgada inconstitucional".

Nessa esteira da relativização, Dinamarco (2003, p. 260), afirma que, em situações excepcionais, a coisa julgada por ser enfrentada por meio de simples ação ordinária e, trazendo aquela grave injustiça, cuja impugnação poderá ocorrer por qualquer meio processual disponível à parte em prejuízo.

Em sentido contrário, portanto, fazem fila juristas de renome, críticos da relativização da coisa julgada do porte de José Carlos Barbosa Moreira, Araken de Assis, Guilherme Marinoni, Ovídio Baptista, Fredier Didier Jr. E, adiante, faz-se uma síntese da opinio iuris desses críticos.

Para Barbosa Moreira (2007, p. 235-265), sua crítica já se inicia com a própria terminologia, uma vez que a coisa julgada já é relativa desde sua origem constitucional, quando admite a possibilidade de ação rescisória. Então, é incoerente falar em relativização do que já é relativo. O que se pretende, de fato, com essa terminologia, seria o alargamento das possibilidades de rescindir a coisa julgada.

E no mesmo trecho, Moreira complementa: "Poucas vezes a parte vencida se convence de que sua derrota foi justa. Se quisermos abrir-lhe sempre a possibilidade de obter novo julgamento da causa, com o exclusivo fundamento de que o anterior foi injusto, teremos de suportar uma série indefinida de processos com idêntico objeto".

E Araken de Assis (2003, p. 10-16), em efusiva crítica ao relativismo da coisa julgada, praticamente esbraveja:

A simples possibilidade de êxito do intento revisionista, sem as peias da rescisória, multiplicará os litígios, nos quais o órgão judiciário de primeiro grau decidirá, preliminarmente, se obedece, ou não, o pronunciamento transitado em julgado do seu Tribunal e até, conforme o caso, do Supremo Tribunal Federal. [...] Por tal motivo, mostra-se flagrante o risco de se perder qualquer noção de segurança e de hierarquia judiciária. 
Percebe-se, desse modo, ser o início da eternização dos conflitos. Pois bem, à época da decisão, não pareceu injusta nem tampouco que tivesse afrontado os princípios constitucionais, pois se assim o fosse, perder-se-ia a oportunidade de reconsideração em instâncias superiores. Agora, veja-se: se para os padrões morais de hoje a decisão é injusta e imoral, nada garante que, para os padrões morais de amanhã, também o seja. E dessa feita, nasceria um novo direito à rescindibilidade ou outro nome que o equivalha, perpetuando-se a disputa, jamais logrando a estabilidade do porto seguro da paz social.

\subsection{A coisa julgada e as relações continuativas}

A compreensão desse tema é importante pilar de sustentação argumentativa do Parecer PGFN-CRJ 492/2011, uma vez que a defesa dessas novas relações nascidas após o objeto específico da sentença que transitou em julgado, não guarda vínculo com aquelas, tratando-se de relações jurídicas novas e independentes.

Zavascki (2012, p. 99-100) divide a temporalidade das relações jurídicas em três categorias distintas: (i) as relações jurídicas instantâneas, sendo elas decorrentes de um vínculo obrigacional que se esgota imediatamente após sua produção (dano material produzido numa colisão entre veículos); (ii) as relações jurídicas permanentes, apesar de nascerem de um fato gerador instantâneo geram vínculos obrigacionais pro futuro (incapacidade física para o trabalho gera pensão para o futuro); (iii) as relações jurídicas de trato sucessivo ou também denominadas de relações jurídicas continuativas, sendo nascidas de fatos geradores instantâneos que se repetem recorrentemente no tempo (auferimento de proventos mês a mês, ou ano a ano, fato gerador da obrigação de pagar o imposto de renda).

Esse tema vem expresso na legislação processual civil, de forma bem clara: (CPC) “art. 471 - Nenhum juiz decidirá novamente as questões já decididas, relativas à mesma lide, salvo: I - se, tratando-se de relação jurídica continuativa, sobreveio modificações no estado de fato ou de direito; caso em que poderá a parte pedir a revisão do que foi estatuído na sentença" (grifou-se).

É ineludível o raciocínio de que o legislador andou na mesma corrente dos direitos e das garantias fundamentais previstos na CF/1988, no que tange ao respeito à coisa julgada. Depreende-se, assim, que a coisa julgada material soberanamente, ou seja, aquela na qual não caiba mais nenhuma espécie de recurso, nem mesmo a ação rescisória, somente sofrerá alteração, nos casos de relações jurídicas continuativas, mediante a competente ação revisional, ocasião em que o juiz verificará a adequação das novas circunstâncias ou novo direito em confronto com decisum prolatado na sentença transitada em julgado.

E é bom que se diga, trata-se de uma ação nova, nascida em decorrência de fatos circunstanciais novos ou de uma nova ordem jurídica em torno daquela pretensão exaurida na sentença transitada em julgado. Portanto, o desiderato dessa nova ação não tem o condão de produzir efeitos ex tunc. Ainda, em se tratando de matéria tributária que trará algum ônus ao contribuinte, terá que obedecer às limitações constitucionais tributárias, tais quais à obediência ao princípio da anterioridade, à irretroatividade e à regra nonagesimal.

Não se pode deixar de mencionar neste tópico a interpretação da Súmula 239, do STF em que se dita: “[...] a decisão que declara indevida a cobrança do imposto em determinado exercício não faz coisa julgada em relação aos posteriores". Ainda bastante utilizada de forma desproporcional ao seu conteúdo e à sua finalidade original, pois direcionada às ações anulatórias e descontitutivas em que por questões até de lógica jurídicas não poderiam ter seus efeitos prolongados para fatos e atos futuros.

\subsection{A coisa julgada inconstitucional}

A coisa julgada inconstitucional tem passagem obrigatória pela análise do memorável voto do ministro Celso de Melo, em decisão monocrática no RE 594.350-RS, de 25.05.2010, pelo que se transcrevm alguns pontos de relevância singular: 
- A sentença de mérito transitada em julgado só pode ser desconstituída mediante ajuizamento de específica ação autônoma de impugnação (ação rescisória) que haja sido proposta na fluência do prazo decadencial previsto em lei, pois, com o exaurimento do referido lapso temporal, estar-se-á diante da coisa soberanamente julgada, insuscetível de ulterior modificação, ainda que o ato sentencial encontre fundamento em legislação que, em momento posterior, tenha declarada inconstitucional pelo Supremo Tribunal Federal, quer em sede de controle abstrato, quer no âmbito de fiscalização incidental de constitucionalidade.

- A decisão do Supremo Tribunal Federal que haja declarado inconstitucional determinado diploma legislativo em que se apóie o título judicial, ainda que impregnada de eficácia "ex tunc", como sucede com os julgamentos proferidos em sede de fiscalização concentrada (RTJ 87/758 - RTJ 164/506-509 - RTJ 201/765) detém-se ante a autoridade da coisa julgada, que traduz, nesse contexto, limite insuperável à força retroativa resultante dos pronunciamentos que emanam, "in abstracto", da Suprema Corte. Doutrina. Precedentes.

Assim, o voto do decano, esposado em forte doutrina, traz luz a um assunto que recorrentemente se aflora, com construções argumentativas críticas aos seus não aderentes, taxando-os de retrógrados ou míopes da modernidade que não têm acompanhado a evolução ou alargamento dos novos conceitos à coisa julgada. São, em regra, ferrenhos defensores do Estado, como se o Estado ainda precisasse de mais poderes.

Para o magistério de Nelson Nery Jr. e Rosa Nery (2010, p. 717), após o transcurso do lapso temporal de dois anos ditados pela Lei (CPC, art. 485, V) para o exercício do direito de requerer novo julgamento da decisão de mérito que transitou em julgado, não será mais possível manejar-se o controle judicial da constitucionalidade, "ainda sob o pretexto de que a sentença seria inconstitucional".

Parece longe de se concluir o julgamento do RE 590.880-CE, cuja relatoria atual encontra-se com a ministra Rosa Weber, no qual se discute a inconstitucionalidade do 884, \ $5^{\circ}$. da Consolidação das Leis Trabalhistas (CLT), e de forma indireta dos artigos 741, parágrafo único e 475-L, $₫ 1^{\circ}$, ambos do CPC, por versarem sobre o mesmo conteúdo daquele, cujo julgamento foi suspenso com pedido de vistas do ministro Gilmar Ferreira Mendes, no momento em que o placar de votação estava em 4 × 3, em favor da inconstitucionalidade dos referidos dispositivos legais. Votaram pela inconstitucionalidade, os ministros Ayres Britto, Eros Grau, Cezar Peluso e Marco Aurélio e foram contrários a relatora, à época, ministra Elen Gracie, a ministra Carmem Lúcia e o ministro Ricardo Lewandowski, enquanto que o ministro Antônio Dias Toffoli declarou-se impedido.

Em eventual retomada do julgamento do RE 590.880-CE, desenha-se um empate na votação, considerando que o ministro Gilmar Ferreira Mendes tem se manifestado doutrinariamente favorável à relativização da coisa julgada e pela decisão monocrática no RE 594.350-RS, se coerente, o voto do ministro Celso de Melo, certamente será pelo prestígio à coisa julgada, o que redundará em empate de $5 \times 5$, necessitando do voto do ministro Presidente Joaquim Barbosa que à época não votou.

O Excelso Pretório está dividido enquanto a doutrina é majoritária a favor do prestígio da coisa julgada, cujo fundamento maior - a segurança jurídica - mais que princípio, é corolário da sustentação dos direitos e garantias fundamentais, protegidos pela própria Constituição Federal. E pelos ensinamentos de Donizetti (2012, p. 673), o título executivo judicial fundado em lei ou normativo, que posteriormente fora julgado pelo STF como inconstitucional, somente em três circunstâncias poderia dizer-se inexigível:

(a) o trânsito em julgado do acórdão do STF, contendo declaração de inconstitucionalidade da lei ou a aplicação ou interpretação tidas por inconstitucional, tiver ocorrido antes do trânsito em julgado da decisão exeqüenda;

(b) os efeitos da declaração de inconstitucionalidade da lei, ou da aplicação ou interpretação tidas por inconstitucional, for erga omnes, isto é, decorrer de acórdão do STF; oriundo de controle abstrato (ADI, ADC e ADPF), ou de controle concreto (RE, por exemplo), se o Senado tiver expedido resolução suspendendo a execução da lei (CF, art. $52, \mathrm{X})$ antes do trânsito em julgado do título exeqüendo;

(c) a argüição de inexigibilidade se der em impugnação (prazo de 15 dias, a contar da intimação da penhora) ou em ação rescisória (art. 485, V), no prazo de dois anos a contar do trânsito em julgado do título exeqüendo.

O ordenamento jurídico deve estar em harmonia e esse entendimento é o que mais resguarda o Estado Democrático de Direito, não se tendo notícia de que o desrespeito à coisa julgada remonta ao Estado ditatorial hitlerista da primeira metade do século XX, não se coadunando com o avanço das garantias fundamentais preconizadas na Constituição Federal de 1988. 


\section{AÇÃo RESCISÓRIA}

A ação rescisória tem previsão constitucional discreta, limitando o legislador constituinte em atribuir-lhe o órgão competente para apreciação e julgamento. Na CF/1988, vem inicialmente prevista no artigo 102: "Compete ao Supremo Tribunal Federal, precipuamente, a guarda da Constituição, cabendo-lhe: I - processar e julgar, originariamente: j) a revisão criminal e a ação rescisória de seus julgados".

No âmbito do Superior Tribunal de Justiça, a previsão constitucional vem no artigo 105: "Compete ao Superior Tribunal de Justiça: I - processar e julgar originariamente: e) as revisões criminais e as ações rescisórias dos seus julgados".

É importante ressaltar que a rescisão de acórdãos provenientes de quaisquer tribunais é processada e julgada pelos próprios tribunais prolatores desses acórdãos. E que somente as sentenças prolatadas por juízes de primeiro grau são submetidas ao respectivo tribunal a que estejam vinculados para processamento e julgamento da ação rescisória de suas sentenças.

No âmbito dos Juizados Especiais, pela leitura direta do texto da lei, inexiste a possibilidade de ação rescisória. Especialmente, no Juizado Especial Estadual, a Lei 9.099/1995, art. 59: "Não se admitirá ação rescisória nas causas sujeitas ao procedimento instituído por esta Lei”. Entretanto, a Lei 10.259/2001 é silente em relação ao assunto, mas em seu art. 1․ "São instituídos os Juizados Especiais Cíveis e Criminais da Justiça Federal, aos quais se aplica, no que não conflitar com esta Lei, o disposto na Lei 9.099, de 26 de setembro de 1995".

Portanto, parece muito claro que, não havendo disposição acerca da ação rescisória na Lei 10.259/2001, aplica-se subsidiariamente a Lei 9.099/1995, que não se admite a propositura de ação rescisória.

Nota-se que o legislador infraconstitucional operou com enaltecido respeito à coisa julgada, demonstrando substancial valor à segurança jurídica. Isso, ao contrário de alguns poucos doutrinadores que trilham pela relativização da coisa julgada, tem uma importância enorme para compreensão da segurança jurídica. Imagine-se uma sentença no âmbito do Juizado Especial, que, após o trânsito em julgado, tenha-se verificado que fora prolatada por juiz absolutamente incompetente ou mesmo, tenha ocorrido a concussão do Juiz para tal mister, ainda assim, não caberá ação rescisória. Ou seja, no âmbito do Juizado Especial, a imutabilidade da sentença, após seu trânsito em julgado, opera-se de forma absoluta.

\subsection{Natureza jurídica}

A doutrina é unânime nesse quesito, ou seja, a ação rescisória ostenta a posição de uma ação autônoma de impugnação. Não é recurso, pois sua ocorrência opera-se fora da relação processual que se pretende desconstituir, até porque, no sistema processual brasileiro, os recursos postos à disposição do jurisdicionado estão consignados taxativamente, o que em tal rol não se faz constar a ação rescisória. Daí poder se afirmar com segurança que a ação rescisória faz nascer um novo e autônomo processo.

A natureza jurídica dos efeitos almejados pela ação rescisória é de desconstituição da decisão de mérito definitiva transitada em julgado (DONIZETTTI, 2012, p. 832). Poderá também ter natureza constitutiva, caso se prolate decisão modificativa daquela que transitou em julgado, constituindo-se, portanto, em direito novo para a parte autora da rescisória.

\subsection{Pressupostos da ação rescisória}

Atendidos as condições da ação e os pressupostos processuais inerentes a todas as ações, deverá ainda atender os seguintes itens: (i) existência de uma sentença de mérito transitada em julgado; (ii) verificação de 
um dos fundamentos de rescindibilidade, elencados no CPC, artigo 485, incisos I a IX; e (iii) seja impetrada no lapso temporal de dois anos, a contar do trânsito em julgado da sentença rescindenda.

Pela análise da normativa processual, verifica-se que a ação rescisória visa a corrigir defeitos processuais graves ou flagrantes injustiças de decisões plenamente válidas.

\subsection{Legitimidade}

O legislador processual civil trouxe de maneira clara os legitimados a proporem ação rescisória: CPC:

art. 487 - tem legitimidade para propor a ação: I - quem for parte no processo ou seu sucessor a título universal ou singular; II - o terceiro juridicamente interessado; III - o Ministério Público: a) se não foi ouvido no processo, em que lhe era obrigatória a intervenção; b) quando a sentença é o efeito de colusão das partes, a fim de fraudar a lei.

Em relação à legitimidade ativa, o legislador trouxe-a, claramente definida, conforme se transcreveu no parágrafo anterior. Entretanto, silenciou com referência ao legitimado passivo. A doutrina e jurisprudência tratam da legitimidade passiva; é exemplo a Súmula 406, I, do Tribunal Superior do Trabalho - TST - "I - O litisconsórcio, na ação rescisória, é necessário em relação ao pólo passivo da demanda, porque supõe uma comunidade de direitos ou de obrigações que não se admite solução díspar para os litisconsortes, em face da indivisibilidade do objeto. [...]"

E por fim, alinhava Fredier Didier e Leonardo Cunha (2012, p. 393), "[...] a legitimidade passiva na ação rescisória deve observar o capítulo da decisão que se busca rescindir, para identificar quem é o titular atual do direito ali certificado, que será a parte legítima nessa ação autônoma de impugnação". Eventualmente, a decisão que se pretende modificar pode não atingir todas as partes contrárias à sua pretensão, por isso a necessidade dessa verificação dos efetivos titulares de direitos que se pretende reformar.

\subsection{Prazo para propositura da ação rescisória}

Conforme expendido no próprio CPC, artigo 495, o direito de propor ação rescisória se extingue em 2 (dois) anos, contados do trânsito em julgado da decisão." O Poder Executivo Federal, em duas oportunidades alterou esse prazo em favor da União: por meio da Medida Provisória 1.577, de 11/06/1997, duplicou o prazo em favor da Fazenda Pública, cujas reedições posteriores alterou para 5 (cinco) anos, cuja constitucionalidade foi questionada pela ADI 1.753, ocasião em que o STF concedeu liminar para suspender a vigência do dispositivo. Não se contentando, novamente, o Poder Executivo Federal editou nova Medida Provisória 1.703, o que novamente questionada via ADI 1.753, tendo o STF reconhecido, novamente, sua inconstitucionalidade.

A Lei 10.267, de 28.08.2001, inseriu o artigo $8^{\circ}$ - C, na Lei 6.739/1979 com o seguinte texto: "É de oito anos, contados do trânsito em julgado da decisão, o prazo para ajuizamento de ação rescisória relativa a processos que digam respeito a transferência de terras públicas rurais".

Portanto, depreende-se que, no direito positivo vigente, apenas dois prazos vigoram para a ação rescisória: (i) 8 (oito) anos como exceção no caso de transferência de terras pública; e (ii) 2 (dois) anos para os demais casos.

\section{A segurança jurídica e o Estado Democrático de Direito}

É a segurança jurídica pilar do Estado Democrático de Direito? Ou é o Estado Democrático de Direito pilar da segurança jurídica? Ou estariam esses direitos em perfeita simbiose que não se poderia responder 
afirmativamente a nenhuma das indagações?

Heleno Torres (2012, p. 131), analisando a complexidade e origem na formação do Estado Democrático de Direito faz a seguinte alusão:

O princípio do Estado Democrático de Direito envolve toda a secularidade inerente ao evoluir do Estado de Direito liberal, seguindo da passagem do Estado Social de Direito, para afirmar-se como meio de realização plena da igualdade, da dignidade da pessoa humana e do conteúdo democrático dos direitos sociais e políticos.

Traz, à vista disso, clara conotação de que o Estado Democrático de Direito é o fio condutor para a realização dos fins colimados e que tanto se busca nesta sociedade complexa e recorrentemente conflituosa. Assim, a busca pelo respeito à dignidade da pessoa humana, pelos seus direitos mais elementares de viver condignamente, podendo ir ao encontro do estado de felicidade e regozijo, sabendo que o Estado estará vigilante e dirigindo esforços para que seus direitos sejam fielmente respeitados, não estando sujeito a sobressaltos ou surpresas em relação à sua propriedade, à liberdade e a demais direitos e garantias individuais constitucionalmente protegidos.

E mais adiante Torres (2012, p. 162-163) alinhava:

[...] o princípio do Estado Democrático de Direito não pode ser aplicado e efetivado sem uma apurada compreensão dos efeitos jurídicos da soberania tanto em relação ao poder constituinte quanto em face da Constituição que institui o Estado de Direito, e não o contrário, como muitos apregoam, como se fosse o Estado a origem ou a razão de existência da Constituição e da soberania. [...]. Da leitura da nossa Constituição depreende-se a presença da proteção da dignidade da pessoa humana como base de fundamentação dos direitos e limitação dos poderes, afora o reconhecimento expresso e implícito de direitos sociais e de programação do Estado com vistas à efetivação de políticas públicas de interesse coletivo. Está posto um Estado Democrático de Direito, cuja hermenêutica há de levar em conta todos os valores que o conformam, sob a garantia da segurança jurídica material. Por tudo isso, a segurança jurídica integra-se à Constituição como forma de garantir a certeza e estabilidade interna do sistema, sem que, para tanto, tenha-se que apelar à superada teoria dos fins do Estado [...].

As razões de existência do Estado Democrático de Direito é a proteção à coletividade, e para isso, no conjunto sistêmico da Constituição, buscará essa proteção a partir do respeito a cada pessoa, individualmente, em sua totalidade de direitos, para isso dispensando todos os esforços para atingir os fins primeiros do Estado, seja pelo estabelecimento de políticas públicas, seja dirigindo seu poder de império para a realização do cumprimento das leis e normas estabelecidas visando esse fim.

\subsection{A segurança jurídica tributária diante da certeza do direito e da confiança legítima}

A segurança jurídica tributária, além do corolário constitucional, já previsto nas garantias individuais, vem acompanhada de uma especial proteção do próprio sistema constitucional tributário, limitando o poder de império do Estado, diante da voracidade com que se comporta a administração pública para extrair cada vez mais tributos dos contribuintes, nesse escopo, vem também “[...] proteger direitos decorrentes das expectativas de confiança legítima na criação ou aplicação das normas tributárias, mediante certeza jurídica, estabilidade do ordenamento ou efetividade de direitos e liberdades fundamentais" (TORRES, 2012, p. 193).

Há de se entender que a segurança jurídica, conforme leciona o magistério de Humberto Ávila (2012, p. 551) “[...] é princípio protetivo de direitos individuais frente ao Estado, e não instrumento de aumento do poder do Estado, como ficou assentado na parte relativa ao exame dos seus fundamentos." Tal compreensão vem claramente expressa na própria Constituição Federal, quando intitula em Limitações ao Poder de Tributar à seção II, do capítulo I, do Título VI.

\subsection{A segurança jurídica, a irretroatividade, a proteção da confiança e a boa-fé}

Quando o constituinte editou a CF/88, temeroso do poder do Estado, sempre insaciável por mais recursos, traçou de forma sistemática alguns pontos de proteção ao contribuinte, denominando-os de limitações 
ao poder de tributar. Nesses pontos, trouxe como de maior relevância a impossibilidade de instituir tributos com validade para retroagir no tempo, dentre outras limitações.

Tal proteção traz uma confiança sistêmica, dando estabilidade nas ações a serem planejadas e desenvolvidas pelos contribuintes. Misabel Derzi (2009, p. 589-590), traçou alguns direcionamentos de proteção, nesse sentido:

[...] (a) a continuidade da ordem jurídica, associada ao princípio da segurança jurídica, fruto do Estado de Direito, em que a confiabilidade do ordenamento jurídico e a previsibilidade das intervenções do Estado conduzem à proteção da confiança; (b) a proteção da continuidade, do ponto de vista material, em que o raciocínio se vincula, em sequência, especificamente, à proteção da propriedade e do patrimônio pelo Direito Constitucional, e a outros direitos e garantias fundamentais; (c) a fidelidade ao sistema e à justiça, que conduzem ao princípio da proteção da confiança, desenvolvida por seu efeito garantidor da igualdade, em especial no direito ao planejamento; (d) a proteção da disposição concreta ou do investimento, como circunstância decisiva no Direito privado, como o componente subjetivo do 'valor da segurança jurídica' [...]

Ainda que se queira desprestigiar o princípio da irretroatividade ou da legítima confiança, não haverá espaço para escapar da proteção à boa-fé objetiva que deve pairar nas relações jurídicas existentes entre Estado e contribuintes, pois, estes, agindo na base estrita da boa-fé, não poderão sofrer os empuxos da falta de estabilidade jurídica que hodiernamente balançam-se as jurisprudências na mais alta Corte de Justiça.

\section{Considerações finais}

Após as análises efetuadas no presente artigo, é de se concluir, alinhando os seguintes pontos:

A modificação jurisprudencial ou alteração do suporte fático incidente sobre os fundamentos da sentença transitada em julgado, no que se refere às relações jurídicas continuativas de natureza tributária material, não geram, ipso facto, efeitos automáticos desconstitutivos da referida sentença, haja vista, a proteção constitucional posta como direito imutável conforme vontade do constituinte originário, na forma de direitos e garantias individuais, sob o amparo das cláusulas imodificáveis, previsto na CF/88, em seu artigo 60, $\int 3^{\circ}$, inciso IV.

Que a previsão legal estatuída no CPC, artigo 741, inciso I, aplica-se perfeitamente às situações em que haja modificações no estado de direito, aí incluídas as alterações ou modificações jurisprudenciais; entretanto, aquele que se encontrar em situação desfavorável deverá ajuizar ação de revisão de sentença com o fito de promover a alteração daquelas relações jurídicas ditas de natureza continuativas.

Que eventual alteração legislativa com o objetivo tão somente de fraudar a vontade do constituinte, no que tange à proteção à coisa julgada, deve ser rechaçada pelo STF, em que o legislador apenas alterou a alíquota ou base de cálculo de tributo para furtar-se ao dever de respeito à coisa julgada material.

Portanto, é por meio da coisa julgada que se verifica a mais pura materialização do sobreprincípio da segurança jurídica, uma vez que de forma definitiva estabiliza as relações conflituosas, desnudando-se em certeza do direito, pelo que tanto se prima no Estado Democrático de Direito.

Nos casos específicos de coisa julgada material amparada por decisão que julgou inconstitucional Lei ou Ato Normativo Federal e que posteriormente vem o STF e decide pela sua constitucionalidade, ainda que doutrinadores da escol de Heleno Torres defendam que nesses casos operam efeitos prospectivos e automáticos, não se pode admitir que, por inércia da Fazenda Pública, ocasião em que negligenciou no encaminhamento de eventual Recurso Extraordinário ao STF que poderia ter resultado nesse mesmo desiderato, faça desmoronar todo o arcabouço de proteção da legítima confiança que o contribuinte depositou nas instituições estatais para planejar e decidir suas ações, entabulando negócios e investimentos, acreditando, sinceramente na estabilidade jurídica que deve permear o Estado Democrático de Direito. 
E, finalmente, em respeito à segurança jurídica, em respeito ao princípio da irretroatividade das leis, das limitações ao poder de tributar, da proteção e da garantia constitucional à coisa julgada material, e em última análise, respeitando-se a boa-fé daqueles que trilham suas ações por acreditarem sinceramente que a ordem jurídica estabelecida dá-lhe a proteção estatuída pelo Estado Democrático de Direito, é de se refutar os efeitos automáticos de desconstituição da coisa julgada, defendidos no Parecer PGFN/CRJ 492/2011.

\section{REFERÊNCIAS}

ANDRADE, Fábio Martins de. Modulação em matéria tributária. O Argumento Pragmático ou Consequencialista de Cunho Econômico e as Decisões do STF. São Paulo: Quartier Latin, 2011.

APPIO, Eduardo. Controle difuso de constitucionalidade. Curitiba: Juruá, 2008.

ASSIS, Araken de. Eficácia da coisa julgada inconstitucional. Revista Dialética de Direito Processual. São Paulo, n. 4. jul./2003.

ÁVILA, Humberto. Segurança jurídica. Entre a permanência e a realização no Direito Tributário. 2. ed. São Paulo: Malheiros Editores, 2012.

COELHO, Fábio Alexandre. Teoria geral do processo. 2. ed. São Paulo: Editora Juarez de Oliveira, 2007.

DELGADO, José Augusto. Pontos polêmicos das ações de indenização de áreas naturais protegidas

- Efeitos da coisa julgada e os princípios constitucionais. In: Revista do Processo, v. 103. São Paulo: Revista dos Tribunais, 2001.

Efeitos da coisa julgada e os princípios constitucionais. Coisa julgada inconstitucional. In: Carlos Valder Nascimento, coord. 4. ed. Rio da Janeiro: América Jurídica, 2003.

DERZI, Misabel Abreu Machado. Modificações da jurisprudência no direito tributário. Proteção da confiança, boa-fé objetiva e irretroatividade como limitações constitucionais ao Poder Judicial de Tributar. São Paulo: Noeses, 2009.

DIDIER JÚNIOR, Fredier; BRAGA, Paula Sarno; OLIVEIRA, Rafael. Curso de direito processual civil. v. 2, 7. ed. Salvador: Editora JusPodivm, 2012.

DIDIER JÚNIOR, Fredier; CUNHA, Leonardo Carneiro da. Curso de direito processual civil - Meios de Impugnação às Decisões Judiciais e Processo nos Tribunais. v. 3, 10. ed. Salvador: Juspdivm, 2012.

DINAMARCO, Cândido Rangel. Nova era do processo civil. São Paulo: Malheiros, 2003.

DONIZETTE, Elpídio. Curso de direito processual civil. 10. ed. Rio de Janeiro: Lumen Juris, 2008.

MACEDO, Luana Vargas. Parecer pgfn/crj 492/2011. Revista da PGFN. Brasília, v. 1, n. 2, p. 199-239, jul/dez 2011. Disponível em: http://www.pgfn.fazenda.gov.br/revista-pgfn/ano-i-numero-ii-2011/001. pdf. Acesso em: 30 nov. 2012.

MARINS, James. Direito processual tributário brasileiro: (administrativo e judicial). 6. ed. São Paulo: Dialética, 2012.

MENDES, Gilmar Ferreira; COELHO, Inocêncio Mártires; BRANCO, Paulo Gustavo Gonet. Curso de direito constitucional. 2. ed. rev. e atual. São Paulo: Saraiva, 2008.

MOREIRA, José Carlos Barbosa. Considerações sobre a chamada relativização da coisa julgada. Temas de direito processual. Nona Série. São Paulo: Saraiva, 2007.

NERY JR., Nelson e NERY, Maria Rosa Andrade. Código de processo civil comentado e legislação extravagante. 11. ed. São Paulo: Editora Revista dos Tribunais, 2010. 
THEODORO JÚNIOR, Humberto; FARIA, Juliana Cordeiro. O tormentoso problema da inconstitucionalidade da sentença passada em julgado. Relativização da coisa julgada: enfoque crítico. Fredie Dedier Jr. (Org.). 2. ed. rev. e ampl. Salvador: Juspodivm, 2006.

TORRES, Heleno Taveira. Direito constitucional tributário e segurança jurídica: Metódica da Segurança Jurídica do Sistema Constitucional Tributário. 2. ed. rev. atual. e ampl. São Paulo: Editora Revista dos Tribunais, 2012.

ZAVASCKI, Teori Albino. Eficácia das sentenças na jurisdição constitucional. 2. ed. rev. atual. e ampl. São Paulo: Revista dos Tribunais, 2012. 


\title{
A segurança jurídica administrativa na jurisprudência do Supremo Tribunal \\ Federal: uma análise acerca dos fundamentos normativos e dos argumentos jurídicos nos julgamentos dos mandados de segurança 24.781 e $25.116^{1}$
}

\author{
The Administrative Legal Security in the \\ Jurisprudence of the Supreme Court: An \\ Analysis of the Normative Grounds and Legal \\ Arguments in the Judgement of Injunctions \\ 24,781 and $25,116^{*}$
}

Ana Paula Sampaio Silva Pereira**

\section{Resumo}

O presente artigo tem por objetivo examinar os Mandados de Segurança 24.781 e 25.116, tendo como foco a segurança jurídica. Neles, o Supremo Tribunal Federal - que até então considerava dispensável a participação dos beneficiários nos processos de controle externo que tratam de atos de concessão inicial de aposentadoria, reforma e pensão - invocou o princípio da segurança jurídica para invalidar decisões do Tribunal de Contas da União sob o entendimento de que a inércia da Corte de Contas por mais de cinco anos, ao apreciar essas concessões, faz surgir para o interessado o direito ao exercício do contraditório e da ampla defesa. Para analisar esses precedentes, este trabalho, inicialmente, define o sentido no qual a segurança jurídica será abordada e a diferencia, como princípio jurídico, das demais espécies normativas. Em seguida, esclarece a distinção e a relação entre a segurança jurídica em sentido objetivo e o princípio da proteção da confiança (dimensão subjetiva da segurança jurídica) para, depois, investigar os respectivos conteúdos. Feito isso, contextualiza a matéria envolvida nos julgados e identifica os argumentos jurídicos e fundamentos normativos neles utilizados para, finalmente, confrontá-los com as opiniões doutrinárias e demais informações colhidas ao longo do estudo, de forma a verificar a compatibilidade entre ambos. Conclui que o entendimento neles firmado, embora represente uma evolução em relação à jurisprudência anterior, não efetiva o princípio da segurança jurídica tal qual se propõe a fazer.

Palavras-chave: Direito constitucional. Direito administrativo. Segurança jurídica. Atos de aposentadoria, reforma ou pensão. Tribunal de Contas da União.

Aprovado em 27/08/2013

** Mestranda em Direito, Políticas Públicas, pelo UniCeub. Pós-Graduada em Direto Tributário pela Faculdade Projeção. Auditora Federal de Controle Externo do Tribunal de Contas da União.Email: anapaula.silva@pop.com.br
1 Este texto, cujo conteúdo está relacionado ao tema da dissertação que será apresentada pela autora como requisito para a obtenção do grau de mestre no Programa de Mestrado em Direito e Políticas Públicas do UniCEUB, foi construído a partir das leituras realizadas como ouvinte da disciplina Jurisdição Política, Ativismo Judicial e Direitos Sociais do Programa de Doutorado em Direito do UniCEUB, ministrada pelo Professor Doutor Luís Carlos Martins Alves Jr. no segundo semestre de 2012. 


\section{Abstract}

This article aims to examine the mandamus 25.116 and 24.781, focusing on the principle of legal certainty. In these, the Brazilian Supreme Court - which until now had considered expendable the participation of beneficiaries in cases about of initial grant of retirement, military retirement and pension acts - invoked the principle of legal certainty to invalidate decisions of the Brazilian Court of Accounts (TCU) with the understanding that the inertia of the TCU for more than 5 years to appreciate these concessions grants the beneficiaries the right to have the opportunity to be heard and to participate in the process of their benefits judgment. To analyze these precedents, this work initially sets the meaning in which legal certainty will be used and explains its difference, as a legal principle, from the other kinds or types of law standards. After that it clarifies the distinction and relationship between legal certainty (objective meaning) and the principle of protection of confidence (subjective dimension of legal certainty) and investigates their contents. Then it contextualizes the questions involved in that mandamus and identifies the legal arguments and normative foundations used. Finally the article confronts them with the doctrinal opinions and other information collected in this study to check their compatibility. The study concludes that although the arrangement they signed represent an evolution in comparison with the previous case law, it don't implement the principle of legal certainty how it wants to do.

Keywords: Constitutional law. Administrative law. Legal certainty. Retirement, military retirement and pension acts. Brazilian Court of Accounts.

\section{INTRODUÇÃO}

O estudo da segurança jurídica não é matéria nova, mas nem por isso deixa de ser um problema atual entre os operadores do direito. Trata-se de tema denso, que possui relevância em toda e qualquer ordem jurídica, podendo ser examinado com enfoques e perspectivas variados. Talvez por isso, a literatura sobre questões envolvendo a segurança jurídica seja tão ampla e rica. ${ }^{2}$

Dentre as discussões envolvendo a segurança jurídica, ganham relevo as situações em que ela entra em conflito com o princípio da legalidade, a exemplo do que ocorre nos casos de invalidação pela Administração Pública dos seus próprios atos administrativos eivados de vícios. Esse conflito também fica evidente quando se trata dos processos de controle externo em que o Tribunal de Contas da União - TCU - aprecia, para fins de registro, os atos de concessão inicial de aposentadoria, reforma e pensão, por força do art. 71, inciso I, da Constituição Federal de 1988. A tutela do princípio da segurança jurídica em relação a esses processos administrativos tem suscitado muitos debates, especialmente no Supremo Tribunal Federal - STF- (responsável por julgar os mandados de segurança impetrados contra atos do TCU) e na própria Corte de Contas.

No âmbito do STF, destacam-se os debates travados no julgamento dos Mandados de Segurança 24.781 e 25.116. Neles, o princípio da segurança jurídica foi invocado para invalidar decisões do TCU que consideraram ilegais aposentadorias concedidas há mais de cinco anos, determinando-se que a Corte de Contas assegurasse aos interessados o direito de exercer as garantias do contraditório e da ampla defesa. A partir desses precedentes, a Suprema Corte relativizou o disposto na parte final do Enunciado Vinculante $n^{\circ} 3$ da Súmula da sua Jurisprudência, que dispensava o chamamento dos interessados para participar dos processos que tratam de concessão inicial de aposentadoria, reforma e pensão - e firmou o entendimento, seguido pelo TCU, ${ }^{3}$ no sentido de que, em respeito ao princípio da proteção à confiança (vertente subjetiva do princípio

2 Inventário das obras sobre o tema foi feito por ÁVILA, Humberto. Teoria dos princípios: da definição à aplicação dos princípios jurídicos. 2. ed. São Paulo: Malheiros, 2003., e por TORRES, Heleno Taveira. Direito constitucional tributário e segurança jurídica: metódica da segurança jurídica do sistema constitucional tributário. 2. ed. São Paulo: Revista dos Tribunais, 2012.

3 No âmbito do TCU, a questão foi decidida por meio do Acórdão 3.245/2010-TCU-Plenário. 
da segurança jurídica), quando transcorrerem mais de cinco anos, contados da entrada do ato no Tribunal, sem que haja a apreciação dessas concessões pelo TCU, este deve assegurar aos interessados o exercício das garantias do contraditório e da ampla defesa. ${ }^{4}$

Contudo, é questionável se, nessas circunstâncias, a abertura do contraditório efetivamente concretiza o princípio da segurança jurídica. Além disso, cabe verificar a coerência dessa tese, cujos próprios debates no âmbito do STF demonstram incertezas dos magistrados em relação às premissas adotadas para construir o raciocínio que a fundamenta.

A matéria envolvida nesses julgados é polêmica, pois possui posicionamentos divergentes tanto na doutrina como na jurisprudência e não é pacífica entre os ministros do STF. Outrossim, possui grande relevância para o ordenamento jurídico brasileiro, na medida em que causa impacto na esfera de direitos subjetivos dos beneficiários dos inúmeros atos de concessão de aposentadoria, reforma e pensão emitidos pela Administração Pública Federal. De maneira reflexa, atinge, ainda, os interesses de toda a população, uma vez que a questão repercute no patrimônio público da União.

Nesse contexto, observa-se que o tema contempla aplicabilidade prática e que as questões nele inseridas merecem tratamento teórico mais aprofundado, sendo de extrema relevância analisar o entendimento firmado pelo STF no julgamento dos Mandados de Segurança 24.781 e 25.116, à luz dos diversos aspectos jurídicos neles envolvidos, notadamente com foco no princípio da segurança jurídica, a fim de verificar a sua coerência e compatibilidade com o ordenamento normativo vigente.

Para isso, será preciso, inicialmente, definir o sentido no qual a segurança jurídica será abordada no presente estudo. Em seguida, será necessário diferenciá-la, como princípio jurídico, das demais espécies normativas, bem como esclarecer a distinção e a relação entre a segurança jurídica em sentido objetivo e o princípio da proteção da confiança (dimensão subjetiva da segurança jurídica) e investigar os respectivos conteúdos. Feito isso, caberá contextualizar a matéria envolvida nos referidos mandados de segurança e identificar os argumentos jurídicos e os fundamentos normativos neles utilizados para invocar o aludido princípio. Por fim, será possível confrontar tais argumentos com as opiniões doutrinárias e demais informações colhidas ao longo deste estudo, a fim de verificar a compatibilidade entre ambos.

\section{A Segurança JURídica E A PROTEÇÃo da CONFIANÇA}

O direito constitucional contemporâneo é marcado pela valorização dos princípios, pela coexistência de valores, pela conformação e pela "ductibilidade". ${ }^{5-6}$ A condição espiritual do nosso tempo assenta-se em uma base material pluralista do direito e pode ser descrita como a aspiração aos muitos princípios e valores que conformam a convivência coletiva, os quais não podem assumir individualmente caráter absoluto para se compatibilizarem com os outros com os quais devem conviver. ${ }^{7}$ Nesse cenário, é de extrema importância

4 Esse entendimento foi adotado inicialmente no MS 25.116 (Relator: Min. Carlos Velloso, DJ 10/02/2011) e no MS 24.781 (Relator para Acórdão: Min. Gilmar Mendes, DJ 09/06/2011), após os quais foram proferidos diversos julgados na mesma linha, a exemplo do MS 28.520/PR (Relator: Min. Ayres Britto, DJ 02/04/2012), MS 28.720/DF (Relator: Min. Ayres Britto, DJ 02/04/2012), MS 27.640/DF (Relator: Min. Ricardo Lewandowski, DJ 19/12/2011) e MS 28.333/DF (Relator: Min. Ricardo Lewandowski, DJ 27/02/2012). Não obstante esses julgados, no Recurso Extraordinário 636.553/RS, ainda pendente de julgamento (conforme pesquisa na internet: < http://www.stf. jus.br/portal/jurisprudencia/pesquisarJurisprudencia.asp>. Acesso em: 15 mar. 2013), o STF reconheceu a repercussão geral da discussão sobre a incidência do prazo decadencial de cinco anos, previsto na Lei n ${ }^{\circ} 9.784 / 1999$, para a anulação de aposentadoria de servidor público pelo TCU, e não reafirmou a jurisprudência dominante sobre a matéria, que será submetida a posterior julgamento (DJ 09/03/2012).

5 O termo "ductibilidade" é usado por Gustavo Zagrebelsky para definir o que autor considera a essência do atual direito constitucional, cujo único valor absoluto seria o pluralismo (ZAGREBELSKY, Gustavo. El derecho dúctil. Ley, derechos, justicia. Trad. Marina Gascón. 9. ed. Madrid: Trotta, 2009).

6 Sobre o papel dos princípios no Direito, ver também GARCÍA DE ENTERRÍA, Eduardo; FERNANDEZ, Tomás-Ramón. Curso de derecho administrativo. 12. ed. Madrid: Civitas, 2005. v. 1, p. 85-92.

7 ZAGREBELSKY, Gustavo. El derecho dúctil. ley, derechos, justicia. Tradução Marina Gascón. 9. ed. Madrid: Trotta, 2009. p. 16. 
conciliar a flexibilidade jurídica que as sociedades atuais, marcadas pelo pluralismo, demandam com a necessidade de segurança e a coerência do ordenamento jurídico.

A segurança jurídica, em sentido amplo, a qual contempla a segurança jurídica em sentido objetivo e a proteção da confiança, ${ }^{8}$ pode ser examinada sob muitas perspectivas, sendo importante especificar em que aspecto ela será abordada antes de se definir o conteúdo normativo do aludido princípio. No presente trabalho, cujo objetivo não é adentrar com profundidade a discussão sobre o conceito de segurança jurídica - matéria que, dada a sua complexidade, demandaria, por si só, um longo estudo - adotar-se-á a definição formulada por Humberto Ávila. Este - propondo-se a adotar um conceito não classificatório, mas gradual e polivalente de segurança jurídica que, em vez de se basear no dualismo segurança-insegurança, funda-se no espectro gradativo que oscila entre um estado de fato de maior ou menor segurança - a define como sendo: ${ }^{9}$

[...] uma norma-princípio que exige, dos Poderes Legislativo, Executivo e Judiciário, a adoção de comportamentos que contribuam mais para a existência, em benefício dos cidadãos e na sua perspectiva, de um estado de confiabilidade e de calculabilidade jurídica, com base na sua cognoscibilidade, por meio da controlabilidade jurídico racional das estruturas argumentativas reconstrutivas de normas gerais e individuais, como instrumento garantidor do respeito à sua capacidade de - sem engano, frustração, surpresa e arbitrariedade - plasmar digna e responsavelmente o seu presente e fazer um planejamento estratégico juridicamente informado do seu futuro.

Estando definido o sentido no qual a segurança jurídica será abordada neste estudo, resta saber o que a diferencia, como norma da espécie princípio, das demais espécies normativas. Feito isso, caberá estabelecer a distinção e a relação entre as dimensões objetiva e subjetiva da segurança jurídica (proteção da confiança), bem como investigar os respectivos conteúdos, para, depois, passar-se ao exame dos casos concretos.

Vários são os autores que se propõem a traçar a distinção entre princípios e regras. ${ }^{10}$ Humberto Ávila, Ronald Dworkin e Robert Alexy, por exemplo, defendem uma distinção forte entre princípios e regras. Para o primeiro, as regras são aplicadas ao modo "tudo ou nada", pois, se a hipótese de incidência de uma regra é preenchida, ou ela é válida e sua consequência normativa deve ser aceita, ou ela não deve ser considerada válida e, no caso de conflito entre regras, uma delas deve ser considerada inválida. Ao contrário, os princípios possuem dimensão de peso, demonstrável na hipótese de colisão entre eles, quando o princípio com peso maior se sobrepõe ao outro, sem que este perca sua validade.

Alexy, partindo das considerações de Dworkin, defende que os princípios jurídicos consistem em espécie normativa por meio da qual são estabelecidos deveres de otimização aplicáveis em vários graus, de acordo com as possibilidades normativas (sua aplicação depende dos princípios e regras a que eles se contrapõem) e fáticas (o seu conteúdo como norma de conduta só pode ser determinado diante dos fatos). A ponderação dos princípios conflitantes é resolvida mediante a criação de regras de prevalência a serem aplicadas diante do caso concreto, de modo a limitar reciprocamente a realização normativa dos princípios colidentes. Por sua vez, as regras são normas que podem ou não ser realizadas, suas premissas são ou não preenchidas e, no caso de colisão, ela é solucionada com a declaração de invalidade de uma delas ou com a abertura de exceção à regra que exclua a antinomia. ${ }^{11}$

8 A distinção entre esses dois aspectos da segurança jurídica será abordada adiante em tópico específico.

9 Essa acepção é utilizada em estudo no qual o autor trabalha com profundidade o conceito de segurança jurídica, tratando dos diversos significados com que ela pode ser empregada e das perspectivas sob as quais pode ser examinada, a fim de, por meio de procedimento analítico, reduzir as ambiguidades do princípio da segurança jurídica e, assim, poder definir os fins e os meios necessários a sua realização. No presente trabalho, assim como o termo "segurança jurídica", as expressões "confiabilidade" e "calculabilidade" também serão empregadas no sentido proposto por esse autor. Dessa forma, o ideal de confiabilidade será utilizado na perspectiva retrospectiva, abrangendo os elementos que proíbem a modificação ou determinado tipo de modificação no presente daquilo que foi conquistado no passado. Já a confiabilidade será empregada na perspectiva prospectiva, referindo-se aos elementos que prescrevem o ritmo da mudança, no futuro, daquilo que está sendo realizado no presente (ÁVILA, Humberto. Segurança jurídica: entre permanência, mudança e realização no direito tributário. 2. ed. São Paulo: Malheiros, 2012. p. 93; 118-119; 274; 437).

10 Acerca da evolução da distinção entre princípios e regras, ver o panorama sobre o pensamento de autores como Josef Esser, Karl Larenz, Claus-Wilhelm Canaris, Ronald Dworkin e Roberto Alexy traçado por ÁVILA, Humberto. Teoria dos princípios: da definição à aplicação dos princípios jurídicos. 2. ed. São Paulo: Malheiros, 2003. p. 26-31. Ver também a crítica à teoria dos princípios e aos diversos critérios distintivos utilizados pela doutrina feita por TORRES, Heleno Taveira. Direito constitucional tributário e segurança jurídica: metódica da segurança jurídica do sistema constitucional tributário. 2. ed. São Paulo: Revista dos Tribunais, 2012. p. 531-535. 11 ÁVILA, Humberto. Teoria dos princípios: da definição à aplicação dos princípios jurídicos. 2. ed. São Paulo: Malheiros, 2003. p. $28-29$. 
Na doutrina brasileira, destacam-se os ensinamentos de Humberto Ávila, que faz uma classificação tripartite, baseada no significado frontal dos dispositivos, a partir dos quais as normas são criadas por meio da interpretação. Segundo essa classificação, de acordo com seu significado preliminar, as normas podem ser regras (dimensão comportamental), princípios (dimensão finalística) e/ou postulados (dimensão metódica). Especificamente com relação aos princípios, o autor os define como "[...] normas imediatamente finalísticas, primariamente retrospectivas e com pretensão de decidibilidade e abrangência", cuja aplicação "[...] se exige a avaliação da correlação entre o estado das coisas a ser promovido e os efeitos decorrentes da conduta havida como necessária à sua aplicação". ${ }^{12}$

Humberto Ávila salienta que as regras são normas que descrevem o que é permitido, proibido e obrigatório. São compostas de uma hipótese, a que se conjuga um mandamento, uma consequência ou uma estatuição, sendo representadas no modelo lógico deôntico pela expressão "se, então". Em razão dessa estrutura normativa, o procedimento de interpretação e aplicação das regras envolve, primordialmente, uma operação terminal de correspondência conceitual entre a situação de fato e a hipótese e a consequência que compõem a norma. Já os princípios jurídicos são normas que estabelecem um estado ideal das coisas (um fim) e, para sua realização, é necessária a adoção de comportamentos cujos efeitos contribuam para a sua promoção (meios), de modo que seu modelo lógico possa ser representado pela expressão "para, então é preciso". Como consequência, o procedimento de interpretação e de aplicação dos princípios difere daquele que é aplicado às normas, e abrange, primordialmente, o exame da correlação entre o estado das coisas, efeitos e condutas. ${ }^{13}{ }^{14}$

Especificamente em relação à segurança jurídica, apesar de também apresentar a estrutura finalística comum a todos os princípios, ela se distingue dos demais princípios e regras na medida em que pressupõe a intermediação de uma realidade jurídica. Para a sua aplicação, é preciso relacionar um elemento normativo (princípio da segurança jurídica) com uma realidade jurídica (seja ela uma norma ou aplicação de uma norma), não com um elemento fático. Assim, enquanto um princípio material qualquer pressupõe uma relação entre uma norma (princípio) e os efeitos de um comportamento (realidade fática), o princípio da segurança jurídica pressupõe o cotejo de uma norma (princípio da segurança jurídica) com os efeitos de outra norma, que pode ser legal, administrativa ou judicial (realidade jurídica). ${ }^{15}$ No presente estudo, por exemplo, será preciso cotejar o princípio da segurança jurídica (norma superior) como uma norma judicial (norma inferior), a fim de verificar se esta última se compatibiliza com aquele.

12 ÁVILA, Humberto. Teoria dos princípios: da definição à aplicação dos princípios jurídicos. 2. ed. São Paulo: Malheiros, 2003. p. 119. 13 ÁVILA, Humberto. Segurança jurídica: entre permanência, mudança e realização no direito tributário. 2. ed. São Paulo: Malheiros, 2012. p. 118-119.

14 Com posicionamento divergente do ora mencionado, Heleno Taveira Torres, embora não negue que exista distinção entre regras e princípios, critica a força que lhe é apregoada pela doutrina, especialmente quando utilizada com o intuito de assinalar alguma preferência das regras sobre os princípios na estrutura do ordenamento jurídico ou como medida de segurança jurídica. Para ele, a distinção existe no plano das normas jurídicas em sentido amplo, mas ambos são como que fragmentos de normas, necessários para a composição da norma de conduta de aplicação, posta sempre no ordenamento sob a forma de regra jurídica. Nessa perspectiva, o autor define os princípios como sendo "normas lato sensu de direito positivo que prescrevem valores objetivos, relativos e vinculantes para todo o sistema jurídico, com ou sem limitação a específicas regras ou subsistemas, obrigam ao máximo de observância e efetividade e vedam qualquer conduta em sentido contrário ao seu âmbito normativo, e, mormente ao seu conteúdo essencial." (TORRES, Heleno Taveira. Direito constitucional tributário e segurança jurídica: metódica da segurança jurídica do sistema constitucional tributário. 2. ed. São Paulo: Revista dos Tribunais, 2012. p. 535-546). Não obstante a coerência desse posicionamento, no presente estudo optou-se por utilizar, de maneira geral, os conceitos e classificações propostos por Humberto Ávila, em razão da maior preocupação desse autor com a precisão terminológica dos termos que emprega, bem como com a prévia definição da perspectiva que utiliza em cada caso. Considera-se essencial essa preocupação, uma vez que, na dogmática jurídica, observa-se que as divergências colocadas pela doutrina, quando examinadas a fundo, muitas vezes, decorrem apenas da diferença de perspectiva adotada por cada autor para examinar determinado objeto ou de imprecisões terminológicas. É o que ocorre, por exemplo, com a própria segurança jurídica, que pode ser analisada sob vários aspectos e cujo termo contempla múltiplos sentidos. Se esses pontos não forem previamente definidos, torna-se inviável qualquer consenso doutrinário. Não há como existir acordo sobre um objeto quando ele é observado sob ângulos completamente diferentes ou quando, apesar da utilização do mesmo termo, trata-se, em verdade, de objetos distintos (sobre o problema dessa imprecisão e sobre as diversas possibilidades de exame que a segurança jurídica comporta, ver: ÁVILA, Humberto. Seguranç jurídica: entre permanência, mudança e realização no direito tributário. 2. ed. São Paulo: Malheiros, 2012. p. 39-189). 15 ÁVILA, Humberto. Segurança jurídica: entre permanência, mudança e realização no direito tributário. 2. ed. São Paulo: Malheiros, 2012. p. $125-126$. 


\subsection{Distinção terminológica: segurança jurídica x proteção à confiança}

A proteção à confiança por vezes é tratada como sinônimo ou como mera vertente da segurança jurídica. Contudo, embora esses conceitos estejam intimamente ligados, atualmente na ciência jurídica já se chegou a uma relativa separação entre eles. A proteção à confiança nasce a partir da segurança jurídica, mas com ela não se confunde, havendo uma tendência, no âmbito da doutrina, a tratá-la como princípio autônomo. Modernamente, no direito comparado, a doutrina prefere admitir a existência de dois princípios distintos: fala-se em princípio da segurança jurídica quando designam o que prestigia o aspecto objetivo da estabilidade das relações jurídicas, e em princípio da proteção à confiança, quando aludem ao que atenta para o aspecto subjetivo. Assim, a segurança jurídica é entendida como conceito ou princípio jurídico que se ramifica em duas partes, uma de natureza objetiva e outra de natureza subjetiva. A primeira (objetiva) é aquela que envolve a questão dos limites à retroatividade dos atos do Estado, até mesmo quando eles se qualificam como atos legislativos. Diz respeito, portanto, à proteção ao direito adquirido, ao ato jurídico perfeito e à coisa julgada. A outra (subjetiva) relaciona-se à proteção à confiança das pessoas no tocante aos atos, aos procedimentos e às condutas do Estado nos mais diferentes aspectos da sua atuação. ${ }^{16} 17$

Humberto Ávila coloca a segurança jurídica como “sobrepríncípio” quando examinada em relação à proteção da confiança, a qual, embora não seja uma mera decorrência, por dedução, do princípio da segurança jurídica, dele deriva, ${ }^{18}$ por ser uma eficácia reflexa da sua aplicação, em conjunto com os direitos fundamentais de liberdade e de propriedade, e com os princípios definidores da atuação estatal. Tratando da dimensão dinâmica da segurança jurídica, ${ }^{19}, \mathrm{o}$ autor distingue a dimensão objetiva da dimensão subjetiva. A primeira está relacionada à ideia de permanência, refere-se ao ordenamento jurídico como um todo, cuja estabilidade é condição do exercício das liberdades dos cidadãos. É voltada ao benefício do conjunto de liberdades, independentemente da demonstração do seu efetivo exercício individual, afetando a credibilidade institucional do Direito como pressuposto do exercício potencial das liberdades. Nessa dimensão da segurança jurídica, tem-se, portanto, a intangibilidade de situacões individuais por questões objetivas, como o decurso do tempo (decadência e prescrição), a consolidação jurídica das situações (ato jurídico perfeito, direito adquirido, coisa julgada e fato gerador ocorrido), a consolidação fática das situações, e a ausência de prejuízo. Já a segunda está ligada à ideia de proteção da confiança, relativa ao exercício da liberdade de alguém, à defesa de interesses individuais nos casos em que o particular, não sendo protegido pelo direito adquirido, pelo ato jurídico perfeito ou pela coisa julgada (questões objetivas), exerce sua liberdade confiando na validade (ou aparecia de validade) de um conhecido ato normativo geral ou individual (neles inclú́dos os atos administrativos e judiciais) e, posteriormente, tem sua confiança frustrada pela descontinuidade da vigência ou dos efeitos desse ato. Em decorrência dessa dimensão da segurança jurídica, fala-se na intangibilidade de situações individuais por questões subjetivas, cuja proteção, que engloba inclusive a confiança baseada em atos normativos inválidos, pressupõe uma análise de circunstâncias concretas e depende de uma ponderação com outros princípios também integrantes da segurança jurídica. Assim, pode-se afirmar que o princípio da segurança jurídica qualifica uma norma objetiva, abstrata e protetiva de interesses coletivos, que serve para a proteção das confianças ou do conjunto de confianças no ordenamento jurídico, vinculando-se, portanto, a uma justiça geral. Já o princípio da proteção da confiança representa uma aplicação reflexiva, subjetiva e concretamente orientada do princípio objetivo da segurança jurídica, sendo o instrumento de proteção "de uma confiança", vinculado à justiça individual. ${ }^{20}$

16 SILVA, Almiro do Couto e. O princípio da segurança jurídica (proteção à confiança) no direito público brasileiro e o direito da administração pública de anular seus próprios atos administrativos: o prazo decadencial do art. 54 da lei do processo administrativo da União: lei no 9.784/99. Revista Eletrônica de Direito do Estado, Salvador, n. 2, abr./jun., 2005. Disponível em: <http://www.direitodoestado.com.br>. Acesso em: 5 maio 2012. p. 3-4.

17 Distinção semelhante é feita por GOMES CANOTILHO, José Joaquim. Direito constitucional e teoria da constituição. 7. ed. Coimbra: Almedina, 2010. p. 257

18 Misabel Abreu Machado Derzi, referindo-se à segurança em sentido amplo, também entende que a proteção da confiança é deduzida da segurança jurídica (DERZI, Misabel Abreu Machado. Modificações da jurisprudência no direito tributário: proteção da confiança, boa-fé objetiva e irretroatividade como limitações constitucionais ao poder judicial de tributar. São Paulo: Noeses, 2009 . p. 381. 19 A distinção entre as dimensões dinâmica e estática da segurança jurídica será tratada mais adiante no tópico destinado ao exame do conteúdo do princípio da segurança jurídica.

20 ÁVILA, Humberto. Segurança jurídica: entre permanência, mudança e realização no direito tributário. 2. ed. São Paulo: Malhei- 
Ávila explica que, segundo Sylvia Calmes, o princípio da proteção da confiança é diferenciado do princípio da segurança jurídica pelos seguintes critérios: a) âmbito normativo: o primeiro relaciona-se com o aspecto normativo do ordenamento jurídico, enfatizando o âmbito microjurídico, e o segundo diz respeito ao ordenamento como um todo, focando o âmbito macrojurídico; b) âmbito pessoal: o princípio da segurança jurídica representa uma norma objetiva, não necessariamente vinculada a um sujeito específico, e o princípio da proteção da confiança protege o interesse de uma pessoa específica; c) nivel de concretização: o princípio da segurança jurídica refere-se, primordialmente, ao plano abstrato, e o da proteção da confiança ao plano concreto de aplicação; d) amplitude subjetiva de proteção: o princípio da segurança jurídica protege interesses coletivos, e o princípio da proteção da confiança protege interesses individuais; e) protetividade individual: o princípio da segurança jurídica é neutro em relação ao interesse dos cidadãos e o princípio da proteção da confiança só é utilizado com a finalidade de proteger os interesses daqueles que se sentem prejudicados pelo exercício passado de liberdade juridicamente originada. ${ }^{21}$

Heleno Torres afirma que a segurança jurídica pode coincidir tanto com a certeza do direito (segurança jurídica formal, princípio da certeza do direito) quanto com a estabilidade do ordenamento ou da confiança legítima stricto sensu. Explica que a segurança jurídica como medida de estabilidade do direito pode ser subjetiva ou objetiva. Essa é a segurança do sistema; trata-se da segurança jurídica por excelência, na função de estabilidade sistêmica (objetiva), a qual se divide em: estabilidade das formas; estabilidade temporal; estabilidade por calibração ou balanceamento do sistema de normas; e segurança jurídica dos princípios (material). Ela não tem nada a ver com a segurança como tutela de interesses individuais ou de bens juridicamente protegidos.

De forma diversa, a segurança jurídica como proteção da confiabilidade legítima (segurança jurídica subjetiva) equivale à certeza como previsibilidade ou expectativas de condutas individuais. Trata-se da garantia de segurança jurídica pelo direito nas relações jurídicas e intersubjetivas e está ligada ao que a Sociologia Jurídica denomina de sentimento social de segurança ou de proteção. A confiança é um estado psicológico que possui íntima relação com a boa-fé objetiva. Para ter eficácia jurídica, a confiança deverá objetivar-se de algum modo, não cabendo vincular esse princípio à simples expectativa, suposição ou esperança.

O princípio da proteção de expectativas de confiança legítima não se vê dotado de autonomia em relação ao princípio da segurança jurídica. Ele requer a confiança dos jurisdicionados no bom funcionamento do sistema jurídico e essa confiança, por sua vez, apresenta-se como uma eficácia do princípio da certeza do direito ou da estabilidade do ordenamento, de modo que sempre que se verificar alguma quebra de segurança jurídica, igualmente haverá afetação à expectativa de confiança legítima. ${ }^{22}$

Apesar da distinção entre os dois princípios, para a melhor compreensão deste trabalho, deve-se considerar que, no direito brasileiro, a legislação federal e, por vezes, a jurisprudência fazem menção à segurança jurídica tendo em mente seu aspecto subjetivo, referindo-se, assim, ao que no direito alemão é denominado de "princípio da proteção à confiança", e no direito da União Europeia é chamado de "princípio da proteção à confiança legítima".23

No presente estudo, considerando que se abordará a atuação do TCU em face de atos administrativos ilegais e a expectativa por eles gerada nos indivíduos em razão da presunção de legitimidade dos atos emanados do Poder Público, ter-se-á em foco, sob esse prisma, o aspecto subjetivo da segurança jurídica, princípio da

ros, 2012. p. 348-352; 367-370; 638-643.

21 ÁVILA, Humberto. Segurança jurídica: entre permanência, mudança e realização no direito tributário. 2. ed. São Paulo: Malheiros, 2012. p. 368-369.

22 TORRES, Heleno Taveira. Direito constitucional tributário e segurança jurídica: metódica da segurança jurídica do sistema constitucional tributário. 2. ed. São Paulo: Revista dos Tribunais, 2012. p. 203-221.

23 SILVA, Almiro do Couto e. O princípio da segurança jurídica (proteção à confiança) no direito público brasileiro e o direito da administração pública de anular seus próprios atos administrativos: o prazo decadencial do art. 54 da lei do processo administrativo da União: lei n ${ }^{\circ}$ 9.784/99. Revista Eletrônica de Direito do Estado, Salvador, n. 2, abr./jun., 2005. Disponível em: < http://www.direitodoestado.com.br>. Acesso em: 5 maio 2012. p. 10. 
proteção à confiança. Por outro lado, tendo em vista que, como se verá adiante, nos precedentes que serão examinados, a argumentação desenvolvida pelo STF se fundamentou, em grande parte, na consolidação das situações em razão do decurso do tempo (elemento objetivo), o tema englobará também o aspecto objetivo da segurança jurídica. Ambas as dimensões estão, portanto, envolvidas no julgamento dos Mandados de Segurança 24.781/DF e 25.116/DF: a objetiva, quando se analisa a consolidação das situações em razão do decurso do tempo na atuação do TCU; a subjetiva, quando se examina a frustração da confiança do particular no ato de aposentadoria, reforma e pensão, baseada, entre outros princípios, na presunção de legitimidade e de legalidade do ato emanado do Poder Público, a qual também pode ser fundamentada pelo decurso do tempo.

Por essa razão, optou-se por abordar os dois princípios, utilizando-se o termo "princípio da proteção à confiança" ou apenas "princípio da confiança" para representar exclusivamente o aspecto subjetivo da segurança jurídica e, genericamente, o termo "princípio da segurança jurídica” para tratar do sobreprincípio, ${ }^{24}$ de caráter mais amplo, que engloba os dois aspectos da segurança jurídica, ou, ainda, para designar apenas o seu aspecto objetivo.

Há que se considerar ainda que, conquanto em algumas situações os princípios da segurança jurídica (vista apenas sob o seu aspecto objetivo) e da proteção à confiança possam apontar para caminhos opostos (uma vez que a proteção da confiança coletiva ou das confianças pode implicar na quebra da confiança de determinado indivíduo e vice-versa), ${ }^{25} \mathrm{em}$ geral, a proteção de um depende da proteção do outro. A recorrente frustração de expectativas individuais (quebra da confiança), por exemplo, termina por colocar em dúvida a credibilidade (confiabilidade e calculabilidade) do ordenamento jurídico como um todo, e, por conseguinte, afeta também a segurança jurídica em seu aspecto objetivo (quebra das confianças). Não é por outro motivo que se diz que a proteção da confiança é uma eficácia reflexa da segurança jurídica. Assim, não obstante a separação conceitual dos dois princípios, em situações concretas como as examinadas neste estudo, ainda que seja para identificar qual deles foi empregado, precisa-se trabalhar com ambos conjuntamente.

\subsection{0 conteúdo do princípio da segurança jurídica objetiva e subjetiva}

O princípio da segurança jurídica em sentido amplo, na linha proposta por Humberto Ávila, pode ser analisado em duas dimensões: estática e dinâmica. A dimensão estática, que está associada ao conteúdo do direito, diz respeito ao problema do conbecimento do direito (ao seu saber) e da comunicaşão no direito. Revela quais as qualidades, os requisitos estruturais, que ele deve possuir para ser considerado seguro e servir de instrumento de orientação ao cidadão. Trata-se, nesse aspecto, das condições ou qualidades necessárias para que o direito possa ser objeto de conhecimento, tanto do ponto de vista material, quanto do intelectual, pois, para poder obedecer a uma norma o cidadão precisa não só ter acesso a ela (cognoscibilidade material), mas também ter a possibilidade de compreender o que ela determina, pró́be ou prescreve (cognoscibilidade intelectual). Nesse sentido, o direto dever ser compreensivel e efetivo.

24 O termo "segurança jurídica" com esse sentido amplo também é empregado por outros autores, a exemplo de Ingo Wolfgang Sarlet (SARLET, Ingo Wolfgang. A eficácia do direito fundamental à segurança jurídica: dignidade da pessoa humana, direitos fundamentais e proibição de retrocesso social no direito constitucional brasileiro. Revista de Direito Constitucional e Internacional, São Paulo: Revista dos Tribunais, v. 14, n. 57, out./dez. 2006. p. 11-12) e Misabel Abreu Machado Derzi (DERZI, Misabel Abreu Machado. Modificações da jurisprudência no direito tributário: proteção da confiança, boa-fé objetiva e irretroatividade como limitações constitucionais ao poder judicial de tributar. São Paulo: Noeses, 2009. p. 381).

25 Sobre a possibilidade de conflito entre os dois aspectos da segurança jurídica, Humberto Ávila menciona que "[...] o princípio da segurança jurídica revelaria, assim, a face geral da segurança jurídica, protegendo o interesse de alguns, apesar, eventualmente, do interesse de todos; ao passo que o princípio da proteção da confiança garantiria o interesse de um ou de alguns apesar, eventualmente, do interesse de todos". Mais adiante, ressalta que “[...] a aplicação desses princípios pode conduzir a resultados opostos, gerando, desse modo, um conflito interno dentro da própria segurança jurídica, considerada como princípio maior: sendo o princípio da segurança jurídica o todo e o princípio da proteção da confiança legítima a parte, pode ser que a garantia desta leve à restrição daquela, e vice-versa." (ÁVILA, Humberto. Segurança jurídica: entre permanência, mudança e realização no direito tributário. 2 . ed. São Paulo: Malheiros, 2012. p. 369). 
A dimensão dinâmica refere-se ao problema da ação no tempo e revela quais ideias devem ser garantidos para que o ordenamento jurídico possa assegurar direitos e expectativas ao cidadão, servindo-lhe de instrumento de proteção. Em tal aspecto, o direito deve ser calculável, permitindo que o cidadão saiba quais mudanças podem ser feitas e quais não podem, para não ter seus direitos frustrados; e confível, garantindo que o cidadão tenha condição de saber como e quando as mudanças podem ser realizadas, para não ser surpreendido. Trata-se, portanto, de se buscarem os requisitos relacionados não mais à norma, como na dimensão estática, mas os relativos aos atos indispensáveis à sua aplicação. ${ }^{26}$

Embora sem utilizar a mesma terminologia, Heleno Torres, ressaltando que a separação se dá apenas para fins heurísticos, adota uma classificação tripartite, a qual guarda certa semelhança com a acima mencionada, quando trata dos âmbitos funcionais do princípio da segurança jurídica. Ele separa a função de certęa da segurança jurídica (segurança jurídica formal) da segurança jurídica por estabilidade do sistema jurídico ou da confiança legítima stricto sensu. $\mathrm{Na}$ primeira, discorre sobre a função de certeza e respectiva acessibilidade da legislação sobre as regras de validade, de procedimentos e de competências que concorrem para a constituição das fontes do direito, e sobre o efeito de orientação e de certeza que elas produzem nos indivíduos. Na segunda, explica que a segurança jurídica como medida de estabilidade do sistema normativo pode ser subjetiva ou objetiva. Essa é a segurança do sistema e trata-se da segurança jurídica por excelência, na função de estabilidade sistêmica (objetiva), a qual se divide em: estabilidade das formas (compreende a coerência estrutural no tocante à coordenação das normas e órgãos entre si, respeito à hierarquia e competências); estabilidade temporal (preservação das situações consolidadas no tempo); estabilidade por calibração ou balanceamento do sistema de normas (princípios implícitos de proibição de excesso, proporcionalidade e razoabilidade); e segurança jurídica dos princípios (material, abrange todos os meios necessários à efetivação dos princípios). Já a segurança jurídica subjetiva, refere-se ao campo experiencial de aplicação do direito por autoridades ou órgãos públicos, à proteção da confiabilidade legítima stricto sensu. ${ }^{27}$

Sob olhar atento, nota-se que a segurança jurídica enquanto efetividade de critérios objetivos de certeza do direito de que fala o autor (princípio de certeza do direito), assemelha-se em grande parte à dimensão estática acima mencionada. Da mesma forma, a estabilidade do ordenamento ou da confiança legítima stricto sensu, perspectiva dentro da qual ele menciona a distinção entre a segurança jurídica subjetiva e a objetiva, possui similitude com a dimensão dinâmica da classificação adotada por Humberto Ávila.

No presente estudo - cujo objetivo é analisar os fundamentos normativos e os argumentos jurídicos relativos à segurança jurídica invocados nos julgamentos dos Mandados de Segurança 24.781 e 25.116 - a segurança jurídica, seguindo a classificação acima proposta, será examinada com foco na dimensão dinâmica. Não obstante a efetivação do princípio envolva necessariamente ambas as dimensões, estática e dinâmica, optou-se por dar ênfase a segunda, na qual estão inseridas as questões relativas ao tempo e à permanência, porque a argumentação dos referidos precedentes se desenvolveu essencialmente em torno do decurso do tempo e da maior aparência de legitimidade que ele confere aos atos emanados do Poder Público. Na dimensão dinâmica, serão abordadas mais duas dimensões da segurança jurídica, objetiva e subjetiva, já mencionadas anteriormente, ao tratar-se da distinção terminológica entre a segurança jurídica e a proteção da confiança. ${ }^{28}$

\subsubsection{Dimensão objetiva: intangibilidade das situações individuais por questões objetivas}

A Segurança jurídica em sentido objetivo corresponde à segurança do ordenamento jurídico, do sistema na sua integridade, não se confunde com a segurança da conformidade das relações intersubjetivas (proteção

26 ÁVILA, Humberto. Segurança jurídica: entre permanência, mudança e realização no direito tributário. 2. ed. São Paulo: Malheiros, 2012. p. 295-298; 305; 345.

27 TORRES, Heleno Taveira. Direito constitucional tributário e segurança jurídica: metódica da segurança jurídica do sistema constitucional tributário. 2. ed. São Paulo: Revista dos Tribunais, 2012. p. 203-215.

28 Para tratar do conteúdo das duas dimensões dinâmicas da segurança jurídica, objetiva e subjetiva, adotar-se á neste estudo a mesma estrutura utilizada por: ÁVILA, Humberto. Segurança jurídica: entre permanência, mudança e realização no direito tributário. 2. ed. São Paulo: Malheiros, 2012. Segunda Parte, Título I, Cap. 2. 
da confiança). Trata-se, segundo Heleno Torres, da segurança jurídica por excelência, na função de estabilidade sistêmica. ${ }^{29}$ Nesse sentido (objetivo), a segurança jurídica, examinada na dimensão dinâmica, envolve os aspectos relativos à permanência do ordenamento jurídico pela manutenção do seu conteúdo (cláusulas pétreas, resistência à modificação do núcleo axiológico da Constituição) e das suas normas (exigência de durabilidade do ordenamento jurídico como um todo, para que ele tenha credibilidade e os cidadãos possam exercer suas liberdades). Engloba, ainda, a exigência de intangibilidade das situações individuais por questões objetivas - parte que interessa ao presente estudo - relativas ao transcurso do tempo, à consolidação fática ou jurídica das situações ou à ausência de prejuízo. ${ }^{30}$

A intangibilidade de situações individuais pelo decurso do tempo ocorre quando se opera a decadência ou a prescrição. ${ }^{31}$ Em ambas, as situações são consolidadas em razão de prazos objetivamente previstas no ordenamento jurídico, com o fim de estabelecer um estado de confiabilidade, os quais são aplicados independentemente de questões subjetivas, como a análise da efetiva manifestação de confiança pelos interessados. ${ }^{32}{ }_{-} 33$ No caso desses institutos, o próprio legislador já pondera o conflito entre os princípios da segurança jurídica e da legalidade (ou entre a segurança jurídica e a justiça) apontando a solução para o problema. Não há, aqui, espaço para o aplicador decidir, com base em critérios subjetivos, qual desses valores vai prevalecer no caso concreto. Atendidos os requisitos estabelecidos na norma, não lhe resta alternativa se não reconhecer a ocorrência da prescrição ou da decadência. ${ }^{34}$

No ordenamento jurídico brasileiro, encontram-se diversas situações em relação às quais o legislador, prestigiando a segurança jurídica, estabeleceu prazos prescricionais ou decadenciais. Como exemplo, citam-se: na Constituição Federal de 1988, o art. 37, inciso III, $\int 5^{\circ}$, que trata da prescrição para ilícitos praticados por qualquer agente, servidor ou não, que cause prejuízos ao erário; o art. $7^{\circ}$, inciso XXIV, o qual estabelece o prazo prescricional da ação relativa a créditos resultantes da relação de trabalho; e o art. 146, inciso III, alínea b, que reserva à lei complementar a disciplina sobre, entre outras questões, prescrição e decadência tributárias, matéria que foi tratada pelo Código Tributário Nacional (Lei no 5.172/1966) nos arts.

29 TORRES, Heleno Taveira. Direito constitucional tributário e segurança jurídica: metódica da segurança jurídica do sistema constitucional tributário. 2. ed. São Paulo: Revista dos Tribunais, 2012. p. 211-212.

30 ÁVILA, Humberto. Segurança jurídica: entre permanência, mudança e realização no direito tributário. 2. ed. São Paulo: Malheiros, 2012. p. 348-366.

31 Além da decadência e da prescrição, Heleno Torres coloca que, na segurança jurídica por estabilidade temporal, têm-se os regimes do direito adquirido, do ato jurídico perfeito, da coisa julgada e da irretroatividade de atos jurídicos não benignos aos seus destinatários. Afirma, ainda, que essa modalidade de segurança jurídica garante o destinatário das normas contra mudanças inoportunas ou frequentes, justifica modulações dos efeitos de decisões, admite a manutenção de atos anuláveis ou revogáveis em função do tempo ou da demonstração de confiança na sua validade (Direito constitucional tributário e segurança jurídica: metódica da segurança jurídica do sistema constitucional tributário. 2. ed. São Paulo: Revista dos Tribunais, 2012. p. 531-535, p. 213). Da forma que o autor abordou a matéria, trata-se de posicionamento coerente, especialmente se considerarmos que as divisões ora propostas visam apenas a facilitar a compreensão do tema, por meio da sua sistematização, pois, na prática, a efetivação da segurança jurídica envolve, simultaneamente, todas as perspectivas (estática, dinâmica, objetiva e subjetiva). Contudo, para manter a coerência deste estudo, todas as referidas questões serão abordadas seguindo-se a divisão utilizada por Humberto Ávila, como já dito.

32 ÁVILA, Humberto. Segurança jurídica: entre permanência, mudança e realização no direito tributário. 2. ed. São Paulo: Malheiros, 2012. p. 352-355.

33 Sobre a desnecessidade de efetiva manifestação de confiança, ver também, na mesma linha Almiro do Couto e Silva, o qual, referindo-se ao prazo decadencial estabelecido no art. 54 da Lei n ${ }^{\circ}$ 9.784/1999, ressalta que o preceito não exige que a confiança do destinatário seja digna de proteção, o que se comprovaria por atos concretos por ele realizados [SILVA, Almiro do Couto e. O Princípio da Segurança Jurídica (Proteção à Confiança) no Direito Público Brasileiro e o Direito da Administração Pública de Anular seus Próprios Atos Administrativos: o prazo decadencial do art. 54 da lei do processo administrativo da União: lei $\mathrm{n}^{\circ} 9.784 / 99$. Revista Eletrônica de direito do Estado, Salvador, Instituto de Direito Público da Bahia, n. 2, abr./jun. 2005. Disponível em: < http:// www.direitodoestado.com.br>. Acesso em: 5 maio 2012. p. 37].

34 Nesse sentido, são as ponderações de Almiro do Couto e Silva, as quais, embora se refiram especificamente à decadência prevista no art. 54 da Lei no 9.784/1999, podem ser aplicadas de maneira geral aos institutos da decadência e da prescrição [SILVA, Almiro do Couto e. O Princípio da Segurança Jurídica (Proteção à Confiança) no Direito Público Brasileiro e o Direito da Administração Pública de Anular seus Próprios Atos Administrativos: o prazo decadencial do art. 54 da lei do processo administrativo da União (Lei no 9.784/99). Revista Eletrônica de Direito do Estado, Salvador, Instituto de Direito Público da Bahia, n. 2, abril/maio/junho, 2005. p. 21-22; 25. Disponível em: <http://www.direitodoestado.com.br>. Acesso em: 5 maio 2012]. 
156, V (causas de extinção do crédito tributário), 168 (extinção do direito de pleitear a restituição), 169 (prescrição da ação anulatória de decisão administrativa denegatória de restituição), 173 (extinção do direito de a Fazenda Pública constituir o crédito tributário) e 174 (prescrição da ação de cobrança do crédito tributário); na Lei n ${ }^{\circ}$ 9.784/1999, o art. 54, o qual estabelece o prazo decadencial do direito da Administração de anular seus próprios atos de que decorram efeitos favoráveis para os destinatários; no Código Penal, o art. 107, inciso IV, (redação dada pela Lei $n^{\circ} 7.209 / 1984$ ), que prevê a decadência e a prescrição como causas de extinção da punibilidade, os arts. 109 a 118, que disciplinam a prescrição penal e o art. 103, instituidor da decadência do direito de queixa ou de representação; e no Código Civil, os arts. 189 a 211, que tratam da prescrição e da decadência.

A consolidação jurídica das situações ocorre nas hipóteses relativas aos institutos da coisa julgada, do ato jurídico perfeito e do direito adquirido35 (expressamente protegidos contra a vontade do legislador entre os direitos e garantias fundamentais consagrados pela Constituição Federal de 1988, em seu art. 5º inciso XXVI), ou, ainda, quando há proteção contra a irretroatividade de normas para atingir fato gerador ocorrido. Segundo a Lei de Introdução às Normas do Direito Brasileiro (art. $6^{\circ}, \int 1^{\circ}$ ), o ato jurídico perfeito é aquele já consumado segundo a lei vigente ao tempo em que se efetuou, de forma que, com a proteção constitucional, ele não pode ser atingido por uma nova norma que venha a alterar os requisitos para a sua constituição.

O direito adquirido - cuja proteção advém da eficácia ampla do direito de proteção patrimonial, decorrente dos direitos fundamentais de liberdade e de propriedade - é aquele surgido pela concretização dos requisitos legais necessários à eficácia de fatos ou de atos jurídicos com base em norma anterior, vigente no momento de sua verificação, os quais não podem ser alcançados por nova norma. Trata-se, assim, da proteção do direito e dos efeitos desses atos ou fatos concretizados com base na norma anterior.

Já a coisa julgada refere-se a situações abrangidas por decisão judicial da qual não caiba mais recurso, cujos efeitos a constituição proíbe que sejam afetados por uma nova norma. A cláusula de proteção visa, nesse caso, por fim a uma discussão de forma objetiva, independentemente da justiça ou da injustiça da decisão (questões subjetivas), de modo a proteger a confiança depositada pelos indivíduos alcançados pela eficácia subjetiva da coisa julgada e respeitar o estado de confiabilidade do ordenamento jurídico. Por fim, tem-se ainda a consolidação jurídica das situações em face da proteção do fato gerador ocorrido contra a incidência de uma lei nova, a exemplo do art. 150, inciso III, alínea “a”, da Constituição Federal de 1988, que proíbe a tributação de fatos geradores ocorridos antes da vigência da lei que os houver instituído. ${ }^{36}$

No caso da Consolidação fática, têm-se situações que, embora não protegidas por norma que dê suporte a produção dos seus efeitos - como nos casos do direito adquirido, do ato jurídico perfeito, da decadência e da prescrição - elas estão de tal forma consolidadas do ponto de vista fático, que a desconstituição retrospectiva dos seus efeitos se revela, no âmbito do Direito, proibida. Em casos assim, o Supremo Tribunal Federal costuma falar em "situação consolidada pela força normativa dos fatos" que não pode ser desconsiderada pelo

35 O enquadramento desses institutos como manifestação da segurança jurídica em seu aspecto objetivo também é ressaltado por Almiro do Couto e Silva, o qual observa que, no direito brasileiro tem-se uma antiga tradição de proteção constitucional ao direito adquirido, ao ato jurídico perfeito e à coisa julgada, pontos nos quais se revela a segurança jurídica no seu aspecto objetivo, motivo porque talvez não tenha havido grande preocupação na identificação da segurança jurídica vista pelo ângulo subjetivo da proteção à confiança, como princípio constitucional, situado no mesmo plano de importância do princípio da legalidade [SILVA, Almiro do Couto e. O Princípio da Segurança Jurídica (Proteção à Confiança) no Direito Público Brasileiro e o Direito da Administração Pública de Anular seus Próprios Atos Administrativos: o prazo decadencial do art. 54 da lei do processo administrativo da União (Lei n $\left.{ }^{\circ} 9.784 / 99\right)$. Revista Eletrônica de Direito do Estado, Salvador, Instituto de Direito Público da Bahia, n. 2, abr./jun. 2005. p. 9. Disponível em: < http:// www.direitodoestado.com.br>. Acesso em: 5 maio 2012.

36 Humberto Ávila, ao tratar do "fato gerador ocorrido" menciona apenas essa hipótese, uma vez que o foco de sua obra é a segurança jurídica no Direito Tributário. Contudo trata-se do mesmo raciocínio aplicado à irretroatividade da lei penal mais grave, prevista no inciso XL do art. $5^{\circ}$ da Constituição Federal de 1988, segundo o qual "a lei penal não retroagirá, salvo para beneficiar o réu”. (ÁVILA Humberto. Segurança jurídica: entre permanência, mudança e realização no direito tributário. 2. ed. São Paulo: Malheiro, 2012. p. 355-362). 
Direito. Foi o que ocorreu, por exemplo, no julgamento do MS 24.268/MG ${ }^{37}$ que tratou de decisão unilateral do TCU por meio da qual foi determinada a suspensão do benefício de uma pensionista que já o recebia por 18 anos. Mesmo considerando tratar-se de situação de fraude, o Supremo Tribunal Federal, com base no princípio da segurança jurídica, concedeu a segurança para determinar a observância do devido processo legal. Na ocasião, embora o voto condutor da deliberação tenha feito referência à proteção da confiança, Humberto Ávila defende que, dada a caracterização de adoção fraudulenta, a rigor, a decisão não teve como base a proteção da confiança legítima, mas a intangibilidade do ato em virtude da sua consolidação temporal. ${ }^{38}{ }^{39}$

Já a intangibilidade de situações individuais em face da ausência de prejuízo se dá quando, embora ilegalmente praticado o ato, a finalidade legal, por via transversa, é atingida, inexistindo qualquer prejuízo para as partes envolvidas. É o que acontece, por exemplo, quando o judiciário reconhece a validade de atos administrativos praticados por funcionários de fato, no exercício irregular da função pública, por não prejudicarem os sujeitos interessados. A ausência de prejuízo opera, nesses casos, como fator estabilizador do ato impugnado. ${ }^{40}$

Todas as hipóteses acima mencionadas como razões justificadoras da preservação de situações individuais referem-se, portanto, a fatores cuja análise independe de elementos subjetivos. Os atos ou fatos jurídicos são conservados em respeito à dimensão objetiva da segurança jurídica, prestigia-se a confiabilidade e a calculabilidade do ordenamento independentemente de questões como a legitimidade originária das situações preservadas, a presença de boa-fé ou a efetiva manifestação de confiança dos envolvidos.

\subsubsection{Dimensão subjetiva: intangibilidade das situações individuais por questões subjetivas}

Além das hipóteses atinentes a aspectos objetivos, existem também situações em que atos ou fatos jurídicos tornam-se intangíveis por motivos relacionados a questões subjetivas, aferíveis diante de situações concretas. Tem-se, aqui, a vertente subjetiva da segurança jurídica, também chamada de princípio da proteção da confiança ou da proteção da confiança legítima stricto sensu, que, como já mencionado, insere-se na dimensão dinâmica da segurança jurídica, por relacionar-se ao problema da ação no tempo.

37 BRASIL. Supremo Tribunal Federal. Mandado de Segurança. MS 24.268. Impetrante: Fernanda Fiuza Brito. Impetrado: Tribunal de Contas da União. Relatora: Min. Ellen Gracie. Brasília, 17 set..

38 ÁVILA, Humberto. Segurança jurídica: entre permanência, mudança e realização no direito tributário. 2. ed. São Paulo: Malheiros, 2012. p. 362-365.

39 Com opinião diferente sobre os fundamentos do citado MS 24.268, Almiro do Couto e Silva, ao comentar o julgado, considera pouco convincente a justificativa do STF para manutenção do ato administrativo inválido, baseada na situação de fato por ele constituída. Afirma que "Não se compreende, na verdade, seguindo a linha da argumentação adotada, como situação de fato, nascida de ilegalidade, pode transformar-se em situação de direito com as características que o habilitam a ser defendido por mandado de segurança". Para o autor, não obstante o exemplo do direito privado da usucapião, em que uma situação de fato resulta na aquisição do direito de propriedade, seria despropositado, à míngua de princípio constitucional ou de disposição legal, tentar estabelecer, no direito público, analogia com aquele instituto. Com base nessas críticas, conclui, referindo-se ao princípio da segurança jurídica em sua dimensão subjetiva, que "A única solução para o problema que se apresenta adequada é a que identifica, no ordenamento constitucional, princípio do mesmo nível hierárquico do que o da legalidade, e que com este possa ser ponderado, num balancing test, em face da situação concreta em exame" [SILVA, Almiro do Couto e. O Princípio da Segurança Jurídica (Proteção à Confiança) no Direito Público Brasileiro e o Direito da Administração Pública de Anular seus Próprios Atos Administrativos: o prazo decadencial do art. 54 da lei do processo administrativo da União (Lei no 9.784/99). Revista Eletrônica de Direito do Estado, Salvador, Instituto de Direito Público da Bahia, n. 2, abr./jun. 2005. p. 19 Disponível em: <http://www.direitodoestado.com.br>. Acesso em: 5 maio 2012.]. Embora não se retire a razão desse autor, cujas ponderações consideram-se extremamente coerentes, parece-nos que a divergência ora apontada, decorre, como muitas outras, mais das diferentes perspectivas pelas quais a discussão foi examinada do que da efetiva discordância quanto à essência da questão envolvida. Se considerarmos que o argumento utilizado pelo STF - de que a situação de fato foi consolidada pelo tempo a tal ponto de transformar-se em situação de direito - baseou-se no princípio da segurança jurídica (com mostram os próprios excertos do julgado citados no estudo do professor a Almiro do Couto e Silva), resolve-se, em nossa opinião, a falha apontada pelo autor. Trata-se, assim, de, em respeito ao princípio da segurança jurídica, considerar-se que ocorreu consolidação fática da situação individual pelo decurso do tempo, tal qual entende Humberto Ávila.

40 ÁVILA, Humberto. Segurança jurídica: entre permanência, mudança e realização no direito tributário. 2. ed. São Paulo: Malheiros, 2012. p. 365-366. 
A propósito, o caráter temporal da proteção da confiança é ressaltado por Misabel Abreu Machado Derzi. A autora, ao abordar a distinção entre o princípio da proteção da confiança e a boa-fé objetiva, afirma que o primeiro tem uma dimensão temporal importante, nem sempre presente em todos os casos de aplicação da boa-fé objetiva. Explica que a proteção da confiança envolve uma relação no tempo, pois, como ensinou Niklas Luhmann, trata-se de um estado, cuja complexidade já foi reduzida no presente, que se pretende seja assegurado no futuro, de modo que a violação da confiança configura o evento que desarranja a estabilidade do presente. Em outra passagem, ela volta a tocar nessa questão, dedicando um ponto específico de sua obra para discorrer sobre a relação entre a formação da confiança e o tempo em Niklas Luhmann. ${ }^{41}$

O princípio da proteção da confiança serve de instrumento de defesa de interesses individuais quando o particular, não protegido pelos institutos do direito adquirido, do ato jurídico perfeito, ou da coisa julgada, exerce sua liberdade confiando na validade, ou na aparência de validade, de um conhecido ato normativo geral ou individual (o qual pode ser judicial, administrativo ou legislativo) e, posteriormente, tem a sua confiança frustrada pela descontinuidade da sua vigência ou dos seus efeitos, seja por simples mudança, seja por revogação, anulação, ou, ainda, por declaração de sua invalidade.

Diferentemente do que ocorre com o direito adquirido, com o ato jurídico perfeito e com a coisa julgada, a proteção da confiança não é amparada de forma expressa pela atual Constituição. No entanto, sendo ela uma eficácia reflexa do princípio da segurança jurídica, e considerando o disposto no art. $5, \int 2^{\circ}$ do texto constitucional, que incorpora outros direitos e garantias decorrentes dos princípios adotados pela Constituição, não há razão para se excluir a proteção da confiança do rol de direitos e garantias ali previstos. A sua falta de previsão expressa tem como consequência apenas o fato de que a sua aplicação depende da ponderação concreta com outros princípios, ao contrário do que ocorre com o ato jurídico perfeito, com a coisa julgada ou com o direito adquirido. ${ }^{42}{ }^{43}$ Não há em nosso ordenamento nenhuma incompatibilidade entre a proteção da confiança e a irretroatividade das leis para alcançar o direito adquirido, o ato jurídico perfeito e a coisa julgada. Pelo contrário, a proteção que a Constituição prevê em tais hipóteses é tão forte que inexiste a necessidade de se testarem os requisitos da confiança porque ser ela está pressuposta. ${ }^{44}$ ??????

Em uma relação vertical, como é a do cidadão com o Estado, esse princípio só pode ser aplicado de maneira unilateral em benefício do particular, para protegê-lo da atuação do Poder Público, quando os atos dele emanados são geradores de confiança. Apenas admite-se a sua aplicação para favorecer uma pessoa jurídica de direito público contra outra pessoa jurídica de direito público ou contra o Estado, nunca contra o cidadão, pois, como ensinou Niklas Luhmann, todo aquele que tem posição soberana em relação aos acontecimentos não tem confiança a proteger. ${ }^{45}$

41 DERZI, Misabel Abreu Machado. Modificações da jurisprudência no direito tributário: proteção da confiança, boa-fé objetiva e irretroatividade como limitações constitucionais ao poder judicial de tributar. São Paulo: Noeses, 2009. p. xxiii-xxiv, 325-328 e 373-374. 42 ÁVILA, Humberto. Segurança jurídica: entre permanência, mudança e realização no direito tributário. 2. ed. São Paulo: Malheiros, 2012. p. 366 e 368.

43 Heleno Taveira Torres defende que o princípio da segurança jurídica, dado o seu caráter de garantia constitucional, não está sujeito a ponderações em termos abstratos, até porque o sopesamento, em si mesmo, é uma expressão da segurança jurídica na concretização de princípios, empregado como medida de solução da colisão destes. O autor tece fortes críticas à utilização do critério ponderador de forma indiscriminada, desprovida de critérios racionais de objetividade e sem limitação do seu cabimento, por entender que isso implicaria a submissão da criação de normas jurídicas à insegurança e a juízos de valor subjetivos. Ressalta que a utilização da ponderação pode e deve ser empregada quando houver efetiva colisão de princípios, mas sempre com preservação do conteúdo essencial dos direitos fundamentais dos princípios envolvidos, pois o sopesamento não pode se converter em uma tentativa retórica de reduzir direitos e liberdades, em um instrumento favorável ao arbítrio judicial, por uma concretização parcial de princípios (TORRES, Heleno Taveira. Direito constitucional tributário e segurança jurídica: metódica da segurança jurídica do sistema constitucional tributário. 2. ed. São Paulo: Revista dos Tribunais, 2012. p. 204; 558-564).

44 DERZI, Misabel Abreu Machado. Modificações da jurisprudência no direito tributário: proteção da confiança, boa-fé objetiva e irretroatividade como limitações constitucionais ao poder judicial de tributar. São Paulo: Noeses, 2009. p. 414.

45 DERZI, Misabel Abreu Machado. Modificações da jurisprudência no direito tributário: proteção da confiança, boa-fé objetiva e irretroatividade como limitações constitucionais ao poder judicial de tributar. São Paulo: Noeses, 2009. p. 324; 366; $395-397$. 
A proteção da confiança tem como pressuposto os seguintes elementos: a) uma base da confiança (manifestação, regular ou irregular, do Poder Público); b) uma confiança nessa base; c) o exercício da confiança na base que a gerou; e d) a frustração dessa confiança por ato posterior e contraditório emanado do Poder Público. ${ }^{46}{ }^{4}{ }^{7}$

No tocante à base da confiança, o âmbito de aplicação do princípio não abrange apenas os atos praticados com base em atos normativos válidos que tenham sido modificados sem que o particular esteja acobertado pelas garantias do direito adquirido, do ato jurídico perfeito ou da coisa julgada. O princípio protege ainda os atos, concluídos ou iniciados, praticados com base em atos normativos revestidos de legalidade meramente aparente, ou nem isso, cuja anulação retrospectiva causaria frustração da expectativa individual sobre eles lançada. ${ }^{48}$ Por essa razão, a sua aplicação sempre envolve uma tensão com outros princípios também integrantes da segurança jurídica como, o princípio democrático e o princípio da separação dos poderes (os quais autorizam o Estado a mudar sua orientação), ou como o princípio da legalidade (quando se trata de proteger a confiança depositada em atos ilegais). ${ }^{49}$

A possibilidade de proteção da confiança gerada por atos administrativos inválidos e por leis inconstitucionais corrobora a tese de que o que caracteriza a base da confiança é a sua aptidão para servir de fundamento para o exercício dos direitos de liberdade e de propriedade, não os requisitos que ela possui. Deve-se superar a divisão draconiana entre bases legítimas e bases ilegítimas da confiança, em favor de uma concepção fundada em critérios de verificação graduais,

46 ÁVILA, Humberto. Segurança jurídica: entre permanência, mudança e realização no direito tributário. 2. ed. São Paulo: Malheiros, 2012. p. 366-367.

47 De forma semelhante, embora não idêntica, Misabel Abreu Machado Derzi enumera os seguintes pressupostos para a proteção da confiança no Direito Público: a) fato comissivo ou omissivo do Estado, realizado no passado, que desencadeara a confiança do cidadão, ou estará apto a fazê-lo; b) configuração da confiança percebida e justificada; c) confirmação da confiança, que incorpore o futuro, por meio de decisões, ações e comportamentos decorrentes (aspecto dispensado em certas circunstâncias); d) avaliação do interesse público predominante, em relação à mudança de comportamento do Estado, que o cidadão caracteriza como violação da confiança; e) consequências positivas para a manutenção da confiança (assegurando-se ao prejudicado o ato indutor da confiança) ou negativas (autorização imediata da modificação, com compensação dos prejuízos sofridos pelo cidadão), a depender da avaliação do interesse público predominante (DERZI, Misabel Abreu Machado. Modificações da jurisprudência no direito tributário: proteção da confiança, boa-fé objetiva e irretroatividade como limitações constitucionais ao poder judicial de tributar. São Paulo: Noeses, 2009, p. 390-393). Já Heleno Torres fala em: a) situação passível de proteção; b) legitimidade da conduta de quem alega a eficácia da confiança; c) titularidade; e d) ato de órgão ou de autoridade pública que contrarie o direito exercido em estado de confiança (TORRES, Heleno. Direito constitucional tributário e segurança jurídica: metódica da segurança jurídica do sistema constitucional tributário. 2. ed. São Paulo: Revista dos Tribunais, 2012. p. 222).

48 Nesse sentido, são também as considerações de Almiro do Couto e Silva, em estudo no qual o autor conclui que a proteção da confiança está hoje reconhecida na legislação e na jurisprudência do Supremo Tribunal Federal como princípio de valor constitucional que serve de limite à invalidação pela Administração Pública dos seus próprios atos eivados de ilegalidade ou de inconstitucionalidade [SILVA Almiro do Couto e. O Princípio da Segurança Jurídica (Proteção à Confiança) no Direito Público Brasileiro e o Direito da Administração Pública de Anular seus Próprios Atos Administrativos: o prazo decadencial do art. 54 da lei do processo administrativo da União: lei no 9.784/99. Revista Eletrônica de Direito do Estado, Salvador, Instituto de Direito Público da Bahia, n. 2, abril/maio/junho, 2005. Disponível em: <http://www.direitodoestado.com.br>. Acesso em: 5 maio 2012. p. 47]. Na mesma linha, Misabel Abreu Machado Derzi, fazendo referência a Luhmann, pondera que, embora as leis sejam instrumentos motivadores do desenvolvimento da confiança, porque estabilizam as expectativas, tornando-as sancionáveis, nos sistemas sociais mais diferenciados e complexos, a lei e a confiança não mais coincidirão inteiramente, pois se poderá falar, como acrescenta a autora, na proteção da confiança mesmo em face de atos ilícitos (DERZI, Misabel Abreu Machado. Modificações da jurisprudência no direito tributário: proteção da confiança, boa-fé objetiva e irretroatividade como limitações constitucionais ao poder judicial de tributar. São Paulo: Noeses, 2009. p. 331). Em sentido diverso, Heleno Torres, tratando dos requisitos da proteção da confiança legítima, afirma que, para justificar uma pretensão sobre a situação a ser protegida, a conduta deve ser lícita. Aduz, ainda que a confiança legítima não consiste em autorização para excepcionar o regime de legalidade, suplantar a isonomia ou para confirmar como válida toda e qualquer espécie de nulidade. Ao contrário, só pode ser arguida por quem demonstre manter expectativa de legítima confiança, ou seja, em situação conforme a legalidade e atendidos os requisitos exigidos para tutelar o direito pretendido. Contudo, ao abordar especificamente a questão da revogação de atos que outorguem benefícios ou direitos a contribuintes, em face da suposição de que esses não atenderam aos requisitos legais, o autor entende que, quando verificado que persista sentimento de confiança legítima, ainda que não se possa admitir a continuidade do aproveitamento da vantagem, "[...] a força desse princípio deve servir, quando menos, para autorizar uma revogação ou nulidade com efeitos ex nunc, admitida a convalidação das situações passadas, mas, em qualquer hipótese, sem efeito retroativo para qualquer exigência gravosa" (TORRES, Heleno, Direito constitucional tributário e segurança jurídica: metódica da segurança jurídica do sistema constitucional tributário. 2. ed. São Paulo: Revista dos Tribunais, 2012. p. 222; 224; 230).

49 ÁVILA, Humberto. Segurança jurídica: entre permanência, mudança e realização no direito tributário. 2. ed. São Paulo: Malheiros, 2012. p. 366-367; 267-268. 
que forneça, não só outros elementos a serem considerados na análise, como também os critérios de harmonização entre eles. Assim, haverá proteção da confiança quando houver, relativamente a esses critérios, mais razões para protegê-la do que para não protegê-la. Existem vários elementos a serem considerados na análise, os quais podem dizer respeito a qualidades objetivas ou a efeitos subjetivos da base da confiança, sendo que a capacidade desses elementos para atribuir confiabilidade à base também decorre dos efeitos que eles, efetiva ou potencialmente, produzem no âmbito de proteção dos direitos fundamentas envolvidos e dos princípios constitucionais relativos à atuação Estatal. Tem-se, assim, mudança de foco, de modo que a proteção da confiança passa a refletir menos aspectos relativos à regularidade formal dos atos do Poder Público e mais aqueles atinentes ao efeito que eles provocam nos princípios ligados à liberdade, à propriedade, à igualdade e à própria atuação estatal. ${ }^{50}{ }_{-51}$

Dentre os critérios de configuração da base da confiança, tem-se o grau de vinculação (quanto maior for o grau de vinculação normativa do ato, maior deve ser a proteção da confiança nele depositada); ${ }^{52}$ a aparência de legitimidade do ato (quanto maior ela for, maior dever ser a proteção da confiança); a modificabilidade (quanto maior o grau de permanência do ato, maior deve ser a proteção da confiança a ele atribuída); a efetividade (quanto maior o alcance da finalidade da regra supostamente violada, maior deve ser a proteção dos efeitos do ato ilegal); a indução (quanto maior o efeito indutor de comportamento do ato, maior deve ser a proteção da confiança com base nele exercida); a individualidade (quanto maior a proximidade do ato em relação ao indivíduo, maior deve ser a proteção da confiança nele depositada); a onerosidade (quanto mais oneroso para o particular o ato, maior proteção merecerá a confiança nele recaída); e a durabilidade (quanto mais duradoura no tempo for a eficácia do ato, maior proteção merecerá a confiança nele depositada). Cada critério depende de uma verificação gradual, ou seja, a base da confiança será tanto maior quanto mais intensamente estiver presente o elemento considerado. A baixa intensidade da presença de um dos elementos deve ser compensada pela alta intensidade da presença dos outros para que se possa comprovar a maior presença de elementos em favor de uma base confíavel de confiança..$^{53}$

No tocante à existência da Confiança (segundo pressupostos anteriormente enumerados), trata-se da necessidade, para a proteção da confiança, de que o particular tenha confiado na base da confiança????, sendo imprescindível para isso que ele tenha conhecimento dessa base, por meio da publicação ou da intimação. O grau da intensidade da confiança varia de acordo com a relação que ela tem com a sua base, mediante o exame dos critérios acima mencionados. Quanto maior a intensidade daqueles elementos, como o tempo de produção de efeitos pelo ato, maior será o grau de confiança. ${ }^{54}$

Para que exista proteção da confiança, é necessário também que haja o exercício da confiança (terceiro pressuposto) ou, nas palavras de Misabel Abreu Machado Derzi, a confirmação da confiança, que incorpore o futuro por meio de disposições (ações ou omissões) e investimento da confiança por parte do cidadão. ${ }^{55-56}$ A doutrina é oscilante

50 ÁVILA, Humberto. Segurança jurídica: entre permanência, mudança e realização no direito tributário. 2. ed. São Paulo: Malheiros, 2012. p. 373-380.

51 A relação da proteção da confiança com os direitos fundamentais de liberdade, de igualdade e de propriedade, com a dignidade da pessoa humana e com o princípio do estado democrático de direito, é ressaltada também por (DERZI, Misabel Abreu Machado. Modificações da jurisprudência no direito tributário: proteção da confiança, boa-fé objetiva e irretroatividade como limitações constitucionais ao poder judicial de tributar. São Paulo: Noeses, 2009. p. 403-408).

52 Sobre esse critério, destacam-se as ponderações de Misabel Abreu Machado Derzi, no sentido de que, em relação à base da confiança gerada pelo Estado, quanto mais forte for a relação de dependência do cidadão e seu reduzido espaço de escolha, mais digna de proteção torna-se a confiança nela depositada (DERZI, Misabel Abreu Machado. Modificações da jurisprudência no direito tributário: proteção da confiança, boa-fé objetiva e irretroatividade como limitações constitucionais ao poder judicial de tributar. São Paulo: Noeses, 2009. p. 400).

53 ÁVILA, Humberto. Segurança jurídica: entre permanência, mudança e realização no direito tributário. 2. ed. São Paulo: Malheiros, 2012. p. 399-400; 414-415.

54 ÁVILA, Humberto. Segurança jurídica: entre permanência, mudança e realização no direito tributário. 2. ed. São Paulo: Malheiros, 2012. p. 403-404.

55 DERZI, Misabel Abreu Machado. Modificações da jurisprudência no direito tributário: proteção da confiança, boa-fé objetiva e irretroatividade como limitações constitucionais ao poder judicial de tributar. São Paulo: Noeses, 2009. p. 393.

56 Sobre a necessidade de objetivação da confiança, ver também TORRES, Heleno Taveira. Direito constitucional tributário e segurança jurídica: metódica da segurança jurídica do sistema constitucional tributário. 2. ed. São Paulo: Revista dos Tribunais, 2012. p. 217, 
quanto à exigência do efetivo exercício da confiança para que haja a proteção da confiança, como enfatiza Humberto Ávila. Este, com base nos critérios de verificação anteriormente mencionados (dentre eles a onerosidade, a permanência e a reversibilidade da atuação do cidadão), sustenta que a falta de atuação intensamente onerosa ou duradoura por parte do particular não é motivo pré-excludente da proteção da confiança, pois o baixo grau de intensidade desses elementos pode ser compensado pela presença mais intensa dos outros. ${ }^{57} \mathrm{~A}$ controvérsia também é colocada por Derzi, a qual afirma que não se pode reduzir a proteção da confiança à proteção dos investimentos feitos pelo cidadão que confiou, especialmente no Direito Público, em que estão em jogo os princípios e as garantias fundamentais, não apenas os direitos de propriedade e de patrimônio, mas também o livre desenvolvimento de personalidade e a dignidade humana. Assim, a existência de uma disposição ou investimento facilita a configuração da existência de confiança, mas não é um elemento essencial. ${ }^{58}$

Por fim, a proteção da confiança tem como pressuposto a frustração da confiança, ou seja, a confiança gerada por um ato estatal anterior deve ser frustrada por uma nova manifestação estatal posterior e contraditória, que afete de maneira significativa os direitos de liberdade, de propriedade e de igualdade. ${ }^{59}$ Cuida-se, portanto, de efeito decorrente da quebra de expectativa de acessibilidade, previsibilidade ou funcionalidade da segurança jurídica. ${ }^{60}$

Por representar uma aplicação reflexiva, subjetiva e concreta de um princípio objetivo, a demonstração dos pressupostos necessários à aplicação do princípio da proteção da confiança depende de provas concretas. A confiança de todos ou da maioria, ainda que presumida, até pode ser analisada de forma abstrata, em face da restrição ao direito de todos à liberdade; contudo, nesse caso, o que se analisa é a face objetiva da proteção da confiança, que nada mais é do que o próprio princípio da segurança jurídica na dimensão objetiva. Ademais, a aplicação do princípio da proteção da confiança sempre envolve uma tensão, a ser solucionada no caso concreto, com outros princípios também integrantes da segurança jurídica, como o princípio democrático e o princípio da separação dos poderes (os quais autorizam o Estado a mudar sua orientação), ou como o princípio da legalidade (quando se trata de proteger a confiança depositada em atos ilegais). ${ }^{61}$ Nesse sentido, a jurisprudência do Supremo Tribunal Federal pondera que a proteção da confiança resulta da dialética entre continuidade das normas, liberdade e segurança de um lado e, de outro lado, desenvolvimento social e dinâmico do Estado distribuidor. ${ }^{62}$ Assim, diante do caso concreto, estando presentes os requisitos para a proteção da confiança e não se tratando de situações em relação as quais o legislador excluiu a possibilidade de ponderação da segurança jurídica frente a outros princípios constitucionais (como nos casos acobertados pelo direito adquirido, pelo ato jurídico perfeito ou pela coisa julgada), caso a finalidade perseguida pela norma que frustrou a confiança não possa ser atingida de outro modo que não restrinja os direitos de liberdade e de propriedade do particular, será preciso fazer a ponderação entre essa finalidade e o princípio da segurança jurídica (em sentido amplo). ${ }^{63}$

Humberto Ávila, a partir de Schwarz Kyrlli-A, explica que, especificamente com relação à manutenção dos atos administrativos praticados em desconformidade com a lei que criam benefícios para o particular, tem-se uma tensão entre o princípio da proteção da confiança e os princípios da legalidade administrativa (que só permite a atuação da administração dentro dos parâmetros legais) e da igualdade (que exige uniformidade na concessão de

$22-223$.

57 ÁVILA, Humberto. Segurança jurídica: entre permanência, mudança e realização no direito tributário. 2. ed. São Paulo: Malheiros, 2012. p. 404-407.

58 DERZI, Misabel Abreu Machado. Modificações da jurisprudência no direito tributário: proteção da confiança, boa-fé objetiva e irretroatividade como limitações constitucionais ao poder judicial de tributar. São Paulo: Noeses, 2009. p. 410-411.

59 ÁVILA, Humberto. Segurança jurídica: entre permanência, mudança e realização no direito tributário. 2 ed. São Paulo: Malheiros, 2012. p. 408.

60 TORRES, Heleno Taveira. Direito constitucional tributário e segurança jurídica: metódica da segurança jurídica do sistema constitucional tributário. 2. ed. São Paulo: Revista dos Tribunais, 2012. p. 217.

61 ÁVILA, Humberto. Segurança jurídica: entre permanência, mudança e realização no direito tributário. 2. ed. São Paulo: Malheiros, 2012. p. 366-367; 370-371.

62 DERZI, Misabel Abreu Machado. Modificações da jurisprudência no direito tributário: proteção da confiança, boa-fé objetiva e irretroatividade como limitações constitucionais ao poder judicial de tributar. São Paulo: Noeses, 2009. p. 399.

63 ÁVILA, Humberto. Segurança jurídica: entre permanência, mudança e realização no direito tributário. 2. ed. São Paulo: Malheiros, 2012. p. 408-413. 
vantagens). Não obstante o entendimento tradicional de que os atos administrativos ilegais sempre poderiam ser anulados pela Administração, dando-se prevalência irrestrita ao princípio da legalidade, atualmente a doutrina, a despeito de posicionamentos contrários como o de Torres acima mencionado, e a jurisprudência já admitem a proteção de atos ilícitos com base na dimensão subjetiva do princípio da segurança jurídica. ${ }^{64}$ Essa evolução decorre do fato de a segurança jurídica ser um valor constitucional que se qualifica como subprincípio do princípio maior do Estado de Direito, ao lado e no mesmo nível hierárquico do princípio da legalidade, também derivado do Estado de Direito. Assim, possíveis conflitos entre esses dois princípios devem ser resolvidos mediante um juízo de ponderação que leve em conta as circunstâncias do caso concreto, não se justificando a exclusão, a priori e em abstrato, de um em detrimento do outro. ${ }^{65}$

\title{
3 CAsos práticos: o julgamento dos mandados de Segurança 24.781 e 25.116
}

\author{
Nos Mandados de Segurança $24.781^{66}$ e 25.116, ${ }^{67}$ o Supremo Tribunal Federal, considerando a demora na
}

64 ÁVILA, Humberto. Segurança jurídica: entre permanência, mudança e realização no direito tributário. 2. ed. São Paulo: Malheiros, 2012. p. 451-453.

65 SILVA, Almiro do Couto e. O princípio da segurança jurídica (proteção à confiança) no direito público brasileiro e o direito da administração pública de anular seus próprios atos administrativos: o prazo decadencial do art. 54 da lei do processo administrativo da União: lei no 9.784/99. Revista Eletrônica de Direito do Estado, Salvador, n. 2, abr./jun., 2005. Disponível em: < http://www.direitodoestado.com.br>. Acesso em: 5 maio 2012.p. 9-11, 20, 44 e 48.

66 Ementa: mandado de segurança. ato do Tribunal de Contas da União. competência do Supremo Tribunal Federal. Negativa de registro a aposentadoria. Princípio da segurança jurídica. Garantias constitucionais do contraditório e da ampla defesa. 1. O impetrante se volta contra o acórdão do TCU, publicado no Diário Oficial da União. Não exatamente contra o IBGE, para que este comprove o recolhimento das questionadas contribuições previdenciárias. Preliminar de ilegitimidade passiva rejeitada. 2. Infundada alegação de carência de ação, por ausência de direito líquido e certo. Preliminar que se confunde com o mérito da impetração. 3. A inércia da Corte de Contas, por mais de cinco anos, a contar da aposentadoria, consolidou afirmativamente a expectativa do ex-servidor quanto ao recebimento de verba de caráter alimentar. Esse aspecto temporal diz intimamente com: a) o princípio da segurança jurídica, projeção objetiva do princípio da dignidade da pessoa humana e elemento conceitual do Estado de Direito; b) a lealdade, um dos conteúdos do princípio constitucional da moralidade administrativa (caput do art. 37). São de se reconhecer, portanto, certas situações jurídicas subjetivas ante o Poder Público, mormente quando tais situações se formalizam por ato de qualquer das instâncias administrativas desse Poder, como se dá com o ato formal de aposentadoria. 4. A manifestação do órgão constitucional de controle externo há de se formalizar em tempo que não desborde das pautas elementares da razoabilidade. Todo o Direito Positivo é permeado por essa preocupação com o tempo enquanto figura jurídica, para que sua prolongada passagem em aberto não opere como fator de séria instabilidade intersubjetiva ou mesmo intergrupal. A própria Constituição Federal de 1988 dá conta de institutos que têm no perfazimento de certo lapso temporal a sua própria razão de ser. Pelo que existe uma espécie de tempo constitucional médio que resume em si, objetivamente, o desejado critério da razoabilidade. Tempo que é de cinco anos (inciso XXIX do art. $7^{\circ}$ e arts. 183 e 191 da CF; bem como art. 19 do ADCT). 5. O prazo de cinco anos é de ser aplicado aos processos de contas que tenham por objeto o exame de legalidade dos atos concessivos de aposentadorias, reformas e pensões. Transcorrido in albis o interregno quinquenal, a contar da aposentadoria, é de se convocar os particulares para participarem do processo de seu interesse, a fim de desfrutar das garantias constitucionais do contraditório e da ampla defesa (inciso $L V$ do art. $5^{\circ}$ ). 6. Segurança concedida. (Relator: Min. Ayres Britto, DJ 10/02/2011).

67 Ementa: Mandado de Segurança. 2. Acórdão da $2^{\mathrm{a}}$ Câmara do Tribunal de Contas da União (TCU). Competência do Supremo Tribunal Federal. 3. Controle externo de legalidade dos atos concessivos de aposentadorias, reformas e pensões. Inaplicabilidade ao caso da decadência prevista no art. 54 da Lei 9.784/99. 4. Negativa de registro de aposentadoria julgada ilegal pelo TCU. Decisão proferida após mais de 5 (cinco) anos da chegada do processo administrativo ao TCU e após mais de 10 (dez) anos da concessão da aposentadoria pelo órgão de origem. Princípio da segurança jurídica (confiança legítima). Garantias constitucionais do contraditório e da ampla defesa. Exigência. 5. Concessão parcial da segurança. I - Nos termos dos precedentes firmados pelo Plenário desta Corte, não se opera a decadência prevista no art. 54 da Lei 9.784/99 no período compreendido entre o ato administrativo concessivo de aposentadoria ou pensão e o posterior julgamento de sua legalidade e registro pelo Tribunal de Contas da União - que consubstancia o exercício da competência constitucional de controle externo (art. 71, III, CF). II - A recente jurisprudência consolidada do STF passou a se manifestar no sentido de exigir que o TCU assegure a ampla defesa e o contraditório nos casos em que o controle externo de legalidade exercido pela Corte de Contas, para registro de aposentadorias e pensões, ultrapassar o prazo de cinco anos, sob pena de ofensa ao princípio da confiança - face subjetiva do princípio da segurança jurídica. Precedentes. III - Nesses casos, conforme o entendimento fixado no presente julgado, o prazo de 5 (cinco) anos deve ser contado a partir da data de chegada ao TCU do processo administrativo de aposentadoria ou pensão encaminhado pelo órgão de origem para julgamento da legalidade do ato concessivo de aposentadoria ou pensão e posterior registro pela Corte de Contas. IV - Concessão parcial da segurança para anular o acórdão impugnado e determinar ao TCU que assegure ao impetrante o direito ao contraditório e à ampla defesa no processo administrativo de julgamento da legalidade e registro de sua aposentadoria, assim como para determinar a não devolução das quantias já recebidas. V - Vencidas (i) a tese que concedia integralmente a segurança (por reconhecer a decadência) e (ii) a tese que concedia parcialmente a segurança apenas para dispensar a devolução das importâncias pretéritas recebidas, na forma do que dispõe a Súmula 106 do TCU. (Relator: Min. Ellen Gracie, Relator para Acórdão: Min. Gilmar Mendes, DJ 09/06/2011). 
atuação da Administração, invocou a segurança jurídica e a proteção da confiança para invalidar decisões do Tribunal de Contas da União proferidas em procedimentos administrativos nos quais os interessados nos atos apreciados não foram ouvidos pela Corte de Contas. Assim, após tratar dos ensinamentos doutrinários sobre a definição e sobre o conteúdo desses princípios, cabe examinar, sob essa perspectiva, os mencionados julgados.

Antes de adentrar nessa análise, é necessário fazer breve contextualização da matéria envolvida nos referidos mandados de segurança, para, depois, verificar os argumentos jurídicos e os fundamentos normativos, especificamente aqueles relacionados aos princípios da segurança jurídica e da proteção da confiança, utilizados pelo Supremo Tribunal Federal nesses precedentes. Assim, será possível confrontar tais argumentos com as opiniões doutrinárias e demais informações colhidas ao longo deste estudo, a fim de verificar a compatibilidade entre ambos e a coerência dos precedentes com o ordenamento jurídico.

\subsection{Contextualização da matéria dos julgados}

\section{Por força do art. 71, caput, da Constituição Federal de 1988, compete ao TCU:}

[...] apreciar, para fins de registro, a legalidade dos atos de admissão de pessoal, a qualquer título, na administração direta e indireta, incluídas as fundações instituídas e mantidas pelo Poder Público, excetuadas as nomeações para cargo de provimento em comissão, bem como a das concessões de aposentadorias, reformas e pensões, ressalvadas as melhorias posteriores que não alterem o fundamento legal do ato concessório.

No caso das concessões de aposentadorias, reformas e pensões - objeto dos Mandados de Segurança 25.116/DF e 24.781/DF -, a autoridade administrativa responsável pelo ato concede a aposentadoria, reforma ou pensão e remete os dados necessários para o órgão de controle interno competente, o qual emite parecer sobre a legalidade desse ato, e o disponibiliza ao TCU. Na Corte de Contas, o ato é submetido à análise da unidade técnica especializada, a parecer do Ministério Público junto ao TCU e, depois, apreciado por uma das Câmaras ou pelo Plenário do Tribunal. ${ }^{68}$

Atualmente, prevalece no STF a tese de que as referidas concessões se caracterizam como atos administrativos de natureza complexa, entendidos esses como "[...] aqueles cuja vontade final da Administração exige a intervenção de agentes ou órgãos diversos, havendo certa autonomia, ou conteúdo próprio em cada uma das manifestações". ${ }^{69}$ Assim, segundo a jurisprudência da Suprema Corte, acompanhada pelo TCU, ${ }^{70}$ esses atos só se aperfeiçoam com o respectivo exame e posterior autorização de registro pelo TCU.71_.72

68 LEITE, Sandro Grangeiro. Análise da compatibilidade entre o conceito de ato administrativo complexo e os contornos jurídicos dados pelo STF ao registro do ato de concessão de aposentadoria, reforma e pensão. 2009. xxf Trabalho de Conclusão de Curso (Especialização)-- Instituto Brasiliense de Direito Público, Brasília, 2009. p. 9.

69 CARVAlHO FILHO, José dos Santos. Manual de direito administrativo. 14. ed. Rio de Janeiro: Lúmen Juris, 2005. p. 112.

70 À guisa de exemplo, citam-se os Acórdãos 41/2008 e 597/2004, da Primeira Câmara, 1.697/2003 e 85/2004, da Segunda Câmara, 241/2006 e 559/2005, do Plenário, e a Decisão n. 1.020/2000, também do Plenário.

71 Nesse sentido, são os seguintes precedentes do STF: MS 28.929/DF (Relatora: Min. Cármen Lúcia, DJ 16/11/2011), MS 25.697/DF (Relatora: Min. Cármen Lúcia, DJ 05/03/2010), MS 25.552/DF (Relatora: Min. Cármen Lúcia, DJ 30/05/2008), MS 25.409/DF (Relator: Min. Sepúlveda Pertence, DJ 18/05/2007), MS 25.072/DF (Relator: Min. Marco Aurélio, DJ 27/04/2007), RE 195.861/ES (Relator: Min. Marco Aurélio, DJ 17/10/1997), entre outros.

72 Sobre a classificação das concessões de aposentadorias e pensões como sendo atos complexos, cabe registrar que, embora essa seja a tese ainda dominante no STF, a matéria não é pacífica entre os membros daquele Tribunal e também encontra divergências na doutrina. No âmbito da Suprema Corte, existem manifestações de ministros que questionam essa premissa, como se observa, por exemplo, nas considerações feitas pelos ministros Ayres Britto, Sepúlveda Pertence e Cesar Peluso no julgamento do MS 25.116/DF (inteiro teor do julgado, p. 172 e 205-209, Relator: Min. Ayres Britto, DJ 10/02/2011), bem como nos debates orais do julgamento do MS 24.781/DF (inteiro teor, p. 55, Relator: Min. Ellen Gracie, Relator para Acórdão: Min. Gilmar Mendes, DJ 09/06/2011). Da mesma forma, na doutrina encontram-se posicionamentos contrários a essa classificação, como o de Flavio Germano de Sena Teixeira, para quem o ato concessório não é complexo, pois nele não há a confluência de vontades de fim e de conteúdo dos órgãos manifestantes inerente aos atos complexos, uma vez que o ato do órgão de controle não visa à concessão da aposentadoria ou pensão, mas o exame de sua legalidade, fim diverso da manifestação do órgão que emite o ato (TEIXEIRA, Flavio Germano de Sena. O controle das aposentadorias pelos tribunais de contas. Belo Horizonte: Fórum, 2004. p. 199-200). Lafayette Pondé também defende a incompatibilidade do conceito de ato complexo com o ato de aposentadoria, ressaltando que o ato de controle não participa da 
Da natureza complexa dos atos concessórios de aposentadorias, reformas e pensões, decorrem duas consequências que merecem ser destacadas no presente estudo. A primeira, de acordo com essa tese ainda dominante no STF, consiste na inaplicabilidade do prazo decadencial estabelecido no art. 54 da Lei no 9.784/1999 (lei do processo administrativo no âmbito da Administração Pública Federal), de cinco anos, para a Administração anular os atos administrativos de que decorram efeitos favoráveis para os destinatários. Isso porque, tratando-se de atos complexos, essas concessões só se aperfeiçoariam após sua apreciação pelo TCU, antes do que, não se operariam os efeitos da decadência. ${ }^{73} \mathrm{~A}$ segunda, de acordo com o entendimento do STF, é a ausência de necessidade do chamamento do interessado na concessão para se manifestar no processo perante o TCU, sob o fundamento de que a apreciação pela Corte de Contas seria "ato de auditoria", realizado em relação "endoadministrativa", sem o envolvimento dos interessados. ${ }^{74}$

Nesse ponto, esclarecem Aguiar, Albuquerque e Medeiros: ${ }^{75}$

Pode, portanto, o Tribunal de Contas da União considerar ilegal uma aposentadoria, determinando a cassação de todos os seus efeitos sem oferecer o contraditório e a ampla defesa ao aposentado. Frise-se que essa situação decorre do fato de que o interessado ainda não garantiu por completo a sua aposentadoria, porquanto o ato jurídico ainda não se aperfeiçoou. O registro é, em suma, o último estágio para o aperfeiçoamento dos atos complexos, que produzem efeitos e são eficazes desde a sua emissão. ${ }^{76}$

Esse entendimento só se aplicará, de acordo com jurisprudência atual, quando se tratar da primeira apreciação do ato pelo TCU, pois, nos casos de sua revisão, pela ilegalidade ou cassação, há necessidade de contraditório prévio, consoante decidido no MS $24.268^{77}{ }^{78}$ e consubstanciado na parte final do Enunciado Vinculante $\mathrm{n}^{\circ} 3$ do STF, in verbis:

Nos processos perante o Tribunal de Contas da União asseguram-se o contraditório e a ampla defesa quando da decisão puder resultar anulação ou revogação de ato administrativo que beneficie o interessado, excetuada a apreciação da legalidade do ato de concessão inicial de aposentadoria, reforma e pensão. (grifo nosso)

Recentemente, no julgamento do MS 25.116/DF, objeto deste estudo, o STF relativizou o entendimento contido na parte final do Enunciado Vinculante no 3 daquela Corte, criando uma exceção à exceção prevista no referido verbete. Ao julgá-lo, o Tribunal adotou a tese de que, transcorridos cinco anos sem a apreciação

natureza do ato controlado (PONDÉ Lafayette. Controle dos atos da administração pública. Revista de Informação Legislativa, ano 35, n. 139, Brasília: jul/set. 1998, p. 132-133). Nessa linha, ver ainda: FURTADO, Lucas Rocha. Curso de direito administrativo. Belo Horizonte: Fórum, 2007. p. 288-290; MARTINS JÚNIOR, Wallace Paiva. Ato Administrativo Complexo. Disponível em: <http:// sisnet.aduaneiras.com.br/lex/doutrinas/arquivos/110406j.pdf>. Acesso em: 8 jan. 2013. CUSTÓDIO, Antonio Joaquim Ferreira. Registro de aposentadorias e pensões, o devido processo legal e a Súmula Vinculante no 3. Jus Navigandi, Teresina, ano 13, n. 1947, 30 out. 2008. Disponível em: <http://jus.com.br/revista/texto/11904>. Acesso em: 7 jan. 2013; e LEITE, Sandro Grangeiro. Análise da compatibilidade entre o conceito de ato administrativo complexo e os contornos jurídicos dados pelo STF ao registro do ato de concessão de aposentadoria, reforma e pensão. Monografia apresentada no Instituto Brasiliense de Direito Público como requisito para especialização. Disponível na Biblioteca Ministro Ruben Rosa. Brasília, DF, 2009.

73 Nessa linha, os seguintes precedentes: 25.256/PB (Relator: Min. Carlos Velloso, DJ 24/03/2006), MS 25.192/DF (Relator: Min. Eros Grau, DJ 06/05/2005), 25.090 (Relator: Min. Eros Grau, DJ 01/04/2005), MS 24.859 (Relator: Min. Carlos Velloso, DJ $27 / 08 / 2004)$, entre outros.

74 Esse entendimento foi registrado, por exemplo, nos seguintes julgados: MS 25.409/DF (Relator: Min. Sepúlveda Pertence, DJ 18/05/2007), MS 25.440//DF (Relator: Min. Carlos Velloso, DJ 28/04/2006) e MS 25.256/PB (Relator: Min. Carlos Velloso, DJ 24/03/2006).

75 AgUiAR, Ubiratan Diniz de; ALBUQUERQUE, Márcio André dos Santos de; MEDEIROS, Paulo Henrique Ramos. $A$ administração pública sob a perspectiva do controle externo. Belo Horizonte: Fórum, 2011. p. 220.

76 Cabe esclarecer que a produção de efeitos desde a sua emissão é uma característica desses atos de concessão, não fazendo parte, contudo, do conceito de ato complexo consagrado na doutrina. Aliás, é por causa dessa característica das concessões de aposentadoria, reforma e pensão, que alguns autores questionam se, efetivamente, elas seriam atos complexos (ver nota anterior). 77 BRASIL. Supremo Tribunal Federal. Mandado de Segurança. MS 24.268. Impetrante: Fernanda Fiuza Brito. Impetrado: Tribunal de Contas da União. Relatora: Min. Ellen Gracie. Brasília, DF, 17 de setembro de 2004. Disponível em: < http://redir.stf.jus. br/paginadorpub/paginador.jsp?docTP=AC\&docID=86111>. Acesso em: 21 mar. 2013

78 Sobre a matéria, ver: LEITE, Sandro Grangeiro. Análise da compatibilidade entre o conceito de ato administrativo complexo e os contornos jurídicos dados pelo STF ao registro do ato de concessão de aposentadoria, reforma e pensão. número Trabalho de Conclusão de Curso (Especialização)-Instituto Brasiliense de Direito Público,Brasília, 2009. p. 10; e CARVALHO, André Luis de. Súmula Vinculante $n^{\circ}$ 3 do STF: considerações e alcance. Revista Âmbito Jurídico, Rio Grande, n. 41, maio, 2007. Disponível em: < http://ambitojuridico. com.br/site/index.php?n_link=revista_juridica\&revista_edicoes=27>. Acesso em: 5 jun. 2012, p. 6-20. 
do ato pelo TCU, em respeito ao princípio da segurança jurídica, haveria a necessidade de se assegurar o exercício do contraditório e da ampla defesa aos interessados. ${ }^{79}$ Com relação ao termo a quo para a contagem do prazo, posteriormente, no julgamento do já mencionado MS 24.781/DF, foi fixado o entendimento de que deveria ser considerada a entrada do ato no TCU. ${ }^{80}$

Dessa forma, a tese construída nos dois julgados que serão aqui examinados, a qual atualmente prevalece no STF, é a de que, passados mais de cinco anos da entrada do ato de concessão de aposentadoria ou pensão no TCU sem a respectiva apreciação, aquela Corte de Contas continua podendo apreciá-lo. Contudo, o transcurso do prazo quinquenal, por aumentar a confiança depositada no ato, faz nascer para o interessado a garantia do exercício do contraditório e da ampla defesa. Criou-se, portanto, uma exceção à exceção prevista na parte final do Enunciado Vinculante $n^{\circ} 3$, incluindo-se um limite temporal até então não existente no verbete, o qual poderia ser reescrito da seguinte forma: nos processos perante o Tribunal de Contas da União asseguram-se o contraditório e a ampla defesa quando da decisão puder resultar anulação ou revogação de ato administrativo que beneficie o interessado, excetuada a apreciação, desde que realizada num prazo máximo de cinco anos após a entrada do ato no Tribunal, da legalidade do ato de concessão inicial de aposentadoria, reforma e pensão.

\subsection{Os fundamentos dos mandados de segurança $25.116 /$ df e $24.781 /$ df}

Estando contextualizada a matéria envolvida nos julgados em questão e esclarecido o entendimento neles adotado, cabe agora identificar quais foram os principais argumentos jurídicos e os fundamentos normativos com base nos quais o STF invocou o princípio da segurança jurídica ao julgar os Mandados de Segurança 25.116/DF e 24.781/DF.

O entendimento que prevaleceu no julgamento dos mencionados mandados de segurança foi o proposto pelo ministro Ayres Britto ao relatar o MS 25.116/DF, impetrado contra o Acórdão no 2.087/2004 - TCU - $1^{\text {a }}$ Câmara, por meio do qual o TCU considerou ilegal o ato de aposentadoria de um servidor do Instituto Brasileiro de Ciência e Estatística - IBGE - aposentado em dezembro de 1998, em face do cômputo indevido do tempo de serviço referente a atividades exercidas pelo interessado entre os anos de 1970 a 1973 . O impetrante pleiteava a anulação do ato do TCU, sob o argumento de que, passados mais de 20 anos do reconhecimento administrativo do tempo de serviço que prestou em caráter eventual e, ainda, depois de quase seis anos contínuos de inatividade, não poderia ver sua aposentadoria desfeita sem que lhe fosse assegurada a oportunidade do contraditório e da ampla defesa. Ao julgá-lo, o Tribunal adotou, por maioria de votos, a tese defendida no voto do ministro relator, no sentido de que, transcorridos cinco anos sem a apreciação do ato pelo TCU, em respeito ao princípio da segurança jurídica, haveria a necessidade de se assegurar o exercício do contraditório e da ampla defesa aos interessados. Foram vencidos os votos dos ministros Celso de Mello e Cezar Peluso, que concediam a segurança em maior extensão, para reconhecer a decadência do direito de anulação do ato pelo TCU, e dos ministros Marco Aurélio, Ellen Gracie e Sepúlveda Pertence, que a denegavam, mantendo o entendimento anterior, sem excepcionar a parte final da Enunciado Vinculante $n^{\circ} 3$.

Em seu voto, o ministro Ayres Britto começa invocando o entendimento adotado no MS 24.268/MG, ${ }^{81}$

79 No mesmo sentido, cita-se o MS 25.403/DF (Relatora: Min.. Ellen Gracie, Relator para Acórdão: Min. Gilmar Mendes, DJ 10/2/2011).

80 Posteriormente, foram proferidos os seguintes precedentes na mesma linha: Agravo Regimental no MS 28.711/DF (Relator: Min. Dias Toffoli, DJ 24/09/2012), MS 25.568/DF (Relatora: Min. Rosa Weber, DJ 10/05/2012), MS 28.520/PR (Relator: Min. Ayres Britto, DJ 02/04/2012), MS 28.720/DF (Relator: Min. Ayres Britto, DJ 02/04/2012), MS 27.640/DF (Relator: Min. Ricardo Lewandowski, DJ 19/12/2011) e MS 28.333/DF (Relator: Min. Ricardo Lewandowski, DJ 27/02/2012), entre outros.

81 Ementa: Mandado de Segurança. 2. Cancelamento de pensão especial pelo Tribunal de Contas da União. Ausência de comprovação da adoção por instrumento jurídico adequado. Pensão concedida há vinte anos. 3. Direito de defesa ampliado com a Constituição de 1988. Âmbito de proteção que contempla todos os processos, judiciais ou administrativos, e não se resume a um simples direito de manifestação no processo. 4. Direito constitucional comparado. Pretensão à tutela jurídica que envolve não só o direito de manifestação e de informação, mas também o direito de ver seus argumentos contemplados pelo órgão julgador. 5. Os princípios do contraditório e da ampla defesa, assegurados pela Constituição, aplicam-se a todos os procedimentos administrativos. 
segundo o qual, tendo em vista que o direito de defesa foi ampliado pela Constituição Federal de 1988, quando o TCU cancela decisão anterior que afeta direitos individuais, considerando ilegal ato já apreciado e cujo registro foi autorizado, deve respeitar os princípios do contraditório e da ampla defesa, uma vez que o ato já estava perfeito e acabado. Contudo, no caso dos atos de concessão inicial de aposentadorias e pensão, em regra, não cabe ao TCU, ao apreciá-los, o dever de garantir aos respectivos beneficiários o exercício do contraditório e da ampla defesa. Isso porque, antes do pronunciamento da Corte de Contas, essas concessões por serem classificadas como atos complexos não se aperfeiçoariam, nem se integrariam ao patrimônio jurídico do servidor, razão pela qual não assistiria ao interessado o direito de ser ouvido.

Feito isso, ele volta à análise do caso concreto envolvido no MS 25.116/DF, que, por se tratar de concessão inicial, enquadrar-se-ia na segunda situação do entendimento acima mencionado. Contudo, chamando atenção para o fato de a recusa do registro pelo TCU ter ocorrido quase seis anos após a concessão unilateral do ato de aposentadoria, o ministro propõe uma análise mais detida da matéria. Argumenta que o gozo da aposentadoria por um lapso prolongado de tempo confere tônus de estabilidade ao ato, ensejando questionamento acerca da incidência dos princípios da segurança jurídica e da lealdade (proteção da confiança). Nesse sentido, tece considerações doutrinárias, colaciona os ensinamentos de Joaquim Gomes Canotilho e de Almiro do Couto e Silva, que tratam, em linhas gerais, da importância dos princípios da segurança jurídica e da proteção da confiança, e do conflito entre eles e o princípio da legalidade, especialmente no tocante à revogação e anulação de atos administrativos pela Administração Pública. Pondera que, a partir da manifestação formal do IBGE, o impetrante passou a gozar da sua aposentadoria, por cinco anos e oito meses, até que o TCU determinou a suspensão dos pagamentos sem ouvi-lo. Diante disso argumenta: ${ }^{82}$

Pois bem, considerando o status constitucional do direito à segurança jurídica (art. $5^{\circ}$, caput), projeção objetiva do princípio da dignidade da pessoa humana (inciso III do art. $1^{\circ}$ ) e elemento conceitual do Estado de Direito, tanto quanto levando em conta a lealdade como um dos conteúdos do princípio da moralidade administrativa (caput do art. 37), faz-se imperioso o reconhecimento de certas situações jurídicas subjetivas ante o Poder Público. Mormente quando tais situações se formalizam por ato de qualquer das instâncias administrativas desse poder, como no caso do ato de aposentadoria.

Em situações como essa, é até intuitivo que a manifestação desse órgão constitucional de controle externo há que se formalizar em tempo que não desborde das pautas elementares da razoabilidade. Todo o Direito Positivo é permeado por essa preocupação com o tempo enquanto figura jurídica, para que sua prolongada passagem em aberto não opere como fator de séria instabilidade inter-subjetiva ou mesmo intergrupal. Quero dizer: a definição jurídica das relações interpessoais ou mesmo coletivas não pode se perder no infinito. Não pode descambar para o temporalmente infindável, e a própria Constituição de 1988 dá conta de institutos que tem no perfazimento de um certo lapso temporal a sua própria razão de ser.

Nesse sentido, o ministro Ayres Britto cita os institutos da prescrição e da decadência, previstos em diversas passagens do texto constitucional (a exemplo do art. 7 , inciso XXIX, do art. 37, $₫ 5^{\circ}$, do art. $53, \S 5^{\circ}$, e do art. 146, inciso III, b), e menciona que, mais recentemente, com a Emenda Constitucional 45/2004, a Constituição passou a albergar a razoável duração do processo, inclusive administrativo (art. $5^{\circ}$, inciso LXXVIII), concluindo que, determinadas pautas temporais são, em si mesmas, um tão relevante aspecto da vida que chegam a merecer direto tratamento constitucional. Em seguida, ele tenta definir uma espécie de tempo médio que resuma em si, objetivamente, qual seria um prazo razoável. Para isso, traz novamente a doutrina de Almiro do Couto e Silva, para quem,

6. O exercício pleno do contraditório não se limita à garantia de alegação oportuna e eficaz a respeito de fatos, mas implica a possibilidade de ser ouvido também em matéria jurídica. 7. Aplicação do princípio da segurança jurídica, enquanto subprincípio do Estado de Direito. Possibilidade de revogação de atos administrativos que não se pode estender indefinidamente. Poder anulatório sujeito a prazo razoável. Necessidade de estabilidade das situações criadas administrativamente. 8. Distinção entre atuação administrativa que independe da audiência do interessado e decisão que, unilateralmente, cancela decisão anterior. Incidência da garantia do contraditório, da ampla defesa e do devido processo legal ao processo administrativo. 9. Princípio da confiança como elemento do princípio da segurança jurídica. Presença de um componente de ética jurídica. Aplicação nas relações jurídicas de direito público. 10. Mandado de Segurança deferido para determinar observância do princípio do contraditório e da ampla defesa (CF art. $\left.5^{\circ} \mathrm{LV}\right)$. (MS 24.268/MG, Relator para Acórdão: Min. Gilmar Mendes, DJ 17/09/2004).

82 BRASIL. Supremo Tribunal Federal. Mandado de Segurança. MS 25.116. Impetrante: Edson de Almeida Miguel Relvas. Impetrado: Tribunal de Contas da União. Relator: Min. Ayres Britto. Brasília, DF, 20 de fevereiro de 2011. Disponível em: < http:/ / redir. stf.jus.br/paginadorpub/paginador.jsp?docTP=AC\&docID=618869>. Acesso em: 22 mar. 2013. fls. 118-122. 
desde a Lei da Ação Popular, o prazo prescricional para a Administração Pública invalidar seus próprios atos é de cinco anos. Corroborando esse referencial de cinco anos, colaciona, como exemplo, os seguintes dispositivos normativos que o adotam: art. 54 da Lei no 9.784/1999 (prazo decadencial para a Administração Pública invalidar os próprios atos), arts. 173 e 174 do Código Tributário Nacional (prescrição e decadência do crédito tributário), art. 19 do Ato das Disposições Constitucionais Transitórias da Constituição de 1988 (estabilidade dos servidores admitidos antes da Constituição de 1988 sem concurso público), arts. 183 e 191 da Constituição Federal de 1988 (usucapião extraordinário), e art. $7^{\circ}$, inciso XXIX da Constituição Federal de 1988 (prescrição dos créditos trabalhistas). Com base nesse raciocínio, conclui: ${ }^{83}$

Bem vistas as coisas, então, já se percebe que esse referencial de 5 anos é de ser aplicado aos processos de contas que tenham por objeto o exame da legalidade dos atos concessivos de aposentadorias, reformas e pensões. Isso na acepção de que, ainda não alcançada a consumação do interregno quinquenal, não é de se convocar os particulares para participar do processo de seu interesse. Contudo, transcorrido in albis esse período, ou seja, quando silente a Corte de Contas por todo o lapso quinquenal, tenho como presente o direito líquido e certo do interessado para figurar nesse tipo de relação jurídica, exatamente para o efeito do desfrute das garantias do contraditório e da ampla defesa (art. $5^{\circ}, \mathrm{LV}$ ).

Em palavras outras: do exame do ordenamento jurídico brasileiro em sua inteireza é possível concluir pela existência de uma norma que bem se aplica aos processos de contas. Que norma? Essa que assegura ao interessado o direito líquido e certo de exercitar as garantias do contraditório e da ampla defesa, sempre que uma dada Corte de Contas deixar de apreciar a legalidade de um ato de concessão de pensão, aposentadoria ou reforma fora do multicitado prazo de cinco anos. Isso pela indesmentida proposição de que, por vezes, a norma jurídica se encontra não num particularizado dispositivo, mas no conjunto orgânico de vários deles. [...]

Diante dessa ampla moldura, concedo a segurança para anular o Acórdão - TCU n ${ }^{\circ}$ 2.087/2004, tão somente no que se refere ao impetrante e para o fim de se lhe assegurar a oportunidade do uso das garantias constitucionais do contraditório e da ampla defesa.

Apresentado o voto do relator, os ministros Marco Aurélio e Sepúlveda Pertence, manifestaram-se, oralmente, contrários à mudança de entendimento, reafirmando a tese anterior. O ministro Gilmar Mendes, mostrando-se favorável à proposta, pediu vista dos autos e apresentou voto-vista no qual teceu uma série de considerações sobre o devido processo legal, a segurança jurídica e a proteção da confiança para, ao final, acompanhar a proposta do relator, no sentido de conceder a segurança para garantir ao interessado o exercício das garantias do contraditório e da ampla defesa.

Em seu voto-vista, ao reforçar a tese do ministro Ayres Britto, o ministro Gilmar Mendes, inicialmente, após reafirmar o entendimento acerca da natureza de ato complexo das concessões iniciais de aposentadorias reformas e pensões, e da consequente ausência de direito do interessado de participar do processo perante o TCU, ponderou que: ${ }^{84}$

Não obstante, é preciso também levar em conta que, muitas vezes, o lapso temporal transcorrido entre as manifestações de vontade dos órgãos administrativos para a formação do ato complexo concessivo da aposentadoria ou pensão pode criar situações jurídicas dotadas de estabilidade e presunção de legalidade e legitimidade, uma vez que amparadas em decisão do próprio Poder Público.

É nessas hipóteses em que incide o princípio da segurança jurídica, como subprincípio do Estado de Direito, no sentido da proteção das situações jurídicas criadas pelo Poder Público e estabilizadas pelo transcurso do tempo em que o próprio Poder Público quedou-se inerte.

Depois, o ministro Gilmar Mendes rememorou as considerações doutrinárias que teceu no julgamento do MS 24.268/MG acerca da proteção da confiança e da segurança jurídica e do conflito entre esses princípios e o princípio da legalidade no âmbito da invalidação de atos administrativos pela própria Administração Pública. Com base nelas, concluiu que, na medida em que o ato do órgão de origem que concede a aposentadoria, reforma ou pensão tem o condão de criar situações jurídicas com plena aparência de le-

83 BRASIL. Supremo Tribunal Federal. Mandado de Segurança. MS 25.116. Impetrante: Edson de Almeida Miguel Relvas. Impetrado: Tribunal de Contas da União. Relator: Min. Ayres Britto. Brasília, DF, 20 de fevereiro de 2011. Disponível em: < http://redir. stf.jus.br/paginadorpub/paginador.jsp?docTP=AC\&docID=618869>. Acesso em: 22 mar. 2013. fls. 123-131.

84 BRASIL. Supremo Tribunal Federal. Mandado de Segurança. MS 25.116. Impetrante: Edson de Almeida Miguel Relvas. Impetrado: Tribunal de Contas da União. Relator: Min. Ayres Britto. Brasília, DF, 20 de fevereiro de 2011. Disponível em: < http://redir. stf.jus.br/paginadorpub/paginador.jsp?docTP=AC\&docID=618869>. Acesso em: 22 mar. 2013. fls. 139-155. 
galidade e de legitimidade, também a atuação do TCU deve estar sujeita a um prazo razoável, sob pena de ofensa ao princípio da confiança, face subjetiva da segurança jurídica.

Quanto à medida que seria esse prazo razoável, construiu raciocínio semelhante ao desenvolvido pelo ministro Ayres Britto, chegado ao mesmo prazo, de cinco anos. Ressaltou que se trata de fixar a prevalência do princípio da segurança jurídica no sentido de proteger a estabilidade das situações jurídicas criadas pelo Poder Público; que a confiança depositada pelo servidor, geralmente imbuído de boa-fé, no ato formal da Administração que lhe concede o benefício, impõe limites ao poder dever do TCU de anulá-lo a qualquer tempo, de modo que o transcurso do tempo faz surgir para o TCU o dever de garantir ao interessado a ampla defesa, o contraditório e o devido processo legal no processo administrativo.

Por fim, após esclarecer que não se trata de estabelecer um tipo de prazo intercorrente para o aperfeiçoamento do ato complexo, uma vez que o TCU não fica impedido de rever o ato, chamou atenção para a gravidade do caso específico em exame. Lembrou que o impetrante já estava na inatividade há quase seis anos e que a decisão do TCU obrigaria o retorno de um cidadão de mais de 60 anos de idade às salas de aula. Salientou que o servidor sempre esteve imbuído de boa-fé, demonstrado pela confiança nos atos praticados pelo IBGE para a concessão de sua aposentadoria, pois, no caso, houve um conjunto de atos praticados pela administração que criou para o impetrante uma situação jurídica dotada de total aparência de legalidade e legitimidade e estabilizada pelo transcurso do tempo, não podendo o TCU considerar que o impetrante tinha pleno conhecimento da precariedade desses atos.

O posicionamento dos ministros Ayres Britto e Gilmar Mendes foi acompanhado pelos ministros Ricardo Lewandowski, Joaquim Barbosa e Cármen Lúcia. A ministra Ellen Gracie pediu vista dos autos e apresentou voto contrário ao do relator, defendendo a manutenção da jurisprudência consubstanciada na parte final do Enunciado Vinculante $\mathrm{n}^{\circ}$ 3, por considerar que, antes da apreciação e autorização de registro pelo TCU, os atos de concessão inicial de aposentadoria, reforma ou pensão ainda não se aperfeiçoaram. Por essa razão, seria incabível o contraditório nessa fase de formação do ato complexo, independentemente do prazo transcorrido entre a emissão do ato e a sua apreciação pela Corte de Contas.

O ministro Cezar Peluso, que, inicialmente, concordara com o relator, apresentou retificação de voto na qual se manifestou pela concessão da segurança em maior extensão, para anular o acórdão do TCU e reconhecer a decadência do direito da Corte de Contas de determinar a anulação do ato de aposentadoria do impetrante. Entendeu o ministro que as concessões de aposentadorias, reformas e pensões não se acomodam às clássicas definições doutrinárias de atos complexos, os quais pressupõem, além da fusão de atos distintos, a identidade de fins e de conteúdo desses atos, só produzindo efeitos após a sua conclusão. Ponderou que, no caso das concessões de aposentadorias, reformas e pensões, estas produzem efeitos imediatos e não há identidade de objetivos entre a atuação do órgão de origem, cujo fim é o de conceder o benefício, e a manifestação do TCU, que tem por competência fiscalizar o ato. Dessa forma, sem pretender pôr fim à discussão sobre o tema, concluiu que tais atos, se complexos, são atípicos, não se lhes podendo negar, dada a sua especial natureza alimentar, a incorporação dos benefícios ao modo de vida do pensionista ou aposentado, que passa a ostentar, desde logo, esse status jurídico e a projetar sua vida nos limites do respectivo orçamento. Por essa razão, entendeu que, para lhes subtrair ou diminuir as vantagens, se lhe impõe a possibilidade de exercício das garantias do contraditório e da ampla defesa, independentemente do prazo transcorrido entre a concessão e a respectiva apreciação pelo TCU, não encontrando razão para deferi-las depois de passados cinco anos.

Além disso, o ministro Peluso, propondo que se desse um passo maior do que o sugerido pelo relator, defendeu que muitos dos argumentos que sustentam a aplicação das garantias do contraditório e da ampla defesa a esses processos administrativos, especialmente aqueles relativos à segurança jurídica, à proteção da confiança e à boa-fé, também justificam a aplicação do prazo decadencial previsto na Lei no 9.784/1999, art. 54. Nesse sentido, teceu as seguintes considerações: $:^{85}$

85 BRASIL. Supremo Tribunal Federal. Mandado de Segurança. MS 25.116. Impetrante: Edson de Almeida Miguel Relvas. Impe- 
Na verdade, o poder de invalidação unilateral dos atos gravosos, como, aliás, os demais poderes típicos da Administração, está predisposto, no ordenamento, à realização de um fim público imediato, reconduzir a atuação administrativa à esfera da legalidade. [...]

Tal interesse - desconstituir ato lesivo, praticado contra ou praeter legem - não é absoluto, nem superior a outros interesses sociais específicos, tão ou mais relevantes no plano dos valores últimos que, compondo a mesma ordem jurídica, devem governar o comportamento da Administração Pública, como aqueles tutelados pelos princípios da segurança jurídica e da boa fé. [...]

Vê-se, pois, que desatenderia a fim normativo transcendente, que está à base da prescrição, v. g., da prescrição, da decadência e do usucapião, porque seria mais danoso à paz social, à qual servem todos esses institutos, anular, após anos de imperturbável estabilidade, ato de que advieram, a administrados de boa-fé, consequências jurídico patrimoniais determinantes do seu próprio destino como pessoa.

Diante desses fundamentos, o ministro Peluso concluiu que, no caso, deveria ser reconhecida a decadência, pois a invalidação da aposentadoria do impetrante, passados cinco anos e oito meses da sua concessão, insultaria os princípios da segurança jurídica e da boa-fé, na medida em que tenderia a desconstituir situação jurídica estabilizada por prazo razoável e de vital importância para a vida do servidor, que se aposentou com sólida presunção de validez do ato administrativo.

Durante os debates orais, os ministros Gilmar Mendes e Ayres Britto louvaram o voto do ministro Cezar Peluso, mas preferiram manter seus votos, de modo que apenas o ministro Celso de Mello acompanhou a proposta de conceder a segurança em maior extensão. Prevaleceu, assim, a tese defendida pelo relator no sentido de que a demora do TCU para apreciar as concessões de aposentadorias, reformas e pensões por prazo superior a cinco anos faz surgir para o interessado o direito de ser ouvido perante a Corte de Contas quando da sua decisão puder resultar a anulação ou a redução do seu benefício.

Embora a questão do termo a quo para a contagem do prazo tenha sido suscitada durante os debates orais do julgamento do MS 25.116/DF, ela não ficou assentada naquela ocasião. Só depois, no julgamento do já mencionado MS 24.781/DF, foi fixado o entendimento proposto pelo ministro Gilmar Mendes, de que deveria ser considerada a entrada do ato no TCU. O referido Mandado de Segurança tratou de decisão do TCU (Acórdão no 1.958/2003 - TCU - 2 Câmara) que, depois de dez anos da concessão do benefício e de cinco anos da chegada do processo administrativo àquela Corte de Contas, considerou-se ilegal a aposentadoria de servidor público no cargo de médico do INSS, em razão da acumulação indevida dos aludidos proventos com os de mais duas aposentadorias, uma no cargo de médico e outra no de professor, e determinou a restituição das quantias recebidas indevidamente pelo inativo. $\mathrm{O}$ impetrante, além de defender a legalidade da acumulação de benefícios, alegava a decadência do direito de a Administração anular o ato e o desrespeito ao contraditório e à ampla defesa. Na ocasião, prevaleceu o voto do ministro Gilmar Mendes, no sentido de, na linha do que foi decidido no MS 25.116, em nome da segurança jurídica, conceder parcialmente a segurança para anular a decisão do TCU tão somente a fim de garantir ao interessado o exercício do contraditório e da ampla defesa. Foram vencidos os posicionamentos da ministra Ellen Gracie, relatora, e do ministro Dias Toffoli, que deferiam a segurança apenas para isentar o impetrante da devolução dos valores recebidos; do ministro Marco Aurélio, que indeferia a segurança; e do ministro Cezar Peluso, que concedia totalmente a ordem para anular a decisão do TCU e reconhecer a decadência, sob o fundamento de que após cinco anos da entrada no TCU o ato não pode mais ser revisto.

O voto-vista apresentado pelo ministro Gilmar Mendes, rememorou a jurisprudência sobre a matéria e ressaltou que ela tem sido objeto de novas reflexões envolvendo, basicamente, dois pontos: a incidência das garantias do contraditório e da ampla defesa nos processos administrativos em que o TCU aprecia concessões iniciais de aposentadorias, reformas e pensões; e a sujeição dessa competência do TCU à decadência prevista na Lei no 9.784/1999. Após trazer, em essência, os mesmos argumentos que fundamentaram a decisão no MS 25.116/DF e reafirmar o entendimento adotado naquele precedente, o ministro teceu algumas

trado: Tribunal de Contas da União. Relator: Min. Ayres Britto. Brasília, DF, 20 de fevereiro de 2011. Disponível em: < http:/ / redir. stf.jus.br/paginadorpub/paginador.jsp?docTP=AC\&docID=618869>. Acesso em: 22 mar. 2013.fls. 211-214. 
considerações sobre as nuances do caso concreto: ${ }^{86}$

No caso em exame, o impetrante gozou da aposentadoria por mais de 11 anos, fato que, por si só, já demonstra a existência de uma situação jurídica, criada pela própria Administração, que se tornou estável com o transcurso do tempo.

É bem verdade, por outro lado, que a acumulação de três aposentadorias pelo impetrante pode ser um indício de sua má-fé, tornando irrelevante para o caso o princípio da proteção à confiança.

Porém, é preciso ressaltar que eventuais dúvidas sobre o conhecimento, pelo impetrante, da legalidade ou não do ato concessivo da aposentadoria, deixaram de ser relevantes após vários anos em que tal ato produziu plenamente seus efeitos. Muitas vezes, como bem analisado por Almiro do Couto e Silva, à medida que o tempo vai passando, eventuais dúvidas sobre a legalidade do ato administrativo vão gradativamente perdendo relevo diante da crescente e sempre mais robustecida confiança na sua legalidade.

Assim, é possível considerar que, nesses casos em que não é possível saber se o destinatário sabia ou não da ilegalidade do ato, o decurso de um prazo razoável - como o de cinco anos estipulado pela legislação para que decaia o direito da Administração de anular seus próprios atos eivados de ilegalidade - pode fazer surgir uma presunção de boa-fé por parte do administrado, o qual permanece por vários anos submetido a uma situação jurídica dotada de presunção de legalidade e legitimidade.

Ademais, a má-fé a que alude o art. 54 da 9.784/99 deve ser comprovada [...].

Com base nisso, ponderou que, diante da ausência de elementos nos autos que indicassem a má-fé do impetrante, e passados mais de onze anos da concessão e mais de cinco da chegada do ato ao TCU, não poderia a Corte de Contas, ao julgar o processo administrativo, considerar que ele tinha pleno conhecimento da precariedade dos atos praticados pelo órgão público. Assim, concluiu ser aplicável ao caso o entendimento firmado no MS 25.116, no sentido de exigir que o TCU assegure a ampla defesa e o contraditório nos casos em que o controle da legalidade das concessões de aposentadorias, reformas e pensões ultrapassar o prazo de cinco anos, sob pena de ofensa ao princípio da confiança. Contudo, sugeriu que o prazo de cinco anos fosse contado da data da chegada ao TCU do processo administrativo de aposentadoria, reforma ou pensão, critério que foi acolhido pelo Colegiado.

\subsection{Análise dos julgados}

Do confronto dos fundamentos e dos argumentos acima mencionados com os posicionamentos doutrinários colhidos ao longo deste estudo, identificam-se alguns questionamentos que merecem ser debatidos: qual das dimensões da segurança jurídica foi aplicada, a objetiva ou a subjetiva? O surgimento do direito ao exercício do contraditório e da ampla defesa em face do decurso do prazo de cinco anos é solução adequada para dar efetividade ao princípio da segurança jurídica? A escolha da entrada do ato no TCU como termo a quo para a contagem do prazo de cinco anos é coerente com os argumentos desenvolvidos nos julgados? Em suma, em que medida a solução adotada pelo STF amolda-se às informações extraídas da doutrina e do ordenamento normativo sobre o tema?

A primeira dessas questões é, sem dúvida, de difícil resposta. Conforme ensina Humberto Ávila, uma coisa é a intangibilidade de situações individuais em razão de sua consolidação fática (vertente objetiva da segurança jurídica), hipótese na qual os efeitos do ato ilegal ou inconstitucional são mantidos porque o longo decurso do tempo os tornou irreversíveis, independentemente da análise de fatores subjetivos, como a boa-fé ou o conhecimento da irregularidade pelo particular. Outra situação distinta, embora nem sempre facilmente diferençável da anterior, refere-se aos casos em que, com base no princípio da proteção da confiança (dimensão subjetiva da segurança jurídica), os efeitos jurídicos do ato viciado são conservados porque o particular atuou confiando na legitimidade dele, sem ter ou dever ter conhecimento da sua ilegitimidade (análise subjetiva). Contudo, a transição entre ambas as situações de proteção não é pontual, mas continua-

86 BRASIL. Supremo Tribunal Federal. Mandado de Segurança. MS 24.781. Impetrante: Mazureik Miguel de Morais. Impetrado: Tribunal de Contas da União. Relatora: Min. Ellen Gracie. Relator para Acórdão: Min. Gilmar Mendes. Brasília, DF, 9 jun. 2011. Disponível em: <http:// redir.stf.jus.br/paginadorpub/paginador.jsp?docTP=AC\&docID=623956>. Acesso em: 22 mar. 2013 fls. $25-50$. 
da, tornando-se difícil distingui-las em situações limítrofes, pois o tempo tanto funciona como fator gerador de irreversibilidade fática ou jurídica quanto como fator gerador de confiança. ${ }^{87}$

A matéria em análise situa-se, a nosso ver, justamente na zona limítrofe a que se refere o autor. Da leitura dos argumentos invocados nos Mandados de Segurança 25.116/DF e 24.781/DF, observa-se que, em ambos, ficou consignada expressamente a intenção de proteger o princípio da proteção da confiança, enquanto face subjetiva da segurança jurídica. Verifica-se, ainda, especialmente no primeiro, que em diversos momentos, foram levadas em consideração questões subjetivas relativas à quebra da confiança do impetrante especificamente nos casos concretos em exame, como a aparência de legalidade e legitimidade do ato, a boa-fé do interessado e a gravidade das consequências da invalidação da aposentadoria pelo TCU. Tais fatos indicariam tratar-se de situação de proteção da segurança jurídica em sua dimensão subjetiva.

No entanto, levando-se em conta que, nesses precedentes, o STF fixou um limite temporal objetivo para que o TCU exercesse a sua competência constitucional sem a necessidade de assegurar aos interessados o exercício das garantias do contraditório e da ampla defesa, parece estar-se diante de uma situação de proteção da segurança jurídica na dimensão objetiva. Conquanto na fundamentação dos julgados tenham sido suscitadas questões subjetivas, o entendimento do STF foi no sentido de exigir que o TCU convocasse os interessados para participar do processo sempre que aquela Corte de Contas demorar mais de cinco anos para apreciar o ato, o que prescinde de uma análise efetivamente subjetiva. Outro ponto que indica tratar-se de uma situação de proteção da vertente objetiva da segurança jurídica refere-se ao próprio termo inicial definido para a contagem do prazo. Se fosse realmente o caso de se estar tutelando o princípio da proteção da confiança, não faria sentido estabelecer-se como termo a quo para a contagem do prazo a data da entrada do ato no TCU, pois tal acontecimento não interfere no fortalecimento da base da confiança na esfera subjetiva do indivíduo. A adoção desse marco temporal mostra que o que está sendo protegido, na verdade, é a segurança do ordenamento jurídico como um todo (vertente objetiva da segurança jurídica). Isso porque há um deslocamento da análise, cujo foco deixa de ser a confiança que o ato emanado do Poder Público gerou no indivíduo, para quem é indiferente se o órgão de origem levou meses ou anos para enviar seu ato ao TCU, e passa a ser conduta da Administração. Ou seja, verifica-se o tempo que o órgão de controle leva para exercer sua competência, não a confiança que o particular efetivamente depositou no ato administrativo, confiança que começa a ser consolidada desde a concessão do benefício, independentemente do momento em que o ato chega ao TCU.

Dessa forma, apesar de se considerar extremamente difícil identificar qual das duas dimensões da segurança jurídica foi tutelada nos Mandados de Segurança 25.116/DF e 24.781/DF, arriscar-se-ia dizer, em face dos critérios objetivos fixados, que prevaleceu a tutela da dimensão objetiva da segurança jurídica. Contudo, isso não muda o fato de que, do ponto de vista prático, na maioria das situações em que o TCU considera ilegal uma aposentadoria, reforma ou pensão, depois de um longo tempo da sua concessão, há a violação da segurança jurídica em ambas as dimensões.

Outro ponto que merece debate é saber se o surgimento do direito ao exercício do contraditório e da ampla defesa em face do decurso do prazo de cinco anos é solução adequada para dar efetividade ao princípio da segurança jurídica. ${ }^{88}$ É bem verdade que o princípio da segurança jurídica envolve a segurança jurídica dos princípios (segurança jurídica material, abrangendo todos os meios necessários a efetivação dos princípios). A ampla defesa e o contraditório também são meios de se garantir a segurança jurídica, por contribuírem para que a aplicação das normas seja feita de forma segura. ${ }^{89}$ Contudo, com a devida vênia, no caso, não nos parece que a decisão do STF tenha realmente efetivado o princípio da segurança jurídica.

87 ÁVILA, Humberto. Segurança jurídica: entre permanência, mudança e realização no direito tributário. 2. ed. São Paulo: Malheiros, 2012. p. 391, 461.

88 TORRES, Heleno Taveira. Direito constitucional tributário e segurança jurídica: metódica da segurança jurídica do sistema constitucional tributário. 2. ed. São Paulo:Revista dos Tribunais, 2012. p. 205; 212-215.

89 ÁVILA, Humberto. Segurança jurídica: Entre permanência, mudança e realização no direito tributário. 2. ed. São Paulo: Malheiros Editores, 2012. p. 148. 
Primeiro porque, muitos dos argumentos utilizados para garantir o contraditório e a ampla defesa, especialmente os relativos à segurança jurídica, confiança e boa-fé, apontam para a fixação de um limite temporal para a atuação do TCU e, no entanto, a solução adotada não impõe esse limite. O chamamento do particular, que já recebe o benefício previdenciário há mais de cinco anos, para participar do processo administrativo por meio do qual o TCU aprecia seu ato de aposentadoria, reforma ou pensão, não terá o efeito de estabilizar a situação do interessado, cuja aparência de legitimidade e legalidade consolidou-se pela passagem do tempo. A situação do sujeito continua por prazo indeterminado a mercê do risco de ser considerada ilegal pelo TCU. A diferença é que agora, caso a Corte de Contas demore a exercer sua competência constitucional, o indivíduo terá assegurado o direito ao contraditório e à ampla defesa, garantias em que o exercício, diga-se de passagem, tende a ser prejudicado pelo transcurso do tempo: quanto maior o prazo entre o ato a ser defendido e a notificação do interessado, mais difícil tende a ser para ele reunir os elementos necessários à defesa de seus interesses.

Depois porque, independentemente de se considerarem esses atos administrativos complexos ou não, discussão que não será aprofundada neste estudo, bem como sem querer adentrar no debate sobre a aplicabilidade do contraditório e da ampla defesa, não se vê razão para que o direito ao exercício dessas garantias nasça em razão do decurso do tempo. Ou o direito a exercê-las existe desde a concessão da aposentadoria, reforma ou pensão - momento em que o indivíduo passa a receber o respectivo benefício e a ostentar o status de pensionista, aposentado, militar na reserva ou reformado - ou esse direito não surgirá apenas pela passagem do tempo. Nesse sentido, foram as considerações do ministro Marco Aurélio no julgamento do Mandado de Segurança 25.116/DF que, posicionando-se contrariamente a tese vencedora, ressaltou tal contradição ao afirmar que o tempo não altera a natureza do ato administrativo, o qual, sendo considerado ato complexo, não deixaria de sê-lo após cinco anos. Enfatizou, ainda, que a passagem do tempo não poderia justificar o surgimento do direito subjetivo ao contraditório, o qual pressupõe a existência de litigantes e, por conseguinte, de uma lide, o que, no entendimento por ele adotado, não ocorre antes do registro dos atos em tela. De fato, nesse ponto, concordamos com o seu posicionamento, pois, caso se parta da premissa que não há uma lide que justifique a abertura do contraditório desde o início, tal pressuposto não surgirá pelo decurso do tempo. O ministro Cezar Peluso, com posicionamento oposto ao do ministro Marco Aurélio, também registrou tal incoerência, observando que, do ponto de vista do contraditório, não haveria diferença substantiva se o beneficiário estivesse a receber, mensal e regularmente, verba de natureza alimentar por três e não cinco anos, pois não lhe seria menos pungente o impacto negativo que a subtração ou a diminuição dessa verba poderia lhe causar.

Por tudo isso, considera-se não só mais coerente com a própria fundamentação dos julgados como também mais consentânea com o ordenamento jurídico vigente a tese defendida pelo ministro Peluso, no sentido de, em nome da segurança jurídica, reconhecer a decadência do direito de o TCU considerar ilegal a concessão inicial de aposentadoria, reforma ou pensão.

Como defendeu o ministro Peluso e na linha dos posicionamentos doutrinários colhidos neste estudo, o poder de invalidação dos atos gravosos está predisposto à realização de um fim público imediato (reconduzir a atuação da Administração à esfera da legalidade), o qual não é absoluto nem superior a outros interesses sociais específicos que compõem a ordem jurídica e também devem nortear o comportamento da Administração Pública. Assim, a invalidação do ato viciado só deve ocorrer quando essa solução for a que melhor concretize os valores consagrados na Constituição. No caso, considerando tratar-se de ato emanado do Poder Público, cuja constituição, em regra, não participa o seu beneficiário, que produz sérias consequências na vida do particular e goza de presunção de legalidade e legitimidade, entende-se que deve haver um prazo limite para a apreciação desse ato. Não pode o particular ficar por período de tempo indeterminado sob a ameaça de ter seu benefício previdenciário cessado ou reduzido.

Ademais, conforme os dados trazidos no voto da ministra Ellen Gracie - ironicamente a fim de defender a inexistência de limite temporal à atuação do TCU - em média, apenas 4\% de todos os atos apreciados 
pela Corte de Contas são considerados ilegais. Assim, considerando-se que parte desses atos ilegais seria apreciada em menos de cinco anos, é possível concluir que, caso houvesse reconhecimento da decadência, o número de atos originalmente ilegais que permaneceriam no mundo jurídico corresponderia a menos de 4\% das concessões de aposentadorias, reformas e pensões emitidas pelo Poder Público federal. Esse percentual, a nosso ver, não justifica o estado de insegurança jurídica provocado pela ausência de prazo para a atuação do TCU, pois se colocam todos os beneficiários de aposentadorias, reformas e pensões - mesmo das não viciadas, que correspondem à maioria dos casos - em uma situação de instabilidade por período indeterminado, até que o TCU delibere sobre o respectivo ato concessivo.

Por fim, com relação ao termo a quo para a contagem do prazo, entende-se que a adequação ou não do critério fixado - entrada do ato no TCU - vai depender de qual das duas dimensões da segurança jurídica está sendo protegida. Como adiantado acima, parece-nos que, tratando-se da dimensão subjetiva da segurança jurídica, ou seja, de proteger a confiança que o particular depositou no ato emanado do Poder Público, seria mais coerente se o prazo fosse contado da data da concessão do benefício, não da entrada do ato no TCU, acontecimento irrelevante para o fortalecimento da confiança na esfera subjetiva do indivíduo. Por outro lado, tendo-se como foco a dimensão objetiva da segurança jurídica - caso o objetivo seja resguardar a segurança do ordenamento jurídico como um todo, por meio da fixação de um prazo para que a Corte de Contas exerça sua competência - ao menos a priori, não se vislumbra problema na adoção da entrada do ato no TCU como marco temporal.

\section{Considerações finais}

O princípio da segurança jurídica, na dimensão dinâmica, refere-se ao problema da ação no tempo e revela quais ideais devem ser garantidos para que o Direito possa assegurar direitos e expectativas ao cidadão, servindo-lhe de instrumento de proteção. Nesse aspecto, o direito deve ser calculável, permitindo que o cidadão possa saber quais mudanças podem ser feitas e quais não podem, para não ter seus direitos frustrados; e confiável, garantindo que o cidadão tenha condição de saber como e quando as mudanças podem ser realizadas para não ser surpreendido.

$\mathrm{Na}$ dimensão dinâmica, a segurança jurídica pode ser objetiva ou subjetiva. A primeira é aquela que envolve a questão dos limites à retroatividade dos atos do Estado, até mesmo quando eles se qualificam como atos legislativos. Dela decorrem as questões relativas à permanência do ordenamento jurídico e as hipóteses de intangibilidade de situações individuais por questões objetivas, como a proteção ao direito adquirido, ao ato jurídico perfeito e à coisa julgada. Já a segunda (sentido subjetivo) se refere à proteção da confiança das pessoas no tocante aos atos, procedimentos e condutas do Estado nos mais diferentes aspectos da sua atuação, está relacionada à proteção de situações individuais por razões subjetivas.

A passagem do tempo tanto funciona como fator gerador de irreversibilidade fática ou jurídica de situações individuais (dimensão objetiva) quanto como fator gerador de confiança individual digna de proteção jurídica (dimensão subjetiva). Assim os efeitos de um ato ilegal ou inconstitucional podem ser mantidos porque o longo decurso do tempo os tornou irreversíveis, independentemente da análise de fatores subjetivos, como a boa-fé ou o conhecimento da irregularidade pelo particular (aplicação da face objetiva da segurança jurídica); ou porque o tempo fortaleceu a confiança depositada pelo particular no ato ilegal, o qual atuou confiando na sua legitimidade, sem ter ou dever ter conhecimento de que o ato era viciado (dimensão subjetiva da segurança jurídica).

A transição entre ambas as situações de proteção, no entanto, não é pontual, mas continuada, tornando-se difícil distingui-las em situações limítrofes, a exemplo do que ocorre em relação aos Mandados de Segurança 25.116/DF e 24.781/DF. Nestes, tratou-se da tutela dos princípios da segurança jurídica e da proteção da confiança em face da demora do TCU ao apreciar, para fins de registro, atos de concessão de 
aposentadoria, reforma ou pensão. Ao julgá-los, a Suprema Corte firmou o entendimento de que, em respeito ao princípio da proteção da confiança, quando transcorrerem mais de cinco anos, contados da entrada do ato no Tribunal, sem que haja a apreciação dessas concessões pelo TCU, este deve assegurar o contraditório e a ampla defesa aos interessados.

Analisando-se os fundamentos desses julgados, especificamente aqueles que dizem respeito à segurança jurídica e à proteção da confiança, e confrontando-os com a doutrina sobre tais princípios, observa-se que o novo entendimento firmado pelo STF, embora represente uma evolução em relação à jurisprudência anterior, não efetiva o princípio da segurança jurídica, tal qual se propõe a fazer. Muitos dos argumentos utilizados apontam para a fixação de um limite temporal para a atuação do TCU e, no entanto, a solução adotada não impõe esse limite. O chamamento do particular, que já recebe o benefício previdenciário há mais de cinco anos, para participar do processo administrativo por meio do qual seu ato de aposentadoria, reforma ou pensão é apreciado, não terá o efeito de estabilizar sua situação, cuja aparência de legitimidade e legalidade consolidou-se pela passagem do tempo. O sujeito continua por prazo indefinido a mercê de ter seu benefício considerado ilegal pelo TCU.

Há que se ter em conta que o poder de invalidação dos atos administrativos viciados só deve ocorrer quando essa solução for a que melhor concretize os valores consagrados na Constituição. No caso, considerando tratar-se de ato emanado do Poder Público, cuja constituição, em regra, não participa o seu beneficiário, que produz sérias consequências em sua vida e goza de presunção de legalidade e legitimidade, entende-se que deve haver um prazo limite para a apreciação desse ato. Não pode o particular ficar por período de tempo indeterminado sob a ameaça de ter seu benefício previdenciário cessado ou reduzido.

Ademais, não se vê razão para que o direito ao exercício das garantias do contraditório e da ampla defesa nasça em razão do decurso do tempo. Ou o direito a exercê-las existe desde a concessão da aposentadoria, reforma ou pensão - momento em que o indivíduo passa a receber o respectivo benefício e a ostentar o status de pensionista, aposentado, militar da reserva ou reformado - ou esse direito não surgirá apenas pela passagem do tempo.

Por tudo isso, considera-se não só mais coerente com a própria fundamentação dos julgados como também mais consentânea com o ordenamento jurídico vigente a tese defendida pelo ministro Peluso, no sentido de que deve haver um prazo para que o TCU aprecie as concessões iniciais de aposentadorias, reformas e pensões, passado o qual, o ato concessivo não poderá mais ser revisto para prejudicar o beneficiário.

\section{REFERÊNCIAS}

AGUIAR, Ubiratan Diniz de; ALBUQUERQUE, Márcio André dos Santos de; Medeiros, Paulo Henrique Ramos. A administração pública sob a perspectiva do controle externo. Belo Horizonte: Fórum, 2011.

ÁVILA, Humberto. Segurança jurídica: entre permanência, mudança e realização no direito tributário. 2. ed. São Paulo: Malheiros, 2012.

ÁVILA, Humberto. Teoria dos princípios: da definição à aplicação dos princípios jurídicos. 2 ed. São Paulo: Malheiros, 2003.

BRASIL. Supremo Tribunal Federal. Agravo Regimental no Mandado de Segurança. AgR 28.711. Agravante: Salomão Francisco Amaral. Agravado: Tribunal de Contas da União. Relator: Min. Dias Toffoli. Brasília, DF, 24 setembro de 2012. Disponível em: <http://redir.stf.jus.br/paginadorpub/paginador. jsp?docTP=TP\&docID=2812518>. Acesso em: 22 mar. 2013.

BRASIL. Supremo Tribunal Federal. Mandado de Segurança MS 24.859. Impetrante: Maria Helena Marques Pinto Simões. Impetrado: Tribunal de Contas da União. Relator: Min. Carlos Velloso. 
Brasília, DF, 27 de agosto de 2004. Disponível em: <http://redir.stf.jus.br/paginadorpub/paginador. jsp?docTP=AC\&docID=86200>. Acesso em: 22 mar. 2013.

BRASIL. Supremo Tribunal Federal. Mandado de Segurança. MS 24.268. Impetrante: Fernanda Fiuza Brito. Impetrado: Tribunal de Contas da União. Relatora: Min. Ellen Gracie. Brasília, DF, 17 de setembro de 2004. Disponível em: <http://redir.stf.jus.br/paginadorpub/paginador.jsp?docTP=AC\&docID=86111>. Acesso em: 21 mar. 2013.

BRASIL. Supremo Tribunal Federal. Mandado de Segurança. MS 24.781. Impetrante: Mazureik Miguel de Morais. Impetrado: Tribunal de Contas da União. Relatora: Min. Ellen Gracie. Relator para Acórdão: Min. Gilmar Mendes. Brasília, DF, 9 de junho de 2011. Disponível em: < http://redir.stf.jus.br/paginadorpub/ paginador.jsp?docTP=AC\&docID=623956>. Acesso em: 22 mar. 2013.

BRASIL. Supremo Tribunal Federal. Mandado de Segurança. MS 25.090. Impetrante: Jandir de Morais Feitosa. Impetrado: Tribunal de Contas da União. Relator: Min. Eros Grau. Brasília, DF, 1 de abril de 2005. Disponível em: <http://redir.stf.jus.br/paginadorpub/paginador.jsp?docTP=AC\&docID=86254>. Acesso em: 22 mar. 2013.

BRASIL. Supremo Tribunal Federal. Mandado de Segurança. MS 25.116. Impetrante: Edson de Almeida Miguel Relvas. Impetrado: Tribunal de Contas da União. Relator: Min. Ayres Britto. Brasília, DF, 20 de fevereiro de 2011. Disponível em: <http://redir.stf.jus.br/paginadorpub/paginador.jsp?docTP=AC\&docID=618869>. Acesso em: 22 mar. 2013.

BRASIL. Supremo Tribunal Federal. Mandado de Segurança. MS 25.116. Impetrante: Ariel Rey Ortiz Olstan. Impetrado: Tribunal de Contas da União. Relator: Min. Ricardo Lewandowski. Brasília, DF, 19 de dezembro de 2011. Disponível em: <http://redir.stf.jus.br/paginadorpub/paginador. jsp?docTP=TP\&docID=1643169>. Acesso em: 22 mar. 2013.

BRASIL. Supremo Tribunal Federal. Mandado de Segurança. MS 25.192. Impetrante: Jecy Serôa da Motta. Impetrado: Tribunal de Contas da União. Relator: Min. Eros Grau. Brasília, DF, 6 de maio de 2005. Disponível em: <http://redir.stf.jus.br/paginadorpub/paginador.jsp?docTP=AC\&docID=86282>. Acesso em: 22 mar. 2013.

BRASIL. Supremo Tribunal Federal. Mandado de Segurança. MS 25.256. Impetrante: Maria José dos Santos Clarindo. Impetrado: Tribunal de Contas da União. Relator: Min. Ayres Britto. Brasília, DF, 24 de março de 2006. Disponível em: <http://redir.stf.jus.br/paginadorpub/paginador.jsp?docTP=AC\&docID=365412 >. Acesso em: 22 mar. 2013.

BRASIL. Supremo Tribunal Federal. Mandado de Segurança. MS 25.403. Impetrante: Ionni Tadeu de Sá. Impetrado: Tribunal de Contas da União. Relator: Min. Ayres Britto. Brasília, DF, 10 de fevereiro de 2011. Disponível em: $<$ http://redir.stf.jus.br/paginadorpub/paginador.jsp?docTP=AC\&docID=618870 $>$. Acesso em: 22 mar. 2013.

BRASIL. Supremo Tribunal Federal. Mandado de Segurança. MS 25.409. Impetrante: Karel Willis Rêgo Guerra. Impetrado: Tribunal de Contas da União. Relator: Min. Sepúlveda Pertence. Brasília, DF, 18 de maio de 2007. Disponível em: < http://redir.stf.jus.br/paginadorpub/paginador.jsp?docTP=AC\&docID=456064>. Acesso em: 22 mar. 2013.

BRASIL. Supremo Tribunal Federal. Mandado de Segurança. MS 25.440. Impetrante: Márcia Aguiar Nogueira Batista. Impetrado: Tribunal de Contas da União. Relator: Min. Carlos Velloso. Brasília, DF, 28 de abril de 2006. Disponível em: <http://redir.stf.jus.br/paginadorpub/paginador.jsp?docTP=AC\&docID=365424 >. Acesso em: 22 mar. 2013.

BRASIL. Supremo Tribunal Federal. Mandado de Segurança. MS 25.552. Impetrante: Jose Claudio Netto Motta. Impetrado: Tribunal de Contas da União. Relatora: Min. Cármen Lúcia. Brasília, DF, 29 de maio de 
2008. Disponível em: <http://redir.stf.jus.br/paginadorpub/paginador.jsp?docTP=AC\&docID=530427 >. Acesso em: 22 mar. 2013.

BRASIL. Supremo Tribunal Federal. Mandado de Segurança. MS 25.568. Impetrante: Associação Nacional Dos Aposentados e Pensionistas do Serviço Público Federal. Impetrado: Presidente da Primeira Câmara do Tribunal de Contas da União. Relator: Min. Dias Toffoli. Relatora para Acórdão: Min. Rosa Weber. Brasília, DF, 10 de maio de 2012. Disponível em: <http://redir.stf.jus.br/paginadorpub/paginador. jsp?docTP=TP\&docID=1979529 > . Acesso em: 22 mar. 2013.

BRASIL. Supremo Tribunal Federal. Mandado de Segurança. MS 25.697. Impetrante: Maria das Graças Consuelo Silveira Alvim de Oliveira. Impetrado: Presidente do Tribunal de Contas da União. Relator: Min. Cármen Lúcia. Brasília, DF, 5 de março de 2010. Disponível em: < http://redir.stf.jus.br/paginadorpub/ paginador.jsp?doc TP=AC\&docID=609265>. Acesso em: 22 mar. 2013.

BRASIL. Supremo Tribunal Federal. Mandado de Segurança. MS 25.702. Impetrante: Terezinha de Jesús Ribeiro Araújo. Impetrado: Tribunal de Contas da União. Relator: Min. Marco Aurélio. Relator para Acórdão: Min. Eros Grau. Brasília, DF, 27 de abril de 2007. Disponível em: <http://redir.stf.jus.br/paginadorpub/ paginador.jsp?docTP=AC\&docID=443450>. Acesso em: 22 mar. 2013.

BRASIL. Supremo Tribunal Federal. Mandado de Segurança. MS 28.333. Impetrantes: Adelino Jaime de Faria, Anízio Abraão Cherin, Antônio José Pichler, Humberto de Jesus Ferreira, Moacir Gangana Filho, Nilton de Rocha Gama e Paulo Roberto Rodrigues da Cunha. Impetrado: Presidente do Tribunal de Contas da União. Relator: Min. Ricardo Lewandowski. Brasília, DF, 27 de fevereiro de 2012. Disponível em: <http:// redir.stf.jus.br/paginadorpub/paginador.jsp?docTP=TP\&docID=1759130 >. Acesso em: 22 mar. 2013.

BRASIL. Supremo Tribunal Federal. Mandado de Segurança. MS 28.520. Impetrante: Glaci Bernardete Heiss. Impetrado: Tribunal de Contas da União. Relator: Min. Ayres Britto. Brasília, DF, 2 de abril de 2012. Disponível em: <http://redir.stf.jus.br/paginadorpub/paginador.jsp?docTP=TP\&docID=1874576 >. Acesso em: 22 mar. 2013.

BRASIL. Supremo Tribunal Federal. Mandado de Segurança. MS 28.720. Impetrante: Maria da Penha Rodrigues Castro. Impetrado: Tribunal de Contas da União. Relator: Min. Ayres Britto. Brasília, DF, 2 de abril de 2012. Disponívelem: <http://redir.stf.jus.br/paginadorpub/paginador.jsp?docTP=TP\&docID=1874415>. Acesso em: 22 mar. 2013.

BRASIL. Supremo Tribunal Federal. Mandado de Segurança. MS 28.929. Impetrante: Sônia Miriam Peixoto Pontes. Impetrado: Tribunal de Contas da União. Relatora: Min. Cármen Lúcia. Brasília, DF, 16 de novembro de 2011. Disponível em: < http://redir.stf.jus.br/paginadorpub/paginador.jsp?docTP=AC\&docID=629666 >. Acesso em: 22 mar. 2013.

BRASIL. Supremo Tribunal Federal. Recurso Extraordinário. RE 195.861. Recorrente: Estado do Espírito Santo. Recorrido: Eduardo Martins Vicente. Relator: Min. Marco Aurélio. Brasília, DF, 17 de outubro de 1997. Disponível em: < http://redir.stf.jus.br/paginadorpub/paginador.jsp?docTP=AC\&docID=234796>. Acesso em: 22 mar. 2013.

BRASIL. Supremo Tribunal Federal. Repercussão Geral no Recurso Extraordinário. RE 636.553. Recorrente: União. Recorrido: João Darci Rodrigues de Oliveira. Relator: Min. Gilmar Mendes. Brasília, DF, 9 de março de 2012. Disponívelem:<http://redir.stf.jus.br/paginadorpub/paginador.jsp?docTP=TP\&docID=2218526>. Acesso em: 22 mar. 2013.

BRASIL. Supremo Tribunal Federal. Sumula $n^{\circ}$ 3. Nos processos perante o Tribunal de Contas da União asseguram-se o contraditório e a ampla defesa quando da decisão puder resultar anulação ou revogação de ato administrativo que beneficie o interessado, excetuada a apreciação da legalidade do ato de concessão inicial de aposentadoria, reforma e pensão. Disponível em: < http://www.stf.jus.br/portal/jurisprudencia/ listarJurisprudencia.asp?s1 = $\% 28 \% 283 \% 2 \mathrm{ENUME} \% 2 \mathrm{E} \% 29 \% 29+\mathrm{E}+\mathrm{S} \% 2 \mathrm{EFLSV} \% 2 \mathrm{E} \& \mathrm{~b} a \mathrm{se}=$ baseSumul 
asVinculantes\&url=http://tinyurl.com/c39hh58>. Acesso em: 22 mar. 2013.

BRASIL. Tribunal de Contas da União. Acórdão nº 1.697/2003 - Segunda Câmara. Aposentadoria. Pedido de Reexame de decisão. Relator: Min. Lincoln Magalhães da Rocha. Brasília, DF, 23 de setembro de 2003. Diário Oficial [da] República Federativa do Brasil, Brasília, DF, 6 out. 2003.

BRASIL. Tribunal de Contas da União. Acórdão no 241/2006. Plenário. Pedido de Reexame de decisão. Relator: Min. Ubiratan Aguiar. Brasília, DF, 8 de março de 2003. Diário Oficial [da] República Federativa do Brasil. Brasília, DF, 15 mar. 2003.

BRASIL. Tribunal de Contas da União. Acórdão no 3.245/2010. Plenário. Pessoal. Pensão civil. Relator: Min. Augusto Nardes. Brasília, DF, 1 de dezembro de 2010.

BRASIL. Tribunal de Contas da União. Acórdão no 41/2008. Primeira Câmara. Pessoal. Aposentadoria. Pedido de reexame. Relator: Min. Valmir Campelo. Brasília, DF, 29 de janeiro de 2008. Diário Oficial [da] República Federativa do Brasil, Brasília, DF, 1 fev. 2008.

BRASIL. Tribunal de Contas da União. Acórdão no 559/2005. Plenário. Aposentadorias. Suframa. Relator: Min. Walton Alencar Rodrigues. Brasília, DF, 11 de maio de 2005. Diário Oficial [da] República Federativa do Brasil, Brasília, DF, 20 mai. 2005.

BRASIL. Tribunal de Contas da União. Acórdão no 597/2004. Primeira Câmara. Pedido de Reexame. Relator: Min. Marcos Bemquerer. Brasília, DF, 30 de março de 2004. Diário Oficial [da] República Federativa do Brasil, Brasília, DF, 8 abr. 2004.

BRASIL. Tribunal de Contas da União. Acórdão no 85/2004. Segunda Câmara. Pedido de Reexame. Relator: Min. Ubiratan Aguiar. Brasília, DF, 5 de fevereiro de 2004. Diário Oficial [da] República Federativa do Brasil, Brasília, DF, 11 fev. 2004.

BRASIL. Tribunal de Contas da União. Decisão no 1.020/2000. Plenário. Solicitação da Procuradoria da União no Estado do Espírito Santo. Relator: Min. Marcos Vilaça. 29 de novembro de 2000. Diário Oficial [da] República Federativa do Brasil, Brasília, DF, 15 dez. 2000.

CARVALHO FILHO, José dos Santos. Manual de direito administrativo. 14. ed. Rio de Janeiro: Lumen Juris, 2005.

CARVALHO, André Luis de. Súmula Vinculante n. 3 do STF: considerações e alcance. Revista Âmbito Jurídico, Rio Grande, n. 41, maio, 2007. Disponível em: <http://ambitojuridico.com.br/site/index.php?n_ link $=$ revista_juridica\&revista_edicoes $=27>$. Acesso em: 5 jun. 2012.

SILVA, Almiro do Couto e. O princípio da segurança jurídica (proteção à confiança) no direito público brasileiro e o direito da administração pública de anular seus próprios atos administrativos: o prazo decadencial do art. 54 da lei do processo administrativo da União: lei no 9.784/99. Revista Eletrônica de Direito do Estado, Salvador, n. 2, abr./jun., 2005. Disponível em: <http://www.direitodoestado.com.br>. Acesso em: 5 maio 2012.

CUSTÓDIO, Antonio Joaquim Ferreira. Registro de aposentadorias e pensões, o devido processo legal e a súmula vinculante no 3. Jus Navigandi, Teresina, ano 13, n. 1947, 30 out. 2008. Disponível em: <http://jus. com.br/revista/texto/11904>. Acesso em: 7 jan. 2013.

DERZI, Misabel Abreu Machado. Modificações da jurisprudência no direito tributário: proteção da confiança, boa-fé objetiva e irretroatividade como limitações constitucionais ao poder judicial de tributar. São Paulo: Noeses, 2009.

FURTADO, Lucas Rocha. Curso de direito administrativo. Belo Horizonte: Fórum, 2007.

GARCÍA DE ENTERRÍA, Eduardo; FERNANDEZ, Tomás-Ramón. Curso de derecho administrativo. 12. ed. Madrid: Civitas, 2005. v.1 
GOMES CANOTILHO, José Joaquim. Direito constitucional e teoria da constituição. 7. ed. Coimbra: Almedina, 2010.

LEITE, Sandro Grangeiro. Análise da compatibilidade entre o conceito de ato administrativo complexo e os contornos jurídicos dados pelo STF ao registro do ato de concessão de aposentadoria, reforma e pensão. Trabalho de Conclusão de Curso (Especialização)-Instituto Brasiliense de Direito Público,Brasília, 2009.

MARTINS JÚNIOR, Wallace Paiva. Ato administrativo complexo. Disponível em: <http://sisnet.aduaneiras. com.br/lex/doutrinas/arquivos/110406j.pdf>. Acesso em: 8 jan. 2013.

PONDÉ, Lafayette. Controle dos atos da administração pública. Revista de Direito Administrativo. Rio de Janeiro, n. 212, abr./jun. 1998.

SARLET, Ingo Wolfgang. A eficácia do direito fundamental à segurança jurídica: dignidade da pessoa humana, direitos fundamentais e proibição de retrocesso social no direito constitucional brasileiro. Revista de Direito Constitucional e Internacional, São Paulo, v. 14, n. 57, out/dez, 2006.

TEIXEIRA, Flavio Germano de Sena. O controle das aposentadorias pelos tribunais de contas. Belo Horizonte: Fórum, 2004.

TORRES, Heleno Taveira. Direito constitucional tributário e segurança jurídica: metódica da segurança jurídica do sistema constitucional tributário. 2. ed. São Paulo: Revista dos Tribunais, 2012.

ZAGREBELSKY, Gustavo. El derecho dúctil. Ley, derechos, justicia. Tradução de Marina Gascón. 9. ed. Madrid: Trotta, 2009. 


\section{REVISTA BRASILEIRA DE POLÍTICAS PÚBLICAS BRAZILIAN JOURNAL OF PUBLIC POLICY}
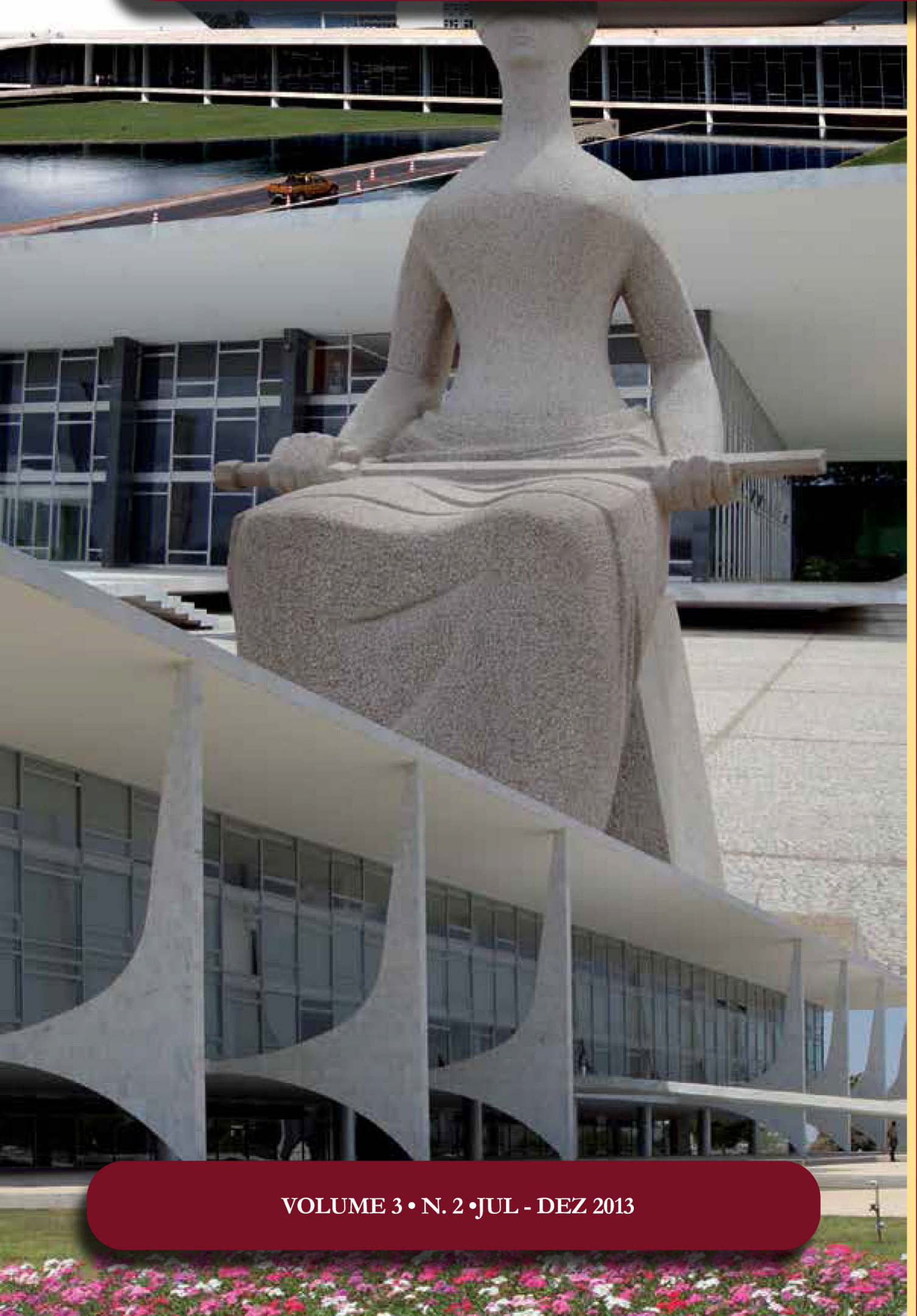

Avaliação legislativa no Brasil: apontamentos para uma nova agenda de pesquisa sobre o modo de produção das leis

Legislative Review in Brazill: Notes on a New Research Agenda on the Mode of production of Laws

Natasha Schmitt Caccia Salinas 


\title{
Avaliação legislativa no Brasil: apontamentos para uma nova agenda de pesquisa sobre o modo de produção das leis
}

\author{
Legislative Review in Brazil: Notes on a New \\ Research Agenda on the Mode of production of \\ Laws*
}

Natasha Schmitt Caccia Salinas**

\section{Resumo}

Este artigo tem por objetivo analisar as potencialidades e limitações da avaliação legislativa para instruir o processo de formulação e revisão de atos normativos no Brasil. A avaliação legislativa constitui uma metodologia destinada a analisar atos normativos sob o enfoque dos efeitos que eles produzem na sociedade. Sob essa perspectiva, ao avaliador compete mensurar, com o uso de ferramentas de pesquisa interdisciplinares, a eficácia, a efetividade, a eficiência e o impacto das leis. Desse modo, este trabalho divide-se em quatro partes. Na primeira, serão analisadas as condições sociais, econômicas e intelectuais que propiciaram o surgimento da avaliação legislativa como metodologia fundamental do processo de produção das leis. Em seguida, o artigo examinará a avaliação legislativa na condição de objeto de estudo da "Legística Material." Essa disciplina, também conhecida como "Metódica da Legislação," tem por objetivo oferecer técnicas para a formulação do conteúdo propriamente dito das leis, sendo que as ferramentas analíticas dessa avaliação assumem destaque nesse processo. $\mathrm{Na}$ terceira parte, serão apresentadas algumas experiências de institucionalização da avaliação legislativa, na qual ela vem sendo adotada oficialmente em algumas jurisdições como mecanismo essencial do processo de produção legislativa. O artigo é concluído com uma análise sobre o modo como pressupostos de "Legística Material" têm sido inseridos no ordenamento jurídico brasileiro, e a forma como essas premissas vêm sendo aplicadas na prática. Ver-se-á que o uso modesto da avaliação legislativa no Brasil decorre do desconhecimento desse importante instrumento de aprimoramento da técnica legislativa.

Palavras-chave: Avaliação legislativa. Ciência da legislação. Eficácia. Efetividade. Eficiência. Impacto.

* Recebido em 02/03/2013 Aprovado em 26/03/2013

** Doutora e Mestre em Direito pela Universidade de São Paulo. Master of Laws (LL.M.) pela Yale University. Email: nscaccia@uol.com.br

\section{Abstract}

This article aims to analyze the strengths and limitations of the legislative review process to instruct the development and review of legislative acts in Brazil . Legislative assessment is a methodology designed to analyze normative acts from the standpoint of the effects they produce in society. From 
this perspective, it pertains to the the evaluator to measure, with the use of interdisciplinary research tools, the efficiency, the effectiveness and the impact of laws. Accordingly, this paper is divided into four parts. At first, we analyze the social, economic and intellectual conditions which favor the development of legislative review as a fundamental methodology in the process of law production. The article then examines the legislative review with the perspective of studying "Legistics Material". This discipline, also known as "methodical legislation" aims to provide techniques for shaping the content of the law itself; in this process the analytical tools used are of paramount relevance. The third part will present some experiences of institutionalization of legislative review where it has been officially adopted in some jurisdictions as an essential mechanism of the lawmaking process. The article concludes by highlighting an analysis of how assumptions of "Legistics Material" have been inserted in the Brazilian legal system, and how these assumptions have been applied in practice. It will be seen that the modest use of legislative review in Brazil stems from the lack of knowledge of this important tool for improving the legislative technique .

\section{Keywords:}

\section{O Re (SURGIMENTO) DA CIÊNCIA dA LEGISLAÇão}

Assistiu-se nas últimas três décadas a um crescente e particular interesse acadêmico europeu pelo processo de elaboração da legislação. O marco inicial desse ganho de credibilidade de uma denominada ciência da legislação na Europa, frequentemente mencionado por estudiosos contemporâneos, constitui a publicação, em 1973, da obra de autoria do penalista suíço Peter Noll, intitulada "Ciência ou Doutrina da Legislação".

O trabalho realizado por Peter Noll, que ensinou disciplina de mesmo nome na Alemanha, contribuiu para a proliferação de outras iniciativas acadêmicas como o surgimento de núcleos de ensino e pesquisa, tal qual o desenvolvido na Faculdade de Direito da Universidade de Genebra, protagonizado por Charles-Albert Morand e Jean-Daniel Delley.

O surgimento de novas abordagens científicas sobre o fenômeno legislativo, paradoxalmente ocorreu ao mesmo tempo em que o direito e, por consequência, suas fontes, como a própria lei, ingressaram numa situação de crise da qual não se vislumbra nenhuma superação. Ou, em outras palavras: enquanto o direito e a lei predominaram como instituições estáveis, não existiu interesse científico pelos métodos de formação da legislação. Esse interesse surgiu apenas recentemente, num momento em que não mais se crê na segurança e na estabilidade proporcionadas pelo direito e pela lei. ${ }^{2}$

Morand ${ }^{3}$ oferece uma explicação para esse paradoxo. Para o autor, os juristas, que sempre assumiram papel privilegiado no cenário de elaboração das leis, nada ou muito pouco fizeram para desenvolver métodos que guiassem a ação de legislar. O positivismo jurídico teria afastado os juristas de uma abordagem científica acerca do processo de elaboração das leis, interrompendo a continuidade de estudos sobre legislação que foram realizados durante o Iluminismo. ${ }^{4}$ Com essa ruptura, os esforços concentraram-se no desenvolvimento de uma metodologia para inter-

1 Há discussões terminológicas a respeito da melhor tradução para Gesetżgebunglehre, título da obra de Peter Noll. João Caupers observa, no entanto, que Noll utilizou ao longo de sua obra as expressões Gesetzgebungslebre e Gesetzgebungwissenschaf indistintamente, sendo que a tradução da última corresponde indiscutivelmente à expressão ciência da legislação. CAUPERS, João. Relatório sobre o programa, conteúdo e métodos de uma disciplina de Metódica da Legislação. Cadernos de Ciência de Legislação, Oieiras, Instituto Nacional de Administração, n. 35, out-dez. 2003, p. 8.

2 CHEVAlLIER, Jacques. A racionalização da produção jurídica. Cadernos de Ciência de Legislação. jan-mar. 1992, p. 9-10.

3 MORAND, Charles-Albert. Les exigences de la méthode législative et du droit constitutionnel portant sur la formation de la législation. Droit et Societé, n. 10, 1988, p. 391.

4 No que diz respeito aos trabalhos sobre legislação realizados no final do século XVIII, Morand (1999, p.23-27) destaca as obras de Montesquieu (De l'esprit des lois), J. Bentham (Nomography or Art of Inditin Law) e G. Falangieri (La Scienza della Legislazione). Caupers (2003, p. 16-17), além das obras mencionadas por Morand, faz remissão ao Tratado da Lei, da obra Summa Theologica, de São Tomás de Aquino, bem como ao trabalho de Karl Salomo Zachariae Von Lingenthal, intitulado Wissenschaft der 
pretar e aplicar as leis, esquecendo-se do aperfeiçoamento de métodos para sua criação. Isso se explica pelo fato de que, ao processo de elaboração das leis, os juristas atribuíram um status puramente político, diferente do tratamento conferido às ações de interpretação e aplicação legislativa tidas como exclusivamente jurídicas. Nesse cenário, a legislação "jamais foi concebida como um ato de conhecimento que seria legitimado por sua qualidade ou pelos resultados que produz", ${ }^{5}$ pois a lei estaria estritamente calcada na observância de procedimentos democráticos previamente estabelecidos, entendidos como os únicos requisitos de legitimidade dos atos legislativos.

Nesse contexto, torna-se compreensível que alguns autores tenham hesitado inicialmente em se valer da expressão "ciência da legislação," preferindo o uso do termo "a arte de legislar" ou a "arte de fazer leis", para não se comprometerem com a atribuição de natureza verdadeiramente científica às investigações acerca do fenômeno legislativo. ${ }^{6}$

A crescente valorização da qualidade da ação normativa surge num contexto de inflação legislativa, em que os governos, "incapazes de atingir seus objetivos sociais, acabam por sofrer uma pressão maior no sentido de recorrer à regulação da atividade privada, para atingir os efeitos pretendidos". 7 Com a crise do Estado intervencionista, a lei perdeu seu caráter sistemático, revelado insuficiente para tratar de uma realidade altamente cambiante. É justamente nesse contexto que surgirá um movimento de racionalização inteiramente novo para o percurso de elaboração das leis.

Sobre esse movimento de racionalização da produção jurídica, surgida nas últimas décadas, é possível identificar posicionamentos céticos que, em essência, consideram que o fortalecimento dessa ciência reduz o direito a mero instrumento de outros ramos científicos, contribuindo assim, para o declínio da própria ciência jurídica.

Chevallier ${ }^{8}$ afirma que essa nova racionalidade transforma as regras de direito em técnicas operacionais de gestão, criadas a partir de rigorosos métodos de elaboração e revisão normativa que, em última instância, verificarão se as normas produzem ou estão aptas a produzir plena eficácia. Enfatiza este autor, no entanto, que:

[...] longe de caminhar no sentido da restauração da racionalidade jurídica tradicional, a racionalização dos processos de produção legislativa não faz mais do que confirmar e acentuar o seu declínio: não só porque demonstra que a norma jurídica se vê obrigada a conquistar uma legitimidade, que já não lhe é inerente, demonstrando o rigor dos seus métodos de elaboração, mas também, e sobretudo, porque essa racionalização é indissociável da nova concepção instrumental do direito, de que ela é a concretização.

Entre nós, Nunes Leal ${ }^{10}$ já observava, na década de 40, o descompasso entre ciência jurídica e o processo de elaboração das leis:

O legislador vai se tornando cada vez mais independente, não só dos chamados direitos naturais, mas também das próprias conquistas da ciência jurídica, que tem de apressar o passo para acompanhar a lei e rever, em função dela, as suas categorias e os seus sistemas. Esse quadro do mundo moderno é bastante desolador para os juristas, que cada dia mais se convencem de que o essencial são os propósitos do legislador, o seu desejo honesto de prover o bem comum, na medida em que a lei o pode fazer. Mas, mesmo quando tais intenções existam, podem ser frustradas, caso se exprimam por instrumentos imperfeitos e inadequados. Que os juristas aperfeiçoem os

Gesetzgebung.

5 MORAND, Charles-Albert. Les exigences de la méthode législative et du droit constitutionnel portant sur la formation de la législation. Droit et Societé, n. 10, 1988, p. 391.

6 Caupers menciona como exemplo o título da obra de Dominique Rémy, intitulada Légistique. L'art de faire dês lois, Paris, 1994 e também do uso da expressão 'gesetzgebund", sinônimo de "arte da legislação", pelo autor Herman Hill (Bermühungen zur Verbesserung der Gesetzgebung. Zeitschrift für Gesetzggebung, n. 1-96, 1993, p, 19 e segs). O autor também faz referência, à obra Introduzione alla legistica. L'arte di preparar lê leggi, de Rodolfo Pagano. 2.ed. Londres: Sweet and Maxwell, 1990. CAUPERS, João. Relatório sobre o programa, conteúdo e métodos de uma disciplina de Metódica da Legislação. Cadernos de Ciência de Legislação, Oieiras, Instituto Nacional de Administração, n. 35, out-dez. 2003, p. 9-12.

7 COURTNEY, Mark. Quadro de uma política para a melhoria da qualidade da ação normativa. Cadernos de Ciência de Legislação, Oieiras, n. 33/34, jan-jun. 2003, p. 107.

8 CHEVALLIER, Jacques. A racionalização da produção jurídica. Cadernos de Ciência de Legislação. jan-mar. 1992 , p. 9.

9 Idem, p. 9.

10 LEAL, Victor Nunes. Técnica Legislativa. In: LEAL, Victor Nunes. Problemas de direito público. Rio de Janeiro: Forense, 1960 , p. 32. 
instrumentos, ficando aos políticos a tarefa de melhorar as intenções. E também colaborem os juristas no ofício dos políticos, na medida de suas forças e inclinações.

Levando em consideração as forças dos grupos de pressão e as influências políticas que cercam o processo decisório inerente à produção legislativa, as quais não se enquadram nos processos racionais e científicos propostos pela ciência da legislação, as limitações dos estudos sobre produção legislativa parecem óbvias. O fortalecimento de uma ciência da legislação não se destina, por essa razão, a superar os contingentes irracionais da produção legislativa. Esta visa, tão somente, a encarar tal contingência com certa dignidade. ${ }^{11}$

Demais disso, a avaliação legislativa, que constitui instrumento fundamental da elaboração de conteúdos normativos, não tem sido defendida apenas por aqueles que acreditam na elaboração racional das leis. Outros motivos justificadores da importância da avaliação legislativa têm sido suscitados, tais como, o uso político estratégico que pode fazer dela minorias parlamentares, no sentido de reintroduzir periodicamente na ordem do dia políticas não consagradas pelo texto original da lei aprovada, ou bases parlamentares que pretendem acelerar a tomada de decisão política, contrabalançando a falta de consenso sobre o projeto com a promessa de avaliação. ${ }^{12}$ Além dessa função estratégica, menciona-se também a função legitimadora da avaliação legislativa: esta pode conduzir à “[...] obtenção de apoio público a um ato normativo, na medida em que oferece a oportunidade de se expressarem livremente objeções e críticas". ${ }^{13}$

Os pressupostos dos trabalhos sobre a legislação que ressurgiram a partir da década de 1970, distinguem-se dos trabalhos de hermenêutica e da teoria da decisão jurídica. Atienza ${ }^{14}$ observa que a principal diferença entre dogmática jurídica e técnica legislativa ${ }^{15}$ diz respeito ao fato de que a primeira encara as leis como um dado, um material pré-existente que deve ser utilizado para obter a otimização da interpretação e aplicação do direito, ao passo que a segunda toma igualmente como dado as normas jurídicas já existentes para, por meio das necessidades sociais, das exigências da linguagem jurídica e de várias outras condições, conseguir obter a otimização da produção de normas por parte do legislador e de certos órgãos administrativos. Essas exigências, tanto de ordem prática como teórica, obviamente buscam em outras áreas do conhecimento como, a linguística, a teoria da comunicação, a sociologia e a ciência da administração os pressupostos para a solução de seus problemas.

A esse respeito, torna-se importante frisar que alguns autores defenderam um redimensionamento da ciência jurídica, procurando inserir a complexidade do fenômeno legislativo no campo do direito ou da metodologia jurídica. ${ }^{16}$ posições, frise-se, são minoritárias, pois a "larga maioria dos mais distintos cultores da ciência jurídica jamais aceitaria tal extensão, que considerariam descaracterizadora da ciência jurídica e do método jurídico". ${ }^{17}$

Compreende-se, nesta ordem de idéias, que não seja fácil encontrar o lugar adequado para uma ciência da legislação: esta não se destina a possibilitar a compreensão da lei mas, sim, a compreensão das condições e técnicas adequadas à produção das leis, de boas leis, de leis eficazes. O seu objeto não é a lei enquanto norma, mas o fenômeno legislativo em toda a sua extensão.

11 “Os mestres e autores que se ocupam da matéria não se iludem quanto ao seu alcance. Na fase de preparação, na de decisão parlamentar, como na de aplicação, os interesses se afrontam e as consequências resultam do jogo de forças existentes. A aplicação do Método Legislativo não vai transformar semelhante contingência. A disciplina seria, antes, um ponto de referência, uma espécie de chamada às exigências da razão, um olhar crítico e vigilante do jogo das forças sociais.” PRATES, Terezinha M. L. Método legislativo, uma nova disciplina? Revista do Ministério Público do Trabalho, Brasília, n. 06, set. 1993, p. 37.

12 VOERMANS, Wim. Avaliação da legislação nos Países Baixos. Cadernos de Ciência de Legislação, Oieiras, Instituto Nacional de Administração, n. 33/34, jan-jun. 2003, p. 67-68.

13 Idem, p. 68.

14 ATIENZA, Manuel. Contribución a una teoría de la legislación. Madri: Civitas, 1997.

$15 \mathrm{O}$ autor atribui a natureza de técnica jurídica tanto à dogmática jurídica quanto à técnica legislativa, já que ambas incidem sobre momentos ou aspectos distintos da realidade jurídica.

16 Caupers observa que defendem a posição de enquadramento do fenômeno legislativo no campo da ciência jurídica Werner Maihoffer e Jean Carbonnier, e no campo da metodologia, Héctor Fix-Zamudio (Metodologia, docência e investigación jurídicas, 4. ed. Cidade do México: Editorial Porrúa, 1996). CAUPERS, João, op. cit., p. 7.

17 Idem, p. 7. 
Sem adentrar na referida discussão acerca do caráter autônomo da ciência da legislação, fato é que esta comporta hoje uma série de disciplinas com diferentes métodos e objetos de estudo. Dependendo da disciplina, os profissionais com formação estritamente jurídica têm relativa contribuição a oferecer ao estudo sobre a criação da legislação, revelando-se, muitas vezes, incapazes de operar com outras áreas do conhecimento que the são imprescindíveis como, a sociologia, a linguística e a teoria da comunicação.

As disciplinas ou ramos da ciência da legislação têm objetivos variados: ora possuem caráter mais abstrato e conceitual, destinando-se ao refinamento de teorias, ora se concentram no aperfeiçoamento de diferentes técnicas, visando à solução de problemas práticos. Além disso, as abordagens teórica e técnica podem incidir tanto sobre o conteúdo, quanto sobre a forma da legislação.

Mader, professor suíço e autor de trabalhos de contribuição significativa sobre avaliação legislativa, identifica oito áreas específicas que se destinam a explicar e instrumentalizar a ação de elaboração legislativa. São elas:

(i) Legistica Material on Metódica Legislativa: preocupa-se exclusivamente com o conteúdo da legislação. Propõe um metódico caminho de elaboração de conteúdos normativos e utiliza-se de ferramentas práticas ${ }^{18}$ facilitando os diferentes passos ou fases deste enfoque metódico.

(ii) Legística Formal: preocupa-se com aspectos formais da legislação, com diferentes tipos de atos normativos, com a sua estrutura formal etc.

(iii) Redação Legislativa: diz respeito a aspectos lingüísticos da legislação, a maneira de expressar conteúdos normativos por textos normativos;

(iv) Comunicação Legislativa: a publicação de textos normativos, ou mais genericamente, a maneira de comunicar conteúdos normativos, incluindo uma grande quantidade de informação sobre legislação, não apenas a publicação oficial;

(v) Processo Legislativo: o processo de elaborar, editar e implementar a legislação segue regras procedimentais de vários tipos; essas regras influenciam em certa medida a qualidade formal e material da legislação;

(vi) A Administração de Projetos Legislativos: a preparação da legislação pode ser vista como uma tarefa pela qual os princípios e técnicas de administração de projeto são aplicáveis;

(vii) Sociologia da Legislação: o processo político precedente à edição da legislação, a implementação do processo e os efeitos da legislação são importantes campos dos estudos sociológicos e constituem um elemento essencial dos estudos sobre a elaboração da legislação;

(viii) Teoria da Legislação: consideração sobre o papel ou função da legislação como um instrumento de controle social pelo Estado. ${ }^{19}$

Por sua vez, Morand, ${ }^{20}$ acompanhando a doutrina francesa, classifica toda a sorte de estudos sobre a formação da legislação em apenas dois segmentos ou disciplinas: a Legística Material e a Legística Formal. A Legística Material se ocupa do processo de produção legislativa em suas diferentes etapas, fornecendo a cada uma delas ferramentas que visam incrementar a eficácia das leis, ao passo que a Legística Formal analisa as leis enquanto sistemas de comunicação, fornecendo princípios destinados ao aprimoramento dos textos legislativos, os quais também serão aplicados a diferentes etapas de emissão da mensagem.

Independentemente da classificação adotada, os autores coincidem no entendimento de que profissionais com formação estritamente jurídica parecem ter melhor desenvoltura para aquelas disciplinas mais atentas a aspectos formais da feitura das leis. Nesse sentido, Mader observa que:

Para lidar com aspectos materiais ou substanciais do trabalho legislativo, advogados, ao menos advogados com formação jurídica tradicional, não parecem ser melhores preparados do que quem quer que seja. Entretanto, a predominância desses profissionais e a posição privilegiada que ocupam na fase de redação do processo legislativo tem lhes conferido particular responsabilidade pelos aspectos materiais da legislação (tradução nossa). ${ }^{21}$

18 Fornecidas pelo desenvolvimento de algumas das demais disciplinas acima descritas, como a sociologia da legislação.

19 MADER, Luzius. Evaluating the effects: a contribution to the quality of legislation. Statute Law Review. vol. 22, n. 2, 2001 , p. 119.

20 MORAND, Charles-Aubert. Éléments de légistique formelle et matérielle. In: MORAND,

Charles-Aubert (Org.). Légistique Formelle et Matérielle. Aix-En-Provence: Presses Universitaires D’Aix Marseille, 1999 , p. $18-45$.

21 MADER, Luzius. Evaluating the effects: a contribution to the quality of legislation. Statute Law Review, vol. 22, n. 2, 2001, 
Essa responsabilidade varia sensivelmente de país para país, dependendo do avanço da ciência da legislação em cada Estado. Países como França, Itália e Inglaterra privilegiam a técnica legislativa ou Legística Formal, ao passo que as já mencionadas Alemanha e Suíça constituem centros de produção em Legística Material.22

\section{LeGística MATERIAL OU METÓdICA DA LEGISLAÇÃo}

A disciplina Legística Material, on Metódica da Legislação $0^{23}$, corresponde a um ramo da Ciência da legislação que se propõe a desenvolver os preceitos metodológicos para cada uma das etapas do processo de elaboração do conteúdo das normas jurídicas, diferenciando-se da Legística Formal, que se ocupa da sistematização, da redação e da comunicação legislativa.

Questões como clareza e precisão da linguagem, articulação do discurso normativo, objetividade e inteligibilidade da lei não são objeto de estudo da Metódica da Legislação. Observa-se, no entanto, que, embora as regras e princípios balizadores dessa disciplina distanciam-se da Legística Formal; ambas constituem disciplinas ecléticas que se utilizam de conhecimentos e técnicas desenvolvidos por outras ciências. Ver-se-á, no entanto, que apenas na Metódica da Legislação a sociologia ocupa papel central. ${ }^{24}$

\section{1 etapas do percurso legislativo}

A Metódica da Legislação é formada por regras da experiência aplicadas ao nascimento da legislação. É constituída, na verdade, por meta-normas - normas sobre a produção de normas. As principais regras que compõem o percurso de produção das leis, também denominado iter legislativo, incluem: ${ }^{25}$

i) identificação e definição de um problema cuja solução é atribuída à ação legislativa;

ii) determinação dos objetivos da legislação;

iii) definição dos meios potencialmente aptos a gerar os efeitos pretendidos pela legislação e das alternativas diversas para a solução do problema;

iv) avaliação legislativa prospectiva ou ex ante, consistente na averiguação da capacidade de os possíveis efeitos a serem produzidos pela legislação serem aptos a realizar os fins declarados ou implícitos da legislação.

p. 120.

22 O fato de haver uma predominância de produção científica em uma determinada área não quer dizer que não haja iniciativas válidas para o desenvolvimento da outra. Ver-se-á que, mesmo países com pouca tradição em Metódica da Legislação têm introduzido experiências de institucionalização da avaliação legislativa, ainda que a produção acadêmica nessa seara não tenha se desenvolvido na mesma intensidade.

23 A expressão Metódica da Legislação é traduzida nas línguas inglesa, francesa e portuguesa, respectivamente, por legislative method, méthode législative e metódica da legislação. O termo, que hoje é sinônimo da expressão Legística Material, traduz-se mais adequadamente pela expressão metodologia a adotar para a elaboração da lei. Neste trabalho, optou-se por utilizar indistintamente as expressões Metódica da Legislação e Legística Material. Morand observa que “[...] o termo Metódica da Legislação fora, entretanto, mal escolhido, porque transmitia a impressão de que a disciplina não oferecia nada além de prescrições, receitas para melhora a qualidade da legislação. $\mathrm{O}$ termo não valoriza devidamente os aspectos cognitivos da disciplina." MORAND, Charles-Aubert. Éléments de légistique formelle et matérielle. In: MORAND,

Charles-Aubert (Org.). Légistique formelle et matérielle. Aix-En-Provence: Presses Universitaires D’Aix Marseille, 1999 , p. 18. Dessa forma, o autor considera apropriado o uso da expressão Metódica da Legislação apenas quando se estiver referindo aos métodos propriamente ditos da legística. Em Portugal, no entanto, o termo Metódica da Legislação, assim traduzido por Joaquim Gomes Canotilho, permanece sendo o mais adotado.

24 Sem prejuízo de outras ciências oferecerem contribuições de destaque, como a economia, para a análise da eficiência, e a psicologia, para o estudo dos comportamentos etc.

25 A relação das principais etapas do iter legislativo foi extraída da leitura das seguintes obras: ATIENZA, Manuel, op. cit., p. 64-71; MADER, Luzius. Evaluating the effects: a contribution to the quality of legislation. Statute Law Review, vol. 22, n. 2, 2001, p. 120121. MORAND, Charles-Albert. Les exigences de la méthode législative et du droit constitutionnel portant sur la formation de la législation. Droit et Societé, n. 10, 1988, p. 393; MORAND, Charles-Aubert. Éléments de légistique formelle et matérielle. In: MORAND, Charles-Aubert (Org.). Légistique formelle et matérielle. Aix-En-Provence: Presses Universitaires D’Aix Marseille, 1999, p. 17-45. 
v) escolha do meio ou solução legislativa que será submetida à votação;

vi) implementação da lei;

vii) avaliação legislativa retrospectiva ou ex post, consistente no exame dos reais efeitos produzidos pela legislação e na sua comparação com os objetivos declarados ou implícitos da legislação;

viii) adaptação, se necessária, da legislação com base na avaliação legislativa.

Para cada uma das etapas acima indicadas, regras deverão ser observadas para que se possa atingir o resultado almejado, que é o de produzir uma legislação de melhor qualidade, viável, do ponto de vista operacional, e equilibrada, no tocante aos interesses de seus destinatários.

A primeira etapa consiste na identificação e na definição de um problema que se pretende solucionar com a edição de um ato normativo. Há que se distinguir, nesse particular, o impulso legislativo da competência legislativa. Embora ambos se destinem a definir o problema que receberá tratamento legislativo, o primeiro se distingue do segundo por se originar da própria sociedade, por ser provocado por pessoas, por entidades ou por grupos diversos, que exercem o direito de petição ou pressionam o órgão competente para a tomada da decisão legislativa. Já o órgão com competência legislativa é aquele que exerce a iniciativa legislativa por meio de uma determinação constitucional, podendo ou não agir em consonância com o impulso legislativo referido.

A segunda etapa do percurso legislativo consiste na determinação dos objetivos da legislação, em que o legislador ou editor de atos normativos deverá identificar com precisão o que pretende alcançar com a medida proposta. Essa ação do percurso legislativo condicionará as estratégias a serem adotadas em todas as etapas seguintes. Para se identificarem os meios aptos a solucionar os problemas inseridos na pauta legislativa, torna-se necessário ter clareza de seus fins. A indefinição ou imprecisão nas definições dos objetivos da legislação enseja, portanto, um rompimento na racionalidade de todo o processo de elaboração normativa.

Nessa etapa será ainda necessário averiguar também a possibilidade, a necessidade e a oportunidade de um ato normativo. Por possibilidade entende-se a viabilidade de uma lei para solucionar problemas. A esse respeito, verifica-se que há fatores de ordem natural, econômica e jurídica que inviabilizam uma lei de solucionar certos problemas. Nesses casos, é possível identificar de antemão a incapacidade de uma lei de atingir os objetivos almejados pelo legislador. Em outras situações, a lei poderá até ser possível, porém não será necessária, em face de alternativas que permitam o alcance dos objetivos pretendidos sem a necessidade de intervenção do legislador. Por fim, uma lei poderá ser possível, necessária, porém o momento de legislar poderá não ser oportuno. "A inoportunidade decorrerá de dificuldades conjunturais insuperáveis em articular e compatibilizar os objetivos da lei com os objetivos de outras intervenções legislativas ou políticas". ${ }^{26}$

A terceira etapa consiste na determinação do conteúdo material da lei. O legislador se vê, ness e momento, empenhado em eleger os instrumentos técnicos que considera mais adequados para a realização dos objetivos por ele estabelecidos e deve se perguntar, portanto, se é preferível impor uma conduta por meio de prescrições, ou instituir estímulos que a favoreçam. O formulador da legislação deverá também se perguntar se deve proibir uma conduta de um particular, ou instituir intervenções administrativas que regulem sua atividade. Deverá também avaliar se um serviço deve ser desempenhado por entidade pública, ou se ele e poderá ser desempenhado por uma entidade privada, por meio de um contrato administrativo ou de um instrumento congênere. O legislador deve ater-se também ao problema da densidade da lei. A lei será mais densa quando se optar pela normatização de comportamentos de forma clara e precisa, em situações em que se prima por absoluta segurança jurídica, como no caso do direito penal. Em outras situações, a lei será mais fluida, de modo a preservar a "flexibilidade das relações jurídico-privadas ou variabilidade dos interesses públicos que à administração pública cumpre prosseguir". ${ }^{27}$

Nessas situações, que são meramente exemplificativas, o legislador deverá conscientizar-se acerca das vantagens e desvantagens de cada um dos instrumentos que detém a seu dispor. Obviamente, essa avaliação dos prós e contras de cada instrumento não pode vir desacompanhada de uma consideração acerca de sua inserção no orde-

26 CAUPERS, João, op. cit., p. 34

27 Idem, p. 39. 
namento jurídico. Essa é uma das razões, inclusive, pelas quais ensinamentos de Metódica sugerem que o legislador deva formular várias alternativas possíveis para a solução de um problema, de modo que, no momento da decisão legislativa, seja possível sopesar as vantagens e as desvantagens de cada uma. Pode ser que uma solução jurídica tenha grandes méritos do ponto de vista operacional, porém não guarde nenhuma harmonia com o ordenamento jurídico vigente, o que poderá trazer mais prejuízos do que benefícios para a adoção dessa opção legislativa.

A quarta etapa de Metódica da Legislação corresponde à avaliação legislativa prospectiva ou ex ante, que consiste em prever as consequências da lei, antes de sua entrada em vigor, com o auxílio da melhor informação possível sobre os problemas que se pretende solucionar com a intervenção normativa. ${ }^{28}$

Historicamente, essa foi a primeira modalidade de avaliação legislativa utilizada na Alemanha, ${ }^{29}$ assumindo hoje grande importância para a tomada de decisão legislativa em diversos países.

Duas análises apontadas por Caupers ${ }^{30}$ são essencialmente importantes para avaliação legislativa ex ante ou prospectiva. A primeira delas é a verificação das condições adequadas para que a lei produza seus efeitos. A lei pode ser condição necessária, porém, não suficiente, para que os objetivos estabelecidos pelo legislador sejam atingidos. Nesse sentido, Caupers aponta três fatores que podem contribuir ou inviabilizar a produção de efeitos de uma lei: (i) recursos financeiros; (ii) infraestrutura técnica; (iii) capacitação e treinamento dos funcionários que velarão pelo cumprimento das normas legais.

A segunda questão a ser enfrentada na avaliação legislativa ex ante diz respeito à antecipação das reações dos destinatários da lei. O legislador, ao instituir uma medida interventiva, terá de se perguntar se o destinatário não encontrará meios de dissuadir do cumprimento da norma. É comum, por exemplo, o aumento de alíquotas tributárias provocar o efeito inverso do esperado: ao invés de o aumento da alíquota contribuir para uma maior arrecadação financeira, aquela pode estimular a sonegação, em razão da baixa probabilidade de se fiscalizar e sancionar o sonegador.

Uma vez concluída a avaliação legislativa prospectiva, introduzem-se no projeto de lei as alterações que porventura ela tenha recomendado, de modo a se estabelecer um texto final que deverá ser submetido à aprovação dos órgãos detentores da competência legislativa, o que corresponde à quinta etapa do percurso de elaboração das leis.

A sexta etapa diz respeito ao que se denomina implementação ou enforcement da lei. Por implementação da lei entende-se um conjunto de ações destinadas a motivar os destinatários da lei a obedecer-lhe. Caupers observa que é muito comum uma lei nova necessitar de implementação por parte de uma entidade pública já existente ou instituída pela própria lei. Em outras situações, a nova lei exigirá, como condição de implementação, agentes com preparação técnica específica. Por fim, dentro do escopo da implementação da lei, encontram-se também as ações de marketing, visando a persuadir os destinatários da norma de sua importância e vantagens em observá-la. ${ }^{31}$

Concluídas as etapas acima descritas, é preciso que haja um controle da qualidade da lei que já se encontra em vigor, em que se procurará identificar: (i) se a norma produziu os efeitos pretendidos pelo legislador; (ii) se os objetivos previstos para a legislação foram atingidos total ou parcialmente; (iii) se foram produzidos outros efeitos, não previstos e nem pretendidos; e (iii) as causas determinantes da produção dos efeitos não esperados. Tal controle recebe a denominação de avaliação legislativa retrospectiva ou expost.

Para que a avaliação legislativa retrospectiva possa identificar as respostas para as questões acima mencionadas, Caupers ressalta a necessidade de que sejam realizadas análises comparativas: (i) entre o que deveria ter acontecido - para que os objetivos fixados tivessem sido atingidos - e o que realmente aconteceu; e (ii) entre a situação anterior à data da entrada em vigor da norma e a situação atual. ${ }^{32}$

28 Idem, ibidem, p. 41.

29 KARPEN, Ulrich. Avaliação legislativa - a experiência alemã. Cadernos de Ciência de Legislação, Oieiras, Instituto Nacional de Administração, n. 33/34, jan-jun. 2003, p. 11

30 CAUPERS, João, op. cit., p. 42-46.

31 Idem, p. 48-49.

32 CAUPERS, João, op. cit., p. 48. 
Note-se que a avaliação legislativa pode se restringir em identificar se os efeitos da legislação foram ou não atingidos, o que demandará uma análise de sua eficácia e efetividade, bem como poderá mapear todas as consequências decorrentes da aplicação de um determinado instrumento normativo, o que implicará em uma avaliação de seu impacto.

Descritas todas as etapas do processo de elaboração legislativa, observa-se que a avaliação legislativa faz parte e depende de toda essa engrenagem construída pela Metódica da Legislação. Para que a avaliação legislativa cumpra seus objetivos, consistentes em analisar os efeitos e os impactos produzidos pela legislação, é preciso que sejam conhecidos os objetivos de uma lei, os problemas que ela pretende solucionar, e os meios escolhidos para que tais finalidades sejam alcançadas.

\subsection{Racionalidade da metódica da legislação}

Cada uma das etapas acima descritas comporta uma série de regras e de princípios cuja racionalidade se distancia daquela aplicável às regras e aos princípios de uma teoria do direito tradicional. Segundo essa teoria, a racionalidade do direito seria pressuposta, ou seja, a lei é considerada racional desde que decorra de um modelo lógico-pressuposto. Para a Metódica da Legislação, no entanto, não basta que a lei tenha sido elaborada mediante regras de processo legislativo e que se coadune com os princípios e regras do ordenamento jurídico. A lei, para ser considerada legítima, tem de servir, de fato, aos propósitos para os quais foi elaborada.

As regras de Metódica da Legislação, dessa forma, assumem uma função eminentemente instrumental. Toda elaboração ou adequação de conteúdo a ser aplicada em qualquer uma das etapas do iter legislativo acima descrito deve, tão-somente, garantir que a legislação que se pretenda elaborar ou revisar constitua meio adequado para a realização de certas finalidades.

Nesse sentido, a avaliação legislativa retrospectiva constitui a "trave mestra do movimento de racionalização"33 do fenômeno legislativo, a peça principal do modelo analítico oferecido pela Legística Material, já que ela é indispensável para se averiguar se uma lei produz, de fato, seus efeitos, e se, portanto, pode ser considerada legítima.

Não cabe, dentro do escopo dessa disciplina, avaliar se os fins declarados ou implícitos de uma determinada legislação são bons ou ruins. Exemplo emblemático é o da lei que tenha sido editada apenas para uso simbólico, ou seja, que possua finalidade (implícita) de que seus destinatários não cumpram a conduta prescrita. ${ }^{34}$ Sob a perspectiva estritamente instrumental, o uso simbólico da lei não é per se irracional. Irracional, sob essa ótica, seria o cumprimento pelos destinatários de uma norma que tenha sido editada com a finalidade - reitera-se, implícita -, de que a norma não seja cumprida, e que, portanto, não exerça nenhum tipo de controle ou transformação social.

$\mathrm{Na}$ tentativa de desmistificar as vozes que procuram desqualificar a racionalidade instrumental das etapas de elaboração das leis, que denunciam um caráter perverso das técnicas legislativas, Atienza ${ }^{35}$ oferece uma visão abrangente da teoria da legislação, em que o processo de elaboração legislativa seria, em última instância, testado em um nível de racionalidade material - e não mais instrumental - a lhes garantir fundamento ético.

Sendo assim, após definidos os problemas e os meios aptos a solucioná-los por meio da edição de uma determinada lei, há que se perguntar se tal instrumento normativo, cuja necessidade se reconhece, é justo, "procedendo a uma composição equilibrada dos interesses em jogo". ${ }^{36}$

33 CHEVALLIER, Jacques, op. cit. p. 18.

34 Um exemplo de lei cujos efeitos almejados pelo legislador são inteiramente simbólicos é a norma constitucional sobre o salário mínimo, cujo valor teria de atender às necessidades sociais vitais do trabalhador e de sua família com moradia, educação, saúde, lazer, vestuário, higiene, transporte e previdência social (Art. $7^{\circ}$, IV da CF). Esse comando normativo tem um significado simbólico importante, que é o de garantir o salário mínimo pela Constituição Federal.

35 ATIENZA, Manuel, op. cit. p. 39-40.

36 Idem, p. 40. Canotilho também incluiu no âmbito da metódica da legislação a análise da justiça da decisão legislativa antes que esta seja concluída. CANOTILHO, Joaquim Gomes. Os impulsos modernos para uma teoria da legislação. Cadernos de Ciência 
O autor observa, no entanto, que esse nível de racionalidade da teoria da legislação cumpre uma função mais negativa do que construtiva, na medida em que a racionalidade ética, diferentemente das demais racionalidades, não se vale de nenhuma técnica legislativa específica, como se observa do texto transcrito, in verbis:

A racionalidade ética - à diferença de outros níveis de racionalidade - não gera nenhuma técnica legislativa específica: não há nenhum procedimento para atingir, com o apoio das leis, a liberdade, a igualdade e a justiça fora das técnicas de caráter eminentemente instrumental. $\mathrm{O}$ único instrumento de que dispõe a ética é um discurso moral, mas justamente se trata de um instrumento que se desnaturaliza se for utilizado para obter finalidades (fins perlocucionários) que vão além do próprio discurso (tradução nossa). ${ }^{37}$

Dessa forma, ao contrário do observado em cada etapa do processo de elaboração legislativa acima referido, que desenvolveu metodologia própria consistente num conjunto de técnicas a serem oportunamente descritas neste trabalho, ${ }^{38}$ não há técnica ou caminho a ser percorrido para que os fins preconizados pela legislação justifiquem-se eticamente. Caberá ao legislador, portanto, apenas verificar se os fins que atribuiu à legislação não são imorais ou ilegítimos em face de determinada teoria ética.

\section{Avaliação legislativa retrospectiva}

Embora a avaliação legislativa, conforme já observado, esteja intimamente relacionada com as outras etapas do processo metódico de elaboração das leis, este tem recebido, nas últimas duas décadas, status de uma disciplina autônoma.

Serão apresentadas, a seguir, as principais questões concernentes a essa disciplina.

\subsection{Tipos de avaliação legislativa}

A avaliação legislativa, conforme já antecipado, pode ser empreendida para identificar tanto os efeitos quanto os impactos decorrentes da aplicação de uma legislação.

Por efeitos, entendem-se aqui somente as consequências pretendidas pelo legislador, ao passo que os impactos representam todas as consequências decorrentes da aplicação de uma legislação, ainda que não previstas ou pretendidas por quem a formulou. No tocante aos efeitos da legislação, este pode ser avaliado sobre três critérios específicos: a efetividade, a eficácia e a eficiência.

A eficácia constitui a observância dos destinatários de uma determinada norma ao comportamento esperado pelo legislador. Mader ${ }^{39}$ salienta que, no exame da eficácia de uma norma, duas questões necessitam ser respondidas: 1) se, do ponto de vista externo, os destinatários se comportam de acordo com o esperado pelo legislador; e 2) se o comportamento dos destinatários pode, de fato, ser atribuído à norma avaliada.

Observa-se que a eficácia não equivale necessariamente à obediência do destinatário da lei ao enunciado da norma. "A obediência é um critério importante para o reconhecimento da eficácia, mas esta não se reduz à obediência." ${ }^{40}$ Nas normas de efeitos simbólicos, é comum não se esperar a obediência do destinatário à norma. A conduta esperada pelo legislador, nesses casos, é a da não obediência ao conteúdo normativo. Levando-se em conta a função instrumental acima assinalada, a não obediência a uma norma de objetivos meramente simbólicos é considerada, dessarte, eficaz.

\footnotetext{
de Legislação, Oieiras, n. 1, abr-jun. 1991, p. 7-14.

37 ATIENZA, Manuel, op. cit., p. 39-40.

38 As principais técnicas aplicáveis em momentos outros que não o da etapa da avaliação legislativa prospectiva ou ex post serão (sucintamente) descritas apenas quando forem úteis para ampliar a compreensão desta.

39 MADER, Luzius. Evaluating the effects: a contribution to the quality of legislation. Statute Law Review, vol. 22, n. 2, 2001 , p. 124.

40 FERRAZ Jr. Tércio Sampaio. Introdução ao estudo do direito: técnica, decisão, dominação. 2.ed. São Paulo: Atlas, 1994, p. 198.
} 
Já a efetividade ou eficácia social diz respeito à aptidão de uma determinada lei para atingir as finalidades que prescreve. Trata-se de um problema pré-jurídico ${ }^{41}$ já que depende da capacidade do legislador, que deverá formular proposições aptas a atingir os objetivos pretendidos. Como consequência prática dessa afirmação, observa-se que, se os objetivos de uma lei não estiverem claramente definidos, torna-se impossível avaliar a efetividade de uma legislação. Tais objetivos, no entanto, não precisam estar necessariamente previstos na própria norma, podendo ser identificados no prêambulo de uma lei, na exposição de motivos do projeto legislativo ou até mesmo nos debates parlamentares antecedentes à sua votação.

Observa-se que a eficácia não corresponde necessariamente a uma garantia da efetividade. A eficácia, segundo Mader, ${ }^{42}$ apenas garantirá a realização da efetividade se a observância à norma realmente conduzir à realização dos objetivos estabelecidos pelo legislador. Observa-se, no entanto, que embora a eficácia não corresponda necessariamente a uma garantia da efetividade, aquela representa um fator condicionante desta, uma vez que a realização dos objetivos de uma norma pode decorrer de outros fatores que não a obediência à legislação, situação esta em que uma lei jamais poderá ser considerada eficaz.

Para ilustrar as dimensões da eficácia e da efetividade, menciona-se o exemplo de uma lei que obrigue todos os motoristas a utilizarem cinto de segurança com o objetivo de reduzir o número de acidentes de trânsito. Se puder se afirmar, com certo grau de confiabilidade, que a maioria dos motoristas usa o cinto de segurança porque há uma norma que os obriga a tal conduta, essa norma será considerada efetiva. Por sua vez, se houver evidências comprovando que o uso de cinto de segurança reduz o número de acidentes de trânsito, então a mesma norma poderá ser considerada efetiva. Observa-se que, nesse exemplo, caso houvesse uma redução no número de acidentes de trânsito não atribuída ao uso do cinto de segurança, a lei em exame não seria eficaz, tampouco efetiva.

Outro exemplo fornecido por Caupers ${ }^{43}$ diz respeito a uma lei que tenha estipulado o uso obrigatório do capacete para motoristas e passageiros que trafegam em rodovias, visando reduzir o número de mortes por traumatismo craniano nos acidentes por choque de veículos. Se a lei conseguir generalizar o uso dos capacetes entre condutores, ela será considerada eficaz. Se, no entanto, as estatísticas comprovarem que, não obstante os motoristas tenham passado a utilizar o capacete, o número de fatalidades causadas por traumatismo craniano não diminuiu, essa lei será então inefetiva.

Costuma-se também definir como critério de avaliação dos efeitos da legislação a eficiência. A eficiência constitui a relação entre os "custos" e os "benefícios" de uma legislação. Segundo Mader, todos os efeitos produzidos pela legislação que forem compatíveis com seus respectivos objetivos podem ser considerados benefícios. A avaliação da ciência da legislação leva em conta, portanto, todos os custos ${ }^{44}$ empreendidos para que a legislação atinja seus objetivos. O autor ainda observa que a avaliação dos custos e benefícios de uma legislação pode ser empreendida sob uma ótica interna, na qual se avalia os sacrifícios a que será submetido o legislador ou o poder público para editar determinada norma, mas também é possível levar em consideração sua dimensão externa, com foco nas inconveniências a serem suportadas pelos destinatários das leis. ${ }^{45}$

Observa-se, ainda, que a eficiência não incide apenas sobre o conteúdo da legislação, não sendo, portanto, um critério exclusivo da avaliação legislativa. A esse respeito, Atienza esclarece que:

[...] mesmo no nível de racionalidade linguística, pode haver situações em que o empenho pela clareza e precisão no texto normativo deve ser feito até determinado ponto, ou seja, não deve ser empreendido quando o 'benefício' que se supõe com um incremento da precisão linguística não compensa o 'custo' no que diz respeito à extensão da lei, ao tempo empregado em sua redação etc. ${ }^{46}$

41 CAUPERS, João, op. cit., p. 56.

42 MADER, Luzius. Evaluating the effects: a contribution to the quality of legislation. Statute Law Review, vol. 22, n. 2, 2001, p. 125.

43 CAUPERS, João, op. cit., p. 54-55.

44 Os custos assumem aqui uma dimensão abrangente, que não só abrange fatores materiais, mas também inconveniências de caráter emocional ou psicológico.

45 MADER, Luzius. Evaluating the effects: a contribution to the quality of legislation. Statute Law Review, vol. 22, n. 2, 2001 , p. 125.

46 ATIENZA, Manuel, op. cit., p. 93. 
A tipologia dos efeitos da legislação os distingue em diferentes categorias, classificando-os como declarados e não declarados, expressos e implícitos, desejados e não desejados, previstos e não previstos, benéficos e prejudiciais, diretos e indiretos, imediatos e atrasados etc.

Veja-se um exemplo fornecido por Atienza. Uma lei, ao regular a estrutura administrativa de uma Universidade, dispõe que o Conselho de Administração dela seja composto por um elevado número de membros. Não sendo possível cumprir o quorum para as reuniões, os conselheiros passam a deliberar em caráter extraordinário, em instâncias com poucos participantes, de forma antidemocrática. Nesse caso, verifica-se que os efeitos não declarados e não desejados pelo legislador ocasionaram consequências prejudiciais à coletividade. ${ }^{47}$

Quando a avaliação legislativa estiver centrada na reconstituição de todos os efeitos produzidos por uma lei, inclusive aqueles não previstos pelo legislador, estar-se-á diante de uma avaliação de impactos da lei. A avaliação legislativa de impacto leva em conta, portanto, outros fenômenos não previstos que podem ter sido impulsionados pela legislação. Numa avaliação de impacto, não basta ao avaliador mediar os graus de eficácia, de efetividade e de eficiência de uma lei. No exemplo dado acima, suponha-se que a lei que instituiu a obrigatoriedade do uso do cinto de segurança tenha, inesperadamente, estimulado motoristas e pedestres a circularem em maior velocidade e que, por consequência, tenha ocorrido um aumento de atropelamentos de ciclistas e pedestres. Esse efeito, por ser destoante das expectativas do legislador, recebe a nomenclatura de impacto. ${ }^{48}$

Observa-se, ademais, que nem sempre os impactos serão prejudiciais aos destinatários de uma lei. É possível que uma legislação produza outros efeitos que, embora não esperados pelo legislador, possam ser benéficos para a sociedade. Este é o caso, por exemplo, de um programa de renda mínima instituído por lei, que tenha por efeitos, além da diminuição da pobreza e desigualdade social, o fortalecimento das relações econômicas numa determinada região.

É preciso, na avaliação dos impactos de uma legislação, assim como na avaliação dos efeitos, identificar se as consequências atribuídas à lei decorrem realmente de sua aplicação. Obviamente, tal análise se situará no domínio da probabilidade ou da plausibilidade, e não da certeza inerente às ciências exatas, de modo que sempre haverá um risco de que os comportamentos atribuídos à lei não tenham sido provocados por ela. ${ }^{49}$

Ambas as modalidades de avaliação legislativa - a dos efeitos e a dos impactos - comportam uma avaliação mais restrita e outra mais abrangente. Numa acepção mais restrita, a avaliação pode se restringir a descrever e mensurar os efeitos e os impactos de uma legislação. Numa concepção mais alargada, como será visto a seguir, caberá ao avaliador explicar os efeitos e os impactos da legislação, reconstruindo os motivos pelos quais eles foram provocados.

\subsection{Avaliação legislativa e alcance dos seus resultados}

Analisar as causas dos comportamentos dos destinatários das normas é das tarefas mais complexas, podendo-se afirmar que, por estar se tratando de fenômenos sociais, não se pode chegar a conclusões absolutas e inequívocas, e sim apenas a probabilidades acerca do nexo de causalidade existente entre os objetivos declarados no enunciado normativo e os efeitos produzidos pela legislação.

Além disso, independentemente da escassez de tempo e de recursos, a avaliação revela-se incompleta muitas vezes porque alguns dados que lhe seriam essenciais não estão disponíveis, por não se encontrarem os métodos analíticos necessários à sua obtenção plenamente desenvolvidos.

47 ATIENZA, Manuel, op. cit., p. 46-47.

48 Na Suíça, país em que o nível de institucionalização da avaliação legislativa encontra-se avançado, os projetos de lei devem ser acompanhados de uma apresentação dos objetivos da lei, que enunciem não só os efeitos desejados, mas também outros efeitos que porventura possam ser provocados pela aplicação da legislação. Cf. MADER, Luzius, Avaliação dos efeitos da legislação - a situação da Suíça. Cadernos de Ciência de Legislação, Oieiras, Instituto Nacional de Administração, n. 33/34, jan-jun. 2003 , p. 143.

49 CAUPERS, João, op. cit., p. 53-54. 
Mader é enfático ao afirmar que isso não diminui a importância ou mesmo a necessidade da avaliação. O objetivo da avaliação legislativa, nesse contexto, seria o de assegurar:

(1) que as relações causais subjacentes à ação legislativa tornem-se mais evidentes e diferenciadas quanto for possível quando novas iniciativas legislativas forem preparadas;

(2) que elas se fundamentem na melhor base teórica possível e na informação mais confiável que esteja disponível;

(3) que sua consistência seja examinada depois que a legislação entre em vigor. ${ }^{50}$

Observa-se, da exposição dos elementos acima, que a avaliação legislativa não necessariamente oferecerá medidas rigorosas de eficácia e de eficiência, mas procurará evidenciar, da maneira mais consistente e confiável possível, as relações causais subjacentes à ação legislativa, que representam, em essência, as finalidades que podem intervir na elaboração e na aplicação de uma determinada lei, bem como de fenômenos que, previstos ou imprevistos pelo legislador, poderão ter sido impulsionados por uma determinada legislação.

Independentemente do alcance dos resultados da avaliação legislativa, observa-se que as avaliações podem ser tanto de tipo descritivo quanto explicativo. As avaliações de cunho descritivo voltam-se exclusivamente para a explicação das relações causais entre efeitos da lei e intenções do legislador. As avaliações de cunho explicativo, por sua vez, têm abrangência mais ampla, pois não só descrevem tais relações causais, mas também oferecem explicações para os fenômenos observados. Conforme observado no item anterior, a avaliação de cunho explicativo assume suma importância quando o nexo de causalidade entre efeitos produzidos pela lei e as intenções do legislador revelar-se inesperado.

É comum, no entanto, observar que os resultados provenientes da utilização da avaliaşão legislativa raramente serão conclusivos no sentido de se corrigir ou revisar a legislação. Isso não elimina, no entanto, a importância da avaliação legislativa. Sua maior contribuição, talvez, não esteja centrada na correção das leis existentes, mas na solução dos problemas relacionados com a real prática de sua aplicação.

\subsection{Experiências de institucionalização da avaliação legislativa}

Diversos países têm se empenhado em prever a adoção da avaliação legislativa como atividade essencial do processo de elaboração das leis.

A institucionalização da avaliação legislativa pode se dar de diferentes formas. Em raras situações, a avaliação legislativa está prevista na Constituição ou em outras leis como uma obrigação imputada ao legislador para que a observe no exercício de sua função legislativa. ${ }^{51} \mathrm{Com}$ muito mais frequência, a competência para uso da avaliação legislativa é apenas prevista nos regimentos internos das casas parlamentares, que especificam as situações nas quais ela deva ser utilizada. Por vezes, o poder executivo também está obrigado, por lei ou por estatuto regulamentar, a empreender a avaliação legislativa quando formula leis de sua iniciativa, quando regulamenta matérias sob a forma de decreto e especialmente quando aplica a lei. De forma mais rara, por sua vez, a avaliação legislativa recebe tratamento jurisprudencial, quando o tribunal competente pelo exercício do controle de constitucionalidade, conforme será mais bem detalhado no item seguinte, afere a legitimidade de uma lei pela observância dos princípios de Metódica Legislativa.

50 MADER, Luzius. Evaluating the effects: a contribution to the quality of legislation. Statute Law Review, vol. 22, n. 2, 2001, p. $122-123$.

51 A Suíça atingiu tal nível de institucionalização. "O artigo 170 da Constituição Federal suíça salienta a responsabilidade do Parlamento na investigação da eficácia das medidas adotadas pela Confederação e, conseqüentemente, a responsabilidade do legislador pelas conseqüências de sua atividade" MADER, Luzius. Avaliação dos efeitos da legislação - a situação da Suíça. Cadernos de Ciência de Legislação, Oieiras, Instituto Nacional de Administração, n. 33/34, jan-jun. 2003, p. 142. Em nível infraconstitucional, uma Lei Federal de 1984 institucionalizou a avaliação prospectiva na Suíça, obrigando o legislador a especificar em seus projetos de lei os seus efeitos em termos financeiros e de recursos humanos, as implicações em termos de custos para os cantões e as autoridades locais etc. Uma alteração sofrida nessa mesma lei em 1999 obrigou ademais, o legislador a demonstrar "de que forma o processo legislativo preliminar avaliou o modo mais fácil de aplicar a proposta de lei e de que forma a experiência adquirida com a aplicação da lei será registrada e avaliada." Idem, p. 143. 
Quanto às modalidades de avaliação legislativa, observa-se que nem sempre os métodos aplicáveis prospectiva, concomitante e retrospectivamente à aprovação das leis são utilizados da mesma forma. Os Estados podem se valer de apenas uma dessas modalidades, ou podem recorrer a todas em diferentes graus de intensidade.

Nos casos em que a avaliação legislativa ex post se faz prevalecer, ela poderá ou não incidir sobre a legislação experimental, em que a lei é submetida a uma experiência de aplicação numa situação real, por um determinado período de tempo, até que seja submetida a novo processo avaliativo. ${ }^{52}$

Além disso, as avaliações podem tanto destacar a eficiência dos atos normativos como critério principal de análise, quanto podem se centralizar na análise dos impactos de natureza não econômica produzidos pelas leis. Nesse particular, observa-se uma tendência em obrigar que o legislador leve em consideração, na formulação das leis, "[...] não apenas seus objetivos estritamente considerados, mas também a globalidade dos efeitos produzidos, nomeadamente a nível econômico, social e ambiental". ${ }^{3}$

As técnicas utilizadas para cada modalidade de avaliação legislativa também se alteram. Enquanto alguns Estados fazem uso de avaliações sistemáticas, com grande potencial para o aprimoramento da qualidade legislativa, outros ainda esforçam-se por implementar instrumentos de avaliação de menor custo e complexidade. A esse respeito, observa-se que as avaliaçoes legislativas empreendidas em legislação experimental assumem destaque na melhoria da qualidade das leis.

As avaliações legislativas podem tanto ser promovidas por órgãos que estão fora do círculo dos diretamente envolvidos na elaboração das leis ou atos regulamentares, ${ }^{54}$ quanto podem ser empreendidas diretamente pelos membros dos poderes legislativo e executivo. ${ }^{55} \mathrm{~A}$ esse respeito, Mader observa que, embora os órgãos não estatais demonstrem maior capacidade para a realização de estudos de avaliação legislativa, a experiência de institucionalização suíça revela que os resultados desses trabalhos são mais bem integrados no processo de tomada de decisão política quando a avaliação é realizada por órgãos da própria Administração. ${ }^{56}$

Em outras situações, observa-se o alargamento das competências de órgãos estatais que tradicionalmente se concentravam na avaliação da legalidade e da legitimidade dos programas de governo, e que agregaram às suas tarefas ordinárias a análise da eficácia e da eficiência das ações governamentais.

Além disso, as avaliações legislativas podem ser aplicadas somente sobre atos normativos primários - as leis - ou também podem ser estendidas aos atos normativos secundários - os decretos, regulamentos e congêneres. ${ }^{57}$ Em ambas as situações, a avaliação pode se dar de modo total ou parcial quando, respectivamente,

52 Um exemplo recorrentemente mencionado é o da legislação experimental suíça sobre a melhoria das condições de vida dos toxicodependentes, que prevê, no quadro de um conjunto de investigações científicas implementadas para a revisão da Lei de Tóxicos, a prescrição de heroína e outras drogas pesadas aos viciados. MADER, Luzius. Avaliação dos efeitos da legislação - a situação da Suíça. Cadernos de Ciência de Legislação, Oieiras, Instituto Nacional de Administração, n. 33/34, jan-jun. 2003 , p. 147.

53 MORAIS, Carlos da Costa. Sistema de Avaliação do Impacto das Normas Jurídicas. Cadernos de Ciência da Legislação, Oieiras, Instituto Nacional de Administração, n. 32, out.-dez. 2002, p. 39-55.

54 Este é o caso de Portugal, em que as avaliações legislativas têm sido empreendidas, em sua maioria, por equipes externas aos departamentos promotores da iniciativa legislativa. ALMEIDA, Marta Tavares; CAUPERS, João; GUIBENTIF, Pierre. Efeitos de algumas normas do Código de Procedimento Administrativo: estudo de caso em avaliação legislativa. Cadernos de Ciência de Legislação, Oieiras, Instituto Nacional de Administração, n. 12, jan-mar. 1995, p. 93-106.

55 Menciona-se a experiência do Reino Unido, em que há uma Unidade de Impacto Normativo junto ao gabinete do primeiroministro, bem como Unidades de Impacto Normativo constituídas nos diversos ministérios, cuja responsabilidade consiste em efetuar a avaliação dos impactos normativos das normas que produzam efeitos substanciais sobre a atividade empresarial, as instituições de beneficência, bem como as organizações sem fins lucrativos. COURTNEY, Mark. Quadro de uma política para a melhoria da qualidade da ação normativa. Cadernos de Ciência de Legislação, Oieiras, n. 33/34, jan-jun. 2003, p.111.

56 MADER, Luzius. Avaliação dos efeitos da legislação - a situação da Suiça. Cadernos de Ciência de Legislação, Oieiras, Instituto Nacional de Administração, n. 33/34, jan-jun. 2003, p. 155.

57 No Reino Unido, não só as leis, mas também os regulamentos administrativos que produzam efeitos substanciais sobre a atividade empresarial, as instituições de beneficência, bem como as organizações sem fins lucrativos, devem ser avaliados quanto ao seu impacto normativo. Além disso, as normas de procedimentos e condutas aprovadas no âmbito interno das empresas que produzam impacto em sua atividade empresarial também deverão submeter-se à avaliação de seus impactos Cf. COURTNEY, Mark. Quadro de uma política para a melhoria da qualidade da ação normativa. Cadernos de Ciência de Legislação, Oieiras, n. 33/34, jan.-jun. 
incidir sobre todos ou apenas alguns dispositivos do texto normativo.

As experiências em avaliação legislativa são muito variadas, adequando-se ao contexto institucional de cada país. É possível, no entanto, constatar alguns traços comuns à maioria das experiências aqui mencionadas. Os relatos dessas experiências confirmam que a prática, ou seja, a aplicação da avaliação legislativa encontra-se muito aquém das possibilidades legais. Para os países que atingiram estágio avançado de institucionalização da avaliação legislativa, a prática, ainda assim, destoa das obrigações legais, sendo muitas vezes ignorada pelos órgãos responsáveis pela avaliação. ${ }^{58}$

No que diz respeito à imputação de obrigações legais, há um consenso no sentido de que a avaliação legislativa não deve ser utilizada indiscriminadamente, ou seja, somente deve ser aplicada "[...] a diplomas que pela sua natureza e/ou complexidade têm particular incidência na sociedade". ${ }^{59}$ Defende-se a seletividade da avaliação legislativa, principalmente em decorrência do caráter dispendioso e moroso de sua realização.

Observa-se no entanto, que, embora haja consenso quanto à seletividade do uso da avaliação legislativa, a mesma unanimidade não permanece no que tange à sua obrigatoriedade. Para alguns autores, deve haver algum consenso, ainda que mínimo, na elaboração de diretrizes legislativas, do contrário "[...] a nova lei não passará de um exercício formal de conflitantes utopias inalcançáveis. Entrará na história, sem ter passado pela vida". 60

As opiniões de especialistas parecem também coincidir na constatação de que a avaliação legislativa ex post contribui muito mais para a melhoria da qualidade legislativa do que a avaliação legislativa ex ante, dada a dificuldade de se esboçar antecipadamente os efeitos de uma legislação de grande impacto social. Isso porque as técnicas predominantes da avaliação legislativa ex ante, consistentes na realização de experimentos em ambientes laboratoriais, "controlam" o contexto social em que as leis produzirão seus efeitos, elegendo apenas algumas variáveis - que poderão não ser as únicas, tampouco as mais relevantes - a determinar o impacto efetivo dos instrumentos normativos na realidade social.

\section{Ciência da legislação no Brasil}

Doutrinariamente, muito pouco se produziu e tem se escrito no Brasil acerca do "processo", "arte" ou "ação" de fazer as leis. Os trabalhos doutrinários anteriores à edição da Lei Complementar ("LC") no 95, de 26 de fevereiro de 1998, que instituiu regras e preceitos de técnica legislativa, foram poucos e esparsos. Tais trabalhos, elaborados sob a denominação de "técnica legislativa", trataram predominantemente sobre temas de "legística formal", em especial sobre estrutura e organização interna do texto legislativo.

O trabalho de Hésio Fernandes Pinheiro, intitulado "Técnica Legislativa e as Constituições e Leis Constitucionais do Brasil," publicado originalmente em 1945, ${ }^{61}$ foi um dos primeiros a tratar de forma sistemática temas caros à "legística formal", como técnicas de redação de conteúdos normativos, estruturação dos conteúdos das leis, os quais devem ser distribuídos em artigos, bem como desdobramentos ou agrupamentos deles.

Nunes Leal, inspirado na obra de Pinheiro, produziu naquele mesmo ano um ensaio sobre técnica legislativa que mantém a originalidade característica de suas obras. O autor, já naquela época, reconhecia:

2003, p. 107-123. A Suíça também é repleta de exemplos de disposições que estabelecem a avaliação legislativa no nível da legislação secundária. MADER, Luzius. Avaliação dos efeitos da legislação - a situação da Suíça. Cadernos de Ciência de Legislação, Oieiras, Instituto Nacional de Administração, n. 33/34, jan.-jun. 2003, p. 145.

58 MADER, Luzius.. Avaliação dos efeitos da legislação - a situação da Suíça. Cadernos de Ciência de Legislação, Oieiras, Instituto Nacional de Administração, n. 33/34, jan.-jun. 2003, p. 149.

59 ALMEIDA, Marta Tavares; CAUPERS, João; GUIBENTIF, Pierre, op. cit., p. 6.

60 FALCÃO, Joaquim. Democracia, direito e terceiro setor. 2.ed. Rio de Janeiro: Editora FGV, 2006, p. 139.

61 PINHEIRO, Hésio Fernandes. Técnica legislativa e as constituições e leis constitucionais do Brasil. Rio de Janeiro: A. Noite, 1945. 
Tal é o poder da lei que a sua elaboração reclama precauções severíssimas. Quem faz a lei é como se estivesse acondicionando materiais explosivos. As conseqüências da imprevisão e da imperícia não serão tão espetaculares, e quase sempre só de modo indireto atingirão o manipulador, mas podem causar danos irreparáveis. ${ }^{62}$

O ensaio aborda assuntos típicos de legística formal, embora no mesmo texto seja possível reconhecer originais, apesar de ligeiros, conselhos para a elaboração do conteúdo das leis. Eis um de seus principais conselhos:

As fontes de informação do legislador devem ser fidedignas. Ao redigir uma lei, o legislador não pode perder de vista a observação real da vida, porque a malícia encontra muitos atalhos por onde infiltrar-se por entre as sanções da lei, sem incidir nelas. Não basta ter em mira o resultado a atingir: é preciso escolher cuidadosamente os meios adequados, velando por que não sejam excessivamente severos, nem inócuos. ${ }^{63}$

No que diz respeito à qualificação que considera indispensável para as pessoas responsáveis pela elaboração das leis, o autor aconselhou que essa incumbência fosse oferecida “[...] a juristas que, além de sólida cultura, tenham muito tirocínio na aplicação do direito, quer como advogados, quer como juízes, homens de mentalidade receptiva, de alma aberta às transformações do mundo". ${ }^{64}$ E prossegue, ainda, sobre o mesmo assunto:

A participação, na redação das leis, de quem não seja jurista, mas conheça bem os assuntos de que elas se ocupam, é também imprescindível em muitos casos. A lei regula, em escala cada vez maior, relações de conteúdo técnico, cujo conhecimento escapa ao jurista. (...) Saúde pública, educação, indústria, comércio, transportes etc., cada um dos setores que a lei vai progressivamente invadindo, reclama a colaboração legislativa de elementos estranhos aos meios jurídicos. ${ }^{65}$

Depois de longo hiato entre os primeiros trabalhos doutrinários da disciplina "técnica legislativa" e o surgimento de propostas de institucionalização de seus conteúdos, é editada, em 1998, a LC n 95, que instituiu regras sobre a "elaboração, redação, alteração e consolidação das leis."

Essa lei, em conjunto com o Decreto $\mathrm{n}^{\circ} 4.176$, de 28 de março de $2002^{66}$, que a regulamenta, trata de assuntos tipicamente de Legística Formal ou, seguindo denominação consagrada no Brasil, Técnica Legislativa.

Tais normas dispõem sobre a estrutura que deve obedecer uma lei, subdividindo-se em partes preliminar, normativa e final $;{ }^{67}$ estabelecem regras de redação legislativa, imputando ao legislador a obrigação de clareza, de precisão e de lógica na linguagem utilizada; ${ }^{68}$ instituem regras de articulação das diversas partes do texto legal, determinando como devem ser mencionados, numerados e articulados os diversos dispositivos da lei, em que o artigo constitui a unidade básica de organização; ${ }^{69}$ estabelecem uma sistemática de consolidação e codificação dos atos normativos, de modo que leis que versem sobre o mesmo assunto sejam reunidas em um único texto legal; ${ }^{70}$ dispõem sobre a alteração dos atos normativos, determinando que o legislador evite a edição de leis extravagantes, de modo que toda e qualquer inovação sobre uma determinada matéria já regulada seja incluída na legislação existente, e que sejam expressamente mencionadas no texto legal as normas que, por conflitarem com a legislação mais recente, devam ser revogadas. ${ }^{71}$

O Decreto $n^{\circ} 4.176 / 02$ introduziu também regras de tramitação dos atos normativos no âmbito do poder executivo, antes que eles sejam remetidos à votação pelo Congresso Nacional, quando se constituírem leis, ou que sejam editados pelo Presidente da República ou demais chefes de entidades da Administração Direta, em se tratando de regulamentos. ${ }^{72}$ Observa-se que o referido decreto estabeleceu ainda que as exposições de

62 NUNES LEAL, op. cit., p. 8.

63 NUNES LEAL, Victor, op. cit., p. 8.

64 Idem, p. 21.

65 Idem, ibidem, p. 22.

66 Inicialmente, a LC n 95 foi regulamentada pelo Decreto $\mathrm{n}^{\circ} 2.954$, de 29.01.1999, substituído pelo Decreto ${ }^{\circ} 4.176$, de 28 de março de 2002.

67 Art. $3^{\circ}$ a $6^{\circ}$ da LC n ${ }^{\circ} 95 / 98$ e Arts. $5^{\circ}$ e $6^{\circ}$ do Decreto ${ }^{\circ} 4.176 / 02$.

68 Art. 11 da LC n ${ }^{\circ}$ 95/98 e Art. 23 do Decreto n ${ }^{\circ} 4.176 / 02$.

69 Art. 10 da LC n ${ }^{\circ}$ 95/98 e Art. 22 do Decreto n ${ }^{\circ} 4.176 / 02$.

70 Arts. 13 a 17 da $\operatorname{LC~n}^{\circ}$ 95/98 e Arts. 26 a 32 do Decreto n ${ }^{\circ} 4.176 / 02$.

71 Art. 12 da LC n ${ }^{\circ}$ 95/98 e Arts. 24 e 25 do Decreto n ${ }^{\circ} 4.176 / 02$.

72 Cf. Arts. 33 a 41 do Decreto n ${ }^{\circ} 4.176 / 02$. 
motivos dos atos normativos de qualquer natureza prevejam: ${ }^{73}$ (i) justificativa e fundamentação do ato, de tal forma que possibilite a sua utilização como defesa prévia em eventual arguição de inconstitucionalidade; (ii) explicação dos motivos pelos quais o ato proposto constitui o melhor instrumento normativo a disciplinar a matéria; (iii) indicação das normas que serão afetadas ou revogadas pela proposição; (iv) indicação da existência de prévia dotação orçamentária, quando a proposta demandar despesas; e (v) demonstração objetiva da relevância e urgência no caso de projeto de medida provisória.

A grande inovação trazida por esse regulamento, no entanto, foi a instituição de regras do Manual de Redação da Presidência da República, ${ }^{74}$ em especial de um formulário ou lista de verificação, que acabou sendo incorporado como anexo do Decreto $n^{\circ} 4.176 / 02$, estabelecendo "[...] questões que devem ser analisadas na elaboração de atos normativos no âmbito do poder executivo." 75 Gilmar Ferreira Mendes, presidente da comissão encarregada de elaborar o referido Manual em 1991, redigiu o capítulo "Questões Fundamentais de Técnica Legislativa", de onde foi extraída a referida lista de verificação.

O capítulo escrito por Gilmar Mendes, posteriormente publicado em diversos periódicos científicos, ${ }^{76}$ constitui um trabalho típico de Legística Material ou Metódica da Legislação, embora o texto também analise ligeiramente tópicos de Legística Formal.

O autor, já no início de seu trabalho, recomenda que o legislador atenha-se à ideia de sistema, em que deverão ser respeitadas as sistemáticas interna e externa da lei. No tocante à sistemática interna, o autor aponta para o desafio da contradição teleológica da lei, que se manifestará quando “[...] houver contradição entre os objetivos perseguidos por disposições diversas, de modo que a observância de um preceito importa a nulificação dos objetivos visados pela outra” (BRASIL, 2002, p. 80).

Inspirado na doutrina alemã sobre Metódica da Legislação, ${ }^{77}$ o referido autor faz uma apresentação sucinta daquilo que denomina processo legislativo interno, o qual "[...] traduz um esforço de racionalização dos procedimentos de decisão [do legislador], que configura uma exigência do próprio Estado de Direito”. ${ }^{8}$

Dentre as etapas a serem observadas nesse processo legislativo interno, encontram-se: (i) identificação e definição do problema; (ii) análise da situação questionada e de suas causas; (iii) definição dos objetivos pretendidos; (iv) crítica das propostas; ${ }^{79} \mathrm{e}(\mathrm{v})$ controle de resultados. ${ }^{80}$

Observa-se que as etapas descritas pelo autor coincidem, ainda que parcialmente, com aquelas ainda hoje consideradas essenciais pelos trabalhos de doutrinadores de Metódica da Legislação sucessores à obra de Peter Noll, utilizada como referência no Manual ora comentado. No entanto, pode-se constatar que o assunto, de natureza altamente complexa por tudo o que já foi observado até aqui, recebeu tratamento muito simplificado e sucinto no Manual, cuja principal ênfase foi dada à Legística Formal.

Por outro lado, o formulário sobre "[...] questões que devem ser analisadas na elaboração de atos normativos no âmbito do poder executivo" foi redigido de forma altamente detalhista e minuciosa. Este documento, inspirado na "Resolução de 11 de dezembro de 1984 do Governo da República Federal da Alemanha, destinada a controlar e racionalizar a elaboração de atos normativos no âmbito do Poder Executivo",

73 Art. 38 do Decreto n ${ }^{\circ} 4.176 / 02$.

74 BRASIL. Presidência da República. Manual de Redação da Presidência da República. 2.ed. Brasília: Presidência da República, 2002.

75 Cf. Anexo I do Decreto n ${ }^{\circ} 4.176 / 02$.

76 Revista Trimestral de Direito Público, n.1, 1993, p. 255-271; Cadernos de Direito Constitucional e Ciência Política, v.

1, n. 2, jan-mar, 1993, p. 36-52; Revista de Doutrina e Jurisprudência, n. 37, set-dez. 1991, p. 41-68, dentro outras fontes.

77 O autor utilizou como referência o trabalho de Peter Noll supramencionado, bem como a obra de Hermann Hill, intitulada Einführung in die Gesetzgebungslebre.

78 BRASIL, op. cit., p. 87.

79 Esta ação equivale à avaliação legislativa ex ante.

80 Equivalente à avaliação legislativa ex post.

81 BRASIL, op. cit., p. 89. 
consiste num rol extenso de perguntas que devem orientar a ação legislativa, buscando averiguar, antes da elaboração da lei (i) que problema(s) que se pretende solucionar com a proposição de uma norma; ${ }^{82}$ (ii) se há alternativas, incluindo aquelas que prescindem da edição da norma, para a solução do referido problema; ${ }^{83}$ (iii) se a União dispõe de competência constitucional para elaborar o ato normativo; (iv) se a matéria deve ser regulada mediante lei em sentido estrito; (v) se não seria o caso de se editar uma lei temporária; (vi) se deve ser editada medida provisória; (vii) o motivo da urgência da edição da lei; (viii) qual a densidade que se deve conferir ao ato normativo; (ix) se as normas propostas afetam direitos fundamentais ou garantias constitucionais; (x) se o ato normativo corresponde às expectativas dos cidadãos e se se encontra inteligível a todos; (xi) se o ato normativo é exeqüível; ${ }^{84} \mathrm{e}$ (xii) se existe uma relação equilibrada entre custos e benefícios. ${ }^{85}$

Observa-se no entanto, que, apesar de o referido formulário constar como documento anexo do Decreto $\mathrm{n}^{\circ} 4.176 / 02$, ao poder executivo não foi imputada a obrigatoriedade de segui-lo à risca, bem como de juntálo no momento da propositura do projeto de ato normativo.

Consta como obrigatória, no entanto, a apresentação de outra lista de verificação, mais simplificada, constante do anexo II do Decreto $n^{\circ} 4.176 / 02$, que determina que o órgão redator apresente:

1. Síntese do problema ou da situação que reclama providências

2. Soluções e providências contidas no ato normativo da medida proposta

3. Alternativas existentes às medidas propostas

Mencionar:

- se há outro projeto do Executivo sobre a matéria;

- se há projetos sobre a matéria no Legislativo;

- outras possibilidades de resolução do problema.

4. Custos

Mencionar:

- se a despesa decorrente da medida está prevista na lei orçamentária anual; se não, quais as alternativas para custeá-la;

- se é o caso de solicitar-se abertura de crédito extraordinário, especial ou suplementar;

- valor a ser despendido em moeda corrente.

5. Razões que justificam a urgência (a ser preenchido somente se o ato proposto for medida provisória ou projeto de lei que deva tramitar em regime de urgência)

Mencionar:

- se o problema configura calamidade pública

- por que é indispensável a vigência imediata;

- se se trata de problema cuja causa ou agravamento não tenham sido previstos;

- se se trata de desenvolvimento extraordinário da situação já prevista.

6. Impacto sobre o meio ambiente (sempre que o ato ou medida proposta possa vir a tê-lo);

7. Alterações propostas (texto atual e texto proposto);

8. Síntese do parecer do órgão jurídico;

- com base em avaliação do ato normativo ou da medida proposta à luz das questões levantadas no Anexo I.

Observação: A falta ou insuficiência das informações prestadas poderá acarretar, a critério da Subchefia para Assuntos Jurídicos da Casa Civil, a devolução do projeto de ato normativo para que se complete o exame ou se reformule a proposta. ${ }^{86}$

82 O autor do projeto de ato normativo deve indicar as repercussões que o problema possui no âmbito da economia, da ciência da técnica e da jurisprudência.

83 O proponente deve se perguntar se os instrumentos de ação são adequados em função de desgaste e encargos para os cidadãos e a economia, a eficácia, os custos e as despesas para o orçamento público, efeitos sobre o ordenamento jurídico, efeitos colaterais e outras consequências, entendimento e aceitação por parte dos interessados e dos responsáveis pela execução, possibilidade de impugnação no judiciário. 84 Dentre as questões essenciais para aferição da exequibilidade do ato, estão a análise dos conflitos de interesse subjacentes à medida proposta, a opinião das autoridades incumbidas de executar tais medidas quanto à clareza dos objetivos pretendidos e a possibilidade de sua execução, bem como a aplicação de testes de execução da medida envolvendo as autoridades encarregadas de aplicá-la. 85 O referido formulário constitui anexo deste trabalho. Cf. BRASIL, op. cit., p. 89-92.

86 Cf. Anexo II do Decreto n ${ }^{\circ}$ 4.176/02. D.O.U. 01.04.2002. 
Observa-se que as questões de ambos os formulários constituem diretrizes que deverão nortear a ação do legislador, de modo que ele defina com o maior grau de precisão possível, antes de formular um ato normativo, quais problemas pretende solucionar, quais os meios que dispõe para atingir seus objetivos e que efeitos prevê decorrerem da solução normativa a ser adotada.

Tais questionamentos, por certo, demandam uma análise das principais questões incidentes sobre cada uma das etapas do processo de formulação das leis já mencionado, constituindo as grandes problemáticas da Metódica Legislativa ou Legística Material, embora no Manual de Redação da Presidência da República tenham sido inseridas como elementos ou tópicos de Técnica Legislativa.

$\mathrm{Na}$ verdade, embora a elaboração desses formulários tenha se inspirado na experiência alemã, observa-se que a adoção das chamadas listas de verificação ou checklists revela-se prática generalizada nos diversos países engajados na institucionalização da avaliação legislativa.

Constata-se, no entanto, que o referido Manual, pela simplicidade com que introduziu o tema da Metódica da Legislação, não constitui referencial suficiente para que o Poder Executivo, para quem se destina a lista de verificação, torne-se apto a seguir as recomendações propostas nesse documento. Além disso, sem esforços conjuntos entre os poderes executivo e legislativo para instruir e capacitar os órgãos responsáveis pela elaboração de atos normativos diante dessa nova perspectiva, a tendência é que as novas diretrizes instituídas pelo Manual de Redação da Presidência da República, bem como pelos Anexos I e II do Decreto nº 4.176/02 venham representar apenas uma carga burocrática a mais para os funcionários que deverão cumprir tais exigências. Conforme será mais bem explicitado no capítulo seguinte, a prática revela que a referida lista de verificação tem sido respondida de forma eminentemente burocrática, em que não raramente o autor da proposta de ato normativo restringe-se a responder todas as perguntas negativamente, - afirmando, por exemplo, que não há alternativas para resolver o problema que a norma se propõe a solucionar, ou que a norma não produz impactos sobre o meio ambiente - sem, no entanto, fundamentar tais respostas.

Demais disso, os órgãos especializados em elaboração legislativa no âmbito do Poder Executivo não preveem em sua estrutura regimental a observância das regras de Metódica da Legislação, tampouco se preocupam em instituir equipes interdisciplinares com competências específicas para realização de avaliação legislativa. Não obstante as novas diretrizes impostas pela regulamentação da LC n ${ }^{\circ} 95 / 98$, a ênfase dos trabalhos de produção das leis parece centrar-se no trabalho de profissionais com formação estritamente jurídica. Menciona-se, como exemplo, a Secretaria de Assuntos Legislativos vinculada ao Ministério da Justiça, cujo Departamento de Elaboração Normativa é competente para "[...] elaborar e sistematizar projetos de atos normativos de interesse do Ministério, bem como as respectivas exposições de motivos”. ${ }^{87}$ O núcleo dos grupos de trabalho formados para a elaboração de projetos de lei e outros atos de natureza normativa de interesse do Ministério da Justiça é formado por comissões de juristas que parecem não observar regras de Metódica Legislativa, especialmente no que tange à avaliação legislativa ex ante e expost.

No que diz respeito à instituição de Comissões para Consolidação e Revisão de Atos Normativos já existentes, o Decreto n ${ }^{\circ} 4.176 / 02$ prevê que estas serão compostas por especialistas, “[...] escolhidos entre juristas de notável conhecimento sobre determinada área, para elaborar projetos de consolidação em matérias que exijam maior nível de especialização". ${ }^{88}$ A esse respeito, observa-se que a tarefa de consolidação de atos normativos implica necessariamente uma simplificação e correspondente revisão da legislação existente. Essa tarefa parece ter sido atribuída exclusivamente a juristas, que deverão fundamentar apenas juridicamente os referidos projetos de consolidação. ${ }^{89}$ Conforme observado no início deste trabalho, os juristas de formação tradicional poderão

87 Art. 20, inciso I do Decreto n 6.061, de 15 de março de 2007, que aprova a Estrutura Regimental e o Quadro Demonstrativo dos Cargos em Comissão e das Funções Gratificadas do Ministério da Justiça.

88 Art. 44 do Decreto ${ }^{\circ} 4.176 / 02$.

89 Art. 48 do Decreto n 4.176/02: "A justificação básica das alterações indicará: I - o dispositivo da lei posterior que revogou expressamente a lei anterior; II - o dispositivo da lei posterior que estaria em conflito com a lei anterior, revogando-o implicitamente; III - o dispositivo da Constituição em vigor que estaria em conflito com a lei anterior, revogando-a implicitamente; IV - a decisão 
oferecer uma limitada contribuição no que tange à avaliação dos impactos das normas, e, enquanto não houver uma mudança cultural que assimile os princípios e regras de Metódica da Legislação, não haverá grandes transformações nas práticas de elaboração, de revisão, de simplificação e de consolidação dos atos normativos.

\section{Considerações finais}

Procurou-se, neste trabalho, apresentar as potencialidades da avaliação legislativa para instruir os processos de elaboração, bem como de revisão, de leis e de regulamentos. Viu-se que a avaliação legislativa preocupa-se em dimensionar os efeitos e os impactos produzidos pelas leis na realidade social, de modo que preocupações centrais da sociologia do direito, como a eficácia e a efetividade das leis, sejam incorporadas ao processo de elaboração, de revisão e de aplicação de atos normativos.

No Brasil, a avaliação legislativa ainda se encontra em estágio embrionário, já que ainda não foi devidamente incorporada ao ordenamento jurídico nacional e não vem sendo adotada sistematicamente como prática no processo de elaboração de atos normativos. Espera-se, com este artigo, ter contribuído para uma discussão, ainda incipiente, sobre tema de fundamental relevância para a melhoria da qualidade da legislação brasileira.

\section{REFERÊNCIAS}

ALMEIDA, Marta Tavares. Avaliação da legislação em Portugal. Cadernos de Ciência de Legislação, Oieiras, Instituto Nacional de Administração, n. 33/34, jan.-jun. 2003, p. 93-106.

ALMEIDA, Marta Tavares; CAUPERS, João; GUIBENTIF, Pierre. Efeitos de algumas normas do Código de Procedimento Administrativo: estudo de caso em avaliação legislativa. Cadernos de Ciência de Legislação, Oieiras, Instituto Nacional de Administração, n. 12, jan.-mar. 1995, p. 5-48.

ATIENZA, Manuel. Contribución a una teoría de la legislación. Madri: Civitas, 1997.

BRASIL. Presidência da República. Manual de Redação da Presidência da República. 2.ed. Brasília: Presidência da República, 2002.

CANOTILHO, Joaquim Gomes. Os impulsos modernos para uma teoria da legislação. Cadernos de Ciência de Legislação, Oieiras, n. 1, abr-jun. 1991, p. 7-14.

CAUPERS, João. Relatório sobre o programa, conteúdo e métodos de uma disciplina de Metódica da Legislação. Cadernos de Ciência de Legislação, Oieiras, Instituto Nacional de Administração, n. 35, out.-dez. 2003, p. 5-87.

CHEVALLIER, Jacques. A racionalização da produção jurídica. Cadernos de Ciência de Legislação. Jan.-mar. 1992, p. 9-23.

COURTNEY, Mark. Quadro de uma política para a melhoria da qualidade da ação normativa. Cadernos de Ciência de Legislação. Oieiras, n. 33/34, jan.-jun. 2003, p. 107-123.

MORAND, Charles-Albert. Éléments de légistique formelle et matérielle. In: MORAND, Charles-Aubert (Org.). Légistique Formelle et Matérielle. Aix-En-Provence: Presse Universitaires d'Aix-Marseille, 1999, p. 17-45.

FALCÃO, Joaquim. Democracia, Direito e Terceiro Setor. 2.ed., Rio de Janeiro: Editora FGV, 2006.

do Supremo Tribunal Federal que declarou a inconstitucionalidade ou a revogação de dispositivo de lei; V - a resolução do Senado Federal que suspendeu a execução de lei na forma do art. 52, inciso X, da Constituição; e VI - as medidas provisórias ainda não convertidas que tratam da matéria consolidada." 
FERRAZ Jr. Tércio Sampaio. Introdução ao estudo do direito: técnica, decisão, dominação. 2. ed. São Paulo: Atlas, 1994.

KARPEN, Ulrich. Avaliação legislativa - a experiência alemã. Cadernos de Ciência de Legislação, Oieiras, Instituto Nacional de Administração, n. 33/34, jan.-jun. 2003, p. 9-14.

LEAL, Victor Nunes. Técnica Legislativa. In: LEAL, Victor Nunes. Problemas de Direito Público. Rio de Janeiro: Forense, 1960, p. 7-32.

MADER, Luzius. Evaluating the effects: a contribution to the quality of legislation. Statute Law Review, vol. 22, n. 2, 2001, p. 119-131.

- Avaliação dos efeitos da legislação - a situação da Suíça. Cadernos de Ciência de Legislação, Oieiras, Instituto Nacional de Administração, n. 33/34, jan.-jun. 2003, p. 135-155.

MADER, Luzius. Lévaluation législative. Pour une analyse empirique des effets de la legislation. Lausanne: Payot, 1985.

MORAIS, Carlos da Costa. Sistema de Avaliação do Impacto das Normas Jurídicas. Cadernos de Ciência da Legislação, Oieiras, Instituto Nacional de Administração, n. 32, out.-dez. 2002, p. 39-55.

MORAND, Charles-Aubert. Éléments de légistique formelle et matérielle. In: MORAND,

Charles-Aubert (Org.). Légistique Formelle et Matérielle. Aix-En-Provence: Presses Universitaires D’Aix Marseille, 1999.

MORAND, Charles-Albert. Les exigences de la méthode législative et du droit constitutionnel portant sur la formation de la législation. Droit et Societé, n. 10, 1988, p. 402-423.

LEAL, Victor Nunes. Técnica Legislativa. In: LEAL, Victor Nunes. Problemas de Direito Público. Rio de Janeiro: Forense, 1960, p. 7-32.

PINHEIRO, Hésio Fernandes. Técnica legislativa e as Constituições e Leis constitucionais do Brasil. Rio de Janeiro: A. Noite, 1945.

PRATES, Terezinha M. L. Método legislativo, uma nova disciplina? Revista do Ministério Público do Trabalho, Brasília, n. 06, set. 1993, p. 35-37.

VOERMANS, Wim. Avaliação da legislação nos Países Baixos. Cadernos de Ciência de Legislação,. Oieiras, Instituto Nacional de Administração, n. 33/34, jan.-jun. 2003, p. 59-72.

BRASIL. Lei complementar no 95, de 26 de fevereiro de 1998. Disponível em: < http://www.planalto.gov. br/ccivil_03/leis/lcp/lcp95.htm>. Acesso em: 08 jul. 2012.

BRASIL. Decreto n 4 $^{\circ} 176$, de 28 de março de 2002. Disponível em: <http://www.planalto.gov.br/ccivil_03/decreto/2002/D4176.htm>. Acesso em: 08 jul. 2012.

\section{Agradecimentos}

Agradeço especialmente a José Eduardo Faria, Carlos Ari Sundfeld, Diogo Rosenthal Coutinho, Fernando Dias Menezes de Almeida e Catarina Barbieri, pela leitura e pelas sugestões para o aprimoramento de versões preliminares deste artigo. 


\section{Políticas públicas, deveres fundamentais e concretização de direitos}

\section{Public policies, fundamental duties, and the effectiveness of rights*}

Julio Pinheiro Faro**

\section{Resumo}

Este trabalho tem como objetivo contribuir para o aprofundamento da discussão sobre os deveres fundamentais. O seu ponto de partida é uma constatação óbvia, mas que, como tudo que é óbvio, tem demorado a ser percebido: a eficácia dos direitos fundamentais depende do cumprimento de deveres fundamentais. Após uma introdução geral sobre a classificação e o conceito de deveres, o trabalho, além da seção final, conclusiva, divide-se em duas grandes seções. Na primeira, discute-se o dever social de financiar o Estado, abordando-se, assim, as questões do abastecimento dos cofres públicos e da reserva do possível. Na segunda, discute-se o dever estatal de concretizar direitos, com uma abordagem específica sobre a alocação eficiente de recursos públicos por meio de políticas públicas.

Palavras-chave: Deveres fundamentais. Direitos fundamentais. Políticas públicas. Direitos sociais. Pagamento de tributos. Eficiência alocativa. Concretização.

\section{Abstract}

The aim of this work is to discuss more extensively about the fundamental duties. Adopting as a starting point the obvious observation, but still unobserved that the fundamental rights effectiveness depends on the fundamental duties fulfillment. After a general introduction on the classification and on the concept of duties, this work, besides the final section is divided into two large sections. The first discusses the social duty of financing the State, with an approach to the questions of supplying the public coffers and the reserve of the possible. The second discusses the state duty of realizing rights, with a specific approach on the efficient allocation of public resources through public policies.

Keywords: Fundamental duties. Fundamental rights. Public policies. Social rights. Taxes payment. Allocative efficiency. Effectiveness.

** Mestre em Direitos e Garantias Fundamentais pela Faculdade de Direito de Vitória (FDV); Diretor Secretário-Geral da Academia Brasileira de Direitos Humanos (ABDH); Pesquisador nos Grupos de Pesquisa "Estado, Democracia Constitucional e Direitos Fundamentais" e "Direito, Sociedade e Cultura" do Programa de Pós-Graduação Stricto Sensu (Mestrado/Doutorado) da FDV; Servidor Público Federal. Email: julio.pfhs@gmail.com
Recebido em 19/01/2013 Aprovado em 01/05/2013 


\section{INTRODUÇÃO}

Que os direitos dependem de deveres não é nenhuma obviedade, como prega o senso comum. ${ }^{1}$ Todavia, é patente o fato de que o tema dos deveres é dos mais esquecidos do constitucionalismo contemporâneo. ${ }^{2}$ A preocupação excessiva em se reconhecer direitos contribuiu para um paradoxo: ${ }^{3}$ o excesso de direitos e a despreocupação com os deveres geram um impedimento na concretização de direitos. Este ensaio que aqui se inicia ocupa-se exatamente de algumas das questões sobre essa tendência engendrada pelo próprio ser humano contra a concretização dos seus próprios direitos. Essas questões serão apresentadas em dois grandes temas: o dever da sociedade de financiar o Estado e o dever do Estado de concretizar direitost.

Antes, porém, de adentrar nas temáticas e seus respectivos aspectos, é preciso firmar linhas gerais sobre o tema geral: deveres fundamentais. A ideia de seres humanos serem ao mesmo tempo sujeitos de direitos e de deveres era comum no mundo antigo, detendo eles um compromisso com a comunidade. Contudo, essa ligação enfraqueceu-se e se perdeu, pelo menos na história ocidental, com o decurso dos anos. Assim, a noção do ser humano detentor de um compromisso com sua comunidade ou sociedade foi perdendo valor, sobretudo a partir da necessidade de se proteger a pessoa das ingerências estatais. Assim, falar de direitos tão só individuais foi muito comum especialmente a partir do constitucionalismo do século XVIII. Entretanto, esse vetusto modelo precisa ser substituído, porque as pessoas possuem tanto direitos quanto deveres, implicando a existência destes na existência daqueles. ${ }^{5}$

Os autores que já se emaranharam no assunto apontam que o conceito de dever tem historicamente influência especialmente da moral religiosa, bem como muitos institutos e conceitos jurídicos que atualmente são utilizados. ${ }^{6}$ No campo jurídico, tal qual no religioso, aos deveres se contrapuseram sanções. Ou seja, a previsão jurídica de um dever e o seu descumprimento pelas pessoas poderia ensejar algum tipo de castigo. Isso aproximou o pecado e o antijurídico, ligação só desfeita com a separação entre Estado e Igreja. É assaz interessante observar que muitos dos deveres que se encontram nas ordens constitucionais, especialmente na brasileira, têm a ver, ainda, com os pecados; exemplo clássico é o do furto, que consta também como um dos dez mandamentos. Da relação entre direito e moral se encontram, a princípio, dois deveres fundamentais: respeitar o sistema jurídico-constitucional e respeitar a situação jurídica de outrem. Deveres universais e naturais das pessoas.

Diante disso, os deveres podem ser divididos em deveres fundamentais do cidadão e deveres de prestação estatal. Uma vez que o foco deste trabalho recai sobre ambos os grupos, a tipologia e a conceituação hão de necessariamente contemplá-los.

Pois bem, uma primeira classificação de deveres fundamentais diz respeito ao fato de que à existência de um direito nem sempre corresponde a existência de um dever, salvo se a intenção for dizer que ao direito de

1 Trabalho produzido no Grupo de Pesquisa "Estado, Democracia Constitucional e Direitos Fundamentais", na linha de pesquisa em "Deveres Fundamentais", do Programa de Pós-Graduação Stricto Sensu da FDV. A linha de pesquisa em Deveres Fundamentais foi lançada no Brasil, pioneiramente, em Programas de Pós-Graduação, pela FDV, em 2010, por sugestão minha e do professor Dr. Adriano Sant'Ana Pedra. 2 CANOTILHO, José Joaquim Gomes. Das constituições dos direitos à crítica dos direitos. Direito Público, n. 7, p. 80, 2005. NABAIS, José Casalta. O dever fundamental de pagar impostos: contributo para a compreensão constitucional do estado fiscal contemporâneo. Coimbra: Almedina, 2004. p. 15.

3 MANTOVANI, Ferrando. La proclamazione di diritti umani e la non effetività dei diritti umani. Rivista Italiana di Diritto e Procedura Penale, anno 51, n.1, 2008, p. 41.

4 Para outros trabalhos meus sobre a temática dos deveres fundamentais, ver: FARO, Julio Pinheiro. Deveres como condição para a concretização de direitos. Revista de Direito Constitucional e Internacional, São Paulo, v. 79, p. 167-209, abr./jun. 2012; FARO, Julio Pinheiro. Solidariedade e justiça fiscal: uma perspectiva diferente sobre a concretização de direitos a partir do dever de pagar impostos. Revista de Direito Constitucional e Internacional, São Paulo, v. 81, p. 229-270, out./dez. 2012. Cito outros trabalhos meus ao longo do texto.

5 LOPES, Ana Maria D’Ávila. A participação política das minorias no Estado democrático de direito brasileiro. In: LIMA, Martonio Mont'Alverne Barreto; ALBUQUERQUE, Paulo Antonio de Menezes (Org.). Democracia, direito e politica: estudos internacionais em homenagem a Friedrich Müller. Florianópolis: Conceito, 2006. p. 84-87.

6 PECES-BARBA MARTÍNEZ, Gregorio Martinez. Los deberes fundamentales. Doxa, n. 4, 1987. p. 329. 
um implica o dever de reconhecimento e respeito de outrem. Nesse passo, é interessante notar que, enquanto direitos fundamentais exprimem o aspecto ativo dos indivíduos perante Estado e a sociedade, deveres expressam o aspecto passivo da mesma relação, daí a coexistência entre direitos e deveres. ${ }^{7}$ Isto é, considerando-se a mesma relação jurídica, os direitos representam o que o Estado deve proporcionar aos indivíduos, e os deveres, o que os indivíduos devem proporcionar ao Estado. Trata-se de um ciclo, onde algumas das prestações estatais dependem, ao menos em parte, do cumprimento de deveres pelos indivíduos, ou seja, há direitos que dependem da realização correta e efetiva de deveres. Portanto, essa primeira classificação divide os deveres fundamentais em deveres autônomos (ou genéricos) e deveres correlatos (ou conexos) aos direitos (ou, ainda, deveres especificos), diferenciando-se porque uns não estão, embora outros estejam relacionados material e diretamente à concretização dos direitos fundamentais. ${ }^{8}$

Outra tipologia divide os deveres em expressos e implícitos, consistindo a diferença no fato de serem, ou não, facilmente identificados em enunciados normativos constitucionais. Dentro dessa classificação, há deveres que são formulações doutrinárias ou jurisprudenciais pacíficas, mas que não têm qualquer pista de sua existência no texto magno, podendo, pois, serem divididos em legais ou constitucionais e em judiciais ou doutrinários, de acordo com sua previsão no ordenamento jurídico - no primeiro caso - ou com sua criação pela doutrina ou pela jurisprudência - no segundo caso.

Pode-se trazer como terceira tipologia a divisão dos deveres em sociais e estatais. Os deveres sociais são exigíveis pelo Estado e pela própria sociedade em relação aos indivíduos que a compõem. Tais deveres podem ser subdivididos em deveres em prol de interesse pessoal e deveres em prol de interesse da sociedade, caso digam respeito à individualidade ou à coletividade, respectivamente. Dentre os deveres sociais em prol do interesse da sociedade está o dever de financiar a sociedade, desenvolvido com mais detalhes na seção n. 1 deste trabalho. Já os deveres estatais são exigíveis do Estado, podendo ser subdivididos em externos e internos, conforme sejam exigíveis por sujeitos de direito internacional legitimado, ou pela própria sociedade, por seus cidadãos e por órgãos legitimados para tanto, podendo-se citar o dever estatal de concretizar direitos, desenvolvido na seção n. 2 deste trabalho.

À apresentação geral acerca dos deveres fundamentais não se poderia furtar de uma tentativa de conceituação, como aquilo que cada indivíduo tem ante o Estado e a sociedade de contribuir para a formação de uma base material que mantenha o maquinário estatal operante e que satisfaça as necessidades mínimas de todas as pessoas. ${ }^{9}$

\section{O DEVER SOCIAL DE FINANCIAR O ESTADO}

O financiamento do Estado, dever social em interesse da sociedade, concretiza-se com o pagamento de tributos. ${ }^{10} \mathrm{~A}$ ideia é corroborada com duas conclusões que têm sido repetidas e ecoadas. Primeira: conferir eficácia aos direitos fundamentais custa dinheiro. ${ }^{11}$ Segunda: a sociedade deve abastecer os cofres públicos

7 NABAIS, José Casalta. O dever fundamental de pagar impostos: contributo para a compreensão constitucional do estado fiscal contemporâneo. Coimbra: Almedina, 2004. p. 65.

8 SARLET, Ingo Wolfgang. A eficácia dos direitos fundamentais: uma teoria geral dos direitos fundamentais na perspectiva constitucional. 10. ed. Porto Alegre: Livraria do Advogado, 2009. p. 228.

9 No mesmo sentido: GARZÓN VALDÉS, Ernesto. Los deberes positivos generales y su fundamentación. Doxa, n. 3, 1986, p. 17; FARO, Julio Pinheiro. Deveres fundamentais e a constituição brasileira. FIDES: revista de filosofia do direito, do estado e da sociedade, v. 1, n. 2, 2010. p. 223.

10 Ver, dentre outros: FARO, Julio Pinheiro. Administración pública, realización y financiación de los derechos fundamentales. In: DEL REAL, J. Alberto; ENRÍQUEZ, Gastón J.; RODRÍGUEZ, Luís G. (Ed.). La maquinaria del derecho en Iberoamérica: constitución, derechos fundamentales y administración (no prelo, 2014); FARO, Julio Pinheiro. Mínimo existencial e o dever de pagar tributos, ou financiando os direitos fundamentais. Constituição, economia e desenvolvimento: Revista da Academia Brasileira de Direito Constitucional, n. 1, 2009.

11 Por exemplo: IMMORDINO, Giovanni; PAGANO, Marco. The cost of rights: an economic analysis. Diritto \& Questioni Pubbliche, n. 4, 2004; HOLMES, Stephen; SUNSTEIN, Cass. The cost of rights: why liberty depends on taxes. New York: W. W. Norton, 
com o pagamento de tributos. ${ }^{12}$ Anexa a essas conclusões, junta-se uma terceira: por meio da atuação da Administração Pública, o Estado deve gerir correta e adequadamente a receita arrecadada, custeando seus serviços e concretizando direitos, por meio de políticas públicas.

A relação entre o dever de pagar tributos e a eficácia dos direitos fundamentais parece bem simples: enquanto os direitos representam tudo o que o Estado deve proporcionar aos indivíduos, os deveres têm a ver com o que os indivíduos devem proporcionar ao Estado e à sociedade. ${ }^{13}$ Assumindo-se que o Estado seja uma grande empresa prestadora de serviços públicos e que precisa ter recursos, tanto para sua manutenção quanto para a realização de tais serviços, duas são as ilações a que se chega. Uma: a prestação estatal devida é a realização de serviços públicos. Outra: a formação de recursos para a manutenção estatal e para a realização dos serviços públicos constitui-se naquilo que é devido pela sociedade e por seus indivíduos, em especial por estes, por serem os sujeitos passivos tributários. O débito dos indivíduos com o Estado na relação obrigacional acima descrita é solvido a partir do cumprimento da prestação decorrente da relação obrigacional tributária: o pagamento de tributos possibilita a formação de recursos que, abastecendo os cofres públicos, possibilitarão que se custeie a eficácia dos direitos. O abastecimento do erário pelos indivíduos é, pois, tanto um dever social em interesse da sociedade direcionado para a atuação do Estado, quanto uma obrigação tributária imposta pelo próprio Estado. Ou, melhor: a sociedade se autoimpõe o pagamento de tributos, para que o Estado possa manter funcionando o maquinário de que dispõe para concretizar direitos.

O tributo é uma prestação obrigatória, que deve ser cumprida com o pagamento preferencial em dinheiro, admitindo-se, excepcional e alternativamente, que ocorra o seu pagamento mediante a entrega de um bem suscetível de avaliação pecuniária, sem caráter de sanção pela prática de um ato ilícito, embora possa decorrer tanto de atos lícitos quanto de atos ilícitos, instituída em lei e cobrada por intermédio de atividade administrativa vinculada. Os indivíduos estão, portanto, obrigados, por força da ordem jurídica a pagar tributos. Entretanto, esse dever há que observar a capacidade que cada um tem de contribuir para o custeio do Estado e dos serviços públicos prestados por ele.

A capacidade econômica contributiva é um critério de aplicação da norma da isonomia tributária que veda a instituição pelas entidades tributantes de tratamento desigual entre os contribuintes em situação equivalente. ${ }^{14}$ De acordo com essa norma, a atividade de cobrança do tributo devido deve levar em conta a situação concreta do sujeito passivo, de maneira que, se não houver uma manifestação de riquezas equivalentes, a tributação deverá considerar critérios de diferenciação. Daí que, em síntese apertada, a tributação será tanto mais onerosa quanto maior for a real capacidade econômica do contribuinte, trabalhando-se, pois, com uma ideia de que "[...] quem tem maior riqueza deve, em termos proporcionais, pagar mais imposto do que quem tem menor riqueza". ${ }^{15}$ Portanto, apesar de o indivíduo ser obrigado a pagar tributos, é preciso que a entidade tributante observe a sua real capacidade de contribuir com um determinado montante.

A isso se junta a norma que veda o tributo que tenha efeito de confisco. A proibição de que o tributo seja utilizado com finalidade confiscatória estabelece que o indivíduo não pode arcar com uma obrigação tributária superior àquela que sua real capacidade econômica permite, impedindo, pois, que o Estado, sob a desculpa do necessário financiamento, aposse-se indevidamente de bens do indivíduo. "É óbvio que os tributos (de modo mais ostensivo, os impostos) traduzem transferências compulsórias (não voluntárias) de

1999; AMARAL, Gustavo. Direito, escassez, e escolba, Rio de Janeiro: Lumen Juris, 2010.

12 Ver, por exemplo: SCAFF, Fernando Facury. Como a sociedade financia o estado para a implementação dos direitos humanos? In: COUTINHO, Jacinto Nelson Miranda; BOLZAN DE MORAIS, José Luiz; STRECK, Lenio Luiz (Org.). Estudos constitucionais. Rio de Janeiro: Renovar, 2007; ATALIBA, Geraldo. Hipótese de incidência tributária. 6. ed. São Paulo: Malheiros, 2009.

13 NABAIS, José Casalta. O dever fundamental de pagar impostos: contributo para a compreensão constitucional do estado fiscal contemporâneo. Coimbra: Almedina, 2004. p. 65.

14 Ver, por exemplo, para aprofundar a discussão: FARO, Julio Pinheiro. O critério da capacidade econômica na tributação. Revista de derecho de la Pontifícia Universidad Católica de Valparaíso, v. 35, n. 2, 2010.

15 CARRAZZA, Roque Antonio. Curso de direito constitucional tributário. 24. ed. São Paulo: Malheiros, 2008. p. 87. 
recursos do indivíduo para o Estado" ${ }^{16}$ Contudo, tal cobrança compulsória não pode ser excessiva, ou seja, o Estado não pode tirar do indivíduo mais do que ele pode dar sob o pretexto do dever fundamental de pagar tributos para o financiamento das ações estatais em favor de direitos fundamentais.

O abastecimento do erário com o devido pagamento de tributos pelos indivíduos tem pelo menos duas consequências. A primeira é de que o indivíduo, mesmo contribuindo de acordo com a sua real capacidade econômica, deixará de contar com recursos para o exercício de parte ou de algum (ou alguns) de seus direitos. A segunda é de que essa contribuição individual, considerada em conjunto com as dos demais membros da sociedade, permitirá a formação de recursos para que o Estado mantenha seus servidores e, principalmente, preste os serviços públicos, especialmente políticas públicas concretizadoras de direitos. Dessa forma, o dinheiro que o indivíduo é levado compulsoriamente a reservar para pagar tributos, embora possa limitar seus direitos, será destinado a custear a eficácia de direitos de que é titular toda a sociedade. Dessa maneira, o dinheiro particular converte-se em recurso público, quando arrecadado pelo Estado, da administração tributária, e gerenciado por meio da administração pública, que o alocará e o investirá na própria sociedade. Portanto, tem-se a atuação do Estado como uma verdadeira empresa gestora da verba pública, devendo reservar pequena parte para a manutenção de seu próprio aparato e aplicar o restante para dar eficácia aos direitos fundamentais, por meio de ações prestacionais.

Um primeiro obstáculo que se deve colocar no discurso acerca do custo da eficácia dos direitos é saber o que significa essa pretendida eficácia. Afirmar que todos os direitos têm aplicação imediata, não é a mesma coisa que dizer que todos os direitos têm eficácia. ${ }^{17}$ Pode-se dizer que aplicabilidade tem a ver com aquilo que é aplicável ou quem tem a possibilidade de sê-lo, sendo capaz de produzir, então, efeitos. ${ }^{18} \mathrm{~A}$ produção de efeitos é o que se denomina eficácia, que será jurídica e social, consistindo aquela na "[...] possibilidade (no sentido de aptidão) de a norma vigente (juridicamente existente) ser aplicada aos casos concretos e de - na medida de sua aplicabilidade - gerar efeitos jurídicos", enquanto a eficácia social "[...] pode ser considerada como englobando tanto a decisão pela efetiva aplicação da norma (juridicamente eficaz), quanto o resultado concreto decorrente - ou não - desta aplicação". ${ }^{19}$ Portanto, aplicabilidade e eficácia, embora conexos, são conceitos distintos. Assumindo-se, pois, em resumo, que aplicabilidade é a capacidade de produzir efeitos e que eficácia é a própria produção de efeitos, ao se dizer que "os direitos têm aplicação imediata" o sentido adotado não é de que eles produzem efeitos imediatos, e sim que eles têm a capacidade de produzi-los.

Note-se a diferença: dizer que um determinado direito é eficaz significa afirmar que ele já foi aplicado e produz efeitos, ao passo que dizer que um determinado direito é aplicável é o mesmo que dizer que ele tem capacidade de ser eficaz. Desse jeito, afirma-se que nem todos os direitos têm a mesma aplicabilidade; para uns, ela é imediata, para outros, diferida. ${ }^{20}$ No entanto, quando se afirma que há normas de aplicabilidade imediata e normas cuja aplicabilidade é diferida, não se adota a ideia de que as primeiras produzem por si só todos os efeitos que lhes são possíveis (são plenamente eficazes), enquanto que as segundas não possuem essa característica (têm eficácia reduzida). O entendimento aqui é de que normas de aplicabilidade imediata têm aplicabilidade maior que as de aplicabilidade diferida. Assim, umas têm capacidade de produzir efeitos com mais facilidade e outra não. E isso tem uma grande influência sobre a eficácia das normas definidoras de direitos fundamentais. Aliás, é basicamente isso o que acontece com as normas definidoras de direitos sociais, econômicos e culturais e normas definidoras de direitos à liberdade. Enquanto aquelas trazem direitos de aplicabilidade diferida, estas trazem direitos de aplicabilidade imediata. Isso tem a ver com a distinção

16 AMARO, Luciano. Direito tributário brasileiro. 13. ed. São Paulo: Saraiva, 2007. p. 144.

17 SARLET, Ingo Wolfgang. A eficácia dos direitos fundamentais: uma teoria geral dos direitos fundamentais na perspectiva constitucional. 10. ed. Porto Alegre: Livraria do Advogado, 2009. p. 238.

18 SILVA, José Afonso. Aplicabilidade das normas constitucionais. 4. ed. São Paulo: Malheiros, 2000. p. 13.

19 SARLET, Ingo Wolfgang. A eficácia dos direitos fundamentais: uma teoria geral dos direitos fundamentais na perspectiva constitucional. 10. ed. Porto Alegre: Livraria do Advogado, 2009. p. 240.

20 Ver: FARO, Julio Pinheiro. Da reserva do possível e da proibição de retrocesso social. Revista do Tribunal de Contas do Estado de Minas Gerais, v. 76, n. 3, p. 46-47, 2010. 
feita entre direitos negativos (liberdades públicas) e direitos positivos (direitos sociais). Apertando-se a síntese, direitos negativos são os que prescindem de qualquer tipo de intervenção estatal, desde que, por certo, os indivíduos possuam meios para exercê-los; e direitos positivos são os que necessitam de uma atividade estatal prestacional, cuja finalidade é possibilitar o exercício de direitos.

Então, a concretização de direitos fundamentais tem um custo que é coberto pelo pagamento de tributos. Os tributos servem para gerar recursos públicos, as receitas derivadas, que podem ser alocadas e destinadas basicamente de duas maneiras: manutenção do maquinário estatal e realização de políticas públicas. Para o esperado posicionamento dessa receita, utiliza-se do critério, razoavelmente seguro, da vinculaşão do tributo, pelo qual se verifica se os tributos vinculam-se, ou não, à atividade estatal. A esse critério junta-se, aqui, um que lhe é muito próximo, permitindo, inclusive, seu melhor entendimento, vale dizer, o critério que se refere à existência de destinação específica do tributo, pelo que se afere se o tributo é instituído para atingir ou não um fim específico. Assim, há quatro possibilidades. A primeira envolve os tributos que não se vinculam a uma atividade estatal específica e nem a uma finalidade específica: são os impostos, com a exceção dos impostos extraordinários de guerra. A segunda abarca os tributos que não se vinculam a uma atividade estatal específica, mas que têm uma finalidade específica: aí se incluem os impostos extraordinários de guerra e os empréstimos compulsórios. A terceira engloba os tributos que se vinculam a uma atividade estatal específica, mas não têm uma finalidade específica: são as contribuições para a seguridade social. A quarta traz os tributos que se vinculam a uma atividade estatal específica e têm uma finalidade específica: aí estão taxas para utilização efetiva ou potencial de serviços públicos específicos ou singulares e divisíveis, taxas de poder de polícia e a contribuição de melhoria.

A receita derivada tributária, auferida pelo Estado, deve ser utilizada para os gastos operacionais estatais (remunerações), para a formação de divisas e, principalmente, para o reinvestimento na sociedade, mediante políticas públicas. Parte dessa receita está, contudo, vinculada à concretização de determinados direitos, como se pode observar das pontuações subsequentes: ${ }^{21}$ Fundo Nacional de Saúde (art. 198, $\$ 2^{\circ}$, I, III e III, CF); manutenção e desenvolvimento do ensino (art. 212, caput, CF); fundo de combate e erradicação da pobreza (art. 80, II e III, art. 82, $\int S 1^{\circ}$ e $2^{\circ}$, do ADCT); pagamento de subsídios a preços ou transporte de álcool combustível, gás natural e seus derivados e derivados de petróleo, financiamento de projetos ambientais relacionados com a indústria do petróleo e do gás e ao financiamento de programas de infraestrutura de transportes (art. 177, $₫ 4^{\circ}, \mathrm{CF}$ ); custeio da seguridade social (art. 195, CF); financiamento de programas de desenvolvimento econômico e financiamento do Fundo de Amparo ao Trabalhador (art. 239, $\iint 1^{\circ}$ e $4^{\circ}$, CF);

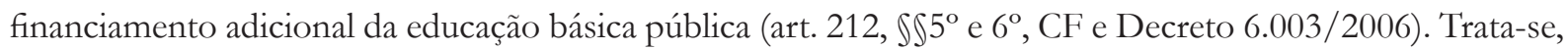
obviamente, de lista aberta, já que não esgota as possibilidades de aplicação das verbas públicas. Ademais, é de se notar que todos esses investimentos estatais necessários e mínimos têm como foco principal a concretização de direitos sociais. Diante disso é que se pode retomar a assertiva de que todos os direitos custam dinheiro.

Aqui se insere, em certa medida, o problema do mínimo existencial, cujo conteúdo ainda é objeto de muita controvérsia. Dizer que o Estado está vinculado aos investimentos acima referidos não é suficiente para determinar o conteúdo do mínimo existencial. Mesmo porque é possível encontrar, na própria constituição, dispositivos que prevejam outro conteúdo para aquilo que se pretende chamar de mínimo existencial, como é o caso do art. $7^{\circ}$, IV, que estabelece que o salário mínimo deva ser capaz de atender necessidades vitais básicas como saúde, moradia, lazer, alimentação, educação, vestuário, higiene, transporte e previdência social. Nota-se, com isso, que o foco para o conteúdo do mínimo existencial recai sobre os direitos sociais, o que é um entendimento incompleto, já que a pessoa deve ter também acesso mínimo às liberdades e aos assim chamados direitos de solidariedade.

O minimo existencial constitui-se no bloco de oportunidades mínimas devidas a todo e qualquer ser humano, para o seu adequado desenvolvimento e para que possa ter uma vida minimamente digna. Dizer que um

21 SCAFF, Fernando Facury. Como a sociedade financia o Estado para a implementação dos direitos humanos no Brasil. In: SCAFF, Fernando Facury (Org.). Constitucionalismo, tributação e direitos bumanos. Rio de Janeiro: Renovar, 2007. p. 16-17. 
sujeito deva desfrutar de oportunidades mínimas implica afirmar que há exigências básicas e vitais a serem atingidas. Porém, não se podem confundir exigências com preferências, já que são gradações distintas de necessidades. ${ }^{22}$ Numa escala hipotética das necessidades humanas variando entre -1 e +1 , as exigências consistem naquilo que permitem aos indivíduos começarem suas vidas do nivel zero, sem que lhes falte qualquer bem necessário para uma vida minimamente digna; são, portanto, as necessidades básicas, ou, ainda, as oportunidades minimas. As preferências, por sua vez, consistem no que é supérfluo, representando os desejos, os interesses e as aspirações individuais. Ao Estado cabe viabilizar as oportunidades mínimas, viabilizando as condições para uma vida minimamente digna, podendo, pois, as pessoas exigirem dele e o controlarem no que se refere à concretização e à manutenção dessas oportunidades. Entretanto, não é obrigação estatal concretizar as preferências dos indivíduos, ou, por outra, o Estado não tem o dever de utilizar recursos para realizar aquilo que as pessoas preferem. Portanto, as necessidades básicas não podem basear-se em escolhas individuais, devendo, sim, apoiarem-se em escolhas genéricas e objetivas, sem que haja a incidência de quaisquer desejos, interesses ou condições particulares, adotando-se, pois, como necessidades básicas as que são realmente imprescindíveis para a persecução de um plano de vida baseado no atendimento de níveis mínimos de dignidade. ${ }^{23}$

Talvez o maior problema sobre a escolha das necessidades básicas que irão formar o mínimo existencial seja a maneira como essa eleição será feita. Para contornar uma possível escolha a partir de preferências individuais, pode-se recorrer a esquemas hipotéticos, em que os indivíduos escolheriam sem a interferência de contingências naturais. Porém, esse não é o melhor caminho, já que tende a estabelecer um mínimo imutável e fixo, haja vista que só seria possível a escolha numa situação originária hipotética em que todos fossem neutros e imparciais e, ainda, em que todos fossem iguais, não havendo, portanto, qualquer tipo de pluralismo. Nesse sentido, há que se criticar um rol de necessidades mínimas baseado em "uma lista predeterminada e canônica" e, às vezes, universal, sem que se considere, assim, o contexto em que ela será aplicada, ${ }^{24}$,embora não se afaste a possibilidade de construir-se uma lista. Assim, a eleição do que é ou do que compõe o mínimo existencial é feita a partir de opções políticas. A escolha em si é baseada em hipóteses (opiniões do que seriam melhores condições ao desenvolvimento social), mas o seu fundo é real, já que há o conhecimento, por exemplo, das desigualdades que cercam a sociedade.

Dessa maneira, a partir daquilo que a CF estabelece, pode-se tentar construir uma lista de direitos que formam o mínimo existencial e que são válidos para a sociedade brasileira: pagamento de uma renda mínima per capita, que varie de acordo com a inflação e com a carga tributária, permitindo ao indivíduo uma dieta equilibrada e a compra de itens básicos para a sua sobrevivência; fornecimento, com qualidade, de moradia básica a todas as pessoas, nela incluídos sistemas eficientes e ambientalmente sustentáveis de energia elétrica, água encanada e esgoto; oferecimento de ensino básico público adequado e gratuito; oferecimento de um sistema público, eficiente e gratuito, de assistência à saúde; oferecimento de transporte público eficiente, seguro e gratuito; manutenção de segurança pública eficiente; realização de políticas públicas adequadas e eficientes de combate e erradicação da pobreza; financiamento de programas de infraestrutura de transportes, de desenvolvimento econômico e de amparo ao trabalhador; manutenção de um sistema de seguridade social eficiente e ao menos não deficitário; oferecimento de subsídios a preços e transporte de álcool combustível, gás natural e seus derivados e derivados de petróleo; financiamento de projetos ambientais relacionados com a indústria petrolífera e de gás.

Embora não haja uma certeza de que o rol acima seja de fato a representação do mínimo existencial, é possível dizer que há uma tendência ao reconhecimento de parte dos direitos ali presentes como necessidades mínimas, devendo, portanto, o Estado concretizá-las a partir do uso do dinheiro arrecadado ao erário

22 DE LUCAS, Javier; AÑÓN ROIG, Maria José. Necesidades, razones, derechos. Doxa, n. 7, p. 60-61, 1990. DE VITA, Álvaro. A justiça igualitária e seus críticos. 2. ed. São Paulo: M. Fontes, 2007. p. 155; WALZER, Michael. Esferas da justiça: uma defesa do pluralismo e da igualdade. Trad. Jussara Simões. São Paulo: M. Fontes, 2003. p. 88.

23 ZIMMERLING, Ruth. Necesidades básicas y relativismo moral. Doxa, n. 7, 1990. p. 24; RAWLS, John. Uma teoria da justiça. Trad. Almiro Pisetta e Lenita Maria Rímoli Esteves. 2. ed. São Paulo: M. Fontes, 2002. p. 97-98.

24 Ver, dentre outros: SEN, Amartya. Human rights and capabilities. Journal of Human Development, v. 6, n. 2, 2005. p. 158. 
com o pagamento de tributos. A maneira certa de esvaziar os cofres públicos é com a aplicação da maior parcela dos gastos na realização dos direitos fundamentais. Quando o Estado desvia o dinheiro público da finalidade à qual ele serviria - seja pelo excesso de economia para o pagamento da dívida pública, seja pelo gasto excessivo com servidores públicos - viola não apenas o mínimo existencial, como os direitos fundamentais e a dignidade humana. ${ }^{25}$ Para contornar a violação de direitos, o Estado utiliza-se de uma visão deturpada do discurso da reserva do possivel, asseverando que é impossível a concretização de direitos porque as necessidades humanas são infinitas e o dinheiro público é escasso. ${ }^{26} \mathrm{O}$ problema é que esse discurso equivocado, além de manter a violação dos direitos fundamentais pela inércia do Estado em concretizá-los, demonstra que recursos públicos são mal geridos e que as opções políticas e orçamentárias são ruins. ${ }^{27}$

A expressão reserva do possivel em seu sentido originário comporta a ideia de que a sociedade deveria delimitar a razoabilidade da exigência de determinadas prestações sociais, a fim de impedir o uso dos recursos públicos disponíveis para realizar preferências. ${ }^{28}$ Em outras palavras, pela doutrina da reserva do possível, o Estado deve concretizar a igualdade mediante políticas públicas voltadas para as necessidades mínimas. A reserva constitui-se, então, na verdade, em uma reserva para o mínimo, estabelecendo o emprego dos recursos financeiro-orçamentários estatais para atender às necessidades básicas e, depois, mantê-las e, se houver sobra de capital, investir no que não for básico. Todavia, esse discurso parece não ser do agrado do Estado. ${ }^{29}$ A ideia de reserva para o minimo, tal qual cunhada pelo Tribunal Constitucional Federal alemão, tem íntima relação com a formação de uma lista de necessidades básicas, escolhidas cuidadosa e detidamente, devido à escassez dos recursos públicos para seu financiamento. ${ }^{30}$ A reserva é fundamental, nesse sentido, para a constituição daquilo a que se chama de conteúdo essencial do mínimo existencial. ${ }^{31}$ Assim, tem-se o conteúdo essencial como uma garantia que limita a atividade estatal excessiva ou deficiente, ou mesmo a inatividade; enquanto o minimo existencial atua como uma garantia ampliadora dos direitos, obrigando o Estado a direcionar recursos à sua concretização adequada e eficaz.

Apesar da reconhecida dificuldade em se indicar com alguma precisão quais direitos formam o mínimo existencial, pode-se dizer, como já ressaltado, que há algum acordo quanto a determinados direitos. Entretanto, o escopo do presente trabalho não permite que se estenda sobre os fatores para a elaboração de uma lista. O que, aliás, convida a uma observação mais detida é aquilo a que se chamou de conteúdo essencial, e que permite uma análise de custo-benefício, em que há a preocupação de maximizar a concretização de direitos a partir do uso adequado da verba pública disponível..$^{32} \mathrm{E}$ nessa análise, é absolutamente saudável que o Estado seja envolvido, já que sua atuação é muito semelhante à de uma empresa prestadora de serviços, não fosse sua vantagem de poder fechar contratos cujo custo é tanto menor que aquele alcançado por empresas privadas prestadoras de serviços. ${ }^{33}$

25 Ver neste sentido, por exemplo: CALIENDO, Paulo. Direito tributário e análise econômica do direito: uma visão crítica. Rio de Janeiro: Elsevier, 2009. p. 201.

26 CANOTILHO, José Joaquim Gomes. Metodología "fuzzy” y “camaleones normativos” en la problemática actual de los derechos económicos, sociales y culturales. Derechos y Libertades, n. 6, 1998. p. 46; CANOTILHO, José Joaquim Gomes. Direito constitucional e teoria da constituição. 7. ed. Coimbra: Almedina, 2003. p. 481.

27 Ver, por exemplo: VAZ, Anderson Rosa. A cláusula da reserva do possível como instrumento de efetivação planejada dos direitos humanos econômicos, sociais e culturais. Revista de direito constitucional e internacional, n. 66, 2009. p. 35.

28 MARTINS, Leonardo (Org.). Cinquenta anos de jurisprudência do Tribunal Constitucional Federal alemão. Montevideo: Fundação Konrad Adenauer, 2005. p. 663-664.

29 Ver, dentre outros: FARO, Julio Pinheiro. Os vinte anos da constituição brasileira: da reserva do possível à proibição do retrocesso social. In: FARO, Julio Pinheiro; TEIXEIRA, Bruno Costa; MIGUEL, Paula Castello (coord.). Uma homenagem aos vinte anos da constituição brasileira. Florianópolis: Boiteux, 2008; KRELL, Andreas Joachim. Realização dos direitos fundamentais sociais mediante controle judicial da prestação dos serviços públicos básicos (uma visão comparativa). Revista de Informação Legislativa, n. 144, 1999. p. 241-242; FREIRE JÚNIOR, Américo Bedê. O controle judicial de políticas públicas. São Paulo: Revista dos Tribunais, 2005 , p. 74.

30 WALZER, Michael. Esferas da justiça: uma defesa do pluralismo e da igualdade. Trad. Jussara Simões. São Paulo: M. Fontes, 2003. p. 88.

31 Ver, por exemplo: LOPES, Ana Maria D’Ávila. A garantia do conteúdo essencial dos direitos fundamentais. Revista de Informação Legislativa, n. 164, 2004.

32 CALIENDO, Paulo. Obra citada, 2009. p. 209.

33 COASE, Ronald H. The problem of social cost. The Journal of Law and Economics, v. 3, 1960. p. 17. 
Tal análise levará em conta o custo de determinadas políticas públicas e o benefício por elas proporcionado aos indivíduos e à sociedade. Dentro do cálculo do custo inclui-se, por exemplo, saber se é mais viável e menos oneroso para a sociedade que o Estado, através de seus órgãos, elabore e execute as políticas públicas, ou se é tanto melhor que haja um procedimento licitatório que permita que empresas privadas concorram, através de critérios como a técnica mais adequada e o menor custo, para a prestação de tais políticas; ou, ainda, em que tipos de políticas públicas (voltadas para a realização de que direitos) o dinheiro público deve ser alocado. Por sua vez, o cálculo do benefício engloba os ganhos que toda a sociedade, ou um determinado grupo de indivíduos obteve com concretização de direitos fundamentais decorrente da realização de políticas públicas. A análise desses dois tipos de cálculo deve ser feita antes de se concretizar qualquer ação em prol de uma política pública, trabalhando-se, portanto, com previsões qualitativas e quantitativas. A análise de custo-benefício permite, portanto, que o Estado direcione com eficiência a receita derivada da arrecadação de tributos, além, é claro de outras receitas (não tributárias). O resultado disso é a melhor concretização dos direitos fundamentais. Ou seja, se o dever dos indivíduos é pagar tributos para a formação de receita para o Estado, então o dever do Estado é gerir e utilizar da melhor forma possível esse capital para concretizar direitos.

\section{O deVER ESTATAL DE CONCRETIZAR DiREITOS}

Retomando a ideia do Estado como uma empresa prestadora de serviços públicos, há que se discorrer sobre o dever estatal de alocar da melhor forma possível os recursos públicos, tanto no que diz respeito ao custeio de seus serviços, quanto à concretização de direitos. O certo é que se trata de uma empresa bastante peculiar, já que dispõe de prerrogativas que nenhuma outra empresa em um regime de livre e aberta concorrência possui. As prerrogativas, é claro, se justificam pela natureza dos serviços prestados e pela necessidade de que isso ocorra segundo o melhor custo-benefício possível.

Dentre as várias teorias que se relativas à análise de custo-benefício, especialmente no que se refere ao custo de políticas públicas para a concretização de direitos fundamentais, pode-se citar aquela segundo a qual os benefícios serão menores que os danos potenciais apenas se o agente for negligente, vale dizer, se não tomar as precauções devidas em termos de custos. ${ }^{34}$ Aplicando-se essa teoria ao campo de estudo aqui desenvolvido, pode-se dizer que a Administração Pública deve tomar todas as precauções cabíveis e realizar todos os estudos prévios possíveis antes de alocar qualquer percentual do dinheiro público na realização de políticas voltadas para a concretização de direitos. Assim, autorizada a execução da política pública, após a sua realização, será feito um acompanhamento e uma avaliação, a fim de se levantarem informações sobre a relação custo-benefício e apurar se houve alguma negligência, com o intuito de responsabilização dos responsáveis. A responsabilização, nesse caso, não tem a ver com o Estado - pois, se assim o fosse, a sanção aplicável recairia sobre a parte prejudicada pela negligência estatal, isto é, a sociedade -, mas com seus agentes - pessoas físicas ou jurídicas, conforme o caso - que não agiram com a devida diligência. ${ }^{35}$

A ideia contratualista aplicada ao Estado é perfeitamente viável. Assim como todos os contratos, há dois polos. A sociedade e cada um dos indivíduos que a compõem estão naquele polo chamado, genericamente, ativo, que deve financiar a realização de políticas públicas e a que se deve a concretização de direitos. O Estado ocupa, por sua vez, o polo passivo, a que se deve o pagamento de tributos e que deve concretizar direitos. Existe, aqui, já uma primeira particularidade: o polo passivo é ocupado por agentes (servidores) públicos que fazem parte do polo ativo também. O que permite que essa peculiaridade não seja determinante é a ficção de que os indivíduos que atuam na Administração Pública ocupam cargos e, na posse deles, pertencem

34 POSNER, Richard A. Problemas de filosofia do direito. Trad. de Jefferson Luiz Camargo, São Paulo: M. Fontes, 2007. p. 73 e 480.

35 Entendimento interessante sobre a responsabilização é desenvolvido em: FARO, Julio Pinheiro; GOMES, Marcelo Sant'Anna Vieira. A disregard doctrine e a administração pública. Revista sintese responsabilidade pública, v. 1, n. 1, 2011. 
apenas ao polo passivo (fição dos cargos públicos). Da relação entre devedor e credor decorre a possibilidade de responsabilização por algum dano provocado por qualquer dos polos: se um contribuinte não pagar certo tributo estará sujeito a uma sanção, por meio da qual pagará o tributo atualizado monetariamente e juros de mora; ou, por outra, se um servidor público deixa de observar normas quanto à alocação de recursos, seja alocando-os mal, seja desviando-os, estará sujeito à responsabilização por improbidade.

E nisso se insere um interessante problema: a questão das prerrogativas de função, decorrentes, inexplicavelmente, da tese da ficção dos cargos públicos. Ora, se um servidor público, em decorrência do exercício de sua função pública, age com negligência, o primeiro efeito a ser gerado deveria ser a desconsideração da ficção a que ele se submete, e sua imediata, com as garantias de praxe, responsabilização. No entanto, o que ocorre é que, além de ser mantida a ficção, é-lhe dada uma prerrogativa, algo como uma bonificação por sua conduta reprovável. Prerrogativa esta que, aliás, transfere, em geral, o processamento e o julgamento de sua causa de um juízo monocrático para um juízo colegiado, diluindo a possibilidade de que haja a aplicação das sanções devidas.

Não obstante essa desproporção decorrente da ficção dos cargos públicos há, ainda, a teoria das cláusulas contratuais exorbitantes. Trata-se de mais outra garantia conferida ao Estado. Se a prerrogativa de função beneficia os servidores públicos em detrimento do polo credor, que não desfruta dessa bonificação, a garantia das cláusulas exorbitantes, além de prejudicar o polo credor, quando o Estado atua como devedor, também opera contra empresas que fazem o papel do Estado. Há que se explicar melhor essa questão. Na primeira relação enunciada, o Estado age como devedor (da realização de políticas públicas para concretização de direitos fundamentais) da sociedade e dos indivíduos, que agem como credores. Na segunda relação, o Estado, incapaz de realizar políticas públicas com seu próprio maquinário, contrata, em nome dos credores da primeira relação, com terceiros, em geral empresas privadas, por meio de licitação, para que se forme um subcontrato administrativo, com o fim de que sejam realizadas as políticas públicas.

Pois bem, no direito contratual comum (regime privado), quando o devedor delega ou mesmo concede a terceiro a realização de sua obrigação, pode fazê-lo em seu próprio nome e por sua própria conta, caso não procure o consentimento do credor, ou em nome e à conta do credor, caso este dê seu consentimento. No direito contratual público, o princípio da supremacia do interesse público gera a presunção de que há o consentimento do credor para que o Estado efetue tais subcontratos. E, em virtude desse princípio e do princípio da indisponibilidade do interesse público, tais subcontratos conferem ao devedor (da primeira relação) certos direitos que se situam fora daquilo que seria comum se esperar, daí serem cláusulas exorbitantes - ou, caso se inverta o polo, certos deveres que estão além do que é comum. Um exemplo curioso é o caso de a Administração Pública, pela falta de planejamento prévio, parar de pagar o terceiro (subcontratado) por seus serviços, e este ter, ainda assim, de manter a prestação, já que os serviços públicos devem ser contínuos.

Ocorre que não há a presunção absoluta do consentimento do credor (da primeira relação) pela realização de um subcontrato, de modo que, havendo, comprovadamente, dolo ou culpa - aí de novo - por parte dos servidores públicos que deviam atuar com diligência do exercício de seus encargos, há a desresponsabilização do credor (da primeira relação) e a consequente responsabilização do devedor (da primeira relação), já que o princípio da supremacia do interesse público não pode servir para justificar a prática de atos ilícitos ou praticados sem a necessária diligência. Portanto, o Estado, nas relações promovidas por seus servidores, possui benefícios que, do modo como são habitualmente utilizados, acabam prejudicando o polo que deveria ser beneficiado, isto é, a sociedade e os indivíduos. Assumindo, contudo e com otimismo, que tais benesses sejam utilizadas apenas em último caso e que os encargos públicos sejam exercidos com a melhor diligência possível, vislumbra-se mais nitidamente uma grande vantagem que a Administração Pública possui - embora não lhe seja exclusiva: a barganha.

A barganha é uma prática comercial bastante comum e que se baseia numa análise de custo-benefício. Nesta análise, não só o comprador como também o vendedor pesam, de acordo com seus respectivos interesses, se o benefício de uma determinada transação supera o seu custo. A barganha leva justamente em 
consideração fatores que permitam diminuir os custos e aumentar os benefícios na transação. O resultado é o mútuo benefício. O procedimento de licitações praticado pelo Estado nada mais é que uma barganha, pelo que a Administração Pública estipula, por exemplo, que a proposta que contiver a melhor técnica e o menor preço para a prestação de um determinado serviço é que sairá vencedora. Tanto o Estado sabe desse seu poder que o utiliza, embora por vezes o faça sem a devida diligência quanto à análise sobre o custo-benefício, como as empresas concorrentes dele têm conhecimento, utilizando-o a seu favor, embora nem sempre com boa-fé, no intuito de ter uma fonte certa e determinada de receita.

Esta ideia, que não é nova ${ }^{36}$ e o que é bastante interessante, permite tratar o Estado como uma superfirma muito peculiar, que pode influenciar por suas decisões administrativas o uso de fatores de produção pelas firmas privadas, gerando uma concorrência em que o vencedor será aquele que atender da melhor forma o Estado, isto é, com a técnica mais adequada e com o menor preço. ${ }^{37}$ Portanto, se a Administração Pública não consegue, por seus próprios meios, isto é, se a combinação entre os recursos públicos e o maquinário estatal e servidores públicos não consegue realizar com eficiência políticas públicas que concretizem direitos, pelo menos uma de duas medidas deve ser adotada, embora seja mais produtiva a adoção de ambas. Pois bem, a primeira medida que se vislumbra é a realização de concursos licitatórios para que se efetuem contratos com empresas capazes de eficientemente realizar as políticas públicas que forem necessárias. A segunda é a criação de órgãos administrativos e/ou agências reguladoras que estabeleçam diretrizes de execução dessas políticas e que fiscalizem cada uma das etapas do processo de contratação. Vale listar: planejamento pré-licitação, autorização da licitação, apuração do resultado da licitação, fechamento do contrato com o vencedor, execução do objeto do contrato, controle e avaliação dos resultados e correção de falhas.

Nessa linha, há que se repisar que o Estado, por meio da Administração Pública, tem o dever de colocar em prática e com eficiência políticas públicas que concretizem direitos, com o uso esperado (correto) dos recursos públicos na melhor relação possível de custo-benefício. A concretização de direitos depende, portanto, da existência de todo um maquinário institucional (estatal) que reúna e direcione os recursos formados a partir da arrecadação de tributos junto à sociedade.$^{38}$ Esse maquinário, assim como a concretização de direitos, tem seu custo. Na verdade, o custo é extremamente alto, já que é comum a falta de planejamento e a presença de burocracia desnecessária para o atendimento das obrigações estatais, aquilo a que se pode denominar de atividade estatal prestacional, consistente na realização de políticas públicas para a concretização de direitos. A burocracia desnecessária e a ausência de um planejamento apropriado são dois dos fatores que compõem aquilo a que se chama falibilidade da administração pública, uma vez que todas as escolhas são políticas e, não raro, os resultados gerados são inapropriados. ${ }^{39}$ Quando as falhas são eventuais, o resultado de alguma tomada de decisão estatal - que pode ser uma ação ou mesmo uma omissão -, apesar de inapropriado, tende a ser irrelevante. No entanto, em geral, essas falhas são habituais, prejudicando, assim, a eficiência da atividade estatal prestacional.

A eficiência é uma característica inerente à Administração Pública. No entanto, há uma séria dificuldade por parte do Estado em alcançá-la adequadamente. A explicação talvez possa estar na ausência de livre iniciativa e/ou livre concorrência em setores de atuação exclusiva ou privativa do Estado. Ora, no mercado, quando a livre iniciativa e a livre concorrência são respeitadas, a eficiência é simplesmente uma consequência natural (ideia de mão invisível): as empresas existentes num mesmo ramo da economia trabalham para que a maior parte dos clientes de determinado produto sejam seus. Para que isso seja possível, a empresa tem de ser eficiente, isto é, o seu processo produtivo tem de ser o melhor daquele setor econômico, vale dizer, a produção deve atender melhor o mercado e com menos custo. Eficiência é, portanto, fazer melhor e com o menor custo.

36 Ver, por exemplo: COASE, Ronald H. The problem of social cost. The Journal of Law and Economics, v. 3, 1960. p. 17.

37 Ver: COASE, Ronald H. The problem of social cost. The Journal of Law and Economics, v. 3, 1960. p. 17-18.

38 IMMORDINO, Giovanni; PAGANO, Marco. The cost of rights: an economic analysis. Diritto \& Questioni Pubbliche, n. 4, 2004. p. 85.

39 Ver, neste sentido: COASE, Ronald H. The problem of social cost. The Journal of Law and Economics, v. 3, 1960. p. 18. 
A atuação estatal funciona como um sistema em que inexiste livre concorrência, devendo o consumidor (a sociedade e os indivíduos) se satisfazer com a única empresa que tem a credencial para atuar em certo ramo (realização de políticas públicas), não tendo como reclamar do padrão de eficiência, já que inexistem concorrentes. A não ser no caso em que o Estado afirma a sua ineficiência e possibilita, conforme critérios próprios de conveniência e oportunidade, que empresas privadas concorram para realizar determinadas políticas públicas. Aliás, apenas para fins de registro, há que se verificar como contrastam a ineficiência estatal e a eficiência de certas empresas privadas em casos paradigmáticos como a educação e a saúde.

Ante esse quadro, a Administração Pública deve buscar, nos três âmbitos do Poder do Estado, especialmente a partir do Legislativo e do Executivo, criar mecanismos e também instrumentos que permitam uma alocação eficiente de recursos. Entende-se, aqui, que, talvez a melhor opção seja adotar uma lista de necessidades humanas básicas ordenadas conforme o seu grau de prioridade para a sociedade ou determinado setor dela e alocar os recursos com a melhor relação custo-benefício que se puder alcançar no intuito de concretizar as necessidades (direitos) consideradas prioritárias. Isso permite retomar dois temas já enfrentados aqui, isto é, possibilita dizer que a realização do mínimo existencial depende que o Estado possua uma reserva de recursos.

Entretanto, alocar os recursos para promover o mínimo existencial ou o seu conteúdo essencial não significa o simples direcionamento, como se a concretização de cada direito não dependesse da concretização dos demais. Ao contrário, é preciso haver um planejamento dos gastos estatais. De aí que se não há recursos suficientes para concluir uma política pública, a sua realização deve ser iniciada ${ }^{40} \mathrm{com}$ o planejamento de que a próxima disponibilidade de recursos seja alocada de melhor jeito para sua conclusão, ou até mesmo para a sua eventual expansão. ${ }^{41} \mathrm{O}$ planejamento e a alocação, que deveriam ser ininterruptos, trazem a questão da irreversibilidade da concretização dos direitos fundamentais. Trata-se de uma vedação que estabelece que aquilo que já foi concretizado deve ser pelo menos mantido, em virtude do necessário respeito ao mínimo existencial ou ao seu conteúdo essencial, e, assim que possível, ser maximizado. Entende-se, então, a irreversibilidade como uma garantia cujo objetivo é manter a concretização de direitos, especialmente aqueles de natureza prestacional. E, nesse sentido, há íntima relação entre a reserva do possível em sua acepção original e a vedação da reversibilidade da concretização de direitos fundamentais, já que ambas se referem àquilo que o indivíduo pode razoável e racionalmente exigir da sociedade. ${ }^{42}$

A finalidade dessa característica intrínseca a todos os direitos fundamentais é evitar que a Administração Pública com suas decisões, ações e omissões cause uma situação de possível retrocesso social. Isso porque, uma vez concretizados determinados direitos, eles passam a vincular o Estado à sua necessária manutenção (irreversibilidade da concretização) e impedem ${ }^{43}$ que a Administração Pública aja com excesso, alocando desnecessariamente recursos, ou no sentido de promover a sua redução ou anulação, deixando de alocá-los devidamente. Esses impedimentos geram duas vedações que a Administração Pública deve observar: uma é a proibição de excesso, outra é a proibição de proteção deficiente. Sob a vedação de excesso, procura-se evitar que sejam alocados desnecessariamente recursos em políticas públicas satisfatoriamente realizadas em detrimento de outras políticas públicas que serviriam para a concretização de outros direitos que carecem de eficácia. Objetiva-se impedir que, sob o argumento da irreversibilidade da concretização de certo direito, não sejam destinados recursos suficientes para concretizar outros direitos. Pela vedação da proteção deficiente, direciona-se a Administração Pública a um dever de dupla finalidade: manter uma destinação de recursos nem excessiva, nem deficiente para a manutenção da

40 FREIRE JÚNIOR, Américo Bedê. O controle judicial de politicas públicas. São Paulo: Revista dos Tribunais, 2005. p. 74.

41 CANOTILHO, José Joaquim Gomes. Metodología "fuzzy” y "camaleones normativos" en la problemática actual de los derechos económicos, sociales y culturales. Derechos y Libertades, n. 6, 1998. p. 47.

42 Neste sentido: KRELL, Andreas Joaquim. Direitos sociais e controle judicial no Brasil e na Alemanha: os (des)caminhos de um direito constitucional "comparado". Porto Alegre: SAFE, 2002. p. 52; QUEIROZ, Cristina M. M. O princípio da não reversibilidade dos direitos fundamentais sociais: princípios dogmáticos e prática jurisprudencial. Coimbra: Coimbra, 2006. p. 68.

43 Ver, dentre outros: DERBLI, Felipe. O princípio da proibição de retrocesso social na Constituição de 1988. Rio de Janeiro: Renovar, 2007. p. 176. 
eficácia de direitos já concretizados e alocar recursos para a concretização de todos os outros direitos que ainda carecem de concretização ou de concretização adequada. Em breve síntese, a Administração Pública tem o papel de elaborar, de implantar e de manter políticas públicas que concretizem com eficiência os direitos que se considerem prioritários, maximizem-nos e impeçam que o Estado influencie negativamente o exercício de direitos fundamentais pelas pessoas, ou seja, que o Estado não dê a devida proteção aos direitos.

A imperiosa necessidade de que o Estado cumpra com o seu dever fundamental, que terá sérias consequências sobre a concretização dos direitos fundamentais, faz com que sejam editados atos administrativos para a elaboração e execução de políticas públicas.

Os atos administrativos são fundamentalmente atos jurídicos. Isto é, declarações de vontade unilaterais e com finalidade pública emanadas da Administração Pública e aptas a produzir efeitos jurídicos para a própria Administração, incluindo seus servidores, e para seus administrados. ${ }^{44}$ Dentro dessa conceituação, destaca-se que os atos administrativos devem ter necessariamente finalidade pública, sendo considerado nulo todo ato que se desviar dessa finalidade.

A concretização dos atos administrativos pode ocorrer de variadas maneiras, mas, em geral, sempre culminará na realização de um serviço público. O conceito de serviço público varia de acordo com a conveniência de quem tenta the estabelecer as bases. Contudo, alguns elementos essenciais podem ser apontados: devem ser prestados pela Administração ou por quem atue em seu lugar, sujeitam-se às normas jurídicas e aos controles externo e interno e vinculam-se à finalidade pública em razão da qual são executados. ${ }^{45} \mathrm{~A}$ conveniência deste trabalho sugere, então, uma conceituação estrita de serviço público, que, na verdade, acaba por ser a conceituação de políticas públicas: prestações estatais com o objetivo de concretizar direitos fundamentais. Nesse sentido, o Estado, por meio de sua Administração Pública, tem o dever de prestar políticas públicas para concretizar os direitos fundamentais. Portanto, uma primeira conclusão que se alcança é de que os atos administrativos dão origem às políticas públicas, cuja finalidade está vinculada à concretização de direitos.

Guardando essa conclusão, deve-se tratar sobre vinculação e discricionariedade dos atos administrativos. Diz-se que a distinção entre atos vinculados e atos discricionários tem a ver ou com o motivo (causação que enseja a prática do ato), ou com o objeto (resultado prático que se quer obter), ou com ambos, porque são esses dois elementos que formam aquilo a que se chama mérito do ato administrativo. Sempre haverá mérito administrativo quando for realizada uma análise de custo-benefício pela Administração. Como se espera que sempre haja essa análise, faz-se imperioso distinguir os dois tipos de atos. Uma premissa é básica: todos os atos administrativos são vinculados à finalidade pública. Como a finalidade é apenas um dos requisitos para a validade e a eficácia dos atos administrativos, é plenamente possível que um mesmo ato tenha finalidade vinculada e motivo e/ou objeto discricionário; aliás, a única combinação inviável é a de que todos os requisitos decorram de discricionariedade. ${ }^{46}$

Afirma-se, então, que a competência para executar ${ }^{47}$ - e não a competência para criar - atos administrativos pode ser vinculada ou discricionária. Todavia, não se pode dizer que haja uma relação antitética, e sim que há uma relativização da ideia de discricionariedade, ${ }^{48}$ já que não há um ato completamente discricionário - ou um ato desvinculado, ou até mesmo arbitrário. Portanto, inexiste um ato administrativo discricionário desvinculado, o que existe é a possibilidade de que a Administração Pública decida, se a lei não dispuser em

44 Nesse mesmo sentido: MEIRELLES, Hely Lopes. Direito administrativo brasileiro. 22. ed. São Paulo: Malheiros, 1997. p. 132-133.

45 Ver: MEIRELLES, Hely Lopes. Direito administrativo brasileiro. 22. ed. São Paulo: Malheiros, 1997. p. 297.

46 Com a mesma percepção, ver, por exemplo: FREITAS, Juarez. Discricionariedade administrativa e o direito fundamental boa administração pública. 2. ed. São Paulo: Malheiros, 2009. p. 82.

47 Nesse sentido, dentre outros: MELLO, Celso Antônio Bandeira de. Discricionariedade e controle jurisdicional. 2. ed. São Paulo: Malheiros, 2008. p. 9 e 18. Para uma crítica à ideia de discricionariedade, ver, por exemplo: OMMATI, José Emílio Medauar. Do ato ao processo administrativo: a crise da ideia de discricionariedade no direito administrativo brasileiro. Revista dos Tribunais, São Paulo, n. 930, abr. 2013.

48 MELLO, Celso Antônio Bandeira de. "Relatividade" da competência discricionária. Anuario Iberoamericano de Justicia Constitucional, n. 8, 2004. p. 18 . 
outro sentido, se a ocorrência de uma determinada situação é causa para a edição de um ato administrativo e determine, com respeito à finalidade do ato, qual o seu conteúdo. Assim, a discricionariedade tem a ver com o como e com que meios a finalidade interesse público será atingida a partir da realização de um serviço público, isto é: que tipo de serviço público será executado, por quem e com qual resultado prático.

Logo, possibilita-se à Administração Pública escolher dentro de padrões razoáveis de clareza, congruência e de custo-benefício que serviços prestar para concretizar direitos. Essa liberdade de escolha é conferida pelas normas jurídicas já estabelecidas, que delimitam o juízo (de mérito) administrativo ao mínimo a ser atingido, a fim de que o benefício público seja maior que o custo para alcançá-lo. E esse mínimo é aquilo a que já se chamou de mínimo existencial ou, ainda, quando for o caso, seu conteúdo essencial, vedando-se a reversibilidade do que já foi concretizado, sempre mediante a alocação eficiente de recursos. É dever, pois, do Estado criar e executar serviços públicos baseado em um estudo prévio que revele o custo-benefício mais viável para a concretização de direitos. Entretanto, se a realização de serviços públicos fosse o único meio para a eficácia de direitos fundamentais, ela certamente estaria confinada em um campo muito restrito, o da atuação da Administração Pública e, quando muito, de seus delegatários. Daí que, não são apenas os serviços públicos que servem à concretização de direitos, mas também as políticas públicas.

A expressão políticas públicas é mais abrangente que a expressão serviços públicos, já que se refere a um planejamento envolvendo um programa e que se executa por meio de atos administrativos que se consolidarão em serviços públicos. ${ }^{49} \mathrm{O}$ conceito de política pública pressupõe, pois, a harmonia entre as atividades desenvolvidas pela Administração e seus delegatários - que é o que se denominou anteriormente de serviços públicos - e pelas entidades privadas em prol da concretização de direitos. Essa possibilidade que o Estado tem de delegar e de permitir que empresas privadas atuem em seu auxílio cria-lhe deveres de regulamentação, de coordenação e de fiscalização, para que a prestação de tais serviços de interesse público seja mais eficiente e atenda aos valores sociais plasmados, ou não, no texto constitucional.

A realização de políticas públicas está sujeita a controle, especialmente no que diz respeito à relação custo-benefício gerada pela alocação de recursos, além dos controles de constitucionalidade, supralegalidade, legalidade e sobre o atendimento dos atos infralegais. No caso dos serviços compartidos, isto é, prestados livremente por empresas privadas, sem a necessidade de qualquer delegação pelo Estado, o controle sobre o custo-benefício ou, ainda, sobre a eficiência do serviço de interesse público prestado, será feito pelo mercado. Por exemplo, se uma escolha fornece o melhor ensino a um preço mais baixo que as concorrentes, se um plano de saúde oferece mais e melhores benefícios a um preço mais baixo do que seus concorrentes, a preferência do consumidor será pela instituição que lhe permita pagar o menor preço e ter os melhores (ou mais) benefícios. Além desse controle mercadológico, há que se considerar o controle estatal sobre a observância pelas empresas privadas das normas legais, regulamentares e constitucionais. Nesse sentido, há que se verificar, por exemplo, se certa instituição de ensino segue todos os requisitos constitucionais para desfrutar de imunidade tributária, além do que se deve checar se ela cumpre a legislação sobre as diretrizes básicas da educação, e também as normas regulamentares que operacionalizam tudo isso. No caso dos serviços públicos e das políticas públicas, como a única concorrência existente ocorre apenas no procedimento licitatório, quando este existe, há, portanto, um controle mais burocrático, pois não é possível simplesmente trocar o fornecedor menos ou ineficiente por um que seja mais ou eficiente. Portanto, o controle não ocorrerá apenas pelos consumidores diretamente atingidos, mas também pelos atingidos indiretamente, já que, ao contrário do que ocorre no caso dos serviços compartidos, o dinheiro utilizado para a prestação de serviços públicos é de toda a sociedade, obtido por meio do cumprimento do dever social de pagamento de tributos.

Tem-se, pois, o controle dos serviços públicos concretizadores de direitos ou, ainda, como se encontra mais frequentemente na doutrina, o controle da Administração Pública, cujo objetivo é realizar o controle de eficiência

49 Ver, no mesmo sentido: BUCCI, Maria Paula Dallari. Políticas públicas e direito administrativo. Revista de Informação Legislativa, n. 133, 1997, p. 90; BUCCI, Maria Paula Dallari. O conceito de política pública. In: BUCCI, Maria Paula Dallari (Org.). Políticas públicas: reflexões sobre o conceito jurídico. São Paulo: Saraiva, 2006. p. 39. 
da atividade estatal na alocação de recursos públicos, a fim de que sejam respeitadas as regras e finalidades que a ordem jurídica impõe a esta atuação, ${ }^{50}$ evitando-se ou corrigindo-se, com isso, alguns desvios que possam vir a ocorrer, como os desvios de finalidade dos atos administrativos, os desvios de recursos públicos, a aplicação excessiva ou deficiente de recursos em determinados serviços públicos, a ausência de planejamento prévio de custo-benefício, a manutenção de contratos onerosos e de serviços equivocados, dentre outros problemas. O controle deve partir, em primeiro lugar, do próprio Estado, que, ao produzir um ato administrativo, deve prestar atenção para que ele atenda ao interesse público. Trata-se, aqui, do autocontrole da Administração Pública, ou controle interno, pelo que o Estado dá a seus cidadãos pelo menos uma certeza teórica de que o interesse público está sendo atendido e de que há planejamento de custo-benefício para alocação eficiente dos recursos públicos. ${ }^{51}$. No controle de seus atos, a Administração pode tanto anulá-los ou revogá-los. A anulação de atos administrativos se dá quando se verificar que o ato é ilegal ou ilegítimo. Por sua vez, a revogação ocorrerá quando a manutenção do ato for inconveniente ou inoportuna para o interesse público, devendo-se resguardar os direitos adquiridos, já que, nesse caso, os atos são legais e legítimos.

Além do autocontrole, existe necessariamente o controle externo, já que é possível, na mais otimista das hipóteses, que o controle interno falhe. Como se depreende do nome, trata-se de controle feito por agentes desvinculados da atividade administrativa do Estado. O controle legislativo ou político é uma das formas de controle externo. Ocorre que o Poder Legislativo tem certas competências exclusivas como, a fiscalização e o controle dos atos da Administração Pública, direta e indireta, a sustação dos atos normativos da Administração Pública que exorbitem suas funções e o julgamento anual das contas prestadas pelo Chefe do Executivo. E poderá também exercer, ao lado do Tribunal de Contas, o controle financeiro, isto é, fiscalizar todas as contas da Administração Pública. Outro tipo de controle externo é o controle jurisdicional ou judicial, pelo que se opera a apreciação quanto à legalidade ou à legitimidade dos atos administrativos. ${ }^{52}$ Nessa senda, cabe ao Poder Judiciário tecer seu juízo podendo anular tais atos se eles estiverem eivados por alguma ilegalidade ou ilegitimidade. São várias as opções disponíveis na ordem jurídica para a correção judicial do comportamento, comissivo ou omissivo, administrativo. Podem-se citar como exemplos, as medidas cautelares, as ações possessórias em geral, o habeas corpus, o mandado de segurança, o babeas data, o mandado de injunção, a ação popular, a ação civil púbica e a ação direta de inconstitucionalidade por ação ou por omissão. Cabe também o controle externo pelo Ministério Público, que pode, valendo-se de sua condição de fiscal do direito, efetuar o controle sobre a prestação de serviços públicos, a partir dos instrumentos que o ordenamento jurídico lhe confere para cumprir o seu papel, isto é, defender o interesse público. O Ministério Público atua ao lado do Poder Judiciário, mas a ele não se vincula. Suas funções básicas (e não as únicas) são: zelar pelo efetivo respeito pelos Poderes Públicos e pelos serviços públicos aos direitos fundamentais, promovendo as medidas necessárias para a sua concretização e promover a ação civil pública para a proteção dos interesses públicos. Por fim, cabe aos cidadãos efetuar, enquanto proprietários do interesse público e dos recursos públicos, o controle social, instrumento do que se convencionou chamar de participação (ou gestão) democrática da coisa pública. Com esse mecanismo, os cidadãos hão de fiscalizar os atos administrativos em prol da defesa da concretização de seus direitos. Há pelo menos dois meios para o exercício desse controle, os direitos de petição e de reclamação relativos aos serviços públicos em geral e específicos para a concretização de direitos fundamentais.

Nesse sentido, verifica-se que o controle de políticas públicas é feito basicamente de três maneiras: pelo controle dos cidadãos (controle mercadológico de serviços compartidos e controle social de serviços

50 BACELLAR FILHO, Romeu Felipe. O controle da administração pública. In: CISNEROS FARIAS, Germán; FERNÁNDEZ RUIZ, Jorge; LÓPEZ OLVERA, Miguel Alejandro (coord.). Control de la administración pública. Segundo Congreso Iberoamericano de Derecho Administrativo. México, DF: UNAM, 2007, p. 34.

51 Nesse sentido, ver: FRANÇA, Phillip Gil. O controle da administração pública: tutela jurisdicional, regulação econômica e desenvolvimento. São Paulo: Revista dos Tribunais, 2008. p. 77.

52 Obra fundamental sobre o assunto é: FAGUNDES, Miguel Seabra. O controle dos atos administrativos pelo Poder Judiciário. 3. ed. Rio de Janeiro: Forense, 1957. 
públicos), pelo controle da Administração Pública (autocontrole ou controle interno) e pelo controle de outros setores do Estado desvinculados da Administração (controles político, financeiro, jurisdicional e pelo Ministério Público). Tudo isso visa a uma mesma meta: fiscalizar o cumprimento do dever estatal de concretizar direitos fundamentais.

\section{Considerações finais}

Pode-se, pois, dizer que a relação jurídica estabelecida entre os indivíduos/sociedade e o Estado deve se pautar na confiança de que ambas as partes cumprirão com suas obrigações e que a elas será dada a igual oportunidade de fiscalizar e de controlar a maneira como as prestações são executadas. Assim, de um lado, os indivíduos/sociedade enquanto credores têm o direito de que os seus direitos sejam concretizados e, como todo credor, devem financiar a atuação do devedor pelo do pagamento de tributos. Do outro lado, o Estado, enquanto devedor, ao receber esse pagamento, deve transformá-lo em capital, gerindo-o e aplicando-o, para que possa investi-lo com eficiência na sociedade por meio da concretização de direitos fundamentais.

Dessa maneira, ante o exposto, é inevitável concluir que os deveres, além de se constituírem em um tema pouco enfrentado, são também condição essencial para a eficácia real dos direitos fundamentais. Ora, dos vários tipos de deveres existentes num sistema constitucional, foram escolhidos dois - dever social de pagar tributos (financiamento de direitos) e dever estatal de concretizar direitos (aplicar os recursos públicos) para o fim de demonstrar o quão importante é a relação entre deveres e direitos e quão é necessário também o estudo daqueles.

Daí se poder dizer que os deveres fundamentais são o óbvio que não se quer ver, e que quando são vistos, normalmente o são de uma maneira egoística, ou seja, apenas o outro tem deveres a cumprir. E isso tem resultado em um paradoxo. O excesso de preocupação com a eficácia dos direitos tem deixado na penumbra a questão dos deveres, resultando em algo bastante interessante, o impedimento da concretização dos próprios direitos. O óbvio que se pretendeu demonstrar com o presente estudo é, assim, o de que os deveres são condição para que haja a concretização de direitos.

\section{REFERÊNCIAS}

AMARAL, Gustavo. Direito, escassez e escolha, Rio de Janeiro: Lúmen Juris, 2010.

AMARO, Luciano. Direito tributário brasileiro. 13. ed. São Paulo: Saraiva, 2007.

ATALIBA, Geraldo. Hipótese de incidência tributária. 6. ed. São Paulo: Malheiros, 2009.

BACELLAR FILHO, Romeu Felipe. O controle da administração pública. In: CISNEROS FARIAS, Germán; FERNÁNDEZ RUIZ, Jorge; LÓPEZ OLVERA, Miguel Alejandro (Coord.). Control de la administración pública. Segundo Congreso Iberoamericano de Derecho Administrativo. México, DF: UNAM, 2007.

BUCCI, Maria Paula Dallari. O conceito de política pública. In: BUCCI, Maria Paula Dallari (Org.). Políticas públicas: reflexões sobre o conceito jurídico. São Paulo: Saraiva, 2006.

BUCCI, Maria Paula Dallari. Políticas públicas e direito administrativo. Revista de Informação Legislativa, n. 133, 1997.

CALIENDO, Paulo. Direito tributário e análise econômica do direito: uma visão crítica. Rio de Janeiro: Elsevier, 2009.

CANOTILHO, José Joaquim Gomes. Das constituições dos direitos à crítica dos direitos. Direito Público, n. 7, 2005. 
CANOTILHO, José Joaquim Gomes. Direito constitucional e teoria da constituição. 7. ed. Coimbra: Almedina, 2003.

CANOTILHO, José Joaquim Gomes. Metodología “fuzzy” y “camaleones normativos” en la problemática actual de los derechos económicos, sociales y culturales. Derechos y Libertades, n. 6, 1998.

CARRAZZA, Roque Antonio. Curso de direito constitucional tributário. 24. ed. São Paulo: Malheiros, 2008.

COASE, Ronald H. The problem of social cost. The Journal of Law and Economics, v. 3, 1960.

DE LUCAS, Javier; AÑÓN ROIG, Maria José. Necesidades, razones, derechos. Doxa, n. 7, 1990.

DE VITA, Álvaro. A justiça igualitária e seus críticos. 2. ed. São Paulo: M. Fontes, 2007.

DERBLI, Felipe. O princípio da proibição de retrocesso social na Constituição de 1988. Rio de Janeiro: Renovar, 2007.

FAGUNDES, Miguel Seabra. O controle dos atos administrativos pelo Poder Judiciário. 3. ed. Rio de Janeiro: Forense, 1957.

FARO, Julio Pinheiro. Administración pública, realización y financiación de los derechos fundamentales. In: DEL REAL, J. Alberto; ENRÍQUEZ, Gastón J.; RODRÍGUEZ, Luís G. (Ed.). La maquinaria del derecho en Iberoamérica: constitución, derechos fundamentales y administración. (no prelo, 2014).

FARO, Julio Pinheiro. Da reserva do possível e da proibição de retrocesso social. Revista do Tribunal de Contas do Estado de Minas Gerais, v. 76, n. 3, 2010.

FARO, Julio Pinheiro. Deveres como condição para a concretização de direitos. Revista de Direito Constitucional e Internacional, v. 79. São Paulo: Revista dos Tribunais, abr./jun. 2012.

FARO, Julio Pinheiro. Deveres fundamentais e a constituição brasileira. FIDES: revista de filosofia do direito, do estado e da sociedade, v. 1, n. 2, 2010.

FARO, Julio Pinheiro. Mínimo existencial e o dever de pagar tributos, ou financiando os direitos fundamentais. Constituição, Economia e Desenvolvimento: Revista da Academia Brasileira de Direito Constitucional, n. 1, 2009.

FARO, Julio Pinheiro. O critério da capacidade econômica na tributação. Revista de Derecho de la Pontifícia Universidad Católica de Valparaíso, v. 35, n. 2, 2010.

FARO, Julio Pinheiro. Os vinte anos da constituição brasileira: da reserva do possível à proibição do retrocesso social. In: FARO, Julio Pinheiro; TEIXEIRA, Bruno Costa; MIGUEL, Paula Castello (Coord.). Uma homenagem aos vinte anos da constituição brasileira. Florianópolis: Boiteux, 2008.

FARO, Julio Pinheiro. Solidariedade e justiça fiscal: uma perspectiva diferente sobre a concretização de direitos a partir do dever de pagar impostos. Revista de Direito Constitucional e Internacional, São Paulo: v. 81. out./ dez. 2012.

FARO, Julio Pinheiro; GOMES, Marcelo Sant'Anna Vieira. A disregard doctrine e a administração pública. Revista Sintese Responsabilidade Pública, v. 1, n. 1, 2011.

FRANÇA, Phillip Gil. O controle da administração pública: tutela jurisdicional, regulação econômica e desenvolvimento. São Paulo: Revista dos Tribunais, 2008.

FREIRE JÚNIOR, Américo Bedê. O controle judicial de políticas públicas. São Paulo: Revista dos Tribunais, 2005.

FREITAS, Juarez. Discricionariedade administrativa e o direito fundamental boa administração pública. 2. ed. São Paulo: Malheiros, 2009.

GARZÓN VALDÉS, Ernesto. Los deberes positivos generales y su fundamentación. Doxa, n. 3, 1986. 
HOLMES, Stephen; SUNSTEIN, Cass. The cost of rights: why liberty depends on taxes. New York: W. W. Norton, 1999.

IMMORDINO, Giovanni; PAGANO, Marco. The cost of rights: an economic analysis. Diritto \& Questioni Pubbliche, n. 4, 2004.

KRELL, Andreas Joaquim. Direitos sociais e controle judicial no Brasil e na Alemanha: os (des)caminhos de um direito constitucional "comparado". Porto Alegre: SAFE, 2002.

KRELL, Andreas Joaquim. Realização dos direitos fundamentais sociais mediante controle judicial da prestação dos serviços públicos básicos (uma visão comparativa). Revista de Informação Legislativa, n. 144, 1999.

LOPES, Ana Maria D’Ávila. A garantia do conteúdo essencial dos direitos fundamentais. Revista de Informação Legislativa, n. 164, 2004.

LOPES, Ana Maria D’Ávila. A participação política das minorias no Estado democrático de direito brasileiro. In: LIMA, Martonio Mont'Alverne Barreto; ALBUQUERQUE, Paulo Antonio de Menezes (Org.). Democracia, direito e politica: estudos internacionais em homenagem a Friedrich Müller. Florianópolis: Conceito, 2006, p. 83-96.

MANTOVANI, Ferrando. La proclamazione di diritti umani e la non effetività dei diritti umani. Rivista Italiana di Diritto e Procedura Penale, anno LI, fasc. I, 2008.

MARTINS, Leonardo (Org.). Cinquenta anos de jurisprudência do Tribunal Constitucional Federal alemão. Montevideo: Fundação Konrad Adenauer, 2005.

MEIRELLES, Hely Lopes. Direito administrativo brasileiro. 22. ed. São Paulo: Malheiros, 1997.

MELLO, Celso Antônio Bandeira de . Discricionariedade e controle jurisdicional. 2. ed. São Paulo: Malheiros, 2008.

MELLO, Celso Antônio Bandeira de. "Relatividade" da competência discricionária. Anuario Iberoamericano de Justicia Constitucional, n. 8, 2004.

NABAIS, José Casalta. O dever fundamental de pagar impostos: contributo para a compreensão constitucional do estado fiscal contemporâneo. Coimbra: Almedina, 2004.

OMMATI, José Emílio Medauar. Do ato ao processo administrativo: a crise da ideia de discricionariedade no direito administrativo brasileiro. Revista dos Tribunais, São Paulo, n. 930. abr. 2013.

PECES-BARBA MARTÍNEZ, Gregorio. Los deberes fundamentales. Doxa, n. 4, 1987.

POSNER, Richard A. Problemas de filosofia do direito. Trad. de Jefferson Luiz Camargo, São Paulo: M. Fontes, 2007.

QUEIROZ, Cristina M. M. O princípio da não reversibilidade dos direitos fundamentais sociais: princípios dogmáticos e prática jurisprudencial. Coimbra: Coimbra, 2006.

RAWLS, John. Uma teoria da justiça. Trad. Almiro Pisetta e Lenita Maria Rímoli Esteves. 2. ed. São Paulo: M. Fontes, 2002.

SARLET, Ingo Wolfgang. A eficácia dos direitos fundamentais: uma teoria geral dos direitos fundamentais na perspectiva constitucional. 10. ed. Porto Alegre: Livraria do Advogado, 2009.

SCAFF, Fernando Facury. Como a sociedade financia o estado para a implementação dos direitos humanos? In: COUTINHO, Jacinto Nelson Miranda; BOLZAN DE MORAIS, José Luiz; STRECK, Lenio Luiz (Org.). Estudos constitucionais. Rio de Janeiro: Renovar, 2007.

SCAFF, Fernando Facury. Como a sociedade financia o Estado para a implementação dos direitos humanos no Brasil. In: SCAFF, Fernando Facury (Org.). Constitucionalismo, tributação e direitos humanos. Rio de Janeiro: Renovar, 2007. 
SEN, Amartya. Human rights and capabilities. Journal of Human Development, vol. 6, n. 2, 2005.

SILVA, José Afonso. Aplicabilidade das normas constitucionais. 4. ed. São Paulo: Malheiros, 2000.

VAZ, Anderson Rosa. A cláusula da reserva do possível como instrumento de efetivação planejada dos direitos humanos econômicos, sociais e culturais. Revista de Direito Constitucional e Internacional, n. 66, 2009.

WALZER, Michael. Esferas da justiça: uma defesa do pluralismo e da igualdade. Trad. Jussara Simões. São Paulo: M. Fontes, 2003.

ZIMMERLING, Ruth. Necesidades básicas y relativismo moral. Doxa, n. 7, 1990. 


\title{
Políticas públicas de guerra às drogas: 0 estado de exceção e a transição do inimigo schmittiano ao homo sacer de Agamben
}

\author{
Public policies of war on drugs: the state of \\ exception and the trasition of schmittian enemy \\ to homo sacer of Agamben*
}

João Victor Nascimento Martins**

\section{Resumo}

No presente artigo, intenta-se estabelecer uma abordagem contextual da intitulada War on drugs - a política pública estadunidense de combate ao tráfico e ao consumo de drogas -, bem como os seus reflexos diretos e indiretos nas políticas públicas latino-americanas de combate ao narcotráfico. Para tanto, o trabalho envolve, dentro da perspectiva de um estado de exceção contemporâneo, uma relação factual entre o conceito de inimigo na obra de Carl Schmitt (2006) e o conceito de homo sacer, conforme descrito na obra do filósofo italiano Giorgio Agamben (2010).

Palavras-chaves: Políticas públicas de guerra às drogas. Estado de exceção. Inimigo. Homo sacer.

\section{Abstract}

In this paper, we attempt to establish a contextual approach of called War on drugs - the U.S. public policy of combating drug trafficking and drug use -, as well as their direct and indirect consequences on the Latin American public policies to combat drug trafficking. Thus, the work involves, from the perspective of a contemporary state of exception, a factual relationship between the concept of enemy in the work of Carl Schmitt and the concept of homo sacer, as described in the work of Italian philosopher Giorgio Agamben.

Keywords: Public policies of war on drugs. State of exception. Enemy. Homo sacer.

* Recebido em 14/05/2013 Aprovado em 30/10/2013

** Mestre em Direito Constitucional e Teoria do Direito (com Bolsa CAPES/DEMANDA SOCIAL). Programa de Pós-Graduação da Faculdade de Direito da UFMG. Professor do curso de Direito da UNIPAC. Advogado. Email: joao_victormartins@hotmail.com

\section{INTRODUÇÃo}

Em 1971, o então Presidente dos Estados Unidos, Richard Nixon, declarou que o governo do país estava em guerra contra as drogas. A declaração, a bem da verdade, dava publicidade à nova política estadunidense de combate ao tráfico e ao consumo de drogas. A denominada War on drugs com- 
preendia um conjunto de políticas internas e externas que envolviam, dentre outras ações, a criminalização abrangente do consumo de drogas; a penalização por encarceramento de traficantes e usuários; a construção em massa de presídios; o combate à entrada de drogas pelo México, com restrições severas à imigração $(O p$ eração Intercept); a invasão ao Panamá, visando dar fim aos cartéis de narcotraficantes ali estabelecidos (Operação Justa Causa); e o fornecimento de ajuda militar e financeira ao governo da Colômbia para o combate ao narcotráfico (Plano Colômbia). ${ }^{1}$

Conforme procurou demonstrar o documentário Quebrando tabu, dirigido por Fernando Grostein An$\mathrm{drade}^{2}$, para os fins que declarou perseguir, a guerra às drogas foi um fracasso completo. Houve um aumento progressivo do consumo de drogas e um fortalecimento do narcotráfico em todo o continente americano, tanto que, em 21 de maio de 2012, o governo dos EUA publicou uma nova versão da sua política de combate às drogas, fundada antes na prevenção e no tratamento e na qual o sucesso não é medido pelo número de penitenciárias construídas. Trata-se de um entendimento, já há muito adotado em países europeus, que privilegia não tanto a criminalização da conduta, mas antes o tratamento dos dependentes, ou seja, o enfrentamento de uma questão de saúde pública.

Uma hipótese contundente para justificar esse suposto fracasso da guerra às drogas se fundaria na ideia de que a finalidade da política de combate às drogas do governo estadunidense não estava relacionada à efetiva eliminação ou redução do tráfico e do consumo de drogas, mas sim à ideia de definição de um inimigo nacional - o inimigo que o governo e o povo dos Estados Unidos deveriam combater: os consumidores de drogas e, sobretudo, os narcotraficantes.

A estipulação desse inimigo concedeu ao governo a confiança e a aprovação popular necessárias à consecução de drásticas políticas internas e externas - sobretudo militares. A definição do narcotraficante como o inimigo foi a estratégia política adotada pelos Estados Unidos para legitimar a sua política internacional de invasão (direta ou indireta) em países latino-americanos. O governo estipulou uma situação "emergencial", um risco iminente que precisava ser combatido, e, mediante esse poder legitimador, executou ações que seriam impensáveis apenas sob a ótica do direito vigente em um Estado Democrático de Direito.

Lado outro, se nos Estados Unidos a política antidrogas se pautou pela afirmação de um inimigo público comum, que seria o estandarte indispensável a mais uma campanha de militarização e ocupação de territórios estratégicos, a importação de uma política de combate ao narcotráfico provocou na América Latina sobretudo no Brasil - a segregação de uma parcela da população a um âmbito externo ao direito. População essa que não figura como um inimigo do Estado no sentido schmittiano, posto que não se presta a servir de meio para a criação e para a manutenção de um estado de exceção, mas no sentido de uma população que pode ser morta sem que se viole o ordenamento jurídico vigente. Uma população que não poderia ser "sacrificada" sob o "rito" do direito, embora possa ser morta, sob o pálio de uma política estatal de combate ao narcotráfico.

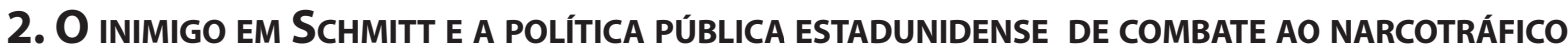

Carl Schmitt (1888-1985) - ilustre, porém controverso jurista alemão do século XX, professor das Universidades de Bonn e de Berlim, bastante criticado por seu posicionamento afeto ao regime nacional socialista, teve como uma das mais importantes obras o livro Teologia política. ${ }^{3}$ Nessa obra, o eminente jurista formulou uma teoria para o estado de exceção, por entender se tratar de um instituto inerente ao direito,

1 VILLA, Rafael Duarte; OSTOS, Maria del Pilar. As relações Colômbia, países vizinhos e Estados Unidos: visões em torno da agenda de segurança Revista Brasileira de Política Internacional, Brasília, v. 48, n. 2, p. 86-110, dez. 2005

2 ANDRADE, Fernando Grostein. Quebrando tabu. São Paulo: Spray filmes, 2011

3 SCHMITT, Carl. Teologia política. Tradução de. Elisete Antoniuk. Belo Horizonte: Del Rey, 2006. 
embora esteja externo a ele. Conforme define Agamben “[...] se a exceção é o dispositivo original graças ao qual o direito se refere à vida e a inclui em si por meio de sua própria suspensão, uma teoria do estado de exceção é, então, condição preliminar para se definir a relação que liga e [...] abandona o vivente ao direito". ${ }^{4}$

Para fazê-lo, Schmitt lança mão dos conceitos de soberano - que "é quem decide sobre o estado de exceção" soberano, por se tratar de um perigo iminente para o Estado.

O título da obra schmittiana que pretende inaugurar essa teoria - Teologia Política - refere-se ao contexto no qual o autor alemão pretende fundamentar a sua teoria do estado de exceção. Segundo Schmitt, “[...] todos os conceitos concisos da teoria do Estado moderno são conceitos teológicos secularizados". ${ }^{6}$ Nesse sentido, Schmitt estabelece, a título de exemplo, uma relação necessária entre o milagre e o estado de exceção, posto que ambos os institutos - o primeiro ligado à teologia e o segundo, ao direito - têm como característica primordial a tentativa de restabelecer a normalidade, o curso normal da vida. Entretanto, para fazê-lo, faz-se necessário o recurso a um instituto externo à normalidade: na teologia, o milagre e, no direito, o estado de exceção. Impossível seria não suscitar, portanto, também uma correlação entre a figura de Deus para a teologia e a figura do soberano para o direito.

Inicialmente já se disse que, para Schmitt, o soberano é quem decide sobre o estado - ou estágio - de exceção e que esse estado de exceção se faz premente no momento em que o Estado se encontra em risco, em que as instituições se encontram ameaçadas por um inimigo. ${ }^{7}$ Nesse momento, os fatos não devem mais ser governados pelas normas de direito, posto que a reação governamental aos fatos encontra fundamento na própria realidade, na rópria iminência do perigo. Conforme Bernardo Ferreira:

Com efeito, observa Schmitt, o "conteúdo preciso" da ação ditatorial depende da "noção de um adversário concreto, cuja eliminação deve ser o que há de mais próximo de uma delimitação do objetivo da ação. A delimitação de que se trata aqui não é uma apreensão dos fatos através dos conceitos do direito, mas uma determinação puramente factual”.

$[\ldots]$

Trata-se de uma ação, portanto, que encontra a sua referência imediata na realidade concreta e que extrai os seus critérios da própria situação das coisas. Ao contrário do que se observaria em um quadro de normalidade, no qual se poderia pressupor que os fatos seriam governados pelas normas de direito, na ditadura, os fatos determinam os rumos da conduta da autoridade pública. Nessa perspectiva, observa Schmitt, "se justifica tudo que é necessário do ponto de vista do resultado concreto a ser alcançado". [...] Em última análise, o que torna a comissão do ditador incondicionada do ponto de vista das normas do direito é o seu condicionamento pela "imediata atualidade de uma situação a ser eliminada". ${ }^{8}$

Nesse sentido, portanto, o soberano deve intervir na vigência das normas jurídicas para salvaguardar o Estado, posto que a iminência de um perigo concreto à manutenção da estrutura estatal é o critério legitimador da conduta do soberano. O soberano está assim, acima do direito, externo a ele, apesar de fazer parte da estrutura jurídica. Isso é possível porque Schmitt entende, em sentido oposto de Kelsen, ${ }^{9}$ que Estado e Direito são estruturas diversas. O direito está a serviço da manutenção do Estado. Portanto, o direito pode vir a sucumbir para que o soberano garanta a sobrevivência do Estado. ${ }^{10}$

Segundo Agamben:

Longe de responder a uma lacuna normativa, o estado de exceção apresenta-se como a abertura de uma lacuna fictícia no ordenamento, com o objetivo de salvaguardar a existência da norma e sua aplicabilidade à situação normal. A lacuna não é interna à lei, mas diz respeito à sua relação com a realidade, à possibilidade mesma de sua

4 AGAMBEN, Giorgio. Homo sacer II: estado de exceção, 1. Tradução de Iraci D. Poleti. São Paulo: Boitempo, 2004. p. 12.

5 SCHMITT, Carl. Teologia política. Tradução de. Elisete Antoniuk. Belo Horizonte: Del Rey, 2006. p. 07.

6 SCHMITT, Carl. Teologia política. Tradução de. Elisete Antoniuk. Belo Horizonte: Del Rey, 2006. p. 35.

7 SCHMITT, Carl. Teologia politica. Tradução de. Elisete Antoniuk. Belo Horizonte: Del Rey, 2006.

8 FERREIRA, Bernardo. O risco do politico: crítica ao liberalismo e teoria política no pensamento de Carl Schmitt. Belo Horizonte: UFMG, 2004. p. 103-104.

9 KELSEN, Hans. Teoria geral do direito e do estado. Tradução de Luis Carlos Borges, São Paulo: Martins Fontes, 1998.

10 SCHMITT, Carl. Teologia política. Tradução de. Elisete Antoniuk. Belo Horizonte: Del Rey, 2006. p. 25. 
aplicação. É como se o direito contivesse uma fratura essencial entre o estabelecimento da norma e sua aplicação e que, em caso extremo, só pudesse ser preenchida pelo estado de exceção, ou seja, criando-se uma área onde essa aplicação é suspensa, mas onde a lei, enquanto tal, permanece em vigor. ${ }^{11}$

De acordo com a teoria do estado de exceção de Schmitt, não é concebível um Estado, ou um ordenamento jurídico, sem a existência de um consenso acerca de alguns princípios básicos comuns. ${ }^{12}$ Quando adversários (ou inimigos) do Estado tentam impor uma ordem que se encontra em sentido inverso ao determinado por aqueles princípios comuns e o Estado, nesse momento, se encontra ameaçado, é que se faz necessária a decisão do soberano no sentido de instaurar a exceção. O soberano prescinde, então, do direito, mas tão somente para garantir a sua devida realização. Trata-se de uma evidente supremacia do Estado sobre o direito. "O fato de a vigência dessa ordem exigir a eliminação daqueles que não reconhecem os seus fundamentos normativos significa, para Schmitt, que o direito para se tornar efetivo não pode prescindir da sua própria negação". ${ }^{13}$

Ao contrário, para isso precisa-se de uma competência, a princípio, ilimitada, ou seja, a suspensão de toda ordem existente. Entrando-se nessa situação, fica claro que, em detrimento do Direito, o Estado permanece. Sendo o estado de exceção algo diferente da anarquia e do caos, subsiste, em sentido jurídico, uma ordem, mesmo que não uma ordem jurídica. A existência do Estado mantém, aqui, uma supremacia indubitável sobre a validade da norma jurídica. A decisão liberta-se de qualquer vínculo normativo e torna-se absoluta em sentido real. Em estado de exceção, o Estado suspende o Direito por fazer jus à autoconservação, como se diz. Os dois elementos do conceito "ordem jurídica" defrontam-se e comprovam sua autonomia conceitual. Assim, como no caso normal, o momento autônomo da decisão pode ser repelido a um mínimo; no caso excepcional, a norma é aniquilada. Apesar disso, o caso excepcional também permanece acessível ao conhecimento jurídico, pois ambos os elementos, a norma e a decisão, permanecem no âmbito jurídico. ${ }^{14}$

Dentro da perspectiva do estado de exceção, Schmitt concebe inevitavelmente, ainda que inconscientemente, o inimigo como uma válvula de escape para a instauração da exceção. A iminência de um risco real provocado pelo inimigo é o fato que legitima a ação soberana de declarar a exceção que garantirá a manutenção do Estado e do direito. "Não existe norma que seja aplicada ao caos. A ordem deve ser estabelecida para que a ordem jurídica tenha um sentido. Deve ser criada uma situação normal [...]”. ${ }^{15} \mathrm{O}$ inimigo permite, então, que a vida seja governada com referência direta aos fatos em detrimento ao direito.

Ocorre que, conforme levantado por Agambem, ${ }^{16}$ esse estado de exceção, na forma teorizada por Schmitt, deixou há muito tempo de ser privilégio dos regimes ditatoriais, autoritários. A existência de inimigos - grupo de indivíduos com anseios contrários aos princípios comuns do Estado -, vem se tornando um meio recorrente para legitimar o estabelecimento de um estágio de exceção permanente, uma situação duradoura.

O totalitarismo moderno pode ser definido, nesse sentido, como a instauração, por meio do estado de exceção, de uma guerra civil legal que permite a eliminação física não só dos adversários políticos, mas também de categorias inteiras de cidadãos que, por qualquer razão, pareçam não integráveis ao sistema político. Desde então, a criação voluntária de um estado de emergência permanente (ainda que, eventualmente, não declarado no sentido técnico) tornou-se uma das práticas essenciais dos Estados contemporâneos, inclusive dos chamados democráticos. ${ }^{17}$

Segundo Agamben, tem-se criado uma "[...] generalização sem precedentes do paradigma da segurança como técnica normal de governo". ${ }^{18}$ Isso é possível por meio da deflagração de um constante estado de necessidade, ou, ao menos, de um estado de necessidade virtual. A necessidade premente é a mais legítima das fontes do direito, ${ }^{19}$ aquela que permite aos governantes (ou ao soberano) introduzir no direito aquilo que anteriormente se encontrava tão somente no campo da vida.

11 AGAmBEN, Giorgio. Homo sacer II: estado de exceção, 1. Tradução de Iraci D. Poleti. São Paulo: Boitempo, 2004. P. 48

12 FERREIRA, Bernardo. O risco do político: crítica ao liberalismo e teoria política no pensamento de Carl Schmitt. Belo Horizonte: UFMG, 2004. p. 105.

13 FERREIRA, Bernardo. O risco do político: crítica ao liberalismo e teoria política no pensamento de Carl Schmitt. Belo Horizonte: UFMG, 2004. p. 107.

14 SCHMITT, Carl. Teologia política. Tradução de. Elisete Antoniuk. Belo Horizonte: Del Rey, 2006. p. 13.

15 SCHMITT, Carl. Teologia política. Tradução de. Elisete Antoniuk. Belo Horizonte: Del Rey, 2006. p.13

16 AGAMBEN, Giorgio. Homo sacer II: estado de exceção, 1. Tradução de Iraci D. Poleti. São Paulo: Boitempo, 2004. p.13.

17 AGAMBEN, Giorgio. Homo sacer II: estado de exceção, 1. Tradução de Iraci D. Poleti. São Paulo: Boitempo, 2004. p. 13.

18 AGAMBEN, Giorgio. Homo sacer II: estado de exceção, 1. Tradução de Iraci D. Poleti. São Paulo: Boitempo, 2004, 2004 . p. 28.

19 AGAMBEN, Giorgio. Homo sacer II: estado de exceção, 1. Tradução de Iraci D. Poleti. São Paulo: Boitempo, 2004. p. 44. 
O status necessitas apresenta-se, assim, tanto sob forma do estado de exceção quanto sob a forma da revolução, como uma zona ambígua e incerta onde procedimentos de fato, em si extra ou antijurídicos, transformam-se em direito e onde as normas jurídicas se indeterminam em mero fato; um limiar, portanto, onde fato e direito parecem tornar-se indiscerníveis. ${ }^{20}$

Ao que tudo indica, a política estadunidense de combate ao narcotráfico, lançada pelo governo Nixon na década de 1970 conhecida como War on drugs, assim como diversas outras políticas de cunho militarista promovidas pelo governo dos Estados Unidos, adequa-se perfeitamente ao referido conceito de status necessitas, ou melhor, a um status necessitas puramente virtual ou fictício. Trata-se, conforme Agamben, da criação voluntária de um inimigo fictício, que possibilita ao governo (ou soberano) a criação de um estado de necessidade, um estado de emergência permanente. ${ }^{21}$

O sufocamento do risco comunista, que vinha perdendo fôlego em todo o cenário mundial, provocou uma carência de fundamento para a política de segurança nacional (e internacional) dos Estados Unidos. Essa carência deveria ser suprida por um motivo alarmante que permitisse ao governo dos Estados Unidos manter tanto o fomento à indústria armamentista, quanto à política de intervenção na América Latina. Esse motivo alarmante foi declarado por Nixon em 1971 e reafirmado por seus sucessores, alcançando o seu ápice em 1986, no governo de Ronald Reagan. Era o risco premente provocado pelo crescente movimento terrorista do narcotráfico.

[...] o governo norte-americano passava a focalizar o tráfico de drogas de maneira ainda mais incisiva, transformando-o em "grande inimigo dos EUA". Em 1986, o presidente estadunidense Ronald Reagan edita a National Security Decision Directive on Narcotics and National Security (NSDD-221), documento no qual o governo norteamericano "oficializa sua percepção de que a principal ameaça aos Estados Unidos e ao hemisfério ocidental passara a residir na simbiose entre terrorismo de esquerda e narcotráfico, [...] a NSDD-221 'diagnosticava' o problema da 'narco-subversão' e expunha a necessidade imperiosa de que os Estados Unidos se defendessem (e defendessem o continente) da grande trama "narcoterrorista"" (Rodrigues, 2001:215). Se desviaria em demasia da discussão atentar para as intrincadas relações dos Estados Unidos e o "narcopatrocínio" às guerrilhas de direita na América Central nestes mesmos anos, contudo, o que cabe frisar é o deslocamento da doutrina de segurança nacional norte-americana que se desenha com a declaração de Reagan. A justificativa maior para a intervenção estadunidense na América Latina iniciava um movimento que reporia no lugar do "combate ao comunismo" uma outra urgência. Quando fuzileiros navais norte-americanos ocupam a Cidade do Panamá e capturam o então presidente da república panamenha, Manuel Noriega, a acusação que pesava sobre ele já não era 'conspiração comunista', recorrente incriminação da guerra fria, mas um crime de nova ordem: "conspiração por tráfico de drogas". 22

Os narcotraficantes e os usuários de drogas ganharam, então, o status de inimigo dos Estados Unidos. Eram aquela parcela da população que se posicionava em desacerto com as diretrizes, ou princípios, comuns do Estado - que colocavam em risco não só os princípios morais básicos das famílias, mas também a segurança e a manutenção do Estado - e que, consequentemente, inseriam o Estado em um alarmante estado de necessidade. Esse status necessitas, por sua vez, legitimou as mais variadas ações excepcionais do governo dos Estados Unidos. A emergência, ainda que virtual ou provocada, legitimou as ingerências do governo, tanto internamente quanto externamente. Exemplos dessa ingerência externa, sobretudo na América Latina, são: a invasão à cidade do Panamá, com a captura do Presidente Manuel Noriega, e a consecução do Plano Colômbia, que viabilizou a criação de bases militares estadunidenses em território latino.

Desde o início da década de 1990, o eixo central dessa "Guerra às Drogas" transformou-se, então, no que passaria a ser conhecido como Estratégia Andina. Tal estratégia condensa quatro pontos fundamentais: fortalecimento das instituições políticas dos países chaves na oferta de drogas ilícitas (Bolívia, Colômbia e Peru); fortalecimento operacional de unidades militares e policiais encarregadas do combate ao circuito da droga (erradicação de cultivos, comércio de precursores químicos, destruição de laboratórios, interdição de drogas, detecção das rotas e criminalização da lavagem de dinheiro), assim como o assessoramento militar e policial direto aos países andinos para o desmantelamento de cartéis (Colômbia) e de firmas (Peru) de drogas. Este último item representa, mais especificamente para o caso colombiano, uma política de extradição de narcotraficantes. Finalmente, assistência comercial e fiscal para minimizar as consequências sociais decorrentes da privação de meios de subsistência de comunidades locais, como de fato ocorreu.

20 AGAMBEN, Giorgio. Homo sacer II: estado de exceção, 1. Tradução de Iraci D. Poleti. São Paulo: Boitempo, 2004. p. 45.

21 AGAMBEN, Giorgio. Homo sacer II: estado de exceção, 1. Tradução de Iraci D. Poleti. São Paulo: Boitempo, 2004. p. 13.

22 RODRIGUES, Thiago M. S. A infindável guerra americana: Brasil, EUA e o narcotráfico no continente. São Paulo em Perspectiva, São Paulo, v. 16, n. 2, p. 102-111, abr./jun. 2002. 
$[\ldots]$

A partir de um sólido consenso bipartidário entre democratas e republicanos, o Congresso dos EUA aprovou em 1999 o Plano Colômbia. A proposta, de 7,5 bilhões de dólares, apresenta três componentes: primeiro, a aproximação do Estado colombiano com as populações afetadas pela violência por meio de investimentos sociais e substituição de plantios de coca, devendo o governo disponibilizar 4 bilhões de dólares para esse fim; segundo, assistência técnica, militar e financeira dos EUA, no montante de 1,3 bilhão de dólares, para o combate ao narcotráfico em toda região andina, especialmente na Colômbia. Desses recursos, cerca de $55 \%$ foram dirigidos às forças armadas e $27 \%$ à polícia, enquanto que os projetos de desenvolvimento alternativo obtiveram somente $9 \%$ dos recursos, assistência a deslocados, 3\%, reforma judicial, $2 \%$, proteção de direitos humanos, $1 \%$, e recursos para a paz, menos de 1\%. Na realidade, somente 180 milhões de dólares seriam destinados aos vizinhos colombianos. Finalmente, como último componente, contribuição européia para a paz. O fato é que nem todos os recursos financeiros previstos na assistência norte-americana chegaram a entrar no país. Conforme observou Anzola, "uma grande parte ficará para a compra de material bélico em empresas norte-americanas e para a contratação de mercenários deste país que virão a combater na Colômbia" ${ }^{23}$.

Posteriormente ao Plano Colômbia, o Congresso dos Estados Unidos ainda implementou, durante o governo Bush, a Iniciativa Andina Antidrogas. O Congresso aprovou um orçamento de 700 milhões de dólares para o ano de 2003 e de 731 milhões de dólares para o ano de 2004. Apesar de 63\% dos recursos se destinarem à implementação de políticas de combate ao narcotráfico na Colômbia, outros três países (Equador, Bolívia e Peru) também se beneficiaram diretamente com os recursos estadunidenses. ${ }^{24}$

O que se observa, portanto, como consequência da definição do narcotraficante como o inimigo schmittiano do Estado, é a desnacionalização e desterritorialização desse inimigo. O narcotráfico é um acontecimento global. Esse caráter internacional do narcotráfico fundamenta então a perseguição e o combate ao inimigo de forma expandida. Como se pode ver, a ação do governo estadunidense na América Latina é difusa, abarcando vários países.

No atual estado de guerra global, as guerras passam a ser declaradas a inimigos não geográficos, inimigos transnacionais como são as "drogas" e o "terrorismo", ampliando seu alcance temporal e espacial, tornando seu estado cada vez mais permanente. A aposta na guerra como forma de manter a ordem social acaba por torná-la um estado contínuo nas sociedades contemporâneas, ao invés de um estado de exceção.

A amplitude transnacional do problema gerado pelo tráfico de drogas confere a essa guerra um caráter difuso, ao mesmo tempo em que intensifica o controle social, identificando as drogas como a encarnação do mal. No campo da guerra global às drogas toda humanidade pode, por um lado, unir-se contra o mal e, por outro lado, qualquer um pode ser um inimigo da humanidade. ${ }^{25}$

Percebe-se, assim, que a declaração da existência (ainda que virtual) do narcotraficante enquanto inimigo dos Estados Unidos, por meio da criação da política do War on drugs, permitiu ao governo dos Estados Unidos a criação de um estado de emergência fictício que, por sua vez, vem legitimando as políticas internas e externas de invasão e militarização de países produtores ou comercializadores de drogas.

\section{A política brasileira de COMbate ao naRCotráfico E O HOMO SACER}

Como consequência imediata da política estadunidense War on drugs, observa-se a criação de uma política "brasileira" de combate ao consumo e tráfico de drogas. Essa política de combate ao narcotráfico resume-se em um conjunto de leis dispersas aprovadas por derivação à assinatura de tratados internacionais propostos pela Organização das Nações Unidas (ONU), bem como por acordos firmados entre o governo dos Estados Unidos e o governo brasileiro. ${ }^{26}$

23 VILLA, Rafael Duarte; OSTOS, Maria del Pilar. As relações Colômbia, países vizinhos e Estados Unidos: visões em torno da agenda de segurança. Revista Brasileira de Política Internacional, Brasília, v. 48, n. 2, p. 86-110, dez. 2005.

24 VILLA, Rafael Duarte; OSTOS, Maria del Pilar. As relações Colômbia, países vizinhos e Estados Unidos: visões em torno da agenda de segurança. Revista Brasileira de Politica Internacional, Brasília, v. 48, n. 2, p. 86-110, dez. 2005.

25 PASSOS, Eduardo Henrique; SOUZA, Tadeu Paula. Redução de danos e saúde pública: construções alternativas à política global de "guerra às drogas". Psicologia e Sociedade, Florianópolis, v. 23, n.1, p. 154-162, jan./abr. 2011..

26 FORTE, Francisco Alexandre de Paiva. Racionalidade e legitimidade da política de repressão ao tráfico de drogas: uma pro- 
Como não poderia deixar de ser, o resultado desse conglomerado legislativo foi a concretização de uma política voltada para o aprisionamento em massa da população relacionada ao narcotráfico, bem como a criação de territórios nos quais o direito é simplesmente ignorado, verdadeiros locais de exceção.

A Convenção Única de 1961 da ONU ampliou o alcance das medidas proibicionistas, além de burocratizar a estrutura regulatória internacional das drogas ilícitas, convenção essa incorporada ao ordenamento jurídico brasileiro pelo Decreto n. 54.216/1964, servindo de instrumento para justificar a atualização da legislação interna brasileira que resultou na lei de tóxicos (Lei n. 6.386/1976, recentemente revogada pela Lei n. 11.343/2006), donde "o procedimento de ratificação de tratados, ato de incorporação de um acordo internacional ao ordenamento legal nacional, foi instrumento primordial utilizado para atualizar as disposições vigentes no País”, fornecendo ao Estado "maiores artifícios" para acionar os aparatos de coerção aos traficantes, a exemplo das Convenções de Genebra de 1931 e 1936 que justificaram a adoção do Decreto-Lei n.891/38.

\section{$[\ldots]$}

Política essa concebida nos Estados Unidos, responsável pelo controle e encarceramento maciço de negros e pobres e que extravasa as fronteiras nacionais. Emblemático nesse ponto é o Acordo de Cooperação Mútua para Redução da Demanda, Prevenção do Uso indevido e Combate à Prevenção e ao Tráfico Ilícito de Entorpecentes, firmado entre o governo brasileiro e o governo norte-americano, assinado em 12 de abril de 1995 (promulgado pelo Decreto n. 2.242/1997) e renovado anualmente, no qual consta expressamente nos memorandos que implementam o acordo a obrigação de comprovar estatisticamente o aumento de prisões e condenações relacionadas a entorpecentes, para que a Polícia Federal receba recursos para compra de equipamentos e treinamento. Não por acaso, a cada vez que se prende um traficante com um quilograma de cocaína, a Polícia Federal chama a imprensa e faz um verdadeiro show. ${ }^{27}$

No mesmo sentido da legislação vigente à época, o governo FHC instituiu, em 1998, a "Secretaria Nacional Antidrogas, que, na sua origem, subordinava-se à Casa Militar da Presidência da República, transformada em 1999, sem perder seu caráter militarista, em Gabinete de Segurança Institucional do Presidente da República". ${ }^{28}$

Dentro desse contexto, percebe-se que o governo brasileiro está, há algum tempo, enredado na política do War on drugs, que havia sido concebida pelos Estados Unidos, mas que ganhou primazia em parte considerável do mundo, sobretudo na América Latina.

Conforme deixam transparecer os relatos contidos na reportagem Expectativa de vida: vinte anos, publicada no livro O olho da rua de Eliane Brum, ${ }^{29}$ a implicação direta da política de combate às drogas importada para o Brasil foi a criação de uma parcela da população que é puramente matável, apesar de não ser alvo da sanção imposta pelo rito jurídico. Os narcotraficantes, dentro das favelas, são seres matáveis, estão inseridos em um espaço de exceção, no qual o direito, apesar de estar vigente, não é aplicado. Trata-se de um verdadeiro estado de exceção permanente, no qual a situação emergencial, ou o status necessitas, permite a consecução de políticas públicas paralelas ao direito - políticas públicas que são determinadas pela urgência da realidade e não pela ordem jurídica.

O que se observa nas favelas brasileiras, sob a ótica da atuação do governo, entretanto, não são inimigos do Estado, que fundamentam a instauração de um estado de exceção, conforme é possível observar nos Estados Unidos; são sujeitos totalmente externos ao direito. O direito parece não lhes ser aplicável. Conforme relata Eliane Brum, nas favelas brasileiras, onde o tráfico se instalou e determina o paradigma de vida para os jovens que não têm o devido acesso ao ensino público de qualidade, a expectativa de vida entre os homens gira em torno dos vinte anos. ${ }^{30}$

Dos dezessete garotos do filme, só um está vivo. Falcão provou que nas favelas brasileiras - e não apenas no Rio de Janeiro - a expectativa de vida dos meninos do tráfico é de vinte anos. São executados antes de virar adultos.

vocação necessária. Estudos Avançado. São Paulo, v. 21, n. 61, p. 193-208, set./dez. 2007

27 FORTE, Francisco Alexandre de Paiva. Racionalidade e legitimidade da política de repressão ao tráfico de drogas: uma provocação necessária. Estudos Avançado. São Paulo, v. 21, n. 61, p. 193-208, set./dez. 2007.

28 KARAM, M. L. Redução de danos, ética e lei. In: SAMPAIO, C; CAMPOS, M. (Org.). Drogas dignidade e inclusão social: a lei e a prática da redução de danos. Rio de Janeiro: Aborda, 2003. p. 79.

29 BRUM, Eliane. O olho da rua: uma repórter em busca da literatura da vida real. São Paulo: Editora Globo, 2011.

30 BRUM, Eliane. O olbo da rua: uma repórter em busca da literatura da vida real. São Paulo: Editora Globo, 2011, p. 203. 
$[\ldots]$

Um estudo da UNESCO, coordenado pelo sociólogo Julio Jacobo Waiselfisz, mostrou que no Brasil a principal causa de morte entre jovens é tiro. Em 24 anos, de 1979 a 2003, a população brasileira cresceu 52\% - e os homicídios por arma de fogo 543\%. O aumento foi causado pelo assassinato de adolescentes: das 550 mil mortes, quase a metade atingiu brasileiros entre quinze e 24 anos. A violência matou mais no país que a Guerra do Golfo e os conflitos entre Israel e Palestina.

$[\cdots]$

A mãe pagou o caixão do filho por quase cinco anos. O menino estava vivo. Mês após mês, ela acertava uma cartela do carnê: quinze reais. $\mathrm{O}$ valor é mais da metade que ela ganha para lavar, engomar e passar uma trouxa de roupas. O garoto tinha quinze anos quando ela começou a quitar sua morte - e vinte quando o enterrou, duas semanas antes do Natal. No dia seguinte, a mãe começou a comprar o caixão do próximo filho. Ele tem dezenove anos e - ainda - está vivo. ${ }^{31}$

Conforme procurou definir Giorgio Agamben, ${ }^{32}$ os seres puramente matáveis, que se encontram externamente ao âmbito de tutela do ordenamento jurídico são como o homo sacer do Direito Romano arcaico. Os homines sacri eram uma figura atípica e contraditória: “[...] aquele que qualquer um podia matar impunemente não podia, porém, ser levado à morte nas formas sancionadas pelo rito [...]". ${ }^{33}$ Esses homens não podiam, então, ser objeto de sacrifício para os deuses, posto que já eram seres sagrados. A despeito disso, entretanto, estavam sujeitos à morte externa ao rito sagrado: "A vida insacrificável e, todavia, matável, é a vida sacra". ${ }^{34}$

É possível, então, dar uma primeira resposta à pergunta que nos havíamos colocado no memento de delinear a estrutura formal da exceção. Aquilo que é capturado no bando soberano é uma vida humana matável e insacrificável: o homo sacer. Se chamamos vida nua ou vida sacra a esta vida que constitui o conteúdo primeiro do poder soberano, dispomos ainda de um princípio de resposta para o quesito benjaminiano acerca da "origem do dogma da sacralidade da vida". Sacra, isto é, matável e insacrificável, é originariamente a vida no bando soberano, e a produção da vida nua é neste sentido, préstimo original da soberania. A sacralidade da vida, que se desejaria hoje fazer valer contra o poder soberano como um direito humano em todos os sentidos fundamental, exprime, ao contrário, em sua origem, justamente a sujeição da vida a um poder de morte, a sua irreparável exposição na relação de abandono. ${ }^{35}$

Figura resgatada por Agamben no Direito Romano arcaico, o homo sacer é, portanto, um ser externo à submissão aos rituais do ius divinum, porém, a sua morte é tratada com total impunidade pelo ius bumanum, ${ }^{36}$ “[...] ele indica, antes, uma vida absolutamente matável, objeto de uma violência que excede tanto a esfera do direito quanto a do sacrifício". ${ }^{37}$

Aplicado ao contexto contemporâneo das favelas brasileiras, o conceito de homo sacer se adequa perfeitamente ao narcotraficante: um ser matável, que é o objeto de demonstração do poder soberano, mas que, entretanto, não se submete ao rito "sagrado" da sanção jurídica. Trata-se, agora, do estabelecimento não mais de um inimigo do Estado, no sentido schmittiano - como procurou fazer os EUA -, mas de um evidente homo sacer, conforme definiu Agamben. Os jovens que entram nas atividades do narcotráfico são homines sacri, no sentido em que são eliminados pela força policial do Estado, conforme uma determinada política adotada, mas não em conformidade com o direito vigente. O direito, o rito jurídico, não se aplica aos homines sacri. Eles se encontram em um espaço - físico e normativo - externo ao direito.

[...] restituído ao seu lugar próprio, além tanto do direito penal quanto do sacrifício, o bomo sacer apresentaria a figura originária da vida presa no bando soberano e conservaria a memória da exclusão originária através da qual se constitui a dimensão política.

31 BRUM, Eliane. O olho da rua: uma repórter em busca da literatura da vida real. São Paulo: Editora Globo, 2011. p. 213.

32 AGAMBEN, Giorgio. Homo Sacer I: o poder soberano e a vida nua. Tradução de Henrique Burigo. Belo Horizonte: UFMG, 2010. p. 74-75.

33 AGAMBEN, Giorgio. Homo Sacer I: o poder soberano e a vida nua. Tradução de Henrique Burigo. Belo Horizonte: UFMG, 2010. p. 74.

34 AGAMBEN, Giorgio. Homo Sacer I: o poder soberano e a vida nua. Tradução de Henrique Burigo. Belo Horizonte: UFMG, 2010. p. 84 .

35 AGAMBEN, Giorgio. Homo Sacer I: o poder soberano e a vida nua. Tradução de Henrique Burigo. Belo Horizonte: UFMG, 2010. p. 85.

36 AGAMBEN, Giorgio. Homo Sacer I: o poder soberano e a vida nua. Tradução de Henrique Burigo. Belo Horizonte: UFMG, 2010. p. 76.

37 AGAMBEN, Giorgio. Homo Sacer I: o poder soberano e a vida nua. Tradução de Henrique Burigo. Belo Horizonte: UFMG, 2010. p. 87. 
Mais interessante, em nossa perspectiva, é o fato de que à soberania do homem vivente sobre a sua vida corresponda imediatamente a fixação de um limiar além do qual a vida cessa de ter valor jurídico e pode, portanto, ser morta sem que se cometa homicídio. A nova categoria jurídica de "vida sem valor" (ou "indigna de ser vivida") corresponde ponto por ponto, ainda que em uma direção pelo menos aparentemente diversa, à vida nua do homo sacer [...].

$[\cdots]$

Justamente porque privados de quase todos os direitos e expectativas que costumamos atribuir à existência humana e, todavia, biologicamente ainda vivos, eles vinham a situar-se em uma zona limite entre a vida e a morte, entre o interno e o externo, na qual não eram mais que vida nua. Condenados à morte e habitantes do campo são, portanto, de algum modo inconscientemente assemelhados a homines sacri, a uma vida que pode ser morta sem que se cometa homicídio. ${ }^{38}$

Dentro do contexto brasileiro, observa-se que o inimigo estipulado pelo governo dos EUA para legitimar a instauração do estado de exceção ganha o status de homo sacer. No Brasil, o narcotraficante não tem mais o caráter de inimigo do Estado, como o é para o governo estadunidense. O narcotraficante, dentro do estágio (e espaço) de exceção implementado pelo governo estadunidense na América Latina, passa a ser um homo sacer - um sujeito externo à aplicação do direito vigente.

\section{Considerações finais}

Como Agamben já havia suscitado, portanto, a instauração do estado de exceção permanente contemporâneo tem como consequência direta não só a perseguição ao inimigo - que promove a possibilidade de um estado de emergência virtual -, mas também a perseguição a todos aqueles seres que, direta ou indiretamente, acabam sendo excluídos do âmbito de aplicação do direito. Seres que, em algum sentido, não pertencem à estrutura estatal que se alinha às necessidades que se fazem prementes com a exceção.

O totalitarismo moderno pode ser definido, nesse sentido, como a instauração, por meio do estado de exceção, de uma guerra civil legal que permite a eliminação física não só dos adversários políticos, mas também de categorias inteiras de cidadãos que, por qualquer razão, pareçam não integráveis ao sistema político. Desde então, a criação voluntária de um estado de emergência permanente (ainda que, eventualmente, não declarado no sentido técnico) tornou-se uma das práticas essenciais dos Estados contemporâneos, inclusive dos chamados democráticos. ${ }^{39}$

Constata-se, portanto, que não só a definição do narcotráfico como o inimigo de Estado, como também todas as diversas formas de instauração de um estado de emergência virtual, são o instrumento de manutenção de um estado de exceção permanente, que viabiliza a consecução de políticas estatais externas ao âmbito jurídico. Como consequências diretas desse status necessitas, as políticas públicas impostas pelo poder soberano não se voltam somente para o inimigo do Estado, mas também a toda parcela da população que não se adequa à estrutura social que é construída com vistas à manutenção do estado de exceção. Tanto o inimigo schmittiano como o homo sacer de Agamben são, nesse sentido, figuras criadas em torno da instauração de um estado de exceção: o primeiro, enquanto causa virtual para a sua instauração, e o segundo, como sua consequência direta.

A política War on drugs, calcada na ideia do narcotraficante enquanto inimigo estatal, e a sua importação pelo governo brasileiro são um retrato fiel do estado de exceção permanente contemporâneo, que vem criando, a cada dia, mais homines sacri.

\section{REFERÊNCIAS}

AGAMBEN, Giorgio. Homo Sacer I: o poder soberano e a vida nua. Tradução de Henrique Burigo. Belo Horizonte: UFMG, 2010.

38 AGAMBEN, Giorgio. Homo Sacer I: o poder soberano e a vida nua. Tradução de Henrique Burigo. Belo Horizonte: UFMG, 2010. p. 155.

39 AGAMBEN, Giorgio. Homo sacer II: estado de exceção, 1. Tradução de Iraci D. Poleti. São Paulo: Bontempo, 2004. p. 13. 
AGAMBEN, Giorgio. Homo sacer II: estado de exceção, 1. Tradução de Iraci D. Poleti. São Paulo: Boitempo, 2004.

ANDRADE, Fernando Grostein. Quebrando tabu. São Paulo: Spray filmes, 2011.

BRUM, Eliane. O olho da rua: uma repórter em busca da literatura da vida real. São Paulo: Globo, 2011.

FERREIRA, Bernardo. O risco do político: crítica ao liberalismo e teoria política no pensamento de Carl Schmitt. Belo Horizonte: UFMG, 2004.

FORTE, Francisco Alexandre de Paiva. Racionalidade e legitimidade da política de repressão ao tráfico de drogas: uma provocação necessária. Estudos Avançado. São Paulo, v. 21, n. 61, p. 193-208, set./dec., 2007. Disponível em: <http://dx.doi.org/10.1590/S0103-40142007000300013>. Acesso em: 19 jul. 2012.

KARAM, M. L. Redução de danos, ética e lei. In: SAMPAIO, C; CAMPOS, M. (Org.). Drogas dignidade e inclusão social: a lei e a prática da redução de danos. Rio de Janeiro: Aborda, 2003.

KELSEN, Hans. Teoria geral do direito e do estado. Tradução de Luis Carlos Borges. São Paulo: Martins Fontes, 1998

PASSOS, Eduardo Henrique; SOUZA, Tadeu Paula. Redução de danos e saúde pública: construções alternativas à política global de "guerra às drogas". Psicologia \& Sociedade, Florianópolis, v. 23, n.1, p. 154-162, jan./abr., 2011. Disponível em: <http://dx.doi.org/10.1590/S0102-71822011000100017>. Acesso em: 19 jul. 2012.

RODRIGUES, Thiago M. S. A infindável guerra americana: Brasil, EUA e o narcotráfico no continente. São Paulo em Perspectiva, São Paulo, v. 16, n. 2, p. 102-111, abr./jun., 2002. Disponível em: < http://dx.doi. org/10.1590/S0102-88392002000200012>. Acesso em: 19 jul. 2012.

SCHMITT, Carl. Teologia política. Tradução de. Elisete Antoniuk. Belo Horizonte: Del Rey, 2006.

VILLA, Rafael Duarte; OSTOS, Maria del Pilar. As relações Colômbia, países vizinhos e Estados Unidos: visões em torno da agenda de segurança Revista Brasileira de Política Internacional, Brasília, v. 48, n. 2, p. 86-110, dez. 2005. Disponível em: <http://dx.doi.org/ 10.1590/S0034-73292005000200005>. Acesso em: 19 jul. 2012. 


\title{
New institutions for the protection of privacy and personal dignity in internet communication - "information broker", "private cyber courts" and network of contracts
}

\author{
Novos Institutos para a Proteção da \\ Privacidade e Dignidade Pessoal na \\ Comunicação pela Internet - "Corretor de \\ Informaçôes", "Cortes Privadas Cibernéticas" e \\ Redes de Contratos
}

Karl-Heinz Ladeur**

\begin{abstract}
Symposium "Beyond Montesquieu: Re-thinking the architecture of contemporary governance": The internet needs new types of legal ordering, which are adapted to self-regulation and the rapid transformation of knowledge and social norms. Data protection, public investigation, "social media" and financial markets challenge the classical orientation of the legal system towards individual behaviour. The new "addressees" of law are networks as quasi-subjects. New regimes of proceduralisation can structure the development of a "net-friendly" paradigm of a law beyond the individual. The article tries to demonstrate the feasibility of such a model with reference to the above-mentioned challenges.
\end{abstract}

Keywords: Privacy, Internet, Private Courts, Networks

\section{Resumo}

A internet precisa de novos modelos de regulação jurídica, adaptados para a auto-regulação da rápida transformação do conhecimento e das normas sociais. A proteção dos dados, a pesquisa pública, a "mídia social” e os mercados financeiros desafiam a orientação clássica do sistema jurídico para a regulação dos comportamentos individuais. Os novos "destinatários" do direito são as redes que figuram como quase-sujeitos. Os novos regimes de procedimentalização pode estruturar o desenvolvimento de um paradigma jurídico "net-friendly" para além do indivíduo. $\mathrm{O}$ artigo procura demonstrar a viabilidade de um tal modelo com referência aos desafios acima mencionados.

Palavras-chaves: Privacidade, Internet, Mecanismos Privados de Solução de Conflitos, Redes

** University Professor of Law Emeritus, University of Hamburg Faculty of Law. Bremen Research Professor, University of Bremen, Bremen Graduate School in the Social Sciences [BIGSSS]. Email: karl-heinz.ladeur@

jura.uni-hamburg.de
Recebido em 11/08/2013 Aprovado em 21/08/2013 


\section{Preliminary Remarks}

This article looks at the reasons for the lack of a discussion on "network oriented" media and internet law. The Internet has fundamentally changed the conditions of communication. ${ }^{1}$ It has broken down or undermined all borders between formats, individual and mass communication, communication content, and technologies of telecommunication. As a "network of networks" (Elie Noam) ${ }^{2}$, it is also a challenge for the legal system which has linked its conceptions and doctrine to those separations and borderlines.

The internet community tends to react to this evolution by a principled opposition to any legal intervention into internet communication which it regards as incompatible with the autonomy of its users. ${ }^{3}$ This is, at least in some respect, due to the fear that the new "relational rationality" of the net may not only raise the number of choices for the users but also for external control which is simplified by the flexible technology of the internet (whereas at the same time this allows for a reaction to escape or curb control strategies). Certainly the internet is "completely different," but this does not exclude the possibility to develop a "completely different" legal ordering which pays tribute to its flexibility and creativity. ${ }^{4}$ In the following, with a view to several domains of conflict, both concerning the traditional conflict of "the man versus the state" and the new constitutional dimension of legal conflict between private persons (and organizations), it shall be tested how far new network friendly rules might be conceived which not only do justice to the logic of the internet, but might reinforce it.

\section{Protection from offensive Communication in the internet (Blogs etc.)}

\subsection{The structure of media law and the transformation of social norms as its infrastructure}

The reciprocal adjustment of the private and public domains, and, as a consequence, the limits of the distribution of knowledge (and ignorance/secrecy), in the past, followed a kind of "separation of powers" inherent in the knowledge basis of society. ${ }^{5}$ These "knowledge rules" cannot be reduced to simple and static border concepts, but were founded on a complex infrastructure of a plurality of legal and social norms, which included bridging concepts and meta-rules on the conflict of norms - both explicit and implicit. ${ }^{6}$

On the one hand, a media-related law of libel and slander about the limits of public communication has evolved over a long period of time. On the other hand, it should not be overlooked that, at the same time, the oral medium of "rumour" allowed for types of communication that remained beyond the control of the law - and not just under conditions of tight social control of communication. ${ }^{7}$ However, a multiplicity of stop rules of discretion, of separations between the private and the professional, the private and the political, the spatial limits of the expansion of "rumours", the differentiation of different fora (art and newspapers, for example), as well as rules of hypocrisy (paying lip-service to the recognition of "honour" in public while, at the same time, secretly spreading unpleasant

1 See Yochai Benkler, The Wealth of Networks (Yale UP, 2006); Clay Shirky, Here Comes Everybody: The Power of Organizing without Organization (Penguin Books 2009); Lawrence Lessig, Code and Other Laws of Cyberspace (Basic Books 2006), who describe the new logic of the internet as not only a new means of communication.

2 Interconnecting the Network of Networks (MIT Press 2001).

3 For the ideology of this movement see the homepage of the Swedish Pirate Party which even gained access to the European Parliament, www.piratpartiet.se/international/english; the German Pirate Party has in the meantime even become more successful. 4 See Tal Z. Zarsky, Law and Online Social Networks: Mapping the Challenges of User-Generated Information Flows, 18 Fordham Intellectual Property, Media and Entertainment Law Journal 741 (2008); Tal Z. Zarsky, Thinking Outside the Box: Considering Transparency, Anomymity and Pseudonimity as Overall Solutions to the Problems of Information Privacy in the Internet Society, 58 University of Miami Law Review 1301 (2004).

5 See Geoffrey R. Stone, Privacy, the First Amendment, and the Internet, in: Saul Levmore \& Martha C. Nussbaum (eds), The Offensive Internet. Speech, Privacy, and Reputation, (Harvard University Press, 2010), 174, at 180.

6 See Karl-Heinz Ladeur, Helmut Ridders Konzeption der Meinungs- und Pressefreibeit in der Demokratie, 32 Kritische Justiz, 281 (1999).

7 Cf. Lior J. Strahilevitz, A Social Networks Theory of Privacy, 72 University of Chicago Law Review, 919 (2005). 
or spiteful gossip) and the respect for the protection of "appearances" as a cultural achievement (as opposed to claims of "essence" and truth) have contributed to the emergence of a complex architecture of overlapping rules of co- and sub-ordination, specification of situations that have transformed the private as much as the public into a multi-faceted construction that has been processed by different social institutions. ${ }^{8}$

All in all, one can start from the assumption that the historical processes of change are related to the evolution of a paradox, the production and protection of the "individual of society" (Markus Schroer), whose form by itself is related to the different regimes of individuality and its normativity. As a consequence, the construction of "privacy" and its complex rules and patterns is also based upon the idea of a reproduction of society and not upon the right of the individual "to be let alone". 9 The observation and evaluation of "private" behaviour in well-defined spaces and integrated communities were both based upon the protection and the continuation of social norms. ${ }^{10}$

The same is true for the construction of "publicity", which produces forms of differentiation and specification with respect to the development of social memory, the processing of common themes for social communication, different fora of exchange (the media), the private-public spheres of the formation of individuals (family, church, school, reading of canonical texts) and the state as the centre of public decision-making. ${ }^{11}$

\subsection{The great unbundling" of the media and its impact on social norms}

One of the crucial phenomena of the transformation of the media and their public in postmodernity is to be seen in a tendency towards "the great unbundling", a formulation which the American Federal Communications Commission (FCC) has chosen for the description of the tendency towards more specialisation and the decline of a focused public of common interests which had been centred around the state in the past. ${ }^{12}$ This evolution finds its repercussion in an increasing tendency to de-contextualise freedom of opinion and to transform it into a right to unlimited self-expression devoid of any public requirements or borders: the American Civil Liberties Union (ACLU) tends to combat any restriction of freedom of opinion as being prone to the creation of "chilling effects" in the individual: in cases of "cyber-mobbing", for example, the ACLU tends to act as amicus curiae with the clear intent to protect any communication, even the most degrading depiction of teachers in the internet (teachers being shown as decapitated on electronically manipulated photos or other images), whereas the protection of competing interests is regarded as the competency of "pedagogical measures". ${ }^{13}$ This is characteristic of the new evolution towards a blurring of the limits and distinctions that had been the object of the above-mentioned architecture of norms on the inter-relationship between the public and the private in the past, and is now regarded as a "right to be let alone" or to communicate with "friends" without being bothered by any unintended third-party effect. ${ }^{14}$ Whereas, in modernity, the "chilling effect" was invoked as a risk to the public function of freedom of opinion, the blurring of borders between the private and the public is characteristic of the hybridity of the new media. ${ }^{15}$

8 See generally Karl-Heinz Ladeur, Das Medienrecht und die Ökonomie der Aufmerksamkeit (von Halem: 2007).

9 Privacy has paradoxically always had different social dimensions, Levmore \& Nussbaum, Introduction, in: idem (eds), supra note 5, 1, at 10.

10 Strahilevitz, supra note 7; Diane L. Zimmermann, Requiem for a Heavyweight: A Farewell to Warren and Brandeis's Privacy Tort, 68 Cornell Law Review, 291, at 332-334 (1983).

11 Cf. for the state-centred conception of publicity Federal Constitutional Court, Reports (BVerfGE) Vol. 7, 198 at 208; vol. 5, 85 at 205.

12 Federal Communications Commission (FCC), "The Changing Media Landscape in a Broadband Age", (June 2011), available at: www.fcc.gov/infoneedsreport.

13 Cf. Karl-Heinz Ladeur, Rechtsfragen des „Cyberbullying" an Schulen und der Lebrerbewertungsportale in den USA, Frankreich und Deutschland, 7 Recht und Bildung, 3 (2010/1).

14 Cf. the timely theoretical reconstruction of the role of freedom of opinion in a liberal society and the rationale of its limits John Deigh, "Foul Language: Some Ruminations on Cohen v. California", in: Levmore \& Nussbaum, supra note 5, 195, at 210-212. 15 Anyone who has doubts about the necessity to impose limits on offensive internet speech should read the impressive article by Brian Leiter, Cleaning Cyber-Cesspools: Google and Free Speech, in: Levmore \& Nussbaum, supra note 5, 155, at 168, which combines case analysis and insightful theoretical reflection. 
This shift demonstrates the legitimacy of a retrospective on the normative and social rules that have determined the acceptability and attunement or evolution of themes in the "old media" (including oral gossip) in explicit legal and implicit social forms: one of the aspects of this normative definition of limits or relevance could be seen in the preservation of social trust in the professional standards of journalism that should be developed by the media as a kind of "epistemic rules", and which served as a frame of reference in the process of the definition of the legal borders of public and private communication. The obligation to control the truth of a factual claim communicated through the media, the separation of comment and message, reflection on the difference between the private and the public, etc., are the foundations of a process of the self-stabilisation of a set of professional rules by which the media have to abide and whose generalisation allows for the development of a reliable legal standard of control. The professionalisation of journalism and the centralisation of the "epistemic rules" that courts have to draw upon allows for a stable practice of differentiation between knowledge and ignorance, the distribution of communications and secrecy.

Apparently, this complex architecture of norms is severed by the anarchic and heterarchic character of Internet communication. ${ }^{16}$ Do we need new "net friendly" institutions for the protection of the personality rights or the secrecy and ignorance that could conflict with general assumptions about the "freedom of internet"? 17

It could be imaginable to respond to the hybrid character of the new media and the tendency to blur the separation of the public and the private by a legal model that corresponds to this hybridity and which would start from the idea, first of all, of observing the societal basis for the self-organisation of the new rules for communication in conditions of complexity, and to use the legal system, court practice in particular, as a reflexive layer of normative re-coding in the mode of a "regulatory agency". In the next paragraph, a further example for a new regulatory function of private law and private law courts will be given. The dynamic transformation of both social and legal norms has an impact on the function of courts, as private actors tend to transform the stable foundations of a spontaneously-evolving common experience. This can be demonstrated with a view to transnational private law in general, and the ICANN-rules in particular. ${ }^{18}$ As a consequence, one could think, as a first step, of imposing a new responsibility for the management of the rules of Internet communication on the providers. This could be done by a combination of "the carrot and the stick": limits imposed on the liability of providers for third-party communication could be made dependent on the establishment of private institutions of an alternative dispute-resolution procedure that would allow for a preliminary settlement of a conflict about conflicts between freedom of opinion and the protection of personality rights. A kind of private, albeit neutral, "Cyber Court" could act as an arbitrating body ${ }^{19}$ which establishes a cheap and simple mode of decision-making upon the basis of a few flexible procedural rules (only by electronic communication). ${ }^{20}$ One could even think about enabling participation by an "avatar" or the email address. All users of Internet services could be obliged to accept such arbitration provisionally, although this should not exclude the possibility of bringing these cases to ordinary state courts. All privileges of restricted liability, etc., could be formulated under the condition that the provider has to establish a functioning mode of arbitration. State courts would, in this case, act as a kind of second instance courts with the function of controlling the private self-regulation ${ }^{21}$ as it is managed by the "cyber courts".

16 See, for the "imbalance" between privacy and freedom of opinion, Daniel J. Solove, Speech, Privacy, and Reputation on the Internet, in: Levmore \& Nussbaum, supra note 5, 15, at 27.

17 See for the US the discussion on anonymous advertising in the ( for example apartments for: "whites only"), Rachel M. Kurth, Striking a Balance Between Protecting Civil Rights and Freedom of Opinion, 26 Cardozo Arts \& Entertainment Law Journal, 805 at 832 (2008).

18 For the evolution of a transnational law beyond the state in general, see Oren Perez, Normative Creativity and Global Legal Pluralism: Reflections on the Democratic Critique of Transnational Law, 10 Indiana Journal of Global Legal Studies (2003) available at: http:// www.repository.law.indiana.edu/ijgls/vol10/iss2/2.

19 See for the US Olivera Medanica \& Kaiser Wahab, Social Media, Recent Developments and Legal Considerations, 26 Cardozo Art \& Entertainment Law Journal, 237, 266 et seq. (2008), who propose a "notice and take down"-rule for libel incombination with a requirement to take the case to court within 10 days. In addition to this they favour the creation of an insurance fund for the compensation of harm inflicted on persons via the internet.

20 See, for a similar approach, Leiter, supra note 15, at 170, for search engines like Google.

21 Cf. only Gralf-Peter Calliess \& Peer Zumbansen, Rough Consensus and Running Code - A Theory of Transnational Private 
Both levels of "private law regulation" 22 could be expected to observe and evaluate primarily patterns of communication, to block problematical forms of communication or to strengthen productive models, new procedures, and, in the long run, the emergence of new rules that would correspond to the old architecture of social and legal norms on social communication and the relationship between knowledge and ignorance. Those providers who failed to act in conformity with these requirements would be treated as if they followed only private interests (and would not support a public system of communication).

\section{DatA PROTECTION IN THE INTERNET - FOR A CHANGE FROM BUREAUCRATIC PROTECTION TO NET FRIENDLY PROCEDURALIZATION}

\subsection{From the protection of individual "ownership" of data toward the observation of data flows and nodes}

The problems of data protection in the internet are so manifold that not all can be raised in the context of this article. This is also the reason why they cannot be tackled by clear-cut rules to be imposed on the net in advance, from outside. The steering of data-communication is impossible. This complexity can, however, be tackled by a version of proceduralization of the legal order of the self-organization process which the internet undergoes as the "network of networks". The internal differentiation of the legal structure of the internet may allow for the generation of new knowledge and its processing via specific institutions of the internet.

A net-specific problématique of the implementation of legal controls consists in the discrepancy between the attention which the single data of the individual meets on the one hand, and the values of the processing and relationing of data through data mining, the construction of personality profiles ${ }^{23}$, the observation of broad data flows, and the operation of linking data by firms and by the state for reasons of security. The interest in closure and disclosure of information are both legitimate.

\subsection{The necessity to observe the collective effects of the processing of data flows}

It would be much more helpful to change the paradigm of the conception of data protection 2.0 to a focus on networks, i.e. to have a closer look at the opportunities and risks of data processing in networks and to adapt its legal structure which is still characterized by its origin in the offline world to the conditions of the media world. ${ }^{24}$ The rapid proliferation and continuous linking of information in networks can no longer be adequately mirrored in the individual right to decide on separate domains of action which are attributed to persons. This construction can no longer do justice to the hybridization of legal constellations. For example: a firm can possibly generate a high information value by data-mining, ${ }^{25}$ which does not correspond to the construction of an accumulation of infringement of individual rights to decide on the use of the data which are of no particular interest to the user himself. A hybrid construction which is more adapted to the collective transsubjective component of the data in a network can bring a more flexible and adequate solution to this dilemma (see below).

A case for a reconceptualization of data protection is the deanonymization of IP-addresses by both private persons and the public security agencies. In this respect it should be taken into consideration that the internet

Law (Hart Publishing 2010, at 134-152.

22 For a theory of regulation, see Julia Black, Proceduralising Regulation, Parts I and II, (2000-2001) 20-21 Oxford Journal of Legal Studies, 597 (2000) \&, 33 (2001).

23 See Joseph Turow \& Lokman Tsui, The Hyperlinked Society: Questioning Connections in the Digital Age (University of Michigan UP, 2008); Karl-Heinz Ladeur, Datenverarbeitung und Datenschutz, bei neuartigen Programmführern in 'Virtuellen Videotheken', 3 Multimedia und Recht 715 (2000).

24 For a first attempt to give an overview of the problems of privacy in the „social media“ see James Grimmelmann, Facebook and the Social Dynamics of Privacy, 94 Iowa Law Review 1137 (2009).

25 Bing Liu, Web Data-Mining: Exploring Hyperlinks, Contents and Data Usage (Springer, 2007). 
as the "network of networks" cannot be dissolved into a number of linear relationships of exchange between individuals - the precondition of the older regime of protection of protection of privacy in telecommunications - but that the old telecommunication has been transformed into an online world with its own rationality of information processing und generation of new information products which is based on the generation of collective and collateral effects between information. These transsubjective effects can no longer be attributed to individual "owners." Examples of these new phenomena are eBay ratings ${ }^{26}$ and ratings of professional achievements (teachers, professors, medical doctors etc.). ${ }^{27}$ The ubiquitous nature of the internet and its new logic comes also to the fore when we take a look at the transformation of the relationship between different types of rights which have been developed and coordinated in the offline world and migrate into the internet. It is inevitable that this entails a major effect of destabilization which has to be compensated by a rebalancing.

\subsection{The self-organization of the "data-owners"vis-à-vis private actors following the example of" "collecting societies" in the protection of intellectual property: A model for a net friendly legal instruments}

A new "control regime" ${ }^{\text {"28 }}$ which is fine tuned to the functioning of the internet and the processing of data and patterns of combination could, for example, consist in the public and private funding of self-organized private institutions for the protection of data in the internet following the model of collecting societies in intellectual property law and practice. ${ }^{29}$ Such a new type of association of users might act as "information broker" in the sense of a representation of the hybrid public-private interests of the users which transcend their own limited privacy concerns and are focused on the transsubjective elements of data processing in the Internet. These associations could make contracts on the conditions of the use of data that are not of much concern for each individual. This approach could correspond to the new transborder effect, which is common for the internet use of data inasmuch as it raises collective effects from mass transactions which hitherto did not have any relation except to a central agent (such as a broadcaster). This "information broker" might make contracts on payment for the use of internet data or make contracts on the quality of protection of privacy. This form might be a productive alternative to the bureaucratic form of data protection by the institution of a public officer for the protection of privacy (Datenschutzbeauftragter)..$^{30}$ This model could present the appropriate levels of flexibility and hybridization (balancing individual and collective interests) which are required by the logic of the internet, whereas traditional legal instruments and procedure are more based on the expectation of stability of rights and public goods.

A new control regime has to adapt to the volatility and ubiquity of internet communication by flexible self-organization of legal positions which are involved in a procedural mode of permanent self-transformation. It has to react to the fact that even identities are no longer stable but are "sampled" and open to transformation. One can even go so far as to assume that networks themselves become quasi-subjects in their own right.

26 In the US eBay offers an electronic mediation procedure via "Square Trade;“" http://pages.ebay.com/services/buyandsell/ disputeres.html

27 Karl-Heinz Ladeur, Die Zulässigkeit von Lehrerbewertungen im Internet, 56 Recht der Jugend und des Bildungswesens 16 (2008); the Federal Court of Justice (Bundesgerichtshof) has regarded ratings of teachers as legal, see Dec. of June 23, 2009, VI ZR 196/08, 64 Juristenzeitung 961 (2009) with a comment by Karl-Heinz Ladeur; for cyber-mobbing in schools in the US see Rita J. Verga, Policing their Space: The First Amendment Parameters of School Discipline of Student Cyberspeech, 23 Santa Clara Computer and High Technology Law Journal 727 (2007); with respect to the differentiation of different types of public spaces in the internet era see Jonathan Zittrain, The Future of the Internet - and How to Stop it 213 (Yale UP, 2008), where classrooms e.g. are regarded as "private public spaces" which should not be turned into "public public spaces"; otherwise there would be a pressure to be always on "press conference behavior".

28 Harrison C. White, Identity and Control: How Social Formations Emerge 345 (2nd ed., Princeton UP, 2008).

29 Karl-Heinz Ladeur, Datenschutz - vom Abwehrrecht zur planerischen Optimierung von Wissensnetzwerken, 24 Datenschutz und Datensicherheit 12 (2000); for a critique to "economization" of data following the model of intellectual property rights, see Thilo Weichert, Die Ökonomisierung des Rechts auf informationelle Selbstbestimmung, 54 Neue Juristische Wochenschrift1463 (2001).

30 Obviously there are limits to the individual decision on data but this process of self-organization might also help determine these limits. 


\section{Criminal law and Criminal procedure in the faCe of "Risky networks"}

\subsection{From organized criminality toward "criminal networks" - the example of Al Khaida}

On February 27th, 2008, the German Federal Constitutional Court ${ }^{31}$ pronounced a new fundamental decision on online investigation for the purpose of criminal prevention. It has pronounced a new "computer freedom ${ }^{632}$ in the sense of the protection of confidentiality and integrity in electronic systems as a new version of the protection of privacy. One may doubt that this general construction fits the emerging logic of networks because the internet is not just a means communication but of production of informational goods and bads as well. From the point of view of the public authorities a balance has to be struck between the protection of informational actors and networks on one hand, and on the protection from the perverse effects of the confidentiality ${ }^{33}$ of the internet in particular. The internet is not a more sophisticated version of the telephone, which is a means of individual exchange. It is a whole new "online world", a "network of networks", including a whole range of different formats and regimes which cannot be paralleled with anything we have known in the past. For example: the Bundesverfassungsgericht (Federal Constitutional Court) has already in the past reduced the level of protection for conventional telecommunication which abuses the anonymity of electronic contacts for criminal purposes or for anonymous harassment. ${ }^{34}$ This looks obvious: why should a person deserve the procedural aspects of the protection of telecommunications for direct criminal purposes? (This is not to be confounded with the control of the content of communication.)

In the internet one has to be aware of the fact that networking as such can be an efficient form of preparing and committing criminal acts which would not be imaginable in traditional telecommunication. So, why should all parts of the network of networks deserve the same level of protection? This cannot be a consequence of the new computer freedom.

The court formulates a number of requirements for online investigation ${ }^{35}$ for purposes of public security in particular, $i$ e. the concrete threat of a danger to be expected for an important public good on the basis of concrete facts which in general have to be checked by a judge. One has to bear in mind that a new type of criminality is emerging, what I would call "network criminality." In the field of terrorism, no longer primarily concrete acts are to be feared which can be attributed to persons. At the same time "risky networks" come to the fore which can no longer be regarded as mere preparatory communications that from a legal point of view are irrelevant below a concrete step of implementation of a criminal plan. The inherent risks of such criminal networks have to be reduced to a certain extent in a strategic mode, their "costs" have to be raised once a clear-cut prevention of any criminal action would appear to be an illusion. Terroristic activities of $\mathrm{Al} \mathrm{Khaida}{ }^{36}$ and like networks are processed in postmodern fractal "cellular businesses" in which different ideological, military, informational, financial, communicative, etc., operations are aggregated in a heterarchical "virtual organization." Criminal law had to adapt to the emergence of organized criminality (e.g. by the adapting doctrine to collaborative action), and the same will be inevitable for "criminal networks." The forms of criminality follow the transformation of the legal evolution of cooperation; in the network society $^{37}$ we have networked criminality.

31 Federal Constitutional Court (BVerfG), 61 Neue Juristische Wochenschrift 822 (2008).

32 See the comment by Martin Eifert, Informationelle Selbstbestimmung im Internet, 28 Neue Zeitschrift für Verwaltungsrecht 521 (2008).

33 See for the English conception of privacy as a regime of "confidentiality" Neil M. Richards \& Daniel J. Solove, Privacy's Other Path: Recovering the Law of Confidentiality, 96 Georgetown Law Journal 123 (2007).

34 BVerfGE 85, 386; see generally A. Michael Froomkin, Legal Issues in Anonymity and Pseudonymity, 15 The Information Society 113 (1999).

35 BVerfG, 61 Neue Juristische Wochenschrift 822 (2008).

36 See RAND Document "Beyond Al-Qeida, "2 Vols., 2006.

37 Manuel Castells, The Rise of the Network Society, Vol. 1: Economy, Society and Culture (2nd ed., Willey-Blackwell, 2000). 
As in franchising networks ${ }^{38}$, we find central integrative nodes (for the ideology). Apart from this element we have "strings" which are set up for the collection of data, the financial transactions which on the face appear to be harmless and do not allow for the identification of "concrete facts" which can be read as the starting point of a criminal act. The functioning of the "risky networks" could not be observed at all if any investigation could only be focused on concrete "facts" that indicate imminent danger. Liberal institutions are adapted to handle danger which can be attributed to persons. They have difficulties in addressing the risk related to criminal organizations, but they have yet to meet the challenge of risky networks.

There is a deep imbalance between the rights of users and third parties - private and public - in the online world: In the offline world the state, in particular, has a lot of formal and informal instruments of observation and investigation in criminal procedure. Traces can be analyzed, testimonials can be collected, experts can be asked, etc. In the internet, "traces" are always digitized; they can only be analyzed if this possibility is introduced into the architecture of the net. If one were to leave this disruption aside, data protection would end up as systematic protection of criminal wrongdoers. In the offline world, protection of privacy, the secrecy of telecommunication, and the presumption of innocence in particular abuse, and the possibility of "false negatives" in criminal investigation is accepted because otherwise unintended perverse effects might have a repercussion on freedom in general and generate a chilling effect on communication $e$. g. by telephone. ${ }^{39}$ If, however, the collection of proofs meets a systematic difficulty linked to the whole technological structure of the online world, this could change the balance between the rights and public goods which are at stake in this constellation. It would generate the certainty that one could not be prosecuted for criminal acts committed under the protection of anonymity in the online world.

The "chilling effect" would in this case be created on the side of the potential victims of criminal acts and the state as defender of individual rights. This is why anonymity cannot be given such far reaching protection against criminal investigation. On the other hand, one has to admit that the reverse reaction the unlimited expansion of public privileges for investigation in criminal procedure - would create a new imbalance because it would ease the investigation even below the threshold of risks which can be attributed to concrete action. However, one has also to consider that the flexible internet communication simplifies the preparation of serious criminality by the protection of anonymity. And in addition to this one has to bear in mind that the limited intrusion into the preparation of criminal acts is not without preconditions: it is based on the assumption that - in political criminality in particular - the plans to commit, for example, a terroristic act may be hampered by the influence of the public fora (discussions with others, radio, TV, press etc.)..$^{40}$ On the other hand, the internet brings to the fore a whole range of new networks which are completely closed off from any irritating influence from other groups, ideas, etc. The internet is a network of networks, but this does not mean that all the networks are interrelated; on the contrary. This means, that the fragmentation of the "internet fora" which replace traditional conceptions of a publicity that is managed by the classical media risks to sever the public debate as a means of rationalization of politics, reflection of individual motives or reciprocal observation and evaluation of behaviour.

\subsection{Criminal procedural investigation}

There is a lot of discussion about data-protection by technology - so why not think about a technology that would not protect privacy in a fundamental way but would impose limits on the use of procedural measures ofpublic investigation? Individuals move actively through the internet with the use of a pseudonym as a kind of avatar. The same could be imagined in the reverse role when they are partially identified as "nodes"

38 Gunther Teubner, Networks as Connected Contracts 21, 235 (Hart Publishing, 2011).

39 For communication in general see Frans Birrer, Data Mining to Combat Terrorism and the Roots of Privacy Concerns, 7 Ethics and Information Technology 211 (2005).

40 See the overview in Mark A. Graber, Transforming Free Speech: The Ambiguous Legacy of Civil Libertarianism 144 (University of California Press, 1991). 
in a risky network: in order to limit public collection of data one can choose an objective limit and reduce investigation by formulating a high level of intervention ("concrete facts") ${ }^{41}$ One could also think about a subjective mode of limiting the linkage of the data found in the internet to the real name of a suspicious person in the offline world. To a certain extent only this avatar of a person may be constructed and used as a frame of reference for the collection of data. Only a second level of investigation would allow under certain conditions to make a link between the online and offline worlds, $i$. e. the real person and its avatar. ${ }^{42}$

The technical basis of such a differentiation could again be seen in the possibility of calculating a hash value which freezes the data and the potential IP-address or other ways of access to the real world in a numerical code and deposits the key to the offline world at a separate institution which might be organized as a kind of cyber court within the agency. The technique of erecting firewalls within the net which separate different informational regimes could be transferred to public investigation procedures. Control regimes could be differentiated according to the potential of the internet and its relational rationality.

A major part of the public concerns about the increasing data collection in public agencies could be mitigated with such a net friendly strategy. At the same time such a formalized operation with firewalls within state bureaucracy might allow for better control than an unstructured mass of data which is collected and processed according to different patterns and rules. The strategy of public officers of data protection to declare any data to be sensitive in advance is not adapted to the strategic mode of operation in networks. Data protection and its control regimes in the internet have to be conceived in a net-related mode. They should focus on nodes of relationships in networks and not (primarily) on persons. (Obviously there are types of data which are sensitive from the outset, e.g. data on health, but this is not the rule.)

\section{Contracts ON THE USE OF SOCIAL MEDia AS „NETWORKS OF CONTRACTS“?}

\subsection{Social media and data protection}

The use of "social media" such as Facebook has raised several legal questions, of data protection, in particular. This problem will exacerbate in the future because - as has been shown by Facebook's entry on the securities market - the high value of a firm such as Facebook is, to a large extent, a valuation of hope. The actual profit drawn from personalised advertising does not yet justify the actual value of the firm. ${ }^{43}$ This is why conflicts concerning data protection are gaining more relevance. The firms have to develop more novel forms of advertising, an evolution which, in turn, raises more concerns about the protection of privacy because "social media" promise more fine-tuned addressing of advertising, and this includes more observation of user- habits and interests. Both the data protection officers of the German Länder and a recent court judgment from the Berlin District Court (Landgericht) ${ }^{44}$ have raised concerns about Facebook's practices of both the collection and the use of personal data for advertising purposes. In the context of a constitutional perspective on the conflicts concerning new electronic media in general, the question should be asked as to whether or not new trans-subjective institutional solutions could be formulated in order to attempt to bear in mind the deep transformation that is taking place in the new media. Both the firms themselves and the protagonists of a more rigid conception of data protection tend to focus on the role of the consent of the individual consent (the will of both the users and the providers) or the individual interest (mainly) of the users.

41 BVerfG, 61 Neue Juristische Wochenschrift 822 (2008).

42 See Kim A. Taipale, "Data-Mining and Domestic Security. Connecting the Dots to Make Sense of Data", 5 Columbia Science and Technology Law Journal 1 (2003); id., Technology Security and Privacy: The Fear of Frankenstein, the Mythology of Privacy, and the Lessons of King Ludd, 7 Yale Journal of Law and Technology 128 at 159 et seq. (2004).

43 http://www.forbes.com/sites/petercohan/2012/05/10/can-facebook-tap-11-billion-mobile-ad-market-to-justify-pe-of-206/

44 LG Berlin, judgement of March 6th, 58 Wettbewerb in Recht und Praxis (WRP) 623 (2012); cf. Christian Solmecke/Annika Dam, Wirksamkeit der Nutzungsbedingungen soz̧ialer Netz̧werke, 15 Multimedia und Recht (MMR) 71 at 732 (2012) (Facebook). 
This is all the more problematical as the right to privacy is in itself a right that lacks transparent contours like a classical liberal right, ${ }^{445}$ and seems to be dependent on the individual self-interpretation of the users. Recent empirical analyses tend to come to the conclusion that there is a wide range of attitudes towards the protection of private data with regard to the diffusion of news among "friends". At the same time, there have been protests on the part of the users against one-sided changes of privacy rules set up by Facebook, for example. The inherent dynamic of transformation of social media leads to a complexity of the rules and patterns of communication ${ }^{46}$, and to their re-coding for commercial purposes, which is not easily accessible to individual users. One could think about a more "trans-subjective" approach to privacy in social media that would include a more institutionalised conception.

This could look plausible because the right to privacy as a new right beyond the realm of classical liberties could be attributed to the new "risk based law" - as opposed to the classical right of being protected from "danger" - as is the precautionary principle in environmental law whose individual component is also only mediated. In data protection law, this seems to be similar. ${ }^{47}$ This is why there is a need for more trans-subjective institutions that are better adapted to the process, such as distributed interest in the control of the "re-coding" and "re-profiling" of data. This assumption is not equivalent to a fundamental break with classical doctrine, but it should open a perspective on the development of a "conception", which would allow for experimentation with the instruments which the current legal system contains, and would opt for public intervention only in a limited way - because of the uncertainties of the markets.

\subsection{The „network contract" as a new paradigm of private law for the „social media“}

First of all, it should be recognised that, besides other legal arguments for the liability of social-media providers, primarily the relationship between users and social media is a contractual one. In the American literature, this type of contract is regarded as an "adhesion contract". ${ }^{48}$

In legal practice, this means that the contract has the legal value of a more or less one-sided submission to the contract because conditions are normally formulated by only one partner of the contract, i.e., the "provider". The construction of a contractual relationship seems to be adequate because one partner, the provider, offers the possibility of using the communication services, whereas the other, the user, gives his consent to the use of the data that he places on his account for advertising strategies. This mutual consent brings about a relationship of reciprocity: the user can expect the conditions of use not to be changed arbitrarily. The provider lays open the conditions of use and the commercial use of the data for advertising, in particular. An exclusion of any forms of advertising is not a choice which is open to the users.

The specific contractual relationship that is brought about in this constellation is characterised by the fact that a high number of similar "exchange" contracts are concluded at the same time, and that conditions of use are formulated by the provider. However, at the same time, there is a second level of inter-relationships among the users themselves, which is not just a multiplication of a standardised version of a contract, although, in this

45 This is why Helen Nissenbaum's conception of "Privacy as Contextual Integrity", 79 Washington Law Review, 119, at 136-8 (2004), does not look promising because contexts are so varied; see, also, the critique by James Grimmelmann, Saving Facebook 94 Iowa Law Review, 1137, at 1169 (2009); whereas in the public-private relationship the idea of "relational surveillance" that might have a "chilling effect" on the use of the freedom of association (and freedom of opinion) as Katherine Strandburg, Freedom of Association in a Networked World: First Amendment Regulation of Relational Surveillance, 49 Boston College Law Review, 741 (2008), the effect of private collection of data on the rights of users is far from obvious (which does not mean that it is non-existent).

46 Arun Mal \& Jenisha Parikh, Facebook and the Right to Privacy: Walking a Tight Rope, 4 National University of Juridical Studies Law Review (NUJS LR), 299 at 305 (2011); Helen Anderson, A Privacy Wake-Up Call for Social Networking Sites?, 20 Entertainment Law Review, 245 (2009), refers to a practice of users to allow for the use of „their“ data by inadvertently neglecting their privacy settings. 47 Cf. Karl-Heinz Ladeur, Das Recht auf informationelle Selbstbestimmung - eine juristische Feblkonstruktion?, 62 Die Öffentliche Verwaltung 45 at 48 (2009).

48 Cf. the seminal article by Friedrich Kessler, Contracts of Adhesion - Some Thoughts About Freedom of Contract, Yale Faculty Scholarship Series Paper 2731, http://digitalcommons.law.yale.edu/fss_papers/2731. 
case, the relationships between the participants including the user - user-relationships - form a "triangular" contract. The consent of the user to make use of the data for advertising only makes sense in the event that the other users allow for this use, too. This constellation might allude to the recent construction of "network contracts" ${ }^{\prime 49}$ - with a principled construction of this new type of contract, although Stefan Grundmann is more prudent in this regard. ${ }^{50}$ The sense of such a construction could consist in the consequence that the triangular nature of the contract does not remain at the factual level but can lead to ideas about a specific "hybrid" institutional component. The relationship is a "hybrid" one in as much as it can be located beyond the level of the bilateral exchange contract, but below the level of a "company" (or, even less so, a corporate association). One has to bear in mind that this is not a normal case of a pre-determined setting of "general terms and conditions" that supplement the consent of the partners on the reciprocal rights and obligations, but of a one-sided competency of the provider to define the main duties of the user and to change them whenever he deems it appropriate. ${ }^{51}$ The differentiation of the informational scheme of Facebook's sites mirrors, in a way, the "hybrid" character of the "regulatory" structure of the network: Facebook has, apart from the site on which the general terms and conditions are laid out, ${ }^{52}$ a separate site on "governance", ${ }^{53}$ which contains rules of procedure on the change of rules, etc. This construction might look promising, although, as a consequence, only those members that click on this site $^{54}$ obtain the information on the procedures. ${ }^{55}$

The trans-subjective ("hybrid") component of the contract is to be seen in the fact that the purpose of the contract is not to be formulated clearly in advance. The relationships within the network are prone to continuous change, they evolve upon the basis of communication processes, which, first of all, are freely formulated and are integrated into a vast open network of relationships that allow for a plethora of communicative options. It is only at a secondary step that the provider observes these inter-relationships and tries to design the possibility of "surfing" on this network with the modelling of a commercial type of interest.

Advertising in the "social media" does not follow the traditional patterns of addressing a mass public; instead, it is characterised by the observation and "appropriation" of specific communicative networks that are spontaneously generated by the users. These differentiated networks process personalised information on consumer interests that may be re-coded by advertising firms. This is also the reason why the consent of the users for the re-processing of personalised profiles cannot be determined in detail ex ante.

This new constellation might fit into the new framework of "networks of contract" which might help develop new rules for the management of a hybrid "network interest" (G. Teubner) between exchange and collective interests. This "network interest" is emergent and heterarchical; at the end of the day, it can only be adopted for purposes of advertising if this is consented to by the users. The provider cannot just follow his own interest, but also has to support the processing of the networks of communications between the users by shaping an adequate institutional framework. ${ }^{56}$ The relevance of the network of the inter-relationships between the users and the openness of the experimental development of communicative patterns and, at the same time, the evolving possibilities of personalised advertising could be a sound basis for the re-formulation and concretisation of the pre-conditions of "informed consent" in a dynamic environment. ${ }^{57}$

\footnotetext{
49 Teubner, supra note 40.

50 Stefan Grundmann, Die Dogmatik der Vertragsnetze, 207 Archiv für die civilistische Praxis, 718, at 757 (2007).

51 For a critique, see Robert J. Ferenzi, Friending Privacy: Toward Self-regulation of Second Generation Social Networks, 20 Fordham Intellectual Property, Media and Entertainment Law Journal 1049, 1056 (2010).

52 www.facebook.com/legal/terms.

53 www.facebook.com/fbsitegovernance.

54 Recently, Facebook has announced a change in the "terms of use" on the governance site and opened a voting procedure for the week of 1 June to 8 June 2012; however, only a tiny fraction of the users that remained far below the quota has participated; cf. "Die Mitbestimmung ist rein virtuell", Frankfurter Allgemeine Zeitung of 6 June 2012.

55 See Ferenzi, supra, note 51, at 308.

56 This complex new network related interests might also give an explanation for the fact that apparently the interests of the individual users concerning their "own" data seem to be limited, as Grimmelmann, supra note 45, at 1182, rightly assumes; see, also, idem, Privacy as Product Safety, 19 Widener Law Journal, 795 at 795-97 (2010).

57 Rebecca MacKinnon, Consent of the Networked: The Worldwide Struggle for Internet Freedom 243 (Basic Books, 2012) and passim;
} 


\subsection{Proceduralisation of „,informed consent ${ }^{\prime \prime}$}

In order to do justice to the emergent character of the rules ${ }^{58}$ and patterns of communication and their re-coding by advertising strategies, one might think about introducing a procedural format that has been used in regulation in conditions of complexity, i.e., the "notice and comment" 59 procedure which the new rules given by the provider should be required to undergo.

This is a new institutional requirement of norm-setting in public procedures. However, it could also be transferred to private processes that have to observe and aggregate the knowledge that is distributed over a high number of users and considers both the normative expectations and the social norms generated over the networks of communication in a process of private norm-making. This procedure seems to be specifically adequate in conditions of a modelling in conditions of complexity. One should think about a transfer of this format at least to contracts on the use of social media. As a procedural element of rule-making, it has not been confined to regulation in domains of public law: in globalised private rule-making ${ }^{60}$, it is quite common to make use of "notice and comment" as a requirement of the adequate balancing of interests. ${ }^{61}$ The process of communication within the networks of social media is also a source of new social norms ${ }^{62}$ concerning privacy expectations, the limits of intimacy and secrecy, of fashions and habits, etc. ${ }^{63}$ which are re-coded by new forms of personalised advertising, and which might become the object of supplementary "web obligations".

The formation of norms through a spontaneous emergence of patterns of communication and their stabilisation through social expectations and norms and their use in advertising strategies all play an important role in social media. This could be regarded as a "network effect" that might be attributed legal value. A legal "network interest" could be formulated in as much as the provider could be come the addressee of a procedural obligation to formulate "net friendly" norms that are open towards the experimentation with new forms and norms of communication and to ascertain a level of reflexivity within the "network of contracts".

Through the architecture of the user formats and the „terms and conditions of use” that are formulated by him, the provider creates the institutional basis whose relevance extends far beyond the narrow limits of an exchange contract. As in the classical media (press, broadcasting, etc.) a public interest concerning

the dynamic of the social media is also emphasised by Grimmelmann, supra note 45, at 1195; the District Court of Berlin (Landgericht) has taken the view that several of the clauses contained in the "Declaration of Rights and Obligation" (German Version) are not in conformity with the German law on the use of clauses on "terms and conditions" in contracts and cannot be regarded as being included in the contract. 58 This transsubjective relevance of rules that are generated in the networks of communication is a focus in Strahilevitz, supra note 7, at 925-7 (2005); the networks as such have to be integrated into the legal system not just the protection of individuals in multifaceted "contexts".

59 Cf. Ferenzi, supra note 51, at 1100; the specific problems of accessing "terms and conditions" in the internet to regard "click through" bettings or a "browse wrap agreement" as being appropriate as procedure of information and as a consequence a "clicked" consent also being "informed" shall only be mentioned, cf. Ferenzi, supra note 51, at 1072-75 \& 1078; see, also, Fteja v. Facebook, Inc., No 11 Civ. 918 (RJH), 2012 (WL 183896) SDNY, 24 January 2012; for a new informational approach to privacy also Joseph M. Reagle jr., P3P and Privacy on the Web FAQ, http//:www.w3p.org/P3P/P3FAQ.html.

60 Cf. only the contributions in Walter Mattli \& Ngaire Woods (eds.), The Politics of Global Regulation (Princeton UP, (2012).

61 The integration of changed "terms and conditions" into a contract via internet communication ("browse wrap agreement") pre-supposes already according to court practice in Canada "reasonable notice" (Kanitz v. Rogers Cable Inc., (2002), 58 O.R. (3d) 299 (Ont. Sup. Ct.); this implies an obligation imposed on the user to check from time to time whether changes have been posted, and not an explicit "I agree" communication; the postion of US courts is quite similar: Register.com, Inc. v. Venlo, Inc. 356 F. 3 d. 393 ; 2004 US App. LEXIS 1074 69; USP. Q.2D (BNA) 1545.

62 Interestingly Facebook Inc. itself observes and refers to the emergence of "social norms" in social media according to which the users do no longer value privacy in the traditional sense, as Mark Zuckerberg, Facebook's founder declared, www.guardian.co.uk/ technology/2010/jan/11/facebook-privacy.

63 This includes the use of biometric data ("autotagging" for "Facial recognition"), a practice that has been criticised by the Irish Data Protection Officer in the "Report of Audit" on Facebook Ireland Ltd., 21 December 2012, in spite of the fact that this issue is not specifically addressed in Irish data-protection law, available at: http://dataprotection.ie/documents/facebook $\% 20$ report/ final $\% 20$ report/report.pdf. 
the functioning of societal communication versus the stateis at stake. At the same time, it is increasingly recognised that - as a kind of reverse side of the protection of communication - an institutional self-limitation against a potential self-endangerment of its function appears to be necessary. This seems to be all the more so because it is the user-generated content, ${ }^{64}$ and not just the use of pre-determined information, that makes the difference ${ }^{65}$ : this situation creates a lock-in effect because the user cannot easily transfer his content to a different network. The specific "web interest" that goes beyond exchange interests demands a type of self-regulation by the provider - this type of self-regulation of a whole group of firms can be found in the laws on the protection of minors in public, for example, in Germany. However, there is no reason why regulation of self-regulation should not be extended to single (powerful) firms. In the past, "self-regulation" was primarily regarded as an alternative to public regulation.

In the meantime, however, a kind of "regulatory private law" - to name only consumer protection law" - has also emerged, which, in contrast to competition law and its focus an the preservation of markets, aims at a direct steering of behaviour with a view to the creation of more variety of choices beyond the traditional narrow control of contracts. A new private-law based construction of the emerging figure of a "network contract" on the use of "social media" could be a new case for the conception of private regulation if one also takes into consideration the impact of a public interest in new hybrid versions of "private public" communication. ${ }^{67}$

The "notice and comment" procedure could be such an element of regulation in the forms of private law. At the same time, one could go a step further and impose a duty on providers to support the the mediation of interest between the firm and the users. These mediators could help the users to participate in the "notice and comment" procedure in a meaningful way. ${ }^{68}$ It has to be borne in mind that the fragmentation of the forms of use, the novelty of the emerging personalised strategies of advertising and the complexities of the "network contracts" including the difficulties in understanding the consequences of the position of individuals in the overlapping networks of inter-relationships are a good reason to think about the protection of a new type of "consumer" i.e., a hybrid type of "netizen", who plays different roles in the dynamic evolving web. A supplementary reason for public intervention could be seen in the fact that, from case to case, the interest of the user might be of only low relevance, and this might block access to courts for factual reasons, whereas the public interest of allowing conflicts about data protection to be brought to court is considerably higher.

\subsection{The impact of constitutional law on private „network contracts“}

In many European countries, this idea could be linked to the conception of the impact of constitutional liberties on private law, on the one hand, ${ }^{69}$ and the procedural dimension of the protection of civil liberties, on the other. This latter dimension has, until now, been considered only for public law, i.e, the German Fed-

64 The protection of user generated content is an element that could also be given more contours if it was more related to the productivity of the networked communication and would not only be regarded as „property " of an individual user: it is content that is generated over the network and should not be easily be attributable by ,informed consent" in a formal way to the service provider; see, only, Ferenzi, supra note 51, at 1064; see, also Mal \& Parikh, supra note 46, at 302, who rightly refer to the fact that the fact that more often than not "content" is distributed over various Facebook sites.

65 In Germany, the District Court of Berlin (Landgericht) in a judgment of 6 March 2012 - judgment No. 16 O 551/10 - published in: 58 Wettbewerb in Recht und Praxis, 613 (2012) has declared the broad reservation of competencies to make use of user generated content in particular has been regarded as being incompatible with data protection law and with the requirement to restrict the breadth of transferred intellectual property rights.

66 Eva Kocher, Funktionen der Rechtsprechung. Konfliktlösung im deutschen und englischen Verbraucherrecht 477 (Mohr, 2007$).$

67 Zittrain, supra note 27, at 213.

68 For the necessity of transparency of terms of use, see the above-mentioned Irish report, supra note 63, at 4.

69 The article by Aurelia Colombo-Ciacchi, The Constitutionalization of European Contract Law: Judicial Convergence and Social Justice, 2 European Review of Contract Law, 167 (2006), demonstrates upon the basis of research in ten European countries that the "horizontal effect" of civil rights is widely recognised by courts in Europe; see, also, ead., Giovanni Commandé \& Gert Brüggemeier (eds), Fundamental Rights and Private Law in the European Union, 2 vols., (Cambridge University Press (2010). 
eral Constitutional Court has, on several occasions, derived a protective, ${ }^{70}$ and, in particular, a procedural, component even from substantive civil liberties; at the same time, it has emphasised the constitutional relevance of duties to be heard not only in procedures that aim at a restriction to be imposed on a civil liberty, but also in the case of a right to be protected from harm that is expected from industrial installations (nuclear power plants, in particular). ${ }^{71}$ Against this background, only a further step would be needed to combine both the doctrine of the expansion of civil liberties to private law and the procedural dimension of civil liberties, and to regard this as a basis for the development of new procedural requirements for the construction of a new network contract on the use and design of "social media". In collective labour law, procedural elements of the protection of privacy have already been developed..$^{72}$ Clearly, one has to bear in mind that Facebook is not only a network, but that it is also a transnational network which raises the problem of determining the applicable domestic law. ${ }^{73}$ This, however, is a complex question that needs differentiation with respect to public and private law, and will not be tackled here. In a context of international or transnational constitutional law, one could at least consider the possibility of constructing a transnational effect of domestic constitutions in the sense that a domestic constitution should not just simply be "applied" to transnational networks, but its trans-border expansion should take into account that other domestic constitutions are also at issue. ${ }^{74}$ This could be a case of heterarchical approach to the constitutionalisation of transnational private law that accepts some leeway for the self-regulation of private actors, and fine-tunes constitutional requirements in a co-operative manner that always considers whether constitutional "irritations" " imposed on private legal relationships would be acceptable for other countries and their legal system, as well.

\subsection{The creation of "information brokers" and cyber courts" as components of a new institu- tional architecture of internet governance}

Finally, one could go one step further and improve the position of the users and the procedure of consenting to the use of their data in advertising by transforming the rights of the users to their data to a quasi- property-like intellectual property, ${ }^{76}$ which could lead to more clarity about the object of the "informed consent" (including a right to financial compensation) and could justify the ability to bring claims to court tocollecting societies as is common in intellectual property law. This task could be transferred to the above-mentioned "information brokers", which need not have a monopoly. They could even develop competing strategies and contribute to a pluralistic conception of the reflection of social media. Such a solution would strengthen the position of the users in the process of formulating and transforming the conditions of use in the social media. At the same time, it would contribute to a strategy of establishing transparency in the networks of contracts and their evolution. In addition to the "proceduralisation" of data protection law outlined in this paper, the development of a more network-friendly "alternative dispute resolution"

70 Cf. the overview in Dieter Grimm, The Protective Function of the State, in: Georg Nolte (ed), European and US Constitutionalism 137, at 154-155 (Cambridge University Press, 2005); Frank Michelman, The Protective Function of the State in the United States and Europe, in: ibid., 156 et seq.

71 Reports of the Federal Constitutional Court (BVerfGE vol. 53, 30, 65 - Nuclear Power Plant Mülheim-Kärlich).

72 Cf. for the role of workers representatives in collective labour law Reports of the Federal Labour Court (BAGE) vol. $127,276$.

73 This is due to the fact that the relationship between "Facebook Ireland" and the American organisation is contested: The Irish Data Protection Commissioner apparently takes (with good reasons) the view that Facebook Ireland Ltd. is the legally autonomous European branch of Facebook and is subject to the control by Irish authorities in the EU; German authorities like the Data Commissioner of the state of Hamburg regard the American Facebook Ltd. as the relevant legal actor, and as a consequence assume a competency for supervision of German authorities, der Hamburgische Beauftragte für Datenschutz und Informationsfreiheit, Datenschutz. Tätigkeitsbericht 2010/2011, 2012, p.158-160.

74 Cf. Karl-Heinz Ladeur \& Lars Viellechner, Die transnationale Expansion staatlicher Grundrechte, 46 Archiv des Völkerrechts, 42 (2008). 75 For the use of this conception that attributes also emergent heterarchical proliferating effects to the law as opposed to a hierarchical construction of a superiority of norms and application or of a ranking of norms, see Gunther Teubner, Legal Irritants. Good Faith in British Law or How Unifying the Law Ends Up in New Differences, 61 Modern Law Review, 11 (1998).

76 This construction is not equivalent to protection of data as object of „ownership“ right away - a construction that is criticised by Grimmelmann, supra note 45 , at 1192 . 
mechanism (that has been modelled for the protection of personality rights in the previous section) should be required also in this domain, which would allow for a simplified (electronic) procedure and decision by a private "cyber court", instead of a decision by a state court. ${ }^{77}$ The advantage of such a procedure would not only consist in easing access to the protection of rights, but also primarily in the acknowledgement that postmodern society needs a new institutional infrastructure that is focused on the observation and reflection of rapidly changing social norms, instead of stable legal norms. ${ }^{78}$

The re-construction of the contractual constellation of the operations that are processed in the social media was meant to venture an idea on how a network-friendly development of private law and the institutionalisation of a specific legal regime for the "online world" might be conceived. Unfortunately, many protagonists regard Internet anarchy as the only version of freedom of communication and look wryly at any attempt to establish institutions for free communication. The development of the "social media" demonstrates the ambivalence of such an aversion against legal institutionalisation of the Internet communication. The case that has been discussed here shows that this anarchy might also have detrimental effects on the position of the users of the said social media.

\section{OUtLOoK}

We need "traffic rules" for the internet and the information society, not the protection of a nomadic individualism which fights against any restriction of its autonomy. A network friendly internet law could make use of the technological flexibility of a digital relational rationality. Data protection is not the core element of civil liberties as its protagonists sometimes try to make the public believe. The risks of the new technologies and the potential perverse side effects of its use can only be managed within the domain of options which the digital online world has created. Hybridization and the proliferation of linkages through networks are two of the characteristics of the internet. Instruments for the protection of the variety of the internet and the limitation of state power in the network of networks should make use of these paradigmatic phenomena. The recent discussion about the activities of the US National Security Agency (NSA) that have been disclosed by Edward Snowden have provoked a lively controversy in Europe. The frame of reference of the criticism is still the interference with the civil rights of the individual of the liberal society and not the collective dimension of risk in the society of networks: "Everybody is a suspect!" This is obviously not the case. It is quite plausible to regard the internet not just as a new means of communication of the individual but to talk about a new "online world" that is related to the "offline world" we are familiar with, but creates new patterns, new social rules and,yes, new pathologies. As has been shown we need a new conception for a law of the "online world", which raises eventually, if one may put it this way, also the problem of managing the conflicts between the two "worlds" and their differing regimes of the "rule of law". We might end up in the development of a new type of a "conflict of norms"-approach that coordinates the two rationalities. First of all, it's time to give the law of the online world contours of its own!

77 This is all the more problematic as according to Facebook's "terms and conditions" (16.1) only the courts of Santa Clara County (CA) shall be competent in cases of legal conflicts. It is dubious, whether this is compatible with European E-Commerce and consumer protection law and the European Council Regulation on Jurisdiction and the Recognition and Enforcement of Judgments in Civil and Commercial Matters (22 Dec. 2000, OJ L 12, 16 Jan. 2001), Article 16 par. 1 (consolidated version: http:/ / eur-lex. europa.eu/LexUriServ/LexUriServ.do?uri=CONSLEG:2001R0044:20100514:EN:PDF).

78 For online dispute settlement in conflicts about consumer contracts see generally Calliess \& Zumbansen, supra note $21,157$. 


\title{
Responsabilidade civil decorrente de erro médico
}

\section{Civil liability as a result of medical error*}

\author{
Edilson Enedino das Chagas** \\ Héctor Valverde Santana***
}

\section{Resumo}

O objetivo deste artigo é analisar a responsabilidade civil decorrente do erro médico, assim como estudar os possíveis avanços da matéria na atualidade. Primeiro, apresenta-se uma visão panorâmica da saúde no Brasil e a necessidade de contar com a suplementação da iniciativa privada na prestação do serviço público de saúde. Em seguida, passa-se ao estudo do erro médico como atividade profissional causadora de dano e a consequente necessidade de sua reparação. Admite-se a factibilidade do erro médico e a violação do dever de cuidado. Discute-se a teoria do diálogo das fontes a fim de encontrar a melhor combinação legal que deva incidir na responsabilização do médico, tudo de acordo com os princípios regentes da proteção do consumidor/paciente. Há abordagem sobre a necessidade da prova da culpa do médico e o afastamento da teoria do risco para a hipótese em questão. Finalmente, realiza-se estudo comparado sobre as dificuldades encontradas pela vítima/paciente para a prova da culpa do médico. Conclui-se que a atividade médica deve ser analisada sob o prisma da responsabilidade subjetiva, não se aplicando ao caso as diversas modalidades da teoria do risco (responsabilidade objetiva).

Palavras-chave: Responsabilidade civil. Erro médico. Diálogo das fontes. Teorias. Prova.

* Artigo convidado

** Edilson Enedino das Chagas. Mestrando em Direito e Políticas Públicas, pelo Centro Universitário de Brasília (UniCEUB). Professor de Direito Empresarial e Civil. Juiz de Direito do Distrito Federal e Territórios. Email: edilson.chagas@tjdft.jus.br

*** Héctor Valverde Santana. Doutor e Mestre em Direito das Relações Sociais pela Pontifícia Universidade Católica de São Paulo (PUC-SP). Professor de Direito do Consumidor e Responsabilidade. Diretor de Assuntos Internacionais do Instituto Brasileiro de Política e Direito do Consumidor (Brasilcon). Juiz de Direito do Distrito Federal e Territórios. Email: hectorvsantana@gmail.com

\section{Abstract}

The objective of this article is to analyze the civil liability as a result of medical error, as well as to study possible improvements of this subject nowadays. First, an overview of the health system in Brazil is presented, followed by the need of assistance from the private sector in the provision of public health service. Subsequently, the topic of medical malpractice as a professional activity that has the potential to cause damage and its consequent need of compensation is examined. It is accepted the feasibility of medical error and the breach of duty of care. The Theory of the dialogue of sources is discussed in order to find the best legal combination that should be accounted for in the doctor's liability, all in accordance with the governing principles of consumer/patient protection. The article also addresses the need of proving fault of the doctor and the exclusion of the strict liability applied in this case. Finally, a comparative study is carried out about the 
difficulties encountered by the victim/patient to prove fault of the doctor. The paper concludes that the medical activity should be analyzed from the point of view of subjective liability, not applying in this case the diverse modalities of the theory of risk (objective liability).

Keywords: Civil liability. Medical error. "Dialogue des sources". Theories. Evidence.

\section{INTRODUÇÃO}

A saúde é direito de todos e dever do Estado (art. 196 da Constituição Federal), ${ }^{1}$ sendo natural que em um país de dimensão continental como o Brasil, com mais de 190 milhões de habitantes, ${ }^{2}$ haja diariamente milhares de atendimentos médico-hospitalares à população em geral. Trata-se de um serviço público de massa a ser prestado prioritariamente pela rede pública de saúde, uma vez que a iniciativa privada atua de forma complementar ao Estado. A Constituição Federal destinou parcela substancial da arrecadação tributária aos serviços de saúde pública, sendo que essa destinação vincula a Administração Pública e o orçamento estatal.

O Estado brasileiro sempre se mostrou incapaz de prestar os serviços de saúde universais a toda população, razão pela qual conta com o desempenho da atividade privada para se desincumbir desse dever que lhe foi imposto pela Constituição Federal. ${ }^{3}$ A legítima expectativa da prestação do serviço de saúde pelo Estado determina que ela seja oferecida de forma eficiente e, supletivamente, à disponibilização de um serviço privado alternativo ou subsidiário.

O Estado e as empresas privadas prestadoras de serviços de saúde (atividade privada ou a serviço do Sistema Único de Saúde - SUS) devem se empenhar na prestação de um serviço eficiente. Caso a empresa privada tenha o interesse de desenvolver atividade econômica em campo complementar ao do serviço público de saúde, deve proceder de forma consciente e séria na atividade que visa desempenhar, tendo em vista a evidente relevância social da área de atividade de saúde.

O Sistema Único de Saúde (SUS) foi idealizado como um "[...] conjunto de relações políticas, econômicas e institucionais responsáveis pela condução dos processos relativos à saúde de uma população". ${ }^{4} \mathrm{O}$ denominado Sistema Único de Saúde (SUS) foi previsto na Constituição Federal (arts. 197, 198, 199 e 200) e, infraconstitucionalmente, estruturado pela Lei n. 8.080/1990 (Lei Orgânica da Saúde) e Lei n. 8.142/1990 (que regulamentou a participação da sociedade na gestão do Sistema Único de Saúde, bem como as transferências intergovernamentais de recursos financeiros na área da saúde).

Os pilares do Sistema Único de Saúde são os princípios da universalidade, integralidade, equidade, descentralização, regionalização e hierarquização. Os princípios da universalidade e da integralidade são identificados pela amplitude dos serviços de saúde disponibilizados: do atendimento ambulatorial até o transplante de órgãos (métodos preventivos e curativos) acessíveis gratuitamente, em perspectiva, a toda a população do país.

Os centros e postos de saúde, os hospitais (incluindo-se os universitários), bem como os laboratórios, hemocentros, os serviços de vigilância sanitária e os institutos de pesquisa (art. $4^{\circ}$, da Lei n. 8.080/1990) integram SUS. Apesar da universalidade almejada, verifica-se, no dia a dia dos pronto-socorros, as vicissi-

1 CF. "Art. 196. A saúde é direito de todos e dever do Estado, garantido mediante políticas sociais e econômicas que visem a redução do risco de doença e de outros agravos e ao acesso universal igualitário às ações e serviços para sua promoção, proteção e recuperação." .

2 INSTITUTO BRASILEIRO DE GEOGRAFIA E ESTATÍSTICA (IBGE). Disponível em: < http://www.ibge.gov.br/home/ estatistica/populacao/censo2010/default.shtm>. Acesso em: 07 maio 2013.

3 MORAES, Irany Novah. Erro médico e a justiça. 5. ed. São Paulo: Revista dos Tribunais, 2003. p. 291.

4 SILVA, Silvio Fernandes. Comparação entre serviços de saúde da Europa e o SUS: pontos para a reflexão da atenção básica. Disponível em: < http://www.redeamericas.org.br/files/ComparacaoSistEuropeus_SUS.pdf>. Acesso em: 24 abr. 2010. 14h. 
tudes de um serviço público essencial que, não raras vezes, encontra-se carente de infraestrutura adequada (número de leitos insuficientes, dentre outros), de recursos materiais (estoque deficitário de utensílios para higienização, dentre outros) e de profissionais da área de saúde. A situação se torna mais grave quando há necessidade de assistência à saúde longe dos grandes centros urbanos, sistematicamente caracterizada pela completa ausência da prestação de serviços públicos de saúde.

A Lei Orgânica da Saúde prevê a "[...] igualdade da assistência à saúde, sem preconceitos ou privilégios de qualquer espécie" (art. $7^{\circ}$, inc. IV, da Lei n. 8.080/1990), compreendendo uma igualdade material de oportunidades, de incremento do acesso aos serviços de saúde, considerando as históricas desigualdades sociais e regionais existentes em nosso país, sendo que essa otimização no acesso aos serviços de saúde fundamenta-se no princípio da equidade.

A prestação do serviço de saúde é plenamente compatível com a forma de Estado Federal adotada no Brasil, caracterizada pela descentralização político-administrativa dos serviços públicos de saúde. Por essa razão, as competências dos entes federativos (União, Estados, Distrito Federal e Municípios) são caracterizadas pela descentralização dos serviços públicos de saúde para os municípios, a regionalização e a hierarquização da rede de serviços públicos à saúde em todo território nacional (art. $7^{\circ}$, inciso IX, alíneas "a" e "b", da Lei do Sistema Único de Saúde - SUS).

Os princípios da regionalização e da hierarquização devem ser entendidos no sentido de que a prestação dos serviços públicos de saúde deve ser cumprida em graus ou níveis distintos de complexidade. A atenção básica ou primária à saúde, essencialmente preventiva e multidisciplinar, idealmente, deveria cobrir toda população. Os serviços públicos de saúde de maior complexidade, menos frequentes, devem ser prestados à parcela específica da população e quando se mostrarem necessários.

A enunciação e a efetividade dos princípios acima mencionados evidenciam que as estratégias para um serviço público de saúde de qualidade refletem o alcance de um federalismo cooperativo. ${ }^{5}$ Do ponto de vista formal, portanto, o Sistema Único de Saúde (SUS), ideológica e administrativamente, é considerado um modelo adequado de prestação de serviço de saúde.

Para validar e avaliar a concretização do SUS como paradigma, elaborou-se no âmbito do Conselho Nacional de Secretarias Municipais de Saúde (CONASEMS), em 2008, relatório substancioso, comparando o Sistema Único de Saúde (SUS) com os sistemas de saúde adotados na União Europeia. Como pressuposto de análise, se verificou que a Atenção Básica à Saúde no Sistema Único de Saúde (SUS) corresponde à

5 Federalismo cooperativo ou assimétrico, que pressupõe o compartilhamento de competências. Entretanto, ainda que haja competências concorrentes no que diz respeito à gestão e organização do SUS, diante da autonomia dos entes federativos e da execução, preponderantemente, pelos Municípios, em caso de erro médico, nas dependências de hospital conveniado, em nível local, a união não é parte passiva na ação de reparação de danos decorrente de erro médico, conforme o seguinte julgado: BRASIL. Superior Tribunal de Justiça. PROCESSUAL CIVIL. ADMINISTRATIVO. RESPONSABILIDADE CIVIL. ERRO MÉDICO. HOSPITAL PRIVADO. ATENDIMENTO CUSTEADO PELO SUS. RESPONSABILIDADE DO MUNICÍPIO. OFENSA AOS ARTS. 7º, IX, A, E 18, I, X E XI, DA LEI 8.080/90. ILEGITIMIDADE PASSIVA DA UNIÃO. PROVIMENTO PARCIAL [...] 4. A Lei 8.080/90 - que dispõe sobre as condições para a promoção, proteção e recuperação da saúde, a organização e o funcionamento dos serviços correspondentes - prevê as atribuições e competências da União, Estados, Distrito Federal e Municípios quanto aos serviços de saúde pública. Nesse contexto, compete à União, na condição de gestora nacional do SUS: elaborar normas para regular as relações entre o sistema e os serviços privados contratados de assistência à saúde; promover a descentralização para os Estados e Municípios dos serviços e ações de saúde, respectivamente, de abrangência estadual e municipal; acompanhar, controlar e avaliar as ações e os serviços de saúde, respeitadas as competências estaduais e municipais (Lei 8.080/90, art. 16, XIV, XV e XVII). Por sua vez, os Municípios, entre outras atribuições, têm competência para planejar, organizar, controlar e avaliar as ações e os serviços de saúde e gerir e executar os serviços públicos de saúde; participar do planejamento, programação e organização da rede regionalizada e hierarquizada do SUS, em articulação com sua direção estadual; celebrar contratos e convênios com entidades prestadoras de serviços privados de saúde, bem como controlar e avaliar sua execução; controlar e fiscalizar os procedimentos dos serviços privados de saúde (Lei 8.080/90, art. 18, I, II, X e XI). 5. "Relativamente à execução e prestação direta dos serviços, a Lei atribuiu aos Municípios essa responsabilidade (art. 18, incisos I, IV e V, da Lei n. . 8.080/90), compatibilizando o Sistema, no particular, com o estabelecido pela Constituição no seu artigo 30, VII: Compete aos Municípios [...] prestar, com a cooperação técnica e financeira da União e do Estado, serviços de atendimento à saúde da população" (REsp 873.196/RS, $1^{\text {a }}$ Turma, Rel. p/ acórdão Min. Teori Albino Zavascki, DJ de 24.5.2007). 6. A União não possui legitimidade para figurar no pólo passivo de ação em que o particular visa ao pagamento de indenização em decorrência de erro médico cometido em hospital conveniado ao SUS.” Recurso Especial 992265/RS. Primeira Turma. Rel. Min. Denise Arruda. DJe 05/08/2009. 
denominada Atenção Primária à Saúde (APS), de acordo com os parâmetros adotados pela Organização Pan-americana de Saúde. Sílvio Fernandes da Silva ${ }^{6}$ registra que o conceito de Atenção Primária à Saúde (APS) identifica elementos estruturais e funcionais que possibilitam a cobertura e o acesso universais, bem como a prevenção e a primeira linha de cuidado.

Entretanto, apesar da coincidência de priorizar a saúde primária, tanto no Brasil quando na União Europeia, as discrepâncias nos resultados se acentuaram.

\section{FaLIBILIDADE hUMANA E FACTIBILIDADE do ERRO MÉdico}

A moderna responsabilidade civil por erro médico busca superar a ideia da prestação do serviço médico como exclusiva relação intuitu personae, pois ainda que o médico não organize a prestação de seus serviços empresarialmente, mesmo assim será considerado fornecedor de serviços, diante do enquadramento de sua atividade como elemento objetivo de uma relação de consumo.

No modelo clássico liberal se percebia que a relação médico-paciente se projetava, primeiramente, na reputação do profissional médico, mas que somente se consolidava pela dedicação que pudesse demonstrar a outros entes da família do paciente, processo, às vezes, longo, que não raro percorria algumas gerações. Do ponto de vista jurídico, a relação médico-paciente se aperfeiçoa no contrato de prestação de serviços médicos, pautado pela autonomia da vontade, sendo que esse princípio atualmente tem as limitações de aplicabilidade introduzidas pelo microssistema de defesa do consumidor (Lei n. 8.078/1990). A quebra desse paradigma contratual clássico, por outro lado, ocorreu gradativamente, com o avanço da medicina, cada vez mais especializada, a reclamar a associação dos profissionais de saúde.

Os planos de assistência privada à saúde (planos de saúde) surgiram paralelamente ao Serviço Público de Saúde, com intuito de congregar profissionais conveniados de diversas áreas do conhecimento da medicina. Os serviços médicos não são mais preponderantemente contratados com base na confiança do paciente no médico, no talento profissional dele, mas sim por imposição do mercado, pela necessidade de usufruir de assistência à saúde não disponibilizada satisfatoriamente pelo poder público.

José Eduardo Barbieri ${ }^{7}$ adverte para a mudança de paradigma na contratação de serviço médico, pois o médico da família, conhecedor de todos os históricos dos integrantes do núcleo familiar deu lugar a outra geração profissional. Atualmente a relação médico-paciente é caracterizada pela impessoalidade, às vezes, o paciente sendo chamado pelo nome da própria doença, fator que provoca o descrédito da atividade médica. Alie-se ao fato de que a imprensa divulga, às vezes, de forma sensacionalista os erros médicos, estabelecendo comparação com o antigo cirurgião grego Arcagato de Esparta, considerado o médico-carniceiro.

A reforçar a ideia de que os serviços em geral, dentre eles os serviços médicos, são reflexos de uma produção em série, pautada e condicionada, predominantemente, pela lei da oferta e da procura, Luis Antônio Rizzatto Nunes ${ }^{8}$ observa que a revolução industrial provocou o surgimento dos aglomerados urbanos, que tornaram a vida social mais complexa e motivaram a implantação de um sistema econômico mais elaborado, passando da produção artesanal e consumo individual para a produção e consumo em série ou massificado.

O século XXI é marcado por uma nova revolução, especialmente em razão da utilização da rede mundial de computadores (internet), com grande fomento do comércio eletrônico, o marketing agressivo, paralelamente aos avanços da medicina para a cura (que passou a adotar métodos equiparáveis à produção industrial

6 SILVA, Silvio Fernandes. Comparação entre Serviços de Saúde da Europa e o SUS: Pontos para a reflexão da Atenção Básica. Disponível em: < http://www.redeamericas.org.br/files/ComparacaoSistEuropeus_SUS.pdf>. Acesso em 24 de abr. 2010. 14:00.

7 BARBIERI, José Eduardo. Defesa do médico (Responsabilidade Civil). São Paulo: Editora de Direito, 2008. p. 16.

8 NUNES, Luiz Antônio Rizzatto. Curso de direito do consumidor. 2. ed. São Paulo: Saraiva, 2005. p. 155. 
em série). Resultou, pois, no incremento da medicina de consumo, não para o doente, e, sim, para o são, para fins de "embelezamento", de que são exemplos até alguns reality shows."

Se passíveis de indenização os erros médicos em casos de acidente de consumo, em que não se promete resultado algum, igualmente são indenizáveis os erros médicos relacionados a tais acidentes, posto que se convence o paciente/consumidor a uma intervenção cirúrgica, na expectativa legítima de determinado resultado. Aqui não se trata de contrato aleatório, não se adquire somente a esperança de que, eventualmente, aquele resultado venha materializar-se. Ao contrário, confia-se e se tem como natural o adimplemento daquilo que foi prometido.

O Conselho Federal de Medicina reagiu ao que se denomina "medicina mercenária”. O Código de Ética Médica (Resolução do Conselho Federal de Medicina n. 1931/2009) ${ }^{10}$ veda expressamente a permissão do médico para a divulgação nos meios de comunicação de sua participação em assuntos médicos sem que tenha caráter exclusivamente de informação e educação da sociedade, bem como proíbe a divulgação de assuntos médicos de forma sensacionalista, dentre outros.

Ainda que não existam estatísticas oficiais no Brasil sobre erro médico, possível inferir, atuarialmente, por projeção, diante da generalização dos serviços médicos, a factibilidade cada vez mais crescente quanto a sua ocorrência. Luis Antônio Rizzato Nunes ${ }^{11}$ ensina que a sociedade de massas é caracterizada pela produção em série, resultando na impossibilidade de assegurar que o produto ou serviço final não terá qualquer anomalia (vício ou defeito).

Estudo científico realizado em 2007 nos Estados Unidos ${ }^{12}$ aponta para o aumento do número de casos de erros médicos, porém há dificuldade na uniformização das informações em razão da diversidade de critérios adotados pelos pesquisadores. Reconhece-se que, em razão do alto número de intervenções realizadas nos pacientes, há grande possibilidade de incidência de erro médico, a exemplo do paciente em unidade de tratamento intensivo que recebe, em média, 178 intervenções por dia. Entretanto, considerando a ocorrência de 1,7 erro por paciente diariamente (1\% do total de intervenções), chega-se à conclusão de que a eficiência nesse tipo de procedimento é de $99 \%$. Cuida-se de pequena margem de erro (1\%); mas, se comparada a outros setores como a produção industrial e a prestação de serviços, essa taxa se mostra inadequada. O referido estudo aponta que, nos Estados Unidos, aproximadamente um milhão de pacientes são vítimas de danos diversos com drogas (administradas por profissionais de saúde), com 140.000 mortes (anualmente).

Sem dúvida, conforme as projeções acima, se há risco de erro médico na simples prescrição de medicamentos, inegável haver risco de intercorrência ou insucesso inerente a qualquer intervenção cirúrgica. ${ }^{13}$ Ruy Rosado de Aguiar Junior ${ }^{14}$ destaca que a doutrina francesa não faz distinção entre a responsabilidade civil

9 Há quase uma década, a TV fechada tem apresentado seriados que ultimaram por banalizar as cirurgias plásticas, preponderantemente estéticas. O "Extreme Makeover" (Reconstrução Total) do canal Sony e, mais recentemente, o "Dr. Hollywood", já exibido pela TV aberta no canal Record, podem ser mencionados como exemplos. Nessa mesma linha, a equipe da Rádio Jovem Pan lançou a campanha promocional "Ovo frito nunca mais" em que exibe, em uma fotomontagem, uma moça com compleição física a denotar seios pequenos, tanto que substituídos por ovos fritos, achatados, incitando as mulheres que tenham biótipo semelhante à cirurgia plástica, com a seguinte chamada: "Faça agora o seu cadastro aqui no site e envie a sua foto* (do busto vestindo biquíni ou top) e responda a seguinte pergunta 'Por que eu mereço turbinar minha comissão de frente?'. A resposta mais criativa leva 6 mil reais** para dar uma turbinada no seu look!” Disponível em:< http://jovempanfm.virgula.uol.com.br/promocao/input/ovofrito1.php>. Acesso em: 27 abr. 2010, às 22h..

10 Resolução Conselho Federal de Medicina n. 1931/2009. "Capítulo XIII. É vedado ao médico: art. 111. Permitir que sua participação na divulgação de assuntos médicos, em qualquer meio de comunicação de massa, deixe de ter caráter exclusivamente de esclarecimento e educação da sociedade. "Art. 112. Divulgar informação sobre assunto médico de forma sensacionalista, promocional ou de conteúdo inverídico."

11 NUNES, Luiz Antônio Rizzatto. Curso de direito do consumidor. 2. ed. São Paulo: Saraiva, 2005. p. 155.

12 Edição 532. Matéria publicada em 10 de março de 2007. Disponível em: < http://www.brasiliaemdia.com.br/ApresentaSite. asp?o=100\&t=1871>. Acesso em: 27 abr. 2010. $2 \mathrm{~h}$.

13 POLICASTRO, Décio. Erro médico e suas consequências jurídicas. 3. ed. Belo Horizonte: Del Rey, 2010. p. 3.

14 AGUIAR JR., Ruy Rosado de. Responsabilidade Civil do Médico. Revista do Instituto de Ciências Jurídicas e Sociais do Centro Universitário de Brasilia, Brasília, n. 5, p. 151-192, jan./jun. 2000. 
do médico decorrente de obrigações de meio e de resultado, responsabilidade que na França será sempre apurada subjetivamente.

Ponto controverso na doutrina e na jurisprudência é quanto ao risco de erro profissional na cirurgia estética idêntico às demais intervenções médicas. A conclusão de que constituem riscos distintos não invalida a relevância da questão para o direito privado em geral. Entretanto, ainda que alguns queiram restringir a responsabilidade civil do médico à esfera contratual, ${ }^{15}$ a de se ver que, independentemente, da espécie de contrato escolhida para enquadramento do serviço prestado como fonte de obrigações (mandato, empreitada, locação de serviços, inominado ou multiforme), a Lei n. 8.078/1990 (art. 14, \ 4º), o Código de Defesa do Consumidor, mais de uma década antes da vigência do atual Código Civil, já havia estabelecido, em casos de acidentes de consumo, a apuração da responsabilidade pessoal dos profissionais liberais (de que são exemplos clássicos os médicos), "mediante a verificação de culpa".

Não só na "medicina para a cura", vinculada aos acidentes de consumo, mas também na "medicina estética", o risco existe. Porém, na "medicina estética", há expedientes para mensurá-la e reduzi-la a níveis aceitáveis. Caso contrário, tornar-se-ia inviável o desenvolvimento de serviços médicos envolvendo obrigações de resultado, das quais são exemplos as cirurgias plásticas embelezadoras.

\section{NeCESSÁRIO diálogo dAS FONTES}

A doutrina e a jurisprudência têm encampado a necessária convivência entre diplomas legais concorrentes, por exemplo, em relação a contratos de planos de saúde. Há legislação específica a tratar desse tipo de negócio jurídico (art. 15 da Lei n. 9.656/1998 - Lei dos Planos de Saúde). Nos casos de contratos de consumo nos quais são constatados reajustes diferenciados em razão da idade dos consumidores-contratantes, salientando a natureza peculiar desses negócios cativos e de trato sucessivo. Entretanto, objetivando a coordenação da aplicação do disposto no art. 15 da Lei dos Planos de Saúde, admissível verificar, nos casos concretos, se tais reajustes não caracterizam o abuso de direito e o desrespeito ao princípio da boa-fé objetiva (art. 187 do Código Civil e arts. 4º inc. III e 51, inc. IV, ambos do Código de Defesa do Consumidor).

A aplicação do Código de Defesa do Consumidor se faz necessária porque um dos contratantes, sobretudo em se tratando de consumidor pessoa física, por presunção legal, será a parte mais fraca, vulnerável do contrato de prestação de serviços médicos (art. 4º, I, da Lei 8.078/1990). Além disso, há consumidores hipervulneráveis, dentre os quais as crianças e os idosos. Entende-se que está autorizada a discriminação positiva, potencializada pela convergência dos estatutos próprios. Leonardo de Medeiros Garcia ${ }^{16}$ informa precedentes do Tribunal do Rio Grande Sul e do Superior Tribunal de Justiça ${ }^{17}$ que adotaram o diálogo das

15 PANASCO, Wanderby Lacerda. A responsabilidade civil, penal e ética dos médicos. Rio de Janeiro: Forense, 1979. p. 86.

16 GARCIA, Leonardo de Medeiros. Direito do consumidor (Código comentado e jurisprudência). 5. ed. Niterói: Impetus, 2009. p. 89.

17 BRASIL. Superior Tribunal de Justiça. Direito civil e processual civil. Estatuto do Idoso. Planos de Saúde. Reajuste de mensalidades em razão de mudança de faixa etária.Vedação. - O plano de assistência à saúde é contrato de trato sucessivo, por prazo indeterminado, a envolver transferência onerosa de riscos, que possam afetar futuramente a saúde do consumidor e seus dependentes, mediante a prestação de serviços de assistência médico-ambulatorial e hospitalar, diretamente ou por meio de rede credenciada, ou ainda pelo simples reembolso das despesas. - Como característica principal, sobressai o fato de envolver execução periódica ou continuada, por se tratar de contrato de fazer de longa duração, que se prolonga no tempo; os direitos e obrigações dele decorrentes são exercidos por tempo indeterminado e sucessivamente. - Ao firmar contrato de plano de saúde, o consumidor tem como objetivo primordial a garantia de que, no futuro, quando ele e sua família necessitarem, obterá a cobertura nos termos em contratada. - O interesse social que subjaz do Estatuto do Idoso, exige sua incidência aos contratos de trato sucessivo, assim considerados os planos de saúde, ainda que firmados anteriormente à vigência do Estatuto Protetivo. - Deve ser declarada a abusividade e conseqüente nulidade de cláusula contratual que prevê reajuste de mensalidade de plano de saúde calcada exclusivamente na mudança de faixa etária - de 60 e 70 anos respectivamente, no percentual de 100\% e 200\%, ambas inseridas no âmbito de proteção do Estatuto do Idoso. - Veda-se a discriminação do idoso em razão da idade, nos termos do art. $15, \int 3^{\circ}$, do Estatuto do Idoso, o que impede especificamente o reajuste das mensalidades dos planos de saúde que se derem por mudança de faixa etária; tal vedação não envolve, portanto, os demais reajustes permitidos em lei, os quais ficam garantidos às empresas prestadoras de planos de saúde, sempre 
fontes entre o Código de Defesa do Consumidor, a Lei dos Planos de Saúde e o Estatuto do Idoso (Lei n. 10.741/2003), “[...] conjuntamente, de modo a evitar o aumento abusivo de mensalidades, principalmente àqueles consumidores que completam 60 anos".

Cláudia Lima Marques ${ }^{18}$ foi a responsável pela divulgação no Brasil do referido diálogo das fontes, com base na doutrina alemã. De forma bastante didática, subdivide o referido diálogo em níveis de otimização, para superar as ortodoxas formas de superação dos eventuais conflitos de leis no tempo (especialidade em sentido estrito, anterioridade e hierarquia). Reporta-se ao Código de Defesa do Consumidor, como legislação prioritária, sempre que em dado negócio jurídico se identifique em um dos polos da relação jurídica um profissional, fornecedor de produtos ou serviços e, do outro, como destinatário final de tais produtos e serviços, sujeito vulnerável. A vulnerabilidade pode ser fática (pelo amesquinhar do direito de escolha, já que existem serviços que são oligopólios), técnica (o consumidor não detém controle sobre as informações e dados específicos dos produtos e serviços produzidos no mercado) ou jurídica (pela imposição das avenças mediante contratos de adesão).

Entende que o Código de Defesa do Consumidor é um conjunto de normas elaborado para sujeitos de direito desiguais, para diferentes, exatamente por concretizar o projeto constitucional que tornou a defesa do consumidor como um direito fundamental (art. $5^{\circ}$, inc. XXXII, da Constituição Federal). O Código Civil é aplicável entre sujeitos iguais, quando não se verifica a disparidade de tratamento evidenciada pelas várias faces do princípio da vulnerabilidade. O Código Civil disciplina uma relação jurídica entre sujeitos iguais. Saliente-se, ainda, que essa paridade pode ser observada entre empresários, o que reclamará a aplicação da legislação específica e própria do Direito Comercial (Empresarial).

A exemplificar um "diálogo" de reciprocidade ou complementaridade de conceitos, entende-se que o risco da atividade criado pelo fornecedor (art. $3^{\circ}$, do Código de Defesa do Consumidor), figura que se aproxima do empresário em sentido amplo (arts. 966 c/c 982, do Código Civil) impõe, para a facilitação da prevenção e da reparação de danos aos consumidores, responsabilidade civil objetiva e solidária.

Nos serviços médico-hospitalares prestados por pessoas jurídicas de direito privado, ainda que desenvolvam suas atividades sem a expectativa do lucro como fim principal (cooperativa), mantém-se a regra de responsabilizar-se objetivamente o fornecedor (leia-se independentemente da perquirição de dolo ou culpa) por eventuais vícios de qualidade (incidentes do mercado de consumo massificado) ou, mais grave, anomalias funcionais que acarretem danos à saúde e à segurança do consumidor (acidentes de consumo).

A pessoa jurídica faz materializar a sua vontade por intermédio de seus sócios ou cooperados, bem como exterioriza o desenvolvimento de sua atividade, por meio dos atos de seus prepostos ou empregados. Há médicos conveniados e também médicos empregados. Ainda que eventual dano seja causado por médico preposto, nesse caso, parceiro empresarial da pessoa jurídica ou, minimamente, terceiro interessado no sucesso da atividade coordenada ou gerenciada pela referida pessoa jurídica, a responsabilidade objetiva é mais consentânea com o projeto constitucional traçado para a defesa do consumidor. ${ }^{19}$

ressalvada a abusividade. Recurso especial conhecido e provido. Recurso Especial 989.380/RN. Terceira Turma. Relatora Ministra Nancy Andrighi. DJe de 20 de novembro de 2008.

18 MARQUES, Cláudia Lima et al. Manual de direito do consumidor. 4. ed. São Paulo: Revista dos Tribunais, 2012. p. 117-132.

19 BRASIL. Superior Tribunal de Justiça. civil e processual. ação de indenização. erro médico. cooperativa de assistência de saúde. legitimidade passiva. CDC, ARTS. $3^{\circ} \mathrm{E}$ 14. I. A Cooperativa que mantém plano de assistência à saúde é parte legitimada passivamente para ação indenizatória movida por associada em face de erro médico originário de tratamento pós-cirúrgico realizado com médico cooperativado. II. Recurso especial não conhecido.” Recurso Especial 309760/RJ. Quarta Turma. Rel. Min. Aldir Passarinho Junior. DJ 18/03/2002.

BRASIL. Superior Tribunal de Justiça. "RESPONSABILIDADE CIVIL. CIRURGIA. QUEIMADURA CAUSADA NA PACIENTE POR BISTURI ELÉTRICO. MÉDICO-CHEFE. CULPA “IN ELIGENDO” E “IN VIGILANDO”. RELAÇÃO DE PREPOSIÇÃO. - Dependendo das circunstâncias de cada caso concreto, o médico-chefe pode vir a responder por fato danoso causado ao paciente pelo terceiro que esteja diretamente sob suas ordens. Hipótese em que o cirurgião-chefe não somente escolheu o auxiliar, a quem se imputa o ato de acionar o pedal do bisturi, como ainda deixou de vigiar o procedimento cabível em relação àquele equipamento. - Para o reconhecimento do vínculo de preposição, não é preciso que exista um contrato típico de trabalho; 
Ruy Rosado de Aguiar Junior ${ }^{20}$ observa que há necessidade de divisar eventuais responsabilidades entre os profissionais, pessoas físicas e pessoas jurídicas, quando se tratar de medicina coletiva. Logo, se possível afastar a relação de preposição ou subordinação, entre o médico, a quem imputado o erro causador do dano, e a pessoa jurídica, hospital (por hipótese), que tenha possibilitado a infraestrutura para a realização de uma intervenção cirúrgica por aquele, sem que se vislumbre concorrência da pessoa jurídica para o infortúnio do paciente, será afastada a solidariedade e também a responsabilidade objetiva. Remanescerá a possibilidade de se responsabilizar o médico pessoalmente. Porém, nessa hipótese, aplicar-se-á o disposto no art. 14, $\ 4^{\circ}$, do Código de Defesa do Consumidor ou, por similitude, o disposto no art. 951, do Código Civil, ${ }^{21}$, ou seja, deverá ser demonstrada a culpa do médico, para que se possa alcançar êxito em eventual ação indenizatória.

Insiste-se na priorização da aplicação do disposto no art. 14, $\ 4^{\circ}$, do Código de Defesa do Consumidor, em relação aos serviços pessoalmente prestados pelo médico, pois inexiste razão para que não seja considerado exemplo típico de profissional liberal.

é suficiente a relação de dependência ou que alguém preste serviços sob o comando de outrem. Recurso especial não conhecido.” (Recurso Especial 200831/RJ. Quarta Turma. Rel. Min. Barros Monteiro. DJ 20/08/2001. BRASIL. Superior Tribunal de Justiça. RESPONSABILIDADE CIVIL. Hospital. Santa Casa. Consentimento informado. A Santa Casa, apesar de ser instituição sem fins lucrativos, responde solidariamente pelo erro do seu médico, que deixa de cumprir com a obrigação de obter consentimento informado a respeito de cirurgia de risco, da qual resultou a perda da visão da paciente. Recurso não conhecido.” Recurso Especial 467878/RJ. Quarta Turma. Rel. Min. Ruy Rosado de Aguiar Junior. DJ 10/02/2003.

BRASIL. Superior Tribunal de Justiça. CIVIL E PROCESSUAL CIVIL - AGRAVO REGIMENTAL NO AGRAVO DE INSTRUMENTO - RESPONSABILIDADE CIVIL - AÇÃO INDENIZATÓRIA - ERRO MÉDICO - OXIGENOTERAPIA FIBROPLASIA RETROLENTICULAR - RETINOPATIA DO NASCITURO - CRIANÇA COM PERDA DE 90\% (NOVENTA POR CENTO) DA VISÃO - RESPONSABILIDADE COMPROVADA PELO TRIBUNAL “A QUO” - SÚMULA 7/STJ - DANOS MATERIAIS, MORAIS E ESTÉTICOS - RAZOABILIDADE DO QUANTUM INDENIZATÓRIO - EXTENSÃO DO JULGAMENTO DO RECURSO ESPECIAL 1.086.451/SC, QUANTO A JUROS, AO AGRAVANTE. I - A responsabilidade civil da Agravante, na espécie, decorreu da comprovada falha na prestação dos serviços hospitalares de acompanhamento do recém-nascido, que deu causa inequívoca à doença da fibroplasia retrolenticular - retinopatia do nascituro -, que comprometeu mais de $90 \%$ (noventa por cento) da visão da criança. Essa conclusão não pode ser afastada nesta Corte, por depender do reexame do quadro fático-probatório. II - Não há como afastar a condenação solidária do médico e do Hospital em que internado o nascituro, na hipótese, pois o corpo clínico, embora possuísse autonomia funcional, subordinava-se administrativamente aos regulamentos da entidade hospital, relação que caracteriza, em sentido amplo, o vínculo da preposição, ademais do fato de que Hospital recebia recursos da Seguridade Social. Precedentes. III - Considerando os danos permanentes à saúde do nascituro e a evidente responsabilização, não há razão para a alteração do quantum indenizatório em face da razoabilidade do patamar em que fixado, sendo R $\$ 76.000,00$ (setenta e seis mil) pelos danos morais e $\mathrm{R} \$ 30.400,00$ (trinta mil e quatrocentos reais) pelos danos estéticos. IV - Quanto aos juros moratórios, estende-se ao Agravante os efeitos do acolhimento parcial do Recurso Especial interposto pelo médico, Dr. Rogério Antônio Gaio (REsp 1.086.451/SC), estabelecendo-se que, também relativamente à ASSEC, os juros moratórios correm a partir da data da citação e não da data do evento danoso. Agravo regimental improvido.” Agravo Regimental no Agravo de Instrumento 1092134/SC. Terceira Turma. Rel. Min. Sidnei Beneti. DJe de 06/03/2009.

20 AGUIAR JR., Ruy Rosado de. Responsabilidade Civil do Médico. Revista do Instituto de Ciências Jurídicas e Sociais do Centro Universitário de Brasília, Brasília, n. 5, p. 164, jan./jun. 2000.

21 BRASIL. Superior Tribunal de Justiça. AÇÃO DE INDENIZAÇÃO. RESPONS ABILIDADE CIVIL. ERRO MÉDICO. NEGLIGÊNCIA. INDENIZAÇAO. RECURSO ESPECLAL. 1. A doutrina tem afirmado que a responsabilidade médica empresarial, no caso de hospitais, é objetiva, indicando o parágrafo primeiro do artigo 14 do Código de Defesa do Consumidor como a norma sustentadora de tal entendimento. Contudo, a responsabilidade do hospital somente tem espaço quando o dano decorrer de falha de serviços cuja atribuição é afeta única e exclusivamente ao hospital. Nas hipóteses de dano decorrente de falha técnica restrita ao profissional médico, mormente quando este não tem nenhum vínculo com o hospital - seja de emprego ou de mera preposição -, não cabe atribuir ao nosocômio a obrigação de indenizar. 2. Na hipótese de prestação de serviços médicos, o ajuste contratual - vínculo estabelecido entre médico e paciente - refere-se ao emprego da melhor técnica e diligência entre as possibilidades de que dispõe o profissional, no seu meio de atuação, para auxiliar o paciente. Portanto, não pode o médico assumir compromisso com um resultado específico, fato que leva ao entendimento de que, se ocorrer dano ao paciente, deve-se averiguar se houve culpa do profissional - teoria da responsabilidade subjetiva. No entanto, se, na ocorrência de dano impõe-se ao hospital que responda objetivamente pelos erros cometidos pelo médico, estar-se-á aceitando que o contrato firmado seja de resultado, pois se o médico não garante o resultado, o hospital garantirá. Isso leva ao seguinte absurdo: na hipótese de intervenção cirúrgica, ou o paciente sai curado ou será indenizado - daí um contrato de resultado firmado às avessas da legislação. 3. O cadastro que os hospitais normalmente mantêm de médicos que utilizam suas instalações para a realização de cirurgias não é suficiente para caracterizar relação de subordinação entre médico e hospital. Na verdade, tal procedimento representa um mínimo de organização empresarial. 4. Recurso especial do Hospital e Maternidade São Lourenço Ltda provido.” Recurso Especial 908359/SC. Segunda Seção. Rel. p/ Acórdão Min. João Otávio de Noronha. DJe 17/12/2008. 
O conceito de empresário (explicitamente referenciado no art. 966 do Código Civil) se aproxima do conceito de fornecedor (art. $3^{\circ}$, do Código de Defesa do Consumidor). Entretanto, ressalte-se, não há plena coincidência. A interpretação do art. 966 do Código Civil permite contextualizar o empresário como aquele com talento e coragem para concatenar os denominados fatores de produção (capital, insumo, mão de obra de outrem e tecnologia) e com profissionalidade, habitualidade, motivado pela expectativa de lucro, dedica-se à produção, à distribuição e à comercialização de produtos e serviços.

O profissional liberal, de que é exemplo o médico, quando se lança ao exercício individual de sua especialidade, também organiza os fatores de produção, anteriormente mencionados. Porém, ao menos teoricamente, no exercício de sua atividade, deveria prevalecer sobre a preocupação econômica a realização de outros valores, mais especificamente, "a saúde do ser humano", conforme estabelece como princípio geral do Código de Ética Médica Brasileiro (Resolução n. 1931/2009, do Conselho Federal de Medicina, cap. I, inc. II). Registre-se que há disposição semelhante no Código Internacional de Ética Médica (1949), que, segundo José Eduardo Barbieri, ${ }^{22}$ dispõe: "[...] o médico deve ter sempre presente o cuidado de conservar a vida humana", acrescentando que a Declaração dos Princípios Éticos dos Médicos para o Mercosul (1995) enuncia como primeiro mandamento, correlacionado ao exercício profissional, a atenção que o médico deve dar à saúde do ser humano.

Ronald Amaral Sharp Junior ${ }^{23}$ salienta que nas atividades econômicas que não se inserem como empresariais, como nas profissões liberais, em que predomina a intelectualidade, haverá o afastamento da empresarialidade, com a consequente exclusão dos profissionais liberais do regime empresarial.

Os enunciados 193, 194 e 195, da III Jornada de Direito Civil, organizada pelo Conselho da Justiça Federal referendam o mesmo entendimento. ${ }^{24}$ À obviedade, se não houver como caracterizar o profissional liberal como empresário, consoante as disposições do Código Civil, não há responsabilidade objetiva por eventuais danos que venha a causar no exercício de sua atividade. A interpretação extensiva e a contrario sensu do art. 931 do Código Civil reforça a conclusão retro.

Os serviços médicos se lançam essencialmente à preservação da saúde, direito difuso, de interesse geral, cuja intercorrência médica que se configure em acidente de consumo somente será indenizável pelo profissional se no respectivo processo judicial restar demonstrada sua culpa no evento. Trata-se de regra excepcional, e, por tal razão, merece interpretação restritiva.

Quando a atividade do profissional liberal caracterizar acidente de consumo, a apuração de sua responsabilidade será subjetiva (pois se cuida de exceção ao regime geral de responsabilidade civil do fornecedor disposto no Código de Defesa do Consumidor).

Verifica-se a distinção entre duas situações jurídicas, a dicotomia entre a obrigação de meio e a obrigação de resultado. ${ }^{25}$ Os serviços médicos se lançam usualmente à prevenção e à recuperação da saúde do paciente/ consumidor, no exercício da medicina para cura, em que as obrigações do profissional corresponderão aos meios ao seu alcance para tanto quanto possível suprir as expectativas do paciente/consumidor, sem, entretanto, garantir o sucesso ou a eficácia do tratamento ou do resultado positivo de eventual intervenção cirúrgica.

Em caráter excepcional, poderá ser firmado o compromisso quanto à concretização de um resultado anunciado, em perspectiva, almejado, e no exercício da medicina que se ousou chamar de medicina para o consumismo, medicina para o são, medicina para o embelezamento.

22 BARBIERI, José Eduardo. Defesa do médico (Responsabilidade Civil). São Paulo: Editora de Direito, 2008. p. 44.

23 SHARP JR, Ronald Amaral. Aulas de direito comercial e de empresa. Rio de Janeiro: Campus, 2007. p. 19-20.

24 Enunciados da III Jornada de Direito Civil do CJF. 193 - Art. 966: O exercício das atividades de natureza exclusivamente intelectual está excluído do conceito de empresa. 194 - Art. 966: Os profissionais liberais não são considerados empresários, salvo se a organização dos fatores da produção for mais importante que a atividade pessoal desenvolvida. 195 - Art. 966: A expressão "elemento de empresa" demanda interpretação econômica, devendo ser analisada sob a égide da absorção da atividade intelectual, de natureza científica, literária ou artística, como um dos fatores da organização empresarial.

25 OLIVEIRA, Mariana Massara Rodrigues de. Responsabilidade civil dos médicos: repensando a natureza jurídica da relação médicopaciente em cirurgia plástica estética e seus reflexos em relação ao ônus da prova. Curitiba: Juruá, 2007. p. 70. 
Nessa hipótese, a obrigação será de resultado. ${ }^{26}$ Se o resultado for alcançado, devidamente restará cumprida a avença. Entretanto, se frustrada a legítima expectativa do consumidor quanto ao resultado do serviço, natural que o paciente/consumidor se proponha a postular a reparação dos danos sofridos pelo profissional médico. Saliente-se que, no processo judicial, o autor/paciente/consumidor tem que demonstrar a conduta (culposa) do médico, o nexo de causalidade e o dano.

Ainda que haja dissenso jurisprudencial acerca do tema, o entendimento dominante no âmbito do Superior Tribunal de Justiça é no sentido de que, em se tratando de cirurgia predominantemente estética, pelo risco do insucesso, deve responder o médico subjetivamente. ${ }^{27}$

O Conselho Federal de Medicina inseriu no Código de Ética Médica que “[...] a natureza personalíssima da atuação profissional do médico não caracteriza relação de consumo". Cuida-se de equívoco normativo, porquanto a relação de consumo está estabelecida em Lei Federal (Código de Defesa do Consumidor - Lei n. 8.078/1990), que prevê a sua incidência obrigatória aos fornecedores de produtos e serviços, inclusive os profissionais liberais (arts. $2^{\circ}, 3^{\circ}, \int 2^{\circ}$ e $14, \int 4^{\circ}$ ). É noção elementar em face da hierarquia das normas jurídicas de que uma norma administrativa não pode revogar disposição legal. O Código de Ética Médica foi editado mediante resolução do órgão de classe, espécie normativa de hierarquia inferior à lei ordinária, portanto não se prestando a derrogar dispositivos do Código de Defesa do Consumidor, que por sua vez regulamenta um direito fundamental - art. $5^{\circ}$, inc., XXXII, da Constituição Federal.

\section{TEORIAS CIVILISTAS SOBRE A RESPONSABILIDADE DO MÉDICO}

Miguel Kfouri Neto ${ }^{28}$ sustenta que a responsabilidade civil do profissional da medicina deve ser aferida de forma subjetiva, ou seja, a culpa dele deverá ser demonstrada, na modalidade de dolo ou de culpa strito senso. O Código Civil admite responsabilidade sem culpa, objetiva, no art. 927, parágrafo único, mas tal disposição não se aplicaria à atividade médica. $\mathrm{O}$ art. 951 do Código Civil, ao dispor sobre as sequelas que podem atingir a vítima e a respectiva indenização, prevê que o dever de reparar dependerá de uma conduta negligente, imprudente ou imperita de quem exerça profissionalmente a atividade. Argumenta que não se deve impor aos profissionais da saúde, agentes de atividade cujo risco é inerente, a adoção da responsabilidade objetiva, com base na teoria do risco criado. A responsabilidade do médico, em regra, continuaria sendo subjetiva.

Sílvio Rodrigues ${ }^{29}$ destaca que a responsabilidade civil somente poderia ser subjetiva (fundada na culpa) ou objetiva (que desconsidera a culpa e se funda na teoria do risco), não havendo outras espécies, mas sim, outras maneiras diferentes de encarar a obrigação de reparar o dano. ${ }^{30}$ Identifica-se, dentre os civilistas, a corrente subjetivista, a salientar a exigência da demonstração da culpa, que por sua vez teria lastro moral,

26 MATIELLO, Fabrício Zamprogna. Responsabilidade civil do médico. 3. ed. São Paulo: LTr, 2006. p. 60.

27 BRASIL. Superior Tribunal de Justiça. Recurso Especial. DIREITO CIVIL. RESPONSABILIDADE CIVIL DO MÉDICO. CIRURGIA PLÁSTICA. OBRIGAÇÃO DE RESULTADO. SUPERVENIÊNCIA DE PROCESSO ALÉRGICO. CASO FORTUITO. ROMPIMENTO DO NEXO DE CAUSALIDADE. 1. O requisito do prequestionamento é indispensável, por isso inviável a apreciação, em sede de recurso especial, de matéria sobre a qual não se pronunciou o Tribunal de origem, incidindo, por analogia, o óbice das Súmulas 282 e 356 do STF. 2. Em procedimento cirúrgico para fins estéticos, conquanto a obrigação seja de resultado, não se vislumbra responsabilidade objetiva pelo insucesso da cirurgia, mas mera presunção de culpa médica, o que importa a inversão do ônus da prova, cabendo ao profissional elidi-la de modo a exonerar-se da responsabilidade contratual pelos danos causados ao paciente, em razão do ato cirúrgico. 3. No caso, o Tribunal a quo concluiu que não houve advertência a paciente quanto aos riscos da cirurgia, e também que o médico não provou a ocorrência de caso fortuito, tudo a ensejar a aplicação da súmula 7/STJ, porque inviável a análise dos fatos e provas produzidas no âmbito do recurso especial. 4. Recurso especial não conhecido. Recurso Especial n. 985888/SP. Quarta Turma. Rel. Min. Luis Felipe Salomão. DJ-e 13/03/2012.

28 KFOURI NETO, Miguel. Responsabilidade civil do médico. 6. ed. São Paulo: Revista dos Tribunais, 2007. p. 27 e 61-62.

29 FALTA REFERÊNCIA!

30 RODRIGUES, Silvio. Responsabilidade civil. 20. ed. São Paulo: Saraiva, 2003. p. 11. 
pois o médico sentir-se-ia responsável e obrigado a reparar dano causado por ato culposo seu, em situação em que houve previsibilidade, reconhecendo-se responsável.

Miguel Maria de Serpa Lopes ${ }^{31}$ ensina que há duas modalidades de responsabilidade objetiva: a) teoria do risco proveito (quem tem proveito econômico com a atividade lucrativa, deve reparar os danos decorrentes dela); b) teoria do risco criado (pelo simples fato de agir, o homem cria riscos para os demais, por isso deve responder pelo dano causado). ${ }^{32}$

A obrigação de reparar o dano sempre existirá, ocorra ela dentro ou fora do contrato. A obrigação do médico, ao assistir o paciente, é de meio (salvo as exceções acima expostas) e não de resultado. A atividade contratada é o objeto do contrato, e não o resultado dela, tendo o médico que se esforçar para obter a cura, mesmo não a conseguindo. Apesar da natureza contratual da relação entre médico e paciente, não se presume a culpa pela ausência do resultado, já que o profissional não se compromete a isso, mas sim de proceder conforme as regras e os métodos de sua profissão.

Em sentido contrário, também para os civilistas, excepcionalmente, a atividade médica poderia corresponder a uma obrigação de resultado, na qual se enquadra a cirurgia plástica estética propriamente dita (pois seria similar a um contrato de empreitada ou de transporte). Em tais hipóteses, o que se negocia é o resultado, sem o qual não cumprida satisfatoriamente a avença.

Quanto à extensão e quantificação dos danos, merecem lembrança os arts. 944 e 945, do Código Civil, pois o grau da culpa volta à tona, para, em perspectiva, evidenciar: a) a excessiva desproporção da gravidade da culpa com a extensão do dano, podendo reduzir o valor do ressarcimento; ou, b) a concorrência de conduta culposa da vítima para a verificação do evento danoso influenciará na fixação do valor do ressarcimento, considerando a gravidade da culpa da vítima em confronto com a do autor.

Miguel Kfouri Neto $^{33}$ considera mais justa tal aferição, pois a fixação do valor ressarcitório levaria em conta a gravidade da imperícia, da negligência e da imprudência na atividade do profissional médico. A culpa, ainda que levíssima, determinaria a responsabilidade civil, enquanto sua gravidade determinaria o quantum indenizatório.

\section{Prova do eRro mÉdico no diReito comparado}

A legislação brasileira exige a demonstração da culpa do profissional; contudo, em outros países, há facilitação para a atividade probatória da culpa médica por parte da vítima. Ressalte-se a ideia da moderna responsabilidade civil quanto à prevalência dos interesses da vítima, garantindo a efetiva reparação dos danos, acentuando-se a tendência da objetivação com a adoção da teoria do risco e a flexibilização das teorias clássicas acerca do nexo causal.

A doutrina indica diversas teorias sobre a prova do erro médico. Miguel Kfouri Neto ${ }^{34}$ esclarece que a teoria da perda de uma chance (perte d'une chance) decorre da jurisprudência francesa a partir de 1965 e visa facilitar a tarefa da vítima em provar a culpa do agente causador do dano. O juiz francês não indaga se o médico agiu com culpa, mas a perda da oportunidade de tratamento ou cura já é suficiente para caracterização da responsabilidade do profissional médico, ao fundamento de que a indenização não é quanto ao prejuízo final, mas a chance perdida de continuar vivo ou de ser curado.

31 FALTA REFERÊNCIA!

32 LOPES, Miguel Maria de Serpa. Curso de direito civil: fontes acontratuais das obrigações: responsabilidade civil. 5. ed. Rio de Janeiro: Freitas Bastos, 2001. p. 200.

33 KFOURI NETO, Miguel. Responsabilidade civil do médico. 6. ed. São Paulo: Revista dos Tribunais, 2007. p. 76.

34 KFOURI NETO, Miguel. Responsabilidade civil do médico. 6. ed. São Paulo: Revista dos Tribunais, 2007. p. 64-69. 
A teoria da res ipsa loquitur (a coisa fala por si) é adotada em parte dos Estados Unidos e no Canadá. Assemelha-se às presunções judiciais de culpa. Decorre da presunção de que o médico agiu com negligência, pelo fato de esquecimento de objetos no corpo do paciente, danos à parte saudável do corpo, remoção equivocada de uma parte do corpo, dentes que caem na traqueia, dentre outros. A formulação da teoria da res ipsa loquitur parte do "direito de evidência circunstancial", aplicando-se quando não há evidência de como ocorreu o dano. Assim, acredita-se que não teria ocorrido o dano se não houvesse culpa, ou recai a responsabilidade sobre o médico que estava atendendo pessoalmente o paciente.

A teoria da carga probatória dinâmica sustenta que a distribuição prévia ou estática do ônus da prova pode resultar em manifesta injustiça em determinados casos concretos. Em situações específicas uma parte tem muita facilidade para provar um determinado fato, enquanto a outra parte da relação jurídica processual tem extrema dificuldade para demonstrar o fato probando. ${ }^{35}$

Leonardo Medeiros Garcia ${ }^{36}$ ensina que houve adoção pelo Código de Defesa do Consumidor da regra da distribuição dinâmica do ônus da prova, uma vez que o juiz poderá inverter o ônus da prova, desde que presentes os requisitos da alegação verossímil e a hipossuficiência do consumidor. Por sua vez, o Código de Processo Civil prevê a distribuição estática do ônus da prova, conforme art. 333, o qual estabelece abstratamente o ônus da prova. Destaque-se que o Código de Defesa do Consumidor não regula a distribuição do ônus da prova, mas tão somente a sua inversão.

Quanto à prova do erro médico, nas hipóteses de acidente de consumo, ainda que a lei brasileira exija do autor-consumidor, em princípio, a demonstração da culpa do médico-prestador do serviço, o consumidor-paciente poderá ser beneficiado com o deferimento da inversão do ônus da prova (art. $6^{\circ}$, inc. VIII, da Lei n. 8.078/1990). Trata-se de direito básico, mas que não tem aplicação automática nas lides de consumo. A inversão do ônus da prova demanda a presença de requisitos a serem aferidos pelo julgador, caso a caso. A lei consumerista prevê a possibilidade de inversão do ônus da prova quando a alegação apresentada na petição inicial é verossímil ou se constatada a hipossuficiência do autor consumidor.

O art. $6^{\circ}$, inciso VIII, do Código de Defesa do Consumidor, positivou no ordenamento brasileiro a teoria das cargas dinâmicas e compartilhadas do Direito argentino. Segundo José Eduardo Barbieri, ${ }^{37}$ a teoria da carga dinâmica da prova teve como finalidade principal evitar o rigor da distribuição do ônus da prova no processo civil brasileiro, bem como buscar alcançar a verdade material e atuação das partes baseada na boa-fé.

\section{Considerações finais}

A regra geral da responsabilidade civil decorrente de erro médico demanda a prova pelo ofendido da culpa individual do profissional, o médico, sendo que, em hipóteses excepcionais, é possível admitir a presunção de culpa nos casos de obrigação de resultado, a exemplo das cirurgias estéticas (embelezamento), exames de laboratório e radiologia, dentre outros. A responsabilidade objetiva das instituições de saúde (hospitais e clínicas) é caracterizada pelo risco da atividade. O médico, mesmo havendo subordinação profissional, continua respondendo subjetivamente, sempre exigindo a prova da culpa para que o dever de reparar o dano the seja imputado.

Por outro lado, do ponto de vista da proteção do consumidor, ressalta-se que há mecanismos hábeis a combater o erro médico, principalmente o erro relacionado à medicina do consumismo. É atual a discussão sobre a minimização dos erros médicos na medicina do consumismo, pois, em perspectiva, pode-se prediz-

35 GIOSTRI, Hildegard Taggesell. Responsabilidade médica: as obrigações de meio e de resultado - avaliação, uso e adequação. Curitiba: Juruá, 2002. p. 190-194.

36 GARCIA, Leonardo de Medeiros. Direito do Consumidor (Código comentado e Jurisprudência). 5. ed. Niterói: Impetus, 2009. p 71-72.

37 BARBIERI, José Eduardo. Defesa do médico (Responsabilidade Civil). São Paulo: Editora de Direito, 2008. p. 120. 
er como tendência, no Brasil, de um aumento das ações de reparação civil em consequência de intervenções cirúrgicas com resultados insatisfatórios.

Percebe-se que a doutrina e a jurisprudência, diante da inevitabilidade do erro médico, têm que buscar a preservação do exercício da atividade dos médicos (fornecedores, prestadores de serviços) e as legítimas expectativas de seus pacientes (consumidores). A atividade médica implica, naturalmente, em riscos ao paciente, cuja compensação (do risco) poder-se-ia minimizar com a adoção de contratação de seguro-saúde. Tal providência, ainda que encareça os honorários do profissional médico, a serem suportados por seus eventuais pacientes, poderá atender aos interesses das vítimas de erros médicos e viabilizar o propósito moderno da responsabilidade civil que é a plena reparação dos danos sofridos pela vítima, sem a necessidade de promover complexas demandas judiciais que o tema envolve.

A imputação de responsabilidade objetiva ao profissional médico é fator de desestímulo à relevante atividade que se destina à assistência ao paciente. Mostra-se, então, mais equilibrado, ao menos nesse estágio da evolução da medicina, inclusive quanto ao anseio de alcançar um padrão de beleza estética, um aprofundamento na análise da culpa, todavia se permitindo a inversão do ônus da prova naquelas intervenções médicas em que se configura a obrigação de resultado.

\section{REFERÊNCIAS}

AGUIAR JR., Ruy Rosado de. Responsabilidade Civil do Médico. Revista do Instituto de Ciências Jurídicas e Sociais do Centro Universitário de Brasilia, Brasília, n. 5, p. 151-192, jan./jun. 2000.

BARBIERI, José Eduardo. Defesa do Médico (Responsabilidade Civil). São Paulo: Editora de Direito, 2008.

COELHO, Fábio Ulhôa. Curso de direito comercial. 10. ed. São Paulo: Saraiva, 2006.

GARCIA, Leonardo de Medeiros. Direito do Consumidor (Código comentado e jurisprudência). 5. ed. Niterói: Impetus, 2009.

GIOSTRI, Hildegard Taggesell. Responsabilidade médica: as obrigações de meio e de resultado - avaliação, uso e adequação. Curitiba: Juruá, 2002.

KFOURI NETO, Miguel. Responsabilidade civil do médico. 6. ed. São Paulo: Revista dos Tribunais, 2007.

LOPES, Miguel Maria de Serpa. Curso de direito civil: fontes acontratuais das obrigações: responsabilidade civil. 5. ed. Rio de Janeiro: Freitas Bastos, 2001.

MARQUES, Cláudia Lima et al. Manual de direito do consumidor. 4. ed. São Paulo: Revista dos Tribunais, 2012.

MATIELLO, Fabrício Zamprogna. Responsabilidade civil do médico. 3. ed. São Paulo: LTr, 2006.

MORAES, Irany Novah. Erro médico e a justiça. 5. ed. São Paulo: Revista dos Tribunais, 2003.

NUNES, Luiz Antônio Rizzatto. Curso de direito do consumidor. 2. ed. São Paulo: Saraiva, 2005.

OLIVEIRA, Mariana Massara Rodrigues de. Responsabilidade civil dos médicos: repensando a natureza jurídica da relação médico-paciente em cirurgia plástica estética e seus reflexos em relação ao ônus da prova. Curitiba: Juruá, 2007.

PANASCO, Wanderby Lacerda. A responsabilidade civil, penal e ética dos médicos. Rio de Janeiro: Forense, 1979.

POLICASTRO, Décio. Erro médico e suas consequências jurídicas. 3. ed. Belo Horizonte: Del Rey, 2010.

RODRIGUES, Silvio. Responsabilidade civil. 20. ed. São Paulo: Saraiva, 2003.

SILVA, Silvio Fernandes. Comparação entre Serviços de Saúde da Europa e o SUS: Pontos para a reflexão da 
Atenção Básica. Disponível em: < http://www.redeamericas.org.br/files/ComparacaoSistEuropeus_SUS. pdf>. Acesso em: 24 abr. 2010. 14h.

SHARP JR, Ronald Amaral. Aulas de direito comercial e de empresa. Rio de Janeiro: Campus, 2007. 


\section{REVISTA BRASILEIRA DE POLÍTICAS PÚBLICAS BRAZILIAN JOURNAL OF PUBLIC POLICY}
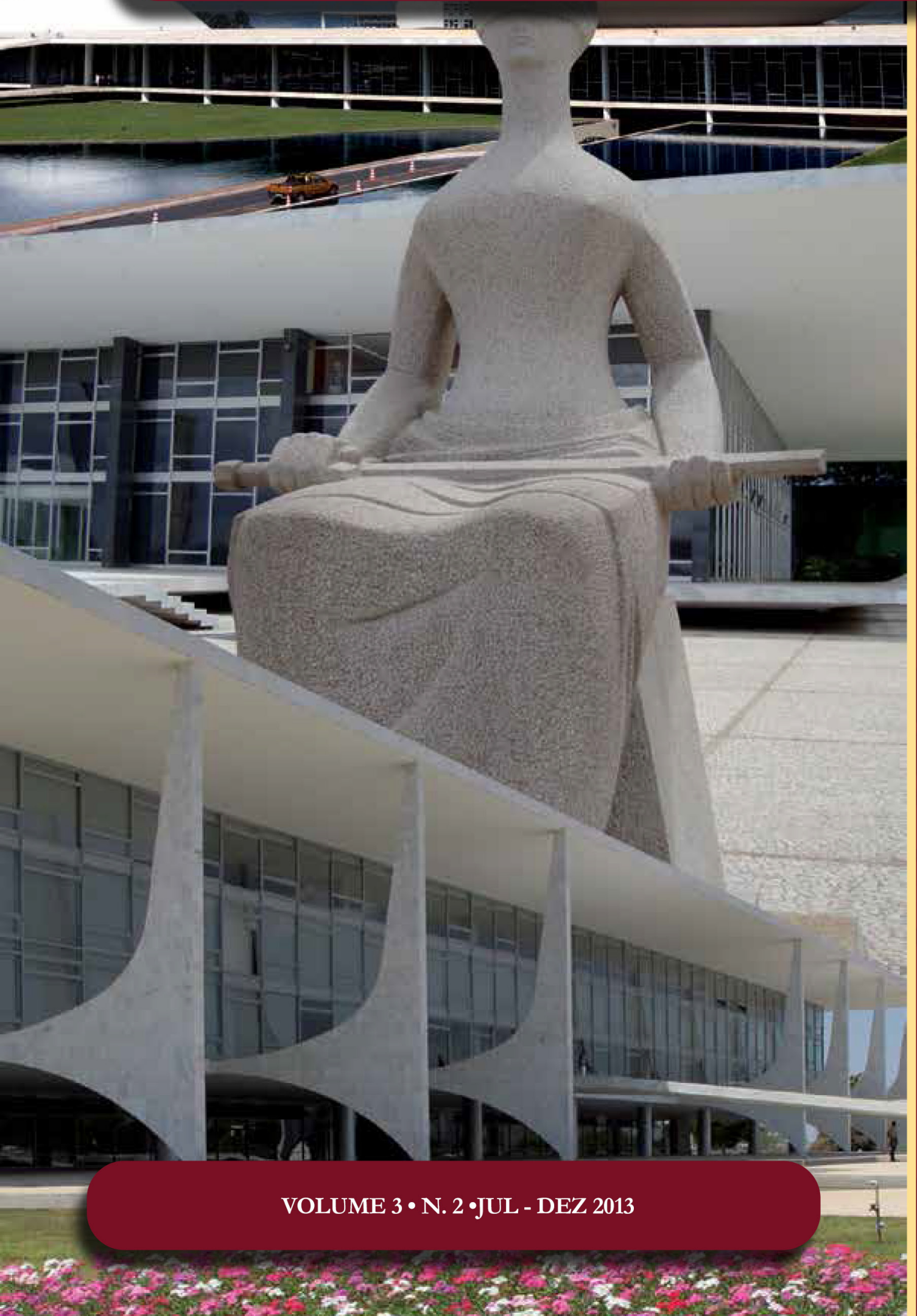

A atual geração de energia elétrica segundo a lógica de mercado e sua ainda caracterização como serviço público

The current electric power generation policy in Brazil according to the market logic and its unaltered characterization as a public service 


\title{
A atual geração de energia elétrica segundo a lógica de mercado e sua ainda caracterização como serviço público
}

\author{
The current electric power generation policy \\ in Brazil according to the market logic and \\ its unaltered characterization as a public \\ service*
}

Humberto Cunha dos Santos ${ }^{1}$

\section{Resumo}

O objetivo deste artigo consiste em compreender a atividade de geração de energia elétrica como serviço público, apesar de as práticas de desestatização e de privatização, vivenciadas no país na década de 1990, terem inserido a lógica de mercado na prestação dessas atividades. Várias outorgas, prorrogadas no período de implementação dessas novas regras de mercado, vencerão em 2015, mostrando-se oportuna essa discussão para auxiliar na fixação dos novos parâmetros da política pública destinada a esses empreendimentos. Primeiramente, são discutidas as práticas de desestatização e de privatização ocorridas no país, com ênfase dada ao Programa Nacional de Desestatização. Após, realiza-se breve contraste com o modelo estatal então vigente e as normas de mercado inseridas para regência das atividades. Postula-se que as práticas de desestatização e de privatização almejaram atrair capital privado para o setor, sem, contudo, descaracterizá-lo como serviço público. São analisados os requisitos jurídicos que permitem classificar uma atividade como serviço público, dissociando-a daquelas tidas como atividades econômicas em sentido estrito. Ao final, conclui-se que a atividade de geração de energia elétrica deve restar compreendida como serviço público.

Palavras-chave: Direito econômico. Energia elétrica. Mercado. Serviço público.

* Recebido em 10/07/2013 Aprovado em 05/11/2013

** Mestre em Direito. Procurador Federal. Professor de Direito Econômico do UniCEUB. Assessor da Agência Nacional de Energia Elétrica. Email: humbertocunhasantos@hotmail. com

\section{Abstract}

This paper's goal consists in understanding the electric power generation activity as a public service, despite the insertion of a market-like logic through the deregulating and privatizing practices experienced in Brazil in the 90's. Many grants, extended in the period in which the implementation of these new market regulations occurred, are to expire in 2015, revealing this discussion timely as to assist in the setting of new parameters for the public policy related to

1 Mestre em Direito. Procurador Federal. Professor de Direito Econômico do UniCEUB. Assessor da Agência Nacional de Energia Elétrica 
these ventures. Firstly, the country's deregulating and privatizing practices are discussed, with particular emphasis on the National Deregulation Program. Subsequently, a brief contrast is made between the state-owned model, valid until then, and the market-like norms inserted for the activity's regulation. Is it thus claimed that the deregulating and privatizing practices aimed to attract private capital to the sector without mischaracterizing, however, the activity as a public service. The legal requirements that allow one to classify a given activity as a public service are then analyzed, in order to distinguish it from economic activities, strictly speaking. Lastly, it is concluded that the electric power generation activity must be understood as a public service.

Keywords: Law and economics. Electric power. Market. Public service.

\section{INTRODUÇÃO}

As práticas de desestatização e privatização vivenciadas no país na década de 1990 inseriram a lógica de mercado no setor elétrico. A mudança de tratamento normativo que possibilitou essa nova realidade restringiu-se a atrair investimentos privados, sem, contudo, descaracterizar o tratamento jurídico das atividades como serviços públicos.

Circunstancialmente, esse debate tem ganhado matizes mais vibrantes em razão da iminência do termo final de várias outorgas de geração, distribuição e transmissão que se encontram exploradas por diversas empresas estatais e privadas e que poderão vir a receber tratamento mais condizente com o regime de serviço público, especialmente na atividade de geração, em que se sinaliza a possibilidade de fixação de preços regulados para comercialização da energia dessas usinas, muitas já depreciadas ou amortizadas, com o objetivo de contribuir na redução de preços e tarifas, tanto para consumidores livres como para cativos. ${ }^{2}$

\section{Privatizações e desestatizações}

Para iniciar o enfrentamento dessas questões, é preciso rememorar o ciclo de privatizações e de desestatizações que marcou a década de 90 no Brasil. Esse ciclo foi influenciado pelas experiências de desregulamentação e de privatização de serviços públicos (public utilities) ocorridas nos Estados Unidos da América e no Reino Unido, cujas experiências repercutiram em vários outros países, inclusive no Brasil, sendo possível identificar muita similitude entre os modelos lá adotados e as regras competitivas aqui implementadas, principalmente a partir da Lei $n^{\circ}$ 9.648/98. Tudo isso pode ser notado mesmo levando-se em conta as substanciais diferenças entre os regimes da common law e a nossa tradição assentada no modelo romano-germânico.

Nos Estados Unidos e no Reino Unido, segundo Martin Chick, o processo de privatização e de desregulamentação, ocorrido no período do pós-guerra até os dias atuais, foi caracterizado pela incorporação de políticas públicas de forte conotação econômica, sobretudo de "marginalist approach", privilegiando instrumentos privados reforçadores de competição para balizamento dos novos investimentos na expansão da geração. ${ }^{3}$ Em sua rica contextualização histórica, o autor situa que, nos EUA:

In 1978, Congress passed the Airline Deregulation Act, the Natural Gas Policy Act and the Public Utility Regulatory Policies Act (PURPA). In terms of the contribution of each piece of legislation to what might be viewed as a programmer of deregulation in the United States, the first opened the skies to airline competition, the second

2 Por força da prevista contida nos artigos 19, 22 e 24 da Lei no 9.074/95, as outorgas de geração, de transmissão e de distribuição foram prorrogadas por 20 anos, a vencerem, portanto, em 2015, situação em que atualmente se noticia o intuito do governo de prorrogar as concessões de geração com definição de "tarifas".

3 O autor destaca que esse tipo de política foi adotado mesmo na França, que manteve o modelo estatal monopolizado da EDF. CHICK, Martin. Electricity and energy policy in Britain, France and the United States since 1945. Edward Elgar: Cheltenham, Northampton, 2007. p. $110-111$. 
decontrolled the most expensive sources of new gas and established a schedule for future deregulation, and the third almost unintentionally pushed the electricity supply industry down the first few steps towards the deregulation and attempted liberalization of the industry and its markets. [...] In 1984, the same year in which AT\&T was deregulated and long-distance calls made competitive, access to natural gas pipelines was liberalized. [...] By 1992, 60 per cent of new capacity in the United States was being built by independent power producers (IPPs) using mainly co-generation and renewable energy facilities.

Já no Reino Unido, observou-se que o início do processo de privatização se deu pelos serviços de utilidade pública de telecomunicações e gás, respectivamente em 1984 e 1986, tendo sido posteriormente implementado no setor de energia pela Electricity Act de $1989 .{ }^{4} \mathrm{O}$ modelo competitivo implantado no setor de energia elétrica daquele país muito se assemelha ao modelo criado pela Lei $n^{\circ} 9.648 / 98$, com desverticalização das atividades e instituição de um operador independente para coordenar a operação do sistema. Destaca o autor:

Given the difficulties of restructuring and liberalizing after its privatization, the government resolved to effect the industrial restructuring required to introduce competition in the electricity supply industry before, rather than after, privatizing the industry. The barebones of such a restructuring required the competitive sections of the industry (for example, generation, marketing and retail supply) to be separated from the regulated sections (distribution, transmission, system operation) and access to the grid to be allowed on a fair basis for all (Joskow, 2005, p.38). Arrangements also needed to be made for an independent system operator (ISO) to manage the operation of the entire network. Competition would occur through a mix of long-term contracts and wholesale spot market trades, with retail tariffs unbundled to separate the price of retail power from the price for the use of distribution and transmission services. New entry would be encouraged in generation ad retail supply. ${ }^{5}$

A tônica da política adotada por esses dois países foi resumida pelo secretário de Estado de Energia britânico, Cecil Parkinson, como: "Introduce competition where it is possible and regulation where it was not'. ${ }^{6}$ Não se deve descurar que o mundo vivenciava a fase de afirmação do capitalismo de mercado, enquanto modelo hegemônico, tendo como marco simbólico a queda do muro de Berlim em 1989 e o abandono de uma ordem global dicotômica, informada pela concorrência ideológica entre os países capitalistas e o bloco comunista, que marcou o período histórico da Guerra Fria. Alan Greenspan realça com forte entonação a consolidação hegemônica desse modelo em que o papel de protagonista é exercido pelo mercado em vez de um modelo estatal planificado. ${ }^{7}$

A influência da "Escola de Chicago" e o que se convencionou chamar de "consenso de Washington", foram, de acordo com Dinorá Adelaide, grandes centros propagadores das novas ideias adotadas pela política brasileira acerca do novo papel a ser exercido pelo Estado. ${ }^{8}$

4 "During the intervening decade of the 1980s, the British government initiated its programme of privatization. Among the large public utilities, first British Telecom and then British Gas were privatized in November 1984 and December 1986, respectively. With these two major privatizations privileging the transfer of ownership over the promotion of competition, is was not until the 1989 Electricity Act that an act of British privatization deliberately and firmly pursued both the restructuring and privatization of a nationalized industry with the specific intent of liberalizing its wholesale and, eventually, retail markets.[...] The privatization of the electricity supply industry in England and Wales by means of the 1989 Electricity Act was neither the first privatization of a utility nor the first attempt to liberalize a fuel and power market. In 1984 British Telecom had been privatized, and British Gas in 1986. In 1982, in the Oil and Gas (Enterprise) Act and in 1983 in the Energy Act, efforts had been made to encourage competition in the relevant markets [...]."CHICK, Martin. Electricity and energy policy in Britain, France and the United States since 1945. Edward Elgar: Cheltenham, Northampton, 2007. p. 114.

5 CHICK, Martin. Electricity and energy policy in Britain, France and the United States since 1945. Edward Elgar: Cheltenham, Northampton, 2007. p. 114.

6 CHICK, Martin. Electricity and energy policy in Britain, France and the United States since 1945. Edward Elgar: Cheltenham, Northampton, 2007. p. 114.

7 "O momento definitivo do capitalismo de mercado, contudo, foi a queda do Muro de Berlim, em 1989, revelando a situação de ruína econômica que predominava no outro lado da cortina de ferro, muito além das expectativas dos mais esclarecidos economistas ocidentais. O planejamento central se encarou como fracasso irremissível, fator que, reforçado pela desilusão crescente em relação às políticas econômicas intervencionistas das democracias ocidentais, contribuiu para a expansão discreta do capitalismo de mercado em boa parte do mundo. O planejamento central já não era mais tema de debates. Muito menos de apologias. A não ser em Cuba, na Coreia do Norte e num punhado de outros focos de resistência, a doutrina foi excluída da agenda econômica do mundo." GREENSPAN, Alan. A era da turbulência: aventuras em um novo mundo. Rio de Janeiro: Elsevier, 2008. p.12.

8 "O ressurgimento dos valores liberais deu-se após o descrédito das ideias keynesianas de intervenção do Estado na economia, 
De fato, a estratégia de inserção internacional do Brasil no mundo globalizado, a partir das políticas econômicas adotadas pelos presidentes Collor de Mello, Itamar Franco e Fernando Henrique Cardoso, pressupunha as "liberalizações comerciais e financeiras".9 Essas liberalizações mudaram a tônica da economia brasileira, caracterizando o ciclo de várias privatizações e concessões da década de 1990, delegando-se ao setor privado atribuições antes realizadas diretamente pelo Estado por intermédio das empresas estatais.

\section{O MOdelo estatal VIGente ATÉ A déCADA DE 1990}

Até a década de 1990, o setor elétrico brasileiro tinha como protagonista as Centrais Elétricas Brasileiras S.A. (Eletrobrás), empresa estatal federal, constituída sob a forma de sociedade anônima pela Lei no 3.890 A, de 25 de abril de 1961, e principal responsável pelos segmentos de geração e transmissão de energia elétrica, possuindo inserção em todo o país por intermédio de suas subsidiárias regionais (Eletronorte, Chesf, Furnas e Eletrosul).10 Themistocles Brandão, após tecer considerações acerca da importância da criação da Eletrobrás, acentua que o propósito de criação da nova empresa não residia em “[...] estabelecer o monopólio estatal da energia elétrica, senão a de ampliar a iniciativa estatal neste setor, sem prejuízo da atividade privada",11 visto que a nova empresa exerceria funções delegadas do Poder Público em um país cada vez mais industrializado e carente de energia.

A atividade de distribuição ficava a cargo de empresas e de órgãos dos governos estaduais, sendo a Eletrobrás controladora de duas distribuidoras que seriam posteriormente privatizadas, a Escelsa (no Espírito Santo) e a Light (no Rio de Janeiro). E, até 1998, ainda não existia a atividade autônoma de comercialização de energia.

O mecanismo de financiamento da expansão das atividades do setor elétrico se dava por intermédio de tributos, consistentes no Imposto Único de Energia Elétrica, instituído pela Lei no 2.308, de 31 de agosto de 1954,12 assim como pelos empréstimos compulsórios. Estabelecida a infraestrutura, cobravam-se tarifas dos usuários em um regime que assegurava remuneração garantida aos concessionários. Em tal regime, os custos de cada segmento eram contabilizados e lançados como créditos ou débitos em uma conta específica, responsável pelo acertamento de diferenças entre credores e devedores, a chamada Conta de Resultados a Compensar (CRC). Segundo a Lei n ${ }^{\circ}$ 5.655, de 20 de maio de 1971, a remuneração dos concessionários era assegurada pela legislação e fixada pelo Poder Concedente, entre 10 e $12 \%$, a ser computada no custo total da atividade. ${ }^{13}$

embora de modo a garantir a manutenção do modo capitalista de produção. Costuma-se situar as origens destes delineamentos teóricos na 'Escola de Chicago', estribando-se, fundamentalmente, em dois eixos teóricos: o pensamento liberal de Friedrich Hayek - prêmio Nobel de Economia em 1974 - e o monetarismo de Milton Friedman - prêmio Nobel de Economia em 1976. Toma forma definitiva no chamado 'consenso de Washington', que indica algumas reformas básicas, como o combate ao déficit público, o aumento da carga tributária e a melhoria da eficiência dos mecanismos de arrecadação, a intensificação dos processos de privatização, e a desregulação da economia, dentre outras." GROTTI, Dinorá Adelaide Musetti. O serviço público e a Constituição Brasileira de 1988. São Paulo: Malheiros, 2003. p.67.

9 FERRARI FILHO, Fernando. Comércio internacional e abertura econômica. In: SOBREIRA, Rogério; RUEDIGER, Marco Aurélio. Desenvolvimento e construção nacional: política econômica. Rio de Janeiro: FGV, 2005. p.72.

10 “Art. $1^{\circ}$ Fica a União autorizada a constituir, na forma desta lei, uma sociedade por ações que se denominará Centrais Elétricas Brasileiras S.A., e usará a abreviatura ELETROBRÁS para a sua razão social. Art. $2^{\circ}$ A ELETROBRÁS terá por objeto a realização de estudos, projetos, construção e operação de usinas produtoras e linhas de transmissão e distribuição de energia elétrica, bem como a (VETADO) celebração dos atos de comércio decorrentes dessas atividades."

11 CAVALCANTI, Themistocles Brandão. Tratado de direito administrativo. 5. ed. Rio de Janeiro: Bastos, 1964. p. 142.

12 "Art. $3^{\circ}$ A energia elétrica entregue ao consumo é sujeita ao impôsto único, cobrado pela União sob a forma de impôsto de consumo, pago por quem a utilizar". "Parágrafo único. O impôsto único de que trata esta lei não isenta nem aos seus contribuintes, nem as entidades produtoras, transmissoras, comerciantes e distribuidoras de energia elétrica, do pagamento dos impostos de renda e do sêlo, incidentes e processados nos têrmos das leis e regulamentos específicos, ficando, porém, mantidas, em sua plenitude, as isenções de impostos outorgadas pela legislação em vigor às referidas entidades." Lei n ${ }^{\circ}$ 2.308/54.

13 "Art $1^{\circ}$ A remuneração legal do investimento, a ser computada no custo do serviço dos concessionários de serviços públicos de energia elétrica, será de 10\% (dez por cento) a 12\% (doze por cento), a critério do poder concedente." Lei no 5.655/71. 
Repleto de atores públicos, com fluxos de pagamentos assegurados pela legislação, não havia obrigatoriedade de formalização de contratos, visto que, ao final, as obrigações eram garantidas pelo Tesouro Nacional. Em um regime que, como o próprio nome indicava, buscava assegurar remuneração garantida a todos os agentes com tarifas equalizadas por todo o país; o seu pressuposto de funcionamento se assentava no regular pagamento dos investimentos realizados, tenham sido eles feitos da forma mais eficiente ou não.

Segundo Maurício Tolmasquim, “[...] esse modelo funcionou bem até fim da década de 1970, quando a União passou a usar as tarifas das empresas do setor elétrico como instrumento de política monetária, a fim de conter a inflação". ${ }^{14}$

Pode-se dimensionar a situação deficitária desse modelo por ocasião da extinção da CRC. Naquela oportunidade, o Tesouro Nacional teve que despender quase 20 bilhões de dólares para honrar suas obrigações. ${ }^{15}$

Essa realidade só começa a mudar com a edição do Programa Nacional de Desestatização (PND) e com as sucessivas alterações legislativas que passam a reordenar não apenas o setor elétrico mas toda a economia nacional. Essas mudanças vieram acompanhadas da instituição de novas estruturas, que prestigiavam um regime informado pela gradativa desindexação da economia, liberalização de preços e inserção de regras competitivas.

Nos setores ainda regulados, houve o surgimento de organismos mais dinâmicos, com estruturas diferentes das demais autarquias, com mandatos concedidos aos seus dirigentes e autonomia decisória reforçada pela perspectiva técnica, privilegiando a adoção de arranjos contratuais de definição de tarifas e preços públicos não mais por regimes pelo custo, ou de remuneração garantida, mas por preços livremente estabelecidos, com técnicas de estímulo à eficiência econômica e que assegurassem o efetivo trespasse dos riscos da atividade ao concessionário privado.

Esse novo cenário do setor elétrico teve por pressuposto, como sintetiza Adriano Rodrigues, “[...] reduzir a participação estatal em atividades que poderiam ser exercidas por agentes privados, concentrando a ação do Governo em atividades de natureza social, que no setor elétrico se restringiram à indicação da política global e ao funcionamento do setor". ${ }^{16} \mathrm{E}$ isso se deu por meio da gradativa delegação à iniciativa privada de atividades anteriormente prestadas diretamente pelo Estado. Ela é considerada, inclusive, como uma das modalidades de desestatização prevista na Lei no $9.491 / 97 .{ }^{17}$

Antônio Dias Leite, consultor participante dos debates que ensejaram a reformulação do modelo estatal outrora vigente - o grupo ficou conhecido como RE-SEB (Reestruturação do Setor Elétrico Brasileiro) -,

14 TOLMASQUIM, Maurício Tiomno. Novo modelo do setor elétrico. Rio de Janeiro: Synergia; EPE: Brasília, 2011. p. 5.

$15 \mathrm{O}$ artigo $7^{\circ}$ da Lei no 8.631/93 extinguiu a Conta de Resultados a Compensar. [Art. $7^{\circ} \mathrm{O}$ regime de remuneração garantida e, em conseqüência, a Conta de Resultados a Compensar - CRC e a Reserva Nacional de Compensação de Remuneração - RENCOR, ficarão extintos na data de publicação do decreto regulamentador desta Lei.] Ao ser regulamentado, e revelado o saldo da conta, viu-se a obrigatoriedade do Tesouro Nacional despender cerca de US\$19,8 bilhões para quitação das obrigações, o que dá uma dimensão do cenário de inadimplência e ineficiência por que passava o setor elétrico. Como referência histórica, são explicativas as razões determinantes ao veto Presidencial ao que seria o artigo 24 da Lei no 8.987/95. Na Mensagem n ${ }^{\circ} 181$, de 13 de fevereiro de 1995, dirigida ao presidente do Senado Federal, naquela ocasião, justificou-se o veto por que garantias como essa do estabelecimento de receita bruta mínima, além de incentivarem ineficiência operacional do concessionário, representam, na realidade, um risco potencial de dispêndio com subsídio pelo Poder Público. O caso mais recente foi o mecanismo instituído pela Lei $n^{\circ}$ 5.655/71, que criou a Conta de Resultados a Compensar (CRC), extinta, em 18.3.93, com a regulamentação da Lei $n^{\circ} 8.631 / 93$, gerando dispêndios líquidos para a União da ordem de US\$19,8 bilhões”.

16 RODRIGUES, Adriano Pires; DIAS, Danilo de Souza. Estado e energia elétrica: experiências internacionais de desregulamentação e o caso brasileiro. Rio de Janeiro: Instituto Liberal, 1994. p.106.

17 "Art. $2^{\circ}$ Poderão ser objeto de desestatização, nos termos desta Lei: [...].

$\int 1^{\circ}$ Considera-se desestatização:

b) a transferência, para a iniciativa privada, da execução de serviços públicos explorados pela União, diretamente ou através de entidades controladas, bem como daqueles de sua responsabilidade.

c) a transferência ou outorga de direitos sobre bens móveis e imóveis da União, nos termos desta Lei." Lei n ${ }^{\circ} 9.491 / 97$ - Altera procedimentos relativos ao Programa Nacional de Desestatização, revoga a Lei n 8.031, de 12 de abril de 1990, e dá outras providências. DOU 10.09.97. 
contextualiza o embate ideológico que permeou o cenário de discussão do novo modelo. ${ }^{18}$

A mudança na forma de atuação buscava, segundo Di Pietro, o almejado desenvolvimento econômico, tendo em vista o esgotamento da capacidade de financiamento do Estado, valendo-se, portanto, da “[...] utilização de métodos de gestão privada mais flexíveis e mais adaptáveis ao novo tipo de atividade". ${ }^{19} \mathrm{O}$ esgotamento da capacidade de financiamento estatal também é destacado por Luís Roberto Barroso como justificativa para a mudança da forma de atuação estatal. ${ }^{20}$

O novo modelo adotado no Brasil, tal como se deu nos Estados Unidos e no Reino Unido, assentado numa perspectiva econômica embasada no custo marginal para a promoção da expansão da geração de energia, buscou privilegiar instrumentos compatíveis com um arranjo típico de mercado, com maior liberdade para gestão da atividade, transferência de riscos, apropriação do resultado e estabilidade dos marcos decisórios.

Pretendia-se, na verdade, atrair investimento privado para o setor elétrico. O setor privado, no entanto, só se mostraria estimulado a investir se fosse assegurada perspectiva favorável de retorno, com regras suficientemente claras e informadas, mais por fundamentos típicos de mercado que propriamente pelas intempéries oscilantes da política. Essas premissas são refletidas na estruturação conferida às Agências Reguladoras encarregadas de equacionar os interesses contrapostos nessas atividades.

Enquanto o país ainda experimentava os resultados das primeiras privatizações ocorridas no setor elétrico, Carlos Kawall Leal Ferreira, atuante junto ao Banco Nacional de Desenvolvimento Econômico e Social (BNDES), órgão com decisivo papel no financiamento das privatizações, concluía favoravelmente pelos resultados obtidos. ${ }^{21}$

\section{Programa Nacional de Desestatização (PND)}

O permissivo legal que embasou as ações de privatização e de desestatização foi a Lei no 8.031, de 12 de abril de 1990, fruto da conversão da Medida Provisória no 155, de 15 de março de 1990, criadora do Programa Nacio-

18 "Os comentaristas convidados, bem como outros que se manifestaram por vontade própria, estavam diante do que lhes parecia uma decisão de governo, dominantemente político-ideológica, de reduzir o Estado às suas atribuições essenciais, de privatizar empresas públicas e de institucionalizar abrangentes mercados competitivos." LEITE, Dias Antônio. A energia do Brasil. Rio de Janeiro: Elsevier, 2. ed. 2007. p. 298.

19 “À proporção que o Estado foi assumindo outros encargos nos campos social e econômico, sentiu-se a necessidade de encontrar novas formas de gestão do serviço público e da atividade privada exercida pela Administração. De um lado, a ideia de especialização, com vistas à obtenção de melhores resultados, que justificou e ainda justifica a existência de autarquias; de outro lado, e com o mesmo objetivo, a utilização de métodos de gestão privada, mais flexíveis e mais adaptáveis ao novo tipo de atividade assumida pelo Estado, em especial a de natureza comercial e industrial; em alguns países, como a Alemanha, isso foi feito com fins de socialização e, em outros, especialmente nos subdesenvolvidos, com vistas ao desenvolvimento econômico.” DI PIETRO, Maria Sylvia Zanella. Parcerias da administração pública: concessão, permissão, franquia, terceirização e outras formas. 4. ed. São Paulo: Atlas, 2002. p. 57.

20 "A constatação de que o Estado não tem recursos para os investimentos necessários e que, além disso, é geralmente um mau administrador, conduziu ao processo de transferência para o setor privado da execução dos serviços públicos. Mas o fato de determinados serviços públicos serem prestados por empresas privadas concessionárias não modifica sua natureza pública: o Estado conserva responsabilidades e deveres em relação a sua prestação adequada. Daí a privatização haver trazido drástica transformação no papel do Estado: em lugar de protagonista na execução dos serviços, suas funções passam a ser as de planejamento, regulamentação e fiscalização das empresas concessionárias. É nesse contexto histórico que surgem, como personagens fundamentais, as agências reguladoras." BARROSO. Luís Roberto. Apontamentos sobre as agências reguladoras. In: MORAES, Alexandre de (Coord.). Agências reguladoras. São Paulo: Atlas. 2002. p. 116-117.

21 "Até o momento, a privatização do setor elétrico do Brasil provou ser bem-sucedida em termos de geração de receita através da venda de ativos, atração do capital estrangeiro para financiamento de um novo modelo competitivo e substituição de um ambiente no qual a maior parte das empresas era afetada por resultados fracos, alto endividamento e níveis baixos de investimentos." BANCO NACIONAL DO DESENVOLVIMENTO ECONÔMICO E SOCIAL - BNDES. FERREIRA, Carlos Kawall Leal. Privatizações do setor elétrico no Brasil. p. 218. Disponível em: < http://www.bndes.gov.br/SiteBNDES/export/sites/default/bndes_pt/Galerias/ Arquivos/conhecimento/ocde/ocde06.pdf >>. Acesso em: 11 jul. 2011. 
nal de Desestatização (PND). ${ }^{22}$ Essa lei tem em seu artigo $1^{\circ}$ prescrições emblemáticas que bem resumem os objetivos visados com a nova postura estatal diante do meio econômico. Por meio desse programa, o país buscava:

(i) reordenar a posição estratégica do Estado na economia, transferindo à iniciativa privada atividades indevidamente exploradas pelo setor público;

(ii) contribuir para a redução da dívida pública, concorrendo para o saneamento das finanças do setor público;

(iii) permitir a retomada de investimentos nas empresas e atividades que vierem a ser transferidas à iniciativa privada;

(iv) contribuir para a modernização do parque industrial do País, ampliando sua competitividade e reforçando a capacidade empresarial nos diversos setores da economia;

(v) permitir que a administração pública concentre seus esforços nas atividades em que a presença do Estado seja fundamental para a consecução das prioridades nacionais; e

(vi) contribuir para o fortalecimento do mercado de capitais, por meio do acréscimo da oferta de valores mobiliários e da democratização da propriedade do capital das empresas que integrarem o Programa.

Na geração, o modelo típico de mercado se deu com a criação do Produtor Independente de Energia Elétrica (PIE), pela Lei no 9.074/95. Seu regime jurídico consiste em: (i) maior liberdade no objeto da outorga, que quando recai sobre empreendimentos hidrelétricos, consistirá na outorga de exploração de bem público (potencial hidráulico), sem a prévia determinação de construção de uma obra pública; (ii) maior assunção dos riscos subjacentes ao fato de se explorar um bem público, pois não há garantia de equilíbrio econômico-financeiro na concessão; e (iii) definição de preços decorrentes de um consenso de livre estabelecimento, inclusive com percentual reservado ao ambiente de contratação livre, em decorrência dos leilões.

Na seara constitucional, a viabilização efetiva do PIE se deu por ocasião da promulgação da Emenda Constitucional $\mathrm{n}^{\circ}$ 06, de 15 de agosto de 1995 (EC no66/95). A referida emenda revogou o artigo 171 da $\mathrm{CF} / 88$, que estabelecia tratamento diferenciado entre empresas brasileiras e de capital nacional e os outros tipos de empresas, prescrevendo tratamento favorecido às empresas que fossem cumulativamente brasileiras e de capital nacional. ${ }^{23}$ Em um mundo globalizado e inspirado pelas práticas liberalizantes vivenciadas pelas principais economias ocidentais, deixaria de fazer sentido distinguir a nacionalidade do capital.

Foi também por meio da $\mathrm{EC} \mathrm{n}^{\circ} 06 / 95$ que se alterou a redação contida no $\$ 1^{\circ}$ do artigo 176 . Em sua redação originária, a exploração de potenciais hidráulicos ficava restrita a "brasileiros" ou à "empresa brasileira de capital nacional". A partir da EC n 06/95, previu-se que essa atividade seria exercida por "brasileiros"

22 Lei no 8.031/90. Cria o Programa Nacional de Desestatização, e dá outras providências. Revogada pela Lei nº 9.491/97, mas sem alteração material quanto a esse dispositivo.

23 "Art. 171. São consideradas:

I - empresa brasileira a constituída sob as leis brasileiras e que tenha sua sede e administração no País; II - empresa brasileira de capital nacional aquela cujo controle efetivo esteja em caráter permanente sob a titularidade direta ou indireta de pessoas físicas domiciliadas e residentes no País ou de entidades de direito público interno, entendendo-se por controle efetivo da empresa a titularidade da maioria de seu capital votante e o exercício, de fato e de direito, do poder decisório para gerir suas atividades.

$\int 1^{\circ}$ - A lei poderá, em relação à empresa brasileira de capital nacional:

I - conceder proteção e benefícios especiais temporários para desenvolver atividades consideradas estratégicas para a defesa nacional ou imprescindíveis ao desenvolvimento do País;

II - estabelecer, sempre que considerar um setor imprescindível ao desenvolvimento tecnológico nacional, entre outras condições e requisitos:

a) a exigência de que o controle referido no inciso II do "capul" se estenda às atividades tecnológicas da empresa, assim entendido o exercício, de fato e de direito, do poder decisório para desenvolver ou absorver tecnologia;

b) percentuais de participação, no capital, de pessoas físicas domiciliadas e residentes no País ou entidades de direito público interno. $\int 2^{\circ}$ - Na aquisição de bens e serviços, o Poder Público dará tratamento preferencial, nos termos da lei, à empresa brasileira de capital nacional." 
ou "empresa constituída sob as leis brasileiras e que tenha sua sede e administração no País". Com a modificação de tratamento, possibilitou-se ao capital estrangeiro a exploração de atividades anteriormente restritas a brasileiros ou empresas de capital nacional. Foi a partir dessas alterações jurídicas que se iniciou o processo de desestatização do setor elétrico e remodelação de suas linhas estruturantes. A fim de salvaguardar os interesses do investidor estrangeiro entrante no país, a $\mathrm{EC} \mathrm{n} \mathrm{n}^{\circ}$ 06/95 trouxe dispositivo novo às Disposições Constitucionais Gerais da Constituição Federal que impedia a regulamentação, por medida provisória, de qualquer artigo da CF/88 cuja redação tivesse sido alterada por meio de emenda promulgada a partir de 1995. ${ }^{24}$ A preocupação desse dispositivo era com a estabilidade dos marcos legais regulatórios, fundamental para estimular a atração de capital a ser alocado em infraestrutura, exigente de vultosas cifras, com altos custos irrecuperáveis e longo prazo de amortização.

Privatização é um termo com forte impacto social. Costuma significar tornar privado o que antes era público. Não é de se estranhar o porquê de sua simples menção suscitar tanta polêmica. Armando Castelar aduz, em pesquisa realizada com 741 magistrados brasileiros, que "[...] é nas decisões envolvendo a privatização que a visão política do magistrado influencia mais acentuadamente o comportamento do juiz: de acordo com 25\% dos entrevistados, nesses casos, a 'politização' das decisões é muito freqüente, e para 31\% deles é algo freqüente". ${ }^{25}$

Pela conceituação jurídica, o termo foi cunhado para envolver a alienação dos direitos da União que assegurassem, direta ou indiretamente, preponderância nas deliberações sociais e o poder de eleger a maioria dos administradores de suas sociedades. ${ }^{26}$ Em outras palavras, o que ficaria sempre privatizado seriam empresas estatais e não setores ou atividades econômicas. A apartação entre os setores livres à iniciativa privada e aqueles titularizados pelo Poder Público é tema constitucional, circunscrito àquela parte da Constituição que se costuma chamar de Constituição Econômica. ${ }^{27}$ Não caberia à legislação infraconstitucional cuidar desse tipo de matéria.

Contudo, algumas perspectivas de cunho eminentemente formal-legalista, postulam que, a partir de uma compreensão assentada na forma e nos regimes como se materializam as outorgas de geração, houve dissociação da atividade de geração de energia elétrica do campo conceitual caracterizador dos serviços públicos. Segundo Alexandre Santos de Aragão, esse seria o entendimento compartilhado por Geraldo Caldas e Maria Aparecida Fagundes. ${ }^{28}$ Além deles, parece coadunar com essa percepção Luis Gustavo Kaercher Loureiro, que compreende as atividades de geração simplesmente como reservadas à União, sem necessariamente associá-las aos serviços públicos. ${ }^{29}$

Conferindo certa autonomia ao artigo $176 \mathrm{da}$ CF/88, ao deferir a medida cautelar na ADI no 2005-6, o Supremo Tribunal Federal chegou a entender que toda regulamentação do setor elétrico, advinda a partir da década de 1990, em razão do seu caráter tipicamente liberalizante, estaria blindada pelas disposições constantes no artigo 246 da CF/88. No voto do ministro Sepúlveda Pertence, destaca-se que:

24 “Art.246. É vedada a adoção de medida provisória na regulamentação de artigo da Constituição cuja redação tenha sido alterada por meio de emenda promulgada a partir de 1995." Esse artigo, depois alterado pela EC n 32/01, serviu de parâmetro para se questionar a regulamentação do novo modelo do setor elétrico, promovida pela Medida Provisória no 144 , de 10 de dezembro de 2003, nas ADI n 3090 e 3100.

25 PINHEIRO, Armando Castelar. Direito, economia e mercados. Rio de Janeiro: Elsevier, 2005. p.6.

26 Segundo o $\int 1^{\circ}$, do artigo $2^{\circ}$ da Lei $n^{\circ} 8.031 / 90$, “[...] considera-se privatização a alienação, pela União, de direitos que lhe assegurem, diretamente ou através de outras controladas, preponderância nas deliberações sociais e o poder de eleger a maioria dos administradores da sociedade".

27 “Constituição Econômica é uma especial focalização da matéria relativa à economia dentro da Carta Magna. [...] vem a ser, pois, o conjunto de normas voltadas para a ordenação da economia, inclusive declinando a quem cabe exercê-la, [...] é a parte da Lei Maior que cuida da regulação da vida econômica, fixando seus princípios fundamentais, determinando algumas regras básicas e definindo, por assim dizer, os atores principais da cena econômica." BASTOS, Celso Ribeiro. Direito econômico brasileiro. São Paulo: Celso Bastos Editor. Instituto Brasileiro de Direito Constitucional, 2000. p. 72-79.

28 ARAGÃO, Alexandre Santos de. Direito dos serviços públicos. Rio de Janeiro: Forense, 2.ed. 2008. p. 277.

29 LOUREIRO, Luis Gustavo Kaercher. Constituição, energia e setor elétrico. Porto Alegre: S. A. Fabris, 2009. 
A conexão entre si de todas as alterações trazidas ao sistema de eletricidade [sic], antes fechado a empresas estatais, faz evidente a imbricação de todas as normas da medida provisória com a efetivação da abertura do setor ao capital privado, só autorizada pela alteração do art. 176, \ $1^{\circ}$, da Constituição.30

Esses entendimentos, contudo, não devem prosperar. Como a seguir se passa a expor, a noção de serviços públicos não foi alterada com as mudanças legislativas advindas, pois a compreensão do conceito radica em acepções formais e materiais que continuam a acompanhar os serviços de energia elétrica.

\section{A NOÇÃO DE SERVIÇOS PÚBLICOS}

A delimitação da noção de serviços públicos não encontra critérios uníssonos na doutrina pátria e estrangeira. Há relativo consenso, contudo, em atribuir à doutrina francesa papel de destaque na delimitação conceitual. Mônica Justen assinala que, no direito europeu, “[...] todos os países apresentam, em maior ou menor grau, alguma influência do direito francês quanto a esse tema". ${ }^{11} \mathrm{O}$ mesmo ocorreu no Brasil, onde a teoria francesa obteve aceitação desde os primeiros esforços conceituais do tema, remontando-se ainda ao período imperial. ${ }^{32}$

Na compreensão do conceito, papel de relevo é atribuído a Léon Duguit. Segundo ele, o fundamento do Estado não reside na soberania ou em qualquer outro elemento especial, mas sim na necessidade de prestar serviços públicos indispensáveis à coexistência social. Sua definição de serviços públicos, fortemente influenciada pelo pensamento de Durkheim, é assinalada como sendo "[...] toda atividade cujo cumprimento é assegurado, regulado e controlado pelos governantes, por ser indispensável à realização da interdependência social, e de tal natureza que não pode ser assumida senão pela intervenção da força do governante". 33

Residiria na relevância atribuída à atividade, segundo Duguit, indispensável à realização da interdependência social, a justificativa de se conceber um regime jurídico diferenciado a reger os serviços públicos, em que se prestigiaria a presença de prerrogativas especiais em favor do Poder Público como forma de se assegurar a efetivação dessas atividades em favor da coletividade.

A noção de puissance publique, entendida como elemento de poder e de autoridade, seria justificada, portanto, como meio para se possibilitar a prestação dos serviços públicos indispensáveis, daí porque os poderes especiais reservados ao Estado - também chamados de "exorbitantes", ou seja, fora da órbita do direito civil - seriam eminentemente instrumentais, o que permitiria sempre vinculá-los a um dever. ${ }^{34}$ Como

30 BRASIL. Supremo Tribunal Federal. Ação Direta de Inconstitucionalidade no 2.005-6. Rel.: Ministro Néry da Silveira. DJ 19.04.2002. p. 377.

31 JUSTEN, Mônica Spezia. A noção de serviço público no direito europeu. São Paulo: Dialética, 2003. p. 19.

32 Nesse sentido, vide GROTTI, Dinorá Adelaide Musetti. O serviço público e a Constituição Brasileira de 1988. São Paulo: Malheiros, 2003.

33 DUGUIT, Leon. Traité de droit constitutionnel. 2. ed. Paris: Fontemoing, 1923. p. 55. v. 2.

34 Segundo o ordenamento positivado brasileiro, vê-se a consagração da presença das cláusulas exorbitantes em diversos diplomas legais. A Lei no 8.666/93, norma geral de disciplina dos contratos administrativos para todos os entes da Federação, reforça a presença do regime jurídico diferenciado com várias cláusulas exorbitantes. Dentre outros dispositivos, destacam-se:

"Art. 54". Os contratos administrativos de que trata esta Lei regulam-se pelas suas cláusulas e pelos preceitos de direito público, aplicando-se-lhes, supletivamente, os princípios da teoria geral dos contratos e as disposições de direito privado. [...]

Art. 58. O regime jurídico dos contratos administrativos instituído por esta Lei confere à Administração, em relação a eles, a prerrogativa de:

I - modificá-los, unilateralmente, para melhor adequação às finalidades de interesse público, respeitados os direitos do contratado; II - rescindi-los, unilateralmente, nos casos especificados no inciso I do art. 79 desta Lei;

III - fiscalizar-lhes a execução;

IV - aplicar sanções motivadas pela inexecução total ou parcial do ajuste;

$\mathrm{V}$ - nos casos de serviços essenciais, ocupar provisoriamente bens móveis, imóveis, pessoal e serviços vinculados ao objeto do contrato, na hipótese da necessidade de acautelar apuração administrativa de faltas contratuais pelo contratado, bem como na hipótese de rescisão do contrato administrativo.

$\int 1^{\circ}$ As cláusulas econômico-financeiras e monetárias dos contratos administrativos não poderão ser alteradas sem prévia concordância do contratado. 
assinala Bandeira de Mello ${ }^{35}$, Duguit chegou a afirmar que o Estado nada mais seria senão um conjunto de serviços públicos. E nisso resumiria sua teoria de Estado.

Essa noção, de cunho eminentemente material, é posteriormente ampliada pelas contribuições de Hauriou e Jéze. Hauriou a complementa ao assinalar que o serviço público é uma organização criada por uma pessoa administrativa, tendo em vista a satisfação de uma necessidade coletiva. É essa organização que vai definir a estrutura para a prestação das atividades, a função dos agentes públicos envolvidos e o regime jurídico aplicável, caracterizado pela presença da puissance publique. Tem-se a percepção do critério orgânico como forma explicativa do serviço público.

Já a contribuição de Gaston Jèze é, na verdade, uma crítica à concepção material proposta por Duguit. Para Jèze, a definição material de serviço público seria vaga e imprecisa, razão pela qual propôs compreender os serviços públicos por uma ótica exclusivamente subjetiva ou formal. Para ele, serviço público seria toda atividade elegida pelo governante ou legislador como sendo serviço público. Na sua definição, falar-se-ia em serviço público quando as autoridades de um país, em determinada época, decidissem satisfazer as necessidades de interesse geral mediante o procedimento de serviço público, ${ }^{36}$ caracterizado por ser dissociado das demais atividades típicas de mercado.

Essas contribuições serviram para consolidar a compreensão de que os serviços públicos possuem um regime jurídico específico, influenciando, por consequência, a própria noção de responsabilidade administrativa.

A consolidação que permitiu a compreensão de um regime jurídico diferenciado para o trato de questões públicas, além das contribuições doutrinárias francesas, adveio com os posicionamentos exarados pelo Tribunal de Conflitos francês. O sistema jurisdicional francês consagra uma típica apartação de competências entre a chamada jurisdição ordinária e a jurisdição administrativa. Demandas que envolvem atuação estatal não são de competência do Poder Judiciário, mas sim do Conselho de Estado. Se, atualmente, a noção de serviços públicos ainda é capaz de suscitar fundadas discussões, é de se esperar que, enquanto estavam sendo forjadas suas características iniciais com maior recorrência, se dessem as divergências na delimitação de competência entre os órgãos envolvidos para julgamento das causas. Mônica Spezia assinala que "[...] tanto o Conselho de Estado quanto a Corte de Cassação tinham opiniões de que sua própria jurisdição, administrativa (para o Conselho) ou comum (para a Corte de Cassação), deveria prevalecer sobre a outra". ${ }^{37}$ Para dirimir essas questões, foi instituído, em 24 de maio de 1872, o Tribunal de Conflitos, que teria a atribuição de resolver as questões de competências envolvendo o Conselho de Estado e a Corte de Cassação.

Um dos importantes julgamentos realizados pelo Tribunal de Conflitos francês, que acabou por reconhecer a competência do Conselho de Estado, foi o acórdão Blanco. Tratou-se de definir a competência para julgamento de demanda de reparação contra a Municipalidade, em razão de a menina Blanco ter sofrido danos físicos, decorrentes de acidente entre vagões em instalações de manufatura de tabaco, em Bordeaux, causado por agentes da municipalidade. Em 8 de fevereiro de 1873, o Tribunal de Conflitos entendeu que, por se tratar de um serviço público, a causa deveria ser analisada segundo as regras de responsabilidade que regem os serviços públicos e não simplesmente pela aplicação do Código Civil, que se reportaria às obrigações entre particulares. Renam Le Mestre consigna a fundamentação central do affaire Blanco: "La

$\int 2^{\circ} \mathrm{Na}$ hipótese do inciso I deste artigo, as cláusulas econômico-financeiras do contrato deverão ser revistas para que se mantenha o equilíbrio contratual. [...]

Art. 65. Os contratos regidos por esta Lei poderão ser alterados, com as devidas justificativas, nos seguintes casos:

I - unilateralmente pela Administração:

a) quando houver modificação do projeto ou das especificações, para melhor adequação técnica aos seus objetivos;

b) quando necessária a modificação do valor contratual em decorrência de acréscimo ou diminuição quantitativa de seu objeto, nos limites permitidos por esta Lei; [...]".

35 MELLO, Celso Antônio Bandeira de. Curso de direito administrativo. 21. ed. São Paulo: Malheiros, 2006. p. 43.

36 JÉZE, Gaston. Princípios generales del derecho administrativo. Buenos Aires: Depalma, 1949. p. 5. Tomo 2.

37 JUSTEN, Mônica Spezia. A noção de serviço público no direito europeu. São Paulo: Dialética, 2003. p. 22. 
responsabilité, qui peut incomber à l'État pour les dommages causés aux particuliers par le fait des personnes qu'il emploie dans le service public, ne peut être régie par les principes qui sont établis dans le Code civil pour les rapports de particulier à particulier?" 38

Teve-se, a partir daí, o reconhecimento de que a percepção de responsabilidade administrativa deveria estar sujeita a um regime de responsabilidade pública, diferentemente do regime de Direito Civil. Benoit reconhece que, a partir desse julgamento, colocou-se um “[...] fim nas tentativas de se considerar a jurisdição comum como competente para julgar questões de responsabilidade de Estado". ${ }^{39}$

Outro expressivo julgamento foi o acórdão Terrier. Por meio dele, o Conselho de Estado reconheceu a ampla abrangência do regime de responsabilidade que envolve o serviço público, abandonando a tradicional distinção entre atos de autoridade e atos de gestão, para assentar a responsabilidade administrativa diante de obrigações que envolvessem dever de indenização. O caso se referia a uma demanda proposta por um cidadão que visava obter da Municipalidade a condenação no pagamento do prêmio oferecido às pessoas que se habilitassem a caçar cobras que assolavam a região. Executado o serviço, a Municipalidade de Saôneet-Loire recusou o pagamento a alguns caçadores, dentre eles, Terrier, alegando que a verba para esse fim havia se esgotado. Segundo o conselheiro Romieu, as regras de Direito Administrativo não poderiam ser derrogadas pela simples alegação de que se tratava de ato de gestão da Municipalidade. Segundo o conselheiro, tudo que se referisse à organização e funcionamento dos serviços públicos estaria ao abrigo da gestão pública, portanto, sujeito à jurisdição administrativa. ${ }^{40}$

Essas decisões serviram para a consolidação em favor de um regime jurídico específico que passou a caracterizar a tratativa dos serviços públicos, assentado na existência de procedimentos típicos de direito público. Gaston Jèze assim o resume:

La idea de servicio público se halla íntimamente vinculada con la del procedimiento de derecho público.

Decir que, en determinada hipótesis, existe servicio público, equivale a afirmar que los agentes públicos, para dar satisfacción regular y continua a cierta categoría de necesidades de interés general, pueden aplicar los procedimientos del derecho público, es decir, un régimen jurídico especial, y que las leyes y reglamentos pueden modificar en cualquier momento la organización del servicio público, sin que pueda oponerse a ello ningún obstáculo insuperable de orden jurídico.41

$\mathrm{Na}$ doutrina brasileira, vê-se que a definição de serviços públicos vem permeada pela combinação dos critérios material, orgânico e formal propostos pela doutrina francesa e acolhidos pela jurisprudência daquele país. Mário Masagão adota o conceito proposto por Jèze. Segundo ele, "[...] é serviço público toda atividade que o Estado exerce para cumprir seus fins". ${ }^{42}$ José Cretella Júnior aproxima-se dessa ampla definição, afirmando que: "Serviço público, lato sensu, é para nós toda atividade que as pessoas jurídicas públicas exercem, direta ou indiretamente, para a satisfação das necessidades coletivas mediante procedimentos peculiares ao direito público". ${ }^{43}$

Ruy Cirne Lima filia-se ao conceito proposto por Duguit, e define serviço público como “[...] todo o serviço existencial, relativamente à sociedade ou, pelo menos, assim havido num momento dado, que, por isso mesmo, tem de ser prestado aos componentes daquela, direta ou indiretamente, pelo Estado ou outra pessoa administrativa". ${ }^{44}$

38 LE MESTRE, Renam. Droit du service public. Paris: Gualino editeur, 2003. p. 24.

39 Apud JUSTEN, Mônica Spezia. A noção de serviço público no direito europen. São Paulo: Dialética, 2003. p. 25.

40 "Tout ce qui concerne l'organisation et le fonctionnement des services publics proprement dits, généraux ou locaux [...] constitue une opération administrative, qui est, par nature, du domaine de la juridiction administrative. Toutes les actions entre les personnes publiques et les tiers ou entre ces personnes publiques elles-mêmes, et fondées sur l'exécution, l'inexécution ou la mauvaise exécution d'un service public sont de la compétence administrative." LE MESTRE, Renam. Droit du service public. Paris: Gualino editeur, 2003. p. 25.

41 JÉZE, Gaston. Princípios generales del derecho administrativo. Buenos Aires: Depalma, 1949. p. 4.

42 MASAGÃO, Mário. Curso de direito administrativo. 6. ed. São Paulo: RT, 1977. p. 267.

43 CRETELLA JÚNIOR, José. Tratado de direito administrativo. Rio de Janeiro: Forense, 1967. p. 55. v. 4.

44 LIMA, Ruy Cirne. Princípios de direito administrativo. São Paulo: RT, 1987. p. 82. 
A ideia do regime jurídico diferenciado para caracterizar as atividades relacionadas à prestação de serviços públicos é reforçada por Themistocles Brandão Cavalcanti para quem "[...] o essencial no serviço público é o regime jurídico a que obedece, a parte que tem o Estado na sua regulamentação, no seu controle, os benefícios e privilégios de que goza, o interesse coletivo a que visa servir". ${ }^{45}$

Do mesmo modo, Djacir Menezes também enfatiza a importância do regime jurídico diferenciado na conceituação dos serviços públicos. Aduz que:

É indiscutível o caráter de direito público que se nota nas relações entre os executores dos serviços públicos e o Estado: daí se considerar essencial no serviço público o regime jurídico a que se amolda. Não se pode deixar de ver a ação do Estado na sua regulamentação, no seu controle, na sua finalidade coletiva que explica e autoriza sua intervenção e direção. ${ }^{46}$

Já para Hely Lopes Meirelles:

Serviço público é todo aquele prestado pela Administração ou por seus delegados, sob normas e controles estatais, para satisfazer necessidades essenciais ou secundárias da coletividade ou simples conveniências do Estado. Fora dessa generalidade não se pode, em doutrina, indicar as atividades que constituem serviço público, porque variam segundo as exigências de cada povo e de cada época. ${ }^{47}$

Celso Antônio Bandeira de Mello realça a importância do regime jurídico administrativo especial dos serviços públicos, bem como a perspectiva material proposta por Duguit. Define:

Serviço público é toda atividade de oferecimento de utilidade ou comodidade material destinada à satisfação da coletividade em geral, mas fruível singularmente pelos administrados, que o Estado assume como pertinente a seus deveres e presta por si mesmo ou por quem lhe faça as vezes, sob um regime de Direito Público - portanto, consagrador de prerrogativas de supremacia e de restrições especiais -, instituído em favor dos interesses definidos como públicos no sistema normativo. ${ }^{48}$

A definição de Di Pietro busca, por sua vez, reunir os três critérios da doutrina francesa. Para a autora, serviço público é "[...] toda atividade material que a lei atribui ao Estado para que a exerça diretamente ou por meio de seus delegados, com o objetivo de satisfazer concretamente às necessidades coletivas, sob regime jurídico total ou parcialmente público". ${ }^{9}$

Alexandre Santos de Aragão, em abordagem mais próxima ao direito econômico, define serviço público como sendo:

[...] atividades de prestação de utilidades econômicas a indivíduos determinados, colocadas pela Constituição ou pela Lei a cargo do Estado, com ou sem reserva de titularidade, e por ele desempenhadas diretamente ou por seus delegatários, gratuita ou remuneradamente, com vistas ao bem-estar da coletividade. ${ }^{50}$

Com maior ou menor aproximação a cada critério, vê-se que a doutrina nacional reconhece a importância da atividade na coesão social para caracterizá-la como sendo serviço público, assim como a prévia definição legal como tal, bem como a existência de um regime jurídico diferenciado. Esses três critérios também são adotados pela jurisprudência do Superior Tribunal de Justiça para identificar as atividades como sendo serviços públicos. ${ }^{51}$

45 CAVALCANTI, Themistocles Brandão. Tratado de direito administrativo. 5. ed. Rio de Janeiro: Freitas Bastos, 1956.

p. 55. v. 2.

46 MENEZES, Djacir. Direito administrativo moderno. Rio de Janeiro: A. Coelho Branco Filho, 1943. p. 228.

47 MEIRELLES, Hely Lopes. Direito administrativo brasileiro. 26. ed. São Paulo: Malheiros: 2001. p. 311.

48 MELLO, Celso Antônio Bandeira de. Curso de direito administrativo. 21. ed. São Paulo: Malheiros, 2006. p. 642.

49 DI PIETRO, Maria Sylvia Zanella. Parcerias da administração pública: concessão, permissão, franquia, terceirização e outras formas. 4. ed. São Paulo: Atlas, 2002. p. 114.

50 ARAGÃO, Alexandre Santos de. Direito dos serviços públicos. Rio de Janeiro: Forense, 2. ed. 2008. p.157.

51 No Conflito de Competência n ${ }^{\circ}$ 104.374, o critério orgânico foi adotado para identificar o serviço de energia elétrica como serviço público. CC 104.374/RS - Rel. Ministro Hamilton Carvalhido - Corte Especial - Julgado em 20/05/09. No Recurso Especial no 389.961-MG, o critério formal balizou a identificação do serviço de transporte ferroviário como serviço público. RESP $\mathrm{n}^{\circ}$ 389.961-MG - Rel. Min. Francisco Falcão. No Agravo Regimental no Recurso em Mandado de Segurança n ${ }^{\circ}$ 27.045-RJ, o critério determinante foi a acepção material do serviço público para caracterizar a atividade de transporte terrestre (ônibus) como sujeita ao princípio da continuidade do serviço público. SUPERIOR TRIBUNAL DE JUSTIÇA. 
A seguir, pretende-se demonstrar que os três requisitos estão presentes nas atividades que envolvem a indústria de energia elétrica, atualmente segmentada nas atividades de (i) geração, (ii) transmissão, (iii) distribuição e (iv) comercialização; não havendo razão para se justificar que o tratamento condizente com regras de mercado tenha dissociado a atividade de geração desse referencial.

\subsection{0 tratamento jurídico da energia elétrica}

O tema referente à energia elétrica, dada sua importância, há vários anos é tratado em esfera constitucional. ${ }^{52}$ Para ser mais preciso, a previsão do tratamento interventivo do Estado na ordem econômica adveio com a Constituição de 1934, visto que a Carta Imperial (1824) e a Constituição Republicana de 1891 não possuíam disposições que cuidassem da ordem econômica e social. Vivenciávamos preocupações nacionalistas, com a ascensão de Vargas ao poder, tendo por corolário a reserva das atividades de energia elétrica a brasileiros ou a empresas brasileiras.

O Título IV - "Da Ordem Econômica e Social" - da Constituição de 1934 também reflete a mudança global na forma de o Estado lidar com a economia. A crise das bolsas em 1929 demandou uma nova postura estatal diante a dinâmica de funcionamento dos mercados, bem como no perfil que o Direito passaria a ter diante do trato econômico. Em 1936, John Maynard Keynes publicou uma obra que mais tarde ganharia enorme aceitação, General Theory of Employment, Interest, and Money, passando a ser um referencial de condução do Estado do bem-estar social no trato de questões econômicas. Uma das contribuições keynesianas mais significativas se assentava na percepção de que os mercados não conseguem se autocorrigir diante de determinados ciclos econômicos, exceto se houver atuação governamental na criação de estímulos, seja em favor do consumo, de investimento ou em prol da expansão do capital. Identifica-se nesse período o nascedouro do Direito Econômico. ${ }^{53}$

Internamente, com a implantação do Estado Novo, o Brasil modificara acentuadamente o seu modelo de Federação, reservando à União várias matérias antes atribuídas aos Estados-Membros.

A reordenação institucional do setor de energia elétrica começou, contudo, um pouco antes, em 15 de setembro de 1931, “[...] quando foram suspensos todos os atos de alienação, oneração, promessa ou começo de transferência de qualquer curso perene ou queda d'água. Foi o primeiro passo para a afirmação da União como poder concedente em matéria de energia elétrica. Com efeito, qualquer ato que envolvesse os dispositivos do decreto passava a depender da autorização expressa do governo federal" ${ }^{54}$

Em 1934, Getúlio Vargas, enquanto chefe do Governo Provisório da República dos Estados Unidos do Brasil, decretou o Código de Águas - Decreto no 24.643, de 10 de julho de $1934^{55}$ - e iniciou a atribuição, vigente até os dias atuais, de exercício das prerrogativas da União enquanto Poder Concedente ${ }^{56}$ para todas

52 A evolução histórica da legislação foi bem condensada no Parecer no 078/01 da Procuradoria-Geral da ANEEL.

53 Conforme Celso Ribeiro Bastos, "O Direito Econômico surgiu a partir do desenvolvimento de um ordenamento jurídico destinado a regular a intervenção do Estado na Economia. Esse desenvolvimento se deu precipuamente a partir da noção de 'Estado do Bem-Estar Social' (Welfare State), ou seja, após a Primeira Guerra Mundial'.’ BASTOS, Celso Ribeiro. Direito econômico brasileiro. São Paulo: Instituto Brasileiro de Direito Constitucional, 2000. p. 57.

54 DIAS, Renato Feliciano (Coord.). Panorama do setor de energia elétrica no Brasil. Rio de Janeiro: Eletrobrás, 1988. p.80.

55 Apesar de ser formalmente um Decreto, pelas disposições constantes da Carta de 1934, o Código de Águas possui força de lei.

56 "Art. 139. O aproveitamento industrial das quedas de águas e outras fontes de energia hidráulica, quer do domínio público, quer do domínio particular, far-se-á pelo regime de autorizações e concessões instituído neste Código.

$\int 1^{\circ}$ Independe de concessão ou autorização o aproveitamento das quedas d'agua já utilizadas industrialmente na data da publicação deste Código, desde que sejam manifestadas na forma e prazos prescritos no art. 149 e enquanto não cesse a exploração; cessada esta cairão no regime deste Código.

$\int 2^{\circ}$ Também ficam excetuados os aproveitamentos de quedas d'agua de potência inferior a $50 \mathrm{kw}$. Para uso exclusivo do respectivo proprietário.

$\int 3^{\circ}$ Dos aproveitamentos de energia hidráulica que, nos termos do parágrafo anterior não dependem de autorização, deve ser, todavia notificado o Serviço de Águas do Departamento Nacional de Produção Mineral do Ministério da Agricultura para efeitos estatísticos.

$\int 4^{\circ}$ As autorizações e concessões serão conferidas na forma prevista no art. 195 e seus parágrafos. 
as atividades referentes à energia elétrica, exceto, é claro, a possibilidade de livre exploração na hipótese de "aproveitamento de energia hidráulica, de potência reduzida e para uso exclusivo do proprietário", segundo os termos daquela Constituição.

O fato de haver um titular das atividades de energia elétrica é fundamental para diferenciá-las das atividades livres a mercado. Diogo de Figueiredo Moreira Neto destaca que:

No Direito Administrativo se tem tradicionalmente entendido o serviço público como uma atividade econômica excluída por lei do mercado para que o Estado a discipline imperativamente e a execute por seus próprios meios ou por delegação, um conceito que admite variações sem maior importância na bem assentada doutrina universal que se construiu a partir de sua origem francesa. ${ }^{57}$

Na jurisprudência do Supremo Tribunal Federal, exerce papel de relevo o enunciado da Súmula no 646 daquele Tribunal ${ }^{58}$ para balizamento do tema. Segundo o referido verbete, se não se trata de serviço público, não há que cogitar na atribuição de titularidade de uma dada atividade ao Poder Público, bem como no estabelecimento de medidas que possam impedir o livre exercício da atividade. Por ocasião da construção desse entendimento, nos autos do Recurso Extraordinário no 193.749-1, interposto por uma drogaria privada em face de outra drogaria concorrente, em razão da recorrente ter aberto filial a menos de 25 metros de distância da drogaria ré, travou-se discussão sobre a aplicação da Lei Municipal Paulista no 10.991/91, que impedia a instalação de estabelecimentos comerciais do mesmo ramo em determinada área. $\mathrm{O}$ acórdão recorrido dispôs que a referida lei:

“[...] não estabelece reserva de mercado ou afronta ao art. 170 da Constituição Federal. Simplesmente disciplina o uso do solo, distribuindo as farmácias de tal forma que atenda todas as camadas da população, evitando a concentração delas em determinado local, com evidentes prejuízos ao povo, visto como um todo". ${ }^{5}$

O voto do ministro Nelson Jobim traz um resumo das questões constitucionais postas ao exame do STF: decidir se "[...] a lei municipal, objeto da causa, é ofensiva à livre concorrência e à defesa do consumidor?" ${ }^{00}$ Segundo o próprio ministro Jobim:

O que se pretende com a legislação municipal é estabelecer faixas de duzentos metros de áreas comerciais da cidade para a exclusiva oferta de produtos por um vendedor só, ou seja, inviabiliza a possibilidade de termos concorrência nesses duzentos metros. [...]

O que há é a redução dos espaços da concorrência, para que ela chegue ao consumidor e não o consumidor vá a ela. Essa é a distinção fundamental. É necessário assegurar que o consumidor - o objetivo final de toda a teoria da concorrência é assegurar preços baixos e produtos de boa qualidade - possa receber a concorrência dos comerciantes, e não ter que fazer a busca dessa concorrência. ${ }^{61}$

Em consonância com esse posicionamento, o ministro Maurício Corrêa assinalou que:

Procedem as alegações. A Constituição Federal, em seu artigo 170 e parágrafo único, assegura o livre exercício de qualquer atividade econômica, independentemente de autorização de órgãos públicos, salvo nos casos previstos em lei. Portanto, a única restrição possível estaria centrada na hipótese da necessidade de autorização ou permissão do Poder Público para o exercício de determinado tipo de atividade econômica, regulando a liberdade de contratar e de fixar preços, exceto nos casos de intervenção direta na produção e comercialização de certos bens. [...]

A limitação geográfica imposta à instalação de drogarias somente conduz à assertiva de concentração capitalista, assegurando, no perímetro, o lucro da farmácia já estabelecida. Dificulta o acesso do consumidor às melhores condições de preço, e resguarda o empresário alojado no local pelo cerceamento do exercício da livre concorrência. ${ }^{62}$

$\int 5^{\circ}$ Ao proprietário da queda d'agua são assegurados os direitos estipulados no art. 148." - Decreto no 24.643/34.

57 MOREIRA NETO, Diogo de Figueiredo. Mutações nos serviços públicos. Direito do Estado: novos rumos. São Paulo: Ed. Max Limonad, 2001. p. 71, v. 1.

58 "Ofende o princípio da livre concorrência lei municipal que impede a instalação de estabelecimentos comerciais do mesmo ramo em determinada área."

59 Recurso Extraordinário no 193.749-1-SP. Redator para o acórdão Min. Maurício Corrêa. Pleno. Supremo Tribunal Federal. DJ 04.05.2001. p. 911.

60 Recurso Extraordinário no 193.749-1-SP. Redator para o acórdão Min. Maurício Corrêa. Pleno. Supremo Tribunal Federal. DJ 04.05.2001. p. 925.

61 Recurso Extraordinário n $193.749-1-S P$. Redator para o acórdão Min. Maurício Corrêa. Pleno. Supremo Tribunal Federal. DJ 04.05.2001. p. 925-927.

62 Recurso Extraordinário n 193.749-1-SP. Redator para o acórdão Min. Maurício Corrêa. Pleno. Supremo Tribunal Federal. DJ 
O desfecho do caso foi, por maioria, pela declaração de inconstitucionalidade do artigo $1^{\circ}$ da Lei $n^{\circ}$ 10.991/91 e pelo provimento do recurso extraordinário. Tomada a redação da Constituição Federal de 1988, ver-se-á que não houve grande alteração do panorama inaugurado pela Constituição de 1934. A Constituição vigente arrolou, entre os bens da União, os potenciais de energia hidráulica (art. 20, VIII), disciplinando forma específica para ratear os benefícios da exploração desses bens. ${ }^{63}$ No artigo seguinte, ao listar o rol de competências que engendra a concepção do equilíbrio federativo, ficou assentada a competência material da União de "[...] explorar, diretamente ou mediante autorização, concessão ou permissão": "b) os serviços e instalações de energia elétrica e o aproveitamento energético dos cursos de água, em articulação com os Estados onde se situam os potenciais hidroenergéticos" (art. 21, XII, "b”).

Verifica-se, pela leitura do texto constitucional, que à União cabe explorar, ela própria ou mediante colaboração com terceiros, três distintos objetos: (i) serviços de energia elétrica; (ii) instalações de energia elétrica e (iii) aproveitamento energético dos cursos de água, desde que o faça em articulação com os Estados onde se situam os potenciais energéticos de matriz hidráulica. Trata-se de competência material e privativa pertencente, de forma expressa, somente à União, no sentido de que os demais entes da federação - Estados, Distrito Federal e Municípios - devem se abdicar de realizar essas funções, exceto quando agirem com alguma concordância do Poder Concedente, sendo o mesmo tratamento estendido aos particulares.

Além da delimitação da competência material da União, a Constituição Federal estabeleceu que, no rol das competências legislativas privativas da União, encontra-se a de legislar sobre energia elétrica (art. 22, IV). Toda essa delimitação expressa de bens e de competências materiais e legislativas que envolvem a matéria de energia elétrica permite compreender melhor sua exata extensão quando associada à sistemática prevista para exploração das atividades econômicas, estabelecida no Título VII, da ordem econômica e financeira do país - arts. 170 a 192 da Constituição Federal.

Nesse título, a Constituição Federal se vale sempre da expressão "atividade econômica" para se referir às práticas fenomênicas que ocorrem no mundo econômico, ora utilizando a acepção enquanto gênero ${ }^{64}$, ora enquanto espécie ${ }^{65}$. Para melhor expressar o sentido de cada uma, Eros Grau dissocia as atividades econômicas em sentido estrito daquelas atividades econômicas caracterizadas como serviços públicos. ${ }^{66}$

De acordo com essa classificação, as atividades econômicas em sentido estrito seriam regidas pelo artigo 173, enquanto os serviços públicos seriam compreendidos sob regência do artigo 175 da CF/88. A classificação assinala a diferenciação entre os regimes jurídicos subjacentes a cada área de atuação estatal, bem como os poderes reservados ao Estado em cada segmento.

Segundo Eros Grau, as atividades econômicas em sentido estrito seriam concebidas como de titularidade da iniciativa privada. ${ }^{67} \mathrm{O}$ Poder Público pode explorá-las diretamente somente nas hipóteses de relevante interesse

04.05.2001. p. 931-932.

63 O Art. 20, parágrafo único, estabelece a obrigatoriedade de compensação financeira ou royalties, regulamentada pela Lei $\mathrm{n}^{\circ}$ 7.990/89 e sucessivas alterações.

64 O Capítulo I faz menção geral aos princípios da atividade econômica. Da mesma forma, a redação trazida pelo artigo 174 , sobre a atuação do Estado como agente normativo e regulador da atividade econômica, também permite identificar uma utilização enquanto gênero.

65 Como espécie, é a utilização da regra geral trazida no parágrafo único do artigo 170 que assegura a todos o livre exercício de qualquer atividade econômica, bem como as menções trazidas no artigo 173 , caput, $\$ 1^{\circ}$.

66 "A prestação de serviço público está voltada à satisfação de necessidades, o que envolve a utilização de bens e serviços, recursos escassos. Daí podermos afirmar que o serviço público é um tipo de atividade econômica. Serviço público - dir-se-á mais - é o tipo de atividade econômica cujo desenvolvimento compete preferencialmente ao setor público. Não exclusivamente, note-se, visto que o setor privado presta serviço público em regime de concessão ou permissão. [...] Daí a verificação que o gênero - atividade econômica - compreende duas espécies: o serviço público e a atividade econômica." GRAU, Eros Roberto. A ordem econômica na Constituição de 1988. 9. ed. São Paulo: Malheiros, 2004. p. 94.

$67 \mathrm{Na}$ ADPF n ${ }^{\circ}$ 46, Eros Grau, na condição de ministro do STF, se posicionou no sentido favorável ao reconhecimento da exclusividade estatal do serviço postal, tendo em vista a dissociação entre a titularidade da atividade, sendo vencedor da tese predominante no desfecho do julgamento. Em seu voto, pontuou que: “[...] por isso digo que o serviço público está para o Estado assim como a atividade econômica em sentido estrito está para o setor privado." Supremo Tribunal Federal. Arguição de Descumprimento 
coletivo ou imperativos da segurança nacional. Em ambos os casos, seria necessária a edição de lei caracterizando tais situações restritivas para permitir a própria intervenção estatal. A lei deveria prever, do mesmo modo, “[...] a sujeição ao regime jurídico próprio das empresas privadas, inclusive quanto aos direitos e obrigações civis, comerciais, trabalhistas e tributários" (art. 173, $\$ 1^{\circ}$, II). Ademais, em razão de a exploração estatal dessas atividades acabar por interferir diretamente no comportamento de um determinado mercado considerado relevante - pois sempre resultará na inserção de um novo agente (ainda que público), para que não haja prejuízo ao princípio da livre concorrência (art. 170, IV) - além da obrigatoriedade de sujeição ao mesmo regime das empresas privadas, reforça-se a determinação de que as empresas estatais exploradoras dessas atividades não possam "[...] gozar de privilégios fiscais não extensivos às do setor privado" (art. 173, $\$ 2^{\circ}$ ). Esse é o regime típico das atividades submetidas a regras de mercado. O Banco do Brasil, assim como a Caixa Econômica Federal, na seara federal, submetem-se a essa lógica de regência justamente por explorarem atividades financeiras caracterizadas como próprias de mercado.

As atividades da indústria da energia elétrica, contudo, não se sujeitam às regras do artigo 173 da CF/88. São todas elas submetidas aos ditames do artigo 175 da CF/88. O artigo 175 atribui ao Poder Público a incumbência de prestar serviços públicos aos cidadãos. Após analisar as várias menções existentes na Constituição Federal sobre "atividades prestacionais atribuídas ao Estado", Alexandre Santos Aragão chega à conclusão de que os serviços públicos são espécies de atividade econômica em que "[...] se pressupõe a titularidade do Estado sobre as atividades, pois do contrário a iniciativa privada não precisaria de um contrato de concessão ou permissão para prestá-las". ${ }^{68}$

O mesmo artigo 175 da CF faculta ao Poder Público a forma de prestar os serviços públicos. Tanto poderá prestá-los diretamente, por intermédio da estrutura governamental concebida, quanto poderá prestá-los valendo-se do esforço de terceiros, especialmente da iniciativa privada, hipótese pela qual se consolidará a delegação de sua execução.

A incumbência, dirigida ao Poder Público, de prestar serviços públicos também traduz uma opção política de dada sociedade. Tradicionalmente, atribuem-se aos entes públicos aquelas atividades que seriam prestadas no interesse geral de todos, consagradoras da justificação de bem comum. Numa linguagem mais afeita à área econômica, caracterizariam-se assim os chamados serviços primários, também concebidos como de utilidade pública. Não há, contudo, uma regra apriorística que possa determinar quais atividades devam ser, necessariamente, tratadas como serviços públicos. Apesar da dificuldade em conceituá-los, visto não haver critérios uníssonos para tanto, há relativo consenso em justificar os serviços públicos pela (i) importância da atividade para a coesão social; (ii) sua caracterização legal; e, (iii) existência de um regime jurídico diferenciado a regê-los.

Tomados os dispositivos constitucionais que envolvem o tema da energia elétrica, pode-se compreendê-los inseridos no conceito de serviços públicos, visto haver (i) classificação legal atribuindo ao Poder Público [União] a prestação dessas atividades, (ii) com caráter de inegável importância à coesão social, por ser inconcebível a vida cotidiana sem esses serviços, (iii) o que permitirá reconhecê-las dotadas de um regime jurídico diferenciado em relação às outras atividades típicas de mercado, visto não serem timbradas por valores individualistas nem terem acepções exclusivistas determinando quando e como se dará sua exploração, o que nos permite reconhecer influxo valorativo da noção de função pública a informá-las.

Admitida a conceituação compatível com a perspectiva do Direito Econômico, como a proposta por Alexandre Aragão, ver-se-á que o Poder Concedente e a ANEEL possuem poderes dilatados para gerir a melhor forma de prestação desses serviços, ${ }^{69}$ permitindo-lhes a promoção de intervenções e ajustes necessários em busca da concretização do interesse público ${ }^{70} \mathrm{sem}$ terem que se sujeitar, portanto, aos estritos comandos do artigo 173.

de Preceito Federal no 46. Relator para o acórdão Min. Eros Grau. Publicado no DJU 26/02/2010.

68 ARAGÃO, Alexandre Santos de. Direito dos serviços públicos. Rio de Janeiro: Forense, 2. ed. 2008. p. 141.

69 Eros Graus sinaliza que a acepção terminológica mais compatível para as atividades caracterizadas como serviços públicos seria "atuação estatal" e não "intervenção estatal", visto que esta ultima pressupõe a ingerência pública em área alheia, própria da iniciativa privada.

70 Respeitadas as legítimas pretensões tipicamente contratuais, o Poder Público sempre poderá modificar os estatutos jurídicos 
Assiste razão a Maria João Pereira Rolim quando enquadra qualquer atividade que envolva energia elétrica na categoria de serviço público, ainda quando se tenha "maior possibilidade de utilização dos aspectos do regime privado". ${ }^{71}$ Isso porque, não se deve confundir a caracterização de uma atividade como serviço público com o regime jurídico que irá informar a sua prestação. Na verdade, uma análise mais acurada da norma revela que a adjetivação como pública recai sobre a atividade e não necessariamente sobre os bens ou a maneira de prestá-la. É sensato esperar que de uma atividade caracterizada como pública surjam benefícios compartilhados entre todos. Mas daí não se mostra pertinente concluir que deva ser adotado um único regime jurídico para informar a maneira de prestação ou exploração dessa atividade. A existência de diversos regimes jurídicos sobre uma mesma atividade é plenamente compatível com o ordenamento jurídico. E isso não se altera pelo simples fato de uma atividade ser caracterizada como serviço público. Caberá sempre à lei conferir a estruturação dos parâmetros de cada regime jurídico aplicável a uma atividade. Eros Grau assinala a existência de "diversos modelos de regime jurídico aplicáveis a situações objetivas díspares entre si". ${ }^{72} \mathrm{Na}$ atividade de geração de energia elétrica, há multiplicidade de regimes jurídicos e eles se assentam em três tipos: (i) autoprodução; (ii) serviço público e (iii) produção independente de energia elétrica.

O fato de haver distintos regimes de outorga contribui no esforço argumentativo daqueles que buscam afastar o referencial teórico dos serviços públicos quando a atividade de geração é prestada em regime distinto do serviço público. Busca-se estender esse mesmo entendimento para atividade específica de comercialização de energia elétrica, tendo em vista que essa atividade pode ser exercida mediante simples autorização. Situação igual não se verifica nos segmentos de transmissão e distribuição em razão de serem tradicionalmente prestados no regime de serviço público previsto pela Lei no 8.987/95.

Esses esforços, contudo, não levam em consideração que as práticas de privatização e de desestatização ocorridas no setor elétrico possibilitaram apenas atrair capital privado para uma área eminentemente pública, sem que tenha havido, contudo, a descaracterização do tratamento dessas atividades.

\section{Considerações finais}

A separação existente entre atividades econômicas em sentido estrito e aquelas caracterizadas como serviços públicos tem grande relevância para a definição e implementação da política pública concebida para determinada atividade.

Na seara dos serviços públicos, há preocupações publicizantes que não se mostram necessariamente presentes em atividades submetidas ao livre mercado. Os serviços públicos são orientados fundamentalmente pela modicidade de preços e tarifas, assim como pela pretensão de universalização de acesso. As atividades sujeitas à lógica de mercado, diversamente, são informadas por decisões individualizadas, variáveis de acordo com os comportamentos da oferta e da demanda, segundo múltiplas preferências, disponibilidades orçamentárias e preços livremente acordados entre consumidores e empresas.

As normas de direito econômico que possibilitarão, em sentido amplo, canalizar os recursos existentes em prol dos objetivos reclamados pela sociedade, precisam partir, inicialmente, da devida caracterização

que determinam a forma de prestação dos serviços públicos. Como exemplo típico na geração, a Lei no 9.648/98, em seu artigo 10, submeteu a comercialização da geração de energia elétrica às regras de livre pactuação de preços, sem que fosse oponível conceber qualquer pretensão de direito adquirido a regime jurídico.

71 "A interpretação daquilo que a Constituição Federal considera como exploração de serviços de energia elétrica não deixa dúvidas acerca da inclusão de toda a atividade correspondente que, direta ou indiretamente, tenha como finalidade a coletividade, envolvendo todas as etapas da 'indústria elétrica': geração, transmissão e distribuição, bem como a comercialização correspondente que afete o mercado.” ROLIM, Maria João Pereira. Direito econômico da energia elétrica. Rio de Janeiro: Forense, 2002. p.160.

72 "Cumpre-me deixar bem fixada, tão-somente, na oportunidade, a circunstância de que a construção dos modelos de regime jurídico - porque há vários deles, aplicáveis a situações objetivas díspares entre si. [...]”.GRAU, Eros Roberto. A ordem econômica na Constituição de 1988. 9. ed. São Paulo: Malheiros, 2004. p. 104. 
da atividade. O fato de o país valer-se de regras de mercado para reger a forma de outorga e execução das atividades de geração de energia elétrica não as desnatura, que, para todos os efeitos, deverão continuar a ser compreendidas enquanto serviços públicos.

Não se mostra necessário que o Poder Público preste os serviços públicos diretamente - pelo menos não aqueles que a Constituição Federal permitiu serem delegados -, mas é fundamental, em qualquer hipótese, que se mostrem adequados à população. A fim de que a prestação seja garantida a todos, o ordenamento jurídico confere ao Poder Público uma série de poderes instrumentais para tanto, mais amplos que aqueles concebidos no trato de atividades consideradas como típicas de mercado.

Por ocasião do advento de várias outorgas do setor elétrico em 2015, ao Poder Público são facultados dilatados poderes para canalizar essas atividades em prol do bem comum, podendo, inclusive, fixar parâmetros para comercialização da energia das usinas já depreciadas ou amortizadas.

\section{REFERÊNCIAS}

ARAGÃO, Alexandre Santos de. Direito dos serviços públicos. 2. ed. Rio de Janeiro: Forense, 2008.

ARAGÃO, Alexandre Santos de. Agências reguladoras e a evolução do direito administrativo econômico. Rio de Janeiro: Forense, 2005.

BANCO NACIONAL DO DESENVOLVIMENTO ECONÔMICO E SOCIAL - BNDES. Privatizações do setor elétrico no Brasil. Disponível em: < http://www.bndes.gov.br/SiteBNDES/export/sites/default/bndes_pt/Galerias/Arquivos/conhecimento/ocde/ocde06.pdf > Acesso em: 11 jul. 2011.

BASTOS, Celso Ribeiro. Direito econômico brasileiro. São Paulo: Instituto Brasileiro de Direito Constitucional, 2000.

CASTRO, Marcus Faro; LOUREIRO, Luiz Gustavo Kaercher (Org.). Direito da energia elétrica no Brasil: aspectos institucionais regulatórios e socioambientais. Brasília: ANEEL, 2010.

CAVALCANTI, Themistocles Brandão. Tratado de direito administrativo. 5. ed. Rio de Janeiro: F. Bastos, 1964. CHICK, Martin. Electricity and energy policy in Britain, France and the United States since 1945. Edward Elgar: Cheltenham, Northampton, 2007.

CRETELLA JÚNIOR, José. Tratado de direito administrativo. Rio de Janeiro: Forense, 1967. v. 4.

DI PIETRO, Maria Sylvia Zanella. Parcerias da administração pública: concessão, permissão, franquia, terceirização e outras formas. 4. ed. São Paulo: Atlas, 2002.

DIAS, Renato Feliciano (Coord.). Panorama do setor de energia elétrica no Brasil. Rio de Janeiro: Eletrobrás, 1988.

DUGUIT, Leon. Traité de droit constitutionnel. 2. ed. Paris: Fontemoing, 1923. v. 2.

GRAU, Eros Roberto. A ordem econômica na Constituição de 1988. 9. ed. São Paulo: Malheiros, 2004.

GREENSPAN, Alan. A era da turbulência: aventuras em um novo mundo. Rio de Janeiro: Elsevier, 2008.

GROT'TI, Dinorá Adelaide Musetti. O serviço público e a Constituição Brasileira de 1988. São Paulo: Malheiros, 2003.

JÉZE, Gaston. Princípios generales del derecho administrativo. Buenos Aires: Depalma, 1949. Tomo 2.

JUSTEN, Mônica Spezia. A noção de serviço público no direito europeu. São Paulo: Dialética, 2003.

JUSTEN FILHO, Marçal. Curso de direito administrativo. São Paulo: Saraiva, 2005. 
LE MESTRE, Renam. Droit du service public. Paris: Gualino editeur, 2003.

LEITE, Dias Antônio. A energia do Brasil. 2. ed. Rio de Janeiro: Elsevier, 2007.

LIMA, Ruy Cirne. Princípios de direito administrativo. São Paulo: RT, 1987.

LOUREIRO, Luis Gustavo Kaercher. Constituição, energia e setor elétrico. Porto Alegre: Sergio Antonio Fabris, 2009.

MASAGÃO, Mário. Curso de direito administrativo. 6. ed. São Paulo: RT, 1977.

MEIRELLES, Hely Lopes. Direito administrativo brasileiro. 26. ed. São Paulo: Malheiros: 2001.

MELLO, Celso Antônio Bandeira de Mello. Curso de direito administrativo. 21. ed. São Paulo: Malheiros, 2006.

MENEZES, Djacir. Direito administrativo moderno. Rio de Janeiro: A. Coelho Branco Filho, 1943.

MORAES, Alexandre de. (Coord.). Agências reguladoras. São Paulo: Atlas, 2002. 


\title{
Empresas, responsabilidade social e políticas de informação obrigatória no Brasil'
}

\section{Corporations, social responsibility and mandated information disclosure policies in Brazil*}

Leandro Martins Zanitelli**

\begin{abstract}
Resumo
O presente artigo examina o potencial e as dificuldades das políticas de informação obrigatória como meio para melhorar o desempenho social e ambiental das empresas no Brasil. Consiste em um trabalho de revisão da literatura acerca das políticas de informação obrigatória e de aplicação do estado da arte da pesquisa às particularidades do capitalismo brasileiro, valendo-se, em relação a esse último ponto, da abordagem conhecida como "variedades de capitalismo" e da tentativa recente de sua aplicação aos países da América Latina. O texto conclui em favor do uso das políticas de informação obrigatória para a promoção da responsabilidade social das empresas, sem deixar, no entanto, de salientar alguns dos obstáculos para o sucesso dessas políticas no caso brasileiro.
\end{abstract}

Palavras-chave: Políticas de informação obrigatória. Responsabilidade social empresarial. Variedades de capitalismo. Brasil.

\section{Abstract}

The article assesses the potential and pitfalls of mandated information disclosure policies as a means to improve the social and environmental performance of corporations in Brazil. It consists of a review of international literature regarding regulation through information and of its application to the Brazilian case, whose particularities are discussed through the lens of the "varieties of capitalism" approach as recently applied to the analysis of Latin American countries' capitalism. The paper finally argues for the use of mandated information regulation as a tool to enhance corporation social responsibility in Brazil, but not without stressing the hazards facing this regulatory strategy in the Brazilian case.

Keywords: Mandated information disclosure. Corporate social responsibility. Varieties of capitalism. Brazil.

1 Agradeço a um revisor anônimo da Revista Brasileira de Políticas Públicas pelos comentários feitos a uma versão anterior deste texto. 


\section{INTRODUÇÃO}

O presente trabalho trata de políticas de informação obrigatória como medidas destinadas a melhorar o desempenho social e ambiental das empresas, com ênfase para a sua aplicação ao caso brasileiro. Como política de informação obrigatória entende-se qualquer medida que, ao invés de impor restrições à atividade empresarial, limite-se a requerer a prestação de informações acerca dessa atividade ou de seu impacto. Um exemplo seria o de uma norma legal que, a fim de combater possível viés racial na admissão de empregados, determine às empresas que divulguem publicamente, a cada ano, o percentual de trabalhadores negros contratados e em exercício de cargo de chefia.

Políticas de informação obrigatória não são, diga-se de saída, uma novidade na regulação da atividade empresarial no Brasil, inclusive no que se refere à regulação que tenha em vista atender a objetivos como o respeito aos direitos humanos e à proteção do meio ambiente. Entre as disposições atualmente em vigor, podem ser citadas as que impõem às empresas o dever de informar aos consumidores sobre as características e, em particular, a periculosidade de produtos, tais como as encontradas no Código de Defesa do Consumidor (Lei 8.078/1990, Arts. 6 $6^{\circ}$ III, $8^{\circ}, 9^{\circ}$ e 31). ${ }^{2}$

Ainda assim, quando comparado ao de outros países, o interesse pela informação obrigatória como meio de regulação da atividade empresarial no Brasil é modesto. ${ }^{3} \mathrm{Na}$ área ambiental, as medidas de informação obrigatória chegam a ser referidas por autores estrangeiros como a "terceira onda" da regulação ambiental, ${ }^{4}$ rivalizando com as políticas tradicionais de "comando-e-controle" e com as soluções ditas "de mercado" (market-based), tais como a tributação e a comercialização do direito de poluir. Um dos exemplos mais conhecidos é o da legislação norte-americana sobre o "Relatório de Despejos Tóxicos" (Toxical Release Inventory, TRI), que obriga indústrias a prestar informações sobre o transporte e a liberação, no meio ambiente, de uma vasta quantidade de substâncias tóxicas. O TRI foi criado na década de 1980 e inspirou medidas similares na União Europeia e em países como Canadá, Austrália, Japão, Coreia do Sul, México e República Tcheca. ${ }^{5}$ No Brasil, em contrapartida, embora a legislação exija a prestação de informações das empresas, sobretudo mediante a entrega de um relatório anual sobre atividades potencialmente poluidoras ou que façam uso de recursos ambientais (Lei 6.938/1981, Art. 17, II; Instrução Normativa/IBAMA 31/2009, Art. 5), as informações obtidas não são divulgadas e, como consequência, acabam impedidas de exercer outra função regulatória que não a de auxiliar as autoridades ambientais na aplicação de medidas de comando-e-controle. ${ }^{6}$

Outra demonstração do desinteresse brasileiro por estratégias de regulação baseadas na informação provém da literatura. Muito embora abundem os estudos sobre deveres de informação atualmente prescritos pela legislação, mormente os do Código de Defesa do Consumidor, são incomuns obras que aventem o uso da informação como solução para novas áreas e examinem, por conseguinte, a conveniência de políti-

2 V. também a Lei 9.294/1996, com determinações sobre informações a serem prestadas por ocasião da venda de produtos oriundos do tabaco, bebidas alcoólicas, medicamentos, terapias e defensivos agrícolas; e o Decreto 4.680/2003, sobre alimentos que contenham OGMs (organismos geneticamente modificados).

3 É importante ressalvar, não obstante, a recente entrada em vigor da Lei de Acesso à Informação (Lei 12.527/11). Embora essa lei tenha por objeto apenas a divulgação de informação, por agentes públicos e organizações privadas sem fins lucrativos, que contém com recursos públicos, ela pode servir indiretamente à divulgação de informações sobre a atividade empresarial ao permitir acesso a informações de órgãos do governo que sejam reguladores das empresas. Além disso, o eventual sucesso da referida lei pode servir de estímulo para o surgimento, no futuro, de medidas de regulação pelas informações endereçadas às empresas.

4 TIETENBERG, Tom. Disclosure strategies for pollution control. Environmental and Resource Economics, v. 11, n. 3-4, p. 587-602, 1998. 5 DASGUPTA, Susmita; WANG, Hua; WHEELER, David. Disclosure strategies for pollution control. In: TIETENBERG, Tom; FOLMER, Henk (Org.). The International Yearbook of Environmental and Resource Economics: A survey of current issues. Cheltenham: Edward Elgar, 2007, p. 93-119. Enquanto as legislações dos países citados se limitam a exigir informações das empresas, em outros, como Indonésia, Filipinas, China, Vietnã e Índia, a política de regulação por intermédio da informação inclui uma classificação pública das empresas de acordo com o seu impacto sobre o meio ambiente.

6 Outra medida sobre informação na área ambiental que obriga a publicar na internet, trimestralmente, lista com os nomes de infratores e as sanções aplicadas (Decreto 6.514/2008, Art. 149) não vem sendo cumprida pela principal agência governamental em âmbito federal, o IBAMA (Instituto Brasileiro do Meio Ambiente e dos Recursos Naturais Renováveis). 
cas públicas baseadas na informação. ${ }^{7} \mathrm{Na}$ literatura estrangeira, em contrapartida, encontram-se trabalhos dedicados não só a avaliar, em geral, as virtudes (e fragilidades) da informação como meio de regulação, ${ }^{8}$ como a defender a sua aplicação para o enfrentamento de problemas pontuais, tais como o da emissão de gases-estufa ${ }^{9}$ e violação a direitos de trabalhadores. ${ }^{10}$

Este trabalho apresenta uma síntese da literatura sobre regulação mediante informação e avalia esta como meio de melhorar o desempenho social e ambiental das empresas no Brasil. Além de ter em vista os debates sobre a divulgação da informação como meio de regulação, o artigo procura considerar as peculiaridades do caso brasileiro, tentando definir, assim, as chances de sucesso de medidas informativas à luz dessas peculiaridades. Para tanto, faz-se uso da economia política comparada e, em especial, da abordagem conhecida como "variedades de capitalismo". ${ }^{11}$ Essa abordagem tem a vantagem de pôr a empresa, alvo das medidas regulatórias a que o presente trabalho se refere, sob o foco da análise. Além disso, embora os trabalhos pioneiros sobre as variedades de capitalismo tenham se limitado a comparar instituições dos países mais industrializados, como EUA e Alemanha, estudos recentes têm tratado de estender a análise para a América Latina ${ }^{12}$ e o Brasil, ${ }^{13}$ oferecendo um promissor ponto de partida para o estudo da regulação empresarial e de técnicas alternativas de regulação, como as que se baseiam na difusão de informações. ${ }^{14}$

$\mathrm{O}$ artigo é organizado como segue. A seção 1 se dedica à definição de políticas de informação obrigatória e a algumas distinções úteis para a análise. A seção 2 revisa as razões apresentadas na literatura para a regulação baseada na informação, o que tanto inclui as razões para procurar alternativas à regulação tradicional de comando-e-controle como as razões, propriamente ditas, em favor do uso da informação com meio de regulação. A seção 3 trata de duas dificuldades enfrentadas pelas políticas de informação obrigatórias, uma que se refere à confiança nas informações divulgadas e outra quanto à importância dessas informações para gestores e trabalhadores das empresas e outros atores capazes de influenciar as suas decisões. A seção 4 tem

7 Para uma exceção, v. FERNANDES, Iêda; BRITO, Brenda; BARRETO, Paulo. Lições para divulgação da lista de infratores ambientais no Brasil. Revista de Direito Ambiental, v. 50, p. 81-101, abr./jun. 2008. Segundo BLACKMAN, Allen. Alternative pollution control policies in developing countries. Review of Environmental Economics and Policy, v. 4, n. 2, p. 234-253, 2010. p. 234. o uso de estratégias de regulação alternativas à regulação tradicional de comando-e-controle na área ambiental é ainda pouco comum nos países em desenvolvimento, embora seja de notar uma tendência à proliferação dessas estratégias, em especial das que se baseiam na disseminação da informação.

8 V., e.g., BEN-SHAHAR, Omri; SCHNEIDER, Carl E. The failure of mandated disclosure. University of Michigan Law School, Empirical Legal Studies Center, Working Paper n. 10-008, 2010. Disponível em: <https://www.law.umich.edu/centersandprograms/ lawandeconomics/abstracts/2010/Documents/10-008benshahar.pdf >. Acesso em: 9 jul. 2012; HESS, David. The three pillars of corporate social reporting as new governance regulation: disclosure, dialogue and development. Michigan Ross School of Business, Working Paper, 2008. Disponível em: <http://deepblue.lib.umich.edu/bitstream/2027.42/60425/1/1112-DHess.pdf>. Acesso em: 10 ago. 2012; VAN ERP, Judith. Reputational sanction in private and public regulation. Erasmus Law Review, v. 1, n. 5, p. 145-162, 2008; WEIL, David; FUNG, Archon; GRAHAM, Mary et al. The effectiveness of regulatory disclosure policies. Journal of Policy Analysis and Management, v. 25, n. 1, p.155-181, 2006; STEPHAN, Mark. Environmental information disclosure programs: they work, but why? Social Science Quarterly, v. 83, n. 1, mar. 2002; KARKKAINEN, Bradley C. Information as environmental regulation: TRI and performance benchmarking, precursor to a new paradigm? Georgetown Law Journal, v. 89, p. 257-370, 2001.

9 SCHATZ, Andrew. Regulating greenhouse gases by mandatory information disclosure. Virginia Environmental Law Journal, v. 26 , p. 335-393, 2008.

10 ESTLUND, Cynthia. Just the facts: the case for workplace transparency. Stanford Law Review, v. 63, p. 351-408, 2011; DOOREY, David J. Who made that? Influencing foreign labour practices through reflexive domestic disclosure regulation. Osgoode Hall Law Journal, v. 43, p. 353-405, 2005.

11 HALL, Peter A.; SOSKICE, David. An introduction to varieties of capitalism. In: HALL, Peter A.; SOSKICE, David (Org.). Varieties of Capitalism: the institutional foundations of comparative advantage. Nova York: Oxford University Press, 2001, p. 1-68.

12 SCHNEIDER, Ben Ross. Comparing capitalisms: liberal, coordinated, network, and hierarchical varieties. 2008. Disponível em: <http://www.ces.fas.harvard.edu/events/papers/Schneider_Comparing_Capitalisms.pdf>. Acesso em: 20 jun. 2012; SCHNEIDER, Ben Ross. Hierarchical market economies and varieties of capitalism in Latin America. Journal of Latin American Studies, v. 41, n. 3, p. 553-575, 2009.

13 NÖLKE, Andreas. A "BRIC" variety of capitalism and social inequality: the case of Brazil. Revista de Estudos e Pesquisas sobre as Américas, v. 4, n. 1, p. 1-14, 2010.

14 Para um ensaio de análise das práticas de responsabilidade social empresarial no Brasil à luz da abordagem das variedades de capitalismo, v. ZANITELLI, Leandro Martins. Capitalismo brasileiro e responsabilidade social empresarial. Sequência, v. 34, n. 66, p. 83-112, 2013. 
em vista certas particularidades do capitalismo brasileiro e suas implicações para as políticas de informação obrigatória, e a seção final resume o trabalho com recomendações acerca do uso das políticas em questão no Brasil.

\section{Políticas de INFORMAÇÃo obRigatóRIA: Definição e distinções}

Políticas de informação obrigatória são as que impõem a certos atores a prestação de informações, diferindo, assim, das políticas tradicionais de comando-e-controle, que se caracterizam por exigir dos atores regulados certa conduta (outra que não a mera prestação de informação) ou resultado. Tome-se, para exemplificar, a conhecida política norte-americana do TRI, que atribui a empresas a obrigação de informar sobre transporte e liberação de substâncias tóxicas. Essa medida claramente se distingue de uma medida de comando-e-controle, já que não trata de proibir ou limitar o uso industrial de substâncias tóxicas, mas apenas de requerer das empresas a informação a respeito desse uso.

Políticas de informação obrigatória e de comando-e-controle não são excludentes. Pode-se, por exemplo, proibir certa atividade nociva ao meio ambiente e, ao mesmo tempo, determinar que empresas informem sobre a eventual ocorrência dessa atividade. É preciso, assim, considerar a conveniência tanto do uso exclusivo da informação com finalidade regulatória como de seu uso combinado com outras medidas.

Uma distinção importante é entre políticas que se limitam a obrigar empresas a prestar informação e políticas que prevejam, além disso, a reunião das informações prestadas de modo a facilitar a comparação do desempenho de diferentes empresas. A legislação brasileira de proteção ao consumidor, por exemplo, impõe amplos deveres de informação com o intuito de ajudar os consumidores em suas tomadas de decisão, mas não reúne as informações prestadas pelos empresários. Embora a tarefa de reunir informações possa ser (e, por vezes, de fato é) executada por outros atores (por exemplo, associações de consumidores, sites de compras), ela não constitui, de um modo geral, parte das políticas públicas brasileiras de informação ao consumidor, já que não fica legalmente incumbida aos órgãos de proteção ao consumidor ou a quaisquer outros agentes. ${ }^{15}$ No caso do TRI norte-americano, em contrapartida, a informação é não apenas apresentada pelas empresas a um órgão governamental, a Agência de Proteção Ambiental (Environmental Protection Agency, EPA), como também se encarrega este órgão de manter um banco com as informações recolhidas, o que facilita a realização de comparações. ${ }^{16}$

Outra distinção é entre políticas de informação obrigatória que exigem a prestação de informação a órgãos governamentais, mas permitem ou imponham manter tal informação sob sigilo, e políticas de informação e divulgação obrigatória da informação. Embora em ambos os casos se possa falar em políticas de informação obrigatória, as políticas do primeiro grupo servem apenas para instruir a ação governamental e não contam, pois, como as do segundo, com outros atores (como sindicatos, associações locais, ONGs em geral) para a realização dos fins a que se propõem.

Por último, observe-se que embora as políticas de informação examinadas neste artigo sejam ditas “obrigatórias", o que sugere se tratar de políticas estatais, boa parte da análise encontrada a seguir é aplicável igualmente à informação espontaneamente prestada (isto é, prestada sem exigência legal) pelas empresas, seja individualmente, seja em decorrência de acordo celebrado com outras empresas ou outros atores (inclusive o próprio Estado).

15 Uma exceção é a informação sobre as taxas de juros e encargos bancários, reunida e divulgada pelo Banco Central do Brasil em seu site. V. <http://www.bcb.gov.br/?LAI>. Acesso em: 16 jul. 2012.

16 KARKKAINEN, Bradley C. Information as environmental regulation: TRI and performance benchmarking, precursor to a new paradigm? p. 286-287. 


\section{JUSTIFICATIVA}

Embora não se refira à informação obrigatória em si mesma, parte da justificativa para estratégias de regulação baseadas na informação tem a ver com os defeitos da regulação de comando-e-controle. Entre os méritos da regulação pela informação estariam, assim, os de não apresentar alguns dos inconvenientes da solução regulatória tradicional.

À regulação de comando-e-controle podem ser atribuídos os seguintes defeitos. ${ }^{17}$ Primeiramente, como estratégia de regulação que prescreve às empresas certo comportamento ou resultado, a regulação de comando-e-controle está sujeita a exigir demais (isto é, a impor mais restrições à atividade empresarial do que o desejável) ou de menos (problema da exatidão). Esse risco é agravado à medida que a tarefa de regular com exatidão se complique, e a complicação aumenta com a amplitude do fim regulatório e a diversidade das situações a regrar. Por exemplo, se não é fácil determinar a quantidade tolerável de emissão de gases-estufa para uma determinada indústria, menos fácil ainda é determinar o nível tolerável dessa e de outras atividades poluidoras não apenas para uma, mas para dezenas de indústrias diferentes. Em particular no caso da regulação da atividade industrial, outro fator a complicar a tarefa de legislar com acuidade é o rápido avanço da técnica, em virtude do qual uma disposição regulatória, mesmo que não o seja inicialmente, pode em pouco tempo se tornar desajustada. ${ }^{18}$

O problema da exatidão pode ser enfrentado mediante a constituição de agências governamentais com poderes e expertise para criar normas adequadas e adaptá-las rapidamente quando for preciso, mas isso põe em evidência outro inconveniente da regulação de comando-e-controle, a saber, o dos custos a arcar com a confecção de normas (problema dos custos com a elaboração de normas). Além disso, e independentemente da sua exatidão, a aplicação das disposições regulatórias de comando-e-controle não se faz sem custos, seja com a fiscalização dos atores regulados, seja com eventuais processos administrativos e judiciais (problema dos custos com a aplicação de normas).

Repare-se agora como a regulação baseada em informação faz frente aos problemas listados. O primeiro problema, da exatidão, é em parte superado no caso da regulação pela informação, já que esse modo de regular não prescreve às empresas qualquer comportamento (afora, claro, o de informar) e, portanto, não corre o risco de exigir das empresas mais do que o que seria desejável. Por outro lado, as políticas públicas de informação obrigatória contam, como se verá adiante, com outros fatores que não a ameaça de sanção legal (por exemplo, as expectativas de consumidores e trabalhadores) para modificar o comportamento das empresas. Assim, o problema da exatidão das políticas de informação obrigatória deve ser examinado à luz de outros fatores de convencimento ou coação que não a lei mesma, fatores esses que, a exemplo dos regramentos de comando-e-controle, podem acabar restringindo a atividade empresarial em uma medida aquém ou além da apropriada.

Ainda no que diz respeito ao problema da exatidão, pode-se afirmar que a grande diferença entre a regulação de comando-e-controle e a regulação baseada na informação decorre do fato de a primeira limitar diretamente a atividade das empresas, enquanto que os limites decorrentes da segunda não são limites impostos pela legislação em si, mas, quando muito, provocados por ela, como no caso de uma empresa que, depois da divulgação de informação negativa sobre mão de obra escrava entre seus fornecedores, toma providências a fim de não ser castigada por investidores ou consumidores éticos. Essa diferença entre limites diretos e

17 Os inconvenientes da regulação de comando-e-controle são esmiuçados em trabalhos nos quais se defendem soluções "de mercado" para problemas ambientais, como incentivos fiscais e a comercialização do direito de poluir. V., e.g., TIETENBERG, Thomas H. Emissions trading: an exercise in reforming pollution policy. Washington, DC: Resources for the Future, 1985; ACKERMAN, Bruce A.; STEWART, Richard B. Reforming environmental law. Stanford Law Review, v. 37, p. 1333-1366, 1985.

18 O problema da exatidão não desaparece quando as normas promulgadas são acentuadamente vagas, já que então se passa a enfrentá-lo por ocasião da aplicação da norma. A vagueza (ainda que quiçá indesejável por outras razões) pode, não obstante, tornar o conteúdo da regulação mais exato à medida que, em comparação com o órgão encarregado de criar as normas, o órgão aplicador esteja mais bem equipado ou consiga responder mais rapidamente a uma alteração das circunstâncias. 
indiretos é também uma diferença entre limites determinados, em última instância, pelo Estado (os limites da regulação de comando-e-controle) e limites oriundos de pressões sociais difusas e até autoimpostos pelas empresas (os da regulação pela informação); estes podem então superar aqueles em precisão, à medida que essa precisão seja uma função da participação de maior número de atores, inclusive dos gestores e trabalhadores, na definição das obrigações sociais da empresa.

Em relação ao segundo problema, dos custos com a elaboração de normas, é plausível afirmar que os custos em questão sejam, em geral, atenuados pela regulação baseada na informação. Embora essa regulação também se componha de normas definidoras do que deve ser informado e por quem (bem como de sanções para o eventual descumprimento), a tendência é que essas normas demandem menos tempo e expertise para a sua elaboração do que as normas de comando-e-controle. Normas segundo as quais as empresas devem informar sobre a contratação de trabalhadores portadores de deficiência, por exemplo, são aparentemente mais simples de criar do que normas que obriguem as empresas a contratar esses trabalhadores, já que as segundas provavelmente precisam considerar particularidades, tais como o tamanho da firma e o setor de sua atividade.

Os custos com a aplicação de normas se traduzem, no caso da regulação pela informação, em custos com a prestação da informação, verificação de sua veracidade e de aplicação de sanções. A magnitude desses custos varia, assim, de acordo com o volume e frequência da informação exigida e com a frequência com a qual a veracidade dessa informação é verificada. Por causa dessa variação, é difícil fazer uma comparação a priori no que se refere aos custos de aplicação, entre as políticas de informação obrigatória e as tradicionais de comando-e-controle. Não obstante, é válido especular que, sendo o custo com o cumprimento das normas de informação para as empresas geralmente inferior ao das normas de comando-e-controle, as violações sejam menos frequentes no primeiro caso, o que enseja uma redução tanto dos custos de fiscalização quanto dos de aplicação de sanções.

Se, por um lado, as políticas de informação obrigatória possuem a vantagem de simplificar a tarefa de elaboração de normas e de não impor (não, ao menos, diretamente) restrições indesejáveis à atividade empresarial, resta, por outro lado, a questão de saber como essas políticas, que nada exigem senão a prestação de informações, são capazes de alterar o comportamento empresarial. Essa é uma questão sobre a qual a literatura estrangeira acerca da regulação pela informação tem frequentemente se debruçado.

Um argumento comum é o de que as políticas de informação obrigatória tornam-se eficazes porque, paradoxalmente, servem para informar os próprios gestores das empresas. ${ }^{19}$ Parte-se da premissa de que algumas informações acerca de uma organização sejam desconhecidas por aqueles que a comandam. Assim, mesmo que a lei não faça outras exigências, o simples fato de impor a obrigação de informar poderia surtir resultado ao levar informações novas sobre a empresa aos seus dirigentes.

Outra hipótese é que a exigência da informação contribua para o "desenvolvimento moral" da companhia. ${ }^{20}$ Ainda que uma política de informação obrigatória não imponha, por si só, alteração no comportamento da empresa, a mera atribuição do dever de informar pode ter o condão de tornar salientes certas normas sociais $^{21}$ e, em consequência, modificar o comportamento de diretores e empregados. Uma medida que

19 KARKKAINEN, Bradley C. Information as environmental regulation: TRI and performance benchmarking, precursor to a new paradigm? p. 295-305; STEPHAN, Mark. Environmental information disclosure programs: they work, but why? p. 194; LEE, E. Information disclosure and environmental regulation: green lights and gray areas. University of Hong Kong, 2010. Disponível em: <http:// hub.hku.hk/bitstream/10722/125310/1/Content.pdf?accept=1>. Acesso em: 9 ago. 2012, p. 8-10; para evidências empíricas, v. LEE, E. Information disclosure and environmental regulation: green lights and gray areas, p. 23-27; BLACKMAN, Allen; AFSAH, Shakeb; RATUNANDA, Damayanti. How do public disclosure pollution control programs work: evidence from Indonesia. Human Ecology Review, v.11, n. 3, p.235-246, 2004; LANOU, Steven M. Production and organization learning: towards a new orientation for environmental policy. Massachusetts Institute of Technology, jun. 1998. Disponível em: <http://web.mit.edu/dusp/etpp/content/ projects/papers/Lanou\%20MIT\%20MCP\%20Thesis\%201998.pdf> . Acesso em: 17 jul. 2012.

20 HESS, David. The three pillars of corporate social reporting as new governance regulation: disclosure, dialogue and development, p. 30-35.

21 CIALDINI, Robert B.; RENO, Raymond R.; KALLGREN, Carl A. A focus theory of normative conduct: recycling the con- 
requeira informações sobre o percentual de trabalhadores portadores de deficiência em uma empresa pode não só revelar o quão raramente esses trabalhadores são contratados como também tornar saliente, entre administradores e empregados, uma norma social avessa à discriminação e, em consequência, provocar um comportamento conforme a essa norma, aumentando a frequência com que trabalhadores com deficiência são admitidos.

Outros argumentos ressaltam o impacto que a informação prestada pode ter sobre outros atores que não os dirigentes da companhia e a importância de pressões externas para uma mudança na conduta empresarial. A ideia é bem representada pela expressão "ciclo de ação" (action cycle) usada em estudo de Weil e colegas. ${ }^{22}$ Informados sobre a atividade de uma corporação, outros atores, como consumidores e investidores, ajustariam seu comportamento à informação recebida e, ao fazê-lo, induziriam, reflexamente, uma alteração no comportamento dos gestores da companhia. ${ }^{23}$ A reação de outros atores às informações sobre o desempenho social da empresa tanto pode ser motivada pelo autointeresse como por preferências sociais (por exemplo, no caso de consumidores éticos ou "verdes"). Em outras palavras, uma política de informação obrigatória pode ter impacto sobre o comportamento desses atores por muni-los de informações relevantes para escolhas autointeressadas ou devido a preferências não egoístas de que a divulgação da informação contribui para satisfazer ou até criar (considerando-se, uma vez mais aqui, o efeito de saliência que a exigência da informação é capaz de suscitar).

Assim, à medida que o sucesso de políticas de informação obrigatória dependa do impacto da informação sobre outros atores que não os gestores da companhia, importa verificar quem são esses atores e por que a informação pode influir em suas decisões. Considere-se, em primeiro lugar, o caso dos investidores. A divulgação de informações sobre o desempenho social e ambiental de uma corporação pode importar para essas pessoas devido a uma preferência por empresas socialmente responsáveis. ${ }^{24}$ Outra hipótese é que mesmo investidores interessados apenas em maximizar o valor de sua carteira sejam atraídos por empresas com bom desempenho social e ambiental, seja por temerem a reação de outros atores, como consumidores e autoridades governamentais, à divulgação de informações negativas sobre uma empresa, seja por tratarem a informação negativa como sinal de risco ou gestão inábil, com consequências indesejáveis em outras áreas além daquela a qual a informação se refere. ${ }^{25}$

Há inúmeros trabalhos empíricos investigando a relação entre a informação quanto ao desempenho social e ambiental das corporações e às decisões de investidores. ${ }^{26}$ A evidência oriunda desses trabalhos é mista, o que, se por um lado sugere a possibilidade de a informação modificar o comportamento dos investidores, por outro mostra a necessidade de perquirir sobre as condições para que isso se verifique.

cept of norms to reduce littering in public places. Journal of Personality and Social Psychology, v. 58, n. 6, p. 1015-1026, 1990.

22 WEIL, David; FUNG, Archon; GRAHAM, Mary et al. The effectiveness of regulatory disclosure policies.

23 A rigor, uma alteração nos rumos da empresa pode não depender de que outros atores reajam, de fato, à informação divulgada, mas apenas de que os dirigentes da companhia prevejam essa reação e tratem, assim, de evitá-la.

24 MACKEY, Alison; MACKEY, Tyson B.; BARNEY, Jay B. Corporate social responsibility and firm performance: investor preferences and corporate strategies. Academy of Management Review, v. 32, n. 3, p.817-835, 2007.

25 KONAR, Shameek; COHEN, Mark A. Information as regulation: the effect of community right to know laws on toxic emissions. Journal of Environmental Economics and Management, v.32, p. 109-124, 1997. p. 112-113; KARKKAINEN, Bradley C. Information as environmental regulation: TRI and performance benchmarking, precursor to a new paradigm?, p. 324-325; STEPHAN, Mark. Environmental information disclosure programs: they work, but why?, p. 194.

26 LEE, E. Information disclosure and environmental regulation: green lights and gray areas; GUPTA; Shreekant; GOLDAR, Bishwanath. Do stock markets penalize environment-unfriendly behaviour? Evidence from India. Ecological Economics, v. 52, p. 81-95, 2005; DASGUPTA, Susmita; LAPLANTE, Benoit; MAMINGI, Nlandu. Pollution and capital markets in developing countries. Journal of Environmental Economics and Management, v. 42, p. 310-335, 2001; KONAR, Shammek; COHEN, Mark A. Does the market value environmental performance? The Review of Economics and Statistics, v. 83, n. 2, p. 281-289, 2001; HAMILTON, James T. Pollution as news: media and stock market reactions to the Toxic Releases Inventory data. Journal of Environmental Economics and Management, v. 28, p. 98-113, 1995; LANOIE, Paul; LAPLANTE, Benoit; ROY, Maité. Can capital markets create incentives for pollution control? Ecological Economics, v. 26, p. 31-41, 1998; SHANE, Philip B.; SPICER, Barry H. Market response to environmental information produced outside the firm. The Accounting Review, v. 98, n. 3, p. 521-538, jul. 1983. 
Outro ator cujo comportamento pode ser influenciado pela informação (e que é capaz, por sua vez, de influenciar as decisões dos gestores das empresas) é o consumidor. A exemplo do que acontece com os investidores, a informação pode ser importante tanto para consumidores autointeressados como para aqueles com preferências altruístas. Um exemplo de informação relevante para consumidores do primeiro grupo é a informação sobre os riscos de um produto, enquanto consumidores do segundo grupo podem ser levados a decidir de acordo com o desempenho social ou ambiental de uma corporação. Sobre essa última hipótese, no entanto, há robustas evidências de um desacordo entre "atitude" e comportamento dos consumidores. ${ }^{27}$ Aparentemente, enquanto são muitos os consumidores que estão dispostos a decidir pela compra de produtos verdes ou éticos, é bem menor o número dos que de fato o fazem.

Hipóteses análogas podem ser levantadas em relação à influência da informação sobre trabalhadores. Para um trabalhador, a informação sobre a responsabilidade social de uma empresa (ou a falta dela) pode ser vital ainda quando a decisão sobre o trabalho seja uma decisão exclusivamente autointeressada. ${ }^{28}$ Por exemplo, a notícia sobre violações a direitos humanos, ocorridas no local de trabalho, é relevante para atuais e potenciais trabalhadores, devido à informação que transmite acerca dos riscos do emprego. ${ }^{29}$ Não é de descartar, além disso, que trabalhadores simplesmente prefiram empresas com comportamento socialmente responsável, e que sua decisão de se empregar, portanto, seja influenciada pela informação sobre o desempenho social de uma empresa, independentemente das consequências desse desempenho para os trabalhadores mesmos. ${ }^{30}$

Uma empresa ainda pode reagir à divulgação de informações negativas sobre o seu desempenho social com o intuito de evitar que essas informações provoquem uma intervenção governamental mais incisiva, já que as políticas de informação obrigatória podem ser percebidas pelas empresas como medidas destinadas a chamar à atenção para as necessidades de regulação mais prementes e a dar lugar, caso elas permaneçam inertes, a medidas mais agressivas. ${ }^{31}$ Esse temor da intervenção governamental pode ganhar força nos casos em que a informação difundida seja usada por outros atores (por exemplo, ONGs e órgãos de imprensa) para exigir providências das autoridades.

No que se refere, em particular, à divulgação de informações sobre o impacto ambiental das empresas, cogita-se ainda de um efeito da informação sobre o comportamento dos habitantes de localidades sujeitas aos riscos ou danos ambientais decorrente da atividade empresarial. A ideia é que, munidas de informação, as vítimas da poluição seriam motivadas a superar eventuais problemas de ação coletiva e a atuar para obter providências das próprias firmas ou das autoridades. ${ }^{32}$

27 CARRINGTON, Michal J.; NEVILLE, Benjamin A.; WHITWELL, Gregory J. Why ethical consumers don't walk their talk: Towards a framework for understanding the gap between the ethical purchase intentions and actual buying behaviour of ethically minded consumers. Journal of Business Ethics, v. 97, p. 139-158, 2010, e referências lá encontradas; para evidências no Brasil, v. BARCELLOS, Marcia Dutra de; KRYSTALLIS, Athanasios; SAAB, Maria Estela de Melo et al. Investigating the gap between citizens' sustainability attitudes and food purchasing behaviour: empirical evidence from Brazilian pork consumers. International Journal of Consumer Studies, v.35, p. 391-402, 2011.

28 KARKKAINEN, Bradley C. Information as environmental regulation: TRI and performance benchmarking, precursor to a new paradigm? p. 325; ESTLUND, Cynthia. Just the facts: the case for workplace transparency, p. 369-373.

29 Como argumenta KARKKAINEN, Bradley C. Information as environmental regulation: TRI and performance benchmarking, precursor to a new paradigm?, p. 325, a informação sobre riscos ambientais pode influenciar as decisões de trabalhadores que prezem pelo próprio bem-estar e pelo de seus familiares no caso em que a decisão sobre o emprego os obrigue a viver em área sob risco.

30 BACKHAUS, Kristin B.; STONE, Brett A.; HEINER, Karl. Exploring the relationship between corporate social performance and employer attractiveness. Business \& Society, v. 41, n. 3, p. 292-318, set. 2002; GREENING; Daniel W.; TURBAN, Daniel B. Corporate social performance as a competitive advantage in attracting a quality workforce. Business \& Society, v. 39, n. 3, p. 254-280, set. 2000; SCHATZ, Andrew. Regulating greenhouse gases by mandatory information disclosure, p. 376.

31 KARKKAINEN, Bradley C. Information as environmental regulation: TRI and performance benchmarking, precursor to a new paradigm? p. 310-312.

32 KARKKAINEN, Bradley C. Information as environmental regulation: TRI and performance benchmarking, precursor to a new paradigm? p. 316-323; LEE, E. Information disclosure and environmental regulation: green lights and gray areas, p. 7-8. 


\section{LIMITES}

Se, por um lado, as hipóteses acerca da influência da informação sobre o comportamento empresarial permitem inferir razões para o sucesso de políticas de informação obrigatória, por outro lado elas também sugerem certos limites aos quais essas políticas se sujeitam. Esses limites, examinados mais detalhadamente a seguir, dizem respeito à confiança nas informações prestadas e à importância dessas informações para as decisões dos gestores da companhia e de outros atores capazes de influenciar o comportamento dos primeiros.

A fim de que a informação tenha impacto sobre atores, tais como investidores, consumidores e trabalhadores, é crucial que haja confiança nos dados divulgados. Não se pode esperar, por exemplo, que um consumidor tome a decisão de compra com base no desempenho ambiental de empresas concorrentes se não confia na informação sobre esse desempenho. Note-se, quanto a isso, que uma informação na qual se confia não é, necessariamente, uma informação verdadeira, bem como, por outro lado, que mesmo uma informação verdadeira pode, por alguma razão, deixar de despertar confiança. No caso das políticas de informação obrigatória, o fato de a informação ser difundida pela própria empresa a respeito da qual essa informação se refere, e o de a veracidade da informação não ser verificada por terceiros, são possíveis causas para a aludida falta de confiança. ${ }^{33}$ A esse respeito, vale observar que embora um meio de combater a desconfiança acerca das informações difundidas seja o controle da sua veracidade por terceiros (por exemplo, agentes públicos e ONGs), o exercício do controle não apenas eleva o custo de aplicação da medida legal como ainda tem o seu sucesso condicionado à crença do público em sua eficácia.

Em relação à importância da informação, aventou-se anteriormente que a informação resultante de uma política de informação obrigatória é capaz, por si só, de levar a uma alteração do comportamento empresarial. Essa alteração tanto pode ser entendida como alteração estratégica quanto institucional. ${ }^{34}$ Em quaisquer das hipóteses, um impacto sobre a atividade da empresa somente pode ser esperado se a informação for importante para os gestores, variando as razões dessa importância de acordo com o modo de atuação, estratégico ou institucional, que venha a ser verificado. No primeiro caso (alteração estratégica), postula-se que as decisões dos gestores estejam destinadas a alcançar certos objetivos, de maneira que a informação resultante da exigência legal importará à medida que esteja relacionada à realização desses objetivos. Por exemplo, a informação sobre a atividade poluidora de uma empresa pode chamar a atenção dos gestores para a ineficiência do processo de produção, levando-os a agir para aperfeiçoar esse processo e, em consequência, elevar os lucros. ${ }^{35}$ No segundo caso (alteração institucional), tem-se em vista o fato de os gestores estarem sujeitos à influência de normas sociais e a possibilidade de a informação resultante de uma política de informação obrigatória ressaltar a necessidade de conformar o comportamento empresarial a essas normas, independentemente do benefício que isso venha propiciar. Por exemplo, se o cumprimento de um dever legal de informar sobre a proporção de negros e brancos em cargos de chefia em uma organização revelar esmagadora predominância desses últimos, a consequência pode ser a tomada de medidas para combater o viés na ocupação de cargos e ajustar a conduta empresarial à norma social respectiva, isso sem ter, necessariamente, em vista resultado algum (como, por exemplo, o aumento das vendas entre consumidores negros).

A importância da informação para outros atores é também uma condição para o sucesso de políticas de informação obrigatória. ${ }^{36}$ Como observado acima, a informação pode importar tanto por razões de autointeresse, como no caso de potenciais investidores para quem a informação sobre o desempenho ambiental de uma empresa sinalize falhas de gestão, quanto devido a preferências por empresas socialmente responsáveis. Deve-se atentar, ainda, para a possibilidade de certas informações interessarem a alguns grupos de atores, mas não a outros.

33 Para evidências sobre a falsidade de informações prestadas por empresas, v. DE MARCHI, Scott; HAMILTON, James T. Assessing the accuracy of self-reported data: an evaluation of the toxics release inventory. Journal of Risk and Uncertainty, v. 32, p. 57-76, 2006.

34 SUCHMAN, Mark C. Managing legitimacy: strategic and institutional approaches. Academy of Management Review, v. 20, n. 3, p. 571-610, 1995.

35 SCHATZ Andrew. Regulating greenhouse gases by mandatory information disclosure, p. 373.

36 WEIL, David; FUNG, Archon; GRAHAM, Mary et al. The effectiveness of regulatory disclosure policies, p. 161. 
A importância da informação para gestores e outros atores deve ser considerada não só abstratamente, como no contexto dos processos de tomada de decisão. Mesmo que uma informação seja, em si mesma, importante, ela pode se mostrar inócua para a tomada de decisão devido à racionalidade limitada dos atores, ${ }^{37}$ isto é, a limitações de tempo e capacidade cognitiva. ${ }^{38}$ Daí a recomendação de que a informação requerida por políticas de informação obrigatória seja simples, de modo a facilitar o seu uso em processos decisórios. ${ }^{39}$ Assim, além de compreensível para o público a que se destina, defende-se que a informação permita uma comparação entre o desempenho de diferentes empresas, como no caso em que os dados sobre a atividade empresarial dão origem a rankings ou classificações. ${ }^{40}$ Considera-se importante, ainda, que a informação seja prestada e ressaltada no local e hora em que a decisão é tomada. ${ }^{41}$

Uma dificuldade a considerar é o risco de, devido à simplificação, a informação não despertar a confiança do público. Isso pode ocorrer quando, em benefício da simplificação, os dados divulgados acabam sendo indicadores imperfeitos do comportamento da empresa. Exemplar, a esse respeito, é o TRI norte-americano, o qual, apesar do reconhecido sucesso, é tido como um indicador falho do desempenho ambiental das empresas, entre outras razões, porque relata o volume de substâncias tóxicas liberadas, mas nada diz sobre a sua toxicidade e sobre o grau de exposição da população local a essas substâncias. ${ }^{42}$ Outro exemplo é o dos rankings de empresas, que podem transmitir uma informação de fácil manuseio sobre a responsabilidade social das empresas classificadas, mas suscitar desconfiança exatamente devido à ignorância sobre a base de dados da qual esse ranking é oriundo, ou simplesmente sofrer com a falta de confiança do público na organização, pública ou privada, encarregada da sua realização. ${ }^{43}$

\section{0 CASO BRASILEIRO}

A avaliação acerca das chances de sucesso de uma estratégia de regulação como a das políticas de informação obrigatória deve levar em conta as particularidades do local no qual a estratégia será empregada. No que se refere, assim, à regulação empresarial, é útil ter em conta a abordagem conhecida como "variedades de capitalismo", " que se propõe trazer, à luz da discursão, diferenças entre países capitalistas determinadas por características institucionais e pelo impacto das instituições sobre o comportamento das empresas. Entretanto, a atenção às empresas apenas não é suficiente, já que, como visto nas seções anteriores, o sucesso das medidas de informação obrigatória depende, em larga medida, da reação de outros atores, como investidores e consumidores, às informações sobre o desempenho das corporações. Assim, uma avaliação do potencial da regulação baseada na informação também precisa levar em conta particularidades locais no que se refere ao comportamento desses outros atores.

37 SIMON, Herbert A. A behavioral model of rational choice. Quarterly Journal of Economics, v. 69, p. 99-118, fev. 1955.

38 SAGE, William M. Regulating through information: disclosure laws and American health care. Columbia Law Review, v. 99 , p. 1701-1829, 1999. p. 1.728-1.731; BEN-SHAHAR, Omri; SCHNEIDER, Carl E. The failure of mandated disclosure, p. 40-54.

39 SAGE, William M. Regulating through information: disclosure laws and American health care, p. 1736-1743; WEIL, David; FUNG, Archon; GRAHAM, Mary et al. The effectiveness of regulatory disclosure policies, p. 161-162.

40 WEIL, David; FUNG, Archon; GRAHAM, Mary et al. The effectiveness of regulatory disclosure policies, p. 161. Um exemplo é o programa de controle de poluição indonésio, o PROPER (Pollution Control Evaluation and Rating), que divide as empresas em cinco grupos segundo o desempenho ambiental. A cada um dos grupos é atribuída uma cor pela qual as empresas pertencentes ao grupo podem ser reconhecidas pelo público. V. AFSAH, Shakeb; VINCENT, Jeffrey R. Putting pressure on polluters: Indonesia's PROPER Program. Harvard Institute for International Development, 1997. Disponível em: <http://web.worldbank.org/archive/website01004/WEB/IMAGES/PUTTINGP. PDF>. Acesso em: 16 ago. 2012. Há, na China, programa similar. V. WANG, Hua; BI, Jun; WHEELER, David et al. Environmental performance rating and disclosure: China's GreenWatch Program. Journal of Environmental Management, v. 71, p. 123-133, 2004.

41 WEIL, David; FUNG, Archon; GRAHAM, Mary et al. The effectiveness of regulatory disclosure policies, p. 161.

42 KARKKAINEN, Bradley C. Information as environmental regulation: TRI and performance benchmarking, precursor to a new paradigm? p. 332.

43 LEE, E. Information disclosure and environmental regulation: green lights and gray areas, p. 33.

44 HALL, Peter A.; SOSKICE, David. An introduction to varieties of capitalism. 
$\mathrm{Na}$ análise das variedades de capitalismo, existe ênfase nas diferenças entre as chamadas economias de mercado liberais, ou LMEs (liberal market economies), como as dos EUA e Reino Unido, e as economias de mercado com coordenação, ou CMEs (coordinated market economies), como as da Alemanha e Japão. ${ }^{45}$ Enquanto as primeiras se caracterizam pelo predomínio de relações estritamente de mercado, baseadas em preços e tendencialmente mais instáveis, nas economias coordenadas, em contrapartida, as estratégias empresariais se encontram mais frequentemente alicerçadas em "contratos relacionais" ou alianças mais duradouras das empresas entre si e com trabalhadores e investidores.

A literatura recente tem se dedicado a descrever outras variedades de capitalismo além das de LMEs e CMEs, estendendo a abordagem às economias de outros países, inclusive da América Latina. ${ }^{46}$ Nos próximos parágrafos, considerar-se-á a caracterização feita por Schneider ${ }^{47}$ dos países da América Latina como economias de mercado hierárquicas, HMEs (bierarquical market economies) e suas implicações acerca do uso de políticas de informação obrigatória para a melhora do desempenho social e ambiental das empresas no Brasil.

De acordo com Schneider, ${ }^{48}$ uma análise das estratégias empresariais em países da América Latina precisa ter em vista o fato de que parte considerável da atividade empresarial nesses países é exercida por multinacionais estrangeiras e pelos chamados "grupos econômicos", grupos de empresas com atividade diversificada, geralmente submetida ao controle familiar. A proliferação das multinacionais e dos grupos atribui ao capitalismo latino-americano as características que se descrevem a seguir, todas elas relevantes para uma avaliação do potencial de políticas de informação obrigatória.

Uma das mencionadas características é a insignificância das associações empresariais. Na América Latina, o fortalecimento dessas associações é por um lado dificultado pela falta de poder decisório dos gestores locais das empresas multinacionais e, por outro lado, pela diversificação da atuação dos grupos econômicos, que acabam se dedicando a setores de atividades dos quais seus controladores se encontram distantes. Acrescentem-se, ainda, como empecilho a um estreitamento das relações do empresariado local com os representantes das multinacionais, possíveis diferenças de idioma e cultura. ${ }^{49}$

A fragilidade deve ser considerada quando se trata de uma estratégia de regulação que, ao invés da aplicação de sanções, pretende se valer do efeito moralizante e reputacional da informação, já que esse efeito é dependente das relações da empresa com outros atores. É verdade, por um lado, que as alianças entre empresas podem elevar a resistência a qualquer tentativa regulatória, inclusive a políticas de informação obrigatória. Por outro, no entanto, as associações empresariais podem servir como fórum de aprendizado sobre o valor (e a conveniência) da responsabilidade social ${ }^{50}$ e de interlocução das empresas com diferentes stakeholders (ONGs, trabalhadores, consumidores etc.), contribuindo para que a difusão da informação surta o resultado esperado. Para que exerçam esse papel, porém, é importante que as associações consistam em mais do que uma união formal de um grupo de empresários, estando alicerçadas em relações de confiança ou dependência capazes de ensejar o aprendizado mútuo e de fazer frente aos problemas de ação coletiva que frequentemente atravancam a melhora no desempenho social das empresas.

Outra característica das economias de mercado hierárquicas ligada à atuação das multinacionais e dos grupos econômicos diz respeito à governança corporativa. Muitas multinacionais não abrem o capital de suas subsidiárias ao mercado de ações, e os grupos econômicos, quando o fazem, costumam manter o controle nas mãos da

45 HALL, Peter A.; SOSKICE, David. An introduction to varieties of capitalism.

46 SCHNEIDER, Ben Ross. Hierarchical market economies and varieties of capitalism in Latin America; NÖLKE, Andreas. $A$ "BRIC" variety of capitalism and social inequality: the case of Brazil.

47 SCHNEIDER, Ben Ross. Comparing capitalisms: liberal, coordinated, network, and hierarchical varieties; SCHNEIDER, Ben Ross. Hierarchical market economies and varieties of capitalism in Latin America.

48 SCHNEIDER, Ben Ross. Hierarchical market economies and varieties of capitalism in Latin America, p. 6-10.

49 SCHNEIDER, Ben Ross. Hierarchical market economies and varieties of capitalism in Latin America, p. 15.

50 CAMPBELL, John L. Why would corporations behave in socially responsible ways? An institutional theory of corporate social responsibility. Academy of Management Review, v. 32, n. 3, p. 946-967, 2007. p. 959. 
família, o que desestimula a participação de acionistas minoritários. ${ }^{51}$ A consequência é a hierarquização da governança, isto é, a reduzida influência de investidores outros que não os sócios majoritários. Essa é uma característica relevante para as políticas de informação obrigatória porque, como visto anteriormente, parte da pressão externa que a divulgação da informação pode suscitar é justamente aquela que provém dos investidores.

Além dos modos de atuação empresarial e de suas implicações para as relações das empresas entre si e entre investidores, é necessário avaliar as chances de sucesso da regulação pela informação tendo em vista particularidades locais atinentes a atores cujas expectativas são capazes de influenciar o comportamento empresarial, como consumidores e trabalhadores. Referindo-se ao uso de políticas de informação obrigatória para a melhora do desempenho ambiental de empresas em países em desenvolvimento, Blackman ${ }^{52}$ ressalva certas dificuldades enfrentadas nesses países. Tais dificuldades são, além da já aludida insignificância dos mercados de capitais, a tímida demanda dos consumidores por produtos verdes, a falta ou debilidade das organizações não governamentais e a impotência do Estado, a qual levaria as companhias a não temer medidas de intervenção mais duras apesar da divulgação de informações negativas sobre o seu desempenho. ${ }^{53}$

No Brasil e em outros países com tradição de intervencionismo estatal e de políticas de bem-estar social, pode ser também que o papel protagonista do Estado contribua para uma cultura de irresponsabilidade social das empresas. ${ }^{54} \mathrm{~A}$ ideia, em outras palavras, é que, ao se incumbir de tarefas de promoção do bem-estar diretamente (por exemplo, pela educação pública e gratuita e a prestação de assistência à saúde) e indiretamente (pela regulação da atividade empresarial), o Estado acabe por atrair não apenas demandas sobre a sua atividade mesma como também as que se referem à responsabilidade social das empresas. Essas últimas seriam então percebidas como agentes cuja ganância só pode ser freada pela mão forte do Estado e que, no limite, estão até legitimados a atuar exclusivamente em seu próprio benefício.

Embora uma cultura de irresponsabilidade social empresarial não constitua necessariamente um óbice intransponível às políticas de informação obrigatória, é importante ter em mente que o impacto dessas políticas depende da sensibilidade do público às informações sobre o comportamento das empresas. Podese, entretanto, ponderar, a esse respeito, que a indiferença ao desempenho social e ambiental das empresas tanto pode ser causa de insucesso de medidas de regulação pela informação quanto resultado da falta dessas medidas. É possível, em outras palavras, que a divulgação mais frequente de informações acabe fomentando expectativas sobre a atividade das empresas e tenha, assim, impacto sobre essa atividade mesmo em países nos quais uma cultura pública de responsabilidade empresarial seja pouco desenvolvida.

\section{Considerações finais}

Esta última seção reúne em tópicos as principais conclusões do trabalho, apresentando-as como recomendações sobre o uso de políticas de informação obrigatória para a melhora do desempenho social e ambiental das empresas no Brasil.

1) Quando se trata de exigir a prestação de informações pelas empresas, há uma vantagem em exigir informações que ainda não sejam conhecidas pelos gestores das companhias. A informação que é nova para

51 SCHNEIDER, Ben Ross. Hierarchical market economies and varieties of capitalism in Latin America, p. 14; NÖLKE, Andreas. A "BRIC" variety of capitalism and social inequality: the case of Brazil, p. 7-8.

52 BLACKMAN, Allen. Alternative pollution control policies in developing countries, p. 234-235.

53 Um empecilho ao sucesso de políticas de informação obrigatória é a incapacidade dos consumidores para compreender a informação divulgada. Em países cuja escolaridade média é baixa, como no Brasil, esse problema é particularmente grave.

54 Para evidências em favor de uma hipótese similar, segundo a qual práticas de responsabilidade social e empresarial (entendida como atuação espontânea, não legalmente prescrita, das empresas) são mais difundidas em países nos quais a intervenção do Estado, nos mercados, é mais tímida, v. KINDERMANN, Daniel. Why do some countries get CST sooner, and in greater quantity, than others? The political economy of corporate responsibility and the rise of market liberalism across the OECD: 1977-2007. WZB Discussion Paper. Disponível em: <http://ideas.repec.org/p/zbw/wzbkpw/spiii2009301.html>. Acesso em: 8 jun. 2012. 
o gestor pode ter um efeito de aprendizado capaz de levar a uma mudança de comportamento independentemente de pressões externas.

2) Mudanças no comportamento empresarial são facilitadas quando as relações entre empresas, eventualmente mediadas por associações comerciais, são estreitas, já que essas relações submetem os gestores à pressão dos seus pares e contribuem para o aprendizado mútuo acerca do valor (e da conveniência) da responsabilidade social. Dada a costumeira fragilidade das associações empresariais brasileiras, deve-se ter em vista o particular potencial das políticas de informação obrigatória nos casos excepcionais (como, por exemplo, os de algumas empresas ligadas a cooperativas) em que a proximidade entre os empresários é maior. Infelizmente, as uniões entre empresas também podem ser um obstáculo para que as referidas políticas (assim como qualquer outra medida de regulação) sejam instituídas.

3) Considerando-se que a confiança nas informações tornadas públicas é vital para que essas informações influenciem as decisões de atores como investidores, trabalhadores, consumidores e autoridades governamentais, é preferível exigir informações cuja veracidade seja fácil de verificar. Além disso, à falta de recursos públicos disponíveis para que tal verificação ocorra, é importante ter em vista que o sucesso da regulação pela informação pode depender de atores privados, como ONGs e movimentos sociais, capazes de se desincumbir da tarefa. Assim, as políticas de informação obrigatória são mais promissoras nos países e nas áreas que já contenham ou que estejam mais propensas a contar com esses atores.

4) É preferível que a informação seja divulgada de maneira a facilitar a compreensão e a comparação do desempenho de diferentes empresas. Há de se ter cuidado, no entanto, para que a simplicidade não ponha em risco a credibilidade e a relevância dos dados revelados para os seus destinatários, tal como pode ocorrer nos casos em que a informação seja usada para classificar as empresas, mas em que os critérios da classificação não fiquem claros ou sejam intrincados a ponto de enfraquecer a percepção sobre a relação entre a posição de uma empresa no ranking divulgado e o desempenho dessa mesma empresa em áreas específicas de interesse do público.

5) A informação é tão mais apta a ter impacto quanto mais saliente se faça, preferencialmente por ocasião da tomada de decisão. Assim, mesmo que informações, comparando o desempenho social e ambiental de empresas, sejam bem divulgadas pela mídia e estejam permanentemente à disposição do público (por exemplo, na internet), é importante cuidar para que consumidores, investidores e outros atores cujas decisões são relevantes para as empresas tenham a sua atenção atraída para a informação na hora de decidir.

6) Quando se trata de contar com a pressão de atores externos para uma mudança no comportamento empresarial, é indispensável procurar obter das empresas informações que sejam relevantes para esses atores. Para diferentes grupos de atores, as informações que importam podem ser distintas, de modo que a definição de uma política de informação obrigatória também precisa ter em vista o público-alvo da informação, isto é, aquele - ou aqueles grupos de atores - cujas reações às empresas sejam mais sensíveis. No caso de países com governança corporativa hierarquizada, como o Brasil, pode ser recomendável difundir informações que interessem a outros grupos de atores que não investidores, como consumidores e trabalhadores.

7) É crucial para o sucesso de políticas de informação obrigatória destinadas a obter mais responsabilidade social empresarial que haja um ambiente normativo favorável a essa responsabilidade, de modo que a divulgação de informações negativas sobre o desempenho social ou ambiental de uma empresa tenha não apenas o efeito de embaraço sobre gestores e empregados, como o de alavancar pressões (dos próprios empregados, de consumidores, investidores etc.) por mudanças de comportamento. Apesar disso, mesmo nos países em que a expectativa geral quanto à responsabilidade social empresarial seja modesta, as políticas de informação obrigatória não devem ser, ao menos de saída, descartadas, já que podem contribuir para uma mudança na cultura pública. 


\section{REFERÊNCIAS}

ACKERMAN, Bruce A.; STEWART, Richard B. Reforming environmental law. Stanford Law Review, v. 37 , p. 1333-1366, 1985.

AFSAH, Shakeb; VINCENT, Jeffrey R. Putting pressure on polluters: Indonesia's PROPER Program. Harvard Institute for International Development, 1997. Disponível em: <http://web.worldbank.org/archive/website01004/WEB/IMAGES/PUTTINGP.PDF>. Acesso em: 16 ago. 2012.

BACKHAUS, Kristin B.; STONE, Brett A.; HEINER, Karl. Exploring the relationship between corporate social performance and employer attractiveness. Business \& Society, v. 41, n. 3, p. 292-318, set. 2002.

BARCELLOS, Marcia Dutra de et al. Investigating the gap between citizens' sustainability attitudes and food purchasing behaviour: empirical evidence from Brazilian pork consumers. International Journal of Consumer Studies, v.35, p. 391-402, 2011.

BEN-SHAHAR, Omri; SCHNEIDER, Carl E. The failure of mandated disclosure. University of Michigan Law School, Empirical Legal Studies Cente. Working Paper, n. 10-008, 2010. Disponível em: <https://www.law. umich.edu/centersandprograms/lawandeconomics/abstracts/2010/Documents/10-008benshahar.pdf>. Acesso em: 9 jul. 2012.

BLACKMAN, Allen. Alternative pollution control policies in developing countries. Review of Environmental Economics and Policy, v. 4, n. 2, p. 234-253, 2010.

BLACKMAN, Allen; AFSAH, Shakeb; RATUNANDA, Damayanti. How do public disclosure pollution control programs work: evidence from Indonesia. Human Ecology Review, v.11, n. 3, p.235-246, 2004.

CAMPBELL, John L. Why would corporations behave in socially responsible ways? An institutional theory of corporate social responsibility. Academy of Management Review, v. 32, n. 3, p. 946-967, 2007.

CARRINGTON, Michal J.; NEVILLE, Benjamin A.; WHITWELL, Gregory J. Why ethical consumers don't walk their talk: Towards a framework for understanding the gap between the ethical purchase intentions and actual buying behaviour of ethically minded consumers. Journal of Business Ethics, v. 97, p. 139-158, 2010.

CIALDINI, Robert B.; RENO, Raymond R.; KALLGREN, Carl A. A focus theory of normative conduct: recycling the concept of norms to reduce littering in public places. Journal of Personality and Social Psychology, v. 58, n. 6, p. 1015-1026, 1990.

DASGUPTA, Susmita; LAPLANTE, Benoit; MAMINGI, Nlandu. Pollution and capital markets in developing countries. Journal of Environmental Economics and Management, v. 42, p. 310-335, 2001.

DASGUPTA, Susmita; WANG, Hua; WHEELER, David. Disclosure strategies for pollution control. In: TIETENBERG, Tom; FOLMER, Henk (Org.). The International Yearbook of Environmental and Resource Economics: a survey of current issues. Cheltenham: Edward Elgar, 2007. p. 93-119.

DOOREY, David J. Who made that? Influencing foreign labour practices through reflexive domestic disclosure regulation. Osgoode Hall Law Journal, v. 43, p. 353-405, 2005.

ESTLUND, Cynthia. Just the facts: the case for workplace transparency. Stanford Law Review, v. 63, p. 351408, 2011.

FERNANDES, Iêda; BRITO, Brenda; BARRETO, Paulo. Lições para divulgação da lista de infratores ambientais no Brasil. Revista de Direito Ambiental, v. 50, p. 81-101, abr.-jun. 2008.

GREENING; Daniel W.; TURBAN, Daniel B. Corporate social performance as a competitive advantage in attracting a quality workforce. Business e Society, v. 39, n. 3, p. 254-280, set. 2000. 
GUPTA; Shreekant; GOLDAR, Bishwanath. Do stock markets penalize environment-unfriendly behaviour? Evidence from India. Ecological Economics, v. 52, p. 81-95, 2005.

HALL, Peter A.; SOSKICE, David. An introduction to varieties of capitalism. In: HALL, Peter A.; SOSKICE, David (Org.). Varieties of Capitalism: the institutional foundations of comparative advantage. Nova York: Oxford University Press, 2001. p. 1-68.

HAMILTON, James T. Pollution as news: media and stock market reactions to the Toxic Releases Inventory data. Journal of Environmental Economics and Management, v. 28, p. 98-113, 1995.

HESS, David. The three pillars of corporate social reporting as new governance regulation: disclosure, dialogue and development. Michigan Ross School of Business, Working Paper, 2008. Disponível em: <http://deepblue.lib. umich.edu/bitstream/2027.42/60425/1/1112-DHess.pdf>. Acesso em: 10 ago. 2012.

KARKKAINEN, Bradley C. Information as environmental regulation: TRI and performance benchmarking, precursor to a new paradigm? Georgetown Law Journal, v. 89, p. 257-370, 2001.

KINDERMANN, Daniel. Why do some countries get CST sooner, and in greater quantity, than others? The political economy of corporate responsibility and the rise of market liberalism across the OECD: 19772007. WZB Discussion Paper. Disponível em: <http://ideas.repec.org/p/zbw/wzbkpw/spiii2009301.html>. Acesso em: 8 jun. 2012.

KONAR, Shameek; COHEN, Mark A. Information as regulation: the effect of community right to know laws on toxic emissions. Journal of Environmental Economics and Management, v.32, p. 109-124, 1997.

KONAR, Shammek; COHEN, Mark A. Does the market value environmental performance? The Review of Economics and Statistics, v. 83, n. 2, p. 281-289, 2001.

LANOIE, Paul; LAPLANTE, Benoît; ROY, Maité. Can capital markets create incentives for pollution control? Ecological Economics, v. 26, p. 31-41, 1998.

LANOU, Steven M. Production and organization learning: towards a new orientation for environmental policy. Massachusetts Institute of Technology, jun. 1998. Disponível em: <http://web.mit.edu/dusp/etpp/content/ projects/papers/Lanou\%20MIT\%20MCP\%20Thesis\%201998.pdf>. Acesso em: 17 jul. 2012.

LEE, E. Information disclosure and environmental regulation: green lights and gray areas. University of Hong Kong, 2010. Disponível em: <http://hub.hku.hk/bitstream/10722/125310/1/Content.pdf?accept=1>. Acesso em: 9 ago. 2012.

MACKEY, Alison; MACKEY, Tyson B.; BARNEY, Jay B. Corporate social responsibility and firm performance: investor preferences and corporate strategies. Academy of Management Review, v. 32, n. 3, p.817-835, 2007.

MARCHI, Scott; HAMILTON, James T. Assessing the accuracy of self-reported data: an evaluation of the toxics release inventory. Journal of Risk and Uncertainty, v. 32, p. 57-76, 2006.

NÖLKE, Andreas. A "BRIC" variety of capitalism and social inequality: the case of Brazil. Revista de Estudos e Pesquisas sobre as Américas, v. 4, n. 1, p. 1-14, 2010.

SAGE, William M. Regulating through information: disclosure laws and American health care. Columbia Law Review, v. 99, p. 1701-1829, 1999.

SCHATZ, Andrew. Regulating greenhouse gases by mandatory information disclosure. Virginia Environmental Law Journal, v. 26, p. 335-393, 2008.

SCHNEIDER, Ben Ross. Comparing capitalisms: liberal, coordinated, network, and hierarchical varieties. 2008. Disponível em: <http://www.ces.fas.harvard.edu/events/papers/Schneider_Comparing_Capitalisms.pdf>. Acesso em: 20 jun. 2012. 
SCHNEIDER, Ben Ross. Hierarchical market economies and varieties of capitalism in Latin America. Journal of Latin American Studies, v. 41, n. 3, p. 553-575, 2009.

SHANE, Philip B.; SPICER, Barry H. Market response to environmental information produced outside the firm. The Accounting Review, v. 98, n. 3, p, 521-538, jul. 1983.

SIMON, Herbert A. A behavioral model of rational choice. Quarterly Journal of Economics, v. 69, p. 99-118, fev. 1955.

STEPHAN, Mark. Environmental information disclosure programs: they work, but why? Social Science Quarterly, v. 83, n. 1, mar. 2002.

SUCHMAN, Mark C. Managing legitimacy: strategic and institutional approaches. Academy of Management Review, v. 20, n. 3, p. 571-610, 1995.

TIETENBERG, Thomas H. Emissions trading: an exercise in reforming pollution policy. Washington, DC: Resources for the Future, 1985.

TIETENBERG, Tom. Disclosure strategies for pollution control. Environmental and Resource Economics, v. 11, n. 3-4, p. 587-602, 1998.

VAN ERP, Judith. Reputational sanction in private and public regulation. Erasmus Law Review, v. 1, n. 5, p. 145-162, 2008.

WANG, Hua; BI, Jun; WHEELER, David et al. Environmental performance rating and disclosure: China's GreenWatch Program. Journal of Environmental Management, v. 71, p. 123-133, 2004.

WEIL, David; FUNG, Archon; GRAHAM, Mary et al. The effectiveness of regulatory disclosure policies. Journal of Policy Analysis and Management, v. 25, n. 1, p.155-181, 2006.

ZANITELLI, Leandro Martins. Capitalismo brasileiro e responsabilidade social empresarial. Sequência, v. 34, n. 66, p. 83-112, 2013. 


\section{REVISTA BRASILEIRA DE POLÍTICAS PÚBLICAS BRAZILIAN JOURNAL OF PUBLIC POLICY}

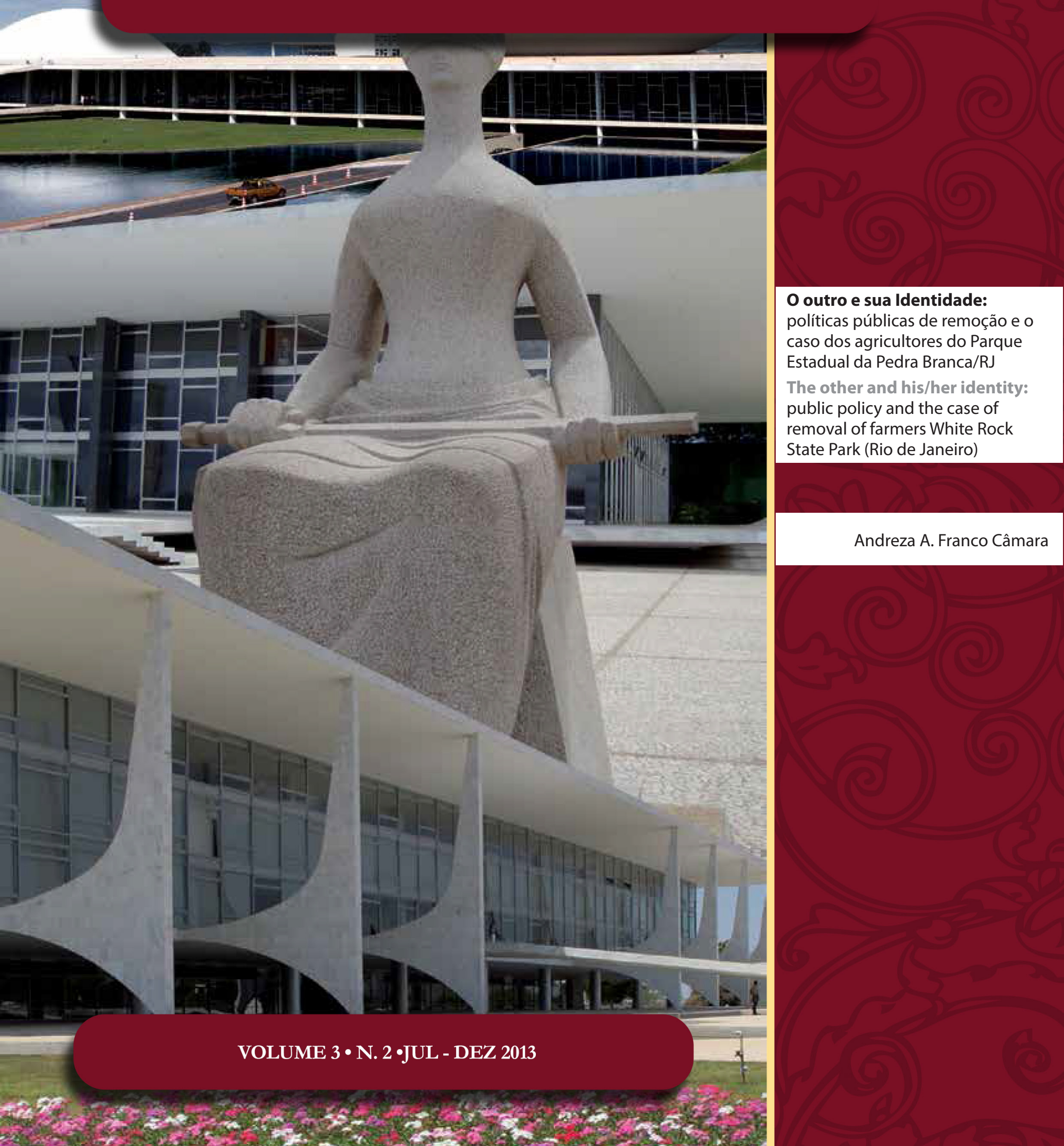




\title{
O outro e sua Identidade: políticas públicas de remoção e o caso dos agricultores do Parque Estadual da Pedra Branca/RJ
}

\author{
The other and his/her identity: public policy \\ and the case of removal of farmers White Rock \\ State Park (Rio de Janeiro)*
}

Andreza A. Franco Câmara**

\section{Resumo}

O presente artigo analisou as políticas públicas de remoção no Rio de Janeiro e a questão da identidade do grupo de agricultores que se encontra no entorno do Parque Estadual da Pedra Branca (PEPB), compreendendo o fenômeno da autoidentidade a partir da reorganização do tempo e do espaço nas sociedades de rede. Examinaram-se o caso dos agricultores instalados anteriormente à constituição do Parque Estadual da Pedra Branca, em Jacarepaguá, a formação do Conselho Consultivo do Parque, a atuação do Governo do Estado do Rio de Janeiro ao adotar uma política de remoção desses assentados e o conjunto de informações repassadas aos conselheiros e aos demais interessados, como aquelas encaminhadas à mídia e que apresentaram um cenário excludente e criminalizador dos pequenos produtores. Utilizaram-se como metodologia de estudo a revisão de literatura sobre o tema, a pesquisa de dados constantes nos arquivos do Conselho do Parque, a análise do relato de alguns conselheiros sobre o problema abordado e das informações colhidas na mídia sobre a participação dos agricultores nos crimes ambientais situados no Parque.

Palavras-chave: Identidade. Agricultores. Parque Estadual da Pedra Branca. Política de remoção. Conselho consultivo.

* Recebido em 18/03/2013 Aprovado em 03/04/2013

** Professora Assistente no Curso de Direito da Universidade Federal Rural do Rio de Janeiro (UFRRJ), Instituto Três Rios. Doutoranda pelo Programa de Pós-Graduação em Sociologia e Direito da Universidade Federal Fluminense. Mestre em Direito da Cidade pela Universidade do Estado do Rio de Janeiro. Pesquisadora. Email: andrezaafc@hotmail.com

\section{Abstract}

This article analyzes the public policies of removal in Rio de Janeiro and the question of the identity of the group of farmers who are in the vicinity of Pedra Branca State Park (PEPB), including the phenomenon of self-identity from the reorganization of time and space in networked societies. We examined the case of farmers previously installed the constitution of the State Park of Pedra Branca in the studied area, the formation of the Advisory Board of the Park and the role of the state government of Rio de Janeiro to adopt a policy of removal of these settlers, as well as all information that are transferred to counselors and other interested parties, as those were gathered media, presenting a scenario of excluding and criminalizing small farmers. For this purpose, we used as a method of study to review the 
literature on the topic, search the data contained in the archives of the Park Board, review of reports of some councilors on the issue discussed and information gathered in the media about the participation of farmers located in the environmental crimes in the Park.

Keywords: Identity. Farmers. State Park of Pedra Branca. Removal policy. Advisory Council.

\section{INTRODUÇÃO}

O interesse em estudar a formação dos processos identitários do grupo de agricultores que vive no Parque Estadual da Pedra Branca ocorreu devido à aprovação do Projeto de Extensão - PROEXT, apresentado à Universidade Federal Rural do Rio de Janeiro - UFRRJ, em 2011. O Projeto também foi aprovado junto ao Ministério da Educação e Cultura para a realização de atividades de ensino, pesquisa e extensão promovidas por um grupo multidisciplinar coordenado pela professora Annelise Fernandez, doutora em Sociologia, e que já realizava pesquisa com os referidos agricultores. Foram inseridos nesse grupo de estudo outros professores e alunos dos cursos de Administração, Biologia, Gestão Ambiental, Economia e Direito, da própria UFRRJ, e pesquisadores da Farmanguinhos. Logo, fui convidada pela coordenadora para realizar as atividades acadêmico-jurídicas do Projeto, as quais ocorrerão, de modo alternado, nas sedes das associações nas seguintes localidades da cidade do Rio de Janeiro: Rio da Prata, Pau da Fome e Vargem Grande, e nas instalações do Laboratório de Biodiversidade de Farmanguinhos na Colônia. Além disso, realizarei atividades de campo no maciço da Pedra Branca, nos municípios contatados, em feiras e em outros eventos.

O grupo de agricultores se organiza em três associações com aproximadamente 150 integrantes do maciço da Pedra Branca, na cidade do Rio de Janeiro, e conta também com visitantes dos municípios de Magé, Nova Iguaçu e Seropédica.

O Programa, que se encontra em desenvolvimento em 2012, intenciona ampliar e fortalecer as atividades agroindustriais de associações de agricultores familiares do maciço da Pedra Branca, com base em princípios participativos, agroecológicos e solidários. Os trabalhos até o momento realizados apresentam a estruturação de empreendimentos da economia solidária em face dos produtos derivados da agricultura familiar - entre eles, plantas medicinais e a fruticultura -, por meio de ações de assessoramento jurídico-contábil e técnico, da organização dos processos de produção e comercialização e da geração de novos produtos.

Com esse conjunto de ações, objetivou-se fortalecer o associativismo e estimular a formação de arranjos comunitários, a organização de redes de cooperação técnica e econômica e o acesso a mercados institucionais. Verificou-se a tendência das novas estruturas sociais que, gradativamente, na era da globalização, são alteradas pela reestruturação do capitalismo e das atividades econômicas e pelas sociedades de rede. As novas tecnologias, as políticas governamentais e os aspectos institucionais e culturais determinam os impactos na questão social e individual, na questão local e regional e, portanto, a partir da trajetória do grupo de agricultores, neste caso em análise.

Pretendeu-se, com o presente ensaio, discutir a questão da identidade do grupo analisado a partir do resgate dos mecanismos da autoidentidade com a reorganização do tempo e do espaço. Para alcançar esse objeto, estudaram-se: o caso dos agricultores instalados anteriormente à constituição do Parque Estadual da Pedra Branca, em Jacarepaguá; a formação do Conselho Consultivo do Parque; a atuação do Governo do Estado do Rio de Janeiro ao adotar uma política de remoção desses assentados; e o conjunto de informações repassadas aos conselheiros e aos interessados, como aquelas encaminhadas à mídia.

Para tanto, os métodos de pesquisa empregados para o presente estudo foram: a revisão de literatura sobre o tema; a pesquisa dos dados constantes nos arquivos do Conselho do Parque; o relato de alguns conselheiros sobre o problema abordado; e a pesquisa e a leitura do material colhido na mídia sobre a participação dos agricultores na formação do Parque, do Conselho e nas ações para resgate de sua identidade. 


\section{A política de Criação de parques no brasil: o caso do parque estadual Pedra Branca}

O parque constitui um refúgio onde se preserva a natureza do desenvolvimento econômico e do crescimento desenfreado. Quando implantado nos Estados Unidos, o modelo de parques sem a presença de pessoas, salvo para rápidas visitas, com o propósito de preservar a vida selvagem, sofreu severas críticas tanto dos próprios preservacionistas puros, quanto dos adeptos ao ecossocialismo e aos movimentos da ecologia social. Segundo Rodman, ${ }^{1}$ a criação dos parques obedece a uma "visão antropocêntrica", pois beneficia os habitantes das cidades ao recriar um valor estético, religioso e cultural do homem e ao destacar que a "[...] natureza selvagem não foi considerada um valor em si”, digno de ser protegido, mas que necessita da intervenção humana para preservar as espécies. Desse modo, atribui-se aos "escolhidos" o poder de selecionar em ilhas os grupos protegidos.

O modelo conservacionista americano foi levado a outros países, inclusive ao Brasil, reafirmando a dicotomia "povos" e "parques". Assim, em decorrência da implantação dessa ideologia, percebe-se que as populações tradicionais de extrativistas, pescadores e índios foram severamente prejudicadas.

No Brasil, os primeiros parques foram criados na década de 1930, especificamente no Rio de Janeiro, e, depois, estendidos às demais regiões do País ${ }^{2}$ embora o ritmo de criação desses espaços tenha diminuído após a década de 1990. No caso da Amazônia, com o propósito de conservar a natureza e de reproduzir o modo de vida das populações locais, esse modelo passou a ser preterido em relação a outras unidades de conservação que admitem a presença do homem. Todavia, ainda no Estado do Rio de Janeiro, o sistema de parques continuou a ser criado pelas agências ambientais e defendido como modelo ideal de conservação. Nas palavras de Gomez-Pompa e Kaus?

Conservacionistas tradicionais veem o valor estético, biológico e ecológico, mas não necessariamente veem as populações humanas. Muitas vezes eles não conseguem ver os efeitos das ações humanas do passado ou do presente, nem diferenciar os diversos tipos de uso, ou reconhecer o valor econômico de um uso sustentado.

Em 1986, foi criado o Instituto Estadual de Florestas - IEF/RJ, que reproduziu as políticas ambientais conservacionistas importadas do modelo norte-americano - seja por intermédio da criação de parques, seja por meio de medidas fiscalizadoras -, sem considerar a escassez de recursos disponíveis para implantar a política adotada nas áreas em questão.

É importante destacar que a coletividade se relaciona com a natureza. "A sociedade é produto do mundo natural por um trabalho de invenção constante", ${ }^{4}$ no entanto, as ideias propagadas pelo conservacionismo induzem ao pensamento de que os parques são criados em espaços vazios, desabitados e sem quaisquer relações sociais travadas por aqueles que ali já se encontravam. O que não é possível é conceber a criação de um parque como um local de natureza intocada, visto que, em sua grande maioria, trata-se de territórios habitados por grupos sociais. Assim, "[...] a ênfase dada pelos ecologistas à localidade e ao controle praticado pelas pessoas sobre seus próprios espaços de existência constitui um desafio aos mecanismos básicos do novo sistema de poder". 5

1 RODMAN apud DIEGUES, Antônio Carlos. O mito moderno da natureza intocada. 4. ed. São Paulo: Annablume; Hucitec, 2002. p. 33.

2 CASTELLS, Manuel. O poder da identidade: a era da informação: economia, sociedade e cultura. Trad. Klauss Brandini Gerhardt. 3. ed. São Paulo: Paz e Terra, 1996. v. 2. p. 157. Segundo Castells, as bases político-econômicas da localidade permitem a constituição de uma consciência pública. Desse modo, o controle sobre o tempo está em jogo na sociedade de rede e o movimento ambientalista é um dos principais protagonistas no cenário de mudanças.

3 GOMEZ-POMPA; KAUS apud DIEGUES, Antônio Carlos. O mito moderno da natureza intocada. 4. ed. São Paulo: Annablume; Hucitec, 2002. p. 35.

4 DIEGUES, Antônio Carlos. Antônio Carlos. O mito moderno da naturęa intocada. 4. ed. São Paulo: Annablume; Hucitec, 2002. p. 49.

5 CASTELLS, Manuel. O poder da identidade: a era da informação: economia, sociedade e cultura. Trad.: Klauss Brandini Gerhardt. 3. ed. São Paulo: Paz e Terra, 1996. v. 2. p. 156. 
Com o propósito de salvar e tornar intocável a natureza, determinadas etapas no processo foram mitigadas, tais como a ausência de critérios e de planejamento de gestão para as unidades de conservação criadas, o fato de essas áreas já serem ocupadas anteriormente ou o de que esses territórios eram conservados mesmo com a presença de populações humanas, em regra, tratadas como invasoras, ilegais e destruidoras da natureza. Apesar disso, com a modificação do capitalismo e com a queda o estatismo no final do século XX, apresentou-se a construção de identidades coletivas as quais “[...] desafiam a globalização e o comospolitismo em função da singularidade cultural e do controle das pessoas sobre suas próprias vidas e ambientes". ${ }^{6}$

A legislação ambiental brasileira prevê regras a respeito do processo de criação e gestão de unidades de conservação, mas se cala na questão das populações que já residiam em unidades de conservação de proteção integral. Isso leva a refletir que a obrigatoriedade de mecanismos participativos na criação e na gestão das unidades de conservação prevê medidas de solução dos conflitos entre gestores, administradores e moradores nos parques. Leva ainda a pensar quais são os instrumentos que garantem o direito de permanência dessa população residente em unidades de conservação ou que minimizem sua mobilidade para preservar as identidades a partir do território. Nessa construção das bases territoriais, a fronteira simbólica amplia os limites espaciais, cujas identidades estão formadas com base em relações histórico-culturais?.

O Parque Estadual da Pedra Branca (PEPB) foi criado por meio da Lei Estadual n . 2.377, de junho de 1974. Em seu art. $3^{\circ}$, a Lei declara que a área atingida, para fins de desapropriação, é de utilidade pública, prevendo a caducidade do dispositivo em 1979. Assim, o parque é concebido como um artefato cultural, ${ }^{8}$ ferramenta utilizada para construir identidades por meio de sentidos que pairam em torno dos pensamentos e dos relacionamentos idealizados pelas pessoas que o consideram como uma área intocável e separada do ambiente vivido. Surge a hipótese de que os parques constituem simbolicamente espaços idealizados e impenetráveis, onde o homem e a natureza não podem conviver. Nesse contexto, o PEPB é considerado a maior reserva florestal em área urbana no mundo e, com aproximadamente $10 \%$ da área total do município do Rio de Janeiro, possui cerca de 12.500 hectares de área coberta por vegetação típica da Mata Atlântica. ${ }^{9}$

O Parque da Pedra Branca e seu entorno dispõem de construções de interesse cultural, como um antigo aqueduto, algumas represas e as ruínas de sedes de antigas fazendas, além do pórtico e da subsede do Pau da Fome, em Jacarepaguá. Nas proximidades do Parque, encontra-se ainda o Museu Nise da Silveira, na Colônia Juliano Moreira. Devido à sua posição geográfica e a características ambientais, a existência do PEPB é estratégica para a conservação ambiental do Estado do Rio de Janeiro, segundo dados da administração do parque.

A administração da área aponta como principais problemas decorrentes de ocupações indevidas, antigas e atuais, os conflitos associados com o tráfico de drogas e com as ações de grupos de milicianos. Desse modo, indica que o PEPB é aquele que concentra os maiores e mais numerosos conflitos territoriais e que, portanto, requer ações emergenciais de médio e de longo prazos para sua adequada gestão e consolidação.

A institucionalização do parque ocorreu por meio de interferências durante os tempos e, construindo a realidade e dividindo as áreas entre a natureza selvagem e a ocupação humana, ${ }^{10}$ representou o controle perpetuado do Instituto Estadual de Florestas - IEF, o qual, em janeiro de 2009, passou a integrar a estrutura do Instituto Estadual do Ambiente - INEA/RJ. Nesse sentido, o tempo é visto como uma instituição social, "[...] antes de ser um fenômeno físico e uma experiência psíquica", empregado para consolidar valores de um determinado grupo dominante na gestão. ${ }^{11}$

6 CASTELLS, Manuel. O poder da identidade: a era da informação: economia, sociedade e cultura. Trad.: Klauss Brandini Gerhardt. 3. ed. São Paulo: Paz e Terra, 1996. v. 2. p. 18.

7 HAESBAERT, Rogério. Desterritorialização e identidade: a rede "gaúcha" no Nordeste. Niterói: EdUFF, 1997.

8 GEERTZ, Clifford. A interpretação das culturas. Rio de Janeiro: Zahar, 1978.

O conceito de artefato cultural foi inicialmente empregado por Geertz no ano de 1978.

9 RIO DE JANEIRO. Parque Estadual da Pedra Branca. Disponível em:

<http://www.parquepedrabranca.com/menu/03/01.htm.>. Acesso em: 27 jul. 2011.

10 BOURDIEU, Pierre. O poder simbólico. Trad. Fernando Tomaz. 14. ed. Rio de Janeiro: Bertrand Brasil, 2010.

11 OST, François. O tempo do direito. São Paulo: EDUSC, 2005. p. 12. 
A administração do IEF e a do próprio PEPB não analisam o território em que se situa a Unidade de Conservação - UC, sob o foco dos usos e dos costumes das populações ali estabelecidas, tampouco analisam as barreiras físicas e as representações ideológicas configuradas ao longo do tempo. Em síntese, constitui-se um jogo de poder orquestrado para nomear oficialmente a área como uma unidade de conservação integral, marginalizando a população que se situa no entorno da área e considerando-a invasora.

\section{A identidade do agricultor no entorno do PEPB}

O tema identidade tem sido rediscutido nas Ciências Sociais a partir das novas dimensões da modernidade. De acordo com Anthony Giddens, ${ }^{12}$ são quatro concepções institucionais da modernidade que influenciam o redimensionamento da sociedade e do próprio conceito de identidade, o que passou a sobrepor a identificação nacional a outras formas culturais particularizadas a partir de um processo híbrido, fluido ${ }^{13} \mathrm{e}$ individual. São elas: o capitalismo, o industrialismo, a vigilância e o poder militar.

A modernidade constituiu uma opção à ordem e ao caos, ou, segundo Bauman, uma luta contra a ambivalência. ${ }^{14}$ Com a modernidade, o sujeito passou a uma busca pelo conhecimento e pelas formas de ordenar o mundo e, assim, o projeto moderno ressignificou aquilo que era natural, visto como desordem, para uma modalidade científica de controle. O homem e a sociedade modernos precisam de controle para alcançar uma vida melhor e, em consequência dessa ideia de racionalidade, surge o Estado Moderno que busca ordenar e classificar seu território, deixando-o de acordo com seu projeto, e categorizar a sociedade, os grupos e as pessoas. Segundo Bauman, esse projeto “[...] fornecia os critérios para avaliar a realidade do dia presente. Esses critérios dividiam a população em plantas úteis a serem estimuladas e cuidadosamente cultivadas e ervas daninhas a serem removidas ou arrancadas". ${ }^{15}$

O projeto de sociedade moderna, de Estado Moderno e da Ciência Moderna resultou na globalização do Ocidente. Nesse sentido, Hall ${ }^{16}$ considera que, com a globalização, a compreensão do tempo e do espaço ${ }^{17}$ passou por um novo sistema de representação influenciador das identidades culturais.

Stuart Hall ${ }^{18}$ considera que, no fim do século XX, diversas alterações estruturais oriundas da sociedade moderna mudaram a ideia sobre o indivíduo e sobre sua identificação. Desse modo, "[...] as velhas identidades, que por tanto tempo estabilizaram o mundo social, estão em declínio, fazendo surgir novas identidades e fragmentando o indivíduo moderno, até aqui visto como sujeito unificado”. Logo, Hall ${ }^{19}$ argumenta que a maior dependência das vantagens da globalização leva ao colapso das identidades tradicionais:

O sujeito, previamente vivido como tendo uma identidade unificada e estável, está se tornando fragmentado; composto não de uma única, mas de várias identidades, algumas vezes contraditórias e não resolvidas. Correspondentemente, as identidades, que compunham as paisagens sociais 'lá fora' e que asseguravam nossa conformidade subjetiva com as 'necessidades' objetivas da cultura, estão entrando em colapso, como resultado de mudanças estruturais e institucionais. O próprio processo de identificação, através do qual nos projetamos em nossas identidades culturais, tornou-se mais provisório, variável e problemático.

12 GIDDENS, Anthony. As consequências da modernidade. 2. ed. São Paulo: UNESP, 1991.

13 BAUMAN, Zygmunt. Modernidade líquida. Rio de Janeiro: Zahar, 2001.

14 BAUMAN, Zygmunt. Modernidade e ambivalência. Rio de Janeiro: Jorge Zahar, 1999.

15 BAUMAN, Zygmunt. Modernidade e ambivalência. Rio de Janeiro: Jorge Zahar, 1999, p. 29.

16 HALL, Stuart. A identidade cultural da pós-modernidade. 10. ed. Rio de Janeiro: DP\&A, 2005. p. 67.

17 GIDDENS, Anthony. As consequências da modernidade. 2. ed. São Paulo: UNESP, 1999. p. 27. A modernidade trouxe grandes modificações ao mundo. Dentre elas, Giddens destaca a radicalização das noções de espaço e tempo. Com o advento dessa nova era, “[...] crescentemente o espaço do tempo fomentando relações entre outros 'ausentes', localmente distantes de qualquer situação dada ou interação face a face. [...]. O que estrutura o lugar não é simplesmente o que está presente na cena; a 'forma visível' do local oculta relações distantes que determinam sua natureza". Além disso, há a "reflexividade" e a criação dos "sistemas peritos".

18 HALL, Stuart. A identidade cultural da pós-modernidade. 10. ed. Rio de Janeiro: DP\&A, 2005. p. 7.

19 HALL, Stuart $A$ identidade cultural da pós-modernidade. 10. ed. Rio de Janeiro: DP\&A, 2005.p. 12. 
A questão da decadência da autoidentidade, para Giddens, ${ }^{20}$ é um problema moderno decorrente do individualismo ocidental e da busca pela solução dos problemas a partir da racionalidade científica. Esse autor observa que a identidade, tal como a individualidade, foram pontos presentes, mesmo nas culturas tradicionais ou pré-modernas, e conclui que a modernidade, principalmente a modernidade tardia, termo cunhado por Giddens, muda o modo de os sujeitos pensarem, viverem e construírem suas identidades.

Após a definição dos primeiros contornos sobre a modernidade e sobre sua influência acerca da identidade, busca-se, neste trabalho, em um segundo momento, examinar como a noção de autoidentidade se transformou a partir da dinâmica de ocupação e da trajetória das famílias mais antigas estabelecidas no maciço da Pedra Branca. Aborda-se, assim, uma situação específica: a do morador de uma área de proteção integral, sujeito a políticas ambientais e integrado ao meio urbano tanto fisicamente quanto em suas relações com o mercado. ${ }^{21}$

A Zona Oeste do Rio de Janeiro tem um histórico de atividades rurais importante. No passado, a região conhecida como Sertão Carioca, constituía-se como polo de abastecimento agrícola da capital. Na atualidade, apesar da existência de representações dominantes sobre suas feições urbanas e industriais, a atividade agrícola persiste e detém relevância econômica e social para a manutenção de famílias de agricultores classificados como tradicionais, já que lutam para manter suas territorialidades específicas. As familias, além de dependerem da renda das atividades agrícolas, estão na região há mais de um século e, mesmo assim, sofrem com a expansão urbana, com as transformações nas relações de produção e de mercado e, sobretudo, com as restrições de órgãos ambientais orientados por uma perspectiva de incompatibilidade entre a presença humana e a conservação da natureza. Muitas dessas famílias, com a venda de suas propriedades, que hoje viraram grandes condomínios residenciais, aumentaram fortemente o impacto ambiental na região, e, ademais, em razão da baixa rentabilidade, seus descendentes não estão suficientemente motivados a dar continuidade à prática exercida há anos por suas famílias.

Entretanto, a agricultura da Zona Oeste também possui grande relevância ambiental, uma vez que sua persistência tem ajudado a manter os limites do Parque Estadual da Pedra Branca. As atividades cotidianas de manutenção da propriedade, de organização da produção e de inserção no mercado e as formas de mobilização política são mecanismos de resistência e de luta pelo direito a permanecer no PEPB e, embora exista o predomínio crescente de usos urbanos no local, continua a ocupação de caráter rural-agrícola que, apesar de inúmeras dificuldades para a reprodução social de seus meios de vida, é, enfim, apoiada sobre a história do grupo, sobre a memória e sobre a manutenção de suas atividades cotidianas. Dessa forma, constrói-se uma identidade vinculada à pequena produção e, apesar de sua base histórica, não se pode negar que ocorre um processo de construção de uma nova identidade social, a partir do aumento de atividades outras não classificadas como tipicamente rurais, o que possibilita novas trajetórias individuais em aparente contradição aos projetos familiares. ${ }^{22}$

Por outro ponto de vista e em sentido contrário, percebe-se a existência da inserção da agricultura no contexto econômico da cidade do Rio de Janeiro, com a propagação de valores ambientais que podem ser implementados quando das práticas agrícolas consolidadas, as quais contribuem para a ressignificação dessa atividade no maciço.

Fica evidenciado um grande desinteresse do poder público em fomentar atividades agrícolas e o predomínio de um imaginário social de afirmação do urbano e de inexistência da agricultura na cidade do Rio

20 GIDDENS, Anthony. As consequências da modernidade. 2. ed. São Paulo: UNESP, 1999.p. 74.

21 HONNETH, Axel. Luta por reconhecimento: a gramática moral dos conflitos sociais. São Paulo: Ed. 34, 2003.

A teoria do reconhecimento elaborada por Axel Honneth se encaixa no caso em exame, porque propõe ser um modelo avaliativo dos conflitos sociais por meio de um conceito moral de luta social, bem como propõe ser um paradigma explicativo sobre o processo de evolução social de um grupo.

22 OLIVEIRA, Luís Roberto Cardoso de. Existe violência sem agressão moral? Revista Brasileira de Ciências Sociais, v. 23, n. 67, p. 136. Cardoso de Oliveira considera que os "[...] direitos acionados em interações que não podem chegar a bom termo por meio de procedimentos estritamente formais e que requerem esforços de elaboração simbólica por parte de seus interlocutores” geram uma integração entre eles e possibilitam a efetivação desses direitos. 
de Janeiro, embora os estudos revelem a possibilidade de construção de uma identidade afirmativa dos pequenos produtores do PEPB, devido à sua importância para a manutenção das fronteiras do Parque e, por consequência, da obtenção da conservação da natureza.

Os dois aspectos relatados acima evidenciam a dimensão política que envolve a inserção dos pequenos produtores na sociedade mais ampla. Encontra-se, na doutrina de Foster, ${ }^{23}$ o ensinamento de que os camponeses têm muito pouco controle sobre as condições que governam suas vidas pobres e despossuídas de poder. Em virtude disso, é necessário considerar a função estatal nos âmbitos municipal, estadual e federal, pois o Estado atua como agente que direciona, interfere ou consolida processos socioeconômicos desenvolvidos junto aos pequenos produtores. Destaca-se, na área urbana da municipalidade, o empenho em fomentar a atuação do capital no mercado imobiliário, pois são acentuados os processos de estratificação da área urbana, ${ }^{24}$ por meio de planos de renovação e de infraestrutura urbana e, indiretamente, com a proliferação de leis e tributos que fazem da cidade um território inviável para populações de pequenos produtores dedicados às atividades rurais.

Ao estudar o processo de urbanização do bairro de Vargem Grande, destaca-se o fato de que o principal atrativo para sua ocupação foi o aspecto de zona rural evidenciado pela presença de atividades econômicas como: haras, hortos, passeios, polo gastronômico e ecoturístico. Além disso, quase todos se apropriaram da natureza como valor agregado ao produto ou ao serviço oferecido. $\mathrm{Na}$ verdade, a criação do PEPB resulta do estabelecimento dessa fronteira entre o rural e o urbano, segundo o ponto de vista do Estado, e gera, com isso, efeitos contraditórios, seja sobre a dinâmica de ocupação, seja sobre a produção agrícola existente. Paralelamente, essa UC contribuiu para a consolidação de valores ambientais que passaram a ressignificar os usos rurais ali estabelecidos, conforme acentua Oliveira. ${ }^{25}$

O estado possui o IEF como órgão responsável pela administração do PEPB, para a concessão ou não de reivindicações de seus moradores, bem como para a realização de projetos dos pequenos produtores do Parque por meio da intermediação com outros órgãos públicos e com agências, como é o caso da Empresa de Assistência Técnica e Extensão Rural - EMATER, da Secretaria de Desenvolvimento Rural e de outras entidades, como o Sindicato Rural e algumas ONGs.

Os pequenos produtores do PEPB são incentivados ao associativismo e ao cultivo agroecológico por mediadores institucionais e do terceiro setor e podem participar do conselho consultivo do Parque. Essa representação se dá graças ao histórico de constituição das três associações, as quais, inicialmente, limitavam-se à Associação de Lavradores e Criadores de Jacarepaguá, a primeira delas. A ALCRI, como é chamada, criada em 1986, encontrava-se desativada e, por intermédio do incentivo de dois engenheiros-agrônomos da EMATER, reiniciou suas atividades em 1998.

Já a Agroprata, a segunda associação, foi fundada em 2003, ao fim do projeto de agricultura orgânica desenvolvido pela ONG Roda Viva. Essa entidade procurou reverter uma agricultura extrativista rudimentar e extensiva, com baixos índices de produtividade, como até então era praticada, pelo sistema de agrofloresta, cultivada em áreas menores, com agregação de valor ao produto orgânico e com beneficiamento de parte dele, como é o caso da banana-passa.

Apesar de mobilizar um número pequeno de agricultores da localidade do Rio da Prata, seus membros se tornaram importantes porta-vozes dos agricultores, além de o aprendizado técnico-científico e institucional e a vivência de experiências tenham possibilitado a construção da identidade do agricultor orgânico em oposição aos demais agricultores convencionais.

A terceira associação, a Agrovargem, foi criada no contexto de mobilização promovido pela equipe do Laboratório de Biodiversidade de Farmanguinhos, que, instalado no entorno do maciço da Pedra

23 FOSTER, George. What is a peasant? In: POTTER, J.; DIAZ, M. Peasant society. Boston: Little Brown and Company, 1967.

24 ABREU, Maurício. Evolução urbana do Rio de Janeiro. 4. ed. Rio de Janeiro: IPP, 2006. p. 147.

25 OLIVEIRA, Clara Machline. O comércio da natureza: a construção do espaço no bairro de Vargem Grande, cidade do Rio de Janeiro. Revista de Graduação de Geografia da PUC. Rio [de janeiro], ano 1, n.1, v.1, jan./jul. 2008. 
Branca, desde 2006, tem buscado conhecer a realidade socioeconômica e cultural dos pequenos produtores do maciço da Pedra Branca, promover a capacitação a respeito das formas de cultivo de plantas medicinais, disponibilizar informação técnica e certificação institucional de seus produtos e buscar, conjuntamente, ações que possibilitem a criação de uma rede de desenvolvimento local, visando à implantação efetiva da Política Nacional de Plantas Medicinais e Medicamentos Fitoterápicos, criada no País também desde 2006.

\section{A formação do CONSELHo CONSULtivo}

O Conselho Consultivo do Parque Estadual da Pedra Branca, criado em 5 de julho de 2005, é composto pelas seguintes entidades: Fundação Instituto Estadual de Florestas (IEF), atualmente vinculada ao INEA; Conselho Estadual de Águas e Esgotos (CEDAE); Fundação Oswaldo Cruz; Secretaria de Defesa Civil/Comando Geral do Corpo de Bombeiros; Fundação Estadual de Engenharia do Meio Ambiente (FEEMA); Secretaria de Estado de Agricultura; Prefeitura Municipal do Rio de Janeiro; Empresa de Turismo do Rio de Janeiro - TURISRIO; Associação de Moradores de Vargem Grande; Grupo de Defesa Ecológica (GRUDE); Amigos da Zona Oeste; SOS Pedra Branca; Associação de Moradores do Monte da Paz; Serviço de Apoio a Micro e Pequenas Indústrias (SEBRAE); Associação de Amigos e Moradores do Rio da Prata; e Federação de Esportes e Montanha do Rio de Janeiro (FEMERJ).

O critério de seleção das entidades decorre, além da proximidade dessas organizações com a administradora da UC nesse período, do histórico de participação e de desenvolvimento de projetos ambientais no Parque. Exercendo o papel de representante simbólica dos demais moradores do PEPB, encontra-se a associação de moradores da Comunidade Monte da Paz, de valiosa importância pela proximidade física à estrutura administrativa. As demais associações são escolhidas conforme a avaliação da gestora acerca do envolvimento com as questões do PEPB.

É importante revelar que os Conselhos Consultivos são avaliados pelos gestores como fóruns destinados à solução de difíceis conflitos e à comunicação. Isso implica, ao longo das atividades cotidianas de administração de uma UC e de sua efetividade, que o gestor está aberto a escutar, negociar e acatar posições divergentes nas práticas gestoras e que a própria instituição desenvolve uma cultura organizacional aberta a esse novo tipo de prática, em oposição ao modelo tradicionalmente formado em uma instituição tecnocrática e verticalizada que, até então, esperava dele um perfil fiscalizador.

$\mathrm{Na}$ prática, não se promove o processo de empoderamento das populações com as quais atuam as organizações, que, ao assegurarem os benefícios financeiros, políticos e simbólicos, evitam os custos da participação. Segundo Mosse, ${ }^{26}$ os conselhos existem para se adequarem à exigência legal de adoção de formas participativas de gestão, obtêm recursos econômicos do governo e de agências promotoras de desenvolvimento social, acumulam capital social, e mais nada ocorre.

Silvana Montes Lima, diretora da DCN no período 2006, atribuiu a demora na instalação dos conselhos à inexistência de diretrizes e de procedimentos para a criação dos conselhos (normatização, escolha dos conselheiros e capacitação). Tais problemas foram sanados a partir da criação de uma portaria, embora, até o final da gestão de Maurício Lobo, na presidência do IEF - RJ, em dezembro de 2006, o Conselho não tivesse sido convocado.

26 MOSSE apud FERNANDEZ, Annelise Caetano Fraga. Um parque no sertão carioca dos anos 70 aos dias de hoje. O que mudou na política de conservação? In: REUNIÃO BRASILEIRA DE ANTROPOLOGIA, 26., 2008. p. 4 Disponível em:<< http:// www.abant.org.br/noticias.php?type $=$ congressoRBA\#453. >. Acesso em: 20 de set. 2011. 
Maurício Lobo afirmou que conselhos com 20 a 30 membros são verdadeiros elefantes brancos ${ }^{27}$ e, por esse motivo, o número de participantes foi estipulado em dezesseis entidades, compostas de oito representantes da sociedade civil e oito representantes do poder público.

A partir de entrevistas com a gestora do PEPB, constata-se que o Conselho, composto por dezoito membros, chegou a se reunir duas vezes antes da mudança da presidência do IEF, não havendo tempo para realizar a capacitação dos gestores, como informa Cohen. Ao realizar um balanço sobre a importância dos conselhos para a gestão passada do IEF e ao compará-la com a gestão seguinte, Cohen sugere que, enquanto a primeira possuía uma visão mais técnica e, de certa forma, receosa acerca da abertura da gestão das unidades de conservação, já que a entendia como demagógica, a nova diretoria é marcada por uma trajetória de práticas ambientais democráticas e por uma forte inserção partidária. Em suma, a mobilização desses atores se limitou à troca de e-mails e a esses dois encontros de caráter informal.

\subsection{A formação do novo conselho consultivo do PEPB}

Em 2007, o novo grupo que assume o IEF indaga sobre o processo de construção dos conselhos já elaborados e inicia um processo de diagnóstico e reestruturação deles. Foi realizada uma oficina, com 32 participantes, na sede do Parque, no dia 25 de maio de 2008, cujo facilitador - Roberto Rezende - aplicou a técnica de diagnóstico rápido participativo. Em fala inicial, o administrador e a diretora da DCN destacaram a vontade da gestão atual do IEF de combater os parques-fortaleza, entendidos como aqueles inspirados no modelo americano, em que nada pode ser feito que não se relacione com a realidade brasileira.

Na referida oficina, Roberto Rezende, arquiteto por formação e especialista em planejamento de áreas protegidas, relatou que, na verdade, especializou-se em atividades de diagnóstico e de desenvolvimento de metodologias participativas na área ambiental. Tal formação é adequada à fiel percepção dos atores, dos conflitos, das disputas e de outras questões relevantes para a implantação do PEPB.

Seguiu-se à oficina a realização de mais sete etapas para a realização dessa primeira fase, identificada como formação e reorganização dos conselhos. Em um momento posterior, deve ocorrer tanto a capacitação dos membros do Conselho no apoio operacional, baseado em seu plano de ação, quanto o monitoramento da atuação dos conselhos, a fim de aperfeiçoar e dar continuidade ao processo de gestão participativa da UC.

Vale ressaltar que o Conselho Consultivo do Parque Estadual da Pedra Branca foi criado pela Portaria IEF/RJ/PR no 269, de 17 de dezembro de 2008, para a orientação e o planejamento das atividades do PEPB, atendendo ao que dispõe o Decreto ${ }^{\circ} 4.340$, de 22 de agosto de 2002, que regulamenta a Lei ${ }^{\circ} 9.985$, de 18 de julho de 2000, e o Decreto Estadual no 29.213, de 14 de agosto de 2001. No caso dos pequenos agricultores do PEPB, o enfrentamento com o IEF se caracterizou por poucas situações de conflitos declarados e tem sido marcado pela negociação e pela resistência por parte dos agricultores, tanto por meio de ações individuais, quanto por meio de ações coletivas, como as formas cotidianas de resistência. Nesse sentido, é possível pensar que o antagonismo frente ao IEF apenas indiretamente contribuiu para a mobilização dos pequenos produtores na história de constituição das duas associações de agricultores do PEPB (ALCRI e AAOPB) e para a mobilização objetivando a constituição de um novo Conselho.

O atual Conselho, constituído de forma participativa, ficou com a composição final de $28 \%$ de organizações governamentais e $72 \%$ de organizações civis. O Conselho organizado pela gestão passada havia estipulado previamente que sua composição deveria ser de $50 \%$ de instituições públicas e $50 \%$ de organizações da sociedade civil. Atualmente, o número de conselheiros é de 36 membros, o que reflete, segundo a diretora atual da DCN, os múltiplos atores envolvidos com o Parque em uma realidade urbana. É impor-

27 COHEN, Marcos. Avaliação do uso de estratégias colaborativas na gestão de unidades de conservação do tipo parque na cidade do Rio de Janeiro. 341 f. 2004. Tese (Doutorado em Administração) - Pontifícia Universidade Católica PUC: Rio de Janeiro, 2004. p. 227. 
tante salientar que somente o Parque da Tiririca em Niterói e o da Pedra Branca, no Rio de Janeiro, ambos urbanos, são as unidades de conservação que possuem os conselhos mais amplos.

Fuks, ${ }^{28}$ ao observar os efeitos causados pela provável desigualdade de recursos entre os participantes dos conselhos, aponta que a efetividade de atuação desses grupos deve ser buscada na história de sua configuração e nas lutas relativas às áreas específicas de políticas públicas. Ele afirma que os membros do Conselho pertencentes ao setor público são os maiores recursos organizacionais de acesso a pareceres técnicos, às redes de comunicação e a outros, para exercer suas atividades de representação, além do fato de que as reuniões ocorrem em sua própria jornada de trabalho. O autor observa ainda que, sobretudo os grupos socialmente mais desfavorecidos, como os pequenos produtores, possuem enorme dificuldade para se ausentar de suas atividades cotidianas e moram em locais de difícil acesso, com grande deficiência de comunicação. Em decorrência disso, existe uma tendência por parte dos membros do Conselho a tratar os moradores do PEPB não como atores envolvidos em conflitos ambientais, mas como problemas ambientais sobre os quais falam os outros participantes, mesmo quando estão presentes no Conselho.

\subsection{A mídia e a criminalização dos agricultores do entorno do PEPB}

Conforme observa Castells, ${ }^{29}$ o sucesso do movimento ambientalista se deve à capacidade de adaptação ao modelo de comunicação diante dos novos arranjos tecnológicos. A esse contexto, a mídia é um dos seus principais aliados, uma vez que divulga valores humanistas e coletivos distantes da política de determinados grupos.

[...] a legitimidade das questões levantadas pelos ambientalistas, diretamente relacionadas a valores humanistas apreciados pela maioria das pessoas, e muitas vezes distantes da política partidária, abriu caminho para que a mídia assumisse o papel de voz do povo, contribuindo para que sua própria legitimidade se firmasse e fazendo com que os jornalistas se sentissem bem ao divulgar o assunto.

Contrariando a tendência apontada por Castells $^{30}$ ao analisar o movimento ambientalista nos Estados Unidos, no caso em análise, os agricultores do entorno do Parque Estadual da Pedra Branca são vistos, pela mídia e pela sociedade em geral, como criminosos que degradam o Parque. Isso se pode verificar tanto na reportagem divulgada em 27 de maio de 2011 no RJTV, ${ }^{31}$ quanto na medida equacionada pela Coordenação Integrada de Combate aos Crimes Ambientais do Estado, por meio da instalação de cerca protetora, com mais de 25 quilômetros, disposta no entorno do parque para afastar a população do contato com a área.

No Dia da Mata Atlântica, imagens feitas pelo Globocop nesta sexta-feira (27) mostram áreas do Parque Estadual da Pedra Branca, na Zona Oeste do Rio, que foram transformadas em plantações de banana. Em fevereiro, a Secretaria Estadual do Ambiente apreendeu criações de gado ilegais na região.

Com uma área equivalente a 12,5 mil campos de futebol, o Parque Estadual da Pedra Branca é a maior floresta urbana do Brasil. A reserva é contornada por 27 bairros da Zona Oeste. A área é quase três vezes o tamanho da Floresta da Tijuca, também no Rio de Janeiro.

Em 1974, o Parque Estadual da Pedra Branca foi transformado pelo governo federal em uma unidade de conservação de proteção integral e, a partir daí, as atividades de pecuária e agricultura passaram a ser proibidas em toda essa área.

De acordo com a Secretaria Estadual do Ambiente, nos últimos dois anos, as áreas de Mata Atlântica protegidas no Estado dobraram com a criação de novas unidades de conservação.

José Maurício Padrone, membro da Coordenadoria de Combate aos Crimes Ambientais, afirma que existem projetos de compensação para a população que vive de culturas como a banana e a mandioca, como

28 FUKS, Mário. Conflitos ambientais no Rio de Janeiro: ação e debate nas arenas públicas. Rio de Janeiro: UFRJ, 2004. p. 28.

29 CASTELLS, Manuel. O poder da identidade: a era da informação: economia, sociedade e cultura. Trad.: Klauss Brandini Gerhardt. 3. ed. São Paulo: Paz e Terra, 1996. v. 2. p. 161-162.

30 CASTELLS, Manuel. O poder da identidade: a era da informação: economia, sociedade e cultura. Trad.: Klauss Brandini Gerhardt. 3. ed. São Paulo: Paz e Terra, 1996. v. 2. p. 161-162.

31 RJTV. Disponível em: <http://g1.globo.com/rio-de-janeiro/noticia/2011/05/imagens-mostram-plantacao-ilegal-de-bananas-em-parque-ambiental-no-rio.html>. Acesso em: 20 ago. 2011. 
é o caso do plantio de mudas nativas de Mata Atlântica. Também há o pagamento de indenizações para a realização de novas atividades: "Existe um projeto, o projeto vai terminar no final do ano e a secretaria vai indenizar essas pessoas que estão lá, e vai acabar com a banana, com essa plantação de banana e plantar mudas de Mata Atlântica nativa daquela região, constituindo uma verdadeira 'intromissão de acontecimentos distantes na consciência quotidiana". ${ }^{32}$ Além disso, os próprios agentes governamentais divulgam versões distorcidas e autoritárias sobre o plano de manejo e sobre o processo decisório que vem a partir dele, o que, segundo a Lei, deve ser feito de forma democrática e socialmente justa.

No mesmo período, foi divulgada uma matéria sobre a apreensão de uma tropa de cavalos que pastava solta no interior do Parque Estadual da Pedra Branca. Os animais comiam e pisoteavam as mudas usadas no reflorestamento da vertente norte do Parque, próxima ao cemitério Jardim da Saudade, na Zona Oeste, além de ocuparem encostas de uma área preservada, provocando grande dano ambiental. Tal apreensão reafirmou o argumento da instalação da cerca delimitadora das divisas do Parque, tornando-o uma área intocável, e, desse modo, somente os autorizados possuíam acesso. Isso configura uma visão do uso ilegítimo da força que, conforme observado por Oliveira, trata-se de uma relação que acarreta o "insulto moral". ${ }^{33}$

Em outra matéria propagada pela mídia, ${ }^{34}$ divulgaram-se, com o propósito de visitação e ecoturismo, a criação de novas trilhas no Parque, a reforma da sede de Jacarepaguá e as obras de recuperação em suas vias de acesso. Segundo afirmação do Secretário Estadual do Ambiente, Carlos Minc, por um lado, serão excluídas dos limites da unidade de conservação áreas favelizadas e, por outro, serão incorporadas áreas preservadas que ficam em seu entorno. Logo, a proposta é revitalizar o Parque da Pedra Branca e tão somente incentivar o turismo no local. Os recursos vêm do Fundo da Mata Atlântica, o qual conta com o pagamento de ações de compensação ambiental depositadas por empresas infratoras.

Segundo Minc não queremos mais um parque morto, que ninguém conhece. A ideia agora é fazer com que ele gere receitas e empregos. A melhor defesa é o bom uso dele. O turismo nos parques estaduais atrai 200 mil pessoas por ano, e queremos que, em quatro anos, esse número chegue a 800 mil.

O processo é construído para compor uma sociedade do espetáculo ${ }^{35}$ com o propósito de chamar as novas atrações e o culto exacerbado à biodiversidade da unidade. A partir daí, inclusive, foi editado um livro em parceria com a UERJ e com a ONG Instituto Terra Brasil.

Em 19 de julho de 2011, foi divulgada outra matéria que noticiou a prisão preventiva do empresário Ricardo de Souza Ferreira, acusado por uma série de crimes, entre eles o loteamento clandestino de um trecho da Área de Preservação Permanente (APP) do Parque Estadual da Pedra Branca, para a construção do Condomínio Floresta Park, na Taquara. O empresário foi acusado de desmatar uma extensa área de mata nativa e represar o curso de água na zona de amortecimento do Parque. ${ }^{36}$

32 GIDDENS, Anthony. Modernidade e identidade pessoal. Trad. Miguel Vale de Almeida. 2. ed. Oeiras: Celta, 2001. p. 24.

33 OLIVEIRA, Luís Roberto Cardoso de. Existe violência sem agressão moral? Revista Brasileira de Ciências Sociais, v. 23, n. 67, p. 135-146. p. 136. O autor adota como características para o fenômeno do "insulto moral": a) a agressão objetiva a direitos que, porém, não se encontram materializados; b) a desvalorização da identidade do outro. Nesse ponto, a proposta se encaixa perfeitamente aos fatos que são noticiados pela mídia, uma vez que transforma os agricultores do PEPB em "criminosos ambientais", desconsiderando seu passado e as atividades que auxiliam a preservação do entorno do Parque e acentuando a visão de natureza intocável que as políticas adotadas pelo governo do Estado do Rio de Janeiro implementam diuturnamente. Tal problemática gera a dicotomia trabalhada pelo autor da consideração/desconsideração e abandona a "identidade singular" dos cidadãos do entorno. 34 O globo. Disponível em: <http://oglobo.globo.com/rio/bairros/posts/2011/07/21/parque-da-pedra-branca-sera-revitalizado-393619.asp. >. Acesso em: 25 ago. 2011.

O globo. Disponível em: <http://oglobo.globo.com/rio/mat/2011/07/15/secretaria-do-ambiente-retira-cavalos-do-parque-dapedra-branca-924916347.asp. >. Acesso em: 18 ago. 2011.

35 A expressão "sociedade do espetáculo" foi criada Guy Debord (1967) como o conjunto das relações sociais mediadas pelas imagens. No contexto empregado, a ideia traduz a crítica ao modo que a natureza é utilizada como símbolo de um querer coletivo e como o poder exercido pela sociedade capitalista.

36 RAMALHO, Sérgio. Empresário tem prisão decretada por lotear área de preservação ambiental. O Globo. Rio, 19 jul. 2011. Disponível em: http://oglobo.globo.com/rio/empresario-tem-prisao-decretada-por-lotear-area-de-preservacao-ambiental-2714036. Acesso em: 28 ago. 2011. 
Na notícia divulgada em 20 de julho de 2011, ${ }^{37}$ a Coordenadoria de Combate aos Crimes Ambientais (Cicca), órgão vinculado à Secretaria de Estado do Ambiente, em parceria com o Núcleo de Defesa Pecuária da Secretaria de Estado de Agricultura e Pecuária e com o apoio do Batalhão Florestal, relata a apreensão de nove cavalos, mulas e burros utilizados no transporte de bananas cultivadas dentro dos limites do Parque Estadual da Pedra Branca. Contaminados pela anemia infecciosa equina, esses animais foram sacrificados numa operação conjunta de órgãos estaduais. Segundo o coordenador da Cicca, José Mauríco Padrone, no momento da apreensão, foi constatado que uma mula, diagnosticada como soro- positivo, já havia falecido em função da patologia, e um burro, também infectado, estava solto na mata. Afirma Padrone que a "[...] fiscalização conjunta das secretarias estaduais do Ambiente e de Agricultura e Pecuária, através da Defesa Agropecuária, vai continuar em outras unidades de conservação".

A coordenação do PEPB afirmou que qualquer atividade agropecuária é proibida na unidade de conservação. Porém, como já residiam na região antes da criação do Parque da Pedra Branca, esses produtores ainda exercem suas atividades, até porque não passaram pelo processo de regularização fundiária e pela provável remoção para outras áreas.

Autores como Queiroz ${ }^{38}$ contestam o mito do isolamento dos pequenos produtores e evidenciam para diferentes formas de integração com a sociedade em sentido amplo do termo. Contudo, destacam também que algumas delas podem levar a situações de decadência, criminalização e miséria, conforme evidenciado nos relatos acima.

\section{Considerações finais}

Os processos recentes de transformação global e os fluxos econômicos de comunicação e de mobilidade de pessoas e objetos modificaram as relações entre espaços, entre o global e o local, conferiram novos significados ao lugar e à produção regional e reconheceram a existência de múltiplas culturas.

Como visto, a identidade se torna um processo de construção constante a partir do redimensionamento do tempo e do espaço. Desse modo, o incentivo às práticas agrícolas do maciço, a partir do resgate de atividades econômicas fortemente enraizadas em bases territoriais, não significa a insistência em resgatar o passado, mas em conferir novos significados ao lugar, incentivando a produção de novidades e de processos de inovação social. Desse modo, subvertem-se formas históricas de desigualdade social e de relações de poder que se manifestam nas relações socioespaciais.

Nesse sentido, os parques não foram criados de forma integrada a um projeto de promoção socioeconômica e cultural da região. Os parques, na verdade, integram uma categoria de conservação da natureza que atende aos anseios, às expectativas e ao modo de vida das populações urbanas elitizadas e excludentes.

A ocupação do Parque Estadual da Pedra Branca e a trajetória dos pequenos agricultores revelam contradições geradas em virtude da categoria de unidade de conservação instituída em 1974. Como observado, mesmo que a legislação ambiental tenha sido um grande entrave à reprodução social desse grupo, a permanência na área protegida se tornou, ao longo dos anos, fundamental para o grupo fazer frente aos processos de expropriação política e econômica trazidos pela crescente ocupação urbana e pelas novas racionalidades de mercado.

Por intermédio da globalização, houve um rompimento das identidades culturais, as quais se alteraram rapidamente a partir da nova dinâmica informacional e se deslocaram a um contexto único. As represen-

37 INEA. CICCA sacrifica animais contaminados no Parque da Pedra Branca. Disponível em: http://www.inea.rj.gov.br/noticias/noticia_dinamica1.asp?id_noticia=1335. Acesso em: 28 ago. 2011.

38 QUEIROZ, Maria Isaura Pereira de, apud FERNANDEZ, Annelise Caetano Fraga. Um parque no sertão carioca dos anos 70 aos dias de hoje. O que mudou na política de conservação? In: REUNIÃO BRASILEIRA DE ANTROPOLOGIA, 26., 2008. p. 4 Disponível em: $<<$ http://www.abant.org.br/noticias.php?type=congressoRBA\#453. >. Acesso em: 20 de set. 2011. 
tações simbólicas dos pequenos produtores situados no entorno do PEPB foram subvertidas e, com isso, esses sujeitos passaram a ser estigmatizados como invasores e depredadores do meio ambiente. A solução deveria ser sua integração à legalidade estabelecida, sem o reconhecimento de que tais grupos são sujeitos de direitos e atores atuantes antes da criação da unidade de conservação e de sua identidade na manutenção das fronteiras territoriais do Parque.

\section{REFERÊNCIAS}

ABREU, Maurício. Evolução urbana do Rio de Janeiro. 4. ed. Rio de Janeiro: IPP, 2006.

BAUMAN, Zygmunt. Modernidade e ambivalência. Rio de Janeiro: J. Zahar, 1999.

BAUMAN, Zygmunt.. Modernidade líquida. Rio de Janeiro: Zahar, 2001.

BOURDIEU, Pierre. O poder simbólico. Trad. Fernando Tomaz. 14. ed. Rio de Janeiro: Bertrand Brasil, 2010.

CARDOSO DE OLIVEIRA, Luís Roberto. Existe violência sem agressão moral? Revista Brasileira de Ciências Sociais, v. 23, n. 67, p. 135-146.

CASTELLS, Manuel. O poder da identidade - A era da informação: economia, sociedade e cultura. Trad. Klauss Brandini Gerhardt. 3. ed. São Paulo: Paz e Terra, 1996. v. 2.

COHEN, Marcos. Avaliação do uso de estratégias colaborativas na gestão de unidades de conservação do tipo parque na cidade do Rio de Janeiro. 2007. 341 p. Tese (Doutorado em Administração) - Pontifícia Universidade Católica PUC, Rio de Janeiro, 2007.

DIEGUES, Antônio Carlos. O mito moderno da natureza intocada. 4. ed. São Paulo: Annablume/Hucitec, 2002.

FERNANDEZ, Annelise Caetano Fraga. Um parque no sertão carioca dos anos 70 aos dias de hoje. O que mudou na política de conservação? In: REUNIÃO BRASILEIRA DE ANTROPOLOGIA, 26., 2008. p. 4 Disponível em: $<<$ http://www.abant.org.br/noticias.php?type=congressoRBA\#453. $>$. Acesso em: 20 de set. 2011.

FOSTER, George. What is a peasant? In: POTTER, J.; DIAZ, M. Peasant society. Boston: Little, Brown and Company, 1967. p. 2-14.

FUKS, Mário. Conflitos ambientais no Rio de Janeiro: ação e debate nas arenas públicas. Rio de Janeiro: UFRJ, 2001.

GEERTZ, Clifford. A interpretação das culturas. Rio de Janeiro: Zahar, 1978.

GIDDENS, Anthony. Modernidade e identidade pessoal. Trad. Miguel Vale de Almeida. 2. ed. Oeiras: Celta, 2001.

GIDDENS, Anthony. As consequências da modernidade. 2. ed. São Paulo: UNESP, 1991.

HAESBAERT, Rogério. Desterritorialização e identidade: a rede "gaúcha" no Nordeste. Niterói: EdUFF, 1997.

HALL, Stuart. A identidade cultural da pós-modernidade. 10. ed. Rio de Janeiro: DP\&A, 2005.

HONNETH, Axel. Luta por reconhecimento: a gramática moral dos conflitos sociais. São Paulo: Ed. 34, 2003.

HORKHEIMER, Max; ADORNO, Theodor. A dialética do esclarecimento. Rio de Janeiro: Zahar, 1985.

OLIVEIRA, Clara Machline. O comércio da natureza: a construção do espaço no bairro de Vargem Grande, cidade do Rio de Janeiro. Revista de Graduação de Geografia da PUC. Rio [de janeiro], ano 1, n.1, v.1, jan./jul. 2008.

OST, François. O tempo do direito. São Paulo: EDUSC, 2005. 


\section{A legitimação do aborto à luz dos pressupostos do estado democrático de direito}

\section{The abortion legitimation in the light of democratic state law assumptions}

Terezinha Inês Teles Pires**

\section{Resumo}

Sob o prisma da tese da constitucionalidade do direito ao aborto, tentaremos apresentar um estudo acerca da validade das premissas das teorias democráticas modernas e contemporâneas. Lançando um olhar crítico sobre o modelo do processo deliberativo, centrado no critério majoritário, explicitaremos as posições conflitantes acerca da distinção entre o plano da moralidade individual e da moralidade política, com a intenção de propor a delimitação de um quadrante razoável para o exercício do direito de autonomia e autodeterminação. Por fim, indicaremos como fundamento central da demanda das mulheres pelo controle do processo reprodutivo, sem a ingerência do Estado, o modelo do pluralismo moral e político e sua exigência do acolhimento das múltiplas crenças e convicções pessoas no contexto do espaço público.

Palavras-chave: Aborto, democracia, moralidade, pluralismo.

\section{Abstract}

From the perspective of the theory of the constitutionality of abortion rights, we will attempt to present a critical study on the validity of the assumptions of modern and contemporary democratic theories. Casting a critical eye on the model of the deliberative process, centered on the major criterion, we will expose the conflicting positions about the distinction between the level of individual morality and political morality, with the intention to propose the definition of a quadrant for the reasonable exercise of the right of autonomy and self-determination. Finally, we will indicate as central foundation of the demand for control of women's reproductive process without the interference of the state, the model of moral and political pluralism and its requirement for admitting multiple persons beliefs and convictions in the context of public space.

* Recebido em 14/10/2013 Aprovado em 13/12/2013

Keywords: Abortion, Democracy, Morality, Pluralism.

** Doutoranda em Direito pela UNICEUB. Estágio sanduíche na American University. Promotora de Justiça do Distrito Federal e Territórios.Email: teresap@mpdft.gov.br 


\section{INTRODUÇÃO}

O propósito de investigar os fundamentos justificadores da admissibilidade do aborto enquanto um direito fundamental derivável dos princípios constitucionais abstratos, relativos às liberdades individuais, exige um estudo acerca das premissas da democracia moderna e contemporânea. Nessa direção, afirmaremos a necessidade de um procedimento de justificação moral da obrigação política, no sentido da exigência da concordância subjetiva dos membros de uma determinada sociedade às regras elaboradas pelo sistema legislativo.

As lições oferecidas pelas doutrinas do direito natural, do liberalismo, e do contratualismo lançaram uma concepção transformadora a respeito dos critérios para a delimitação da coação do Estado na esfera das decisões pessoais em matérias não vinculadas aos interesses públicos. O princípio da autonomia da vontade e o pluralismo ideológico, como tentaremos demonstrar, permitem a reelaboração do paradigma do consentimento político, em bases morais, de modo a redimensionar o espaço do exercício da liberdade de consciência no contexto do procedimento deliberativo-democrático.

A democracia representativa e a democracia participativa constituem formas historicamente apresentadas para a concretização de um sistema político contraposto ao exercício do poder absoluto, sem parâmetros ponderados de controle direto ou indireto da ação do Estado. Entretanto, uma nova abordagem daqueles modelos tradicionais é algo que se impõe para o avanço de visões transformadoras no âmbito dos mecanismos jurídicos substanciais facilitadores do acolhimento das concepções morais de todas as camadas da sociedade. Pretendemos questionar a aceitação acrítica do critério majoritário na formação das decisões políticas, independente da natureza do assunto em debate, lançando uma percepção diferenciada do conceito de minorias centrado na liberdade de formação, no plano do desenvolvimento da personalidade, de convicções morais e religiosas. Tomaremos o alcance abrangente da liberdade de consciência como o fundamento último da defesa do direito da mulher à condução do processo reprodutivo, o que importa na legalização do aborto, em condições razoáveis, em contraposição à dominação de uma única concepção, no tocante ao valor da vida pré-natal, no contexto da vida pública.

Faremos, ainda, uma leitura da distinção entre as esferas da eticidade, da moralidade pessoal e da moralidade política, com o objetivo de formular uma compreensão da admissibilidade do direito ao aborto que escape ao modelo do consenso deliberativo. Nessa perspectiva, iremos adotar a doutrina do pluralismo moral e religioso enquanto uma paradigma essencial para a afirmação do direito de escolha de convicções individuais e do exercício do controle sobre o processo reprodutivo em conformidade com o princípio da autonomia da vontade.

\section{Democracia e Liberdade política}

A opção pelo aborto passou a ser reivindicada pelas mulheres com o aperfeiçoamento da defesa dos direitos humanos, o que, com fundamento na doutrina do jusnaturalismo, assentou a obrigatoriedade da garantia do exercício de determinados direitos a todos os cidadãos. ${ }^{1}$ A edificação de uma carta de direitos humanos resultou da introdução do modelo liberal de organização do Estado, responsável por uma radical transformação na estrutura da relação "entre indivíduo e sociedade". Daí se consolidou a necessidade do estabelecimento "dos limites jurídicos do poder estatal", e dos princípios do "contratualismo" moderno. Em

1 Efetivamente, os direitos sexuais e reprodutivos, de modo geral, foram alçados à categoria de direitos humanos por ocasião da Conferência Mundial da ONU sobre População e Desenvolvimento, realizada em 1994 na cidade do Cairo (Disponível em http:// www.iisd.ca/linkages/cairo.html) e da IV Conferência Internacional sobre a Mulher, realizada em 1995 em Beijing/199 (disponível em http://www.un.org/womenwatch/daw/ beijing/platform/). 
linhas gerais, os direitos naturais, o liberalismo e o contratualismo configuram três vertentes do pensamento político que se interconectam para a asserção do "Estado de Direito" enquanto um modelo contraposto ao do "Estado absoluto". Na dimensão do Estado de Direito a liberdade é afirmada como liberdade "em relação ao Estado", ${ }^{2}$ o que, como se verá mais adiante, possibilitou o aperfeiçoamento da doutrina do constitucionalismo, com a afirmação da liberdade como um dos pilares do sistema jurídico-institucional. E, dentre as liberdades em espécie, firmou-se a noção de liberdade reprodutiva, na qual se insere a perspectiva do aborto, na qualidade de um direito vinculado ao princípio da autodeterminação da vontade.

Desde meados do século XVII autores da filosofia política se empenham em traçar as bases da constituição da sociedade civil como uma necessidade derivada das ameaças existentes no estado de natureza. John Locke e Thomas Hobbes foram os pensadores modernos a problematizar a impossibilidade da preservação incondicional da liberdade de ação individual, diante da inevitabilidade da reunião dos homens em sociedade sob a égide de um sistema legislativo. ${ }^{3}$ Kant, igualmente, enfatiza que o homem renuncia à sua "liberdade irrestrita" porque sente a necessidade, para sua própria proteção contra a ação desregrada dos demais cidadãos, de se submeter à coação social. A racionalidade do homem faz com que ele "deseje uma lei que ponha limites à liberdade de todos". Tal perspectiva vincula-se à busca de um estado de segurança por intermédio de uma "constituição legal". ${ }^{4} \mathrm{O}$ consectário natural dessa visão foi a legitimação das ideias de soberania e do "contrato social", que, na linguagem de Rousseau, confere ao "corpo político" o poder de submeter a vontade individual à "vontade geral". 5

Muito se discutiu sobre o fundamento do "consentimento", pilar da validade do contrato social. Para Locke, o poder político só pode instalar-se com o consentimento dos membros da comunidade, o que se realiza por intermédio da predominância dos votos da maioria. ${ }^{6}$ Hobbes acentua, igualmente, que a formação de uma "cidade" exige que "cada um" "aceite o que for aprovado pela maior parte como constituindo a vontade de todos". ${ }^{7}$ Desde então, essa tradição alicerçada na ideia do consentimento domina a abordagem do tema da obrigação política. No entanto, a fundamentação do consentimento pessoal como condição primordial para a legitimidade da autoridade do governo sobre os cidadãos não é tarefa cuja solução se vislumbre com tanta facilidade. A princípio, parece simples dizer que o acordo coletivo pressupõe o consentimento prévio de cada indivíduo, dada a garantia da participação democrática. Na prática, porém, tal visão termina adquirindo um viés não muito realista. O liberalismo democrático, especialmente representado pela teoria lockeana, deparou-se com a impossibilidade de se viabilizar o consenso universal nas decisões políticas, com o que sempre haverá uma parcela da comunidade que não terá efetivamente assentido com as deliberações realizadas. $^{8}$

Para justificar a obrigação, em matéria política, o estabelecimento de uma regra legal não é o suficiente. Além disso, o indivíduo deve sentir-se subjetivamente, no sentido moral, vinculado à norma que lhe é imposta. Em outros termos, a obrigação política pressupõe um nível razoável de consentimento moral por parte dos membros da comunidade às ações planejadas pelas instituições estatais, e às prescrições construídas pelos corpos legislativos. ${ }^{9}$ Sendo assim, pode-se dizer que a criminalização do aborto, por exemplo, para

2 BOBBIO, Norberto. Liberalismo e Democracia. 6a edição. São Paulo: Brasiliense, 2005, p. 15-18, 21.

3 LOCKE, John. Dois Tratados sobre o Governo. $2^{a}$ tiragem. São Paulo: Martins Fontes, 2001, Livro II, 13】 (p. 391), \89-90 (p. 4601); e HOBBES, Thomas. Do Cidadão. $3^{\text {a }}$ edição. São Paulo: Martins Fontes, 2002, capítulo V, p. 98, capítulo VI, p. 113-14.

4 KANT, Immanuel. Ideia de uma história universal com um propósito cosmopolita. In A pazperpétua e outros opúsculos, 1988A, A 394-397, A 398-401.

5 ROUSSEAU, Jean Jacques. Do Contrato Social. Coleção os Pensadores, volume I. São Paulo: Nova Cultural, 1999, capítulo IV, p. 95.

6 LOCKE, op. cit. livro II, capítulo VIII, \ 95-98 (p. 468-71).

7 HOBBES, op. cit. capítulo VI, p. 102.

8 Sobre as origens históricas da vertente contratualista no âmbito da fundamentação da obrigação política, consulte-se SIMMONS, A. John, Moral Principles and Political Obligations, Princeton, New Jersey: Princiton University Press, 1981, p. 57-61.

9 Ibidem, p. 3. Simmons defende que a obrigação política é "uma espécie de obrigação moral” (p. 4), não se identificando, portanto, com a obrigação legal. No mesmo sentido, Isaiah Berlin afirma que a "teoria política é um ramo da filosofia moral, a qual começa pela descoberta, ou aplicação, das noções morais na esfera política” (Two Concepts of Liberty, in Liberty, Oxford/New York: 
deixar de ser somente uma prescrição legal, e representar uma obrigação política, vinculante para todos os cidadãos, no contexto do Estado Democrático de Direito, demanda um procedimento de justificação moral de sua proibição, em quaisquer circunstâncias.

Em todos os países que ainda tipificam o aborto como conduta criminosa, boa parte da população não concorda com a posição institucionalmente adotada no tocante ao tema, o que denota a incompatibilidade moral dessa porção de indivíduos, em regra mulheres, com o impedimento jurídico à livre escolha reprodutiva. ${ }^{10}$ Se a obrigação de obedecer a lei que penaliza o aborto é um dever político antes que um dever legal, como concebido pelas teorias contratualistas, então, nos termos assentados por Simmons, não parece legítimo coagir as mulheres à submeterem-se à lei, em espécie, mesmo diante do seu não consentimento, seja tácito ${ }^{11}$, seja expresso, aos valores morais que a embasam. Não seria razoável dizer que as mulheres, na qualidade de cidadãs, conferem tacitamente seu consentimento, através do voto, à eliminação de seu direito de escolha reprodutiva. Isso seria o mesmo que afirmar a possibilidade da renúncia ao princípio da responsabilidade pessoal, o que comprometeria a dignidade moral individual. É sempre bom lembrar que o direito ao aborto se insere no rol das liberdades básicas, que direcionam o debate para uma margem ampliada de sua efetividade, e indicam, no mesmo passo, maior grau de restrição à validade da obrigação política, portanto, aos fundamentos do consentimento.

A postulação do consentimento tácito como razão suficiente para a submissão à autoridade do governo conduz, ainda, a algumas impropriedades, quando o comando da lei ou da ação política não é adotado universalmente. Nesses casos, ao indivíduo confere-se o direito de mudar-se para outro país, cujas leis melhor acomodem seu senso de moralidade. Tal como explicitado por Nozick, em sua concepção de uma comunidade utópica, a condição ideal da vida em comum consiste na possibilidade de as pessoas viverem em um sistema social que voluntariamente escolham como sendo o melhor para si mesmas. Nessa dimensão, se um método de filtragem permitisse que as pessoas avaliassem, por seus próprios critérios, cada sistema, elas poderiam escolher onde querem viver. A investigação de Nozick não se limita a buscar um tipo ideal de comunidade na qual todos gostariam de viver, mas antes de se buscar vários tipos ideais, com o que cada indivíduo descobriria o seu tipo ideal, o que mais se compatibiliza com seus valores e metas pessoais. ${ }^{12}$

Oxford University Press, 2009, p. 168). Simmons esclarece que algumas vezes o dever de submeter-se à lei se aproxima muito da caracterização da obrigação política, sendo imposto, com essa conotação, sem nenhuma justificação moral. O que se pretende dizer com isso é que a regra legal, por si só, não é fundamento suficiente para a imposição de uma obrigação política, no seguinte sentido: o dever legal, para representar um compromisso necessariamente assumido por todos os membros da comunidade, exige a pressuposição de premissas morais aceitáveis, as quais se construam independentemente do conteúdo do comando legal. No campo da cidadania, se formulam obrigações legais; mas, a imposição da obediência efetiva às leis demanda a obtenção da concordância individual com as razões morais fundamentadoras das respectivas prescrições jurídicas. (SIMMONS, op. cit., p. 17, 20-21). Intuitivo é perceber que a diferença aqui firmada entre dever legal e dever moral segue, em seu cerne, a posição kantiana, segundo a qual o primeiro é legitimado externamente, através do exercício dos poderes institucionais, enquanto o segundo parte de uma justificação racional subjetiva. Essa é a base da vertente contratualista, e é o que se impõe adensar, para os propósitos do presente estudo.

10 O tema do aborto não promove um consenso coletivo em nenhum país no qual a questão é levada ao debate público, de modo que uma parcela da comunidade inevitavelmente é forçada a submeter-se à opinião da maioria, quando, no contexto da democracia representativa, a lei produzida pró́be sua prática. Mais adiante, o problema do desacordo moral relativo ao aborto, e a polaridade dos grupos favoráveis e contrários à sua regulamentação em determinados países, escolhidos como emblemáticos para o propósito desta pesquisa, será detalhadamente pontuado.

11 A ideia de consentimento tácito foi sedimentada por Hobbes (Leviatã, "Uma Revisão e Conclusão"), Locke (Segundo Tratado sobre o Governo, seção 119) e Rousseau (Contrato Social, IV). O critério adotado para a afirmação da legitimidade do consentimento tácito é o da residência, melhor explicitado no argumento de Locke: qualquer indivíduo que usufrui de alguma porção do território dominado por um determinado governo, adquirindo propriedades e utilizando os serviços públicos que lhe são oferecidos, se obriga a obedecer a suas leis, não se fazendo necessário o consentimento expresso ao seu conteúdo. No entanto, Locke, ao mesmo tempo, inspirado em sua radical defesa da liberdade individual, salienta que a validade do consentimento tácito não é absoluta, pois não se legitima quando a autoridade do governo se mostra tirânica ou arbitrária (op. cit., seção 171-172).

12 NOZICK, Robert. Anarquia, Estado e Utopia. São Paulo: Martins Fontes, 2011, p. 409-10. A título de conclusão, Nozick esclarece ter oferecido um "arcabouço da utopia”, Esse arcabouço é um modelo idealizado, que, como tal, não considera os detalhes inerentes às comunidades específicas que existam dentro dele. Isso não quer dizer que não se repute relevante a avaliação de todos os detalhes das comunidades concretas. Ao contrário, o autor considera necessária essa avaliação, sendo que, para tanto, o arcabouço se apresenta enquanto uma ideia condutora. O arcabouço, grosso modo, "equivale ao Estado mínimo". Um Estado que respeita a 
Se as pessoas pudessem escolher livremente onde querem residir e inserir-se nos deveres da cidadania, sem a existência de normas, nacionais e internacionais, limitadoras dessa liberdade, seria fácil, seguindo a direção de Nozick para a construção de "uma utopia", garantir o respeito à autodeterminação. Para praticar o aborto, por exemplo, a mulher brasileira, não se sentido moralmente comprometida com o banimento do respectivo direito, poderia deslocar-se e estabelecer-se no território dominado por outro governo. Mas cada indivíduo, regra geral, já nasce vinculado a um determinada organização política, seja pelo critério do local de nascimento, seja pelo critério da nacionalidade dos seus genitores, não lhe sendo conferido, nessa seara, o direito de livre escolha. Em relação ao aborto, a mulher, possuindo condições financeiras, costumeiramente viaja e faz o procedimento no território de outro país em que sua prática seja legalizada, já que, como se sabe, a lei penal aplicável é a do local onde o ato é realizado. Nem todas, entretanto, têm acesso a essa possibilidade, o que conduz, inclusive, à violação do princípio da equidade.

Vê-se, assim, que o modelo da teoria do consentimento, calcado no sistema representativo, evidencia, se interpretado de forma irrestrita, paradoxos insolúveis para a acomodação da independência ética dos indivíduos na condução de suas próprias vidas, o que permite por em questionamento, em tal esfera, a legitimidade da autoridade política do Estado, especialmente no tocante ao direito ao aborto. ${ }^{13}$

Supondo-se que a doutrina clássica do consentimento não é isenta de problemas, é salutar, assumindo uma posição crítica, refletir acerca da necessidade de se delimitar quais os assuntos devem, e podem, ser propostos e decretados por uma "assembléia", ou, melhor dizendo, os assuntos em relação aos quais o acatamento das decisões da maioria, portanto, a submissão às leis, é obrigatório para os cidadãos. É preciso redimensionar o método da deliberação política, na tentativa de superar seus antagonismos, retirando da esfera do consenso coletivo alguns temas, que, por natureza, configuram prerrogativas individuais em matéria de definição dos projetos de vida. ${ }^{14}$ Um novo paradigma da teoria do consentimento deve ser firmado, a partir dos seus próprios postulados, sem que se os negue, mas lançando-se um olhar analítico sobre suas implicações no que diz respeito à validade da obrigação política. Numa linguagem kantiana, o propósito seria estabelecer uma crítica da racionalidade da teoria do consentimento, com a delimitação do seu campo de aplicação, considerando a natureza do tema a ser decidido.

Antes de tudo, a submissão dos indivíduos às deliberações coletivas se justifica no que concerne à proteção contra "a violência dos outros", para que se "possa viver em segurança". ${ }^{15}$ Não se discute, como já pontuado, que os indivíduos renunciam a parcela significativa de sua liberdade para assegurarem para si mes-

inviolabilidade dos direitos individuais e a liberdade de escolha dos planos de vida, contando cada um com o auxílio da "cooperação voluntária" dos outros (op. cit., p. 428-30).

13 Convém esclarecer que o argumento ora proposto parte da visão moral tradicional da categoria do consentimento, construída pelos pensadores acima citados (sobretudo Kant e Rousseau). Por isso, não iremos adentrar nas teorias utilitaristas clássicas, focadas na dimensão da maximização da felicidade. Apenas faremos referências pontuais a alguns dos seus argumentos pertinentes à defesa da liberdade de escolha. Isso porque consideramos, acompanhando o raciocínio de Simmons, que os postulados utilitaristas são insatisfatórios para a abordagem da obrigação política como um todo, tendo em vista que, nesse âmbito, os direitos de liberdade possuem primazia até mesmo sobre os interesses individuais de ampliação da perspectiva da felicidade. A questão central, do ponto de vista dos parâmetros democráticos, reside na conciliação entre a autoridade política institucional e o direito individual de autodeterminação (Idem, op. cit., p. 46-9 e 69). Para um conhecimento detalhado do utilitarismo moral e político, recomendamos a leitura de seus expoentes: HUME, David, A Treatise of Human Nature (Book III, Part II); MILL Stuart, Utilitarianism (Chapter 2); On Liberty (Chapter 1); BENTHAM, Jeremy, A Fragment of Government (Chapter 1); An Introduction to the Principles of Morals and Legislation. Igualmente, não pretendemos abordar as teorias antirracionalistas, tais como as de Schopenhauer, Nietzsche, e Kierkegaard, que são hostis a qualquer tipo de fundamentação argumentativa da obrigação política. Partindo de uma leitura intermediária, que escape à censura de estar pendendo excessivamente para o individualismo, o que iremos postular é a defesa da admissibilidade moral do aborto com base em ponderações racionais que equacionem, nos moldes do regime democrático, a relação entre a liberdade de escolha reprodutiva e o exercício da autoridade do Estado.

14 Ao fazer uma análise dos aspectos antidemocráticos da categoria da "representação" política, Bruno Leoni afirma que "o único caminho para a liberdade individual, no presente" seria "a redução no número de questões acerca das quais as pessoas sejam representadas". Segundo o autor, isso traria vantagens a todas as pessoas, nos "casos em que venham a ser "vítimas" de um processo legislativo irrestrito" (LEONI, Bruno. Liberdade e a lei: os limites entre a representação e o poder. São Paulo: Instituto Ludwig von Mises Brasil, 2010, p. 33.

15 HOBBES, op. cit. capítulo VI, p. 103. 
mos uma situação de segurança. Por outro lado, o "poder da sociedade", diz Locke, não pode estender-se "para além do bem comum", cingindo-se à preservação da "paz", da "segurança" e do "bem público". O poder legislativo não pode ser "arbitrário sobre a vida e os haveres do povo" ${ }^{16}$ Além disso, diz Rousseau, o pacto social só é justo quando regula apenas “o interesse comum”, não sendo legítimo quando regula uma questão "particular". Nessas questões, os indivíduos conservam sua liberdade, fixando-se aí os limites da soberania estatal. ${ }^{17}$

A liberdade individual, no sentido político, enquanto direito a uma esfera de ação em relação a qual se restrinja o poder do Estado de ditar normas reguladoras da conduta humana, colhe sua fonte principal na doutrina liberal. Não há que se falar nesse aspecto de contraposição entre a vertente liberal e a democracia, pois não estamos tratando da liberdade econômica, cujo exercício se subordina aos limites interventivos do poder público, na condução dos assuntos distributivos. A liberdade de ação individual, cuja concretização exige a intervenção mínima do Estado é aquela que se direciona à singularidade "espiritual", ${ }^{18}$ às convicções de cada indivíduo, pelas quais ele pode pautar suas decisões.

A relação entre o liberalismo e a democracia apresenta, certamente, algumas dificuldades e divergências pontuais. O ideal é encontrar um enfoque diferenciado das exigências da democracia de acordo com a questão a ser decidida pelo sistema político. No concernente aos temas que mais se aproximam da definição dos projetos particulares destinados ao desenvolvimento da vida e da personalidade individual, parece acertado dizer que o liberalismo e a democracia são não apenas dois referenciais políticos "compatíveis", como também que "estão ligados necessariamente entre si". ${ }^{19}$ Isso se se admite que a democracia tenha, como um dos seus pilares, a garantia da autonomia da conduta humana fora dos limites da coerção social legítima. Pois, como se verá adiante, a identificação da democracia com a ideia de participação, tradicionalmente definida pelo direito ao voto, pode significar nada mais "que um disfarce especial" da "tirania", ${ }^{20}$ situação na qual os postulados do liberalismo se veriam totalmente rejeitados.

A liberdade de vontade, como contraponto à autoridade política, é definida por Isaiah Berlin em dois sentidos paradigmáticos: no "sentido negativo", configurador de uma área de atuação individual conforme as preferências de cada um, sem a "interferência de outras pessoas", e no "sentido positivo", que remete à legitimação das instâncias políticas dotadas de autoridade para ditar as regras de conduta naquilo que se enquadra em seus poderes específicos. Sob o ângulo da justificação da obrigação política, dentre os dois sentidos formulados, ressalta a precedência do primeiro. Contudo, a efetivação da liberdade individual só se complementa com a conexão lógica entre os dois sentidos de liberdade. Inicialmente, firma-se o direito à não intervenção alheia nas decisões de índole privada (sentido negativo), para, em seguida, firmar-se, igualmente, no tocante a esse mesmo tipo de decisões, o direito à autonomia legislativa, ou seja, à determinação das regras de conduta a partir dos próprios valores, "ideias e propósitos", com a assunção da responsabilidade pelas consequências das escolhas pessoais. ${ }^{21}$

Por óbvio, o espaço privado de liberdade é passível de delimitação jurídica, mas há uma fronteira além da qual o Estado, inclusive a lei, não pode invadir, sob pena de comprometer o "desenvolvimento mínimo" das "faculdades naturais" do homem. Trata-se de um espaço da vida humana que "deve permanecer" fora do alcance do "controle social", espaço esse no qual se enquadram as questões que em nada interferem nos assuntos afetos ao "progresso" e à "harmonia social", como acreditam os filósofos liberais da modernidade. $^{22}$

16 LOCKE, op. cit. Livro II, \ 131 (p. 499-500), \ 135 (p. 504).

17 ROUSSEAU, op. cit., capítulo IV, p. 97-8. No mesmo sentido, GALSTON, William A. Diversity, Toleration and Deliberative Democracy. In: MACEDO Stephen. Deliberative Politics. New York/Oxford: Oxford University Press, 1999, 47.

18 BOBBIO, N., 2005, op. cit., p. 47.

19 Ibidem, p. 53.

20 BERLIN, I., op. cit., p. 178.

21 Ibidem, p. 169 e 178.

22 Idem, p. 171, 173. 
Nessa linha de raciocínio, se existem limites para a ingerência "da opinião coletiva na independência individual", como defende Stuart Mill, então a formulação das regras políticas e das leis deve ter por parâmetro não ultrapassar o domínio sobre o qual efetivamente se inserem os assuntos públicos. O domínio da liberdade de ação, por outro lado, compreende, primeiramente, o espaço da "consciência", do "pensamento", da "opinião", e do "sentimento, em todos os assuntos, práticos ou especulativos, científicos, morais ou teológicos", que estruturam nossas vidas de forma a "seguir nosso próprio caráter". Obviamente, os atos que causam prejuízos aos interesses dos outros, "sem causa justificável”, se subordinam ao controle da sociedade, mas não os atos que concernem ao indivíduo. ${ }^{23}$ Não se trata de negar categoricamente a validade da coerção, que não é classificável, em si mesma, como algo bom ou ruim. Pode se mostrar necessária para a prevenção de "grandes males". Igualmente, a "não-interferência" não representa, em si mesma, algo bom ou ruim. ${ }^{24} \mathrm{~A}$ resposta mais aceitável aos ataques liberais ao exercício da autoridade do Estado deve ser buscada em uma delimitação ponderada dos assuntos atinentes aos interesses sociais e dos assuntos atinentes aos interesses individuais. Quanto aos interesses individuais, deve-se estabelecer, ainda, em quais circunstâncias não há lugar para a interferência social, sendo admitidas algumas restrições adequadamente impostas.

A investigação central que se repete em todos os círculos de discussão atinente à liberalização do aborto diz respeito exatamente a essa indagação: em que condições o aborto é algo que concerne à vida da mulher, e não a de outrem, ou ao interesse social? Se a mulher, encontrando-se em um determinado país, pode livremente escolher o aborto no lugar da maternidade não planejada, e estando em outro país, não pode fazê-lo, de acordo com o posicionamento assumido pela respectiva legislação penal, é porque existem graus diferenciados de proteção à "espontaneidade" e à "individualidade". Não se perca de vista que o desenvolvimento da democracia, no que pese afirmar a essencial fundamentalidade da igualdade de direitos e oportunidades, acarreta, até em decorrência dessa afirmação, se levada ao extremo, uma tendência a minimizar a garantia das escolhas pessoais e a padronizar o "caráter humano". 25

Usualmente, em nome da preservação de valores sociais, em grande parte de natureza mística, vigora uma concepção comunitária em relação a qualquer tipo assunto, não se perquirindo se a natureza da questão não inere exclusivamente à consciência individual. O juízo do que é certo ou errado no plano da "conduta pessoal" não se sujeita à "opinião da maioria", e não pode ser imposto "como uma lei à minoria". Somente as "formas de conduta" condenadas universalmente são passíveis de proibição social. ${ }^{26} \mathrm{O}$ aborto, todos sabem, não é condenado universalmente, ao contrário, é legalizado na maioria dos países, com exceção daqueles cuja garantia do pensamento laico não é respeitada. Isso mostra que sua proibição não se compatibiliza com a democracia, no tocante às liberdades civis. O que se situa no campo de liberdade moral não pode ser transformado em obrigação imposta por lei, pois, nesse caso, o conteúdo da lei foi além dos limites dos poderes do Estado.

O princípio da não produção de prejuízos aos outros, postulado por Stuart Mill como sendo "a única restrição legal não problemática à liberdade individual”, é aplicável ao tema do aborto? Não se for o único princípio utilizado, ou seja: sim, a rigor o aborto não fere os interesses de terceiros, exceto na esfera de suas crenças pessoais. Mas aqui há de prevalecer a tolerância às diferenças. Contudo, o Estado organizado, por meio das forças dominantes, sempre terá a oportunidade de alegar o direito à vida nascitura, e enquadrar

23 MILL, John Stuart, On Liberty, Mineola/New York: Dover Publications, INC, 2002, p.4, 10, 46, 63. O direito à autodeterminação deriva, em síntese, da percepção de "que o indivíduo mantém, na sua intimidade, uma esfera onde seus comportamentos e ideais estão fora do poder de penetração das regras sociais; a essa esfera dá-se o nome de direitos primeiros ou fundamentais, que tem por escopo tutelar a individualidade e a personalidade, protegendo de quaisquer invasões ou ataques tanto de outros indivíduos como pela própria sociedade organizada, ou seja, o Estado". A crise contemporânea da identidade individual leva o ser humano a lutar "para encontrar e afirmar sua personalidade, mas se vê lutando contra modelos de comportamento e valores impostos, e o resultado, quando não é a sublimação absoluta da individualidade, é a relativização total dos valores" (OLIVEIRA, Alexandre M. A. Direito de autodeterminação sexual. São Paulo: editora Juarez de Oliveira, 2003, p. 6, 1).

24 BERLIN, I., op. cit., p. 175.

25 MILL, S., op. cit., p. 50-1.

26 Ibidem, p. 70-1. 
o feto como uma categoria especial de "terceiro" prejudicado pela interrupção voluntária da gravidez. Em outros termos, "para definir prejuízo", como base da legitimidade da obrigação política, pode-se "apelar para os padrões sociais", o que torna o princípio do "não prejuízo" um princípio insuficiente para restringir a "coerção". 27

Sob o prisma filosófico, a autonomia da vontade kantiana, preanunciada por Rousseau, por meio da noção de "autodeterminação política do cidadão", "como participação no governo", adiciona elemento essencial à rejeição da opressão desarrazoada à individualidade moral. ${ }^{28} \mathrm{~A}$ filosofia de Kant encontrou forte expressão política no pensamento de Hans Kelsen. Este define "a reação contra a coerção" do Estado como um "protesto contra o tormento da heteronomia". A submissão dos cidadãos a uma única "ordem jurídica estatal" não resultou na total eliminação do individualismo, ou seja, "uma parte maior ou menor da vida humana sempre escapa" à ordem social; dizendo de outra forma, "existe uma certa esfera em que o indivíduo é livre do Estado". ${ }^{29}$ Aproveitamos aqui a oportunidade para antecipar que o conceito de liberdade da vontade, como formulado por Kant, funciona como um pressuposto racional da afirmação da "Liberdade Civil, ou Social". ${ }^{30}$ A primeira diz respeito ao caráter racional da consciência humana, que, como tal, constrói a lei moral, derivada dos princípios puros práticos como regra universal para o julgamento da ação humana. A segunda postula a capacidade racional do indivíduo de ditar para si mesmo suas regras de conduta no contexto de uma comunidade política.

O argumento a favor da liberdade de escolha pela realização do aborto se fundamenta, de toda sorte, nos dois conceitos de liberdade. Para a vontade kantiana, legisladora para si mesma nos assuntos que não envolvam interesse político, um comando coletivo, derivado da opinião da maioria dos concidadãos, não é legítimo. Para a liberdade civil do utilitarismo inglês, a exigência de obediência a uma regra pública, formulada pela ordem estatal, não se justifica no tocante às escolhas de caráter ético. Certamente, a mulher que decide praticar o aborto segue os comandos de sua consciência individual, que não visualiza bloqueio moral à realização da conduta, e busca promover maior grau de felicidade à sua vida, o que se inviabilizaria se viesse a assumir os deveres da maternidade.

Após essa exposição e análise da base da teoria política moderna, é importante salientar, em linhas gerais, a título de conclusão parcial do problema ora tratado, que os pressupostos da teoria democrática de perfil individualista fortaleceram a doutrina das liberdades privadas, aperfeiçoando, desse modo, a concepção do Estado de Direito. Em um primeiro momento, tais pressupostos firmaram a supremacia do "positivismo jurídico", logo, do "princípio da legalidade", sobre o jusnaturalismo, que anteriormente havia representado importante papel na efetivação da liberdade política de resistência à opressão estatal. Legitimou-se, então, a separação entre o direito e a moral, entre a "validade das normas" e a "noção de justiça". Posteriormente, na condição de uma doutrina em constante transformação no ambiente na prática social, o Estado de Direito

27 WOJCIECH, Sadurski. Moral Pluralism and Legal Neutrality. Dordrecht/Boston/London: Kluwer Academic Publishers, 1990 , p. 89 e 99 .

28 O presente trabalho terá, ainda nessa parte, item específico para a análise da relação entre o modelo de razão prática kantiano e o pluralismo moral. Assim, não vamos enunciar, por ora, a exposição dos argumentos pertinentes. Os poucos comentários que se seguirão acerca da moralidade em Kant são somente os necessários para a indicação de suas semelhanças e distinções, em caráter sucinto, em relação ao paradigma individualista de Mill.

29 KELSEN, Hans. A Democracia. São Paulo: Martins Fontes, 1993, p. 172 e 27, 36 e 183.

30 É Stuart Mill quem identifica a liberdade civil à social (2002, op. cit., p. 1). Nesse trecho, Mill distingue com clareza a "Liberdade da Vontade" da "Liberdade Civil ou Social", para pontuar que seu ensaio é sobre a natureza da segunda. Mill foi um autêntico liberal, mas preocupava-se igualmente com a democracia, e tinha por maior interesse filosófico, em seus escritos, traçar limites ao exercício do "poder público" e alargar o terreno da liberdade civil. No entanto, fundamentou sua doutrina da liberdade não nos princípios abstratos do direito natural, mas no utilitarismo de Jeremy Bentham, fortemente voltado para a maximização da felicidade. Ainda assim, embora Mill não tenha penetrado no território moral da liberdade da vontade, sua distinção entre a esfera pública e "a esfera privada" tem o mesmo sentido da distinção kantiana entre "ações externas" e "liberdade individual". Em ambos os pensadores, somente quando as ações humanas podem "interferir no interesse de um outro" é que se sujeitam ao controle do "poder público". São doutrinas antipaternalistas "por excelência" (Cf. BOBBIO, N, 2005, op. cit., p. 62-66), e calcadas na ética da responsabilidade, que advogam o direito de cada um de guiar-se por sua consciência, assumindo as consequências de suas escolhas (MILL, cit., p. 70). 
assumiu, com a crise contemporânea do "Estado legislativo", uma concepção crítica no que diz respeito à institucionalização do positivismo jurídico como fonte única do sistema normativo. Adveio dessa nova concepção o que pode ser denominado "Estado constitucional", estabelecendo-se como critério essencial para legitimar a validade das leis sua compatibilidade com as "normas constitucionais substanciais". ${ }^{31} \mathrm{Tal}$ reviravolta representou, em uma linguagem diferenciada, o resgate da vinculação do direito aos princípios morais universais, inicialmente introduzida pela teoria do direito natural, dando corpo ao desenvolvimento dos direitos humanos, da concretização das liberdades básicas de pensamento e de consciência, e do pluralismo,

\section{Democracia Representativa e democracia participativa}

A criminalização do aborto voluntário constitui uma situação que põe em xeque a validade da estrutura do regime democrático, em qualquer de suas formas, haja vista a ausência de temperamentos ao critério majoritário. Continuar negando à mulher o poder de decisão pessoal no tocante ao prosseguimento da gravidez, a despeito da evolução presenciada nas últimas décadas no direito internacional, em matéria de abertura à pluralidade de convicções morais, é algo que impõe uma reflexão acerca dos limites dos métodos democráticos de elaboração e revisão das leis positivadas. Não se revela plausível que a possibilidade de modificação da lei penal, no caso, fique restrita ao embate de argumentos apresentados por dois grupos cujas crenças se perpetuam ao longo do tempo, sob o único fundamento da prevalência da crença da maioria dos seus representantes.

O regime democrático é reconhecido como o mais adequado para a construção de um acordo social que determine, de forma justa, os limites da liberdade individual e da coerção do Estado. A formação do Estado legitima a submissão das pessoas a uma ordem jurídica, o que resultou na adoção do modelo de democracia representativa, calcada na prevalência da vontade da maioria. Mas não é sem dificuldades que se sustenta esse modelo, em face da inevitável opressão das minorias. ${ }^{32}$

Rousseau, na opinião de Kelsen "talvez o mais importante teórico da democracia", defende que a "associação" "ideal” é a que reduz "ao mínimo" "a possibilidade de uma decisão imposta à minoria". Kelsen é um crítico do critério majoritário de tomada de decisões políticas, no que pese considerar a democracia o melhor dos regimes. Chama a atenção para o fato de que o processo político, por funcionar através dos partidos políticos, pode submeter a democracia não ao "interesse comum", mas aos interesses "de um grupo dominante". Considerando ser escasso o espaço da democracia direta, mantendo-se todos as sociedades sob a égide quase exclusiva da democracia "indireta", "a liberdade" dos titulares do poder político se reduz ao "simples direito de voto". 33

31 FERRAJOLI Luigi. O Estado de Direito entre o passado e o futuro. In: O Estado de Direito: história, teoria, crítica. Pietro Costa e Danilo Zolo (org.). São Paulo: Martins Fontes, 2006, pp. 422-25. As mesmas lições são proporcionadas pelo autor citado em outro texto de sua autoria, para o qual remetemos o leitor: Sobre los derechos fundamentales. In Teoría del Neoconstitucionalismo: ensayos escogidos. Madri: Editorial Trotta, 2007, p. 71-2. O constitucionalismo é concebido como uma doutrina que prescreve a submissão dos poderes do Estado ao controle jurídico, com vistas à preservação das liberdades individuais. Sobre o assunto, inclusive no tocante ao conceito de Estado constitucional, consulte-se, também, REYES, M. A., La Constitución como Paradigma. In Teoría del Neoconstitucionalismo, op. cit., 2007, p. 32-39; GUASTINI, R., In Teoria del Neoconstitucionalismo, op. cit., p. 16-22;

32 Entendemos o termo "minorias" como representando o grupo de pessoas cuja vontade não se coaduna com a vontade da maioria. Não se trata de um grupo social específico, necessariamente menos numeroso no seio da sociedade, mas antes do grupo de pessoas que não concordam com a posição majoritária estabelecida no processo de elaboração das leis. Em relação ao aborto, por exemplo, não se pode dizer que as mulheres simbolizem, como um todo, uma minoria coagida pela proibição de interromper uma gestação indesejada. Muitas mulheres são contra o aborto, e reforçam a posição que se opõe à sua legalização. Em caso de plebiscito, por exemplo, essas mulheres votariam pela não descriminalização do aborto. Representam a minoria, no sentido usado neste estudo, a qual se vê obrigada a não conduzir seu destino reprodutivo de acordo com sua própria vontade, as mulheres que consideram o aborto uma opção moralmente legítima de controle de natalidade.

33 Cf. KELSEN, 1993, op. cit. p. 29, 40. 
A relação entre as opiniões da maioria e os interesses da minoria, no interior das decisões políticas, é o aspecto não solvido na fundamentação da legitimidade da democracia representativa. Sempre, em caso de ausência de unanimidade de opiniões, uma posição antagoniza com a outra, sem que o critério quantitativo, referente ao número de votantes, signifique garantia de se chegar à decisão correta ou justa, levando-se em conta os interesses de todos. No regime monárquico, o "poder absoluto" de um único homem pode ser mal utilizado com o objetivo de minimizar a força dos adversários. Porque não pressupor que a maioria, no regime democrático, possa incidir no mesmo erro $?^{34}$ Se a maioria pode incidir em erro, porque, em assuntos de valoração ética, em que é justo conceder ao indivíduo ampla autonomia decisória, insiste-se na predominância da opinião do grupo majoritário?

No processo parlamentar, base da democracia representativa, os direitos individuais fundamentais não têm primazia, por isso a defesa desses direitos se solidifica por meio do argumento da necessidade da proteção da "minoria contra a maioria". A questão é complexa, porque "a vontade da maioria" não equivale à "vontade geral", por isso termina simbolizando o "domínio da maioria sobre a minoria". Kelsen rejeita essa tese por entender que o que existe na prática democrática é um embate de vontades, onde a vontade da minoria tem espaço para interferir nas decisões, podendo, em outro momento político, converter sua opinião na opinião majoritária. Isso, em tese, favoreceria a criação de "um compromisso na formação da vontade geral”, que sintetiza "os interesses opostos". 35

Ocorre que a perspectiva de revisão da vontade da maioria, pela evolução natural dos valores sociais, não elimina a facticidade da opressão da minoria, ao menos até o momento em que seus argumentos não alcançam eco na elaboração das leis. Nos países nos quais o aborto é ainda considerado crime, os interesses das mulheres que recorrem ao aborto clandestino, em condição de riscos à própria vida, não vêem sendo levados a sério pelos legisladores, e não se vislumbram, regra geral, grandes esperanças de que isso se modifique, diante da tendência à continuidade da supremacia dos grupos representados pelas autoridades que defendem os interesses do nascituro. Em sua situação como essa, as mulheres que se decidem pelo aborto, minorias no sentido político, são levadas, por razões pessoais, à desobediência à lei e à prática de infração penal, sem que se atente para a necessidade da proteção de suas vidas. Como destacado por Hamilton, o processo de escolha dos representantes políticos pode favorecer "uma classe particular de cidadãos", excluindo, assim, a proteção dos interesses de uma parcela minoritária da sociedade cuja garantia é dever institucional do Estado democrático. ${ }^{36}$

Em um contexto contratual, pressupõe-se que os acordos entabulados coletivamente serão equitativos, protegendo-se os interesses de todos os membros da sociedade, e, ao mesmo tempo, mantendo-se o maior grau de liberdade possível. Entretanto, como afirma Ferrajoli, "a democracia" não se confunde "com a vontade da maioria", razão pela qual uma "presunção apriorística de legitimidade da vontade popular" não é válida. ${ }^{37}$ A perspectiva de um "compromisso" democrático com as posições minoritárias depende do

34 TOCQUEVILLE, Alexis. Democracy in America. United States: Pacific Publishing Studio, 2010, p. 111-112. Nessa obra, escrita em 1835, na qual o autor, embora se mostre fascinado pela eficiência da democracia nos Estados Unidos da America, considera como uma "coisa ruim e perigosa" "o ilimitado poder" conferido pelo país ao critério majoritário. Em nenhum outro país a lei se modifica com tamanha rapidez, o que se garante pela mudança anual dos representantes dos órgãos legislativos e pela forma resoluta em que as decisões são executadas. Tão logo elas se mostrem ineficientes para a realização do princípio da equidade, protegendo os interesses de todos, tão logo elas são alteradas na legislatura seguinte (p. 110). Mas, mesmo com esse nível excelente de funcionalidade, a "onipotência da maioria", segundo Tocqueville, pode assumir uma forma tirânica e despótica, pois todas as instâncias decisórias, desde os poderes constituídos até a opinião pública, se posicionarão em conformidade com um único e mesmo critério, o da dominância majoritária (p. 112). O ilimitado poder da maioria, assim entendido, é ruim em si mesmo, e compromete a liberdade, eis que os indivíduos se enxergam submetidos aos seus ditames até nas questões mais íntimas de sua personalidade. (Para uma compreensão mais detalhada da democracia norte-americana no século XIX, e da abordagem do autor acerca dos riscos do critério majoritário, recomendamos a leitura do próprio livro citado, capítulos XV e XVI, p. 109-123).

35 KELSEN, 1993, op. cit., p. 67-70.

36 HAMILTON, Alexander, JAY John and MADISON James. The Federalist. The Gideon Edition. Indianapolis: Liberty Fund, 2001, p. 310. Ver, no mesmo sentido, TOCQUEVILLE, A, 2010, op. cit. p. 116.

37 FERRAJOLI, Sobre los derechos fundamentales, op. cit., 2007, p. 85. 
estabelecimento de requisitos racionais que promovam a aceitação geral das restrições individuais. Essas restrições precisam ser razoáveis, para que as pessoas não as reputem arbitrárias e opressivas.

Recorrer a um método procedimental tal como o idealizado por Rawls, através das ideias de "posição original" e de "véu da ignorância", certamente é um caminho positivo, do ponto de vista lógico-metodológico, para se alcançar esse resultado. Para aqueles que entendem desnecessária a remissão a tais premissas abstratas de sua teoria da justiça, talvez simplesmente por em prática, no processo político, a concepção segundo a qual os membros da associação política, "como pessoas morais", possuem o direito de participar na escolha dos princípios de justiça, e de argumentar a favor de suas razões, fosse suficiente para a otimização do "compromisso" coletivo com a realização dos interesses antagônicos. Tendo-se em mente o alcance do princípio da equidade, paradigma para o juízo acerca da adequação das restrições políticas às "concepções razoáveis do bem individual", ${ }^{38}$ poder-se-iam assentar, numa visão constitucionalista, limites para além dos quais as decisões parlamentares impeditivas do exercício das liberdades individuais se convertessem em decisões ilegítimas.

Nem é preciso enfatizar que a concretização do ideal "de justiça procedimental perfeita", que requer a inclusão das "liberdades de cidadania igual" - "liberdade de consciência e de pensamento, a liberdade individual e a igualdade de direitos políticos" - não se efetiva nos processos políticos particulares, pois sempre pode ser produzido um resultado injusto. O máximo que se pode alcançar é o sistema "da justiça procedimental imperfeita", cuja tarefa é escolher dentre os vários "arranjos procedimentais" possíveis aquele que tem "maior probabilidade de conduzir a uma ordem jurídica justa e eficaz." 39

É aí que a prática da democracia indireta evidencia suas falhas e seus limites na proteção das liberdades individuais. Em tese, a Constituição deve "garantir uma igualdade equitativa de participação e de influência no processo político". Em um regime democrático, todos devem participar do debate público, todos devem ter condições de avaliar em que medida as "políticas promovem sua concepção do bem público". Para evitar a prevalência dos interesses dos mais poderosos economicamente deve "haver medidas de compensação". "Historicamente", o "governo constitucional" não tem sido capaz "de assegurar o valor equitativo da liberdade política" em razão das "desigualdades do sistema socioeconômico". ${ }^{40}$

Por isso, a teoria constitucionalista gestou outra concepção de democracia, a chamada democracia participativa, segundo a qual o critério majoritário apresenta maior grau de legitimidade se for o resultado da manifestação direta dos cidadãos. Superados os pressupostos do jusnaturalismo e do "positivismo", a noção de uma "Constituição aberta" trouxe nova substância à normatividade jurídica, afastando-a "dos modelos representativos clássicos". A supremacia da "Constituição" é o sustentáculo da "democracia participativa", por ser "o meio mais seguro de concretizar o Estado de Direito". Entender que "a regra" vale "mais que o princípio" é um "contra-senso jurídico", e compromete a "integridade" constitucional. ${ }^{41}$

Firmando a contraposição da democracia participativa ao legalismo jurídico, Paulo Bonavides faz referência à teoria estruturante do Direito de Friederich Müller como sendo a "metodologia interpretativa" por excelência para a implantação de um constitucionalismo dissociado da representação eleitoral. Segundo essa metodologia, a regra do texto legal somente se completa após sua concretização na "dimensão material", construída pelo intérprete do direito no âmbito da "realidade fática". ${ }^{42}$ Com efeito, Müller, logo na introdução de sua doutrina, não deixa dúvidas quanto à originalidade e clareza do método proposto: os "textos de

38 RAWLS, John. Uma Teoria da Justiça. $3^{\text {a }}$ edição. São Paulo: Martins Fontes, 2008, p. 21-3, 38.

39 Ibidem, p. 242-3.

40 Idem, p. 276-9, 282-3.

41 BONAVIDES Paulo. Teoria Constitucional da Democracia Participativa: por um direito constitucional de luta e resistência, por uma nova hermenêutica, por uma repolitização da legitimidade. $3^{a}$ edição. São Paulo: Malheiros, 2008, p. 35, 37, 134. A leitura de Bonavides centraliza-se na interpretação dos artigos $1^{\circ}$, parágrafo único, e 14, da Constituição Brasileira, que enunciam a igualdade da participação política de todos os cidadãos com direito a voto, pela via direta e indireta. Advoga o autor que a não regulamentação do "plebiscito", do "referendum" e da "iniciativa popular" significa impedir a efetivação da "democracia direta", carimbando a atuação do legislativo com a marca da "inconstitucionalidade material por omissão". (op. cit., p. 40,127).

42 Ibidem, p. 38-9. 
normas" são "pré-formas legislativas da norma jurídica, que por sua vez está por ser produzida no decurso temporal da decisão". Em outra linguagem, O texto positivado na lei é apenas uma "norma-programa", do qual se parte para a construção do "âmbito da norma", na concretude da prática jurídica, em que aquele texto adquire conteúdo empírico, reconciliando o ser e o dever ser, o direito e a realidade. Nesse enfoque, Müller insere na estrutura da norma jurídica os "elementos materiais" da vida social. ${ }^{43}$

Pois bem. O que o paradigma da ressignificação material da normatividade jurídica e a dimensão da democracia participativa nos ensinam no que diz respeito ao controvertido tema do aborto? Afigura-se de todo subsistente afirmar que a invalidação das normas penais proibitivas do aborto depende de que se firme sólida posição, nas instâncias decisórias, no sentido de serem elas interpretadas à luz dos princípios constitucionais, pressupondo-se sua primazia sobre a regra textual das leis infraconstitucionais. No contexto brasileiro, a discussão deve situar-se dentro da teoria do constitucionalismo, reputando-se desarrazoado o argumento em defesa da vontade dos representantes dos poderes institucionais de 1940, já que as regras penais em questão foram elaboradas quase cinquenta anos antes da carta de princípios firmada pela Constituição Federal vigente. As técnicas de interpretação conforme a Constituição, utilizadas nas ações de controle de constitucionalidade propostas perante o Supremo Tribunal Federal, têm por fundamento exatamente a concepção de que é no âmbito da aplicação da regra jurídica, com a consideração dos valores imanentes à realidade sócio-empírica, que se confere caráter normativo à regra-texto.

Outro fator a ser sopesado é a dificuldade de se assegurar uma interpretação principiológica nos moldes da democracia representativa. O legislador ordinário, no que pese atuar em nome daqueles que o elegeram, portanto, em nome dos interesses sociais, não tem se mostrado sensível à transformação axiológica que contorna a fundamentalidade das liberdades individuais de escolha de convicções morais e religiosas, que são a expressão maior do pluralismo político, expressamente previsto no artigo $1^{\circ}$, inciso V, da Constituição Federal, como um dos alicerces do "Estado Democrático de Direito". Na perspectiva da democracia participativa, avulta consistente o crescimento da atuação dos juízes, chamados por Paulo Bonavides legisladores de "terceiro grau". O juiz, "desde o advento da Nova Hermenêutica" e pela própria característica de sua função de intérprete da lei, tende a resolver com adequação "as antinomias do positivismo", combinando "a doutrina com a realidade". Em suma, o juiz, ao interpretar a norma, a toma, na esteira de Müller, como ponto de partida, e impõe "a prevalência" "do direito vivo" "sobre a regra oxidada do direito vigente de vestes formais". ${ }^{44}$

Considerando a centralidade do pluralismo moral e político na ordem constitucional, tampouco seria válida a proposta de uma Emenda Constitucional com o objetivo de manter a proibição do aborto salvo nos casos admitidos pelo Código Penal e no caso de anencefalia. Uma tentativa como essa, flagrantemente focada na intenção de impedir a ampliação das hipóteses de legalização do aborto, sofreria a pecha da ilegitimidade democrática, haja vista sua inteira contraposição aos pressupostos adotados pela lei maior no tocante aos direitos fundamentais. Qualquer espécie de revisão da Constituição somente é admissível quando não importa em modificação de sua "identidade material ou axiológica". Reforma tem o significado de uma "modificação marginal” para a concretização de aspectos não detalhados na Constituição. Do contrário, não seria uma mera reforma, mas sim a "instauração de uma nova Constituição". Os "princípios" fundamentais, especialmente os relativos ao direito de escolha de convicções morais, são limites (lógicos) infranqueáveis para a reforma constitucional". ${ }^{45}$

43 MÜLLER, Friedrich. O Novo Paradigma do Direito: Introdução à Teoria e Metódica Estruturantes. $3^{\text {a }}$ edição. São Paulo: Revista dos Tribunais, 2013, p. 11,13,17. É digno de observação o fato de que o constitucionalista alemão é um crítico da jurisprudência do "Tribunal Constitucional Federal" do seu próprio país, que se pauta, na interpretação constitucional, pelo respeito não à "vontade subjetiva do legislador", mas à sua "vontade objetivada". Müller acredita, entretanto, que mesmo essa "vontade objetivada", seja qual for sua compreensão, precisa ser "verificada de modo fundamentado" (cf. op. cit., p. 39). Para um conhecimento mais aprofundado da teoria estruturante do direito, sobretudo dos critérios para a composição dos valores sociais na definição prática do "âmbito da norma", recomenda-se a leitura direta de Müller, op. cit., especialmente da parte B, item 2.

44 BONAVIDES, P, 2008, op. cit., p. 21-2

45 GUASTINI, R. El concepto de Constitución. In Teoría del Neoconstitucionalismo: ensayos escogidos, op. cit, 2007, p. 24-5. 
A importância do controle da constitucionalidade das leis na mitigação "dos excessos da democracia", no sentido dos resultados inadequados da regra majoritária, é destacada nas teorias políticas, sobretudo a partir do século XIX, como o mais poderoso elemento da garantia das próprias premissas do Estado democrático. O debate empreendido nas cortes judiciais, com tendência ao adensamento dos princípios constitucionais, proporciona um balizamento dos "vícios" do "governo popular", equilibrando a influência das paixões e da "impetuosidade" dos argumentos particulares na tomada de decisões que direcionam a prática jurídica. O controle judicial dos atos legislativos representa o "controle" exercido pelo direito sobre a "democracia", o que se coaduna com a perspectiva do aperfeiçoamento máximo da concretização dos direitos no cerne do sistema político. É de acentuar, nesse ponto, a permeabilidade da atuação conjunta das instituições políticas e das instituições jurídicas, estando fora de cogitação, no tempo atual, falar-se, ainda, do descabimento da interferência judicial na vida política. Qualquer tentativa de "diminuir o poder judicial" pode produzir "consequências fatais" ao desenvolvimento da democracia, sobretudo na seara das liberdades civis. ${ }^{46}$

O tema do aborto é um exemplo clássico da pouca abertura do procedimentalismo democrático ${ }^{47}$ à inclusão da liberdade decisória da mulher, na esfera dos direitos reprodutivos. Os problemas socioeconômicos marcam profundamente a condição das mulheres que enfrentam uma gravidez indesejada, e, até por isso, os argumentos favoráveis à regulamentação do aborto, à luz dos direitos de liberdade, deveriam encontrar maior acolhimento no modelo da democracia representativa. Por outro lado, sob o prisma da democracia participativa, postulada por Paulo Bonavides, também não há mecanismos eficazes para que as vozes das mulheres sejam ouvidas no espaço político, haja vista a polarização do debate em torno dos direitos da vida fetal como uma barreira intransponível para a justificação de suas concepções morais particulares. ${ }^{48}$

Ainda assim, é louvável que o "parâmetro tradicional da legalidade", como fonte exclusiva do direito, tenha sido quebrado sob a perspectiva da democracia participativa. A partir daí, as regras do Código Penal criminalizadoras do aborto podem ser questionadas e postas sob o controle de sua "juridicidade". O conceito de "legalidade" estrita foi substituído pelo conceito de "legitimidade", estando este centrado na garantia dos "direitos fundamentais". Os pressupostos da prática jurídica "pós-positivista" agregaram ao paradigma da legalidade os conceitos de "legitimidade" e de "licitude", constituindo o primeiro "um fundamento político" e o segundo "um fundamento moral", ambos essenciais para a dicção do direito sob a ótica de um sistema de justiça. A criação de novas fontes de legitimação, pela participação direta dos cidadãos no processo político, relativizou "o caráter absoluto das leis parlamentares", engrandecendo a atuação de outras instâncias de poder como a dos órgãos que desempenham "as funções essenciais da justiça" ou a dos órgãos executivos. ${ }^{49}$

46 TOCQUEVILLE, A, 2010, op. cit., p. 117,120.

47 Usa-se esse termo no sentido imaginado por Kelsen e Rawls da possibilidade da construção de "arranjos procedimentais" capazes de otimizar uma justa composição entre a equidade e as liberdades individuais.

48 As demandas femininas encontram pouca projeção na mídia, que dá mais espaço para a veiculação dos "dogmas religiosos", deixando de enfatizar, por exemplo, a insegurança do aborto sob a ótica da saúde pública. Em regra, a mulher é ignorada na qualidade de sujeito central da abordagem do tema. Embora os periódicos "jornais, revistas "estejam abertos à informação acerca das liberdades fundamentais e aos direitos reprodutivos, não se reconhece a autoridade da bioética enquanto uma área de conhecimento responsável pela definição dos limites morais da admissibilidade do aborto. Prefere-se a apresentação do drama feminino de uma maneira em que a mulher é mostrada como vítima, e não como sujeito ao qual se nega a capacidade decisória (DINIZ, D, et al. Série Anis: mulheres, mídia e aborto. Série Anis 20, Brasília, Letras Livres, 1-8, maio, 2001, Versão PDF, p. 2-4. Disponível em http://www. anis.org.br/serie/artigos/sa20(dinizdamasceno)mídia aborto.pdf). Saliente-se que, no caso do Brasil, tem-se, atualmente, como autoridade máxima uma mulher. A presidente Dilma Rousseff manifestou-se publicamente, em 04/10/2007, a favor da legalização do aborto. Posteriormente, devido à grande repercussão negativa do seu pronunciamento perante os grupos religiosos e à proximidade da eleição, a presidente se viu forçada a retratar-se, afirmando, em 29/09/2010, ser pessoalmente" contra o aborto, considerando-o "uma violência"(cf. Revista Veja, Editora Abril, edição 2186, ano 43, n. 41, 13/10/2010, capa e p. 62-3. Disponível em www.veja. com).

49 MOREIRA NETO, Diogo de Figueiredo. Juridicidade, Pluralidade Normativa, Democracia e Controle Social. In Fundamentos do Estado de Direito: estudos em homenagem ao Professor Almiro do Couto e Silva. São Paulo: Malheiros, 2005, p. 92-4, 99. 104-5. O autor aborda os novos "critérios de juridicidade para a ação do poder público", os quais contribuem muito para a possibilidade da revisão das leis ordinárias em sede constitucional, e para a solidificação de "uma autêntica democracia material", que vai "muito além dos restritos horizontes da democracia representativa". Um sistema "estritamente procedimental" é ineficaz, porque se alicerça exclusivamente 
Com base na abordagem da democracia participativa, ou material, a investigação acerca dos mecanismos políticos e jurídicos à disposição da mulher para pleitear o direito ao aborto adquire um perfil mais fluido. No Brasil, as mulheres, assim como outros grupos sociais, vêm encontrando canais de aproximação às esferas decisórias do poder executivo. ${ }^{50}$ Contudo, os projetos de reforma da legislação penal, no tocante ao aborto, esbarram nos impedimentos criados pela posição majoritária. A ideia de um plebiscito, como uma forma de trazer a decisão para o plano da democracia direta, com a participação de todos os cidadãos, configura uma proposta inovadora, mas pode não conduzir ao resultado esperado em relação à ampliação da autonomia da mulher. Em caso de vitória da posição contrária, o engrandecimento do exercício do poder da mulher, como sujeito de direitos, seguiria impedido pelo critério majoritário, não sendo demais enfatizar que os aspectos morais da formação da personalidade não se subordinam à chancela popular ou estatal.

\section{TEORIAS DA JUSTIÇA: ÉTICA E MORALIDADE POLÍTICA}

O debate sobre o aborto direcionou-se, nos tempos atuais, para o aprofundamento das teorias morais, que procuram delinear parâmetros gerais de definição das obrigações políticas que os indivíduos assumem perante a comunidade em que estão inseridos. Aliás, separar o que pertence à esfera da livre condução da própria vida e o que constitui dever moral, em relação aos direitos e interesses dos outros, é questão essencial para o propósito de delimitar a ação legítima do Estado na restrição dos direitos individuais em geral, não só no que tange ao aborto.

A distinção filosófica entre os valores éticos e os valores morais é o ponto de origem para a divisão entre o âmbito do exercício das liberdades subjetivas e o âmbito do exercício do poder coercitivo do Estado. Na tentativa de investigar esse controverso tema, nas sociedades democráticas, tomaremos como referência maior o magistério de Ronald Dworkin, que afirma o seguinte: os princípios éticos configuram juízos acerca das ações humanas que os indivíduos podem livremente realizar para o seu próprio bem-estar. O fundamento da liberdade decisória, em assuntos pertencentes à ética, é o "princípio da responsabilidade pessoal", do qual deriva o conceito de "independência ética". Por outro lado, os princípios morais dizem respeito àquilo "que nós devemos fazer, e não fazer, aos outros". ${ }^{1}$

Dworkin, através de uma interpretação que integra a ética e a moral, constrói uma teoria objetiva substancialista, com o intuito de justificar seu princípio da "independência ética". Em outras palavras, procura estabelecer critérios para a classificação dos juízos éticos entre juízos verdadeiros ou falsos. Ao mesmo tempo, rejeita as premissas metaéticas, que, para algumas teorias filosóficas, constituem fundamentos transcendentais que conferem objetividade, ou caráter de verdade ou falsidade, aos juízos éticos. A filosofia substancialista de Dworkin se alicerça em argumentos morais, e não metafísicos. Em seu esforço de refutar o relativismo moral, Dworkin firma critérios argumentativos que possam levar, por meio de uma "reflexão compreensiva", a uma decisão correta para os problemas práticos da vida sócio-política. ${ }^{52}$

nas regras formais para a escolha dos agentes políticos, não importando o conteúdo das leis ou das políticas públicas (op. cit., p. 105-7, 109-10).

50 Não há lugar, nesse ensaio, para a consideração do grau de eficácia das políticas públicas do Ministério da Saúde e áreas técnicas do executivo, além de outras entidades de direitos humanos. Deixaremos o tema para estudo futuro, que queremos realizar seguindo as premissas ora desenvolvidas da urgência da implementação de um paradigma constitucional de legitimidade e aplicação das leis.

51 DWORKIN, Ronald. Justice for Hedgehogs. Cambridge/Massachusetts: Harvard University Press, 2011, p. 1-2, 4, $13,25$.

52 Ibidem, p. 23-27. Entenda-se o termo relativismo como significando a negação da existência de critérios racionais para o julgamento dos juízos morais, o que importa em tomar todos os argumentos na condição de argumentos igualmente válidos, não se atentando para o parâmetro de sua razoabilidade. Nesse sentido, relativismo não se identifica com pluralismo, no qual a aceitabilidade dos argumentos depende de sua compatibilidade com os princípios morais universalmente aceitos. A tortura e a escravidão, por exemplo, não são justificáveis sobre o prisma do pluralismo, embora possam o ser sob o prisma do relativismo. Este, devido à total ausência de objetividade na avaliação da validade das proposições morais, pode desembocar na institucionalização de ideologias 
Os julgamentos de natureza moral subsumem-se à distinção entre a esfera da "moralidade pessoal" e a esfera da "moralidade política". No primeiro caso, o juízo de valor é definido a partir de um enfoque individual, incumbindo a cada pessoa delimitar o dever que possui "de ajudar os outros e de não prejudicá-los", independentemente da deliberação coletiva. No segundo caso, trata-se de definir as obrigações impostas a todos os membros comunitariamente organizados sob a forma de Estado social, no que concerne aos interesses dos outros..$^{53}$ Desse modo, o poder coercitivo da sociedade organizada somente deve ser exercido na regulação das questões de moralidade política, que, como tal, caracterizam uma espécie de eticidade unitária, de cunho coletivo. $\mathrm{Na}$ dimensão da moralidade política, para os assuntos que lhe são próprios, é legítimo, portanto, falar-se em obrigações morais culturalmente construídas, a partir de valores e convicções comunitárias, reduzindo-se, nessa esfera, a proteção da autonomia individual.

Nessa perspectiva, Dworkin problematiza a possibilidade de se afirmar uma solução correta para a efetivação do direito ao aborto. Para o autor, a incerteza das respostas dadas pelas duas posições conflitantes, a favor e contra o aborto, não implica na certeza de que não exista uma acomodação correta entre elas. $\mathrm{O}$ argumento que defende a proibição do aborto não seria, assim, "mais forte ou mais fraco" que o argumento que defende sua permissão. Normalmente, nos casos difíceis (hard cases) não se alcança uma decisão que se pretenda correta adotando-se completamente uma das posições antagônicas, ou seja, nenhum dos dois lados apresenta o melhor argumento como um todo. ${ }^{54}$

Sob o enfoque do Estado Democrático de Direito, a normatização de julgamentos morais a respeito de assuntos complexos e sensíveis, dentre os quais se destaca aquele em estudo, depende, em primeiro lugar, da consolidação de um paradigma fundado não somente nos interesses sociais, mas, com igual peso, na ampliação dos direitos individuais. Compreender se o aborto, na linguagem de Dworkin, é um tema de natureza ética, de moralidade pessoal ou de moralidade política é essencial para o desenvolvimento da reflexão. Nas duas primeiras hipóteses, não seria o caso de se exigir um acordo coletivo sobre a admissibilidade do aborto, o que retiraria a legitimidade do Estado de impor uma valoração única obrigatoriamente vinculante no âmbito da vontade individual. Na terceira hipótese, em sendo o aborto uma questão de moralidade política, o poder decisório da mulher demandaria uma acomodação racional no interior do processo político-deliberativo, não se perdendo de vista as devidas restrições ao poder coativo do Estado.

É razoável propor, ainda, que a justificação do direito ao aborto possa envolver conclusões distintas de acordo com o desenvolvimento do processo gestacional. O que se quer dizer com essa proposição é que o aborto pode, por exemplo, ser considerado um tema afeto à liberdade ética ou à moralidade pessoal até determinado estágio da gestação, e um tema afeto à moralidade política após esse tempo. Em sociedades mais liberais, como a norte-americana, admite-se a liberdade decisória da mulher, no que concerne ao aborto, até o final do segundo trimestre de gestação, sendo que os estados podem regular sua realização após o final do

políticas totalitárias e absolutistas. Com efeito, John Rawls, em sua defesa do pluralismo político, preocupa-se em enfatizar que a noção de "consenso sobreposto", que, segundo o autor, possibilita a conciliação entre diferentes concepções de bem e de justiça, não configura uma perspectiva de Indiferença à definição de uma concepção como sendo mais razoável que as demais. Não se trata, portanto, como voltaremos a falar adiante, de uma proposição cética ou relativista (Cf. RAWLS, J. Political Liberalism. Expanded Edition. New York: Columbia University Press. 2005, p. 150).

53 Idem, p. 327-8.

54 Idem, p. 42,44, 95. A rigor, Dworkin acredita ser possível justificar uma posição a favor ou contra o aborto com base em "fundamentos morais", e que, por isso, as diversas opiniões sobre o assunto não são igualmente válidas, a maneira do que é afirmado pelos autores céticos, dentre os quais Dworkin destaca Rorty. Se o aborto fosse considerado certo ou errado exclusivamente com base nas opiniões subjetivas das pessoas, não seria possível buscar uma resposta que fosse sustentável como a mais correta do ponto de vista dos valores constitucionais objetivos (Cf. Objectivity and Truth: You'd Better Believe it. In: Philosophy and Public Affairs, Vol. 25, No. 2, Spring, 1996, p. 95-99. Disponível em < http://www.jstor.org/stable/296192>. Acesso em 10/08/12). O significado de objetividade em relação aos juízos morais, que Dworkin defende em substituição ao conceito de verdade das teorias realistas, atende à pretensão de fundamentar um modelo de avaliação das convicções morais que se desprenda da visão cognitivista. Pretensões morais não se validam por sua correspondência a fatos, ou, melhor dizendo, não possuem estatuto ontológico. Ver também, no mesmo sentido, TERSMAN, Folke. Moral Disagreement. Cambridge/New York: Cambridge University Press, 2006, p. 18. 
primeiro trimestre de gestação. ${ }^{55} \mathrm{Na}$ maioria dos países europeus, assim como em alguns países latino-americanos, que na última década legalizaram o aborto, como o México e o Uruguai, essa liberdade é garantida, grosso modo, até doze semanas, ou, no mínimo, até dez semanas de gestação. ${ }^{56}$

Adotando-se essa gradação na definição da natureza do direito ao aborto, sob o enfoque da teoria da moralidade, fácil é concluir que no Brasil tanto o Congresso Nacional quanto o poder judiciário estão autorizados, no exercício dos poderes que lhe são próprios, a submeter a legislação punitiva do aborto a um procedimento de atualização hermenêutica, sopesando sua compatibilidade com a índole principiológica da Constituição vigente. Nem seria importante ponderar se o aborto, nos estágios iniciais do desenvolvimento embrionário ou fetal, ainda utilizando a conceituação de Dworkin, é uma questão que pertence à esfera da moralidade individual ou da ética, pois, em ambos os casos não se caracterizaria a legitimidade do Estado de impedir a efetivação da liberdade de escolha.

Sob qualquer ângulo de análise, a discussão moral sobre o aborto se centraliza na tensão existente entre as obrigações políticas legitimamente impostas aos indivíduos e suas liberdades básicas. Uma comunidade é uma espécie de categoria coletiva do pensamento político, que se sobrepõe aos interesses individuais nos assuntos de interesse público. A obrigação moral de tratar todos os cidadãos com "igual consideração e respeito" certamente limita as liberdades individuais. Contudo, podemos dizer, junto com Dworkin, que "liberdade e igualdade" não são "valores conflitantes", o que fornece fundamento para a compatibilização entre os poderes coercitivos do Estado e a liberdade de decisão individual nos projetos de natureza ética. Para isso, os direitos reprodutivos, particularmente o direito ao aborto, em algumas circunstâncias fáticas, devem "ser regulamentados com fundamento na independência ética", e não com fundamento na "verdade ou" "popularidade de um julgamento ético coletivo". ${ }^{57}$

A liberdade de definição de perspectivas de vida, e sua vinculação ao princípio da igual proteção "perante a lei” (CF, art. $5^{\circ}$, caput), é assunto bastante desenvolvido pelas teorias da justiça, que procuram estabelecer até que ponto a sociedade pode exigir dos cidadãos que se sacrifiquem em prol do bem comum. John Rawls assenta um modelo de estrutura social calcado na prevalência do princípio da liberdade. Os princípios da justiça de Rawls demandam a não imposição de sacrifícios excessivos aos indivíduos, na seara dos seus projetos de vida. ${ }^{58} \mathrm{~A}$ análise é conduzida sob o prisma do sentimento de "auto-respeito", que importa no direito de cada um de levar adiante sua "própria concepção do bem". 59

Não obstante o suporte filosófico-jurídico fornecido por teóricos de perfil liberal, como Rawls e Dworkin, para a justificação da admissibilidade moral do aborto, temos consciência da dificuldade argumentativa envolvida nesse propósito. A distinção entre moralidade e eticidade é bastante problemática, e recebe abordagem variada nas distintas teorias de justificação moral. Além disso, são enormes as dificuldades encontradas na operacionalidade prática dessa distinção, não se alcançando um consenso. O tema do aborto é emblemático nesse sentido, pois pode ser considerado um tema próprio da razão pública, que, como tal,

55 Conforme decisão da Suprema Corte, caso Roe v. Wade, 410 U. S. (1973).

56 Apenas mencionamos a informação acima a fim de ponderar a existência de possibilidades diferenciadas de incorporação da proteção das liberdades individuais em um sistema jurídico-constitucional. Não podemos tratar, no espaço desse texto, da regulamentação do aborto nos diversos países democráticos. Mas podemos afirmar não haver mais lugar para a não legalização do aborto em nível adequado à evolução do acolhimento dos direitos de liberdade. O Brasil, diga-se de passagem, deu início a uma mudança interpretativa em direção a essa meta, com a decisão proferida na ADPF 54, que autorizou a antecipação do parto de feto anecéfalo, com fundamento na autonomia reprodutiva e na proteção da saúde da mulher (Acórdão disponível em www.stf.jus.br).

57 DWORKIN, 2011, p. 331, 376.

58 Ver, a esse respeito, PIEROTH, Bodo e SCHLINK, Bernhard, Direitos Fundamentais - Direito Estadual II, 2008, p. 113; Em regra, essa ideia se apresenta na doutrina sob o prisma do que se costuma chamar: "direito de personalidade em geral". Ver, também, CANOTILHO, J. J. Gomes, Direito Constitucional e Teoria Constitucional, $3^{\text {a }}$ edição. Coimbra: Livraria Almedina, 1999, que chega a afirmar que "cada vez mais os direitos fundamentais tendem a ser direitos de personalidade e vice-versa" (1999, p. 372). DWORKIN concebe a mesma ideia, vinculando-a expressamente ao princípio da dignidade enquanto uma dignidade humana individual (Life`s Dominion, 1994, p. 233-237).

59 RAWLS, John. Uma Teoria da Justiça. $3^{a}$ edição. São Paulo: Martins Fontes, 2008, p. 217-9. Rawls se preocupa em estabelecer qual o modelo de justiça melhor edifica "a base moral pública da sociedade". (p. 223). 
exige uma definição comunitária à qual todos obrigatoriamente devem submeter-se, independentemente de suas valorações pessoais, ou pode ser considerado uma questão cujo conteúdo moral deve ser determinado autonomamente pela mulher, decidindo ela própria, sem interferências alheias, em caso de gravidez indesejada, pela realização ou não do aborto.

A teoria moral de Jürgen Habermas é um exemplo de fundamentação de uma racionalidade moral fundamentada no consenso argumentativo. Trata-se de uma perspectiva procedimental na qual não há lugar, ao menos de forma significativa, para a afirmação dos princípios éticos enquanto princípios centrados na concepção individual de bem-estar. Os conceitos éticos e os conceitos morais, inclusive, são diferenciados por Habermas de maneira não coincidente àquela definida por Dworkin. Em Habermas, a esfera da moralidade corresponde ao modelo monológico da razão prática kantiana. Sendo assim, afirmar a ilegitimidade da ingerência social nos direitos de liberdade, em determinadas matérias, se assim se pretende, é algo que se situa, na ética do discurso de Habermas, no plano da moralidade abstrata, estruturada a partir de princípios derivados da razão pura. Por outro lado, a "vida ética" (Sittlichkeit) se sedimenta no contexto interpretativo-pragmático de uma comunidade sócio-política. ${ }^{60}$

Habermas é enfático em posicionar-se, a partir de seus postulados teóricos, no sentido "da primazia da vida ética sobre a moralidade", propondo um modelo de normatividade historicamente contextualizada. Sob tal enfoque, até mesmo as decisões em relação às quais seria razoável a proteção primal do respeito às escolhas individuais estão subordinadas ao procedimento de justificação argumentativa, ou seja, as convicções morais individuais somente são passíveis de adquirir validade normativa quando objeto de um acordo coletivo. Afirmar o respeito pelas crenças e convicções pessoais razoáveis, sob o prisma da ética da responsabilidade de Dworkin, é algo que se contrapõe, em princípio, ao critério da validade intersubjetiva dos julgamentos morais, em um sistema de cooperação discursiva, tal como o construído por Habermas. ${ }^{61}$

A pergunta que ressurge no âmbito dessa controvérsia reflexiva é a seguinte: qual o espaço concedido pela ética do discurso às liberdades individuais? O "princípio da universalização", como "regra de argumentação" essencial da ética do discurso, não conduz, por certo, à exclusão de qualquer noção de autonomia da vontade. Em última instância, a teoria moral habermasiana preserva as premissas democráticas por meio do perfil não coercitivo da prática comunicativa, que assegura a todos os membros da comunidade igual oportunidade de participação e de apresentação de suas razões. Ocorre que o acolhimento social de uma pretensão de validade individual depende de que o interessado consiga convencer o grupo de participantes acerca da admissibilidade dos seus propósitos. ${ }^{62}$ Desse modo, a ética do discurso restringe o caminho jurídico para a legalização do aborto, porque, de acordo com suas premissas procedimentais, somente duas únicas vias parecem dotadas de legitimidade para o encaminhamento da questão: ou uma reforma legislativa, cuja validade estaria firmada pelo postulado da representatividade popular dos membros do parlamento, ou um plebiscito, em que a comunidade seria chamada a decidir diretamente quais os direitos da mulher no co-

60 Esclareça-se que Habermas segue a distinção originariamente estabelecida por Kant entre os termos Moralität e Sittlichkeit (Apud ROSENFELD, M., Law, Justice, Democracy, and the Clash of Cultures - a Pluralist Account. Cambridge/New York: Cambridge University Press, 2011, p. 27). Voltaremos a falar acerca desses conceitos na análise do sistema da razão prática kantiana. Enfatizese, contudo, que não importa tanto a modificação operada por Dworkin no significado desses conceitos, como exposto acima, por tratar-se de uma divergência meramente terminológica. Eticidade em Habermas e Kant é imanente à realidade sócio-política, no que pese em Kant ser uma categoria não remetida ao contexto de uma justificação discursiva intersubjetiva, e sim conectada ao exercício da faculdade racional em si mesma. Eticidade em Dworkin concerne à dimensão da independência individual na definição de valores e crenças subjetivas. A rigor, como já afirmado, a esfera da moralidade política, para Dworkin, corresponde à esfera da eticidade de Habermas, porém, com uma pretensão de se restringir o poder interventivo da sociedade nas decisões individuais. Sua tentativa de especificar os temas de moralidade política tem por escopo exatamente a formulação de um critério para delinear tais restrições, portanto, para legitimar um quadrante decisório que não se insira no procedimento deliberativo coletivo.

61 Cf. HABERMAS, Jürgen. Moral Consciousness and Communicative Action. Cambridge/Massachusetts: The MIT Press, 1990, p. 44, 18-20.

62 Ibidem, p. 57, 27, 36-7. Habermas procura estabelecer a especificidade da "argumentação moral" em relação às outras formas de argumentação. Acentue-se que os juízos de validade moral podem ser considerados certos ou errados no sentido normativo, e não no sentido das proposições cognitivas, às quais se atribui verdade ou falsidade. 
mando sobre o seu corpo e sobre sua vida reprodutiva. A rigor, estaria excluída a atuação jurisdicional no controle de constitucionalidade das leis ordinárias enquanto uma via procedimental legítima na defesa dos direitos subjetivos, o que se contrapõe à perspectiva defendida nesse estudo no sentido de que o aborto, assim como o casamento homossexual, não deve ser submetido à consulta popular.

Em seus textos fundamentais de elaboração da teoria da ação comunicativa, Habermas não aborda o tema do aborto; mas não é difícil extrair do seu sistema normativo que a perspectiva da sua legalização deve ser remetida à comunidade discursiva, o que exige, em quaisquer circunstâncias, um acordo democrático. Quer dizer, as "intenções individuais" devem ser "coordenadas" para o estabelecimento de uma decisão conjunta. Avaliar, por exemplo, se a mulher tem condições de assumir, de forma responsável, os encargos da maternidade, sem prejudicar excessivamente sua própria vida, e se isso pode ser aceito no que pesem os interesses da vida nascitura envolvida no processo gestacional, é uma questão que necessariamente deve ser objeto de uma formulação legislativa. Habermas acredita sobremaneira que a exigência de que todos tenham igual oportunidade de defender seus interesses, e expor suas razões de maneira autônoma, "neutraliza" possíveis "desequilíbrios de poder". Com isso, estaria preservada a "autonomia na formação da vontade", bem como o objetivo da busca de um "compromisso" em prol da conciliação dos "interesses particulares". ${ }^{63}$ Aqui, as mulheres teriam que acatar o júzo coletivo, pressupondo-se seu acerto em decorrência do estatuto democrático-procedimental da ação comunicativa.

Pode-se dizer que o procedimentalismo de Habermas contrapõe-se ao substancialismo de Dworkin, e ao conceito deste de independência ética, porque elimina do procedimento de justificação dos princípios morais o menor nível de "decisionismo", que seria defensável, inclusive, sob a ótica da doutrina dos direitos fundamentais. Habermas, aliás, entende que a preservação de um "resíduo de decisionismo" reforça a posição do cético, que não exige um consenso acerca dos assuntos morais, situando tais questões no campo do relativismo valorativo. Para Habermas, a recusa da inserção de um dilema moral, por mais sensível que seja, na comunidade argumentativa, não se sustenta, porque simplesmente não há como neutralizar "uma forma de vida sociocultural compartilhada". Todos os indivíduos nascem e crescem em "uma rede de ação comunicativa". O cético, prossegue Habermas, pode se contrapor aos princípios morais abstratos, mas não à dimensão da eticidade, na qual ele "é continuamente forçado a tomar uma posição respondendo sim ou não". A própria formação da "identidade" individual parte do "pertencimento a grupos sociais". Em última instância, o "princípio do discurso ético" "não provê diretrizes substantivas mas somente um procedimento", o que não implica na abstração de qualquer conteúdo, cotidianamente apresentado na ação comunicativa. Porém, esse conteúdo, em seu caráter contingencial, subordina-se ao procedimento discursivo, que descarta "os valores particulares" como "não suscetíveis de consenso". Habermas não está preocupado com "afirmações valorativas" que se relacionem à ética da "boa vida", e que, por isso mesmo, não tenham sentido normativo. O "bem", estando voltado para as expectativas individuais, não se mistura com o "justo". Uma "ética deontológica" está dirigida exclusivamente a questões da razão prática "que podem ser debatidas racionalmente", isto é, que podem ser objeto de um consenso. ${ }^{64} \mathrm{Em}$ suma, moralidade e eticidade em Habermas constituem duas categorias normativas centradas em um procedimento de justificação de pretensões de validade que se subsumem ao princípio discursivo da universalização. A autonomia da vontade individual, moral ou ética, não seria, então, assunto de conteúdo normativo.

Considerando que a legalização do aborto envolve diretamente a abordagem dos limites da autonomia decisória, logo se vê que uma investigação a esse respeito impõe que se parta de premissas distintas, que possibilitem a atribuição de conteúdo normativamente aceitável à perspectiva da descriminalização do aborto. Aqui, não há como não retornar a reflexão para o adensamento da utilização do conceito de "independência ética" de Dworkin na qualidade de um parâmetro fundamental para a tese da inconstitucionalidade da proibição incondicional do aborto voluntário fora das hipóteses de violência sexual ou de anomalia fetal. Em

63 Idem, p. 71-2;

64 Idem, p. 99-104. 
outra linguagem, uma teoria ética, do ponto de vista da proteção dos direitos subjetivos e da consequente necessidade de se restringir o poder coativo do Estado nas escolhas individuais afetas à concepção de uma "boa vida", exige sim a atribuição de estatuto normativo a juízos morais que não se sustentem sob o paradigma do consenso argumentativo. Do contrário, a regulamentação do aborto estaria limitada à ação política coletiva, fechando-se as portas para as instâncias institucionais com maior potencialidade para a promoção de uma ampliação do respeito às liberdades individuais.

Tendo isso em mente, concluímos que a admissibilidade ético-normativa da decisão de realizar o aborto é passível de acomodação sócio-política com fundamento nas liberdades constitucionais fundamentais. Uma conclusão coerente com o Estado de Direito é a de que durante o primeiro trimestre da gestação os interesses da vida pré-natal não são tuteláveis ao ponto de se sobreporem à independência ética da mulher, ou, utilizando-se uma terminologia jurídica, à liberdade de crença e de convicções filosóficas. A primazia dessas liberdades subjetivas atribui solidez à afirmação de que, a escolha da mulher, nos estágios iniciais da gestação, de ter ou não o filho que está no seu ventre, é uma questão de moralidade pessoal, incumbindo unicamente a ela definir o valor a ser conferido à vida do embrião ou feto. A ausência de previsão constitucional expressa do direito à vida nascitura desde a concepção legitima o entendimento de que a proibição do aborto não pode ser imposta, desde o início da gestação, no âmbito da moralidade política. Em outras palavras, submeter a vontade da mulher ao consenso majoritário, nesses parâmetros, importa no desrespeito a uma liberdade básica.

\section{LIBERDADE DE DECISÃO REPRODUTIVA: UM COMPONENTE DO PLURALISMO MORAL E RELIGIOSO}

A defesa da descriminalização do aborto se sustenta na noção de pluralismo moral, que acolhe "a diversidade de crenças e valores". O pluralismo, "como princípio ético", garante a conformação de todas as crenças "que respeitem os valores fundamentais da democracia", ou seja, aquelas que se mostrem "razoáveis". Isso não implica, como já salientado no presente texto, na adoção de uma visão integralmente relativista, e na inviabilização do julgamento racional da validade política das opiniões pessoais. ${ }^{65}$

As restrições morais são impostas às pessoas sob a pressuposição da existência de características comuns a todos nós, como a racionalidade, o livre-arbítrio e a capacidade de agir em conformidade com princípios e projetos de vida. As restrições morais constituem, a rigor, limitações à maneira em que cada indivíduo pode tratar os outros, porque os outros merecem a mesma consideração que cada um dispensa a si próprio. ${ }^{66}$ Por outro lado, a ideia de igual consideração também serve de parâmetro para a afirmação do direito à diferença, com a "máxima" "acomodação dos diversos modos de vida". A tolerância às divergências interpessoais, em matéria de valoração moral e religiosa, é o paradigma contemporâneo da legitimidade do poder estatal. A democracia recebe novo significado, para que os assuntos cuja definição não exige a "unidade cívica" sejam postos no espaço da primazia do princípio do pluralismo. Quer dizer, nesses assuntos os indivíduos ou grupos não se obrigam a obedecer às posições prevalentes, ainda que estas representem a "voz da comunidade política inteira", podendo seguir suas convicções sem serem compelidos a apresentar justificativa às autoridades políticas ou instâncias sociais no tocante às razões de suas escolhas. ${ }^{67}$

65 DINIZ, Débora. Ética, Aborto y Democracia. despenalizacion.org.ar: por la despenalización del aborto, nº 6/Febrero 2008 , p. 1. Disponível em http://www.despenalizacion.org.ar/pdf/Organoformativas/ 06_Diniz.pdf. Acesso em 03/02/12.

66 NOZICK, op. cit., p. 61-64.

67 GALSTON, William A., Diversity, Toleration and Deliberation Democracy, in MACEDO Stephen. Deliberative Politics. New York/ Oxford: Oxford University Press, 1999, p. 43, 45, 40. Prescrevendo, igualmente, a tolerância pública às diferenças, no aspecto das convicções morais, Michel Rosenfeld pondera: "Deve-se, no mínimo, ser permitido ao indivíduo, e, melhor ainda, ser encorajado, a desenvolver e perseguir um plano de vida por si mesmo, e as diferenças entre os planos de vida individuais devem ser, em princípio, respeitadas". (...) "acomodar a pluralidade requer que se encontre uma forma plausível e legítima de reconciliar e harmonizar unidade e diversidade". Dizendo de outra forma, deve ser sedimentada "qualquer estrutura normativa que possa oferecer o melhor con- 
Como já pontuado, uma visão renovadora da democracia, sob o ângulo da afirmação das liberdades individuais, possui uma relação bastante próxima com a "filosofia política do liberalismo". Da mesma forma, não há como falar-se em pluralismo moral e religioso, cujo significado vincula-se essencialmente ao acolhimento de múltiplos valores ou visões de mundo, sem recorrer às premissas originais da teoria liberal. Nas palavras de William Gaston, o liberalismo é definido como uma doutrina que justifica a "proteção da diversidade e a promoção da autonomia". Tal perspectiva deve ser concebida como parâmetro para a elaboração das "políticas constitucionais" "do pluralismo valorativo", que tenham como escopo restringir a imposição de normas obrigatoriamente vinculantes a um nível compatível com as necessidades do interesse público ${ }^{68}$ Concordamos com a proposição de um sistema político aberto à participação "dos vários grupos ou camadas sociais" na composição "da vontade coletiva", ou seja, um modelo de sociedade na qual "o indivíduo tem a máxima possibilidade de participar na formação das deliberações que lhe dizem respeito" . ${ }^{9}$ O pluralismo insere-se no contexto das liberdades fundamentais, sobretudo no que diz respeito à defesa e garantia da multiplicidade psíquica, ideológica, ética e religiosa.

Algumas críticas são feitas ao privilégio conferido pela teoria liberal aos interesses individuais em relação aos interesses de grupos, representantes de camadas específicas, muitas vezes discriminadas, da sociedade. Entretanto, a abordagem do liberalismo adequada ao sistema democrático aponta um padrão suficiente para "separar as diferenças que podem ser acomodadas daquelas que não podem", balizando "a separação entre a esfera pública e a esfera privada". Assegura-se, assim, o respeito às liberdades básicas sem ameaçar a proteção constitucional aos interesses de cada uma das camadas sociais, que sejam reivindicados no espaço do debate democrático. Equilibrar a vinculação da teoria liberal ao individualismo, de acordo com a necessidade imposta pelos interesses coletivos, não é o mesmo que repudiar "a capacidade individual para a escolha moral". ${ }^{70}$

$\mathrm{Na}$ esfera da liberdade moral de escolha, destaque-se que o aborto é um assunto tipicamente associado ao direito à diferença, cuja contraposição aos interesses coletivos somente seria arguível a partir de uma leitura que atribua ênfase demasiado estendida à prevalência da moralidade majoritária. A mitigação dessa prevalência, e uma posição a mais neutra possível, por parte do poder institucional, nas definições particulares de bem, no sentido de valor moral ou ético para a condução da própria vida, é estratégia imposta pela dimensão do pluralismo.

Em nenhuma leitura, a legalização do aborto representa uma ameaça a qualquer direto coletivo, seja em termos gerais, seja em termos da demanda de um grupo social determinado. Salvo melhor compreensão, não é plausível confundir perspectivas de inclusão de grupos marginalizados com o interesse de se preservar valores tradicionais. $\mathrm{O}$ direito ao aborto é ele próprio postulado por um grupo social específico, o grupo daqueles que são favoráveis ao direito de escolha, mas existe uma peculiaridade, no caso, na estrutura do conflito de posições. Pode-se afirmar, à primeira vista, que o que se está a reivindicar não configura "direitos coletivos pertencentes ao grupo como um todo", mas como "direitos individuais" pertencentes às pessoas que não compactuam a visão convencional de que interromper a gestação seja um ato absolutamente reprovável, do ponto de vista moral. ${ }^{71}$ Efetivamente, existe uma permeabilidade conceitual entre direitos individuais e coletivos, não havendo razão para que se dê importância à definição categorial dos direitos

junto de preceitos morais e legais para propriamente sustentar a pluralidade e a singularidade individual” (ROSENFELD, M, Law, Justice, Democracy, and the Clash of Cultures - a Pluralist Account. Cambridge/New York: Cambridge University Press, 2011, p. 24, 25).

68 GASTON, W., Legal and Political Implications of Moral Pluralism, The. In Maryland Law Review, volume 57, 1998, p. $241,243,246$.

69 BOBBIO, N. As Ideologias e o Poder em Crise. Brasília: Editora UNB, 1999, pp. 16 e 22.

70 ROSENFELD, M., op. cit., p. 78-9.

71 Essa distinção entre duas concepções de direitos minoritários é apresentada por Michel Rosenfeld, que explica que há uma controvérsia doutrinária entre a caracterização dos direitos coletivos e dos direitos individuais. Analisados corretamente, todos os direitos tendem a ser, no fundo, direitos individuais. Mas, para Rosenfeld, "pelo menos do ponto de vista legal e político", deve ser mantida a diferença entre as duas categorias de direito. Inclusive, pensa o autor, a resolução do conflito pode ser facilitada se os direitos individuais forem apresentados como direitos de um grupo, significando uma parcela da comunidade manifestando sua opinião sobre o melhor esquema de relação entre o público e o privado (op. cit., p. 99, 101). 
no embate argumentativo concreto, o que teria sentido meramente retórico. De todo modo, seja o direito ao aborto classificável, no contexto político e jurídico, como um direito puramente individual ou como um direito que favorece um grupo social específico, indubitavelmente minoritário, é legítimo dizer que a controvérsia está na afirmação de um modelo de sociedade pluralista que comporte a autonomia da vontade no tocante à decisão reprodutiva. Rejeitar a acomodação do aborto voluntário implica na derrota do pluralismo, pela desconsideração dos valores pertencentes a uma parcela dos membros da associação política.

Se a filosofia racionalista e seus princípios de autodeterminação da vontade se mostram inteiramente adequados à garantia do pluralismo de valores, exatamente o contrário se pode dizer no tocante às doutrinas religiosas. É nesse campo que a sociedade contemporânea enfrenta o maior desafio na seara da evolução dos direitos individuais. A emergência de diferentes concepções religiosas traz para o mundo político a necessidade de se empreender grande esforço no sentido da pacificação e da concretização da "tolerância mútua" no contexto da vida civil. ${ }^{72} \mathrm{O}$ crescimento da população aderente às crenças muçulmanas e do número de pessoas que adotam outras religiões cristãs que não o catolicismo é fator que favorece o dimensionamento do pluralismo. Por outro lado, contudo, a participação das forças religiosas nas decisões políticas tende a dificultar a construção de um modelo secularizado que efetive o direito daqueles que não professam nenhum tipo de crença, e reivindicam do poder público a não interferência das visões de mundo místicas na delimitação das liberdades básicas, cujas restrições devem necessariamente estar pautadas por "razões públicas", utilizando-se a linguagem de Rawls. ${ }^{73}$

A necessidade de se combater a intolerância religiosa, que tende a monopolizar a verdade, é bem situada também por Michel Rosenfeld, que propõe, uma estrutura de sociedade onde exista uma interação entre o que ele chama de "identidade constitucional" e as múltiplas identidades culturais e religiosas geradas no interior de uma determinada comunidade política. Nesse movimento dialético, a incorporação, no plano jurídico, das concepções religiosas a respeito do bem somente se legitima na medida em que não haja a prevalência de uma única, dentre elas, em detrimento das demais, ou em detrimento das concepções não religiosas. ${ }^{74} \mathrm{~A}$ fim de garantir "o igual respeito a todas as diferentes identidades culturais" a estratégia política não pode ser outra senão a da interação entre "o universalismo dos direitos fundamentais" e "o multiculturalismo". Todas as pessoas, professem elas as crenças ou não crenças que queiram, devem "superar" os "preconceitos" e o "presunçoso analfabetismo cultural". ${ }^{75}$

A "homogeneização" do pensamento religioso coloca em risco a liberdade de consciência, enquanto um conceito que abrange as opções religiosas, agnósticas e ateístas. Assim, mesmo o propósito de um "ecumenismo religioso" não pode ser "fomentado pelo Estado", na medida em que se afirma "o fato do pluralismo como elemento insuperável da sociedade contemporânea e democrática" . ${ }^{76}$ A Constituição brasileira, no artigo 215 , caput e parágrafo $1^{\circ}$, proclama o direito ao "pleno exercício dos direitos culturais" e a livre manifestação "das culturas populares, indígenas e afro-brasileiras" e de "outros grupos participantes do processo civilizatório nacional”. Assim, no que pese o predomínio numérico de católicos e protestantes no Brasil, a identidade nacional é ampla o suficiente para justificar a proteção das manifestações culturais e religiosas não cristãs, autorizando ao Estado a prática de condutas positivas e intervencionistas em situações fáticas nas quais se evidencie que a liberdade de expressão de pensamento ou de crença está sendo obstada.

O banimento do preconceito e da discriminação das minorias é uma questão multidisciplinar, tendo que ser enfrentada nas esferas jurídica, social, política e econômica. Nesse particular, basta lembrar, a título ilustrativo, que a Constituição/88 definiu a prática do racismo como crime inafiançável e imprescritível

72 GASTON, W., op. cit., p. 243.

73 A proposta de Rawls de sedimentação do pluralismo na esfera do discurso público, a partir do critério da razoabilidade das razões apresentadas com pretensão de validade será objeto de análise no próximo item.

74 ROSENFELD, Michel. The Identity of the Constitucional Subject. London/New York: Routledge, 2010, 2.3.1, p. 37.

75 FERRAJOLI, L. Sobre los derechos fundamentals, in op. cit., 2007, p. 87.

76 SORIANO, Aldir G. O direito à liberdade religiosa sob a perspectiva da democracia liberal. In MAZZUOLI, Valério de O./SORIANO A. G. (Coordenadores). Direito à Liberdade Religiosa: Desafios e Perspectivas para o Século 21. Belo Horizonte: Fórum, 2009, pp. 173-74. 
(art. 5', XLII), e no artigo 231 reconheceu "aos índios sua organização social, costumes, línguas, crenças e tradições". Cite-se, ainda, o art. 26-A da Lei 9.394/96, que tornou obrigatório "o ensino sobre História e Cultura Afro-Brasileira" ${ }^{77}$ nas escolas públicas e particulares (ensino fundamental e médio). No Brasil ainda existe uma segregação negra velada, assim como de outras etnias (judeu, índio, etc.), o que reproduz um sério quadro de intolerância e perseguição, impedindo a incorporação dos valores culturais e práticas sócio-religiosas desses grupos no espaço público ${ }^{78}$.

Denota-se uma tendência à hegemonia de uma visão uniforme na escala valorativo-existencial, com o não reconhecimento efetivo das concepções particulares do pensamento e da conduta humana, em todas as suas dimensões. As disposições protetivas do "Estado constitucional" esbarram na realidade empírica da intolerância, que não é vencida até mesmo devido às desigualdades sociais e econômicas, impeditivas da organização daqueles grupos historicamente desfavorecidos. Ademais, enfrenta-se atualmente o "desafio do fundamentalismo", "fenômeno cultural" que, principalmente em sua vertente religiosa, desconstrói as bases do "estado democrático de direito", haja vista seu potencial de infiltração em "partidos e associações". Movimentos fundamentalistas podem desenvolver-se em "qualquer religião", sendo mais comuns "nas três religiões monoteístas: judaísmo, cristianismo e islamismo". ${ }^{79}$ A interferência desses movimentos no processo parlamentar reflete diretamente, mais do que em qualquer outro tema, no debate acerca do aborto, impedindo, em países como o Brasil, o sucesso de todas as tentativas até aqui empreendidas no sentido de sua ponderada legalização. Há de ser respeitada a autonomia ética e metafísica dos cidadãos, que podem livremente aderir a qualquer crença, inclusive as de caráter fundamentalista, mas não se pode admitir que a adesão a uma confissão religiosa implique em riscos à integridade física e moral das demais pessoas.

Observe-se que a abordagem do pluralismo moral envolve internamente a abordagem do pluralismo religioso, não havendo porque separar, do ponto de vista da argumentação metodológica, a consideração de um e de outro. Em tese, assegurar a validade do princípio do pluralismo moral importa em estabelecer limites à intervenção das doutrinas religiosas no espaço público, instituindo-se a primazia da justificação racional razoável sobre qualquer outro tipo de justificação fundada em princípios metafísicos. Isso importa, assumindo a teoria da integridade de Dworkin, na postulação de que a totalidade das leis seja elaborada de maneira "moralmente coerente", no que pese a impossibilidade, em sociedades pluralistas, de uma concepção homogênea de moralidade. Segundo Jeremy Waldron, o princípio da "equidade política" impõe um "controle sobre as decisões" "tomadas pelos legisladores", no tocante ao equacionamento das diversas visões acerca das questões morais. A tensão entre os princípios da autonomia e da igual consideração não é insolúvel, por não serem eles contraditórios entre si. ${ }^{80}$ Em realidade, esses dois princípios se complementam quando se trata de acomodar a multiplicidade de valores na elaboração das leis. A rejeição da visão não religiosa na solidificação de um direito individual, por exemplo, viola ao mesmo tempo a autonomia decisória e o preceito da igual consideração, já que impede os não crentes de exercer sua liberdade de convicção moral. Nessa medida, são violadoras dessas garantias fundamentais as leis que flagrantemente foram construídas a partir de outro parâmetro que não o da laicidade.

O Estado tem o papel de oferecer garantia satisfatória ao pluralismo moral, incluindo-se o religioso, abrindo-se espaço para a penetração na vida social das visões próprias das diversas etnias e concepções filosóficas, metafísicas ou não, seja no plano da elaboração das leis, seja no plano da revisão judicial de sua constitucionalidade. A questão complexa, nesse aspecto, consiste na conciliação entre a "moralidade convencional", ou "pública", entendida como o conjunto de valores predominante na comunidade política, e

77 SZKLAROWSKY, L. F., Religião e racismo: a constituição e o Supremo Tribunal Federal. In MAZZUOLI, op. cit., p. 334.

78 A atualidade desse quadro social está minuciosamente explicitada no histórico julgamento do caso Ellwanger por parte do Supremo Tribunal Federal ( $\left.\mathrm{HC} \mathrm{n}^{\circ} 82.424 / \mathrm{RS}\right)$, concernente à discriminação contra o povo judeu.

79 WEINGARTNER, Jaime Neto. Liberdade Religiosa na Constituição. Porto Alegre: Livraria do Advogado Editora, 2007, p. 47, 48 e 52. $\mathrm{O}$ autor defende a aceitação do fundamentalismo-crença e a não aceitação do fundamentalismo-militante, sendo que o segundo deve ser bloqueado pelo Estado (p. 247-251).

80 WALDRON, Jeremy, Law and Disagreement. Oxford/New York: Oxford University Press, reprinted, 2004, p. $190,194$. 
a perspectiva do "julgamento moralmente neutro". Nos hard cases, sobretudo, nos quais uma decisão justa não necessariamente corresponde à opinião da maioria, a atuação das cortes judiciais denota grandes dificuldades na delimitação do nível de comprometimento que deve ser preservado com os valores comunitários dominantes. Muitas vezes, para favorecer uma receptividade social tranqüila das decisões controversas, as cortes mitigam o alcance dos seus veredictos, em deferência à “opinião popular". Muitos autores acreditam que isso pode implicar no não cumprimento do papel da revisão judicial na proteção das minorias. Ely, um dos maiores representantes do "argumento anti-consenso", enfatiza que a opinião popular prevalente já encontra suporte na lei que está sob revisão, não podendo ser parâmetro para as decisões judiciais. Wojciech, apoiando o pensamento de Ely, acrescenta que as cortes se utilizam de mecanismos meramente retóricos para escapar à impopularidade acima mencionada, e não deveriam ceder aos "argumentos ortodoxos", que tentam lhes impor a submissão à moralidade convencional. ${ }^{81}$

Por outro lado, a "moralidade convencional" pode ser concebida como uma "fonte" para a concretização dos "princípios legais". ${ }^{82}$ O problema é que os valores não são universais, razão pela qual as várias visões morais entram em conflito na seara da delimitação dos direitos individuais. Veja-se o tema do aborto, que, em regra, não encontra suporte nos valores convencionalmente dominantes, na maioria das sociedades. Como conciliar as moralidades que disputam a prevalência de suas opiniões no tocante aos direitos da vida nascitura? Legalizar o aborto com base no entendimento de que o feto não é pessoa, sem adensar adequadamente o argumento jurídico, implica em não levar em conta as crenças das pessoas adeptas à visão pro-life. ${ }^{83}$ De fato, o grupo pro-life acredita que o feto, se não é pessoa, ao menos é a ela equiparável em relação ao direito à vida. O caminho da composição do conflito exige, portanto, na forma explicitada por Calabresi, que se tome por fundamento da decisão não somente o direito à privacidade, mas também outros princípios fundamentais, como, por exemplo, a liberdade de consciência.

O princípio da igualdade do sujeito moral, alicerce da teoria da neutralidade do juízo, na esfera da razão prática, parece não ser suficiente para o reconhecimento do direito ao aborto, salvo em uma sociedade historicamente identificada com o liberalismo, como a norte-americana, ou em sociedades nas quais se concretiza amplamente o paradigma do Estado laico, como, por exemplo, a Alemanha e a França. Em geral, dizer que o aborto é simplesmente uma questão privada não indica resposta que satisfaça todos os modelos de democracia implantados no mundo. Tampouco agregar ao credo pro-choice a bandeira feminista da igualdade e do direito a não discriminação soluciona a questão no nível de uma justificação razoável. Assim, a direção de Calabresi, no sentido de conduzir o debate para a busca de um balanceamento das posições conflitantes, é salutar para a legalização do aborto, em especial nos países sul-americanos, como o Brasil, que passam por um processo de adaptação às premissas do pluralismo. Em outras questões morais, como o reconhecimento do direito ao casamento de homossexuais, não há meio-termo; ou se lhes concede o direito pretendido, por exigência do princípio da igual proteção, ou se lhes o nega, sob o argumento do respeito à moralidade convencional. No caso do aborto, ao contrário, admite-se o balizamento, considerando a ponderação de uma

81 WOJCIECH, Sadurski, op. cit., p. 38, 11, 27, 29, 12, 43. Sobre a teoria de J. H. Ely, ver Democracy and Distrust. A Theory of Judicial Review. Cambridge: Harvard University Press, 1980., p. 68-9.

82 Essa é a posição assumida, dentre outros, por Wellington H. H., in The Nature of Judicial Review. Yale Law Journal 91 (1982) 486, 493-94. Apud WOJCIEH S., op. cit., p. 47. WOJCIECH rebate os argumentos de Wellington, afirmando não ser possível optar por uma moralidade convencional nas sociedades pluralistas, pois sequer há critérios para indicar qual moralidade deve ter a primazia. A escolha por uma, dentre elas, significaria converter uma moralidade privada em pública. Além disso, prossegue o autor, não é crível, no regime democrático, a possibilidade de um consenso em matéria de princípios fundamentais (op. cit., p. 47, 51, 54).

83 Nesse sentido, veja-se CALABRESI, G., Ideals, Beliefs, Attitudes and the Law. Syracuse: Syracuse University Press, 1985, p. 97 (Apud WOJCIECH, op. cit., capítulo 4, p. 120, 211, nota 73). A crítica de Calebresi está centrada na análise da decisão da corte norte-americana, no caso Roe $\times W$ ade, que acolheu exclusivamente o princípio da privacidade para fundamentar sua decisão. Com isso, teria considerado somente as crenças do grupo pro-choice, deixando de acomodar os dois importantes valores conflitantes. Wojciech, comente-se, acha que falar em sopesamento de posições conflitantes não passa de uma hipocrisia, pois assegurar as liberdades individuais não depende de um ato de barganha moral ou social, mas da exigência da igualdade do sujeito como agente moral. Nessa ótica, cada pessoa é livre para escolher sua própria moralidade, não importa o peso a ser atribuído a uma ou outra das posições conflitantes (op. cit., p. 121). 
tutela aceitável dos interesses do feto a partir de um dado estágio da gestação, em atendimento aos valores do grupo pro-life. Defendemos uma abordagem da neutralidade moral e política, não com um viés absolutamente liberal, mas levando-se em conta a necessidade da acomodação das convicções plurais na qualidade de uma premissa democrática fundamental.

Em suma, acreditamos que a conjugação, em uma medida apropriada, entre algumas premissas do individualismo e outras das doutrinas comunitárias, permite avaliar "o relativo peso a ser atribuído a uma exigência individual de autonomia" no contexto da vida política. Considerando a demanda pelo exercício da autonomia como uma demanda não advinda simplesmente de indivíduos isolados, mas de um grupo social, ainda que minoritário, a questão precisa ser enfrentada sob o enfoque do princípio do "respeito mútuo entre o eu e o outro", e da "integridade de todas as concepções de bem". Assim situado o debate acerca do aborto, a "ordem de prioridade" apta a "facilitar a resolução do conflito" é a da prevalência daquele direito cuja satisfação se mostrar mais importante para o bem-estar, ou até mesmo "a sobrevivência", do demandante, ou o indivíduo ou a coletividade..$^{84}$

\section{Considerações finais}

Legitimar a liberdade de escolha reprodutiva com fundamento no pluralismo moral implica na reformulação das premissas democráticas, especialmente daquelas que estruturam o sistema político representativo. Nessa dimensão, deve-se, primordialmente, delimitar qual o espaço da intervenção coletiva e qual o espaço da autonomia da consciência individual nos assuntos que tocam diretamente à condução responsável da vida privada.

A instauração do modelo constitucionalista de controle judicial das leis busca destituir o estatuto absoluto da moralidade política e do consenso coletivo enquanto instâncias definidoras da justiça. O critério da decisão majoritária deve ser reformulado, no que concerne aos assuntos de natureza ética que se refiram à concepção de valores não vinculados aos interesses públicos. Trata-se de uma reflexão necessária para que o processo deliberativo se adeque à ênfase conferida pelos princípios constitucionais às liberdades individuais relacionadas à escolha de convicções morais e religiosas. A precedência da liberdade, e com ela a da igualdade, no sentido de igual cidadania, em matéria de afirmação dos direitos subjetivos, introduz no mundo jurídico o paradigma do respeito pelas capacidades morais de autodeterminação individual, as quais, se compreendidas adequadamente, se sobrepõem, de acordo com as circunstâncias fáticas, às perspectivas de legitimação do discurso intersubjetivo.

Não há justificativa que legitime o controle do Estado sobre a liberdade sexual e reprodutiva da mulher, ao ponto de lhe impor a assunção da maternidade, desconsiderando-se sua autonomia decisória. A releitura da teoria do consentimento político, de acordo com os fundamentos contemporâneos das concepções plurais de bem e de justiça, introduz uma tensão entre a obrigação política e as liberdades básicas. Dentro de uma visão transformadora da democracia, o direito ao aborto voluntário, no primeiro trimestre da gestação, não exige uma definição comunitária. Ao contrário, as diferenças nas posições adotadas pelas pessoas no tocante à moralidade ou amoralidade da conduta são passíveis de acomodação política e jurídica, sendo isso o que se espera de um sistema de neutralidade razoável do poder institucional.

Em síntese, o reconhecimento do direito de escolha da mulher em relação ao prosseguimento da gestação é passível de ser racionalmente articulado a partir de dois argumentos essenciais: a autonomia decisória em questões de natureza ética e a irreversibilidade contemporânea do pluralismo moral. Sendo assim, a receptividade à legalização do aborto é imperativa sob o pressuposto da admissibilidade da adoção de convicções morais individuais diversas, de acordo com a experiência concreta de vida de cada um. Em uma situação

84 ROSENFELD, M., 2011, op. cit., p. 110-3. 
de gravidez indesejada, não se pode deixar de conferir à mulher o direito de definir seu próprio destino, até determinado período da gestação, sem restrições que comprometam sua identidade como sujeito moral.

\section{REFERÊNCIAS}

BERLIN, Isaiah, Two Concepts of Liberty, in Liberty, Oxford/New York: Oxford University Press, 2009, p. 166-217.

BOBBIO, Norberto. Liberalismo e Democracia. $6^{a}$ edição. São Paulo: Brasiliense, 2005.

. As Ideologias e o Poder em Crise. Brasilia: Editora UNB, 1999.

BONAVIDES, Paulo. Teoria Constitucional da Democracia Participativa: por um direito constitucional de luta e resistência, por uma nova hermenêutica, por uma repolitização da legitimidade. $3^{\text {a }}$ edição. São Paulo: Malheiros, 2008.

CALABRESI, G., Ideals, Beliefs, Attitudes and the Law. Syracuse: Syracuse University Press, 1985.

CANOTILHO, J. J. Gomes. Direito Constitucional e Teoria Constitucional. $3^{a}$ edição. Coimbra: Livraria Almedina,1999.

COHEN Joshua. Moral Pluralism and political consensus, in Philosophy of Rawls: Reasonable Pluralism. New York/ London: Garland Publishing, Inc., 1999, p. 56-77.

DINIZ, Débora. Ética, Aborto y Democracia. despenalizacion.org.ar: por la despenalización del aborto. no 6/ Febrero 2008. Disponível em http://www. despenalizacion.org.ar/pdf/Organoformativas/06_Diniz.pdf. Acesso em 03/02/12.

DINIZ, Débora e DAMASCENO, Ana Paula. Série Anis: mulheres, mídia e aborto. Série Anis 20, Brasília, Letras Livres, 1-8, maio, 2001, Versão PDF, p. 2-4. Disponível em http://www.anis.org.br/serie/artigos/ sa20(dinizdamasceno)mídiaaborto.pdf. Acesso em 10/05/13.

DWORKIN, Ronald. Justice for Hedgehogs. Cambridge/Massachusetts: Harvard University Press, 2011.

. Principles for a New Political Debate - Is Democracy Possible Here? Princeton/ Oxford: Princeton University Press, 2006A

. O Direito da Liberdade: a leitura moral da Constituição norte-americana. São Paulo: Martins Fontes, 2006B.

Objectivity and Truth: You'd Better Believe it. In: Philosophy and Public Affairs, Vol. 25, No. 2 (Spring, 1996), pp. 87-139. Disponível em < http://www.jstor.org/stable/ 296192>. Acesso em 10/08/12.

. Life's Dominion. New York: Vintage Books, 1994.

. Conferência proferida na cidade de Tóquio/Japão. 1990. In: Cadernos da Escola do Legislativo. Belo Horizonte, 3(5): 27-71, janeiro/junho, 1997. Tradução/Revisão: Raíssa R. Mendes e Menelick de Carvalho Netto. Disponível em < http://www.almg.gov.br/opencms/export/sites/default/consulte/publicacoes_assemble$\mathrm{ia} /$ periodicas/cadernos/arquivos/pdfs/05/dfi.pdf>. Acesso em 08/-08/12.

ELY, J. H. Democracy and Distrust. A Theory of Judicial Review. Cambridge: Harvard University Press, 1980.

FERRAJOLI, Luigi. Sobre los derechos fundamentales. In Teoría del Neoconstitucionalismo: ensayos escogidos. Madri: Editorial Trotta, 2007, p. 71-89.

Los Fundamentos de los Derechos Fundamentales. In: Los Fundamentos de los Derechos Fundamentales. $3^{\text {a }}$ edição. Madri: Editorial Trotta, 2007, pp. 287-381.

O Estado de Direito entre o passado e o futuro. In: O Estado de Direito: história, teoria, crítica. Pietro Costa e Danilo Zolo (org.). São Paulo: Martins Fontes, 2006. 
GALSTON, William A. Diversity, Toleration and Deliberative Democracy. In: MACEDO Stephen. Deliberative Politics. New York/Oxford: Oxford University Press, 1999, p.

GASTON W. Legal and Political Implications of Moral Pluralism, The. In Maryland Law Review, volume 57: 236250. 1998.

GUASTINI, Riccardo. GUASTINI, R. El concepto de Constitución. In Teoría del Neoconstitucionalismo: ensayos escogidos. Madri: Editorial Trotta, 2007, p. 15-27.

HABERMAS, Jürgen. O Futuro da Natureza Humana. São Paulo: Martins Fontes, 2004.

. Verdade e Justificação - ensaios filosóficos. São Paulo: Edições Loyola, 1999.

. Moral Consciousness and Communicative Action. Cambridge/Massachusetts: The MIT Press, 1990

HAMILTON, Alexander, JAY John and MADISON James. The Federalist. The Gideon Edition. Indianapolis: Liberty Fund, 2001.

HOBBES, Thomas. Do Cidadão. $3^{a}$ edição. São Paulo: Martins Fontes, 2002.

KANT, Immanuel. Ideia de uma história universal com um propósito cosmopolita. In A pazperpétua e outros opuisculos, Lisboa: Edições 70, 1988A.

KANT, I. A Paz Perpétua. In: A pazperpétua e outros opúsculos. Lisboa: Edições 70, 1988B, p. 119-172. Fundamentação da Metafísica dos Costumes. Lisboa: Edições 70, 1986.

KELSEN, H. A Ilusão da Justiça. São Paulo: Martins Fontes, 1995.

A Democracia. São Paulo: Martins Fontes, 1993.

LEONI, Bruno. Liberdade e a lei: os limites entre a representação e o poder. São Paulo: Instituto Ludwig von Mises Brasil. 2010.

LOCKE, John. Dois Tratados sobre o Governo. $2^{\mathrm{a}}$ tiragem. São Paulo: Martins Fontes, 2001.

MATOS, Murílio Castro de. A Criminalização do Aborto em Questão. Coimbra: Edições Almedina, 2010.

MENDES Gilmar Ferreira. Direitos Fundamentais e Controle de Constitucionalidade. $3^{a}$ edição. São Paulo: Saraiva, 2009.

MILL, Stuart. On Liberty. Mineola/New York: Dover Publications, INC, 2002.

MOREIRA NETO, Diogo de Figueiredo. Juridicidade, Pluralidade Normativa, Democracia e Controle Social. In Fundamentos do Estado de Direito: estudos em homenagem ao Professor Almiro do Couto e Silva. São Paulo: Malheiros, 2005, p. 91-113.

MÜLLER, Friedrich. O Novo Paradigma do Direito: Introdução à Teoria e Metódica Estruturantes. $3^{\mathrm{a}}$ edição. São Paulo: Revista dos Tribunais, 2013.

NOZICK, Robert. Anarquia, Estado e Utopia. São Paulo: Martins Fontes, 2011.

OLIVEIRA, Marcelo Andrade Cattoni. Jurisdição Constitucional. Poder Constituinte Permanente? In: Hermenêutica e Jurisdição Constitucional. José Adércio L. Sampaio e Álvaro R. de S. Cruz (Coord.). Belo Horizonte: Del Rey, 2001, pp. 67-91.

PIEROTH, B./SCHLINK, B. Direitos Fundamentais - Direito Estadual II. Lisboa: Coleção Manuais, 2008.

RAWLS, John. Uma Teoria da Justiça. $3^{\text {a }}$ edição. São Paulo: Martins Fontes, 2008.

Political Liberalism. Expanded Edition. New York: Columbia University Press. 2005.

ROESLER, Cláudia Rosane. Os Diversos Enfoques da Teoria Contemporânea do Direito e a Passagem para uma Teoria 
Constitucional do Direito. In: Direito \& Argumentaşão no Pensamento de Manuel Atien₹̧a. Rio de Janeiro: Ed. Lumen Juris, 2007.

ROSENFELD, Michel. Law, Justice, Democracy, and the Clash of Cultures - a Pluralist Account. Cambridge/New York: Cambridge University Press, 2011.

ROSENFELD, Michel. The Identity of the Constitucional Subject. London/New York: Routledge, 2010.

ROUSSEAU, Jean Jacques. Do Contrato Social. Coleção os Pensadores, volume I. São Paulo: Nova Cultural, 1999.

SARLET, Ingo Wolfgang. A eficácia dos Direitos Fundamentais. Porto Alegre: Livraria do Advogado, 2007.

SARMENTO, Daniel. Por um Constitucionalismo Inclusivo: História Constitucional Brasileira, Teoria da Constituição e Direitos Fundamentais. Rio de Janeiro: Lumen Juris, 2010.

SIMMONS, A. John, Moral Principles and Political Obligations, Princeton, New Jersey: Princeton University Press, 1981.

SORIANO, Aldir G. O direito à liberdade religiosa sob a perspectiva da democracia liberal. In MAZZUOLI, Valério de O./SORIANO A. G. (Coordenadores). Direito à Liberdade Religiosa: Desafios e Perspectivas para o Século 21. Fórum. Belo Horizonte. 2009, pp. 173-

SZKLAROWSKY, L. F., Religião e racismo: a constituição e o Supremo Tribunal Federal, in MAZZUOLI, Valério de O./SORIANO A. G. (Coordenadores). Direito à Liberdade Religiosa: Desafios e Perspectivas para o Século 21. Fórum. Belo Horizonte. 2009, p. 334-

TOCQUEVILLE, Alexis. Democracy in America. United States: Pacific Publishing Studio, 2010. ISBN: 1453730508 .

TERSMAN, Folke. Moral Disagreement. Cambridge/New York: Cambridge University Press, 2006.

TORRES, Sílvia Faber. A Flexibilização do Princípio da Legalidade no Direito do Estado. Rio de Janeiro: Renovar, 2012.

WALDRON, Jeremy. Law and Disagreement. Oxford, New York: Oxford University Press, reprinted, 2004. .

WEINGARTNER, Jaime Neto. Liberdade Religiosa na Constituição. Porto Alegre: Livraria do Advogado Editora, 2007.

WOJCIECH, Sadurski. Moral Pluralism and Legal Neutrality. Dordrecht/Boston/ London: Kluwer Academic Publishers. 1990.

ZOLO, Danilo. Teoria e Crítica do Estado de Direito. In: Pietro Costa e Danilo Zolo (org.). O Estado de Direito: bistória, teoria, crítica. São Paulo: Martins Fontes, 2006.

. Libertad, Propriedad e Igualdad en la Teoria de los Derechos Fundamentales. In: Luigi Ferrajoli (autor). Los Fundamentos de los derechos fundamentales. $3^{a}$ edição. Madri: Editorial Trotta, 2007, pp. 75-104. 


\section{REVISTA BRASILEIRA DE POLÍTICAS PÚBLICAS BRAZILIAN JOURNAL OF PUBLIC POLICY}

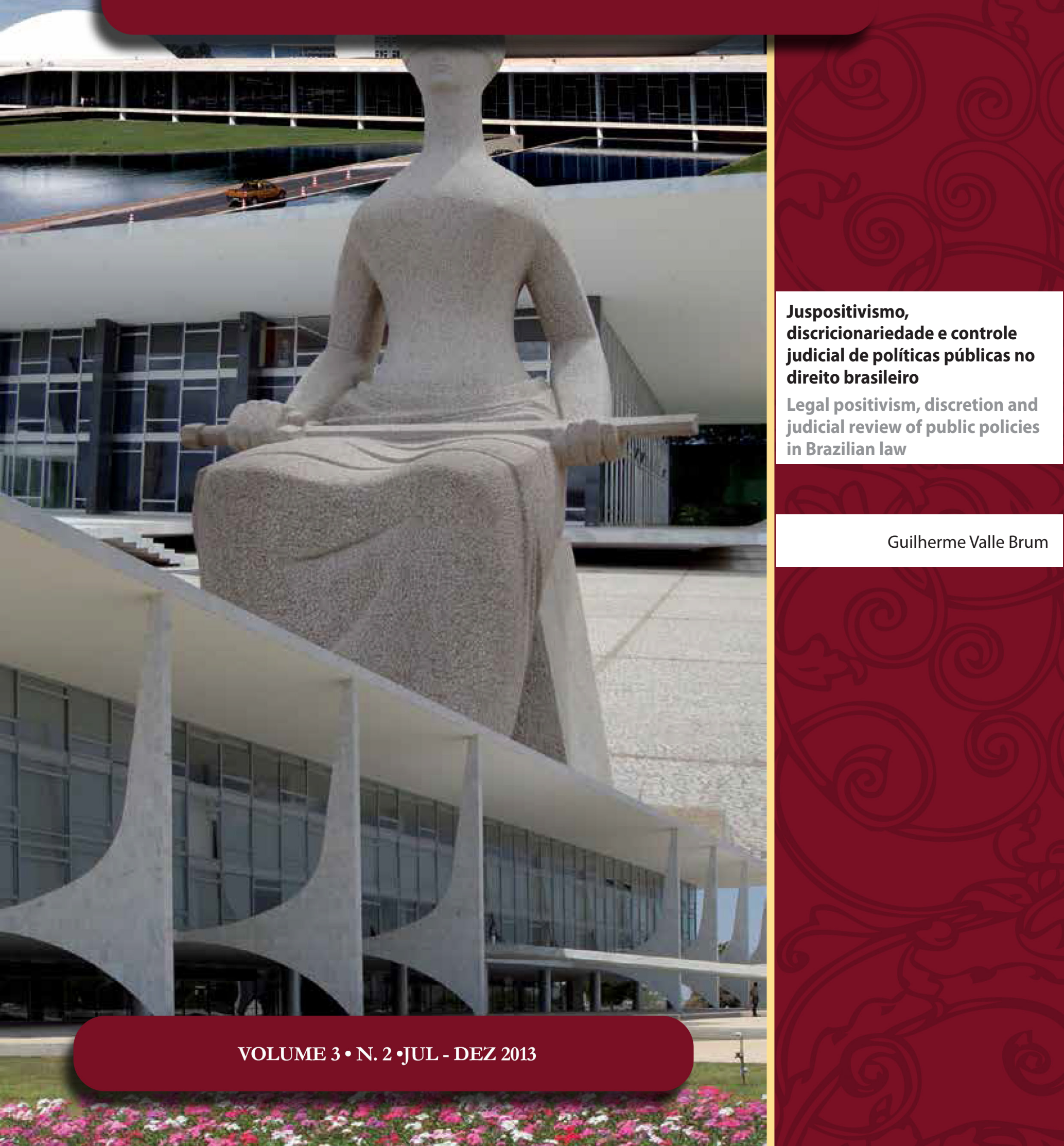




\title{
Juspositivismo, discricionariedade e controle judicial de políticas públicas no direito brasileiro
}

\author{
Legal positivism, discretion and judicial \\ review of public policies in Brazilian law*
}

Guilherme Valle Brum**

\section{Resumo}

O trabalho procura discutir o estado da arte da literatura jurídica brasileira que versa a respeito do controle judicial de políticas públicas e sua relação com o paradigma do positivismo jurídico. A conclusão central é a de que se formou um novo senso comum teórico nesse campo de estudo, que entende ser possível lidar com o problema valendo-se de princípios e de valores situados na fronteira entre a Moral e o Direito e positivados, implícita ou explicitamente, na Constituição. O nível de preocupação do novo senso comum com a descrição desses princípios e valores não é observado com a questão correlata dos limites da discricionariedade judicial, o que o impede de atingir o intento de superar o paradigma do juspositivismo.

Palavras-chave: Positivismo jurídico. Controle judicial de políticas públicas. Senso comum teórico. Discricionariedade judicial.

\section{Abstract}

The paper discusses the Brazilian legal literature on the judicial review of public policies and its relation to the paradigm of legal positivism. The central conclusion is that a new theoretical common sense has emerged in this field of study. Such new common sense deals with the problem using moral values and constitutional principles. The level of concern with the description of these principles and values is not observed with the related question of the limits of judicial discretion. This problem prevents it from achieving the aim of overcoming the paradigm of legal positivism.

Keywords: Legal positivism. Judicial review of public policies. Theoretical common sense. Judicial discretion.

Embora a ligação entre positivismo jurídico e controle judicial de políticas públicas não seja muito evidente, eles orbitam um eixo comum: o problema da discricionariedade judicial. O presente trabalho discute, precisamente, as interconexões entre tais temáticas. Pretende-se discorrer sobre o estado da arte da literatura jurídica brasileira que versa a respeito do controle judicial de políticas públicas, examinando a sua proposta para o enfrentamento do debate sobre os limites e possibilidades da atuação do Poder Judiciário nessa seara. O intuito é verificar se essa proposta supera o paradigma contra o qual se volta. 
Impõe-se uma indagação preliminar à discussão pretendida: é possível falarmos em "paradigmas" no Direito? A resposta a essa pergunta está longe de ser simples e, desde logo, anuncia-se que este texto não a fornecerá. Mas, para desenvolver o argumento, é imprescindível que algumas considerações sobre essa problemática sejam ao menos apresentadas. É preciso deixar claro que o conceito de paradigma desenvolvido originalmente por Thomas Kuhn ${ }^{1}$ foi pensado para as ciências exatas e biológicas, "[...] que possuem um grau de verificabilidade certamente mais preciso e atingível do que as ciências humanas e sociais". Isso significa que essa conceituação deve ser utilizada, no Direito, com "reserva terminológica".2

Kuhn apresenta um conceito de paradigmas como "[...] as realizações científicas universalmente reconhecidas que, durante algum tempo, fornecem problemas e soluções modelares para uma comunidade de praticantes da ciência". ${ }^{3}$ Esse sentido de paradigma é estreitamente relacionado com a noção de "ciência normal", que pode ser caracterizada como uma "[...] pesquisa firmemente baseada em uma ou mais realizações científicas passadas”, as quais, por seu turno, “[...] são reconhecidas durante algum tempo por alguma comunidade científica específica como proporcionando os fundamentos para sua prática posterior". ${ }^{4}$ Ao longo de sua obra, o pensador demonstra as condições para a mudança paradigmática, que tem comumente seu início com a descoberta de alguma anomalia na ciência, anomalia essa que pode evoluir para uma crise e, assim, proporcionar uma revolução.

O conceito kuhniano de revolução parece efetivamente mais afeto às ciências naturais, em que "[...] o exercício da pesquisa por vezes produz novos paradigmas, novas maneiras de entender a natureza, de ler seus textos. Mas as pessoas responsáveis por essas mudanças não as buscavam". ${ }^{5}$ Essa possibilidade de existirem provocações involuntárias de mudanças evolutivas é utilizada pelo próprio autor, em trabalho posterior ao seu texto seminal, A Estrutura das Revoluções Científicas, como critério de diferenciação entre as ciências naturais e sociais. ${ }^{6}$ De fato, as mudanças no Direito são sempre ou pelo menos quase sempre deliberadas. Nada ou quase nada há de involuntário aí. Diversamente das ciências naturais, nas quais pode haver uma revolução mesmo que a comunidade científica não a esteja buscando, as mudanças no campo jurídico decorrem de opções políticas. Longe estão, portanto, de ser o resultado de um exercício de pesquisa que produziu um novo paradigma sem que os pesquisadores se dessem conta do que estavam fazendo.

Todavia, apesar dessas dificuldades, a literatura jurídica brasileira e estrangeira vem recorrentemente se valendo da expressão paradigma. Ora para designar uma espécie de saber hegemônico do momento, ora para reportar-se a aspectos supostamente incontestáveis do conhecimento no interior da disciplina. Em algumas vezes, utiliza o texto de Kuhn para tanto; em outras, apenas enuncia a expressão sem preocupação em detalhar

1 KUHN, Thomas S. A Estrutura das Revoluções Cientificas. Trad. Beatriz Vianna Boeira e Nelson Boeira. São Paulo: Perspectiva, 2005.

2 FREITAS FILHO, Roberto. Crise do direito e Juspositivismo. A exaustão de um paradigma. Brasília: Brasília Jurídica, 2003. p. 30.

3 KUHN, Thomas S. A Estrutura das Revoluções Científicas. Trad. Beatriz Vianna Boeira e Nelson Boeira. São Paulo: Perspectiva, 2005. p. 13. Entretanto, em um posfácio editado no ano de 1969, Thomas Kuhn admite que, no corpo do texto, utilizou a expressão paradigma para designar coisas diversas. E uma delas seria a chamada matriz disciplinar de um saber. "Disciplinar porque se refere a uma posse comum aos praticantes de uma disciplina particular; matriz porque é composta de elementos ordenados de várias espécies, cada um deles exigindo uma determinação mais pormenorizada". Alguns dos principais componentes de uma matriz disciplinar são: (1) as generalizações simbólicas, que funcionam em parte como leis e em parte como definições de alguns dos símbolos que elas empregam; (2) os modelos, identificados como compromissos coletivos com crenças, tais como "[...] o calor é a energia cinética das partes constituintes dos corpos", fornecendo ao grupo as analogias ou metáforas preferidas ou permissíveis e auxiliando, desse modo, a determinar o que será aceito como uma explicação; (3) por fim, os valores aceitos pelo grupo, os quais, em geral, são mais amplamente partilhados do que as generalizações simbólicas e os modelos, contribuindo, por um lado, para proporcionar aos cientistas um sentimento de pertencimento a uma comunidade global e, por outro, para identificar uma crise ou escolher entre maneiras incompatíveis de praticar a disciplina (Ibid, p. 228-239).

4 KUHN, Thomas S. A Estrutura das Revoluções Científicas. Trad. Beatriz Vianna Boeira e Nelson Boeira. São Paulo: Perspectiva, 2005. p. 29.

5 KUHN, Thomas S. As ciências naturais e as ciências humanas. Trad. Cesar Mortari. In: KUHN, Thomas S. O Caminho desde a estrutura. São Paulo: Editora UNESP, 2006, p. 272.

6 KUHN, Thomas S. As ciências naturais e as ciências humanas. Trad. Cesar Mortari. In: KUHN, Thomas S. O Caminho desde a estrutura. São Paulo: Editora UNESP, 2006, p. 272. 
seu sentido. Um autor que utiliza esse termo com um significado peculiar, tendo o cuidado de explicá-lo, é Ronald Dworkin. Para ele, os paradigmas do Direito são "[...] exemplos concretos aos quais qualquer interpretação plausível deve ajustar-se”. Essa assertiva de Dworkin significa que os argumentos contra uma proposta interpretativa de determinado problema jurídico consistirão, geralmente, em demonstrar que ela é afrontosa ao paradigma. "Quem rejeitar um paradigma dará a impressão de estar cometendo um erro extraordinário". Os paradigmas, portanto, fixam as interpretações possíveis, mas nenhum paradigma é imune a ser contestado "[...] por uma nova interpretação que considere melhor outros paradigmas e deixe aquele de lado, por considerá-lo um equívoco"?

Não é necessária uma demorada pesquisa para se encontrarem escritores de tradições jurídico-filosóficas bem distintas falando sobre paradigmas no Direito. São exemplos: Roberto Freitas Filho, ${ }^{8}$ Lenio Luiz Streck, ${ }^{9}$ Menelick de Carvalho Netto e Guilherme Scotti, ${ }^{10}$ no Brasil, e Friedrich Müller ${ }^{11}$ e o citado Ronald Dworkin, alhures. É interessante observar que todos eles, à exceção de Dworkin, consideram, cada qual a seu modo (fazendo ou não menção a Kuhn), o positivismo jurídico como um paradigma ou, pelo menos, como um movimento teórico integrante de um paradigma. O sentido de paradigma atribuído ao positivismo jurídico por esses autores é em alguma medida equivalente a um conhecimento hegemônico, amplamente aceito e reproduzido tanto pelos discursos de legitimação (doutrina) como pelos técnico-operativos (decisões). Desse modo, para não alongar uma discussão que fugirá dos objetivos deste texto, mas ciente das dificuldades expostas acima, ${ }^{12}$ passa-se a falar, tal como esses autores, no juspositivismo como um "paradigma" do Direito.

A nota distintiva e a originalidade do paradigma juspositivista estão, na síntese de Barzotto, ${ }^{13}$ na adoção, como condição de juridicidade, do critério de pertinência ou pertencimento. A norma é jurídica desde que pertença a um ordenamento jurídico. É isso que, a um só tempo, permite-lhe obter um conceito autônomo de Direito e o opõe a dois outros paradigmas, o "jusnaturalismo" e o "realismo". Com efeito, para o realismo, a nota definitória do Direito está na sua eficácia, ou seja, o que o define é o comportamento efetivo das pessoas pertencentes a uma determinada comunidade. Trata-se de um conceito sociológico de Direito. Para o jusnaturalismo, por seu turno, o critério de juridicidade reside na justiça: só é Direito o que for justo. Apresenta, pois, um conceito moral de Direito.

O paradigma do juspositivismo rejeita essas duas ideias: a do realismo porque, ao se definir "aquilo que é eficaz", resvala-se para o arbítrio e a sua consequente imprevisibilidade, e a do jusnaturalismo porque, para se chegar "àquilo que é justo", deve-se invariavelmente passar pelo subjetivismo e incerteza provenientes da multiplicidade de concepções de justiça. Parece evidente, porém, que "aquilo que pertence ao ordenamento jurídico" como critério de juridicidade carece de um desenvolvimento maior. Afinal, uma vez rejeitadas a justiça e a eficácia como critérios possíveis, o que, para o positivismo, pertence ao ordenamento jurídico? A resposta é direta

7 DWORKIN, Ronald. O império do Direito. Trad. Jefferson Luiz Camargo. São Paulo: M. Fontes, 2007. p. 88-89. O autor retoma seu conceito de paradigma em outros escritos. É exemplo a seguinte passagem de um de seus conhecidos textos DWORKIN, Ronald. A justiça de toga. Trad. Jefferson Luiz Camargo. São Paulo: M. Fontes, 2010. p. 348: "Podemos identificar o que aparentemente nem é preciso dizer que faz parte de nosso direito - o limite de velocidade, o código tributário, as regras de propriedade do dia a dia, os contratos etc., coisas com as quais estamos todos familiarizados. Podemos dizer que se trata de paradigmas do direito" [grifei].

8 FREITAS FILHO, Roberto. Crise do direito e Juspositivismo. A exaustão de um paradigma. Brasília: Brasília Jurídica, 2003.

9 STRECK, Lenio Luiz. Hermenêutica Jurídica e $(m)$ Crise. Uma exploração hermenêutica da construção do Direito. 8. ed. Porto Alegre: Livraria do Advogado, 2009.

10 NETTO, Menelick de Carvalho; SCOTTI, Guilherme. Os direitos fundamentais e a (in)certeza do Direito. A produtividade das tensões principiológicas e a superação do sistema de regras. Belo Horizonte: Fórum, 2011.

11 MÜLLER, Friedrich. O novo paradigma do Direito. Introdução à teoria e metódica estruturantes do Direito. 3. ed. São Paulo: Revista dos Tribunais, 2013.

12 Com efeito, a partir daqui farei referência, na linha dos autores mencionados, ao positivismo jurídico e a outros movimentos teóricos que a ele se opõem (notadamente, o jusnaturalismo, o realismo e o pós-positivismo) como paradigmas, sabedor, porém, das dificuldades da utilização desse conceito no Direito, pelo menos no controvertido sentido que lhe deu Kuhn. A opção pela utilização do termo se deve, acima de tudo, à necessidade de clareza - que por vezes requer "acordos semânticos" desse tipo - na exposição das ideias.

13 BARZOTTO, Luis Fernando. A positivismo jurídico contemporâneo: uma introdução a Kelsen, Ross e Hart. 2. ed. Porto Alegre: Livraria do Advogado, 2007. p. 19. 
e simples: aquilo que é válido. A validade, portanto, é a nota distintiva. "Norma jurídica não é a norma justa ou a norma eficaz, mas a norma válida". ${ }^{14} \mathrm{E}$ dizer que uma norma é válida equivale a afirmar que faz parte de um ordenamento jurídico, daí que o critério da validade é, em certo sentido, "genético". Assim, como no Direito moderno, é ele (o Direito) quem regula a sua própria produção, considera-se válida toda norma produzida em conformidade com o ordenamento. É o próprio Direito, pois, que determina quais são as normas válidas, sendo então o Direito, e não o comportamento dos homens ou seus ideais de justiça, que diz o que é ou não jurídico. ${ }^{15}$

O positivismo produziu ao longo dos séculos XIX e XX - e ainda produz - forte influência no pensamento jurídico ocidental. Poucas pessoas negariam isso. Para Roberto Freitas Filho, ${ }^{16}$ por exemplo, o paradigma vigente é uma construção teórica consolidada no decorrer da modernização socioeconômica do país, entre os anos 1960 e 1980, e é vinculado ao caráter normativista do positivismo de inspiração kelseniana. Esse paradigma, segundo o autor, considera o Estado como fonte central de todo o Direito, sendo a lei sua única expressão. Forma, portanto, um sistema fechado e formalmente coerente, cuja pretensão de completude despreza, como metajurídicas, todas as indagações de natureza social, política e econômica. ${ }^{17}$

Precisamente pela importância do movimento juspositivista, o intenso debate sobre sua superação prossegue até hoje. ${ }^{18}$ Surgiram, nessa ambiência, influentes teorias, notadamente nos Estados Unidos da América e na Europa, que se propuseram a criticar o positivismo e, ao mesmo tempo, apresentar modelos teóricos no intuito de aperfeiçoá-lo ou mesmo substituí-lo. Considerem-se aqui apenas com os exemplos de Friedrich Müller, Neil MacCormick e Ronald Dworkin. É interessante notar que os dois primeiros autores denominaram, literalmente, suas teorias de pós-positivistas. ${ }^{19}$ No Brasil, também surgiram - e ainda vêm surgindo - propostas teóricas que pretendem avançar em relação ao positivismo jurídico. Talvez a mais conhecida e influente seja a de Luís Roberto Barroso, o qual também insere seu pensamento no paradigma pós-positivista, embora seja consideravelmente diferente das teorias de Müller e MacCormick.

Para Barroso, "[...] a superação histórica do jusnaturalismo e o fracasso político do positivismo abriram caminho para um conjunto amplo e ainda inacabado de reflexões acerca do Direito, sua função social e sua interpretação" ${ }^{20}$ Eis aí, segundo o autor, o pós-positivismo, “[...] designação provisória e genérica de um ideário difuso, no qual se incluem a definição das relações entre valores, princípios e regras, aspectos da chamada nova hermenêutica e a teoria dos direitos fundamentais" ${ }^{21}$. De acordo com o constitucionalista brasileiro, o pós-positivismo não surge com o ímpeto da desconstrução, tampouco almeja um retorno ao jusnaturalismo, mas pretende superar o conhecimento tradicional, introduzindo no ordenamento positivo as ideias de justiça e legitimidade. Promove, portanto, "[...] uma volta aos valores, uma reaproximação entre ética e Direito". 22 Tais valores compartilhados pela sociedade se materializam em princípios, tendo sua normatividade reconhecida e passando a estar abrigados, de modo implícito ou explícito, na Constituição.

14 BARZOTTO, Luis Fernando. A positivismo jurídico contemporâneo: uma introdução a Kelsen, Ross e Hart. 2. ed. Porto Alegre: Livraria do Advogado, 2007. p. 19.

15 BARZOTTO, Luis Fernando. A positivismo jurídico contemporâneo: uma introdução a Kelsen, Ross e Hart. 2. ed. Porto Alegre: Livraria do Advogado, 2007. p. 20.

16 BARZOTTO, Luis Fernando. A positivismo jurídico contemporâneo: uma introdução a Kelsen, Ross e Hart. 2. ed. Porto Alegre: Livraria do Advogado, 2007. p. 40-41.

17 Assim também parece pensar Tercio Sampaio Ferraz Junior, para quem a ciência dogmática do Direito na atualidade “[...] costuma encarar seu objeto, o direito posto e dado previamente, como um conjunto compacto de normas, instituições e decisões que lhe compete sistematizar, interpretar e direcionar, tendo em vista uma tarefa prática de solução de possíveis conflitos que ocorram socialmente. O jurista contemporâneo preocupa-se, assim, com o direito que ele postula ser um todo coerente, relativamente preciso em suas determinações, orientado para uma ordem finalista, que protege a todos indistintamente" FERRAZ JUNIOR, Tercio Sampaio. Introdução ao estudo do Direito: técnica, decisão, dominação. 6. ed. São Paulo: Atlas, 2011. p. 57.

18 Basta que nos lembremos da conhecida discussão entre Hart e Dworkin.

19 Vide: MACCORMICK, Neil. Retórica e o Estado de Direito. Trad. Conrado Hübner Mendes e Marcos Paulo Veríssimo. Rio de Janeiro: Elsevier, 2008. p. 2, e MÜLLER, Friedrich. O novo paradigma do Direito. Introdução à teoria e metódica estruturantes do direito. 3. ed. São Paulo: Revista dos Tribunais, 2013. p. 9-15.

20 BARROSO, Luís Roberto. Interpretação e Aplicação da Constituição. 6.ed. São Paulo: Saraiva, 2006, p. 325.

21 BARROSO, Luís Roberto. Interpretação e Aplicação da Constituição. 6.ed. São Paulo: Saraiva, 2006, p. 325.

22 BARROSO, Luís Roberto. Interpretação e Aplicação da Constituição. 6. ed. São Paulo: Saraiva, 2006. p. 326. 
Essas ideias espalharam-se no Brasil, tendo frutificado, notadamente, na literatura que versa sobre o controle judicial de políticas públicas. E isso ocorreu, muito provavelmente, por se tratar de campo de estudo situado no epicentro do debate sobre os limites e possibilidades do Poder Judiciário no desempenho da função de fazer atuar - muitas vezes diretamente, isto é, sem interposição legislativa - princípios constitucionais em situações concretas. Fala-se aqui, notadamente, dos princípios que positivam os chamados direitos sociais, cuja implementação a Constituição reserva, com primazia, aos Poderes Executivo e Legislativo. Dessa forma, fazendo ou não menção ao advento do "pós-positivismo", diversos autores que escrevem sobre o assunto têm na invocação de princípios e valores situados em uma zona de indefinição entre o moral e o jurídico (expressos ou implícitos no texto da Constituição) a fórmula necessária e suficiente para que Poder Judiciário delibere sobre políticas públicas.

Eduardo Cambi, por exemplo, afirma que a função do Poder Judiciário está sendo alterada: não mais se restringe à tarefa de subsunção do fato à letra da lei, mas compreende o exame do exercício discricionário do poder de legislar e de administrar a fim de aferir se estão conduzindo à efetivação dos resultados objetivados, no que chama de "responsabilidade finalística do juiz". Para Cambi, o Poder Judiciário passa a exercer uma "função socioterapêutica", corrigindo desvios na consecução das finalidades exigidas para a proteção dos direitos fundamentais, "[...] além de assumir a gestão da tensão entre igualdade formal e justiça social”. ${ }^{23}$

Na mesma linha, Osvaldo Canela Junior sustenta que, no controle de políticas públicas, toda a cognição do juízo gira em torno da ocorrência ou não de desigualdade social. Essa desigualdade deve ser aferida, no caso concreto, em cotejo com as possibilidades de fruição do direito social (artigo $6^{\circ}$ da Constituição de 1988) objeto da lide. Ele alerta, no entanto, que não se trata da discussão acerca da desigualdade social "em termos genéricos". A discussão, no caso concreto, é sobre "[...] a eventual desigualdade social gerada pela ausência de satisfação espontânea e adequada do bem da vida indicado no pedido". ${ }^{24}$

Carlos Alberto de Salles, ${ }^{25}$ por sua vez, adota o "interesse público" como um componente fundamental de sua teoria sobre o controle judicial de políticas públicas. Não acredita ser possível, porém, fornecer $a$ priori um critério suficiente, fechado e exaustivo para servir de base para a definição de interesse público, mas apenas indicar um princípio de justiça distributiva materializado em opções concretas de alocação de recursos sociais. Para ele, a indivisibilidade característica dos bens comuns traduz um critério de justiça segundo o qual os bens necessários ao desenvolvimento da coletividade são alocados a todo e qualquer de seus membros, não permitindo utilizações excludentes e devendo orientar a atividade jurisdicional.

Essas ilações são suficientes para amparar a hipótese, mas parece pertinente invocar aqui o pensamento de mais uma jurista, sobremodo conhecida no Brasil, Ada Pellegrini Grinover, para quem o Poder Judiciário pode exercer o controle das políticas públicas para aferir sua compatibilização com os objetivos fundamentais da República Federativa do Brasil, intervindo para implementá-las ou para corrigi-las quando equivocadas. Os limites a essa intervenção do Poder Judiciário nas políticas públicas são: a restrição à garantia do mínimo existencial, a razoabilidade da pretensão individual/social deduzida em face do Poder Público, a irrazoabilidade da escolha do agente público e a reserva do possível. ${ }^{26}$

Esses autores - e muitos outros ${ }^{27}$ - são representativos do que pode ser considerado um novo "senso comum

23 CAMBI, Eduardo. Neoconstitucionalismo e neoprocessualismo: direitos fundamentais, políticas públicas e protagonismo judiciário. São Paulo: Revista dos Tribunais, 2009. p. 195.

24 CANELA JUNIOR, Osvaldo. Controle judicial de políticas públicas. São Paulo: Saraiva, 2011. p. 156.

25 SALLES, Carlos Alberto de. Processo civil de interesse público. In: SALLES, Carlos Alberto de (Org.). Processo civil e interesse público: o processo como instrumento de defesa social. São Paulo: Revista dos Tribunais, 2003. p. 65-66.

26 GRINOVER, Ada Pellegrini. O controle de políticas públicas pelo Poder Judiciário. Revista de Direito Bancário e do Mercado de Capitais, v. 42, p. 11-32, 2008.

27 Por exemplo: BARCELLOS, Ana Paula de. Neoconstitucionalismo, direitos fundamentais e controle das políticas públicas. Revista de Direito Administrativo, São Paulo, n. 240, p. 83-103, 2005; MÂNICA, Fernando Borges. Teoria da reserva do possível: direitos fundamentais a prestações e a intervenção do Poder Judiciário na implementação de políticas públicas. Revista Brasileira de Direito Público - RBDP, Belo Horizonte, ano 5, n. 18, p. 169-186, jul./set. 2007; BUCCI, Maria Paula Dallari. Controle judicial de políticas públicas: possibilidades e limites. Fórum Administrativo - Direito Público - FA, Belo Horizonte, ano 9, n. 103, p. 7-16, 2009; FONTE, Felipe de Melo. A legitimidade do Poder Judiciário para o controle de políticas públicas. Revista Brasileira de Direito Público - RBDP, Belo Horizonte, 
teórico dos juristas" no campo do controle judicial de políticas públicas, que aposta no uso - e abuso - dos princípios constitucionais para opor-se, pelo menos na sua específica área de estudo, ao paradigma do positivismo jurídico. ${ }^{28}$ Essa expressão - "senso comum teórico" - foi desenvolvida, no interior do Direito brasileiro, pelo recentemente falecido jusfilósofo argentino Luis Alberto Warat. ${ }^{29}$

O senso comum - ou "as vozes incógnitas das verdades jurídicas" - designa, de uma maneira geral, “[...] as condições implícitas de produção, circulação e consumo das verdades nas diferentes práticas de enunciação e escritura do Direito". Trata-se, portanto, de um neologismo proposto por Warat a fim de obter um conceito operacional que sirva para mencionar a dimensão ideológica das verdades jurídicas. ${ }^{30}$

Não parece haver dúvidas de que tanto a doutrina como a jurisprudência são influenciadas “[...] por uma constelação de representações, imagens, pré-conceitos, crenças, ficções, hábitos de censura enunciativa, metáforas, estereótipos e normas éticas" que anonimamente pauta seus atos de enunciação e decisão. O senso comum teórico forma, desse modo, a relação imaginária dos juristas com suas atividades, proporcionando um campo de significado por meio do qual se determina a aceitabilidade do real. "É o tempo imaginado da história”. ${ }^{31}$ O problema é que esse campo de significado do novo senso comum teórico na questão do controle de políticas públicas leva os juristas que nele (no senso comum) estão inseridos a acreditarem que, ao defenderem suas ideias, estão tensionando o paradigma do juspositivismo, fazendo-lhe explícita ou implícita oposição. Acabam, porém, bem ao invés disso, por involuntariamente reproduzi-lo, pelo menos em certo sentido. Explico-me.

v. 6, n. 20, p. 91-125, jan./mar. 2008; WATANABE, Kazuo. Controle jurisdicional das políticas públicas - mínimo existencial e demais direitos fundamentais imediatamente judicializáveis. Revista de Processo, São Paulo, v. 36, n. 193, p. 13-36, mar. 2011; MARQUES, Lilian Patrus. Políticas públicas em juízo: meios de controle jurisdicional. Revista Dialética de Direito Processual - RDDP, São Paulo, n. 104, p. 62-77, nov. 2011; FARENZENA, Suélen. A busca pela efetividade dos direitos fundamentais sociais e a problemática atinente ao controle judicial das políticas públicas e orçamentos estatais. Revista de direitos e garantias fundamentais, Espírito Santo, n. 9, p. 77-104, jan./ jun. 2011; MOURA, Emerson Affonso da Costa. Do controle jurídico ao controle social das políticas públicas: parâmetros à efetividade dos direitos sociais. Revista de Direito Constitucional e Internacional, São Paulo, v. 19, n. 77, p. 131-184, out./dez. 2011; FIGUEIREDO, Marcelo. O controle das políticas públicas pelo Poder Judiciário no Brasil: uma visão geral. Interesse Público, Belo Horizonte, v. 9 , n. 44, p. 27-66, jul./ago. 2007; FREIRE JUNIOR, Américo Bedê. O controle judicial de políticas públicas. São Paulo: Revista dos Tribunais, 2005. Além desses, há o livro seminal de Eduardo Appio APPIO, Eduardo. Controle judicial das políticas públicas no Brasil. Curitiba: Juruá, 2005, p. 60, em que a abordagem do tema é em boa parte diferenciada, mas que entendo guardar algumas semelhanças com os demais por trechos como este: "Ao interpretar o alcance de um princípio constitucional, o juiz manifestará um ato de vontade, na medida em que não existe objetividade apreensível no texto interpretado. A interpretação a ser conferida ao texto constitucional dependerá, portanto, das pré-compreensões histórico-filosóficas do juiz acerca do tamanho ideal do Estado contemporâneo e o princípio democrático".

28 Apesar de não se valerem da expressão "senso comum teórico", há jusfilósofos que criticam a adesão dos constitucionalistas a esse "pós-positivismo brasileiro", a exemplo de Elival da Silva Ramos. RAMOS, Elival da Silva. Ativismo Judicial. Parâmetros Dogmáticos. São Paulo: Saraiva, 2010. p. 35-36 e Dimitri Dimoulis, que, na introdução à versão brasileira da obra "H. L. A. Hart”, de Neil MacCormick, faz a seguinte constatação: "MacCormick designa sua abordagem como 'pós-positivista' []. Mas os juristas brasileiros que utilizam o termo não citam suas obras, nem são por elas influenciados” MACCORMICK, Neil. H. L. A. Hart. Trad. Claudia Santana Martins. Rio de Janeiro: Elsevier, 2010, p. 17.

29 WARAT, Luis Alberto. Introdução geral ao direito. Porto Alegre: S. A. Fabris Editor, 1994. p. 13-18, v. 1. Roberto Freitas Filho utilizou essa concepção de Warat para construir seu conceito de "cultura jurídica", a qual, no sentido preconizado pelo autor, deve ser subdividida em cultura jurídica de formação e de atuação prática do jurista: a primeira fornece "[...] o universo conceitual e determinada matriz ideológica aos operadores do Direito, propondo sua socialização política e conferindo-lhe uma determinada referência de função social"; a segunda é a que "[...] se revela na praxis do ator jurídico, no cotidiano de suas atividades profissionais", ou seja, quando o operador do Direito coloca em prática o conjunto de valores que traz consigo desde a sua formação. FREITAS FILHO, Roberto. Crise do Direito e Juspositivismo. A Exaustão de um Paradigma. Brasília: Brasília Jurídica, 2003. p. 24-29. Outro jurista que se valeu do conceito de senso comum teórico para denunciar um certo status quo do saber jurídico, formatado pelo que chama de "crise de paradigma" do Direito, é Lenio Luiz Streck. Essa crise, para Streck, é sustentada ideologicamente por um emaranhado de crenças, fetiches, valores e justificativas legitimadas mediante discursos produzidos pelos órgãos institucionais (parlamentos, tribunais, escolas de direito, associações profissionais e administração pública). Tal emaranhado ideológico sufoca as possibilidades interpretativas, autorizando dissidências apenas possíveis, delimitadas previamente, de modo que tais dissidências "não ultrapassem o teto hermenêutico prefixado (horizonte do sentido)". Vide: STRECK, Lenio Luiz. Hermenêutica Jurídica e(m) Crise. Uma exploração hermenêutica da construção do Direito. 8. ed. Porto Alegre: Livraria do Advogado, 2009. p. 65-75.

30 WARAT, Luis Alberto. Introdução geral ao direito. Porto Alegre: S. A. Fabris Editor, 1994. p. 13, v. 1.

31 WARAT, Luis Alberto. Introdução geral ao direito. Porto Alegre: S. A. Fabris Editor, 1994. p. 13-14. Devo referir aqui que não desconheço que Warat deu um maior desenvolvimento, nesse mesmo texto, a seu conceito de senso comum teórico, descrevendo-o em mais detalhes, deixando-o, pois, mais minucioso e abrangente. Porém, para o meu argumento, não será necessário um maior aprofundamento nessas ilações. 
Os autores do novo senso comum teórico acreditam na forte atuação do Poder Judiciário no controle de políticas públicas, atuação essa fenomenalizada por meio da interpretação de princípios e valores constitucionais que incorporam cânones de moralidade abstrata como justiça social, justiça distributiva, igualdade, interesse público, mínimo existencial, reserva do possível e razoabilidade, mas deixam de trabalhar com um problema central do juspositivismo: o não enfrentamento da questão da discricionariedade judicial acarretada pela inerente indeterminação do Direito. ${ }^{32}$ Essa questão não era tida pelos positivistas em geral e por provavelmente seu maior expoente em particular, Hans Kelsen, como um problema jurídico, mas moral ou político. ${ }^{33} 34$

Ao fazer uma profissão de fé nessa gama de princípios e valores com conteúdo semanticamente muito aberto sem tratar dos limites da atividade interpretativa, o novo senso comum não está indo de encontro ao ideário do positivismo jurídico. Bem ao contrário disso, tal postura representa, consciente ou inconscientemente, uma atitude de aceitação da incontrolabilidade jurídica da discricionariedade dos juízes, típica do paradigma juspositivista. Para que não restem dúvidas quanto a isso, consideremos as ideias expostas por Hans Kelsen na sua clássica "Teoria Pura do Direito", uma das mais (senão a mais) importantes teorias do positivismo jurídico orientado para normatização no século XX. ${ }^{35}$

Kelsen sustentava que o problema da interpretação das normas jurídicas não pertence ao Direito, mas à política. No conhecido capítulo VIII (“A interpretação") da Teoria Pura, ${ }^{36}$ o jusfilósofo dizia haver uma

32 Registro, no entanto, que o problema da indeterminação do Direito e da correlata discricionariedade dos juízes, embora não trabalhado pelos autores que compõem o novo senso comum teórico na seara do controle de políticas públicas, é estudado por uma significativa parte de juristas brasileiros ligados às disciplinas da filosofia do Direito e da hermenêutica, os quais efetivamente lidam com essa problemática do paradigma do juspositivismo. Ver, por todos, Roberto Freitas Filho e Lenio Luiz Streck, além de Rafael Tomaz de Oliveira: FREITAS FILHO, Roberto. Crise do Direito e juspositivismo. A exaustão de um paradigma. Brasília: Brasília Jurídica, 2003; FREITAS FILHO, Roberto. Intervenção judicial nos contratos e aplicação dos princípios e das cláusulas gerais. O caso do leasing. Porto Alegre: S. A. Fabris, 2009; STRECK, Lenio Luiz. Hermenêutica Jurídica e (m) Crise. Uma exploração hermenêutica da construção do Direito. 8. ed. Porto Alegre: Livraria do Advogado, 2009; STRECK, Lenio Luiz. Verdade e Consenso. Constituição, Hermenêutica e Teorias Discursivas. Da possibilidade à necessidade de respostas corretas em Direito. 3. ed. Rio de Janeiro: Lumen Juris, 2009; STRECK, Lenio Luiz. O que é isto " decido conforme minha consciência? Porto Alegre: Livraria do Advogado, 2010; OLIVEIRA, Rafael Tomaz de. Decisão judicial e o conceito de princípio. A hermenêutica e a (in)determinação do Direito. Porto Alegre: Livraria do Advogado, 2008.

33 É como pensa Albert Calsamiglia: CALSAMIGLIA, Albert. Postpositivismo. Doxa - Cuadernos de Filosofía del Derecho, Alicante, n. 21, p. 209-220, 1998.

34 Michelon faz uma crítica semelhante: A expressão "princípio jurídico" tem tido uma presença frequente em decisões judiciais e na doutrina brasileiras. A expressão foi popularizada entre os profissionais e teóricos do direito no Brasil a partir de uma leitura direta ou, frequentemente, indireta de autores como Ronald Dworkin e Robert Alexy. Ironicamente, um conceito que foi originalmente elaborado [por Dworkin] como uma forma de estabelecer critérios de racionalidade que limitam a discricionariedade judicial é mais comumente associada no Brasil a um instrumento que permite ao juiz mais liberdade em relação à lei e ao direito posto. De fato, os princípios são muitas vezes utilizados por tribunais e doutrinadores como uma forma de eliminar dificuldades postas por regras complexas e/ou que destoam da concepção de justiça do juiz ou escritor. [...] O que se coloca em questão a partir do modo como os princípios jurídicos vêm sendo utilizados tanto na doutrina como na prática do direito brasileiro é a própria noção de que o direito é algo criado dinamicamente pela comunidade política e não algo derivado de um conjunto abstrato e vago de bens ou valores por especialistas que têm um insight privilegiado sobre como esses bens e valores fundamentais devem conformar nossas instituições e decisões políticas. Ou seja, o que está em jogo é a legitimidade democrática desse arranjo institucional. MICHELON, Cláudio. Princípios e coerência na argumentação jurídica. In: MACEDO JR., Ronaldo Porto; BARBIERI, Catarina Helena Cortada (Org.). Direito e interpretação: racionalidades e instituições. São Paulo: Saraiva, 2011. p. 261-262.

35 Assim pensa Robert Alexy ALEXY, Robert. Conceito e validade do Direito. Trad. Gercélia Batista de Oliveira Mendes. São Paulo: M. Fontes, 2009. p. 22-23: “Os representantes mais importantes do positivismo jurídico orientado para a normatização no século XX são Hans Kelsen e Herbert Hart. Kelsen define o direito como um 'ordenamento normativo coativo', cuja validade baseia-se numa norma fundamental pressuposta [...]. Segundo Hart, o direito é um sistema de regras que pode ser identificado por meio de uma regra de recognição ou de reconhecimento (rule of recognition). A função dessa regra corresponde à da norma fundamental de Kelsen [...]”. 36 KELSEN, Hans. Teoria pura do Direito. Trad. João Baptista Machado. 8. ed. São Paulo: M. Fontes, 2009. p. 387-397. A versão do capítulo oitavo a que me refiro aqui corresponde àquela revista por Kelsen em 1960, quando realizou o que alguns autores chamam de "giro decisionista". Eis o que referem a respeito Carvalho Netto e Scotti: "[...] na edição revista da Teoria pura do direito, de 1960, Kelsen procede ao famoso giro decisionista, alterando o capítulo oitavo da obra dedicado à questão da interpretação. Precisamente o que distingue, para Kelsen, a interpretação científica da interpretação que denomina autêntica, é o fato de a primeira ser neutra e de não ter o poder de vincular as pessoas tão somente em razão da pronúncia, como as autoridades estatais competentes para decidir e aplicar a norma jurídica o fazem. Ele se indaga agora o que aconteceria se a autoridade decidisse por um sentido que não estivesse contido no interior do quadro dos sentidos admissíveis traçados pela doutrina, e responde: azar da Ciência do Direito, é 
relativa indeterminação no ato de aplicação do Direito. A relação entre um nível hierárquico superior e outro inferior da ordem jurídica, como a relação entre lei e Constituição ou lei e decisão judicial, é de vinculação, todavia a determinação nunca é completa. A norma de maior hierarquia não pode vincular em todas as direções o ato por meio do qual é aplicada. Resta sempre uma margem - ora maior ora menor - de livre apreciação, de modo que a norma do nível superior apresenta-se, em relação ao ato inferior de produção normativa ou à decisão judicial, como um quadro ou moldura a ser preenchida.

A indeterminação, segundo o pensamento kelseninano, sempre existe; às vezes, intencionalmente. Quando não é intencional, ela decorre da própria pluralidade de significações de uma palavra ou de uma sequência de palavras em que o ato normativo se exprime: “[...] o sentido verbal da norma não é unívoco, o órgão que tem de aplicar a norma encontra-se perante várias significações possíveis". ${ }^{37} \mathrm{Na}$ hipótese de uma norma intencionalmente indeterminada, há - de modo expresso ou não - uma delegação voluntária do processo de determinação do(s) sentido(s) da norma ao órgão de produção normativa inferior ou ao aplicador da lei. É o que ocorre com as normas ditas "gerais". Nas exatas palavras de Kelsen: "[...] o estabelecimento ou fixação de uma norma simplesmente geral opera-se sempre $[\ldots]$ sob o pressuposto de que a norma individual que resulta da sua aplicação continua o processo de determinação". ${ }^{38}$

Fiel ao seu ideal positivista, Hans Kelsen afirmava não haver qualquer critério jurídico com base no qual uma das possibilidades inscritas na moldura de interpretações de determinada norma possa ser preferida à outra. Não existe, segundo sua teoria, método capaz de ser qualificado como de Direito positivo que aponte qual das várias significações verbais possíveis de uma norma pode ser destacada como "correta". Não é, pois, um problema de teoria do Direito, mas de política do Direito, regido por normas de moral ou de justiça. Daí que, na visão kelseniana, a interpretação feita pelo órgão aplicador do Direito ${ }^{39}$ corresponde não a um ato de conhecimento, mas a um ato de vontade, que pode realizar não apenas "[...] uma das possibilidades reveladas pela interpretação cognoscitiva da mesma norma, como também pode produzir uma norma que se situe completamente fora da moldura que a norma a aplicar representa". ${ }^{40}$

No momento em que admite que a interpretação jurídica "[...] pode produzir uma norma que se situe completamente fora da moldura que a norma a aplicar representa”, Hans Kelsen está aceitando que a discricionariedade judicial desconhece limites. A sua postulação geral, portanto, era a de que a interpretação, ou melhor, o resultado da atividade interpretativa não pode ser sindicado por meio das regras postas pelo Direito, o que está longe de significar que ele entendia isso como algo bom. Kelsen pode ser considerado um pessimista ou um fatalista em relação a essa situação. Aliás, em outro estudo, ${ }^{41}$ chegou a lamentar o fato de as constituições positivarem regras expressas em termos tão vagos, aumentando ainda mais o poder discricionário dos magistrados e a sua consequente incontrolabilidade. ${ }^{42}$

Na medida em que o novo senso comum teórico aposta, para propiciar o controle de políticas públicas,

a autoridade que pode impor a observância das normas e não o cientista" NETTO, Menelick de Carvalho; SCOTTI, Guilherme. Os direitos fundamentais e a (in)certeza do Direito. A produtividade das tensões principiológicas e a superação do sistema de regras. Belo Horizonte: Fórum, 2011, p. 49-50.

37 KELSEN, Hans. Teoria pura do Direito. Trad. João Baptista Machado. 8. ed. São Paulo: M. Fontes, 2009. p. 389.

38 KELSEN, Hans. Teoria pura do Direito. Trad. João Baptista Machado. 8. ed. São Paulo: M. Fontes, 2009. p. 389.

39 Kelsen chama-a de "interpretação autêntica".

40 KELSEN, Hans. Teoria pura do Direito. Trad. João Baptista Machado. 8. ed. São Paulo: M. Fontes, 2009. p. 391-394.

41 KELSEN, Hans. Jurisdição constitucional. Trad. Alexandre Krug. 2. ed. São Paulo: M. Fontes, 2007. p. 262-263.

42 Nas exatas palavras de Kelsen: "Caso se deseje restringir o poder dos tribunais, e, assim, o caráter político da sua função - tendência que sobressai particularmente na monarquia constitucional, podendo, porém, ser observada também na república democrática -, deve-se então limitar o máximo possível a margem de discricionariedade que as leis concedem à utilização daquele poder. Além disso as normas constitucionais a serem aplicadas por um tribunal constitucional, sobretudo as que definem o conteúdo de leis futuras - como as disposições sobre direitos fundamentais e similares -, não devem ser formuladas em termos demasiado gerais, nem devem operar com chavões vagos como 'liberdade', 'igualdade', 'justiça' etc. Do contrário existe o perigo de uma transferência de poder - não previsto pela Constituição e altamente inoportuno - do Parlamento para uma instância externa a ele, a qual pode tornar-se o expoente de forças políticas totalmente distintas daquelas que se expressam no Parlamento" KELSEN, Hans. Jurisdição constitucional. Trad. Alexandre Krug. 2. ed. São Paulo: M. Fontes, 2007. p. 262-263. 
na incorporação de princípios e de valores morais ao discurso jurisdicional sem problematizar a discricionariedade dos decisores, reafirma a tese fatalista de Kelsen e de outros positivistas no sentido da impossibilidade de sindicar a atividade interpretativa do Poder Judiciário. Nesse mesmo sentido, Lenio Streck sustenta que "[...] há uma imensa dificuldade de libertação de toda carga conceitual que foi legada pelos anos de predomínio do positivismo". O resultado disso é a repristinação das velhas teses positivistas que tinham na discricionariedade judicial a solução do problema da decidibilidade. "A discricionariedade passou a ser a condição de possibilidade da decisão". ${ }^{3}$

Essa discricionariedade judicial agasalhada pelo novo senso comum teórico dos juristas - mesmo bem intencionada, como acredito que seja - equivale àquela de "sentido forte" descrita por Dworkin, ${ }^{44}$ a qual redunda em um agir arbitrário. E o arbítrio, ainda que "prudente", não pode ser a melhor solução para os problemas de (in)suficiência de políticas públicas, problemas para os quais não temos respostas fáceis. Ora, de que forma se interpreta o direito à integridade física do preso no contexto de uma ação em que o Ministério Público postula do Estado a construção de um presídio? O direito fundamental à moradia autoriza que se peça ao Estado a concessão gratuita de uma casa para quem não a possui? O portador de uma doença rara pode pedir ao Estado que lhe custeie um tratamento médico no exterior? Definitivamente, a só invocação de valores e princípios não nos fornecerá as necessárias respostas.

Apesar disso, o novo senso comum teórico no campo do controle de políticas públicas é fortemente compartilhado pelo discurso jurisdicional, tendo em vista as naturais e recíprocas interações entre este e o discurso doutrinário. ${ }^{45}$ Um bom exemplo é a decisão do ministro do Supremo Tribunal Federal Celso de Mello na conhecida arguição de descumprimento de preceito fundamental (ADPF) 45, quando, embora tenha declarado a ação prejudicada em virtude da perda superveniente do objeto, fez considerações, em obiter dictum, reproduzidas em diversos precedentes formados posteriormente. O ministro destacou, na oportunidade, que, embora não se inclua, ordinariamente, no âmbito das funções institucionais do Poder Judiciário a atribuição de formular e de implementar políticas públicas, tal incumbência, ainda que em bases excepcionais, poder-lhe-á ser atribuída, “[...] se e quando os órgãos estatais competentes [...] vierem a comprometer, com tal comportamento, a eficácia e a integridade de direitos individuais e/ou coletivos impregnados de estatura constitucional". Salientou, outrossim, que a cláusula da reserva do possível não pode ser invocada, pelo Estado, com a finalidade de exonerar-se do cumprimento de suas obrigações constitucionais, sendo os condicionamentos impostos por essa cláusula traduzidos em um binômio que compreende a razoabilidade da pretensão individual/social deduzida em face do Poder Público e a existência de disponibilidade financeira do Estado para tornar efetivas as prestações positivas dele reclamadas. Desse modo, ainda em conformidade com o decisor, se os Poderes Legislativo e Executivo agirem de modo irrazoável, comprometendo a eficácia dos direitos sociais, econômicos e culturais, atingindo seu “[...] núcleo consubstanciador de um conjunto irredutível de condições mínimas necessárias a uma existência digna e essenciais à própria sobrevivência do indivíduo", aí estará justificada “[...] a possibilidade de intervenção do Poder Judiciário, em ordem a viabilizar, a todos, o acesso aos bens cuja fruição lhes haja sido injustamente recusada pelo Estado". ${ }^{46}$

Não é possível extrair desse precedente os casos em que, efetivamente, será permitida a intervenção judicial em políticas públicas. É muito difícil discernir, a partir desse discurso, quando e até que ponto o Estado

43 STRECK, Lenio Luiz. O que é isto - decido conforme minha consciência? Porto Alegre: Livraria do Advogado, 2010. p. 91-92.

44 DWORKIN, Ronald. Levando os direitos a sério. Trad. Nelson Boeira. São Paulo: M. Fontes, 2010. p. 50-63.

45 Há, de fato, uma significativa quantidade de juízes que apostam na sua discricionariedade (chamada, às vezes, de "prudente arbítrio" ou de "livre convencimento") para a resolução dos problemas de uma alegada insuficiência dos textos de lei. Streck elenca bons exemplos disso nos capítulos segundo e terceiro (respectivamente, "As práticas judiciárias em terrae brasilis ou 'de como fluem os sentidos que desnudam um paradigma" e "Nas nesgas da linguagem, as manifestações doutrinárias que des-cobrem o DNA do solipsismo judicial") de seu livro sugestivamente intitulado "O que é isto - decido conforme minha consciência?" STRECK, Lenio Luiz. O que é isto - decido conforme minha consciência? Porto Alegre: Livraria do Advogado, 2010.

46 BRASIL. Supremo Tribunal Federal. Disponível em: < http://www.stf.jus.br.>. Acesso em: 16 set. 2012. 
estará descumprindo, na prática, a principiologia constitucional e quando estará agindo dentro dos limites legítimos proporcionados por determinadas interpretações dos postulados genéricos que lhe balizam o atuar, como a reserva do possível ou o mínimo existencial. Em uma palavra: o problema da discricionariedade judicial está aí marcadamente presente e, por conseguinte, a indagação sobre "até onde o magistrado pode ir nesse campo" também.

Aliás, não é possível tratar da judicialização das políticas públicas de uma forma assim tão ampla e abstrata. Para que os limites do atuar do juiz sejam fixados, parece necessário que sejam levadas em consideração as características da específica política pública que está, no momento, sendo objeto de apreciação jurisdicional. Muitas vezes, todavia, é um tanto difícil até mesmo divisar quando se está diante de uma política pública judicializada ou de meras decorrências dela, traduzíveis em direitos subjetivos exequíveis individualmente.

Explico com um exemplo: as tão conhecidas ações em que se pleiteiam a dispensa de medicamentos pelo Estado. Nessas demandas, comumente não se discute a política pública de saúde, mas apenas uma prestação específica de uma política já bem regulamentada em nível infraconstitucional. Quando falta, nas prateleiras dos órgãos que compõem o sistema único de saúde, um remédio que deveria ser ofertado pelo poder público e, para a sua concessão, é aforada uma ação, está-se requerendo apenas o cumprimento de uma política desenvolvida e em funcionamento, o que torna possível a extração de um direito subjetivo a essa prestação material.

Em uma simplificação, pode-se dizer que o raciocínio desenvolve-se por meio do seguinte silogismo: o Estado obrigou-se a fornecer, por meio do SUS, determinado fármaco (premissa maior); o particular pediu administrativamente mas não o obteve (premissa menor); e então o Poder Judiciário determina que a Administração Pública cumpra uma obrigação que ela própria se impôs. Parece ser esse o entendimento manifestado por Sueli Gandolfi Dallari ao referir que "[...] o direito ao medicamento é parte do direito à saúde; é uma parte pequena, certamente". ${ }^{47}$

A situação seria bem diferente caso se tratasse de uma ação civil pública ajuizada com a pretensão de fazer incluir, no âmbito do SUS, para fornecimento gratuito a todos os potenciais beneficiários, uma nova droga, de caráter, por exemplo, experimental, não aprovada pela ANVISA, mas que fosse defendida por parte da comunidade médica como eficaz para o tratamento de uma doença cuja medicação não estivesse prevista para dispensação pelo poder público. Aí sim poder-se-ia falar em judicialização de uma política pública de saúde, a demandar uma interpretação muito mais complexa do fenômeno.

Essa diferenciação parece receber o respaldo de José Reinaldo de Lima Lopes, quando refere que os direitos sociais - os quais, em boa parte, devem ser implementados por meio de políticas públicas - têm a característica de não serem, em princípio, fruíveis de modo individual, o que não quer dizer que não possam, em determinadas circunstâncias, ser exigidos judicialmente como se exigem outros direitos subjetivos. "Mas, de regra, dependem, para sua eficácia, de atuação do Executivo e do Legislativo por terem o caráter de generalidade e publicidade". ${ }^{48}$

Todas essas dificuldades inerentes ao fenômeno devem ser discutidas para que possamos evoluir no tema da judicialização de políticas públicas. Tais problemas estão, como se pode observar, intimamente ligados com a questão da discricionariedade judicial, que deve ser trazida para a agenda dos autores brasileiros que tratam do assunto, a fim de que os limites do agir dos magistrados quando analisam políticas públicas passem a figurar como uma preocupação central da disciplina. Mas não serão discutidos agora os parâmetros que devem ser observados pelos juízes nesses casos; isso ficará para outra oportunidade.

Por ora, a guisa de desfecho deste breve artigo, enunciam-se algumas conclusões parciais: (1) formou-se

47 AUDIÊNCIA PÚBLICA: Saúde. Brasília: Supremo Tribunal Federal, 2009. p. 225.

48 LOPES, José Reinaldo de Lima. Direitos subjetivos e direitos sociais: o dilema do judiciário no Estado Social de Direito. In: FARIA, José Eduardo (Org.). Direitos humanos, direitos sociais e justiça. São Paulo: Malheiros, 1998. p. 129. 
um novo senso comum teórico no campo de estudo da judicialização de políticas públicas, que entende ser possível lidar com a questão valendo-se de princípios e de valores situados na fronteira entre a Moral e o Direito, positivados implícita ou explicitamente na Constituição; (2) há alguma coisa de arbitrário nessa aposta, pois o nível de preocupação do novo senso comum com a descrição desses princípios e valores não é observado com o problema correlato da discricionariedade judicial; (3) a ausência de preocupação com os limites do agir discricionário dos juízes impede que o novo senso comum atinja o intento de superar o paradigma do positivismo, cujo maior representante, Hans Kelsen, apresentou uma conhecida visão fatalista do problema, considerando-o, em face da inerente indeterminação do Direito, não apenas inevitável como insindicável juridicamente.

\section{REFERÊNCIAS}

ALEXY, Robert. Conceito e validade do Direito. Trad. Gercélia Batista de Oliveira Mendes. São Paulo: M. Fontes, 2009.

APPIO, Eduardo. Controle judicial das políticas públicas no Brasil. Curitiba: Juruá, 2005.

AUDIÊNCIA PÚBLICA: Saúde. Brasília: Supremo Tribunal Federal, 2009.

BARCELLOS, Ana Paula de. Neoconstitucionalismo, direitos fundamentais e controle das políticas públicas. Revista de Direito Administrativo, São Paulo, n. 240, p. 83-103, 2005.

BARROSO, Luís Roberto. Interpretação e aplicaşão da Constituição. 6. ed. São Paulo: Saraiva, 2006.

BUCCI, Maria Paula Dallari. Controle judicial de políticas públicas: possibilidades e limites. Fórum Administrativo - Direito Público - FA, Belo Horizonte, ano 9, n. 103, p. 7-16, 2009.

CALSAMIGLIA, Albert. Postpositivismo. Doxa - Cuadernos de Filosofía del Derecho, Alicante, n. 21, p. 209220, 1998.

CAMBI, Eduardo. Neoconstitucionalismo e neoprocessualismo: direitos fundamentais, políticas públicas e protagonismo judiciário. São Paulo: Revista dos Tribunais, 2009.

CANELA JUNIOR, Osvaldo. Controle judicial de políticas públicas. São Paulo: Saraiva, 2011.

CASAGRANDE, Renato; FREITAS FILHO, Roberto. O problema do tempo decisório nas políticas públicas. Revista de Informação Legislativa, Brasília, a. 47, n. 187, jul./set. 2010.

DWORKIN, Ronald. O império do direito. Trad. Jefferson Luiz Camargo. São Paulo: M. Fontes, 2007.

DWORKIN, Ronald. Levando os direitos a sério. Trad. Nelson Boeira. São Paulo: M. Fontes, 2010.

DWORKIN, Ronald. A justiça de toga. Trad. Jefferson Luiz Camargo. São Paulo: M. Fontes, 2010.

FARENZENA, Sulen. A busca pela efetividade dos direitos fundamentais sociais e a problemática atinente ao controle judicial das políticas públicas e orçamentos estatais. Revista de direitos e garantias fundamentais, Espírito Santo, n. 9, p. 77-104, jan./jun. 2011.

FERRAZ JUNIOR, Tercio Sampaio. Introdução ao estudo do Direito: técnica, decisão, dominação. 6. ed. São Paulo: Atlas, 2011.

FIGUEIREDO, Marcelo. O controle das políticas públicas pelo Poder Judiciário no Brasil: uma visão geral. Interesse Público, Belo Horizonte, v. 9, n. 44, p. 27-66, jul./ago. 2007.

FONTE, Felipe de Melo. A legitimidade do Poder Judiciário para o controle de políticas públicas. Revista Brasileira de Direito Público - RBDP, Belo Horizonte, v. 6, n. 20, p. 91-125, jan./mar. 2008. 
FREIRE JUNIOR, Américo Bedê. O controle judicial de políticas públicas. São Paulo: Revista dos Tribunais, 2005.

FREITAS FILHO, Roberto. Crise do Direito e Juspositivismo. A Exaustão de um paradigma. Brasília: Brasília Jurídica, 2003.

FREITAS FILHO, Roberto. Intervenção judicial nos contratos e aplicação dos princípios e das cláusulas gerais. O caso do leasing. Porto Alegre: S. A. Fabris, 2009.

GRINOVER, Ada Pellegrini. O controle de políticas públicas pelo Poder Judiciário. Revista de Direito Bancário e do Mercado de Capitais, v. 42, p. 11-32, 2008.

HART, H. L. A. O conceito de Direito. Trad. Antônio de Oliveira Sette-Câmara. São Paulo: M. Fontes, 2009.

KELSEN, Hans. Jurisdição constitucional. Trad. Alexandre Krug. 2. ed. São Paulo: M. Fontes, 2007.

KELSEN, Hans. Teoria pura do Direito. Trad. João Baptista Machado. 8. ed. São Paulo: M. Fontes, 2009.

KUHN, Thomas S. A Estrutura das revoluções científicas. Trad. Beatriz Vianna Boeira e Nelson Boeira. São Paulo: Perspectiva, 2005.

KUHN, Thomas S. Algo Más Sobre los Paradigmas. Trad. Roberto Helier. In: KUHN, Thomas S. La Tensión Esencial. Estudios selectos sobre la tradición y el cambio em el ámbito de la ciencia. México: Fondo de Cultura Económica, 1996.

KUHN, Thomas S. As ciências naturais e as ciências humanas. Trad. Cesar Mortari. In: KUHN, Thomas S. O caminho desde a estrutura. São Paulo: UNESP, 2006.

LOPES, José Reinaldo de Lima. Direitos subjetivos e direitos sociais: o dilema do judiciário no Estado Social de Direito. In: FARIA, José Eduardo (Org.). Direitos bumanos, direitos sociais e justiça. São Paulo: Malheiros, 1998.

MACCORMICK, Neil. Legal Reasoning and Legal Theory. New York: Oxford University Press, 1978.

MACCORMICK, Neil. Argumentaşão jurídica e teoria do direito. Trad. Waldéa Barcellos. São Paulo: M. Fontes, 2006.

MACCORMICK, Neil. Retórica e o Estado de Direito. Trad. Conrado Hübner Mendes e Marcos Paulo Veríssimo. Rio de Janeiro: Elsevier, 2008.

MÂNICA, Fernando Borges. Teoria da reserva do possível: direitos fundamentais a prestações e a intervenção do Poder Judiciário na implementação de políticas públicas. Revista Brasileira de Direito Público - RBDP, Belo Horizonte, ano 5, n. 18, p. 169-186, jul./set. 2007.

MARQUES, Lilian Patrus. Políticas públicas em juízo: meios de controle jurisdicional. Revista Dialética de Direito Processual - RDDP, São Paulo, n.104, p. 62-77, nov. 2011.

MICHELON, Cláudio. Princípios e coerência na argumentação jurídica. In: MACEDO JR., Ronaldo Porto; BARBIERI, Catarina Helena Cortada (Org.). Direito e interpretação: racionalidades e instituições. São Paulo: Saraiva, 2011. p. 261-262.

MOURA, Emerson Affonso da Costa. Do controle jurídico ao controle social das políticas públicas: parâmetros à efetividade dos direitos sociais. Revista de Direito Constitucional e Internacional, São Paulo, v. 19, n. 77, p. 131-184, out./dez. 2011.

MÜLLER, Friedrich. O novo paradigma do Direito. Introdução à teoria e metódica estruturantes do direito. 3. ed. São Paulo: Revista dos Tribunais, 2013.

NETTO, Menelick de Carvalho; SCOTTI, Guilherme. Os direitos fundamentais e a (in)certeza do Direito. A produtividade das tensões principiológicas e a superação do sistema de regras. Belo Horizonte: Fórum, 2011. 
OLIVEIRA, Rafael Tomaz de. Decisão judicial e o conceito de princípio. A hermenêutica e a (in)determinação do Direito. Porto Alegre: Livraria do Advogado, 2008.

SALLES, Carlos Alberto de. Processo civil de interesse público. In: SALLES, Carlos Alberto de (Org.). Processo civil e interesse público: o processo como instrumento de defesa social. São Paulo: Revista dos Tribunais, 2003.

STRECK, Lenio Luiz. Verdade e Consenso. Constituição, Hermenêutica e Teorias Discursivas. Da possibilidade à necessidade de respostas corretas em Direito. 3. ed. Rio de Janeiro: Lumen Juris, 2009.

STRECK, Lenio Luiz. Hermenêutica Jurídica e $(m)$ Crise. Uma exploração hermenêutica da construção do direito. 8. ed. Porto Alegre: Livraria do Advogado, 2009.

STRECK, Lenio Luiz. O que é isto - decido conforme minha consciência? Porto Alegre: Livraria do Advogado, 2010.

WARAT, Luis Alberto. Introdução geral ao Direito. Porto Alegre: S. A. Fabris Editor, 1994. v.1.

WATANABE, Kazuo. Controle Jurisdicional das políticas públicas - mínimo existencial e demais direitos fundamentais imediatamente judicializáveis. Revista de Processo, São Paulo, v. 36, n. 193, p. 13-36, mar. 2011. 


\title{
A governança transnacional ambiental na Rio +20
}

\section{Transnational environmental governance at Rio + 20*}

\author{
Paulo Márcio Cruz ${ }^{* *}$ \\ Zenildo Bodnar***
}

\section{Resumo}

Este artigo possui como objetivo investigar as limitações do atual modelo político e jurídico de gestão e tutela dos bens ambientais numa perspectiva global, em especial a partir das reflexões da conferência sobre o meio ambiente Rio+20, ocorrida na cidade do Rio de Janeiro em junho de 2012. De maneira indutiva, nota-se que na atual Sociedade de risco há uma crise/ carência de governança global que torna oportuna e necessária a implementação de novos modelos de gestão e regulação. Essa crise/carência de governança decorre tanto da obsolescência do modelo estatal, limitado pelas fronteiras territoriais, como também da insuficiência do sistema e da lógica jurídica do Direito Internacional atual para a eficaz tutela planetária do meio ambiente, especialmente no que diz respeito ao risco futuro e à tutela das futuras gerações. O presente artigo trata de confirmar que é imprescindível o desenvolvimento de novas estratégias de Governança Transnacional Ambiental que sejam capazes de articular atitudes solidárias, inclusivas, democráticas e cooperativas e agregar as pessoas , as instituições e os Estados na luta pela proteção de bens e de valores imprescindíveis para assegurar, inclusive para as futuras gerações, uma vida digna, sustentável e promissora.

* Recebido em 21/08/2013

Aprovado em 08/10/2013

** Doutor em Direito pela Universidade Federal de Santa Catarina - UFSC. Professor dos Programas de Doutorado e Mestrado na Universidade do Vale do Itajaí (SC) - UNIVALI (SC, Brasil). Juiz Federal em Santa Catarina. Email: pcruz@univali.br

*** Pós-Doutor em Direito do Estado pela Universidade de Alicante, na Espanha, Doutor em Direito do Estado pela Universidade Federal de Santa Catarina e Mestre em Instituições Jurídico-Políticas também pela Universidade Federal de Santa Catarina - UFSC. Coordenador e professor do Programa de PósGraduação Stricto Sensu em Ciência Jurídica da Universidade do Vale do Itajaí - UNIVALI em seus cursos de Doutorado e Mestrado em Ciência Jurídica. Foi Secretário de Estado em Santa Catarina e Vice-reitor da UNIVALI. É professor visitante nas universidades de Alicante, na Espanha, e de Perugia, na Itália. Email: zenildo@univali.br
Palavras-chave: Transnacionalidade. Governança transnacional. Meio ambiente.

\section{Abstract}

This article has the goal of investigating the limitations of current political and legal model for the management and protection of environmental goods in a global perspective, especially based on the reflections brought by the RIO +20 Conference. With the use of the inductive method, there is the conclusion that in the current risk society there is a global governance crisis which causes the implementation of new management and regulation models to be necessary and opportune. This governance crisis stems from both the obsolescence of the state model, limited by territorial boundaries, but also from the inadequacy of the legal system and the logic of traditional international Law for the effective protection of global environment, especially regarding future risk and protection of future generations. Development of new strategies of transnational environmental governance 
capable of articulating cohesive, inclusive, democratic and cooperative attitudes and of aggregating people, institutions and states in the fight for protection of property and values essential to ensure, even for future generations, a decent sustainable and promising life is presented as essential.

Keywords: Transnationality. Transnational governance. Environment.

\section{NOTA INTRODUTÓRIA}

As profundas mudanças ocorridas com a intensificação do fenômeno da globalização alteraram de maneira irreversível a configuração do Estado Constitucional Moderno, em especial a sua pretensão de soberania. Os novos desafios sociais, econômicos e ecológicos, a complexidade e a amplitude das novas demandas transnacionais, em plena escalada progressiva de surgimento, também colocam à prova e denunciam as limitações de capacidade resolutiva do modelo de organização política e jurídica estatal territorializado, hoje existente.

Nesse contexto, surge um cenário extremamente receptivo para que sejam discutidas e teorizadas novas e estratégicas formas de governança que, sem desconsiderar a importância das esferas de poder local, projetem a proteção efetiva do meio ambiente para toda a comunidade mundial.

O tema é atual e relevante, especialmente considerando a inclusão da temática da governança como um dos assuntos centrais da Rio+20. Assim, este artigo analisa inicialmente a evolução e a obsolescência dos Estados Modernos para garantir a sustentabilidade em todo o planeta. Em seguida, avalia-se a necessidade da emergência de novas e efetivas estratégias políticas e jurídicas de Governança Transnacional Ambiental, tendo os desafios globais ambientais como seu principal fator desencadeante, e a cooperação e a solidariedade como princípios fundamentais.

Para os objetivos do presente artigo, entende-se que governança ambiental refere-se ao conjunto de iniciativas, regras, instâncias e processos que permitem às pessoas, por meio de suas comunidades e organizações civis, exercerem o controle social, público e transparente das estruturas estatais e das políticas públicas, por um lado, e da dinâmica e das instituições do mercado, por outro, visando atingir objetivos ambientais sustentáveis. Assim, governança ambiental abrange tanto mecanismos governamentais como informais e/ou não estatais. Significa a capacidade social (os sistemas, seus instrumentos e instituições) de dar rumo, ou seja, de orientar condutas dos Estados, das empresas, das pessoas em torno de certos valores e de objetivos ambientais de longo prazo para a sociedade transnacional..

\section{EvoluÇÃo do eSTADo CONSTITUCIONAL MOdERNO PARA A SUSTENTABILIDADE GLOBAL}

Até a Primeira Guerra Mundial, os Estados desempenhavam um papel formal, passivo e meramente de abstenção, pois as Constituições apenas proclamavam os direitos individuais clássicos de primeira dimensão que eram exercidos, como regra, diretamente pelos cidadãos. As esferas econômicas e sociais se regulavam por si mesmas. Isso supôs a existência de um consenso de base ideológica por parte dos grupos que formavam a opinião pública e controlavam todos os meios de comunicação da sociedade. ${ }^{1}$

Todavia, com a evolução da sociedade, este modelo estatal se revelou incapaz para atender às novas demandas da nova ordem social massificada e hipercomplexa. ${ }^{2}$ Com isso, foi fundamental uma mudança

1 CRUZ, Paulo Márcio. Política, poder, ideologia e estado contemporâneo. 3. ed. Curitiba: Juruá, 2004. p.104.

2 Hipercomplexidade significa, para o escopo do presente artigo, o aumento exponencial da complexidade na sociedade de risco ocasionado pela intensificação das globalizações econômica, social e cultural. 
contundente de atitude e de função, pois se no Estado Liberal a estratégia de ação era não interferir para resguardar os direitos liberais (liberdade, propriedade, dentre outros), no Estado Social, passou-se a requerer uma atitude positiva para que a garantia plena dos direitos aconteça também por intermédio do Estado, que passou a ser responsável por uma grande quantidade de prestações sociais, como, por exemplo, saúde, educação, segurança pública.

Assim, somente a partir de 1917 e 1919 é que as Constituições passaram a estabelecer um novo papel aos Estados. Já não era mais suficiente garantir a liberdade formal e a independência jurídica do indivíduo, pois também passou a ser imprescindível a criação de condições para o alcance da independência social. Assim, legitima-se a intervenção do Estado com um papel de destacada relevância na correção de situações de injustiça geradas pelo individualismo.

A partir desse momento, ocorreu uma profunda redefinição no papel dos Estados e na sua relação com a sociedade. Os direitos passaram a ser fruídos por intermédio dos Estados e estes passaram a interferir muito mais vigorosamente na sociedade mediante o estabelecimento de obrigações e pautas de conduta, tudo para garantir a solidariedade social.

Contudo, é muito importante, especialmente nos países em desenvolvimento, que o Estado tenha o tamanho certo, ou seja, que desempenhe apenas aquelas funções que sejam imprescindíveis para a promoção da justiça social e para concretizar a solidariedade em todos os planos. O atendimento da sua verdadeira função social, enquanto articulador estratégico da solidariedade social, só será possível com pretensões adequadas que não usurpem as funções da sociedade livre e não corroam o imprescindível protagonismo coletivo e individual, pois este deve e pode ser alcançado sem a atuação paternalista dos Estados.

Ao abordar os excessos do Estado de bem-estar, o espanhol Fernando Suárez propõe inclusive a substituição do Estado de bem-estar pela Ssociedade do bem-estar, exatamente para que ela possa recuperar a responsabilidade e o poder de ação perdidos. Defende que, “[...] desde uma perspectiva humanista, não se pode aceitar que a responsabilidade pela sorte de nossos concidadãos recaia sobre os ombros do Estado". ${ }^{3}$

$\mathrm{Na}$ evolução histórica do papel dos Estados e da configuração dos direitos, também é muito valiosa a análise das relações estabelecidas entre o Estado e a sociedade. Essas relações, que muitas vezes foram marcadas por tensões e colocaram até em questionamento a legitimidade de determinadas imposições estatais ou de determinados papéis por eles desempenhados, devem agora estar sintonizadas na busca de objetivos comuns.

As lições históricas advindas das múltiplas e complexas relações entre a sociedade e o Estado deixaram como legado muito claro que o Estado não deve suplantar nem substituir a sociedade, mas sim servi-la, isso mediante estratégias de promoção e articulação solidária.

No contexto da Sociedade de risco, ${ }^{4}$ hipercomplexa e policonflitiva, a relação entre o Estado e a sociedade deve ser de parceria e cooperação. Com o surgimento dos novos direitos de terceira dimensão, em especial o direito ao meio ambiente sadio e equilibrado, impõe-se uma redefinição do modo de organização política estatal. O Estado passa a não mais atuar apenas como garantia dos direitos de liberdade e provedor de direitos sociais, mas precisa agir em parceria com a sociedade para assegurar, inclusive para as futuras gerações e para toda a comunidade de vida, condições ideais de habitabilidade.

A partir dos novos desafios gerados pela crise ecológica e que caracterizam a Sociedade de risco, teoriza-se acerca da necessidade da consolidação de um Estado de Direito Ambiental ou Estado Ecológico, especialmente considerando as suas novas funções e o conteúdo das novas Constituições democráticas. Essa

3 SUÁREZ, Fernando. Informe espanhol. In: MARZAL, Antônio (Ed.). Crisis del Estado de bienestar y derecho social. Barcelona: J. M. Bosch, 1997. p. 100.

4 Sobre a Sociedade de risco ver BECK, Ulrich. Sociedade de risco: rumo a outra modernidade. Tradução de Sebastião Nascimento. São Paulo: Ed. 34, 2010. Especialmente a primeira parte. 
necessidade inclusive ganha relevo numa perspectiva transnacional. ${ }^{5}$

A proteção e a defesa da integridade ambiental são uma das funções mais importantes de um Estado comprometido com a sustentabilidade. No Brasil, por exemplo, a Constituição da República de 1988, seguindo as tendências das constituições brasileiras que a precederam, redimensiona o papel do Estado, conferindo-lhe um profundo conteúdo social e ambiental - conteúdo esse que se agrega aos institutos jurídicos, como ocorre com a função social e ambiental da propriedade.

Herman Benjamin ${ }^{6}$ explica que a Constituição da República 1988 instituiu uma verdadeira ordem pública ambiental, fato esse que conduz o Estado de Direito Social e o modelo político-econômico a assumirem também a forma de Estado de Direito Ambiental.

A atenção especial conferida pelas Constituições levou a doutrina internacional a refletir acerca da existência de um verdadeiro Estado de Direito Ambiental ou, como denominou Canotilho, "Estado Ecológico", 7 isso a partir da obra de Steinberg R. Der Ökologische Verfassungsstaat, 1998. Independentemente do acerto científico dessa adjetivação, o importante não é o qualificativo que se agrega na caracterização do Estado Democrático de Direito, mas sim os valores, princípios, deveres e missão que devem nortear o seu agir. ${ }^{8}$

Nesse contexto, é de se reconhecer a importância dessa construção teórica que possui o mérito de destacar que os Estados, incluídos os Poderes Judiciários, Executivo e Legislativo, devem pautar o seu agir nos valores, princípios e deveres estatuídos nas Constituições para assegurar a higidez ambiental.

Dentre as funções do Estado de Direito Ambiental merece realce o papel de promoção, de transformação e de modernização das estruturas econômicas e sociais, funções essas que também devem ser implementadas por intermédio das instituições. Conforme destaca Araújo, quando se faz referência a um Estado de Direito Ambiental, significa que a preocupação ambiental é o vetor determinante do comportamento estatal nos dias atuais e com consequências práticas. ${ }^{9}$

A solidariedade social passa a ser então a razão da existência, fonte de legitimação e maior objetivo a ser alcançado neste novo modelo de Estado Ambiental. Isso porque é com a cooperação global e com a articulação da solidariedade em grande escala que serão mais bem alcançados os objetivos de um mundo sustentável.

Apesar da inegável importância do desenvolvimento e da consolidação de verdadeiros Estados de Direito Ambiental, regidos por princípios e comprometidos com a consecução ampla dos seus deveres ecológicos, essa forma de organização política não será suficiente, enquanto estratégia de governança, para alcançar a proteção efetiva do meio ambiente, posto que as questões ambientais têm vocação essencialmente transnacional. $^{10}$

5 Sobre o tema, ver: BODNAR, Zenildo; CRUZ, Paulo Márcio. Pensar globalmente y actuar localmente: el Estado transnacional ambiental en Urich Beck. Revista Aranzadi de Derecho Ambiental, Alicante, Espanha, n. 1, 2008.

6 BENJAMIN, Antônio Herman. Constitucionalização do ambiente e ecologização da Constituição brasileira. In: CANOTILHO, José Joaquim Gomes; LEITE, José Rubens Morato (Coord.). Direito constitucional ambiental brasileiro. São Paulo: Saraiva, 2007. p. 121.

7 CANOTILHO, J. J. Gomes. Estado constitucional ecológico e democracia sustentada. In: FERREIRA, Helini Silvini; LEITE, José Rubens Morato. Estado de direito ambiental: tendências: aspectos constitucionais e diagnósticos. Rio de Janeiro: Forense Universitária, 2004. p. 03 e ss.

8 Conforme Armandino Teixeira: "A edição do Estado de Direito Ambiental converge, necessariamente, para mudanças profundas nas estruturas da sociedade organizada, de modo a apontar caminhos e oferecer alternativas para a superação da atual crise ambiental [...]. Busca-se assim um novo paradigma de desenvolvimento, fundado na solidariedade social, capaz de conduzir à proteção (concreta) do meio ambiente e à promoção (efetiva) da qualidade de vida". NUNES JR., Amandio Teixeira. Estado de Direito ambiental. Revista de Informação Legislativa, Brasília, n. 163, p. 297-307, jul./set. 2004.

9 ARAÚJO, Thiago Cássio D’Avila. Estado ambiental de Direito. Revista da Advocacia Geral da União, n. 14, p. 167-177.

10 Leite e Ayala também consideram o esvaziamento da capacidade regulatória do Estado em face dos: "[...] novos fenômenos de dimensão global e a intensificação da pressão exercida por entidades não governamentais de alcance transnacional”. In: LEITE, José Rubens Morato; AYALA, Patryck de Araújo. Direito ambiental na sociedade de risco. 2. ed. Rio de Janeiro: Forense Universitária, 2004. p. 29. 


\section{NeCESSIDADE DE NOVAS E EFETIVAS ESTRATÉGIAS POLÍtiCAS E JURÍDICAS DE GOVERNANÇA TRANSNACIONAL AMBIENTAL}

A crise ecológica, além de ser espacialmente global, não significa apenas o descompasso entre a geração de bens e serviços ambientais e a sua utilização antrópica. É na verdade a crise da própria civilização contemporânea. O modo de organização política não é mais adequado para as novas demandas transnacionais. O Direito, enquanto estratégia de gestão de conflitos e de articulação da solidariedade, também está fracassando por não fomentar a melhora contínua nas relações entre os seres humanos e a natureza, fato esse que potencializa o aumento da crise de valores que é também cultural e espiritual.

Esse quadro impõe que urgentemente sejam repensadas e reconfiguradas as estruturas políticas, ${ }^{11}$ as instituições e o próprio Direito, que não pode ser apenas uma técnica simplória de controle social.

As profundas alterações ocorridas nos últimos tempos, e ainda em contínua e progressiva marcha, contribuíram para o agravamento dos problemas sociais e ecológicos, gerando múltiplas e complexas situações de injustiça socioambiental e dificuldades de governança.

A superação da crise/carência global de governança requer, dentre outras medidas: cidadania planetária com intensa e qualificada participação e controle social; solidez institucional; instrumentos legais efetivos e cogentes; fortalecimento de capacidades e profissionalização; enfoque holístico, sistêmico e integrado; intercâmbio de informações e de mecanismos de controles; compartilhamento solidário de custos e principalmente de benefícios.

O ponto de partida para esse câmbio imprescindível é a necessidade de uma forte consciência geral impulsiva que desencadeie novas atitudes cooperativas e solidárias em escala global. ${ }^{12} \mathrm{O}$ exercício substancial de uma cidadania ambiental planetária é imprescindível para mudanças duradouras e consequentes. Necessita-se do fortalecimento dos espaços públicos e de controle social especialmente qualificado e amplo, ou seja, de uma democracia também transnacional para conduzir e reorientar práticas e ações impostas apenas para atender à lógica de mercado dominante. ${ }^{13}$

Frederico Mayor Zaragoza alerta para a carência de um marco ético em escala planetária, a falta de democracia em âmbito global, e enfatiza que a democracia, que forma um triângulo interativo envolvendo a paz e o desenvolvimento, não se pode reduzir aos confins nacionais, mas estende-se ao mundo em seu conjunto. ${ }^{14}$ É como destaca Boaventura de Sousa Santos: “O movimento democrático transnacional é o único sinal de esperança na luta contra a iniquidade do mundo em que vivemos". ${ }^{15}$

Esse caminho de mudança deve prosseguir com a redefinição da ideia clássica de Nação ${ }^{16}$ e reconfiguração da ideia de Estado e para que seja também possível a emergência de novos espaços públicos de regulação, de intervenção e de gestão. ${ }^{17}$

Ao falar da formação das nações, enquanto matéria-prima dos Estados, Maurice Hauriou as define como: “[...] grupos de população fixados ao solo, unidos por um laço de parentesco espiritual que envolve o

11 Sobre o tema, recomenda-se ler: CRUZ, Paulo Márcio ; SIRVENT, J. F. C. . Ensaio sobre a necessidade de uma teoria para a superação democrática do Estado Constitucional Moderno. Revista Novos Estudos Jurídicos, v. 11, p. 41-62, 2006.

12 Nesse sentido também é o que em essência aborda a obra: RIFKIN, Jeremy. La civilización empática: La carrera hacia una conciencia global en un mundo en crisis. Madrid: Paidós, 2010.

13 Sobre o tema sugere-se: CRUZ, Paulo Márcio; FERRER, Gabriel Real. Os Novos Cenários Transnacionais e a Democracia Assimétrica. UNOPAR Científica. Ciências Jurídicas e Empresariais, v. 11, p. 11-18, 2010.

14 ZARAGOZA, Frederico Maior. Prólogo. In: MAÑAS, José Luis Piñar (Dir.); CARO, Sabastián F. Utrera (Coord.). Desarrollo sostenible y protección del medio ambiente. Madrid: Civitas, 2002. p. 18.

15 SANTOS, Boaventura de Souza. A escala do despotismo. Revista Visão, Coimbra: Universidade de Coimbra, 2006. p. 1.

16 O conceito de Nação é algo em constante construção, ou seja, forma-se historicamente permeado por influências culturais, políticas, jurídicas e sociais. Essa dinâmica evolutiva é observada ainda com maior intensidade nos dias atuais.

17 Na linha dessas reflexões: CRUZ, Paulo Márcio; BODNAR, Zenildo. O clima como necessidade de governança transnacional: reflexões pós-Copenhague 2009 - Florianópolis - SC. Sequência (UFSC), v. 31, p. 319-339, 2010. 
pensamento da unidade do mesmo grupo". Explica que o vínculo de parentesco espiritual não diz respeito a crenças, mas sim à forma de pensar, de agir, em suma, a mesma mentalidade. Destaca também o pensamento e a vontade atual de unidade nacional como elemento imprescindível para caracterizar uma nação. E acrescenta que o sentimento que anima cada coração é o amor desse meio nacional que se chama pátria. ${ }^{18}$

Tal concepção, baseada no que o autor chama de parentesco espiritual, não é mais suficiente para sedimentar eticamente vínculos duradouros e a imprescindível sensação de pertencimento a uma única morada, pela qual todos são responsáveis e da qual depende necessariamente o destino comum. Nem a unidade de língua nem a religião servem como justificativa para a homogeneidade de determinação do povo. Em muitos países há duas ou mais línguas oficiais, como a Suíça, por exemplo, que é trilíngue. O pluralismo religioso também hoje é um fenômeno comum em praticamente todas as nações modernas.

As grandes causas nacionais, historicamente defendidas, justificaram inclusive a eclosão de guerras mundiais, e hoje, nem sempre aparecem com propósitos eticamente sustentáveis, considerando os objetivos não tão nobres de determinados líderes nacionais.

A conquista de novos territórios com o sacrifício de múltiplos direitos humanos, bem como a dominação e a imposição de culturas, são projetos que devem ser repudiados no atual estágio de desenvolvimento da civilização. Afinal, de que valem as glórias comuns do passado se não há um propósito ético nobre e grandioso com o futuro? A maturidade civilizatória deve ser dimensionada pelo grau de comprometimento com a garantia dos Direitos Humanos, com a consolidação da paz e da sustentabilidade. Estas sim devem ser as grandes causas de um mundo transnacionalizado.

Pode-se até questionar se um modelo de democracia transnacional para a ordem global iria alterar a dinâmica de produção e distribuição de recursos e as regras de criação e execução na era contemporânea. Todavia, independentemente da imediatidade dos resultados, considerando a amplitude dos desafios, é inegável que o substrato embasador de qualquer projeto de civilização deve estar ancorado no intenso e efetivo controle social e na ampla e qualificada participação popular e definitivamente não poderá estar apenas a serviço do capital global. ${ }^{19}$

A sensação de pertencimento de todos os cidadãos do planeta deve ser mundial. Trata-se de um apelo à cooperação e à solidariedade em todos os níveis e dimensões, para que sejam superadas as formas individualistas de viver, de conceber e de perceber o próximo e de agir dos Estados Modernos, baseados em princípios e valores individualistas. ${ }^{20}$

Na busca do ideário da "paz perpétua”, fundada na razão e na inteligência humana, Kant já sugeria a formação de uma liga de povos, que não seria o mesmo que um Superestado envolvendo povos e territórios, pois, no seu entendimento, cada Estado tem e deve conservar a sua individualidade. A liga de povos resultaria de um contrato mútuo entre Estados livres, aliados por objetivos e por compromissos comuns ${ }^{21}$ e seria fundamentada num "Direito Cosmopolita". O direito de visita e o de hospitalidade promoveriam a comunicação e o relacionamento pacífico entre pessoas dos mais variados pontos do mundo e contribuiriam para transformar em realidade o ideal de uma "Constituição cosmopolita". Enfatizava o filósofo alemão que esse desejo não era mera fantasia, “[...] mas um complemento necessário do código não escrito tanto do direito de Estado como do direito das gentes para um direito público dos homens em geral e, assim, para a paz perpétua [...]". 22

18 HAURIOU, Maurice. Princípios del Derecho público y constitucional. Tradução, Estudio preliminar, Notas y Adiciones Carlos Ruiz del Castillo. Granada: Camares, 2003. p. 35-36.

19 Sobre a crítica contundente ao modelo atual de Estado, enquanto servo do capital global, sugere-se a leitura de SANTOS, Boaventura de Souza; GARAUTI, Cesar A. Rodrigues (Ed.). El derecho y la globalización desde abajo: hacia una legalidad cosmopolita. Barcelona: Anthropos, 2007. p. 50 e ss.

20 Maurice Haruriou explica que a base do Estado Moderno é formada por princípios individualistas e que as declarações de direitos também contribuíram para a construção da ordem jurídica individualista. In: HAURIOU, Maurice. Princípios del Derecho público y constitucional. Tradução, Estudio preliminar, Notas y Adiciones Carlos Ruiz del Castillo. Granada: Camares, 2003. p. 68 e ss.

21 KANT, Immanuel. À paz perpétua. Porto Alegre: L\&PM, 1989. p. 43 e ss.

22 KANT, Immanuel. À paz perpétua. Porto Alegre: L\&PM, 1989. p. 44, 46. 
A ideia de uma comunidade cosmopolita não é recente, porém não pode ser um projeto impositivo de um saber ou de uma cultura dominante, pois qualquer projeto consequente de reconfiguração das esferas políticas e jurídicas, não necessariamente na forma de comunidade única, deve corresponder aos anseios mais legítimos de todas as nações e efetivamente caracterizar uma pauta axiológica de consenso de todos os povos.

A nova ordem mundial, influenciada por diversos fatores decorrentes da intensificação do fenômeno da globalização, torna oportuna e necessária a discussão sobre a organização de espaços públicos transnacionais que viabilizem a democratização das relações entre Estados, relação essa fundada na cooperação e na solidariedade com o intuito de assegurar a construção das bases e das estratégias para a governança, a regulação e a intervenção transnacionais. ${ }^{23}$

No mesmo sentido, Tomas Villasante ${ }^{24}$ sugere que a "internalização" do Poder Público da modernidade, provavelmente, cederá passo ao processo de transnacionalização do Poder Público. ${ }^{25}$ Caso contrário, a incapacidade do Estado Constitucional Moderno $^{26}$ poderá conduzir a civilização às perigosas posições de confronto.

$\mathrm{Na}$ atualidade, é questionável a concepção de Estado Moderno como modelo de construção político-jurídica capaz de fazer frente à complexidade do ambiente transnacional global. Como se tem observado, as intensas mudanças ocorridas na sociedade atual exigem também novas estratégias de governança, regulação e intervenção. As complexas demandas da realidade transnacional ${ }^{27}$ não estão sendo adequadamente atendidas pelas instituições nacionais, fato esse que potencializa situações de riscos e de ameaças a bens transnacionais fundamentais.

Nesse contexto de crise multidimensional, surge um cenário extremamente receptivo para a emergência de novas instituições políticas e jurídicas que sejam capazes de agregar e articular atitudes solidárias e cooperativas, envolvendo as pessoas, as instituições e os Estados na luta pela proteção de bens e de valores imprescindíveis para assegurar a vida plena e duradoura no planeta. ${ }^{28}$

A partir também dessa constatação é que a governança foi um dos temas principais da Rio+20. O objetivo de tal agenda foi o de articular estratégias de longo prazo e envolver o maior número de países e instituições, com ou sem a participação do Sistema das Nações Unidas e seus programas, para viabilizar atitudes concretas e com dimensão planetária para o tema do ambiente.

Nessa linha, Gabriel Real Ferrer defende que o modelo estatal de organização política patrimonializa os recursos naturais e os submete a um suposto benefício exclusivo de determinados cidadãos nacionais, o que é to-

23 No Brasil, uma publicação da Fundação Getúlio Vargas, já em outubro de 1998, projetava uma nova realidade transnacional: "Poderosas correntes econômicas, financeiras e tecnológicas estão rompendo as fronteiras nacionais e desenhando uma nova geografia. Por sua vez, o Estado, tal qual concebemos hoje, caminha para fantásticas transformações”. In: O novo Estado transnacional. Indicadores Sociais, outubro de 1998, conjuntura econômica. p. 40-42.

24 VILLASANTE, Tomas. Las democracias participativas. Madrid: HOAC, 2003. p. 63

25 Sobre a transnacionalização do Direito e do Estado sugere-se a leitura de: CRUZ, Paulo Márcio; STELZER, Joana. Direito e transnacionalidade. Curitiba: Juruá, 2009.

26 Por Estado Constitucional Moderno entende-se aquele tipo de organização política surgida das revoluções burguesas e norteamericana nos séculos XVIII e XVIX, que tiveram como principais características a soberania assentada sobre um território, a tripartição dos poderes e a paulatina implantação da democracia representativa. In: CRUZ, Paulo Márcio; BODNAR, Zenildo. A transnacionalidade e a emergência do Estado e do Direito transnacionais. In: CRUZ, Paulo Márcio (Org.). Direito e transnacionalidade. Curitiba: Juruá, 2009. p. 03.

27 Sobre a insuficiência do modelo atual de Estado, na perspectiva fiscal, ver BODNAR, Zenildo. A responsabilidade tributária do sócio administrador. Curitiba: Juruá, 2005. Neste livro, defende-se a necessidade de "uma nova feição ao Estado - 'Estado Transnacional" " no qual o centro do poder não pode estar limitado geograficamente, a sua legitimidade deve decorrer da efetiva proteção outorgada aos direitos humanos.

28 Michel Bachelet é enfático ao afirmar que: "A menos que a Sociedade internacional aperfeiçoe e, sobretudo, aplique as normas de uma Solidariedade multissectorial à escala de todos os habitantes do planeta, populações inteiras desaparecerão pura e simplesmente pelos efeitos conjugados da SIDA e dos jogos da economia mundial”. In: BACHELET, Michel. Ingerência ecológica: Direito ambiental em questão. Lisboa: Instituto Piaget, 1995. p. 19. 
talmente incompatível com a gestão de bens pertencentes a toda a humanidade, e assim, há necessidade de que a gestão de determinados recursos seja atribuída a entes supraestatais representativos de toda a espécie humana. ${ }^{29}$

É também importante salientar que se está vivendo uma acelerada etapa de transição a de novas formas de organização, em escala mundial. Nesse contexto, a globalização só terá sentido e será verdadeiramente universal se for capaz de estruturar e criar um conjunto de relações de um novo tipo, mais solidário, inclusivo e democrático.

Além da reordenação do político, o jurídico também precisa ser revitalizado, para que as normas, com pretensão de ultrapassar os caprichosos limites das fronteiras dos Estados, não sejam entendidas e concebidas apenas como conselho, sugestão ou argumento retórico inconsequente.

Trata-se de uma inegável tendência já constatada pela doutrina especializada. Paulo Canelas de Castro explica que a globalização tornou-se uma força propulsora da juridicização e judicialização. Esse fenômeno também se caracteriza pela menor relevância das fronteiras nacionais, crescentemente penetradas por fenômenos migratórios, comerciais e ambientais transfronteiriços. A partir dessa nova realidade, os Estados tiveram que, crescentemente, concordar na emissão de regras de tipo novo, "além-fronteira", ou regras "transnacionais", que, diversamente das regras internacionais tradicionais, ou regras de boa vizinhança, regulam não somente a conduta dos Estados relativamente a outros Estados, mas também as suas próprias sociedades. ${ }^{30}$

O ordenamento jurídico transnacional deve ser estruturado como um conjunto ou sistema, baseado numa pauta axiológica comum ${ }^{31}$ mínima, necessária para garantir a sustentabilidade em escala global e também deve ser dotado de força cogente na perspectiva nacional e transnacional.

Na perspectiva da produção do Direito, como exemplo de prática jurídica transnacional, e que muito bem ilustra as ideias defendidas neste trabalho, podem-se citar as convenções que versam sobre a proteção global da questão vital ambiental, em especial a ECO/92, elaborada no Rio de Janeiro.

Trata-se de um dos mais completos e abrangentes instrumentos destinados à proteção de bem jurídico transnacional, que, apesar da sua notável qualidade propositiva, tem se mostrado extremamente deficiente na sua implementação em nível global por falta de capacidade cogente, ou seja, de institutos capazes de tornar concreta a sua aplicação como norma jurídica.

Todavia, a emergência de novas formas de governança e de produção do Direito não pode ser uma imposição decorrente da vitória do mais forte, ${ }^{32}$ deve ser o resultado da emancipação de valores, posições jurídicas e subjetividades esquecidas, fragilizadas e em situação de risco manifesto, como é o caso do meio ambiente especialmente na sua perspectiva futura.

Apesar da certeza quanto à necessidade de um novo paradigma jurídico, ${ }^{33}$ mais flexível, plural e democrático e não tão dependente do sistema econômico, ainda há muito a ser teorizado e conquistado nesse campo, o qual ainda se mostra incerto quanto à sua configuração. ${ }^{34}$

29 FERRER, Gabriel Real. La construcción del Derecho ambiental. Revista Aranzadi de Derecho Ambiental, Pamplona, Espanha, n. 1, p. 73-93, 2002. Disponível em: <http://www.dda.ua.es/documentos/construccion_derecho_ambiental.pdf>. Acesso em: 10 fev. 2012.

30 CASTRO, Paulo Canelas. Globalização e Direito internacional: rumo ao Estado de Direito nas relações internacionais? In: FACULDADE DE DIREITO DA UNIVERSIDADE DE COIMBRA (Org.). Nos 20 anos do Código das Sociedades Comerciais: homenagens aos Professores Doutores A. Ferrer Correa, Orlando de Carvalho e Vasco Lobo Xavier. Coimbra: Coimbra Editora, v. 3, 2007. p. 815.

31 A referida pauta deve ser estabelecida por seleção consensual de valores, em especial o meio ambiente, considerando o fato de que a sua proteção não poderia ser viabilizada eficazmente por intermédio das instituições nacionais, comunitárias ou internacionais atualmente existentes.

32 Sobre esse tema, são sempre muito oportunas as lições de Boaventura de Souza Santos, quando adverte que a nova governança não pode ser o triunfo da legalidade ou do projeto neoliberal que silencia conceitos como: transformação social, participação, contrato social, justiça social. In: SANTOS, Boaventura de Souza; GARAUTI, Cesar A. Rodrigues (Ed.). El derecho y la globalización desde abajo: hacia una legalidad cosmopolita. Barcelona: Anthropos, 2007. p. 33, 36.

33 Sobre o tema recomenda-se consultar: CRUZ, Paulo Márcio; BODNAR, Zenildo. O novo paradigma de Direito na pósmodernidade. Revista de Estudos Constitucionais, Hermenêutica e Teoria do Direito, v. 3, p. 75-83, 2011.

34 Ao discorrer sobre o paradigma jurídico da globalização, Alfonso de Julios-Campusano afirma que, nestes tempos de crise 
Graciela Chichilnisky, professora de Economia na Universidade de Columbia e uma das economistas mais respeitadas na atualidade, ao comentar a crise econômica, destaca a necessidade de novas instituições mundiais e de uma nova economia mundial, que seja intensiva no uso do conhecimento e conservadora dos usos dos recursos. ${ }^{35}$

Dentre os autores que teorizam sobre as novas formas de organização estatal, merece destaque a proposta do sociólogo alemão Ulrich Beck, ${ }^{36}$, quando sugere a substituição das relações "internacionais" de conflito e/ou disputa por relações "transnacionais" de solidariedade e cooperação.

Ulrich Beck enfatiza que a transnacionalização é uma conexão forte entre os espaços nacionais, inclusive de modo que não seja pensado internacionalmente, e sim no surgimento de algo novo, de um espaço transpassante que já não se encaixa nas velhas categorias modernas. ${ }^{37}$

A liberalização do mercado mundial, como escreve Habermas, progrediu muito. A mobilidade do capital acelerou e o sistema industrial foi modificado, saindo da produção de massa e passando a se adequar às necessidades da "flexibilidade pós-fordista". Com os mercados cada vez mais globalizados, o equilíbrio alterou-se, prejudicando claramente a autonomia e a capacidade de ação político-econômica dos Estados constitucionais modernos. ${ }^{38}$

O Direito Internacional, mesmo considerando a criação de novas estruturas e de organizações interestatais, não gera mecanismos eficazes de governança, de regulação, de intervenção e de coerção para as demandas transnacionais. Mesmo o Direito Comunitário, que regula uma das manifestações da nova ordem mundial, caracterizada por novas relações e novas manifestações de atores e instituições, não apresenta bases teóricas suficientes para a caracterização de um ou mais espaços públicos transnacionais.

A grande diferença qualitativa de uma governança internacional para novas estratégias de governança transnacionais está exatamente na forma de articulação entre o poder local e o global, ou seja, não é possível prescindir da indispensável parceria cooperativa das esferas locais de poder.

A governança transnacional poderá surgir da emergência de novos espaços públicos plurais, solidários e cooperativamente democráticos e livres das amarras ideológicas da modernidade, decorrentes da intensificação da complexidade das relações globais, dotados de capacidade jurídica de governança, de regulação, de intervenção - e de coerção, e com o objetivo de projetar a construção de um novo pacto de civilização. ${ }^{39}$

A emergência de novas estratégias globais de governança, de regulação e de intervenção, baseadas num paradigma de aproximação entre povos e culturas, na participação consciente e reflexiva do cidadão na gestão política, econômica e social, deve ser um novo e estratégico projeto de civilização para o futuro, pautado na consciência crítica acerca da finitude dos bens ambientais, e na responsabilidade global e solidária pela sua proteção.

O fenômeno da transnacionalidade deve ser uma força que opera em duas direções: uma que age na superação do modelo clássico e ultrapassado de Estado Nacional, mediante a criação de novos espaços de governança; e a outra, que agrega, fomenta e coordena a ação local dos Estados com efeitos no plano global a partir de pautas axiológicas de amplo consenso.

paradigmática, não é só o modelo de Estado que está debilitado, como também o modo de produção jurídica: sua estrutura hierárquica, sua configuração unidimensional e conclui que o Direito do Estado não é mais a única forma de juridicidade ao defender o pluralismo jurídico. In: JULIOS-CAMPUZANO, Alfonso de; MARTIN, Nuria Belloso (Coord.). ¿Hacia un paradigma cosmopolita de derecho?: pluralismo jurídico, ciudadanía y resolución de conflictos. Dykinson, 2008. p. 49 e ss.

35 CHICHILNISKY, Graciela. Precisa-se de um novo Bretton Woods. Disponível em: < http://www.monitormercantil.com. br/mostranoticia.php?id=59210>. Acesso em: 10 jan. 2012.

36 BECK, Ulrich. ¿Qué es la globalización?: falácias del globalismo, respuestas a la globalización. Tradução Bernardo Moreno e Maria Rosa Borras. Barcelona: Paidos, 2004. p. 132.

37 BECK, Ulrich. Liberdade ou capitalismo. Tradução Luiz Antônio Oliveira de Araújo. São Paulo: Littera Mundi, 2001. p. 100.

38 HABERMAS, Jürgen. A constelação pós-nacional. Tradução Márcio Selligmann-Silva. São Paulo: Litera Mundi, 2001. p. 99.

39 CRUZ, Paulo Márcio; BODNAR, Zenildo. A transnacionalidade e a emergência do Estado e do Direito transnacionais. In: CRUZ, Paulo Márcio (Org.). Direito e transnacionalidade. Curitiba: Juruá, 2009. p. 5. 
É o que também propõe Gabriel Real Ferrer, quando assinala que não se trata de se estabelecer uma república planetária, mas sim da busca de mecanismos institucionais que assegurem a eficaz materialização da solidariedade, no mesmo diapasão de inspiração de novos direitos transnacionais, como é o caso do Direito Ambiental e da sustentabilidade. ${ }^{40}$

\section{Os desafios eCológicos globais Como fundamento da GOVERNANÇA tRANSNACIONAL}

As lesões ao meio ambiente afetam a coletividade, perpassam fronteiras, atingem as futuras gerações e toda a comunidade de vida e os elementos abióticos que lhe dão sustentação e definitivamente não respeitam os confins territoriais dos Estados.

Como principal característica do Direito Ambiental está a sua perspectiva global. Considerando a forma pela qual os ecossistemas se relacionam e a vida se desenvolve em todo o planeta, é manifestamente impossível implementar uma tutela efetiva ao meio ambiente restrita a determinado país ou território delimitado.

Ao discorrer sobre as características do Direito Ambiental, Loporeta Rota enfatiza a sua vocação espacialmente planetária e denuncia que a organização da sociedade humana em Estados, pretensamente soberanos, faz com que o âmbito de aplicação das suas normas seja restrito aos limites das suas fronteiras e isso não serve para o Direito Ambiental, já que o objeto sobre o que se projeta é insuscetível de submeter-se às caprichosas linhas que temos traçado. Defende que a proteção da biosfera não é compatível com esse esquema e tampouco o Direito que a protege, pois necessita de ferramentas comuns a todos os cidadãos e países. ${ }^{41}$

Martín Mateo aponta que é exatamente a disposição institucional em parcelar a terra em Estados soberanos que inviabiliza o estabelecimento de uma ordem mundial coerente para sistemas naturais intrinsecamente planetários. ${ }^{42}$

Nessa mesma linha de raciocínio, Leff explica que hoje o conceito de ambiente se defronta necessariamente com estratégias fatais de globalização e a reinvenção de um mundo (conformado por uma diversidade de mundos) que "abre o cerco da ordem econômica-ecológica globalizada". Destaca que "[...] o princípio de sustentabilidade surge como uma resposta à fratura da razão modernizadora e como uma condição para construir uma nova racionalidade produtiva, fundada no potencial ecológico e em novos sentidos de civilização a partir da diversidade cultural do gênero humano". ${ }^{43}$

Silvia Jaquenod enfatiza a necessidade de novos limites geopolíticos para a governança dos recursos naturais, enfatizando que a posição baseada na cooperação e no compartilhamento supera a situação real entre Estados. ${ }^{44}$

Numa perspectiva ecológica, são evidentes as atuais limitações decorrentes da ordenação das esferas de poder, de coerção, de fomento e de gestão. Francisco Días Pineda, Catedrático de Ecologia da Universidade de Madrid, explica que os sistemas naturais e praticamente todos os sistemas culturais têm pouco a ver com a "delimitação de fronteiras em um mapa", pois o ciclo da água, a dinâmica do ar ou os movimentos migratórios biológicos "não entendem de fronteiras". ${ }^{5}$

40 FERRER, Gabriel Real. La construcción del Derecho ambiental. Revista Aranzadi de Derecho Ambiental, Pamplona, Espanha, n. 1, p. 73-93, 2002. Disponível em: < http://www.dda.ua.es/documentos/construccion_derecho_ambiental.pdf>. Acesso em: 10 fev. 2012.

41 ROTA, Demétrio Loporeta. Los princípios de derecho ambiental. Madrid: Civitas, 1998. p. 27-28.

42 MATEO, Ramón Martín. Tratado de derecho ambiental: recursos naturales. Madrid: Trivium, v. III, 1997. p. 58.

43 LEFF, Henrique. Saber ambiental: sustentabilidade, racionalidade, complexidade, poder. Tradução Lúcia Mathilde Endlich Orth. Petrópolis: Vozes, 2005. p. 31.

44 ZSÖGÖN, Silvia Jaquenod de. Derecho ambiental sistemas naturales y jurídicos. Barcelona: Dycinson, 2008. p. 207.

45 ZSÖGÖN, Silvia Jaquenod de. Derecho ambiental sistemas naturales y jurídicos. Barcelona: Dycinson, 2008. p. 6 (prólogo). 
Martín Mateo também é categórico ao afirmar que a biosfera é única, inter-relacionada e olimpicamente alheia a jurisdições nacionais e zelosas soberanias. ${ }^{46} \mathrm{E}$ acrescenta ainda que: "[...] o Direito que estamos familiarizados é de âmbito nacional, emana de organização peculiares com limites físicos rígidos e plotados nas fronteiras do território em que se exerce soberania. Todavia os sistemas ambientais tendem a ser indefinidamente globais e, portanto, ignoram olimpicamente a geografia política interior".

Nesse contexto, está correto o entendimento de Arnaldo Miglino, ${ }^{47}$ ao sustentar que o problema ecológico provavelmente levará à criação de um centro de poder transnacional que supere a ideologia e a estrutura jurídica das relações internacionais.

A salvaguarda do ambiente poderá ser assegurada de forma mais eficaz se a tutela for sempre mais ampla do que as fronteiras dos Estados por intermédio dos poderes do governo e da jurisdição que ultrapassem os limites da soberania estatal. ${ }^{48}$

Todos os aspectos, muito expostos pelos autores acima citados, evidenciam a necessidade da superação da lógica das relações internacionais, baseada na criação de regras bilaterais ou multilaterais, ${ }^{49}$ destituídas de real juridicidade concreta e efetividade por não vincularem diretamente os potenciais e principais degradadores, mas apenas os Estados contratantes.

Os desafios ecológicos também apresentam inegáveis vantagens qualitativas na teorização de novas estratégias globais de governança. Isso porque, dentre os princípios fundacionais do Direito Ambiental e da Sustentabilidade, estão a cooperação e a solidariedade, que servirão como pilastras maiores na edificação dessa nova e necessária ordem governativa.

A cooperação e a solidariedade devem ser os grandes fundamentos da Governança Transnacional Ambiental. Sem uma atuação global cooperativa nenhum projeto de civilização vindouro será exitoso. A solidariedade também é imprescindível como razão de existência, fonte de legitimação e objetivo maior a ser alcançado por esse novo modelo de governança.

Já em 1945, no preâmbulo da Declaração da UNESCO, Declaração e Programa de Ação sobre a Cultura de Paz da ONU, a solidariedade intelectual e moral constava como diretriz fundamental. Da mesma forma a "Carta da Terra" também preconiza a necessidade de uma "[...] base ética sólida para a Sociedade civil emergente e ajuda na construção de um mundo sustentável baseado no respeito à natureza, os direitos humanos universais, a justiça econômica e uma cultura de paz". ${ }^{50}$

A Constituição Espanhola de 1978, no seu artigo 45, preceitua que a proteção do meio ambiente será concretizada com a indispensável solidariedade coletiva. Na França, já desde 1946, há na Constituição referência direta ao princípio da solidariedade. Em diversos países a solidariedade consta como objetivo a ser alcançado pelos Estados e também como valor fundamental diretamente relacionado com a proteção e a defesa do meio ambiente, inclusive na sua dimensão solidária intergeracional.

Conforme ainda destaca Gabriel Real Ferrer, a solidariedade é o fundamento de qualquer grupo humano e também do Estado, indispensável para a coesão social e para gerar a imperativa sensação de pertencimento

46 MATEO, Ramón Martín. La revolución ambiental pendiente. In: MAÑAS, José Luis Piñar. Desarrollo sostenible y protección del medio ambiente. Madrid: Civitas, 2002. p. 54, 73.

47 MIGLINO, Arnaldo. Uma comunidade global para a tutela do ambiente. Revista Archivo Giuridico, v. CCXXVII, 2007, editada por Filippo Serafini e publicada pela Mucchi Editore, em Roma, Itália. (www.mucchieditores.it). Título original: Uma comunitá mondiale per la tutela dell'ambiente.

48 CORDINI, Giovanni. Diritto ambientale comparato. Padova: CEDAN, 1997. p. 07.

49 Como exemplo de tutela de bens ambientais verdadeiramente planetários, pela lógica do Direito Internacional Clássico, cite-se a Convenção de Ransar, que estabelece cooperação internacional para proteção de áreas úmidas situadas nas zonas fronteiriças, por intermédio de acordos interestatais. Dentre os acordos celebrados, citem-se os seguintes ecossistemas: a) Parque Transfronteiriço Lagos de Prespa (Albânia, Grécia e Ex-República Yuguslava da Macedônia); b) Polisie (Bielrússia, Polônia e Ucrânia); c) Vallé de la Haute-Súre, criado pela Bélgica e Luxemburgo, dentre outros.

50 A carta da terra. Disponível em: < http://www.mma.gov.br/estruturas/agenda21/_arquivos/carta_terra.doc>. Acesso em: 22 jan. 2012. 
entre os cidadãos. ${ }^{51}$ Também é enfático ao afirmar que a eficácia das soluções depende da alteração da organização social do planeta e que a solidariedade deve ter aplicação generalizada, não apenas na perspectiva ética, mas também como princípio jurídico formalizado. ${ }^{52}$

Embora não seja o objetivo específico deste trabalho teorizar acerca da forma pela qual serão institucionalizadas ou implementadas as novas estratégias de Governança Transnacional Ambiental, desde logo é possível antecipar que tal fato não depende apenas da criação de sofisticadas e complexas instituições, mas principalmente de atitudes concretas voltadas à proteção efetiva de bens jurídicos de vocação planetária, por parte de instituições, organismos e autoridades locais e transnacionais.

Nesse sentido, a Governança Ambiental Transnacional será um locus privilegiado para incorporar, nas diretrizes de condutas a serem ditadas em cada país, os valores éticos e principiológicos que já estão teoricamente bem expostos nas declarações e recomendações dos organismos internacionais, ou seja, para a consolidação gradual de um espaço público transnacional que forneça respostas mais satisfatórias e consequentes para os dias vindouros.

Outra questão que deve ser especialmente fomentada, em termos de Governança Transnacional Ambiental, é a criação e a consolidação de órgãos judiciais de vocação universal para a tutela do meio ambiente. ${ }^{53}$ Porém, antes até da criação de novas instâncias decisórias, é fundamental que os órgãos já existentes estejam sensibilizados e considerem a variável da sustentabilidade nas suas decisões, mesmo quando o objeto da controvérsia não guarda relação direta com o meio ambiente.

\section{Avanços e retrocessos no tema da governança transnacional na Rıo + 20}

Os conteúdos tratados nos itens anteriores permitem concluir ter sido a instituição de efetiva Governança Transnacional Ambiental um dos temas mais importantes na pauta da Rio+20. Foram basicamente três as propostas; a primeira foi a de criar um novo organismo na ONU específico para a área ambiental; a segunda foi de dar ao PNUMA (Programa das Nações Unidas Para o Meio Ambiente) um novo status, igualando-o a organismos como a OMC (Organização Mundial do Comércio); a terceira proposta foi a de se promover a elevação do poder da Comissão de Desenvolvimento Sustentável da ONU.

Durante a Rio+20, foi o diretor executivo do Programa das Nações Unidas para o Meio Ambiente (PNUMA), Achim Steiner, ${ }^{54}$ presente à reunião, quem liderou as discussões em torno do tema Governança Transnacional Ambiental. A capacidade de gerir as ações de meio ambiente nos países de maneira sustentável e a necessidade de fortalecimento dos órgãos que cuidam do setor em todo o mundo foram os principais temas discutidos durante a conferência.

A Governança Transnacional Ambiental para o desenvolvimento sustentável foi um dos principais propulsores para a maioria das discussões do evento. Os debates convergiram para que, independentemente

51 FERRER, Gabriel Real. La solidaridad en el Derecho administrativo. Revista de Administración Pública (RAP), n. 161, p. 123-179, mayo/agosto 2003.

52 FERRER, Gabriel Real. La construcción del Derecho ambiental. Revista Aranzadi de Derecho Ambiental, Pamplona, Espanha, n. 1, p. 73-93, 2002. Disponível em: < http://www.dda.ua.es/documentos/construccion_derecho_ambiental.pdf>. Acesso em: 10 fev. 2012.

53 Atualmente são órgão judiciais com vocação universal também para a concretização da tutela do meio ambiente: TEDH (Tribunal Europeu de Direitos Humanos); TIJ (Tribunal Internacional de Justiça); TIDM (Tribunal Internacional de Direito do Mar); CIDH (Corte Interamericana de Direitos Humanos). Há também a possibilidade remota de o próprio TPI (Tribunal Penal Internacional) atuar na defesa indireta do meio ambiente quando, por exemplo, num crime de guerra o fato resultar em danos graves ao meio ambiente. No âmbito das soluções de controvérsias comerciais, a OMC (Organização Mundial do Comércio), embora criada para fomentar a livre concorrência comercial, também pode atuar na defesa do meio ambiente, pois várias controvérsias concorrenciais são geradas exatamente pela falta ou inadequação de medidas e cautelas para com o meio ambiente, um exemplo muito expressivo foi o caso envolvendo a importação de pneus recauchutados.

54 Revista Veja, Editora Abril, edição de 04/06/2012, pg. 36. 
do formato que tenha a proposta de mudança a ser feita no PNUMA, o importante é que se constitua uma instância com autonomia e mandato.

Como já assinalado, o tema da Governança Transnacional Ambiental provocou vivo interesse e controvérsia nos debates para elaboração do documento base da Rio+20. As discussões disseram respeito à governança dos temas ambientais na estrutura da ONU. Houve consenso sobre sua prioridade nas discussões. Permaneceram, entretanto, dúvidas e divergências quanto ao formato que ela deve assumir. De um lado, países europeus defenderam a criação de uma organização internacional, a Organização Mundial do Meio Ambiental (OMMA) que, nos moldes de outras entidades (Organização Mundial do Comércio, Organização Mundial da Saúde), substituiria o Programa das Nações Unidas para o Meio Ambiente (PNUMA), criado em 1972, na Conferência de Estocolmo. Segundo seus defensores, tal ação fortaleceria politicamente o organismo, aumentaria seu orçamento e tornaria suas decisões muito mais efetivas no âmbito transnacional. Em posição oposta, estão aqueles que rejeitam mais um órgão burocrático, que poderia interferir em políticas internas e até encobrir ações protecionistas de países ricos.

Porém, o mais importante foi a aproximação que houve em direção a um conceito consolidado de Governança Transnacional Ambiental. Essa expressão vem sendo repetida com frequência nos últimos tempos, mas nem sempre compreendida em sua devida dimensão, como anota Alcindo Gonçalves. ${ }^{55}$ Tendo-se em conta o que foi debatido durante a Rio +20 , poder-se-ia defini-la como a arquitetura do sistema de gestão transnacional do meio ambiente. A palavra arquitetura é bem expressiva, na medida em que traduz o desenho da organização e o projeto de administração dos problemas relativos ao meio ambiente, especialmente no que diz respeito à forma com que eles serão tratados.

Para entender esse movimento de consolidação do conceito, é importante considerar os debates atuais sobre o tema. Governança seria mais do que um simples conjunto de formatos de gestão. A categoria se desdobraria em quatro planos, que a definiriam de modo muito mais preciso. Em primeiro lugar, é preciso não perder de vista, quando se menciona a Governança Transnacional Ambiental, seu caráter instrumental. Ela é meio e processo capaz de produzir resultados eficazes. É ferramenta importante para a solução de problemas globais, ao mesmo tempo em que sua efetivação desencadeia processos (muitas vezes longos e complexos) por meio dos quais as questões envolvidas são tratadas. Nessa linha, a Comissão sobre Governança Global, criada pela ONU no começo dos anos 1990, definiu governança como "a totalidade das maneiras pelas quais os indivíduos e as instituições, públicas e privadas, administram seus problemas comuns".

Governança só existe com participação ampliada em todos os processos (diagnósticos e estudos preliminares, articulação de interesses, discussão dos problemas, análise das alternativas, tomada de decisões, implementação e monitoramento/controle). Nesse segundo importante ponto, fica evidente que a governança se distingue dos mecanismos clássicos do Direito Internacional (dos quais apenas sujeitos de direito, como os Estados nacionais ou as organizações internacionais, participam). A efetiva Governança Transnacional Ambiental exige, portanto, a presença e o envolvimento ativo de Estados e organismos transnacionais ao lado da sociedade civil, representada pelas organizações não governamentais (ONGs), empresas transnacionais e a comunidade científica.

Enquanto as ações governamentais são baseadas na coerção, na obrigação de cumprir, os fundamentos da governança estarão no consenso e na cooperação. Esse é o terceiro aspecto que caracteriza os processos que envolvem os diferentes atores na efetivação da Governança Transnacional Ambiental. Mesmo em face de divergências (como entre países ricos e em desenvolvimento na questão das mudanças climáticas e da redução da emissão de gases de efeito estufa, ou nas disputas entre empresas e ONGs), o objetivo central é sempre construir pontos comuns capazes de trazer avanços, em muitos casos para superar a ineficiência

55 GONÇALVES, A. F; COSTA, J. A. F. Governança Global e Regimes Internacionais. São Paulo: Almedina, 2011. p. 73 a 102. Alcindo Gonçalves, Doutor em Ciência Política pela Universidade de São Paulo. Atualmente é coordenador do Programa de Pós-Graduação Stricto Sensu em Direito da Universidade Católica de Santos - Mestrado e Doutorado. 
do sistema internacional ou minimizar dilemas de ação coletiva, em que alguns buscam evitar os custos da cooperação sem deixar de usufruir dos benefícios.

Gonçalves ainda destaca que não há governança sem um conjunto de instituições internacionais, ou seja, de princípios, de regras e de normas, formais ou informais, que buscam dar conta dos problemas, balizar comportamentos e estabelecer metas para controle e limitação de ações predatórias ou ameaçadoras ao meio ambiente.

Pôr em pé o edifício da Governança Transnacional Ambiental é tarefa inadiável. Sem ela, é impossível imaginar a possibilidade de avanço na proteção do meio ambiente e na sustentabilidade. A Organização Mundial do Meio Ambiente, sem dúvidas, será um elemento importante para sua construção. Não é, porém, o único caminho. Nesse sentido, a posição da diplomacia brasileira durante a Rio+20 foi interessante e realista. Criticou a criação de uma agência ambiental mundial, mas apontou uma alternativa: uma agência transnacional sobre desenvolvimento sustentável, para tratar de modo equilibrado e simultâneo problemas econômicos, ambientais e sociais.

A proteção ao ambiente e a adoção de critérios de sustentabilidade não são problemas isolados, que dizem respeito exclusivamente às questões de poluição, à biodiversidade ou a mudanças climáticas. É por meio da ideia do desenvolvimento sustentável que o ambiente poderá articular-se com as várias dimensões: cultural, política, econômica e social. Durante a Rio+20, apesar dos poucos avanços formais havidos, foi reforçado o entendimento de que é preciso não esquecer, em nenhum momento, que a Governança Transnacional Ambiental será o meio essencial para tal promoção. ${ }^{56}$

\section{Conclusões finais}

Notou-se, ao longo do articulado nas páginas anteriores, que os novos desafios gerados pela intensificação da globalização e pela crise ecológica multidimensional, que caracterizam a Sociedade de risco, hipercomplexa e policonflitiva, propiciam também uma crise de governança global sem precedentes e tornam oportuna e necessária a implementação de novos modelos de gestão e regulação.

A crise de governança decorre tanto da obsolescência do modelo estatal, limitado pelas fronteiras territoriais, como também da insuficiência do sistema e da lógica jurídica do Direito Internacional para a eficaz tutela planetária do meio ambiente e da sustentabilidade.

Apesar dos avanços, propiciados pela inserção de postulados ecológicos nas constituições dos Estados, há ainda um déficit substancial na implementação das normas ambientais propostas apenas pelos Estados exatamente pela falta de políticas, estratégias de ação e normas com maior força cogente e dotadas de eficácia global.

A inclusão da governança como um dos temas centrais da Rio+20, embora os resultados não tenham sido os mais promissores, foi oportuna e necessária. Afinal, é por meio da ideia do desenvolvimento sustentável que o ambiente poderá articular-se com as várias dimensões: cultural, política, econômica e social. $\mathrm{Na}$ oportunidade, apesar dos poucos avanços formais havidos, restou reforçada a compreensão acerca da importância da temática Governança Transnacional Ambiental, pois essa estratégia global constitui o meio essencial para a promoção da sustentabilidade com a dimensão necessária.

Afinal, trata-se de um momento histórico único para que sejam repensadas as estratégias de implementação das normas de proteção do ambiente em escala planetária, bem como o papel das instituições.

56 GONÇALVES, A. F; COSTA, J. A. F. Gover

nança Global e Regimes Internacionais. São Paulo: Almedina, 2011. p. 73 a 102. 
Em síntese, o futuro desafia a consolidação de novas formas de governança, estruturadas como uma grande teia de proteção do planeta, regida por princípios ecológico-sociais e que assegurem alternativas e oportunidades democráticas mais inclusivas, participativas e emancipatórias, e tenham como preocupação garantir um mundo melhor para as futuras gerações. Só com novas estratégias globais de governança, baseadas na cooperação e na solidariedade, é que será possível assegurar um futuro com sustentabilidade e com mais justiça. ${ }^{57}$

\section{REFERÊNCIAS}

A CARTA da terra. Disponível em: < http://www.mma.gov.br/estruturas/agenda21/_arquivos/carta_terra.doc>. Acesso em: 22 jan. 2012.

ARAÚJO, Thiago Cássio D’Avila. Estado ambiental de Direito. Revista da Advocacia Geral da União, n. 14.

BACHELET, Michel. Ingerência ecológica: Direito ambiental em questão. Lisboa: Instituto Piaget, 1995.

BECK, Ulrich. Liberdade ou capitalismo. Trad. Luiz Antônio Oliveira de Araújo. São Paulo: Littera Mundi, 2001.

¿Qué es la globalización?: falácias del globalismo, respuestas a la globalización. Trad. Bernardo Moreno e Maria Rosa Borras. Barcelona: Paidos, 2004.

Sociedade de risco: rumo a uma outra modernidade. Trad. de Sebastião Nascimento. São Paulo: Ed. 34, 2010.

BENJAMIN, Antônio Herman. Constitucionalização do ambiente e ecologização da Constituição brasileira. In: CANOTILHO, José Joaquim Gomes; LEITE, José Rubens Morato (Coord.). Direito constitucional ambiental brasileiro. São Paulo: Saraiva, 2007.

BODNAR, Zenildo. A responsabilidade tributária do sócio-administrador. Curitiba: Juruá, 2005.

; CRUZ, Paulo Márcio. Pensar globalmente y actuar localmente: el Estado transnacional ambiental en Urich Beck. Revista Aranzadi de Derecho Ambiental, Alicante, Espanha, n. 1, 2008.

CASTRO, Paulo Canelas. Globalização e Direito internacional: rumo ao Estado de Direito nas relações internacionais?. In: FACULDADE DE DIREITO DA UNIVERSIDADE DE COIMBRA (Org.). Nos 20 anos do Código das Sociedades Comerciais: homenagens aos Professores Doutores A. Ferrer Correa, Orlando de Carvalho e Vasco Lobo Xavier. Coimbra: Coimbra Editora, 2007. v. 3.

CANOTILHO, J. J. Gomes. Estado constitucional ecológico e democracia sustentada. In: FERREIRA, Helini Silvini; LEITE, José Rubens Morato. Estado de direito ambiental: tendências: aspectos constitucionais e diagnósticos. Rio de Janeiro: Forense Universitária, 2004.

CHICHILNISKY, Graciela. Precisa-se de um novo Bretton Woods. Disponível em: < http://www.monitormercantil.com.br/mostranoticia.php?id=59210>. Acesso em: 25 jan. 2012.

CORDINI, Giovanni. Diritto ambientale comparato. Padova: CEDAN, 1997.

CRUZ, Paulo Márcio. Política, poder, ideologia e estado contemporâneo. 3. ed. Curitiba: Juruá, 2004.

; BODNAR, Zenildo. A transnacionalidade e a emergência do Estado e do Direito transnacionais. In: CRUZ, Paulo Márcio (Org.). Direito e transnacionalidade. Curitiba: Juruá, 2009.

57 BODNAR, Zenildo; CRUZ, Paulo Márcio. Pensar globalmente y actuar localmente: el Estado transnacional ambiental en Urich Beck. Revista Aranzadi de Derecho Ambiental, Alicante, Espanha, n. 1, p. 51-59, 2008. 
; BODNAR, Zenildo. O clima como necessidade de governança transnacional: reflexões pós-Copenhague 2009. Sequência (UFSC), v. 31, p. 319-339, 2010.

; BODNAR, Zenildo. O novo paradigma de Direito na pós-modernidade. Revista de Estudos Constitucionais, Hermenêutica e Teoria do Direito, Porto Alegre, v. 3, p. 75-83, 2011.

; FERRER, Gabriel Real. Os novos cenários transnacionais e a democracia assimétrica. Revista Unopar Científica: Ciências Jurídicas e Empresariais, v. 11, p. 11-18, 2010.

; SIRVENT, J. F. C. Ensaio sobre a necessidade de uma teoria para a superação democrática do Estado Constitucional Moderno. Revista Novos Estudos Jurídicos, v. 11, p. 41-62, 2006.

.; STELZER, Joana. Direito e transnacionalidade. Curitiba: Juruá, 2009.

FERRER, Gabriel Real. La construcción del Derecho ambiental. Revista Aranzadi de Derecho Ambiental, Pamplona, Espanha, n. 1, 2002. Disponível em: <http://www.dda.ua.es/documentos/construccion_derecho_ambiental.pdf>. Acesso em: 10 fev. 2012.

. La solidaridad en el Derecho administrativo. Revista de Administración Pública (RAP), n. 161, maio/ago. 2003.

FUNDAÇÃO GETÚLIO VARGAS. O novo Estado transnacional. Indicadores Sociais, outubro de 1998, conjuntura econômica.

GONÇALVES, A. F; COSTA, J. A. F. Governança Global e Regimes Internacionais. São Paulo: Almedina, 2011.

HABERMAS, Jürgen. A constelação pós-nacional. Tradução Márcio Selligmann-Silva. São Paulo: Litera Mundi, 2001.

HAURIOU, Maurice. Princípios del Derecho público y constitucional. Tradução, Estudio preliminar, Notas y Adiciones Carlos Ruiz del Castillo. Granada: Camares, 2003.

JULIOS-CAMPUZANO, Alfonso de; MARTIN, Nuria Belloso (Coord.). ¿Hacia un paradigma cosmopolita de derecho?: pluralismo jurídico, ciudadania y resolución de conflictos. Dykinson, 2008.

LEITE, José Rubens Morato; AYALA, Patryck de Araújo. Direito ambiental na sociedade de risco. 2. ed. Rio de Janeiro: Forense Universitária, 2004.

KANT, Immanuel. À paz perpétua. Porto Alegre: L\&PM, 1989.

LEFF, Henrique. Saber ambiental: sustentabilidade, racionalidade, complexidade, poder. Trad. Lúcia Mathilde Endlich Orth. Petrópolis: Vozes, 2005.

MATEO, Ramón Martín. La revolución ambiental pendiente. In: MAÑAS, José Luis Piñar. Desarrollo sostenible y protección del medio ambiente. Madrid: Civitas, 2002. p. 54, 73.

Tratado de Derecho ambiental: recursos naturales. Madrid: Trivium, v. III, 1997.

MIGLINO, Arnaldo. Uma comunidade mundial para a tutela do ambiente. Revista Archivo Giuridico, Roma: Mucchi, v. CCXXVII, 2007. Trad. Uma comunitá mondiale per la tutela dell'ambiente.

NUNES JR., Amandio Teixeira. Estado de Direito ambiental. Revista de Informação Legislativa, Brasília, n. 163 , jul./set. 2004.

RIFKIN, Jeremy. La civilización empática: La carrera hacia una conciencia global en un mundo en crisis. Madrid: Paidós, 2010.

ROTA, Demétrio Loporeta. Los princípios de Derecho ambiental. Madrid: Civitas, 1998.

SANTOS, Boaventura de Souza. A escala do despotismo. Revista Visão, Coimbra: Universidade de Coim- 
bra, 2006.

; GARAUTI, Cesar A. Rodrigues (Ed.). El derecho y la globalización desde abajo: hacia una legalidad cosmopolita. Barcelona: Anthropos, 2007.

SUÁREZ, Fernando. Informe espanhol. In: MARZAL, Antônio (Ed.). Crisis del Estado de bienestar y derecho social. Barcelona: J. M. Bosch, 1997.

VILLASANTE, Tomas. Las democracias participativas. Madrid: HOAC, 2003.

ZARAGOZA, Frederico Maior. Prólogo. In: MAÑAS, José Luis Piñar (Dir.); CARO, Sabastián F. Utrera (Coord.). Desarrollo sostenible y protección del medio ambiente. Madrid: Civitas, 2002.

ZSÖGÖN, Silvia Jaquenod de. Derecho ambiental y sistemas naturales y jurídicos. Dykinson: Barcelona, 2008. 


\section{REVISTA BRASILEIRA DE POLÍTICAS PÚBLICAS BRAZILIAN JOURNAL OF PUBLIC POLICY}

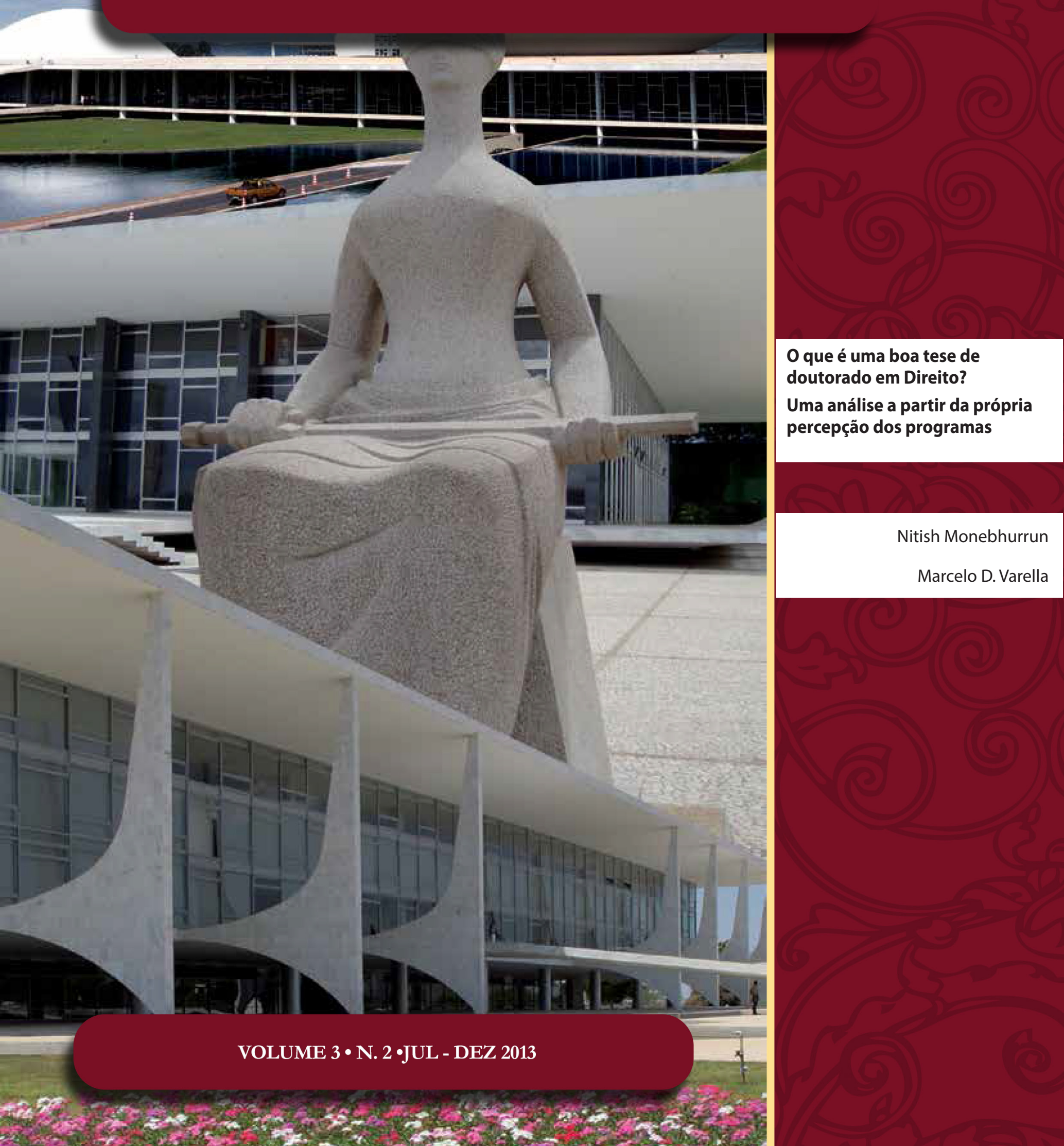




\section{O que é uma boa tese de doutorado em Direito? \\ Uma análise a partir da própria percepção dos programas}

Nitish Monebhurrun

Marcelo D. Varella**

\section{Resumo}

Este artigo analisa as teses de doutorado defendidas no âmbito do direito no Brasil, estudando, para tanto, o que as escolas de direito consideram como uma tese excelente. Utilizando um método empírico, o artigo identifica e destaca os critérios que caracterizam as teses brasileiras indicadas para o Prêmio de Tese da CAPES e as compara com os outros trabalhos defendidos durante o mesmo período. Para esta comparação, os critérios utilizados são tanto qualitativos quanto quantitativos. A pesquisa feita revelou trabalhos de excelente qualidade, sendo, no entanto, maculados por uma quantidade significativa de teses de má qualidade. Como não existe um órgão estatal que unifica os critérios que devem ser cumpridos ao preparar uma tese de direito, a situação parece caótica até certo ponto: o esforço mínimo ou máximo esperado do doutorando não é nítido. Este artigo alerta as faculdades de Direito e as instituições públicas relevantes sobre essa problemática, explicando, ao mesmo tempo, como a valorização das teses competindo para o prêmio pode ser um passo inicial para construir um caminho doutoral de excelência.

Palavras-chaves: Tese de doutorado, Direito, Programas de Pós-Graduação, qualidade das teses no Brasil, estudo qualitativo e quantitativo, critérios de uma boa tese.

\section{Abstract}

This article examines the $\mathrm{PhD}$ theses defended in the law field in Brazil, thereby studying what the law schools consider as an excellent thesis. Using an empirical method, the article identifies and highlights the criteria which characterise Brazilian theses shortlisted for the Capes Thesis Prize and compare them to other works defended during the same period. For the purposes of this comparison, the criteria used are both qualitative and quantitative. The research done has revealed works of excellent quality, the latter being however blurred by a significant quantity of poor theses. As there are no central State organs which unify the criteria to be fulfilled by law theses, the situation appears chaotic to some extent: the minimum or maximum work expected from the doctoral candidate is confuse. This article alerts the law schools and concerned public institutions on the matter while highlighting how valuing theses competing for a prize can act as an initial leading way towards excellence.

Os autores agradecem especialmente a Ana Maria Davila Lopes, Arnaldo Sampaio de Moraes Godoy e Martônio Mont'Alverne Barreto Lima, pelas contribuições a este artigo.
** Doutores em Direito pela Universidade de Paris I, Panthéon-Sorbonne (Escola de Direito de Sorbonne). Professores do Programa CEUB. Emails: nitish.monebhurrun@gmail. com e marcelodvarella@gmail.com 
Key words: PhD thesis, Law, Doctoral Programs, quality of theses in Brazil, qualitative and quantitative study, criteria for $\mathrm{PhD}$ thesis of good quality.

\section{INTRODUÇÃo}

É possível identificar o que os Programas de Pós-Graduação em Direito entendem como uma tese de doutorado de excelência, a partir do que os próprios programas indicam como a sua melhor tese do ano para o Prêmio Nacional de Teses da CAPES. Tais teses são, de fato, diferentes da qualidade média das teses dos mesmos programas, tanto em relação aos aspectos qualitativos, quanto quantitativos. Contudo, seja uma tese excelente, seja uma tese média, algumas críticas podem ser colocadas aos critérios para a excelência de tese de doutorado em direito no Brasil.

Qualitativamente, uma tese excelente tem uma melhor introdução, onde define bem seu objeto de pesquisa; tem um melhor desenvolvimento, com análise da teoria nacional e estrangeira sobre seu tema, a partir de livros, artigos em periódicos e outras teses; conhece e analisa a legislação e tem domínio da jurisprudência brasileira e estrangeira quando for necessário. No entanto, não é apenas isso. Um estudo empírico revela que há evidentes diferenças quantitativas entre a melhor tese do programa em um determinado ano e a sua média. A tese indicada ao prêmio apresenta, quase sempre, mais de 300 páginas, analisa mais de 250 referências bibliográficas, tem um número maior de notas de rodapé, além de uma introdução e uma conclusão mais desenvolvida. Cada um destes fatores, qualitativos e quantitativos, pode ser melhor discutido.

O objetivo deste artigo é entender se existem - e sob quais critérios formais e materiais _ diferenças entre uma tese considerada excelente e uma tese média, aprovada pelos programas e tecer certas críticas a textos medíocres que têm sido aceitos como teses de doutorado em Direito. Trata-se de uma pesquisa realizada a partir de uma análise empírica de um conjunto considerado representativo de teses, selecionadas pelos próprios programas de pós-graduação em Direito.

Não há uma definição única ou uma acepção rígida da metodologia de uma tese de doutorado em Direito. Cada cultura jurídica tem o seu próprio código e os seus princípios e métodos para preparar e redigir uma tese. Mesmo que todas as teses busquem contribuir com uma análise original e uma resposta inédita a uma problemática nova, não pode ser negado que há formas e métodos diferentes para apresentar uma tese. Por exemplo, uma tese defendida na França é metodologicamente diferente de uma apresentada na China, na Alemanha, nos Estados-Unidos ou no Brasil. E uma não é necessariamente melhor ou pior que a outra. Cada tese é válida se ela respeita os critérios universitários nacionais do país onde ela é defendida. Foge também da razão esperar - ou impor - uma uniformização e uma universalização da metodologia das teses, independentemente do contexto. É uma regra de identidade do método de construção da tese.

Ora, essa reserva não impede um estudo geral do método de preparação e de organização de teses num sistema universitário definido aqui, o do Brasil. No mesmo sentido, observar e examinar como são construídas as teses brasileiras em direito não impede ter um marco geral da definição de uma tese. De fato, na origem, é preciso definir o que, in abstracto, é uma tese de doutorado em Direito, pois, se há variações contextuais e culturais no método da argumentação para defender a tese, não há uma diferença fundamental entre o que os vários sistemas de direito consideram como sendo objetivamente uma tese. Portanto, se existem critérios subjetivos e contextuais que determinam a metodologia de uma tese, a definição objetiva de uma tese sólida e convincente transcende as fronteiras nacionais sem violar a regra de identidade da metodologia jurídica que caracteriza cada país: uma problemática clara e o seu tratamento minucioso, o rigor, a apresentação, a escrita, o volume e a qualidade da pesquisa, a argumentação geral, a originalidade da abordagem, as críticas, as conclusões e o estilo definem, entre outros, a qualidade de uma tese em qualquer sistema universitário. Os processos de pensamento, de aprendizado e de estruturação destes são relevados pela forma da escrita ${ }^{1}$.

1 RE, Edward D. Increased Importance Of Legal Writing In The Era Of “The Vanishing Trial” in Touro Law Review, v. .21, 2005 , p.676. 
Por ser a consagração da formação universitária, o doutorado apresenta-se como a produção de um alto nível de pesquisa: é um teste que reflete a capacidade e a aptidão do candidato, ao entrar no mundo universitário, não apenas como professor, mas também como um jurista. Na percepção francesa até meados do século passado, a tese de doutorado era o grande trabalho da carreira de um acadêmico. Na percepção anglo-saxã, hoje compartilhada internacionalmente, seria o primeiro grande trabalho de um professor pesquisador. Em qualquer caso, deve ser um trabalho sério, com rigor metodológico. Para tanto, uma tese respeitada faz um professor respeitado.

Nesse sentido, uma tese universitária é aquela cujo autor demonstrou que ele domina os instrumentos e as técnicas de pesquisa e de metodologia para transmiti-las à universidade e aos alunos, como professor. Julgar uma tese é identificar o professor que queremos; validar uma tese de doutorado é equiparado a autorizar a entrada de um formador nas universidades, dando-lhe, assim, um selo de confiança nesse âmbito. Um doutor é um potencial professor de mestrado e doutorado, logo, um professor de professores.

Esse processo é obviamente seletivo e os que se destacam demonstram rigor, técnica, método, organização e capacidade de pesquisa intensa de trabalho. Essas qualidades são indicadores que traçam o limite entre o jurista formado e o compilador de textos. Numa tese de doutorado, a substância é tão valiosa quanto a metodologia, porém é esta que dissocia as melhores teses das outras. Um aluno aplicado de segundo ou de terceiro ano em Direito pode fazer uma pesquisa avançada e detalhada, mas ainda não domina as técnicas e os métodos que lhe permitem utilizar as informações recolhidas para construir uma argumentação com um raciocínio rigoroso e indefectível. Os doutorandos e os doutores em Direito se destacam com essa capacidade metodológica que deve obrigatoriamente acompanhar e caracterizar os seus trabalhos. Caso não haja tais características, é possível afirmar que as teses por eles apresentadas não cumprem as qualidades objetivas de uma tese universitária.

Há, nesse sentido, teses que formam professores pesquisadores potenciais e outras que buscam apenas o título de doutor. Objetivamente, cada um pode ter as suas razões pessoais ao fazer um doutorado. No entanto, a situação pode se tornar problemática quando os que buscam apenas o título aparecem depois no âmbito universitário, isto é, com uma tese de má qualidade -, às vezes, com uma "tentativa de tese". O problema se amplifica porque a qualidade de doutorado proposto por essas universidades é automaticamente questionada.

É na base dessas questões que este trabalho busca fazer um estudo qualitativo e quantitativo das teses de doutorado em Direito no Brasil.

Escolas doutorais em Direito no Brasil são fenômenos relativamente novos, mas que se afirmam cada vez mais. Há, atualmente no Brasil, 31 doutorados em Direito. A grande maioria destes foi criada há menos de 10 anos. A maior parte destes cursos é composta por professores de diferentes escolas, sobretudo: PUCSP (maioria), USP (2 lugar), UFSC, PUC-MG, UFMG, UERJ e UFGRS, além de um número razoável de doutores formados no exterior, sobretudo na França, na Espanha e na Alemanha. Cada uma destas escolas tem uma metodologia e uma concepção próprias de doutorado.

Por serem novos e controlados à posteriori, vários doutorados ainda não foram submetidos a um controle de qualidade, o que é sine qua non para situar e avaliar as escolas de Direito no Brasil. O objetivo não é fazer uma classificação destas, mas entender o valor que cada uma atribui a esse diploma. Considerando que um dos objetivos principais de uma formação doutoral é a preparação dos docentes e pesquisadores do futuro, a busca da qualidade dos doutorados oferecidos pelas universidades brasileiras é plenamente justificada. Ao mesmo tempo, a garantia de qualidade é um elemento fundamental para permitir e para favorecer a participação das faculdades de Direito do Brasil no mundo acadêmico internacional. Assim sendo e na base dessas considerações, é possível propor um estudo criterioso para examinar as teses feitas no Brasil.

Posto isso, a metodologia escolhida (2) facilitará o levantamento das teses em Direito (3) para propor uma análise do valor dado às teses no Brasil (4). 


\section{UMA METOdOLOGIA PARA AVALIAR AS TESES}

Um estudo desse tipo precisa de um método para que as observações e as conclusões sejam fundamentadas numa base objetiva. É pouco pertinente falar de teses em geral, de uma forma abstrata, com o objetivo de demonstrar resultados concretos e efetivos. $\mathrm{O}$ assunto estudado deve ser cientificamente enquadrado e, por conseguinte, a metodologia escolhida basear-se-á emuma delimitação do universo de teses estudadas (2.1) antes de apresentar os critérios a serem utilizados para a análise (2.2).

\subsection{A delimitação do universo de teses estudadas}

A delimitação será temporal e, nessa delimitação temporal, as teses serão categorizadas para conduzir e organizar o estudo.

No tocante ao aspecto temporal, idealmente seria relevante examinar todas as teses em Direito defendidas no Brasil, para traçar uma eventual evolução. Essa abordagem foge, todavia, do presente estudo: o objetivo não é elaborar uma tese sobre as teses nem de trazer uma fotografia estática destas, mas de mostrar uma tendência nas teses recentes na busca de critérios de uma tese universitária brasileira. Para tanto, serão examinadas as teses defendidas entre 2008 e 2013. Eis a delimitação temporal escolhida para categorizar as teses estudadas. Assim sendo, no tocante a escolha das teses em si, optou-se por dois universos: serão escolhidas todas as teses apresentadas ao Prêmio Nacional de Teses da CAPES (prêmio da Capes), em um primeiro conjunto, e teses escolhidas a partir de uma amostra feita aleatoriamente no Portal Domínio Público da Capes, de cada programa que submeteu teses ao prêmio da CAPES. Chamaremos as teses indicadas ao prêmio como "teses excelentes", porque assim foram consideradas pelos Coordenadores dos Programas para disputar o prêmio nacional de teses. Procura-se distingui-las das demais teses, que serão sempre compreendidas em função de números médios. As teses indicadas ao prêmio representam, em teoria, a melhor tese de cada ano, de cada Programa com Doutorado no Brasil. Todas as teses do período, submetidas ao prêmio, foram examinadas. As demais teses servirão de base para uma comparação entre o que os programas consideram "aprováveis" e o que consideram "excelente". Escolhemos não detalhar a autoria das teses, para cada situação, para evitar discriminar os autores.

Os autores reconhecem que em muitos casos, questões políticas são levadas em consideração na escolha da melhor tese do ano pelo programa, mas considerou-se que, de qualquer modo, o programa indicará uma tese dentre aquelas consideradas excelentes em um determinado ano e que variações a esta premissa são desprezíveis.

Com essa delimitação do estudo, é preciso também escolher e explicar os critérios que permitem uma análise objetiva da questão.

\subsection{Os critérios utilizados no estudo}

Os critérios desdobram-se entre aspetos qualitativos (2.2.1) e quantitativos (2.2.2). Entende-se por critérios qualitativos - que é o núcleo principal da presente análise -, a leitura de partes nucleares da tese (como introdução, partes centrais do texto), a compreensão da sua metodologia e a qualidade e variedade das fontes utilizadas. Por critérios quantitativos, entende-se critérios objetivos, numéricos. Serão aqui avaliados o número de páginas das teses escolhidas, o número de referências bibliográficas e a quantidade de citações.

\subsubsection{Avaliação qualitativa}

Nesse estudo, a avaliação substancial focalizar-se-á principalmente na problematização, na argumentação e nas fontes de consulta das teses. Uma tese puramente descritiva não é uma tese, pois ela não inova com 
uma ideia original ou com uma problemática nova. Espera-se que uma tese seja analítica e argumentativa com respostas claras às questões definidas. As questões encontram-se na introdução do trabalho e as respostas, no corpo do trabalho com uma ênfase na conclusão geral. Tais respostas se justificam com uma argumentação clara que se baseia numa demonstração jurídica, com técnicas jurídicas e que se estende por toda a tese.

Esse conjunto indica a contribuição efetiva de uma tese, salientando se ela é original, com uma identidade, ou trata-se de uma mera compilação de textos que não sirva à ciência jurídica - e que fica no alcance de qualquer aluno. É a capacidade de problematizar e de argumentar usando instrumentos, métodos e técnicas do Direito que destaca o jurista, cuja tese pode, consequentemente, qualificá-lo de doutor. Esses critérios substanciais serão, portanto, utilizados para avaliar as teses escolhidas.

"Uma tese é antes de tudo um trabalho de pesquisa e não um tratado ou um manual, com a atualização do estado atual do conhecimento." Uma tese em Direito deve, na parte substancial, trazer exemplos reais do seu tema, sobretudo quando não se trata de uma tese meramente filosófica. Uma tese em que se propõe a analisar um determinado instituto jurídico e o seu reconhecimento ou não pela jurisprudência, por exemplo, deve trazer os exemplos práticos do instituto jurídico e apresentar os casos concretos de jurisprudência que negaram ou que reconheceram tal instituto.

Uma tese em Direito tem que consultar fontes compatíveis com a ciência jurídica, com variedade e atualidade. Uma tese sem análise de legislação e de jurisprudência faz pouco sentido, exceto em raros temas, como os essencialmente teóricos, a exemplo de Filosofia ou Teoria do Direito e, mesmo assim, estes ramos do direito, muitas vezes, têm forte relação com a prática. A análise de casos concretos é essencial. Mesmo nestas subáreas do Direito, o aporte de elementos jurídicos primários, legislação e jurisprudência, são obrigatórios para um bom trabalho.

Portanto, em geral, a tese deve consultar a teoria, a jurisprudência e a legislação aplicável. Mesmo uma tese de Direito brasileiro deve revelar conhecer como os autores e tribunais estrangeiros tratam o tema. É difícil pensar qualquer tema que seja exclusivamente interno. Mesmo assuntos a priori internos como Direito civil (aborto, eutanásia, herança, propriedade), processo civil (acesso à justiça, modalidades processuais), Direito penal (progressão de pena, formas de ressocialização, presídios) devem mostrar que conhecem como o problema é pensado fora do país.

Assim uma boa tese, deve analisar:

a) Teoria: Livros, artigos de periódicos e outras teses, nacionais e estrangeiros;

b) Jurisprudência: nacional e estrangeira. Conforme o tema, também a jurisprudência de tribunais internacionais;

c) Legislação: nacional e estrangeira e, conforme o tema, também tratados e outras fontes de direito internacional.

A análise qualitativa das teses completa-se com uma avaliação quantitativa. Esse método de análise pode ser sujeito à polêmica; porém, ele não perde para tanto a sua relevância.

\subsubsection{Avaliação quantitativa: Um tema polêmico}

A pesquisa realizada demonstra que existe uma diferença muito clara entre o número de páginas do trabalho como um todo, da introdução, bem como do número de citações e de referências das "teses excelentes" e das "teses aprovadas" pelos programas. Se os próprios programas criam tal diferença, é porque

2 OST, F. La thèse de doctorat em droit: du projet à la soutenance, disponível em http://www.fusl.ac.be/fr/pdf/Droit/rapport_fr.pdf, acesso em 11.11.2013 p. 12 
ela é um indicador objetivo que deve ser levado em consideração. Ignorar esta realidade significaria maquiar a pesquisa.

Seguramente, a quantidade de páginas de uma tese de doutorado não reflete a sua qualidade: o aforismo é certamente valioso, como se verifica em diversos casos, mas não deve por isso se tornar uma facilidade retórica ou uma caricatura.

O número de páginas é um indicador imprescindível ao avaliar uma tese. É uma ferramenta objetiva e formal, para dissociar uma tese de doutorado de uma dissertação de mestrado ou de uma monografia de final de curso. Numa tese de doutorado, a argumentação, a demonstração, o tratamento da problemática, as referências são muito mais desenvolvidos e, portanto, mais extensos. O estudo é mais aprofundado, mais sofisticado e técnico, o que justifica um volume de trabalho intenso e denso. Isto se reflete no tamanho do trabalho. Uma razão, em especial, explica a objetividade desse critério: é difícil imaginar que uma universidade brasileira revalide um doutorado feito numa universidade estrangeira se a tese contiver, por exemplo, apenas 100 páginas $^{3}$.

No mesmo sentido, a tese se torna duvidosa se o número de páginas é o mesmo que o de uma dissertação de mestrado. Logicamente, espera-se que um trabalho de três a cinco anos seja mais importante e mais desenvolvido que um feito durante um ou dois anos. Há um problema se uma tese de doutorado contiver o mesmo número de páginas ou somente cinquenta páginas a mais que um trabalho de mestrado que, normalmente, contém entre 120-170 páginas. ${ }^{4}$ Nesse contexto, é possível questionar o valor real que as faculdades atribuem às teses de doutorado. Essa lógica quantitativa aplica-se, ademais, às referências bibliográficas.

Uma tese de doutorado excelente se destaca pelo teor das referências: textos jurídicos, jurisprudência, doutrina recente e clássica, nacional e estrangeira, documentos oficiais, entre outros. A quantidade de referências é um indicador da pesquisa feita, e a pesquisa esperada é de um alto nível de excelência. As referências podem se constatar de duas formas: a bibliografia no final do trabalho e as notas de rodapé. A bibliografia é, no entanto, um indicador mais objetivo porque ela apresenta uma fotografia definitiva e concreta da pesquisa; as notas de rodapé nem sempre cumprem esses critérios, porque nem todas contêm uma referência e também porque há várias repetições das mesmas referências em muitas notas ${ }^{5}$. Não obstante, elas se mantêm como um indicador complementar ou subsidiário que esse trabalho considerará: uma tese com 1000 notas de rodapé mostra potencialmente uma qualidade de pesquisa mais avançada e de uma melhor qualidade que uma com apenas 100 ou 200.

A análise numérica das fontes bibliográficas também inclui uma análise qualitativa subentendida. Tal análise poderia estar em qualquer uma das partes do artigo, tanto na quantitativa, quanto na qualitativa, mas que se optou por realizar nesta etapa. Uma boa tese de doutorado em Direito, exceto em raras exceções, deve levantar o estado da arte do tema, em um determinado momento.

Esses parâmetros qualitativos e quantitativos serão utilizados para examinar as teses de direito no Brasil, comparando assim o teor das teses "excelentes" com o das teses "aprováveis". O objetivo é entender quais critérios qualitativos e quantitativos traçam a linha de demarcação e de destaque entre essas duas categorias de teses, pois são esses critérios que permitem uma categorização destas - e, in fine, uma valorização das teses "excelentes". Nessa lógica, esse trabalho não pretende ressaltar o que deve ser uma tese em Direito, mas como são as teses de doutorado em Direito no Brasil. O estudo busca contribuir ao debate universitário

3 Mesmo títulos obtidos em universidades sérias, como Harvard, quando com poucas páginas, têm tido dificuldades de validação no Brasil. A validação de teses obtidas no exterior segue dois aspectos: formal e material. No tocante aos aspectos materiais, analisa-se se o texto corresponde, na sua qualidade, a uma verdadeira tese de doutorado. Ver: VARELLA, M. D. e LIMA, M. M. B. Políticas de revalidação de diplomas de pós-graduação em Direito no Brasil. Dificuldades e desafios para o sistema brasileiro in Revista Brasileira de Políticas Públicas, v. 2, 2012.

4 O mesmo problema ocorre em todo mundo. François Ost, por exemplo, coloca a pressão dos órgãos de controle belgas sobre o tempo da tese e a redução do seu tamanho. Ver OST, ob. Cit., p. 2

5 O que justifica o uso dos ibid, ibidem, op. Cit., etc. 
sobre a qualidade dos doutorados no Brasil, levando em consideração a preocupação das instituições como o CNPQ ou a CAPES sobre esse assunto.

Com base nessa metodologia, é possível começar o levantamento das teses a serem examinadas.

\section{O Levantamento das Teses de Doutorado em Direito no Brasil: teses “excelentes" E "TESES APROVÁVEIS"}

Esse estudo tentou encontrar as características comuns às teses brasileiras (3.1), e os elementos que caracterizam as que foram indicadas para um prêmio no Brasil (3.2).

\subsection{As características das teses de doutorado no Brasil.}

O exame feito das teses em Direito ressalta algumas características que, em muitos casos, dissociam as teses "excelentes" das que são "aprováveis": são características substanciais por um lado (3.1.1) e formais por outro (3.1.2).

\subsubsection{Característica substancial na argumentação das teses: a constatação de uma desordem nas teses "aprováveis"}

Essa desordem já foi criticada pelo Professor Luciano Oliveira no seu artigo "Não fale do código do Hamurábi". Ele salientava, com toda razão, que trabalhos que começam com uma litania histórica ou com um "manualismo" excessivo sobre o assunto a ser tratado não são úteis - além de serem, muitas vezes, entediados ${ }^{6}$. Ele acrescentava no mesmo sentido:

\footnotetext{
"É na esteira dessa avaliação que enfatizaria que alguns problemas de estilo, verdadeiros cacoetes que precisam ser evitados. Um deles, provavelmente decorrência do uso abusivo de manuais e de livros de doutrina, é o que tenho chamado de "manualismo", ou seja, a tendência a escrever na dissertação ou tese verdadeiros capítulos de manual, explicando redundantemente - pois trata-se de coisas amplamente sabidas por quem já passou por um curso de Direito - o significado de princípios e conceitos que são como que o bê-a-bá da disciplina.”"
}

Essa digressão - salientar inúmeras informações em vez de ir direitamente ao ponto e ao tratamento da problemática desde o início do trabalho - é um elemento que diferencia, em muitos casos, as teses "excelentes" das que são "aprováveis". Note-se que as primeiras acostumam ser mais organizadas com uma demonstração e uma articulação de argumentos mais convincentes; em alguns casos, as aprováveis têm uma tendência maior a ser digressivas. A capacidade de organizar e de ordenar logicamente as informações e os argumentos, que decorrem da (sólida) pesquisa feita, traça uma diferença entre teses "excelentes" e teses "aprováveis" no Brasil. Essa constatação resulta da mera observação da maioria das teses que os Programas de Pós-Graduação consideram como sendo excelentes e, portanto, aptas a ser enviadas ao Prêmio da melhor tese. Assim sendo, qualitativamente, muitas teses indicadas a um prêmio são dotadas de um valor agregado que as destacam das outras: um método do raciocínio jurídico que corrobora que o autor é um bom jurista. Nas teses "aprováveis" examinadas, há algumas cuja introdução - já de poucas laudas - desenha cronologicamente a história toda da disciplina, de um princípio, de uma lei ou do assunto a ser tratado. Outras começam o primeiro capítulo da mesma forma. Não que a contextualização histórica não seja útil. No entanto, referir-se à história não deve ser o reflexo primeiro do jurista e ao utilizar tais referências, ele deve apontar as razões metodológicas e lógicas que justificam essa abordagem para a defesa da tese. Caso

6 OLIVEIRA, Luciano. Não fale do código do Hamurábi, disponível em OLIVEIRA, disponível em http://www.uniceub.br/ media/180293/Texto_IX.pdf, acesso em 13/01/2014 p.10-11.

7 OLIVEIRA, ob. cit., p.6. 
contrário, o trabalho é confuso com o seu "sincretismo metodológico". Existe na realidade uma confusão entre uma tese e um manual, um livro. Muitos autores constroem o seu trabalho como um manual, isto é, com uma grande tendência a descrever em vez de analisar. ${ }^{9}$ Há uma preocupação dos autores em descrever os conceitos e os princípios ou um contexto qualquer durante as primeiras partes do trabalho; a intenção é de informar e não de argumentar ou de convencer pela argumentação ${ }^{10}$. Isso significa que o assunto é realmente abordado - começa a ser tratado - somente após essas partes, às vezes, no final do trabalho, no último capítulo, nas últimas páginas. Não há, portanto, uma demonstração nem uma argumentação linear, constante e coerente, pois as questões apresentadas na introdução começam, às vezes, a ser examinadas apenas no final da tese. O trabalho é assim feito de uma grande parte descritiva e simplesmente inútil. Nada aprendemos com tais construções e apresentações de ideias porque são informações facilmente disponíveis em livros e artigos, e não devemos ler uma tese para obtê-las.

O leitor ou o examinador da tese espera que esta traga uma opinião original e nova para contribuir com a resolução de uma questão jurídica importante. Para tanto, a tese toda deve ser estimulada pela originalidade; caso contrário, o trabalho tem pouco interesse.

Um exemplo fictício pode ilustrar o que constatamos, às vezes, na construção de várias teses identificadas. Com um assunto de tese do estilo "Desafios do novo código florestal brasileiro", é fortemente provável obter um trabalho sob a forma seguinte:

I. Introdução.

II. Princípios do Direito ambiental.

III. A (história da) proteção do meio florestal no Brasil.

IV. O novo código florestal brasileiro.

V. Os desafios do novo código florestal brasileiro.

Em muitos casos, o título do último capítulo ou da última parte é o mesmo que o da tese, mostrando assim que é somente a partir desse ponto que o trabalho começa realmente. Isso quer dizer que há três partes basicamente descritivas e uma que é potencialmente analítica. Em muitas teses "aprováveis", a pesquisa é completa, a substância é sólida, mas o tratamento das questões é frágil por essa razão. Muitos autores não aproveitam da pesquisa substancial para começar o processo de convencimento desde o início. Uma tese é um processo de convencimento; portanto, este não pode se iniciar no final do trabalho. Todas as partes da tese, todos os capítulos, todas as seções, todos os parágrafos devem ser refletidamente construídos e relacionados para que o resultado final seja convincente. Conseguintemente, uma justaposição da pesquisa feita não faz uma tese; e uma compilação tampouco ${ }^{11}$.

Por isso, a introdução do trabalho é imperiosa. É nessa parte que o processo da problematização começa e que a organização substancial da tese é explicada. Muitas teses analisadas negligenciam a introdução. A quantidade de páginas dedicada a esta corrobora isso em primeiro lugar e, em segundo lugar, a qualidade da apresentação confirma a nossa observação em muitos casos: é impossível justificar seriamente a problemática, a originalidade do assunto, a escolha deste, a sua delimitação contextual, a metodologia, sem esquecer as definições das palavras- chaves em menos que cinco páginas.

Note-se que muitos autores começam o trabalho sem definir os termos importantes do assunto - o que implica começar uma tese com categorias dúbias ou com apenas uma impressão do significado. E uma tese não se faz com impressões, mas com tecnicidade. Um autor salienta que um trabalho jurídico baseia-se

8 OLIVEIRA, ob. cit., p. 13.

9 SCHIESS, Wayne. Legal Writing Is Not What It Should Be in Southern University Law Review, v.37, n.1, 2009, p.13.

10 RE, ob. Cit., p.677.

11 OLIVEIRA, ob. cit., p.12. 
em alguns fatores: "analyze cogently, organize logically, distill accurately, argue persuasively, cite knowledgeably, punctuate skillfully, and phrase smoothly $(. . .)^{12}$ ". Em certas teses, a introdução aparece como uma parte optativa ou decorativa, sem a qual o trabalho ainda faria sentido -, mas que deve ser cumprido porque é o protocolo... $\mathrm{O}$ resultado é várias vezes óbvio: não há uma explicação nem uma justificação inicial da argumentação e, portanto, há inúmeras lacunas na demonstração, ou não há demonstrações. A introdução anuncia nitidamente a qualidade do trabalho esperado pelo leitor; é o primeiro contato que o autor tem com o leitor. Se este não é convencido imediatamente desde o início, é pouco provável que o seja depois.

As fontes de pesquisa são um problema constante em parcela importante das teses. Dentre as teses examinadas, quase todas usam uma bibliografia essencialmente brasileira, composta por livros monográficos. Os autores estrangeiros são lidos na sua tradução. Há basicamente três problemas identificados na maioria das teses: há pouca utilização de artigos em periódicos, pouca consulta aos textos mais recentes das fontes estrangeiras e quase nenhuma consulta aos autores dos próprios programas.

O conhecimento circula mais rapidamente por meio de artigos em periódicos. A publicação em periódicos permite divulgar ideias novas, de forma mais sintética e gerar um debate acadêmico, inacessível aos livros.

O problema em usar livros traduzidos não reside necessariamente na qualidade da tradução, mas também no tempo. Certamente, várias traduções para o português são mal feitas, sobretudo quando se compara com traduções para o espanhol ou francês. No entanto, em geral, um livro demora 10 a 20 anos para ser traduzido para outro idioma. É comum identificar nas teses analisadas o uso de argumentos jurídicos desenvolvidos por autores estrangeiros, mas com base em textos desatualizados. Em grande parte dos casos, outros autores estrangeiros já avançaram o conhecimento com novas ideias, a partir da crítica aos argumentos dos primeiros autores, isso quando o próprio autor já não alterou seu ponto de vista em escritos posteriores não traduzidos.

Os docentes e discentes dos programas de todo o Brasil são estimulados a publicar artigos, mas, ao que demonstra as teses analisadas, eles não são lidos. Mais alarmante: quase nenhuma tese cita um periódico da própria instituição. Em outras palavras, os alunos sequer conhecem (ou valorizam) o que os seus próprios professores e colegas publicam.

Importa ressaltar, neste sentido, que os trabalhos americanos, europeus, brasileiros e mesmo as demais teses brasileiras podem ser fácil e gratuitamente acessados em portais eletrônicos, como www.ssrn.com, www.dominiopublico.gov.br, www.persee.fr e vários outros.

As fontes de informação, mesmo em sites de artigos, devem ser qualificadas. Nota-se que o segundo "periódico" mais citado em teses no Brasil é o jus navigandi, frequente em parte substantiva dos trabalhos defendidos ${ }^{13}$. Trata-se de um portal da internet sem análise por pares, que publica qualquer informação recebida, mesmo de graduandos. É espantoso pensar que parte importante das teses de doutorado fundamente alguns dos seus argumentos de pesquisa em um periódico que publica artigos sem qualquer rigor científico, onde mesmo um estudante de primeiro semestre de direito publica suas impressões sobre qualquer tema. Mesmo dentre as teses indicadas a prêmio, o jus navigandi aparece como fonte bibliográfica em 16\% dos trabalhos.

Outro problema identificado foi a falta de análise de estudos de casos e jurisprudências. Nas teses analisadas, cerca de $40 \%$ não contêm estudos de caso ou análise dos julgados. É como se o direito existisse apenas como uma disciplina puramente teórica, uma ciência social não aplicada. Uma pesquisa séria em direito

12 GARNER, Bryan A. A Message to Law Students: Effective Writing Takes a Lifelong Commitment in Michigan Bar Journal, september 2006, p.52.

13 Pesquisa realizada a partir de 3000 dissertações e teses, com base em todos os trabalhos disponíveis on line nas bases de dados oficiais. O trabalho não foi publicado, mas apenas apresentado nas reuniões de Coordenadores de Programas e no CONPEDI ee dezembro de 2013. 
dificilmente pode ignorar o direito vivo, tal como aplicado na prática. Uma boa pesquisa em direito, exceto em raros temas, pressupõe estudos de casos, análise de jurisprudências nacionais, estrangeiras e, conforme o caso, internacionais. Com a multiplicação dos tribunais internacionais, é difícil não encontrar jurisprudência. Dentre as teses indicadas a prêmio, este número é menor, mas ainda é substantivo, cerca de $70 \%$ traz análises de jurisprudência, número que pode ser relativizado se considerarmos que $20 \%$ das teses apresentadas são de teoria do direito ou filosofia do direito, sem estudos de caso. A diferença entre os universos amostrais revela que os próprios programas valorizam os estudos de caso e o uso da jurisprudência, embora isso não seja sempre cobrado.

\begin{tabular}{|c|c|c|c|}
\hline & Teses excelentes & Conjunto das teses & Teses ruins \\
\hline Introdução & $\begin{array}{l}\text { 1. Há uma problemati- } \\
\text { zação do assunto. } \\
\text { 2. Há uma boa delimitação } \\
\text { do trabalho. } \\
\text { 3. Há um método claro de } \\
\text { trabalho } \\
\text { 5. Transparece, desde o } \\
\text { início, que o autor domina } \\
\text { o assunto. } \\
\text { 6. Há uma demonstração } \\
\text { jurídica nítida que o leitor } \\
\text { pode acompanhar sem se } \\
\text { perder. } \\
\text { 7. O raciocínio jurídico } \\
\text { é palpável assim como a } \\
\text { maturidade jurídica. }\end{array}$ & $\begin{array}{l}\text { 1. Percebe-se uma tendência a } \\
\text { descrever. } \\
\text { 2. Os elementos fundamentais } \\
\text { da pesquisa são presentes, mas } \\
\text { não sempre utilizadas para va- } \\
\text { lorizar a tese. } \\
\text { 3. A metodologia é clara, mas } \\
\text { em parte importante das teses, } \\
\text { não é apresentada. } \\
\text { 4. O fio condutor da tese é va- } \\
\text { riável, muitas vezes não linear. } \\
5 \text {. A problematização da intro- } \\
\text { dução e a articulação dos argu- } \\
\text { mentos sofrem consequente- } \\
\text { mente. }\end{array}$ & $\begin{array}{l}\text { 1. Há uma introdução de } \\
\text { poucas laudas (3-5) que, } \\
\text { às vezes, aparece como } \\
\text { sendo mais decorativa } \\
\text { que substancial. } \\
\text { 2. Não existe uma pro- } \\
\text { blemática nítida; tam- } \\
\text { pouco se encontra um } \\
\text { fio condutor claro desde } \\
\text { o início. } \\
\text { 3. Não há uma delimi- } \\
\text { tação do trabalho. } \\
\text { 4. A perspectiva da de- } \\
\text { monstração não é justi- } \\
\text { ficada; a originalidade do } \\
\text { trabalho tampouco. } \\
\text { 5. O raciocínio jurídico } \\
\text { do trabalho não é sempre } \\
\text { perceptível. } \\
\text { 6. Há um problema de } \\
\text { método grave. }\end{array}$ \\
\hline Conclusão & $\begin{array}{l}\text { As conclusões respondem } \\
\text { às questões salientadas na } \\
\text { introdução e ao longo do } \\
\text { trabalho. }\end{array}$ & $\begin{array}{l}\text { Não há diferenças substanciais } \\
\text { para as teses excelentes. }\end{array}$ & $\begin{array}{l}\text { Não há diferenças sub- } \\
\text { stanciais para as teses } \\
\text { excelentes. }\end{array}$ \\
\hline $\begin{array}{l}\text { Fontes: Uso de } \\
\text { livros em idiomas } \\
\text { estrangeiros }\end{array}$ & $\begin{array}{l}\text { Constata-se uma referên- } \\
\text { cia importante à doutrina } \\
\text { estrangeira. }\end{array}$ & $8 \%$ do total das referências & $\begin{array}{l}\text { Praticamente inexiste, } \\
\text { exceto livros traduzidos. }\end{array}$ \\
\hline $\begin{array}{l}\text { Fontes: artigos em } \\
\text { periódicos }\end{array}$ & $\begin{array}{l}\text { A maioria dos trabalhos } \\
\text { consulta artigos em perió- } \\
\text { dicos. }\end{array}$ & $7 \%$ do total das referências & Praticamente inexistente \\
\hline $\begin{array}{l}\text { Fontes: jurisprudên- } \\
\text { cia }\end{array}$ & $\begin{array}{l}\text { Cerca de } 70 \% \text { referem-se à } \\
\text { jurisprudência. }\end{array}$ & $\begin{array}{l}\text { Cerca de } 40 \% \text { referem-se à ju- } \\
\text { risprudência. }\end{array}$ & $\mathrm{n} / \mathrm{a}$ \\
\hline
\end{tabular}

Ao lado das diferenças qualitativas entre teses "excelentes" e teses "aprováveis", existem elementos formais que ajudam também a entender essa categorização. 


\subsubsection{As características formais das teses de doutorado no Brasil.}

É difícil encontrar uma diretriz metodológica uniforme ao examinar as teses de doutorado em Direito no Brasil. É possível afirmar que não há um guia típico e intrinsecamente brasileiro sobre como conduzir uma tese. Não existe um modelo predefinido a seguir. Portanto, cada tese obedece aos critérios definidos pelo autor e, certamente, pelo orientador. Assim, o estudo demonstra uma variedade de teses e, em muitos casos, é complicado costurar uma lógica de método comum entre si.

Para o observador, o sistema brasileiro de tese em Direito parece, até certo ponto, caótico. Há, por exemplo: teses de 400 páginas, com 39 páginas de bibliografia e 1016 notas de rodapé; teses de 220 páginas com 14 páginas de bibliografia e 224 notas de rodapé; teses de 290 páginas, 16 páginas de bibliografia e 722 notas de rodapé; teses com 150 páginas incluindo 25 páginas em anexos com 5 páginas de bibliografia e 147 notas de rodapé; teses de 125 páginas com 9 páginas de bibliografia e 111 notas de rodapé; teses de 1200 páginas com apenas 470 páginas escritas e o resto constituído de anexos. O ecletismo impressiona e um denominador comum e unificador dificilmente aparece. Há teses com uma bibliografia de 40-50 páginas e outras cuja bibliografia se constitui de apenas 5-6 páginas. Há teses com introduções de 20-30 páginas e outras com 3-6 páginas.

Na média geral do Brasil, as teses "aprováveis" têm 250 páginas e as indicadas ao Prêmio de Teses da CAPES têm 305 páginas. Dentre as teses em geral, dependendo do ano, a quantidade de teses maiores, por exemplo, que 300 páginas variam entre 20 - 30 \%. Uma vez mais, 300 páginas não é uma meta obrigatória, e uma média de 250 páginas não é uma crítica. Há teses excelentes de 250-300 páginas - com uma qualidade técnica e analítica apreciável.

No entanto, na percepção dos próprios programas, as teses excelentes, indicadas ao prêmio, têm praticamente todas mais de 250 páginas -, e a maioria acima de 300 páginas escritas. Portanto, quando se considera as teses submetidas ao prêmio da CAPES, nota-se que o universo aumenta razoavelmente. Quase nenhum Programa do Brasil considerou excelente uma produção com menos de 200 páginas. Mesmo teses com menos de 250 páginas são muito raras dentre aquelas consideradas aptas ao prêmio.

Além disso, dentre as poucas teses com menos de 250 páginas, praticamente todas são de Filosofia do Direito, que tratam um assunto essencialmente teórico, sem estudos empíricos e com objetos bastante delimitados, uma característica de um campo específico, mas que dificilmente poderia ser expandido outros ramos do Direito, sem prejuízo do conteúdo. Neste sentido, nota-se que o número de páginas é objetivamente percebido pelos programas como um diferencial entre uma tese excelente e uma tese aprovável.

Evidencia-se também uma diferença de percepção entre as escolas doutorais no Brasil sobre o que é uma tese. Em alguns Programas, é difícil encontrar qualquer tese com menos de 300 páginas, mesmo analisando todas as teses defendidas no período. Em outros, o padrão se situa em teses bastante resumidas, com 150 a 250 páginas ${ }^{14}$. independente dos números, é claramente perceptível que não existe um diálogo entre as escolas doutorais ou que não há uniformização das regras de apresentação formal e de construção metodológica de teses. É difícil entender qual é o mínimo que deve ser cumprido pelo doutorando, pois existem teses com 110-120 páginas escritas que conferem o título de doutor, enquanto há escolas doutorais que exigem, no mínimo, teses com 300 a 400 páginas escritas para dar acesso ao mesmo título.

A fotografia é confusa e a confusão, às vezes, se resolve por interpretação e por representação; a representação convida ao julgamento e, nessa lógica, a tese com apenas 110-120 páginas escritas com 90-135 referências bibliográficas aparece como sendo pouco séria. Importa ressaltar que a média dentre cursos de mestrado é mais ou menos 100-110 referências ${ }^{15}$. A conclusão decorre da comparação feita com outras teses que, na representação, demonstram um esforço maior, uma pesquisa relativamente mais volumosa e um tratamento do assunto mais aprofundado - o que se espera de um trabalho feito a longo prazo e com dedicação.

14 Os autores preferiram não nominar as escolas, em função do perfil identificado.

15 Ver VARELLA, M. D. ROESLER, C., ob. cit., 
As mesmas diferenças ocorrem em relação ao número de referências bibliográficas e notas de rodapé. A média de referências das teses indicadas pelos programas ao Prêmio é superior a 300 fontes consultadas. A média geral das teses é de 212, enquanto as teses medíocres ficam com uma média de 90 a 105 citações, inferior inclusive a média das dissertações de mestrado de cursos fracos. O número de notas das teses indicadas a prêmio é superior a 600 , enquanto a média geral das teses é de 400 a 450. As teses aprováveis em certos programas têm 200 a 250 referências bibliográficas.

\begin{tabular}{|l|l|l|l|}
\hline & $\begin{array}{l}\text { Teses excelentes (indi- } \\
\text { cadas a prêmio) }\end{array}$ & $\begin{array}{l}\text { Média Geral das } \\
\text { Teses }\end{array}$ & $\begin{array}{l}\text { Teses aprováveis em } \\
\text { certos cursos }\end{array}$ \\
\hline Número de páginas total & 305 em média & 260 em média & $120-150$ em média \\
\hline $\begin{array}{l}\text { Quantidade de referên- } \\
\text { cias }\end{array}$ & $\begin{array}{l}300-340 \text { referências em } \\
\text { média }\end{array}$ & $\begin{array}{l}212 \text { referências em } \\
\text { média }\end{array}$ & 90-105 em média \\
\hline $\begin{array}{l}\text { Quantidade de notas de } \\
\text { rodapé }\end{array}$ & $600-650$ em média & $400-450$ em média & 200-250 em média \\
\hline
\end{tabular}

Ao analisar o sistema brasileiro de tese em Direito, é impossível não fazer essa comparação: como a diversidade de teses sobressai, as teses que fogem do princípio de uma tese universitária se destacam. Não é preciso buscá-las; elas se abrem às críticas da parte de um observador objetivo por razão da sua única existência. E o fato de que elas tenham poucas páginas não é um indicador de uma grande capacidade sintetizadora. Uma aparência de tese não é uma tese. Obviamente, essas críticas feitas às teses são também relevantes para as escolas de Direito que as validam. Na ausência de harmonização nacional de regras para as teses, cabe à faculdade de Direito obrigar o respeito do princípio de uma tese universitária para que esta seja respeitada. Faz parte da sua responsabilidade. Caso contrário, ela incita à produção acadêmica medíocre.

É, todavia, claro que há assuntos que não precisam de um tratamento volumoso para concluir uma demonstração no quadro de um trabalho que não deixa de ser uma tese. No mesmo sentido, um jurista com uma capacidade sintética eficiente pode desenvolver o seu raciocínio em poucas páginas - considerando que o objetivo de uma tese é de ir diretamente ao ponto sem tergiversar. É possível achar várias qualidades nas teses brasileiras com 250 páginas: muitas têm uma problemática bem formulada, um volume de pesquisa razoável, uma bibliografia interessante, uma análise jurídica madura, um foco novo e original, um tratamento satisfatório do assunto e uma demonstração convincente ${ }^{16}$.

É justamente para a proteção do valor intrínseco dessas teses que é preciso se interessar às outras teses, também de menor porte, mas sem necessariamente ser equipadas com a qualidade esperada. $\mathrm{Na}$ ausência de regras brasileiras para definir ou identificar o que é uma tese em Direito, essas duas categorias de teses podem facilmente ser confundidas. Nesse caso, o problema é que pode haver um nivelamento por baixo. Uma determinada quantidade de teses de má qualidade pode baixar o nível geral. Nesse sentido, é possível constatar uma tendência na produção de teses com menos de 200 páginas que não mostram uma grande capacidade de pesquisa e cujo teor, como sendo uma tese de doutorado, pode ser questionado. Por exemplo, e a título de amostra, em 2013, podemos encontrar teses de 180, 125, 128, 116, 196, 167, 192, 193 ou de 191 páginas; em 2012, houve teses de 133, 188, 186, 128, 145, 113, 193, 151, 203 ou de 119 páginas; em 2011, teses com 145, 160 ou 156 páginas foram defendidas; em 2009, existem teses de 187, 182,161, 129 ou de 208 páginas; em 2010, se encontram teses de 203, 168, 200, “75”!, 147, 151, 167, ou de 166 páginas; em 2008, foram defendidas teses com 190,153,160,199, 184, 204, 185 ou de 182 páginas ${ }^{17}$.

São trabalhos desse tipo que formulam dúvidas por parte de um observador, pois as teses de baixa qualidade maculam o programa que ofuscam os bons trabalhos. A possibilidade que haja uma tese de 75 páginas

16 Isso ocorre, sobretudo, em temas como Filosofia do Direito.

17 Esses dados são facilmente verificáveis nos sites mencionados acima. É precisar notar também que há muitas teses de 200-250 páginas cuja parte escrita é menor que 200 páginas. 
atesta da gravidade da situação e da ausência de um controle sério. Portanto, na sua representação, as teses tendo apenas cerca de 200 laudas, com 100-130 referências bibliográficas, podem ser assimiladas às teses de má qualidade. E com uma tendência palpável de validar teses de menos que 200 páginas, a confusão é inevitável. O sistema caótico possibilita teses a la carte e reflete uma imagem muito negativa - e duvidosa - do doutorado em Direito no Brasil.

Encontram-se também, teses com uma introdução de apenas 2 - 3 páginas, o que é claramente insuficiente para explicar a problemática no nível de um doutorado, para justificar a escolha do assunto, para demonstrar a sua originalidade, para defender a sua utilidade e o seu interesse para a prática, para defender a linha geral da argumentação ou para apontar a metodologia a ser adotada. Dentre as teses indicadas a prêmio, nota-se que, no período avaliado, nenhum programa considerou excelente uma tese com introdução de 3 páginas, ficando as menores teses com 6 páginas, mas a média em torno de 9 a 10 páginas de introdução ${ }^{18}$ - a média das teses "aprováveis" tendo uma introdução de 6-7 páginas.

Cerca de 30\% das teses defendidas no Brasil são trabalhos com poucas páginas (menos de 200 páginas), sem uma análise bibliográfica compatível com a produção de doutorado. Trata-se de uma minoria, mas que pode multiplicar-se quando estes novos doutores tornarem-se professores de programas de mestrado e doutorado e entenderem que o padrão de qualidade é aquela da sua própria tese.

Ao afirmar que é preciso de mais doutores nas faculdades de Direito, a CAPES tem como objetivo o aumento e o fortalecimento de pesquisa séria no Brasil - esta é ainda insatisfatória. A possibilidade que existam teses aceitas e validadas, apesar do baixo nível de pesquisa, é contrária a esse objetivo. Por isso, são necessários critérios para valorizar as teses universitárias que contribuem ao avanço da pesquisa e que se demarcam dos trabalhos patológicos supramencionados. Além de critérios puramente formais, constata-se que a metodologia que caracteriza muitas teses convence pouco por não valorizar a pesquisa feita e por favorecer uma desordem substancial na demonstração.

Com essa conclusão preliminar, outros fatores devem ser considerados ao afiar o estudo. Existe no Brasil, um prêmio atribuído às melhores teses de doutorado. É, destarte, um campo a explorar na busca do entendimento da tese de Direito no Brasil, em especial de teses de excelência.

\subsection{Os critérios comuns às teses selecionadas para um prêmio no Brasil.}

Anualmente, a CAPES concede um prêmio de melhor tese do ano, em cada área do conhecimento. Os coordenadores de programas são convidados a selecionar qual é a melhor tese do ano e enviá-la para a competição. Não significa necessariamente que seja uma tese excelente. É possível que não haja teses consideradas excelentes em um determinado ano e o coordenador não envie nenhum trabalho ou escolha o mais apropriado. Cada programa pode ter critérios internos próprios de julgamento, seja por uma comissão composta para tanto, seja por decisão do próprio coordenador. Pressupõe-se que se refira ao melhor trabalho do ano. Logo, trata-se de uma boa amostragem do que se considera qualidade a cada ano.

As teses selecionadas para um prêmio demonstram, para a maioria, uma pesquisa relativamente mais importante e uma clareza na apresentação da problemática. Pode ser percebido que essas teses se caracterizam por uma bibliografia e por referências relativamente mais amplas. É, portanto, a pesquisa e a capacidade de pesquisar que são valorizadas e que destacam o trabalho. Isto é um indicador que o doutorando estudou todas as perspectivas da argumentação por ele defendida: ele está ciente dos contra-argumentos que existem e os considerou ao formular o seu raciocínio; com a pesquisa ampla feita, ele está ademais ciente - do que é mais importante - de que a tese defendida se demarca pela sua originalidade por não ser uma repetição dos discursos dos outros.

18 Mais precisamente $9,78$. 
Além disso, com um trabalho denso e com profundidade, o autor demonstra o seu potencial de Professor e Pesquisador. As teses indicadas ao prêmio apresentam também a característica de ter uma problemática nitidamente formulada. O leitor entende a tese ao começar a ler o trabalho, pois este vai diretamente ao ponto sem equívocos, sem descrições fúteis e sem relatar a opinião da toda doutrina, de forma repetida e enfadonha, mas utilizando-a para fortalecer e justificar a sua argumentação. Os pontos contrários são levantados e expostos com neutralidade, de forma a identificar com clareza os limites da divergência. O problema a ser tratado é claro e, em muitos casos, a metodologia para tanto é também salientada. O leitor é direcionado desde o início: ele é levado às questões jurídicas, à sua relevância, à sua atualidade e ao seu tratamento jurídico. Ele não deve adivinhar o posicionamento ou a opinião do autor que lhe chega ao ler a introdução.

As teses selecionadas para um prêmio têm uma introdução mais rigorosa, mais estendida e menos descritiva em que a tese é tratada sem disfarce. A tese é contextualizada, problematizada, colocada nos trilhos metodológicos escolhidos pelo autor e apresentada de forma clara, sem estilos de linguagem rebuscados e confusos. Na maioria dos casos, com uma introdução desse tipo, o tratamento do assunto é quase naturalmente mais denso o que justifica, com certeza, o número de páginas das teses indicadas para prêmios.

Como já mencionado, as teses “excelentes" também têm um marco quantitativo diferente, possuindo, na maioria dos casos, mais de 300 páginas escritas.

Não obstante, as teses selecionadas para um prêmio ainda não são seguidas como modelos de excelência. Se estas fossem modelos imperiosos ou recomendados, as teses mais recentes os seguiriam na forma e no método, o que não é o caso: por exemplo, muitas teses defendidas, em 2013, não têm o mesmo teor qualitativo que o supramencionado das teses “excelentes” e contêm, além disso, menos de 200 páginas, com 100-130 referências bibliográficas, isto já com os anexos e a bibliografia, estas sendo pouco desenvolvidas e aquelas sendo uma mera compilação de instrumentos jurídicos - aliás, disponíveis facilmente no domínio público. Em outras palavras, o que antes se denominava dissertação de mestrado, agora professores tendem denominar tese de doutorado. Haveria uma mediocrização do nível das teses de doutorado no Brasil, que atinge $30 \%$ da produção da área, mas que os próprios programas não consideram excelentes, mas aprováveis. Atualmente, parece que a tradicional relação de trabalho conjunto orientador-aluno cede espaço a um enquadramento institucional, perdendo-se o elo de responsabilidade sobre a orientação ${ }^{19}$. Tecnicamente, o objetivo dos programas de Pós-Graduação é alcançar um nível de excelência; as teses selecionadas para o Prêmio fazem parte do universo da excelência no Brasil; destarte, uma forma para direcionar os programas doutorais, nesse universo, é difundir melhor as teses premiadas para que estas se tornem, pouco a pouco, modelos a seguir. Seria, nesse sentido, útil que os Programas tivessem uma banca eletrônica organizada com todas as teses premiadas no âmbito nacional, para que os doutorandos pudessem seguir qualitativamente e quantitativamente o que a CAPES - e, portanto, o Ministério da Educação -, esperam de uma tese de doutorado em direito. É uma forma para construir o caminho para uniformizar um modelo de excelência.

$\mathrm{Na}$ realidade, a questão latente a esse debate é saber se é preciso um modelo de tese em Direito no Brasil, e o porquê. A existência de um modelo ou de indicadores é imperativa para evitar que todo tipo de trabalho se revista do estatuto de tese e para que os doutores em Direito formados no Brasil e que fizeram uma tese séria não sejam reduzidos ou comparados aos que escolheram um caminho mais rápido e mais fácil, apenas para obter o título. Caso contrário, não haverá incentivo para se esforçar e submeter um trabalho real e completo; bastará fazer uma tese com critérios a minima e com a garantia, in fine, de obter o título. O título de doutor se transforma em uma fatalidade cronológica do ingresso no doutorado, aconteça o que acontecer.

A ausência de um modelo favorece uma banalização do estatuto da tese de doutorado com trabalhos que buscam títulos, avanço profissional e financeiro ou honra, e não inovação e vocação para servir à educação. É, também, a imagem das universidades brasileiras que entram em consideração nessa discussão. E no campo internacional é a imagem - a qualidade - das universidades e dos doutores brasileiros que está em causa,

19 OST, F., op. cit. p. 5 
se o Brasil deseja que as suas universidades e os seus professores sejam respeitados nos outros países. Um estudo sobre o valor dado às teses de doutorado em Direito no Brasil nos alerta sobre a degradação possível e, talvez, já em tramitação, do estatuto do doutor brasileiro e do seu trabalho.

\section{O Valor Dado às Teses de Doutorado em Direito no Brasil}

A análise das teses em Direito ressalta uma tendência segundo a qual o doutorado é, em muitos casos, apenas funcional e carreirista. O caminho da tese é escolhido para uma autovalorização. Nesse sentido, a tese é apenas um instrumento para satisfazer ambições profissionais, o que não ajuda a fortalecer a academia brasileira (4.1) que precisa de teses mais vocacionais cuja realização decorre da vocação de (ser) Professor-Pesquisador (4.2).

\subsection{As teses com uma conotação funcional: um obstáculo para o fortalecimento da academia brasileira.}

Na sua representação, muitas teses aparecem como uma condição a minima, cumprida unicamente para um avanço profissional. São teses que buscam apenas o título de doutor (4.1.1.), o que se faz em detrimento da qualidade esperada de uma tese universitária respeitada, favorecendo, desse modo, a formação do Professor sem vocação (4.1.2).

\subsubsection{As teses que buscam apenas um título.}

Por que a forma e o método de uma tese são tão importantes e tão apontados nesse artigo? Afinal, pode ser um rigor muito elevado que, talvez, não seja culturalmente aceitável. No entanto, a forma e o método são indicadores da existência do pensamento real, leal, novo e útil do autor. A forma é o pensamento sobre a matéria ${ }^{20}$. Na realidade,

\footnotetext{
“(...) quanto o importante é a forma, já que a matéria é acessível a todos, ou já conhecida, portanto quando apenas o que é pensado pode dar valor ao esforço de pensar sobre esse tema, só uma mente de destaque é capaz de nos oferecer algo digno de ser lido. Pois os demais escritores pensam apenas o que qualquer outra pessoa pode pensar. Eles nos oferecem a impressão do seu espírito, mas qualquer um já possui o original dessa impressão. ${ }^{21}$ ”
}

As teses com pouca reflexão, com uma pesquisa pouco aprofundada, com uma argumentação construída de forma ligeira, com a vontade de concluir rapidamente já perceptível nas primeiras frases da introdução estão ao alcance de qualquer aluno. As universidades que estimulam a produção científica nessa direção não contribuem para melhorar a formação de juristas no Brasil, mas se tornam distribuidores fáceis de título de doutorado e podem, por essa razão, ser escolhidas pelos doutorandos, cujo objetivo é apenas o título.

Não seria reacionário nem revolucionário afirmar que um controle estatal é fundamental sobre essas questões. O controle é o de qualidade. O Brasil tem mais faculdades de Direito no seu território que todos os outros países do mundo, juntos ${ }^{22}$. Em breve, terá mais cursos de doutorado do que qualquer outro país do mundo ${ }^{23}$. Ao observar o crescimento destas, é obvio que o objetivo é mais lucrativo que educativo. A análise da qualidade das teses pela CAPES se faz primordial para a avaliação do curso, mas precisa ser mais efetiva durante as avaliações trienais.

20 SCHOPENHAUEUR, Arthur. A arte de escrever. Porto Alegre, L\&PM, 2012, p.63.

21 Ibid., p.64.

22 Vejam essa nota do Conselho federal da OAB: http://www.oab.org.br/noticia/20734/brasil-sozinho-tem-mais-faculdadesde-Direito-que-todos-os-paises.

23 VARELLA, M. D. e ROESLER, C. R. Dificuldades de avaliação de publicações na área Direito in Revista Brasileira de PósGraduação, v. 18, p. 663-701, 2012 
Os cursos de Doutorado não trazem lucro. No entanto, o Ministério da Educação fixa um número mínimo de doutores para cada curso de graduação. Para atender a demanda, multiplicam-se os cursos de doutorado, além de trazerem status para as instituições, como uma vitrine de qualidade para a instituição. Logo, consegue-se melhorar os cursos de graduação. $\mathrm{O}$ aumento numérico pode ser muito positivo, desde que com qualidade. Com essa exigência, houve - e está havendo - uma produção quase industrial de doutores, e não a formação deles. Muitas universidades podem ter uma tendência de entrar nesse processo industrial na ausência de uma intervenção do Estado ou de uma autorreflexão. Há, assim, uma busca de títulos com uma relegação ou uma regressão da qualidade, o que cria o Professor e o Pesquisador sem vocação.

As teses resumidas parecem uma imitação do modelo americano, mas sem a qualidade. Obter um doutorado se torna mecânico. A constatação é fria, mas relata uma realidade brasileira que é preocupante. A dedicação do doutorando é essencial. Uma pesquisa realizada em um ou dois anos dificilmente terá a mesma qualidade de um trabalho desenvolvido em três ou quatro anos. Um trabalho realizado com várias horas de estudo por dia, nos períodos do dia mais produtivos do doutorando, tem fortes chances de ser melhor do que uma tese que se escreve aos finais de semana ou em uma licença capacitação de três meses. Nas palavras de François Ost, para fazer uma tese em Direito, não basta motivação, interesse, assiduidade, é preciso paixão. É preciso trabalhar de forma contínua, sem parar $^{24}$.

É certo que o tempo para realizar uma tese foi bastante reduzido com a informática e o acesso à informação. Há quinze anos, para conseguir um livro indicado em uma nota de rodapé, era necessário ir até a biblioteca, identificar o código do livro em um sistema de fichas, solicitar no balcão, aguardar 40 minutos, para então conseguir o livro. Em seguida, era preciso ler o livro quase todo para encontrar o que se procurava. Em várias situações, era preciso esperar semanas para ter a obra, via sistema de comutação de obras entre bibliotecas. Hoje, com um clique no computador, tem-se o livro imediatamente. Em outro comando automático, encontra-se o trecho procurado. No entanto, parece que, ao mesmo tempo em que a informação ficou mais fácil, a disponibilidade da leitura concentrada e focada, com a análise profunda dos textos, se torna mais rara.

Assim, teses que buscam apenas o título não inovam, apenas replicam conhecimento já estabelecido. Pode ser um texto novo, mas com ideias antigas. A função de reproduzir conhecimento estabelecido pode ficar com outros multiplicadores, sem doutorado, mas não com doutores. O doutor é um inovador, que produz ideias novas. E se ele não tiver a vocação, o doutorado é apenas uma busca de títulos.

\subsubsection{A busca dos títulos em detrimento da qualidade: a criação do Doutor sem vocação}

Pelas razões supramencionadas, a preparação de uma tese é, em paralelo, a preparação quase ritual da formação do Professor. O tempo e a atenção dedicados a uma tese são facilmente perceptíveis ao abrir o trabalho e anunciam a qualidade do futuro Professor e Pesquisador. Aquele que não se dedicou plenamente ao fazer a sua tese e que produz uma obra científica desleixada terá poucas coisas a oferecer ao meio universitário. Com uma metodologia aproximativa e com uma capacidade de pesquisa (e então de trabalho universitário) média, é difícil esperar uma contribuição real e produtiva na formação dos futuros juristas no Brasil. Alguém que defendeu a tese em Direito com menos que 200 páginas - o que implica ainda menos páginas escritas - e com uma bibliografia com 100-130 referências, sem uma análise profunda do instituto jurídico, sem jurisprudência, sem casos concretos, com pouca legislação, sem conhecer como o seu problema é trabalhado em outros países, é um perigo potencial para as faculdades de Direito. Mas, ao mesmo tempo, são, em muitos casos, essas faculdades que abrem o palco para teses e doutores dessa qualidade.

24 "Cela fait au moins dix-sept ans que vous étudiez, mais aujourd'hui on vous demande, pour la première fois, de produire du savoir (un savoir original) - alors, il s'agit de passer à la vitesse supérieure, « en danseuse sur les pédales » (lorsque vous abordez une côte en vélo, il n’y a pas 36 solutions : ou vous accélérez pour garder le rythme, ou vous restez à vitesse constante... et vous ne tarderez pas à rétrograder et mettre bientôt pied à terre)." OST,., ob. cit., p. 6. 
É um círculo vicioso, no qual os que fizeram um trabalho sério, completo e afinado podem ser assimilados aos outros. Os esforços deles merecem uma valorização maior. Essas teses não são raras, mas podem facilmente ser abafadas pelas teses industriais. O doutor completo e aguerrido é, assim, empurrado para baixo e reduzido àquele título de 'Doutor' que se reveste de uma conotação cada vez mais banal; essa desvalorização piora com aquele costume dos advogados que gostam de se chamar de 'Doutor'... Por isso, a intervenção da CAPES é primordial para garantir a qualidade da formação, dos diplomas, mas também dos Professores do ensino superior. Caso contrário, o cargo de Professor é apenas um hobby e um estatuto social - e o Pesquisador, por seu lado, é apenas um fantasma, cujo nome as pessoas sabem, mas cujos trabalhos são invisíveis. A educação não se faz com e nas aparências. Para melhorar a academia brasileira, é preciso incentivar a produção de teses vocacionais.

\subsection{A necessidade de teses vocacionais: uma solução para melhorar a academia brasileira}

Uma reserva pode ser formulada perante essa afirmação de uma autoridade:

"Todo jovem que acredite possuir a vocação de cientista dever dar-se conta de que a tarefa que espera reveste duplo aspecto. Deve ele possuir não apenas as qualificações de cientistas, mas também do professor. Ora, essas duas características não são absolutamente coincidentes ${ }^{25}$ ".

No entanto, é possível dissociar o porte, a prestação e as capacidades de comunicação e de transmissão do Professor da sua preparação: as primeiras características decorrem das qualidades pessoais e a última, da sua formação. Por ser Doutor, uma pessoa não adquire automaticamente todas as qualidades do Professor. Todavia, um Doutor com uma formação séria e completa, que se reflete na sua tese, já tem boas predisposições para ser um Professor competente. Ele pode, por exemplo, não ter um talento oratório, mas a base dele é sólida e a qualidade do seu trabalho será presumida elevada, porque o Professor deve também à academia uma produção científica, além de ministrar aulas. Por conseguinte, a necessidade de respeitar o espírito intrínseco de uma tese é um caminho sério e importante para a formação e a seleção dos Professores-Pesquisadores (4.2.1) e a qualidade vocacional ou não das teses determina também a imagem do Brasil no âmbito acadêmico internacional (4.2.2).

\subsubsection{A necessidade de respeitar o espírito intrínseco de uma tese: um caminho para a for- mação de Professores.}

O espírito intrínseco de uma tese é a produção científica sobre uma questão não resolvida com uma problemática original e um tratamento imensamente rigoroso; a vontade de contribuição, de críticas e de inovação é palpável. Esse espírito se respira imediatamente ao abrir o trabalho, mas não se encontra em muitas teses examinadas para esse estudo. Cientificamente, há dissertações de mestrado que valem mais do que essas teses, o que é um problema acadêmico grave: não indica que o mestre tem o nível de um doutor, mas afirma o contrário.

Se a formação dos juristas é um assunto sério, no Brasil, não pode existir um equívoco sobre o teor de uma tese de doutorado. Se existe uma dúvida, significa que formadores não formados estão provavelmente atuando nas universidades. É preciso repetir que a maturidade jurídica de um Professor Doutor se verifica na qualidade da sua tese. Alguns defenderão que muitos Doutores não querem ser Professores, mas já são advogados, juízes, promotores ou procuradores. Eis um argumento pouco convincente, aliás, nada convincente por não ser um argumento. Não é porque a tese é feita fora da dedicação exclusiva à vida universitária - o que é perfeitamente possível - que ela deve ser medíocre, pouco criteriosa, sem rigor, sem pesquisa completa e aprofundada, sem método, sem originalidade e com uma argumentação geral de baixa qualidade. Caso contrário, precisa de pouco para ser doutor e, ao estudar as teses brasileiras, parece justamente que, às vezes, precisa de pouco para tais fins.

25 WEBER, Max, Ciência e Politica: Duas vocações, Berlim, Dunker \& Humblot, 1968, p.22. 
Pela análise realizada neste trabalho, nota-se que a fixação de padrões mínimos para a aprovação de teses bastaria seguir o que os próprios programas consideram excelentes para indicar seus trabalhos ao prêmio da CAPES: objetos bem delimitados, boas introduções, conhecimento da teoria brasileira e estrangeira, análise do direito construído pela jurisprudência e da legislação, no Brasil e no exterior, um esforço em ler uma quantidade razoável de textos de base (uma bibliografia com pelo menos 250 referências utilizadas no trabalho), indicar aos doutorandos que conheçam os trabalhos desenvolvidos pelos pares em periódicos e que usem fontes sérias (evitem o jus navigandi!).

Em consequência, a questão da qualidade de teses de doutorado em Direito é fundamental por indicar o posicionamento e a imagem do Brasil no âmbito acadêmico internacional.

\subsubsection{Os efeitos das teses vocacionais: o posicionamento e a imagem do Brasil no âmbito acadêmico internacional}

As universidades brasileiras estão cada vez mais implicadas nas colaborações, nos intercâmbios e nas parceiras com as universidades estrangeiras. A imagem da universidade brasileira não se limita mais ao meio estritamente nacional, mas propaga-se além das fronteiras. É, então, outra razão que justifica um controle de qualidade dos trabalhos dos futuros professores. A formação dos juristas brasileiros deve permiti-los se destacar também fora do Brasil com o alto nível de produção científica que se espera deles.

No mundo como um todo, parece ser necessário recolocar a ciência sobre trilhos. A busca desenfreada por números, sem uma análise qualitativa, leva à produção contínua de textos de baixa qualidade. Três quartos da produção mundial de artigos científicos são mera repetição de conhecimentos anteriores ${ }^{26}$. $\mathrm{O}$ aumento da qualidade das teses está diretamente relacionado, no contexto nacional, com a maior e melhor inserção da academia brasileira no ensino de graduação e, no âmbito internacional, na produção global de conhecimento.

Para tanto, o trabalho de jurista aparece seriamente, ou não, com a preparação da tese de doutorado. Poucas são as universidades estrangeiras sérias que convidarão um professor de Direito cuja tese é apenas um ersatz: O objetivo de um controle de qualidade estatal é duplo: permitir uma melhor formação dos doutores para que o Brasil tenha uma representação de alta qualidade no âmbito acadêmico internacional; evitar que pessoas incompetentes tenham esse papel.

\section{Considerações finais}

Uma boa tese de doutorado em Direito, de acordo com a própria percepção dos programas no Brasil, reúne elementos qualitativos e quantitativos. Qualitativamente, há diferenciais em toda a tese: na introdução, no corpo do texto, nas conclusões e na bibliografia. A introdução é detalhada, aponta a ideia central do trabalho, as principais categorias, desenvolve as principais partes e apresenta a forma de estruturação do texto. O corpo do texto é construído com base em análises metodologicamente melhor organizadas, com estudos de caso e conhecimento da legislação e jurisprudência. As conclusões retomam as ideias centrais, organizam o conhecimento sistematizado e as contribuições para o campo do conhecimento. As fontes do trabalho incluem teoria, jurisprudência e legislação. Uma tese excelente usa livros e artigos em periódicos, outras teses de doutorado e dissertações de mestrado, nacionais e estrangeiros analisam a jurisprudência nacional, estrangeira e internacional; legislação brasileira e estrangeira. Logicamente, há variações em certos ramos mais teóricos do direito.

26 THE ECONOMIST (Leaders). How science goes wrong in The Economist, 19/10/2013, disponível em http://www.economist.com/news/leaders/21588069-scientific-research-has-changed-world-now-it-needs-change-itself-how-science-goes-wrong, acesso em 13/01/2014. 
Quantitativamente, também há diferenças nítidas entre as teses indicadas pelos Programas ao prêmio de melhor tese da CAPES. Uma tese excelente tem, em geral, mais de 300 páginas, com pelo menos 250 a 300 referências bibliográficas e umas 700 notas de rodapé. As introduções têm, normalmente, cerca de nove páginas. A média das teses aprovadas no Brasil é $20 \%$ menor, com cerca de 250 páginase 210 referências bibliográficas.

No entanto, há uma percentagem significativa de 30\% de teses ruins, que merece ser citada. São teses com introduções, corpo de texto e conclusões superficiais, mal construídos, sem hipóteses contestáveis, sem ideias novas e com uma metodologia dificilmente identificável. Em geral, fundamentam-se em uma bibliografia medíocre, composta apenas com autores nacionais, por manuais de direito e sites de internet que publicam qualquer texto que for submetido, sem análise por pares. O uso da bibliografia estrangeira é raríssimo, ainda que se exijam dois idiomas para ingressar no mestrado. Os livros traduzidos são antigos e as críticas aos autores clássicos publicadas no exterior são desconhecidas, mesmo quando tais autores são a base do conhecimento discutido na tese. Neste universo de trabalhos medíocres, quase não há estudos de caso, a jurisprudência e legislação são ignoradas. Neste universo, há teses com pouco mais de 100 páginas, aprovadas em certos programas no país, que em nada se diferenciam de bons trabalhos de conclusão de graduação ou dissertações de mestrado.

Um debate na academia brasileira sobre o tema se mostra fundamental. O conhecimento de critérios de qualidade adotados por diferentes programas é essencial para a disseminação de boas práticas de orientação e redação de teses de doutorado com qualidade.

Anexo I. Comparativo entre as teses

\begin{tabular}{|c|c|c|c|}
\hline & Teses excelentes & Conjunto das teses & Teses ruins \\
\hline \multicolumn{4}{|l|}{$\begin{array}{l}\text { Aspectos } \\
\text { qualitativos }\end{array}$} \\
\hline Introdução & $\begin{array}{l}\text { 1. Há uma problemati- } \\
\text { zação do assunto. } \\
\text { 2. Há uma boa delimi- } \\
\text { tação do trabalho. } \\
\text { 3. Há um método claro } \\
\text { de trabalho } \\
\text { 5. Transparece, desde o } \\
\text { início, que o autor do- } \\
\text { mina o assunto. } \\
\text { 6. Há uma demon- } \\
\text { stração jurídica nítida } \\
\text { que o leitor pode acom- } \\
\text { panhar sem se perder. } \\
\text { 7. O raciocínio jurídico } \\
\text { é palpável assim como a } \\
\text { maturidade jurídica. }\end{array}$ & $\begin{array}{l}\text { 1. Percebe-se uma tendência } \\
\text { a descrever. } \\
\text { 2. Os elementos fundamen- } \\
\text { tais da pesquisa são presen- } \\
\text { tes, mas não sempre utiliza- } \\
\text { das para valorizar a tese. } \\
\text { 3. A metodologia é clara, } \\
\text { mas em parte importante } \\
\text { das teses, não é apresentada. } \\
\text { 4. O fio condutor da tese é } \\
\text { variável, muitas vezes não } \\
\text { linear. } \\
\text { 5. A problematização da in- } \\
\text { trodução e a articulação dos } \\
\text { argumentos sofrem conse- } \\
\text { quentemente. }\end{array}$ & $\begin{array}{l}\text { 1. Há uma introdução de } \\
\text { poucas laudas (3-5) que, às } \\
\text { vezes, aparece como sendo } \\
\text { mais decorativa que sub- } \\
\text { stancial. } \\
\text { 2. Não existe uma pro- } \\
\text { blemática nítida; tampouco } \\
\text { se encontra um fio condutor } \\
\text { claro desde o início. } \\
\text { 3. Não há uma delimitação } \\
\text { do trabalho. } \\
\text { 4. A perspectiva da demon- } \\
\text { stração não é justificada; a } \\
\text { originalidade do trabalho } \\
\text { tampouco. } \\
\text { 5. O raciocínio jurídico do } \\
\text { trabalho não é sempre per- } \\
\text { ceptível. } \\
\text { 6. Há um problema de } \\
\text { método grave. }\end{array}$ \\
\hline
\end{tabular}




\begin{tabular}{|l|l|l|l|}
\hline Conclusão & $\begin{array}{l}\text { As conclusões respon- } \\
\text { dem às questões salien- } \\
\text { tadas na introdução e ao } \\
\text { longo do trabalho. }\end{array}$ & $\begin{array}{l}\text { Não há diferenças substan- } \\
\text { ciais para as teses excelentes. }\end{array}$ & $\begin{array}{l}\text { Não há diferenças substan- } \\
\text { ciais para as teses excelentes. }\end{array}$ \\
\hline $\begin{array}{l}\text { Fontes: Uso de } \\
\text { livros em idio- } \\
\text { mas estrangeiros }\end{array}$ & $\begin{array}{l}\text { Constata-se uma re- } \\
\text { ferência importante à } \\
\text { doutrina estrangeira. }\end{array}$ & $8 \%$ do total das referências & $\begin{array}{l}\text { Praticamente inexiste, exce- } \\
\text { to livros traduzidos. }\end{array}$ \\
\hline $\begin{array}{l}\text { Fontes: artigos } \\
\text { em periódicos }\end{array}$ & $\begin{array}{l}\text { A maioria dos trabalhos } \\
\text { consulta artigos em pe- } \\
\text { riódicos. }\end{array}$ & $7 \%$ do total das referências & Praticamente inexistente \\
\hline $\begin{array}{l}\text { Fontes: juri- } \\
\text { sprudência }\end{array}$ & $\begin{array}{l}\text { Cerca de } 70 \% \text { referem- } \\
\text { se à jurisprudência. }\end{array}$ & $\begin{array}{l}\text { Cerca de 40\% referem-se à } \\
\text { jurisprudência. }\end{array}$ & n/a \\
\hline $\begin{array}{l}\text { Aspectos } \\
\text { quantitativos }\end{array}$ & 305 em média & 260 em média & $120-150$ em média \\
\hline $\begin{array}{l}\text { Número de } \\
\text { páginas total }\end{array}$ & $\begin{array}{l}300-340 \text { referências em } \\
\text { média }\end{array}$ & 212 referências em média & $90-105$ em média \\
\hline $\begin{array}{l}\text { Quantidade de } \\
\text { referências }\end{array}$ & $\begin{array}{l}600-650 \text { em média } \\
\text { Quantidade de } \\
\text { notas de rodapé }\end{array}$ & $400-450$ em média & $200-250$ em média \\
\hline
\end{tabular}

\section{Referências}

GARNER, Bryan A., A Message to Law Students: Effective Writing Takes a Lifelong Commitment in Michigan Bar Journal, setembro 2006.

OLIVEIRA, Luciano, Não falei do código do Hamurábi, disponível em http://www.uniceub.br/media/180293/Texto_IX.pdf, acesso em 13/01/2014

OST, F. La thèse de doctorat em droit: du projet à la soutenance, disponível em http://www.fusl.ac.be/fr/ pdf/Droit/rapport_fr.pdf, acesso em 11.11.2013, p. 2

RE, Edward D., "Increased Importance Of Legal Writing In The Era Of “The Vanishing Trial” in Touro Law Review, v. 21, 2005.

SCHIESS, Wayne, "Legal Writing Is Not What It Should Be”, Southern University Law Review, v. 37, n.1, 2009. SCHOPENHAUEUR, Arthur, A arte de escrever, Porto Alegre, L\&PM, 2012.

VARELLA, M. D. e Roesler, C. R. Dificuldades de avaliação de publicações na área Direito in Revista Brasileira de Pós-Graduação, v. 18, 2012

VARELLA, M. D. e LIMA, M. M. B. Políticas de revalidação de diplomas de pós-graduação em Direito no Brasil. Dificuldades e desafios para o sistema brasileiro in Revista Brasileira de Políticas Públicas, v. 2, 2012.

WEBER, Max, Ciência e Política: Duas vocações, Berlim, Dunker \& Humblot, 1968.

THE ECONOMIST (Leaders). How science goes wrong in The Economist, 19/10/2013, disponível em http://www.economist.com/news/leaders/21588069-scientific-research-has-changed-world-nowit-needs-change-itself-how-science-goes-wrong, acesso em 13/01/2014. 


\section{Normas Editoriais}

1. Serão aceitas colaborações inéditas e a publicação de um artigo está condicionada à sua adequação às normas editoriais, e seu simples recebimento desobriga a sua publicação. A revista Prismas: Direito, Políticas Públicas e Mundialização classificará as colaborações de acordo com as seguintes seções:

1.1 Artigos: compreende textos que contenham relatos completos de estudos ou pesquisas concluídas, matérias de caráter opinativo, revisões da literatura e colaborações assemelhadas.

1.2 Resenhas: compreende análises críticas de livros, de periódicos recentemente publicados, dissertações e teses.

2. Excepcionalmente, a comissão editorial poderá aceitar a submissão de trabalhos que já tenham sido publicados e caso isso ocorra, serão submetidos ao mesmo processo de avaliação pelos pares que aqueles inéditos. $\mathrm{O}$ autor deverá apresentar autorização por escrito do editor da revista na qual seu trabalho tenha sido originalmente publicado, acompanhado de cópia do mesmo.

3. O processo de avaliação dos artigos e resenhas compreende duas fases: a primeira destinada à análise da adequação do trabalho à linha editorial da revista (Comissão Editorial) e a segunda referente à avaliação do conteúdo e qualidade dos trabalhos. Esta segunda fase é realizada mediante o processo de avaliação pelos pares, ou seja, os artigos serão submetidos à aprovação de no mínimo 2 pareceristas adhoc.

4. Os trabalhos serão enviados para a avaliação sem a identificação de autoria

5. Os trabalhos devem ser enviados no seguinte padrão:

$1^{a}$ Página: Começar com o título do título do trabalho, seguido do texto. Não inseriro nome dos autores ou outros elementos queidentifiquem a autoria. A autoria do artigo e a qualificação dos autores são inseridas nos campos específicos do formulário eletrônico. O objetivo aqui é garantir uma avaliação cega por pares. Os textos deverão ser digitados em Arial 12, espaço 1,5 margem de 2,5 $\mathrm{cm}$, numeração arábica das páginas no ângulo superior direito, em programa compatível com o World para Windows.

Título do trabalho: o título deve ser breve e suficientemente específico e descritivo para representar o conteúdo do texto e deverá ter a sua tradução para o inglês.

Resumo: em todos os artigos submetidos deve ser incluído um resumo informativo com o máximo de 250 palavras e espaço entre linhas simples. O resumo deve ser estruturado com as seguintes informações:

Objetivo do artigo (obrigatório);

Metodologia (obrigatório);

Conclusões (obrigatório);

Limitações da pesquisa e suas implicações (se aplicável);

Limitações práticas (se aplicável)

Originalidade ou valor (obrigatório); 
A evolução da comunicação científica e da transmissão de conhecimentos possibilitou ao UniCEUB a criação de meios para o intercâmbio de idéias entre pares e a disseminação de informações.

As novas tecnologias da informação produzem sensíveis alterações nos processos de comunicação científica. Atualmente, a editoração das publicações acadêmicas do UniCEUB é informatizada em todas as suas etapas, com a utilização da plataforma SEER, Sistema de Editoração Eletrônico de Revistas. A aplicação do SEER permitiu acrescentar, no processo editorial, a avaliação dos pareceristas ad hoc e deu aos membros dos comitês editoriais e aos editores condições para consolidar a produção científica no UniCEUB e difundi-la por meio dos periódicos acadêmicos em mídia impressa e eletrônica.

Todas as edições das publicações científicas do UniCEUB estão disponíveis no site www.publicacoesacademicas.uniceub.br, com infraestrutura para acesso livre.

O UniCEUB publica as seguintes revistas:

- Padê: estudos em filosofia, raça, gênero e direitos humanos

- Prismas: direito, políticas públicas e mundialização

- Universitas Arquitetura e Comunicação Social

- Universitas Ciências da Saúde

- Universitas Gestão e TI

- Universitas Humanas

- Universitas JUS

- Universitas Relações Internacionais

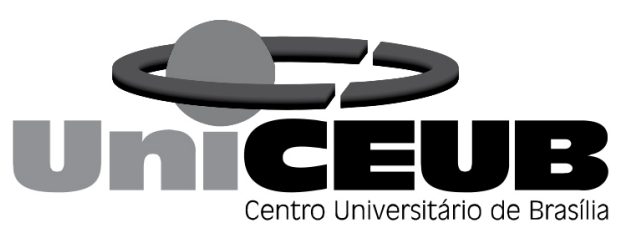


Destacar no mínimo três e no máximo seis palavraschave que representem o conteúdo do texto. O resumo e as palavras-chave deverão ter a sua tradução para o inglês.

Agradecimentos: agradecimentos a auxílios recebidos para a elaboração do trabalho deverão ser mencionados no final do artigo.

Notas: notas referentes ao corpo do artigo deverão vir no rodapé do texto.

Apêndices: apêndices podem ser empregados no caso de listagens extensivas, estatísticas e outros elementos de suporte.

Materiais gráficos: fotografias nítidas e gráficos (estritamente indispensáveis à clareza do texto) poderão ser aceitos e cada fotografia ou gráfico deverá vir no texto e além disso cada um deverá ser enviado em arquivo separado. Se as ilustrações enviadas já tiverem sido publicadas, mencionar a fonte e a permissão para reprodução.

Quadros: os quadros deverão ser acompanhados de cabeçalho que permita compreender o significado dos dados reunidos, sem necessidade de referência ao texto. Assinalar, no texto, pelo seu número de ordem, os locais onde os quadros devem ser intercalados.

Referências: as referências redigidas segundo a norma NBR 6023/2002 da Associação Brasileira de Normas Técnicas (ABNT), deverão ser apresentadas por ordem alfabética e constituir uma lista única no final do artigo. A exatidão e adequação das referências a trabalhos que tenham sido consultados e mencionados no texto do artigo são da responsabilidade do autor. Informações procedentes de comunicação pessoal, de trabalhos em andamento ou não publicados não devem ser incluídas na lista de referências, mas indicada em nota de rodapé. Não utilizar o sistema Autor data para citações. O formato utilizado pela revista é o sistema numérico, onde a citação é indicada por número sobrescrito e a referência mencionada em nota de rodapé.

Recomendações: recomenda-se que se observem as normas da ABNT referentes à apresentação de artigos em publicações periódicas (NBR 6022/2002), apresentação de citações em documentos (NBR 10520/2002), apresentação de originais (NBR 12256), norma para datar (NBR 892), numeração progressiva das seções de um documento (NBR 6024/2003) e resumos (NBR $6028 / 2003)$

A revista se reserva o direito de efetuar nos originais alterações de ordem normativa, ortográfica e gramatical, com vistas a manter o padrão culto da língua, respeitando, porém, o estilo dos autores.

A partir de 2009, consideramos útil formular algumas sugestões (não obrigatórias) aos autores, com base nos principais motivos por recusa de artigos nos anos anteriores.

7. Com a publicação do artigo o autor receberá cinco exemplares da revista. No caso de resenha o autor receberá dois exemplares.

8. Responsabilidades e conflitos de interesse: A responsabilidade pelas informações e opiniões indicadas nos artigos é exclusiva dos autores. Eventuais conflitos de interesse serão de responsabilidade dos próprios autores e não do periódico.

\section{Envio dos trabalhos:}

1. Os trabalhos deverão ser enviados para a equipe editorial da revista no endereço eletrônico www.rdi.uniceub.br

2. Cada autor deve enviar declaração de responsabilidade nos termos abaixo:

“ Eu XXXX certifico que participei da concepção do trabalho tornar pública minha responsabilidade pelo seu conteúdo, que não omiti quaisquer ligações ou acordos de financiamento entre os autores e companhias que possam ter interesse na publicação deste artigo."

3. Para as colaborações inéditas, cada autor deve enviar a transferência de direitos autorais nos termos abaixo:

"Eu XXXX declaro que em caso de aceitação do artigo inédito, a revista Prismas: Direito, Políticas Públicas e Mundialização passa a ter os direitos autorais a ele referentes. 


\section{REVISTA BRASILEIRA DE POLÍTICAS PÚBLICAS \\ V. $3, \mathrm{n} .2$}

Dossier Federalismo

Forma de Estado: Federalismo e repartição de competências

Carlos Bastide Horbach

Imunidade recíproca e federalismo: da construção norte-americana à atual posição do STF

Fernando Santos Arenhart

Justiça fiscal, paz tributária e obrigações republicanas: uma breve análise da dinâmica jurisprudencial tributária do Supremo Tribunal Federal

Luís Carlos Martins Alves Jr

Federalismo, estado federalista e a revalorização do município: um novo caminho para o século XXI?

Efeitos político-jurídicos da não institucionalizada paradiplomacia no Brasil

Antonio Celso Batista Minhoto

The Management of Public Natural Resource Wealth

Gustavo de Souza Abreu

Paul Rose

A (in)competência do CONAMA para edição de normas sobre licenciamento ambiental: Análise de sua juridicidade

André Fagundes Lemos

Artigos sobre outros temas

Teoría de la presión tributaria en base a la igualdad intergeneracional: una perspectiva financiera y tributaria del caso argentino

Crédito tributário: garantias, privilégios e preferências

Luciano Carlos Rezzoagli e Bruno Ariel Rezzoagli

Luís Carlos Martins Alves Júnior

Tributário - O parecer PGFN/CRJ 492/2011 e os efeitos da coisa julgada inconstitucional em face da segurança jurídica no Estado Democrático de Direito

Antônio Frota Neves

A segurança jurídica administrativa na jurisprudência do Supremo Tribunal Federal: uma análise acerca dos fundamentos normativos e dos argumentos jurídicos nos julgamentos dos mandados de segurança 24.781 e 25.116

Ana Paula Sampaio Silva Pereira

Avaliação legislativa no Brasil: apontamentos para uma nova agenda de pesquisa sobre o modo de produção das leis

Natasha Schmitt Caccia Salinas

Políticas públicas, deveres fundamentais e concretização de direitos

Julio Pinheiro Faro

Políticas públicas de guerra às drogas: o estado de exceção e a transição do inimigo schmittiano ao homo sacer de Agamben

João Victor Nascimento Martins

New institutions for the protection of privacy and personal dignity in internet communication - "in-

formation broker", "private cyber courts" and network of contracts

Karl-Heinz Ladeur

Responsabilidade civil decorrente de erro médico

Edilson Enedino das Chagas e Héctor Valverde Santana A atual geração de energia elétrica segundo a lógica de mercado e sua ainda caracterização como serviço público

Humberto Cunha dos Santos

Empresas, responsabilidade social e políticas de informação obrigatória no Brasil

Leandro Martins Zanitelli O outro e sua Identidade: políticas públicas de remoção e o caso dos agricultores do Parque Estadual da Pedra Branca/RJ

A legitimação do aborto à luz dos pressupostos do estado democrático de direito

Andreza A. Franco Câmara

Terezinha Inês Teles Pires

Juspositivismo, discricionariedade e controle judicial de políticas públicas no direito brasileiro

Guilherme Valle Brum

A governança transnacional ambiental na Rio +20

Paulo Márcio Cruz e Zenildo Bodnar O que é uma boa tese de doutorado em Direito? Uma análise a partir da própria percepção dos programas Nitish Monebhurrun e Marcelo D. Varella 